Filipe Eduardo Moreau

\title{
ARQUITETURA MILITAR EM SALVADOR DA BAHIA SÉCULOS XVI A XVIII
}

Tese de Doutorado apresentada ao programa de Pós-Graduação da FAU-USP

Área de concentração História e Fundamentos da Arquitetura e Urbanismo

Orientador: Prof. Dr. Mário Henrique Simão D’Agostino

São Paulo

Fevereiro de 2011 
AUTORIZO A REPRODUÇÃO E DIVULGAÇÃO TOTAL OU PARCIAL DESTE TRABALHO, POR QUALQUER MEIO CONVENCIONAL OU ELETRÔNICO, PARA FINS DE ESTUDO E PESQUISA, DESDE QUE CITADA A FONTE

E-MAIL: filipemoreau@gmail.com

Moreau, Filipe Eduardo

M837a Arquitetura militar em Salvador da Bahia - séculos XVI a XVIII / Filipe Eduardo Moreau. --São Paulo, 2011. 373 p. : il.

Tese (Doutorado - Área de Concentração: História e Fundamentos da Arquitetura e Urbanismo) - FAUUSP.

Orientador: Mário Henrique Simão D’Agostino

1.Edifícios militares - Salvador(BA) 2.Fortificações Salvador (BA) 3.Planejamento territorial urbano - Salvador(BA) I.Título

CDU 725.18(814.21)

Ilustração de capa: partes do desenho Elevasam e Fasada... de Carlos Julião, 1779 (do DSE - em REIS Fo, 2000: 39). 
Trabalho de pesquisa dedicado a Gustavo e Isabel 
Nossos agradecimentos aos professores mais diretamente envolvidos, doutores Mário Henrique Simão D’ Agostino, Mário Mendonça de Oliveira, Beatriz Piccolotto Siqueira Bueno, Anna Beatriz Ayrosa Galvão, Nestor Goulart Reis Filho e Rafael de Faria Domingues Moreira. Também agradecemos a professores da FAU que sempre nos incentivaram, doutores Beatriz Kühl, M. Cecilia Lourenço, Fernanda Fernandes, Renina Katz, Ana Belluzzo, Luiz Munari, Joaquim Guedes (in memoriam), Luciano Migliaccio, Ricardo de Azevedo, Benedito de Toledo, Paulo Bruna, Lúcio Gomes e J. Eduardo Lefévre, bem como a funcionários de bibliotecas, arquivos, fundações e secretarias (em especial a Eneida, Ana, Maria José, Isa e Márcia).

Agradecemos aos familiares e amigos que nos ajudaram, Caloca Fernandes (com visitas a livrarias, biblioteca e arquivos portugueses, guarda de material copiado), Heloísa Bellotto (com instruções importantes para essas visitas), Sônia Robatto e Dri Guimarães (com visitas a livrarias, bibliotecas e arquivos no Brasil), Cláudio Furtado e Paula Perrone (com visita a arquivo italiano, guarda de material fotografado e dicas práticas), Taia (com volumoso material de pesquisa presenteado), Hite, Edu, Ana e Tomás Mariani (com hospedagens em Salvador, Ponta de Santo André e Rio de Janeiro), Lou Nascimento e Alain Moreau (com livros presenteados e fotografados), Xico Guedes (com reinstalação de Cad) Cauê Alves (com gravação de áudio na qualificação) João Sodré (com mapas do crescimento urbano), Dan (com os primeiros ensinamentos de pesquisa), Gi e Zaba Moreau (com outros ensinamentos), filhos e sobrinhos (sempre amados) e outros tios, primos, muitos amigos e amigas que estiveram próximos e nos apoiaram, trazendo com isso o equilíbrio necessário para a realização deste trabalho. 
Sumário

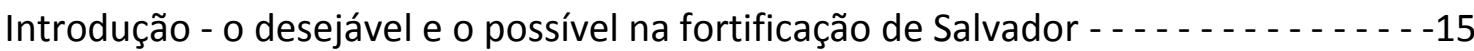

PARTE I - Os engenheiros militares: arte da guerra e de desenhar cidades

1. Origens da fortificação moderna: advento do baluarte - - - - - - - - - - 33

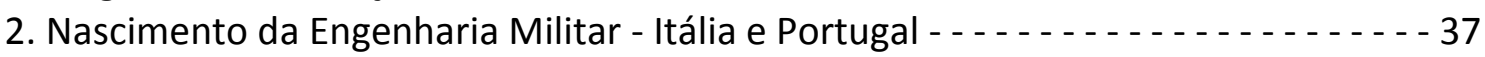

3. Tratadística italiana de Arquitetura e Fortificação - - - - - - - - - - - - - - - - 39

4. As chamadas escolas de fortificação: italiana, holandesa, francesa - - - - - - - - - 43

5. Formação dos que atuavam no Brasil: Aulas e Tratados de Arquitetura Militar - - - 49

5.1. Escola de Moços Fidalgos do Paço da Ribeira (tratado de Antônio

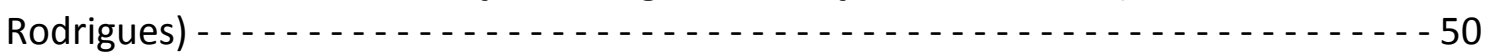

5.2. Aula de Architectura do Paço da Ribeira (Terzi e o tratado de Matheus do

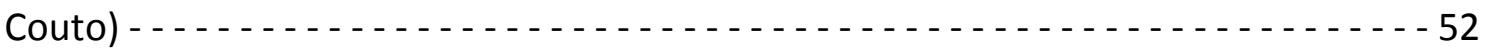

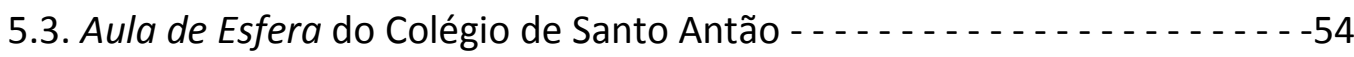

5.4. Aula de Fortificação e Arquitectura Militar da Ribeira das Naus - - - - - - - - - - - - -55

Luís Serrão Pimentel e o Methodo Lusitanico... - - - - - - - - - - - - - - - - - - - - - -

Manoel de Azevedo Fortes e O Engenheiro Portuguez - - - - - - - - - 60

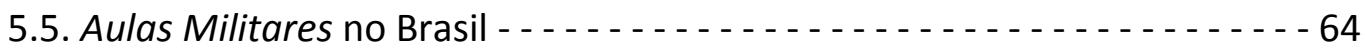

6. Outras atribuições: obras civis e religiosas - - - - - - - - - 66

PARTE II - Século XVI: a cidade fortificada de Salvador

1. Anos 1540: ambiente renascentista na Corte e primeira ocupação da capitania

1.1. Cultura clássica em D. João III: conhecimentos assimilados da tratadística

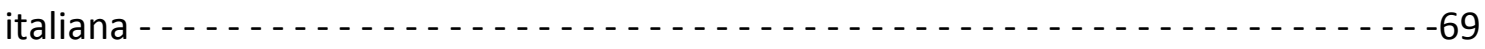

1.2. Experiência de Mazagão (primeira cidade renascentista construída fora da

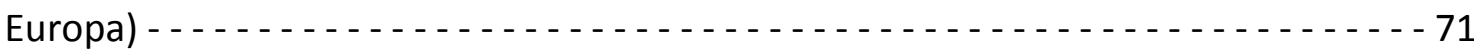

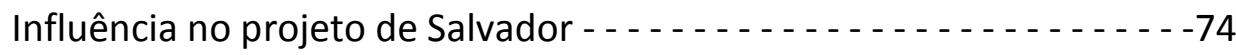

1.3. Cenário anterior à fundação: capitania da Baía e Povoação do Pereira - - -76

As torres de terra: Caramuru e Coutinho - . - - - - - - - - 78

1.4. Regimento (1548) -

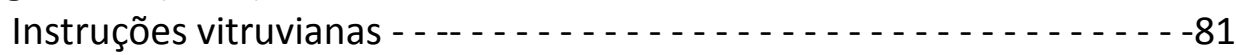

1.5. Preparativos e início da Construção (1549) - . - . - . - . - . - . - . - 84

2. Anos 1550: cinta primitiva - depoimentos de Nóbrega e Luiz Dias

2.1. Relato pouco posterior (Gabriel Soares, 1584-7): dados populacionais e de

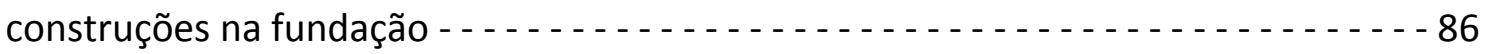

2.2. Relatos da época -

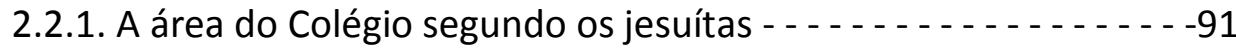

2.2.2. As defesas segundo Luiz Dias

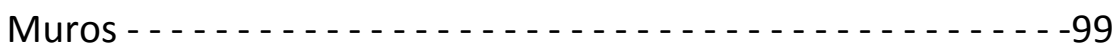

Portas de Santa Catarina e Santa Luzia - - - . - . - - - - - - - 101

Baluartes em terra: São Jorge, São Tomé, São Tiago... - - - - - - 102

Baluartes no mar: Ribeira e Santa Cruz - - - - - - - - - - - - - 105

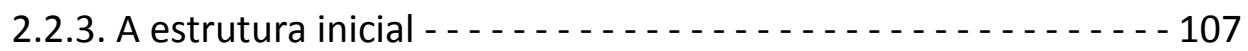

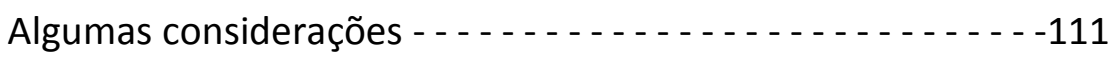


2.3. Três interpretações para o primeiro traçado - - - - - - - - - - 112

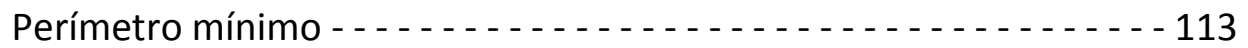

Perímetro máximo -

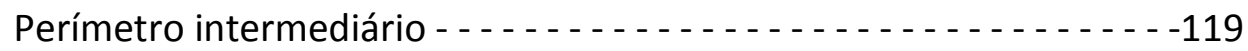

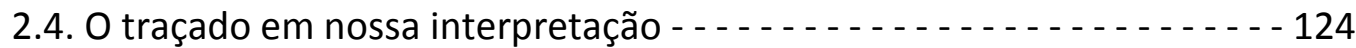

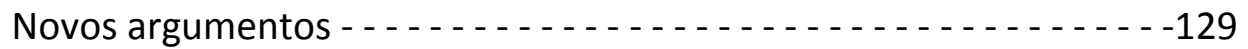

3. Anos 1580: a cidade descrita por Gabriel Soares de Sousa

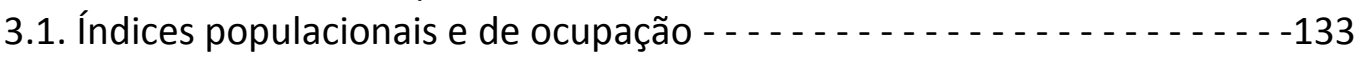

3.2. Estratégias de defesa - - - - 135

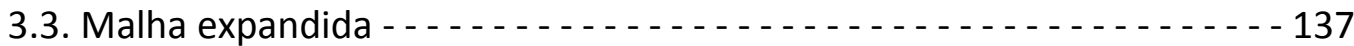

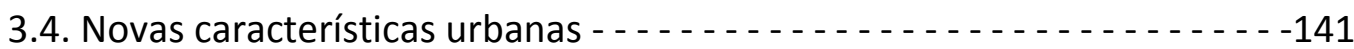

Partido tirado da topografia do local (eleito em função da defesa) - - 142

Participação de ordens religiosas (Terreiro de Jesus e outras áreas) - 143

4. Anos 1590: A nova muralha e as primeiras fortalezas de pedra

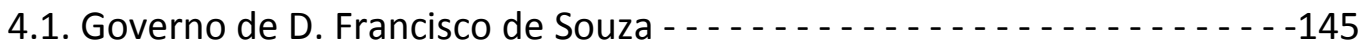

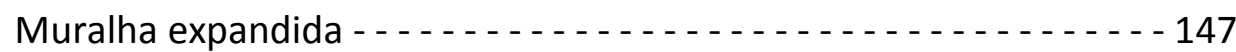

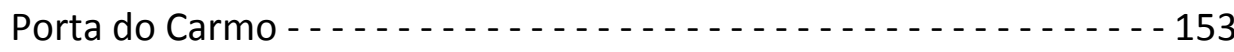

4.2. Fortalezas da época - atribuídas a Baccio di Filicaia

Forte de Santo Alberto (desaparecido no século XVII) - - - - - - - - - - 154

Forte de Santiago (ou Torre, depois também Santo Alberto) - - - - - -155

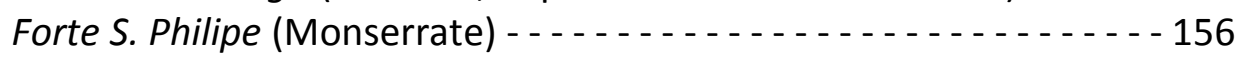

Forte de S. Antonio (da Barra) - _ _ _

PARTE III - Século XVII: o sistema de fortificações na enseada

1. Cidade e Fortificação nos tempos de Diogo Campos Moreno e Francisco Frias de Mesquita (1600-20)

1.1. Crescimento e novo sistema de defesa: projeto de cidadela e confirmação

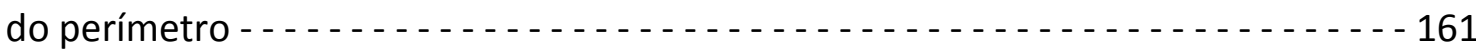

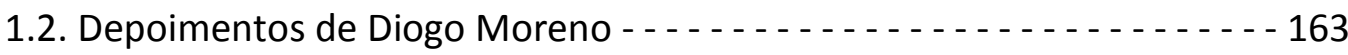

1.3. Francisco Frias de Mesquita e alguns novos fortes (governos de Diogo Botelho a Diogo Mendonça Furtado)

Laje - - - - - - - - - 166

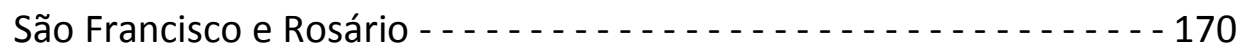

2. Guerras holandesas (1620-40)

2.1. Ameaça de um ataque - . - . - . - 172

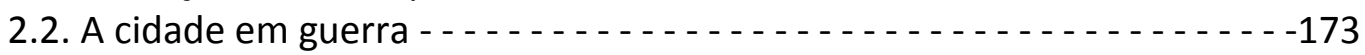

2.3. Ocupação holandesa

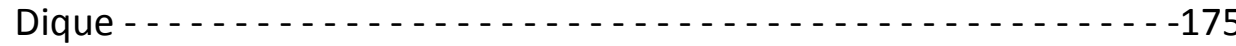

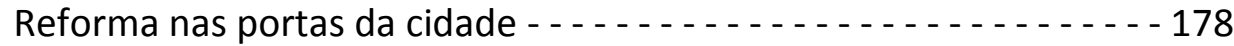

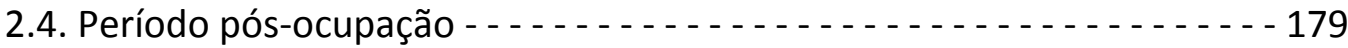

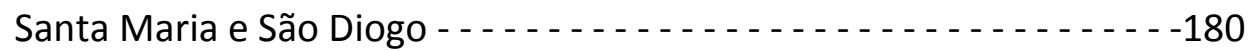

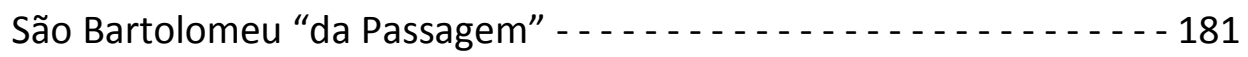

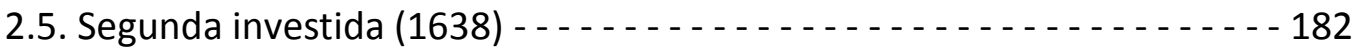

3. A nova fase (1640-70)

3.1. Crescimento da cidade e ampliação do perímetro fortificado - - - - - - 183

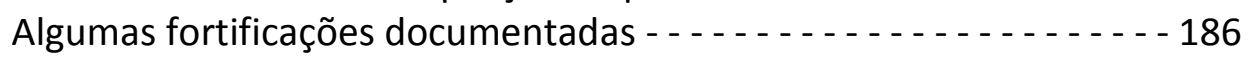


3.2. São Marcelo

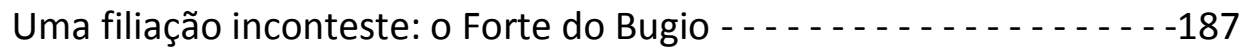

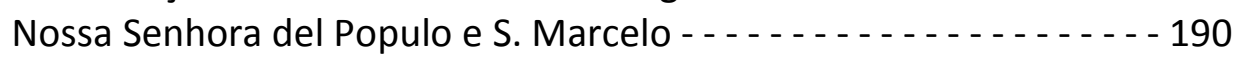

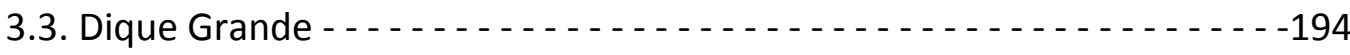

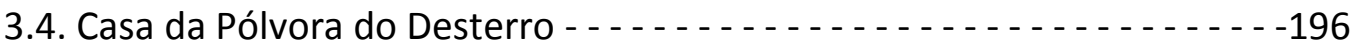

4. Relatórios importantes e consolidação da Arquitetura Militar em Portugal (1670-

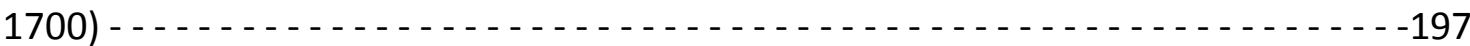

4.1. Antonio Correia Pinto e o relatório de 1671-2 - 198

4.2. João Coutinho e sua proposta de fortificação (1685) - - - - - - - - - - - - 199

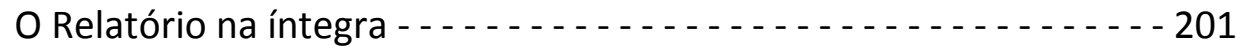

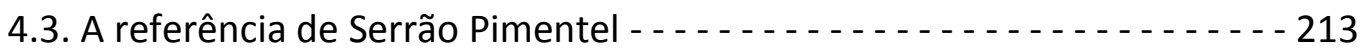

PARTE IV - Século XVIII: novo plano de fortificação e a formalização do ensino

1. Novos planos e grandes reconstruções (1700-40)

1.1. Um engenheiro em destaque: Miguel Pereira da Costa - . - - - . - - - - 219

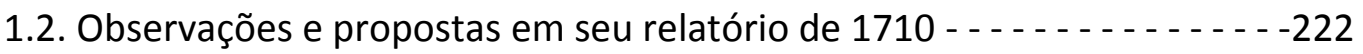

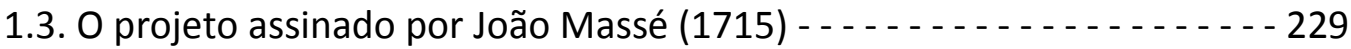

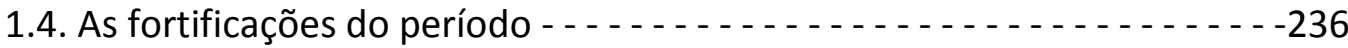

Santo Antonio além do Carmo - - - - - - 237

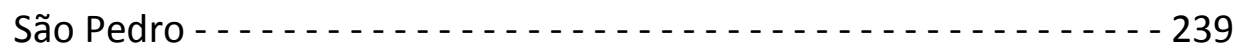

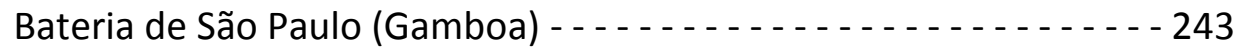

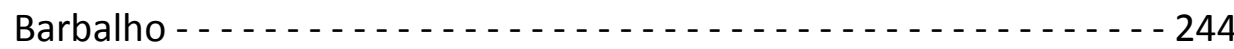

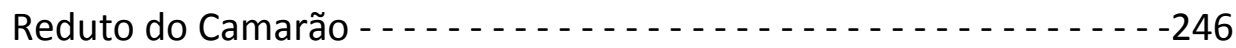

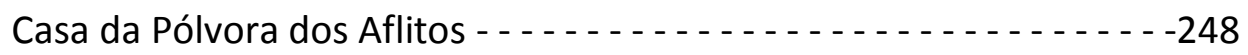

Obra ligada à defesa da cidade: o Fortim do Rio Vermelho - - - - - - - - 248

2. O bom nível técnico e a grande produção de desenhos (1740-80)

2.1. A Aula Militar da Bahia - . . . . . . . . . . . . . . . . . . . . . 249

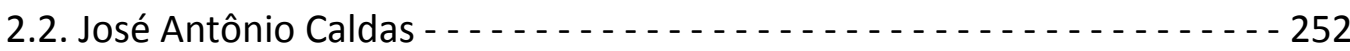

2.3. Tipologias e dimensões variadas nas fortificações - - - - - - - - - - - - 261

Tipos - - - - - - - - - - - - - - - - - - - - - 262

2.4. Os fortes da Bahia nos desenhos de José Antonio Caldas

Forte de S. Antonio da Barra - - . - . - -

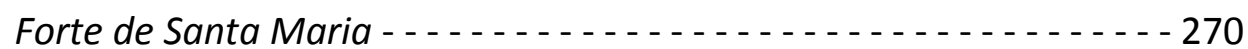

Forte de S. Diogo - -

Fortaleza de S. Pedro -

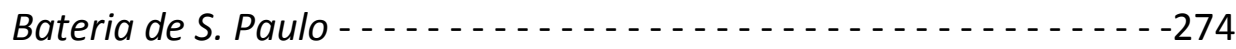

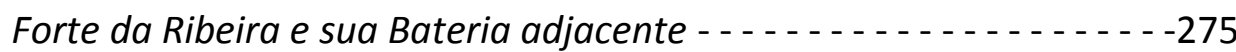

Fortaleza do Mar - - - - - 278

Forte de S. Francisco - - - - - - - - - - - - - - - - 280

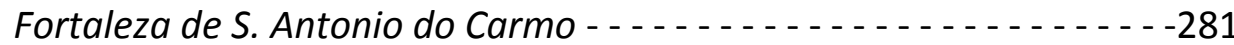

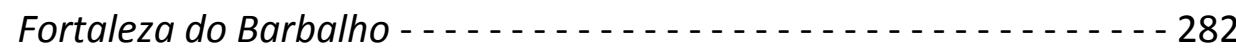

Fortaleza de N. S. de Mont Serrate - - - - - - - - - - - - - - - - - - -

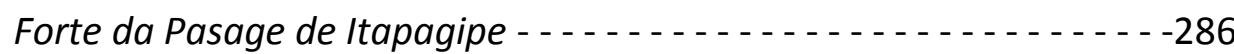

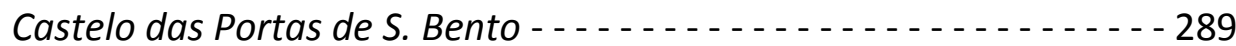

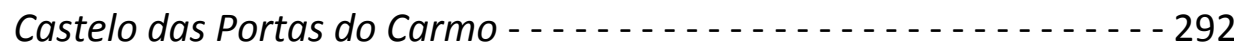

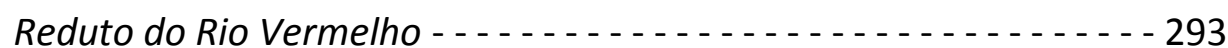




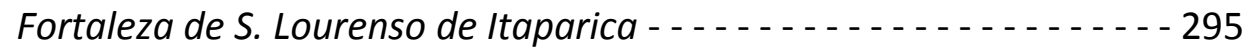

Forte de Paraguasu (e da Forsa) - .

Morro de S. Paulo - -

Fortinho de S. Alberto -

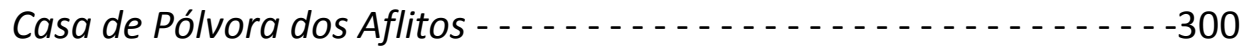

3. As épocas seguintes

3.1. Final do século XVIII e início do XIX (mudança de capital e Relatório Galeão)

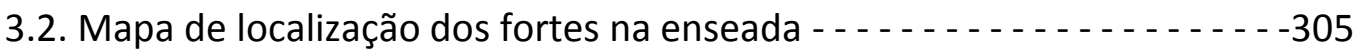

3.3. Alguns registros de épocas posteriores (pintura e fotografia) - - - - - - - 306

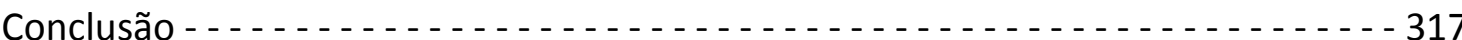

ANEXOS

1. Cartas de Luís Dias

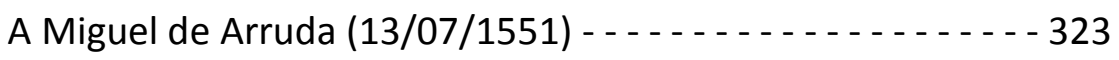

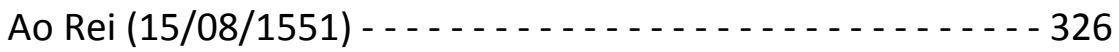

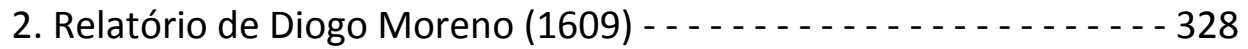

3. Pareceres de engenheiros sobre o Relatório de João Coutinho - - - 335

4. Cartas de Miguel Pereira da Costa

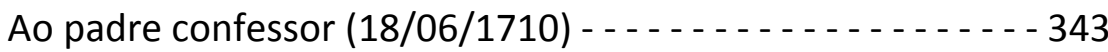

... do Engenheiro da Bahia (28/02/1712) - . - . - . - . - - - - 346

5. Relatório assinado por João Massé, Miguel Pereira da Costa e Gaspar de Abreu (04/02/1716) - . . . . . . . . . . . . . . . . . . . . . . . 350

6. Amostra dos documentos transcritos - . - . - 356

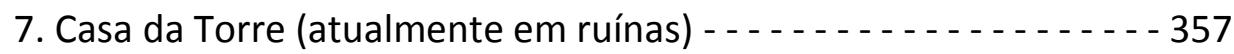

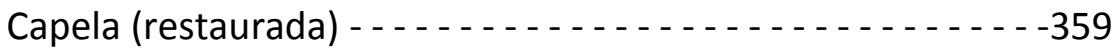

8. Algumas notas biográficas

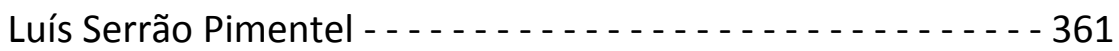

Manoel de Azevedo Fortes - - - - - - - - - - - - - - - 362

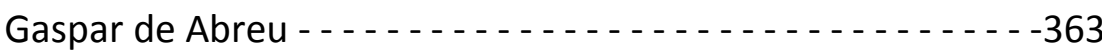

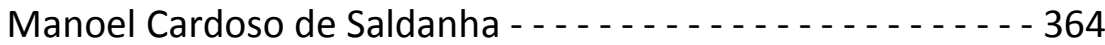

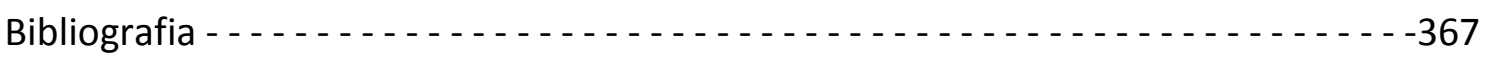




\section{$\underline{\text { Abreviaturas usadas }}$}

$A B$ - Arquivo da Bahia

$A C L$ - Academia Real de Ciências de Lisboa

AHM - Arquivo Histórico Militar do Exército Brasileiro (Rio de Janeiro)

AHU - Arquivo Histórico Ultramarino (Lisboa)

AMM - Arquivo Militar de Madri (Espanha)

AMS - Arquivo Municipal de Salvador (BA)

ANTT - Arquivo Nacional da Torre do Tombo (Lisboa)

BAj - Biblioteca da Ajuda (Lisboa)

BME - Biblioteca Municipal de Évora (Portugal)

BMP - Biblioteca e Arquivo Municipal do Porto (Portugal)

BN - Biblioteca Nacional (Rio de Janeiro)

BNL - Biblioteca Nacional de Lisboa

BNP - Biblioteca Nacional de Portugal (digital, http://purl.pt/854/1/P1.html)

DSE - Direcção dos Serviços de Engenharia (Exército Português)

FCM - Fundação Clemente Mariani (Salvador)

FGM - Fundação Gregório de Mattos (Salvador)

IGHBA - Instituto Geográfico e Histórico da Bahia

IHGB - Instituto Histórico e Geográfico Brasileiro (Rio de Janeiro)

IPAC-BA - Inventário de Proteção do Acervo Cultural (Bahia)

IPHAN - Instituto do Patrimônio Histórico e Artístico Nacional

ISCAG - L' Instituto Storico e di Cultura dell' Arma del Genio (Roma)

SGE - Serviço Geográfico do Exército (Rio de Janeiro) 
A primeira experiência urbanística feita no Brasil aplicava conhecimentos de tratados italianos. Em Salvador, os conceitos de "cidade" e "fortificação" caminharam juntos por todo o período colonial, notando-se em sua Arquitetura Militar a assimilação de novas teorias vindas da Europa, em especial da Holanda e da França. Embora não se conheça as traças e amostras que deram origem à fortaleza e povoação de 1549, imagina-se seu desenho (do arquiteto e engenheiro militar Miguel de Arruda) como o de uma cidade fortificada tipicamente renascentista. Além da referência de poucos documentos escritos (cartas de Luiz Dias, Nóbrega e a crônica de Gabriel Soares, 35 anos depois), conjectura-se sua configuração e desenvolvimento inicial principalmente pelo registro cartográfico de 1605, a planta de Albernaz. Com esse desenho, feito para dar-se execução à fortificação daquela cidade, Salvador recebia o primeiro plano de defesa e ordenação urbana, ainda sob domínio espanhol. Depois das guerras holandesas e da Restauração de Portugal (1640), surgiram novos projetos que ampliaram o seu perímetro defensivo. Pela proximidade conceitual entre cidade e fortificação, passamos em revista as principais avaliações e propostas (relatórios de João Coutinho, 1685, Miguel Pereira da Costa, 1710 e o chamado “Projeto Massé", de 1715), notando-se uma urbe pensada sempre em sua integridade, em constante elaboração e de zelo projetual e administrativo ligado à expectativa de cumprimento do seu desígnio. Na permanente atenção às estruturas de defesa e coesão do tecido urbano também se nota, a cada plano, uma tensão entre o que se idealizava e o que era possível fazer, entre a cidade pensada e a que se realizava. Finalizamos com uma rápida exposição dos projetos de edifícios militares coloniais de Salvador (ainda existentes, na maioria) com base no registro de meados do século XVIII (c. 1760) do engenheiro militar José Antônio Caldas, que desenvolveu intensa atividade na Aula Militar da Baía.

\section{$\underline{\text { Abstract }}$}

The first urban experience done in Brazil applied knowledge from Italian Treaties. In Salvador, the concepts of "city" and "fortress" marched together throughout the colonial period, and in its Military Architecture it is possible to notice the assimilation of new theories coming from Europe, particularly Holland and France. Although the traces (traças e amostras) that gave rise to the fortress and settlement of 1549 are not known, its drawing (by architect and military engineer Miguel de Arruda) can be imagined as a typical Renaissance fortress city. Despite the reference of a few written documents (letters by Luiz Dias, Nóbrega and chronicle by Gabriel Soares, 35 years later), its initial configuration and development is conjectured mainly through the 1605 cartographic record, the Albernaz floor plan. With this drawing, made to execute the fortification of that city, Salvador received the first plan for urban defense and ordination, still under Spanish Domination. After the Dutch Wars and the Restoration of Portugal (1640), more projects emerged and expanded its defensive perimeter. Due to the conceptual proximity between city and fortification, we have reviewed the main proposals and evaluations (reports by João Coutinho, 1685, Miguel Pereira da Costa, 1710 and the so called "Projeto Massé", 1715), and have portrayed a 
city (urbe) always envisioned in its integrity, under constant elaboration and with project and administrative zeal linked to the expectation of fulfilling its designation. In the permanent attention to the defense and cohesion structures of the urban fabric it is also possible to notice, on each plane, a tension between what was idealized and what was possible to be done, between the envisioned city and the one accomplished. We have concluded with a brief presentation of projects for colonial military edifices in Salvador (still existing, most of them) based on the record of the mid eighteenth century (c. 1760) by military engineer José Antonio Caldas, who developed intense activity in the course Aula Militar da Baía. 
Introdução

\section{O desejável e o possível na fortificação de Salvador}

Nosso urbanismo colonial não poderia ser estudado em separado da arquitetura militar trazida pelos portugueses. Não só porque os profissionais que cuidavam da "ruação" e da fortificação de urbes eram os mesmos, mas porque muitas de nossas vilas de desenvolveram a partir de construções militares. Mais do que isso, porque fez parte da política portuguesa de ocupação do território a construção de verdadeiras cidades fortificadas, aplicando-se o que havia de melhor nas teorias de defesa e organização urbana da época. Foi com grande conhecimento teórico, organizado na forma de tratados de fortificação, que os portugueses implantaram suas bases mais importantes na América.

Salvador é um caso privilegiado entre cidades que receberam planos militares e urbanísticos em desenho. Capital da colônia de 1549 a 1763, sua fundação é de um tempo em que o conceito de cidade trazia junto a idéia de fortificação, notando-se isso pelos desenhos de toda a época seguinte. Não por acaso, o construtor dessa primeira cidade tinha o título de Mestre Fortificador. A sede administrativa nasceu de um projeto renascentista, recebendo de tempos em tempos novos planos de fortificação e modernização do crescimento. O que partia de um mesmo princípio: haver planejamento. Nele, uma visão de cidade: a idéia de compreender o todo a partir da inter-relação de suas unidades, em uma atitude tipicamente renascentista. Foi nessa condição que Salvador recebeu os principais investimentos, os projetos de edifícios e planos urbanísticos que a Coroa se dispôs a desenvolver na sede de sua Colônia.

É do começo do século XVII o uso do termo Engenheiro Militar para nomear profissionais ligados a essas duas atividades (pertencentes na época a um mesmo campo do saber). No Brasil, além de desenhar e construir as fortalezas que vigiavam costa, eles eram os responsáveis pelas principais cidades, onde faziam os muros, portas, o traçado urbano e os projetos de muitos edifícios públicos, religiosos e particulares. ${ }^{1}$ Mais do que isso, em Salvador e nos principais centros, eles prestavam contas ao governo português do estado de crescimento urbano, fazendo plantas, perspectivas e elaborando muitas vezes um planejamento para as décadas seguintes.

Com tantos afazeres e especializações, entre elas a representação em desenho dos desígnios (intentos, planos, projetos) da Coroa portuguesa nos diferentes territórios (não só o nosso "além-mar"), eram construtores militares "infatigáveis", 2 que apoiavam sua larga prática em um conhecimento teórico elaborado de forma bastante organizada em Portugal. Seguindo os melhores exemplos das tradições estrangeiras, que variaram no tempo da tradadística italiana às academias francesas, os portugueses desenvolveram nessa área a sua própria transmissão de conhecimento, também em forma de tratados, dando apoio às chamadas aulas de engenharia e arquitetura militar.

\footnotetext{
${ }^{1}$ Cf. REIS Fo, 2003: 12. Nestor Goulart acrescenta a construção de estradas e pontes, a feitura dos mapas de cada região do Brasil (nas expedições em que as medidas eram tiradas com base em cálculos astronômicos). Lembra que no século XVIII eles atuavam como geógrafos, naturalistas e antropólogos, registrando as características naturais e dos povos contatados (serviço que continuou depois da Independência).

${ }^{2}$ Expressão de Carlos Lemos (1989: 237).
} 
Os tratados de fortificação estavam ligados à necessidade de formar mais e mais profissionais para atender a novas necessidades, cuidados de segurança e planejamento no Reino e nas chamadas conquistas. No Brasil, vinculam-se a eles os primeiros cursos de arquitetura, acontecidos bem antes da Independência. Foi inclusive escrito aqui um tratado de fortificação, concluído em 1743, pelo engenheiro militar português Diogo da Sylveyra Vellozo, professor em Pernambuco. Entre as muitas considerações desse interessante livro (Arquitetura Militar ou Fortificação Moderna, de 2005), ${ }^{3}$ está a de que... Engenheyro chamão hoje todas as nações politicas ao architeto das fortificações. ${ }^{4}$ Além de elucidar possíveis dúvidas quanto ao uso dos termos Engenharia e Arquitetura Militar (mostrando que ambos podiam definir uma mesma área de atuação), ${ }^{5}$ essa frase resume uma realidade histórica: as nações mais "políticas" (civilizadas) investiam na formação de profissionais especializados no desenho e construção dos edifícios militares, o que se estendia ao planejamento de cidades.

Desde a concepção de "Arquitetura" apresentada por Vitrúvio (que em seu tratado se diz conhecedor das regras e práticas construtivas, entre elas a elaboração em desenho, por ter feito carreira militar ligada às obras públicas), ${ }^{6}$ na construção imbuída de beleza convergem ciências aparentemente distantes como Música e Matemática. ${ }^{7}$ Quando Sylveyra Vellozo fala no architeto das fortificações, refere-se à maneira como era chamado no Renascimento o projetista da construção, especializado primeiramente na representação em desenho, arte então associada à Pintura e à Escultura. Rafael Moreira fala dos Mestres Fortificadores portugueses ressaltando que eram "autênticos engenheiros". ${ }^{8}$ A palavra "engenho" era comumente usada para as máquinas de guerra e aparelhos mecânicos que seguiam a Gnomonica e Machinatio vitruvianas, levando ao uso da palavra "engenheiro", que aparece no título

\footnotetext{
${ }^{3}$ Publicado por iniciativa do Prof. Dr. Mário Mendonça de Oliveira, da UFBA.

${ }^{4}$ VELLOZO, 2005: 48.

${ }^{5}$ Veremos na parte inicial deste estudo que a arquitetura não era uma arte separada, embora houvesse escolas pontuais, como a Aula de Arquitetura de Filipe II e a cadeira de arquitetura fundada por Pedro II (dada pelo Padre Gonzaga em 1700, na Aula da Esfera do Colégio de Santo Antão), que eram cursos restritos a um pequeno círculo. Só com D. José I, após o terremoto de 1755, houve uma primeira escola de arquitetura em Lisboa, a Casa do Risco (com Eugênio dos Santos sendo seu primeiro mestre), refletindo a consciência de uma necessária especialização. Nela se ensinava Geometria Prática e as Ordens Clássicas de Arquitetura, em simultâneo à Aula de Fortificação iniciada com Luís Serrão Pimentel em 1647 e depois chamada Academia Militar (substituída em 1790 pela Academia Real de Fortificação, Artilharia e Desenho, no reinado de D. Maria I). D. José I nomeou Frederico Ludovice, que estudou na Itália, "Arquiteto-mor do Reino", título especial que se distinguia do de Engenheiro-mor, mas que não foi continuado.

${ }^{6}$ No Preâmbulo do Livro I, ele lembra a Otávio César Augusto que antes de se tornar escritor esteve com outros... ao serviço na preparação de balistas [máquinas de arremesso de pedras] e de escorpiões [de flechas], bem como na reparação das restantes máquinas de guerra e com eles recebi os salários... (VITRÚVIO, 2006: 29).

${ }^{7}$ Que na teoria vitruviana estão próximas, já que o bom efeito visual resultaria de uma boa relação de proporção (matemática) entre as partes, da mesma maneira que o bom efeito auditivo (música).

${ }^{8}$ Cf. MOREIRA, 2003: 17. Rafael explica que a tentativa de organização profissional do Arquiteto das fortificações (neologismo vitruviano que no Renascimento começava a ter uso como scientico ou cientista) foi variada nas regiões do império, sendo a especialização cada vez mais necessária. 0 título passou por Mestre-Pedreiro, Mestres de Obras, Mestre das fortificações e muros, Fortificador e finalmente Engenheiro Militar.
} 
Engenheiro-mor de Francisco Frias de Mesquita no início do XVII (vinda dos tratados italianos).

Ao longo deste estudo apontaremos algumas características próprias do Engenheiro Militar, do Arquiteto e do Mestre Fortificador, mas atentando principalmente aos nomes desses profissionais, envolvidos na concepção, desenho e construção das fortificações mais importantes, associadas tanto à defesa (por eficiência técnica ou mesmo imponência) quanto ao processo de urbanização de Salvador e do Brasil nos três primeiros séculos. A existência desse profissional parece ter sido ignorada por parte dos historiadores há apenas algumas décadas, como na frase de Sérgio Buarque de Holanda:

A cidade que os portugueses construíram na América não é produto mental, não chega a contradizer o quadro da natureza, e sua silhueta se enlaça na linha da paisagem. Nenhum rigor, nenhum método, nenhuma previdência, sempre esse significativo abandono que exprime a palavra "desleixo". ${ }^{9}$

Ao contrário do que a frase sugere, as cidades portuguesas na América (tendo em Salvador o maior exemplo) eram acompanhadas de perto pela Coroa, com suas transformações resultando de muitos esforços de planejamento e investimento material. Do mesmo modo, não se pode falar de nossas construções militares como o resultado de experimentações e improvisos ao longo de toda época colonial. ${ }^{10}$ Havia engenheiros militares altamente capacitados, envolvidos não só em fortalezas modernas, mas, como dissemos, em todas as grandes obras imaginadas, planejadas e encomendadas pela Coroa (pontes, calçadas, hortos botânicos, chafarizes, cais, calçamento de ruas e praças, e mesmo igrejas, normalmente consideradas edifícios de arquitetura mais erudita). ${ }^{11}$

Mais do que donos de uma prática construtiva, eram engenheiros escolarizados, detentores de um saber teórico altamente desenvolvido em Portugal desde os primórdios da expansão ultramarina. Destacamos aqui uma frase da pesquisadora Beatriz P. S. Bueno, que ao mencionar os dois tratados de Antônio Rodrigues (1576-9), enfatiza serem eles a prova de que...

... a teoria orientava a prática; de que houve um investimento da parte da Coroa na formação de profissionais; que as ações políticas estiveram norteadas por objetivos claros e não se deram ao sabor das circunstâncias; que os profissionais estavam habilitados para desenhar (i.e. 'raciocinar') e adaptar-se aos mais variados contextos. ${ }^{12}$

Ainda nas palavras da pesquisadora, os tratados seriam as provas materiais de que "a razão norteou as ações dos portugueses como das demais nações do período; a

\footnotetext{
${ }^{9}$ HOLANDA, 1995: 10. Neste estudo também faremos questão de mostrar o diferente tratamento dado a vilas e cidades, já que para alguns autores, essa a frase poderia valer (quando muito) para as primeiras vilas de donatários (cf. TEIXEIRA \& VALLA, 1999: 217; Manuel Teixeira entende que essa afirmação corresponde "com reservas" às nossas primeiras fundações urbanas, ou a alguns casos específicos cidades mineiras do início do século XVIII - sem ter relação com o panorama geral das cidades brasileiras de fundação portuguesa).

${ }^{10}$ Carlos Lemos considera todo o período de colonização anterior à União das Coroas (1580) como de "muita improvisação" e sem o planejamento dos "recentes aperfeiçoamentos técnicos desenvolvidos pelos italianos" (1989: 237).

${ }^{11}$ Cf. BUENO, 2001: 561 (nota 335).

12 BUENO, 2001: 337 (grifo nosso).
} 
razão marcada por objetividade e pragmatismo". ${ }^{13}$ A "razão" a que ela se refere é anterior a Descartes, filiando-se mais ao desenvolvimento do traçado geométrico no Renascimento, em que a linha reta simbolizava racionalidade e poder, marca do urbanismo ocidental. ${ }^{14} \mathrm{~A}$ regularidade do traçado urbano não foi inventada no Renascimento, mas ganhou importância na época ao ser resgatada junto a inúmeros conhecimentos da cultura clássica (ela era bastante desenvolvida entre os gregos e foi depois teorizada por Vitrúvio). O traçado geométrico representa uma equalização espacial, que não seria necessariamente a solução mais "racional" (característica inerente a toda atividade humana não apenas sentida), mas resultante do esforço de abstração em atender a múltiplas questões da organização urbana, funcionais e de crescimento. $^{15}$

Uma das origens dessa "razão" renascentista, em época de importantes transformações culturais, foi a "descoberta", divulgação e valorização da obra de Vitrúvio, que ajudou no reconhecimento da arquitetura como arte "liberal" (não mais "mecânica") pelo seu exercício de reflexão a priori. ${ }^{16}$ De dentro dela veio a Arquitetura Militar, de princípios já esboçados no tratado do escritor romano. ${ }^{17}$ Também se encontra em Vitrúvio, o "símbolo da própria arquitetura", ${ }^{18}$ uma de nossas principais observações ao longo deste estudo, operada no caso específico do contexto brasileiro em dois séculos de colonização na sua principal cidade: ao arquiteto não basta o conhecimento organizado por um sistema de regras e medidas; muitas de suas decisões terão de ser tomadas com base em um juízo próprio (que será mais acertado quanto maior for o conhecimento). ${ }^{19}$ Esse juízo aparece subentendido em muitas passagens dos Dez Livros..., como a que diz que as melhores soluções arquitetônicas são conseguidas com engenho e arte. ${ }^{20}$

\footnotetext{
${ }^{13}$ Id. ibid.

${ }^{14}$ Beatriz lembra que em todas as cidades portuguesas existe uma Rua Direita, que muitas vezes é torta, mas chama-se "Direita" por levar diretamente à Praça Principal, à Casa da Câmara, ao Hospital, à Misericórdia, à Casa dos Governadores.

${ }^{15} \mathrm{O}$ que se pode discutir é o grau de racionalidade de cada modelo, não a racionalidade em si: uma cidade não planejada significa apenas não ter sido submetida a uma diretriz única.

${ }^{16}$ Para Beatriz Bueno, esta seria mesmo a "tônica central" renascentista. A pesquisadora lembra que em Portugal o embate pela "legitimação da Arquitetura no âmbito das Artes Liberais" não foi igual ao da Itália, mas o emprego do instrumental técnico nos canteiros, acompanhado de teoria, levou a "outra ordem de disputas entre os tradicionais mestres pedreiros e os arquitetos à maneira italiana" (BUENO, 2001: 339).

${ }^{17}$ Segundo Vitrúvio, a arte da edificação é uma das três partes da arquitetura (ao lado da gnomônica e da mecânica), dividida entre a de edifícios públicos e a de privados. Tratando-se de obras públicas, ela se divide em três gêneros, ou classes: defensio, religio e opportunitas. No 1o par. do cap. 3, livro l, ele diz: As partes da própria arquitetura são três: edificação, gnomônica, mecânica. A edificação, com efeito, é dividida em duas partes, uma das quais consiste na instauração dos recintos fortificados e das obras comuns nos lugares públicos; a outra diz respeito ao levantamento dos edifícios privados. Por sua vez, as obras comuns públicas dividem-se em três classes, sendo a primeira a defesa, a segunda a religião e a terceira a utilidade pública. É próprio da defesa a disposição das muralhas, das torres e das portas, tendo em vista a rejeição contínua do ataque dos inimigos... (VITRÚVIO, 2006: 4 - grifos nossos).

${ }^{18}$ MACIEL, 2009: 21.

19 Vitrúvio responsabiliza o arquiteto de dizer a melhor entre as soluções possíveis, devendo ter presente as circunstâncias e singularidades impostas por condições topográficas, de insolação, etc. Também cita a sollertia (= solércia, astúcia, manha, ardil).

${ }^{20} \mathrm{Ou}$, na "feliz expressão vitruviana ingeniorum acuminibus" (MACIEL, 2009: 22, citando VITRÚVIO, 2006: 227 - VI, 2, 4). Há muitas referências à necessidade do arquiteto se aperfeiçoar na tomada de decisões a partir das características específicas de cada problema. Um pequeno exemplo aparece em
} 
Do tratado romano divulgado no Renascimento vieram todos os outros de tema principal ou ligados à Arquitetura, desde aqueles em que ela é tratada como uma das três artes do desenho (ao lado da Pintura e da Escultura, como em Alberti), até os que a associam à cidade e fortificação, sendo mais voltada às construções militares (como em Francesco di Giorgio). Todas essas maneiras de entender Arquitetura chegaram a Portugal, onde no século XV havia dois tipos de profissionais que intervinham nas cidades: um especializado em questões urbanas e de fortificação e outro nos edifícios propriamente ditos. Na formação deles, era nítida a influência de uma cultura tratadística desenvolvida na Itália, havendo também a aplicação desse modelo de organização dos conhecimentos nas idéias locais. ${ }^{21}$

Na época em que o Brasil começava a ser colonizado, já eram produzidos em Portugal os conhecimentos sistematizados em forma de tratados de arquitetura. 0 mais antigo preservado é o do lente Antonio Rodrigues, ${ }^{22}$ que lecionava Arquitetura ou Fortificação na Escola Particular de Moços Fidalgos, ${ }^{23}$ instalado no Paço da Ribeira em meados do século XVI. Ele se baseava em Vitrúvio:

Comvem que haquele que houver de fazer profição destas artes que tenha emgenho, por que syemsya sem emgenho não haproveita nada nem emgenho sem syemsya menos; portamto emtemdase ho que dis Vetruvio, que alem de hu omem ser syemtico tenha descurso, porque esta arte criouse da fabrica e do descurso. Fabrica sam haquelas couzas que são nesessarias pera se fazer ho edefisyo, hasy como he pedra, e call, e area, he tejollo, e madeira, e pregadura, e telha, e os estrometos com que se estas couzas hapuram para se por hem hobra. Descurso é hemtemder as propriedades de todas estas couzas, e emtemder ho laurar e asemtar delas pera emtemder se estam em sua debita rezão lavradas e hasemtadas; pera ho qual dis Vetruvio que pera hu home emtemder ysto que a mester largo tempo para ser aversado nelas, e portanto dis "descurso" ho qual descurso não he outra couza senão tempo... ${ }^{24}$

relação à orientação dos templos, normalmente determinada pela iluminação natural. Vitrúvio diz que tanto a uespertina regio quanto a pars caeli orientis eram normas a ser seguidas apenas quando não houvesse impedimento ou sobreposição de outras várias condicionantes. Nas escolhas formais sempre poderia haver exceção à norma quando... a natureza do lugar o impedir... (VITRÚVIO, 2006: 153 - IV, 5, 2). Por isso, nas palavras de Justino Maciel, "compete ao arquiteto, juntamente com o plano geral da obra que projeta, definir a sua orientação no horizonte dos pontos cardeais, a qual integra o edifício, seja na sua salubridade, seja na exposição à luz, seja na integração na paisagem humanizada, interagindo a orientação com o acabamento final e beleza da obra (MACIEL, 2009: 24 - grifo nosso). Refere-se a: Quando se considera que a obra foi magnificentemente realizada, louvar-se-ão as despesas feitas pela capacidade econômica do proprietário; quando se olha à subtileza, apreciar-se-á a perfeição do artista; mas quando se apresentar esteticamente como modelo nas suas proporções e sistemas de medidas, então a glória será do arquitecto (VITRÚVIO, 2006: 241 - VI, 8, 9).

${ }^{21}$ Um exemplo, já no começo do século XVI, é a organização do Livro das Fortalezas, encomendado por D. Manoel a Duarte de Armas.

${ }^{22}$ Os professores da época eram chamados lentes porque liam seus tratados, que eram uma espécie de apostila em que se estruturavam os cursos. Em 1564, Antônio Rodrigues substituiu Miguel de Arruda (autor do projeto para a Cidade do Salvador em 1548) e se tornou Mestre de Todas as Obras Régias.

${ }^{23}$ Curso que era destinado a jovens de origem nobre, como diz o nome.

${ }^{24}$ Tratado de Antonio Rodrigues (1576), fl. 5 - apud BUENO, 2001: 312. Rodrigues se baseou na tradução de Daniele Barbaro (de 1556, fl. 8-9). Compara-se a Vitrúvio (2006: 30), que na tradução de Justino Maciel diz na abertura do Cap. I, Livro I: A ciência do arquiteto é ornada de muitas disciplinas e de vários saberes, estando a sua dinâmica presente em todas as obras oriundas das restantes artes. Nasce da prática e da teoria. A prática consiste na preparação contínua e exercitada da experiência, a qual se consegue manualmente a partir da matéria, qualquer que seja a obra de estilo cuja execução se pretende. Por sua vez, a teoria é aquilo que pode demonstrar e explicar as coisas trabalhadas proporcionalmente ao engenho e à racionalidade. 
Por meio dessa origem vitruviana de um conhecimento organizado é que vamos encontrar, já nesse primeiro tratado, algumas passagens que remetem ao chamado juízo do arquiteto, a competência (como define Justino Maciel) para tomar decisões mais práticas do que teóricas. Um exemplo clássico é na escolha dos materiais de uma obra qualquer. ${ }^{25}$ Em Antonio Rodrigues, há um capítulo específico (6) em que ele apresenta a justificativa teórica para a Fortificação de Terra, indicada no contexto das Conquistas (como o Brasil, que exigia agilidade e objetividade nas obras), por ser mais rápida e econômica do que as construções de pedra: $E$ porque tenho dito que o bom forteficador a de forteficar de muro hou de terra, e aquylo que temos atras dito trata mais de fabryca de muro que de terra, ho que agora tratarmos daquy adiamte trataremos da forteficasão da terra e de suas cõdisoys. ${ }^{26}$

Por esse exemplo se percebe que era um tratado essencialmente prático (esmiuçando aspectos importantes na economia de recursos e adaptação a contextos). Por outro lado, o Mestre Antônio Rodrigues segue a linha vitruviana ao dizer que além de ter emgenho e syemsya, o arquiteto (ou fortificador) ${ }^{27}$ deveria ser grave, allegamte e reitoryco. Para isso, deveria dominar a teoria (descurso) e a prática (fabrica) profissional, seguindo o programa de sua disciplina. É este, simplesmente, o "fundamento epistemológico" de Vitrúvio: cada uma das artes é composta de duas coisas: a obra [opus] e sua teoria [ratiocinatio]. ${ }^{28}$ Dele também se poderia dizer que é um tratado principalmente prático, porque o que apresenta não são teorias e sim

\footnotetext{
${ }^{25}$ Cf. VITRÚVIO, 2006: 48 (I, 5, 8). Ainda a propósito da fortificação, não se deverá definir de antemão em que material será construída ou aperfeiçoada, porque não podemos dispor dos recursos que desejamos. Mas onde houver cantaria, alvenaria, pedra miúda, tijolo cozido ou cru, será isso que se utilizará (explica que na Babilônia se fez muralha de tijolo cozido com betume líquido... em vez de cal e areia).

${ }^{26}$ Tratado de Antonio Rodrigues (1576), fl. 12v - apud BUENO, 2001: 318. O mesmo "pragmatismo" aparece no capítulo seguinte (fl. 17 a 18v), em que são dadas instruções para o uso e fabricação da cal, imprescindível às fortificações de terra (todas as fortificações de Salvador nessa época eram ainda de terra, o que está plenamente de acordo com a teoria de Rodrigues; elas receberiam depois suas versões definitivas em pedra e cal; tanto no Brasil como na África, adotou-se a cal de ostras, pela ausência de pedra específica).

${ }^{27}$ Como veremos, há duas versões do tratado de Antonio Rodrigues, uma de 1576 e outra de 1579 . Ao longo da primeira, a palavra "fortificador" foi seguidamente riscada e substituída por "architecto" (e a palavra "fortaleza" por "edifício"), o que já não ocorre na versão de 1579, declaradamente dirigida a architectos e oficiais. O tratado seria inicialmente mais voltado à Arquitetura Militar, notando-se depois que suas questões falavam da arquitetura em geral (cf. BUENO, 2001: 315 - nota 199). Também o dicionário do Padre Jerônimo não trazia ainda a palavra "architecto", pois ela é justamente do período de transição e definição de tal profissional entre os portugueses.

${ }^{28}$ VITRÚVIO, 2006: 35 (I, 1, 15). Também: a ciência do arquitecto... nasce da prática [fabrica] e da teoria [ratiocinatio] (VITRÚVIO, 2006: 30 - I, 1, 1). Ou ainda, na feliz tradução de Justino Maciel, a Arquitetura é feita de significado e significante, "a realização da obra e o seu projeto" (MACIEL, 2009: 24, referindo-se a VITRÚVIO, 2006: 30 - I, 1, 3 - In architectura haec duo insunt: quod significatur et quod significat. Significatur proposita res de qua dicitur; hanc autem significat demonstratio rationibua doctrinarum explicate - significado é "a coisa proposta" e significante "a evidência baseada na lógica dos conceitos").

A prática e a teoria estão presentes em todas as atividades e é quase impossível dissociá-las (só em um jogo lingüístico se pode falar na "prática da prática", ou na "teoria da prática pela prática"). Mesmo nas de aparente especulação puramente intelectual, como a filosofia, a crítica literária, a poesia, existe a prática de formatação do discurso (e não por acaso Vitrúvio fala na importância da oratória para a elaboração e transmissão do conhecimento teórico). É o uso correto desses dois conceitos que leva a avanços tecnológicos, pela anotação teórica do experimento científico.
} 
preceptivas (embora haja muitas explicações teóricas sobre o desenvolvimento da técnica). ${ }^{29}$

Depois de cem anos em relação à época de Antonio Rodrigues (de acontecimentos relevantes que serão analisados ao longo deste estudo) vamos encontrar, no fim do século XVII, o primeiro tratado de fortificação impresso em Portugal, o Methodo Lusitanico..., de Luís Serrão Pimentel. Nele há um capítulo específico sobre cidades, ${ }^{30}$ em que as questões de sua distribuição interna são tiradas da própria fortificação. Ao falar da hierarquia dos espaços urbanos (distribuição de ruas, praças, edifícios públicos, particulares), ele estabelece suas diretrizes, deixando claro que nem sempre era possível usar princípios de uma fortificação regular em obras existentes, sendo necessária uma adaptação:

... \& todas as medidas sobreditas de mais, ou menos se entendem tambem, conforme a capacidade da povoação, sobre q o engenheiro deve proceder com juizo, \& boa consideração, tomando as medidas, \& tirado a planta, para que no papel veja primeiro como em hum espelho a representação de toda a obra, \& que sitios lhe ficão para os edificios, \& casas de que diremos. ${ }^{31}$

A importância dessa recomendação se nota pela repetição em outros trechos, como ao apresentar as medidas recomendáveis de uma cidade fortificada (praça central, ruas principais, secundárias, estradas à volta das cortinas, praças diante de baluartes, praças menores, lotes, casa do governador), em que deixa clara a flexibilidade do modelo, devendo-se contar com o "bom senso" do engenheiro na hora de ser empregado:... O Engenheiro experto, \& de juizo poderá accõmodar as mais particularidades com bom discurso, \& consideração... ${ }^{32}$

A idéia de que os modelos não existem para ser copiados, mas servem de referência, também está clara em outro tratadista lusitano das fortificações, Manuel de Azevedo Fortes, autor do segundo tratado impresso, O Engenheiro Portuguez. Ao falar das vantagens da regularidade, ele delega ao engenheiro de juízo a adequação às condições do meio. ${ }^{33}$ É nesse sentido que os engenheiros eram orientados a agir de forma pragmática, sem reproduzir automaticamente o modelo pronto (às vezes

\footnotetext{
${ }^{29}$ Tanto em Vitrúvio quanto nos tratados renascentistas o que se desenvolve não é propriamente uma doutrina arquitetônica, mas preceitos, exemplos a serem seguidos.

30"Das partes interiores da Fortaleza, Cidade, ou Villa fortificada" (PIMENTEL, 1993: 319 - Parte I, Secção II, Cap. XI).

31 PIMENTEL, 1993: 321.

32 PIMENTEL, 1993: 325 - grifo nosso. Pimentel chama o seu tratado de "método facílimo" para mostrar que era acessível a leigos da teoria, mas indica que para atingir esse bom discurso, \& consideração... o bom engenheiro deveria aprofundar-se e conhecer os fundamentos teóricos dos modelos nos inúmeros tratados da biblioteca da Aula Régia.

Outro exemplo da importância de um discernimento próprio em Pimentel é quando cita Palmanova como modelo ideal, sem nunca sugerir que fosse reproduzida mecanicamente. Embora houvesse a regularidade como referencial abstrato para toda obra, achava que o Engenheiro... de juizo devia adequá-la às condições do meio. Havia, portanto, flexibilidade e pragmatismo em suas propostas, rejeitando a cópia simples de um modelo importado: o Methodo lusitanico... não fornecia fórmulas prontas, mas ensinava a raciocinar ("desenhar") e propor soluções adequadas à conjuntura (cf. BUENO, 2001: 452).

33 ...pelos preceitos, e regras de huma fortificação regular devem obrar os engenheiros na irregularidade dos terrenos, approximando-se quanto for possivel à regularidade, isto he, à observancia das regras da fortificação regular... (FORTES, 1729: II, 57).
} 
importado, ou voltado a outras situações). ${ }^{34}$ O método de ensino nas Academias Militares portuguesas não fornecia fórmulas prontas, mas, nas palavras de Beatriz Bueno, ensinava o engenheiro a "raciocinar e propor soluções adequadas à conjuntura adequada". Assim, como já demonstraram importantes pesquisadores (Rafael Moreira, Beatriz Bueno), por trás do que muitos chamam de "pragmatismo" português havia a aplicação precisa de um conhecimento teórico não exclusivo daquela cultura, mas oriundo de toda a tratadística. ${ }^{35}$

Ainda se discute se aquelas construções mais sofisticadas, que acompanhavam preceitos e ditames de uma arquitetura moderna desenvolvida na Europa (elaborada com base em tratados e discussões teóricas) seriam em número significativo face à grande quantidade de construções improvisadas e áreas ocupadas sem qualquer regulamentação (ou orientação, tanto arquitetônica quanto urbanística). É uma discussão que tem sua razão de ser em determinadas áreas, mas que em nossa abordagem se tornaria ociosa por nos atermos aos fundamentos urbanísticos que foram aplicados, à origem desses conhecimentos e ao modo como eram transmitidos. Queremos mostrar que nas fortificações está espelhado todo um pensamento de cidade, que se não era universal no processo de colonização, era aquele desenvolvido em meios mais eruditos, estando ligado ao centro de decisões na Coroa.

Recentemente o historiador Paulo César Marins, no excelente texto "A cidade colonial na América Portuguesa...", ${ }^{36}$ procurou contextualizar e dar importância às idéias de Sérgio Buarque, considerando as observações feitas em Raízes do Brasil um "ponto básico" para a reflexão das "especificidades" das vilas e cidades portuguesas na América, que estaria inclusive "sendo retomado por todos os outros pesquisadores voltados ao estudo das formas urbanas no Brasil". ${ }^{37}$ Entendemos que a postura de Marins reflete um método de trabalho. Para ele, como para outros historiadores sociais, há mais interesse nas "múltiplas conformações formais" dos nossos espaços urbanos coloniais, ${ }^{38}$ decorrentes da interação dos diversos atores sociais que transformam a construção feita a partir de um desígnio, do que nesse desígnio em si. ${ }^{39}$

\footnotetext{
34 Daí o "pragmatismo da formação e rejeição à reprodução acrítica de um modelo importado" (BUENO, 2001: 487).

${ }^{35} \mathrm{O}$ nome pragmatismo chega a ser inadequado, não só porque a teoria prescrevia o julgamento do profissional responsável por uma ou outra decisão de ordem prática, como induz a pensar que existisse um experimentalismo, ou a "prática pela prática". Esse erro é comum a muitos historiadores, estando presente na paradigmática frase de Sérgio Buarque de Holanda.

Na racionalidade está implícita a adaptação à realidade, o jogo de cintura e o estudo caso a caso que não é privilégio dos tratados portugueses, mas está na primeira organização em tratado de Arquitetura, com Vitrúvio. A economia de meios não é aqui entendida como conciliação entre o "desleixo" e a obra organizada, mas como parte da teoria. Em linguagem atual, representaria o esforço de busca do melhor aproveitamento dentro de uma relação custo-benefício.

${ }^{36}$ A cidade colonial na América Portuguesa: morfologia urbana, atores sociais, presença do Estado (Salvador, séculos XVI a XVIII). MARINS, 2005: 229-46.

${ }^{37}$ Idem, p. 229.

${ }^{38}$ Id. ibid.

${ }^{39}$ Em outras palavras, o seu interesse está menos no entendimento da teoria urbanística em si do que na realidade configurada, os espaços moldados por múltiplos fatores e componentes. Como ele mesmo diz, entender o "caráter particularista" (p. 231) interessa a outros estudos relacionados aos espaços urbanos coloniais, não tão ligados à forma, à aplicação de teorias, e sim às dinâmicas sociais (estudadas
} 
Mas a contraposição encontrada por Sérgio Buarque entre os modelos urbanos do "semeador" português e do "ladrilhador" espanhol diz respeito a um tipo de aglomeração urbana que Júlio Katinsky chamou de "povoados 'em fita', aqueles que nasceram e cresceram de modo mais "espontâneo", sem incentivo ou acompanhamento feito de perto pela Coroa.

Esse tipo (ou a ausência) de urbanismo representa, na análise de Katinsky, um dos três modelos básicos dos núcleos urbanos brasileiros da época colonial. ${ }^{40}$ É a esse caso específico (mesmo que majoritário) de urbanização que correspondem as características apontadas por Sérgio Buarque, que na explicação de Marins causariam sensação de desordem pela predominância de um "traçado linear, curvilíneo, moldado segundo as oscilações do terreno", mas, sobretudo, pelo "caráter particularista da experiência colonial lusitana no continente". ${ }^{41}$

O próprio Marins lembra que essa idéia já foi contraposta por Paulo Santos (Formação de Cidades no Brasil Colonial, ${ }^{42}$ de 1968) e principalmente Nestor Goulart (Contribuição ao Estudo da Evolução Urbana..., de 1963-4), que relacionou vários traçados de regulações geometrizantes, resultantes de uma expressiva presença de engenheiros militares no Brasil (que como agentes da Coroa promoviam a ocupação sistemática do território a partir de pontos estratégicos, aplicando modelos urbanos dos mais modernos). ${ }^{43}$

É o caso de Salvador, que por ser a cidade mais importante, recebeu também uma rica representação cartográfica. ${ }^{44}$ Com ela, Marins aponta em seu estudo o

mais propriamente pela História e Ciências Sociais do que pela Arquitetura e Urbanismo). Os espaços urbanos nunca deixarão de ser locais de conflito, exploração, contestação, contrabando, tráfico de produtos ilícitos, sonegação fiscal, depredação, corrupção, eventos que "escapavam ao poder ordenador dos agentes da Coroa" (MARINS, 2005: 233).

40 Para Katinsky (2004: 81-92), os traçados de povoados, vilas e cidades coloniais brasileiras teriam três modelos: o aldeamento jesuítico (ordenado em torno da capela, com casas térreas cercando a praça retangular em frente a ela - a terra, como na cultura indígena, era de propriedade comum, assim como o cultivo), o "povoado em fita" (trazido pelos imigrantes até o fim do XIX, de crescimento em "travessas esguelhadas" - becos e "beões" - de uma malha irregular, geralmente seguindo curvas de nível) e as vilas e cidades de iniciativa governamental (traçadas em "malha" ou "rede" - "nas primeiras cidades do século XVI, modelo provavelmente resultante das técnicas dos mestres fortificadores", de conhecimento baseado em "teorias de corporações religioso-militares do tipo da Ordem de Cristo" - p. 90). Explica que enquanto muitas vilas e cidades foram implantadas com a dupla finalidade política (militar) e econômica (com seus aglomerados projetados em malha de xadrez com as ruas e praças, localização de edifícios públicos representando o Estado e a Igreja - interesses econômicos e sociais da Coroa), os povoados "em fita" tiveram o seu início e crescimento ("espontâneo") baseados na exploração econômica.

${ }^{41}$ MARINS, 2005: 229 - grifo nosso.

${ }^{42} \mathrm{~V}$ Colóquio Internacional de Estudos Luso-Brasileiros, em Coimbra.

${ }^{43}$ Cf. MARINS, 2005: 230.

${ }^{44}$ Marins explica que escolheu Salvador para mostrar sua idéia por ser a cidade mais importante e que "fugia do padrão majoritário anunciado por Sérgio Buarque de Holanda" (p. 233 - sendo ressaltado "o tumulto face à normativa oficial, a aparente desordem e o empreendedorismo particular" - p. 232), entendendo que sua expansão urbana teria desvirtuado "completamente tanto aquela intenção reguladora inaugural, contornada pela primeira cinta de muralhas, quanto sua primeira expansão, em direção às portas do Carmo, também ela geometrizante (p. 233; por esta frase se nota sua adesão à hipótese de crescimento inicial de Teodoro Sampaio, que será largamente discutida neste estudo). Daí a importância de se compreender os fatores sociais: lembra que a cidade “... foi palco de constantes enfrentamentos entre as vontades normativas e aquelas cuja sobrevivência se fazia possível justamente no ignorar dos dispositivos reguladores da câmara ou mesmo dos governadores e vice-reis" (p. 233).

Mostra que fontes diversas (atas da câmara, depoimentos individuais) indicam uma difícil relação entre "práticas e agentes sociais e intenções reguladoras", que seriam oscilantes tanto na administração 
contraste entre os arruamentos intramuros, "bastante retilíneos", e as inúmeras ruas de traçado livre nas freguesias externas (Passo, Santo Antonio além do Carmo, Sant' Anna, S. Pedro), o mesmo se podendo notar nas plantas holandesas. ${ }^{45}$ Ele vê nesse contraste exemplos da dinâmica social, tendo de um lado o "desígnio", o plano da Coroa de uma urbanização moderna de exemplo às demais regiões, e de outro a realidade sócio-econômica, que se expressa, em seu destaque, na desobediência às regulamentações. ${ }^{46}$

Notamos que para mostrar “... o quanto as práticas sociais da cidade esgueiradas e rapidamente móveis - fugiam ao controle dos padrões de uma polícia iluminada", Garcez se apóia na História Social: "a natureza do crescimento da cidade, mais do que a de sua fundação patrocinada e arruada pela Coroa, fizera de Salvador emblema de transtornos em que se enquadrava a cidade à vista de anseios ilustrados, ou de receios temerosos e irônicos de Vilhena". ${ }^{47}$ Mas foi compreendendo esse "campo de forças estabelecido entre as autoridades administrativas da Coroa e as práticas sociais realizadas pelos súditos", observado por Marins que, ${ }^{48}$ amplificando o seu sentido, resolvemos concentrar nossos esforços na análise de uma questão mais geral envolvendo a fortificação de Salvador.

Começamos por observar que ao longo de todo o período estudado existe uma realidade de construções que resulta de uma primeira tensão, entre o que era proposto (recomendável) e o que era feito (o possível, ou "negociável"). ${ }^{49}$ Dessa tensão, passamos a entender a realidade das obras construídas como sendo o possível dentro do desejável, em uma cultura ou universo de conhecimentos que se quis implantar e desenvolver. Mesmo que na elaboração de cada plano houvesse uma leitura realista (o necessário estudo de viabilidade, intermediando o projeto e sua execução), muito do que era proposto nunca pôde ser realizado (nem foi pensado nos moldes iluministas de um projeto integral de cidade).

direta quanto na Câmara (veremos que Mário Oliveira, do mesmo modo, chama atenção para as medidas reeditadas, indicando que estavam sendo descumpridas). Haveria assim "fronteiras móveis, dentro e fora dos muros" (p. 234 - mas como veremos, na época em que essa questão era mais grave, provavelmente já não havia muros), em função do que chama de um "cômodo particular".

${ }^{45}$ Que o "arruamento era francamente contrastivo com aquele inicial” (p. 234).

${ }^{46}$ Ressalta que pelas atas da Câmara subseqüentes à expulsão dos holandeses (1625) se nota que "a desobediência às posturas relativas à edificação era tão reincidente que obrigava à reedição dos textos normativos" (p. 225). As autoridades locais tinham muita dificuldade em submeter a população "à necessidade de obterem sua anuência para as novas construções". A reedição de posturas indica que, se não era por fraqueza, havia "leniência em fiscalizar" o que era visível, "uma construção irregular ao alinhamento da rua". Para Garcez, "o tenso equilíbrio em que as principais cidades coloniais se mantinham apoiava-se no lapso de força que a fraca Coroa portuguesa provavelmente se via obrigada a tolerar, numa composição elástica com as temerosas mas exigentes elites locais" (p. 244).

47 MARINS, 2005: 245 (grifo nosso). O desfecho do texto apenas confirma o seu foco de interesse na realidade urbana (o presente como resultado de conflitos históricos) e não no estudo das modalidades de pensamento sistematizado e transmissão de um conhecimento sobre a cidade: "compreender a especificidade dos espaços urbanos luso-brasileiros pede, portanto, uma atenção redobrada às múltiplas relações que eram mediadas por esses espaços, relações essas tão constitutivas do emaranhado de ruas tortuosas e lotes que se expandiam, quanto possíveis no meio que, afinal, era a seu próprio habitat e evidência" (p. 246).

${ }^{48}$ Idem, p. 234-5.

49 Reconhecendo de um lado os casos específicos de tensão provocada por pressões sociais, acidentes de percurso (mau uso do solo, invasões, desabamentos) e de outro os ligados aos custos de empreendimento. Veremos que muitos deles já eram previstos, dentro do conhecimento urbanístico e da dinâmica política da época. 
Não é preciso dar o braço a torcer para notar evidências de que em Salvador tudo era mais precário do que se desejava. Desde um primeiro balanço independente, feito por Gabriel Soares de Sousa (quase quarenta anos depois da fundação), houve repetidas queixas de abandono, mostras de insatisfação pelo pouco que se construía, pela falta de manutenção, de novas execuções e de planejamento. Críticas ásperas podem ser lidas nos relatórios dos especialistas fortificadores e engenheiros militares (Campo Moreno em 1609, Antonio Pinto em 1671, João Coutinho em 1685, Miguel Pereira da Costa em 1710, Caldas em 1759, Domingos Muniz Barreto em 1797), de secretários de Estado (Bernardo Ravasco em 1660 e 1691) e nas impressões de outros cronistas independentes (além de Vilhena, em 1780).

Sabemos que ao mesmo tempo em que podia ser o campo de experimentação das altas teorias do Renascimento, nossa urbe colonial abrigava (como é dito na apresentação do livro de Eduardo Bueno) "uma sociedade marcada pela desigualdade, pelo desrespeito às leis, pelo uso do aparelho de Estado para a obtenção de benefícios pessoais, pelo clientelismo, pelo nepotismo e pela corrupção generalizada". ${ }^{50}$ Mas ao lado das críticas que se pode fazer ao modelo de civilização que nos foi imposto (de hábitos predatórios não só em relação às riquezas naturais, mas também à força de trabalho), ${ }^{51}$ pode-se também questionar qual teria sido o destino civilizatório da nossa região, não fosse a intervenção dos portugueses. ${ }^{52}$

Em termos simbólicos, Salvador representa o contrário do "desleixo": o planejamento de uma sede administrativa para o imenso território que se pretendia dominar, significando uma aposta no sedentarismo definitivo, de reprodução do modelo urbano europeu. ${ }^{53}$ Mas como a prioridade da Coroa não era, obviamente, criar aqui uma sociedade exemplar em termos de bem estar social e material, mas solucionar problemas de sua Metrópole (econômicos e principalmente de ordem demográfica), as inúmeras decisões contraditórias que foram tomadas ora melhoravam o nível das construções locais, ora deixavam-nas à própria sorte.

Com sua política naturalmente dúbia, em que a Coroa tinha na sede colonial ao mesmo tempo o seu espelhamento e a ferramenta de exploração, há nas obras de urbanismo e fortificação principalmente casos intermediários, de grandes projetos com execuções medianas. É nesse sentido que destacamos a importância de observar esses dois pólos: o desejável e o possível. Seria possível construir (fortificar, urbanizar) ou colonizar Salvador (e de lá o Brasil) na "melhor das perfeições"? É óbvio que não.

\footnotetext{
${ }^{50}$ BUENO, 2006-2: contracapa (referindo-se ao século XVI, é bom que se diga).

${ }^{51}$ Portugal simplesmente reintroduziu a escravidão na cultura ocidental, trazendo da África o costume já substituído pelo sistema servil durante a época medieval.

$52 \mathrm{Em}$ uma troca de e-mails com o prof. Dr. Rafael Moreira, de que ainda falaremos, ele respondeu à provocação sobre os portugueses terem feito coisas boas, mas também cometido atrocidades contra os índios, com a seguinte pergunta: “... preferia que o Brasil (essa grande criação dos Portugueses) fosse uma federação de Tupis e Tapuias e mil tribos falando línguas incompreensíveis entre si, em plena Idade da Pedra? Havia de ser um grande país: uma espécie de Bornéu ou de aborígenes da Nova Guiné e Austrália...".

${ }^{53}$ Mais do que um produto material, sobressai o valor simbólico da constituição de uma capital como centro político de todo o império colonial na América (onde se faria a residência oficial dos altos funcionários da Coroa, governador geral, ouvidor geral e provedor-mor da Fazenda, do bispo e do provincial da Companhia de Jesus).
} 
Mas vemos como fundamental o estudo dos casos em que houve mais empenho no espelhamento do que seriam "moldes" da civilização portuguesa em outro território. ${ }^{54}$

O caso de Salvador é paradigmático porque houve em sua gênese a tentativa de aplicação de um modelo integral, capaz de gerar todo um entusiasmo construtivo. Sobre o processo de sua adaptação à realidade (o real como ponto de junção entre o desejável e o possível), encontramos vários depoimentos, podendo-se estimar que o "possível" constitui a própria idéia de planejamento. E quando nesse planejamento (em que a busca de funcionalidade e solidez já está implícita) se inclui a intenção de ordem plástica, entramos no cerne da arquitetura (civil ou militar) como obra superior à mera construção.

É este o principal aspecto que iremos ressaltar em nosso estudo: desde os primórdios da formação brasileira se deu importância à atitude de projeto. A construção dos principais espaços urbanos se deu em seguimento a uma ordem préestabelecida, muitas vezes descumprida, mas que representava uma diretriz culta. Se até hoje no Brasil, em decorrência principalmente da grandeza territorial, o cumprimento de um desígnio é menos regra do que exceção, isso não quer dizer que ele não exista, ou que seus propósitos não devam ser postos em exame (afinal, mostram visões de cidade, de ordem civil, concepções políticas, de sociedade e sociabilidade; se os exemplos de bom urbanismo ainda são casos minoritários, isso não significa que não devamos entender seus fundamentos e avaliar os resultados).

Tão importante quanto saber as razões dos muitos fracassos e dos sucessos da empreita é entender suas diretrizes teóricas, o conhecimento prévio que se quis aplicar ou legitimar. Por isso, procuramos seguir as informações de pesquisadores atuais sobre o estudo teórico desenvolvido em Portugal nas aulas e tratados de arquitetura militar, que juntos com suas técnicas de representação em desenho representam a origem da nossa história de doutrinas arquitetônicas. Os planos nos interessam de um lado pelo seu valor cultural, social e político, e de outro pela sua importância na história da cidade. São eles que fixam horizontes e norteiam toda a empresa colonial de Salvador (a principal urbe fortificada da época), mostrando que nada estava entregue ao acaso. Eles normalmente acompanhavam ou eram antecedidos por relatórios de avaliação, onde se apoiavam as propostas. Nesse sentido, contêm em si os dois aspectos: o olhar retrospecto da realidade concreta até o seu presente e a perspectiva criada com sua implantação. Suas características mais interessantes são a de trazer os ideais para o primeiro plano e ao mesmo tempo reiterar a prática do planejamento, uma visão (ou idéia) integral de cidade, levando à sua posterior avaliação.

É nessa avaliação subseqüente que se expressa a tensão entre o proposto e o realizado de que falamos, pois é pela execução de uma obra que se põe à prova a teoria. Ao longo de várias gerações houve uma alternância de planos e idéias, começando pela cultura renascentista italiana e passando pelas novas escolas de fortificação, a holandesa e a francesa. Trabalhamos com a hipótese de que no começo houve um plano de ocupação ainda mais ambicioso do que pôde ser realizado. Pela forma de execução, seguiria o cronograma de demarcação das portas, da cerca e do fosso, para uma delimitação precisa da área urbana. Mesmo que a ordem tradicional

\footnotetext{
54 Mesmo na Europa, não se implantava o desejável, simplesmente porque o modelo teórico em última instância é individual e totalitário, e a realidade resulta da interação dos muitos agentes sociais (as grandes reformas urbanas da época neoclássica, por exemplo, apoiavam-se no autoritarismo político).
} 
não tenha sido obedecida, observamos reiteradas vezes a aplicação de preceitos doutrinais: a urbe como objeto de uma visão integral, onde as partes foram pensadas em função do todo. A cidade era sempre reelaborada, reavaliada de tempos em tempos pelos planos de fortificação. Foi pela fixação de diretrizes que sabemos hoje o que em cada momento era o mais desejável (e pelo relatório seguinte o que foi possível implementar). Daí o interesse na sofisticada formação e erudição desses engenheiros.

Para simplificar o que dissemos até aqui, convém enfatizar uma idéia básica que acompanha este estudo, visando a melhor compreensão do processo de urbanização da cidade de Salvador na Bahia, primeira capital portuguesa no Brasil. Consideramos que em toda a época colonial os conceitos de cidade e fortificação se articulam estreitamente, sobretudo para cidades fundadas ou controladas de perto pela Coroa (havendo interesse no bom desempenho político-econômico e, naturalmente, na defesa, como era o caso de Salvador). Observar essa articulação nos faz identificar na forma de alguns edifícios militares (fortes coloniais) e na relação espacial entre eles (sistemas defensivos) modelos e idéias objetivas que se tinha de cidade, oriundos, a nosso ver, de modernas concepções que remontam ao Renascimento italiano.

Como parte dessa idéia, observamos que o modelo urbano de prioridade na locação de suas fortificações foi determinado, mesmo em locais extremamente distantes da Europa, por um amplo desenvolvimento do conhecimento português, seja com base na experiência de fortificações, seja pelo elevado nível de informação nas prescrições de toda uma tratadística. ${ }^{55}$ Esse desenvolvimento teria proporcionado uma prática de projeto e construção cada vez mais criteriosa e voltada para a racionalidade, com seus fundamentos teóricos sendo levados diretamente aos profissionais envolvidos na ruação e fortificação das cidades (que a partir do início do século XVII foram chamados de engenheiros militares).

Ainda como parte dessa idéia, enfatizando esse desenvolvimento do conhecimento teórico, nota-se, desde o início da colonização e atravessando todas as fases da época colonial, haver na concepção de cidade uma visão abrangente, quase totalizadora: princípios gerais e atitudes de planejamento podem ser observados tanto na evolução da malha urbana quanto nas modificações em desenho dos edifícios militares e das estruturas de defesa. Essa visão se mostra principalmente na arquitetura militar, onde cada fortificação é vista como elemento de um sistema maior, planejado e integrado (podendo-se confundir o termo "praça fortificada" com a própria cidade). A origem dessa visão está na tratadística renascentista, onde o todo -

\footnotetext{
${ }^{55}$ Os tratados de engenharia militar escritos em português (em Portugal e, no Brasil, o de Vellozo), editados ou não (o de Vellozo não o foi na época), mostram que quase todos esses profissionais conheciam bem a tratadística clássica italiana de arquitetura, de Vitrúvio ao Barroco. Muitos engenheiros e arquitetos portugueses, mesmo depois de criada a Aula Militar de Lisboa (coordenada por Serrão Pimentel), estudaram na França, Itália e outros países da Europa. Também veremos pelos desenhos dos alunos de José Antonio Caldas, lente da Escola Militar da Baía, um claro conhecimento do vocabulário da Arquitetura Clássica no Brasil, além de uma grande eficiência nas práticas de levantamento de campo.
} 
a cidade fortificada - é o conjunto harmonioso que resulta da relação das partes entre si, de modo a compor a unidade orgânica (o que retorna à idéia básica).

A questão inicial passa, portanto, por demonstrar que urbanização e fortificação eram conceitos indissociáveis. Urbanizar era conquistar, colonizar, apropriar-se militar e culturalmente de um território disputado por grupos ou nações de interesses conflitantes. Não havia a palavra "urbanismo" (do século XIX) ou métodos iguais aos de hoje, mas uma prática de ruação em grande parte atribuída aos profissionais da Engenharia Militar. Comparando-se à prática atual, pertencia a um campo do saber de diferentes implicações culturais em sua atividade. Nas colônias portuguesas da época monárquica, a prática objetiva de urbanizar ou "fazer cidade" era, nesta ordem, fortificar e arruar. ${ }^{56}$

O exemplo de Salvador como cenário de transformações técnicas e culturais é importante por vários motivos. Afinal, foi a primeira cidade, de mais longa duração como capital brasileira na época colonial (1549-1763), concentrando-se nela os principais esforços de melhoria urbana, a começar pelo sistema fortificado. Eram melhorias técnicas, antecedidas de formulações teóricas que não seriam propriamente experimentais, mas tentativas de adaptação local ao que era previamente elaborado.

Salvador não foi a primeira vila, mas como primeira cidade se tornou logo o principal núcleo urbano português na América e Atlântico Sul, assim permanecendo até meados do século XVIII (quando houve a transferência da sede administrativa para o Rio de Janeiro). Ninguém duvida que sua fundação fosse de caráter essencialmente militar, sendo considerada a própria cidade, centro das decisões políticas de toda a Colônia, uma fortaleza. ${ }^{57}$ Essencialmente militar, pois, era a sua configuração inicial: a cidade fortificada atendia em seu projeto a regras e prescrições do que havia de mais moderno na engenharia militar no período.

Com essa premissa, fazemos na primeira parte do estudo um apanhado histórico mostrando o contexto da fortificação de Salvador e trazendo dados sobre a evolução técnica e teórica (importante na transmissão do conhecimento) dessa "ciência ou arte", com aspectos próprios da arquitetura militar portuguesa e alguns fatos relevantes ocorridos na época colonial. Em função da amplitude do tema (arquitetura militar, evolução do traçado urbano, história colonial), toda essa parte assume um caráter mais puramente informativo. Enfatizamos que em paralelo à história de Salvador havia uma permanente necessidade portuguesa de aperfeiçoar os seus sistemas defensivos em várias partes do mundo, de se adequar às novas tecnologias de guerra e ao mesmo tempo de estabelecer regras para implantar novos núcleos e consolidar os existentes (precisando para isso de formar técnicos nessas duas questões). ${ }^{58}$ Pelo menos desde Antônio Rodrigues (com seu tratado de 1576),

\footnotetext{
${ }^{56}$ Cf. MOREIRA, 2003: 7-30.

${ }^{57} \mathrm{Na}$ escolha do local e da orientação, os portugueses tiveram como principal critério a capacidade de dominar o máximo de território à volta. Por isso a cidade foi construída em local alto, com um barranco íngreme à frente, dando ampla visão da recém batizada Baía de Todos os Santos, que tinha no trecho imediatamente abaixo uma praia com águas profundas, de ótimas condições portuárias.

58 Entre 1624-54, na Bahia e Nordeste próximo, muitas das primeiras fortalezas foram reformadas e aperfeiçoadas pelos holandeses, que já tinham técnicas mais avançadas. Os tratados portugueses absorveram essas e outras regras de fortificação, que influenciaram na formação não mais de mestres fortificadores mas de engenheiros militares, de perfil profissional bem mais sofisticado (ao mesmo tempo os mapeadores - cartógrafos terrestres e celestes - e agentes construtivos das conquistas portuguesas, administradores territoriais e econômicos).
} 
eram produzidos manuscritos de Arquitetura Militar em Portugal, abordando questões urbanísticas em decorrência da grande experiência das fundações em todo o mundo. Juntando-se ao de Mateus Couto (1631, também manuscrito didático), notamos que os principais conceitos teóricos vigentes na Itália, Alemanha, Holanda e França também circulavam no meio cultural português. ${ }^{59}$

A partir da segunda parte do estudo mergulhamos na história da fortificação de Salvador, mostrando seu "planejamento" em 1548 e início da construção no começo do ano seguinte, com a vinda do primeiro Governador Geral Tomé de Souza e do Mestre das obras da fortaleza e cidade do Salvador Luiz Dias (título de 14/01/1549). Este reportava na Metrópole ao "arquiteto" Miguel de Arruda, coordenador oficial das obras e fundações coloniais na época. ${ }^{60} \mathrm{~A}$ cidade nasceu fortificada e passou por importantes reformulações e ampliações de seu sistema defensivo nos períodos subseqüentes. ${ }^{61}$

Ao abordar o século $\mathrm{XVI}$, destacaremos a polêmica sobre o traçado inicial da cidade, que envolve, sobretudo, o sentido de modernidade da empreita. Se de um lado a fortaleza seguia um plano regular e racional, de outro era erguida na crista de uma montanha, o que viria da tradição medieval (ou antiga). ${ }^{62}$ Há bastante evidência de que a cidade foi pensada já na dimensão em que aparece desenhada no século seguinte, correspondendo à expectativa de uma cidade renascentista. ${ }^{63}$

Na síntese de Júlio Katinsky (2004: 81-92), ao longo do século XVII, os mestres fortificadores, influenciados pelos tratados italianos com modelos de cidade-estado, teriam aos poucos deixando de lado o amplo conhecimento em fortalezas e náutica para se dedicarem à defesa terrestre das cidades. Assim, passaram a cuidar das vilas e cidades como engenheiros militares, que no fim do século XVII já se instruiriam por orientação mais próxima à dos engenheiros franceses.

${ }^{59}$ Como dissemos, a primeira publicação só ocorreria em 1680, o Méthodo Lusitanico de Desenhar as Fortificaçoens das Praças Regulares, e Irregulares de Luís Serrão Pimentel. O Engenheiro Português, de Manoel Azevedo Fortes, é de 1728. Esses dois tratados são obras meticulosas, que começam ensinando a tirar medidas e construir as formas geométricas (usando instrumentos e regras matemáticas) essenciais à "arte de fortificar" (expressão bastante usada para definir Arquitetura Militar).

${ }^{60}$ Luiz Dias fez junto com Tomé de Souza a escolha de sítio, adaptou as "traças" de Miguel de Arruda e por fim administrou a obra. Apesar do desaparecimento dos desenhos, a existência de um projeto é declarada no Regimento a Tomé de Sousa, ficando mais evidente pelas informações passadas na tese Beatriz Bueno (2001) sobre a proliferação de "debuxos" e "modelos" em canteiros de obra tanto em Lisboa quanto no além-mar, na época de D. João III. Também na carta de Luiz Dias a Miguel de Arruda (1551) revela-se que ele enviou ao Rei "amostras" (talvez especificações em desenho) do conjunto amuralhado (de taipa de pilão rebocada a cal) no topo da colina (onde se situavam a Casa de Câmera e Cadeia, principal edifício civil) e seu desnível em relação à área da Ribeira (que estava sendo protegida pelos baluartes do Góis e de Santa Cruz).

${ }^{61}$ Destacaremos que a época da fundação coincide com o auge do interesse português pela arte tratadística italiana, que vinha crescendo desde o início do século XVI. No reinado de D. João III (152157) foram enviados profissionais do desenho para adquirir conhecimentos em cortes italianas, e também chamados de lá fortificadores que trabalhariam no Reino e nas Conquistas. Entre 1537-62, época em que se pensou e começou a fazer Salvador, os principais tratados italianos também foram traduzidos para o português.

62 Pode-se pensar que se fossem seguidas de fato as inovações renascentistas trazidas da Itália, seria mais adequada a sua construção em área plana (como era proposto para as praças de guerra), mas, como veremos, os modelos renascentistas de cidade eram variados, também considerando importante para a defesa tirar partido das condições de relevo.

${ }^{63}$ Nas cartas de Luiz Dias estão registradas as construções do Palácio do Governador, da Casa da Cadeia e Câmara, da Sé e sua igreja no núcleo central da Cidade Alta, onde havia ordem geométrica de inspiração clássica. A existência de traças e amostras revela a intenção de reproduzir em solo um traçado regular e ordenado. Mas o projeto seria pragmaticamente adaptado às condições de terreno, 
Para finalizar, falaremos de nosso objeto de estudo inicial, os fortes coloniais de Salvador (valioso patrimônio histórico-arquitetônico que deverá receber os devidos cuidados de preservação). Para entendê-los foi necessário colocar questões mais do que óbvias: quem os projetou, com que finalidades, quais suas referências, se a construção correspondia ao projeto, quais e como eram, por fim, os profissionais envolvidos? Para essa última questão, havia na grande maioria dos casos uma resposta simples: os engenheiros militares. Buscando entender quem eram esses profissionais, passamos a perguntas um pouco mais sofisticadas: no que se inspiravam os projetos, a que tipo de formação eram submetidos? Nesse tema, a tese Desenho e Desígnio... da professora Beatriz Bueno foi nossa primeira, grande e esclarecedora referência. Como dissemos por citações, ela mostra que os profissionais dessas obras eram altamente instruídos. Para se ter idéia do alto nível de alguns dos nossos engenheiros militares, ${ }^{64}$ a presença de alguns deles na Bahia pode ser comparada, na Arquitetura Religiosa, à do arquiteto jesuíta Francisco Dias, que trabalhou com Terzi na igreja de S. Roque (Lisboa), projetou o colégio dos jesuítas e bem possivelmente a atual Catedral Basílica de Salvador. ${ }^{65}$

Sobre o significado de Salvador, lembramos que na notável publicação do prof. Nestor Goulart Reis Filho, Imagens de Vilas e Cidades do Brasil Colonial, a cidade sede

surgindo assim os dois diferentes tipos de quadra, algumas ruelas e largos que alguns consideram tipicamente medievais (as partes adjacentes e não planejadas, como as ladeiras e a Cidade Baixa, geraram áreas residenciais que seguiriam essa tradição, gerando o "contraste" observado por Paulo Marins). Para muitos autores (como Marins), em função das condições de terreno, mesmo nesse "coração administrativo" o traçado era menos regular do que o de cidades espanholas na América.

${ }^{64}$ Em relação aos que atuaram na Bahia, na parte sobre o século XVIII dedicamos capítulos a dois ilustres deles, o Mestre de Campo Miguel Pereira da Costa e o Sargento-mor José Antonio Caldas. O primeiro por relacionar todas as fortificações da época, acompanhar de perto a reconstrução das maiores fortalezas e por ser o principal mentor do importantíssimo projeto de fortificação da cidade coordenado pelo Brigadeiro João Massé. O segundo pela imensa produção de desenhos, seus e de seus alunos, um legado de valor inestimável. Mas há muitos outros, sendo que dos principais procuramos trazer algumas informações em notas de rodapé: Luiz Dias (representante de Miguel de Arruda, importantíssimo arquiteto militar da Corte e provável autor do projeto da cidade-fortaleza do Salvador, em 1548), Baccio da Filicaia (florentino que projetou no fim do século XVI as primeiras quatro fortalezas de pedra e cal da Bahia, das quais ainda há três, duas delas muito conhecidas, o já modificado Forte de Santo Antonio da Barra e o de Monserrate, que manteve a forma original), Francisco Frias de Mesquita (provável autor do primeiro grande projeto de fortificação de Salvador depois da fundação, no início do século XVII, e autor da reforma de pelo menos um dos fortes que aparece na Planta que representa esse projeto - 1605), Gaspar Pinheiro Lobo (provavelmente quem concebeu e deu início a construção de um novo perímetro fortificado para a cidade, após a Restauração em Portugal, nos anos 1640), João Coutinho (idealizador, em 1685, de reformas urbanas e do grande projeto de fortificação e que fora esboçado por G. Pinheiro Lobo, nos qual se basearam os relatórios de Miguel Pereira da Costa em 1710 e João Massé em 1715), Gaspar de Abreu (o terceiro engenheiro a assinar este último relatório e provável autor dos desenhos) e Manuel Cardoso de Saldanha (professor e incentivador de Caldas, provável autor da planta da Igreja da N. S. da Conceição da Praia, em meados do século XVIII). Outros também importantes têm suas biografias sintetizadas no importante livro de Mário Mendonça de Oliveira, professor emérito da UFBA, As fortalezas portuguesas de Salvador..., nossa segunda, também grande e esclarecedora referência ao longo do processo (essas biografias têm como principal fonte a obra de Francisco de Souza Viterbo, Diccionario dos Architectos, Engenheiros e Constructores Portuguezes, também muito citada por Beatriz Bueno e pelos portugueses Manuel Teixeira e Margarida Valla).

${ }^{65}$ Cf. TOLEDO, 1983: 132. 
do governo português na Colônia aparece nas primeiras 33 estampas (incluindo a que serve de capa). ${ }^{66}$ Entre as portuguesas, todas foram feitas por cartógrafos ou engenheiros militares, algumas retratando a realidade, outras mostrando esquemas, idealizações e em alguns casos projetos. ${ }^{67}$ Pela confrontação com os documentos escritos, na maioria em forma de relatórios oficiais (há também os relatos de cronistas e missionários), formulamos aqui algumas hipóteses sobre a realidade física e humana da cidade em épocas passadas.

Já a maior parte das informações aqui relacionadas que dizem respeito diretamente aos redutos e fortalezas construídos na Bahia em toda a época colonial seguem a síntese organizada pelo Professor Emérito da UFBA, Dr. Mário Mendonça de Oliveira, no livro As Fortificações Portuguesas de Salvador... (2004), em que estão indicadas as leituras mais importantes realizadas para este estudo (principalmente fontes primárias, mas também as publicações de Gabriel Soares, Campos Moreno, Vilhena, Teodoro Sampaio, Edison Carneiro e muitos outros). Tivemos o prazer de conhecer e conversar com este professor em várias oportunidades durante a pesquisa. ${ }^{68}$

Também tivemos a honra de conseguir ao longo deste estudo uma interlocução direta com dois grandes pesquisadores da FAU, os professores Beatriz P. S. Bueno e Nestor G. Reis Filho, ${ }^{69}$ além de um breve intercâmbio por escrito com o Prof. Dr. Rafael de F. D. Moreira, da Universidade Nova de Lisboa, maior autoridade internacional em fortificações portuguesas.

Com a professora Beatriz Bueno, além de sua gentil participação em nosso exame de qualificação, os contatos giraram em torno de um assunto específico que é o primeiro perímetro fortificado de Salvador, da época de Tomé de Souza e Luiz Dias (1549-53). A hipótese de um circuito mínimo, indo da atual Praça Municipal (ou Tomé de Souza) à Praça Castro Alves, foi construída por Teodoro Sampaio e divulgada (por outros, contra sua vontade) em meados do século passado, ${ }^{70}$ sendo imediatamente contestada por Edison Carneiro. ${ }^{71}$ Apesar disso, ela foi adotada por muitos

\footnotetext{
66 Retratada do início do século XVII até pouco antes da Independência, não havendo imagens da segunda metade do século XVI (não foram preservadas), época da fundação e crescimento inicial. Mas muitas das construções desse período ainda aparecem nos registros posteriores.

67 Não apenas por terem sido produzidas por engenheiros é que vamos notar em quase todas as imagens um destaque para os aspectos defensivos, com a identificação de fortalezas e principais redutos estratégicos: é porque a questão urbana, durante muito tempo, dizia respeito antes de tudo à engenharia militar. Como voltaremos a enfatizar, no caso da sede do governo colonial é ainda mais evidente a integração entre a cidade e o seu sistema de defesa.

68 O contato direto com o professor se deu por intermédio de outra professora da UFBA, hoje superintendente do IPHAN-SP, a gentilíssima colega (de curso fundamental e agora da FAU) Anna Beatriz Ayroza Galvão. Fazemos questão de registrar toda a atenção e solicitude com que o prof. M. M. de Oliveira nos atendeu, recebendo-nos algumas vezes em sua casa e colocando à disposição a sua biblioteca particular para consultas e fotografias no local, além de nos deixar à vontade para questionar e tirar dúvidas sobre todos os assuntos do livro e de seu conhecimento. Presenteou-nos, inclusive, com algumas publicações de que fez parte, documentos digitalizados e uma transcrição.

${ }^{69}$ Beatriz foi muito amável em aceitar participar da nossa banca de qualificação, quando nos passou informações e recomendações importantes, alertando-nos sobre a vulnerabilidade de alguns pontos da pesquisa. Nestor, Professor Catedrático titular da USP, além de nos receber duas vezes em sua sala, presenteou-nos gentilmente com duas de suas publicações.

${ }^{70}$ O livro História da Fundação da Cidade do Salvador, lançado em 1949, é uma publicação póstuma, sem sua autorização (possivelmente porque reconheceu o erro de sua análise).

${ }^{71}$ Logo no ano seguinte, pelo texto "A Cidade do Salvador", transformado em livro em 1954.
} 
historiadores, o que até hoje causa indignação nos estudiosos da arquitetura militar portuguesa.

Hoje se considera a hipótese construída por Teodoro Sampaio como ultrapassada, dando-se mais crédito à análise de Edison Carneiro, muitíssimo reforçada pelos argumentos de Rafael Moreira. Mas apesar do erro "crasso" de Teodoro, ao considerar um projeto de cidadela feito em torno de 1605 como a representação em desenho das muralhas e fossos que teriam sido construídos nos anos 1550, procuramos mostrar neste estudo evidências de que talvez não houvesse, realmente, o perímetro maior, limitado pelas portas que aparecem na mesma planta. Apontamos algumas dificuldades construtivas e depoimentos contrários à análise que se faz atualmente desse início tão impactante, procurando, sobretudo, argumentar que o assunto não estaria totalmente esgotado.

A partir desses contatos com os mais importantes teóricos de todas essas áreas somadas (Urbanismo Colonial, Arquitetura Militar, Formação de Engenheiros Militares, Fortes Coloniais), o trabalho que aqui se inicia assumiu uma responsabilidade analítica inimaginável quatro anos atrás. E com bastante consciência de nossas limitações, fazemos questão de dizer que tentamos corresponder às expectativas, dentro do que nos foi possível fazer. 
PARTE I - Os engenheiros militares: arte da guerra e de desenhar cidades

\section{Origens da fortificação moderna: advento do baluarte}

Nos anos 1530, época dos primeiros donatários no Brasil, ainda se começava a usar baluartes em muralhas e fortes portugueses. Mesmo nos anos 1550, os primeiros de Salvador, continuava a haver muralhas e torres medievais em Portugal. A fortificação abaluartada era uma prática recente, que acompanhava o desenvolvimento da pirobalística nas artes da guerra. ${ }^{72}$

O primeiro uso de uma artilharia pesada ocorreu por volta de $1450,{ }^{73}$ levando a inúmeras experiências de fortificação entre os séculos XVI e XVIII. As primeiras e principais novidades surgiram na Itália, onde a mudança para o sistema abaluartado foi lenta no século XV e ainda nas primeiras décadas do XVI, até acelerar-se por várias cidades nos anos 1525-30, gerando novos experimentos de desenho na década seguinte.
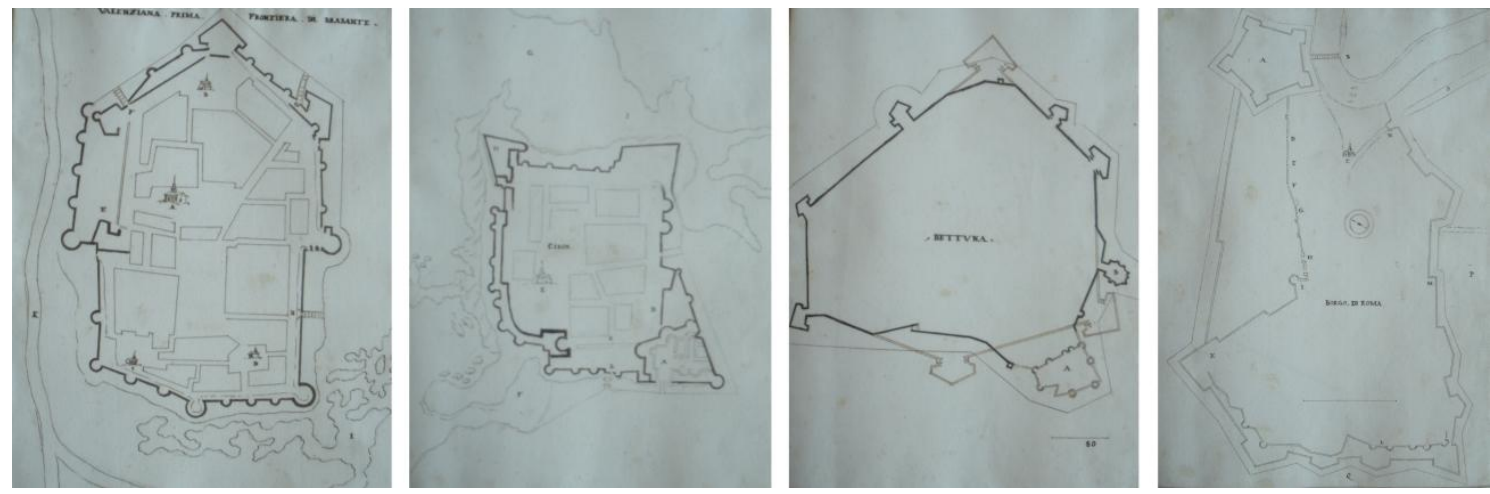

Fortificações de cidades italianas, em Città Difese e Archittetura..., ISCAG.

Da muralha medieval foram abolidos os parapeitos estreitos (desenhados para armas pequenas, não permitindo a manobra da nova artilharia), as muralhas e torres altas (alvo fácil e capaz de desabar com o novo impacto) e as seteiras, reforçando-se nos novos desenhos principalmente os ângulos e portões. Segundo Ackerman, no final do século XV a solução mais adotada foi uma fortaleza de planta quadrada ou triangular baixa com torres redondas nos cantos (pesadas e de coberturas

\footnotetext{
${ }^{72}$ As armas de fogo evoluíram lentamente entre os séculos XII e XIV, não se sabendo ao certo a origem da pólvora. Supõe-se, pelas narrativas de Marco Pólo, que foi inventada na China no séc. I, onde teria uso apenas pirotécnico (os chineses desconheciam as bocas de fogo em 1621, quando viram demonstrações da artilharia portuguesa). Também há relatos de alquimistas que usaram pólvora, mas as bocas de fogo chegaram à Europa possivelmente nas guerras ibéricas contra os árabes. Há crônicas que se referem a trons, tiros de ferro e tiros de trons, sendo as mais famosas: 1- sobre a batalha de 1108, em que mouros de Tunis tinham tiros de ferro com que davam trons de fogo contra os de Sevilha; 2- sobre a tomada de Saragoça de 1118, em que D. Affonso I o Batalhador empregou tiros de trons (de onde vem a palavra troneira); 3- sobre a defesa de Sevilha de 1247, com artilheria de fogo que quebrava as armaduras dos cavaleiros; 4- sobre a conquista de Niebla por Affonso X o Sábio de 1257, em que os sitiantes lançaram pedras com tiros de trons, e os sitiados dardos e pedras com armas de arremesso e de trovão com fogo (cf. OLIVEIRA, 2004: 22-3 e BAÊNA, 1989: 73-5). Segundo Rafael Moreira, a primeira menção à artilharia de fogo é de 1381, no final do reinado de D. Fernando (cf. MOREIRA, 1994: 17).

${ }^{73}$ Cf. ACKERMAN, 1986: 120-35.
} 
abobadadas). ${ }^{74}$ Serve de exemplo português a torre de Castro Marim, do início do século XVI, que aparece no Livro das Fortalezas de Duarte de Armas.
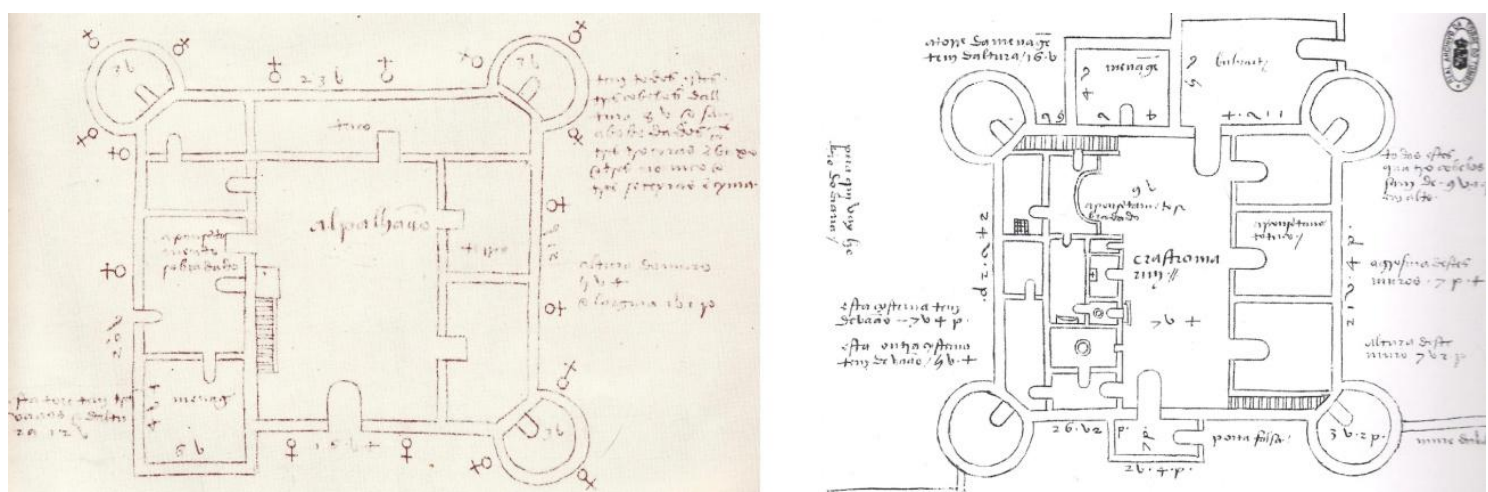

Fortalezas portuguesas da época de transição. À dir., a de Ajudá, em Castro Marim (ARMAS, 2006: 121).

Sobre a origem e a evolução do baluarte, observemos a proposição de Mário Oliveira: ${ }^{75}$ "... a elaboração de um muro bastionado vinha de longa experiência, uma tradição cujas raízes repousavam na remota Antiguidade e os progressos que este sistema murado ensejou foram, relativamente, muito poucos ao longo do tempo" (antes do desenvolvimento acelerado da pirobalística).

Dessa "remota Antiguidade" nos foi legado apenas o tratado de Vitrúvio, referência dos sistemas construtivos antigos e fonte primeira de inspiração a toda a tratadística italiana de Arte e Arquitetura. Ele mostra que as torres romanas eram arredondadas ou poligonais, ${ }^{76}$ dispostas nos ângulos das muralhas (as colônias romanas eram cidades fortificadas) e tornavam-se muito mais seguras quando unidas a terraplenos. Principalmente, deveriam ficar salientes para o lado exterior, porque além das vantagens de visibilidade, os atacantes que se aproximassem da muralha podiam ser feridos nos flancos desprotegidos, à direita e à esquerda, com os dardos lançados das torres. ${ }^{77}$

M. Oliveira faz a seguinte simplificação: com o advento da artilharia moderna, "como as velhas torres não poderiam propiciar boa defesa, fizeram-se novas,

\footnotetext{
${ }^{74}$ Esse método recebeu variantes nos estudos de Leonardo e Dürer, aparecendo na Fortaleza de Ostia (1483, por Giuliano da Sangallo e Baccio Pontelli), no Castelo Sant' Angelo em Roma (1490, por Giuliano e Antonio da Sangallo, "o Velho"), Sarzanello na Toscana (1490, de desenhista desconhecido), no Porto de Civitavecchia (1508, Bramante) e, com Leonardo, influenciou no desenho do Château de Chambord.

75 OLIVEIRA, 2004: 22. Sobre a etimologia do termo, cf. MOREIRA, 1989: 146. O bolwerk ("obra feita com vigas grossas"), de origem alemã ou borgonhesa (do neerlandês medieval bol ou do alto-alemão bohle), chegou à França (francês antigo) como boloart ou balouart. Deve ter passado pela língua d'oc ou pelo catalão (baluard) para chegar ao castelhano na Vida de D. Álvaro Luna (1460). Em português aparece em documento próximo a 1500, mas possivelmente já era usado antes. "Bastião", de outra origem (do francês bastir = construir), chegou a quase todas as línguas européias, virando em português sinônimo de baluarte (concorrendo erradamente com esta palavra, tida em geral como galicismo).

${ }^{76}$ Pois... as máquinas destroçam mais rapidamente as quadradas, porque os aríetes, batendo repetidas vezes, destroem os ângulos, enquanto que nas formas circulares, forçando as pedras para o centro como se fossem cunhas, não podem causar danos (VITRÚVIO, 2006: 47 - I, 5, 5). Desde tempos imemoriais se observa a diferente capacidade da pedra em resistir à compressão e à tração.

${ }^{77}$ Assim, o flanqueamento não é nem poderia ser uma preocupação moderna: as torres antigas, nos ângulos das muralhas, também ficavam a uma distância que pudessem se defender umas às outras. Vitrúvio explica que o intervalo entre cada torre não deveria ser maior do que o alcance de um dardo, para que se uma fosse atacada, as outras pudessem defender, mesmo que à época fosse com escorpiões e outros disparos de armas de arremesso $(1,5,4)$.
} 
colocadas nos ângulos das cortinas, cada vez mais salientes, cada vez mais baixas, cada vez mais robustas, até se chegar ao baluarte". ${ }^{78}$ Importa-nos que o sistema abaluartado se impôs no século XVI, depois de algumas hesitações e mudanças técnico-funcionais de transição. Com todos os requisitos de conhecimento de balística e estratégia militar, tornou-se importante exercício intelectual, levando à produção de inúmeros tratados de fortificação. ${ }^{79}$

No século XVI, a fortaleza passou a ser vista como "um sistema de defesa coerente e articulado em que qualquer ponto está sempre interconectado com outro e em que o baluarte poligonal acabará por desempenhar o papel decisivo". ${ }^{80}$ Mais do que o baluarte, passou-se a trabalhar a frente abaluartada, "conjunto e dois ou mais baluartes contíguos, corretamente desenhados e posicionados no terreno", ${ }^{81} \mathrm{em}$ defesa mútua e cobrindo por todos os lados ("varrendo" com tiros frontais $e$ flanqueantes) o território à frente, impedindo qualquer aproximação hostil. Como todas as invenções, o baluarte resultou de uma série de experiências acumuladas, neste caso na Itália central do século XV, com relativa simplicidade: uma "plataforma angular saliente em relação ao muro" que de início era maciça, com o espaço necessário à instalação e manobra das peças de fogo de maior alcance.

Para Rafael Moreira, pode-se considerar uma fortaleza (não mais um castelo medieval) desde a do Poggio Imperiale, entre Florença e Siena, em sua forma acabada pelo engenheiro Giuliano da Sangallo por volta de 1482 (nas décadas seguintes apenas se aperfeiçoou e adaptou a outros usos) ao tipo pentagonal dos anos 1530-40. Até lá houve uma longa evolução passando por Brunelleschi (com a Rocca Sismonda de 1436, em Rimini, para Sigismundo Malatesta, tirando partido dos torreões poligonais), Francesco di Giorgio Martini (que desde 1477 trabalhando para Montefeltro, aumentou as formas pontiagudas como espigões e revelins), Antonio da Sangallo 0 Jovem (que em 1492 consagrou a nova forma modernizando em Roma as torres redondas do Castelo de Sant' Angelo com baluartes angulares), Fra Giocondo, Sanmicheli e até Leonardo e Michelangelo. ${ }^{82}$

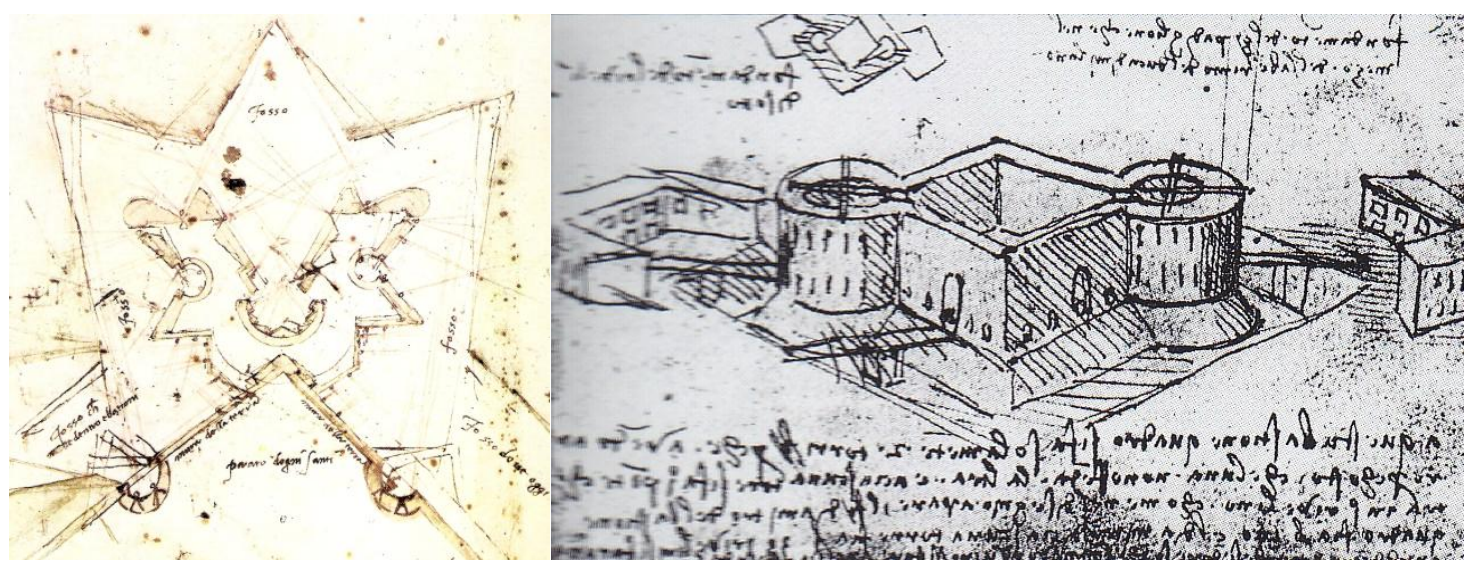

Defesas de Michelangelo (em RASPONI, 1978) e projeto de fortaleza de Leonardo (em MOREIRA, 1994: 131).

\footnotetext{
${ }^{78}$ OLIVEIRA, 2004: 36. As torres ficaram mais baixas para diminuir o alvo de tiro a longa distância, e as paredes mais robustas para resistir ao impacto maior das armas de fogo.

${ }^{79}$ Cf. PEREIRA, 1994: 39.

80 PEREIRA, 1994: 39.

${ }^{81}$ MOREIRA, 1994: 85.

${ }^{82}$ Cf. MOREIRA, 1994: 85.
} 
Moreira explica que a perfeita cronologia desse estilo de transição não é consensual, mas são conhecidos os marcos históricos principais, suas fases e a filiação dos grandes tipos, em progresso contínuo por causa da crescente eficácia. ${ }^{83}$ Lembra que o mesmo vale para a tipologia dos navios portugueses desenvolvidos ao longo do século XV (que permitiram a conquista do oceano e expansão da cultura européia por todo o mundo): a possibilidade da tomada e colonização da América só se deu pelo desenvolvimento dessas duas áreas, mas ainda segundo Rafael Moreira, "nenhum elemento foi tão decisivo para o sucesso da expansão européia quanto o baluarte, suporte da moderna artilharia de fogo" ${ }^{84}$

Dessa maneira, o Renascimento e a arquitetura italiana se ligam diretamente à nossa história colonial. Rafael Moreira assinala que em Portugal as formas medievais resistiram durante todo o período de transição, dificultando o processo e levando a ser tardia, com características próprias, a teorização da guerra e da fortificação. ${ }^{85}$ Não por simples coincidência com o que ocorria na Itália, o salto se deu ao redor de $1530{ }^{86} \mathrm{Em}$ meados do século XVI (quando Salvador foi construída a cargo de um discípulo de Miguel de Arruda, que trabalhou com Benedetto da Ravena), a influência italiana era

${ }^{83} \mathrm{Na}$ incursão ao mesmo tema feita por M. Oliveira (2004: 36-51), ele faz questão de frisar que o moderno baluarte é uma invenção italiana, e que embora apareça no Tratado de Fortificações do alemão Albrecht Düher, este só foi editado em 1527, bem posterior ao de Giorgio Martini e mais ainda aos escritos do Taccola, morto em 1458. Relaciona as hipóteses de ter aparecido pela primeira vez em Turim (com Canale, em 1461, aplicando-o nos ângulos da muralha quadrada de origem romana e medieval à volta de cidade), Verona (com Sanmichelli fortificando sua cidade natal) e Siena (saindo dos escritos de Mariano di Jacopo, il Taccola, primeiro a tratar especificamente as artes de defesa para os tempos modernos: não torres pouco espessas mas baluartes com o terrapleno ao nível das plataformas laterais, com a ponta em direção ao inimigo e baterias baixas nos flancos...).

Ackerman (1986) inicia essa cronologia pelo tratado de Francesco di Giogio Martini, escrito em Siena entre 1487-92, assistido pelo grande especialista do Quattrocento condottieri, Federigo da Montefeltre, assinalando que "Francesco construiu algumas fortificações abaluartadas no Ducado de Urbino de Federigo". Passa à possibilidade de "ter sido inventado pelos membros da família Sangallo a serviço do papado na passagem para o século XVI" (há versões primitivas nos esboços de Giuliano da Sangallo para Siena em 1503), cita "dois pequenos fortes costeiros no território papal - em Civita Castellana (1494-7) e Nettuno (1501-2)", revelando "sucessivos estágios na evolução da forma", e diz que até o Saque de Roma foram levantados apenas dois sistemas defensivos maiores na Itália, "em Ferrara (1512) e no Porto de Civitavecchia (1515-19)". Lembra que Sanmicheli, provável discípulo de Sangallo, "recebeu de Vasari o crédito de inventar o Baluarte" e o desenho dos exemplos mais antigos que ainda restam (os "delle Maddalene", em Verona, de 1527, ano em que Baldassare Peruzzi também construiu seis baluartes em Siena). A partir daí, outras grandes cidades italianas seguiram a liderança: "Ancona (1532), Turin (1536), Castro (1537), Naples (1538), Perugia e Nepi (1540)".

Ackerman, para destacar a importância dos desenhos de fortificações de Michelangelo (estariam "entre os mais engenhosos da moderna arquitetura militar, justo no momento mais fluido e inventivo de sua história"), faz a importante observação de que "a experiência não se apoiava em nenhuma fórmula consagrada de desenho": diferente da situação em outras artes, "as lições da antiguidade e as gerações precedentes tiveram pouca influência", já que se tratava de um novo tipo de construção, com regras ainda sendo desenvolvidas pela experiência e nova tratadística do Renascimento, em especial as obras de Francesco di Giorgio e Düher.

${ }^{84}$ MOREIRA, 1994: 85. Rafael cita J. Hale, para quem o baluarte foi a única "invenção verdadeiramente original da arquitetura do Renascimento". Em outro texto (MOREIRA, 1989: 144) também o considera a "a única criação arquitetônica absolutamente nova desde a Antiguidade" (o mesmo que diz Ackerman).

${ }^{85}$ Cf. MOREIRA, 1989: 143-4. Dá como exemplo o Regimento de Martim Afonso de Melo, escrito já nas primeiras décadas do século XVI, mas cheio de conceitos medievais (chegou-se a achar que fosse da época de D. Afonso V). Já no tratado Das Instruções Militares (Isidoro de Almeida, Évora, 1574) há muitas citações humanistas.

${ }^{86}$ Quando na Itália houve o cerco a Florença e o saque de Roma por Carlos V. 
notada tanto nas construções quanto nas representações em desenho. Depois, com D. Sebastião, haveria novo entusiasmo pelos assuntos militares, aparecendo o ensino teórico da fortificação ministrado no Paço da Ribeira pelo arquiteto-mor Antônio Rodrigues, começo das atuais academias militares em Portugal e no Brasil. ${ }^{87}$

A radical transformação das fortificações portuguesas ao longo do século XVI explica por que no Brasil ainda se construíram torres de características ditas medievais, tanto no começo das capitanias hereditárias quanto nos anos seguintes da construção de Salvador.

\section{Nascimento da Engenharia Militar - Itália e Portugal}

Também associado à crescente eficiência das armas de fogo (e à conseqüente política agressiva dos grandes Estados) foi o aparecimento da engenharia militar, que levou à substituição do artista no desenho das fortificações em meados do século $\mathrm{XVI},{ }^{88}$ processo igualmente iniciado na Itália. No começo da tratadística renascentista, Alberti (De Re Aedificatoria) dava pouca atenção às armas e procedimentos de defesa da cidade, mas pouco depois, Francesco di Giorgio Martini (Trattati di Architettura Ingegneria e Arte Militare, um dos precursores em engenharia militar) dedicou grande parte do seu trabalho às novas formas de defesa, em função da ameaça dos canhões. ${ }^{89}$

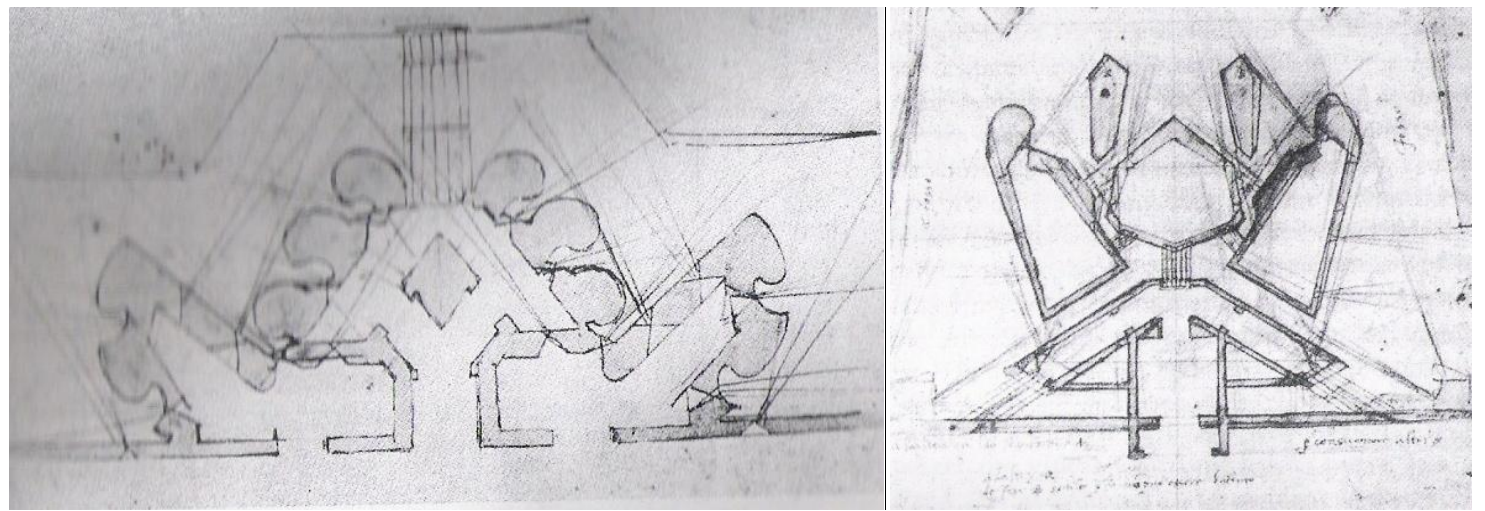

Desenhos de Michelangelo para fortificações de Florença (em ACKERMANN, 1986: 127-33).

Em Portugal, o profissional ligado à engenharia militar existia pelo menos desde os tempos de Afonso Henriques (rei entre 1143-85)..$^{90}$ No reinado de D. Dinis (1279-

87 Para R. Moreira, o Tratado de Antônio Rodrigues (1576-9) transparece "a cada linha a lição dos
italianos" (quase um plágio de Pietro Cataneo) e é "a adaptação possível da arte de fortificar do
classicismo às condições próprias da realidade portuguesa".
88 Cf. ACKERMAN, 1986: 120-35 e MUMFORD, 2008: 430 - "O desenvolvimento da arte da fortificação
transferiu a ênfase da construção da arquitetura para a engenharia, do desenho estético para os
cálculos materiais de peso, número e posição: prelúdio às técnicas mais amplas da máquina". Cf.
também OLIVEIRA, 2004: 21 - No século XVI a Itália "vê nascer a engenharia militar" como "ciência
autônoma da arquitetura", arte que antes era "exclusivamente exercida pelos arquitetos".
89 Segundo M. Oliveira (id. ibid.), a "necessidade de criar especialistas das fortificações" foi um
"corolário dos avanços da artilharia", pois "a muralha antiga tinha um traçado pouco intelectualizado,
que poderia ser concebido por um mestre-de-obras qualificado que, buscando organicamente a
morfologia do terreno e a lógica construtiva de implantação dos muros, conseguia a defesa desejada".
90 Nota-se pelo livro de Duarte das Armas (de 1516, produzido a mando de D. Manuel, rei entre 1495-
1521) uma clara continuidade de soluções, concepções e aperfeiçoamentos (o que também se observa 
1325) foram construídas muitas fortalezas, movimento que foi acompanhado de uma intensa atuação urbanística, com tecidos antigos sendo reformulados pela abertura de ruas (como, em Lisboa, a Nova dos Ferros). ${ }^{91}$

O vínculo entre fortalezas e núcleos urbanos é maior do que a simples construção militar, explicando-se pela atuação dos engenheiros como urbanizadores. A relação entre engenharia militar e urbanismo é anterior à construção das fortalezas: mesmo quando as muralhas que cercavam núcleos urbanos ainda não tinham a base matemática complexa dos baluartes do Renascimento, os seus desenhistas e construtores eram os mesmos da malha urbana. ${ }^{92}$

Mas nesse tempo não havia propriamente uma engenharia: até o século XVI, os profissionais envolvidos tanto no urbanismo quanto na defesa militar eram chamados Mestres Fortificadores. Historicamente, eles tiveram perfis e papéis distintos. ${ }^{93}$ Havia primeiro os grandes construtores das fortalezas e praças de armas erguidas durante a Reconquista (de qualidade construtiva que as fez durar séculos). ${ }^{94}$ Do século XII ao XIV, esses mestres fortificadores eram donos do maior conhecimento sobre fortalezas, castelos e cidades. ${ }^{95}$

No século XV e início do XVI, parte desses técnicos foi destacada para os planos da Coroa Portuguesa. Conquistadas as terras na Europa, partiu-se por mar e terra para o Norte da África e ilhas atlânticas, com a Corte incentivando a formação de um novo técnico de alto nível ao longo do século XV. Recrutado dos mestres fortificadores, ele deveria também entender de navegação (principalmente astronômica), mapas, artilharia com armas de fogo e construção naval. Com esse perfil, que retomava técnicas da navegação mediterrânea e tinha recursos da Coroa Portuguesa (bem maiores que os das cidades-estado italianas), foi possível dar o salto tecnológico que colocou Portugal momentaneamente à frente dos outros países europeus em conhecimentos de geociência. ${ }^{96}$ Tudo tinha um objetivo claro: manter e ampliar as conquistas. Essa técnica, somada a algumas inovações italianas (principalmente fortificações militares), seriam bem aplicadas nos primeiros núcleos brasileiros. Aqui, os Mestres Fortificadores seriam os responsáveis pelas primeiras cidades. ${ }^{97}$

nos levantamentos de fortalezas na África, na segunda metade do século XV, e Índia, na primeira metade do XVI, em especial na escolha de sítio - cf. KATISNSKY, 1999).

${ }^{91}$ Algumas vilas foram feitas quasi de novo (Rui de Pina, s/ ref. - apud ARAÚJO, 1989: 255).

92 No urbanismo colonial português há muitos exemplos de vilas desenvolvidas a partir de construções militares. Trata-se de uma lógica simples: todas as colonizações implicavam em conquista territorial e defesa do que já estava implantado. Na costa do Brasil, assim como nas da África e Índia, foram erguidas sucessivas fortalezas em defesa de feitorias, que acabaram estimulando a criação de núcleos populacionais (cf. ARAÚJO, 1989: 255-72 - na frase de Renata Araújo, p. 255, “'A cidade nascida à sombra da fortaleza' foi o paradigma do início do urbanismo colonial português", realidade que se manteria por longo tempo).

${ }^{93}$ Cf. KATINSKY, 2004: 81-92.

94 A maioria dessas construções ficava na fronteira com a Espanha, sendo "inventariada" no livro de Duarte das Armas. As fortalezas, chamadas de "castelos", abrigavam famílias e agregados dos senhores de terra, que se protegiam das guerras contra espanhóis e muçulmanos.

95 Que no sul da França eram chamadas de bastidas, palavra do godo longínquo que trouxe ao português o bastião, usado para torres e torreões de técnica militar mais antiga (cf. KATINSKY, 2004).

${ }^{96}$ Apesar de haver pouca documentação sobre isso, aparentemente a Coroa Portuguesa impulsionou a ciência e tecnologia no século XV. A Escola de Sagres, mesmo não sendo exatamente uma escola, mostrava o investimento do Estado em pesquisas e inovações técnicas. Também há muitos exemplos de pioneirismo na arte cartográfica, navegação astronômica, construção naval e armas de fogo.

${ }^{97}$ Luiz Dias, construtor de Salvador, era chamado de Mestre Pedreiro. 


\section{Tratadística italiana de Arquitetura e Fortificação}

No começo do século XVI, as intervenções urbanísticas da Coroa portuguesa em Braga mostravam sintonia com os estudos teóricos de cidades produzidos em cortes italianas. Se o contato com o Renascimento vinha de antes, foi nessa época que os tratados de Alberti, Francesco di Giorgio e Serlio, principalmente, começaram a ter cópias circulando em Portugal. A arquitetura passava a seguir as regras clássicas inspiradas em Vitrúvio, enquanto os desenhos de cidade adquiriam conceitos desenvolvidos nos demais tratados. Os tratados renascentistas que associavam arquitetura e fortificação, na maioria italianos, continuaram a ser referência até $o$ século XVII, quando se quis aplicar teorias de defesa nas regras de traçado urbano e arquitetura (ao mesmo tempo em que conceitos de traçado urbano seriam aplicados na organização espacial interna das fortalezas).

Os portugueses se especializaram na arquitetura militar pela necessidade de defender os principais portos na costa africana, Oriente e Extremo Oriente. Depois, com a expansão territorial no Brasil, para fundar vilas e cidades na costa e no interior. A arte de fortificar implicava conceitos de urbanismo muitas vezes aplicados mesmo sem a muralha ou fortificação envolvente. ${ }^{98}$

Arquitetos e engenheiros militares portugueses sabiam das novas concepções de cidade do Renascimento, tendo também em sua formação o conhecimento e grande experiência científica de matemáticos e cosmógrafos envolvidos nas explorações marítimas. A ocupação e defesa dos novos territórios pela construção de fortes e conjuntos fortificados logo levaram ao desenvolvimento da Engenharia Militar, fazendo surgir escolas de geometria, cosmografia e arte de fortificar, em que se desenvolveram os princípios modernos de fortificação.

Se as intervenções urbanas de Portugal nos séculos XV e XVI seguiam o conhecimento urbanístico europeu da época, a maior referência era o tratado de Vitrúvio, que a partir de 1521 recebeu importantes traduções e publicações, com desenhos e comentários. Sobre cidades, Vitrúvio fala daquelas que foram construídas pelos romanos e também de novas diretrizes teóricas. Nas principais interpretações, a urbe aparece em forma poligonal, inscrita num círculo e com ruas que se irradiam a partir de uma praça central, princípio que influenciaria praticamente todas as formulações renascentistas do que depois se chamou de "cidade ideal". ${ }^{99}$

\footnotetext{
${ }^{98}$ No século XVII seria desenvolvido o método de construir sistemas de defesa em pontos estratégicos, com fortes e fortalezas (Cf. TEIXEIRA \& VALLA, 1999: 128).

99 Sobre fundação de cidade, destaca-se em Vitrúvio no Livro I os capítulos 4 (escolha de sítio), 5 (construção de muralhas), 6 (distribuição de praças e ruas) e 7 (locações de foros e templos). Se com Filarete a exaltação à Geometria (ou à Matemática em geral, como Vitrúvio) fez com que a regularidade chegasse à muralha, para Francesco Di Giorgio, pensando a cidade a partir da arquitetura militar, a "cabeça" do reino era o castelo do Rei. Há uma apresentação clara deste tema, comparando e diferenciando os conceitos de cidade nas traduções de Cesare Cesariano (1521) e Daniele Barbaro (1567), além de explorar aqueles desenvolvidos em Antonio Averlino (Filarete), Francesco di Giogio Martini e Leonardo da Vinci, no trabalho A Cidade Fortificada, Vitrúvio e o Renascimento: visões modernas sobre um ideal antigo de cidade, de Ana Paula G. Pedro (FAU-PUC, 2008).
} 


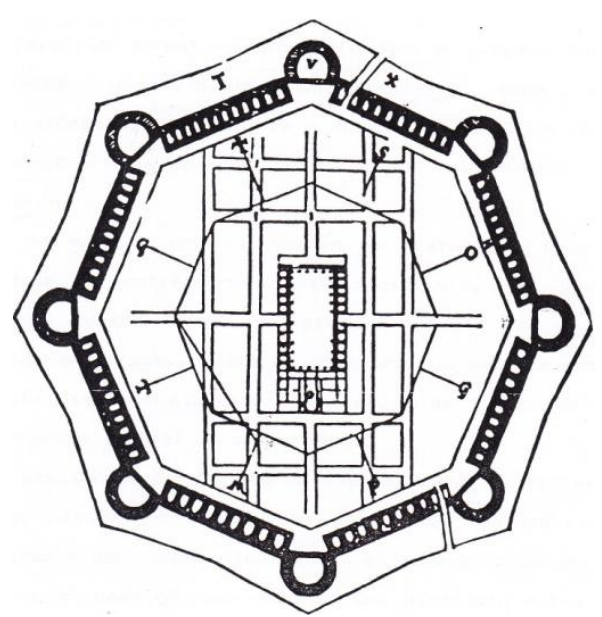

Cidade vitruviana na edição de D. Barbaro, de 1574 (em SILVA, 1991: 52).

Alberti, pela época em que viveu (1404-72), é talvez o renascentista que mais influenciou D. Diogo de Sousa. ${ }^{100}$ Sobre questões urbanas, sua contribuição mais importante está no tratado De Re Aedificatoria, apresentado em manuscrito a Nicolau V (1452, só publicado, postumamente, em 1485). A tradução para o português do século XVI nunca foi publicada. No tratado não há ilustrações, planos de cidades ou exemplos urbanísticos. Destaca-se em sua argumentação o formato das ruas: as principais seriam largas e diretas, facilitando o deslocamento na cidade (particularmente o de tropas) e enfatizando a monumentalidade. ${ }^{101}$ Já as outras ruas deveriam ser estreitas e sinuosas por motivos climáticos, de defesa dentro da própria cidade e porque dariam melhor visão a cada edifício que as compunha: a sinuosidade faria com que a cada passo se mostrasse uma nova estrutura, com a porta principal de cada casa interferindo na visão da rua. Para Alberti, nas cidades pequenas essa perspectiva criada a cada casa pelas curvas da rua era agradável e saudável. ${ }^{102}$

100 D. Diogo de Sousa, bispo do Porto (1496-1505) e arcebispo de Braga (1505-32), foi responsável por romper a cintura medieval e alargar a cidade extramuros, onde construiu novas ruas, uma nova porta (o Arco da Porta Nova) e novas igrejas (como a Senhora-a-Branca). Existem ainda o Campo dos Remédios (Largo Carlos Amarante), o Campo da Vinha (Pça Conde de Agrolongo), o Largo das Carvalheiras e a Avenida Central.

101 Incluem-se aí as desenhadas por um motivo específico: “... por exemplo, aquelas que conduzem a algum templo, ou a um campo de corridas ou a algum palácio da justiça... porque desta forma, para além de parecerem muito mais longas, e contribuírem para a idéia de grandiosidade da cidade, elas são muito mais belas e convenientes, e são muito mais seguras contra todos os acidentes e emergências" (ALBERTI, 1996).

${ }^{102} \mathrm{Na}$ sugestão de vias de pequeno porte, como em todas as outras, Alberti (Livro IV, cap. V) está atento às questões do decoro: "Quando se chega a uma cidade, caso ela seja famosa e potente exigirá estradas retas e muito amplas, condizente com seu decoro e com sua dignidade. Se ao contrário for uma colônia ou simples praça-forte, as vias de entrada mais seguras não são aquelas que conduzem direto à porta, mas sim aquelas que se estendem à direita e à esquerda ao longo da muralha, ainda melhor se passarem sob as ameias; e ao interior da cidade não deverão seguir em linha reta, mas dobrar em amplas curvas, como as curvas de um rio, com voltas por uma parte e outra" (ALBERTI, 1996).

Alberti foi consultor do Papa Nicolau V e fez projeto para o Borgo Leonino, bairro entre São Pedro e o castelo de Sant' Angelo. Mesmo só realizado parcialmente, é um dos primeiros exemplos de planos geométricos renascentistas. Em cada extremo, Alberti propôs a construção de uma praça, e na que ficava em frente a São Pedro, que se erguesse um obelisco (origem da idéia depois realizada por Sixto V, de erguer obeliscos nos pontos mais importantes da malha urbana, inclusive na praça de S. Pedro (cf. TEIXEIRA \& VALLA, 1999: 121). 
O Tratado de Arquitetura Civil e Militar (1495) de Francesco di Giorgio Martini (1439-1501) também era conhecido e estudado em Portugal por meio de cópias manuscritas (a publicação é do século XIX). Como Vitrúvio, Martini desenvolveu modelos urbanos de esquemas centralizados (todos aplicáveis, embora tidos depois como propostas de uma "cidade ideal") e também adaptações dos padrões ideais a terrenos irregulares. Ao contrário de Alberti, incluiu muitos desenhos em seu tratado, dentro da cultura profundamente visual do final do século XV (de recorrer a ilustrações a cada conceito desenvolvido). No Livro III, Martini discute em detalhes os traçados possíveis para as cidades, aprofundando propostas de Alberti, Filarete e outros. A idéia básica ainda era a estrutura radial, adaptada por ele a diversas condições geográficas planície, colina, margem de rio - explorando as diversas formas resultantes. Os seus esquemas teóricos levaram em conta dois fatos novos: o uso de quadras, adotados em vários crescimentos urbanos da época, e o desenvolvimento de técnicas de fortificação, nas quais era especialista. ${ }^{103}$

Francesco di Giorgio combinou o traçado quadrangular no interior da cidade (facilitador da divisão em lotes) e a valorização urbanística pela uniformidade em traçados radiais, de perímetro exterior circular ou poligonal. O perímetro exterior poligonal, se de um lado satisfazia as reflexões teóricas sobre a cidade radial (e valores simbólicos e cósmicos a ela associados), de outro tinha uma justificativa prática: baseava-se nas novas técnicas de fortificação das cidades em função da artilharia moderna. Francesco di Giorgio era reconhecido como um dos grandes especialistas da engenharia militar e teria construído cerca de 70 fortificações para o Duque de Urbino. Pelas novas técnicas, a melhor fortificação era uma muralha poligonal com baluartes nos ângulos, estes ligados ao espaço interno por largas artérias para se ajudar mutuamente. ${ }^{104}$

\footnotetext{
${ }^{103}$ Cf. TEIXEIRA e VALLA, 1999: 122.

${ }^{104}$ Martini formou-se em pintura, mas teve a prática profissional em construção, escrevendo o seu tratado voltado à arquitetura militar. Nota-se em seus trabalhos uma convergência entre teoria e a prática. A disposição da trama viária no interior da cidade, forte ou castelo (as três estruturas urbanas tratadas por ele) "deve ser estabelecida em função do sítio destinado a ela, do posicionamento no terreno" (enquanto em Vitrúvio o fator predominante é a direção dos ventos): “... as vias podem ser espiraladas, radiocêntricas ou mesmo de trama ortogonal, desde que se adéqüem perfeitamente ao sítio onde serão construídas..." (PEDRO, 2008: 22-3).

Martini mostra em diversas passagens que "sua concepção de cidade, forte ou castelo está diretamente vinculada à estrutura e à figura corpórea humana" (idem, p. 54 - alguns autores chegam a considerá-lo o principal porta-voz do antropomorfismo). No capítulo I (Fortezze), ele diz: "Portanto o forte deve ser o principal membro da cidade, assim como a cabeça é o principal membro do corpo, pois perdida a fortaleza perdida a cidade por essa assenhoreada" (MARTINI, 1967: 3).

$\mathrm{Na}$ análise de Nicholas Adams (L'Architettura militare di Francesco di Giorgio. In: Francesco di Giorgio Architetto. Milão: Electa, 1993, p. 130 - apud PEDRO, 2008: 55), “... as fortalezas de Francesco di Giorgio, de um ponto de vista topográfico, ocupam uma posição elevada e muito dominante, colocadas, como Francesco di Giorgio deve ter pensado, ao comando e controle de seu território assim como a cabeça comanda e controla o corpo". Assim, coloca "em correspondência com os braços, os acréscimos e recintos murários que circundam partitamente [os acréscimos se repetem radialmente no perímetro da muralha] como ligação de toda a grande cidade/ corpo; a praça principal com o umbigo, devido à sua posição central, que facilita o acesso a todos os citadinos" (PEDRO, 2008: 55-6).
} 
Deve-se ainda destacar ainda a relação intrínseca entre a formulação de cidade renascentista e o desenvolvimento do baluarte ${ }^{105}$. As fortificações evoluíram ao longo dos séculos, aparecendo em seus desenhos os modelos de cada época, associados sempre às concepções de cidade. A partir do século XVI, elas estavam intimamente ligadas ao desenho urbano, com a introdução do baluarte no sistema defensivo renascentista determinando a remodelação das cidades existentes.

O castelo de Sant' Angelo, em Roma, foi dos primeiros exemplos, sendo reforçado com baluartes ao redor dos torreões existentes (1493). ${ }^{106}$ Eles foram desenhados por Antônio Sangallo, irmão mais velho da família de artistas, conhecedor de engenharia militar. O baluarte (ou "bastion") era a forma mais avançada de defesa, com paredes difíceis de destruir e pela melhor maneira de defender as cortinas (lados da muralha), que eram sempre os pontos mais fracos (por isso eles tinham de ser simétricos em relação a elas).

Em 1467, Francesco di Giorgio foi incumbido de construir uma cidadela em Anvers. Ele optou pela forma do pentágono, que seria a mais perfeita para defender todos os lados da fortificação. A construção, que representa o começo da arquitetura ligada à fortificação, levou um ano e contou com dois mil operários, servindo de exemplo aos novos sistemas. Na Alemanha, Albrecht Düher desenvolveu idéias para a cidade modelo ligada a sistemas de fortificação, escritas e desenhadas em seu tratado (impresso em 1527 e traduzido para o latim em 1535). ${ }^{107}$
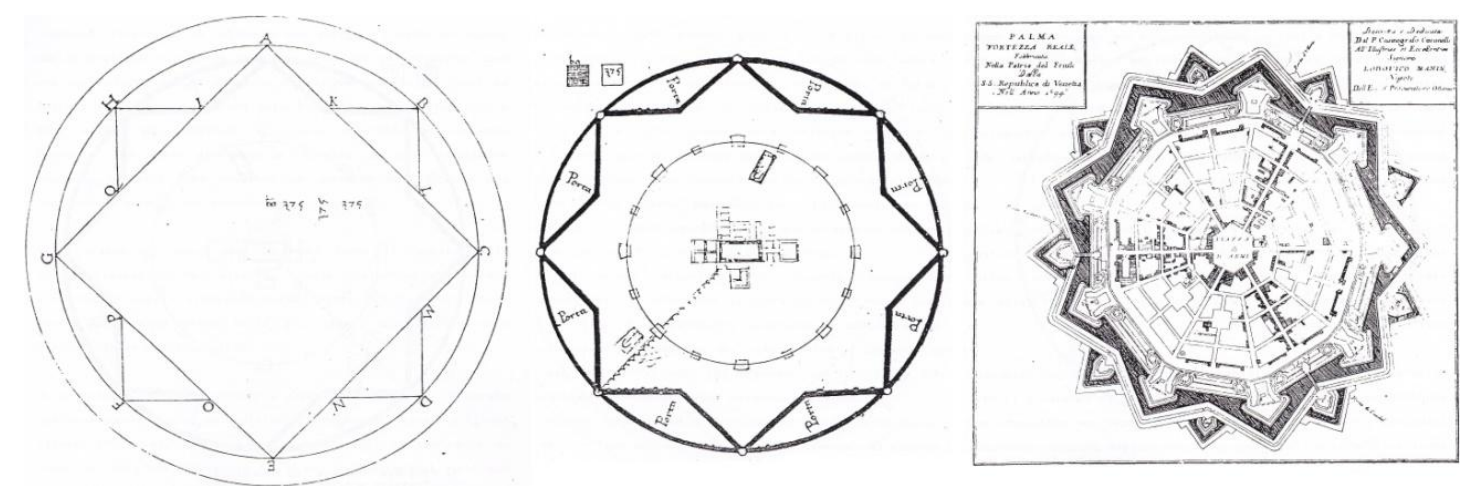

À esq. e ao centro, o esquema planimétrico e a planta de Sforzinda por Filarete no Trattato $d^{\prime}$ Architettura de 1460. À dir., a planta de cidade de Palmanova, em Veneza, 1594 (em SILVA, 1991: 80-3).

Dentro dos exemplos de fortificação regular encontrados em Salvador, de forma definitiva alcançada no começo do século XVIII, devemos também falar no tratado de Pietro Cataneo, I Quattro Primi Libri di Architettura, de $1554,{ }^{108}$ o último a abordar conjuntamente as arquiteturas militar e civil. ${ }^{109}$ Trilhando o conhecimento

\footnotetext{
105 "A cidade ideal desenvolvida pelos teóricos italianos implicava um sistema defensivo que iria substituir as torres cilíndricas e quadradas e as muralhas medievais por fortificações baseadas em figuras poligonais e com baluartes" (Margarida Valla em TEIXEIRA \& VALLA, 1999: 123).

${ }^{106}$ Em sua origem, o castelo era o mausoléu do imperador Adriano, de estrutura iniciada no ano 139. Já em 403 adquiriu função militar, integrando a Muralha Aureliana. De planta circular, seu desenho renascentista teria influenciado a traça do Forte do Bugio (próximo a Lisboa) e do S. Marcelo (Salvador). 107 DÜHER, Albrecht. Pictoris et Architecti Praestantissimi de Urbibus, Arcibus, castellisque condendis, AC muniendis rationes aliquot, praesenti bellorum necessitati accommodatissimae. Paris: 1935.

${ }^{108}$ Reeditado em 1567 como L'Architettura di Pietro Cataneo Senese.

109 Depois dele, os tratadistas passaram a se ocupar de uma ou outra. Em arquitetura civil, destacam-se, sendo universalmente conhecidos, os tratados de Vignola e Palladio. Em arquitetura militar (de
} 
vitruviano com influência direta de Francesco di Giorgio, ele considera o perímetro angulado para as cidades fortificadas o mais eficiente contra o novo tipo de artilharia (sem diminuir a virtude da cidade circular vitruviana). ${ }^{110}$

$\mathrm{Na}$ apresentação dos tipos possíveis de cidade fortificada (baseados em figuras geométricas elementares) ele dá atenção especial à colocação dos baluartes. Destacase em sua argumentação que para as fortalezas valem os mesmos procedimentos de concepção das cidades fortificadas, pois elas seriam uma cidade em escala reduzida. Em centros urbanos maiores, haveria uma fortaleza dentro do perímetro amuralhado (funcionando como cidadela). Seguem-se os modelos de planta quadrada, pentagonal e hexagonal, havendo uma progressiva angulação do perímetro amuralhado.
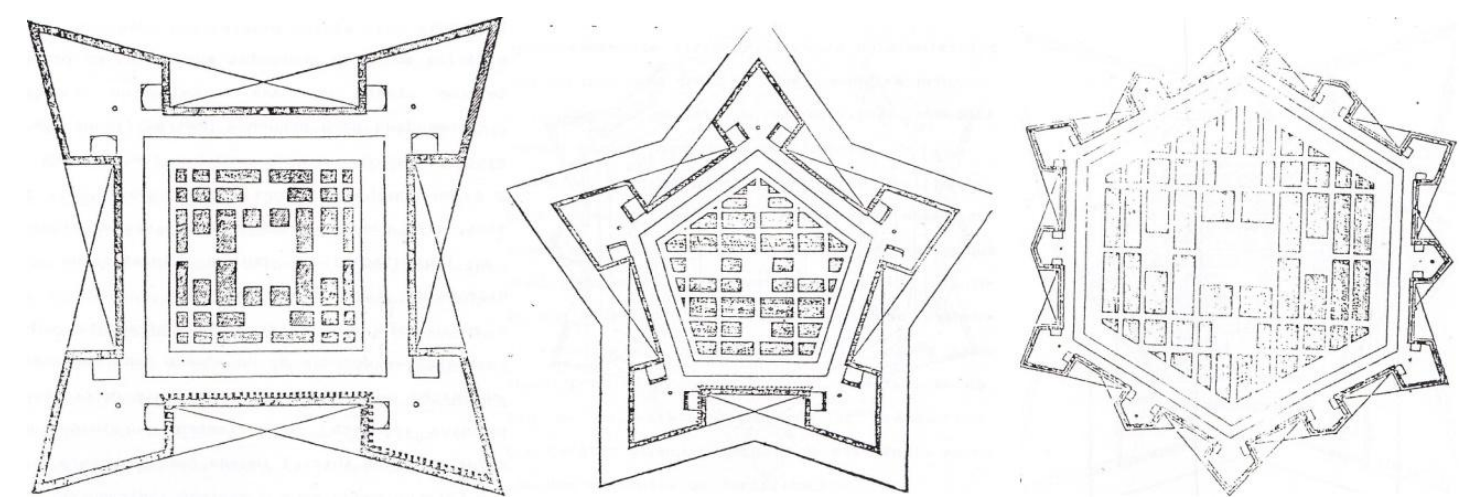

Plantas de cidades com baluartes nos ângulos, de Pietro Cataneo, 1567 (em SILVA, 1991: 121-3).

\section{As chamadas escolas de fortificação: italiana, holandesa, francesa}

No final do século XVII, as referências na arte ou ciência da fortificação passaram a ser as escolas holandesa, francesa, espanhola e alemã. Eram seguidoras da escola italiana, mas trouxeram mudanças significativas no decorrer das novas práticas de guerra. As mais importantes eram a holandesa e a francesa, já que a alemã, mesmo também antiga, era uma variante da italiana. Os portugueses, como os espanhóis, criaram variações de procedimento com base na escola holandesa (com Serrão Pimentel) e na francesa (com Azevedo Fortes).

Holandeses e franceses desenvolveriam modelos mais sofisticados, com elementos militares que exigiam conhecimento cada vez maior de geometria, matemática e trigonometria. As guerras entre muitos estados europeus (Guerra de Trinta Anos, Guerra da Sucessão na Espanha) trouxeram rápida evolução tecnológica. Cidades mais centrais, francesas, espanholas, holandesas ou de principados alemães, tiveram seguidas guerras e foram sucessivamente conquistadas (Aire, francesa em

tratadística mais autônoma e original na segunda metade do século XVI) também se destacou Francesco de Marchi, com Dell' architettura Militare (1599).

110 Cf. SILVA, 1991: 117-27. Defendia também o ideário renascentista de que as partes da cidade deveriam ser organizadas como as partes do corpo humano, devendo-se primeiro determinar o perímetro angulado dos muros (de tamanho suficiente para que a cidade realizasse todas as suas funções) para depois traçar as estradas e praças no interior, deixando o centro da cidade reservado à praça principal para que fosse igualmente cômoda a todos os habitantes. As ruas eram organizadas pelo modelo em tabuleiro, sem adotar, nesse aspecto, o desenho centrífugo da "cidade ideal". Na escolha do sítio, prioriza a direção dos ventos, necessários à boa salubridade da área urbana. 
1641, foi logo depois tomada pelos espanhóis e em 1710 pelos aliados; Philippeville, de 1555, foi tomada pelos espanhóis em 1578 e pelos franceses em 1659). ${ }^{111}$

As guerras entre Carlos V e Francisco I no século XVI se prolongaram no XVII com Filipe II e Luís XIV. Elas não se davam numa perspectiva de conquistar países, mas cidades, como forma de aumentar o poder em uma Europa ainda dividida por estados e condados. Essas duas escolas teriam seus métodos aplicados na Europa, em cidades construídas para serem inexpugnáveis.

Italiana. A escola que criou a fortificação abaluartada é de meados do século XV, continuando importante nos tempos de efervescência intelectual e política na Itália. Se no começo a tarefa de fortificar era dos próprios arquitetos do Renascimento e do Barroco, aos poucos apareceram os engenheiros, que muitas vezes trabalhavam mais no exterior do que em suas cidades, pois eram chamados por diversas nações européias e para colaborar em colônias do além-mar, como o Brasil.

Nos primórdios, havia uma imensa distância entre os baluartes. Logo se notou a incompatibilidade com a cobertura de fogo no flanqueamento, pois os disparos de armas leves que cobriam as muralhas não alcançavam a amplitude necessária. Criou-se depois o front italiano melhorado, incorporando o que havia de melhor nas outras escolas. As estruturas das fortificações eram quase sempre construídas em alvenaria de pedra ou tijolo, conforme a disponibilidade da região. Era uma técnica de maior durabilidade, mas aumentava o custo e podia causar danos à defesa por ricochetes e produção de estilhaços. ${ }^{112}$

${ }^{111}$ Cf. OLIVEIRA, 2004: 45.

112 Cf. OLIVEIRA, 2004: 45-7. Em Salvador, no século XVII, a polêmica entre construir os fortes de alvenaria ou terra aparece em muitas Cartas Régias e pareceres dos engenheiros.

Afora grandes arquitetos do Renascimento e do Barroco (Brunelleschi, Michelangelo, Guarini) que também se ocuparam com fortificações, seguem-se, citados por Mário Oliveira, os nomes que deram prestígio à Escola Italiana de Arquitetura e Engenharia Militar: Michele Sanmicheli (1484-1559) durante muito tempo atribuiu-se a ele a criação do primeiro baluarte moderno, o da Madalena, na cinta fortificada de Verona; fortificou Veneza e, no Oriente, a llha de Candia; Nicollò Tartaglia (1500-62) - quis reduzir a arte de fortificar e a artilharia a princípios científicos, incorporando às defesas das cidades parte do território circundante, uma primeira idéia dos campos entricheirados; Francesco de Marchi (1504-76) - reuniu em sua Architettura Militare inventos modernos da castramentação, com propostas de aperfeiçoamento; Jacopo Fusti (1510-68) - trabalhou na Itália e na França, propondo um front depois adaptado por Vauban; seu tratado de fortificação, escrito em parceria com Girolamo Maggi, é considerado um clássico quinhentista; Giulio Savorgnano (1516-95) - propôs muros revestidos em alvenaria só até certa altura para absorver impacto, preceito só seguido muito tempo depois; trabalhou nas fortificações de Bérgamo, Verona, Peschiera e na emblemática obra de defesa de Palmanova; Francesco Paciotto (1521-91) - dos mais famosos, teria construído as cidadelas de Turim e Anversa, fortificado em Montecchio, Guastalla, Villafranca e Savigliano e trabalhado também na Holanda; Buonaiuto Lorini (1540-1611) - da aristocracia florentina, começou a carreira militar com Cosimo de Médici, serviu em Flandres, trabalhou na fortificação da Antuérpia, foi engenheiro militar em Veneza, operou em fortificações na Dalmácia, Zara, Legnano, Brescia e Bérgamo, trabalhou com Savorgnano nos planos de Palmanova, escreveu Delle fortificationi libri cinque, muito citado por Serrão Pimentel; Pietro Sardi (1560 a após 1642) - romano, escreveu Corona Imperiale dell' architettura militare, Corno dogale dell' architettura militare, Dircorso sulla necessita dell' architettura militare e outros; muito citado na tratadística, também pelos portugueses; Pietro Paolo Floriani (1585-1638) - de Macerata, educado por Giovanni de Médici e pelo Marquês Alessandro Palavicini, serviu na Alemanha, Boêmia, Hungria, Espanha, Vaticano - foi vice-comandante do Castelo de Sant' Angelo - e deu consultoria em Viena; em 1634 fortificou Ferrara e iniciou em 35 a fortificação de Valetta, na llha de Malta, para os Cavaleiros da Ordem; escreveu Diffesa et offesa delle piazze, citado por Serrão Pimentel. 
Holandesa. Os holandeses desenvolveram sistemas de fortificação ampliando o uso de fossos aquáticos, às vezes em terrenos abaixo do nível do mar. O sistema de muralhas era baseado em cortinas pequenas, com flancos perpendiculares a elas. A escola se destacava pelo uso da matemática aplicada, geometria, trigonometria de perspectivas, mecânica e hidráulica, matérias desenvolvidas em tratados de fortificação como os de Adam Fritrach e Matthias Dogen.

Em 1592 o engenheiro militar holandês Maurício de Nassau venceu os espanhóis e conquistou a cidade de Coerverdan, reconstruindo o seu sistema de fortificação em forma de polígono regular. A praça forte se tornou importante referência nos tratados de fortificação. Maurício de Nassau também foi incumbido de construir no Brasil a cidade fortificada na llha de Antônio Vaz, em Recife. ${ }^{113}$

A escola holandesa se desenvolveu na Guerra dos Oitenta Anos contra a Espanha, ${ }^{114}$ tendo como pai Symon Stevin, matemático que transformou o sistema duodécimo (12 polegadas = 1 pé, 12 pés = 1 verga) em decimal, facilitando os cálculos. Trouxe as seguintes transformações na Arquitetura Militar: 1- preferência por fossos com água de rio ou mar; 2 - uso de fortificações de terra (mais econômicas e rápidas há pouca pedra na Holanda); 3- preferência por falsabragas (como as barbaças das muralhas antigas, o segundo muro da fortaleza que defende o fosso); 4- flancos de baluartes perpendiculares à muralha ou cortina; 5- uso original das chamadas obras exteriores (revelins, hornaveques, obras coroas); 6- uso de revelins pequenos na face da cortina; 7- fortificações e obras exteriores conforme um sistema de proporção, de todas as medidas relacionadas entre si (para isso foram publicadas inúmeras tabelas orientando a boa proporção nas fortificações, algumas reproduzidas em Serrão Pimentel); 8- o ângulo saliente do baluarte era sempre de $90^{\circ}$; 9- fossos geralmente cavados em forma cônica. ${ }^{115}$

Na tomada de Salvador (1624-5), um dos reforços de fortificação foi a barragem do Rio das Tripas, criando-se um dique artificial como fosso aquático. ${ }^{116}$ Também em Recife eles usaram os rios: eram especialistas em tirar partido da água como defesa. 0 elemento mais importante atribuído aos holandeses é, porém, a estrada coberta, descrita por Serrão Pimentel. O livro de Adam Freytag, impresso inicialmente em 1630, resume os princípios gerais dessa fase.

Um segundo período segue-se à independência da Holanda, invadida em fins do século XVII pela França (de Luís XIV, com o Marechal Vauban em seus quadros). 0 Barão Minno Von Coëhoorn, rival de Vauban, reestruturou as defesas resgatando o prestígio dessa escola. Em seu tratado de 1687 estabeleceu a subtração de partes muradas aos tiros do inimigo, a execução de zonas secas para contra-atacar nos fossos

\footnotetext{
${ }^{113}$ Cf. TEIXEIRA \& VALLA, 1999: 123-4.

${ }^{114}$ As características próprias da escola holandesa estão relacionadas a fatores geográficos (ocupação parcial de áreas marítimas) e históricos (território disputado por diversos grupos locais e regionais, chegando a envolver grandes nações). Atacados pelos outros Países-Baixos e pela Espanha, os holandeses criaram alternativas para resistir em condição numérica inferior. Na segunda metade do século $\mathrm{XVI}$, com o ataque espanhol em terrenos de lençol freático superficial, eles usaram fossos aquáticos mais largos, escarpa e contra-escarpa, tudo geralmente de terra. Também o emprego de falsabraga permitiu maior cobertura de tiro aos fossos e a criação de defesas sucessivas (cf. OLIVEIRA, 2004: 47).

${ }^{115}$ Cf. PAAR, Edwin. As fortificações seiscentistas de Elvas e o primeiro sistema holandês de fortificação. 2001 / BUENO, 2001: 430-1.

${ }^{116}$ Ele hoje está desaparecido. Foi conhecido por Dique dos Holandeses, estendendo-se na Baixa dos Sapateiros pela Rua da Vala, atual Rua J. J. Seabra, da Barroquinha aos fundos do Convento do Carmo.
} 
aquáticos (que também dificultavam a defesa) e o estabelecimento de flancos longos e bem cobertos com obras exteriores. ${ }^{117}$

Francesa. O progresso francês começou no fim do século XVI, com Sully, que Henrique IV nomeou Grande Mestre da Artilharia e Superintendente das Fortificações. Podendo influir em grandes decisões, ele criou o corpo de engenheiros militares franceses que acabou substituindo o de italianos trazidos à Corte (que tinha a desvantagem de uma lealdade precária, sendo composto por Girolamo Marini, Girolamo Bellarmati, Jacopo Fusti, Bartolomeu Campi, Francesco Bernardino da Vimercate, Francesco de Marchi e Francesco Paciotto e outros).

A escola ganhou reconhecimento com os tratados de Antoine de Ville (1628) e do Conde de Pagan (1640). Neles se destacavam técnicas de construção de base menos teórica, principalmente adaptadas às condições de terreno. Os dois tratados seriam importante referência para o Methodo Lusitanico... de Luís Serrão Pimentel (1680). ${ }^{118}$ Nesses tratados, substituem-se as idealizações (sempre embasadas em Vitrúvio e Sérlio) por uma prática de defesa das cidades existentes. Por isso, algumas fortificações começaram a adotar polígonos irregulares (como, na Bahia, a ampliação do Forte de Santo Antônio da Barra), também abordados no livro de Adam Fritach. ${ }^{119}$

$\mathrm{Na}$ segunda metade do século XVII, com Luís XIV, reforçou-se o sistema defensivo das cidades pela política de delimitação e ampliação do território francês. $O$ engenheiro Sebastien le Preste de Vauban é reconhecido por seus métodos de fortificação, aplicados em cerca de 60 cidades, e por comandar cerca de 50 cercos. 0 seu sistema de defesa é de enorme complexidade construtiva, resultando do sistema e técnica de ataque, também importante em sua atuação. ${ }^{120}$ Vauban criou uma cintura

\footnotetext{
117 Além de Symon Stevin, os maiores expoentes da escola holandesa (ou mais citados nos tratados portugueses) foram: Samuel Marolois (1572-1627) - matemático de origem francesa, discípulo e assistente direto de Stevin, desenvolveu um sistema de fortificação com base no de Frencesco d' Marchi, tendo seus escritos publicados em várias línguas, inclusive o inglês; Adam Freytag (em francês, Fritach, 1602-64) - o mais importante da primeira escola holandesa, reelaborou questões de Stevin e Marolois e sintetizou as características básicas de sua escola (cf. BUENO, 2001: 430-1); muito citado por engenheiros portugueses nos séculos XVII e XVIII, inclusive os que serviram no Brasil, considerando o seu tratado um "clássico"; Matthias Dögen (1605-72) - estudou em Leiden e trabalhou em Amsterdã, tendo seu tratado editado em latim, francês e alemão entre 1647-8; teve muitas referências de Serrão Pimentel; Nicolaus Goldmann (1611-45); arquiteto e engenheiro militar também referido pelos portugueses, ele foi reconhecido por sua descrição e traçado da voluta jônica; muito didático em seu texto, estabeleceu no prefácio relações da história humana com o planejamento de cidades e a arquitetura militar (cf. OLIVEIRA, 2004: 48); foi ativo nos exércitos holandeses; Minno Coëhoorn (16411704) - mencionado como figura máxima da segunda fase, foi Tenente General da Infantaria, General de Artilharia e Governador de Flandres; Hendrik Hondius - desenhista, gravador, impressor, editor e matemático (cf. BUENO, 2001: 431); Hendrick Ruse - ativo nos exércitos flamengos (id. ibid.).

${ }^{118}$ Cf. TEIXEIRA \& VALLA, 1999: 124.

119 Cf. BUENO, 2001: 415-6/ PAAR, Edwin. Luís Serrão Pimentel and the 'Dutch School' of fortification. 1995, p. 10-2. Para Beatriz Bueno, a escola francesa era tributária direta da holandesa. Embora introduzisse algumas alterações no sistema de flancos, seria apenas uma releitura da escola holandesa representada nas idéias de Samuel Marolois e do próprio Symon Stevin (pai da escola, de quem Marolois era discípulo), Hendrik Hondius e Adam Freitag (de origem alemã, o maior expoente, com seus seguidores Mathias Dogen, Nicolaus Goldmann e Hendrik Ruse. Cf. também BUENO, 2001: 432/ PAAR, E., op. cit., 2001.

${ }^{120}$ Cf. GUTIÉRREZ, Ramón \& ESTERAS, Cristina. Territorio y Fortificación, Vauban, Fernández de Medrano, Ignacio Sala y Félix Prósperi, Influencia en España y America. Madrid: 1977, p. 7/ TEIXEIRA \& VALLA, 1999: 123.
} 
dupla de muralhas com revelins, tenalhas e torres nos baluartes, que tinham a forma de "orelhão" para melhor defender as cortinas. As obras tinham dimensão exagerada e só com milhares de trabalhadores era possível construir (como a cidadela de Lille, com seis mil homens). O seu método foi teorizado no tratado de fortificação que foi a base, entre outros, do tratado de Azevedo Fortes, O Engenheiro Portuguez (1728).
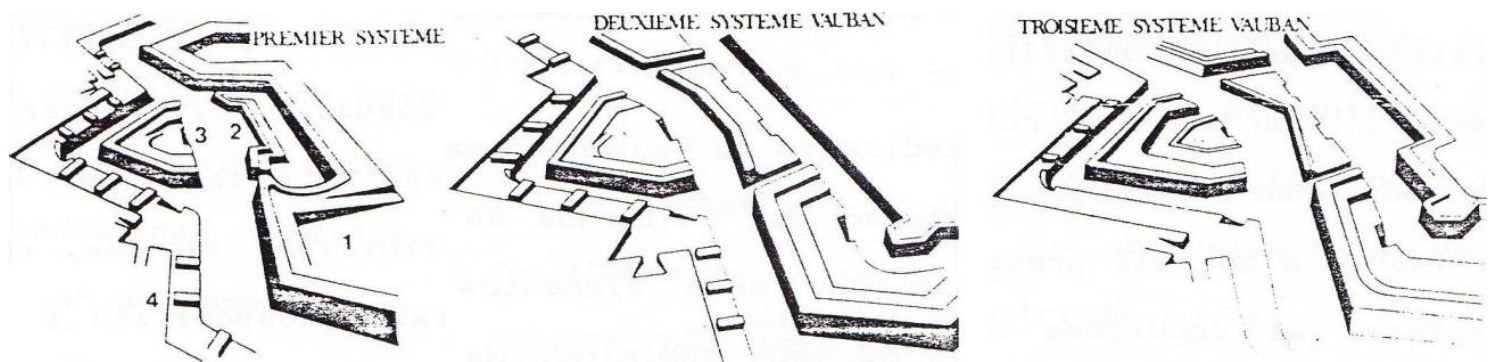

Os "três sistemas defensivos" de Vauban (em SILVA, 1991: 137).

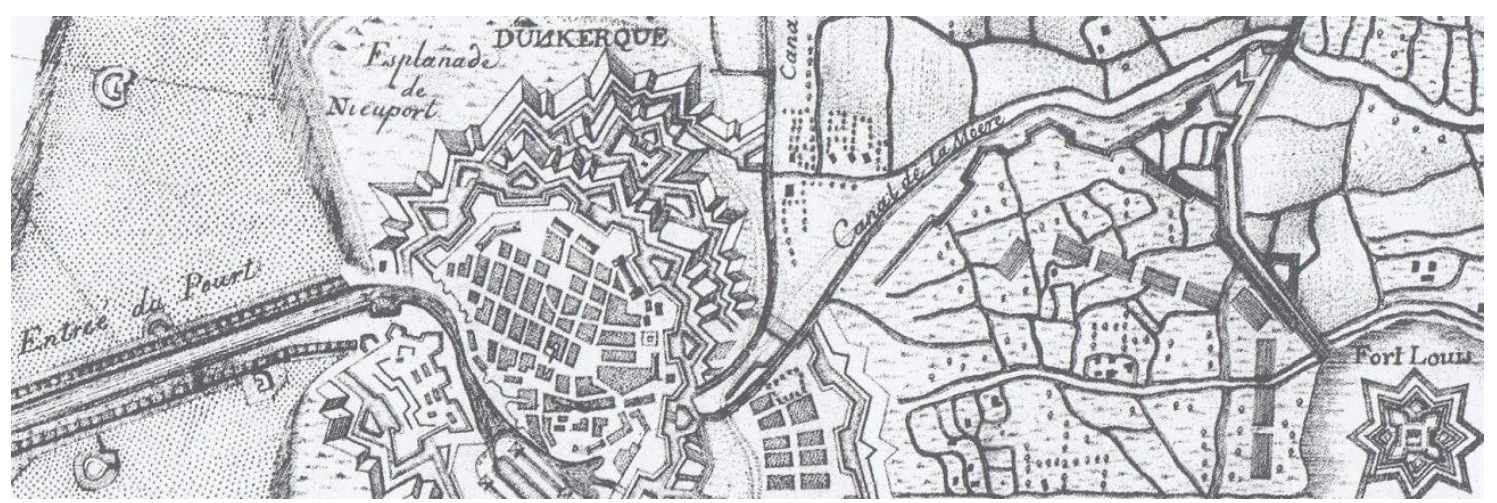

Detalhe de cópia de estampa européia do sistema fortificado de Vauban para Dunquerque, feita pelo partidista da Aula Militar da Bahia José de Sousa, aluno de J. Caldas em 1778 (em OLIVEIRA, 2004: 23).
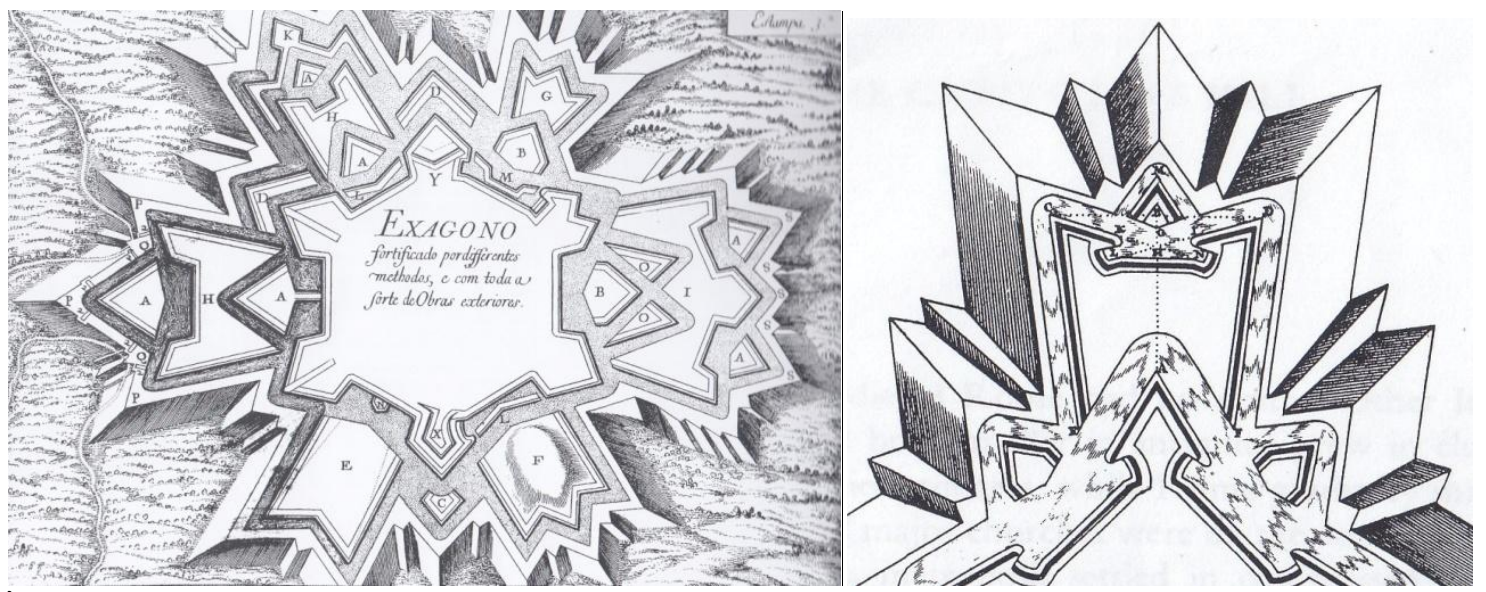

À esquerda, estampa do tratado de Azevedo Fortes que mostra o repertório de obras externas de defesa de uma praça de guerra, provavelmente copiada do tratado de Nicolas de Fer, 1695 (em OLIVEIRA, 2004: 42). À direita, exemplo do sistema abaluartado de fortificações com revenlins em Vauban, 1689 (em ACKERMAN, 1986: 134).

O Marechal Sebastien Vauban foi assim a principal figura da escola francesa, que acabou predominando no século XVIII. Não existe uma total inovação em relação aos sistemas anteriores de ataque e defesa das praças, pois a cultura bélica do período Iluminista acumulava experiências do Renascimento Italiano (para muitos, o sistema francês é uma simples continuidade do italiano, que foi o primeiro utilizado pelos 
fortificadores locais, podendo adaptá-lo e melhorá-lo combinando com suas tradições). ${ }^{121}$ A partir do impulso de Sully, no fim do século XVI, toda uma geração de engenheiros franceses foi bastante prestigiada, com destaque para Vauban. ${ }^{122}$

Sobre os reflexos dessas escolas em Salvador, alguns autores vêem nas fortalezas mais antigas da Bahia, como S. Antônio da Barra e Monserrate, desprovidas de baluartes em ponta de lança, exemplos da Escola Italiana, enquanto as de S. Pedro e Barbalho, providas desses baluartes, seriam da Escola Francesa. Essa classificação não procede, já que a fortificação abaluartarda é uma invenção italiana. ${ }^{123}$ Mais do que isso, a Escola Holandesa também foi seguida ou adaptada pelos portugueses nos séculos XVII e XVIII (M. Oliveira considera esta, depois das invasões, a de maior influência, já que nos tratados portugueses há freqüentes citações a Freytag, Stevin, Marolois, Dögen, Goldman e outros). ${ }^{124}$ No século XVIII Vauban recebeu adeptos, como foi, aparentemente, o Brigadeiro João Massé. ${ }^{125}$

${ }^{121}$ Cf. OLIVEIRA, 2004: 48. M. Oliveira também considera que parte do prestígio de Vauban se deve ao de Luís XIV.

122 Cf. OLIVEIRA, 2004: 48-50. Jean Errard de Bar-le-Duc (1554-1610) - pai da Escola Francesa, mesmo sem inovar em relação à matemática e fortificações que aprendeu na Itália, foi o primeiro tratadista francês a sistematizar o desenho moderno dos fortes; serviu a Henrique IV em várias batalhas e seguia um conceito vitruviano de que a prática sem a teoria era cega, e que a teoria sem a prática era desajeitada; também deve ter se baseado em tratadistas da arquitetura italiana nas suas especulações representadas por outros - sobre o desenho da "Cidade Ideal"; Antoine de Ville (1596-1657) - dedicouse às arte da guerra, construindo e destruindo praças; iniciou seus estudo pelo tratado de Errard de Barle-Duc, serviu em Veneza entre 1630-5 fortificando a cidade de Póla; participou de várias batalhas e escreveu muito, especialmente Les Fortifications, depois editado como Les Fortifications ou l'ingénieur parfait; o seu método é tido como o mais característico dos franceses; Blaise François (1604-65) tratadista que trouxe propostas de fortificações realmente inovadoras à Escola Francesa, iniciando a carreira militar aos 12 anos, participando aos 16 dos assédios de Caen e S. Jean d'Angely e aos 17 no de Montauban, quando perdeu um olho; participou de outras campanhas, duas com Luís XIII, perdendo o outro olho aos 38 anos, quando já era Marechal de Campo, mas continuou a estudar matemática, transformando sua casa numa espécie de academia de cultuadores de ciências e letras; seu tratado de fortificações é dos mais importantes; Sebastien le Preste de Vauban (1633-1707) - serviu por 56 anos a Luís XIV, chegando a Marechal, restaurando ou reconstruindo cerca de 200 fortificações, e fazendo 33 novas; deixou uma série de escritos, mas não um texto específico, acadêmico, sobre a arte de fortificar, nem um tratado que propusesse traçados, talvez por tática defensiva, ou porque sua grande habilidade era entender e tirar partido da realidade dos terrenos, apelando para expedientes de diversas escolas; após sua morte, suas aplicações foram organizadas em três sistemas: a) aprimorando idéias de Errard de Bar-le-Duc, aumentou as faces dos baluartes até $160 \mathrm{~m}$ em Estrasburgo, tendo os flancos dos revelins cerca de $120 \mathrm{~m}$, aumentando assim a linha de atiradores de infantaria, importantes para ele na defesa das praças; em Lille e Toulon; b) baluartes desdobrados e bem destacados das cortinas para aumentar a profundidade das defesas e torres bastionadas com casamatas para canhões de flanqueamento; em Belfort e Landau; c) cortinas em linhas quebradas entre duas torres abaluartadas para facilitar o flanqueamento e possibilitar tiros rasantes no fundo do fosso das casamatas inferiores e reduto na parte posterior do revelim; em Neuf-Brisach. Os principais objetivos em Vauban eram de ter baixas mínimas nos aproches, máximo planejamento logístico de munição e bocas, integração do sistema defensivo ao território e adequação da fortificação ao terreno.

${ }^{123}$ Cf. OLIVEIRA, 2004: 44.

124 Para M. Oliveira, a suposição de que as fortalezas de maior interesse apresentam elementos que permitem classificá-las como mais próximas à Escola Italiana se deve apenas a que "havia, nos primeiros tempos (segunda metade do século XVI e início do XVII), um predomínio muito grande de engenheiros italianos", vindos a trabalho ou supervisionando projetos de Portugal ou da Espanha, como Felippo Terzi, Vicente Casali, Tibúrcio Spanoqui e Leonardo Turriano (OLIVEIRA, 2004: 45).

${ }^{125}$ Há muita dificuldade em reconhecer uma escola ou a filiação de uma fortificação específica. Entre elas: 1- o desaparecimento das obras externas que caracterizavam os sistemas; 2 - não haver suficientes 


\section{Formação dos que atuavam no Brasil: Aulas e Tratados de Arquitetura Militar}

No final do século XV havia dois tipos de ensino de arquitetura em Portugal: um mais ligado à estrutura da malha urbana, que incluía técnicas e formas de fortificação; outro mais ligado às belas artes, em que a arquitetura, pintura e escultura (as três artes do desenho) interagiam numa mesma obra. Ambos se voltavam à cidade, pois a arquitetura dos edifícios considerava a escolha de sítio, implantação e tratamentos do entorno, influindo no crescimento e aspecto urbano.

Em alguns casos, o ensino era eminentemente prático, sendo as próprias escolas as grandes obras públicas de vários reinados, que abrigavam mestres e aprendizes. ${ }^{126}$ Os principais edifícios eram o convento de Tomar e os mosteiros da Batalha e de Belém (depois doado à ordem dos Jerônimos), por onde passaram os principais arquitetos da época. Eles percorriam todas as obras, substituindo uns aos outros. Outros edifícios públicos importantes eram os paços reais de Coimbra, Évora e Vila Viçosa. ${ }^{127}$
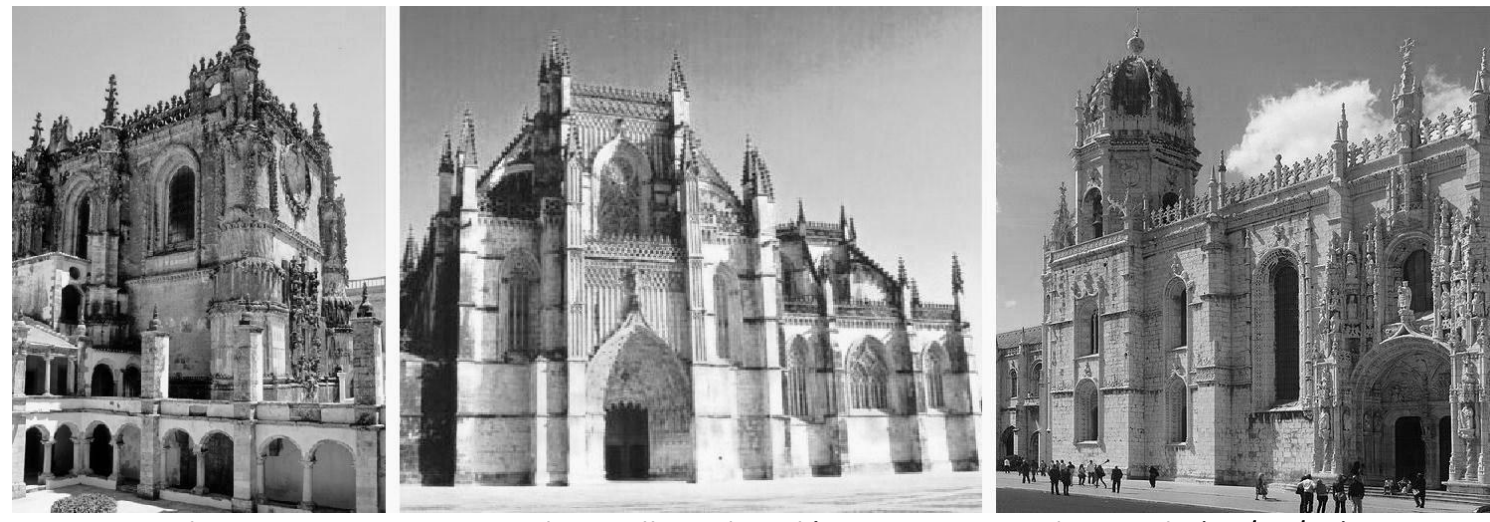

O convento de Tomar e os mosteiros da Batalha e de Belém, em imagens do Google (07/09/09).

No século XVI, em paralelo às escolas práticas, alguns de seus mestres iam à Itália, como João de Castilho e Antonio Rodrigues. Outros de dons artísticos, como

levantamentos cadastrais antigos que mostrem com precisão as relações de proporção entre os baluartes e o perímetro central, os ângulos flanqueados e os de inserção dos flancos nas cortinas, além de muitos outros detalhes geométricos; 3- os "sincretismos" de engenheiros militares que se diziam conhecedores de muitos autores, como mostram os relatórios e textos deixados sobre essa questão (cf. OLIVEIRA, 2004: 45).

Para o desenvolvimento desse assunto, M. Mendonça sugere a leitura de Pfeffinger, traduzido para o português em 1713 (PFEFFINGER, M. Fortificaçam moderna ou recopilaçam de differentes methodos de fortificar, de que usão na Europa. Lisboa: Deslandesiana, 1713), que "estuda os principais elementos da fortificação comparando as escolas e os teóricos mais importantes da sua época".

${ }^{126}$ A graduação era concluída com um trabalho concreto. Os mestres arquitetos, chamados Pedreiros ou Mestres de Obras, também podiam ser estrangeiros, chamados a construir uma obra que depois seria sua escola (como o italiano Boytac - cf. TEIXEIRA \& VALLA, 1999: 125).

${ }^{127}$ Inúmeras obras de Lisboa, Évora e Coimbra também funcionaram como escola. A importante escola do Convento da Batalha começou com D. João I e durou mais de dois séculos. Foi na prática uma oficinamodelo, em que os melhores arquitetos podiam mostrar sua arte. O primeiro mestre foi Afonso Domingues (1402). Também foram mestres João de Castilho (1528) e Miguel de Arruda (1533), além de Carlos Mardel (em 1747 nomeado arquiteto das várias obras reais e do Real Mosteiro de N. S. $\underline{a}$ da Victoria da villa da Batalha). A Escola de Coimbra teve à frente Diogo de Castilho, mestre das obras de toda a cidade de Coimbra (que como Évora era importante centro literário e artístico), desde 1524, já no reinado de D. João III (Cf. TEIXEIRA \& VALLA, 1999: 125). 
Francisco de Holanda, eram escolhidos pelo Rei para viajar, estudar e difundir a arte da fortificação. ${ }^{128}$

A cultura humanística do Renascimento favoreceu a circulação de idéias e o contato entre técnicos. O conhecimento adquirido pelos portugueses era aplicado e desenvolvido em novos contextos, fazendo experimentos fora de seu território. Os mestres eram levados a outros continentes, às vezes percorrendo inúmeras cidades ao longo de anos, fazendo anotações do andamento das obras e do que era necessário fazer. As viagens que começaram no século XV (primeiro ao Norte da África, depois à Índia e ao Brasil) passaram a ser uma espécie de percurso profissional, uma segunda escola de formação. ${ }^{129}$

\subsection{Escola de Moços Fidalgos do Paço da Ribeira (tratados de Antônio Rodrigues)}

No começo do século XVI já se pensava em um ensino formalizado sobre conceitos e técnicas usadas na Europa, que teorizasse a prática portuguesa. São de meados desse século as aulas ligadas à cosmografia no Armazém da Guiné e da Índia, onde os mestres de cartas de marear trabalhavam desde 1514. Com Pedro Nunes, matemático e cosmógrafo-mor do Reino desde 1547, começaram a ser dadas cartas de ofício e aulas de matemática a pilotos. Em 1559 ele já ensinava na Aula do Paço, reorganizada em 1562 por D. Catarina para preparar jovens de origem nobre (como o futuro Rei D. Sebastião, provável razão de ser da Aula), que serviriam nas conquistas. Em 1568, Pedro Nunes introduziu o estudo elementar das Matemáticas e da Esfera (Cosmografia), mas por morar em Coimbra, foi substituído provavelmente por João Baptista Lavanha, também cosmógrafo. Junto com geometria e cosmografia, o curso ensinava arquitetura, o que implicava em arquitetura militar.

Em 1564 Antônio Rodrigues se tornara Mestre de Todas as Obras Régias (substituindo Miguel de Arruda) e no ano seguinte (com a morte de Afonso Álvares) o Mestre das Obras das Fortificações, acumulando os dois cargos até 1590. Nessa posição, e ainda como cosmógrafo-mor, passou a ensinar arquitetura, produzindo os tratados manuscritos de 1576 e $79 .{ }^{130} \mathrm{O}$ de 1576 discorre sobre Arquitetura Militar, Geometria, Trigonometria e Perspectiva, com base em Vitrúvio (traduzido por Daniele Barbaro), Pietro Cataneo e nos II Primo Libro e II Secondo Libro di Perspectiva di Sebastian Serlio Bolognese. O de 1579 é uma nova versão do mesmo, ${ }^{131}$ aprofundando questões específicas de geometria com base no Livro I de Sérlio.

Os tratados de Antônio Rodrigues eram as "apostilas" de suas aulas de teoria e prática aos jovens fidalgos, mostrando as referências teóricas dessa primeira iniciativa

\footnotetext{
${ }^{128}$ Ele voltou a Portugal depois de freqüentar a oficina de Antonio Sangallo em Roma, entusiasmando-se com as artes (transmitindo-as à Corte) e ideais renascentistas (desenvolvendo também os próprios).

129 Os Mestres de Obras passaram a ampliar suas ações, sendo não só arquitetos, mas fortificadores, fazendo relacionar a cidade e sua fortificação, edifícios públicos e malha urbana, com uma aplicação mais direta dos ideais renascentistas de associar cidade e representação do poder, na imposição de seu modelo civilizatório a outros povos.

${ }^{130}$ Cf. MOREIRA. Um tratado português de Arquitectura do século XVI (1576-1579). Lisboa, Dissertação de Mestrado em História da Arte, Faculdade de Ciências Sociais e Humanas da Universidade Nova de Lisboa, 1982/ BUENO, 2001: 311.

${ }^{131}$ Nele o autor alude ao primeiro livro, que Rafael Moreira (op. cit., 1982) afirma ser o manuscrito da BNL (1576), pelo mesmo tipo de papel. A versão da BMP seria a redação definitiva (versão de luxo) do de Lisboa.
} 
oficial de ensino de Arquitetura Militar. ${ }^{132} \mathrm{~A}$ iniciativa didática da Escola de Moços Fidalgos do Paço da Ribeira teria impressionado Filipe II e Juan de Herrera quando estiveram em Lisboa no início da União das Coroas (1581-2), levando-os a criar uma instituição semelhante no Alcázar de Madri, a Academia de Matemáticas $e$ Arquitectura (1583). ${ }^{133}$

${ }^{132}$ A formação incluía as sete Artes Liberais: o Quadrívio (Aritmética, Geometria, Astronomia e Física) e o Trívio (Lógica, Sofistica e Retórica), além das principais questões de Cosmografia: ... hos movimemto dos séos, ... estrelas herraticas..., ho yclysar do sol por que ocazião ho fazia, ... ho heclysar da lua, ... que couza era lua chea ... e ... lua noua, ... latitude e longitude... pera que por hela souberem dezer quamto hua pouoação estaua hapartada da houtra... (tratado manuscrito de Antonio Rodrigues, fl. $3 \mathrm{v}$ - apud BUENO, 2001: 312). Em Arquitetura ou Fortificação, que Antônio Rodrigues lecionava, o lente se baseava em Vitrúvio O programa da disciplina era organizado pelos capítulos do tratado de 1576: 1 Escolha de sítio (na construção de povoassão ou edefisyo deveria se considerar: região, vento, água, terra fértil, pasto, lenha, não ser serra ou vale, altitude, acesso); 2 - Região (características e recomendações; segundo Cataneo, países quentes deveriam ter ruas estreitas, e países frios, largas); 3 Ventos (teoria dos quatro elementos - fogo, ar, água e terra - como parte do ensino de Cosmografia, que para Cataneo diz respeito à implantação de edifícios e cidades); 4 - Águas (resumo do que é dito por Pietro Cataneo); 5 - Conhecimentos necessários ao arquiteto (como Vitrúvio, ele enumera: Latim, Aritmética, Geometria, Desenho, Cosmografia, Física, Astrologia [“Estorlogia”], Música [... para que hemteda as porposois das vozes, porque por estas porposoys etemdera as proporsois que am de ter seus edefisios;... ], Arte da Artilharia [...he emtemdemdo bem a força da artelharia saberá a pramtar domde faça mayor hefeito cõtra seus ynemygos... - apud BUENO, 2001: 317], além de conhecer a qualidade da pólvora e outros materiais - pedra para se fazer a cal, areia para misturar e fazer muros, madeira, terra -, e ser grave, allegamte e reitoryco); 6 - Construções de terra (para que fortificação de terra fosse durável, era feita a "fachyna", que... não é outra couza senão ramos de árvore delgados... de cõprimento de tres palmos ate quatro muyto dereyto, asy como são os vymes [fl. 13], enquanto a "frasca" não he houtra couza que ramos de arvores da grossura da perna de hu ome aryba do artelho, os quais são dereytos e terão de cõprymento quatorze ou quymze palmos [fl. 13v]; apresenta em seguida um estudo sobre as melhores árvores par extração de madeira). 7 - Fabricação da cal; 8 -... d'areia e de sua cõdisam; 9 -... da propriadade do baro pera teyolo; 10 -... do tempo em que se a de fazer o edefísio; 11 - ... do tempo cõvenyemte para se poder fabricar de terá; 12 -... do tempo conveniente para se cortar a madeira; 13 -... da propriedade das aruores e quais sam boas pera os edefisios; 14 -... Giometria (a Geometria Euclidiana era baseada em II Primo Libro... de Serlio, impresso em Paris em 1545 e principal referência didática da época); 15 (sem título, sobre Trigonometria) e 16 (idem, sobre Perspectiva - sobre a qual se mostra atualizado, seguindo o Livro da Prespetiua de Serlio). Cf. BUENO, 2001: 314-30.

Esses tratados deram início à divulgação das teorias referentes à Arquitetura italiana no âmbito de Academias, e assim de métodos sistemáticos na elaboração da forma. Os principais lentes da Escola de Moços Fidalgos do Paço foram Pedro Nunes (cosmógrafo-mor do Reino, lente de Matemática e ciências afins - tradutor de Vitrúvio a autor de muitos tratados), António Rodrigues (Mestre de todas as obras régias e Mestre das obras das fortificações, lente de Arquitetura Militar e ciências afins) e João Baptista Lavanha (cosmógrafo e matemático, substituto de Pedro Nunes como professor de Matemática e Geometria).

${ }^{133}$ A transferência da Escola de Moços... de Lisboa para a Alcázar de Madri no momento da união das Coroas foi significativa, chegando alguns autores a entender que "Felipe II teria assimilado uma estrutura de ensino já consolidada em Portugal desde 1562 e sem precedentes na Espanha" (BUENO, 2001: 346).

Na Academia de Madri foram produzidas muitas obras, como as traduções de Vitrúvio (De Architettura, por Miguel de Urrea, Alcalá, 1582), Alberti (Los Diez Libros de Architectura, por Francisco Lozano, Madri, 1582), Euclides (por Pedro Ambrósio Onderiz, La Perspectiva y Especularia de Euclides, Madri, 1584) e Vignola (Regla de los cinco ordenes de Architectura, por Patricio Caxexi, Madri, 1593), surto editorial que lembra o ocorrido em Portugal nos anos 40 e 50 (cf. MOREIRA, 1987, op. cit., p. 73-5/ BUENO, 2001: 349). Rafael Moreira também ressalta a grande biblioteca particular de Juan de Herrera, contendo a Algebra de Pedro Nunes (e sua obra completa) e o manuscrito De la conserbación de los aquadutos, en português (cópia ou original da tradução de André de Resende encomendada por D. João III para os Dois Livros dos Aquedutos de Frontino). Também foi dele (estando na relação de 1610 de seu 
Com Filipe II foi criada a Aula do Risco (1594), de três vagas, sendo o primeiro mestre de arquitetura Filippo Terzi, que chegara a Portugal no reinado de D. Sebastião. Com o fim da Escola de Moços... (ou sua transferência para Madri na criação da Academia...), e a morte de António Rodrigues (1590), Filippo Terzi foi nomeado Mestre das obras de El-Rei e depois Arquitecto Geral, encarregado de supervisionar a formação de três discípulos. Era uma aula paralela à de Madri (dada por Herrera), com disciplinas que iam da matemática à arquitetura civil, fortificação e cosmografia. ${ }^{134}$

A Aula do Risco não era uma escola nos moldes atuais, mas um estágio remunerado com o Mestre das obras de El-Rei. Pelos alvarás de nomeação dos partidistas, os três prestariam serviços no Gabinete das Obras d'el Rei, ajudando para as trassas de obras oficiais. Deles, os discípulos de partido, ${ }^{135}$ exigiam-se conhecimento, experiência e suficiência na arte da Arquitetura (não havia aprendizagem teórica da matéria). Também tinham de freqüentar a cadeira de geometria, do Cosmógrafo-mor do Reino (João Baptista Lavanha, já em Portugal). Nomeados pelo Rei, recebiam 20 mil réis anuais, sendo depois de formados colocados em cargos para especialização. ${ }^{136}$

O Tractado de Architectura quê leo o Mestre, \& archit Mattheus do Couto o velho (1631) exemplifica o ensino dado na época na Aula de Architectura do Paço, com questões teóricas relacionadas à Arquitetura Civil, Religiosa, Militar e específicas do desenho. Junto com os tratados deixados pelos padres jesuítas, mostra como era a formação desses profissionais no século XVII. Eram quatro livros divididos em capítulos, mais um tratado de Perspectiva em que as primeiras 12 páginas foram literalmente copiadas de II Secondo Libro di Serlio. Também menciona um livro de arquitetura militar, desaparecido. ${ }^{137}$

Além de incompleto, o tratado já não traz as ilustrações (nem as mencionadas no texto), apenas as do tratado de Perspectiva. ${ }^{138}$ Ma o conteúdo é suficiente para se ter noção do Programa da Aula, estruturado (como talvez o curso) em: Livro I Questões teóricas gerais: Arquitetura, Arquiteto e Teoria das Ordens; Livro II Questões específicas referentes ao edifício: forma, distribuição e materiais; Livro III -

discípulo e herdeiro Francisco de Mora) a tradução de Pedro Nunes para o De Architectura de Vitrúvio (1541), dada como desaparecida.

${ }^{134}$ Entre o fim da Escola de Moços... e o professorado de Terzi se passaram onze anos, período em que os padres jesuítas ganharam terreno, criando por volta de 1590 a Aula de Esfera no Colégio de Santo Antão para jovens nobres e técnicos em geral. Mas por sete anos (1583-90) não houve ensino oficial de Arquitetura em Portugal.

135 Cf. SMITH, 1998: 57 (nota 160): “A tradução da palavra 'partido' parece aqui autorizada pela implicação da idéia de 'ganho', que a palavra possui. D. Raphael Bluteau, o eminente lexicógrafo português do século XVIII, dá os seguintes exemplos: 'dar partido ao parceiro, he concederlhe alguma condição vantajosa'; ;..".

${ }^{136}$ As novas vagas ocorriam com a morte ou ascensão profissional do partidista, que ao se formar ostentava o título de arquiteto ou engenheiro. O ex-partidista também podia se tornar lente da Aula, como foi o caso de Matheus do Couto.

$137 . .$. E naõ tratamos aqui o como dentro da agua se poderão edificar estas Pontes, sem a esgotar; porq hey de tratar no Lo da Architectura Militar como se poderá fundar toda a fabrica no mais fundo Rio, ou mar que houver... (Tratado de Matheus do Couto , 1631, p. 70 - apud BUENO, 2001: 356-7).

${ }^{138}$ A versão da BNL (cód. 946) é a cópia não concluída de um discípulo, que menciona serem 189,5 os fólios do tratado, mas há 98. 
Desenho, Galhardia e Compostura; Livro IV (inacabado); Tratado de Perspectiva (incompleto). Os dois autores mais citados são Alberti e Vitrúvio (traduzido por Daniele Barbaro), em questões gerais da Arquitetura e do Arquiteto. Nas demais questões, incluindo a Teoria das Ordens, cita Serlio (Livro IV). Para definir Arquitectura, Matheus do Couto cita o Livro I de Vitrúvio e o prólogo do Livro I do De re aedificatoria. ${ }^{139}$

Em nossa arquitetura colonial da segunda metade do século XVII há muitas diretrizes mencionadas por Couto, também presentes em seus projetos. ${ }^{140} \mathrm{Em}$ arquitetura religiosa há o exemplo do Mosteiro de São Bento (RJ), trassa de Frias de Mesquita, ex-aluno da referida Aula. Nem os tratados de Antônio Rodrigues nem o de Couto são simples manuais práticos de construção, mas dão uma boa dimensão teórica, sintética e pragmática, orientando a prática profissional de seus alunos. ${ }^{141}$

Foram docentes da Aula de Arquitetura do Paço: ${ }^{142}$ Filippo Terzi (1594-7, falecendo neste último ano), Nicolau de Frias (a partir de 1598), Matheus do Couto, o velho (a partir de 1631) e Antonio Torres (não se sabe a data).

${ }^{139}$ B. Bueno (2001: 361-6) transcreve do Livro I os capítulos 1 (sem título), 2 - Em q se define que couza hé Architectura, 3 - Que partes deve ter o Architecto, 4 - Em q se declara que couza he edificar, e que couza seja edifício e 5 - Qual deve ser o sítio para edificar Cidades, Villas, ou Lugares e porque indícios conheceremos sua bondade. Também traz os títulos de cada Livro, nas páginas 358-9.

Como Vitrúvio, ele define onze saberes tradicionais necessários ao arquiteto: Gramática, Desenho, Geometria (prática), Perspectiva, Aritmética, História, Filosofia, Música, Medicina, Leis, Matemática aplicada à Astrologia, Cosmografia, Gnomônica. Ao definir edificar, faz uso implícito do princípio albertiano de reflexão a priori - praecogitare, praedefinire - antes da construção. Concebe o edifício como um corpo feito de membros (mais elegantes quanto mais proporcionados) contendo forma (figura), distribuição (composição) e materiais (pedra, cal, madeira...). Também como Vitrúvio, aponta as características ideais de sítio para edificar Cidades, Vilas e Lugares, mostrando a preocupação urbanística no programa da Aula: lugar sadio; nem frio nem quente aos extremos; eminente; facilmente acessível de carro ou a cavalo; dotado de animais sadios e boa vegetação; com boas águas; com homens bem dispostos, crianças e mulheres sadias; bons ares e frutos (cap. 5 do Livro I).

O seu resumo dos cinco gêneros de coluna - Toscana, Dórica, Jônica, Coríntia e Compósita - tem como principais referências Serlio (Livro IV), Vitrúvio (tradução de Daniele Barbaro, Liv. III, Cap. 3 e Liv. IV, Cap. 1 e 7), Palladio (Liv. I) e Alberti (Liv. VI, Cap. 13, ao versar sobre a origem das colunas, principais ornatos do edifícios). Ele se apóia principalmente em Serlio, mas em nenhum momento copia mecanicamente suas passagens e sim elabora uma síntese prática, mostrando opiniões (citando as fontes), comentando-as e dando o seu parecer.

No Cap. 1 do Livro II (cf. BUENO, 2001: 379), ele fala da teoria das proporções, mostrando analogias entre Arquitetura e Música. Faz depois as considerações teóricas que levariam sempre à escolha do ângulo reto, plantas retangulares ou quadrangulares (que se nota no partido da maioria das igrejas e edifícios civis do Brasil Colônia feitos por engenheiros militares).

Beatriz Bueno considera o tratado de Matheus do Couto um dos mais importantes documentos portugueses sobre Arquitetura, por ser densamente informativo e conhecedor da tratadística clássica. Não é especulativo: aborda as questões com objetividade e concisão (quando cita Alberti, por exemplo, são questões mais práticas que teóricas). Sendo a apostila da lição dada aos três partidistas da Aula de Architectura do Paço da Ribeira, mostra o tipo de arquitetura praticada e sua grande fundamentação teórica. É um tratado de Arquitetura Civil, mencionando um livro específico sobre Arquitetura Militar que integraria este ou outro tratado de mesma autoria (não é claro), o que mostra que o ensino do Paço da Ribeira envolvia as duas matérias, e outras relacionadas ao desenho (pois há um tratado de Perspectiva, copiado das primeiras 12 páginas e suas ilustrações do // Secondo Libro de Prespectiva de Serlio - cf. BUENO, 2001: 392.

${ }^{140}$ B. Bueno reproduz um dos projetos, encontrado por ela na Biblioteca Nacional de Lisboa (fig. 142-a).

${ }^{141}$ Cf. BUENO, 2001: 393-5.

${ }^{142}$ Cf. BUENO, 2001: 356 (quadro com base em VITERBO, 1904: II, cap. V-VII). 


\subsection{Aula de Esfera do Colégio de Santo Antão}

Antes de haver uma aula específica para formação dos engenheiros militares, ${ }^{143}$ a instrução das matérias se dava na Aula de Architectura do Paço da Ribeira, de apenas três partidistas, e na Aula de Esfera do Colégio de Santo Antão. O Colégio começou em 1545 (ano em que os jesuítas, antes sediados em Roma, instalaram-se em Portugal), oficializando a Aula da Esfera em 1590. Nela os padres ensinavam matérias ligadas à Cartografia (matemática, geografia) que dariam base à engenharia militar como ciência. ${ }^{144}$

No início, a Aula da Esfera seria semelhante à de matemática dada pelo cosmógrafo-mor, mas com o tempo teve alterações e afastou-se da prática de marear. Numa primeira fase, a especialização no ensino náutico distinguia a escola de Santo Antão das outras européias dirigidas por jesuítas, fazendo com que muitos estrangeiros a freqüentassem. Preparava missionários para a Índia e era o único colégio com ensino regular de matemática acima do nível elementar, buscando a máxima profundidade científica. ${ }^{145}$ Assim como o curso, o público era heterogêneo, composto de fidalgos e não fidalgos, compensando a lacuna deixada pela Coroa em relação à formação de técnicos para a política imperialista da época. ${ }^{146}$

Entre 1630-5 foi lente o padre irlandês Inácio Stafford, escrevendo um compêndio de matemática com a última parte dedicada especificamente à fortificação. Em 1635 assumiu o também irlandês Padre Simão Fallônio, a quem D. João IV encarregou de desenhar fortalezas na costa de Portugal, concedendo-Ihe o título de engenheiro-mor do reino. ${ }^{147} \mathrm{O}$ ensino da Aula de Esfera, com base na matemática

${ }^{143}$ A Aula de Fortificação... da Ribeira das Naus, de que falaremos a seguir.

144 Tornou-se uma cadeira específica de matemáticas aplicadas à Ciência Náutica, Astronomia, Cosmografia (= Esfera), Geometria Prática, Geografia e Arte de Fortificar, dirigida a pilotos, cartógrafos, construtores de instrumentos náuticos, homens do mar, fidalgos, arquitetos e engenheiros militares (cf. TEIXERA \& VALLA, 1999: 125-6).

Mais uma vez, o ensino se justificava pela crescente necessidade de formar técnicos em fortificação. Se no final do século XVI o desafio da Coroa era mudar os rumos da política ultramarina de expansionista para controladora de terras conquistadas, já em meados do XVII ela precisou redefinir o seu sistema de defesa na Europa em função da guerra de Restauração. Era preciso um novo profissional, mais engenheiro-geógrafo do que cosmógrafo-cartógrafo. Novos procedimentos, técnicas, instrumentos e agentes eram necessários ao desbravamento e mapeamento de terras no novo mundo, à oficialização dos territórios continentais e das Conquistas, pela construção de um sistema eficiente de defesas. Os padres jesuítas, grandes matemáticos, geógrafos e cosmógrafos, ajudaram a formar esse novo profissional, não só fortificador ou architecto, mas agrimensor, topógrafo, geógrafo e cartógrafo (cf. BUENO, 2001: 397).

${ }^{145}$ Cf. TEIXEIRA \& VALLA, 1999: 126.

${ }^{146}$ Sem uma escola oficial no Paço para o público em geral, os fidalgos interessados em servir ao Rei nas conquistas se dirigiam a Santo Antão. Entre outros, estudaram no Colégio: Baccio da Filicaia (primeiro engenheiro-mor do Brasil), João Teixeira Albernaz I (dos mais importantes cosmógrafos no século XVII), Bartolomeo Zanit, João Nunes Tinoco (arquiteto e também ex-partidista da Aula de Architectura do Paço da Ribeira), Luís Serrão Pimentel.

147 Cf. AlBUQUerque, Luís de. A "Aula de Esfera” do Colégio de Santo Antão no Século XVII. Anais da Academia Portuguesa da História. Lisboa: 1972, v. LXX, p. 18/ TEIXEIRA \& VALLA, 1999: 126.

Beatriz Bueno (2001: 415) considera relevante a participação de muitos missionários estrangeiros pela introdução de novos paradigmas. Segundo Edwin Paar, Stafford conhecia a fundo os principais tratados italianos da época (Nicola Tartaglia - 1556-60, Bonaiuto Lorini - 1597 e Scala - 1621) e teria introduzido os tratados holandeses e franceses no Colégio de Santo Antão, pois era leitor do holandês 
aplicada à Ciência Náutica, Artilharia e Fortificações, estabelecia pontos comuns entre engenheiros e cosmógrafos, produzindo um número relativamente alto de apostilas. ${ }^{148}$

\subsection{Aula de Fortificação e Arquitectura Militar da Ribeira das Naus}

Com a Restauração na guerra contra a Espanha (1640), precisando fortificar as cidades portuguesas e diminuir a cara dependência de profissionais estrangeiros, ${ }^{149} \mathrm{D}$. João IV criou em 1641 a Aula de Artilharia e Esquadria, uma instituição específica de ensino de Arquitetura Militar no Paço da Ribeira. Em 1647 ela foi transferida para a Ribeira das Naus com o nome de Aula da Fortificação e Arquitectura Militar, sendo também chamada de Academia Militar ou Aula Régia (foi a primeira instituição portuguesa direcionada a formar somente engenheiros militares, oficializando-se $o$

Samuel Marolois (edição latina de 1633) e dos franceses Errard de Bar le Duc (edição de 1620) e Antoine de Ville (1628).

148 Pela lista dos professores dessa principal cadeira e pelo conteúdo de suas lições, nota-se uma mudança em três direções: 1- disciplinas ligadas à Geometria Prática, Geografia e Arquitetura Militar sobrepujando matérias mais relacionadas à Ciência Náutica (Cosmografia e Astrologia); 2- a convivência com os engenheiros militares levando os cosmógrafos a ter conhecimentos mais sólidos no desenho das Cartas Geográficas, Corográficas e Topográficas; 3- a cultura italiana cedendo lugar à holandesa e francesa, mais atualizadas. Foi nesse contexto de mudança que se formou o futuro Cosmógrafo e Engenheiro-mor do Reino, Luís Serrão Pimentel (cf. BUENO, 2001: 420-1).

O Padre Luiz Gonzaga lecionou na Aula de Esfera do Colégio de Santo Antão de 1700 a c. 1710, depois de transferido da Universidade de Évora (onde ensinava letras humanas) para ser mestre do futuro rei D. João V. Em seu curso havia lições de Cosmografia, Astrologia e Matemática (Geometria Prática), e principalmente de Arquitetura Militar. Redigiu os seguintes "tratados" (apostilas): Exame militar [Tratado de Architectura riscado]: mandado ditar por ordem do Augusto Senhor Dom Pedro 20 em o Collegio de $S^{\text {to }}$ Antam aos depois mandado ensinar a todos seos tres filhos. Pello P. Luiz Gonzaga (BAj "Códice E", BAj, 46-VIII-23 - c. 1700); Esphera Astronomica composta e dividida em círculos (BAj "Códice C" ou BGUC - "Códice J"); Tratado Astrológico, Fragmentos de Geometria Prática, Scala Mensoria, Scala Aritmetica (BAj - "Códice D”). Cf. BUENO, 2001: 417-20.

Enquanto os tratados de Antônio Rodrigues e Matheus do Couto mostravam dependência exclusiva da tratadística italiana, os tratados do século XVII (e os padres jesuítas do Colégio de Santo Antão encarregados de ensinar Matemática na Aula de Esfera) evidenciam "sua substituição progressiva [por] tratados holandeses e franceses" (BUENO, 2001: 414).

149 Na Restauração, o intercâmbio com a França e a Holanda se fortaleceu. Na falta de engenheiros militares, D. João IV (1640-56) enviou embaixadores a Paris e Haia (principais centros de cultura e divulgação de modelos da época) para contratar profissionais experientes. A partir 1641 foram nomeados embaixadores portugueses nos Países Baixos (Trystão de Mendonza, depois Francisco de Andrade Leytão em 1642 e depois D. Francisco de Sousa Coutinho em 1644, ficando até 1650) e em Paris (Francisco e Melo e depois o Conde da Vidigueira). O intercâmbio resultou na contratação de muitos engenheiros militares: os franceses Charles Lassart e Pierre Girles de St. Paul (1641), Michel Lescole (de L'Ecole - 1643), Nicolas de Langres (1644), Pierre de Sainte Colombes (1648) e Alain Manesson Mallet (1664); os holandeses Michael Timmermans (1645-63), Jean Gillot e o Padre João Cosmander (Jan Ciermans) - os dois últimos sem experiência prática na Arte da Fortificação, mas foram bem acolhidos em Portugal, recebendo de D. João $V$ cargos elevados no exército, o que mostra a falta de engenheiros militares na época (o Padre Cosmander chegou a ensinar Elementos de Euclides e fortificação a D. Teodósio, primogênito de D. João IV). A contratação de engenheiros militares franceses importantes (Lassart, Langres e Gilot) também explica o reconhecimento progressivo dos tratados de Antoine de Ville e Conde de Pagan entre os engenheiros militares portugueses (cf. PAAR, Lewis. As influências teóricas holandesas na arquitectura militar portuguesa seiscentista: Luís Serrão Pimentel e a "Escola holandesa" de fortificação (1995, p. 12)/ As fortificações seiscentistas de Elvas e o primeiro sistema holandês de fortificação, 2001/ As influências holandesas na arquitectura militar em Portugal no século XVIII: as cidades alentejanas. Arquivo de Beja, v. VII e VIII, série III/ BUENO, 2001: 416-7). 
título e diminuindo a importância do Colégio de Santo Antão na preparação de técnicos em ciência náutica e Arquitetura Militar). ${ }^{150}$

A escola propiciaria a produção e impressão de dois tratados de fortificação, o de Luís Serrão Pimentel - Methodo Lusitanico de Desenhar as Fortificaçoens... (1680) e o de Azevedo Fortes - O Engenheiro Portuguez (1728). Esses tratados representam além da teorização de uma prática desenvolvida por mais de um século, a necessidade de ensinar métodos adequados às novas teorias de fortificação. ${ }^{151}$ Até então, o ensino se baseava em tratados estrangeiros ou manuscritos dos próprios lentes. A Aula da Ribeira era o modelo de outras escolas que se pretendia fundar em Portugal.

\section{Luís Serrão Pimentel e o Methodo Lusitanico...}

Serrão Pimentel foi titular da Aula Régia da Corte entre 1647-78, quando escreveu vários manuscritos. ${ }^{152}$ No reinado D. Pedro II (também lente das aulas de fortificação), decidiu-se pela impressão de um tratado reunindo informações estrangeiras e manuscritos portugueses. Foi primeiro apresentado, em 1670, o de Miguel de L'Escol, engenheiro francês que serviu no norte de Portugal, mas que acabou sendo censurado por Simão Mateus. ${ }^{153} \mathrm{Em} 1680$ foi impresso o primeiro tratado português, principal documento sobre o conteúdo da Aula de Fortificação $e$ Arquitectura Militar: ${ }^{154}$

\footnotetext{
${ }^{150}$ A nova Cadeira da Ribeira das Naus tinha os mesmos objetivos da lição dada pelo cosmógrafo-mor desde a época de Pedro Nunes (a pilotos, homens do mar, cartógrafos, etc.), que além de dar formação teórica, examinava seus instrumentos, cartas náuticas e demais elementos da profissão (o que explica por que a partir de meados do século XVII as funções de cosmógrafo e engenheiro-mor foram exercidas pela mesma pessoa).

${ }^{151}$ Cf. TEIXEIRA \& VALLA, 1999: 126-9. Para Margarida Valla, os dois séculos de experiência em fortificações e traçados urbanos levaram os portugueses a criar uma escola prática de adaptação a características de sítio e intervenção maleável, a partir das atuações dos engenheiros encarregados das diferentes tarefas em locais variados. Essa escola prática se obrigaria a definir um método próprio de aplicação dos conceitos teóricos desenvolvidos na Europa e criar as próprias regras. Os dois tratados impressos teorizam essas regras e métodos, "consolidando" uma escola portuguesa de fortificação e urbanismo (estando os dois campos "intimamente ligados nessa prática de intervenção"). Objetivavam a divulgação, pelo ensino oficializado, de conceitos teóricos de intervenção e, ao mesmo tempo, "de métodos de aprendizagem de tecnologias" que permitissem de medições e levantamentos de terrenos a desenhos e construções dos componentes de fortificação.

${ }^{152}$ Eles eram, como para outros lentes, o seu material de apoio no curso. O primeiro trabalho, não editado (mas que se refere como seu primeiro tratado sobre fortificação), foi a Hercotectonica Militar (possível neologismo criado por ele - cf. OLIVEIRA, 2004: 51). Já o Tratado da Opugnação, e Defença das Praças (BNL, Cod. 1640) abordava táticas de guerra, de ataque e defesa (cf. TEIXEIRA \& VALLA, 1999: 129). A Architectura Militar ou Fortificação foi ditada por ele e escrita por Francisco de Osório em 1659 (cf. OSÓRIO, Francisco. Architectura Militar ou Fortificação, dictada por Luis Serrão Pimentel, 1659, BNL, Cod. 6408). O Extracto ichnographico do Methodo Lusitanico, Novo facillimo, e apuradíssimo, Pera desehar, As Fortificaçoens, de 1670 (BNL, Cod. 2044), era o resumo do livro que estava elaborando (Methodo...), impresso depois (cf. TEIXEIRA \& VALLA, 1999: 129). M. Oliveira (2004: 50-1) destaca-o como o mais interessante (compacto em relação ao Methodo..., com cópias manuscritas na BAj, BNL e AML, podendo haver outras). A introdução com um panegírico a Cosimo III (exemplar da BAj) mostra a sua grande erudição: conhecimento de autores clássicos, cultura humanística, latim e outras línguas.

${ }^{153}$ Cf. TEIXEIRA \& VALLA, 1991: 128.

154 Os demais textos-apostilas são manuscritos, copiados e re-copiados por inúmeros discípulos, sem uma versão impressa. Para Pimentel, o seu Método sahido da Aula Regia sintetizava a longa atividade de mestre:... lendo mais de 32. annos diversas materias de Mathematica em que entrou por vezes a
} 
Methodo Lusitanico de Desenhar as Fortificaçoes Regulares, \& Irregulares, Fortes de Campanha, e outras Obras pertencentes a Architectura Militar. Distribuido em duas Partes Operativa e Qualificativa. Ao muito Alto, e Poderoso Principe Dom Pedro Nosso Senhor. Por Luis Serrão Pimentel Engenheiro mor, e Cosmografo mor do Reyno, e Senhorios de Portugal, Tenente Geral da Artilheria em qualquer das Provincias do Reyno. Em Lisboa com as licenças necessarias. Na impressão de Antonio Craesbeeck de Mello Impressor de S. Alteza. Anno 1680. ${ }^{155}$

Era sua apostila de aula: ${ }^{156}$ um método, como diz o título, para ensinar alunos da Aula Regia a projetar fortificações regulares e irregulares, conforme o sítio. Os engenheiros militares portugueses passariam a fortificar segundo um livro, uma teoria que orientasse a prática. No proêmio está definido o corte temático: o Método Lusitano se diferia dos estrangeiros por se adequar às necessidades locais, ${ }^{157}$ orientando os engenheiros naturaes a aprender sciencia de modo acessível, pois a experiencia exigida pela prática não era suficiente.

... pello que nem sò a sciencia, nem sò a experiencia bastão; hua, \& outra saõ necessarias para formar hum bom Engenheiro... ${ }^{158}$ Daqui nasce o que em algum vi o qual por naõ ter liçaõ, nem doutrina precedente, depois de largo exercicio ainda naõ obrava cousa a proposito acerca dos desenhos; \& pello contrario outros q' entrarão com liçaõ, em brevíssimo tempo porem se logo na practica do que hua vez virão, \& da qui habeis para o desenho, \& execução de outras q' naõ havião visto obrandoas com acerto... ${ }^{159}$

O tratado fala da hercotectonica (delineação e fábrica, ou, desenho e construção), propondo dois modos de desenhar com base em regras geométricas: um partindo dos lados exteriores para dentro do polígono e outro dos lados interiores para fora. A primeira parte do livro, "Operativa", ${ }^{160}$ traz regras para os desenhos de fortificação. Como os estrangeiros, Pimentel propunha que a fortificação irregular se aproximasse o mais possível da regularidade. ${ }^{161}$ Lembrando o predomínio da irregularidade no século XVII (pela necessária adaptação a terreno de sistemas complexos de fortificação em cidades existentes), ensinava como regularizar os elementos, a forma poligonal do perímetro, muros e baluartes. A segunda parte, "Qualitativa", ${ }^{162}$ traz a teoria das regras anteriores, muito apoiada nos tratados de fortificação da época - métodos de Maralois, Fritach, Dogen, Cellario, Goldman, Antoine de Ville e Conde Pagan (sendo mais reverenciados os dois últimos). Para Pimentel, nenhum desses autores fez com que as regras fossem de fácil aplicação, o que era a proposta de seu livro, um método também com novas técnicas de medição.

Fortificacaõ, he força q andem espalhadas, não sòmente entre os discipulos, mas entre outros que as trasladarão (PIMENTEL, 1993: última página do Proêmio).

155 PIMENTEL, 1993 (título na página interna).

156 ... donde eu deduzi este compendio há muitos annos, o qual hei lido na Aula regia onde professo as Mathematicas, para exercício dos calculos da Hercotectonica que ditei (PIMENTEL, 1993: 540).

${ }^{157}$ A comentada falta de profissionais em Portugal levava à cara contratação de estrangeiros.

158 É uma citação a Vitrúvio, que diz que os Arquitetos - nome genérico para civis e militares - devem lidar simultaneamente com a prática e a teoria (fabrica e raciocinato).

159 PIMENTEL, 1993: Proêmio.

${ }^{160}$ Cf. PIMENTEL, 1993: 1.

161 ... trattei de assim o conseguir pellos Methodos que proponho, com tanto extremo, que em todas as figursa, por mais irregulares que sejao, fortificadas dos lados do Polygonos exteriores para dentro, fica cada hum dos lados fortificado regularmente, \& por tanto o Polygono interior parallelo ao exterior (PIMENTEL, 1993: Proêmio). Assim a fortificação passa a ser uma ciência de busca da maior regularização possível do irregular, por métodos baseados na geometria.

${ }^{162}$ Cf. PIMENTEL, 1993: 330. 

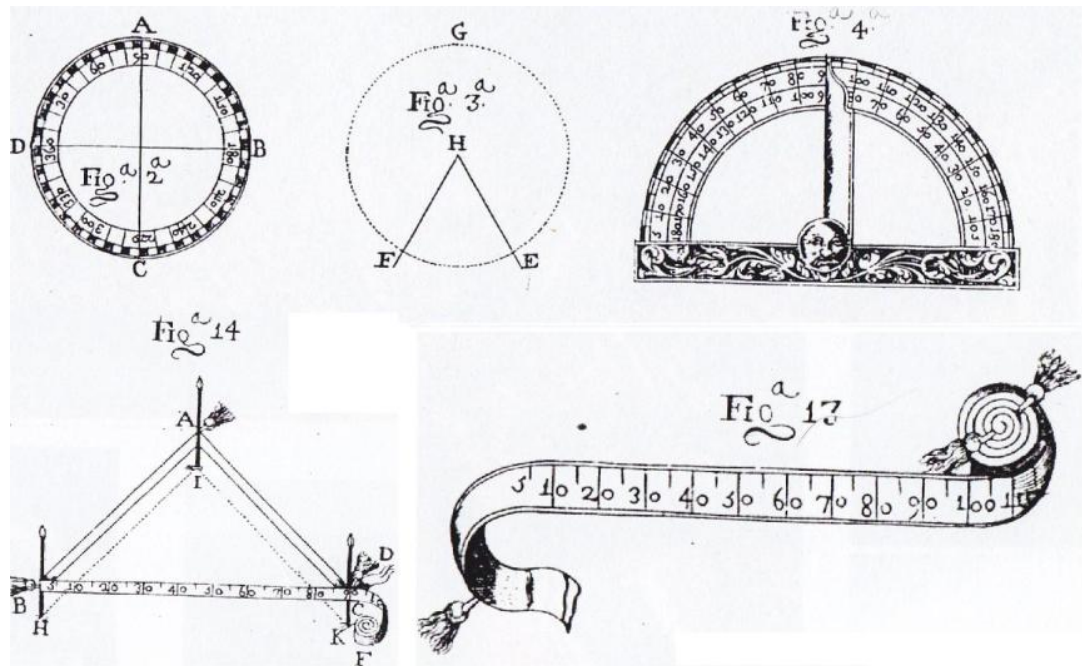
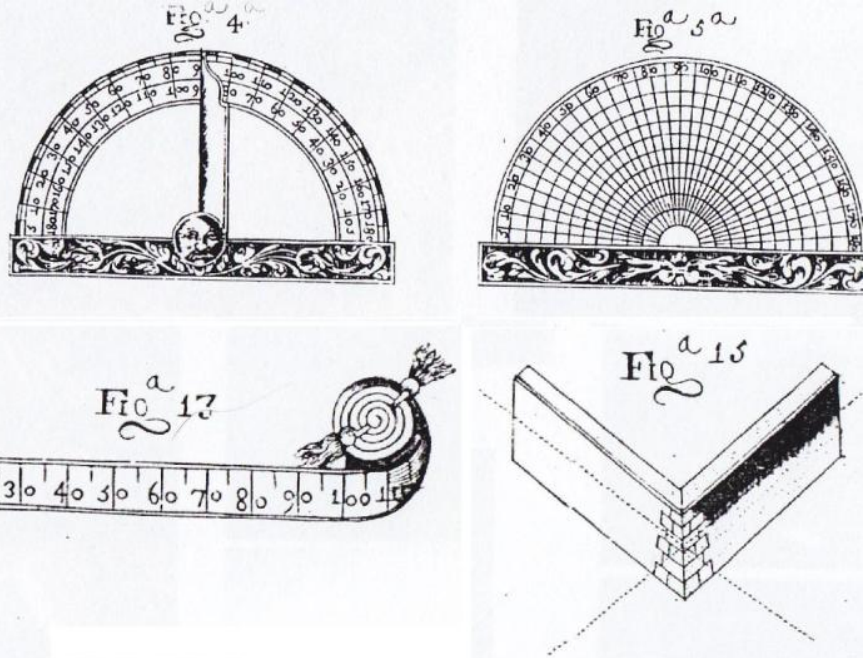

Partes da ilustração sobre Instrumentos usados para desenho em papel e no terreno (em PIMENTEL, 1993: 15). A Secção I da parte Operativa trata exclusivamente do desenho das Fortificações dos lados dos Polygonos exteriores para dentro. ${ }^{163}$

Na parte de léxico e llustrações, ele define Arquitetura Militar como Ciência ou Arte que ensina a fortificar uma Praça (para os muitos autores de tratados europeus, era importantíssima a definição das obras de fortificação, como "forte", "fortaleza" e "cidadela", diferentes em sua função). Também são descritos e definidos todos os elementos dos sistemas fortificados, como baluartes, redutos, cortinas e flancos (mostrando que o tratado era mesmo dirigido a principiantes e justificando o ensino ir desde a construção de elementos básicos de geometria, como o círculo, até formas

\footnotetext{
${ }^{163}$ Nos capítulos I e II ele ensina a medir os ângulos de um polígono no papel, sendo descritos os instrumentos necessários, mostrando-se que a forma do semicirculo de latão aberto no meyo para se poderem ver no papel as linhas que formão o ângulo he como parece na figura 4. A lamina pode ser transparente he sem abertura como se vé na figura 5 (PIMENTEL, 1993: 3). O Cap. III apresenta uma tabela com os ângulos externos e internos das figuras regulares (4 a 72 lados) que podiam ser empregadas no desenho das fortificaçõe (a Taboada Primeira, em PIMENTEL, 1993: 6). O Cap. IV ensina como descrever no papel qualquer Polygono regular até o de 20 lados. O Cap. V ensina a fazê-los em campo: desenharem os angulos na campanha, medirem os desenhados, e os das obras jà feitas, utilizando uma fita gradual. Esse instrumento, muito simples, substituiria os complexos cálculos trigonométricos, depois descritos, que necessitam do conhecimento de senos e do emprego do semicírculo de latão, considerado às vezes muito custoso.

Assim, para a medição e demarcação dos ângulos de uma fortificação em campo, Serrão Pimentel propôs o método prático com uso da fita gradual (fig. 13 da ilustração acima). Era uma fita de seda ou cetim, bem fina, que contornava três pernas $(A B C)$ de 8 palmos de altura cada (fig. 14). No meio da perna $A$ era colocada uma bobina que permitia o movimento das outras duas, conforme o ângulo BAC. Outra bobina era colocada em B para permitir o movimento do resto da fita (BCF), que tinha 16 palmos de comprimento, servindo de subtensa. A subtensa devia ser graduada em até $180^{\circ}$, indicando o número de graus pela abertura das pernas $A B$ e $A C$ (cf. BUENO, 2001: 246-7).

No Cap. VI são dados os procedimentos do desenho dos ângulos de uma fortificação em campo, empregando-se a fita gradual. Para desenhar um ângulo em um ponto (I), riscava-se uma linha indefinida IH na direção escolhida, ajustando-se sobre ela a perna $A B$ da fita gradual, colocando-se a bobina (A) sobre o ponto I. Para determinar o ponto $\mathrm{K}$ desse ângulo, estendia-se a subtensa graduada (F) até o número de graus desejado, de modo que a perna $(\mathrm{AC})$ da fita ajustasse sua extremidade (C) ao número de graus desejado, marcado na subtensa, "riscando-se no terreno as linhas IH e IK e sinalizando os pontos I, H e K com balizas" (BUENO, 2001: 438).
} 
geométricas mais complexas que permitissem desenhar elementos de fortificação de sofisticada tecnologia, com regras de concepção e construção). ${ }^{164}$

164 1- Forte = Praça cercada de fossos, reparos, baluartes, defensável da força inimiga com poucos solados. 2- Forte de campanha = forte de quatro ou cinco ângulos com baluartes, fora das Praças (Vilas e Cidades), junto a rios ou passagens, para defendê-las. 3- Cidadela ou Castelo $=$ fortes de quatro ou cinco ângulos nas Praças ou junto a elas, reforçando sua defesa. 4- Fortaleza = Castello ou cidadella mais forte, capaz, \& de mais Baluartes... para segurança das Provincias, Cidades, portos... 5- Obras cornutas = Cornas = Hornaveques = obras exteriores avãçadas na campanha, com dous lados longos [ramais] e a frente guarnecida com dois meios baluartes. Eram feitas em frente à parte mais fraca da Praça para impedir os Approxes do inimigo... 6- Coroas = Obras coroadas = obras exteriores avançadas na campanha por meyo de dous Ramais longos à maneira das cornutas [hornaveques] mas cõ um, dous ou mais Baluartes no meyo, \& dous meios Baluartes nos extremos... 7- Tenaz = Tenalha = obra semelhante ao hornaveque, mas sem meyos Baluartes, \& com hum angulo reintrante no meyo. 8- Estrelas = Fortins ou Redutos em forma de estrella de quatro, cinco, ou seis angulos com os lados retirados para dentro, \& outros tantos angulos reintrantes. 9- Reduto = obra menor quadrada, ou algum tãto prolongada, feita nas Trincheiras dos Approxes, e na campanha para proteção do sítio. 10- Revelim = obra menor exterior em forma triangular, ou de Trapezio, com flancos como o baluarte, feita fora das praças defronte das Cortinas lõgas, \& lugares mais fracos, começando logo alèm da Contrascarpa; cujo fosso se communicava com o da Praça. Serve para melhor defender os lugares mais fracos, \& tambem para cubrir melhor as Portas... dar ossos que roer ao inimigo preservando o corpo da Praça principal. 11Meias luas = obras exteriores menores, feitas diante dos Baluartes na forma dos revelins triangulares; mas pella banda interior são em forma de meya lua. Para alguns, = revelins. 12- Baterias = obras offensivas de terra, para colocar a artilharia. 13- Reparo = terreno levãtado à roda da Praça revestido de muros de pedra, \& cal ou de formigão, adobes, tepes, terra battida, salchichas [faxinas],... com Escarpa proporcionada para bem se sustentar. Sobre ele se assenta o parapeito. 14- Baluarte = obra avançada do Reparo delineada cõ quatro lados, \& tres angulos exteriores além dos dous que formam com as Cortinas. 15- Casamata = Praça cuberta de abobada como uma casa feita nos Flancos dos Baluartes, onde se aloja a Artilheria para atacar \& defender a face do Baluarte opposto. À época eram feitas descubertas com nome de Praça baixas. 16- Parapeito = terra levantada por cima do reparo com grosura conveniente, \& altura bastante para cubrir os soldados... 17- Banqueta = pequena altura de terra á roda do pé do parapeito pella parte interior, onde os soldados sobem para descubrir, \& atirar no inimigo. 18Terrapleno = resto interior do Reparo do principio interior de sua base atè a Banqueta;... nelle se aloja a Artilheria a demais da dos baluartes. 19- Caminho das Rondas = Falsabraga = caminho... entre o Reparo, \& e Lizira, ou Margem interior do Fosso (também chamado Berma), funcionando quasi como as Barbacans das muralhas antigas. Pouco usado nas fortificações portuguesas, comum nas holandesas, em fortalezas antigas da Itália era feito na borda exterior do Reparo, o que Pimentel recomenda seguir ainda hoje este estilo na forma, \& com as medidas que em seu lugar se verà. 20- Parapeito da Falsabraga = Parapeito semelhante ao do Reparo, que alguns fazem dentro do Fosso principal... 21- Margem, Lizira ou Berma = margem de terra que se deixa entre o Parapeito da Falsabraga, \& e o Fosso. Como os portugueses não costumavam fazer falsabraga, subindo as muralhas de dentro do fosso, não faziam essas bermas. Mas quando a fortificação era de taipa, não saindo do fundo do fosso, mas assentada sobre o terreno natural (ou sobre uma fiada de um ou dois palmos de pedra e cal para evitar os danos da umidade), deixava-se então essa Berma entre a taipa, \& o Fosso. 22- Fosso = Cava = profundidade aberta no terreno natural, ou feita artificialmente..., que rodea toda a Praça pella parte de fòra. 23Estrada encoberta = Corredor = caminho alèm do Fosso em roda da Praça amparado de hum parapeito que vai fenecer no livel da campanha... (Pimentel prefere "encoberta" a "coberta", como dizem alguns). 24- Parapeito da estrada encoberta = terra levantada diãte della para cobrir os soldados. 25- Plataforma = terra levantada em forma quadrangular (como Bateria) posta sobre o Reparo, da qual se resiste, \& offende o inimigo com a Artilheria. 26- Cavalheiro = terra mais levantada em forma quadrangular, ovada, ou semelhante sobre o Baluarte, ou Terrapleno da Cortina, \& sustentada de muros... ou de formigaõ, ou taipa; donde se offende o inimigo ao longe com a Artilheria; ou para se igualarem com algûa de terreno exterior. 

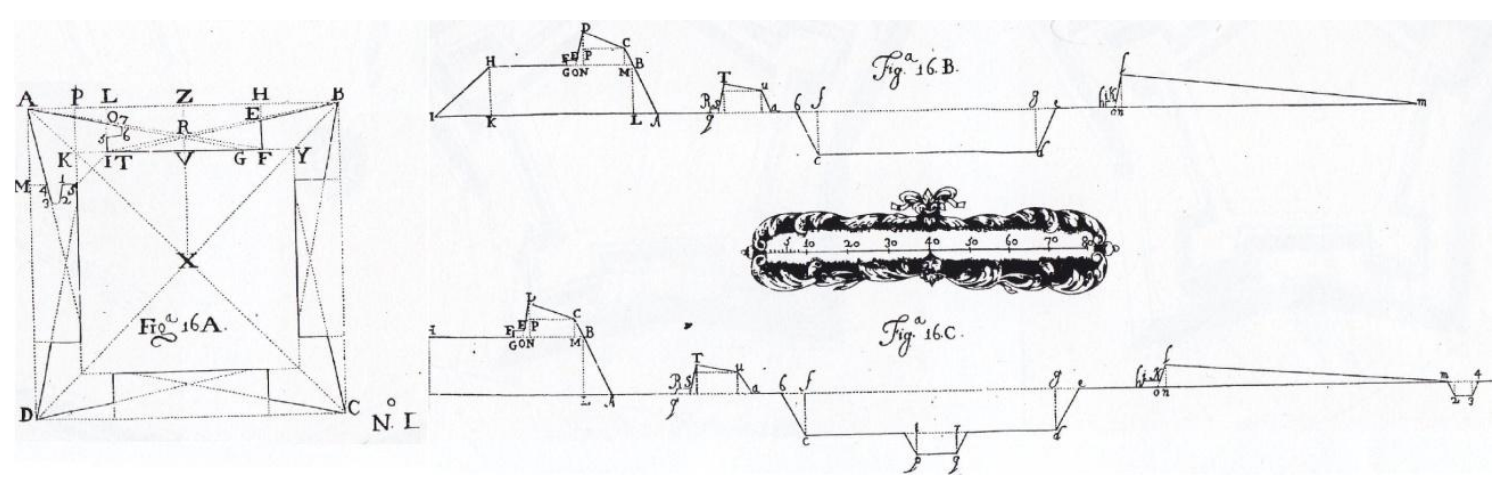

Ao apresentar o léxico dos principais elementos (reunindo pela primeira vez em um tratado português, de forma bastante completa, o conjunto de termos e suas definições), Pimentel (1993: 15-8) fala em três tipos de representação necessários ao desenho de uma fortificação: icnografia, ortografia e perspectiva (militar). ${ }^{165}$ Alguns dos termos descritos foram mostrados em representação ichnographica (planta, p. 24-5), outros em orthographica (perfil ou corte, p. 56-7).
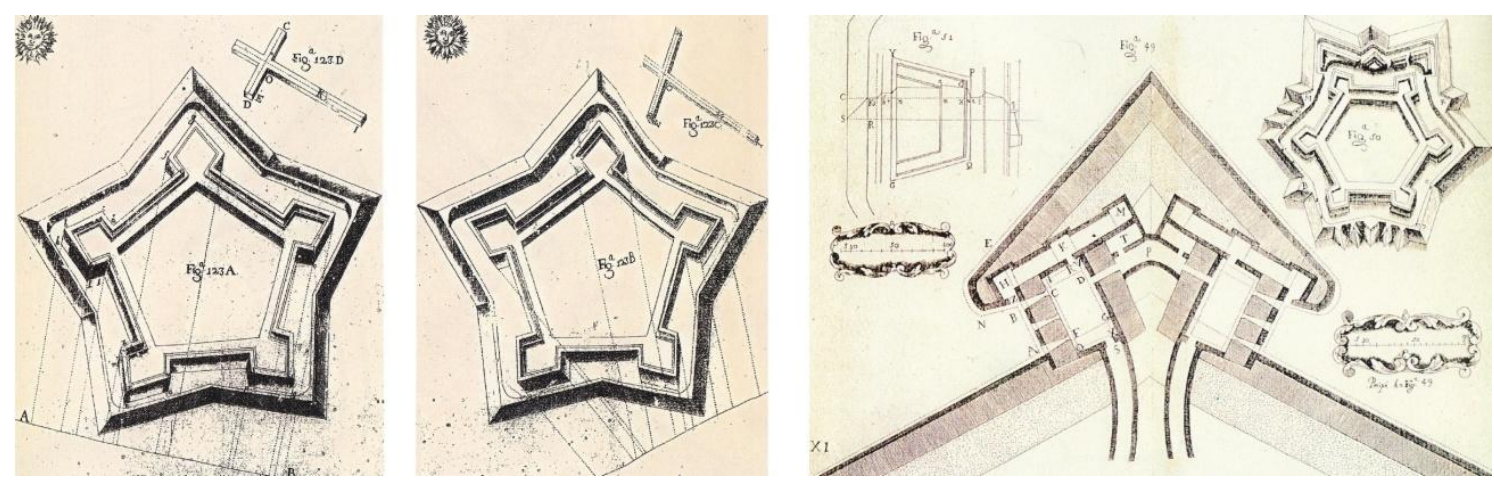

Exemplos de sua perspectiva militar (p. 236-7) e um desenho (p. 128-9) reunindo os três tipos de representação.

\section{Manoel de Azevedo Fortes e o O Engenheiro Portuguez}

Em 1728, no reinado de D. João $V$, foi impresso o segundo tratado, $O$ Engenheiro Portuguez, de Manoel de Azevedo Fortes, também engenheiro-mor na época. Ele atualizava o de Pimentel, citando sistemas mais avançados em tecnologia de fortificação, como o método de Vauban. Depois de suceder Francisco Pimentel como engenheiro-mor do Reino e lente da Academia Real da fortificaçam, em condições delicadas (1719), ${ }^{166}$ Azevedo Fortes passou a comandar um movimento de renovação do ensino nas Academias Militares, incluindo o desenho entre as disciplinas. Ao convocá-lo, a prioridade de D. João $\mathrm{V}$ era promover o mapeamento do território brasileiro, para fundamentar futuras negociações com Castela. ${ }^{167}$

165 No Cap. VI da Parte I, Secção II, ele trata "Do modo de relevar hua Planta para que represente a
Fortificação levantada sobre o terreno" (p. 235), em que diz: Deste modo resultarà hûa Planta bem
relevada para representar a obra futura; pois fica sem alteração das medidas; o não succede na
Perspectiva rigorosa que as altera, \& torna a fig. disforme com menos intelligencia dos que não saõ
practicos naquella sciencia (p. 237). Não era a perspectiva tradicional, que para ele alteraria as medidas
e enganaria a vista simulando efeitos naturalistas com artifícios gráficos. Os militares usavam outro tipo,
denominado "perspectiva militar", sobre a qual ele discorre.
${ }^{166}$ Francisco Pimentel era engenheiro-mor do Reino possivelmente desde a morte de seu tio, Serrão
Pimentel (cf. BUENO, 2001: 459-60).
167 O mapa-mundi e a dissertação de Guillaume Delisle na Academia Real de Ciências de Paris,
Determination Géographique de la Situation et l'etendue des differentes parties de la Terra (1720)
mostravam publicamente a Colônia do Sacramento não fazendo parte do território português. Os 
Em 1720, Azevedo Fortes redigiu a Representação feyta a S. Magestade... Sobre a forma, e direcçam, que devem ter os Engenheyros para melhor servirem ao dito Senhor neste Reyno \& suas Conquistas... ${ }^{168} \mathrm{O}$ documento apontava deficiências no ensino da matéria em Portugal e mostrava a necessidade de novas diretrizes nos cursos, para suprir a carência de engenheiros militares habilitados. Ele sugeriu que D. João V executasse o Decreto de D. Pedro II (20/07/1701), ${ }^{169}$ estabelecendo novas Academias de Fortificação nas Províncias do Reino e estados ultramarios. Em 1721, preocupado com o ensino do desenho de Cartas Geográficas (para compensar a falta de livros em português e precisando fazer uma equipe de trabalho orientada por um método comum), ele anunciou na Academia Real de História sua redação do Tratado do modo o mais fácil e exato de fazer as cartas geográficas... (1722), pequeno livro como primeira síntese da matéria em Portugal. ${ }^{170}$

Em 1728, Fortes publicou seu mais completo tratado, ${ }^{171} O$ Engenheiro Portuguez, que além de abordar questões de Geometria Prática no papel e no terreno, aprofundava assuntos da Arquitetura Militar. ${ }^{172}$ Também neste caso, os dois tomos são cartesianamente claros e objetivos, escritos em linguagem simples, já que seriam usados como apostila (método) pelos alunos da Academia Militar da Corte. ${ }^{173}$ Segundo um dos "censores" (críticos), o tratado era útil porque... nestes nossos tempos a

levantamentos franceses feitos por triangulação, de maior precisão nas latitudes e longitudes, deram o alerta sobre problemas futuros de soberania. Reis, ministros e altos funcionários viram a necessidade do conhecimento geográfico, deflagrando um processo de intercâmbio de profissionais, tratados, atlas e instrumentos entre Portugal e os centros divulgadores de modelos.

${ }^{168}$ BNL - AS 11346P. FORTES, Manoel de Azevedo. Representação feyta a S. Magestade... Lisboa, 1720, p. 3 - apud BUENO, 2001: 462.

169 Em 1701, D. Pedro II havia ordenado a criação de novas Academias de Fortificação com quatro partidos de aulas nas províncias do Minho, Beira e Alentejo. No Minho foi implantada a aula de Viana do Castelo, dada pelo engenheiro militar Manuel Pinto de Villa Lobos, discípulo de Miguel de L' Escol (o precursor dessa escola, portanto). Formalizava-se uma teoria para o que até então só se baseava na prática ativa das obras de fortificação no Norte de Portugal, desde a Restauração. Mais tarde, no reinado de D. João V, abriram-se as aulas de Elvas e de Almeida (cf. TEIXEIRA \& VALLA, 1999: 126).

${ }^{170}$ Como membro dessa Academia, era incumbido das questões geográficas e de produzir Mappas ou Cartas Geograficas; assim a geral do Reyno, e Conquistas, como as particulares dos seus Bispados, e Prelasias (FORTES, Manoel de Azevedo. Tratado do Modo o mais facil e exacto de fazer as cartas geographicas... Lisboa: 1722, Proêmio - apud BUENO, 2001: 468). Para essa tarefa, precisaria dos melhores engenheiros de cada Província, desde que houvesse um método comum. $O$ índice do Tratado... introduz o conjunto de novas matérias que seriam incluídas no Programa das Academias Militares.

Ao lado das medidas comandadas por Azevedo Fortes, os portugueses que trabalhavam no estrangeiro passaram a servir ao Rei, informando sobre as novidades científicas mais importantes. Em março de 1722, D. Luís da Cunha foi encarregado de conseguir uma cópia da dissertação de Delisle e de fazer o contato entre o geógrafo francês e Azevedo Fortes. Em abril, foi pedido ao Conde de Tarouca, Ministro de Haia, que comprasse os melhores atlas holandeses (cf. BUENO, 2001: 471).

${ }^{171}$ Publicaria ainda, em 1744, o tratado Lógica Racional, Geometria e Analytica.

172 Mesmo a Geometria Prática sobre papel e terreno era aplicada aos tipos de fortificação regular e irregular, defesa e ataque das praças, já numa perspectiva de guerra e não de simples edificação.

173 Como nos outros casos, o tratado de fortificação era o método seguido pelos praticantes da Academia Militar. Azevedo Fortes justifica a obra citando o tratado de Serrão Pimentel, de métodos que já não se usava na Europa fazia cinqüenta anos e com poucos exemplares disponíveis. Também se refere a outro livro importante, Fortificação Moderna, de Bluteau, traduzido a mando de D. João V: uma compilação de vários métodos que interessava mais pela informação histórica do que pelos conhecimentos passados. O livro cita os métodos de três autores célebres, o Conde Pagan, Antoine de Ville e Vauban, sendo este considerado o mais moderno (cf. TEIXEIRA \& VALLA, 1999: 131). 
principal defensa dos Reinos consiste nas praças, que são as chaves com que se fechão aos inimigos. ${ }^{174}$ Outro fala na importância da Fortificação, lembrando que sem ela não era possível conservar o Reino (compara aos romanos, que foram vitoriosos por muito tempo dedicando-se à arte militar). No prólogo ao leitor, Azevedo Fortes diz:

...Esta obra (amigo leitor) naõ foy feita para se dar ao publico: o primeiro fim, que me propuz, foy a minha propria instrucçaõ; e passou depois em postila para servir de methodo aos Praticantes da Academia Militar, de que Sua Magestade foy servido encarregar-me... A ordem, em que as materias se seguem, he natural, e vaõ tratadas em seus proprios lugares, e o estilo familiar, e claro. E porque a escuridaõ, e ambiguidade dos termos he hum dos maiores obtaculos para poder chegar ao perfeito conhecimento das Sciencias; puz hum grande cuidado em os definir exactamente, determinando-Ihes a sua verdadeira significação; ${ }^{175}$ e o mesmo observey nas definições: e como as da Geometria, e Fortificaçaõ por claras que sejaõ, sempre se inculcaõ, e percebem melhor por figuras, e por exemplos; procurey, que as figuras nas Estampas, ajudadas de exemplos conhecidos, dessem huma nova luz à materia, e a fizessem inteiramente perceptível. ${ }^{176}$

O tomo I é um tratado de Geometria Prática que seria a base da construção militar. ${ }^{177}$ Divide-se em três partes: Longimetria (medição de distâncias), Planimetria (de superfícies) e Estereometria (dos sólidos ou corpos, com apêndice sobre trigonometria retilínea ensinando a resolver a medição dos triângulos), concentrandose em questões topográficas. ${ }^{178} \mathrm{O}$ capítulo fala da representação das plantas militares, cores e métodos de desenho segundo normas européias. ${ }^{179}$

${ }^{174}$ Censura do Muito Reverendo Padre João Baptista Carbone da Companhia de Jesus, Mathematico de Sua Magestade. In: FORTES, 1993: I, s/n.

${ }^{175}$ Como Vitrúvio, toca em questões da lingüística.

${ }^{176}$ FORTES, 1993: I, 5.

177 Azevedo Fortes defende no livro Logica Racional que a matemática pura é a base de todas as ciências. O uso da aritmética decimal, em época que se usavam diversas medidas (pés, braças e outras), facilitaria o trabalho dos medidores e engenheiros que examinavam obras.

${ }^{178} \mathrm{Na}$ prática ele aprimora as questões do seu tratado anterior (... do modo o mais fácil e exato de fazer as cartas geográficas..., de 1722, em que aborda principalmente questões geográficas, orientando para o método mais fácil e exato de levantar terrenos de longa distância e transpô-lo ao papel) e acrescenta um capítulo específico ( $\mathrm{X}$, da Stereometria) sobre convenções e códigos de como riscar e aquarelar plantas militares: Esta arte até o presente naõ tem sido praticada neste Reino, nem as suas regras conhecidas, e só de sete, ou outo annos a esta parte se vay introduzindo, pela real providencia de sua magestade, que fez partido ao hum bom desenhador, para instruir os praticantes da Academia Militar, entre os quaes se acha já hum bom numero, que imitaõ perfeitamente ao mestre... (FORTES, 1993).

${ }^{179}$ Caminhos, ruas, praças e também rios e poços não levariam cor. Já igrejas, templos e ermidas seriam representados em carmim. Obras de pedra e cal das fortificações teriam como referência uma aguada em vermelho. Essa descrição detalhada da execução em tinta mostra o caráter meticuloso da abordagem do ensino no tratado. Também é assinalada nas plantas militares a definição de todo o entorno da fortificação, como vinhas, olivais, pomares, arvoredos, hortas e jardins.

Foi a primeira vez que se uniformizaram os códigos de representação gráfica, pelo estabelecimento de Regras e máximas como as que eram praticadas em outros Reinos, baseadas, sobretudo, no tratado de Buchotte (Les Règles du dessein et du lavis, pour les plans particuliers des Ouvrages \& des Bâtimens, \& pour leurs Coupes, Profils, Elevations \& Façades, tant de l'Architecture Militaire que Civile: Comme aussi pour le Plan en entier d'une Place; pour as Carte particulière, \& pour celles des Elections, des Provinces, \& des Royaume - 1720; cf. BUENO, 2001: 475), no qual Azevedo Fortes se inspirou até mesmo nas estampas do Engenheiro Portuguez.

A atualização de conhecimentos e teorias vigentes na Europa era a principal preocupação dos engenheiros militares e da política de afirmação de Portugal, que após a Restauração queria se integrar ao contexto cultural europeu. A representação em desenho de Fortes seguia o exemplo dos Reinos do Norte (França), onde... os Praticantes das Academias Militares, que se destinaõ para a profissão de Engenheiro, começã̃ pelo Dessenho; e os que entre elles sahem bons Desenhadores, servem alguns 
O tomo II, Fortificação ou Arquitetura Militar, define inúmeros conceitos, como no tratado de Serrão Pimentel, descrevendo vários elementos de arquitetura militar. ${ }^{180}$ Também são dadas as máximas da fortificação, como: Que em todo o recinto de huma fortificaçaõ não haja parte alguma, que não seja vista, e deffendida pela frente, e pelos lados, ou ao menos por hum lado, que he o fim principal, que se propoem quem fortifica. $^{181}$

O núcleo no interior das praças fortes é tratado de modo ainda mais sucinto que em Serrão Pimentel, com poucas menções ao seu traçado e à circulação, mas entendendo que a distribuição regular das ruas atendia a uma necessidade militar, devendo ser retas em direção às cortinas e golas dos baluartes, para que a comunicação fluísse em toda parte:

... e assim fazendo-se huma praça de novo de devem mandar cordear as ruas, deixando no meio uma boa praça, e dirigindo-as, ao meio das cortinas, às golas dos bauartes, deixando nos seus extremos humas pequenas praças para se formarem nellas os defençores, e bastante espaço entre os terraplenos, e as casas mais proximas a elles, para que por toda a parte seja livre e dezembaraçada a communicação. ${ }^{182}$

Como Serrão Pimentel, Azevedo Fortes citou Palmanova como modelo ideal, sem nunca sugerir a sua reprodução mecânica.

... Ainda que raras vezes succede fazer-se huma fortificação regular, e só dizem, que o he Palmanova, Praça do Estado de Veneza, e algumas cidadelas, como a de Milão; com tudo he precizo que concideremos a fortificação como regular (e será facil fazer-se sendo o terreno livre)... ${ }^{183}$

annos com este exercicio, assistindo aos Engenheiros Directores das Provincias, para Ihes riscarem as plantas, que projectaõ... Beatriz Bueno observa que os avanços na "ciência do desenho" tiveram grande repercussão nos reinados seguintes, mostrados nas expedições científico-demarcatórias: com o impulso renovador do ensino a partir de Azevedo Fortes, na segunda metade do século XVIII aumentou muito o número de engenheiros militares portugueses, mesmo brasileiros, com grande habilidade, havendo multiplicação e aprimoramento técnico nos desenhos.

${ }^{180}$ As definições de forte, fortaleza, cidadela e fortificação regular e irregular mostram o grande campo de atuação dos engenheiros militares, desde a construção de um pequeno forte à da fortaleza e do sistema de fortificações de uma cidade, o que abrangia a definição do limite urbano no terreno e regras de intervenção em sua estrutura.

${ }^{181}$ FORTES, 1993: II, 30. As máximas acompanham a escolha de sítio em monte, planície, mar ou rio, descrevendo-se vantagens e desvantagens para a melhor defesa em caso de cerco. As teorias de fortificação têm na defesa das praças seu caráter dominante, sempre baseadas no ideal da cidade renascentista e suas regras geométricas.

${ }^{182}$ FORTES, 1993: II, 126 - grifos nossos. Beatriz Bueno (2001: 484) observa que "a partir do século XVII a fortificação passou a ser concebida enquanto um sistema, onde cada elemento se encontrava articulado aos demais, visando a atingir a máxima eficiência do conjunto". Nessa perspectiva, os núcleos interiores das Praças fortificadas eram apenas um entre os muitos elementos que as compunham, sempre vinculados a questões técnicas de construção e distribuição interna delas. A concepção de fortificação como "sistema" era típica da escola francesa, que se mostrou o grande paradigma do século XVIII e inspirou o tratado de Fortes segundo ele mesmo (que ao dizer que... a idea geral de uma fortificação compreende o sítio ou terreno em que deve ser edificada, cita como referência básica à fortificação um autor anônimo, que para R. Moreira e R. Araújo seria J. F. Bernard - Nouvelle manière de fortifier les places, tirées de méthodes du Chevalier De Ville, du comte de Pagan et de monsieur de Vauban , Paris, 1689 - trabalho que mesclava e aperfeiçoava os métodos considerados melhores da época: Vauban, Antoine De Ville e Conde de Pagan - cf. MOREIRA e ARAÚJO, 1999: 176).

${ }^{183}$ FORTES, 1993: II, 57. Margarida Valla (1999: 132) compara O Engenheiro Portuguez (1728) ao Methodo Lusitanico... (1680) e vê principalmente semelhanças, já que ambos se voltam "a um ensino básico de geometria prática para se entender as regras de fortificação". O de Azevedo Fortes é mais 
Em 1754 Azevedo Fortes deixou o posto de engenheiro-mor do Reino. Foi substituído por Manuel de Maia (1677-1768), que liderou no ano seguinte (aos 78 anos) o movimento de reconstrução da cidade, após o terremoto de Lisboa. Para isso também foi constituída em 1756 a Casa do Risco das Obras Públicas, no lugar da extinta Aula de Arquitectura do Paço da Ribeira. Seus membros, quase todos engenheiros militares, redesenhariam a Capital o mais racionalmente possível. ${ }^{184}$

\subsection{Aulas Militares no Brasil}

Quando o Brasil foi "descoberto", o pensamento sobre cidades passava pelo período de maior proliferação. ${ }^{185}$ Pouco depois da fundação de Salvador, a partir de 1573, a Coroa investia na formação de fidalgos para realizar os seus "desígnios" de conquista (por contratar ainda profissionais estrangeiros, sobretudo italianos, para construções religiosas, civis e militares). Essa iniciativa levou a uma alta erudição no conhecimento teórico dos portugueses, sendo a maior evidência a provável biblioteca institucional da Escola de Moços Fidalgos do Paço (mencionada nos tratados de Rodrigues). Dela viriam as teorias que fundamentavam a prática dos profissionais portugueses na época em que o Brasil começava a ser colonizado.

Em pouco mais de um século, foram montadas as primeiras instituições de ensino oficial de Arquitetura no Brasil, ${ }^{186}$ as aulas de Arquitetura Militar, ministradas em Salvador (1696), Rio de Janeiro (1698), São Luís (1699), Recife (1701) e Belém (1758). ${ }^{187}$ Criar uma Aula das Fortificações e Arquitetura no Brasil era necessário pela

meticuloso nesse ponto, enquanto o de Serrão Pimentel consegue "ultrapassar o conceito de fortificar" restrito aos sistemas defensivo e ofensivo da guerra para atingir conceitos de urbanismo na cidade fortificada, citando Palmanova e "definindo funções para os espaços e medições dos seus vários elementos". Os dois tratados abordam os temas da Teoria e da Prática, de um lado defendendo a aplicação de métodos mais simples na prática, e de outro explicando a teoria que serve de base à intervenção. Os dois livros aparecem em contexto político especial: o primeiro ainda na guerra da Restauração (reinado de D. Pedro II), de implantação de uma política de fortificação das cidades em Portugal; o segundo, um período de grandes intervenções no Brasil (reinado de D. João V) e começo da política de delimitação do território brasileiro pela implantação de novos núcleos urbanos e construção de fortificações.

184 Cf. BUENO, 2001: 493-5. Construiu-se uma malha regular com ruas bem calçadas e mais largas (as principais com 60 palmos - 13,2 m - e as secundárias com 40 - 8,8 m) e edifícios regulares e simétricos (de gabarito proporcional à largura das ruas, o que proporcionava incidência de luz e ventilação adequada). As fachadas foram padronizadas em três tipos básicos, facilitando a execução dos diversos elementos de cantaria, cunhais, portas e janelas (vergas, ombreiras, soleiras).

185 Sendo seu principal difusor as cidades italianas, berço da tratadística de Pintura, Escultura e Arquitetura.

${ }^{186}$ Cf. BUENO, 2004: 93-100. Só em 1816, com a vinda da chamada Missão Artística Francesa, foi criada a Escola Real de Ciências, Artes de Ofício, alcunhada Academia Imperial de Belas Artes em 1826. As aulas militares também foram anteriores aos ensinos de engenharia na Escola Central (1858) e Escola Politécnica (1874) do Rio de Janeiro.

${ }^{187}$ Elas eram circunscritas a capitais regionais: Salvador (Capital do Estado do Brasil), Rio de Janeiro (Capital regional do Sul) e São Luís do Maranhão (Capital do Estado do Maranhão), à exceção de Recife, que em 1701 sequer era Vila (passou a ser em 1709 - cf. REIS FILHO, 1968: 88), mas tinha importância regional como centro urbano desde a invasão holandesa.

Robert Smith (1998: 38) mostra que o primeiro estabelecimento oficial de Aulas fora da Europa é de 1699 (essa política também se destinava à Índia, África e Províncias do Reino, criando-se ao mesmo tempo Aulas em Goa e Angola, em 1699, e em Viana do Castelo, em 1701), mas que as lições na Bahia ocorreram a partir de 1696 (ou mesmo antes, como ainda veremos), sendo anteriores ao Decreto. 
dificuldade em trazer mais e mais engenheiros para o vasto território. ${ }^{188}$ A Aula da Baía tinha o nome Escola de Artilharia e Arquitetura Militar, sendo à imagem da Aula da Ribeira. $O$ engenheiro-mor em Portugal era quem escolhia os engenheiros militares para ensinar (por exemplo, Nicolau Abreu de Carvalho foi nomeado pelo então engenheiro-mor do Reino Azevedo Fortes para lecionar na Bahia em 1723).

Foram destacados para o ensino engenheiros militares de importante atuação no Brasil, como José Fernandes Alpoim (RJ) e José António Caldas (BA), este por carta régia de 1761:

... e por haver dado o dito José António Caldas prompta satisfação á ordem de que foy encarregado, ... , Hey por bem fazer lhe mercê de o nomear (como por esta nomeyo) no posto da capitão engenheiro como o mesmo soldo com que o forão André de Brito Gramacho, e Niculau de Abreo de Carvalho, ..., com obrigação porem de ditar na Aulla melitar da sobredita cidade da Bahia defenças de praças, expugnação dellas e Geometria especulativa. ${ }^{189}$

O processo de ensino se ligava à estrutura militar, com a nomeação implicando em obrigação. ${ }^{190}$ Diferentemente do início, a nomeação de cargos acabou sendo determinada mais pelo conhecimento teórico do que pela prática. Como a Aula de Arquitetura de Filipe II, de três vagas, as Aulas do Brasil foram criadas com três lugares, levando a um processo semelhante em que os discípulos seriam os futuros mestres na abertura do cargo. ${ }^{191}$ Todas as escolas tinham o ensino baseado em matérias ligadas à geometria, cosmografia e arte de fortificar, proporcionando aos alunos especialidades práticas e uma ação abrangente. Essa ação ia da fortificação em si à arquitetura civil e definição de traçado urbano, do desenho à execução no terreno e ainda à elaboração de cartografia das cidades e levantamentos geográficos maiores. ${ }^{192}$

Nossas Aulas Militares vieram em conseqüência direta do "estímulo renovador" da Arquitetura Militar liderada por Luís Serrão Pimentel após a Restauração (1640). ${ }^{193}$ Houve experiências esporádicas de preparação de aprendizes nas Conquistas, como a contratação do engenheiro militar holandês Miguel Timermans (1648-50) para preparar 24 alunos do Brasil nas funções de engenheiro (incluindo artifícios de fogo). 0 próprio rei estimulava e acompanhava a missão. ${ }^{194}$

Apenas as Aulas do Rio de Janeiro, São Luís do Maranhão e Recife foram decorrência direta dele. Pelo quadro de docentes, nota-se que só houve constância em Salvador e no Rio de Janeiro. Em geral coube a Sargentos-mores, Engenheiros Diretores da Capitania ou Engenheiros-Chefe da Praça, dirigir a cátedra como lente principal, normalmente assistidos por um lente assistente.

${ }^{188}$ A ação colonizadora que no século XVI se baseava na formação de núcleos urbanos, no XVII também tinha uma política de defesa: os ataques de franceses e holandeses, freqüentes desde o começo daquele século, levaram ao reforço de obras militares nas novas vilas e cidades. Com isso, o número de engenheiros militares trazidos ao Brasil aumentava.

${ }^{189}$ Carta Régia de D. José I, 1761 - apud VITERBO, 1899: I, 157.

190 Há exemplos disso em cartas de nomeação, como a de Gaspar de Abreu, para o posto de Capitãoengenheiro da Baía em 1711. Uma carta endereçada ao Rei diz:... tendo respeito ao capitão engenheyro Gaspar de Abreu estar exercitando o dito posto na praça da Bahia com bom procedimento, ensinando na aulla a fortificação melitar, hey por bem fazerlhe mercê de o acrecentar ao posto de sargento mor com declaração que será obrigado a continuar no exercissio e ocupação da lição de aulla (Carta Régia de D. João V, 1716 - apud VITERBO, 1899: I, 2).

${ }^{191}$ A substituição do professor em geral só era feita no final da vida, geralmente dando a vaga a um exaluno.

${ }^{192}$ Cf. TEIXEIRA \& VALLA, 1999: 127.

193 BUENO, 2001: 499.

${ }^{194}$ Cf. TAVARES, 1965: 38 e BUENO, 2001: 500. 
No conceito, as Aulas de Arquitetura Militar do Brasil eram bem diferentes de uma Academia atual, apresentando lições teóricas e práticas com prioridade a um pequeno número de partidistas - jovens do exército com especial talento para profissão - que tinham remuneração e eram anualmente examinados. Não eram restritas a eles: admitiam outros interessados na matéria, mas que não teriam benefício de bolsa (só há notícias de profissionais militares interessando por conta própria nas lições). Houve casos de lições com 3, 5 e 6 anos, e o número de partidistas variou de 3 a $12 .{ }^{195}$

\section{Outras atribuiç̃ões: obras civis e religiosas}

Para fechar esta parte inicial, faremos uma rápida menção à presença dos engenheiros em diferentes campos do desenho arquitetônico, em especial o da arquitetura religiosa (que, desde Vitrúvio, é onde se concentram os maiores esforços da erudição teórica). Junto com a definição de malhas urbanas em novos núcleos, eles contribuíram com inúmeros edifícios civis e religiosos. Normalmente eram obras controladas pela Coroa, mas também há casos de contratação de particulares para aquelas de interesse público. ${ }^{196}$

Sobre arquitetura civil, escolhemos como exemplo o desenho encontrado por Robert Smith no Arquivo Nacional Colonial de Lisboa, identificado apenas como "Modelo da Obra que se há de fazer na Alfândega da Bahia". Smith vê evidente semelhança entre as características desse risco e a construção da Casa da Torre, ${ }^{197}$ conjecturando serem obras de um mesmo engenheiro militar: Francisco Frias de Mesquista.

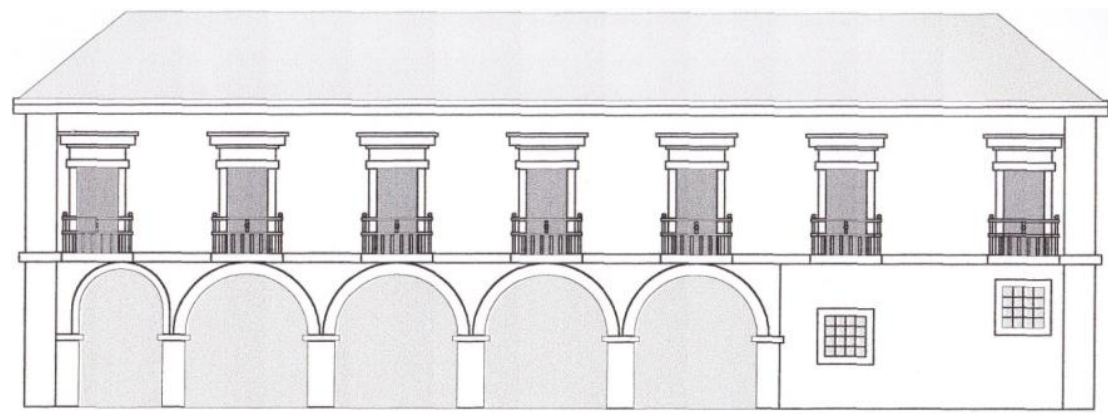

Reprodução em Cad do Risco para a Alfândega de Salvador, desenho colorido, anônimo e sem data, ${ }^{198}$ que Robert Smith atribui a Frias de Mesquista.

\footnotetext{
${ }^{195}$ Cf. SMITH, 1998: 36-69; MOREIRA \& ARAÚJO, 1999: 174; TAVARES, 1965: 37-55.

${ }^{196}$ Como no caso em que Miguel Pereira da Costa se envolveu no projeto e construção do fortim da Praia do Forte, nas vizinhanças da Casa da Torre (1712). Segundo M. Oliveira (2004: 108), os governadores prometiam essa fortificação a Garcia d' Ávila Pereira porque "naquelas paragens, residia a sentinela avançada das defesas de Salvador".

197 “... nas arcadas do térreo, cunhais, colocação das janelas e no tratamento do beiral, assim como no telhado de quatro águas" (SMITH, 1969: 43). No livro Arquitetura Colonial, Smith reafirma: "Este desenho fornece indícios valiosos sobre a aparência original da fachada do pátio da residência conhecida como Torre de Garcia d' Ávila, ora em ruínas, na costa de Tatuapara e indica a origem da tradição dos edifícios municipais da colônia do Estado da Bahia" (SMITH, 1955: 65). Ainda para ele, o projeto da Casa da Torre "mostra perfeita compreensão dos princípios formalísticos de disposição de planta do Renascimento" (SMITH, 1969: 40).

${ }^{198}$ Acompanha o desenho uma carta de 1618 do provedor real da Fazenda (Pedro de Gouveia e Melo) a Filipe III (II de Portugal) falando da recusa da Câmara da Bahia em custear a obra em função de despesas
} 
Mesmo que Smith não esteja certo, não poderíamos deixar de citar deste engenheiro a autoria do Mosteiro de São Bento no Rio de Janeiro. ${ }^{199}$ Entre tantos exemplos, que passam por Baccio di Filicaia e chegam a José Antonio Caldas (de quem mostraremos desenhos na parte final), ${ }^{200}$ escolhemos o da igreja de Nossa Senhora da Conceição da Praia, que no século XVIII recebeu um projeto de enorme sofisticação geométrica (como eram os de igrejas do Rio de Janeiro) atribuído ao Eng. Manuel Cardoso de Saldanha. É uma planta de nave única retangular com os cantos chanfrados, capelas nos lados e corredores que levam à sacristia nos flancos. ${ }^{201}$
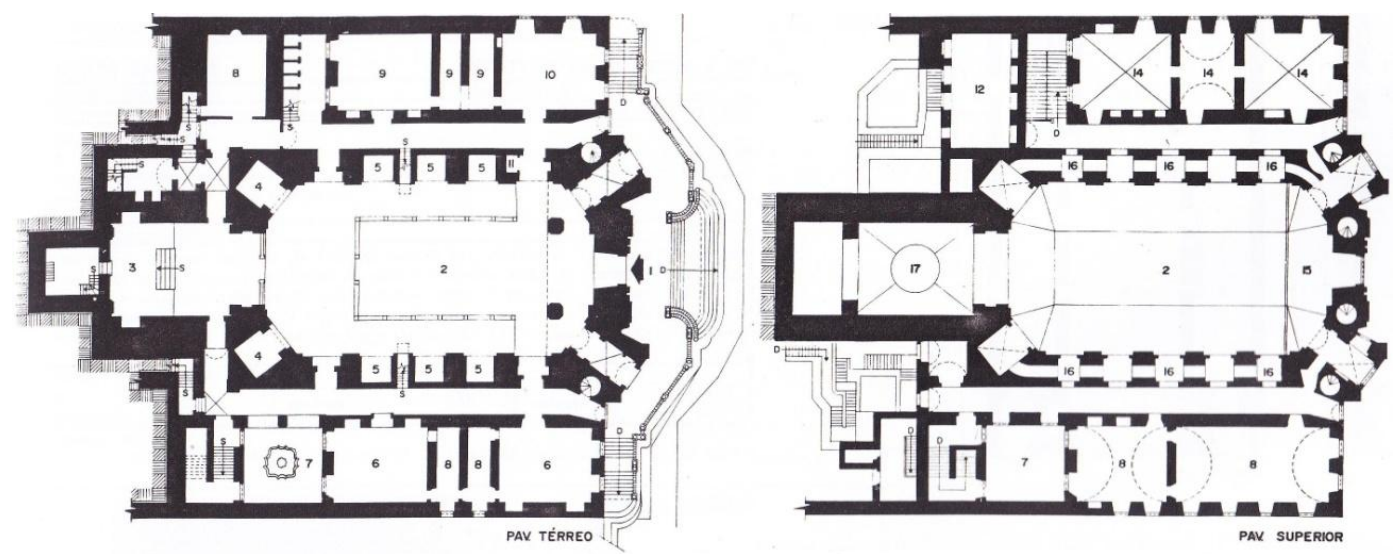

Dois dos quatro níveis da igreja de N. S. da Conceição da Praia no levantamento do IPAC-BA (AZEVEDO, 1975: I, 37).

A planta certamente deriva dos "exercícios gráficos de inserção de um octógono numa oval, usuais na aprendizagem das 'aulas militares'", como disseram Rafael Moreira e Renata Araújo. ${ }^{202}$ O projeto foi concebido em Lisboa, sendo todo o frontispício em pedra lioz enviado a Salvador e montado pelo pedreiro de Lisboa Eugênio da Mota. É dos mais raros no Brasil, com duas torres salientes em losango, como as da Igreja de N. S. da Piedade de Elvas (1753). ${ }^{203}$

com a Sé. É provável que o desenho tenha sido feito na Bahia, já que era comum enviar à Metrópole os riscos dos edifícios públicos para aprovação.

199 Cf. LEMOS, 1989: 243 e OLIVEIRA, 2004: 133 (a comprovação da autoria estaria em documento transcrito por Silva Nigra em 1942). Curiosamente, Francisco Doria (1999: 90) vê semelhanças entre este Mosteiro beneditino e a Casa da Torre, que seria, mais do que um castelo, uma "mistura de convento e casa fortificada".

200 Baccio de Filicaia, segundo Silva Nigra, teria desenhado o mosteirinho beneditino de Monserrate, próximo ao forte.

${ }^{201}$ Cf. BUENO, 2001: 574-5.

202 MOREIRA \& ARAÚJO, 1999: 177. Essa tipologia teve sucesso em Lisboa com a Igreja do Menino Deus (1711) do arquiteto João Antunes, mas suas origens estão nos arquitetos-engenheiros militares, já que foi empregada no Forte de São João das Berlengas (1654) de Matheus do Couto (o engenheiro e lente da Aula de Architectura do Paço da Ribeira, autor do tratado de 1631).

${ }^{203}$ Cf. BAZIN, 1956: I, 165-6 e 171 e II, Prancha 46. Foi a terceira igreja construída no local (a primeira, que abordaremos, foi construída logo na fundação da cidade, sendo depois mantida pela família Aragão, da casa da Torre; a segunda não se sabe a data da construção, mas que foi elevada a matriz da nova freguesia em 1623; a deliberação de sua reconstrução é de 1736 - cf. AZEVEDO, 1975: I, 36).

Existem divergências quanto à autoria do projeto, já que foi enviado do Reino, assim como todas as pedras da cantaria. A hipótese de que é do Cel. Manoel Cardoso de Saldanha se reforça pela citação em documento da Irmandade:... principiaram a dispor todas as cousas para em tempo próximo dar começo à obra, encarregando o Ten. ${ }^{e}$ Cor $^{e l}$ de Engenheiros, Manoel Cardozo de Saldanha de delinear o risco: $e$ sendo este prompto e apresentado, consultou a Mesa, sobre elle os homens mais entendidos da materia, 
Outro exemplo é o desenho do Mestre de Campo Miguel Pereira da Costa para a igreja da Palma.

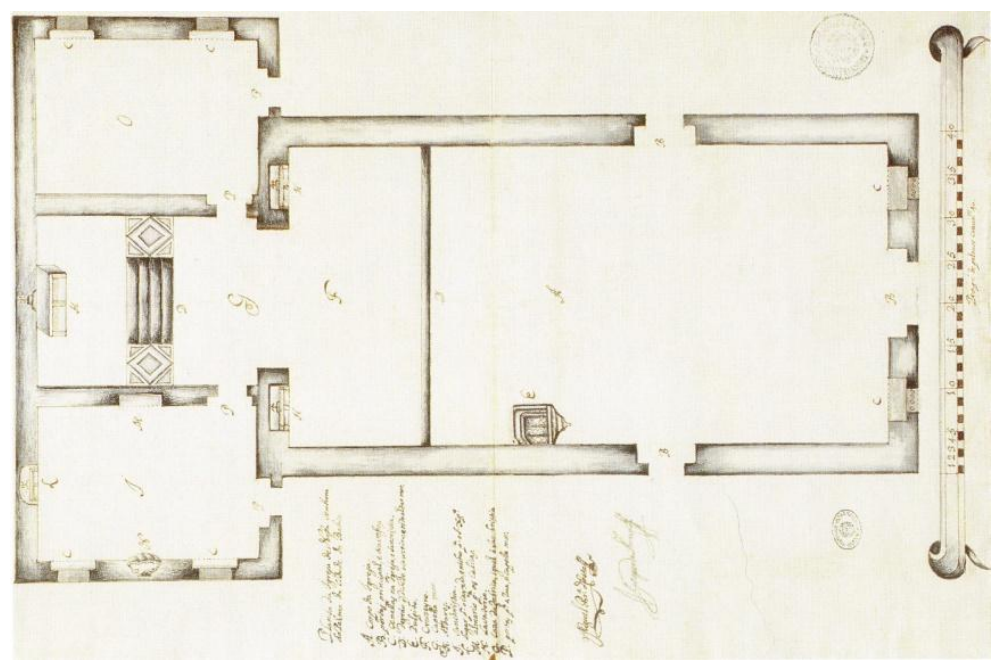

Planta da Igreja da Palma em Salvador, de M. Pereira da Costa e G. de Abreu, c. 1710 (AHU - Cartografia manuscrita, Bahia, no 961/ OLIVEIRA, 2004: 113).

e merecendo de todos plena aprovação... (O Bi-centenário de um monumento baiano. Salvador: Irmandade da Conceição, 1971, p. 100 - apud OLIVEIRA, 2004: 120). O problema estaria na data em que o então capitão foi designado a servir no Brasil, 1749, quando lhe acrescentaram a patente de Sargentomor (servindo na Bahia até 1767), enquanto as obras começaram entre 1736 e 39 (é pouco provável que Saldanha tenha vindo antes ou feito o risco em Portugal, porque a patente de Tenente Coronel foi adquirida no Brasil). Mas isso se explicaria por uma construção lenta, que ao estar ainda nos alicerces mudou de projeto, o que é possível (na Europa muitas igrejas mudaram o projeto depois de iniciadas, como a notória Catedral de Milão). A Basílica baiana, segundo Bazin, teve grande impulso em 1758 e só foi concluída em 1765. 
PARTE II - Século XVI - A cidade fortificada de Salvador

\section{Anos 1540: ambiente renascentista na Corte e primeira ocupação da capitania}

\subsection{Cultura clássica em D. João III: conhecimentos assimilados da tratadística italiana}

Para entender as transformações que levaram à construção da Cidade do Salvador no Brasil, convém falarmos da figura de D. João III, rei de Portugal entre 1521-57. Ele e seu irmão, o Infante D. Luís, eram adeptos da cultura humanística, tendo herdado do pai os ideais renascentistas e o gosto pela arquitetura. Enquanto o rei colecionava maquetes de edifícios romanos em geral, ${ }^{204}$ D. Luís admirava construções militares. Este formou em casa um grupo de estudos com o matemático e cosmógrafo-mor Pedro Nunes (anos 1536-41), que nessa época produziu os tratados De Esfera (1537) e De Crepusculis (1542), além do Livro de Álgebra em Aritmética e Geometria (1535) e de traduzir Vitrúvio (1537-41). ${ }^{205}$ Foi a partir dos anos 1540 que se fizeram as traduções e publicações de importantes tratados, além da divulgação de traduções castelhanas. Entre eles, Vitrúvio (Da Arquitetura), Alberti (De Re Aedificatoria - por André de Resende em 1551), Diego de Sagredo (Medidas Del Romano - três edições entre 15412, uma com ilustrações e apêndice da versão francesa), Frontino (De Aquaeductibus por André de Resende em 1543) e Isidoro de Almeida (De Condendis Arcibus - provável tradução da edição latina do Método de Fortificação De Urbicus et Arcibus Condendis de Düher, em 1552). ${ }^{206}$

Também era parte da política da Coroa pagar viagens de instrução à Itália a artistas, ${ }^{207}$ como forma de investir na formação de profissionais locais e aos poucos substituir a contratação de estrangeiros. No intenso intercâmbio com as Cortes italianas foram enviados, entre outros, Duarte Coelho (antes de 1529) e Francisco de Holanda (1538-40). Manteve-se, no entanto, a presença de mestres fortificadores italianos trabalhando em Portugal e nas Conquistas, como Garcia de Bolonha (1526), Gabriel Tadino di Martinengo (1528), Benedetto da Ravenna (1541) e Antônio Ferramolino (1549). Havia em Portugal, portanto, muito interesse por conhecimentos desenvolvidos na Itália, especialmente estudos sobre Vitrúvio e o tratado de Francesco di Giorgio. Há uma interessante passagem em Gabriel Soares de Sousa que diz:

Como el-rei D. João III de Portugal soube da morte de Francisco Pereira Coutinho, sabendo já das grandes partes da Bahia, da fertilidade da terra, bons ares, maravilhosas águas e da bondade dos

\footnotetext{
${ }^{204}$ Ele encomendou a Gonçalo Bayão, artista do Porto, um modello do Coliseu (cf. BUENO, 2001: 124, nota 132 - informação original em MOREIRA, Rafael. Um tratado português de Arquitectura do século XVI [1576-1579]. Lisboa, Dissertação de Mestrado em História da Arte, Faculdade de Ciências Sociais e Humanas da Universidade Nova de Lisboa, 1982).

205 Segundo Beatriz Bueno (2001: 126), foi o interesse direto da família real que contribuiu para que a técnica de representação sofresse grandes alterações, afastando-se das inscrições em notação árabe e adotando procedimentos mais científicos do disegno a Alberti, pela busca das regras de proporção, simetria e harmonia na definição de medidas.

${ }^{206}$ Cf. MOREIRA, op. cit., e BUENO, 2001: 127.

207 Gonçalo Bayão, na volta de sua estadia (1540-7) escreveu ao rei contando das medições que fizera para realizar a maquete (cf. BUENO, 2001: 124-5 - trecho da carta foi publicado em VITERBO, 1899: I, 945).
} 
mantimentos dela, ordenou de a tomar à sua conta para a fazer povoar, como meio e coração de toda esta costa, e ajudar a socorrer todas as mais capitanias e povoações dela como membros seus... ${ }^{208}$

A citação aos bons ares e maravilhosas águas nos remete a um tópico vitruviano, mas deixaremos essa observação para a análise do Regimento dado a Tomé de Souza, documento de teor prescritivo que serviu de base às ações portuguesas no Brasil. Já pensar a capital como meio e coração de um organismo, sendo as outras capitanias os membros seus, enquadra-se perfeitamente em uma concepção difundida principalmente a partir de Francesco di Giorgio. Da mesma maneira, o termo repetidamente usado pelos portugueses em referência à sua capital colonial nas Américas, "cabeça", ${ }^{209}$ mostra o caráter orgânico com que era pensada a ocupação do território. Em Martini, a "cabeça" é o castelo do Senhor, que significa o núcleo de resistência, enfatizando a importância de existir uma cidadela. Tudo isso reforça ainda mais a relação cidade-fortificação, havendo um paralelo entre as teorias renascentistas (em particular a de Francesco di Giorgio) e a prática portuguesa.

Lembremos que a primeira analogia entre arquitetura e corpo humano aparece em Vitrúvio (tendo origem no pensamento grego). Pressupondo que os membros do corpo têm proporção e correspondência com o todo, ${ }^{210}$ ele recomenda ao arquiteto buscar essas proporções em todas as construções, principalmente nos templos e nas colunas. ${ }^{211}$ No século XV, com Alberti, explorou-se ainda mais a relação cidade-corpo: o edifício é um corpo e como todos os outros corpos consiste de forma e matéria. ${ }^{212}$ Para Alberti, as partes dos edifícios se combinavam como em um organismo animal, com os edifícios grandes devendo ter partes maiores.

Já o antropomorfismo, a referência não mais no corpo de um animal, mas de um homem, ganhou força nas obras de Filareto e Francesco di Giorgio. Enquanto Filareto elogiou a perfeição da forma humana e proporção de seus membros, explorando os vários padrões possíveis, Martini desenvolveu ampla teoria de relação entre corpo humano, cidades e fortalezas. Chegou a criar um modelo preceptivo, sobrepondo graficamente a forma de uma fortaleza à de um corpo humano: ${ }^{213}$ os pés

\footnotetext{
${ }^{208}$ SOUSA, 1971: 127.

${ }^{209}$ Por exemplo, em Diogo de Campos Moreno (Relação das praças... de 1609 - ANTT, fl. 25): Sempre fes cabeça' de todo o estado do Brasil a sidade do salvador bahia de todos os santos que está em 13 graos ao sul do iquinocial...

${ }^{210}$ Outras questões conhecidas, associadas a esta e também tiradas do conhecimento grego, são a das medidas geométricas puras (por analogia à música) e a das proporções humanas cabíveis no círculo e no quadrado, ilustrada na tradução de Vitrúvio de Cesare Cesariano, em Francesco di Giorgio e, na versão mais famosa, por Leonardo da Vinci (que sendo anatomista, corrigiu o tratadista romano, mostrando no desenho que o umbigo é o centro do círculo, mas não do quadrado, de centro na região da virilha).

${ }^{211}$ Como exemplo, ao desenvolver sua fundamentação para a orientação dos edifícios, Vitrúvio dá explicações teóricas sobre o aproveitamento de luzes matinais e vespertinas para diversos edifícios (a basilica [5, 1, 4], o theatrum [5, 3, 1-2], os balnea [5, 10, 1 e 6, 4, 1], o pórtico duplo da palaestra [5, 11, $1]$, os triclinia de outono, de inverno, de primavera e verão $[6,4,2]$, os cubicula $[6,4,1]$ as bibliothecae, pinacothecae, ateliers de pintura e demais oficinas de arte [6, 1, 1-2]), mas é explícito em relação aos templos, onde a Arquitetura se manifesta de modo mais sofisticado (é também esta uma questão de decoro: onde a Arquitetura deve ser mais evidente e onde ela deve passar despercebida a olhares desatentos).

${ }^{212}$ ALBERTI, 1996: 9 (prólogo).

${ }^{213}$ Cf. COELHO Fo, 2004: 318. Luiz W. C. Filho tentou encontrar relações diretas entre os preceitos de F. di Giorgio e o primeiro desenho de Salvador, e será retomado na discussão sobre as possibilidades de um primeiro traçado feito na cidade.
} 
e os cotovelos corresponderiam aos torreões, o umbigo à praça central; no peito, o templo, na cabeça a cidadela (bastion). A porta ficaria no meio do muro oposto à cabeça. Assim, "a cidade é um corpo humano". ${ }^{214}$ Martini, no seu prólogo, já adianta o que descreverá de modo preciso,... havendo a cidade razão, medida e forma do corpo humano da sua circunferência e partição...., ${ }^{215}$ afirmando depois em seu tratado que...

... toda vez que alguma parte principal da cidade ou outros edifícios possam ser relacionados à medida de algum membro do homem, esta parte deveria ter a mesma proporção com a cidade em relação com aquele membro ao qual foi comparado. ${ }^{216}$

Para ele, o arquiteto deveria imaginar um grande corpo humano deitado no sítio, traçando com um fio um círculo a partir do umbigo. As medidas e proporções perfeitas do corpo deveriam ser passadas à cidade. Outros preceitos da cidade renascentista vieram de Alberti e Francesco di Giorgio. Alberti teorizou sobre a função estética da entrada, que deveria ser reta e ampla (padrão conveniente ao seu decoro e dignidade, como a própria existência de uma porta). Já a via de ingresso deveria conduzir à porta com uma volta à direita ou esquerda ao longo dos muros (entrando aí uma questão defensiva) sendo a passagem preferencialmente sob a muralha. ${ }^{217}$ Francesco di Giorgio, por sua vez, propõe que a porta: 1- esteja na parte mais segura (difícil de ser atacada), de preferência no flanco, protegida pela face de uma das torres (ou protegida por um anteparo, ou revelim); 2 que cada porta fosse servida por uma rua principal, reta até a porta oposta, tendo no meio a praça principal. ${ }^{218}$

\subsection{Experiência de Mazagão (primeira cidade renascentista construída fora da Europa)}

D. João III era cunhado de Carlos V. Em 1541 ele pediu ao cardeal de Toledo, ministro espanhol, a cessão dos serviços do engenheiro militar italiano Benedetto da Ravenna ${ }^{219}$ que um ano antes teve negado o cargo de capitão general de artilharia (vago com a morte de Miguel de Herrera). ${ }^{220}$ A intenção era que Ravenna inspecionasse fortalezas portuguesas na costa do Marrocos. Feito o acordo, Benedetto foi à África em companhia de Miguel de Arruda, já um dos mestres das obras reaes de D. João III, inspecionar primeiro Ceuta e depois Mazagão, na costa Atlântica. ${ }^{221}$

\footnotetext{
${ }^{214}$ Id. ibid.

215 MARTINI, 1967: I, 20.

${ }^{216}$ MARTINI, 1967, II, 362.

${ }^{217}$ Cf. COELHO Fo, 2004: 232-3.

${ }^{218}$ Cf. COELHO Fo, 2004: 233.

219 Benedetto da Ravenna (1485-1556) era da geração que desenvolveu pioneiramente na Itália (anos 1525-50) o baluarte poligonal, revolucionário na concepção de fortalezas. Também foram dessa geração os arquitetos Antonio da Sangallo el Giovane (o Jovem, 1483-1546) e Michele Sanmicheli (1484-1559), os engenheiros militares Gabriele Tadini da Martinengo e Pedro Luis Scrivá (espanhol que atuou no reino de Nápoles) e o quarto duque de Urbino, Francesco Maria Della Rovere (1490-1538), que com o influente cargo de capitão-general das forças terrestres de Veneza patrocinou os inovadores militares mais ativos da época (cf. BURY, 1994: 130-4).

${ }^{220}$ Ravenna era considerado o mais apto para esse cargo, mas Carlos V Ihe negou por não ser espanhol, dando compensação em dinheiro.

${ }^{221}$ Cf. MOREIRA, 2003: 14. Em carta de 07/06/1541 a D. João III, o governador de Ceuta, D. Afonso Noronha informava que em 26 de maio os dois inspetores cheguarã aquy bespora daçemção (apud VITERBO, 1899: I, 67-9).
} 
Com a perda para os mouros do castelo de Santa Cruz do Cabo de Gué em março de 1541 (após cerco de seis meses), não havendo meios para uma contraofensiva, D. João III e o irmão, o infante D. Luís (seu conselheiro militar), decidiram concentrar em Mazagão a presença portuguesa no Marrocos Ocidental, sem dividir os poucos recursos entre esta e as praças-fortes secundárias de Safim e Azamor. A idéia era construir uma fortaleza inexpugnável, superior ao castelo de 1514-7. ${ }^{222} \mathrm{Em}$ Mazagão, Benedetto da Ravenna e Miguel de Arruda encontraram outro Mestre das Obras Reais, Diogo de Torralva, que estava lá desde maio. Seguidas suas recomendações e de comandantes militares e navais locais, estabeleceu-se a melhor localização para a nova fortaleza. Os dois ficaram em Mazagão até a chegada de João de Castilho (também mestre de obras reais e cavaleiro da casa d' el-Rei) e de trabalhadores necessários à construção. ${ }^{223}$ Este já estava em Mazagão em 16/07, supervisionando a construção das fortificações por mais de um ano conforme os apontametos de Benito de Revena (como escreveu ao rei em 15/12/1541). ${ }^{224}$ Em 18/07/1542 a nova fortaleza estava quase concluída. Benedetto e Arruda ainda visitaram Safim e Azamor, sendo provável que seus relatos (sobre o alto custo para modernizar as defesas e renovar a artilharia) tenham influenciado na decisão de $D$. João III de abandonar as duas cidades.

Também é possível que o projeto de Mazagão tenha recebido contribuição do jovem e talentoso artista-cortesão Francisco de Holanda (1516/7-1584), ${ }^{225}$ que voltou a Portugal na primavera de 1541, ano em que Benedetto da Ravena e Miguel de Arruda trabalhavam em Ceuta. Holanda esteve por mais de três anos na Itália com instruções particulares de D. João III: El Rei me mandou a Itália ver e desegnar as fortalezas d'ella. ${ }^{226}$ Sobre a viagem de volta, relatou depois: ... se servio de mi El Rei e o Infante na fortaleza de Mazagão $q$ he feita por meu Desegno e modello, sedo a primeira força be fortalecida q se fez e África, a qual desegnei vindo De Italia e de frança. ${ }^{227}$ Acreditando-se em suas palavras, seus desenhos (talvez inspirados nos das fortificações de Pesaro, tidas como modelo em 1540) teriam sido levados a Mazagão (possivelmente por Diogo de Torralva) e servido de orientação geral na concepção da fortaleza. Mas seriam adaptados por Benedetto da Ravenna às condições e materiais

Ravenna inspecionou canhões e muros, parecendo a Noronha ser omem muy symgular e sabedor deste modo de fortificar cidades e asy de todo outro modo demgenho de guerra, e ouvilo falar niso he hua musica (uma música = pessoa instruída e informada; Francisco de Holanda - Da pintura antiqua, 1548, comentada por Vasconcelos, Porto, 1918 - usa o termo freqüentemente como adjetivo, sobretudo na negativa, como fidalgos desmusicos [p. 199; cf. p. 198-233] ou papa Paulo não é muito musico na pintura [p. 228] - apud BURY, 1994: 134).

${ }^{222}$ Cf. BURY, 1994: 133.

${ }^{223}$ Id. ibid. Supõe-se que apesar da participação desses outros construtores, o que havia de mais erudito no período se devia a Ravenna e Arruda.

${ }^{224}$ Cf. VITERBO, 1899: I, 193-5.

225 Filho de Antônio de Holanda (iluminador e funcionário do Colégio das Armas, 1485-1557). Cf. BURY, 1994: 133.

${ }^{226}$ HOLANDA, F. Da Fabrica que falece ha cidade de Lisboa, de 1571, publicado por Joaquim de Vasconcellos no Porto em 1879 - apud BURY, 1994: 133.

${ }^{227}$ HOLANDA, F. Da sciencia do desegno, de 1571, também publicado por Joaquim de Vasconcellos no Porto em 1879 - apud BURY, 1994: 133. 
disponíveis, além de melhorados com projetos específicos e detalhados no local, que João de Castilho teve de aceitar. ${ }^{228}$

Mas deve-se destacar principalmente a participação de Miguel de Arruda. ${ }^{229}$ Ele foi co-autor do projeto e trabalhou na construção dos alicerces da fortaleza de Mazagão, lado a lado com Benedetto da Ravena, que o elogiou publicamente como um mui grande homem no seu mister. Os conhecimentos de fortificação adquiridos junto ao engenheiro do imperador Carlos $\mathrm{V}$ e a experiência na aplicação deles renderam ao antigo Mestre das Pedrarias o título de Mestre das Obras dos Muros e Fortalezas (1548).

Mazagão era a primeira cidade fora da Europa a seguir o modelo ideal do Renascimento . O feito prodigioso (nas palavras de Rafael Moreira), em que se escavou na ponta de uma rocha comida pelo Atlântico uma cidade "tão perfeita e

${ }^{228}$ Cf. BURY, 1994: 133-4. Na viagem de regresso da Itália em 1541, Francisco de Holanda desenhou os baluartes poligonais feitos para reforçar os muros de San Sebastián e Fuenterrabía, cidades fronteiriças inspecionadas por Ravenna em 1534 e 37, podendo ser dele a recomendação desses baluartes pouco convencionais, desenhados por Holanda.

${ }^{229}$ Cf. MOREIRA, 2003: 41-2. Arruda, arquiteto-mor das obras da Coroa em Portugal e no império, era autor e supervisor delas. Foi ele quem nomeou Luiz Dias para a Bahia, como mostra a carta: pois foi sua vontade que eu viese qua. Para Rafael Moreira, a figura Arruda, praticamente desconhecida até o início de suas pesquisas, tornou-se "imprescindível" ("quase... essencial") à "história da fundação da cidade do Salvador" (MOREIRA, 2003: 40).

Miguel de Arruda (1500-63), filho de Francisco Arruda, autor da Torre de Belém, era da mais importante dinastia de mestres-pedreiros tardo-góticos e manuelinos, que já na 3a ou 4a geração adotou claramente a nova linguagem artística do Renascimento. Aprendeu com o pai e o tio, Diogo de Arruda, nas obras do castelo de Azamor, em Marrocos (aparece citado em 1516). Morando em Évora, seguiu os passos da família e herdou os cargos de Mestre das obras do Mosteiro da Batalha (1533) e dos palácios reais do Ribatejo (1543), colaborando com o escultor francês Nicolau Chanterene (introdutor do pleno estilo renascentista em Portugal) no convento da Graça (1532 - idem, p. 41: “... panteão régio eborense inspirado em Vitrúvio, Bramante e na última tratadística italiana, como a Divina Proporção de Luca Pacioli"). Nota-se seu prestígio no batismo da filha Hipólita (nome de origem nos livros clássicos) na Sé de Évora, com a presença dos melhores artistas portugueses, celebrado pelo humanista André de Resende, ("êmulo de Erasmo") e tendo como padrinho Diogo de Castiho ("mestre das obras da Universidade de Coimbra" - id. ibid.).

Era amigo do Infante D. Luís e D. João de Castro (de cujo círculo participavam o Conde da Castanheira e Tomé de Souza), e foi eleito "cavaleiro-fidalgo da casa real" em 1534, sendo o único arquiteto quinhentista a ser citado pelos cronistas da época, recebendo o epíteto de insigne. Seu estilo seria "um Renascimento simplificado em grandes massas, culto sem ser livresco: o melhor intérprete do gosto oficial de D. João III, que podemos classificar de classicismo nacionalizado" (id. ibid.)

Teria sido um grande compositor de volumetrias, e inventado tipologias originais na arte religiosa: “... as Sés renascentistas joaninas, inspiradas no Libro V do tratado de Sebastiano Sérlio (Miranda do Douro, 1549; Leira, 1551; Portalegre, 1556; Ribeira Grande em Cabo Verde, 1560; Goa, 1562 - a maior catedral portuguesa -; e,... Salvador...); e as 'igrejas-salão' já ao gosto da Contra-Reforma (Santarém e Estremoz, 1559, além de uma dezena de outras)" (id. ibid.). No paço real em Xabregas (iniciado em 1559 segundo plano pedido a Roma - o Palácio Farnese de Michelangelo -, mas ficando inacabado) haveria um afastamento dos modelos do Alto Renascimento.

Credita-se a ele uma extensa lista de obras espalhadas pelos três continentes do Velho Mundo (Ceuta e Tanger, 1546; baluartes de S. Jorge da Mina, 1547-8; fortaleza de Moçambique, 1558; cercas abaluartadas no Golfo Pérsico e Goa, 1560). Notabilizou-se principalmente como arquiteto militar urbanista (o que não havia distinção na época), e foi continuamente solicitado a dar projetos, avaliações, pareceres, fazer correções de colegas. Foi o perito de renome mesmo nas maiores obras de engenharia, como o aqueduto de Elvas, com 370 arcos e 7 km de extensão (1535), a fortaleza de Seinal (1549), que deu brado em toda Europa, o desvio do rio Tejo na Cardiga e a consolidação com pedras das "barrocas" do Chiado (1555). 
inexpugnável" que nunca foi tomada pelos mouros (foi abandonada a mando do Marquês de Pombal em 1769, para que sua população colonizasse a Amazônia na "Nova Mazagão" do Amapá), fez com que Miguel de Arruda se afirmasse como arquiteto de nível internacional, adaptando com primor às necessidades práticas e condições locais a sua cultura, em que Alberti foi talvez a maior influência teórica.

\section{$\underline{\text { Influência no projeto de Salvador }}$}

Por esses e outros motivos, Rafael Moreira afirma que Miguel de Arruda teria sido "o verdadeiro autor, o 'cérebro' de toda a operação material da fundação de Salvador". ${ }^{230}$ Para Rafael Moreira...

... o projeto da 1a capital do Brasil traz seu estilo com toda a clareza nas formas irradiando energia, fruto duma concepção orgânica em que o todo é pensado como um organismo vivo animado duma força de expansão de dentro para fora, como se resultasse da explosão de forças em tensão, e não da cristalização de eixos geométricos, como nas simétricas fortalezas seiscencistas. ${ }^{231}$

Embora não haja informação segura sobre o primeiro perímetro construído, Rafael considera que o plano de Salvador compreendia já toda a área construída até os anos 1590 (que aparece na Pranta da Çidade D. Salvador..., de 1605), ${ }^{232}$ tendo neste caso um contorno muito claro e regular "se corrigirmos as deformações impostas pela mudança de sítio e a irregularidade do novo terreno escolhido". ${ }^{233}$

Tratava-se dum imenso retângulo muito alongado, com um "baluarte real' em cada ângulo e dois outros a meio, sendo o mais forte a estamçia de soobre o mar ou Baluarte de S. Jorge - a cidadela, que defendia a Praça do Palácio, o nome de 1551 vindo decerto da identificação com o Castelo de S. Jorge em Lisboa - com a área intramuros preenchida por uma retícula quase ortogonal separada em zonas sociomorfológicas bem diferenciadas (política, episcopal, missionária) e as cortinas inclinadas em ângulos côncavos muito obtusos. ${ }^{234}$

\footnotetext{
${ }^{230}$ Rafael Moreira (2003: 40 e 49/ Anais..., 2001: 129-30) credita quase tudo que se sabe sobre Miguel de Arruda à descoberta da carta de Luiz Dias, seu discípulo e subordinado. Chega a dizer que na época (1999) o documento era "praticamente inédito", tendo passado despercebido porque durante muito tempo o nome de Miguel de Arruda era praticamente desconhecido (em 1972, o americano George Kluber o chamou de uma incógnita - "an unkown quantity"), havendo depois uma série de estudos esclarecedores do teor da carta e sobre o seu destinatário. Mas explica em nota que conheceu o documento (ANTT, Corpo Cronológico, Parte I, maço 86, doc. 87) em 1990 no decurso de seu doutorado, sabendo depois de sua publicação nos Anais da Biblioteca Nacional do Rio de Janeiro, v. 57, 1935 Documentos históricos, p. 24-8, "onde jaz tão esquecido quanto no arquivo".

Da mesma maneira que a análise da malha urbana feita por Manuel Teixeira é pouco creditada aos estudos de Teodoro Sampaio, Moreira desconsiderou o texto de Edison Carneiro publicado em 1954 ( $A$ Cidade do Salvador), fazendo várias referências à carta de Luiz Dias a Miguel de Arruda (em outra coincidência, no suplemento da edição de 1980, Edison Carneiro faz a mesma comparação de Rafael Moreira no capítulo "Uma Brasília do século XVI" - p. 149-51).

${ }^{231}$ Id. ibid. No final de carreira (1558), Miguel Arruda faria esse tipo de fortaleza em S. Julião da barra do Tejo, aonde faleceria em 03/01/1563.

${ }^{232}$ Acreditamos, diferentemente, que a cidade possa sim ter sido pensada nessa dimensão, mas que muito de sua configuração foi decidida ao longo de um primeiro processo de crescimento, que durou cerca de 40 anos, questão que será ainda bastante discutida.

${ }^{233}$ MOREIRA, 2003: 45.

${ }^{234}$ Id. ibid.
} 
Para Rafael, essa seria "a base da planta da vila-fortaleza de Mazagão", desenhada por Arruda seis ou sete anos antes (1541).

Embora muito menor (cerca de $1 / 8$ da área de Salvador), também aí encontramos o dispositivo dos muros dobrados - as cortine piegate dos tratadistas italianos, que o teorizaram mas não tiveram ocasião de aplicar em Itália -, cuja experimentação em Marrocos tem de ser atribuída a Ravena e ao seu convívio no círculo dos Sangallo, pois só a partir de 1554 seria divulgado na imprensa. Podemos, assim, reconstituir o mecanismo mental seguido por Arruda ao solucionar o desafio de projetar uma capital para o Novo Mundo: ampliou o modelo familiar de Mazagão mantendo a idéia da praça central do poder polarizado e os truques que aprendera do mestre italiano, mas juntando-lhe sugestões de Francesco di Giorgio Martini para as cidades portuárias e "puxando" o centro para frente marítima da Ribeira, na melhor tradição urbanística portuguesa. ${ }^{235}$

Seguindo essa idéia, voltando-se atrás em todas as adequações que precisaram ser feitas (houve principalmente uma escolha de sítio diferente da que era imaginada), o modelo elaborado por Miguel de Arruda poderia ser, entre tantos outros, algo do tipo:
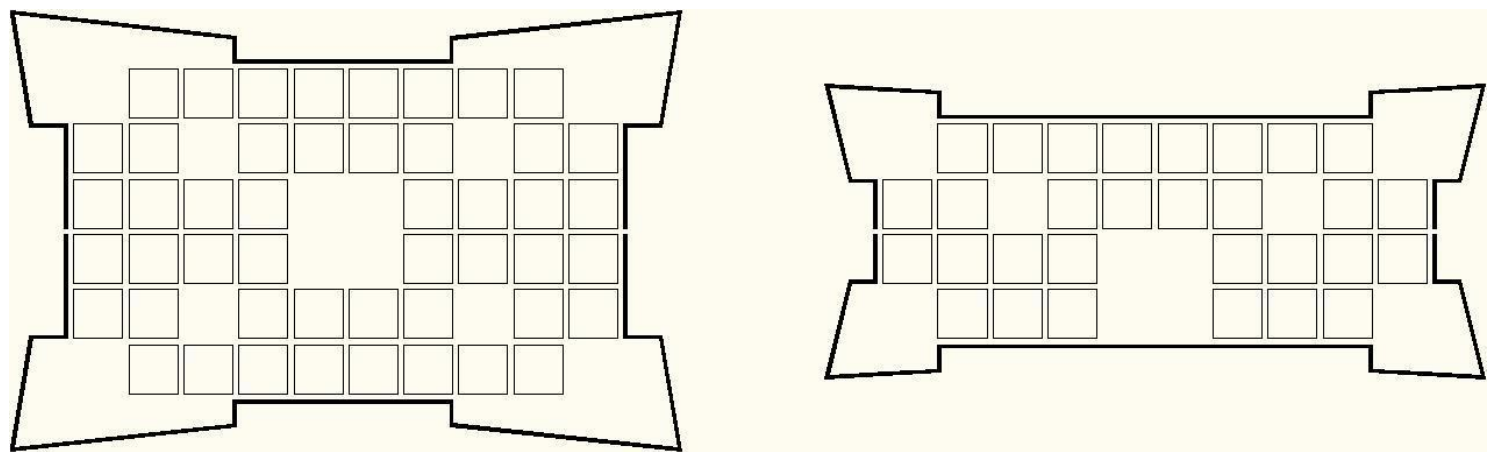

Esquemas (improváveis) do que poderia ser o esboço de Miguel de Arruda para a Fortaleza de Salvador.

Uma referência mais segura do que seria o projeto de Miguel de Arruda, nos parece, é a planta de Pietro Cataneo para uma cidade situada no monte. ${ }^{236}$ Observa-se nela (como o fundamento teórico necessário) os cortes oblíquos praticados na construção de Salvador, formando quadras trapezoidais ou triangulares. Há também uma hierarquia de várias praças (diferindo do modelo espanhol) e a grande preocupação de defesa (os baluartes maiores) ocorrendo na parte baixa, possivelmente de entrada. Esse modelo poderia servir de referência teórica até mesmo para explicar a cidade em seu perímetro mínimo (Luiz Dias não se refere em nenhum momento à existência de duas portas). ${ }^{237}$

\footnotetext{
${ }^{235}$ MOREIRA, 2003: 45-6.

${ }^{236}$ Embora o livro seja de 1554 (reeditado em 1567), acreditamos que o seu conteúdo pudesse estar acessível a Miguel de Arruda antes disso (da mesma forma, que os conhecimentos portugueses chegavam à Itália mesmo sem haver publicações).

${ }^{237}$ E aí teríamos de concordar com a suposição Edison Carneiro, como ainda veremos, de que a chamada porta de Santa Catarina era na verdade a de Santa Luzia.
} 


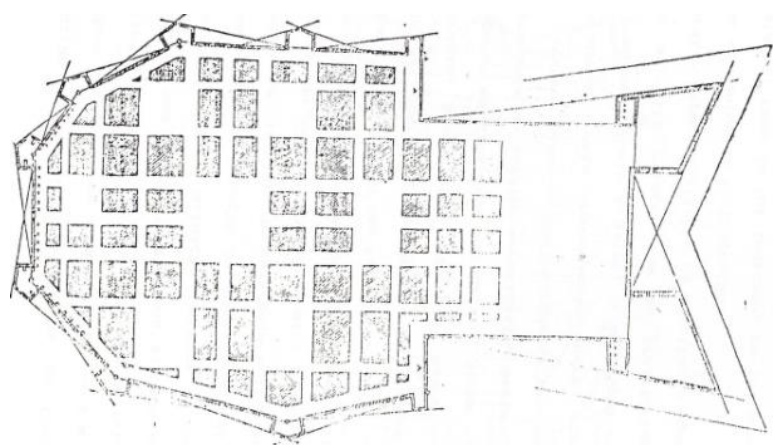

De Pietro Cataneo, planta de cidade situada num monte (em SILVA, 1991: 125).

Mas, com base na realidade documentada por escritos dos anos 1580 (Gabriel Soares) e desenhos do século XVII, preferimos acreditar que a idéia dos portugueses era de ocupar toda uma saliência topográfica, talvez menor em sua primeira concepção, mas de qualquer forma sendo programados acessos nas duas extremidades. É nesse sentido que acreditamos que a planta de Miguel de Arruda apresentasse algo parecido com os modelos apresentado há pouco.

\subsection{Cenário anterior à fundação: Capitania da Baía e Povoação do Pereira}

Em 1534, a implantação das donatarias por D. João III representava o primeiro movimento de uma ação efetivamente colonizadora no Brasil, que visava assegurar a posse de todo o território. Observar esse cenário anterior à fundação da primeira cidade portuguesa na América serve para comparar e entender a transição entre duas culturas que conviveram ao longo daquele reinado, podendo-se contrapor a influência renascentista aos chamados "atavismos medievais" (que para Mário Oliveira estariam bem exemplificados na vila e torre de Francisco Pereira Coutinho). Por esse cenário ficará mais claro o que havia de significativamente inovador e moderno na implantação de Salvador.

A exploração da capitania ficara a cargo do guerreiro Francisco Coutinho, ${ }^{238}$ que se instalara com colonos e na entrada da Baía de Todos os Santos (1536). O local escolhido era próximo às instalações do galego Diogo Álvares Correa, o Caramuru, ${ }^{239}$

\footnotetext{
${ }^{238}$ Filho de Afonso Pereira, alcaide-mor de Santarém, e de D. Catarina, ele era veterano da conquista da Índia (cf. JOHNSON e SILVA, 1992: 124-6 e CARNEIRO, 1980: 27-8).

${ }^{239}$ Vindo em nau francesa, ele escapou de um naufrágio nas pedras do atual bairro do Rio Vermelho (c. 1508-11) e acabou se instalando no atual bairro da Graça junto com outros povoadores europeus (cf. DORIA, 1999: 15-38 - segundo Edison Carneiro, entre os homens de Diogo Álvares não haveria mais que "três ou quatro cristãos, naufragados na costa ou deixados ali pela armada de Martim Afonso" CARNEIRO, 1908: 26). Cf. SOUSA, 1971: 128-9 - “... no tempo que Tomé de Sousa desembarcou, achou na Vila Velha a um Diogo Álvares, de alcunha o Caramuru, grande língua dos gentios, o qual, depois da morte de Francisco Pereira, fez pazes como gentio; e, com elas feitas, se veio dos Ilhéus a povoar o assento das casas em que dantes vivia, que era afastado da povoação, onde se fortificou e recolheu com cinco genros que tinha, e outros homens que o acompanharam, dos que escaparam da desventura de Francisco Pereira, os quais, ora com armas, ora com boas razões, se foram defendendo e sustentando até a chegada de Tomé de Sousa, por cujo mandado Diogo Álvares quietou o gentio e o fez dar obediência ao governador, e oferecer-se ao servir; o qual gentio em seu tempo viveu muito quieto e recolhido, andando ordinariamente trabalhando na fortificação da cidade a troco do resgate que lhe por isso davam" (grifo nosso).
} 
que chegara à região cerca de vinte e cinco antes e se casara com a índia Paraguaçu, ${ }^{240}$ passando a ter uma boa relação com os nativos. ${ }^{241}$ Coutinho deu ao povoado o nome de Vitória, mas com o tempo ele passou a se chamar Povoação do Pereira e depois (com a fundação de Salvador) Vila Velha. Ficava na primeira pequena enseada dentro da baía (atual Porto da Barra), após a Ponta do Padrão (do atual Farol). Dali ele distribuiu com rapidez as terras em regime de sesmaria, ${ }^{242}$ dando a uma autonomia que acabou levando os colonos à dispersão.

Diogo Álvares ajudava na relação com os índios locais, ganhando assim a oficialização de suas posses (ainda em 1536), mas outros índios, de regiões próximas, passaram a hostilizar o donatário. Os donos de outras sesmarias, com interesses individuais, não se juntavam contra os ataques, e em meio a dificuldades no abastecimento de água (trazida por navios vindos do sul) e dispersão de colonos para outras capitanias, Coutinho escolheu um local perto do porto de desembarque (o Alto de Santo Antônio da Barra, ao pé da atual igreja) para construir uma fortaleza rudimentar de taipa, guarnecendo-a com armas de fogo para eventuais ataques de índios. Para alguns, seria "o baluarte de Coutinho a primeira fortificação erguida na Bahia". ${ }^{243}$

Em um cerco prolongado de índios, Coutinho recebeu ajuda pelo mar da capitania vizinha, mas se viu obrigado a fugir para Porto Seguro. Com promessas de paz oferecidas pela esposa de Diogo Álvares, tentou voltar, mas naufragou em Itaparica onde, diz a lenda, foi devorado pelos tupinambás locais. ${ }^{244}$ Para alguns, a morte do donatário foi decisiva na escolha da capitania para o projeto seguinte de D. João III. ${ }^{245}$

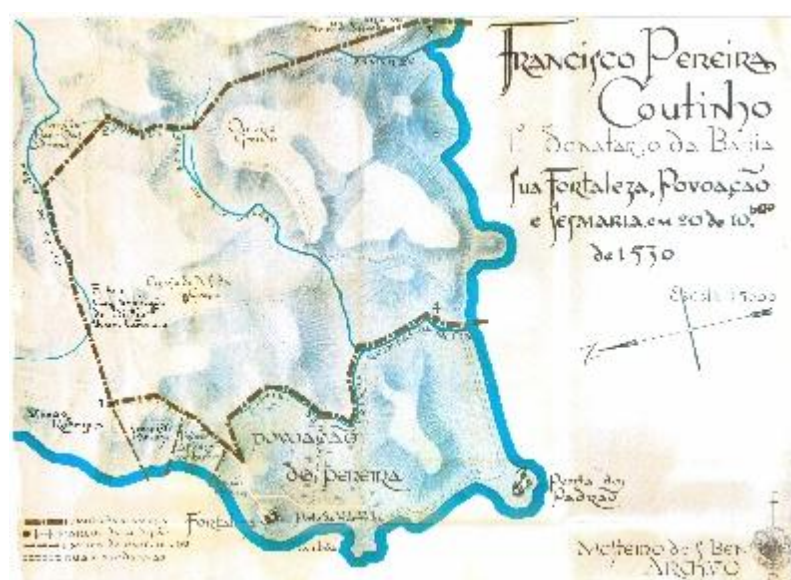

A povoação do Pereira em documento do Arquivo do Mosteiro de S. Bento (em NUNES, 2006).

\footnotetext{
${ }^{240}$ Batizada na França (1528) como Catarina.

${ }^{241}$ A ponto de influenciar a ação portuguesa nos anos seguintes.

242 Ao bombardeiro Pedro Afonso, a Sebastião Aranha, Francisco de Azevedo, Fernão Dolores, Paulo Dias e, principalmente, Diogo Álvares (cf. JOHNSON e SILVA, 1992: 124-6).

${ }^{243}$ FALCÃO, 1942: 42 (grifo nosso). O termo "baluarte", neste caso, só se justifica como sinônimo de fortificação, do mesmo modo que Luiz Dias definiu assim o seu recinto fortificado em syma do rochedo, provavelmente não se referindo à "saliência provida de flancos que articula as variações de rumo das cortinas das fortificações" (cf. LEMOS, 1989: 238).

244 Também diz a lenda que quase todos os povoadores que vieram com ele tiveram a mesma "sorte".

245 PRADO, 1945: 56-72. Como o General Domingos A. M. Barreto (Observaçoens Sobre a Fortificação da Cidade da Bahia...fl. 4v), que diz: com este inesperado sucesso [o naufrágio de Coutinho, tendo sido todo o seu pessoal tragado do Gentio] fizerão estas terras reversão para a Real Corôa, e então ordenou o S. $^{r}$ Rey D. João $3^{0}$ se levantasse uma Cidade $q^{\prime}$. fosse cabeça do Estado.
} 


\section{As torres de terra: Caramuru e Coutinho}

Há raros registros tanto sobre a fortificação de Francisco Coutinho quanto sobre a de Diogo Álvares. Sobre o Forte da Graça, ou torre de Caramuru, José de Pinho se apóia em documento do Livro Velho do Tombo de São Bento para dizer que "ao redor da ermida da Graça espalham-se casas de ermitães e de romeiros, residências e currais da família Caramuru, e, para trás do pequeno templo, as ruínas... da antiga fortaleza que outrora defendera 'o assento e a casa' em que vivera Diogo Alvares...". ${ }^{246}$ O Livro Velho do Tombo diz:

Provaria que no tempo em que se pasara a sesmaria de que os autores se querem valer nam havia os fortes que há hoje porque entam nam ouvera outro forte, nem fortaleza se nam o padram que está detras da hermida de Nossa Senhora da Graça onde estavam ainda os vestígios e as paredes onde estavam duas pesoas [peças] para se defenderem do Gentio e nem dahi a quarenta annos se fizeram fortes que hoje há que chamam de Santo Antonio... ${ }^{247}$

Provariam que posto que a carta faça mensão do forte nam podia nunca ser a dos vestígios que estam detras de Nossa Senhora da graça que he no sertam e distancia muita do mar e a Carta declara forte, e que está junto da Camboa, nam se faz no sertam donde se verificou ser o forte de Santo Antonio q' despois se fizera de novo que dantes era um reduto e forte de taipa... ${ }^{248}$

São, portanto, menções de 1639 às ruínas do Forte da Graça, diferenciando-o da antiga fortificação de Coutinho, que ficava no Porto da Barra, e do Forte de Santo Antônio da Barra, que seria erguido quarenta anos depois na Ponta do Padrão. Ele seria semelhante a outras construções primitivas que acumulavam funções de defesa e habitação (como, depois, a Torre de Garcia d' Ávila), de partido próximo ao de construções medievais.

Sobre a Fortificação de Coutinho, deve-se considerar na época de sua chegada as condições arredias de sobrevivência e recrutamento de mão-de-obra especializada. Seria uma espécie de torre militar muito simples, de taipa de pilão, que por isso durou pouco. Para Mário Oliveira, era pequena e de base quadrada, já precisando de reparos quando Salvador foi fundada. ${ }^{249}$ Haveria semelhança com as torres de outras capitanias, como a de Duarte Coelho, em Pernambuco, que tem uma pequena referência em Varnhagen: seria "uma espécie de castelo quadrado, à maneira das torres de menagem dos solares da Idade Média". ${ }^{250}$ Sobre a torre de São Vicente, de Martim Afonso de Sousa, Varnhagen cita o cronista Frei Gaspar da Madre de Deus e diz

\footnotetext{
${ }^{246}$ PINHO, José Wanderley de. Prefácio in CONGREGAÇÃO BENEDITINA DE SALVADOR. Livro Velho do Tombo de S. Bento. Salvador (grifo nosso) - apud OLIVEIRA, 2004: 248 (nota 16).

247 Documento de 05/09/1639: Sentença dos P. ${ }^{\text {es }}$ de S. Bento contra os Testam. ${ }^{\text {iros }}$ de Antonio Borges... in CONGREGAÇÃO BENEDITINA DE SALVADOR. Livro Velho do Tombo de S. Bento. Salvador, p. 66 (grifos nossos) - apud OLIVEIRA, 2004: 248 (nota 17).

${ }^{248}$ Idem, p. 67.

249 Cf. OLIVEIRA, 2004: 175. Uma Provisão da época determinava que o taipeiro Balthazar Fernandes reconstruísse 31 braças $(68,2 \mathrm{~m}$ ) de sua taipa (BN - Documentos históricos, 1929, v. 14, p. 252 - apud OLIVEIRA, 2004: 176). Na descrição de E. Carneiro (1980: 28), “um simples quadrado de pedra e taipa com alguma artilharia".

250 VARNHAGEN, 1962: I, 173. Gabriel Soares descreve a torre de Pernambuco como de pedra e cal, existindo ainda nos anos 1580: Chegando Duarte Coelho a este porto, desembarcou nele e fortificou-se, onde agora está a vila em um alto livre de padrastos, da melhor maneira que foi possível, onde fez uma torre de pedra e cal, que ainda agora está na praça da vila, onde muitos anos teve grandes trabalhos de guerra com o gentio e franceses... (SOUSA, 1971: 58).
} 
que era "uma torre quadrada com três seteiras, flanqueada por duas como guaritas circulares da mesma altura". ${ }^{251}$

Um documento transcrito por Vernhagen ajuda a entender o aspecto da povoação de Pereira Coutinho: Poz a villa no melhor assento que achou, em que tem feito casas para cem moradores e tranqueiras de redor e uma torre já no primeiro sobrado. ${ }^{252}$ No croqui apresentado por Teodoro Sampaio (baseado no mesmo partido da torre de menagem do Castelo de Bragança, em Portugal) a torre aparece com guaritas suspensas no alto da muralha, em vez das circulares construídas no solo, de mesma altura. ${ }^{253}$ Mas, sendo de terra, é mais provável que fossem torretas saídas do solo (como no Forte Santo Alberto e na torre de S. Vicente).
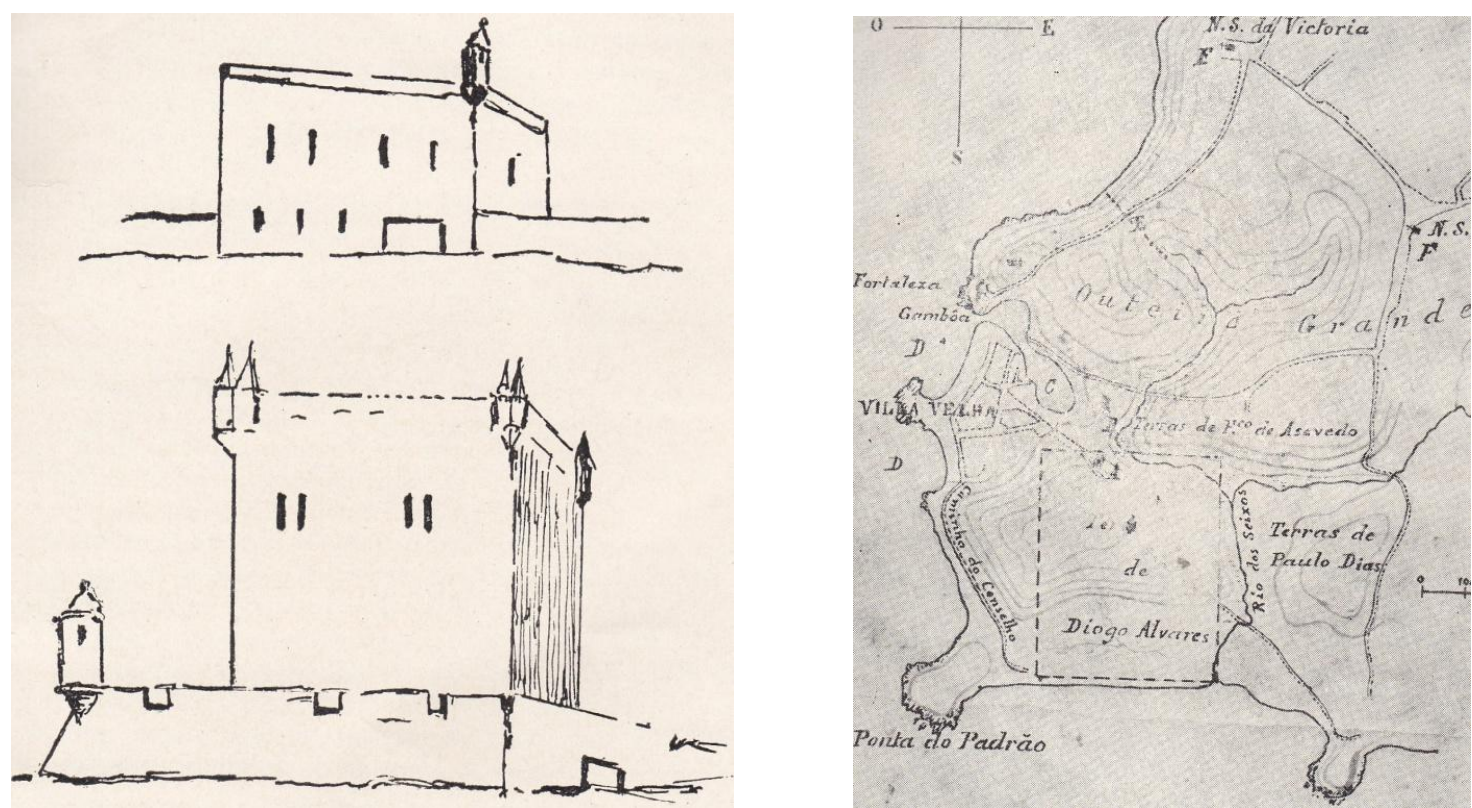

À esquerda, a Torre de Coutinho, que para Teodoro Sampaio teria dois andares e "não primava pela elegância". As quatro paredes grossas seriam guarnecidas com seteiras e guaritas de vigia. Teria sido construída "no ângulo mais saliente e mais alto do terreno a ser defendido e ligava-se com as estacadas e fossos que the serviam de cortina". À direita, um mapa das localidades (em SAMPAIO, 1949: 136-7 e 144-5).

\footnotetext{
${ }^{251}$ VARNHAGEN, 1962: I, 168. No Livro das Fortalezas de Duarte D’Armas se observa uma preferência portuguesa por torres de menagem de base quadrada, como a apresentada na parte inicial deste estudo (p. 36, o partido arquitetônico explorado no traçado da fortaleza de Ajudá, em Castro Marim, do início do século XVI): um modelo de duas entradas com dois pares de torres para cobri-las (lembrando que os quadriláteros com torres circulares nos cantos não eram só portugueses, havendo muitos exemplos na Europa, como o Castelo Maniace, em Siracusa, na Sicília). Mas a comparação só poderia ser feita levando-se em conta as condições precárias das torres do Brasil.

${ }^{252}$ Apud VERNHAGEN, 1962: I, 208 - s/ ref: ("em uma coleção de papéis velhos da Biblioteca Nacional... se encontra a seguinte cópia").

${ }^{253} \mathrm{O}$ croqui se baseia na descrição de outras torres primitivas, sendo criticado por Mário Oliveira principalmente pelas guaritas elevadas.
} 

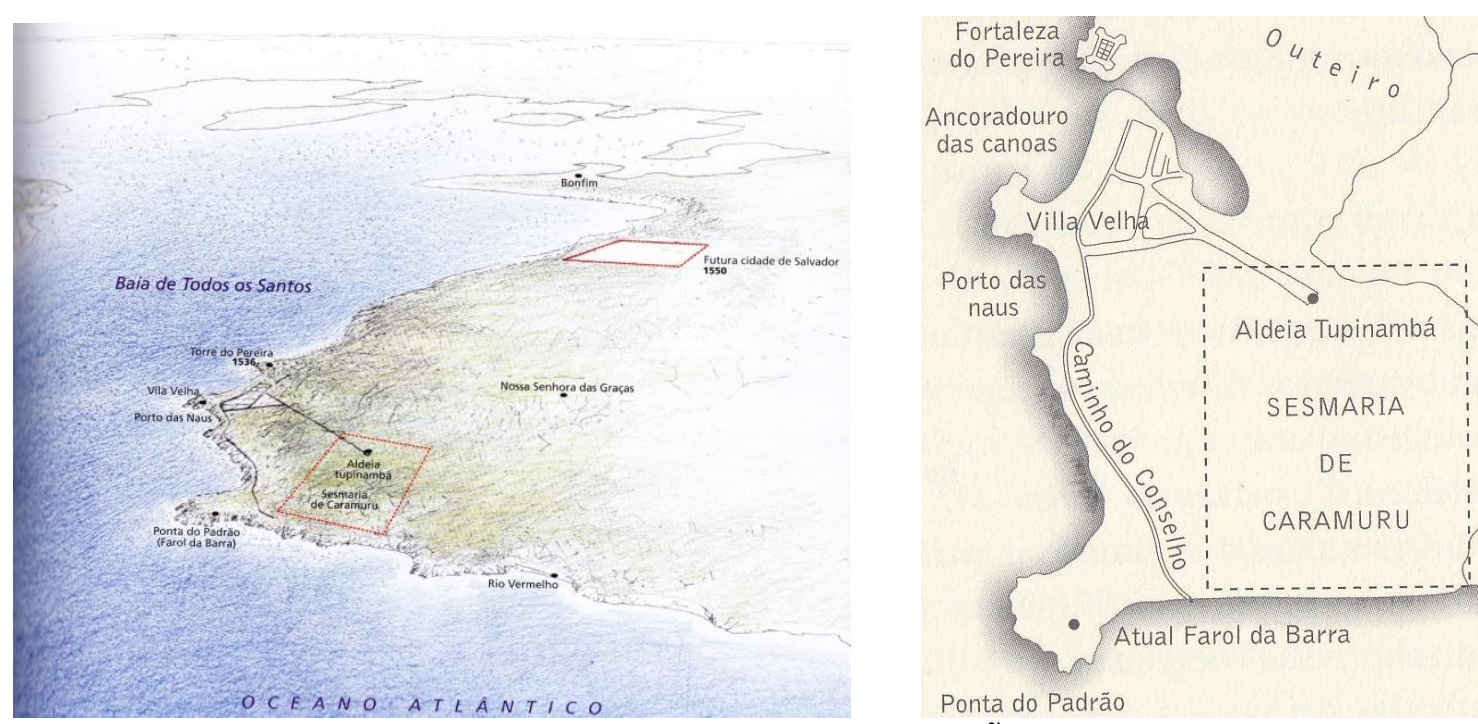

$\mathrm{Na}$ "vista aérea" de uma publicação recente (KEATING \& MARANHÃO, 2008: 77), como nos livros de Eduardo Bueno (2006-1: 231 e 2006-2: 22), as informações foram tiradas de Teodoro Sampaio.

Pelo depoimento de Nóbrega, falando da capitania em sua primeira carta, vê-se que o vilarejo estava em franco esvaziamento na chegada de Tomé de Souza (1549): Achamos a terra de paz e quarenta ou cincoenta moradores na povoação que antes era. $^{254}$

\subsection{Regimento (1548)}

Alguns meses antes dessa chegada narrada por Nóbrega, estava pronto o Regimento do Governador e Capitão-General Tomé de Souza dado em Almeirim, Portugal, a 17 de dezembro de 1548, que como está no subtítulo de sua publicação recente da Fundação Gregório de Mattos, era uma "constituição prévia" do então nascente Estado do Brasil. Meses ou até anos antes de sua oficialização, portanto, estava em estudo essa nova empresa que associava a construção de uma sede colonial à política econômica de produção do açúcar.

O Regimento, elaborado por D. Antônio da Ataíde (o Conde da Castanheira, Vedor da Fazenda de D. João III), tinha métodos de ação e metas bem definidas, entre elas a inclusão dos índios na pirâmide social. ${ }^{255} \mathrm{O}$ documento definia poderes, normas e prioridades da administração centralizada, que se justificava pelo fraco desempenho das donatarias. ${ }^{256}$ Com Tomé de Souza viriam os primeiros jesuítas, ${ }^{257}$ muitos funcionários, soldados, artesãos e colonos. Também a escolha da Bahia para implantação do Governo Geral (tendo provável relação com a morte de Pereira Coutinho, que deixou sem donatário uma capitania central em relação às outras)

\footnotetext{
${ }^{254}$ NÓBREGA, 1988: 71.

255 Obviamente na base, pois na visão oficial a terra era de propriedade portuguesa, sendo a ocupação dos índios uma mera casualidade. A idéia era arregimentá-los como mão-de-obra agrícola (cf. MONTEIRO, 1995: 42 e MOREAU, 2003: 204-8).

${ }^{256}$ Além de instruções para a construção de Salvador, são recomendados procedimentos em relação aos índios e dadas regras de relacionamento entre a Cidade e as demais capitanias (cf. RIBEIRO e MOREIRA NETO, 1992: 142-8)

257 Introduzindo "um novo elemento de ação política e religiosa e de controle social" (RIBEIRO e MOREIRA NETO, 1992: 142).
} 
partiu do Conde da Castanheira. A nova cidade teria na Vila do Pereira, na entrada da baía, apenas um ponto de apoio.

É pelo Regimento que sabemos que havia um projeto, ou plano traçado de cidade: o Governador Capitão General é incumbido de erguê-la e organizá-la conforme as orientações em desenho, ou, conformando-vos com as traças e amostras que levais. ${ }^{258}$ Quando se imagina esquematicamente os desenhos de Miguel de Arruda para a construção da cidade, há duas referências principais: ${ }^{259} 1$ - os relatos sobre o que foi feito em cartas do Mestre das Obras Luiz Dias escritas a ele e ao Rei (1551); ${ }^{260}$ 2- a cartografia mais antiga que se preservou da cidade, de $1605 .{ }^{261}$ Uma terceira referência possível seriam os inúmeros desenhos de cidades fortificadas produzidos no Renascimento, especialmente os mais divulgados em Portugal, entre eles os de Francesco di Giorgio. $^{262}$ A quarta referência, que Rafael Moreira considera importantíssima, seria o projeto de Mazagão, do qual Arruda também teria participado. Mas, como pretendemos mostrar aqui, o desenho de M. de Arruda mostraria algo bem diferente do que foi depois traçado em solo por Luiz Dias. A configuração das ruas e a localização das praças foram determinadas principalmente pelas condições topográficas.

\section{Instruções vitruvianas}

Como acabamos de lembrar, em 1604-5 foi desenhada uma carta representando um novo projeto de fortificação para Salvador, o que seria comparável atualmente a um plano diretor de crescimento, já que na época colonial a cidade nunca deixou de ser tratada como fortaleza. Esta idéia está mais do que presente no Regimento de D. João III, quando se ordena a fundação da cidade recomendando que se faça uma fortaleza e povoação grande e forte em um lugar conveniente. ${ }^{263}$ Antes de ser construída, portanto, Salvador foi concebida como "fortaleza" (cidade fortificada), condição em que se manteria por mais de dois séculos.

Nas instruções a Tomé de Souza (Regimento de 1548), notam-se preocupações com o modelo urbano pela frase mencionada, conformando-vos com as traças $e$ amostras que levais. Teóricos modernos do urbanismo português, como Manuel Teixeira e Rafael Moreira, destacam este trecho para dizer que houve cuidados especiais com a "regularidade do traçado da nova cidade", ${ }^{264}$ que deveria, segundo Teixeira, estruturar-se de modo planejado e organizado. Mas uma análise, ou afirmação segura sobre o primeiro traçado de Salvador, só poderia ser feita a partir de

\footnotetext{
258 Regimento..., 1998: 14. Havia plantas e "modelos" (talvez elevações, perspectivas) aos quais o construtor deveria se conformar (obedecer, seguir).

${ }^{259}$ Como mencionamos ao abordar Mazagão, sabe-se pela carta de Luiz Dias, que a autoria dessas traças e amostras, ou do primeiro desenho para a Cidade de Salvador da Bahia (1548), era do arquiteto e engenheiro militar Miguel de Arruda.

${ }^{260}$ O título de Mestre das Obras da Fortaleza e Cidade do Salvador foi dado em 14/01/1549 (cf. MOREIRA, 2003: 38 - a autoria de Miguel de Arruda para o plano inicial de Salvador está demonstrada ao longo do mesmo texto, p. 34-59).

${ }^{261}$ Projeto de fortificação da cidade desenhado pelo cosmógrafo Albernaz I, representando o plano do Eng. Mil. Francisco Frias de Mesquita, a princípio conferido (talvez modificado) pelos engenheiros-mores de Portugal e Espanha, Leonardo Turriano e Tibúrcio Spanoqui.

262 Nos quais nos baseamos para apresentar aquele esboço imaginário, mas sem qualquer pretensão.

${ }^{263}$ Regimento..., 1998: 11-2.

264 TEIXEIRA \& VALLA, 1999: 218.
} 
uma representação em desenho, sendo a mais antiga, conservada, a de 1605. Antes dela, a descrição mais próxima de apontar uma regularidade é a de Gabriel Soares para a cidade recém expandida (1584-7), em que aparece o terreiro cercado em quadro de nobres casas além de outras qualidades urbanas. ${ }^{265}$ Uma segunda descrição importantíssima acontecerá em 1609, o relatório do engenheiro militar Diogo Campos Moreno.

Essa frase chave (conformando-vos com as traças...), acabou sendo reproduzida em muitos trabalhos importantes sobre o início do urbanismo no Brasil, levando a ofuscar outras informações importantes do documento. Nota-se ao longo dele estarem explicitadas várias questões relacionadas ao conhecimento urbanístico da época. Por exemplo, na passagem que fala de um dos critérios para a escolha de sítio (subordinado ao outro, mais importante para os portugueses, de estar em local protegido, preferencialmente uma acrópole), mostrando a base de sua referência teórica: ... deve de ser em sitio sadio e de bons ares e que tenha abastança de águas e porto em que bem possam amarar os navios... ${ }^{266}$

Desde a Antiguidade, a questão da salubridade era lembrada na fundação de vilas e cidades (por sua vez imbricada na da fortificação). O Regimento mostra os preceitos antigos (sistematizados por Vitrúvio no século I a. C.) adotados pelos portugueses na fundação de feitorias em regiões distantes. Como foi mencionado, havia em Portugal, nos século XV e XVI, enorme interesse pelo Tratado de Arquitetura romano. ${ }^{267}$ Vale para as fundações portuguesas em geral o que está preconizado por Vitrúvio na abertura do Capítulo 5 (que também mostra que na Antiguidade as cidades nasciam fortificadas):

Quando... se verificar o requisito de salubridade dos recintos urbanos a levantar, forem escolhidas regiões em frutos para alimentar a cidade, quando construções de vias, localizações favoráveis de rios ou comunicações marítimas através de um porto proporcionarem facilidades de transportes para as cidades, do seguinte modo deverão ser construídos, então, os fundamentos [fundações] das torres e das muralhas: escavar-se-ão até ao chão firme... com uma espessura mais larga do que as paredes que ficarão acima da terra, enchendo-se de concreto ... ${ }^{268}$

Toda a tratadística italiana difundida pela Europa, com Alberti e outros, ${ }^{269}$ começou pelo amplo estudo e divulgação (com posteriores traduções em várias línguas, inclusive o português) do Tratado de Vitrúvio, que apresenta uma série de conhecimentos ligados a construções militares e, mais ainda, à relação entre a fundação de uma cidade e, à época, o seu sistema de defesa. Sobre as condições exigidas em escolhas de sítio para as fundações portuguesas há semelhanças com o

\footnotetext{
${ }^{265}$ SOUSA, 1971: 136.

${ }^{266}$ Regimento..., 1998: 14.

267 A primeira impressão do tratado é de 1486-8, sabendo-se que havia um exemplar na biblioteca do arcebispo de Braga. Têm-se notícia de mais de 70 manuscritos medievais, certamente alguns sendo conhecidos do infante D. Henrique em seu contato com os italianos - cf. MOREIRA, 2003: 29 (nota 8).

${ }^{268}$ VITRÚVIO, 2006: 45-8 (Livro I, capítulo 5).

269 Lembramos que a época da fundação de Salvador foi o auge do interesse português pela arte tratadística italiana (cada vez maior desde o começo do século XVI, havendo traduções não só de tratados de arquitetura, mas de estudos científicos em geral). Rafael Moreira (2003: 8-32) ressalta que o intercâmbio com as cortes italianas envolvendo profissionais do desenho e da arte de fortificar mostra o interesse em desenvolver novas técnicas de representação construtiva, que incluíam desenhos e modelos, quando Portugal já ocupava dezenas de pontos em três continentes.
} 
que é prescrito por Vitrúvio. ${ }^{270} \mathrm{Em}$ Salvador, foram tomados como condições ideais o sítio estratégico (alto e naturalmente protegido) e o abrigo no interior do Recôncavo junto a um bom porto. ${ }^{271}$ Não por coincidência, Vitrúvio também abre o Capítulo 4 do Livro I (sobre Urbes e Fortificações) com: No que respeita às cidades, serão estes os princípios. Em primeiro lugar, a eleição de um lugar o mais saudável possível. Este será alto e não nebuloso... ${ }^{272}$

Seguem-se em Vitrúvio outras recomendações como estar voltado para um quadrante temperado, não sujeito a geadas e longe de pântanos. Por questões de salubridade (evitando-se a presença de animais pestilentos, como mosquitos), o tratado não recomenda que se construam cidades junto ao mar quando orientadas para o Sul ou para o Ocidente, em que o sol ferve à tarde (Salvador, dentro de uma baía, é um caso raro no Brasil de cidade voltada ao mar a Noroeste). Ao contrário, fala na importância de escolher exposições celestes mais temperadas quando se tratar da salubridade na fundação das cidades. ${ }^{273}$ Nesse aspecto, a opção dos portugueses pela baía de Salvador (e não pela do Rio de Janeiro) se explicaria novamente pela posição central em relação à costa que se pretendia primeiro colonizar, e por estar mais próxima à Metrópole. ${ }^{274}$

$\mathrm{Na}$ verdade, havia uma gama de fatores relacionados à escolha de sítio: salubridade, defesa, abastecimento, fertilidade da terra (agricultura e pasto), presença de árvores de boa qualidade, materiais de construção, água abundante e potável. Segue-se uma transcrição mais abrangente do trecho citado do Regimento, mostrando como foram descritas as condições necessárias à fundação.

... deve de ser em sítio sadio e de bons ares e que tenha abastança de águas e porto em que bem possam amarar os navios e vararem se quando cumprir porque todas estas qualidades ou as mais delas que puderem ser cumpre que tenha a dita fortaleza $e$ povoação por assim ter assentado que dela se favoreçam e provejam todas as terras do Brasil e no sítio que vós melhor parecer ordenareis que se faça uma fortaleza da grandura e feição que a requerer o lugar em que a fizerdes, conformando-vos com as traças e amostras que levais praticando com os oficiais que para isso lá mando e com quaisquer outras pessoas que o bem entendam e para esta obra vão em vossa companhia alguns oficiais assim pedreiros e carpinteiros como outros que poderão servir de fazer cal telha tijolo e para se poder começar a dita fortaleza vão nos navios dessa armada alguns achegas e não achando na terra aparelho para se a dita

\footnotetext{
${ }^{270}$ Para Rafael Moreira (2003: 8-28), a única grande diferença dos romanos seria o fato dos portugueses serem grandes navegadores, dando preferência às fundações portuárias. Ele destaca a expansão ultramarina portuguesa como o primeiro império marítimo desde Cartago e Roma, mas já em escala planetária, com uma rede de fundações interligadas em fluxo constante por rotas regulares (as carreiras). O cenário eram os oceanos e não os continentes: no lado oriental, o Estado da Índia (1504) ia do Índico ao Pacífico; no ocidental, os Estados do Brasil e do Maranhão e todo o espaço atlântico, das ilhas dos Açores à costa do golfo da Guiné, Mina e Angola.

${ }^{271}$ Cf. MOREIRA, 2003: 35-48.

${ }^{272}$ VITRÚVIO, 2006: 41 (grifo nosso).

273 VITRUVIO, 2006: 44. Associando a importância do saber medicinal com o reconhecimento da salubridade na escolha do sítio, Vitrúvio explica como os ancestrais (devem ser recordadas com insistência as disposições antigas) expunham primeiro os animais a determinadas áreas, e depois de examinados seus fígados é que se deduzia se o local era adequado e saudável aos homens: Tendo experimentado várias vezes e ficado convictos da natureza íntegra e sólida dos fígados na sua ligação à água e ao pasto, aí levantavam as fortificações.

${ }^{274}$ Embora D. João III justifique a escolha pelas qualidades físicas ligadas à salubridade, independente do calor: ... por ser informado que a Bahia de Todos os Santos é o lugar mais conveniente da costa do Brasil para se poder fazer a dita povoação e assento assim pela disposição do porto e rios que nela entram como pela bondade abastança e saúde da terra e por outros respeitos... (Regimento..., 1998: 12).
} 
fortaleza fazer de pedra e cal far-se-á de pedra e barro ou taipais ou madeira como melhor puder ser de maneira que seja forte e como na dita fortaleza for feita tanta obra que vos pareça que seguramente vos podereis nela recolher e agasalhar com a gente que levais vos passareis a ela deixando porém na dita cerca que está feita alguma gente que baste para povoar e defender. ${ }^{275}$

\subsection{Preparativos e início da construção (1549)}

Vimos pelo Regimento que, na armada de Tomé de Souza, Luiz Dias trazia as representações em planta e modelo da futura cidade, com diretrizes razoavelmente precisas para a escolha de sítio. A primeira das cartas preservadas de Luiz Dias mostra que essas diretrizes, e ainda a orientação e o traçado urbano, seriam de Miguel de Arruda, mestre-arquiteto e engenheiro-chefe das fortificações do reino, luguares dalem e Indias, ${ }^{276}$ a quem reportava. Luiz Dias, administrador das obras, teria decidido com Tomé de Souza o local de implantação: considerando vulnerável Itapagipe, ${ }^{277}$ o local recomendado, eles escolheram o centro da enseada que tinha ao norte essa península e ao sul a Ponta do Padrão (próxima à qual havia a povoação de Francisco Pereira Coutinho, depois chamada de Vila Velha). ${ }^{278}$ Escolhido o sítio para a implantação, tratou-se de fortificar a cidade e basear sua configuração nas traças

${ }^{275}$ Regimento..., 1998: 14 (grifos nossos). Outra informação contida no Regimento, pouco comentada, refere-se às dimensões máximas da povoação, que por serem amplas, talvez se refiram a uma primeira área de influência (município): Porque minha tenção é que a dita povoação seja tal como atrás fica declarado hei por bem que ela tenha de termo e limite seis léguas para cada parte e sendo caso que para alguma parte não haja as ditas seis léguas por não haver tanta terra chegará o dito termo até onde chegarem as terras da dita capitania o qual termo mandareis demarcar de maneira que em todo o tempo se possa saber por onde parte (idem, p. 14-5; a légua de sesmaria tinha cerca de 3000 braças, ou $6600 \mathrm{~m}$; toda a enseada onde foi feita a cidade teria duas léguas, sendo ela construída... uma légua da barra para dentro... - SOUSA, 1971: 133). Essa informação, aliás, aparece em alguns historiadores sem que esteja explicitada a referência: “... Tomé de Sousa tomou medidas para organizar a vida do município baiano, cujos limites fixou em seis léguas para cada lado" (JOHNSON \& SILVA, 1992: 144).

${ }^{276}$ Título citado em VITERBO, 1899.

277 Ou Itapegipe (aparecem as duas formas). O Regimento do Rei e as cartas de Luiz Dias a Arruda indicam que além do plano da "capital" (ou "cabeça", como era chamada) ter sido coordenado em Lisboa pelo arquiteto e urbanista da Corte, o lugar de preferência era aquela península. Mas o Rei deixava em aberto a uma junta de autoridades e peritos a escolha do local exato.

${ }^{278} \mathrm{Na}$ interpretação de Rafael Moreira, o local "correspondia melhor ao duplo critério defensivo $e$ portuário: uma chapada de feitio aproximadamente triangular rodeada de alagadiços em fosso natural e caindo em barreiras sobre a praia, uma estreita faixa de areia onde se ergueram a igreja de Nossa Senhora da Conceição da Praia e a capela do Corpo Santo, ou Sant' Elmo, a padroeira dos marinheiros" (MOREIRA, 2003: 39 - grifo nosso). Cf. também BUENO, 2001: 613-4. “As Cidades quinhentistas... sempre que possível, contaram com... um engenheiro... A situação escolhida para implantar Salvador... foi a entrada de uma baía. ... a nova Capital do Brasil foi desenhada por Miguel de Arruda e executada por Luiz Dias. O desenho... projeto de gabinete... em Lisboa, adaptou-se à conjuntura encontrada... Luiz Dias, e o astrólogo Filipe Guillén tiveram autonomia suficiente para implantar a cidade no sítio mais apropriado, escolhido a seu critério, adaptando-Ihe às traças e amostras trazidas por Tomé de Sousa. ... foi uma escolha perfeita, no topo plano de uma colina, margeada por fossos naturais constituídos pelos c. 80 m em relação ao nível do mar e uma enorme grota ao fundo".

No final do século XVIII haveria a voz destoante (e um tanto ociosa, pela distância no tempo) do Cap. Domingos Alves Branco Muniz Barreto (Observaçoens..., 1797): Não posso porem deixar pelo que toca á Cidade da Bahia, ... demostrar, em 10 lugar: A pessima escôlha do torreno, em $q^{\prime}$ se fundou a Cidade... (fl. 2). Para ele, o local adequado seria mesmo Itapagipe, mais fácil de fortificar fechando-se o acesso à ponta pelo continente (cf. fl. 7). 
trazidas por Luiz Dias. A cidade foi então iniciada, em 1549, na ampla colina que dominava a baía.

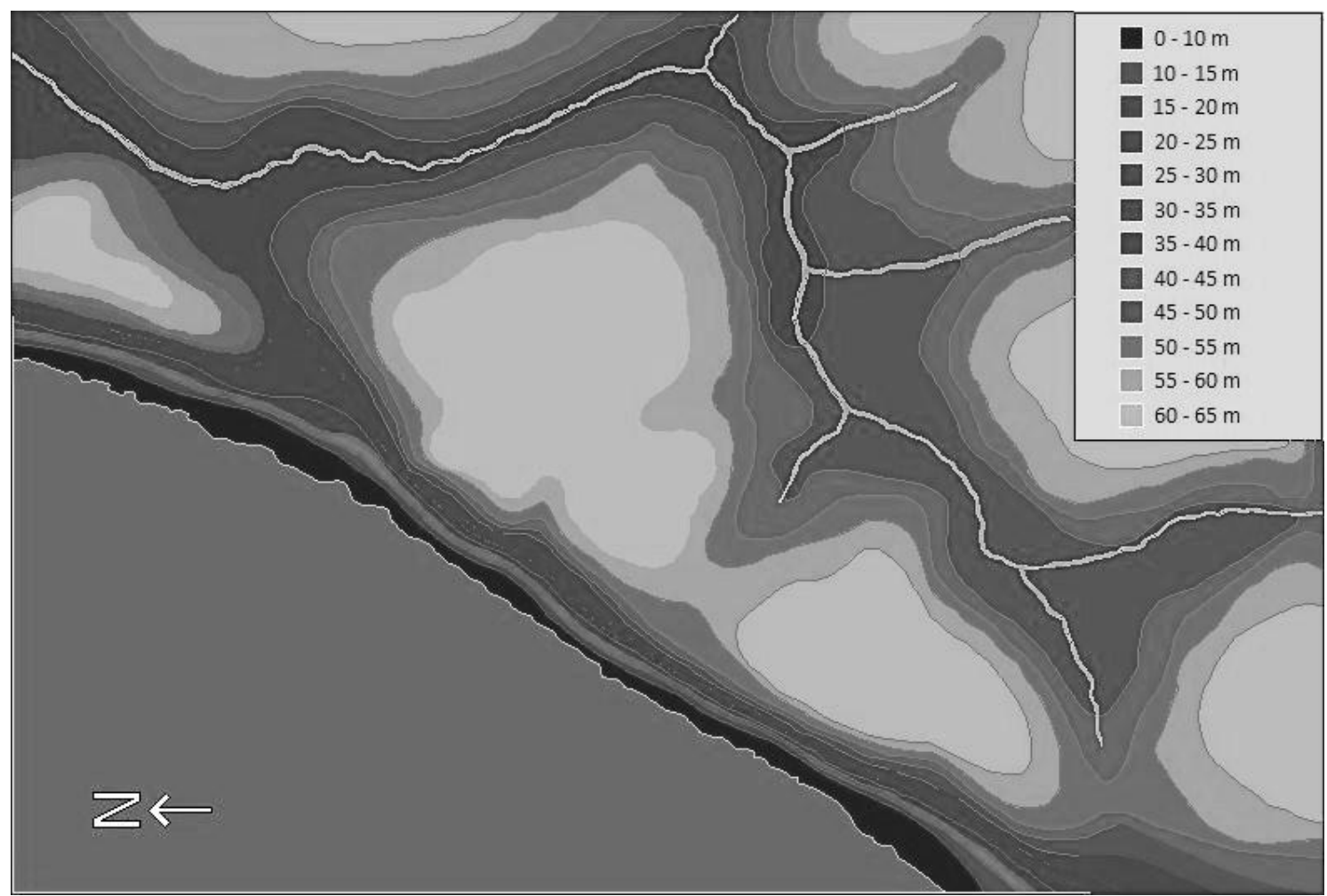

Mapa das características topográficas da área escolhida para a implantação da cidade.

A parte alta, em sítio "sobranceiro ao mar" (próximo à praia, de enseada que proporcionava ótimo porto natural), ${ }^{279}$ abrigaria os principais edifícios institucionais e a maior parte das moradias, enquanto a baixa teria funções portuárias e mercantis. A construção de Salvador representaria uma nova fase na colonização do Brasil, centralizada na Coroa e que teria a cidade como sede do Governo Geral e capital da Colônia.

${ }^{279}$ Cf. FALCÃO, 1942: 42-3. Na interessante narrativa de Edgar Falcão sobre a fundação de Salvador é enfatizado que Tomé de Souza foi recebido por Diogo Álvares, que já estaria avisado por carta do Rei (carta reproduzida em DORIA, 1999: 23, mas que é tida como falsa). Também ressalta que a capital deveria ser fundada em local de boa possibilidade de defesa, não só em relação a corsários estrangeiros, mas contra os índios, que estariam cada vez mais aguerridos contra os colonizadores. Descreve Falcão: “... Estudando o terreno em derredor, bem depressa encontrou Thomé de Souza o ponto apropriado à elevação da cidade, que deveria vir a ser uma povoação grande e forte, como lhe recomendava a Carta Régia. Meia légua para o interior do golfo, na margem oriental, apresentava-se magnífica colina escarpada sobre o mar, de difícil acesso pela banda de terra, a dispor de boa aguada e servida de ótimo ancoradouro, com a extensão suficiente para nela instalar-se a urbe em perspectiva. Resolveu-se, enfim, após madura reflexão, lançar aí os fundamentos daquela que, desde então e pelo tempo afora, ficou a chamar-se Cidade do Salvador./ Roçados os matos na área indicada para o traçado das praças e ruas, mandou o governador... levantar forte estacada, a fim de proteger os trabalhadores... Por outro lado, incumbiu mestre Luiz Dias, vindo do reino consigo, de erguer, em substituição ao cercado da primeira hora, muros de taipa grossa, a circundar o perímetro urbano de então, equivalente ao atual distrito da Sé...". 
2.1. Relato pouco posterior (Gabriel Soares, 1584-7): dados populacionais e de construções na fundação

Antes de olharmos os principais documentos produzidos nos anos 1550 - as cartas de Luiz Dias e as de Manuel da Nóbrega - convém termos como referência a narrativa de Gabriel Soares, feita quase quarenta anos depois. A segunda parte do seu Tratado Descritivo do Brasil (1584-7) é sobre as "grandezas da Bahia", ${ }^{280}$ trazendo informações variadas, que incluem questões urbanísticas. A parte é iniciada pela descrição da natureza local, seguindo-se uma narrativa sobre a época anterior à fundação da cidade. Sobre a construção, não menciona que houvesse projeto, talvez porque em sua visão não fosse esta uma questão relevante. ${ }^{281}$

Depois de narrar a saída de Tomé de Souza de Lisboa (02/02/1549), fala de sua chegada à Vila Velha (Povoação do Pereira) em 29/03,... onde pôs mil homens...: seiscentos soldados e quatrocentos degradados e alguns moradores casados, que consigo levou, e outros criados del-rei, que iam providos de cargos, que pelo tempo em diante serviram. ${ }^{282}$

Esses números são importantes na análise de uma primeira área urbana construída, ou, do perímetro fortificado original. Nota-se ser esta a fonte de informação de muitos autores, que falam em cerca de mil o número de pessoas que vieram com o governador fundar a cidade. Por exemplo, nas Observaçoens Sobre a Fortificação da Cidade da Bahia... (1797), o Cap. Domingos Alves Branco Muniz Barreto diz que Tomé de Souza chegou... acompanhado de mil homens; a saber 600 Soldados, e 400 degredados, alem do Officiaes, que forão providos em Empregos publicos, $e$ alguns Religiozos da Companhia de Jesus, para missionar. ${ }^{283}$

A maioria dos autores modernos defende esse número: entre os cerca de mil homens, passando por funcionários administrativos e os primeiros seis jesuítas vindos ao Brasil (chefiados por Manoel da Nóbrega), estariam Luiz Dias e cerca de cem artífices - pedreiros, cavouqueiros, carpinteiros de casa e de navios, calafates, serradores, telheiros, oleiros, empreiteiros de caminhos, carreiros e ainda, cesteiros, tanoeiros, ferreiros, serralheiros, relojoeiros, pescadores, barbeiros, carvoeiros, vaqueiros, o físico e o cirurgião -, um conjunto de especialistas trazidos para a fundação e funcionamento inicial da cidade. Para a maioria dos autores, eram 320

\footnotetext{
${ }^{280}$ O Tratado... foi escrito a partir de 1584 e apresentado à Corte de Madri em 1587, circulando em Portugal a partir de 1599 sob o título Notícia do Brasil. Só foi publicado em 1825.

${ }^{281}$ A questão da autoria de projeto (e de muitos mapas) tanto era de pouca importância para as pessoas em geral que até hoje se faz conjecturas.

282 SOUSA, 1971: 128.

${ }^{283}$ Edison Carneiro mostra que os números de Gabriel Soares também foram repetidos pelo Frei Vicente do Salvador (História do Brasil, 1500-1627) e por Jaboatão, outro franciscano cronista da Bahia (leitor e seguidor de Frei Vicente). Nas palavras de Edison Carneiro, "Frei Vicente repete Gabriel Soares, mas acrescenta, por sua parte, que os degredados estavam incluídos entre os soldados - 'mil [homens] de peleja, em que entravam quatrocentos degredados'. Jaboatão se faz eco de Frei Vicente" (CARNEIRO, 1980: 141). Também Simão Vasconcelos, depois de dizer que Salvador foi escolhida para cabeça do Estado, reproduz os números de Gabriel Soares:... constava o grosso da gente de mil homens, os seiscentos soldados, os quatrocentos degredados, mas acrescida de outros muitos moradores com suas casas; e alguns criados del-Rei, que vinham providos em ofícios...(VASCONCELOS, 1977: I, 195).
} 
soldados, 280 colonos e 400 degredados dando início ao povoamento. ${ }^{284}$ Mas há quem discorde, como o sociólogo Edison Carneiro:

O governador Tomé de Sousa não poderia ter trazido consigo 600 homens d' armas e 400 degredados. Nos seis navios da armada não caberia tanta gente, mesmo superlotados como era costume, contandose ainda funcionários civis, artífices, trabalhadores etc., além da carga, que parece ter sido apreciável. Os mandados de pagamento sugerem um número muito mais modesto e razoável - um total de cerca de 500 pessoas, inclusive pouco mais de 200 homens de soldo de terra e mar. Os degredados não seriam mais de 100 , talvez 62 apenas. ${ }^{285}$

Os números apresentados por Carneiro são criteriosos, pois ele se baseia em mandados de pagamentos, provisões, alvarás e outros papéis da série Documentos Históricos da Biblioteca Nacional, ${ }^{286}$ chegando mesmo a apresentar uma "relação dos habitantes da Cidade do Salvador no ano de 1549". ${ }^{287}$ Na mesma linha, o historiador Eduardo Bueno fala em um número razoável de seis naus com 130 homens cada (o que somaria 780 pessoas). ${ }^{288}$

Há também uma passagem de Luiz Dias, na Carta a Miguel de Arruda, que coloca muito em questão os números apresentados por Soares de Sousa (embora tenhamos dúvida se não seria esta apenas uma figura de retórica):

Enquanto esta Bahia não tiver cem moradores em que entrem cinqüenta de cavalo nunca deles farão bons nem comerão bom bocado, porque terras de criação de todas as coisas deste mundo não há aí em toda a terra como esta, mas o gentio dela é demônios. ${ }^{289}$

Nóbrega também traz indícios de que a população inicial era muito pequena, como os insistentes pedidos de que fossem enviados do Reino mais padres e principalmente mulheres (mesmo as de má fama) ou meninas órfãs para se casarem com os colonos. ${ }^{290}$ Em carta de 1552 ele fala no crescimento da escola (talvez já na

${ }^{284}$ Cf. SAMPAIO, 1949: 178-82, REIS Fo, 1968: 80 e TEIXEIRA \& VALLA, 1999: 224. Também na conta de Rafael Moreira (2003: 38), na fundação haveria 600 soldados (número que entendemos já agrupar os colonos), 400 degredados e equipe de 14 pedreiros, 8 carpinteiros, caiadores e taipeiros.

${ }^{285}$ CARNEIRO, 1980: 20. Conferir também p. 74-9 e p. 140-1: “Não é possível que as três naus as duas caravelas e o bergatim em que vieram os homens do governo geral tenham trazido mais de 500 pessoas, ao todo. Destas... pouco mais de 200 recebiam soldo, como homens d' armas, besteiros, espingardeiros, bombardeiros e marinheiros. O resto eram auxiliares do governador, oficiais da Cidade, artífices, trabalhadores, etc. O espaço de carga nos navios estava ocupado com as 'achegas' a que se referia o rei... - objetos de resgate, material para as obras da Cidade, mantimentos, roupas, artilharia... a bagagem profissional de serralheiros, ferreiros, carpinteiros... a bagagem pessoal dos homens da armada... desde a roupa domingueira até o barrete de dormir. E água para dois meses, para centenas de pessoas. Parece certo, por outro lado, que o número de civis era superior ao da gente de soldo." "Quanto aos degredados, só há notícia certa de 62 deles...".

${ }^{286}$ BN, 1937, vs. 35 e 37-8.

${ }^{287}$ CARNEIRO, 1980: 107-20.

288 BUENO, 2006-2: 79. Na obra deste autor há muitas informações desatualizadas, mas esses dados populacionais, especificamente, merecem crédito.

${ }_{289}$ Carta de Luiz Dias a Miguel de Arruda. ANTT, Corpo Cronológico, Parte I, maço 86, doc. 87 - apud BUENO, 2001: 137-41. Tivemos dúvida se cem moradores em que entrem cinqüenta de cavalo não seria uma expressão para indicar a qualidade dos moradores.

290 Por exemplo, na carta $A^{\prime}$ El-Rei D. João (1552), diz (após considerar que... vai tudo em crescimento, assim no espiritual [catequização de índios] como temporal): ... o temporal também vai em crescimento, posto que devagar, porque Vossa Alteza não manda moradores, que aproveitem a terra./ Para mim tenho averiguado que, se vierem moradores, que este Gentio de senhoreará, e serão todos cristãos... (NÓBREGA, 1988: 135)... se vierem moradores, que rompam a terra, escusar-se-á o trato com eles 
nova casa), mas se percebe que os números eram ainda modestos:... vai a casa em muito crescimento... de maneira que $d^{\prime}$ onde antes... mantínhamos a sete ou oito, agora mantém a casa cincoenta e tantas pessoas... ${ }^{291}$

Ainda sobre a posterior narrativa de Gabriel Soares, há um trecho bastante significativo sobre a construção:

... E tomada esta resolução, se pôs em ordem para este edifício, fazendo primeiro uma cerca muito forte de pau a pique, para os trabalhadores e soldados poderem estar seguros do gentio. Como foi acabada, arrumou a cidade dela para dentro, arruando-a por boa ordem com as casas cobertas de palma, ao modo do gentio, nas quais por entretanto se agasalharam os mancebos e soldados que vieram na armada. E como todos foram agasalhados, ordenou de cercar esta cidade de muros de taipa grossa, o que fez com muita brevidade, com dois baluartes ao longo do mar e quatro da banda da terra, em cada um deles assentou muito formosa artilharia que para isso levava, com o que a cidade ficou muito bem fortificada para se segurar do gentio;... ${ }^{292}$

Pela narrativa não se distingue o traçado dessa primeira cerca de pau pique daquele dos muros de taipa, feitos a posteriori. Curiosamente, nenhum teórico se preocupou em especificar a área dessa primeira cerca, que foi considerada provisória. Uma vez que a cidade foi construída "dela para dentro", todos entendem que ela passaria pelo terreno dos muros que a substituíram, tanto na hipótese de uma malha inicial grande quanto na de uma pequena. Mas por delimitar, em sua descrição, um simples acampamento (para estarem "seguros do gentio" os homens da empreita), entendemos como mais lógica a hipótese de que cercasse apenas a área em que se começou a construir a cidade: para que houvesse já de início uma grande malha, é de se estranhar que se fizesse de imediato uma cerca tão larga, muito mais trabalhosa. $\mathrm{E}$ o comentário de que os muros seguintes foram construídos "com muita brevidade" dá a entender que o primeiro perímetro correspondesse a essa primeira área cercada, como quis Teodoro Sampaio. ${ }^{293}$

Nota-se aqui o método vitruviano, incorporado provavelmente a todas as fundações portuguesas e de outros povos, desde a Antiguidade, de primeiro cercar a área e então traçar a malha, fazendo a distribuição interna: circundado o recinto, seguir-se-ão as divisões das áreas dentro da muralha e as orientações das praças e das

[índios], e a terra de todo se assegurará./ [A pobreza há de se]... remediar em parte, com V. A. mandar moradores que rompam e queiram bem à terra... [p. 134]/ [Também o alto custo dos oficiais diminuirá]... si vieram moradores...

291 “Ao Padre Mestre Simão" (NÓBREGA, 1988: 138-9). Nessa época já eram dez os jesuítas. Cinco chegaram com Nóbrega em 1549: Juan de Azpiucuelta Navarro (mais culto, experiente, conhecedor de línguas), Vicente Rodrigues (noviço), Antonio Pires ("médico", carpinteiro e artífice), Leonardo Nunes (muito ativo, logo abaixo de Nóbrega) e Diogo Jácome (noviço). No ano seguinte vieram outros quatro: Salvador Rodrigues, Manuel de Paiva, Affonso Braz e Francisco Pires. Como veremos, houve desentendimentos com o clero secular (primeiro na pessoa do vigário Manuel Lourenço) e uma necessidade de distância que influenciou na escolha da área em que o colégio finalmente se estabeleceu.

292 SOUSA, 1971: 129 - grifos nossos.

293 Em nossa interpretação, a área inicialmente cercada e desmatada correspondia apenas ao platô onde foi feita a Praça Principal, como quis Teodoro Sampaio. Em relação aos muros, entendemos sim que já se quis construí-los cercando toda a área maior, sendo essa "brevidade" de que Gabriel Soares ouviu falar (sem presenciar o fato) talvez um indício de que foram demarcados e construídos apenas em alguns trechos. 
ruas. $^{294}$ Gabriel Soares confirma, portanto, que no caso de Salvador foi primeiro estabelecido o perímetro e depois se traçou a cidade. Já a observação de que foi feita "arruando-a por boa ordem" não deixa dúvida sobre o caráter renascentista do empreendimento. $^{295}$

Já sobre a fase seguinte, o "cercar esta cidade de muros de taipa grossa", há uma imensa discussão sobre o traçado dos primeiros anos, da qual não deixaremos de participar. Como primeiro ponto discutível, há mesmo os que defendem nunca ter havido muralha alguma, hipótese que já descartamos de início, considerando o comentário de Gabriel Soares de que... agora não há memória aonde eles [os muros] estiveram... (mostrando que realmente existiram).

Esta frase de Gabriel merece ser contextualizada, uma vez que o trecho traz outras informações importantes. Ela aparece após a afirmação categórica de que com Tomé de Souza a cidade foi murada e torreada.

A cidade do Salvador... situada na Bahia de Todos os Santos uma légua da barra para dentro, num alto, com o rosto ao poente, sobre o mar da mesma baía... foi murada e torreada em tempo do governador Tomé de Sousa, que a edificou,... cujos muros se vieram ao chão por serem de taipa e se não repararem nunca, no que se descuidaram os governadores, pelo que eles sabem, ou por se a cidade ir estendo muito por fora dos muros; e, seja pelo que for, agora não há memória aonde eles estiveram. ${ }^{296}$

Há aí uma segunda evidência de que a cidade inicialmente seria menor: nos anos 1580 ela já estava muito por fora dos muros, o que não faria sentido se o perímetro inicial fosse extenso, pois não se observa esse crescimento em direção ao norte nas plantas de 1605, na da Restituição, nas gravuras em Montanus e Barlaeus e mesmo em mapas e gravuras do século XVIII. O que há são construções isoladas, não uma malha urbana definida. ${ }^{297}$

Voltando à primeira cerca, tudo indica que era uma simples paliçada de troncos pontiagudos, similar às tranqueiras de pau-a-pique das aldeias indígenas e feitorias das primeiras vilas. A idéia era substituí-la pelos muros que caracterizariam a cidade-fortaleza, mais altos, de madeira e taipa, pedra e barro, rebocados de cal. Estes teriam um valor principalmente simbólico. ${ }^{298}$ Adentramos já aí na questão do chamado

${ }^{294}$ VITRÚVIO, $2006: 48$ - I, 6, 1. Logo em seguida ele estabelece a direção dos ventos predominantes
como fator determinante dessas orientações: Serão, de fato, traçados como deve ser se habilmente se
afastarem das ruas os ventos que, se forem frios, prejudicam, se quentes, corrompem, se úmidos, são
nocivos... (id. ibid.), o que será reforçado nos parágrafos 7 (sobre o alinhamento das ruas considerando
as direções dos ventos) e 8 (prescrição de que as orientações das ruas - ortogonais - deve ser diferentes
das dos ventos) do mesmo livro e capítulo (I, 6,7 (p. 50-1) e 8 (p. 51): ... com esta metodologia e com
esta distribuição se afastará das habitações e das ruas a força nociva dos ventos. Se, efetivamente, as
praças ficarem diretamente expostas a eles, o ímpeto vindo do espaço aberto do céu e a brisa constante
contida na entrada estreita das vielas andarão por aqui e por ali com uma veemência mais forte. Eis
porque não se deverão voltar para as orientações dos ventos os direcionamentos das ruas, de modo que,
ao chegarem, eles se enfraqueçam contra os ângulos das insulas e, repelidos, se dissipem (VITRúVIO,
$2006: 51$ - I, 6, 8).
295 Cf. MOREIRA, $2003: 7-32$ (A Arte da Ruação e a Cidade Luso-brasileira).
296 SOUSA, 1971: 133 (cap. VII).
297 Mas não descartamos que houvesse já de início um limite oficial, correspondendo às portas que
aparecem nas primeiras representações cartográficas. Interpretamos que na passagem Gabriel Soares
quis dizer que nas áreas de expansão da época (Carmo e S. Bento) havia uma harmoniosa continuidade
(entre a área de traçado geométrico e as demais), sem precisão dos limites.
298 Na simplificação do urbanista Walter Rosa, “... no Portugal da Baixa Idade Média, 'fazer vila' equivalia
ao ato de cercar..., enquanto... nas crônicas da Índia, 'fazer fortaleza' confunde-se com a própria ação 
pragmatismo, ou capacidade de adaptação dos portugueses. Teodoro Sampaio mostra que para construir esses muros, como os primeiros baluartes (ou estâncias), foi preciso mudar o método previsto, substituindo a mão-de-obra assalariada pelo regime de empreita (demonstra isso pelas muitas ordens de pagamento, feitas principalmente a Pero de Carvalhais, Rui Gonçalves e aos irmãos Belchior). Os materiais (madeira, pedra e barro) foram fornecidos pelos índios, aproveitando-se também deles, junto à mãode-obra, algo de sua técnica construtiva. Se os prédios oficiais eram em estilo europeu (alguns já de início em pedra e cal, depois cobertos com telhas de barro), as primeiras moradias eram de pau-a-pique e taipa de pilão (cobertas de palma, como diz Gabriel Soares, referindo-se às folhas da palmeira pindó). ${ }^{299}$ Começamos a observar, já no nascimento da cidade (na madeira para cerca, muro e construção de baluartes "comprada" dos índios), ${ }^{300}$ não propriamente uma realidade que se impôs, mas um novo sistema sendo adotado por uma razão de ordem prática.

\subsection{Relatos da época}

Em Gabriel Soares não há informação sobre o número de casas construídas na época de Tomé de Souza. As poucas referências sobre isso estão nos depoimentos contemporâneos a essa primeira etapa, que passaremos a analisar. Uma delas é de Nóbrega, em sua carta Ao Dr. Navarro, seu mestre em Coimbra (1949), dizendo que... pode-se já contar umas cem casas e se começa a plantar canas de açúcar e muitas outras coisas... ${ }^{301}$ A outra é de Luiz Dias, na carta a Miguel de Arruda, em trecho sobre uma amostra, ${ }^{302}$ que representava os dois vales pequenos (informa que no maior fez um poço de excelente água). Nela fez anotações das quadras de oito e seis casas, dez já taipadas e as outra em pau-a-pique, parecendo-Ihe que se tudo corresse bem, construiriam muitas casas nas ladeiras.

E na mostra vão escritas as casas que são feitas [;] e tem cada chão dos que estão povoados 8 casas, e o que menos tem dão 6 casas; e são as 10 de taiparia, que as outras são de parede de mão e de

de urbanizar" (apud BUENO, 2006-2: 102). Ou, na definição do Dictionnaire de Furetiére (1609), "uma cidade só poderia ter direito a esse título caso fosse cercada por muralhas" (id. ibid.).

${ }^{299}$ Que estão na origem do nome "pindorama", região ou "país" dessas palmeiras.

300 Teodoro Sampaio (1949: 186-7) mostra pela documentação dos resgates (pagamento em espécie) que pela madeira da cerca, muro e baluartes foram dados aos índios 32 machados, 48 foices, 11 enxadas, 51 dúzias de tesouras, 4 peças, 51 mil anzóis, 144 furadores, 49 podões, 14 dúzias de facas da Alemanha. Pela palha de cobertura do armazém da cidade, foram dados 1770 anzóis, 11,5 dúzias de tesoura, uma machadinha, 20 espelhos, uma foice, um machado e três furadores. Pelo carreto da madeira foram pagos 2 mil anzóis. Etc. No resgate com os índios a mercadoria mais aceita era o ferro, pois eram civilizações do neolítico.

Eduardo Bueno (2006-2: 101) também mostra pela data de verba para vestir os degradados que tanto o desmatamento da área da cidade quanto a construção da estacada no topo e laterais da colina foram feitos com mão-de-obra indígena (cita outra ordem de pagamento, envolvendo 22 foices, 4 enxadas, 6 machados, 24 machadinhas, 60 espelhos, 156 pentes, 42 tesouras, uma tesoura "das da Alemanha" e 9210 anzóis).

${ }^{301}$ NÓBREGA, 1988: 89.

302 Na explicação de Beatriz Bueno, “... essa amostra parece mesclar planta e alçado numa mesma representação gráfica", como era no desenho de Diogo Teles (BUENO, 2001: 138 - nota 145). 
madeira de barro e feno. Vai a amostra o melhor que eu entendi e V. M. a manda retirar pera a ver elrei. Muitas casas se podem fazer nestas ladeiras, se isto houver de ir avante. ${ }^{303}$

Essas informações nos ajudam a imaginar como seria a divisão em lotes dentro das primeiras quadras, mas não são suficientes para se calcular o número de quadras ocupadas (no caso de Nóbrega, ele não especifica se as cem casas estariam dentro da cerca), ou o número de moradores (não se sabe se havia habitações multi-familiares, se estavam computados os albergues, etc.). ${ }^{304}$ Entendemos da frase de Luiz Dias que as quadras tinham 6 a 8 casas em casa face, como é até hoje, ${ }^{305}$ o que sugere uma distribuição mais ou menos assim:

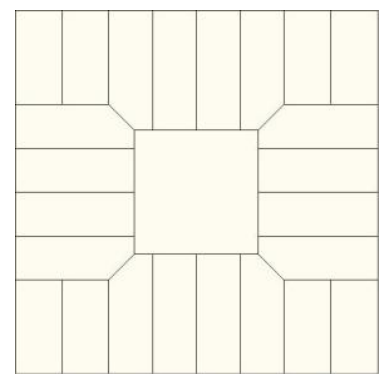

Possibilidades da divisão da quadra padrão (24 x 24 braças) em casas que mediam 2,9 braças de frente $\left(6,38 \mathrm{~m}\right.$, com duas janelas e uma porta) por 7,9 braças $(17,38 \mathrm{~m})$ de fundo. ${ }^{306}$ Os lotes de canto mediriam 3,1 x 6,2 braças $(=6,82 \times 13,64 \mathrm{~m})$.

\subsubsection{A área do Colégio segundo os jesuítas}

As cartas de Nóbrega, contemporâneas às de Luiz Dias sobre a construção de Salvador, foram escritas cerca de 30 anos antes do tratado de Gabriel Soares (15847), ${ }^{307}$ sendo também bem anteriores à imagem mais antiga que se preservou da cidade (1605). Elas ajudam a entender o primeiro movimento de expansão urbana e algumas transformações ocorridas na malha já nos anos 1550. Escrevendo até 1560, ele deixou muitos registros sobre as construções jesuíticas, mas foi principalmente o trecho de uma de suas primeiras cartas que teve maior repercussão entre os teóricos, ${ }^{308}$ já que sua interpretação leva a acreditar ou não na possibilidade de um perímetro reduzido no ano da fundação. No trecho polêmico, o chefe dos jesuítas no Brasil comenta duas possibilidades de área para a construção de sua igreja e colégio. Uma delas era oferecida pelo governador.

E trabalhei por escolher um bom lugar para o nosso Collegio dentro na cerca e sómente achei um que lá vai por mostra a Sua Alteza, o qual tem muitos inconvenientes, porque fica muito junto da Sé e duas

\footnotetext{
${ }^{303}$ Carta de Luiz Dias a Miguel de Arruda, op. cit. A declaração de Dias de que fez a amostra o melhor que pôde, recomendando a Arruda mostrá-la ao Rei, é importante porque evidencia que havia métodos e exigências.

${ }^{304}$ Havendo uma ampla maioria de homens solteiros era possível que dividissem as casas em grupos de até dez pessoas.

${ }^{305}$ Também é esta a interpretação de Manuel Teixeira.

${ }^{306}$ Cf. COELHO Fo, 2004: 476.

${ }^{307}$ Neste último ano vieram os franciscanos, a quarta ordem a se instalar próxima ao centro de cidade, depois de jesuítas, carmelitas e beneditinos.

${ }^{308}$ A terceira: Ao Padre Mestre Simão (1549), em NÓBREGA, 1988: 83-4. Simão Rodrigues era seu superior, fundador da Ordem em Lisboa.
} 
egrejas juntas não é bom, e é pequeno, porque onde ha de fazer a casa não tem mais que dez braças, posto que tenha ao comprido da costa quarenta, e não tem onde se possa fazer horta, nem outra cousa, por ser tudo costa mui ingreme, e com muita sujeição da cidade.

Ele vê vantagens em outra, que está fora da área cercada.

E portanto a todos nos parece melhor um teso que está logo além da cerca, para a parte d' onde se ha de estender a cidade, de maneira que antes de muitos annos podemos ficar no meio, ou pouco menos da gente, e está logo ahi uma aldêa perto, onde nós começamos a baptisar, em a qual já temos nossa habitação. ${ }^{309}$ Está sobre o mar, tem agua ao redor do Collegio, e dentro delle tem muito logar para hortas e pomares; é perto do Christãos, assim velhos como novos. Sómente me põe um inconveniente o Governador; não ficar dentro da cidade e poder haver guerra com o Gentio, o que me parece que não convence, porque os que hão de estar no Collegio hão de ser filhos de todo este Gentio, que nós não temos necessidade de casa, ${ }^{310}$ e posto que haja guerra, não lhes póde fazer mal;...

Apóia-se nesse trecho a hipótese construída por Teodoro Sampaio de que a cidade tinha um perímetro inicial menor, que ainda aprofundaremos. Os que defendem a idéia de que a cidade já nasceu e foi murada com limites estabelecidos nas portas desenhadas na Planta de 1605, como Edison Carneiro e Rafael Moreira, fazem uma interpretação diferente sobre essas duas áreas. Enquanto para Teodoro e seus seguidores, a primeira descrição é referente à área oblíqua vizinha ou próxima ao Largo da Ajuda, e a segunda àquela em que foi de fato construído o colégio, para outros (inclusive os que defendem um perímetro intermediário, como Mário Oliveira), Nóbrega não foi autorizado a ocupar essa segunda área, resignando-se à primeira onde de fato teria se instalado a casa de ensino (a segunda descrição corresponderia à região do Carmo, próxima ao Monte Calvário, onde já haviam construído uma primeira casa). Mas analisamos bastante essa passagem para acreditar que a primeira área descrita é mesmo a dos quarteirões oblíquos próximos à igreja da Ajuda, como entendeu Teodoro Sampaio, e a segunda ao local próximo ao Terreiro de Jesus, de fato ocupado pelos jesuítas com suas construções.

Sobre a primeira área, ele diz ser muito junto da Sé, o que entendemos não ser a igreja que se preservou até o século $X X^{311}$ (que por sinal era ainda mais próxima de outra, a da Misericórdia, a cerca de $50 \mathrm{~m}$ ), mas sim sobre a antiga, de palha, da qual ainda falaremos. Em seguida diz que o terreno é pequeno, o que absolutamente não condiz com o da área em que foram implantados Colégio e Igreja. Faz então a descrição mais significativa: o lugar onde há de fazer a casa teria apenas dez braças e ao comprido da costa quarenta, sendo a costa mui íngreme e o local de muita sujeição (subordinação, dependência) da cidade. Pela medida padrão da braça antiga $(2,2 \mathrm{~m})$, seria um terreno de aproximadamente 22 por $88 \mathrm{~m}$. Os quarteirões da malha primitiva eram de aproximadamente $24 \times 24$ braças $(53 \times 53 \mathrm{~m})$, separados por ruas que variavam na largura entre 2,3 e 3 braças $(5$ e $6,5 \mathrm{~m}) .{ }^{312}$ Já a área em que os jesuítas se instalaram, sem contar o terreiro, era de pelo menos $70 \times 200 \mathrm{~m}$.

\footnotetext{
${ }^{309}$ No monte Calvário.

${ }^{310}$ Eles residiam ainda na Ajuda.

${ }^{311}$ De 1553, sendo demolida em 1933 para dar lugar a trilhos de bonde.

${ }^{312}$ Cf. COLHEO Fo, 2004: 198 e 323.
} 


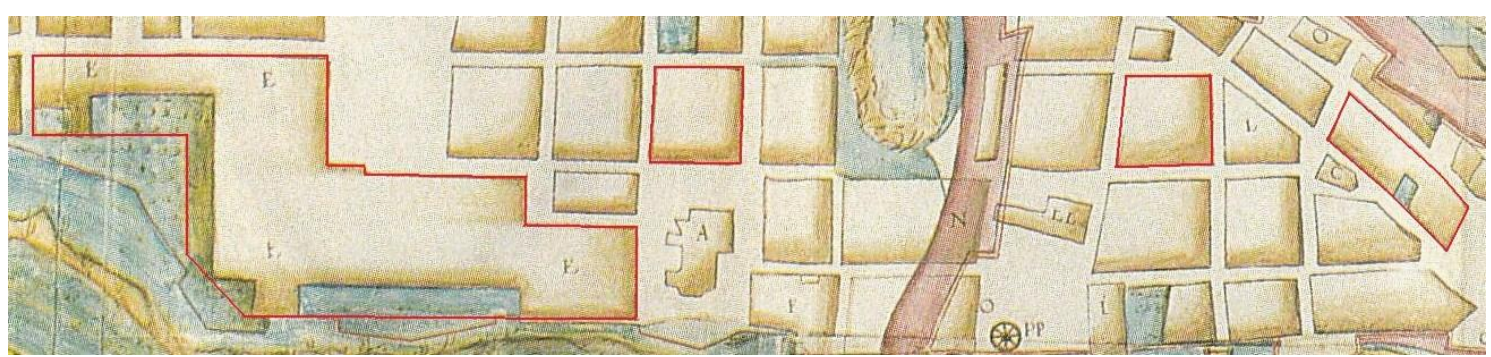

Em destaque na Pranta... de 1605, a área efetivamente ocupada pelos jesuítas (à esq.), duas quadras de tamanho padrão ( 24 × 24 braças) e o provável primeiro terreno disponível (10 x 40 braças - à dir.).

Entendemos esta muita sujeição da cidade estar relacionada ao fato dos jesuítas trabalharem primeiramente no Monte Calvário, onde já tinham uma casa, como mostra o texto (era onde depois foi construído o convento do Carmo). Como o primeiro local de instalação deles era na Ajuda (sendo atrás dela a área sugerida por Tomé de Souza, como entendemos), em seu percurso eles teriam de passar sempre pela Praça Principal.

A medida e a proporção descritas por Nóbrega não deixa dúvida, a nosso ver, de que a primeira opção de Nóbrega, autorizada pelo governador, eram os terrenos oblíquos voltados para o interior, diagonais à malha principal. Mesmo porque, na descrição da área desejada, ele diz que está sobre o mar, dando a entender que a primeira não estava. Eram áreas muito próximas à Sé antiga, de palha, onde foi construída a igreja da Ajuda, ${ }^{313}$ como explica Gabriel Soares: ...uma formosa igreja de Nossa Senhora da Ajuda...; no qual sítio, no princípio desta cidade, esteve a Sé. ${ }^{314}$

Essa requisição de Nóbrega serviu de argumento para Edison Carneiro dizer que os primeiros muros (e a Porta de Santa Catarina) estariam mais ao norte. Ele entende que se o lugar reservado ao Colégio estava dentro da cerca e ficava muito junto da Sé, "onde seria se não no Terreiro, onde os jesuítas realmente construíram o seu Colégio?". ${ }^{315} \mathrm{O}$ deslocamento da Sé responde a essa pergunta.

São evidências, portanto, de que a área inicialmente destinada ao colégio era um dos quarteirões compridos da área detrás do largo triangular onde estava a igreja da Ajuda: 1- era uma área dentro da cerca, muito junto da Sé (a antiga, não a da planta, que Edison Carneiro afirma ser no mesmo terreno "desde os primeiros dias") a que Nóbrega reclama ter costa mui íngreme; 2- a queixa de Nóbrega sobre as dimensões, dizendo que... onde ha de fazer a casa não tem mais que dez braças, posto que tenha ao comprido da costa quarenta, e não tem onde se possa fazer horta, nem outra cousa... (são exatamente essas as proporções, 1 para 4, das quadras da única área oblíqua representada na Pranta... de 1605 - que Manuel Teixeira considera de "estrutura idêntica aos quarteirões de cidades medievais planeadas"). ${ }^{316}$

Embora não se possa provar que Nóbrega "venceu a parada" (ou que o inconveniente posto pelo governador não significasse uma proibição, havendo o relaxamento dessa posição logo nos primeiros anos, pela construção de alguns

\footnotetext{
${ }^{313}$ Nome dado em referência a uma das naus da armada de Tomé de Sousa, e "que surgia em várias das ruas do triângulo meridional" (cf. CARNEIRO, 1980: 64).

${ }^{314}$ SOUSA, 1971: 137.

${ }^{315}$ CARNEIRO, 1980: 126.

316 TEIXEIRA \& VALLA, 1999: 225. Também o argumento de Edison Carneiro de que "costa quer dizer terra fronteira ao mar" (p. 126) não procede. Nóbrega fala em costa mui íngreme e ao comprido da costa no sentido de "encosta" (pelo dicionário, costa = encosta, declive; encosta = declive de montanha; vertente). Não há na parte alta da cidade, voltada para o mar, quarteirões ao comprido da costa.
} 
caminhos e edificações fora da área murada), acreditamos sim que pôde dar início à construção de sua Igreja e Colégio no terreno mais vantajoso. ${ }^{317}$

Em defesa da idéia de que a cidade teve um perímetro inicial menor convém enfatizar alguns pontos. O primeiro deles, de que a interpretação da área onde foram construídos Igreja e Colégio como sendo inicialmente "fora da cerca" não foi exclusiva de Teodoro Sampaio, não se tratando, portanto, de uma simples "invenção". Comecemos por esta informação categórica do Padre Serafim Leite, autor da História da Companhia de Jesus no Brasil: ${ }^{318}$ "O Terreiro formava, então, uma suave colina, fora da primeira cerca da cidade, entre ela e a Aldeia dos índios do Calvário". ${ }^{319}$

Tomemos agora uma frase sutil e preciosa, que por causa do erro de uma publicação, ${ }^{320}$ achamos primeiramente que fosse do padre Simão Vasconcelos (autor da Crônica da Companhia de Jesus de 1663, muito anterior, portanto, à interpretação de Teodoro - o que nos levou à quase certeza de termos a interpretação correta):

Razão tinha Manuel da Nóbrega para dar a Tomé de Sousa, quando este lhe objetava estar fora da cidade o local escolhido para o Colégio, a mesma resposta que o P. Simão Rodrigues deu a El-Rei D. João III perante a objeção idêntica, a respeito da casa de S. Roque, em Lisboa: - Não se arreceie Vossa Alteza de ficar a casa fora da cidade; a cidade virá juntar-se ao redor da casa. E assim foi. O grande bairro dos Andrades teve como célula genética a casa de S. Roque, como o Colégio da Bahia veio a fazer do Terreiro de Jesus o ponto central de Salvador. ${ }^{321}$

Manuel Teixeira já havia citado parte dessa frase, indicando como referência a obra de Serafim Leite (sugerindo ser dele), ${ }^{322}$ onde finalmente encontramos a autoria,

\footnotetext{
${ }^{317}$ O depoimento de Gabriel Soares também não esclarece sobre qual dos lados deu o braço a torcer, mas enfatiza a grande quantidade das obras conduzidas por Luiz Dias. Diz:... o governador fundou logo um colégio dos padres da Companhia, e outras igrejas e grandes casas, para viverem os governadores, casas da câmara, cadeia, alfândega, contos, fazendas, armazéns, e outras oficinas convenientes ao serviço de Sua Alteza (1971: 129-30).

${ }^{318}$ A imensa e detalhada obra em 10 volumes integra a Monumenta Historia Societatis Jesu, de 80 volumes, tratando-se da Monumenta Brasilica. Como uma dos mais importantes braços da ContraReforma, os jesuítas forma cuidadosos no registro da própria história (cf. MOREAU, 2003: 52).

${ }^{319}$ LEITE, 1938: 22. Ele antes descreve a área “... onde, depois, fundaram o seu Colégio os Padres da Companhia, motivo para aquele Terreiro se chamar de Jesus..." (p. 21). Faz em seguida um resumo histórico de que ainda falaremos: "Não se estabeleceu logo ali a Companhia. Primeiro edificaram os Padres, perto dos antigos Paços da Câmara, uma igreja de taipa, coberta de palha... / A nova ermida, fundada pelos Padres, chamou-se de Nossa Senhora da Ajuda e foi cedida, algum tempo depois ao clero secular" (p. 22 - grifo nosso). Lembra que esta igreja foi "a primeira dos Jesuítas no Brasil".

Verificou-se depois uma boa explanação sobre o tema feita por W. Coelho Filho (2004: 473-8), interpretando como fora da primeira cerca (não haveria ainda os muros) e onde foram depois construídos a igreja e o colégio a primeira área almejada por Nóbrega. Ela teria sido negociada depois (1561), com Mem de Sá, explicando-se assim a construção da nova igreja feita pelo governador (inaugurada em 1572). As aquisições dos jesuítas "na banda do Pelourinho" ocorrem nos anos 1590, para "assegurar a expansão do Mosteiro" (p. 477). Coelho Filho cita documentos de negociações de lotes entre os jesuítas e os descendentes de Caramuru.

${ }^{320}$ A atribuição da frase a Simão de Vasconcelos (Crônica...) estaria em LEAL, Fernando Machado. Catedral Basílica de São Salvador da Bahia. Salvador: IPAC/ Solisluna, 2002 (2a ed. - 1ạ em 1998).

${ }^{321}$ Apud LEITE, 1938: I, 48.

322 Cf. TEIXEIRA \& VALLA, 1999: 226. Ele cita apenas a suposta fala de Simão Rodrigues (“- não se arreceie..."), dando como referência o livro de Serafim Leite (História da Companhia...) citado em SIMAS Fo, Américo (coord.). Evolução Física de Salvador (2 vols). Salvador: UFBA, 1979, v. 1, p. 37. Comenta que de fato, como ocorreu com o Bairro Alto em Lisboa, em Salvador a cidade se desenvolveu rapidamente na direção do colégio e logo o Terreiro de Jesus foi rodeado de casas, tornando-se um
} 
que é do padre Luiz Gonzaga Cabral no livro Jesuítas no Brasil. ${ }^{323}$ E uma importante observação de Serafim: ele estaria "fundado em Vasconcelos".

Serafim Leite diz outra coisa interessante sobre a frase: que não se pode averiguar se é "história ou lenda" porque não foi encontrada em "documentos coevos" (e realmente se estranharia o uso da expressão "célula genética" tanto na época de Nóbrega quanto na de Simão de Vasconcelos). ${ }^{324}$ Mas a simples menção de ser "história ou lenda" já indica que essa idéia (de uma resposta de Nóbrega semelhante à de Simão Rodrigues) era antiga, bem anterior ao registro de Luiz Cabral.

É pela história oficial dos jesuítas, narrada por Serafim Leite, que sabemos que suas primeiras moradas eram "umas pobres casas de taipa cobertas de palha", construídas com seu "suor e trabalho". ${ }^{325}$ Serafim explica serem essas as "casas da Ajuda" e que... "antes de as deixar, fizeram outras no Monte Calvário, então fora da cidade, e deu-lhes o Governador uma casa de barro dentro dela, perto dos muros" ${ }^{326}$ "Foram as três primeiras moradas dos Jesuítas na Baía" e "em todas se fez catequese e se ensinaram os rudimentos de ler e escrever", mas "nenhuma delas dispunha dos requisitos indispensáveis para o Colégio". ${ }^{327}$

Já se poderia perguntar se Tomé de Souza, sendo tão rigoroso na proibição do colégio fora da cerca, não teria também impedido que os jesuítas construíssem a segunda casa no Monte Calvário. ${ }^{328}$ Mas o importante é saber que foi depois disso que Nóbrega "buscou local apropriado": 329

Aquela casa de barro, que lhe deu o Governador, estava em bom sítio, mas comprimida contra os muros da cidade. Todavia, a Ajuda já se tinha entregue ao clero secular e o Monte Calvário era demasiado exposto. Com a chegada dos meninos órfãos, em 1550, não teve outro remédio senão decidir-se pelo sítio junto aos muros da cidade. ${ }^{330}$

Foi "neste local" que "se começaram a fazer as acomodações do Colégio, sendo que “... em 1551, já estavam construídos alguns edifícios, rodeados de uma forte cerca de taipa". ${ }^{331}$ Chamamos a atenção de que seria difícil imaginar a necessidade de rodeá-los em uma área que já estivesse anteriormente cercada. ${ }^{332}$ Ainda segundo Serafim Leite, ${ }^{333}$ nessa época ainda "estava a Sé por fazer".

importante centro da cidade (em 1551 já teriam se iniciado as obras no novo local, ficando alguns edifícios do colégio prontos naquele ano).

${ }^{323}$ CABRAL, Luiz G. Jesuítas no Brasil (3 vols). São Paulo: Melhoramentos, 1925, p. 266-7. Como o padre L. G. chegou ao Brasil em 1917 e a publicação é de 1925, escreveu provavelmente neste intervalo. Notase que a interpretação dele é a mesma, de que a área do Colégio era a almejada por Nóbrega, "fora da cidade", mas na direção em que esta veio a crescer, tornando-se "ponto central". Não é impossível, mas é pouco provável que sua interpretação estivesse influenciada pela de Teodoro Sampaio.

324 LEITE, 1938: I, 48.

${ }^{325}$ Respostas de padres jesuítas a um Capítulo de Gabriel Soares, apud LEITE, 1938: 47.

${ }^{326}$ LEITE, 1938: 47 (grifo nosso).

${ }^{327}$ Id. ibid.

${ }^{328}$ E da mesma maneira, poder-se-ia relativizar a proibição de Tomé de Souza lembrando que a igrejinha de N. S. da Conceição também ficava fora dos muros. Ela foi construída na mesma época que a da Ajuda. ${ }^{329}$ Idem, p. 47.

${ }^{330}$ Id. ibid.

${ }^{331}$ LEITE, 1938: 48.

332 Na seqüência sobre a construção do Colégio, cita uma frase de Nóbrega em 1552, trabalhamos por dar princípio a casas que fiquem para emquanto o mundo durar (Nóbr., CB, 137 - apud LEITE, 1938: 48) informando que foram então compradas algumas casas com ajuda do Rei (por $17 \$ 000$ réis, pagos a Luiz Dias), mas que "por serem de taipa e cobertas de palha, duraram pouco, dois, três anos" (LEITE, 1938: 
Antes de entendermos a verdadeira autoria da frase (de que embora Tomé de Souza objetasse "estar fora da cidade o local escolhido para o Colégio", lá ele foi construído e "veio a fazer do Terreiro de Jesus o ponto central de Salvador"), procuramos com insistência encontrá-la, com outras referências, na Crônica da Companhia de Jesus do padre Simão de Vasconcelos, para mostrar que quase três séculos antes de Teodoro Sampaio esboçar sua hipótese, haveria já em 1663 o entendimento de que Nóbrega "dobrou" Tomé de Souza e construiu sua igreja e colégio onde quis, fora dos muros da cidade. Apesar de obviamente não encontrarmos essa referência em especial, ${ }^{334}$ outras informações vieram de sua leitura, sendo mais significativa a de que realmente foram os jesuítas que construíram a igreja da Ajuda, e lá moraram. Quando o governador... tinha demarcado e começado a fundar a cidade...

... foi força mudarem-se também nossos religiosos, e no mesmo tempo, em que os moradores edificavam casas, fazer as suas, e igreja, no lugar onde hoje se vê a de Nossa Senhora da Ajuda, invocação que então Ihe puseram; e foi a primeira que no Brasil teve a Companhia. Esta obraram com próprias mãos, e suores; porque como andavam os moradores ocupados em semelhantes obras, e principalmente em cercar a cidade para defensão de alguns gentios, que ainda não estavam sujeitos, não havia quem pudesse ser-lhes de ajuda. ${ }^{335}$

Neste sítio de Nossa Senhora da Ajuda perseveraram, exercitando na forma referida, juntamente com os ministérios da Companhia, o de pároco dos portugueses; até que chegando do Reino um sacerdote, lhe entregaram a vigaria, e com ele a casa, a igreja, que com tanto suor tinham edificado; $e$ se foram contentes assentar nova habitação fora da cidade em um alto, que hoje chamam Monte Calvário, com novos trabalhos, semelhantes aos já referidos. Era o sítio do Monte Calvário aquele, onde hoje vemos fundado no mosteiro da sagrada religião de Nossa Senhora do Carmo. Naquele tempo era o principal assento das aldeias dos índios, de toda esta Capitania, por seus bons ares, vizinhança do mar, e outras melhorias, que nele conheciam... ${ }^{336}$

A Sé, do clero secular, foi então construída pelos jesuítas, sendo depois entregue ao primeiro vigário Manuel Lourenço. Entende-se que inicialmente houve

49, baseado em carta de Grã, Bras. 3 (1), 145 - provavelmente Luiz da Grã, que aparece em carta de Nóbrega de 1557 - "Para o Provincial de Portugal"). Em 1555 "já estavam cobertas de telha as casas mais novas" (quando o Rei escreveu a D. Duarte e ao Bispo "para se fazer o Colégio dos Padres").

333 1938: 49.

334 Junto à decepção veio a surpresa de uma passagem que evidenciava justo o contrário, que a área do Colégio que aparece na Planta de 1605 já estava dentro dos muros nos primórdios da cidade. Trata-se da narração de um episódio em que os índios da aldeia próxima foram interrompidos em seu ritual antropofágico por dois padres que, a pedido de Nóbrega, adentraram o terreiro da aldeia, bradando "ao Céu" e fazendo "asperadamente" suas censuras, até apreenderem o corpo do tapuia sacrificado para enterrá-lo em lugar escondido. Incitados pelas velhas (as mais "carniceiras", que diziam "injúrias aos homens" da tribo, chamando-os de "infames, covardes"), os índios... levantaram motim, e em forma de guerra feitos em um corpo, foram desmandar os padres. Tivera aviso o Governador do que passava, $e$ tinha mandado aos mesmos, que se retirassem à cidade (e o tinham feito em secreto a umas pobres casas de barro, onde hoje se vê o colégio; e foi tão fero o ímpeto com que deram os bárbaros, que não achando já os padres, faltou pouco que não arrombassem os muros, e destruíssem a mesma cidade (VASCONCELOS, 1977: I, 201). Na seqüência, conta que... Foi forçado acudir o Governador com todo seu presídio, e parte com espanto das armas de fogo (que eles admiram) parte com razões eficazes de eloquentes línguas, houveram de ceder e retirar-se. Mas nem esta passagem é conclusiva: pode-se interpretar tanto que as pobres casas de barro estavam dentro dos muros como que os índios quisessem arrombá-los porque achavam que os padres estivessem na cidade e não naquelas casas. Ela atesta apenas, mais uma vez, que havia muros.

${ }^{335}$ VASCONCELOS, 1977: I, 198 - grifos nossos.

${ }^{336}$ Id. ibid. 
convivência e até prática conjunta de exercícios espirituais, mas também desentendimentos, e os jesuítas, para guardar distância, construíram uma "maneira de casa" no Monte Calvário, junto à aldeia dos índios tupinambás.

Voltando ao ponto, há também em Vasconcelos uma boa indicação que o segundo Colégio, próximo ao Terreiro, não era dentro da Cidade: Junto à cidade tinha também a indústria do Padre Nóbrega, e seus companheiros, levantado casa de seminário com suas próprias mãos, e trabalhado. ${ }^{337} \mathrm{O}$ autor da Crônica... narra também, de 1552,... a chegada de D. Pedro Fernandes Sardinha, primeiro bispo do Brasil, que trouxe consigo alguns sacerdotes, cônegos, e dignidades, para formar sua Sé e igreja catedral nesta cabeça do Estado... ${ }^{338}$

Aproveitemos essa narrativa da chegada do bispo para voltar a Nóbrega. Como vimos, o colégio jesuíta começou em 1550, com a chegada de sete meninos órfãos de Lisboa, ainda na instalação vizinha à Ajuda. Em 1551 começou a ser construído na área fora da cerca, com alguns edifícios cercados por muros de taipa. Nóbrega ainda morava na Ajuda (na igreja ou em área vizinha) quando da chegada do bispo em $22 / 06 / 1552,{ }^{339}$ que teve sua moradia definitiva (a Casa do Bispo) adquirida algumas semanas depois, em frente à segunda Sé (que se confirmou). ${ }^{340}$

A seguinte passagem poderia indicar que a área da Sé e do futuro Palácio do Bispo estava ainda fora do perímetro murado: O Bispo veiu pousar comnosco, até que Ihe cercaram umas boas casas, em que agora está. ${ }^{341}$ Novamente, por que cercar uma área que já estaria dentro dos muros? É nesse sentido que não se torna absurda uma hipótese de que dentro dos muros haveria ainda uma cerca, formando uma espécie de

\footnotetext{
${ }^{337}$ VASCONCELOS, 1977: I, 223.

338 Idem, p. 234.

339 Apesar das diferenças com o clero secular (primeiro com o vigário geral e depois com o bispo) há muitas indicações de que dividiam com ele os aposentos da Ajuda. Eduardo Bueno (2006-2: 139) dá como certo que "por cerca de 15 dias, Sardinha morou com os jesuítas na igreja da Ajuda". Também Informa que o chamado "palácio do bispo", em frente à Sé, era o imóvel construído por Pero de Góis, considerado uma das melhores casas do começo de Salvador. Ela foi vendida para o Rei (em duas parcelas de 40 mil reais) para que o bispo se mudasse de imediato.

Antes de se desentenderem, a vinda do bispo tinha sido pedida insistentemente por Nóbrega, que queria transformar o Brasil em bispado para se separar da diocese de Funchal, na ilha da Madeira. Entre as desavenças de Sardinha com Nóbrega estavam a proibição da pregação em tupi, o uso de cânticos e instrumentos nativos, a confissão por meio de intérpretes, a freqüência de índios nas igrejas. No fundo o bispo era contrário à catequização de índios, e teria dito a Nóbrega que... Ihe pareciam incapazes de toda a doutrina por sua bruteza e bestialidade, e que... não as tinha por ovelhas de seu curral, nem que Cristo se dignaria de as ter por tal. O próprio Sardinha, em carta ao Rei, diz: Vossa Alteza verá o quão pouco aparelhados são estes bárbaros para se converterem e mais devemos nos ocupar em que não se pervertam os brancos do que se convertam esse negros - apud BUENO, 2006-2: 140). Essa postura ia contra todo o projeto e empreendimento jesuítico. Muitos entendem que o interesse do bispo em vir ao Brasil era apenas econômico, e que a causa de sua volta era não ter recebido a quantia almejada.

${ }^{340}$ Gabriel Soares narra a chegada do bispo como se fosse em 1550, explicando que nessa época... Sua Alteza mandava cada ano em socorro dos moradores desta cidade uma armada com degredados, moças órfãs, e muita fazenda, com o que a foi enobrecendo e povoando com muita presteza... (SOUSA, 1971: 130). Segundo a lenda, o bispo Sardinha teria sido caprichosamente devorado por índios caetés, recebendo por isso a homenagem antropofágica de Oswald de Andrade no século XX.

${ }^{341}$ NÓBREGA, 1988: 128-9 - Para o Padre Provincial de Portugal, 1552. Chegamos a nos perguntar se essa expressão "cercar uma casa" não poderia significar "construir casas sólidas", mas não encontramos essa referência. Da mesma maneira, quando diz "cercadas as casas de taipa", se não estaria se referindo às taipas das próprias casas, mas não nos parece que seja isso.
} 
cidadela, que talvez pudesse se deslocar em direção ao norte, conforme a cidade crescia.

Voltando ainda às primeiras cartas de Nóbrega (à segunda, datada apenas como de 1549, anterior à do trecho polêmico), ${ }^{342}$ a indicação é de que o terreno escolhido pelo governador era mesmo atrás da Ajuda, em direção ao vale: $O$ Governador nos tem escolhido um bom valle para nós; parece-me que teremos água, $e$ assim m'o dizem todos. Aqui devíamos de fazer nosso valhacouto [refúgio, abrigo], e d' aqui combater todas as outras partes. No ano seguinte, ${ }^{343}$ Nóbrega volta a falar da localização do colégio, em texto também passível de mais de uma interpretação.

Fizemos construir em logar mais conveniente uma egreja onde os Christãos ouvem missa e junto uma casa onde o irmão Vicente Rodrigues e Simão Gonçalves ensinam os meninos, e existe entre a cidade e a aldeia ao pé de um rio um logar, segundo o parecer de todos os Irmãos, muito a proposito e conveniente para se fazer um collegio, como já escrevi a Vossa Reverendissima.

Interpretamos que essa casa e igreja construídas "em logar mais conveniente" (não mais na Ajuda) corresponda ao iníco de ocupação da área em que se consumou a obra, quando ainda se almejava a construção do colégio na direção do monte Calvário ("entre a cidade e a aldeia"). Em outra carta, de 1551, ${ }^{344}$ tudo indica que se dava andamento à construção do colégio no terreno antes almejado (sendo ainda uma obra recente), mas surge aí, como já dissemos, uma evidência de que não estaria na área fechada por muros, pois estão sendo construídos muros próprios.

A casa da Bahia, que fizemos para recolher e ensinar os moços, vai muito adeante, sem El-Rei ajudar a nenhuma coisa, somente as esmolas do Governador e de outros homens virtuosos. Quis-nos o Senhor deparar um oficial pedreiro [Diogo Peres?], e este a vai fazendo pouco a pouco; tem já feito grande parte da casa e têm também cercadas as casas de uma taipa mui forte.

Ainda em relação à polêmica entre o chefe dos jesuítas e o governador, queremos destacar que ela reforça a idéia de uma cidade una em seu aspecto defensivo (como defendemos). Vimos que os jesuítas foram instalados provisoriamente na Ajuda e no Monte Calvário, escolhendo depois o local para a construção de sua igreja e colégio fora dos limites iniciais da cidade (como também interpretou Manuel Teixeira). ${ }^{345}$ Mas a área escolhida não era distante e sim próxima à cerca (dentro do futuro perímetro amuralhado, em direção ao qual se daria, de modo já previsto, o primeiro crescimento da área urbana), ficando evidente pelo depoimento do jesuíta que o Colégio pensava na proteção da cidade (o que mostra uma concepção de urbe integrada). ${ }^{346}$ Se por vantagem ou necessidade houve a escolha de se construir

342 "Para o Padre Mestre Simão", de 1549 (NÓBREGA, 1988: 77-8). Na seqüencia ele fala na "necessidade de Vigario Geral", evidenciando que era anterior à chegada de Manuel Lourenço e sua instalação na Ajuda.

${ }^{343}$ Também “Ao Padre Simão Rodrigues”, em carta de 06/01/1550 - NÓBREGA, 1988: 103-13.

344 “Aos Padres e Irmãos" (NÓBREGA, 1988: 114-7). No mesmo ano [1551] na carta "A' el-Rei" (1988: 126), diz: O Colégio da Bahia seja de Vossa Alteza para favorecer porque está já bem principado e haverá nele vinte meninos pouco mais ou menos, e mande o Governador que faça casas para os meninos, porque as que têm são feitas por nossas mãos e são de pouca duração... Também em carta 1552, "Para o Padre Provincial de Portugal" (1988: 129), diz: Este colégio dos meninos de Jesus vai em muito crescimento, e fazem muito fruto; ...

${ }^{345}$ Cf. TEIXEIRA \& VALLA, 1999: 226.

${ }^{346}$ Sobre o Colégio não ficar dentro da cidade e poder haver guerra com o Gentio, Nóbrega (1988: 84) discorda do governador por estarem os jesuítas a guardar e doutrinar meninos índios. Mas em casos 
inicialmente fora da cerca, isso não aumentou ou diminuiu a eficiência da fortificação (como argumentava Nóbrega).

\subsubsection{As defesas segundo Luiz Dias}

Com Luiz Dias, Mestre das Obras da Fortaleza e Cidade do Salvador, isto é, nosso primeiro urbanista, nota-se melhor a proximidade dos ideais renascentistas de cidade, pelo fato de haver muralha, posições fortificadas e um traçado urbano que só não é mais geométrico por condições adversas do terreno. Há muita discussão sobre o primeiro traçado, assunto que abordaremos adiante.

Vimos com Gabriel Soares que foi feita primeiro uma cerca de paus, reforçada e barreada (... uma cerca muito forte de pau a pique...), ${ }^{347}$ depois substituída pelo muro de taipa de pilão enquanto a cidade era construída. É provável que a primeira forma externa à cidade, obra coordenada por Luiz Dias, pouco tivesse dos desenhos de Miguel de Arruda. Na adaptação ao terreno das traças gerais vindas do Reino, foi necessário acomodar duas malhas oblíquas, em função da topografia.

Embora alguns possam ver nessa barreira um "sabor de defesa medieval", 348 o caráter do projeto é plenamente renascentista: a cidade teorizada nos tratados italianos era, como a medieval, totalmente murada e tida como fortaleza, mas, diferentemente desta, coordenava o traçado geral da muralha a uma concepção integral de cidade, articulando o arruamento, as praças e a disposição dos edifícios principais.

\section{$\underline{\text { Muros }}$}

Na Carta a Miguel de Arruda, Luiz Dias cita um dos trechos da muralha, narrando que... no ano de 50 em quarta feira a derradeira oitava de Páscoa começaram as taiparias que então acabávamos de fazer, de cair da Porta de Santa Catarina até a estância sobre o mar... Diz que depois de um forte temporal,... até o cunhal e para baixo... muito pouco dela se aprovei[tou porque foi...] para nenhuma ficar de pé..., o que representou um prejuízo de se[ssen]ta mil réis a seis oficiais. ${ }^{349}$

Ele indica que a essas alturas já havia uma primeira camada de reboco, mas a construção tinha defeitos estruturais: $E$ a culpa que aí eles têm e [minha cons]ciência é que foram mal taipadas e muito [mal reboca]das de riba e de baixo, que não

extremos de ataques aos engenhos, diz que tudo é recolher á cidade, que já funcionaria assim como cidadela.

Pode-se ainda citar a outra carta de 1949, escrita "Ao Dr. Navarro, seu mestre em Coimbra" (NÓBREGA, 1988: 89), pelo que expressa de conhecimento de salubridade e pelo registro do uso da mão-de-obra indígena também nas construções e fortificação de Salvador, já nessa época: Desde logo se fez a paz com o Gentio da Terra e se tomou conselho sobre onde se fundaria a cidade, chamada do Salvador, onde muito ainda obrou o Senhor, deparando logo muito bom sítio sobre a praia em local de muitas fontes, entre mar e terra e circundado das águas em torno aos novos muros. Os mesmos índios da terra ajudam as fazer as casas e as outras coisas em que se queira empregá-los [construções e plantio de cana];... É muito salubre e de bons ares, de sorte que sendo muita a nossa gente e mui grandes as fadigas, e mudando da alimentação com que se nutriam, são poucos os que enfermam e estes depressa se curam... [A região] é muito fresca e mais ou menos temperada...

${ }^{347}$ SOUSA, 1971: 129 (trecho reproduzido na p. 90).

${ }^{348}$ OLIVEIRA, 2004: 56.

${ }^{349}$ Carta de Luiz Dias a Miguel de Arruda (13/07/1551), op. cit. 
andavam senão [... e] eu com um dardo que trazia na mão as desmanchava [em alguns] lugares, que me não podia valer com eles ${ }^{350}$

Em outro trecho, apresenta os novos parâmetros de altura, em função do desabamento: ... E agora ao presente o que temos feito é termos já tudo levantado $e$ na altura de 11 palmos, que dantes eram o mais baixo de 16 e 18, e tudo abaixamos nesta outra altura. ${ }^{351}$ Além da redução de altura, a revisão da técnica inicial incluía a aplicação do reboco de proteção:... a teremos levantada e rebocada de cal em que agora andamos rebocando até o Natal...

Apesar disso, a vida útil da muralha foi curta, como testemunhou Gabriel Soares, algumas décadas depois. Mas dentro do que era previsto por Luiz Dias (o que reforça a idéia de um planejamento criterioso - apoiado no que chamaríamos de uma economia de meios): ao mencionar a técnica do reboco, ele apontou a Miguel de Arruda uma previsão otimista para a duração dos muros. Diz: Senhor, o meu parecer é que estas taipas rebocadas de cal muito bem como imos fazendo e com os baluartes que estão não... [devem du]rar $\mathbf{2 0}$ anos, e que não devia [gastar mai]s dinheiro até não ver se ia esta [cidade em aument]o e não tivesse muita renda...

Portanto, previa corretamente que em 20 anos já se construiria outra muralha para acompanhar o crescimento da cidade, que teria seus próprios rendimentos para arcar com a despesa. Esta é justamente uma das principais idéias que defendemos: as decisões, bastante racionais, eram embasadas em uma economia de meios, tal como prescrito nos tratados. Por que investir demais em uma construção que seria substituída em prazo médio? A construção inicial deveria ter a grandeza suficiente para proporcionar riquezas que numa etapa seguinte pagariam a nova construção (além de lucros à Metrópole).

Na outra carta, escrita ao Rei, Luiz Dias repete a informação de que a muralha desmoronava de tempos em tempos, principalmente nas chuvas de inverno. Ele lamenta que...

... depois de feito ho muro ... hûa envernada tamanha que nos deribou parte dos que feito tínhamos, ainda que não foy em tanta cantidade por me parecer que no caso isto de serem hum pouco altas pera taipa sem cal, os emendamos e fizemos de maneira que estão pera ha tera muito bons, fiquom já asy acabados e se compesão jaguora [começam agora?] a revocar de cal de dentro e de fora, de maneira que com elas revocadas ficarão tam fortes que duraram muitos anos ate $\mathrm{V}$. A. tenha na terra mais rendimentos com que pelo tempo em diante posa gastar mais em fazelos como qiser e hos baluartes estão muito fortes e muito ... lados como madeira pela taiparia de dentro que durão depois que tão bem forem revocados ho que qiserem. Isto me parece que sobeja e abasta pera esta terra. ${ }^{352}$

Apesar de tudo, a muralha era reconstruída, porque devia cumprir bem sua função de deter incursões indígenas, além de caracterizar a cidade-fortaleza prescrita

\footnotetext{
350 Mostrando assim como era feito o controle de qualidade da obra. Sobre o desmoronamento, há uma interessante colocação de Rafael Moreira (2003: 50 - nota 22, grifo nosso): “... Dias não teria erguido uma muralha em taipa de 4 metros no rebordo de barrancos frágeis, que caíram com as primeiras chuvas, se não estivesse condicionado por um traçado prévio, que teve que reduzir para caber no terreno disponível".

351 Edison Carneiro diz ter confrontado as cartas de Luiz Dias com Provisões de pagamentos a empreiteiros, chegando à conclusão que o muro de taipa preliminar teria "no mínimo, 16 a 18 palmos [3,52 a 3,96 m] de altura" (CARNEIRO, 1978: 61). Mas nota-se que essa informação está explicitada na Carta a Miguel de Arruda.

352 ANTT, Corpo Chronológico, Parte I, 86, III. Carta de Luis Dias ao Rei, de 15/08/1551 - apud BUENO, 2001, 145-6 (grifos nossos).
} 
no Regimento de D. João III. Essa última frase de Luiz Dias (isto me parece que sobeja...) serviu para que alguns autores observassem em suas cartas uma sugestão de falta de cuidado e até menosprezo pelo que fazia, o que reforçaria a chamada teoria do desleixo. De fato, Luiz Dias estava cansado do Brasil, como é explicitado em trechos desta e da outra carta. Mas discordamos desse significado para a frase, entendendo que seja mais um exemplo de comedimento (economia de meios, racionalidade necessária) entre as muitas decisões deixadas a critério do profissional responsável. Seria, enfim, um simples parecer técnico. ${ }^{353}$

\section{Portas de Santa Catarina e Santa Luzia}

De todas as fortificações erguidas como portas da Cidade, a de Santa Catarina tem o registro mais antigo, figurando na Carta de Luiz Dias a Miguel de Arruda (... as taiparias... de cair da Porta de Santa Catarina até a estância sobre o mar...). ${ }^{354}$ Entendemos que na primeira fase da cidade haveria algum tipo de porteira controlando o acesso direto à praça administrativa, correspondendo à passagem para o interior da primeira cerca de quem viesse da parte ainda vazia ao norte ou pelos caminhos inclinados a partir da Cidade Baixa.

Sabe-se que o nome, Santa Catarina (provável homenagem à rainha, na época ainda esposa de D. João III), corresponde ao da porta de acesso ao Carmo, que

\footnotetext{
${ }^{353}$ Luiz Dias permaneceu contra a vontade em Salvador durante toda a gestão de Tomé de Sousa, apesar dos apelos insistentes (até patéticos) de voltar ao Reino (na Carta a Miguel de Arruda há trechos em que ele implora pelo seu retorno à Pátria: ... um taipeiro que cá há o melhor que há o mundo basta para ter cuidado desta taiparia... E duma maneira ou doutra folgaria que V. M. me mandasse ir, por amor de Nosso Senhor, porque Ihe certifico que se cá morrer hei de ir direto ao inferno). Não se pode atribuir os erros de fortificação de Salvador a ele, que aplicou corretamente as traças e provavelmente contribuiu no desenho da cidade (não havia levantamento topográfico preciso e as traças de Miguel de Arruda tiveram de ser adaptadas).

Há poucas informações sobre Luiz Dias, entre elas um papel de 1524, citado por Viterbo, em que certo Luiz Dias morador da Çafim (Safim) é nomeado para o cargo de Mestre e Obras da Cidade (Safim, na África, era dominada pelos portugueses no início do século XVI), onde, em sendo a mesma pessoa, ele teria morado. Mais segura é a informação de que viveu nas vizinhanças da Batalha, de onde teria se relacionado com Miguel de Arruda, porque quando vinha ao Brasil, um Alvará Régio dava uma tença de dois moios (medida antiga equivalente a 60 alqueires ou 828 litros na região de Lisboa) de trigo à sua mulher Catarina Pires, começando com: Eu elRey faço saber a quantos este meu alvará virem que por fazer merce a Caterina Pirez, morador na Batalha, molher de Luiz Dias, que ora por meu mãdado vay ao Brasyll por mestre da fortaleza e obra que la mando fazer... (ANTT - Chancellaria de D. João III, liv. 67, fl. 143 - apud VITERBO, 1899: I, 280/ OLIVEIRA, 2004: 91-2).

O resto da documentação sobre Luiz Dias são as cartas que escreveu de Salvador para o Rei e para Miguel de Arruda, em que descreve o trabalho desenvolvido (também há algumas Provisões e Portarias de Tomé de Souza e do Provedor-mor para execução de medições e vistorias nas obras da Cidade). Ele era auxiliar de Miguel de Arruda (a quem tratava como meu Senhor e Vossa Mercê em sua correspondência), profissional de maior prestígio e reconhecido por adquirir com inteligência os ensinamentos de fortificação com Benedetto da Ravenna (cf. VITERBO, 1899: I, 67-8). Entende-se que na época dificilmente um arquiteto de prestígio no Reino arriscaria a vida em viagem de mais de dois meses para trabalhar em terras inóspitas. Luiz Dias teria sido persuadido com promessa de melhorias, que virariam tormento quando esteve à frente das obras de Salvador (cf. OLIVEIRA, 2004: 91 - algum tempo depois, Leonardo Turriano alegou vários motivos para evitar a temerosa viagem, e no seu tempo a vida em Salvador já não era tão dura quanto na fundação; para os profissionais construtores virem ao além-mar, acenava-se com bons salários e promessas, quase sempre não cumpridas, sem dizer que o custo de vida era caro - exceto a carne e a farinha).

${ }^{354}$ Carta a Miguel de Arruda (13/07/1551), op. cit.
} 
entendemos ser dos anos 1590. Na hipótese de que essa estância sobre o mar, o baluarte de São Jorge, estivesse nos limites do terreno da segunda Sé (como aparece na Planta de Restituição...), ao não se considerar a construção de uma muralha tão extensa logo nos primeiros dois anos da cidade, acreditamos que o mesmo nome possa ter sido dado a essa suposta porta anterior e provisória, que tendo sua estrutura em taipa de pilão, teria desaparecido junto com a primeira muralha (sem aparecer em gravuras). Mas se desde o início, de fato, estivesse no local mais ao norte (daquela que acreditamos tê-la substituído na época seguinte, aparecendo no Livro da Rezão... de 1612 com o mesmo nome, mas em referência às Portas do Carmo), esse trecho de muro corresponderia à descida lateral em área inclinada, sendo a estância sobre o mar o próprio baluarte da Ribeira, muito mais ao norte do que supuseram todos (ou quase todos) os autores aqui citados.

Embora Luiz Dias tenha se referido apenas à Porta de Santa Catarina, que limitaria a cidade pelo norte, é quase certo que no projeto de Miguel de Arruda constasse a de Santa Luzia, limitando-a pelo sul. O nome Santa Luzia só aparece com Gabriel Soares de Sousa, que diz ter havido uma ermida próxima a ela, de mesma invocação. No Livro da Rezão... (1612) a fortificação aparece como Portas de Santa Luzia (no plural, por ser fechada por duas, talvez dois pares de porteiras), já figurando no Sermão do Dia de Reis do Padre Antonio Vieira (1641) como Portas de São Bento (por estar próxima à cúpula do mosteiro). Também aparece registrada como Porta do Sul e Portas do Sudeste e, mais comumente, a partir do século XVIII, como "Castelo" de São Bento ou de São Pedro.

Voltada para o sul, ela inicialmente controlava o acesso de um dos caminhos que ligavam a cidade ao porto, passando depois a dominar o acesso a um caminho aberto até Vila Velha (antes Vila do Pereira, próxima ou contígua à aldeia de Caramuru). No começo era de taipa e certamente não tinha a forma desenhada por Caldas em 1759. Em 1581, no governo de D. Lourenço da Veiga, seria construída a porta interior como parte de uma primeira reforma (ocorrida bem antes, portanto, da chegada de Diogo Moreno à Bahia, no início do século XVII). ${ }^{355}$

\section{Baluartes em terra: São Jorge, São Tomé, São Tiago...}

Segundo Gabriel Soares, Luiz Dias teria instalado quatro baluartes em terra. Seriam plataformas, estâncias fortificadas, pequenos redutos em trechos da cerca apoiando o muro de taipa de pilão, que se somavam às duas estâncias na zona da Ribeira. Luiz Dias, na carta a Miguel de Arruda, refere-se a três, entre eles um que estaria voltado para o mar, talvez dando proteção ao porto e dificultando desembarques inimigos:... a estância sobre o mar, que se agora chama de São Jorge, $e$ logo no baluarte de São Tiago até a estância de São Tomé. ${ }^{356}$

É a mesma frase sobre as taiparias que caíram, vindas da Porta de Santa Catarina. Entendemos que ele se refere a dois trechos independentes (e distantes) dos muros que desabaram. O primeiro, em nossa hipótese de que a antiga Porta de Santa Catarina fosse mesmo próxima à Praça Principal, corresponderia ao seguinte trecho:

\footnotetext{
${ }^{355}$ Cf. CAMPOS, 1940: 262-3.

${ }^{356}$ Carta a Miguel de Arruda (13/07/1551), op. cit.
} 

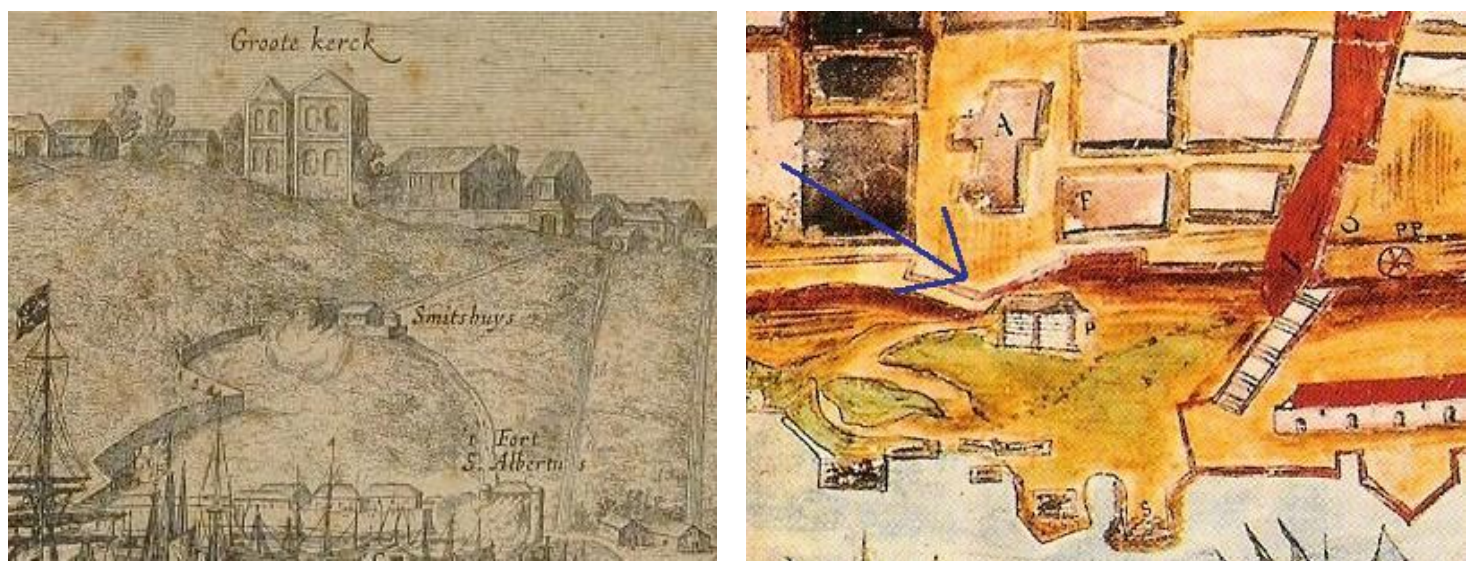

Imagens de Gerritsz (c. 1624, Seção de Iconografia da BN) e Albernaz (plantas de 1605, em REIS F, 2000: 18), mostrando uma possível localização para o antigo baluarte de São Jorge, entre a futura igreja da Sé (na parte alta) e o futuro forte de S. Alberto (na baixa, aparecendo na gravura holandesa como Smits huys e em Albernaz como aestançia de S. dioguo), na hipótese da Porta de Santa Catarina próxima à Praça. Acreditamos ser na plataforma descrita por Diogo Moreno em 1609 (... no meio da montanha debaixo... a misericordia esta tamben huma plataforma $q^{\prime}$ defende a... no porto junto a sidade... Relação..., fl. 27), próxima à da futura Bateria do Palácio (descrita por J. A. Caldas - 1951: 383).

Portanto, ao falar das muralhas que caíram, ele cita essas três defesas: São Jorge, São Tiago e São Tomé. Muitos historiadores (Borges de Barros, Teodoro Sampaio, Silva Campos, Braz do Amaral, Alberto Silva, Luiz Monteiro, D. Clemente) teorizaram sobre a localização desses primeiros redutos, não se chegando a uma conclusão definitiva. ${ }^{357}$ Mesmo o fato de serem seis (contando-se as duas do mar) é uma suposição, geralmente aceita pela referência geralmente confiável de Gabriel Soares (mas que não chega a dar nomes). ${ }^{358}$

Sobre os seis baluartes mencionados por Gabriel Soares, Edison Carneiro prefere acreditar que fossem apenas os quatro conhecidos: os dois do mar e as duas portas. ${ }^{359}$ Afirma que "não há notícia de fortificações especiais debruçadas sobre o interior" (mas no contexto de demonstrar não havia preocupação especial com a ameaça dos índios). ${ }^{360}$ Não chega a dar explicações mais detalhadas, mas coincide com

357 Sobre essa controvérsia das localizações, M. Oliveira lembra quase todas as argumentações se fundamentam nas plantas do Livro da Razão..., que "não são cadastros, mas projetos para a cidadela" (que podem não ter sido realizados, realizados parcialmente, ou de outra maneira), não tendo relação, portanto, com as estâncias de Luiz Dias (OLIVEIRA, 2004: 177-8).

${ }^{358}$ Cf. SOUSA, 1971: 129 -... ordenou de cercar esta cidade de muros de taipa grossa, o que fez com muita brevidade, com dois baluartes ao longo do mar e quatro da banda da terra... Alguns autores (como Teodoro Sampaio) conjecturam que esses seis baluartes poderiam estar em terra, com dois deles voltados para o poente (ao longo do mar). A frase de fato dá margem a essa interpretação, mas vamos argumentar adiante que seriam seis ao todo.

${ }^{359}$ Como foi alertado por alguns autores, o depoimento de Gabriel Soares sobre a fundação, já distanciado no tempo (a crônica fala do ocorrido havia 35 anos, com informações provavelmente vindas da tradição oral; ao contrário de Nóbrega, que narrava o presente), pode conter falhas. A primeira delas, muito criticada por Edison Carneiro, foi sobre o cálculo da população, em que o número aproximado divulgado por ele foi difundido sem o devido cuidado de cálculo dos viajantes das naus. Outra é a questão dos seis baluartes, que ele não viu (mas de algum modo "ouviu", e essa não era uma questão difícil de corresponder à realidade). Em outro exemplo de imprecisão, Gabriel Soares narra a chegada do bispo em 1550 (cf. SOUSA, 1971: 130), quando Nóbrega, contemporâneo aos fatos, narra-a em 1552 (enfatizando que ele só iniciou os trabalhos no ano seguinte).

${ }^{360}$ CARNEIRO, 1980: 21. A afirmação serve para fortalecer sua tese pessoal de que Tomé de Sousa "não 'despejou' aldeias de índios para assentar a Cidade" (como queria Jaboatão, apontando três: no 
o fato de Gabriel Soares só descrever duas posições artilhadas, uma na Praça principal e outra na Porta de Santa Luzia. ${ }^{361}$ E neste caso, estaria falando da cidade nos anos 1580. Para Carneiro, as estâncias de São Tiago e São Tomé corresponderiam às portas norte e sul, sendo a quarta estância o baluarte de Santa Cruz. ${ }^{362}$ As cartas escritas a Miguel de Arruda e ao Rei são de datas próximas (13/07 e 15/08/1551, respectivamente), tornando-se difícil concordar com sua interpretação de que a estância de São Jorge fosse o baluarte da Ribeira de Góis (assim chamado na carta ao Rei). Ele possivelmente se baseia na colocação de Luiz Dias sobre a estância sobre o mar, que se agora chama de São Jorge, mas seria estranho que na carta seguinte não a chamasse pelo mesmo nome.

A interpretação de Edison Carneiro é a que aparece na legenda do historiador Eduardo Bueno, com o "Baluarte de São Jorge", no cais do porto, protegendo a ribeira.

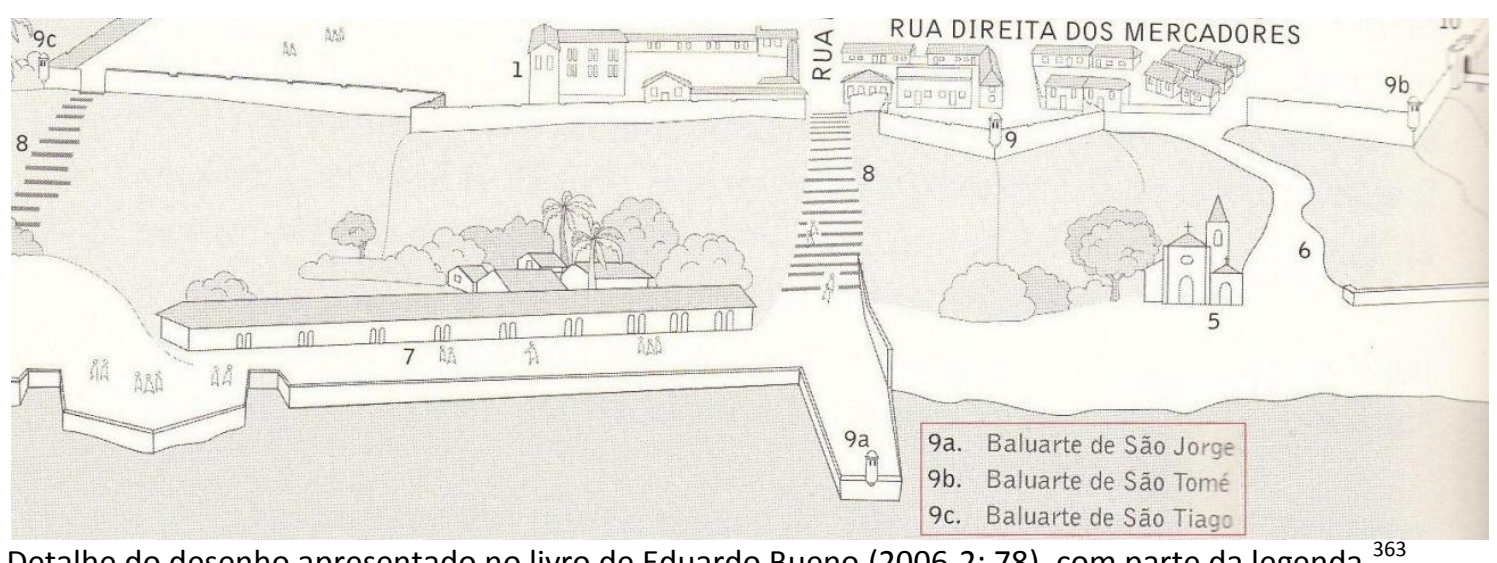

Detalhe do desenho apresentado no livro de Eduardo Bueno (2006-2: 78), com parte da legenda. ${ }^{363}$

Já Teodoro Sampaio aponta o que seriam os quatro baluartes em terra: "um protegia a porta do Sul ou de Santa Luzia e os restantes occupavam os angulos do polygono, de modo a ficar um á meia distancia da face de leste, na extremidade da sobredita travessa" (exatamente como está no projeto de 1605). ${ }^{364}$

Terreiro, no Carmo e no Desterro; mas Nóbrega dizia que a mais próxima - de onde vinham os meninos - ficava além do Carmo). Não sendo a invasão de índios uma ameaça grave (na opinião de Nóbrega e outros), não haveria necessidade de baluartes defendendo o interior. É um assunto controverso. Luiz Dias tinha instruções de como fortificar a cidade (até mesmo um projeto): mesmo que de início não houvesse a ameaça dos índios, poderia passar a haver outras.

361 SOUSA, 1971: 134 - ...desabafada com grande vista sobre o mar; onde estão assentadas algumas peças de artilharia grossa,... ; SOUSA, 1971: 137 -... no cabo da qual está uma ermida de Santa Luzia, onde está uma estância com artilharia.

362 "No alto da colina havia a estância de São Tomé, na Porta de Santa Luzia, do lado do sul, e o baluarte São Tiago, talvez na Porta de Santa Catarina, do lado do norte" (CARNEIRO, 1980: 63). Na seqüência, uma frase do autor fortalece a tese de uma fortificação estruturadora da malha urbana: "Estes fortes marcavam os pontos extremos da Cidade, no norte e no sul, na parte alta e na parte baixa".

363 Em outra interpretação da frase de Luiz Dias, Coelho Filho (2004: 233-4) entende que a primeira Porta ao norte (para ele, "na passagem da atual Praça da Sé para o Terreiro de Jesus") ficaria eqüidistante de dois baluartes (como na fase seguinte), sendo o da banda do mar a Estância São Jorge e o outro de nome desconhecido. Sobre a Porta Sul não haveria "quase nenhuma certeza", já que ao dizer que desmoronou o trecho entre o baluarte São Tiago e a estância São Tomé, Luís Dias não fala da porta. 364 SAMPAIO, 1949: 188. Teodoro faz sua própria interpretação de Gabriel Soares, aos dizer que "seis eram esses baluartes; dous delles na face do mar e quatro da banda de terra..." (idem, p. 187). 

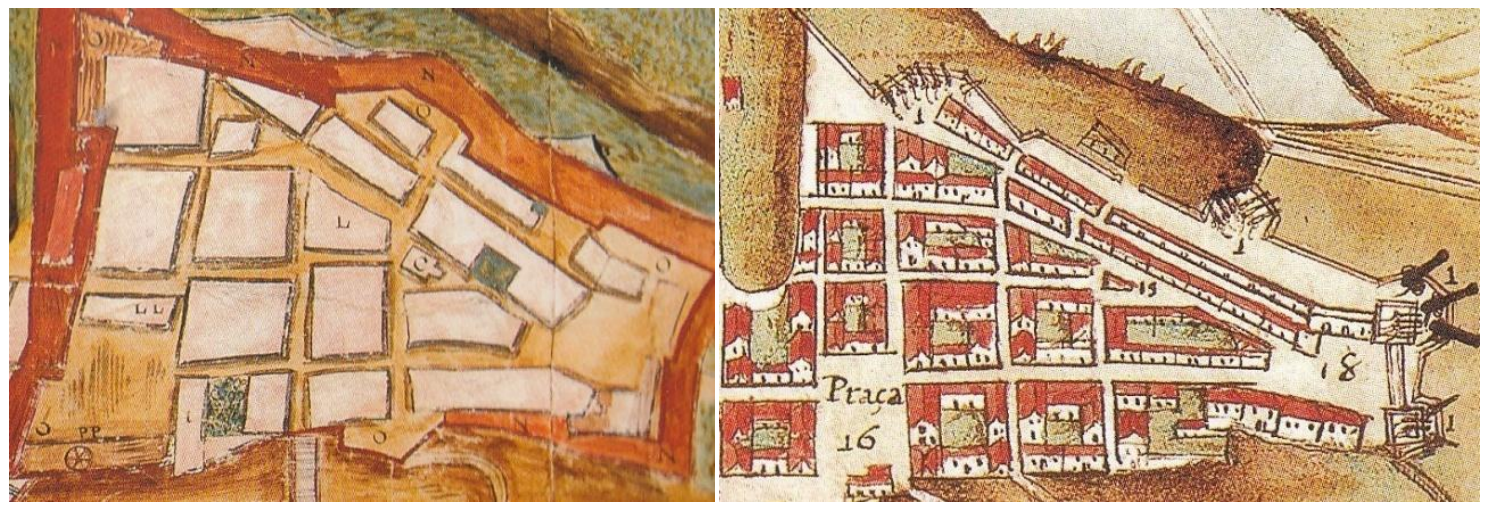

O projeto de novos baluartes da Pranta... de 1605 (versão do IHGB) e outra possível referência, a Planta de Restituição... (c. 1627), mas que representa o núcleo inicial da cidade 75 anos depois.

O que protegia a Porta de Santa Luzia e o caminho da Vila Velha do Pereira seria o de São Tomé. ${ }^{365}$ Outro estaria "em agudo, com os seus flancos e faces avançadas a Nordeste", ${ }^{366}$ junto a uma casa nobre, com brasões de armas sobre a porta de entrada (talvez o Solar dos Sete Candeeiros). Outro estaria no fim do Beco das Vassouras, depois conhecido por Beco do Mocotó, e outro próximo à depressão da atual igreja da Barroquinha. É evidente que sua referência é apenas a planta de 1605, principalmente quando diz: "fossos profundos, corridos em torno dos muros, do lado de terra completavam a fortificação, como, por exemplo, o que descia pelo leito da actual Ladeira da Praça, que representava a face norte do polygono". ${ }^{367}$

$\mathrm{Na}$ explicação de Teodoro Sampaio sobre os baluartes voltados para o mar (que contradiz a posterior e também duvidosa suposição de E. Carneiro), "um ficava na praça, juncto ao palácio do Governador e outro no extremo da travessa, corrida pela frente da egreja da Ajuda, ambos podendo varrer o ancoradouro das naus e impedir a approximação da armada inimiga". ${ }^{368}$

\section{Baluartes no mar: Ribeira e Santa Cruz}

Atendendo a ordens de Tomé de Souza, ou seguindo indicações das traças que trouxera do Reino, Luiz Dias construiu os primeiros "baluartes" que defendiam o porto. Os muros de taipa e as ladeiras íngremes dificultavam o acesso inimigo do mar até a cidade, mas eram distantes para impedir desembarques, sendo necessárias defesas "na Ribeira".

\footnotetext{
365 É também o que afirma Silva Campos (1940: 274-5), citando um mandado de pagamento a Belchior Fernandes (26/07/1552) pela obra na estância de São Tomé (nome em homenagem ao governador) que "estava na porta de Santa Luzia". Outro pagamento foi feito a Gonçalo Fernandes (18/10/1552) pela construção da Estância de São Jorge, que considera "de ubdicação ignorada". Ainda outro pagamento (10/08/1552) foi feito a Gonçalo Fernandes... por ter cargo do Baluarte Santiago (Documentos históricos XIV, p. 271 - apud CAMPOS, 1940: 275), sobre o qual faz algumas conjecturas até concluir ser provavelmente aquele "sobre a laje do porto... mais tarde chamado Fortinho de Santiago da Ribeira" (o que é improvável, pois a "Torre de Santiago", dos anos 1590, era afastada da cidade; talvez fosse a que no livro de Eduardo Bueno aparece como Baluarte de São Jorge - cf. também SILVA, 1931: III, 393).

${ }^{366}$ SAMPAIO, 1949: 195.

367 Idem, p. 188.

${ }^{368}$ Idem, p. 187. Eles atirariam para baixo, portanto.
} 
As fortificações do mar, Ribeira e Santa Cruz foram nominalmente citadas por Luiz Dias na carta ao Rei. ${ }^{369}$ A da Ribeira de Góis, sobre um rochedo, era armada com 2 esperas, 2 camelos, 2 falcões e 12 berços. A de Santa Cruz seria menor, já que tinha menos armamento: 1 espera, 2 falcões e 6 berços. Luiz Dias diz da primeira que foi construída com terra e paus de mangue que se criam n'água e são como ferro, acreditando poder durar cerca de 20 anos e deixando ao Rei a decisão de reconstruí-la em pedra e cal. Mas há documentos mostrando que o sistema construtivo dessas estâncias logo deixou de ser de pau a pique: uma provisão de 16/12/1551 ordenava o pagamento ao pedreiro Belchior Gonçalves em... $16 \$ 665 \mathrm{rs}$. que Ihe ficaram a dever da empreitada, que tomou, por que se obrigou fazer tres paredes na Ribeira de Góes, e na Estancia de Santa Cruz; uma de pedra insossa, e duas de pedra e barro. ${ }^{370}$

Sobre a localização do "baluarte" da Ribeira do Góes, alguns autores (Teodoro Sampaio, Alberto Silva e Edison Carneiro) indicam o porto próximo à antiga ermida da Conceição (onde está a atual Basílica). Para outros, ${ }^{371}$ em 1549 o outro cabo da Ribeira seria onde é hoje o Plano Inclinado, em que à beira-mar foi feito depois o forte de São Francisco. O de Santa Cruz estaria situado na Ribeira dos Pescadores, parte sul, perto da Preguiça (segundo Monteiro da Costa, Alberto Silva e Silva Campos), ou, para alguns (Edison Carneiro), ao norte. ${ }^{372}$ Mas não se pode dizer ao certo a localização dessas fortificações ao nível do mar, que talvez já não existissem na época seguinte (sequer foram citadas por Gabriel Soares). ${ }^{373} \mathrm{Em}$ geral, a interpretação que se faz dessas localizações se associa à do perímetro original da cidade, que logo analisaremos.

${ }^{369}$ Carta ao Rei (15/08/1551), op. cit. E asy fizemos dous baluartes, hum na Ribeira de Goes, muito poderoso, em syma do rochado, que $V$. A. verá na mostra que joga pera todo o mar da baya e joga as duas esperas de marqa mayor que vierão e dous camelos e dous falcões e hûa dúzia de berços: este ainda que he de madeira tão forte que durará segundo dizem vinte anos por ser de paos de mange que se criam nagoa e sam como fero.

O outro baluarte de Santa Cruz he mais pequeno e joga nele hûa espera e dous falcões e meya duzia de berços e isto ate saber se V.A. os quer ter asy ate os diante os fazer de pedra e cal ou logo como ele ordena.

${ }^{370}$ BN - Docs. Históricos, 1929, v. 14, p. 66 - apud OLIVEIRA, 2004:178.

${ }^{371}$ Cf. COSTA, 1958: 21. Seria o único caso em que faria sentido a interpretação que expusemos para a Porta de S. Catarina já no extremo norte, tendo desabado o muro de lá até a praia.

372 "Mais para o Norte, na Ribeira, estava o baluarte de Santa Cruz, de proporções menores. Era de taipa, obra do taipeiro Pedro André..." (CARNEIRO, 1980: 63).

${ }^{373}$ Carlos Lemos chega a dizer que "o Baluarte da Ribeira de Góes, citado por Luiz Dias, talvez venha a ser o chamado 'Fortinho da Ribeira'” do levantamento de Caldas no século XVIII (indica sua reprodução em MENEZES, 1986). Refere-se, certamente, à localização, pois reconhece que "não se trata da construção quinhentista de Luis Dias, porque esta foi feita de madeira de paus de mangue..." (LEMOS, 1989: 238-9). O Forte da Ribeira (século XVIII) foi uma provável reconstrução do Forte da Laje (que será abordado adiante), tendo possivelmente outra localização (outra rocha), no que estaria equivocada a dedução de Lemos de que "situado sobre uma rocha, dificilmente teria um perímetro diferente daquele que foi levantado dois séculos depois". Perguntado sobre isso, M. Oliveira considerou possível que ambos tenham sido construídos na mesma rocha, não sendo tantas as apropriadas, o que levaria a que tivessem um perímetro semelhante. Mas em nenhum momento é dito em Luiz Dias que o "baluarte" ficasse em uma coroa que aflorava na maré baixa, como era o da Laje. Há um equívoco maior em Lemos quando diz que "a pequena fortificação chamada de 'Santa Cruz' também aparece naquela citada obra [MENEZES, 1986] e é de reduzido perímetro" (LEMOS, 1989: 239). A fortificação que aparece em Menezes (p. 154), também desenhada por Caldas, é o "Fortinho de Santa Cruz", situado na margem do rio Paraguassú distante 9 legoas da Bahia (VILHENA, 1921: 240). A confusão é desculpável porque não há lógica na exposição de Menezes, apresentando o de Santa Cruz do rio Paraguaçu seguido do da Ribeira (p. 153), assim como apresenta a Fortaleza do Morro de S. Paulo e a Bateria de S. Paulo como se fossem a mesma (p. 134-6). 


\subsubsection{A estrutura inicial}

Além de executar o plano da cidade, Luiz Dias construiu e foi talvez o projetista de alguns edifícios institucionais importantes. Alguns deles estavam fora da área de traçado geométrico, na Povoação da Praia, ou Ribeira. Essa parte se desenvolveu primeiro e teve no começo mais população e casario que a alta, construindo-se nela a primeira ermida de Salvador, a de Nossa Senhora da Conceição. Na ribeyra de Goes, além dos dois redutos, Luiz Dias construiu a casa da fazenda e alfândegas e almazens e ferarias, tudo de pedra e baro revocadas de cal e telhados com telha... ${ }^{374}$ Eram, portanto, construções definitivas, a infra-estrutura de atividades comerciais e portuárias que se desenvolveriam.

A ligação entre as cidades Alta e Baixa era feita por ladeiras íngremes, primeiro as da Conceição e da Preguiça (Caminho de Carro), depois outras. A parte alta da cidade, o local escolhido para fazer uma fortaleza grande e forte, era o principal objetivo do plano executado por ele. Foi lá que as principais funções administrativas se instalaram desde o início:... e asy fezemos cadeya muito boa e bem acabada com casa daudiencia e camara em syma... ${ }^{375}$ Eram principalmente por causa desses edifícios que entendemos ter sido necessária a construção de uma cerca provisória.

A escolha de sítio e a estrutura básica, dividindo a cidade em partes alta e baixa, tiveram exemplos em várias cidades portuguesas. São comumente lembrados os casos de Lisboa e Porto, modelos que teriam originado a dupla estrutura de Salvador: na cidade alta ficariam os poderes civis e eclesiásticos, e na baixa os mercadores. Essa dualidade, característica de muitas cidades medievais na Europa, teve grande expressão em Salvador e em outras cidades portuguesas pela natureza do comércio marítimo que as desenvolveu. ${ }^{376}$

Entendemos que Luiz Dias começou a construir a Cidade Alta a partir da localização da Praça, estabelecendo primeiro o traçado entre esta e a Porta de Santa Luiza, ao sul. Para adaptar a geometria proposta às características do terreno, foi justamente nesse trecho da fase inicial que se configurou a única irregularidade: em função do terreno, definiu-se uma proporção diferente nas quadras voltadas para o interior (as tais que Nóbrega achou inconvenientes para a instalação do Colégio). Essa

\footnotetext{
${ }^{374}$ Carta ao Rei (15/08/1551), op. cit.

${ }^{375}$ Id. ibid. (grifo nosso em negrito).

376 Duas colocações de Manuel Teixeira (em TEIXEIRA \& VALLA, 1999) retratam bem o processo da fundação de Salvador e a idéia que se tinha de plano urbano. A primeira, de que "a fortificação era uma necessidade primordial para a defesa da cidade", e por isso a cerca de taipa foi construída primeiro, adaptando-se ao terreno acidentado. A segunda, uma de nossas premissas já antes de conhecer seus textos, de que as cidades fundadas por iniciativa do Rei, começando por Salvador (ao contrário das vilas fundadas por donatários, ou originadas de aldeamentos, como São Paulo), eram "concebidas como um todo, segundo uma idéia de regularidade e com um plano na medida do possível geometrizado, de acordo com o moderno pensamento urbanístico renascentista" (p. 225 - grifo nosso).

Manuel Teixeira considera que a primeira organização urbana de Salvador foi determinada por três fatores (em ordem de importância): 1- as características do terreno escolhido (em função da defesa); 2a natureza das funções (político-administrativas e comerciais) que a cidade deveria cumprir para que se desenvolvesse; 3- a tradição portuguesa de urbanismo (isto é, baseava-se em modelos existentes). A estrutura em cidades Alta (poderes civis, militares e religiosos) e Baixa (comerciantes e marinheiros) seguiria um modelo de origem medieval, enquanto o planejamento regular da Cidade Alta (a malha urbana ortogonal e o principal tipo de quarteirão já em sua primeira fase), as áreas com funções distintas e a forma abaluartada das muralhas são claramente renascentistas (cf. p. 227).
} 
exceção não fez com que o traçado deixasse de mostrar sua nítida intenção de regularidade. No geral, cidade organizada das muralhas para dentro, tinha bastante rigor geométrico em sua estrutura de quarteirão, já na primeira parte da malha construída. ${ }^{377}$ Assim, a cidade delineada por Luís Dias teve inicialmente em seu interior dois conjuntos de quarteirões, ambos retangulares, mas de proporções diferentes. ${ }^{378}$

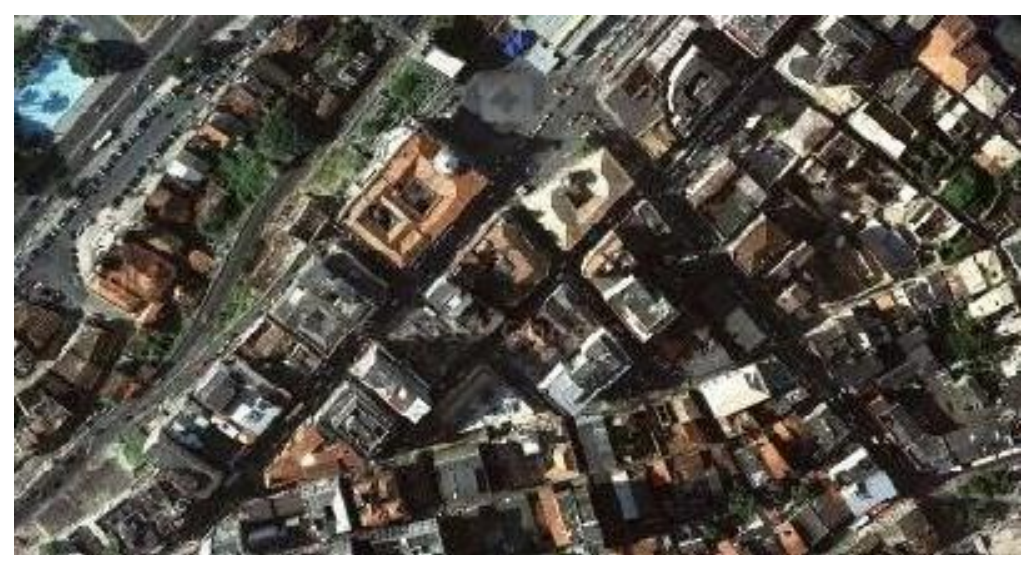

Na parte de baixo da fotografia de satélite, a estrutura paralela de quarteirões que se manteve até os dias atuais, de primeira configuração que se deveu às características do terreno - os lados maiores acompanhavam as curvas de nível (Google, 23/01/11, mostrando no alto, ao centro, a Praça Municipal).

Já as quadras do conjunto no topo da colina foram traçadas e se mantiveram em sua forma mais quadrada, com cada quarteirão tendo os lotes dispostos fundos com fundos, virados para ruas opostas (nas quatro faces). ${ }^{379}$ As ruas já não se alternavam como ruas de frente e de trás, mas tinham hierarquias mais elaboradas associadas à sua articulação com outros elementos da malha urbana (a Praça, os largos, limites, edificações importantes). ${ }^{380}$

Nessa estruturação inicial, formaram-se três áreas livres no encontro dessas duas malhas urbanas e entre elas e os limites do que supomos tenha sido a primeira fortificação: a Praça Principal, o largo da Ajuda (em torno da igreja) e o largo junto à Porta de Santa Luzia (correspondendo hoje à Praça Castro Alves). Nota-se uma eqüidistância entre essas áreas, que evidenciariam o eventual uso que teriam como praças, mas é importante destacar, observando as descrições de Gabriel Soares, que apenas a Praça Principal recebia esse nome. ${ }^{381}$

A Praça principal, abrindo-se para o lado da baía, foi desde o início o elemento fundamental de estruturação da cidade. Nela foram construídos os principais edifícios

\footnotetext{
377 Com a orientação das primeiras ruas e quadras sendo determinada principalmente pelas características topográficas da área cercada, ela resultou em uma malha regular, mas não perfeitamente ortogonal, explicando-se assim o formato trapezoidal (como o definiu Manuel Teixeira, o que é válido independente dos baluartes desenhados por ele e Teodoro S., copiando o projeto de cidadela da Planta) do perímetro fortificado.

378 TEIXEIRA \& VALLA, 1999: 225. Dentro do que se poderia chamar de uma malha secundária, observase na parte mais ao interior (separada pela Rua da Ajuda que faz o corte diagonal) os quarteirões que Manuel Teixeira diz serem de estrutura idêntica aos de cidades medievais planejadas: forma retangular alongada, com lotes paralelos que iam provavelmente de uma rua a outra.

${ }^{379}$ Como desenhamos na p. 91.

380 Segundo Manuel Teixeira, também havia esses dois tipos de estrutura de loteamento e de quarteirões em Lisboa, que se desenvolvia na época e teve sucessivas fases construtivas no Bairro Alto.

${ }^{381}$ Mesmo o Terreiro, existente em sua forma atual já nos anos 1580 (quando recebia... festas a cavalo, por ser maior que a praça... - SOUSA, 1971: 136) jamais teve tal nomenclatura.
} 
públicos: a Casa da Câmara e Cadeia (referida por Luiz Dias), a dos Governadores e, tempos depois, a da Relação e a da Moeda. ${ }^{382}$ A importância desta praça no traçado de Salvador está associada à relevância de seus edifícios institucionais, tornando-se assim o centro administrativo da cidade e importante pólo aglutinador do crescimento urbano. Nessa primeira fase, acreditamos que ela ficaria em posição lateral à parte inicialmente construída. ${ }^{383}$

Na descrição da Praça principal, feita quase 40 anos após a implantação (defendemos a idéia de que o crescimento foi previsto exatamente como se deu, para que em algumas décadas ela ocupasse a posição central), Gabriel Soares diz:

... Está no meio desta cidade uma honesta praça, em que se correm touros quando convém, na qual estão da banda sul umas nobres casas, em que se agasalham os governadores, e da banda norte tem as casas do negócio da Fazenda, alfândega e armazéns; e da parte de leste tem a casa da Câmara, cadeia e outras casas de moradores, com que fica esta praça em quadro e o pelourinho no meio dela, a qual, da banda do poente, está desabafada com grande vista sobre o mar... ${ }^{384}$

Em relação ao Largo da Ajuda, o fato de haverem duas malhas distintas, de ortogonalidades oblíquas (em cerca de 40 graus), faz supor que, longe de pertencer ao projeto original de Miguel de Arruda, essa configuração só ocorreu pela necessidade de adaptação ao terreno. ${ }^{385}$ Embora se possa concordar com Manuel Teixeira que os quarteirões de forma retangular alongada sejam idênticos aos de "cidades medievais planeadas", o terreno inclinado certamente foi determinante para que na direção do declive houvesse uma dimensão menor (em relação às quadras próximas à Praça Principal, em cota mais elevada). Talvez para compensar essa diferença, mantendo-se

${ }^{382}$ Cf. TEIXEIRA \& VALLA, 1999: 225. O autor mostra que a existência de várias praças em Salvador e outras cidades é característica do urbanismo português, uma concepção diferente da dos espanhóis (diferença de tradição que se reproduziria nos traçados urbanos das respectivas colônias). Para os espanhóis prevalecia o partido da Plaza Mayor, que concentrava todas as principais funções institucionais. Já os portugueses, preferiam o traçado das praças múltiplas com funções distintas.

383 Manuel Teixeira (1999: 225) interpreta que nessa situação ela não seria ("nem conceptual nem formalmente") a geradora da malha urbana que se desenhava.

Em Francesco di Giorgio (MARTINI, 1967) há uma clara recomendação para que a piazza (p. 22) fique "o mais possível" no centro ou meio da cidade (como umbigo do corpo do homem, por onde passaram os primeiros nutrientes), em função de muitas "comodidades". Se o sítio não o permite (p. 24-5), o arquiteto deve aproximá-la ao máximo, com recursos como a construção de aquedutos. Sobre cidades atravessadas por rio, Martini prescreve (tomo II, p. 366, par. 25) que sendo toda ela plana, deve-se dividi-la "em quadro" (quadras perpendiculares), construindo-se junto à borda três ou quatro pontes correspondendo às suas entradas. Se bem protegida, a praça poderia estar nas margens do rio (pelo menos uma das ilustrações traz duas praças frente a frente, uma de cada lado do rio, no centro da fortaleza), sendo recomendadas fortificações de entrada e saída nos extremos do rio na área urbana. Francesco di Giorgio também faz prescrições para outras situações de controle do território a partir da cidade, sendo possível interpretar para algumas delas que a praça estivesse na lateral. No caso da Praça Municipal de Salvador, essa localização proporcionou amplo domínio visual da baía, ao mesmo tempo em que o acesso pelo lado do mar era defendido por um imenso despenhadeiro, de difícil escalada e impossibilitando bombardeios a partir dos navios.

Vamos ainda enfatizar nossa idéia de que em Salvador a Praça estaria apenas provisoriamente próxima à fortificação, já sendo previsto o crescimento da cidade em direção ao norte (fazendo com que ela ficasse relativamente central em relação à fortaleza).

${ }^{384}$ SOUSA, 1971: 134 - grifos nossos.

${ }^{385} \mathrm{O}$ que se pode observar pelas curvas de nível dos mapas aqui apresentados. Lembramos que a adequação à topografia era certamente prevista e autorizada por Arruda. 
as áreas dos quarteirões altos (possivelmente recomendadas nas diretrizes de Miguel de Arruda), eles tenham recebido de Luiz Dias a forma alongada.

$\mathrm{Na}$ citada descrição de Gabriel Soares sobre a Rua da Ajuda e seu largo triangular (... e no topo dela está uma formosa igreja de Nossa Senhora da Ajuda...), ele se refere ao "topo dela" porque, como indicam as curvas de nível, a Rua da Ajuda vinha em subida a partir da porta ao sul, tornando a descer depois do largo central. Mas esse destaque era apenas em relação à rua, já na parte um pouco mais baixa da cidade. É diferente da recomendação dos tratados renascentistas para a construção de igrejas, e de como elas aparecem nas áreas mais importantes de influência religiosa, descritas por Gabriel Soares. ${ }^{386}$

A localização da igreja da Ajuda se torna interessante quando se considera a hipótese de muros de Teodoro Sampaio, porque estaria bem próxima ao centro da fortaleza. A mudança da Sé pode indicar tanto que a cidade foi repensada ao longo de sua construção (Nóbrega teria influenciado nesse sentido ao escolher uma área ao norte para a sua igreja e colégio, que seriam pólos de atração para o crescimento), ou como havendo mesmo o plano de expansão para os primeiros anos: antes (pelo tempo em que foi necessário um perímetro fortificado menor, como acreditamos), ela estava casualmente bem no centro da primeira fortificação; na etapa seguinte, prevista para estar do lado da Praça Principal, passaria a ser o centro da cidade em relação ao novo perímetro (também como previsto).

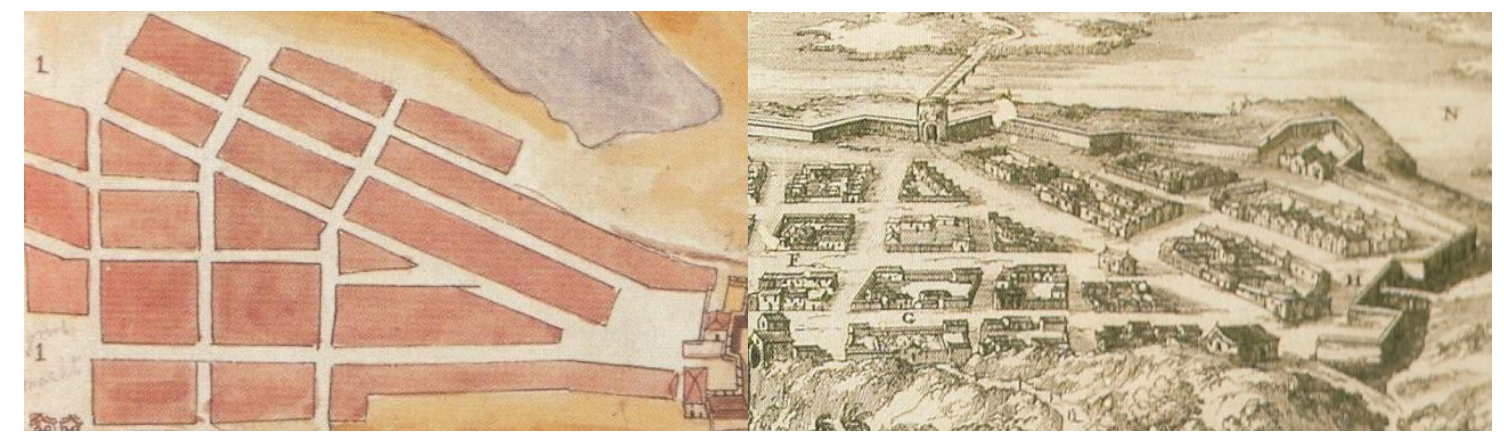

Pela hipótese de Teodoro Sampaio, o largo da Ajuda seria relativamente central em relação à primeira linha de fortificação. À esq., detalhe da malha inicial no Desenho das forteficaçoes... do museu de Haia (em REIS Fo, 2000: 32-4), registro em que a área da Ajuda aparece como uma quadra ocupada. À dir., detalhe da estampa do livro de Montanus (em REIS Fo, 2000: 28) em que é representando o largo, tendo apenas a igrejinha ao centro.

Sobre o largo formado próximo à Porta de Santa Luzia (ao sul), queremos apenas destacar a informação passada por Edison Carneiro (repetida por Eduardo Bueno) de que era provavelmente a parte mais movimentada (e por isso mais bem defendida) da cidade, havendo lá uma feira semanal de pequenas mercadorias (o local

\footnotetext{
${ }^{386}$ Do projeto renascentista para fundação de Salvador, resultou curiosamente, junto a questões de adequação ao terreno e alterações no traçado das quadras, essa disposição da primeira igreja da Sé, estranha às formas de implantação do Renascimento: ela se situa em um pequeno largo, eleito talvez pela posição relativamente central e claramente pelo seu destaque na topografia, o que seria um critério aparentemente pré-renascentista (da igreja articulada ao pequeno largo, que marca toda a tradição medieval). Por isso chamamos atenção para o seu caráter provisório (ou transitório), em paralelo ao de uma primeira linha de fortificação.
} 
foi possivelmente escolhido por corresponder ao acesso mais fácil ao porto e, algum tempo depois, em função do caminho por terra até Vila Velha). ${ }^{387}$

\section{Algumas considerações}

Enfatizamos sobre essa fase o aspecto de uma cidade coesa, pensada em sua integridade. Em nossa interpretação, foram fixadas desde o início as perspectivas de uma primeira expansão em direção ao norte, para que atingisse uma dimensão previamente estabelecida, correspondente ao seu status de cidade.

Se nesse primeiro momento foram fortificados os pontos mais críticos (em especial o gargalo que serviu de proteção à área institucional), conjecturamos que já se planejasse reconstruir toda a muralha dali a vinte anos (a que aparece na cartografia). Além de reerguida de forma mais sólida, ela abraçaria toda a área prevista da ocupação (os dois platôs que aparecem cercados nas primeiras imagens), configurando assim uma cidade renascentista de traçado regular.

Esse primeiro tempo de história ainda não permite observar grandes diferenças entre a cidade pensada e a que foi realizada. Nas cartas que passamos em revista, praticamente não há ênfase na particularidade do bairro, na periferia, então restrita à Cidade Baixa. Também ainda não se pode falar de uma cidade expandida a partir da fortificação. Destaca-se nessa fase, portanto, uma urbe já nascida com percepção de unidade e visão de conjunto, sendo pensada desde o começo com a idéia de um todo.

Imaginamos que o projeto de Miguel de Arruda trouxesse mesmo uma praça central conforme as prescrições dos tratados renascentistas italianos, ${ }^{388}$ já deslocada para um dos lados, para estar sobre o despenhadeiro, proporcionando a vista (por questões de segurança) de quase toda a baía. Nesse sentido, o local escolhido para a construção por Tomé de Souza e Luiz Dias não mudou sensivelmente sua proposta original. Mas devido às características do terreno, não foi possível fazer uma praça quadrangular extensa (geradora de uma malha regular com quarteirões de dimensões iguais nos quatro lados) nesse centro lateral da fortaleza (o terreno era especialmente acidentado naquela parte). Ele propiciava, por outro lado, o fechamento inicial de uma área menor, para início da construção.

A Praça Principal teria sido assim colocada na parte mais alta do terreno escolhido, ficando provisoriamente junto a um dos acessos (não dos muros estabelecidos em projeto, mas de uma cerca inicial), o que aparentemente desfigurava o projeto. ${ }^{389}$ Acreditamos que em sua locação já estivesse prevista toda uma primeira

\footnotetext{
${ }^{387}$ Cf. CARNEIRO, 1980: 91 e BUENO, 2006-2: 104 e 117-8. No outro extremo, a Porta de Santa Catarina (de localização original que passaremos a discutir), na hipótese de que já existisse bem distante da Praça (como defende Rafael Moreira), eles entendem que seria de uso quase exclusivo dos jesuítas, em suas visitas diárias à aldeia de índios no Carmo.

${ }^{388}$ Por outras cidades-fortalezas da época (na África, Índia e, pouco depois, o Rio de Janeiro, de maior regularidade), evidencia-se a intenção dos portugueses de construir uma cidade regular, como acabou sendo a área triangular próxima à Praça Central e toda a área ao redor do Terreiro de Jesus (de condições topográficas mais favoráveis a isso), construída a seguir.

${ }^{389}$ A teorização de uma Praça Principal junto à Porta não figura no tratado de Antônio Rodrigues, que em questões de urbanismo segue principalmente Vitrúvio. Para a "Praça Central" de Mazagão, que não está exatamente junto à entrada principal (de acesso ao continente), mas intermediada apenas por outra praça (em seqüência, como eram em Salvador a Praça da Sé e o Largo da Misericórdia em relação à Praça Municipal), não houve uma teorização própria feita em Portugal, mas a interpretação do conhecimento renascentista expresso nos tratados italianos (intermediada pela atuação dos
} 
fase de crescimento em direção ao norte, estabelecendo-se de partida (como defendem Edison Carneiro e Rafael Moreira) o limite da área a ser murada, toda ela de traçado geométrico, a ser ocupada ao longo das décadas seguintes. Pensava-se, portanto, em uma futura simetria a partir da Praça Municipal. Dois ou três anos depois houve o já previsto deslocamento da Sé, pelo qual também se ampliava a cerca do primeiro perímetro fortificado (nos anos 90 , com o novo amuralhamento, a Sé passaria a configurar um centro lateral de todo o perímetro, como aparece no desenho de 1605).

A área dos jesuítas, escolhida por Nóbrega mais ao norte da Praça da Sé (de deslocamento já previsto enquanto se negociava o terreno a ser ocupado pela ordem religiosa) seria o primeiro pólo de atração do crescimento, com sua enorme praça retangular que teria balizado a malha subseqüente. As demais áreas religiosas (São Francisco, Carmo e São Bento) seriam os pólos de atração ao crescimento em épocas seguintes, estando fora (à exceção da área franciscana) do perímetro murado que demarcava a área de traçado geométrico. ${ }^{390}$

\subsection{Três interpretações para o primeiro traçado}

As documentações deixadas pelos primeiros colonizadores e agentes da conquista (reis, cartógrafos, funcionários de registro) são insuficientes para se estabelecer a forma e as dimensões da cidade nos primeiros anos de sua fundação. 0 que existem são conjecturas, possibilidades mais ou menos seguras, com base na interpretação dos textos do século XVI e da cartografia e outras imagens do XVII. Há principalmente duas hipóteses para o primeiro perímetro, demarcado e amuralhado (ao menos nos trechos mais importantes) por Luiz Dias. Ambas se baseiam na carta mais antiga, a Pranta... de 1605: uma, que chamaremos de perímetro mínimo, restringindo-o à área da cidadela projetada na planta; outra, que chamaremos de perímetro máximo, estendido a toda a área murada representada no mesmo desenho, que a nosso ver corresponde (ou é próxima) à área murada apenas nos anos 1590.

Curiosamente, os teóricos portugueses mais importantes praticamente repetem as suposições de brasileiros que se debruçaram sobre o assunto: Manuel Teixeira segue a hipótese de Teodoro Sampaio; ${ }^{391}$ Rafael Moreira, a de Edison Carneiro. Existem também as hipóteses de um perímetro intermediário, como a de

engenheiros aqui citados). Uma teorização mais específica aparecerá no Tratado de Serrão Pimentel (1680), mas referente à fortificação regular de uma cidade idealizada, como não pôde ser o caso de Salvador. Nas condições ideais de superfície plana e regularidade da malha, o tratado prescreve que a Praça Principal ficaria no centro (em Pimentel também há praças diante de baluartes, como ocorre em Salvador, havendo inclusive a recomendação de medida - 150 a 200 palmos de lado): Primeiramente no centro da Fortaleza, ou povoaçã̃ se deve deixar hû terreiro, ou praça grande que deve ser a principal das armas;... A ditta Praça de armas no centro da Fortaleza deve ser com os lados parallelos às Cortinas da Fortificaçaõ regular;... (PIMENTEL, 1993: 319 - Parte I, Secção II, Cap. XI).

390 Só nos perímetros que aparecem em desenhos do século XVIII (que já não seriam pensados apenas como muros - ilustrando o conceito em que há a passagem da cidade fortificada para aquela dotada de um sistema de fortes, ou defesas abertas) é que elas foram envolvidas. Com esse futuro perímetro, a cidade perderia algumas de suas características renascentistas, pois apenas à área central corresponderia o traçado geométrico regular.

391 Também defendida em SILVA, Alberto. A cidade de Tomé de Sousa: aspectos quinhentistas. Rio de Janeiro: Pongetti, 1949, p. 167-77 (cf. OLIVEIRA, 2004: 178-9). 
Teixeira Barros, explicada e defendida por Mário Oliveira, ${ }^{392}$ e a de Coelho Filho, que faremos questão de criticar. E queremos deixar clara a grande diferença que há entre a suposição de Teodoro Sampaio, que entende esse perímetro mínimo como o projeto de fato para a cidade, e a nossa, em que haveria uma primeira área construída como parte de um projeto maior.

\section{Perímetro mínimo}

Teodoro Sampaio e Manuel Teixeira representam os muros de Luiz Dias repetindo, praticamente, o desenho da cidadela projetada que aparece na Pranta... de 1605.

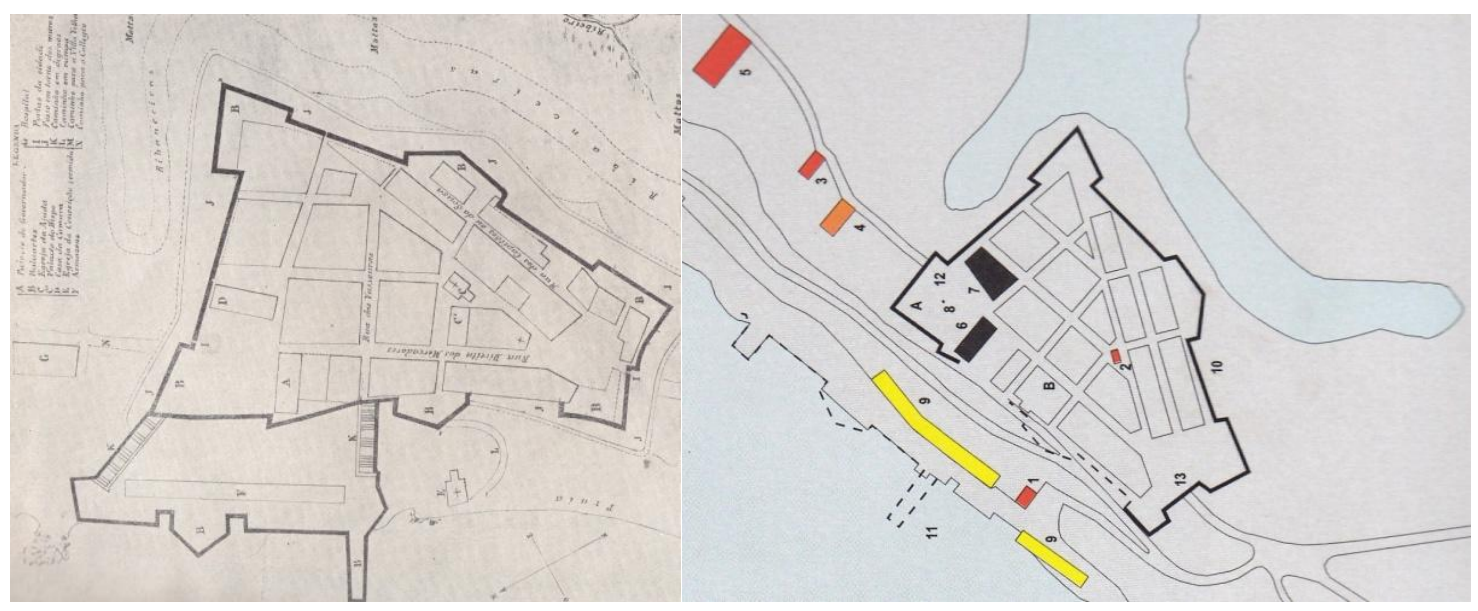

O desenho de Teodoro Sampaio (1949: 184-5) para a fortaleza original foi praticamente reproduzido em Manuel Teixeira (1999: 234). Discordamos dessa segunda representação nos seguintes pontos: 1- No lugar do Rio das Tripas aparece uma imensa área alagada, o que só aconteceu na ocupação holandesa (1624-5); 2- A grande variedade de caminhos e a existência de construções ao norte não foram, provavelmente, contemporâneas aos muros de Luiz Dias.

Não há dúvida de que a Pranta... de 1605 mostra uma cidadela em projeto, pois está nas palavras de Diogo Moreno:

Na dita carta vê-se a cidadela que Sua Majestade manda se fabrique para por aquela parte se assegurar o todo, tanto da povoação como do Recôncavo, que a qualquer rebate vivem em tormento e descomposição, havendo com suas armas a à sua custa de acudir a cidade; mas remedeia-se esta falta com a dita cidadela, que se assinala com o fosso vermelho, mostrando sua largura e os baluartes e cortinas por onde se ordenam;... ${ }^{393}$

Portanto, a primeira grande crítica que se faz ao modelo apresentado por Teodoro Sampaio (seguido por Manuel Teixeira) é ter reproduzido, como se fossem muralhas reais, o desenho do que seria um projeto de cidadela (Pranta... de 1605). Diogo Campos Moreno foi claro em relação a isso, havendo também, na legenda direita (das duas versões da Pranta...) uma letra E que menciona a cidadela.

\footnotetext{
392 O artigo original infelizmente não foi localizado: BARROS, José Teixeira. Muros da Cidade do Salvador. Revista do Instituto Geográfico e Histórico da Bahia 36. Salvador: IGHBA, 1910, p. 73-7 (cf. OLIVEIRA, 2004: 179).

393 MORENO, 1955: 141. Sobre a planta, diz ao descrever a cidade (p. 140-1): ... o seu assento ou planta mostra-se à fol. ...[em branco], é cópia do original que à Sua Majestade se apresentou no ano de 605, para dar-se execução à fortificação da cidade...
} 

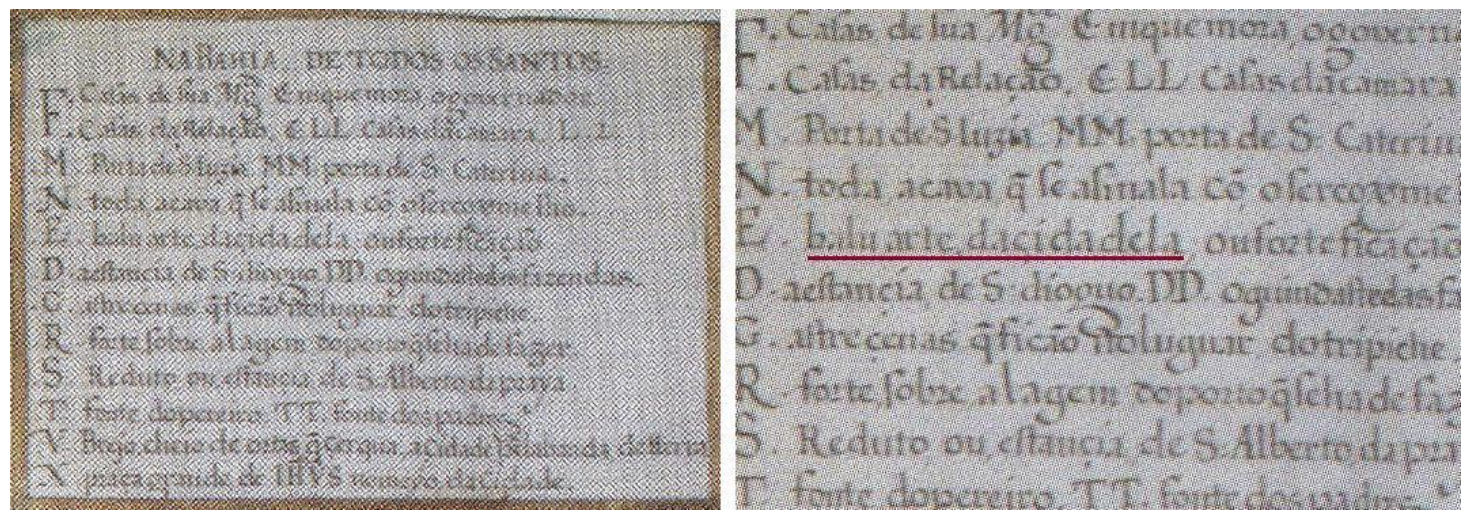

Legenda do canto superior direito da Pranta... de 1605, na versão da BMP (em REIS Fo, 2000: 17).

A mesma idéia de T. Sampaio e M. Teixeira é que aparece em Eduardo Bueno, tratando de mostrar uma vista em perspectiva, sendo sua interpretação ainda literalmente copiada na ilustração de Vallandro Keating:

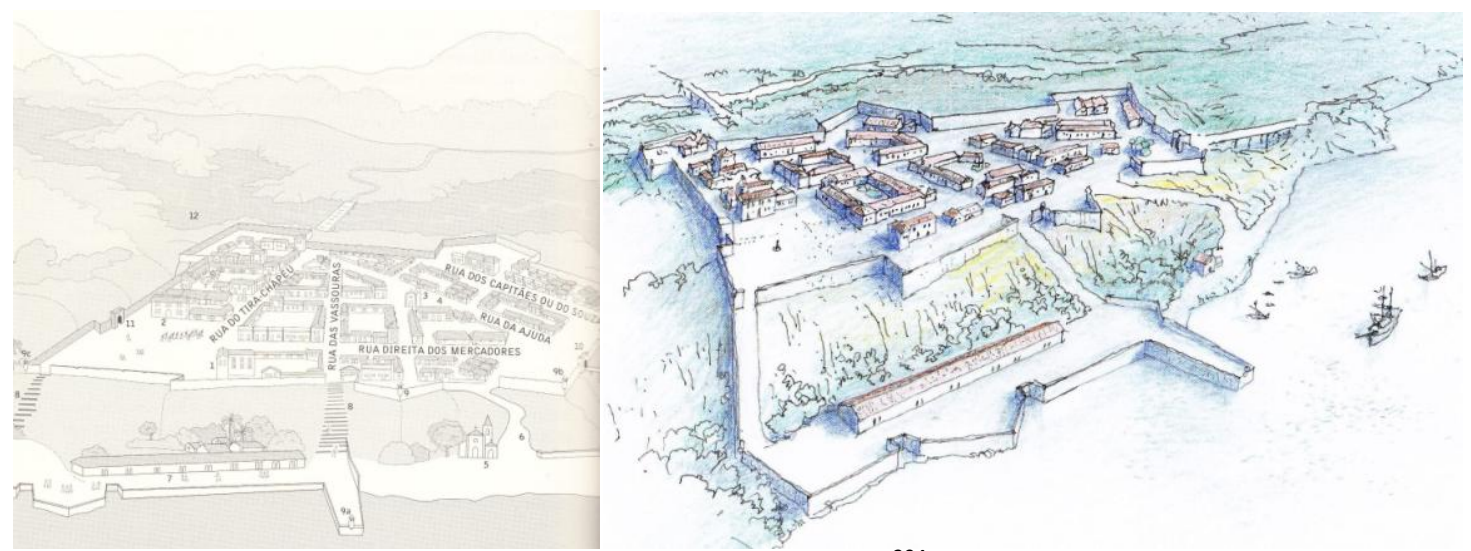

À esq., hipótese de Teodoro Sampaio em BUENO, 2006-2: $68 .{ }^{394}$ À dir., perspectiva da mesma hipótese em KEATING \& MARANHÃO, 2008: 80. Apesar da edição luxuosa e invejável projeto gráfico deste segundo caso, as informações da publicação estão desatualizadas. Por exemplo, a legenda do desenho diz que a construção foi feita "sob os planos e a execução do arquiteto da Casa Real Luiz Dias" (o mesmo que diz Eduardo Bueno), dando ainda a entender que ele representa a cidade "no final do século XVI". ${ }^{395}$

Sobre a hipótese de Teodoro Sampaio, ${ }^{396}$ M. Oliveira, professor da UFBA e maior conhecedor na atualidade das fortificações construídas na Bahia, reconhece que além de haver lógica do ponto de vista tático (um perímetro menor é mais facilmente defensável), existia uma "quebrada" no início da atual Rua da Misericórdia, favorável à localização da Porta de S. Catarina ao norte da atual Praça Tomé de Souza (ou

\footnotetext{
${ }^{394}$ Na questão dos jesuítas, a interpretação de Eduardo Bueno (que habilmente mistura as informações de Edison Carneiro e Teodoro Sampaio sem que se notem facilmente as contradições, localizando a Porta de Santa Catarina, por exemplo, ora colada à praça, ora no Largo do Pelourinho) também é de que eles receberam do governador uma área a norte da nova cidade, onde os padres, liderados por Nóbrega, construíram, nos primeiros anos da década de 1550, uma primeira capelinha de taipa e o primeiro edifício do colégio (cf. BUENO, 2006-2: 101-9).

${ }^{395}$ Em outro exemplo, o livro diz que antes da chegada dos portugueses os grupos tupis, para ocupar o litoral, "deslocaram antigos ocupantes para o interior, como aconteceu com os tapuias" (p. 76). Tapuia era o nome tupi dado a todos os outros grupos étnicos (goitacás, aimorés, tremembés, cariris, puris), ou seja, abrangia todos que estavam sendo deslocados (cf. MOREAU, 2003: 77-80).

396 "Ardorosamente defendida pelo professor Alberto Silva" (A cidade de Tomé de Sousa..., p. 167-77), segundo Oliveira (2004: 178-9).
} 
Municipal, a antiga Praça do Palácio). Mas ressalta que seria estranho do ponto de vista urbanístico pela "excentricidade da praça do poder administrativo", ou Praça Principal, o que toca a questão mais importante e complexa referente a esta primeira fase da cidade: havendo mesmo "traças" e "amostras" de um projeto urbanístico para a fundação de Salvador, não estaria prescrita a centralidade, na medida do possível, dessa "praça do poder administrativo"? Como a hipótese aqui defendida se aproxima da de Teodoro Sampaio (ao dizer que a cidade começou com um período mínimo), trataremos especificamente dessa questão mais adiante.

\section{Perímetro máximo}

Os que defendem o perímetro máximo se queixam que a hipótese de Teodoro Sampaio, de tantas vezes repetida, adquiriu o status de uma história oficial (vide as ilustrações dos livros de Eduardo Bueno e Keating \& Maranhão). A idéia de que já em sua fundação a cidade teria as dimensões em que aparece na totalidade da Planta de 1605 parte, provavelmente, da coerência de um projeto renascentista, o que a nosso ver só se confirmou nos anos 1580 , quando já havia as quadras de uma malha mais regular, e nos anos 1590, quando há informações de que foi novamente murada. No final do século XVI, ela ocupava os dois padrastos, havendo uma distribuição uniforme e três grandes "praças" (com a "praça" da Sé ao centro) e também um afunilamento semelhante correspondendo às entradas norte e sul, por delimitações oblíquas da muralha nessas extremidades.

O primeiro a defender essa hipótese, Edison Carneiro, levanta ainda a possibilidade de que a Porta de Santa Catarina, referida por Luiz Dias, fosse na verdade a de Santa Luzia. Sugere que os muros "em vez de rodear 'toda a coroa da colina', como parecia a Vilhena, desciam a ribanceira em direção ao porto e à aguada dos navios". ${ }^{397}$ Como para ele a estância sobre o mar, que se agora chama de São Jorge, seria o baluarte da Ribeira, ${ }^{398}$ a muralha desceria à praia talvez próxima à Ladeira da Conceição (envolvendo até mesmo a ermida, como escreveu Manuel Teixeira, talvez por engano, já que o seu desenho não mostra isso).

Muito semelhante à proposição de Edison Carneiro é a de Rafael Moreira, em palestra de 1999: ${ }^{399}$

A cidade de Tomé de Sousa corria, portanto, exatamente entre a Praça Castro Alves e o sobrado da Fundação Jorge Amado, onde se erguiam os complexos defensivos das portas, com corpo da guarda para guarnição e portas que fechavam realmente durante a noite. Essa extensão de 1,6 km de fachada sobre o mar é atestada pelos dois belíssimos desenhos do Arquivo Real de Haia revelados por Sousa Leão - um perfil e planta - datados de 1609-1612 e 1638, respectivamente, da autoria do engenheiro Cristóvão Álvares. ${ }^{400}$

\footnotetext{
${ }^{397}$ CARNEIRO, 1980: 61.

398 "O mais importante desses baluartes era a estância de sobre o mar, depois chamada de São Jorge, plantada em cima dum rochedo, na Ribeira, do lado sul" (CARNEIRO, 1980: 63).

${ }^{399}$ 40 Congresso de História da Bahia (27/09 a 01/10 de 1999). Reproduzido em MOREIRA, 2001: 123-45 e MOREIRA, 2003: 35-59.

${ }^{400}$ MOREIRA, 2003: 43.
} 


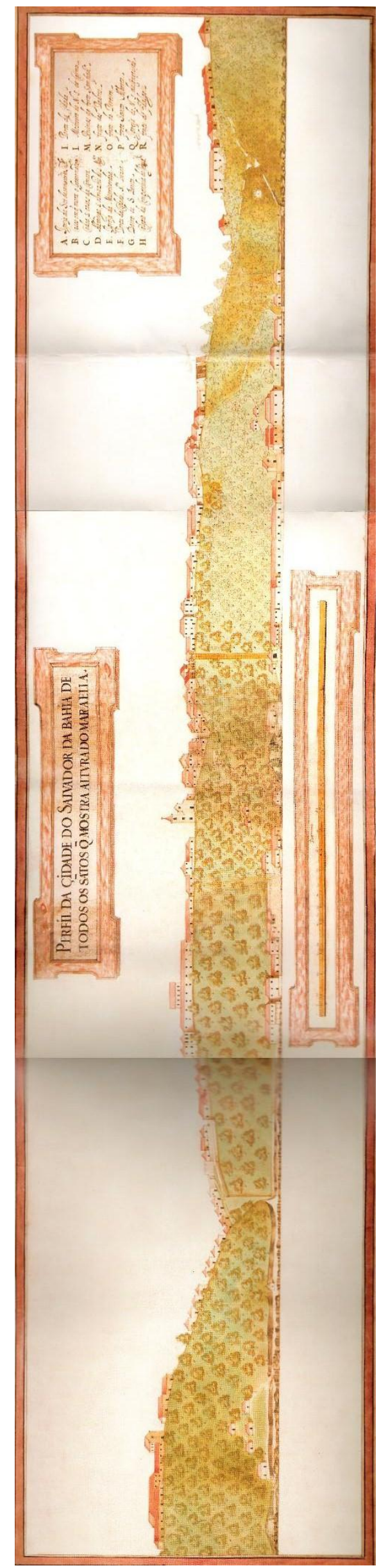

O original do Perfil da Çidade do Salvador da Bahia de Todos os Sãtos q mostra altvra do mar a elle, encontrado em Haia por Joaquim de Sousa-Leão, não tem indicação de autoria ou data. É bem provável que seja do engenheiro militar Cristóvão Álvares, que já estaria no Brasil em 1603 (Sousa-Leão considerou a qualidade do papel e as cartelas com molduras retangulares de mesmo acabamento semelhantes às do desenho feito para um forte de Recife em 1629).

Nestor Goulart argumenta para a data do desenho (certamente anterior a 1616, possivelmente de 1611) que as construções da Cidade Baixa terminam ao norte na mesma linha do primeiro pavilhão transversal da igreja dos Jesuítas, enquanto todos os desenhos de 1624-5 mostram construções além desse ponto.

Outra observação é sobre haver apenas um guindaste, como aparece na Pranta... de 1605 e na descrição de Pyrard (1611), ao contrário do registros posteriores, em que aparecem dois desenhos (a partir de 1624) ou são descritos (já em 1618, com Ruiters) no plural.

Já o muro que sai da Porta de Santa Catarina ainda não aparecia na Pranta... de 1605.

Na datação deste perfil Nestor Goulart também leva em conta a representação da igreja da Sé, de nave central alteada, duas naves laterais baixas, frontão simples e uma só torre, um aspecto anterior ao da reforma feita no governo de Gaspar de Souza (1612-6).

Cf. LEÃO, 1957 e REIS Fo, 2000: 20-2 e 310-11. 


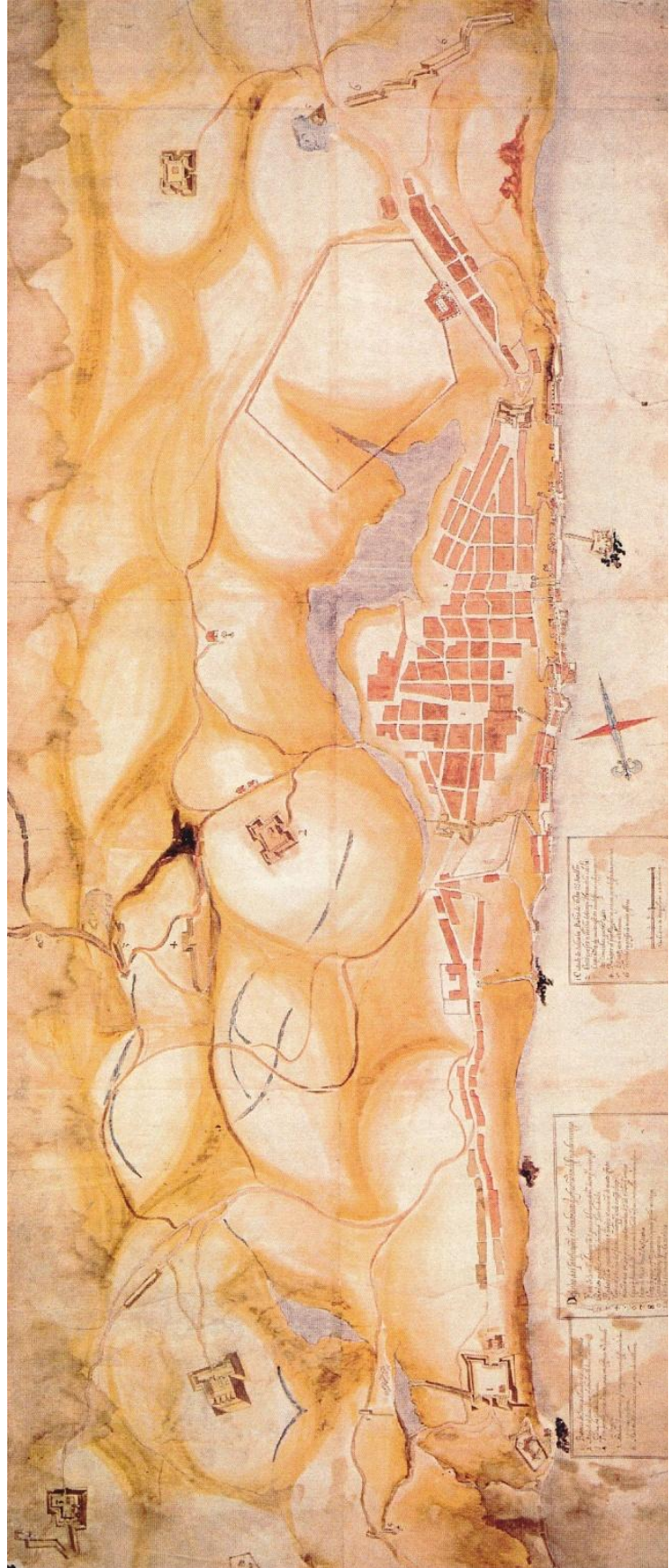

O Desenho das forteficaçoes e trincheiras q se fizeraõ em deffença do inimigo, original manuscrito do Algemeen Rijksarchief (Haia), mostra as obras de defesa feitas até 1638 , à espera do ataque holandês.

São várias folhas aquareladas, mostrando as quadras da cidade e dando destaque às áreas de interesse militar. As portas, muros e fortalezas aparecem na chamada "perspectiva militar", estando também em perspectiva os guindastes, os edifícios da Cidade Baixa e o mosteiro de São Bento (diferentemente do de S. A. do Carmo).

Segundo Sousa-Leão, haveria ainda uma folha à esquerda mostrando uma bateria holandesa, a casa do Conde de Nassau e um arraial onde a tropa se alojou.

Os detalhes que aparecem na igreja de S. Bento (fachada simples, porta central e óculo no frontão) e na da Conceição da Praia são iguais aos do perfil atribuído a Cristóvão Álvares (1611).

Nestor Goulart chama atenção para o excelente nível técnico deste desenho, que mostra o alto padrão dos registros de engenheiros militares portugueses mesmo antes do grande direcionamento feito depois da Restauração (1640).

Cf. LEÃO, 1957 e REIS Fo, 2000: 32-4 e 314. 
A afirmativa de Rafael Moreira se baseia, portanto, em desenhos que retratam a cidade em 1611 (segundo Nestor Goulart) e 1638. Não há dúvida de que nessas épocas a cidade apresentasse as dimensões em que foram retratadas: em 1611 ela já tinha a igreja nova da Sé, o colégio jesuíta e a porta do Carmo, entre outras construções; em 1638 já tinha inclusive o Dique dos Holandeses, que tornou desnecessária a muralha que cercava a cidade pelo interior.

Entre os que defendem que desde o início o perímetro de Salvador era a totalidade do que aparece na Pranta... de 1605, levanta-se a possibilidade de que os muros seriam construídos apenas nas extremidades norte e sul. A interpretação de que eles cercassem apenas esses acessos, contanto as demais direções com defesas naturais, parece-nos estranha: se não houvessem tais muros (os de trás), por que seriam tantas vezes desenhados (mesmo que para ilustrar textos estrangeiros)? Se foram construídos para deter incursões indígenas (como informam Gabriel Soares e outros), seriam esses acidentes naturais (declive e brejo) capazes de detê-los? Entende-se que em momento futuro, na criação do Dique dos Holandeses (1624-5), foi sim possível (e as gravuras assim o mostram) dispensar tais muralhas, que quando a cidade voltou a ser portuguesa (1640), passaram a ser novamente desenhadas.

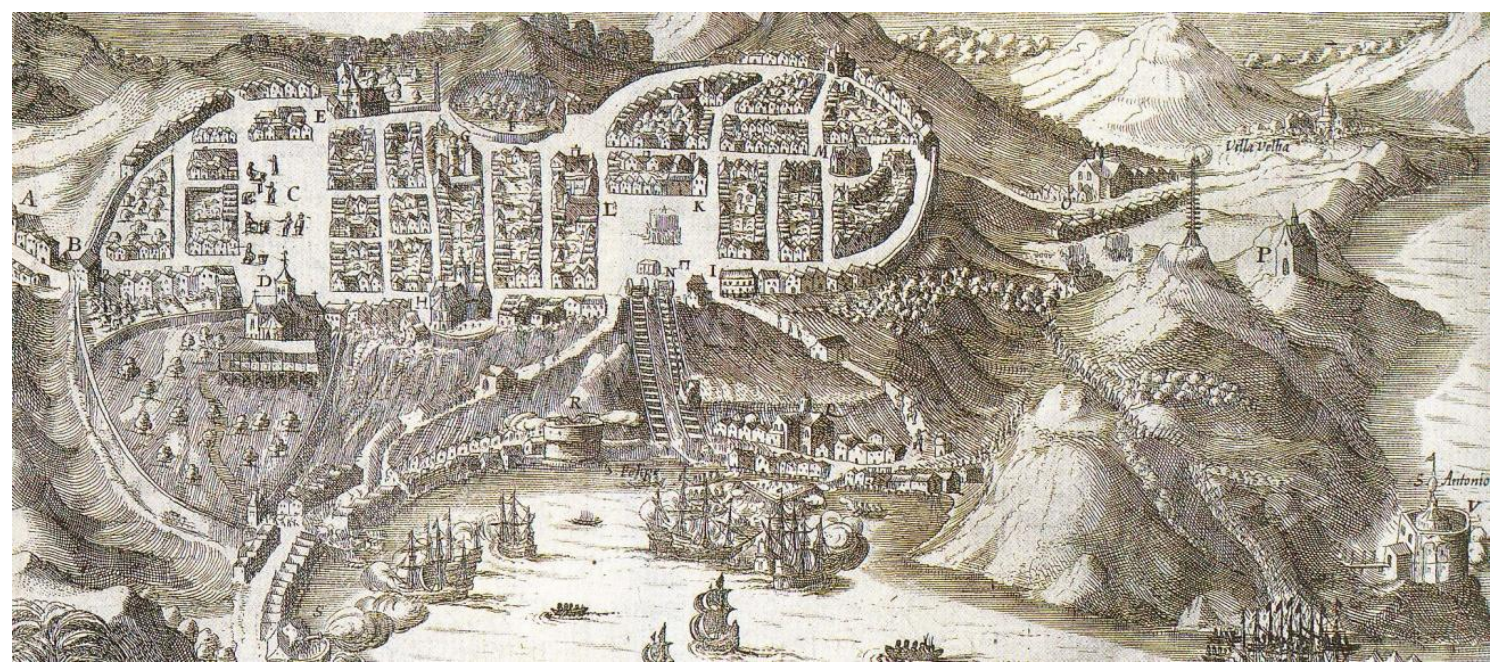

A cidade cercada por muros em representação (não confiável) do Reys-boeck (c. 1624 - S. SALVADOR/ Baya de todos los Santos, em REIS Fo, 2000: 19).

Sobre essa possibilidade, há argumentos de que na parte de trás da cidade haveria um declive quase tão íngreme quanto na da frente, não sendo necessária, portanto, da muralha. Contra essa hipótese, observa-se no perfil da figura de Frézier que a área correspondente ao futuro Dique dos Holandeses quase não apresenta depressão, comparada à área do Adiq Grande quando, de fato, a muralha perderia sua importância.

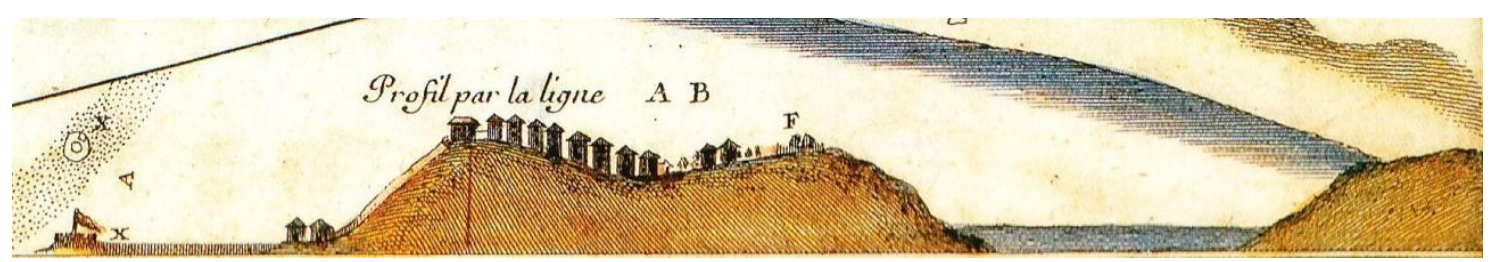

No perfil que aparece na ilustração do livro de Frézier (em REIS Fo, 2000: 30 - parte inferior da gravura original), nota-se que a baixada correspondente ao antigo dique dos holandeses é branda (uma pequena depressão); apenas a encosta do Adiq Grande (na grafia de João Coutinho) dispensaria a muralha. 


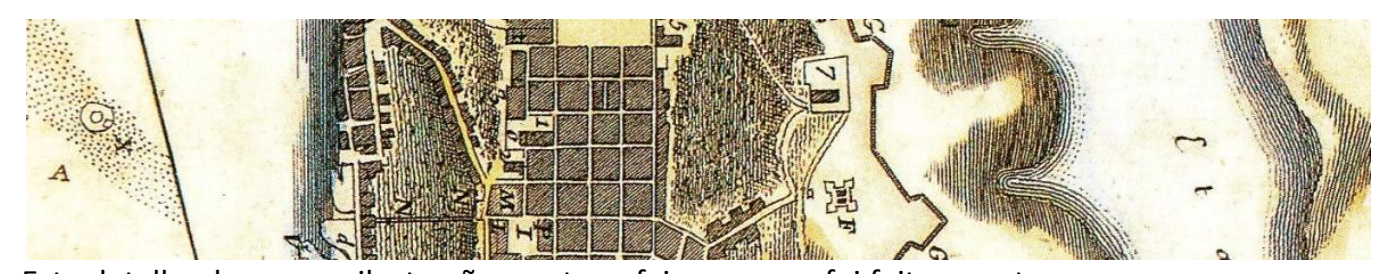

Este detalhe da mesma ilustração mostra a faixa em que foi feito o corte.
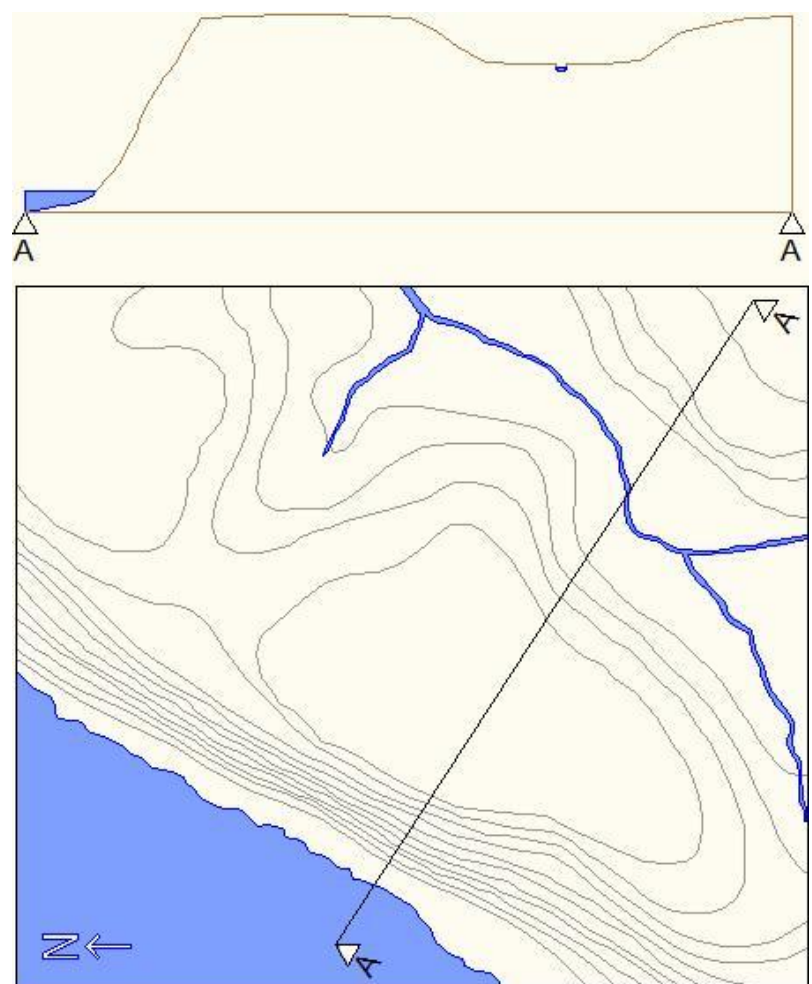

No corte feito a partir da representação topográfica mostrada em Teodoro Sampaio, notamos uma situação parecida, com a declividade até mais acentuada na direção do mar (o que em nossa observação in loco pareceu corresponder à realidade). Já na parte de dentro o desnível também é brando, insuficiente para se abrir mão do fechamento.

Queremos registrar que há uma diferença importante entre as interpretações de Rafael Moreira e de Edison Carneiro, pois para o primeiro, o baluarte de S. Jorge estaria assentado no "subsolo" da Misericórdia, como também entendemos.

\section{Perímetro intermediário}

$\mathrm{Na}$ polêmica sobre o primeiro perímetro e conseqüentes interpretações diferentes para o traçado das muralhas e a localização da Porta de Santa Catarina, além da comentada "excentricidade" da Praça Principal junto à Porta, Mário Oliveira, provavelmente entendendo que o governador não permitiu que os jesuítas se instalassem no terreno pleiteado (que seria fora da cerca), vê como mais lógica a hipótese de Teixeira Barros, em que os muros passariam logo depois do Colégio, estendendo-se posteriormente ao Largo do Pelourinho. ${ }^{401}$

Entendemos de outro modo: que o terreno pleiteado era justamente o que pertence até hoje à Catedral Basílica e aonde foi construído o Colégio, depois

${ }^{401}$ Cf. OLIVEIRA, 2004: 179/ BARROS, José Teixeira. Muros da Cidade do Salvador, op. cit., p. 73-7. 
Faculdade de Medicina. Na verdade, a questão levantada por Mário Mendonça é a mesma de Edison Carneiro, quando diz:

... se o governador não queria dar a Nóbrega o teso que escolhera, por ficar fora da Cidade, por que lhe daria chãos no Terreiro, se essa zona também ficava - de acordo com Teodoro Sampaio e os seus seguidores - extramuros? Se o Terreiro e o Carmo ficavam foram da cerca, por que negaria o governador permissão para levantar o Colégio no Carmo - e deixaria fazê-lo no Terreiro? ${ }^{402}$

Carneiro entende que a pretensão de Nóbrega era de construir no Carmo, e que o local onde foi finalmente construído o Colégio era o inicialmente permitido por Tomé de Souza, já que a cerca passaria no atual bairro do Pelourinho. Nota-se que em sua "lógica elementar" ele desconsidera o passar do tempo. Se num primeiro momento o governador não queria construções desprotegidas de uma cerca inicial (que durou dois ou três anos), passou a permiti-las com a segurança conquistada nos primeiros tempos de implantação. Mais: se a idéia de não permitir construções religiosas fora das áreas muradas fosse fixa, não se construiriam lá, em futuro próximo, ${ }^{403}$ os conventos do Carmo e de São Bento, eqüidistantes da Sé que se tornou permanente. ${ }^{404}$

Sobre esse ponto, analisamos pelas palavras de Nóbrega que o terreno escolhido (atual) poderia estar realmente fora do perímetro fortificado, o que de alguma maneira acabou sendo autorizado por Tomé de Souza. É difícil imaginar uma porta desvinculada da muralha, o que ocorreria caso ela fosse desde o começo no Carmo ou próxima ao Colégio, como é sugerido. E se a muralha passasse mais longe, não haveria o dilema sobre a localização do Colégio (que já estaria dentro do perímetro fortificado), a não ser que a área reivindicada fosse bem distante da cidade (onde depois se instalaram os carmelitas), o que nos parece estranho para este primeiro momento. Daí a nossa idéia de que havia simultaneamente o muro (em projeto, ou parcialmente construído) e a cerca a que Nóbrega e Tomé de Souza se referiam.

Também de um perímetro intermediário é a recente proposta de um advogado baiano, Luiz W. Coelho Fo, sobre a qual em um primeiro momento não íamos nos deter muito. ${ }^{405}$ Mas pela relação com aspectos teóricos importantes do pensamento português, presentes, de qualquer forma, no planejamento e empreendimento inicial de Salvador, devemos ao menos anotar algumas de suas referências. No livro $A$ Fortaleza do Salvador na Baía de Todos os Santos (2004), ele propõe na concepção da cidade uma aplicação radical do ideal renascentista: o desenho da cerca erguida por Luiz Dias imitaria as proporções do corpo humano de acordo com as prescrições de Francesco di Giorgio.

Como se verá em seu desenho, a área desse perímetro seria de aproximadamente duas vezes aquela proposta por Teodoro Sampaio. Adiantamos, sobre o tamanho da cidade, nosso entendimento de que ela possa (deva) ter sido pensada na dimensão maior. Mas o que Coelho Filho apresenta é como se fosse a construção de Luiz Dias, o que dificilmente corresponderia à realidade.

\footnotetext{
${ }^{402}$ CARNEIRO, 1980: 128-9.

403 Já de pé nos anos 1580, época de G. Soares de Sousa.

${ }^{404} \mathrm{E}$ a igreja de N. S. da Conceição, na Cidade Baixa.

${ }^{405}$ Entendíamos que se tratava de um livre pensar.
} 
Por seguir um ideal renascentista, é possível ver na configuração inicial da cidade relação com as proporções do corpo humano? Para ele sim, "os modelos teóricos elaborados por Martini suscitam inevitáveis comparações como a planta da Fortaleza do Salvador". ${ }^{406}$

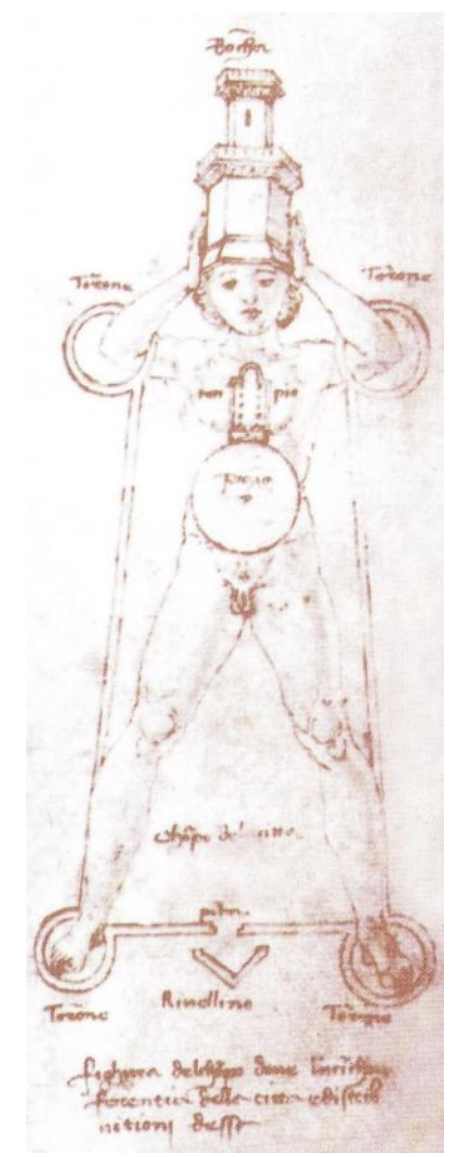

Como no desenho de Francesco di Giorgio, a cidade teria "a praça principal na mediana do corpo; a catedral no peito; nos limites dos pés e nas mãos, os baluartes. No geral, as proporções da Fortaleza do Salvador imitam às do corpo humano. É tanta beleza que encanta a imaginação" ${ }^{407}$

Duas idéias de Martini estariam presentes na Fortaleza do Salvador: 1- a localização de edifícios correspondendo à de órgãos no corpo humano, sendo o templo o coração, pouco acima da metade do corpo/ cidade; 2- a proporção desses edifícios em relação ao tamanho da cidade (correspondendo à das partes do corpo). ${ }^{408}$

Seus argumentos podem ser numerados: 1- a praça principal (redonda, quadrada ou poligonal) estaria colocada no centro, como "umbigo do corpo humano"; ${ }^{409} 2$ - se o terreno impedisse, o arquiteto faria ajustes; ${ }^{410} 3$ - nos desenhos de

\footnotetext{
${ }^{406}$ COELHO Fo, 2004: 318-9.

407 COELHO Fo, 2004: 326 - grifo nosso. A frase grifada mostra que há certo auto-deslumbramento em sua proposta, podendo-se ainda criticar o autor pelo uso (até inconsciente) de uma linguagem persuasiva (talvez recorrente na prática dos advogados, quando convencer chega a ser mais importante do que esclarecer).

${ }^{408}$ Cf. COELHO Fo, 2004: 320-1. Em seu estudo, consultou MARTINI, 1967.

409 Em Martini (II, 363), a associação com o umbigo serve para lembrar o nascimento, mas é também pela eqüidistância entre centro e periferia.

${ }^{410}$ Esta é talvez nossa tese mais cara, de que havia um juízo dado ao arquiteto/ engenheiro para que ele tomasse as decisões adequadas.
} 
Martini, a praça acompanha o formato da cidade; ${ }^{411}$ 4- Martini não fala de proporção, mas nos desenhos a praça ocupa cerca de $1 / 5$ da medida maior da cidade; ${ }^{412} 5$ - a Casa dos oficiais, a prisão e principalmente a Casa do Senhor (no caso de Salvador, a do governador) deveriam estar na praça ou o mais próximo possível dela; ${ }^{413} 6$ - a Catedral seria vizinha à Praça, no lado oposto à casa do Senhor (como é em Salvador); ${ }^{414} 7$ - as vias seriam retas e opostas, cortadas ao meio pela praça; ${ }^{415} 8$ - as igrejas paroquiais poderiam estar nas extremidades (como pés e mãos, assim como os baluartes).

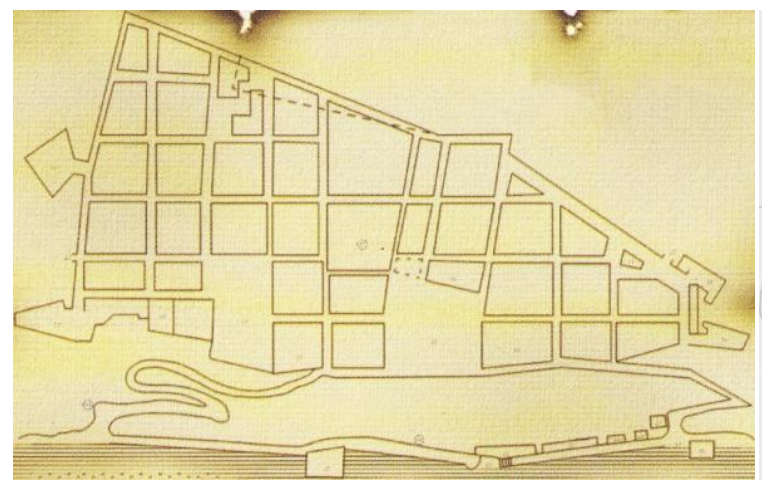

O desenho à esquerda (p. 150-1) resume a proposta do autor, mostrando as proporções que serão mencionadas a seguir (no livro ele está ampliado e apresenta toda a margem queimada, brincando com a possibilidade de ser antigo e inédito). Já o da direita (p. 52-3), ilustrando a escolha pela topografia original, apresenta dois platôs independentes, o que justifica, ao contrário, que se fortificasse apenas um deles na fase inicial.

Coelho Filho justifica o perímetro proposto com o argumento de que o norte da praça municipal ficaria no centro do lado da Fortaleza voltado para o mar. Luiz Dias não teria feito coincidir o centro da praça com o da fortaleza porque sobraria terreno na banda da Misericórdia - o quarteirão anterior à ladeira seria de apenas $13 \mathrm{~m}$ de comprido e a depressão abrupta não permitia novo quarteirão. O Mestre teria dividido o comprimento da fortaleza em dez e definido o centro; ao norte, traçou quarteirões de 24 braças (com pequenas variações em função da topografia) e ao sul, por causa do relevo, teria dividido em cinco partes desiguais.

Toda essa hipótese causa de cara uma estranheza: a depressão da Misericórdia (que não aparece na planta da cidade) se configuraria como o centro da área urbana ou fortaleza, entre as duas praças principais. Mas o autor afirma com todas as letras que a medida principal da Fortaleza (o comprimento acompanhando a linha da praia) era de $528 \mathrm{~m}$ (240 braças), ${ }^{416}$ indo "do limite norte da atual Praça da Sé até o alto da Praça Castro Alves". Ao mesmo tempo, mistura critérios subjetivos: "O limite norte poderia ter sido expandido na direção do Pelourinho, mas alguma razão limitou o espaço até aquele ponto". ${ }^{417}$

\footnotetext{
${ }^{411} \mathrm{O}$ que foi o mais determinante no perímetro sugerido por Coelho Filho, como veremos a seguir.

412 Também será discutido.

${ }^{413}$ Esta sim é uma característica renascentista importante, mas que se restringe à configuração da Praça, não do perímetro.

${ }^{414}$ No desenho de Francesco di Giorgio, fica na altura do peito, pouco acima da Praça.

${ }^{415}$ Suas partes pareceriam membros bem proporcionados,... segundo nós vemos no corpo humano onde de um membro ao outro há igual correspondência (MARTINI, 1967: I, 21).

${ }^{416}$ Por essa medida total se definiriam (proporcionalmente) as outras (a quadra padrão nessa área de Salvador é de 24 braças $=52,8 \mathrm{~m}$ ).

${ }^{417}$ COELHO Fo, 2004: 321 - grifo nosso.
} 
Em resumo, acredita que se estipulou o norte da Praça como centro e dividiu cada lado em cinco partes de um décimo. Só que do lado sul aumentou a quadra da praça para 1/6 (por causa do grotão) e a sobra fez juntar no quarteirão do palácio, voltando os dois últimos do sul a ter $1 / 10$ (enquanto entendemos como mais provável que as malhas sejam desiguais por outras questões topográficas, e que houve menos precisão na fase construtiva inicial).

Também em relação ao limite Norte, entende que o Terreiro de Jesus foi formado porque "a técnica militar proibia edificações na área externa das fortalezas": a face norte do muro "senhoreava o platô que suavemente despenca para o Pelourinho". ${ }^{418}$ Ele afirma (não apenas propõe) que "os jesuítas desejavam aquele teso e um dia o conquistaram". Com Mem de Sá teria sido demolido o que restava do muro e traçadas as quadras em direção ao Pelourinho. O Terreiro e o Adro franciscano teriam sido ("foram") "concebidos como espaços de ligação entre as duas etapas distintas" da cidade. ${ }^{419}$

Entre as suposições que não raramente apresenta em caráter afirmativo, está a de que o vértice formado no terreiro, vindo do adro, "é remanescente do traçado original", a "linha do muro", já que "Luiz Dias escolheu três pontos extremos no terreno favoráveis à defesa e depois cruzou duas retas", e na convergência "construiu um baluarte". ${ }^{420}$ Lembrando que para Martini "a imaginação do autor é que deveria orientar a visão do corpo humano repousando sobre o sítio", diz que "essa liberdade de criação foi desenvolvida com criatividade na Baía de Todos os Santos". ${ }^{421}$

Entre as imprecisões (ou incongruências) de sua proposta, estão: 1- não considerou que a Sé inicialmente era na Praça da Ajuda (foi transferida); 2-considerou a área de charco como quadra, o que só aparece em gravuras do século XVIII; 3- não haveria de início os quarteirões compridos a leste (mas por que eles seriam depois traçados, fora da muralha?); 4- não considerou a população inicial, que era bem menor (com uma baixa densidade para o perímetro proposto), nem calculou o número de casas; 5 - pelas próprias prescrições de Martini, a cidade seria menor.

Em relação ao terceiro item, percebe-se que ele aboliu, simplesmente, 0 conjunto de quadras oblíquas voltadas para o interior, aquelas de proporção 4 x 1, em que, entendemos, Tomé de Souza teria permitido inicialmente que Nóbrega construísse o Colégio. Seguindo o seu raciocínio, entende-se bem a razão: além de um muro contínuo na face leste (interior), com uma quadra no eixo da Praça fazendo as

\footnotetext{
${ }^{418}$ COELHO Fo, 2004: 173.

${ }^{419}$ Não se deveria aqui criticar o autor pela forma com que apresenta suas idéias, mas chama a atenção, junto ao auto-enaltecimento pelas suas descobertas, a técnica de apresentar versões como se fossem fatos: "A porta norte denominava-se Santa Catarina e estava localizada exatamente na passagem da atual Praça da Sé para o Terreiro de Jesus" (COELHO Fo, 2004: 233 - grifo nosso, em mais uma afirmação feita com todas as letras, ao invés de dizer que "poderia estar localizada..."). Em geral, são formulações que partem de uma certeza pouco fundamentada (usando a técnica de argumentar como se fosse uma hipótese já comprovada).

${ }^{420}$ Na mesma passagem, curiosamente, ele anuncia (prescritivamente) sua estratégia de comprovação: “A demonstração da tese deve ser feita inicialmente a partir da correspondência do Padre Manuel da Nóbrega e de alguns títulos de domínio de terrenos que pertenceram à Companhia de Jesus. Essa prova é complementada e confirmada pela análise dos padrões de simetria e proporção que orientaram a construção da Fortaleza. Por fim, o exame geométrico do traçado e as diferenças existentes no tamanho dos quarteirões e ruas de um lado e do outro do Terreiro de Jesus" (p. 174). Antes mesmo de adentrar pela demonstração (que não segue à risca), já arremata: "O conjunto de provas é harmônico" (idem).

${ }^{421}$ COELHO Fo, 2004: 321 - grifos nossos.
} 
vezes de um baluarte intermediário, dessa maneira o perímetro todo teria uma forma próxima à da Praça Principal, umas das idéias insistentemente defendida por ele (que estaria em Francesco di Giorgio). Mas fica a questão: como e por que essas quadras teriam sido depois construídas, pelo lado externo da muralha?

Aparentemente foi pelo mesmo motivo de se assemelhar ao formato da Praça Principal que foi incluída a fileira de quarteirões que faz divisa com o Terreiro de Jesus e o Adro franciscano (curiosamente com um "baluarte" mal desenhado ao centro, que justificaria o campo aberto do Terreiro). Ao considerar que os desenhos de Martini apresentam praças com cerca de $1 / 5$ do comprimento maior da cidade, se fosse para levar em conta a teoria, ele deveria colocar uma fileira de quarteirão a menos, tornando o perímetro de Salvador menor.

Embora esteja correto ao dizer que a topografia era determinante e cuidadosamente estudada pelos militares, considerou prioritário na escolha de sítio não haver padrastos próximos à fortaleza, o que além de não proceder totalmente (havia os da Sáude, Desterro, Piedade, S. Bento), foi um critério de certa forma descuidado pelos portugueses, pois como se verá, muitos fortes foram construídos próximos a eles.

\subsection{O traçado em nossa interpretação}

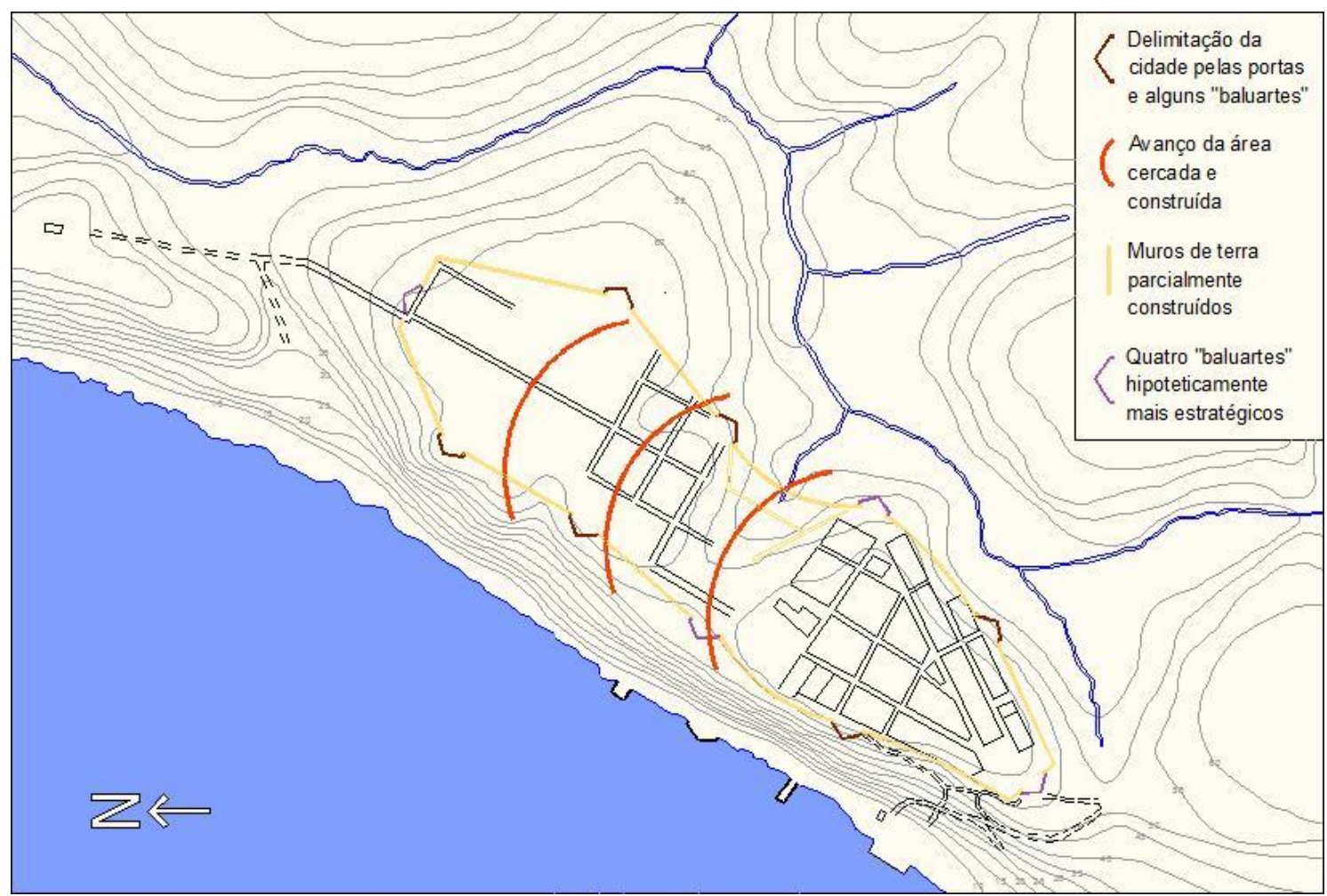

A primeira área cercada seria menor do que a que estava previamente estabelecida como dentro dos limites da cidade. A delimitação da área maior seria feita pela construção de alguns novos baluartes (o formato, a escala e mesmo as localizações aqui desenhadas são arbitrárias - não há documentação suficiente para se afirmar qualquer coisa com segurança).

A interpretação aqui apresentada considera em muitos aspectos a proposta de Teodoro Sampaio: na face norte do primeiro polígono defensivo, a primeira cerca passaria próxima ao limite norte da Praça do Palácio, na área do atual prédio da 
Prefeitura (próxima à parte baixa do terreno entre os dois platôs). Ela seria concomitante à construção dos muros programados para fechar os dois platôs (de traçado e dimensão próximos aos que aparecem na Planta). Essa primeira cerca teria um perímetro bastante irregular e não se pode falar propriamente em baluartes nas suas angulações. Entende-se, ao contrário da idéia de Edison Carneiro (de que a Porta chamada por Luiz Dias de Santa Catarina era na verdade a de Santa Luzia), que poderia mesmo existir uma porta provisória, dando acesso direto à Praça Principal enquanto essa área de construção inicial da cidade era fechada (o que se assemelha ao que foi desenhado por Teodoro Sampaio).

Há muitos indícios de que inicialmente foi cercada uma área menor, como o depoimento sobre o Colégio Jesuíta estar inicialmente fora da cerca (que procuramos insistentemente analisar) e o de Gabriel Soares que, como outros, narra a construção da cidade num alto, sem falar na ocupação de dois platôs. Mas a maior evidência de que havia uma entrada próxima à Praça Principal são os caminhos, não só representados em todas as gravuras, como descritos por Gabriel Soares:

... fica esta praça em quadro..., ... com grande vista para o mar; ... , donde a terra vai muito a pique sobre o mar;... ao longo do qual é tudo rochedo mui áspero; e desta mesma banda da praça, dos cantos dela, descem dois caminhos em voltas para a praia, um da banda do norte, que é serventia da fonte que se diz Pereira, e do desembarcadouro da gente dos navios; o caminho que está da parte do sul é serventia para Nossa Senhora da Conceição, aonde está o desembarcadouro geral das mercadorias, ao qual desembarcadouro vai ter outro caminho de carro, por onde se estas mercadorias e outras coisas que aqui se desembarcam levam em carros para a cidade. ${ }^{422}$

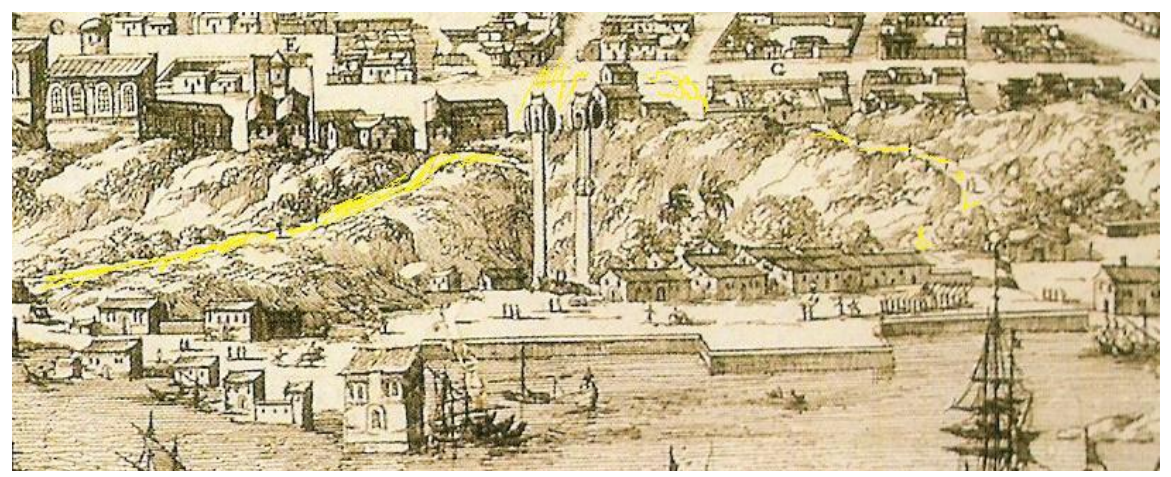

$\mathrm{Na}$ interessante perspectiva da gravura que ilustra o livro de Montanus (que combina pelo menos dois ângulos de visão - em REIS Fo, 2000: 28), vê-se bem os dois caminhos que saíam da Praça Principal.

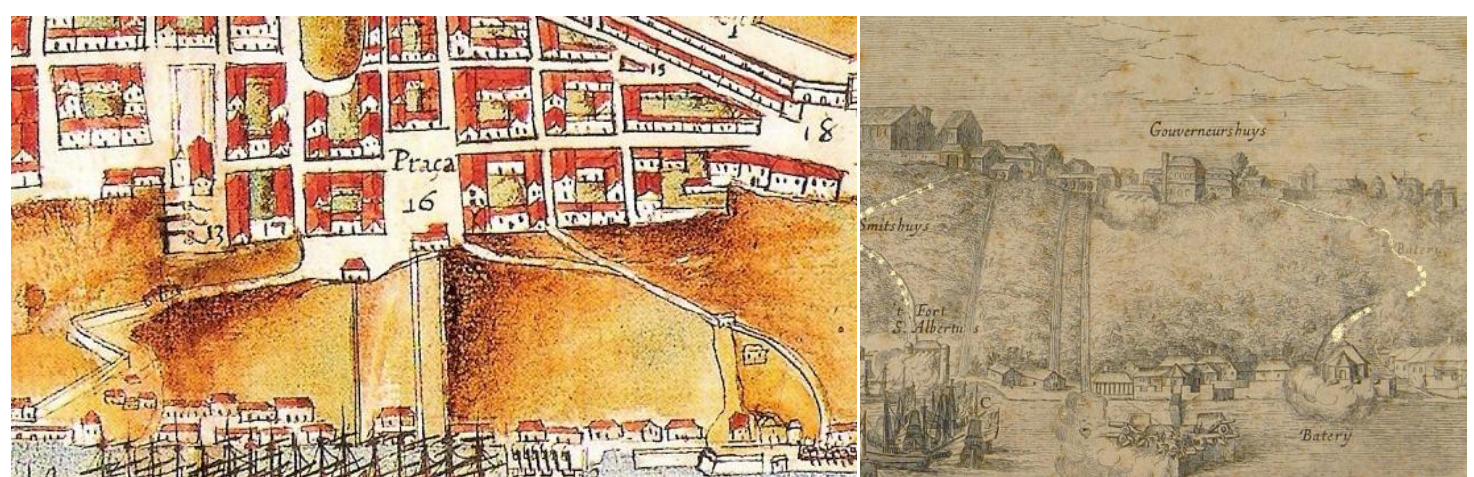

Em todas as cartas e gravuras, como a Planta da Restituição... (em Atlas..., 1997) e a Sanct Salvador, de Gerritsz (Seção de Iconografia da BN), eles estão nítidos e são praticamente coincidentes.

${ }^{422}$ SOUSA, 1971: 134 
O fato de haver dois caminhos saindo da Praça, representados em várias imagens, sugere que haveria lá uma porta de acesso à cidade. Era provavelmente uma das entradas principais nos primeiros tempos (mesmo sem existir uma porta edificada, que constasse em projeto), que se manteve como acesso em épocas posteriores pelo seu uso continuado.

Também não descartamos a hipótese de que o percurso do monta-cargas, escolhido primeiramente em função do porto, tenha influenciado na escolha de localização da Praça. Entendemos como seqüência de decisões que foram tomadas (o que não podemos afirmar, como também não aceitamos como fato consumado que se tenha cercado a cidade de início em seus perímetros máximo ou intermediário) para a implantação de Salvador: 1- escolha do porto combinada ao platô mais alto, onde seria a Praça Principal, ligando-se os dois por um monta-cargas (o que constaria nas diretrizes de Miguel de Arruda); ${ }^{423}$ 2- delimitação de uma área inicial a ser fortificada; 3- reprodução em solo de um traçado urbano regular nessa área inicial (o que não ocorreu na área voltada para interior pela inadequação do terreno), estabelecendo-se a localização dos edifícios institucionais junto à Praça e prevendo-se o crescimento inicial em direção ao norte (até que se justificasse o fechamento do segundo platô, passando a Praça Principal a ser relativamente central em relação às portas). Como passo seguinte já se reproduziria em solo o traçado regular em direção ao norte.

Passando finalmente a argumentar sobre a possibilidade real de que a cidade tivesse um perímetro mínimo em seu início, lembramos que pela cultura renascentista (resgatando conhecimentos dos antigos), ela deveria ser feita "de fora para dentro" (os tratados prescrevem para a fundação de novas cidades que seja feita primeiro a muralha e depois se trace a cidade - o que no caso de Salvador é confirmado por Gabriel Soares), com a praça próxima ao centro. Para o traçado inicial aqui proposto, portanto, a questão mais delicada (ou mesmo uma contradição) estaria na Praça junto a um dos extremos da primeira parte construída.

Em primeiro lugar, na tão estranhada existência de uma Porta colada à Praça Principal, da mesma maneira que a topografia propiciava a escolha desta área para a

\footnotetext{
${ }^{423}$ Ao menos pelo que descreve Gabriel Soares, a escolha de sítio não teria se dado em função das traças (que neste caso tiveram, elas sim, de se adaptar ao local): mais do que isso, ela teria se dado antes mesmo de um conhecimento prévio do terreno, já que foi determinada não só pela encosta alta uma constante em quase toda a enseada -, mas, a partir da praia, pela proximidade do melhor ponto a se construir o porto. Gabriel Soares diz que depois de atracar e se estabelecer com a tropa em Vila Velha, Tomé de Souza... mandou descobrir a baía, e que Ihe buscassem mais para dentro alguma abrigada melhor que a em que estava a armada...; e por se achar logo o porto e ancoradouro, que agora está defronte da cidade, mandou passar a frota para lá, por ser muito limpo e abrigado; e como teve a armada segura, mandou descobrir a terra bem, e achou que defronte do mesmo porto era melhor sítio que por ali havia para edificar a cidade (SOUSA, 1971: 129).

Portanto, enquanto estava instalado em Vila Velha, Tomé de Sousa "mandou descobrir a baía" para encontrar lugar seguro, o que compreenderia os dois fatores, porto e fortaleza. Mas a descrição (feita depois, não se podendo garantir que esteja correta) aponta que a decisão se deu a partir do local apropriado ao porto. Também houve outros fatores: segundo Gabriel Soares, havia três fontes de água doce nas imediações da cidade, que certamente influenciaram na escolha da instalação de um cais e terminais marítimos mais importantes. O principal seria em frente à ermida de N. S. da Conceição: Tem esta cidade grandes desembarcadouros, com três fontes na praia ao pé dela, nas quais os mareantes fazem sua aguada, bem à borda do mar, das quais se serve também muita parte da cidade, por serem estas fontes de muito boa água. No principal desembarcadouro está uma fraca ermida de Nossa Senhora da Conceição, que foi a primeira casa de oração e obra em que se Tomé de Sousa ocupou (SOUSA, 1971: 138 - cap. XII).
} 
feição de uma cidadela no início do século XVII, propiciaria o primeiro fechamento em 1549. A idéia de amuralhar tal recinto, favorecida pela topografia, não pode ser descartada, uma vez que foi retomada 50 anos depois: da mesma maneira que haveria uma Porta colada à Praça da cidade em sua implantação, haveria a Porta da Cidadela junto à Praça, mesmo que essa proposta não fosse usual na tratadística italiana. A cidadela em projeto mostra sim esta possibilidade, pois seria da mesma maneira estranha em teoria, mas está desenhada e, portanto, confirmada como idéia.

O projeto de cidadela atesta que aquele núcleo era a parte mais apropriada ao fechamento inicial, como também mostra o perfil de 1611. Na imagem se nota bem a "grota" existente entre a "Praça" da Sé (de igreja voltada para a baía, como aparece à esquerda na figura) e a Praça Municipal (com o monta-carga ao centro e o Palácio do Governador à direita).

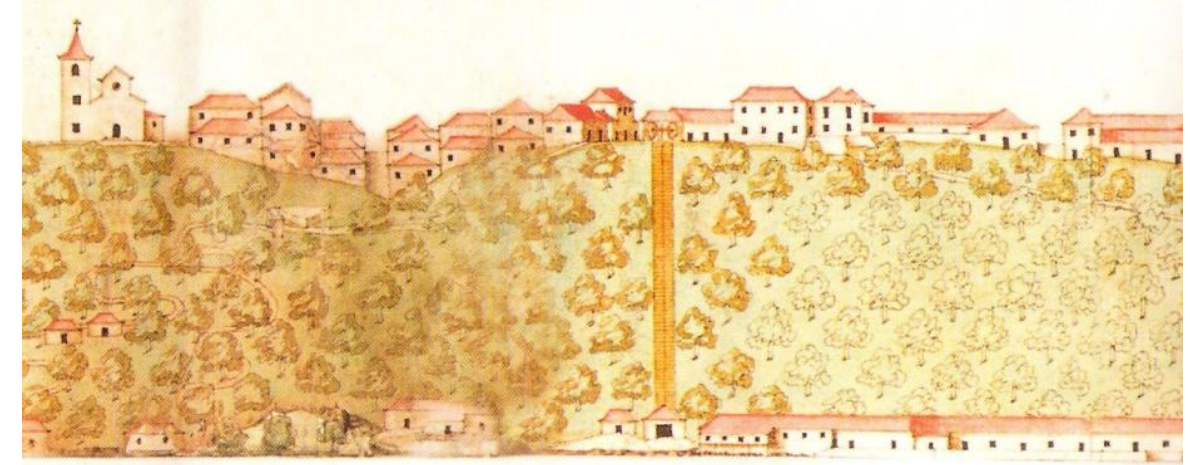

A “grota” no perfil anônimo (provavelmente de Cristóvão Álvares) de c. 1611 (em REIS Fo, 2000: 20-2).

Diferentemente da interpretação de que haveria muros apenas nas extremidades, entendemos como esta a análise a ser feita a partir do perfil de 1611 (de data próxima à da Pranta... de 1605, mostrando a cidade em seus 50 anos de existência): em um primeiro momento, aproveitou-se o grotão para fechar a cidade, mas prevendo-se, certamente, o crescimento naquela direção. Mas há outra questão que chegou a nos pareceu passar despercebida por Rafael Moreira. Na tão propalada filiação entre os projetos de Mazagão (de Ravenna, Arruda e eventualmente tendo base nos desenhos de Francisco de Holanda) e de Salvador (Miguel de Arruda), observa-se no primeiro a existência da Praça Principal bem próxima à Porta de entrada.
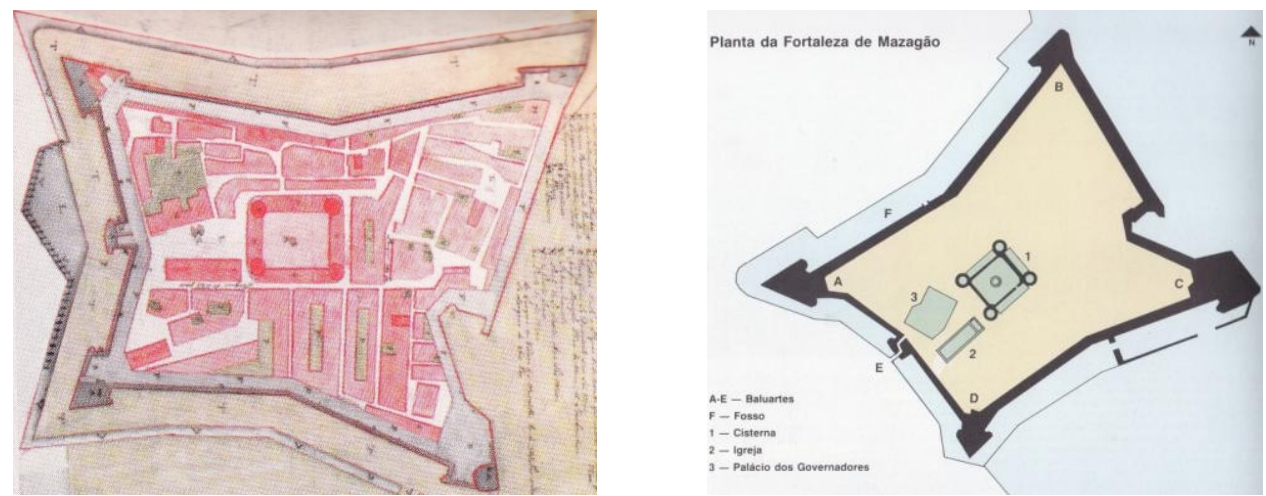

A Vila de Mazagão, atual Cité Portuguaise, em Marrocos, principal exemplo de aplicação dos conceitos de "cidade ideal" renascentista, caracteriza-se por um grande eixo ligando o Porto à entrada principal em Terra. Entre a Porta e a Cidade há uma enorme praça com a igreja e o Palácio dos Governadores (à esq. em COELHO Fo, 2004: 375, à dir. em MOREIRA, 1989: 150). 
O perímetro menor da fase inicial da construção de Salvador justifica inclusive a localização da Praça Principal. Se a área cercada na fundação compreendesse toda a área representada na Pranta... de 1605, é mais provável que fosse escolhido como local institucional o centro, isto é, a atual Praça da Sé. Também: se fosse já tudo planejado para ser construído de início como está na Planta, por que fariam o Terreiro de Jesus maior do que a Praça Principal (tornando-se mais requisitado para festas, como atesta Gabriel Soares)? Já havendo a preocupação de cercar inicialmente uma área menor, em um dos lados, o local da Praça (que não poderia deixar de existir desde os primeiros tempos, pois estariam à volta dela os principais edifícios) seria o mais próximo possível desse futuro centro.

As cartas de Luís Dias são de 1551. Acreditamos que até 1553 (quando voltou a Portugal, junto com Tomé de Souza) possa ter ao menos traçado boa parte das áreas restantes, pela semelhança, ou excelente padronização (para a época) das quadras. Também acreditamos, como propôs E. Carneiro, que o limite inicial dessa área de ampliação passasse por detrás da quadra em que está hoje a igreja de S. Domingos, já que os franciscanos puderam adquirir sua área no final dos anos 1580.

Haveria ainda um enigma, já mencionado, para o qual a hipótese de Coelho Filho pode nos ser útil. Por que o Terreiro de Jesus seria superior em área à Praça Principal (levando para lá festividades importantes)? Coelho filho sugere que o local era reservado ao uso militar, uma vez que representaria um começo de área não murada. ${ }^{424}$ É provável, independente dos muros, que sua ocupação tenha sido tardia em relação àquelas mais ao sul, ocasionando a oportunidade de se mantê-la aberta.

Em nossa interpretação, houve muita negociação em relação a isso. Não só o acréscimo de áreas jesuíticas conseguido por compras e doações, mas uma decisão político-urbanística de deixar um corredor aberto entre as principais áreas religiosas. $^{425}$ O Terreiro corresponde exatamente ao espaço de duas quadras. Talvez uma delas, mais próxima à igreja, fosse pensada já de início como área aberta (adro), sendo a outra mantida livre para valorizar o acesso à área franciscana, ou mesmo já se pensasse nas duas igrejas que ocupariam a sua volta.

Tudo indica que havia um só plano, ou ao menos uma só diretriz, que se não foi concluída nos primeiros quatro anos, foi seguida coerentemente pelos sucessores de Luiz Dias (sendo o primeiro deles, talvez, seu sobrinho). ${ }^{426}$

\footnotetext{
${ }^{424}$ Entre seus argumentos de que os primeiros muros passariam no lado sul do Terreiro estão: 1- a interpretação de Serafim Leite para a área do Colégio; 2- Salvador estaria assim entre os tamanhos de Mazagão (1541) e Damão (1572); 3- nesse ponto, principalmente, a cidade atingiria o tamanho recomendado por Francesco di Giorgio.

${ }^{425} \mathrm{O}$ que é diferente da interpretação de Coelho Filho, para quem essa já seria estrategicamente uma área aberta, beirando os muros, para que se construísse o quarto baluarte da fortaleza. Ele discorda da interpretação de que a finalidade fosse "assegurar maior visibilidade à Igreja de São Francisco", uma vez que ela "não existia com as atuais características" (COELHO Fo, 2004: 181).

426 O sucessor de Luiz Dias na implantação de Salvador pode ter sido seu sobrinho, o pedreiro Diogo Peres, segundo Provisão Real de 14/01/1549 [?] assinada em Alverim (BN - Documentos históricos, 1937, v. 35, p. 22. Provimentos seculares e eclesiásticos [1549-59] - OLIVEIRA, 2004: 92). Mas isso parece não ter ocorrido, porque na Provisão de 12/03/1553, Lopo Machado foi designado para o cargo de Mestre-de-Obras da Cidade, com salário de $72 \$ 000$ réis por ano, a partir de quando chegasse a Salvador (BN - Documentos históricos, 1937, v. 35, p. 183. Provimentos seculares e eclesiásticos 1549-59 - OLIVEIRA, 2004: 92). Em 1557, o cargo foi ocupado pelo veterano Pedro de Carvalhaes, mestre de construção e fabricante de cal, destacado no ofício durante a fundação da Cidade.
} 


\section{Novos argumentos}

A poucos meses da entrega final deste estudo, fomos prestigiados com e-mails do professor de História da Arte da Universidade Nova de Lisboa, Dr. Rafael Moreira, principal pesquisador da Arquitetura Militar portuguesa espalhada pelo mundo. Já em suas primeiras palavras (ao todo nos enviou sete e-mails), argumentou contundentemente sobre a impossibilidade de que a primeira fortificação de Salvador tivesse um perímetro menor do que o que aparece na Planta de 1605. A "estória" do perímetro inicial menor seria uma invenção de Teodoro Sampaio, fruto de sua má interpretação da planta.

Nos e-mails Rafael se mostrou cauteloso em assumir como sua a tese da construção de Salvador já no tamanho em que aparece na planta de 1605, preferindo dizer que de tão evidente ela estava no ar. "Não falo na minha 'tese', porque não acho que o seja: é a evidência mesma, que ninguém viu porque todos têm estado cegos pelas ideias do 'núcleo primitivo' de Teodoro Sampaio...". Notamos que sua análise, apesar de baseada principalmente na interpretação de uma planta de Arquitetura Militar, pouco se difere da de Edison Carneiro, defendida em 1950. ${ }^{427}$ Ambos alegam principalmente que a suposição de que Salvador tivesse inicialmente um perímetro menor teve origem no erro de Teodoro Sampaio. Edison Carneiro foi o primeiro a escrever isso: "Teodoro Sampaio tomou por feito, e existente já em 1549, o que estava por fazer ainda em 1612". ${ }^{428}$ Ou: "Os historiadores que vieram depois se desorientaram - e o resultado foi que o mapa de 1612 passou a ser o mapa da Cidade do Salvador em 1549". "Vale a pena examinar melhor a questão do espaço ocupado pela Cidade em 1549 - não somente à luz dos argumentos de Teodoro Sampaio, mas utilizando todas as fontes históricas disponíveis". ${ }^{429}$

Rafael se referiu a duas concordâncias de peso à sua tese de um perímetro inicial máximo, vinda de excelentes estudiosos. A primeira delas, de Manuel Teixeira, que teria atentado melhor à estrutura dos quarteirões de Salvador e verificado serem da mesma época: "não há 2 fases, mas só uma, a inicial". ${ }^{430}$ A segunda, igualmente importante, veio do prof. Dr. Nestor Goulart ("figura... intocável", palavras dele e que também faço minhas). Segundo Rafael, Nestor "contou os habitantes da capital nos anos '50 e constatou que eles não cabiam de jeito nenhum no espaço da suposta "1a cidade". ${ }^{431}$

Em nossa conversa introdutória com o professor da FAU, ele confirmou sua posterior (ao livro Evolução Urbana...) concordância com Rafael, vinda do cálculo da população inicial (que não caberia em um perímetro reduzido). Chegou a mencionar uma estimativa de duas mil pessoas, somando-se as que vieram com Tomé de Souza às

\footnotetext{
${ }^{427}$ A monografia A Cidade do Salvador - 1949 teve uma primeira edição mimeografada, de pouco mais de cem exemplares, em 1950 e foi publicado em 1954 pelas Org. Simões - RJ.

${ }^{428}$ CARNEIRO, 1980: 137.

${ }^{429}$ Idem, p. 135.

${ }^{430}$ E-mail de Rafael. Ficamos felizes pela concordância de Manuel Teixeira ter vindo dessa observação, que também fizemos: a estrutura de quarteirões em toda a malha que aparece na Planta de 1605 é a mesma, e se não foi feita exatamente na mesma época, teve uma só diretriz.

${ }^{431}$ E-mail de Rafael. Segundo ele, “... Salvador TEM de ser vista, com seus quase mil povoadores em 1549 - que nunca caberiam no exíguo espaço da Cidadela projetada em 1605 por Turriano e 'retrospetivada' tontamente pelo pobre (mas honesto) Teodoro Sampaio para meio século atrás - como o Prof. Nestor provou".
} 
da chegada de alguns navios, dados que estariam em sua publicação de 2004. Conferindo o livro, encontramos uma breve comparação entre as populações de $S$. Paulo e Salvador, em que ele diz vagamente: "na mesma época [o século XVI] a cidade de Salvador, o maior núcleo urbano do Brasil, com 1.000 a 2.000 habitantes, teria cerca de 5 hectares construídos e 7 a 8 no total". ${ }^{432}$

Nota-se que pela construção de apenas cinco hectares $\left(=50 \mathrm{mil} \mathrm{m}^{2}\right)$, a área construída poderia se estender apenas da Porta de S. Luzia às proximidades da atual Praça da Sé.

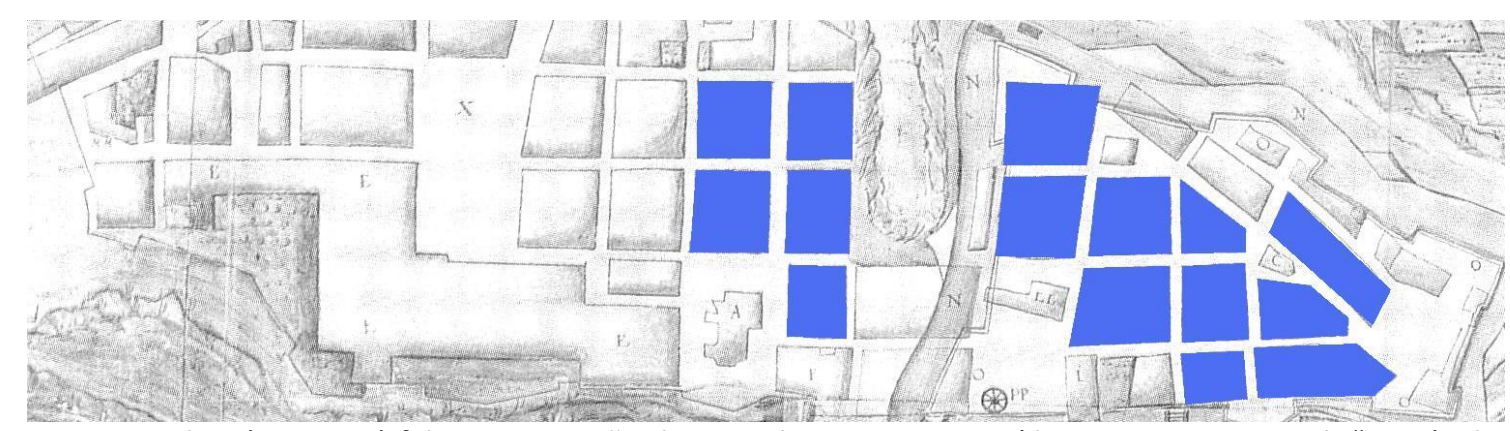

Nestor Goulart (2004: 23) fala na ocupação de cinco hectares construídos em 7 a 8 no total, "no século XVI" podendo significar, por exemplo, esta ocupação (dividindo-se 50 mil por quadras de $3,2 \mathrm{mil} \mathrm{m}^{2}$ consideradas as faixas de rua - seriam aproximadamente 15 quadras no padrão de 24 x 24 braças).

Lembremos que na opinião de Edison Carneiro, primeiro defensor de um perímetro amplo desde o início, a quantidade de habitantes na fundação seria substancialmente menor (em torno de 600 pessoas), mostrando que este não seria um fator decisivo na defesa de sua hipótese. Outros dados reforçam os indícios de que a população da Fortaleza nos anos 1550 era pequena. Primeiro o de que a Cidade Baixa seria inicialmente a mais populosa, como defendem alguns autores. ${ }^{433} \mathrm{E}$ segundo, como mostram os historiadores H. Johnson e M. B. Nizza da Silva, Tomé de Souza, estrategicamente, ${ }^{434}$ pediu que alguns moradores continuassem na Vila Velha. ${ }^{435}$

432 REIS Fo, 2004: 23 (São Paulo, Vila, Cidade, Metrópole). Reproduzimos parte da frase anterior para mostrar que o contexto a que se refere é "o século XVI", o que é muito vago (até 1600?): "No século XVI, os 60 a 80 moradores da vila de São Paulo, com suas famílias (200 a 300 habitantes), adensados de início no interior dos muros, ocupariam no máximo 4 hectares construídos e 7 a 8 no total... Na mesma época a cidade de Salvador..." (REIS Fo, 2004: 23). Note-se que pelo mesmo raciocínio, os 50 moradores necessários para que a cidade fosse em frente, do comentário de Luiz Dias (1551), significaria uma população de cerca de 180 habitantes.

433 "A Povoação da Praia ou Ribeira foi a parte de Salvador que se desenvolveu primeiro, possuindo de início mais população e mais casario do que a Cidade Alta" (TEIXEIRA \& VALLA, 1999: 225).

${ }^{434}$ A intenção era manter uma boa relação com os índios. "Cerca de dois meses depois, num momento em que os colonos se encontravam já instalados no lugar escolhido para a sede do governo, não deixaram de ficar alguns, aqueles que tinham maiores ligações com a gente de Diogo Álvares, na Vila Velha. Interessava a Tomé de Sousa manter esta povoação, que constituiria um ponto de contacto com a cultura autóctone, cujas potencialidades não eram negligenciáveis" (JOHNSON \& SILVA, 1992: 144 grifos nossos). Cf. também CARNEIRO, 1980: 57, em citação ao Regimento.

${ }^{435}$ Em conversa posterior e mais longa com o prof. Nestor, ele explicou sua base de cálculo. Comparando com São Paulo, estimou uma densidade populacional entre 200 (baixa) a 300 (alta) habitantes por hectare, podendo chegar ao máximo de 400 (uma "lotação"). Também é elástica a sua avaliação da população total nos primeiros "quatro ou cinco anos" (sendo os primeiros quatro o período em que se pode falar em "cidade de Tomé de Souza", ou "de Luiz Dias"): 1000 a 2000 pessoas. Para isso se baseia na hipótese de que a primeira expedição já trouxe "mil, talvez mil e quinhentas pessoas" (com o que, apoiados principalmente em Edison Carneiro, tendemos a discordar). Mas seguindo o seu cálculo, 
Na conversa com o prof. Nestor também pudemos lembrar, contrapondo-se à do cálculo populacional, a questão do imenso movimento de terra necessário à construção dos muros na amplitude defendida por Rafael Moreira. ${ }^{436}$ Em uma conta por alto, com uma muralha inicial de $3,5 \mathrm{~m}$ de altura por 1,5 de espessura (considerando-se haver próximo ao topo um caminho de ronda de pelo menos $50 \mathrm{~cm}$ de largura) e 3.200 de comprimento, ${ }^{437}$ chegaríamos a $16.800 \mathrm{~m}^{3}$ de terra movimentada nas condições inóspitas dos dois primeiros anos. ${ }^{438}$ Sobre esse assunto, o prof. Nestor também lembrou o uso da mão-de-obra indígena (mesmo que novata no uso de algumas ferramentas, como a pá), ${ }^{439}$ especulando sobre a possibilidade de se chegar a uma nova referência a partir das ordens de pagamentos em dinheiro (a portugueses) e resgate (a índios). Verificando as que foram transcritas por Teodoro Sampaio e Edison Carneiro, ${ }^{440}$ notamos que nenhuma se relaciona diretamente a uma quantidade de braças construídas de muro, o que realmente elucidaria praticamente tudo. Em geral são pagamentos feitos por tempo de serviço (mês, ano) ou material (não contabilizado em quantidade, a não ser a cal, usada em construções variadas). Enfim, bastaria que Luiz Dias tivesse relatado o número de braças construídas em seu muro para que essa questão não estivesse mais sendo discutida. A nosso ver, ela continuará sem solução definitiva nos próximos tempos.

Dois dos argumentos de Rafael Moreira foram os mais contundentes para que nossa opinião fosse em parte revista. O primeiro, já citado, de que o terreno dos jesuítas que aparece na Planta resulta de compras e doações posteriores (enfraquecendo o argumento da metragem descrita por Nóbrega). O segundo, bastante pertinente, é sobre as dimensões de Salvador (e a grandeza simbólica) em relação a outras colônias, alegando que “... durante 300 anos Brasil e Índia foram um mesmo país". 441

adotando-se um adensamento de $250 \mathrm{hab} / \mathrm{hm}^{2}$ e uma população total de 1.500 indivíduos, a cidade ocuparia em 1553 algo como 6 hectares, o equivalente a 18,6 quadras padrões de 0,32 hm² - $53 \times 53 \mathrm{~m}$ mais uma faixa de rua). Acrescentar-se-ia, portanto, mais três quadras e meia em azul à ilustração anterior, o que representaria uma cidade atingindo talvez a área do Terreiro, como propôs L. W. Coelho Fo. Mas isso depois de pelo menos cinco anos, sendo que a cerca à qual Nóbrega se referia era de 1549.

${ }^{436}$ Esse cálculo nos foi sugerido pelo professor Mário M. de Oliveira, também em conversa.

437 O próprio Rafael Moreira fala em "64 ha de área amuralhada" (2003: 45), o que representa como perímetro mínimo um quadrado de $800 \mathrm{~m}$ em cada lado. Em um cálculo mais aproximado, pode-se pensar em um retângulo de 1.400 por $457 \mathrm{~m}$, que daria um perímetro ainda maior de $3.900 \mathrm{~m}$.

${ }^{438}$ No mesmo livro, Nestor Goulart (2004: 22) cita a interessante descrição de Frei Vicente do Salvador da construção de uma primitiva fortaleza (1579) quando da fundação de Filipéia de N. S. das Neves (hoje João Pessoa, PB). Era um forte de planta quadrada com muros de aproximadamente $30 \mathrm{~m}$ de lado (ao todo 120 m de muros), de taipa de pilão com quatro braças $(8,80 \mathrm{~m}$ ) de altura (o que é muito, mas não impossível). Passaria pelo lado de dentro uma cerca mais baixa, de paus amarrados sem revestimento, a uns $80 \mathrm{~cm}$ do muro. O vão era preenchido com terra, entulho e faxina (feixes de varas), formando o que era chamado de andaime, sobre o qual passavam os guardas, podendo atirar pelas seteiras dos muros. Para os "andaimes" havia uma pequena cobertura de palha, protegendo a taipa e os soldados.

${ }^{439} \mathrm{Na}$ conversa, Nestor lembrou que os índios também deviam calcular o quanto em resgate lhes poderia ser vantajoso, pensando, por exemplo, em quantos meses (luas) de pesca seriam economizados com o uso de anzóis.

440 Mandados de pagamento, provisões, alvarás e outros papéis da série Documentos Históricos da BN, 1937, v. XXXV a XXXVIII.

${ }^{441}$ E-mail de Rafael. 
Salvador foi em 1548-49 (quando foi decidida e projetada na Côrte) a capital da nova província do Brasil, a par do velho Estado da Índia - do Sul da África ao Japão - com sua capital desde 1530 em Goa. Era, com Lisboa, a tríade do maior império do mundo, cidades que se projetavam para metrópoles com milhares de habitantes (Goa tinha mais de 200 mil) numa visão de futuro próximo, ou já presente no caso de Goa e Baçaim (a "mãe" da atual Bombaim, uma megalópole de 18 milhões de hab.) ou Macau (que está superando Las Vegas). ${ }^{442}$

De fato, o tamanho com que Salvador aparece na Planta de 1605 é semelhante ao de algumas fortalezas indianas, como podemos observar nas fotografias de satélite que se seguem. Mas nelas também observamos que Mazagão, o "balão de ensaio" de Salvador, era menor. E se entendermos que Salvador foi cercada e construída em etapas para que chegasse ao tamanho maior, previamente estudado e determinado, como defendemos, não há contradição em relação às observações dele.

Mas nosso principal argumento para responder a isso seria o da anterioridade de Salvador em relação às fortalezas indianas: nossa capital era pouco posterior à construção de Mazagão (que era menor) e precedeu os grandes empreendimentos na Índia. O historiador Eduardo Bueno, por exemplo, considera nossa cidade a "pedra de toque", o verdadeiro marco inicial de "uma revolucionária política de urbanização dos territórios ultramarinos", ${ }^{443}$ estabelecendo o ponto em que "o projeto imperial começou a voltar-se em projeto colonial". ${ }^{444}$ Ele cita Walter Rosa, para quem "Salvador foi o primeiro tramo [?] a marcar o vínculo entre as cidades 'reguladas' e as cidades da futura escola portuguesa de urbanização da Índia". ${ }^{445}$

Se por um lado havia em nossa cidade-fortaleza a intenção de "transformar as meras franjas litorâneas" do império de então em um verdadeiro "território colonial, fortificado e urbanizado", ${ }^{446}$ por outro, na época de sua fundação, o Brasil não tinha a lucratividade e importância das cidades orientais. Basta pensar que em Mazagão e nas cidades da Índia se construía muralhas de pedra, o que aqui não chegou a ser feito.

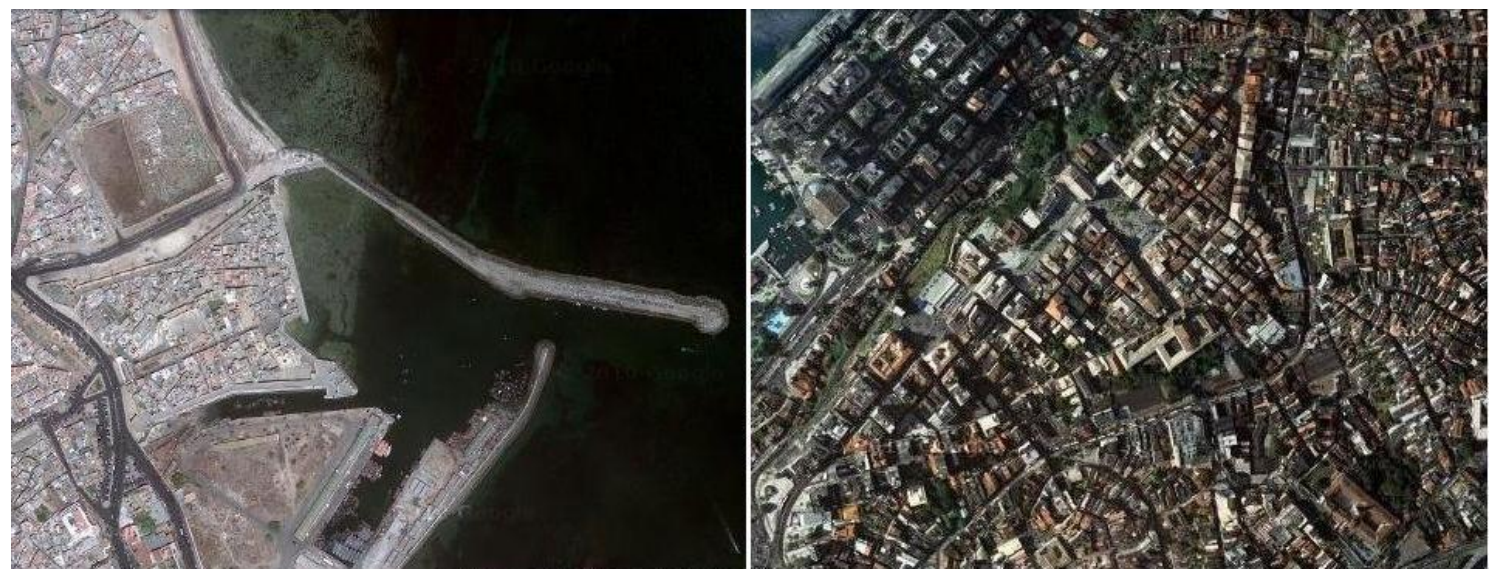

Fotografias de satélite (Google, dez/2010), reproduzidas com mesma aproximação, das fortalezas de Mazagão (1541) e do centro histórico de Salvador (1549).

\footnotetext{
442 Idem.

${ }^{443}$ BUENO, 2006-2: 97.

${ }^{444}$ ROSA, Walter. Cidades Indo-portuguesas - apud BUENO, 2006-2: 97.

${ }^{445}$ Idem - apud BUENO, 2006-2: 97-8 - grifo nosso.

${ }^{446}$ BUENO, 2006-2: 98.
} 


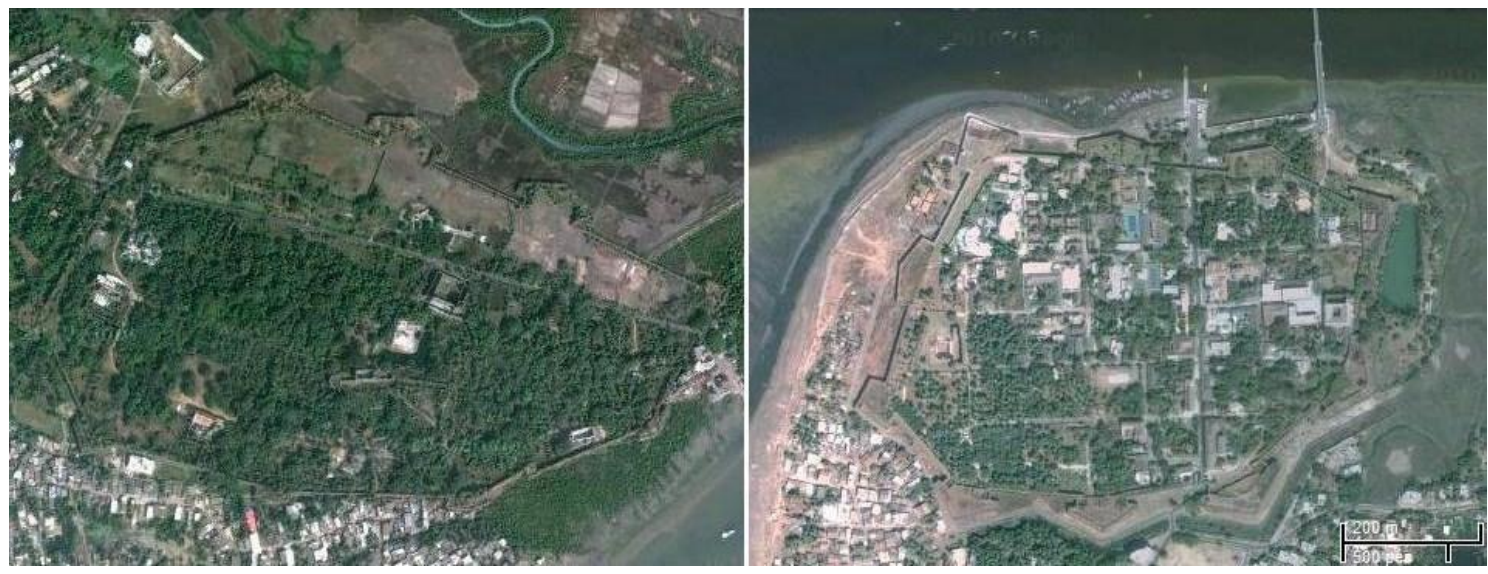

Idem, na mesma aproximação, das cidades fortificadas de Baçaim e Damão. Em Baçaim, os muros foram erguidos entre 1552-82 (só nesta última data a cidade estava envolvida pela imponente muralha de pedra e cal, apoiada em dez baluartes modernos). Damão só foi definitivamente tomada em 1559 (em 1534 a cidade foi bombardeada por Martim Afonso de Sousa que arrasou os baluartes mouriscos, mas a substituição definitiva das fortificações islâmicas é bem posterior). O próprio Rafael, em um de seus textos (1989: 156), data de 1595 os "polígonos estelares para as cercas urbanas" de Damão e Baçaim.

Ao longo da correspondência houve insistente apelo para que compreendêssemos a hipótese de Teodoro como mal formulada e vinda de uma interpretação errônea da primeira planta. Procuramos expor nosso argumento dizendo, resumidamente, que quando Frias de Mesquita estudou a cidade e concluiu ser aquela a área mais adequada para uma fortificação reforçada nos moldes de uma cidadela, deparava-se, certamente, com as mesmas condições topográficas que levaram Luiz Dias a escolhê-la como melhor local para dar início à construção da cidade. Mais: se a idéia inicial fosse ocupar e fortificar logo, inteiramente, os dois platôs, a lógica não seria construir a Praça Principal onde está, mas no meio, onde foi feita depois a "Praça" da Sé. E também não teria sentido fazer o Terreiro de Jesus maior (e mais imponente) do que ela.

\section{Anos 1580: a cidade descrita por Gabriel Soares de Sousa}

\section{1. Índices populacionais e de ocupação}

Podemos agora falar da época em que Gabriel Soares de Sousa escreveu a sua Notícia do Brasil (1584-7), com muitos capítulos dedicados especialmente à Cidade do Salvador, de trechos aqui já citados. O Tratado Descritivo... mostra que as notícias rarefeitas (ou a lacuna de informações) das décadas de 1560 e 70 se devem (junto à ausência de um cronista da cidade à altura dos que foram citados) ao relativo abandono da Colônia por parte da Metrópole. ${ }^{447}$ Depois de explicar que o governo de

\footnotetext{
${ }^{447}$ Contrapondo-se à época inicial, em que... Sua Alteza mandava cada ano em socorro dos moradores desta cidade uma armada com degredados, moças órfãs, e muita fazenda, com o que a foi enobrecendo e povoando com muita presteza... (SOUSA, 1971: 130).
} 
Tomé de Souza foi sucedido pelo de D. Duarte da Costa (1553-7), ${ }^{448}$ e este pelo de Mem de Sá (de catorze anos, até 1572), ${ }^{449}$ mostra que com a morte de D. João III (1557) e a ascensão de D. Catarina...

... foram esfriando os favores e socorros que cada ano esta nova cidade recebia, para a qual não mandaram dali por diante mais que um galeão da armada, em que iam os governadores que depois a foram governar, pelo que este Estado tornou atrás de como ia florescendo. E se esta cidade do Salvador cresceu em gente, edifícios e fazenda como agora tem, nasceu-lhe da grande fertilidade da terra, que ajudou aos moradores dela... ${ }^{450}$

Sobre a descrição física da cidade nos anos 1580, já não é duvidosa como a narrativa sobre o ano de 1549, porque feita a partir da observação direta (ao contrário das suposições que fizemos sobre o colégio jesuíta, por exemplo, em qualquer das interpretações). Na época em que escreveu, o Recôncavo já contava com... quarenta engenhos de açúcar, mui prósperos edifícios, escravaria e outra muita fábrica, ${ }^{451}$ pouco menos, portanto, do que teria cerca de 25 anos depois, quando na Relação de Diogo Moreno (1609) foram enumerados 46 deles. Outros dados que aparecem nessas duas fontes mostram o constante crescimento da população e de construções nesse período. Sobre a população e um possível exército nos anos 1580, Gabriel Soares diz:

Terá esta cidade oitocentos vizinhos, pouco mais ou menos, e por fora dela, em todos os recôncavos da Bahia, haverá mais de dois mil vizinhos, dentre os quais e os da cidade, se ponde ajuntar, quando cumprir, quinhentos homens de cavalo e mais de dois mil de pé, afora a gente dos navios que estão sempre no porto. ${ }^{452}$

\section{Em outro trecho, Gabriel Soares declara:}

[A cidade] pode ser socorrida por mar e por terra de muita gente portuguesa até a quantia de dois mil homens, de entre os quais podem sair dez mil escravos de peleja a saber: quatro mil pretos da Guiné, e seis mil índios da terra, mui bons flecheiros, que juntos com a gente da cidade, se fará mui arrazoado exército.... ${ }^{453}$

Essas informações são comparáveis ao seguinte trecho de Diogo de Campos Moreno, no relatório de 1609:

Juntão-se nessa sidade perto de mil homens en doze companhias a saber defesa: oito da ordenança e duas mais da cidade [cas] duas de prezidio toda a mais gente fica en goarda das fazendas de fora per [amor] dos negros da terra e de gine'; [ten conhed ${ }^{\circ}$ ] asi de' capitania mais de tres mil moradores brancos q' oje chegão ate o camamu e morro de s. Paulo mas estes não acoden a sidade a couza' alguma' porq' viven longe: .... ${ }^{454}$

\footnotetext{
${ }^{448}$ Que segundo Gabriel Soares, teve de... fortificar e defender esta cidade do gentio que em seu tempo se alevantou, e cometeu grandes insultos, aos quais combateu fazendo-Ihes crua guerra (idem, p. 131).

${ }^{449}$ Ainda mais arrasador,... subjugou e desbaratou todo o gentio tupinambá da comarca da Bahia e a todo o mais até o Rio de Janeiro... (id. ibid.).

450 SOUSA, 1971: 132.

${ }^{451}$ Id. ibid.

452 SOUSA, 1971: 133-4. Não está claro se entre esses 2.800 vizinhos, dos quais 2.500 e ainda os marinheiros poderiam servir a uma guerra, estão incluídas a mulheres. Se sim, elas seriam em número bem reduzido.

${ }^{453}$ SOUSA, 1971: 140-1.

454 Relação... (1609), fl. 28 v. Para defender a Cidade, Diogo Moreno diz haver em 1609 cerca de mil homens distribuídos em doze companhias: oito da ordenança, duas da cidade e duas de presídio. Mas se poderia também contar com os seguranças e escravos índios e negros das fazendas. A Capitania teria ao
} 


\subsection{Estratégias de defesa}

Vimos no capítulo anterior (ilustrando a favor da hipótese de E. Carneiro de haver apenas dois baluartes em terra, já que Gabriel Soares só descreve duas grandes posições artilhadas, a Praça e a Porta de Santa Luzia) que embora na Planta da Restituição... (c. 1627) a Praça Municipal (ou Principal) já não estivesse artilhada, e sim a Praça da Sé, ela era de fato bastante artilhada à época em que estamos tratando:... fica esta praça em quadro... com grande vista para o mar; onde estão assentadas algumas peça de artilharia grossa, donde a terra vai muito a pique sobre o mar... ${ }^{455}$

Gabriel Soares estava atento às questões estratégicas. Há um trecho em que, mais do que antecipar a idéia dos holandeses de represar o rio das Tripas, ele aparentemente sugere cercar a cidade por fora dele, como foi pensado e trabalhado pelos portugueses só em meados do século XVII. Ao elogiar a cidade vista do mar por suas casas com quintais cheios de árvores e por ela se estender muito ao longo dele, neste alto, diz:

Não tem a cidade nenhum padrasto, de onde a possam ofender, se a cercarem como ela merece, o que se pode fazer com lhe ficar dentro uma ribeira de água, que nasce junto dela, que vai a cercando toda, a qual se não bebe agora... mas, limpa, é muito boa água, da qual se não aproveitam os moradores por haver outras muitas fontes... todas de boa água. ${ }^{456}$

É mais provável que sua proposta fosse fazer uma cerca semelhante à representada na Pranta... de 1605, a nosso ver construída nos anos 1590 . Ficaria dentro dela uma das nascentes, a que separa parcialmente as duas áreas correspondentes os topos de morro (que aqui entendemos serem construídas em seqüência, em fases bem próximas, uma já concluída no início dos anos 1550, sendo que o outro topo já estava totalmente ocupado na época de Gabriel Soares). ${ }^{457} \mathrm{Na}$ avaliação do cronista, mesmo que os padrastos além do rio das Tripas (atuais bairros da Palma, Desterro e Saúde) e os já então ocupados pelos mosteiros de S. Bento e do Carmo fossem tomados, a cidade poderia resistir com uma boa fortificação.

Uma reflexão importante é feita ao longo do capítulo "Que trata de como se pode defender a Bahia com mais facilidade". Se a cidade-fortaleza de Luiz Dias serviu para deter incursões indígenas, nessa época, com a cidade em crescimento pelo comércio de toda a produção do Recôncavo, sua riqueza começava a ser cobiçada por outras nações européias (em especial a Holanda, rival do reino de Espanha, ao qual Portugal acabara de se submeter). A seguinte passagem de Gabriel Soares mostra a consciência de uma fragilidade, caso uma grande nação resolvesse atacar Salvador com artilharia moderna.

Não parece despropósito dizer neste lugar, que tem El-rei nosso senhor obrigação de, com muita instância, mandar acudir ao desamparo em que esta cidade está, mandando-a cercar de muros e

todo três mil moradores brancos contando com os de Camamu e Morro de São Paulo, mas estes não poderiam defendê-la por causa da distância.

Por essa descrição, está mais evidente que nesses números não entram mulheres e crianças.

455 SOUSA, 1971: 134.

${ }^{456}$ SOUSA, 1971: 138-9 (cap. XII - grifo nosso). Segue-se o trecho em que diz que... A terra em que esta cidade tem, uma e duas léguas à roda, está quase toda ocupada com roças... (p. 139).

${ }^{457}$ Uma das críticas feitas no capítulo anterior ao estudo de L. W. Coelho Filho foi ele representar a área dessa nascente como quadra ocupada já na época de Luiz Dias. 
fortificar, como convém ao seu serviço e segurança dos moradores dela; porque está arriscada a ser saqueada de quatro corsários, que a forem cometer, por se a gente espalhada por fora, e a da cidade não ter onde se possa defender, até que a gente das fazendas e engenhos a possa vir defender. ${ }^{458}$

É também interessante a defesa que faz da necessidade de se prepararem para uma eventual batalha naval, com a consideração de que... se não levarem a cidade do primeiro encontro, não a entram depois, uma vez que ela seria socorrida por mar e terra pelos demais moradores do Recôncavo.

... enquanto não for cercada, não tem remédio mais fácil para se poder defender dos corsários que na baía entrarem, que pelo mar com quatro galeotas que com pouca despesa se podem fazer, e estarem sempre armadas; às sombras das quais podem pelejar muitas barcas dos engenhos, e outros barcos em que se pode favorecer com as naus do reino, que de contínuo estão no porto oito e dez, e daqui para cima até quinze e vinte, que estão tomando carga de açúcar e algodão, nas quais se pode meter gente da terra a defender, e alguma artilharia com que ofender aos contrários... ${ }^{459}$

Há na parte final do tratado (sobre recursos naturais) o capítulo "Em que se declara a pedra que tem a Bahia para se poder fortificar", mencionado pedras... de alvenaria e cantaria, de que há em todo o seu circuito muita comodidade, e grande quantidade para se poder fazer grandes muros, fortalezas e outros edifícios. ${ }^{460}$

Outra questão estratégica relevante aparece em Gabriel Soares, contradizendo alguns autores. No seguinte trecho, ele atesta a existência de um forte (ou posição fortificada) na Ponta do Padrão, onde foi construído o Santo Antônio da Barra, provavelmente pelo projeto de Baccio di Filicaia no governo do Francisco de Souza (1591-1602), o que para alguns autores já teria sido iniciado (em suas fundações) no governo de Telles Barreto (1583-7). ${ }^{461}$ Já havia nessa época, como se vê, uma fortificação defendendo o acesso pelo sul, diferente da Torre de Coutinho (no atual Porto da Barra). A informação se segue à da capacidade de artilharia da cidade, somando-se à do forte (fazendo já uma crítica à sua localização, que retomaremos ao falar dos primeiros de pedra, nos anos 1590):

Tem esta cidade catorze peças de artilharia grossa, e quarenta, pouco mais ou menos, de artilharia miúda; a artilharia grossa está assentada nas estâncias atrás declaradas [Praça e Porta Sul], e em outra que está na ponta do Padrão para defender a entrada da barra aos navios dos corsários, se a

\footnotetext{
${ }^{458}$ SOUSA, 1971: 140 (cap. XIV - grifos nossos).

459 Id. ibid. Observa-se que o relato aparentemente independente de Gabriel Soares (mas como colono, dono de terras e empreendedor, ele é um agente da Coroa) cumpre o papel de avaliar e propor estruturas defensivas, o que passará a ser atribuição dos engenheiros militares.

${ }^{460}$ SOUSA, 1971: 342-3 - cap. CLXXXVII. Também informa que na construção de Salvador se fez uso de... uma pedra cinzenta boa de lavrar, que iam buscar por mar ao porto de Itapitanga..., a sete léguas da cidade,... da qual fizeram as colunas da Sé, portais e cunhais e outras obras de meio relevo, e muitas campas e outras obras proveitosas; mas depois se descobriu outra pedreira melhor...

461 Cf. FALCÃO, 1942: 44. Ao afirmar que as primeiras providências de erguer baluartes de proteção contra grandes ataques remontam à administração do primeiro governador do Brasil nomeado pelo rei da Espanha (Telles Barreto, 1583-7), Falcão diz: “Na ponta do Padrão, ao sul, e na que lhe fica oposta ao norte, formando os extremos da enseada semilunar em cujo centro, a cavaleiro da praia, se debruçava a primitiva capital brasileira, assentaram-se nessa época os fundamentos de dois fortes, dedicados a princípio a Santo Antônio e São Felipe."

Telles Barreto (1583-7) foi o primeiro governador do Brasil nomeado pelo rei de Espanha. Além de reconstruir o baluarte de Luiz Dias sobre o rochedo da Ribeira do Góes (cf. FALCÃO, 1942: 44), mostrouse preocupado em proteger a cidade de ataques maiores, preparando a construção de dois grandes fortes nos extremos da enseada: ao sul, o de Santo Antônio da Barra; ao norte, o de Monserrate.
} 
cometerem, donde não lhe podem fazer mais dano do que afastá-los da carreira, para que não possam tomar o porto do primeiro bordo, porque é a barra muito grande e podem afastar as naus que quiserem, sem lhes a artilharia fazer nojo.

\subsection{Malha expandida}

O fato de não existirem muralhas na época de Gabriel Soares, somado à descrição urbana feita por ele, em que estão registrados os vários novos bairros e até a regularidade das quadras, faz-nos entender que a configuração da cidade já era bem próxima à que aparece na carta de 1638 (descontando-se o Dique dos Holandeses, as Portas e muralhas laterais):

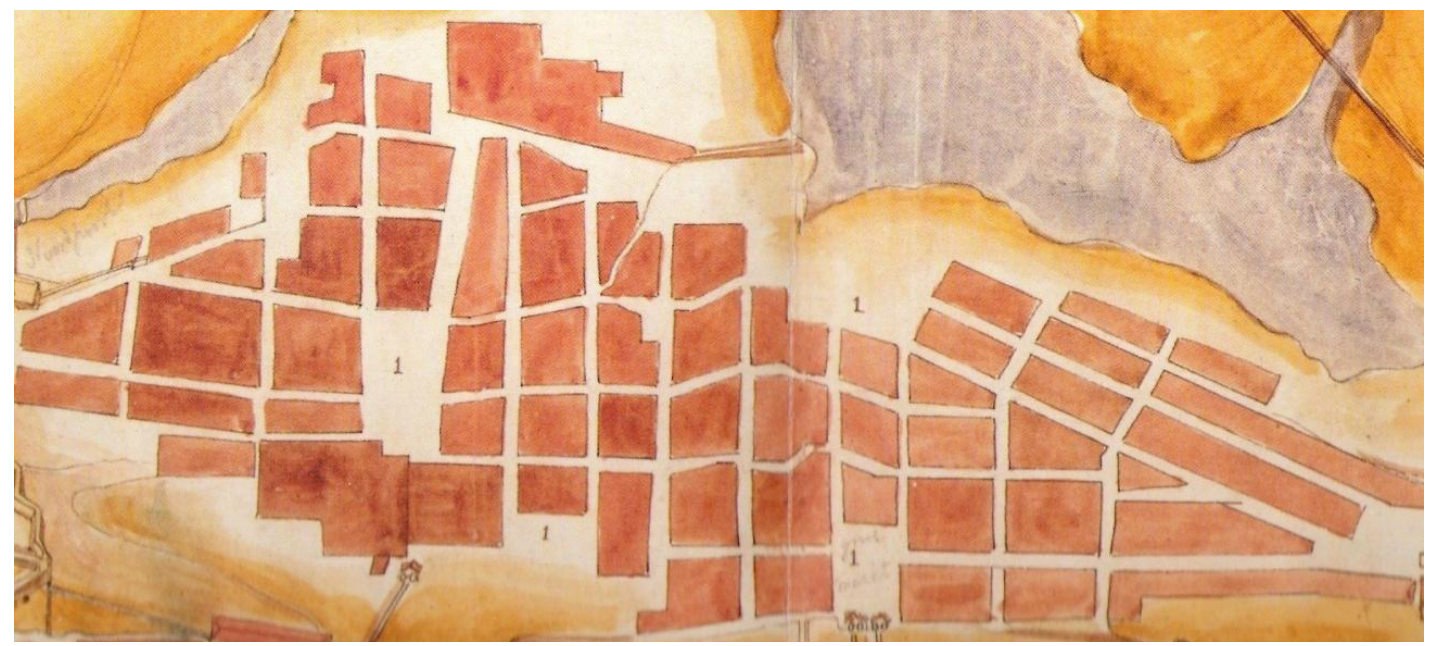

A malha de Salvador no mapa de Haia (1638): já configurada nos anos 1580 (em REIS Fo, 2000: 32-4).

Além da Praça Principal, de descrição já reproduzida aqui (uma honesta ${ }^{462}$ praça...), mostrando que era retangular, desabafada com grande vista para o mar e tinha ao centro o pelourinho (por representar já nos anos 1550 o centro administrativo onde ficavam a Casa do Governador, a da Câmara e Cadeia e a da Fazenda), Gabriel Soares mostra que em sua época já havia outras duas importantes áreas cumprindo o papel de praças, com funções distintas: a da Sé e o Terreiro jesuíta. Sobre a "Praça" da Sé, ele diz:

A Sé da Cidade do Salvador está situada com o rosto sobre o mar da Bahia, defronte do ancoradouro das naus, com um tabuleiro defronte da porta principal, bem a pique sobre o desembarcadouro, donde tem grande vista. ${ }^{463}$

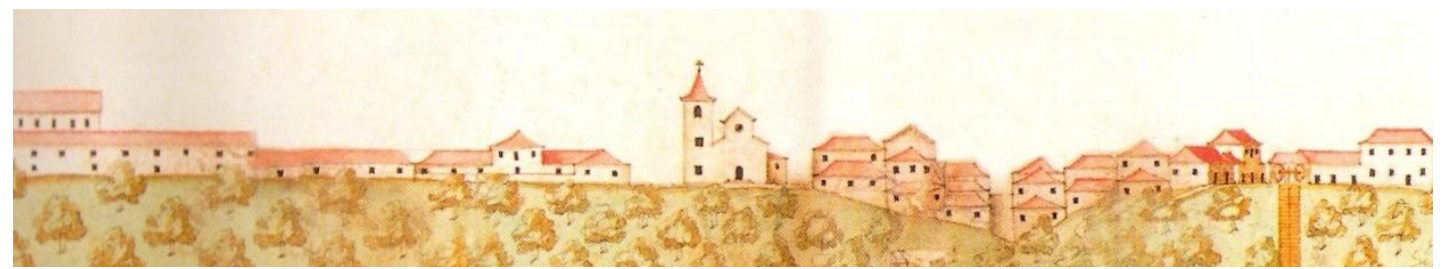

A igrejinha da Sé, voltada para o mar, no perfil de 1911 (em REIS Fo, 2000: 21 - ela marca exatamente o centro do perfil).

\footnotetext{
${ }^{462}$ SOUSA, 1971: 134. O adjetivo expressa conhecimentos de decoro do autor, tanto literário quanto urbanístico.

${ }^{463}$ SOUSA, 1971: 135.
} 
Perto dela estava o terreiro do Colégio, mui bem assentado e grande, aonde se representam as festas a cavalo, por ser maior que a praça, já então cercado em quadro de nobres casas. O centro religioso, fora do perímetro amuralhado inicial, seria rapidamente um dos principais pólos da cidade, confirmando-se as previsões dos padres. $^{464}$

Passando além da Sé pelo mesmo rumo do norte, corre outra rua mui larga, também ocupada com ruas de mercadores, a qual vai dar consigo num terreiro mui bem assentado e grande, aonde se representam as festas a cavalo, por ser maior que a praça, o qual está cercado em quadro de nobres casas. E ocupa esse terreiro a parte da rua da banda do mar um suntuoso colégio dos padres da Companhia de Jesus, com uma formosa e alegre igreja... ${ }^{465}$

Embora as construções religiosas não sejam nosso objeto de estudo, voltamos a elas com algumas considerações ligadas ao crescimento inicial da cidade. Começamos pela seguinte citação de Gabriel Soares ao Colégio, para reforçar nosso ponto de vista de que já se previa uma construção grande, que não caberia no terreno inicialmente oferecido a Nóbrega, de 10 × 40 braças.

Tem este colégio grandes dormitórios e muito bem acabados, partes dos quais ficam sobre o mar, com grande vista; cuja obra é de pedra e cal, com todas as escadas, portas e janelas de pedrarias, com varandas, e cubículos mui bem forrados, e por baixo lajeados com muita perfeição, o qual colégio tem grandes cercas até o mar... ${ }^{466}$

Rafael Moreira rebateu por e-mail o argumento de que o primeiro terreno oferecido aos jesuítas era pequeno lembrando que foi aumentado por compras e doações ao longo do tempo, até chegar ao tamanho em que está na Planta (não se podendo levar muito em conta a metragem mencionada por Nóbrega). ${ }^{467}$ Mas enfatizamos ainda nossa interpretação de que foi pela presença dos jesuítas que o largo à frente passou a ser conhecido como Terreiro de Jesus. ${ }^{468}$

Ainda sobre a área religiosa, embora Gabriel Soares tenha se referido já em 1584 (na penúltima citação) à ocupação do terreiro da parte da rua da banda do mar por um suntuoso colégio dos padres da Companhia de Jesus, com uma formosa e alegre igreja, sabemos que o edifício do colégio só ficou pronto em 1590. Também entendemos que a primeira igreja jesuítica construída na área do terreiro, substituída

\footnotetext{
464 As ordens religiosas, particularmente os jesuítas, tiveram importante contribuição no desenvolvimento urbano de Salvador. No início do século XVII já estariam delineadas as áreas das igrejas de São Francisco e do Carmo (recém adquirida na época de Soares de Sousa), próximas ao Terreiro de Jesus e também fora do perímetro original demarcado pelos muros de taipa em 1549.

${ }^{465}$ SOUSA, 1971: 136.

${ }^{466}$ Id. ibid. - grifos nossos. O Colégio jesuíta teve no século XVIII um importante levantamento de plantas feito por um engenheiro militar, o Sargento-mor José Antonio Caldas, resgatado e primeiramente analisado por Robert Smith (cf. SMITH, 1998).

467 Os cadernos do IPAC informam que em 1575 houve a "compra de terreno e materiais para o novo Colégio, segundo projeto do arq. Francisco Dias S. J." (AZEVEDO, 1975: I, 24). Mas como dissemos, a questão estaria no formato do lote, de um tipo que aparece unicamente próximo ao largo da Ajuda.

${ }^{468}$ Em e-mail, Rafael Moreira fez a seguinte consideração: “O Terreiro de Jesus (que ainda em 1605 se chamava a "Praça Grande de Jesus no meyo da cidade") era o adro... mas da igreja de S. Francisco. Tal como se vê hoje, é uma obra-prima de urbanismo aberta no meio das casas pelo "arruador da câmara" eng. Francisco Pinheiro em 1708: obra-prima da arruação barroca, insisto. A relação com o adro dos Jesuítas é de mera contiguidade espacial". É de se estranhar, porque na mesma planta em que se lê o nome citado na legenda (1605), o terreiro já aparece em sua forma atual, não havendo indício de que foi ocupado por casas em nenhuma outra época.
} 
pela atual Catedral Basílica, foi aquela inaugurada no governo de Mem de Sá, em 1572, discordando assim da interpretação de Robert Smith, para quem a igreja atual é a quarta. ${ }^{469}$

Sobre essa igreja desaparecida e transversal à atual, deparamos com a curiosa observação de Bazin, feita a partir da planta do padre B. Guerreiro, de que "as construções do colégio e das escolas formavam um conjunto inorgânico", ${ }^{470}$ agrupado de sul a norte ao longo do Terreiro, estando a igreja também neste sentido (perpendicular à atual, com a torre no ângulo sudeste das construções).
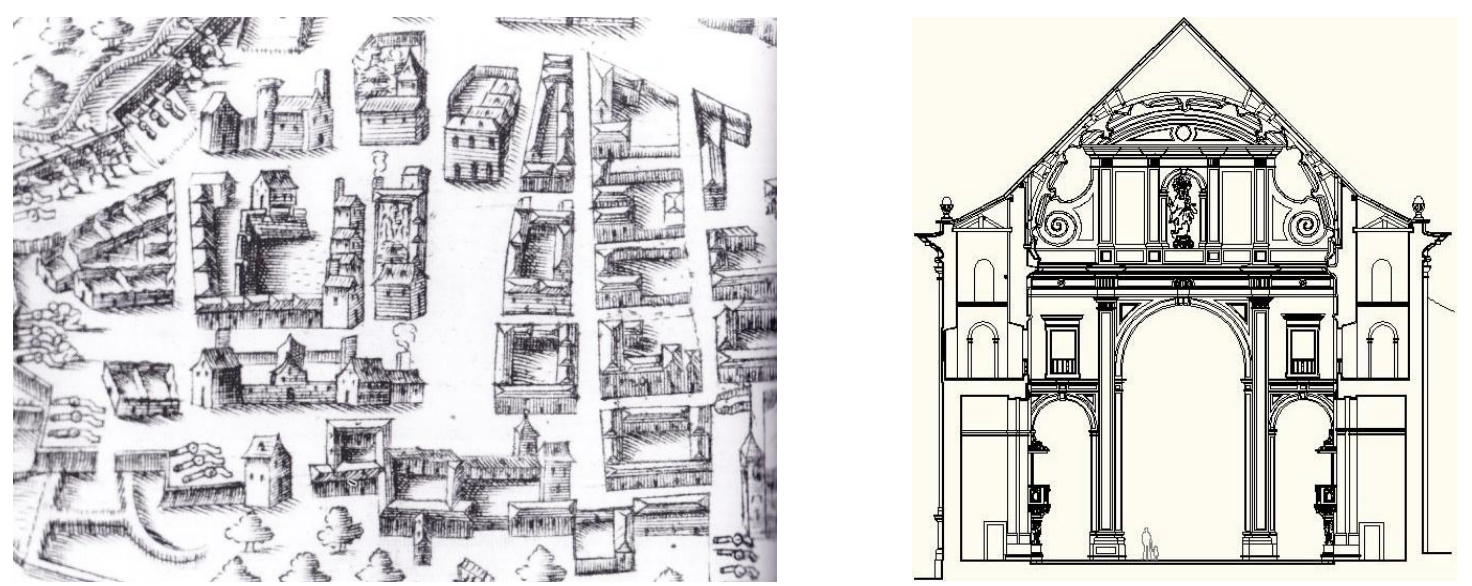

À esquerda, detalhe da planta da cidade gravada na Jornada dos Vassalos da Coroa de Portugal do padre B. Guerreiro (Lisboa, 1625 - em REIS F, 2001: 144). À direita, o frontispício da igreja do Colégio em 1650, transversal à atual (refeito em Cad a partir do desenho publicado em SANTOS, 1951, 106-7). ${ }^{471}$

469 Robert Smith (1962: 66 - nota 69/ 1998: 52 - nota 70) interpretou de Serafim Leite que "a primeira, de adobe e madeira, durou de 1549 a 1553", quando foi construída a segunda. A terceira foi "inaugurada em 1572", dando lugar "à quarta, consagrada em 1672" (construída a partir de 1652 por arquitetos jesuítas anônimos, seguindo o projeto de Francisco Dias, como acreditamos). Bazin entende que a primeiras já foi construída no terreiro, junto com as primeiras construções do colégio, em taipa, cobertas de palha. Em 1552, prestes a desmoronar, teria sido refeita com os mesmos materiais, estando já em ruínas em 1564. Mem de Sá teria pagado a construção da terceira, de pedra e cal, iniciada em 1561 (consagrada em 1572 e concluída em 1585). São as mesmas datas que aparecem nos cadernos do IPAC (AZEVEDO, 1975: I, 24): “1549 - Chegada dos jesuítas e construção da primeira igreja em taipa e palha; 1553 - Construção da 2a . igreja; 1561/ 72 - Terceira igreja construída por Mem de Sá; 1575 Compra de terreno e materiais para o novo Colégio, segundo projeto do arq. Francisco Dias S. J.; 1583 Conclusão do claustro; 1591 - Inauguração do Colégio (segundo); 1604 - Compra de Materiais para construção da 'nova' igreja (atual); 1657/ 72 - Construção do terceiro Colégio; 1691 - Chegam pedras de Portugal para a 'nova igreja'...".

Notamos em Bazin uma sobreposição de datas (uma em ruínas em 1564 e outra iniciada em 1561) que também aparece no livro de Paulo Santos, O Barroco e o Jesuítico...: "A igreja dos jesuítas no Brasil foi construída na cidade do Salvador e chamou-se Nossa Senhora da Ajuda - nome de uma das naus... Era de taipa, coberta de palha. Construíram-na os padres... com as próprias mãos. A essa igreja seguiuse outra, também de palha e coberta de palha - erguida no lugar que tomou a denominação até hoje conservada, de Terreiro de Jesus. Como 'em 1552, estava já a cair', começou-se uma nova, ainda coberta de palha, a qual em 1564 'abria por algumas partes'. Para substituí-la Mem de Sá determinou a ereção, à sua custa, de uma igreja de pedra e cal, que foi começada em 1561 e em 1572 estava pronta. É a ela que se refere Cardim quando diz que é 'Capaz, bem cheia de ricos ornamentos'... (SANTOS, 1951: 106-7). Por essa sobreposição, e pela semelhante descrição das igrejinhas de palha, conjecturamos que a segunda seria uma reconstrução da primeira (como entendeu Bazin, mas supondo-a no Terreiro), na Ajuda ou mesmo onde depois seria erguida a da Sé.

470 BAZIN, 1956: II, 22.

${ }^{471}$ A reconstrução que originou a atual foi primeiramente proposta pelo padre Fernão Cardim, ainda em 1604. O projeto foi retomado em 1616 e suspenso com a invasão holandesa. 
Gabriel Soares também descreveu outras áreas importantes, como a de Santo Antônio do Carmo:

Passando avante do colégio vai outra rua muito comprida pelo mesmo rumo do norte, muito larga e povoada de casas e moradores, além da qual, no arrebalde da cidade, num alto, está um mosteiro de capuchinhos de Santo Antonio, que há pouco se começou... ${ }^{472}$

Nota-se que não há menção à Porta de Santa Catarina, ${ }^{473}$ nem na Praça nem aqui, onde haveria em futuro próximo a Porta do Carmo. Como diz Silva Campos, não se pode precisar quando esta foi construída, sabendo-se apenas que "já existia em fins do século XVI". 474

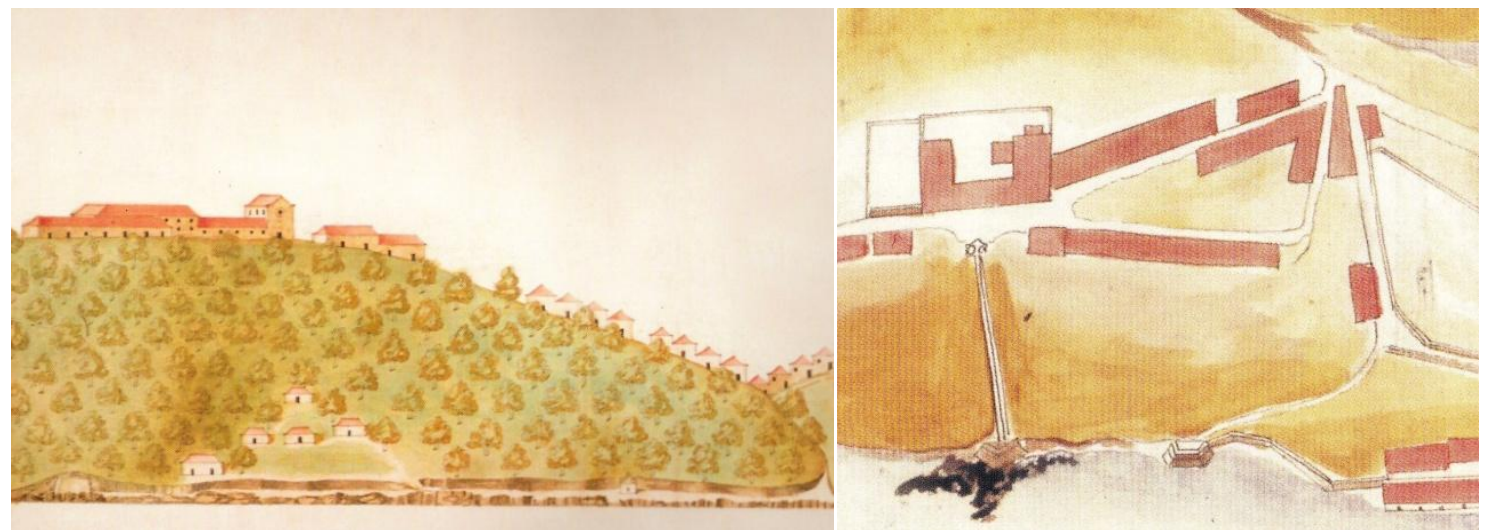

A área do Carmo no perfil de 1611 e na planta de 1638 (em REIS Fo, 2000: 20 e 33).

Saindo do Carmo, Gabriel Soares descreve uma nova área nobre, que nos anos 1550 estaria ainda pouco ocupada com construções:

E tornando desse mosteiro para a praça pela banda da terra vai a cidade muito bem arruada, com casas de moradores com seus quintais...; ${ }^{475}$ a qual cidade por esta banda da terra está toda cercada com uma ribeira de água, que serve de lavagem e de se regarem algumas hortas, que ao longo dela estão.

Sobre o largo na entrada ao sul (Santa Luzia), diz: Tornados à praça pondo o rosto no sul, corre outra rua muito formosa de moradores, no cabo da qual está uma ermida de Santa Luzia, onde está uma estância com artilharia. ${ }^{476}$ De lá, fala do largo da Ajuda (a que já fizemos referência) como uma espécie de praça triangular: ${ }^{477} E$ ao

\footnotetext{
472 SOUSA, 1971: 137 (grifos nossos). Especifica que era construção é paga com dinheiro das esmolas, também usado na compra do outro terreno, em que lhe os moradores fizeram uma igreja...

473 Lembrando que no capítulo anterior rebatemos com essa falta de referência a idéia de Rafael Moreira de que as primeiras portas eram "estruturas colossais, erguidas duma vez por todas, no lugar onde sempre estiveram" (e-mail).

${ }^{474}$ CAMPOS, 1940, 266. Cf. p. 262-7. O autor não chega a diferenciá-las (as do Carmo) da antiga Porta de Santa Catarina que seria colada à Praça. Ao longo de seu livro não se observa que tivesse conhecimento da Carta de Luiz Dias a Miguel de Arruda, reproduzida em alguns trechos por Edison Carneiro (1949) e publicada depois por Rafael Moreira (2001).

475 Id. ibid. ... povoados de palmeiras... laranjeiras e outras árvores... A descrição do local lembra a de Nóbrega (1988: 89): Similham os montes grandes jardins e pomares, que não me lembra ter visto panno de raz tão bello.

476 Id. ibid. Trecho já mencionado por mostrar uma das posições artilhadas. A ermida que teria dado nome à Porta, de todos os documentos, só está registrada nesta passagem.

477 Teodoro Sampaio também entende que o largo tivesse função de praça: "Na outra praça, muito menor que a primeira, à guisa de pequeno pátio, estava da parte de sul a modestíssima igreja de Nossa
} 
longo dessa rua lhe fica muito bem assentada, também toda povoada de lojas de mercadores, e no topo dela está uma formosa igreja de Nossa Senhora da Ajuda com sua capela de abóbada... ${ }^{478}$

Sobre a área de São Bento, diz: Passando mais avante com o rosto ao sul, no outro arrebalde da cidade, em um alto e campo largo, está situado um mosteiro de São Bento, com sua claustra, e largas oficinas, e seus dormitórios... ${ }^{479}$

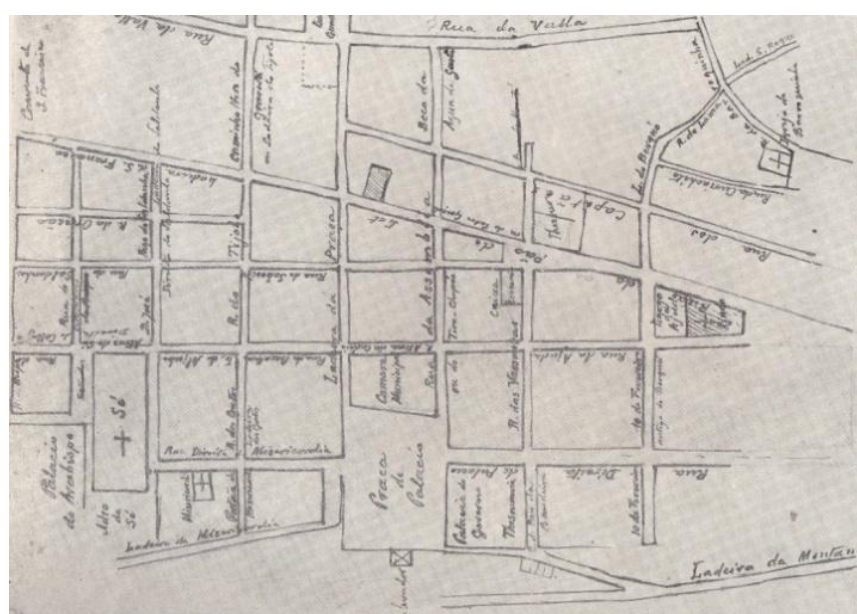

Desenho de Teodoro Sampaio (1949: 192-3) para a malha urbana ampliada de Salvador em fins do séc. $\mathrm{XVI}$.

\subsection{Novas características urbanas}

Chama atenção na Pranta... de 1605 a maior regularidade de traçado nas quadras que a nosso ver representam uma primeira área de expansão (mas já prevista em projeto), construída entre os anos 1550 e 1580. Essa maior regularidade parece ter sido conseguida a partir na criação do Terreiro de Jesus.

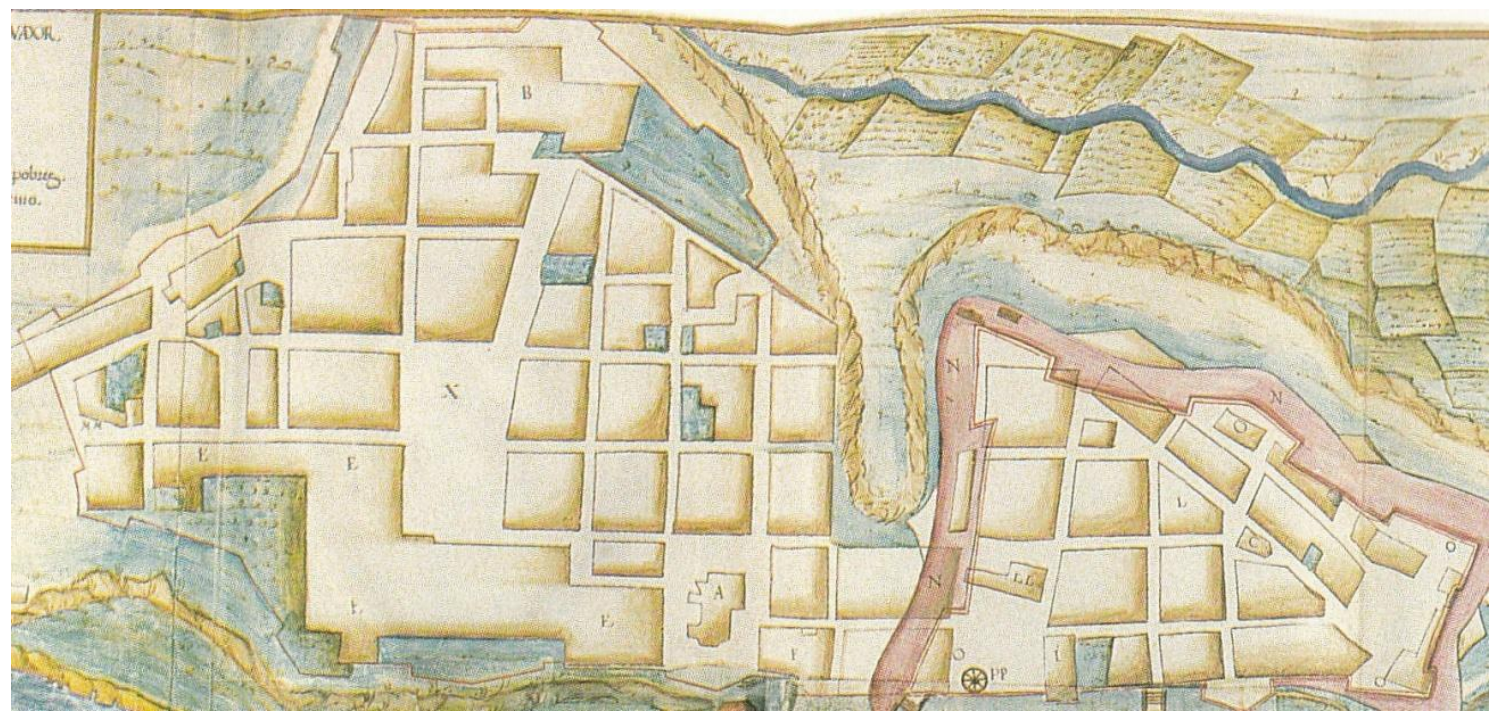

A Pranta... de 1605 mostra a área de quadras já praticamente ocupada nos anos 1580.

Senhora da Ajuda que lhe dava o nome. No âmbito acanhado da cidade não havia espaço para mais" (SAMPAIO, 1949: 139).

478 SOUSA, 1971: 137.

${ }^{479}$ SOUSA, 1971: 138. 
Voltando às "sínteses" de modelos proposta por Manuel Teixeira, a estrutura e os espaços de Salvador teriam sido moldados por uma "síntese de múltiplas referências, vernáculas e eruditas, medievais e renascentistas", o que é verdade, mas que nessa época, com menos de 40 anos, a cidade teria se tornado a "síntese... mais completa e perfeita, de diferentes modelos e concepções de cidade", o que é uma interpretação exageradamente enaltecedora. ${ }^{480}$ Qualquer forma urbana que resulte de mais de uma influência original poderá ser interpretada como "síntese perfeita" na medida em reflete o resultado dessa combinação em seus diferentes níveis, exatamente como se deu em realidade.

O que mais se destaca nesta segunda fase é a malha ortogonal desenvolvida ao redor do Terreiro de Jesus, que passou a ser um novo centro de expansão. As referências formais e de concepção dessas quadras foram os modelos modernos de espaço urbano já seguidos nas primeiras construídas (institucionais e residenciais), definindo o tipo comum usado em crescimentos subseqüentes. ${ }^{481}$

\section{Partido tirado da topografia do local (eleito em função da defesa)}

Manuel Teixeira observa que os traçados urbanos das colonizações portuguesas são característicos de uma "cuidadosa adaptação de modelos urbanos racionais e de traçados regulares às condições topográficas encontradas em cada local". É nesse mesmo sentido que apesar do conhecimento teórico dos engenheiros, seria característico do urbanismo português no Brasil "o pragmatismo das soluções adotadas em cada caso". ${ }^{482}$ Trata-se, convém ressaltar, de um pragmatismo de muita fundamentação e base teórica, como temos discutido.

\footnotetext{
${ }^{480}$ TEIXEIRA \& VALLA, 1999: 227.

${ }^{481}$ A muralha dos anos 1590 (que aparece no desenho em 1605) envolvia praticamente toda a cidade, com uma área cerca de três vezes maior que a original. Como previa Nóbrega, o Colégio e o Terreiro de Jesus já estavam no centro da nova expansão. O bairro à volta do Colégio se desenvolveu ao longo da segunda metade do século XVI (assim como o Bairro Alto em Lisboa), com um traçado claramente ortogonal e mais regular que o do núcleo original. Segundo Manuel Teixeira, haveria três razões para isso: a evolução técnica do urbanismo português (pela consolidação do ensino teórico de arquitetos e engenheiros militares e pelo contato com a urbanística teórica e prática dos italianos renascentistas), a influência espanhola (pela união das coroas) e a influência jesuítica (no traçado do bairro próximo ao Colégio e à volta do Terreiro de Jesus, como deve ter sido em Lisboa, mas com um "significado e implicações mais profundas" em Salvador. Para M. Teixeira, é quase certo que a maior regularidade resultou da combinação desses três fatores.

A divisão dos lotes nos quarteirões do bairro novo também foi regular, com as frentes voltadas para as quatro ruas, formando conjuntos uniformes de medidas idênticas às de Portugal na época (já adotadas desde o séc. XIII). No lado ocidental do Terreiro de Jesus é ainda mais evidente a regularidade de loteamento, com lotes de cerca de 30 palmos de frente $(=6,60 \mathrm{~m})$ determinando uma tipologia habitacional repetida, de dimensões e proporções iguais, com as habituais três fileiras de vãos na fachada, também de mesmas dimensões (essa regularidade pode ainda ser observada no Largo do Pelourinho). O Terreiro de Jesus já foi concebido como espaço regular, e por suas características seria "o verdadeiro elemento gerador da malha urbana envolvente". Não teve características de espaço residual ou marginal, de pouca definição, pois sua importância não vinha só do valor institucional dos edifícios à volta (como era o caso da Praça do Palácio). Tratou-se de uma concepção "radicalmente diferente" e moderna, de espaço e de estruturação urbana (cf. TEIXEIRA \& VALLA, 1999: 226-7 - grifo nosso).

482 TEIXEIRA \& VALLA, 1999: 227. Essa “cuidadosa adaptação" é a mesma defendida por Rafael Moreira (2003: 8-28) em sua denominação de urbanismo "tendencialmente regular". A idéia de que deve haver estudos caso a caso, a critério dos engenheiros, é talvez a mais enfatizada tanto no tratado de Serrão Pimentel quanto no de Azevedo Fortes.
} 
Por essa época já se nota em Salvador uma estrutura resultante da fortificação: a preocupação defensiva que levou à escolha do terreno alto, de topografia acidentada, gerou novas soluções urbanísticas, por meio de ortogonalidades de altura variada e possibilidades específicas de integração da construção à paisagem. Essa prática aberta às possibilidades fez com que Salvador e outras cidades que não eram rigorosamente geométricas em planta apresentassem nos espaços construídos uma grande regularidade, que é ainda ressaltada pela exploração de particularidades locais. É o caso de soluções (todas elas presentes em Salvador) como o aproveitamento de desníveis para valorizar determinados edifícios e monumentos com escadarias, pontuando-se as colinas com igrejas ou conventos e perspectivando-se as ruas em direção a edifícios singulares (como a igreja de S. Francisco).

Para Manuel Teixeira, em Salvador (e outras cidades brasileiras), mesmo obedecendo-se a um esquema geral definido em moldes renascentistas (que traria "unidade e regularidade"), tirou-se partido de acidentes e particularidades do sítio com escolhas às vezes vindas da tradição vernácula (mostrando uma "eficaz construção de raiz", nas palavras dele). A integração e articulação com o esquema ordenador da ordem maior urbana enfatizariam essas particularidades.

No caso de Salvador a tradição vernácula estaria presente, a nosso ver, apenas na técnica construtiva, havendo mesmo uma otimização de seus resultados pela teorização que surgia na Escola de Moços... e, já nessa época, em sua materialização pelo Tratado de Antonio Rodrigues (1576-9), do qual alguns mestres que vieram ao Brasil (mais ligados à Corte) teriam conhecimento.

\section{Participação de ordens religiosas (Terreiro de Jesus e outras áreas)}

Além do colégio jesuíta e do convento franciscano, outros edifícios religiosos foram construídos em Salvador, tornando-se também pólos de crescimento da cidade: o mosteiro dos capuchinhos de Santo Antônio, o convento das carmelitas e o mosteiro de São Bento. ${ }^{483} \mathrm{Um}$ jogo de forças entre os poderes civis e religiosos acabou sendo uma das bases estruturais da cidade, ${ }^{484}$ levando o tecido urbano a se tornar variado na organização administrativa, estrutura de planejamento, forma dos espaços e arquitetura dos edifícios.

Os conventos foram influentes na urbanização de algumas áreas de Salvador, promovendo o povoamento de suas imediações. Como em todo o Brasil, obedeciam a regras pontifícias documentadas de localização que definiam áreas privilegiadas nas quais as outras ordens não podiam se estabelecer, com distâncias mínimas entre os

\footnotetext{
${ }^{483}$ Cf. TEIXEITA \& VALLA, 1999: 226.

${ }^{484}$ As terras eram distribuídas pelas Câmaras Municipais. Nas áreas propriamente urbanas, isso era feito por lotes para construção, e nas extramuros, na forma de "pequenas sesmarias, que iriam dar origem à formação de chácaras" (REIS Fo, 1968: 114). O regime de sesmarias se subordinava a disposições de ordenações do Reino, especificamente do Livro IV das Ordenações Manuelinas. Normalmente era feito pagamento de um foro por essas terras, mas eles tendiam a desaparecer, pois os foreiros sempre tentavam evitar o pagamento. Em Salvador havia concessões de foro sem nenhuma renda: o Regimento de Tomé de Souza diz que... terras dareis livremente sem foro algum. Somente pagarão o dízimo à Ordem de Nosso Senhor Jesus Cristo... (Regimento..., 1998: 15). Geralmente os terrenos intramuros custavam um foro, enquanto nos arrebaldes eram cedidos sem foro ou tributo. Nos dois casos havia exigências, sendo a mais importante a ocupação efetiva da terra com obrigação de feitorias, e no caso dos terrenos intramuros a construção de uma casa em prazo determinado - de quatro a seis meses, ou até um ano - sob pena de perder o terreno. Essas medidas incentivaram a rápida urbanização.
} 
conventos de cada ordem. Essas distâncias variaram no tempo de 140 a 300 vergas (cerca de 520 a 1115 metros) para carmelitas, franciscanos e outros dentro de uma mesma cidade. Só os jesuítas tinham do Papa o privilégio de se estabelecer a menos de 140 vergas de outros conventos. ${ }^{485}$

O Terreiro de Jesus de Salvador foi o primeiro construído no Brasil e a matriz de todos os que vieram depois. Algumas de suas características formais e elementos estruturadores seriam reproduzidos nos séculos seguintes em muitos terreiros e pátios de colégios jesuítas, e nas praças centrais de seus aldeamentos e reduções. ${ }^{486}$ Como em Salvador, os colégios jesuítas eram pólos importantes de crescimento das cidades, com os pátios do colégio ou terreiros de Jesus logo se transformando em praças urbanas de construções ordenadas ao redor. Os princípios estruturantes baseados no predomínio de dois eixos ortogonais aparecem em todas as praças ou terreiros de Jesus das aldeias e colégios jesuítas brasileiros. ${ }^{487}$

Como particularidade, o Terreiro de Salvador, em sua forma quadrangular, é contíguo e está urbanisticamente muito associado ao espaço alongado do Adro de São Francisco pelo fato das igrejas dos dois conventos serem frontais e estarem próximas, o que difere das prescrições sobre distâncias entre conventos e produz o que $\mathrm{M}$. Teixeira chama de "exemplo único de conjugação harmoniosa destes dois tipos de espaços". ${ }^{488}$

${ }^{485}$ Cf. ANDRADE, Francisco de Paula Dias de. Subsídios para o Estudo da Influência da Legislação na Ordenação e na Arquitetura das Cidades Brasileiras. São Paulo (Dissertação para concurso a Cátedra, USP, 1966), p. 87/ TEIXEIRA \& VALLA, 1999: 219. Nem sempre as distâncias eram cumpridas em função da topografia ou limite apertado das cercas urbanas, mas os conventos sempre deixavam distâncias entre si, que na fase inicial das cidades representavam grandes vazios. Isso fazia a cidade crescer de duas maneiras simultâneas: do núcleo urbano inicial em direção aos conventos (que eram os pólos de atração) e a partir deles, desenvolvendo-se ao redor (em suas "áreas de privilégio") pequenos núcleos de urbanização que aos poucos se articulavam.

A centralidade e o poder de atração dos conventos se explicam por ser a única forma de apoio assistencial das populações, além de darem proteção física e de bens em casos de invasão.

${ }^{486}$ Os terreiros jesuíticos, seguindo o modelo de Salvador, geraram nos séculos seguintes os traçados urbanos das vilas originadas de aldeamentos, no Brasil e em outras regiões da América do Sul. Esse novo conceito de estruturação, em que o elemento dominante e gerador da malha era a praça (não mais os edifícios singulares e as ruas que os articulavam) influenciaria não só as fundações jesuíticas, "mas toda a teoria e a prática urbanística portuguesa, civil e militar" (TEIXEIRA \& VALLA, 1999: 227). O conceito evoluiria com casos diversos no século XVII, estando plenamente desenvolvidos nos traçados urbanos do XVIII - joaninos e pombalinos - no Brasil e na metrópole. A decisão de Nóbrega de erguer o colégio fora dos limites murados talvez não se relacionasse só ao desejo de uma área ampla, mas (sem explicitar) para que os jesuítas pudessem desenvolver sua própria concepção de cidade.

${ }^{487}$ Os jesuítas foram uma referência importante para o urbanismo colonial português. $O$ ensino desenvolvido em seus colégios (geometria, matemática, arquitetura, engenharia militar e fortificação) influenciou na formação religiosa dos engenheiros militares responsáveis pelos traçados urbanos. Alguns padres chegaram a ter cargos importantes, como o Padre Falônio, engenheiro-mor do Reino. Além das atividades de ensino, a ação urbanizadora dos jesuítas também teria influenciado a teoria e prática urbanística, sendo referência importante na compreensão dos traçados urbanos regulares no Brasil. Essa influência ocorreu de diferentes modos, destacando-se o papel que tiveram na estruturação de novos bairros residenciais associados a seus colégios (como em Salvador, na segunda metade do século XVI, ou em Lisboa, no Bairro Alto que se desenvolveu nos arredores do colégio de São Roque, também nesse período). Mesmo que os padres não interviessem diretamente no planejamento desses bairros, a presença de sua igreja e colégio já determinava a urbanização das zonas adjacentes.

${ }^{488}$ TEIXEIRA \& VALLA, 1999: 219. Em todo o Brasil, os adros franciscanos têm a forma alongada e são centrados em um cruzeiro, de onde saem as procissões. 

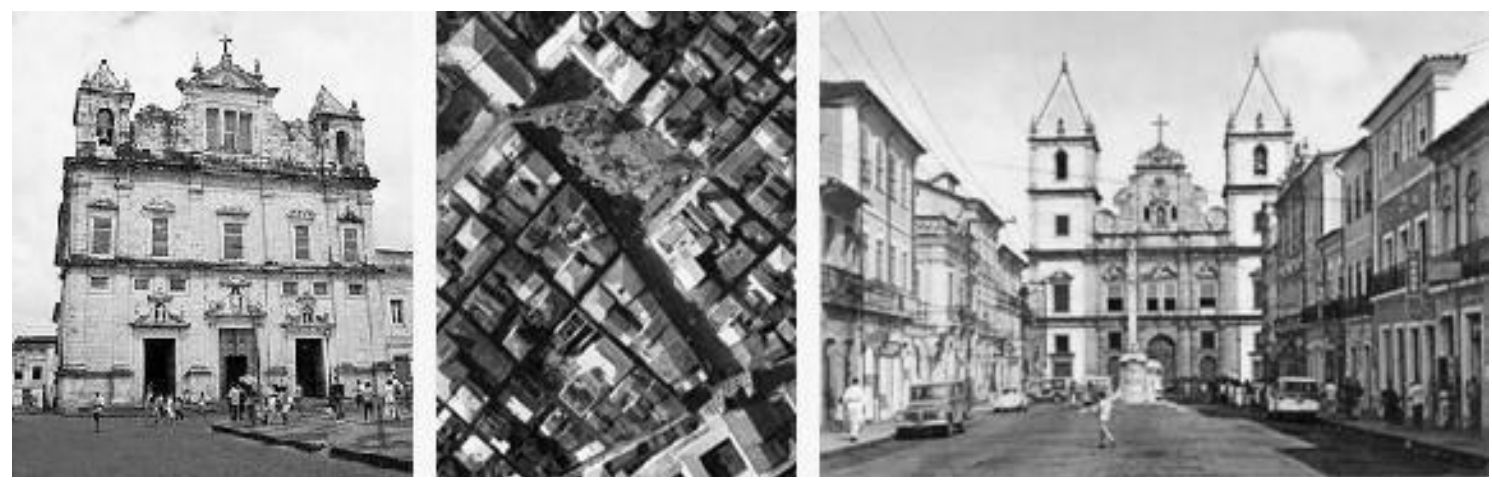

Nas laterais, vistas em perspectiva dos frontispícios da Catedral Basílica (esq.) e da Igreja de S. Francisco (dir.), tiradas do ponto de encontro entre o Terreiro de Jesus e o adro franciscano (em "Google images" e cartão postal antigo - anos 1960). Ao centro, fotografia de satélite (Google, 14/08/10) mostrando a conexão entre essas duas áreas, com as igrejas praticamente de frente uma para a outra (atualmente, está realmente de frente para a Catedral Basílica, do outro lado do Terreiro, a igreja de S. Domingos, havendo ainda em uma das laterais a de S. Pedro). Tanto a Catedral Basílica quanto a Igreja de $S$. Francisco tomaram suas formas atuais no séc. XVII.

\section{Anos 1590: nova muralha e primeiras fortalezas de pedra}

\subsection{Governo de D. Francisco de Souza}

Gabriel Soares mostrou que nos anos 1580 a cidade já estava quase sem defesas:... tem el-rei nosso senhor obrigação de... acudir ao desamparo em que esta cidade está, mandando-a acercar de muros e fortificar... ${ }^{489} \mathrm{O}$ primeiro incumbido da re-fortificação foi Francisco Giraldes, que traria com ele o engenheiro militar Alexandre Massai (ou Alexandre Italiano), que estava a serviço de Portugal. ${ }^{490}$ Mas com problemas nas duas viagens, ele não chegou a assumir o governo, desembarcando em outras partes e desistindo do cargo.

A missão de fortificar Salvador e outros pontos estratégicos coube então a D. Francisco de Souza, que desenvolveu muita atividade nesse sentido. A ele estão associadas obras do engenheiro militar italiano Baccio di Filicaia, ${ }^{491}$ que os principais

\footnotetext{
${ }^{489}$ SOUSA, 1971: 140.

490 Mário Oliveira (2004: 82) observa que Viterbo (1904: 27) se refere a Massai e ao Italiano como se fossem dois, mas eram um só (cf. GUEDES, Lívio da Costa. Alexandre Massaii, corógrafo e engenheiro militar. Boletim do Arquivo Histórico Militar. 1988, v. 57, p. 67-82 - Viterbo cita o decreto em que ele é designado a vir o Brasil sem lembrar que Giraldes não chegou a assumir o governo). Na Addenda et Corrigenda de Viterbo (p. 152-461) há informações biográficas sobre esse engenheiro militar, sobrinho de Pedro Casale e casado com uma das filhas de Nicolau de Frias.

491 Alguns documentos associam a administração de D. Francisco de Souza ao nome de Baccio di Philicaia, Filicaia ou Filicaya (aparecem diferentes grafias; Margarida Valla usa Filicaccia - TEIXEIRA \& VALLA, 1999: 133), italiano da Toscana (Florença) que esteve na Bahia a serviço do Rei de Portugal no fim do século XVI, a quem se atribui a autoria do fortim de Monserrate (antigo Castelo de S. Filipe), que manteve sua versão original. Também pode ter participado de uma das antigas versões do Forte de Santo Antônio da Barra, do reduto de S. Alberto e da Torre de Santiago em Água de Meninos. Ele foi provavelmente o primeiro a receber o título de Engenheiro-mor do Brasil, dado depois a Frias de Mesquita (a pouca informação sobre a participação dos engenheiros nas primeiras fortificações talvez se explique pela queima de arquivos e outros papéis da Câmara na rendição dos holandeses em 1625).
} 
autores dizem ter contribuído na edificação de quatro fortalezas de pedra e cal, ${ }^{492}$ e que acreditamos ter também acompanhado a construção das novas muralhas, definindo a cerca abaluartada que aparece nas primeiras imagens do século XVII.

Baccio di Filicaia estava entre os técnicos trazidos para a melhoria das defesas, sendo possivelmente quem projetou suas fortificações. Nas palavras de Frei Vicente Salvador, D. Francisco fez três ou quatro fortalezas de pedra e cal, ${ }^{493}$ o que incluiria a de Monserrate, de desenho mais sofisticado, seguramente de Filicaia. Seriam quatro fortalezas, das quais duas já estariam iniciadas (provavelmente as fundações) no governo de Telles Barreto (1583-7), marcando as extremidades da grande enseada: Forte de S. Antonio e Forte S. Philipe (na grafia de Albernaz). As outras duas eram fortins à beira-mar, o Forte de Santo Alberto e o Forte de Santiago (idem).

Entre as poucas informações sobre Filicaia estão as notas de Capistrano e Garcia para a História Geral... de Varnhagen, com a transcrição de duas de suas cartas ao Grão-Duque Ferdinando I da Toscana e uma em que é recomendado por este ao Conde Orso, seu embaixador na Corte da Espanha. A correspondência (encontrada pelo pesquisador italiano Giácomo Gorrini) também menciona um relatório de Filicaia a Ferdinando I, que traria muitas informações, mas que não foi encontrado (cf. VARNHAGEN, 1962: II, 85: "Outro companheiro de D. Francisco foi Baccio de Filicaya, gentil-homem florentino de que se tem notícia através de uma comunicação do Dr. Giàcomo Gorrini, inserta nos Atti Del Congresso Internazionale di scienze storiche com o título: Um viaggiatore italiano nel Brasile - Baccio di Filicaja [1565-1609]" [Roma, 1903, v. X, p. 39-54, de onde foram copiadas as duas cartas]).

A correspondência mostra que Filicaia viveu jovem em Lisboa, colaborando em negócios da família. Por razões econômicas voltou à pátria e se apresentou ao Grão-Duque da Toscana, seu protetor. Na volta a Florença, quis redirecionar a vida:... como os negócios andassem muito calamitosos e eu muito inclinado às virtudes da matemática do que a eles, para não desviar-me, pus-me a aprender a arquitetura militar, artilharia e cosmografia, favorecido e incitado por excelentíssimos mestres que por $V$. A. Sereníssima são continuamente estipendiados; e com o decurso do tempo, vendo que a teoria me podia muito pouco sem a prática resolvi a sair fora e a correr mundo, buscando lugar onde pudesse por em execução este meu desejo, para depois de bem exercitado tornar à pátria... (apud VARNHAGEN, 1962: II, 85-8 - grifo nosso). Como em Florença trabalhavam grandes nomes da engenharia militar, Filicaia tentou a sorte em outras partes, embarcando para Portugal e depois para o Brasil. Pelo que informa, não veio com D. Francisco de Souza (1591-1602), mas chegou durante o seu governo, servindoIhe por cinco anos e por seis outros anos, provavelmente depois que D. Francisco foi para o sul (em outubro de 1598, não mais voltando para governar - não há contradição entre esses seis anos terem sido no governo de Diogo Botelho [1603-7] e as cartas que escreveu já em Portugal [1608-9, ano em que faleceu, segundo Gorrini]). Com o cargo de Engenheiro-mor recebido de D. Francisco, visitou várias partes do Brasil, restaurando diversas fortificações e construindo algumas novas. Também recebeu de D. Francisco o cargo de Capitão de Artilharia, acomodando toda a artilharia de ditas praças fortes (s/ ref. - apud OLIVEIRA, 2004: 93).

No governo de Diogo Botelho, foi para as conquistas do Maranhão e Amazonas, sendo sargento-mor de uma tropa sob o comando geral de um militar português (que não diz o nome), onde participou de combates a índios. No fim da estadia no Brasil foi parar no Caribe por causa de um problema no navio (1607). Voltando a Lisboa, escreveu a Ferdinando I pedindo apoio para voltar ao Brasil em companhia de D. Francisco de Souza, que recebera outra missão, mas faleceu antes.

492 Cf. OLIVEIRA, 2004: 64 O envolvimento de Filicaia é citado por outros além de Varnhagen, mas para Mário Oliveira não há prova documental: as cartas enviadas e recebidas por Filicaia (encontradas pelo pesquisador italiano Giaccomo Gorini) falam de um relatório de suas atividades no Brasil entregue a Ferdinando I, Grão-Duque da Toscana, mas que não foi encontrado. Oliveira, no entanto, vê sentido em atribuir a ele os projetos das fortalezas do fim do século XVI, já que Frei Vicente Salvador (1965: 311) diz serem construções da época de D. Francisco de Souza, que era acompanhado de Filicaia, autor dos projetos ou partícipe nos traçados e obras.

${ }^{493}$ SALVADOR, 1965: 311. 
Edgard Falcão inclui como construção da época o fortim de São Francisco, no lado norte da ribeira próxima à cidade. ${ }^{494}$ Justifica pela construção da Torre de Santiago em ponto eqüidistante entre ele e o de Monserrate, mas não consideramos que haja consistência nessa hipótese, preferindo falar do fortim de S. Francisco como feito em outra gestão. Por sua vez, Teodoro Sampaio inclui como obra de D. Francisco de Souza (além dos quatro mais importantes, Santo Antônio da Barra, Monserrate, Santo Alberto e Santiago) o forte de S. Bartolomeu, na Ponta de Itapagipe, para controlar a entrada marítima da região. ${ }^{495}$ Mas segundo M. Oliveira há pouco fundamento nisso: "se qualquer coisa existiu, foi alguma trincheira provisória". ${ }^{496}$

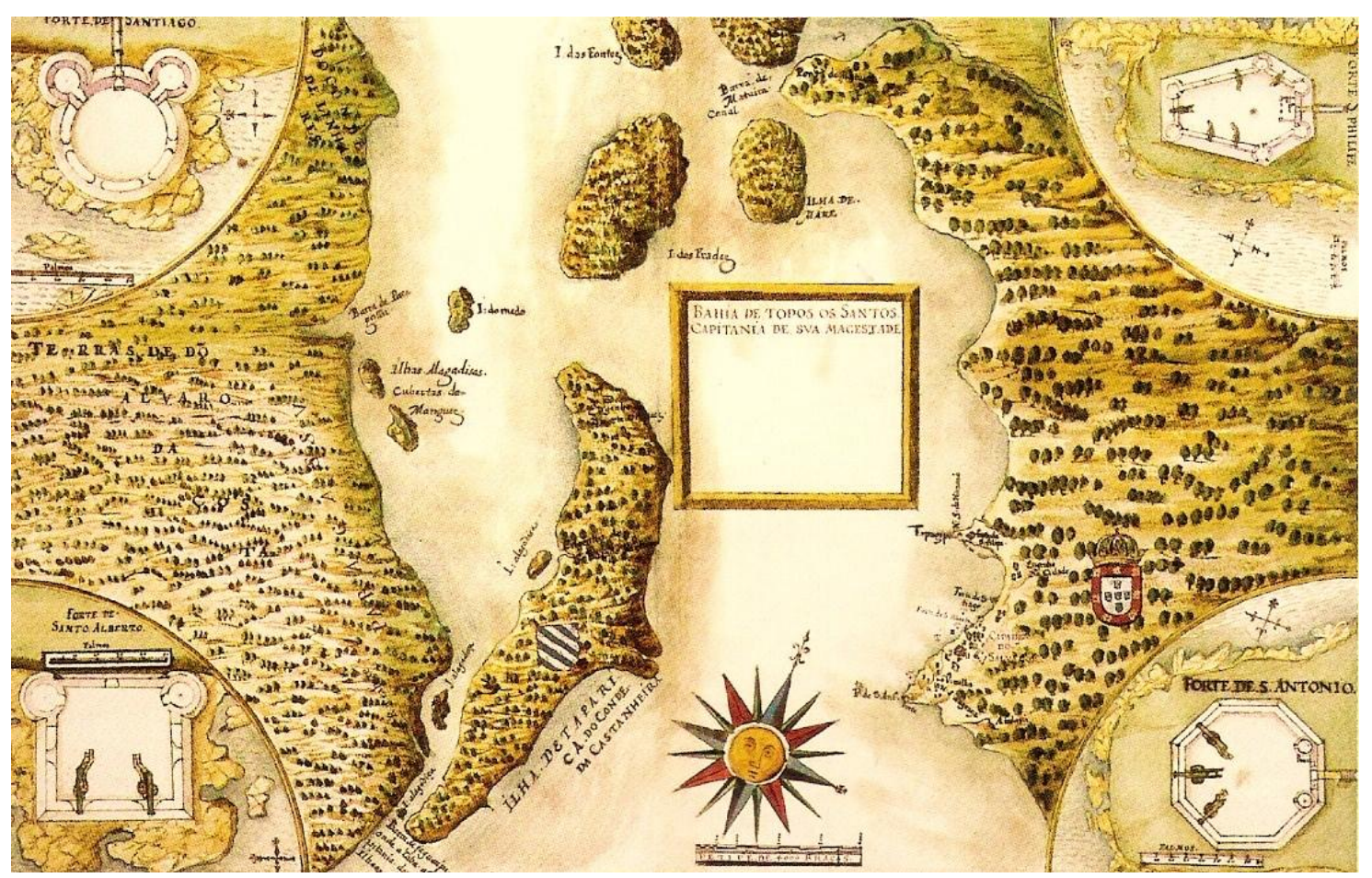

As prováveis quatro fortalezas dos anos 1590 foram desenhadas por Albernaz nos cantos da carta BAHIA DE TODOS OS SANTOS CAPITANIA DE SVA MAGESTADE (em Atlas do Estado do Brasil..., 1997: fl. 21).

D. Francisco de Souza teria ainda dado o acabamento em alvenaria aos antigos redutos, além de refazer os muros de taipa da cidade.

\section{Muralha expandida}

Como se observa, os anos 1590 praticamente coincidem com a gestão do governador Francisco de Souza, que por ser longa (1591-1602) favoreceu a realização de importantes obras de defesa (dando continuidade aos empreendimentos). Mário Oliveira se refere em duas passagens à reconstrução das muralhas nesse governo, embora não explicite no livro a fonte de informação. ${ }^{497} \mathrm{Em}$ uma delas, ao mencionar a

\footnotetext{
494 Cf. FALCÃO, 1942: 44. Seria da época de D. Francisco “... a feitura de mais três fortins à beira-mar: Santo Alberto e São Francisco, mas imediações e ao norte do da Ribeira, e São Tiago d'Água de Meninos, a igual distância entre este último e o de São Felipe".

${ }^{495}$ Cf. SAMPAIO, 1949: 294.

496 OLIVEIRA, 2004: 235.

497 Muito criterioso, M. Oliveira se apóia em documentos em quase todas as suas informações (neste caso ele confirmou por e-mail haver base documental, mas não pôde localizá-la naquele momento).
} 
queda dos muros de Luiz Dias, diz: "mesmo as que foram reconstruídas por D. Francisco de Souza, no final do século XVI, com a mesma técnica [taipa de pilão rebocada de cal], duraram pouco" ${ }^{498} \mathrm{Na}$ outra, ao mencionar as quatro fortificações de pedras erguidas naquele governo, diz: “... além de fazer, novamente, muros de taipa para a cidade". ${ }^{499}$

Entendendo-se que a muralha construída na época de Francisco de Souza é a que aparece nas gravuras do século XVII, ela seria, portanto, diferente da que marcava o perímetro inicial (da qual, nos anos 1580, Gabriel Soares dizia não haver memória aonde... estiveram). Seriam delaos únicos vestígios encontrados no século $\mathrm{XX}$, de um trecho próximo a onde estariam as Portas do Carmo, como afirma M. Oliveira. ${ }^{500} \mathrm{~A}$ sua forma abaluartada, que associada à geometria das quadras caracteriza a cidade renascentista, desta vez, na fase de ampliação, está atestada principalmente pelos registros cartográficos (ou iconográficos em geral) que se preservaram. Na mais antiga gravura da cidade (1605), nota-se bem a muralha em forma de baluartes. Trata-se de projeto, a nosso ver, somente a cidadela, correspondente à parte em que se iniciou a construção da cidade, voltando a ser cercada. Acreditamos que em todo o resto, demarcando o perímetro oficial da cidade nos anos 1590, a muralha deva ter sido de fato construída, abandonando-se depois a conservação em função dos muitos desabamentos (e por questionamentos sobre sua necessidade, que relacionamos à sempre presente economia de meios).

Se para os fortes da época é quase certa a autoria do engenheiro militar florentino Baccio di Filicaia, braço direito de D. Francisco, conjecturamos não só que essas muralhas tenham sido efetivamente construídas nos anos 1590 (talvez com qualidade precária, mas pelo traçado em que aparecem nas várias imagens), mas que tenham sido previamente desenhadas e acompanhadas por ele em sua construção, depois de um estudo possivelmente criterioso.

Aproveitamos essa passagem para fazer uma conjectura ainda mais ousada, levando em conta o grande aprimoramento técnico dos portugueses na representação em desenho. Das duas versões da planta mais antiga de Salvador (1605), a da Biblioteca do Porto é aquela em que se vê melhor a aquarela avermelhada, que representa o projeto da cidadela "assinalada" pelo fosso. Repara-se ali uma sobreposição no que seriam áreas existentes. ${ }^{501}$ Descartando-se a hipótese de que os limites da cidade sobrepostos na representação do fosso à volta da nova muralha (aquarela vermelha) sejam obras externas (eventualmente revelins), conjecturamos que representariam o traçado então existente das muralhas, tal como executado no governo de Francisco de Souza (sob orientação de Baccio di Filicaia, como supomos). Esta parte é que estaria sendo aprimorada (refeita) na Pranta... de 1605. Na questão

\footnotetext{
498 OLIVEIRA, 2004: 56. Efemeridade que também teria como motivo o “castigo" das chuvas.

499 OLIVEIRA, 2004: 179. Teodoro Sampaio também cita essa reconstrução (cf. SAMPAIO, 1949: 293).

500 Lembrando que para a muralha de Luiz Dias há apenas "conjecturas", M. Oliveira diz que "não foram encontrados testemunhos além de um trecho de muralhas nas portas do Carmo" (OLIVEIRA, 2004: 56 grifo nosso). Neste caso ele se refere aos antigos muros em geral (se fosse aos primeiros, teria aderido às teses de Edison Carneiro e Rafael Moreira), tanto que por e-mail (de24/11/2010) informou que... "os muros que restaram na Porta do Carmo (dentro de um dos edifícios do SENAC)... não são de taipa". São provavelmente os mesmos restos a que Rafael Moreira se referiu por e-mail: "Paulo Ormindo descobriu restos de uma, que se pode visitar, e tem um bom artigo de jornal".

${ }^{501}$ Também se nota que a linha que representa as novas muralhas (projetadas) é que foi reproduzida na interpretação de autores importantes (Teodoro Sampaio e Manuel Teixeira) sobre o traçado inicial.
} 
do fechamento inicial, chegamos a fazer seguinte representação gráfica para um perímetro menor do núcleo urbano inicial, na suposição (duvidosa) de que o traçado pudesse coincidir com o dos muros iniciais de Luiz Dias:
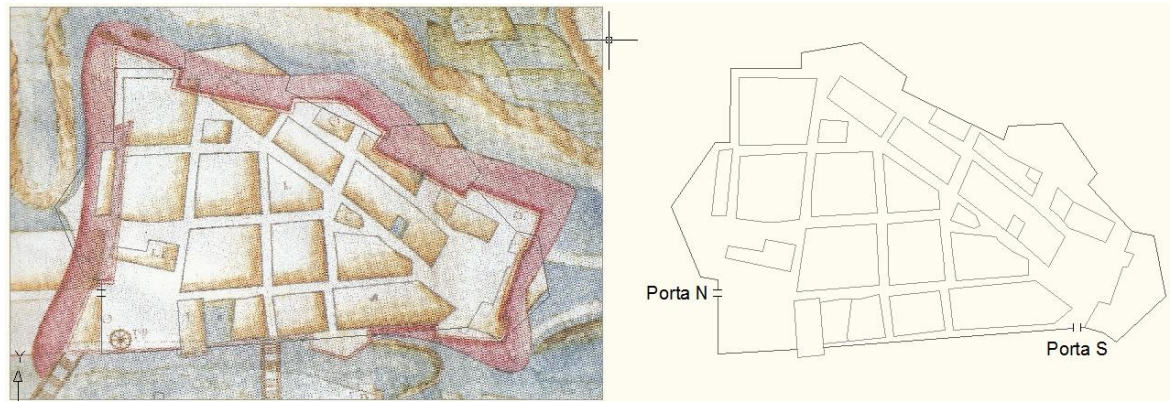

À esquerda, exercício em desenho por cima da gravura de João Teixeira Albernaz, PRANTA DA ÇÍDADE D. SALVADOR... (detalhe da parte mais antiga), de c. 1605 (em REIS Fo, 2000: 17). À direita, o resultado desse exercício, sem a referência, para um suposto perímetro inicial ${ }^{502}$

Logo desistimos dessa hipótese, por acharmos mais lógico (principalmente a partir da troca de e-mails com Rafael Moreira) que já se tenha partido da idéia de uma cidade mais ampla, com uma cerca provisória delimitando e fortificando a área urbana inicial, mas que não teria o aspecto de um muro com baluartes. Pode-se reparar, no entanto, que os dois baluartes voltados para a face leste (interior) aparecem em muitas plantas e representações da Cidade do Salvador na primeira metade do século XVII, notando-se claramente pela Planta de Restituição... (c. 1627) que os baluartes de cima correspondem exatamente à localização dessas aparentes obras externas.

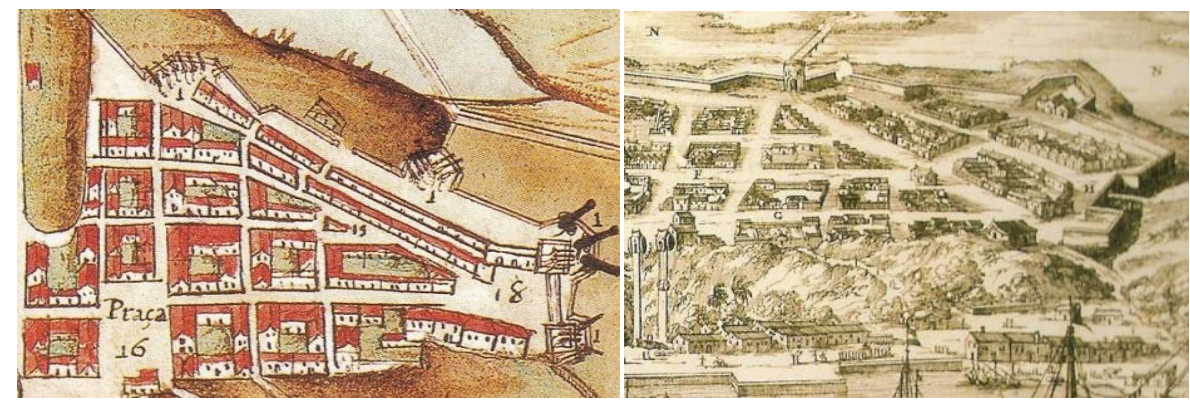

A Planta de Restituição da Bahia e a gravura que ilustra o livro de Montanus, representando a cidade em $1625 .^{503}$

\footnotetext{
${ }^{502}$ A colocação da Porta Sul voltada para o Porto se baseava nos caminhos sugeridos nesta e em outras imagens. Na época de Luiz Dias, o primeiro acesso liga a cidade apenas ao Porto e suas adjacências (como a primeira igreja de N. S. da Conceição da Praia).

Embora tenhamos desistido dessa hipótese, destacamos que ela responderia à descrição de Gabriel Soares de... dois baluartes ao longo do mar e quatro da banda da terra... Para Mário Oliveira não é certo que estejam incluídos aí os dois baluartes da praia (Gabriel Soares poderia estar falando apenas da face voltada para a baía, como interpretou Teodoro Sampaio), mas uma referência para se interpretar a expressão "banda de terra" de Gabriel Soares, que se oporia a uma "banda do mar", é o uso semelhante feito por Luiz Dias, que é de sentido inequívoco: E nela verá de banda do mar, digo da Ribeira do Góis uma estância de madeira, digo fez Pero de Góis porque lhe disse o Governador que pusesse o seu trabalho e o da sua gente e que se chamaria o Baluarte de Góis... (Carta a Miguel de Arruda de $13 / 07 / 1551$, op. cit.). Os quatro baluartes em terra citados por Gabriel Soares, três dos quais nomeados por Luiz Dias (diferenciando-se, neste caso, o de S. Jorge do baluarte da Ribeira) seriam assim os dois de cima (que estão destacados em várias gravuras), o colado à Porta de Santa Luzia (depois transformado em dois, a partir do projeto de cidadela) e o colado a uma suposta Porta de Santa Catarina provisória.
} 
Entendemos que a muralha redesenhada na Planta com o objetivo de fortificar com mais eficiência a cidadela não foi uma obra executada (havia outras prioridades, como a construção de fortes). Assim, seria a muralha reconstruída por Francisco de Souza a que aparece em gravuras posteriores à ocupação holandesa (e bem posteriores à Pranta..., que era um projeto). Em relação à diferença, no lado sul, entre o desenho apresentado (o baluarte único com a porta ao lado) e as gravuras da Restituição e do livro de Montanus, ela se explicaria por ter sido esta a única parte reconstruída, ou modificada, a partir da Pranta... de 1605.

Foi em consideração a essa possibilidade que acrescentamos esse detalhe no desenho da página seguinte, sobre o que seria a cerca abaluartada dos anos 1590.

Sobre os testemunhos de uma muralha existente no início do século XVII, provavelmente construída nos anos 1590, embora se possa discutir sempre a credibilidade das fontes, há uma descrição de Salvador feita em 1611 por Francisco Pyrard que diz categoricamente: É esta cidade cercada por muros e bem edificada. ${ }^{504}$ Rafael Moreira, ao comentar que Luiz Dias previu que sua muralha já rebaixada e rebocada a cal não deveria durar vimte annos, dá razão ao Mestre das Obras... e diminui a importância desse testemunho, afirmando que...

... todo o circuito amuralhado, por aluimentos sucessivos provocados pelas chuvadas, acabou por desaparecer (já mal se via em 1570, embora Pyrard de Laval, que por ali passou em 1610, ainda a diga cercada) e foi achado inútil a sua reconstrução. ${ }^{505}$

503 Há, portanto, uma grande coincidência na posição dos baluartes desenhados na "Planta da Restituição da Bahia" (Atlas... de 1631), indicando que as pontas (para alguns, revelins, ou sobras de terreno - a forma geométrica é que sugere que fossem revelins, ou obras antigas) desenhadas sob a aquarela que representa o fosso projetado talvez fossem os baluartes construídos nos anos 1590 .

${ }^{504}$ PYRARD, 1944: 228. As informações mais importantes sobre Salvador estão nos seguintes trechos: “A cidade de S. Salvador é um sítio muito alto, no topo de uma alta montanha de difícil acesso e que do lado do mar é talhada a pique. Tudo quanto ali se leva ou dali sai, sobe ou desce somente por meio de um certo engenho maravilhoso; e não se usam ali carretas, porque seria mui difícil e dispendioso, mas por meio daquela máquina custa pouco./ Nas fraldas da montanha [Cidade Baixa], em extensão de mais de um quarto de légua, há casas bem fabricadas de uma e outra parte, formando uma bela e grande rua, bem povoada de toda a sorte de lojas de misteres e artífices. É ali que estão situadas todas as tercenas e armazéns de carga e descarga das mercadorias, assim de El-Rei como de particulares. E não se fazem subir à cidade por aquele engenho, que disse [elevadores], as mercadorias, senão à proporção que se distribuem e vendem. Porque para pôr lá em cima uma pipa de vinho custa vinte soldos e outro tanto para pôr em baixo, de sorte que são quarenta soldos o custo de cada giro, porque quando se leva acima uma pipa ou outra coisa pesada, vem para baixo outra do mesmo peso ao mesmo tempo e é como os baldes que sobem e descem num poço (p. 227)./ É esta cidade cercada por muros e bem edificada. É bispado e há nela um colégio de jesuítas, afora os que há nos campos; um convento de franciscanos; um de S. Bento; um de Nossa Senhora do Carmo; que todos são casas e igrejas bem feitas e bem edificadas. Cada dia se converte ali grande número de pessoas... (p. 228) Enquanto ao mais, os portugueses governam-se no Brasil em tudo como em Portugal e não como nas Índias orientais. El-Rei de Espanha sustenta na cidade de S. Salvador três companhias de infantaria, de cem homens cada uma, das quais entra cada dia uma de guarda ao palácio do vice-rei ou governador do Brasil” (idem). Observa-se que com essas companhias não seria mesmo possível deter os holandeses, que chegaram com cerca de 1.700 homens.

505 MOREIRA, 2003: 43. É na frase em seqüência que Rafael Moreira, tendo como apoio "os dois preciosos desenhos do recifense Cristóvão Álvares", acende-nos a percepção de uma grande mudança ocorrida nessa época, começada pelos fortes de pedra e cal dos anos 1590 e consumada no Plano de 1605: "Passou-se, assim, da tradição medieval da 'cidade fechada' para um sistema mais dinâmico de fortes ligados entre si, numa concepção já barroca de defesa avançada". 


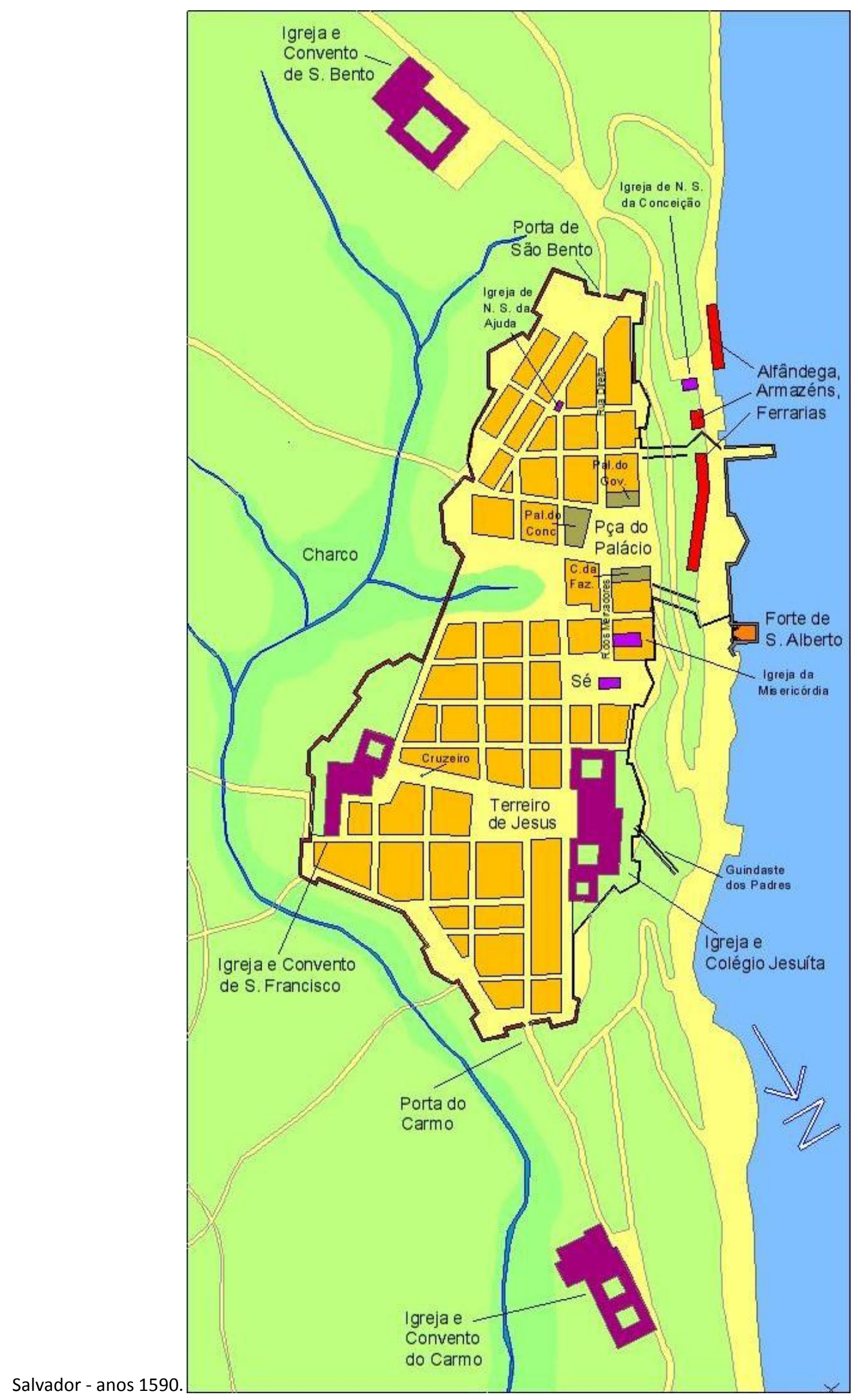


Mas entendemos aqui que a muralha testemunhada por Pyrard já não era a de Luiz Dias (que "mal se via em 1570") e sim a do governo de Francisco de Souza. Podemos também citar uma frase de Vieira sobre a retomada de Salvador (1625), quando depois de alguns dias da chegada da armada espanhola... começou a bateria formada e mui furiosa a varejar de todas as partes da cidade, derrubando grande parte do muro e muitas casas... ${ }^{506}$

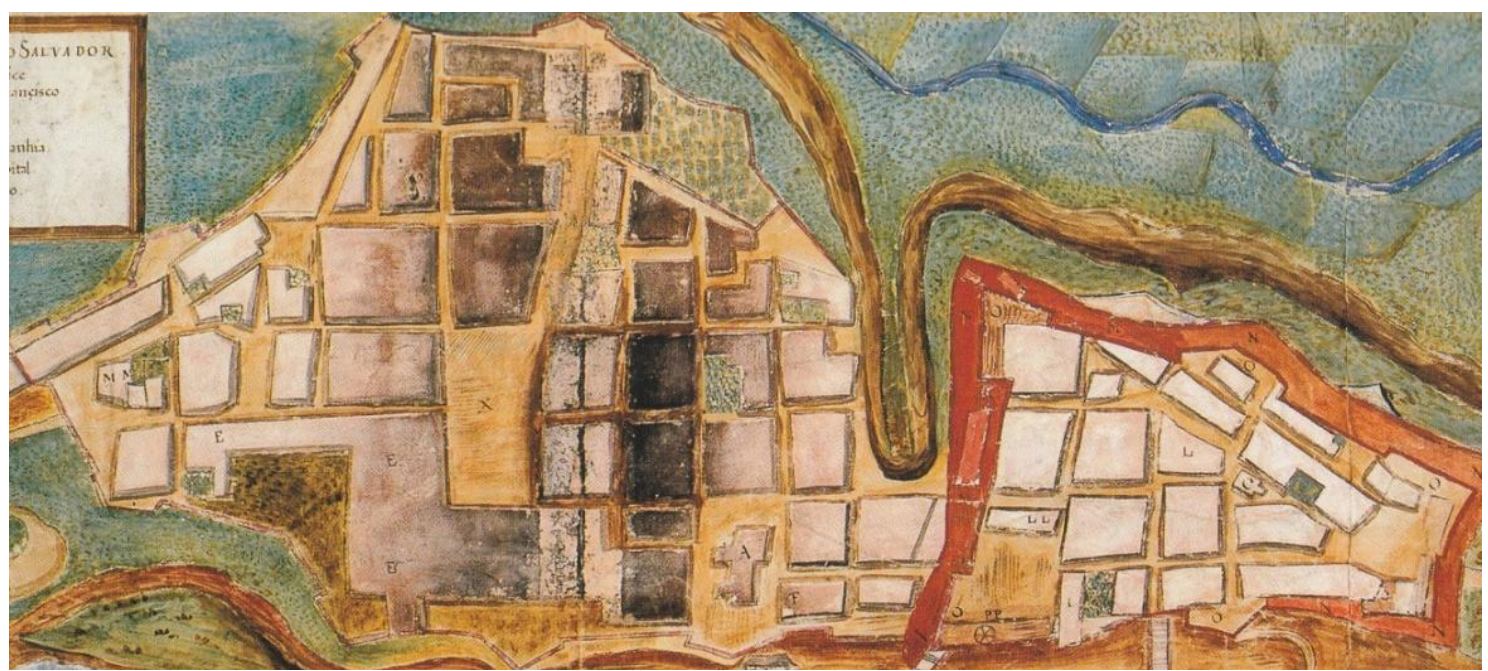

Detalhe da muralha em forma de baluartes na Pranta da Çidade do Salvador... de c. 1605 na cópia manuscrita do IHGB (c. 1626 - em REIS Fo, 2000: 18)...

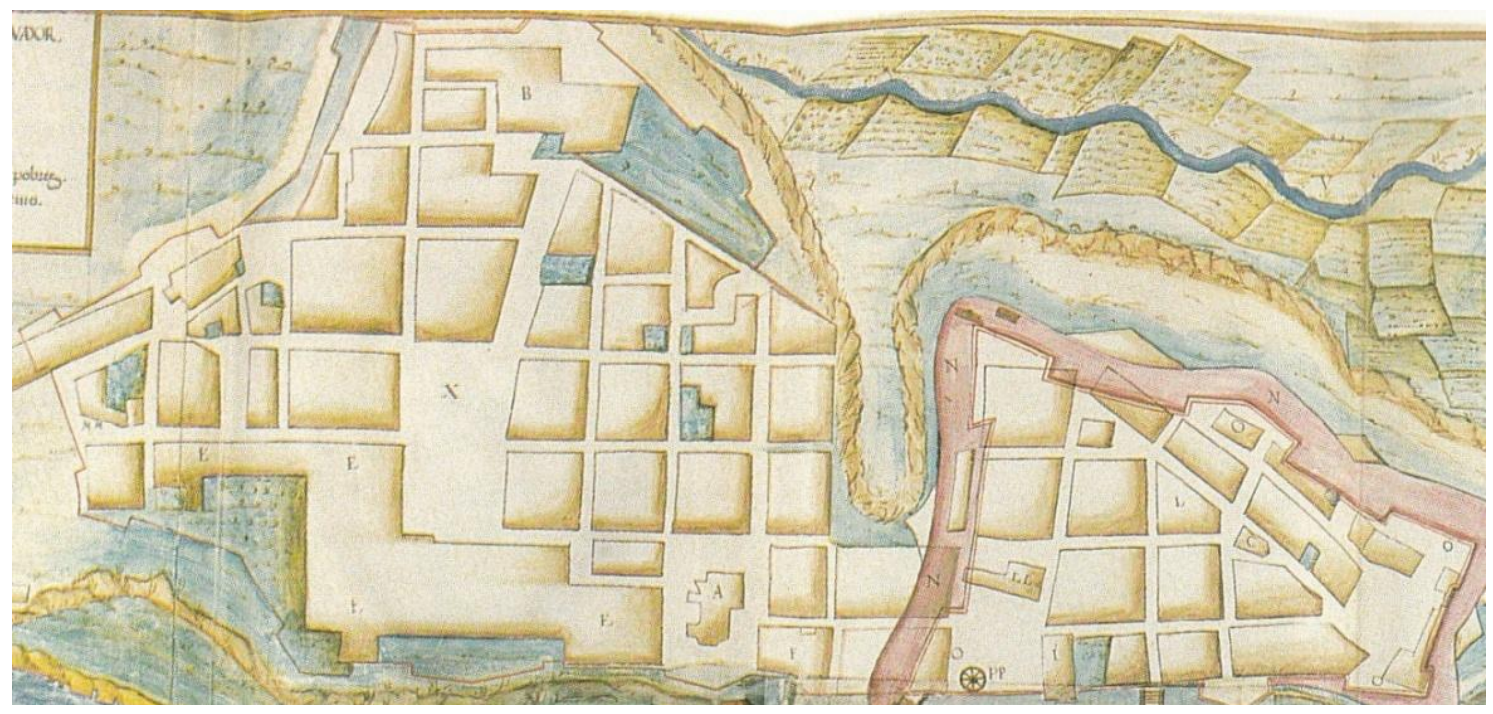

... e da Biblioteca Pública do Porto (c. 1616 - em REIS Fo, 2000: 16-7). Especificamente em relação ao traçado da cerca, há uma pequena diferença entre as duas plantas no trecho entre o brejo que separa as duas partes da cidade e a área do mosteiro de São Francisco.

Os baluartes são ainda mais visíveis na Planta de Restituição da Bahia (1625) e na Urbs Salvador (livro de Montanus).

${ }^{506}$ HANSEN, 2003: 100. 


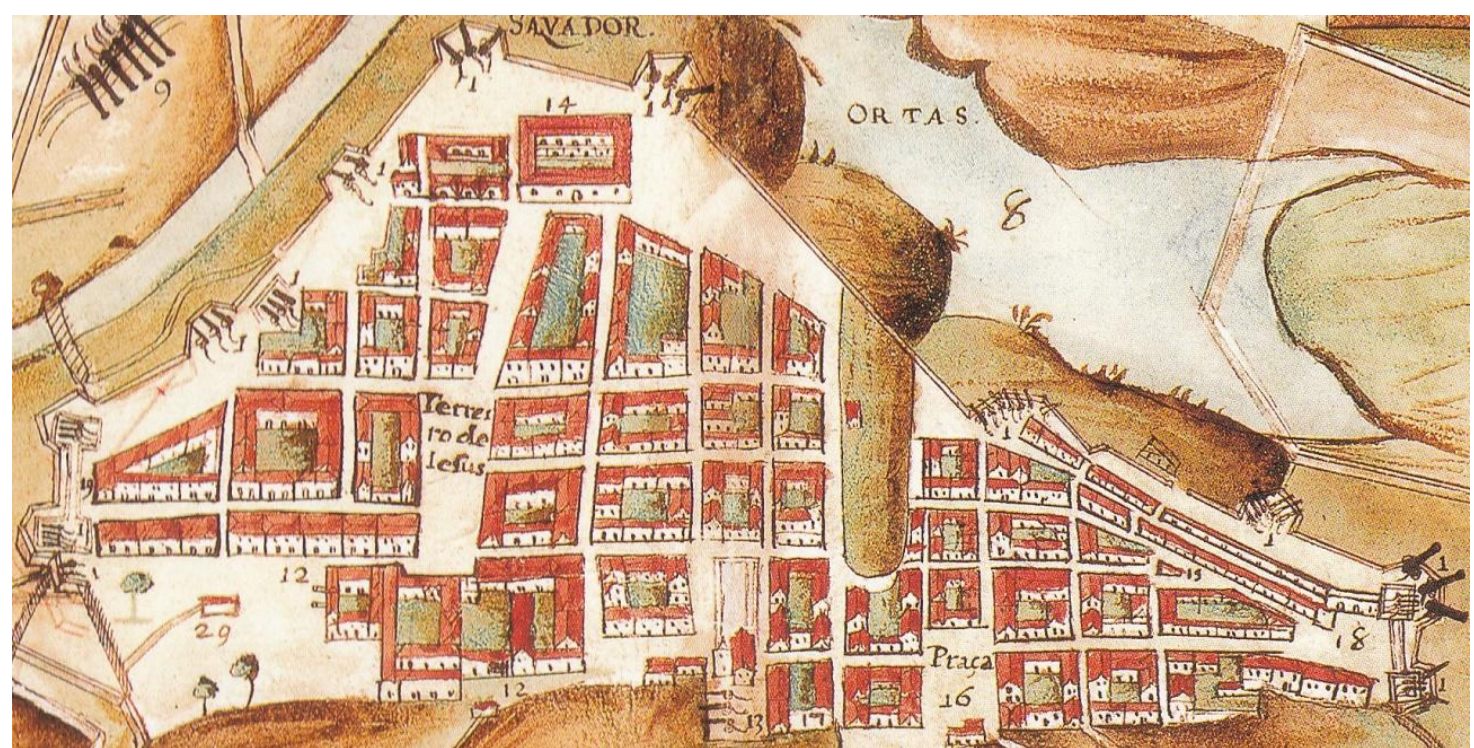

Planta da Restituição da Bahia, desenho de João Teixeira Albernaz I que integra a coleção de1631 (em Atlas..., 1997: 22). ${ }^{507}$

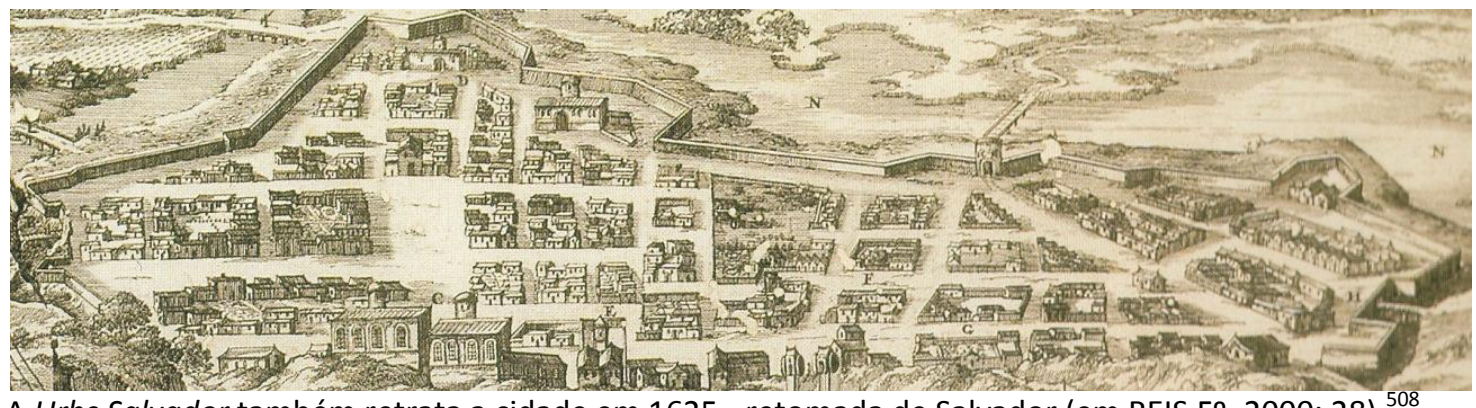

A Urbs Salvador também retrata a cidade em 1625 - retomada de Salvador (em REIS Fo, 2000: 28).

\section{Porta do Carmo}

Como parte da nova muralha construída nos tempos de Dom Francisco de Souza, haveria essa Porta, como acreditamos, já nos anos 1590. É também o que afirma Silva Campos, dizendo que só há base documental de sua existência nessa época ("já existia em fins do século XVI"), aparecendo depois no Livro da Rezão... (1612) ainda com o nome Portas de Santa Catarina. Como mostram os desenhos, ela representava o extremo norte da cidade, dando acesso ao caminho que levava a Água de Meninos. Sabe-se que era simples, de taipa de pilão, até ser substituída na gestão de Gaspar de Sousa (1612-17) por outra de pedra e cal, obra paga e conduzida pelo Capitão-mor Baltazar de Aragão (rico e famoso senhor do Engenho Mataripe), quando se temia um ataque francês (1613). ${ }^{509}$

\footnotetext{
${ }^{507}$ Ela ilustra a vitória luso-espanhola sobre os holandeses. É a mesma cidade da Urbs Salvador (do livro de Montanus, que colocamos a seguir) e de uma gravura de Mealius, tendo provavelmente a mesma fonte informativa. Entre outros detalhes, a legenda sobre o Dique diz ser obra dos holandeses para ampliar as defesas: $p .^{a}$ fota. ${ }^{\text {Iza }}$ da Cite (cf. REIS Fo, 2000: 27 e 313).

${ }^{508}$ É uma estampa avulsa do Itamarati (RJ), talvez espanhola (as legendas estão em latim e as muitas imprecisões - a Casa de Câmara e Cadeia é indicada como Carcer, o Colégio de Jesus está em cota superior à das casas à volta do Terreiro - indicam não ser portuguesa). Cf. REIS Fo, 2000: 313.

${ }^{509}$ Cf. CAMPOS, 1940: 266.
} 


\subsection{Fortalezas da época - atribuídas a Baccio di Filicaia}

\section{Forte de Santo Alberto (desaparecido no século XVII)}

O antigo forte (fortim ou torre) de Santo Alberto é um dos que aparecem nos cantos da cartografia de Albernaz, ${ }^{510}$ o que mostra sua importância. Teria a forma quadrangular e duas torres de canto na entrada, assemelhando-se a uma torre de base quase quadrada. No relatório de Diogo Moreno (1609) ele aparece como obra da administração de D. Francisco de Souza. ${ }^{511}$ Pela representação se nota que era uma obra pequena, com cerca de 50 a 60 palmos de comprimento (11 a 13,20 m), podendo acomodar duas plataformas de artilharia trabalhando em direções opostas.

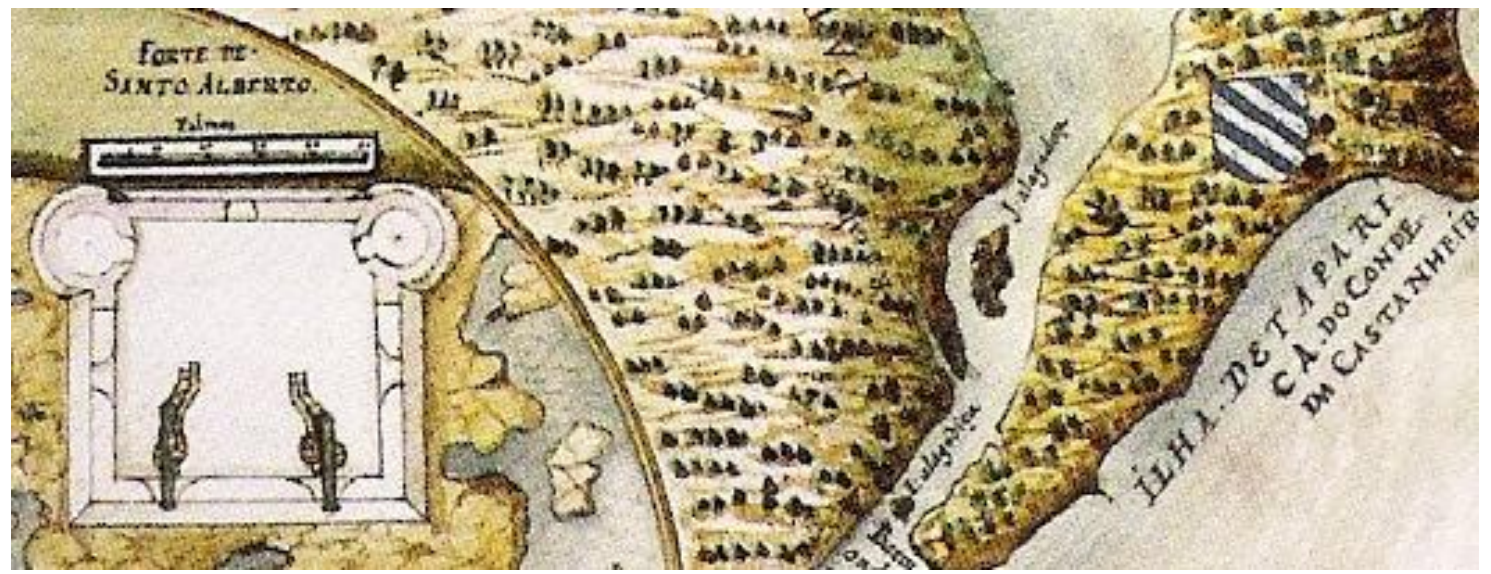

Detalhe de canto na cartografia atribuída a Albernaz I (Atlas..., 1997: fig. 21)

Por outro lado, a gravura de Gerritsz mostra uma construção de dois andares, com as pequenas torres cilíndricas do desenho representadas como se ficassem para fora das linhas do parapeito.
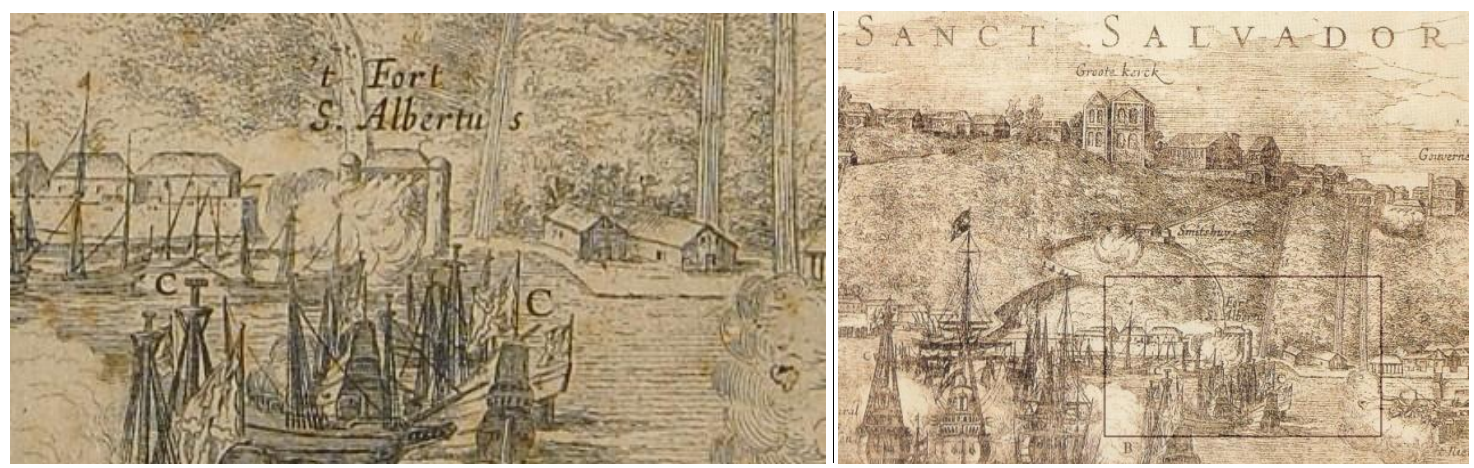

Detalhe da gravura Sanct Salvador, de H. Gerritsz (c. 1627, BN Seção de Iconografia), mostrando o Forte (ou Torre) de Santo Alberto (a figura à direita serve para mostrar a localização desse detalhe na estampa, que é mais rica do que outras em detalhes construtivos - sobretudo na ribeira -, mas de leitura não tão simples, identificando-se as posições artilhadas pela fumaça dos disparos).

A feição pode ter sido ainda outra. Era um reduto de pouco poder de fogo, com apenas duas troneiras voltadas para o mar e duas flanqueando. Essas duas

\footnotetext{
${ }^{510}$ Em Atlas do Estado do Brasil..., de 1631, sendo os desenhos um pouco anteriores.

${ }^{511}$... esta Santo Alberto instancia de pedra e cal que fes Don fran ${ }^{c o}$ de Souza con tres pessas de bronze... (Relação das praças..., fl. 27 - ANTT).
} 
representações mostram que era um forte construído à beira d'água, apoiado em afloramento rochoso que adentrava o mar. $O$ edifício foi demolido na segunda metade do século XVII: em portaria de 1673, o Governador Geral mandava o Provedor "ir ver" o Forte de Santo Alberto (expressão que sugere uma condenação), podendo-se notar pelo texto o seu estado precário:

Porquanto sou informado que na praia desta cidade, está um sítio que antigamente foi forte (a que chamam de Santo Alberto) e hoje está arruinado sem ter artilharia, e não servir de utilidade alguma para defensa desta praça, e há pessoas que querem comprar o dito sítio: O Provedor-mor da Fazenda Real deste Estado com o Procurador e com o Tenente General da artilharia vão ver o dito sítio, e do que acharem me darão conta para se tomar a resolução que mais convier ao serviço de Sua Alteza. Bahia e Março 13 de $1673 .^{512}$

O parecer da comissão fez a Mesa da Fazenda decidir pelo leilão do forte. ${ }^{513} \mathrm{~A}$ partir de então deixou de figurar da relação das fortalezas, restando apenas a documentação antiga e a menção de alguns cronistas. ${ }^{514}$

\section{Forte de Santiago (ou Torre, depois também Santo Alberto)}

A Torre de S. Tiago de Água de Meninos também foi construída na administração de D. Francisco de Souza, mas no início do século XVIII teve a adição de um terrapleno projetado pelo Mestre de Campo Miguel Pereira da Costa (provavelmente foi com essa ampliação que, já não existindo o outro, ganhou o nome de Forte de S. Alberto, sendo vulgarmente chamado de "Lagartixa"). ${ }^{515}$ A torre ainda fazia parte da nova construção quando foi feito o levantamento de Caldas, sendo depois demolida (já não aparece na planta do 1 을 Tenente João da Silva do início do século XIX), havendo ainda os seus vestígios arqueológicos sob o forte.
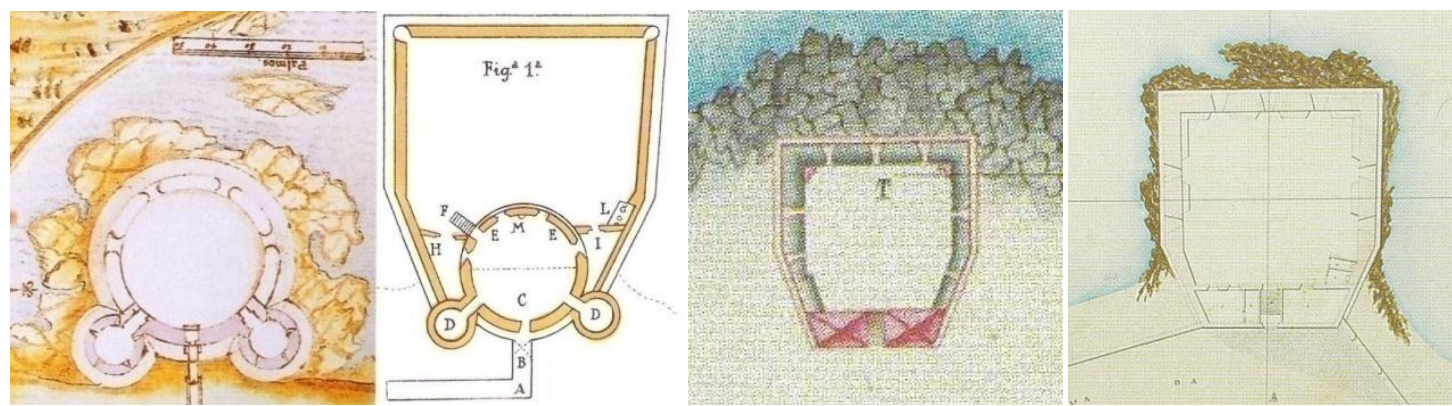

À esq., a Torre de Santiago em detalhe de canto da cartografia de Albernaz (imagem invertida para comparação), seguida do desenho do livro de Vilhena (talvez cópia do de Caldas) em que aparece já com o terrapleno desenhado por M. Pereira da Costa (passando a se chamar Forte de Santo Alberto), seguindo-se dois desenhos em que a torre já estava demolida (o do 1o Ten. João da Silva Leal T., do início do séc. XIX, e o de Tomás Paranhos, de meados do séc. XIX - em OLIVEIRA, 2004: 191-4), dando lugar à casa de guarda e alojamento do comandante.

\footnotetext{
${ }^{512}$ BN - Documentos históricos, 1928, v. 8, p. 152 - apud OLIVEIRA, 2004: 181 (grifos nossos).

${ }^{513}$ Cf. OLIVEIRA, 2004: 181. Já havia uma oferta de 560\$000rs.

514 Sem o forte, o nome (a invocação) passaria para a Torre de Santiago de Água de Meninos, provavelmente no início do século XVIII.

515 Além das mudanças de nome e do apelido de Fortinho dos Franceses, sua denominação é ainda confundida por cronistas estrangeiros (Aldenburgk), cartógrafos (Barleus), e pela explicação de alguns autores modernos sobre os antigos. Para Oliveira (2004: 193), nem os cronistas locais, às vezes distanciados no tempo, nem os estrangeiros, de propósitos específicos ou observando dos barcos, podem ser tomados ao pé da letra.
} 
Sua planta aparece no desenho de Albernaz como uma variante do partido circular, com entrada também flanqueada por torres menores, configuração que se manteve, segundo os desenhos de Caldas, até o fim do século XVIII. Para M. Oliveira, o desenho é semelhante ao do Forte da Laje no Recife, que as iconografias antigas mostram ter sido também uma torre circular.

A torre foi construída à beira-mar para defender o acesso à Cidade Alta pelo trecho da enseada de Água de Meninos, controlando também os navios nas vizinhanças. Foi mencionada por diversos cronistas desde o início do século XVII, mas a primeira e única cartografia que comprova os seus traços arquitetônicos iniciais é a de João Teixeira Albernaz I (c. 1627). ${ }^{516}$ Apesar do desenho pequeno e de pouca exatidão, pela escala gráfica se percebe um diâmetro da parte superior próximo a 44 palmos $(9,68 \mathrm{~m})$, e na parte baixa da muralha, próximo a $54(11,88 \mathrm{~m}) \cdot{ }^{517}$ Era, portanto, uma construção pequena, o que também mostram os números de sua artilharia no Livro da Razão...: Um camelo pedreiro, de bronze, de quatorze quintais; joga pedra de quatorze libras. Um falcão pedreiro, de sete quintais. ${ }^{518}$

A planta baixa da torre em forma circular, flanqueada por dois bastiões também circulares, era um partido arquitetônico repetido no século XVI. O desenho em si não comprovaria sua existência ou forma, mas sim o seu cadastro executado primeiramente pelo Cap. Eng. José Antônio Caldas no Álbum de desenhos de Fortificações.

\section{Forte S. Philipe (Monserrate)}

Arquitetos especializados em História, como Carlos Lemos e Mário Oliveira, enfatizam a importância e as qualidades estéticas e funcionais dessa fortificação. 0 primeiro, pela possibilidade de que seja "a última fortificação projetada e construída por um arquiteto italiano especialmente trazido para tal mister", ${ }^{519}$ o florentino Baccio di Filicaya (na grafia de Lemos), que teria trazido "novidades arquitetônicas não só referentes às construções militares, mas também às obras religiosas e particulares, cuja produção ainda aguarda um pesquisador paciente". ${ }^{520}$

\footnotetext{
${ }^{516}$ Como um dos três ou quatro fortes de pedra e cal da administração de D. Francisco de Souza citados por Frei Vicente do Salvador, seu projeto ou construção teria a participação do engenheiro militar florentino Baccio di Filicaia (sendo uma das fortificações novas a que se refere na carta ao Grão-Duque Ferdinando I, da Toscana - cf. OLIVEIRA, 2004: 191). Para M. Oliveira, citando Varnhagen, é improvável (embora possível) que a torre-fortaleza fosse do governo de D. Diogo de Menezes (1607-12) como quis Teodoro Sampaio, já que Diogo de Campos Moreno faz referência a ela no relatório de 1609 . Ainda segundo ele, sua concepção seria arcaica mesmo para a época, "com atavismos medievais, como foram as obras do tempo de D. Francisco". Oliveira sugere que a contratação de Filicaia se deu mais pela sua vinda da Itália, "cuja escola de fortificar encontrava-se no apogeu", do que por experiência profissional. Argumenta que ele teria confessado, com honestidade, o seu "pouco tirocínio", sendo a Bahia o "palco da sua experimentação" (como mostra a parte final do trecho transcrito por Varnhagen da carta ao Grão-Duque, que mostramos ao falar da vida de Filicaia).

${ }^{517}$ Essa medida inferior é bem próxima à que foi encontrada em prospecções (cf. C. Santiago. Da Torre de São Tiago.../ OLIVEIRA, 2004: 192), mostrando que o desenho tinha um significativo grau de precisão. ${ }^{518}$ MORENO, 1955: 144.

${ }^{519}$ LEMOS, 1989: 244.

${ }^{520}$ Id. Ibid.
} 
Oliveira considera o fortim Nossa Senhora de Monserrate, ${ }^{521}$ originalmente chamado Castelo de São Filipe (em homenagem ao rei espanhol) "um exemplar de extraordinária importância da nossa arquitetura fortificada primitiva". ${ }^{222}$ Seria "o modelo mais arcaico de nossas defesas que sobreviveu sem maiores transformações", "talvez o mais antigo existente de todo o Brasil". Como "imagem da cidade", seria uma referência como outros, mas especial pela "posição privilegiada e em extrema harmonia com a morfologia do terreno".

Na representação em planta na cartografia de Albernaz (c. 1627) ele está com a feição atual, apesar de sofrer reformas em 1650-4 (Conde de Castelo Melhor), 1735-49 (Vice-Rei André de Melo e Castro), 1742 (Conde das Galveias) e 1927 (restauração de Góis Calmon). ${ }^{523}$ É o documento mais antigo sobre ele.

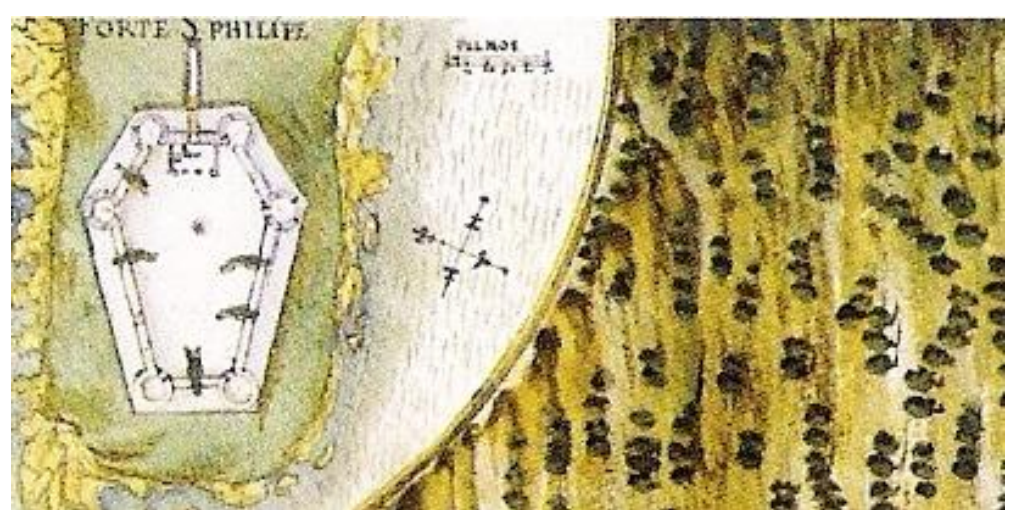

O Forte de Monserrate como uma das imagens de canto na cartografia atribuída a Albernaz I (em Atlas... [1631], 1997: fl. 21).

Teodoro Sampaio o define como um "velho fortim clássico, flanqueado de bastiões redondos", 524 que para Oliveira seriam "muito a gosto da arquitetura italiana da transição", ${ }^{525}$ mas em escala modesta. O historiador D. Clemente M. da Silva Nigra afirma que na Ordem Beneditina há documentos comprovando sua construção (e a do Mosteirinho) a mando de D. Francisco de Souza (como propuseram Teodoro Sampaio e outros, enquanto Mirales o considerou da época de Manoel Teles Barreto), ${ }^{526}$ sendo assim praticamente certo que a traça seja de Baccio di Filicaia.

É umas das fortalezas a que se refere Diogo de Campos Moreno no relatório de $1609,{ }^{527}$ declarando depois (no Livro da Razão..., 1612) que o forte tinha uma artilharia modesta: Uma espera de dezenove quintais, de bala dez libras. Uma espera de dezoito quintais, de bala nove libras. Uma espera de vinte e dois quintais, de bala dez libras. ${ }^{528}$

\footnotetext{
${ }^{521}$ Esta é a forma mais portuguesa e antiga da palavra, havendo as outras: Monteserrate, Monte Serrate, Monserrat e Mont-Serrat. O nome do forte não tem relação com o do Baluarte de Monserrate, que depois fez parte do perímetro defensivo de Salvador (situado provavelmente na encosta da cidade, abaixo da fortaleza de Santo Antônio Além do Carmo, segundo João Coutinho).

522 OLIVEIRA, 2004: 187 (entende-se a expressão "arquitetura fortificada primitiva" como mais antiga entre as construções coloniais duráveis).

${ }^{523}$ Cf. CAMPOS, 1940: 124.

${ }^{524}$ Apud CAMPOS, 1940: 122 ("clássico" talvez no sentido de "típico").

525 OLIVEIRA, 2004: 187 (grifo nosso)

${ }^{526}$ Cf. OLIVEIRA, 2004: 250 - nota 56.

527 ... para a banda do norte desta sidade ha uma legoa está outra ponta chamada tapagipi q' na planta se asinala con a leyta [sic] $G$, donde paresse outro forte de pedra e cal da mesma traça de $S$. Ant. ${ }^{\circ}$, dizen $q^{\prime}$ ten huma sisterna dentro... (ANTT - Relação..., fl. 27v).

${ }^{528}$ MORENO, 1955: 144.
} 
Laet foi o único a considerá-lo o grande castelo do Tapagipe e grande forte de Tapagipe, possivelmente para valorizar a vitória inicial dos holandeses.

Ao contrário de outros, o forte esteve envolvido em conflitos da cidade contra inimigo estrangeiro, havendo controvérsias sobre a ação dos defensores. Na primeira invasão holandesa, foi tomado depois de trocar tiros com algumas naus inimigas. Não teria feito muita resistência porque a cidade estava ocupada e a única alternativa era a retirada. Também não era difícil desembarcar nas praias da península de Itapagipe e cortar sua comunicação com a guarnição da cidade. As tropas coloniais só puderam contar com a guerra de emboscada dos nativos, que permaneciam na vizinhança investindo de tempos em tempos contra os detentores da praça, como fizeram Antônio Morais e Manuel Gonçalves.

Como para a Porta de S. Bento, há versões diferentes sobre o que se passou no forte na vinda de D. Fradique (1625). Para alguns, a chegada da enorme frota fez os holandeses o abandonarem e se recolherem à cidade. Aldenburgk diz que a guarnição ainda atirou contra os navios e só se retirou na noite seguinte. Brito Freire, para valorizar os portugueses, diz que o forte foi tomado de surpresa. Na invasão de Nassau em 1638, o major holandês van den Brand conduziu parte da tropa pela praia portando cinco peças e tomou o forte do Cap. Pedro Aires de Aguirre, que tinha poucos soldados e seis canhões. ${ }^{529} \mathrm{O}$ forte só foi desocupado pelos holandeses quando eles voltaram a Pernambuco.

\section{Forte de S. Antonio (da Barra)}

Até mais do que a transformada Torre de Santiago em Forte de Santo Alberto, o Forte de Santo Antônio da Barra sofreu grandes modificações em seus mais de quatrocentos anos de existência. $O$ documento mais antigo sobre a construção é um alvará de $1598,{ }^{530}$ em que aparece como Bastião do comandante Brito Correia. ${ }^{531} \mathrm{O}$ forte de Santo Antônio era comesado na barra daquela Cidade em sua primeira versão, talvez para substituir a torre quadrada de taipa erguida por Coutinho nas proximidades, como sugere o Livro Velho do Tombo do Mosteiro de S. Bento. ${ }^{532}$

Silva Campos diz que a fortificação octogonal foi feita no governo de Manoel Teles Barreto (1583-7), tendo começado em forma de torre, como na representação de Albernaz. A representação de Albernaz parece fidedigna, já que traz uma escala gráfica e as fortificações da estampa aparecem em outros desenhos (Santo Alberto e São Tiago) ou conservam a forma (Monserrate).

\footnotetext{
${ }^{529}$ Cf. CAMPOS, 1940: 127.

${ }^{530}$ AHU - Códice Ms 112. Livro de ofícios, regulamentos e mercês (1597-1602): Alvará de 21/05/1598, fl. 65 - Cf. OLIVEIRA, 2004: 182-7. Mas como “notícia” de sua posição fortificada, aparece no Tratado... de Gabriel Soares, como vimos.

${ }^{531}$ Habitante de Vila Velha casado com a neta de Caramuru, segundo Varnhagen, sendo possivelmente sucedido por Francisco de Barros, também da família de Caramuru, que já idoso comandava o forte quando da invasão de 1624 (cf. OLIVEIRA, 2004: 249 - nota 37).

${ }^{532}$ Cf. CONGREGAÇÃO BENEDITINA DE SALVADOR. Livro Velho do Tombo..., p. 67 - texto reproduzido em trecho sobre os anos 1540, "as torres de terra...", p. 80.
} 


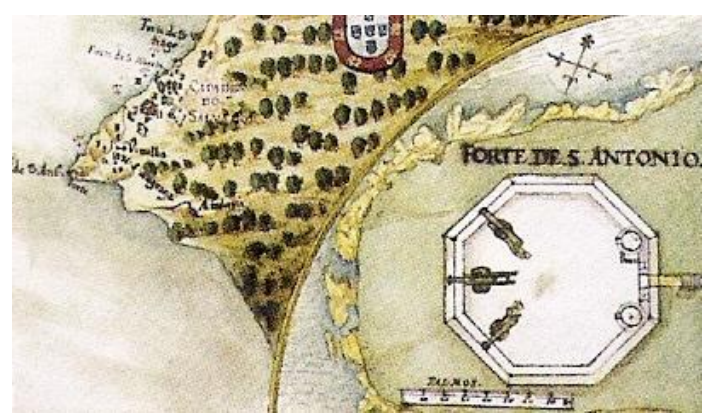

Imagem de canto na cartografia atribuída a Albernaz I (Atlas do Estado do Brasil... [1631], 1997: fig. 21).

São curiosas, no desenho, as pequenas torres de flanqueamento da entrada pelo lado interno dos parapeitos, que são à barba. Pela escala gráfica, os eixos do octógono regular teriam 120 palmos (c. 26 m). Como nos outros três redutos desenhados, a entrada era alta, ligada por escada e ponte levadiça. ${ }^{533}$ Como torre octogonal, poderia de longe parecer uma torre cilíndrica, como aparece em muitas gravuras. Mas neste caso específico, a forma talvez não fosse essa. ${ }^{534}$

No Relatório de Diogo Moreno, em trecho ainda sobre a Capitania de Pernambuco (as anotações são feitas de norte para sul, com a descrição seguinte começando pela cidade de Salvador), ${ }^{535}$ o autor cita nas páginas finais alguns elementos da Capitania da Bahia, havendo na ilustração abaixo (à direita) os seguintes dizeres: Verdadeiro retrato do forte $S$. Ant ${ }^{\circ}$ na entrada da barra' da bahia de todos os santos e desta feição são todos os mais $q^{\prime}$ fundou de Pedra e cal o $g^{\text {or }}$ Dom fran ${ }^{c o}$ de Souza. [na fegura] adiante se verão os lugares de sua fundação e o que defendem.
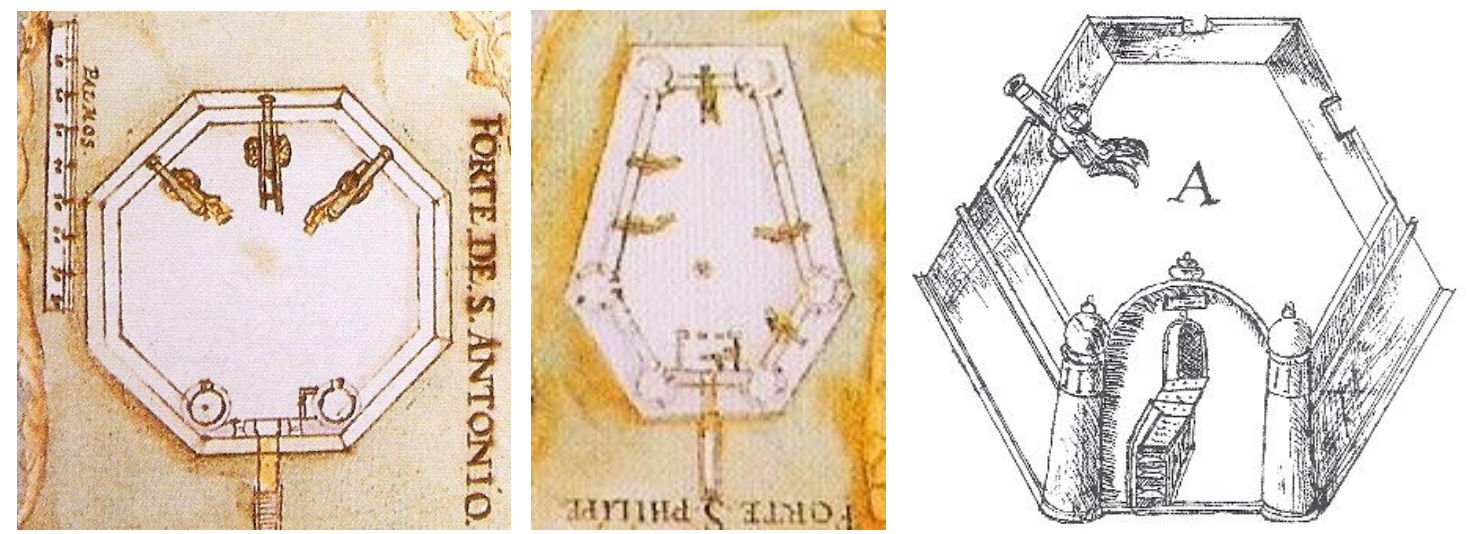

À esq. e ao centro, os fortes da época de D. Francisco de Souza como aparecem na estampa de Albernaz (com imagens giradas para efeito de comparação). À dir., desenho do Forte de Santo Antônio que aparece na fl. 24 do Relatório de Diogo Moreno de 1609 (antes de chegar à Capitania da Baía).

O desenho de Moreno não mostra um octógono, como aparece na ilustração de Albernaz I (à esquerda), mas um hexágono, realmente semelhante ao Fortim de Monserrate (ao centro), a não ser pelas torres. A entrada ainda é alta e com ponte levadiça, mas as torres que a protegem passaram para o lado externo da cortina. Os parapeitos têm canhoeiras, mesmo que poucas (as mesmas três do outro desenho).

\footnotetext{
${ }^{533}$ A "solução tipológica da época" (OLIVEIRA, 2004: 184).

${ }^{534}$ As formas das fortalezas usadas na decoração dessa estampa podem ser mais antigas do que carta de Albernaz, copiadas de outras estampas.

${ }^{535}$ Cf. ANTT - Relação... A descrição da Capitania de Pernambuco é feita nas folhas 17-24, citando-se aqui as folhas $23 v$ e 24.
} 
Além do desenho, ao se referir ao Fortim de Monserrate, Diogo Moreno qualificou-o como um forte de pedra e cal da mesma traça de $S$. Ant. ${ }^{\circ}$... Pela seriedade do seu testemunho (militar, conhecedor de fortificações e incumbido de inspecionálas, levando ao Reino os projetos do Cap. Frias de Mesquita e trazendo de lá as traças emendadas, munições, armamentos e suprimentos das defesas em geral), ${ }^{536}$ é bem provável que o forte tenha passado por essa forma.

A artilharia relacionada no Livro da Razão, de quatro peças, mostra que era uma construção pequena, mesmo que de pedra e cal: ... Um canhão de bronze de trinta e oito quintais; joga vinte e quatro libras de bala. Dois sacres ou meias-esperas de bronze, de dezoito quintais; jogam dez libras de bala. Um falcão de dado, de seis quintais. ${ }^{537}$

Nenhum engenheiro militar deu grande valor estratégico ou tático ao Forte de Santo Antônio da Barra. ${ }^{538}$ Já no início do século XVII, Moreno dizia que por lá ...entran e saien cada dia naos armadas de corsarios sem $q^{\prime}$ artilharia que aqui esta lhe faça dano, e inda que tenha colubrias de sessenta quintais nunca totalmente poderá defender a barra. ${ }^{539}$ Pouco depois, chama-o ironicamente de "adorno da barra". Diogo Moreno diz ainda:

Por muitas vezes se tem advertido à Sua Majestade que os Fortes de Santo Antônio, de Itapagipe e da Água dos Meninos, que se assinalam à fl. [19] nos pontos AA e no ponto BB e CC, não são de nenhum efeito, assim por que não defendem nada, como pelo risco com que se sustentam por sua fraqueza $e$ má traça... ${ }^{540}$

Como veremos, os holandeses tomaram o forte na invasão de 1624. Para não ter inimigos na retaguarda após o desembarque, mantiveram-no apenas com uma pequena guarnição. Logo depois ele foi retomado por Francisco Nunes Marinho a mando de Matias de Albuquerque. Era consenso entre os defensores locais que não valeria a pena dividir as pequenas tropas da cidade na defesa dos fortes da Barra e Monserrate. ${ }^{541}$

\footnotetext{
${ }^{536}$ Cf. OLIVEIRA, 2004: 184.

537 MORENO, 1955: 144. Já pela relação de Caldas em meados do século XVIII, o perímetro de cortinas do fim do século XVII (provável época de sua modificação, que será vista adiante) tinha 16 peças de diferentes calibres, compatível com a linha de fogo que fora ampliada (cf. CALDAS, 1951: 353-6 e OLIVEIRA, 2004: 185).

${ }^{538}$ Entre os historiadores, apenas Carlos Ott.

539 ANTT - Relação..., fl. 26v. Também vimos com Gabriel Soares que se a intenção fosse proteger a entrada da barra dos corsários com canhões,... não lhe podem fazer mais dano do que afastá-los da carreira... (SOUSA, 1971: 140).

540 MORENO, 1955: 143.

${ }^{541}$ Cf. OLIVEIRA, 2004: 186.
} 
PARTE III - Século XVII: o sistema de fortificações na enseada

1. Cidade e Fortificação nos tempos de Diogo Campos Moreno e Francisco Frias de Mesquita (1600-20)

\subsection{Crescimento e novo sistema de defesa: projeto de cidadela e confirmação do perímetro}

Vimos que já nos anos 1580 a cidade ocupava toda a área ao norte com uma malha que seguia o mesmo padrão regular dos primeiros quarteirões. Salvador passava a ter três grandes espaços públicos: a Praça do Palácio, a área da Sé e o Terreiro de Jesus. Entendemos que já em meados dos anos 1590, com D. Francisco de Souza e Baccio da Filicaia, a fortificação da cidade foi refeita, com um novo muro de taipa (também de pouca duração) envolvendo a área expandida.

A necessidade de melhorar as defesas da cidade, alertada desde Gabriel Soares, relacionava-se ao crescimento rápido e desordenado, ${ }^{542}$ que dificultava a edificação de um perímetro fortificado dentro das normas da poliorcética. ${ }^{543}$ Outro problema era em relação à entrada da Baía de Todos os Santos, com uma abertura que não permitia impedir a passagem de naus inimigas (elas passavam longe da artilharia da época), podendo, como uma das maiores baías do mundo, abrigar várias esquadras.

Portugal não era um país rico e estava endividado com outros países europeus. Os recursos da Fazenda Real para Salvador eram comedidos, já que colônias e possessões na África e Ásia demandavam mais investimento do que lucravam. As fortificações na Bahia dependiam principalmente das imposições locais sobre vinho, açúcar, óleo de baleia e outros comércios, de ingresso de recursos não compatível com a fortificação em larga escala necessária à cidade.

\footnotetext{
542 O crescimento acelerado de Salvador, que já nas primeiras décadas havia impressionara Gabriel Soares, também seria objeto de observação no Relatório de Diogo Moreno (1609), podendo-se observálo pelos seguintes números: a cidade ocupava 15 hectares em 1549, passando a 65 em 1580 (cf. NUNES, 2006 - um hectare equivale ao quarteirão de $100 \times 100 \mathrm{~m}$ ). Na mudança de século, estavam consolidadas as seguintes áreas: 1- todo o interior do novo perímetro no alto da escarpa a ser amuralhado (com taipa ou adobe) pelo desenho de Albernaz I (1604-5), incluindo o Colégio Jesuíta com o Terreiro de Jesus, o Mosteiro Franciscano e seu adro, o hospital da Misericórdia e as duas portas; 2- a expansão extra-muros, de crescimento linear acompanhando o mar e ultrapassando o limite das portas, ao sul e ao norte, principalmente pela construção do Mosteiro de São Bento (sul, 1582) e dos Hospital das Carmelitas (norte, 1585); 3- a povoação da praia, na área do porto, com construções de apoio à navegação. Por questões militares também foram implantados os novos fortes, fora dos limites.

As principais vias da época eram: 1- Rua Direita dos Mercadores, da Misericórdia, da Praia, da Ajuda, as atuais José Gonçalves, do Tira-chapéu, das Vassouras e Guedes de Brito; 2- Ladeira da Montanha, da Misericórdia, da Conceição e da Praia. Além dos militares, estavam construídos os seguintes edifícios: 1(civis) Casa de Câmara e Cadeia (1a de taipa em 1550, 2 a de taipa em 1660), Casa do Governador (taipa em 1549, pedra e cal em 1663); 3- (religiosos) N. S. Conceição da Praia (antiga, 1549), Catedral da Sé (1552), Igreja de S. Pedro Velho (de 1554, demolida no século XX), Igreja e abadia de N. S. da Graça (1535 - Paraguaçu), Igreja e Mosteiro de São Bento (1582), Santa Casa da Misericórdia (1550), Hospício [Hospital] dos Carmelitas (1585), Colégio dos Jesuítas (10 em 1551).

${ }^{543}$ No dizer dos engenheiros militares, das máximas postuladas pelas escolas de fortificação modernas, principalmente as mais famosas, que passariam a ser, junto com a italiana, a francesa e a holandesa.
} 
A necessidade de um plano de defesa se dava em função do crescimento e dessa fragilidade, com corsários de várias nacionalidades já tendo atacado Salvador de forma cada vez mais ousada (ingleses em 1587, franceses em 1595 e holandeses em 1599). No começo se cogitou a vinda do próprio engenheiro-mor de Portugal, Leonardo Turriano, para fortificar a Cidade. ${ }^{544}$ Foram contrários a ela o ex-governador D. Francisco de Souza e o Bispo D. Pedro de Castilho (que em carta ao rei disse haver defesas suficientes). ${ }^{545} \mathrm{Em} 1604$ houve nova incursão holandesa, com uma esquadra de sete naves, comandada por Paulus van Caarden, fazendo grandes estragos pela baía. Diogo Botelho (governador entre 1603-7) trabalhou para atenuar os danos e alertou com insistência a Coroa para a possibilidade de uma invasão ampla.

Com autorização do Rei, por volta de 1605 foi encomendado a Leonardo Turriano (engenheiro-mor de Portugal) e Tiburcio Spanochi (engenheiro-mor da Espanha) o novo projeto que confirmava a expansão de Salvador e adequava a cidade aos princípios de fortificação da época. ${ }^{546}$ Como enfatizamos em relação à interpretação da Planta, primeiro registro cartográfico da cidade, o sistema se baseava principalmente em uma...

... cidadela que Sua Majestade manda se fabrique, para por aquela parte se assegurar o todo, tanto da povoação como do Recôncavo, que a qualquer rebate vivem em tormento e decomposição, havendo com suas armas e à sua custa de acudir a cidade; mas remedeia-se esta falta com a dita cidadela... ${ }^{547}$

Pouco desse projeto foi executado, principalmente em função das limitações orçamentárias. O encarregado dessa execução foi o engenheiro-mor do Brasil, Francisco Frias de Mesquita, que pôde apenas construir alguns dos fortes indicados,

${ }^{544}$ Cf. BAj - Documentos Avulsos [51-VIII-19], fl. 166-166v. Documento no 140 de 02/06/1605: Sn. ${ }^{\text {or }}$ Com esta envyo a V.M. ${ }^{d e}$ duas consultas do Cons. ${ }^{\circ}$ da India $q$. visa desp. ${ }^{\circ}$, húa sobre a fortificação $q$ diogo boelho $g .{ }^{\text {or }}$ do Brazil lembra que se deve fazer na Cid. ${ }^{e}$ da Baya, e en outras $p .{ }^{\text {tes }}$ daquelle estado, $e$ com esta vão os traços dellas e paresseme $q$ antes de V.M. ${ }^{\text {de }}$ se rezolver esta materia deve ir aquellas partes Lionardo Turriano p. $^{a}$ pessoalm. ${ }^{\text {te }}$ ver os sitios, e informar a V.M. ${ }^{\text {de }}$ do que ouver por mais convenie'te para as ditas fortificasões se fazer... - apud MENDONÇA, 2004: 78.

${ }^{545}$ Cf. BAj - Documentos Avulsos [51-VIII-18], fl. 211v. Envio de consulta do Conselho da Índia. Cópia de Carta Régia de 07/06/1607: E porque D. Francisco de Souza é de parecer que não é necessário fortificar a Bahia, porque o forte que tem é bastante... - apud MENDONÇA, 2004: 57 e 78. Na interpretação de Mário Oliveira (p. 57), “ou D. Francisco não entendia do assunto, o que era bem provável, ou procurava justificar a sua posição de não ter cuidado melhor da situação quando esteve na condição de fazê-lo".

${ }^{546}$ Diogo Botelho encomendou as traças ao Cap. Eng. Francisco Frias de Mesquita (cf. BNL - Coleção Pombalina, Códice Ms 459, fl. 184: Provisão para o Eng. Francisco Frias, registrada em Olinda em 07/06/1603 e autorizada pelo Governador Geral, ainda em Pernambuco, em 25/06/1603 - OLIVEIRA, 2004: 64), que se destacaria por seu valor e competência nos primeiros tempos da Engenharia Militar no Brasil. O projeto foi levado às Cortes por Diogo de Campos Moreno, Sargento-mor da Costa do Brasil (cf. Relação..., 1609 - ANTT e MORENO, 1955).

Alguns testemunhos do início do século XVII também associam Spanoqui e Turriano ao desenho de algumas fortificações brasileiras, mas não há indicações de que vieram ao Brasil. Spanoqui teria feito trabalhos para Recife e regiões da América espanhola (cf. REIS FILHO, Nestor Goulart. Brasil. In: SOLANO, Francisco de - dir. Historia Urbana de Iberoamerica. Madri: 1990, vol. II, p. 529-30/ TEIXEIRA \& VALLA, 1999: 226). Turriano foi cogitado para vistoriar as fortificações de Salvador e convocado pelo rei espanhol a "participar da Jornada de Todos os Vassalos na libertação da Bahia, em 1625, ocupada pelos batavos, mas escusou-se alegando velhice e achaques" (OLIVEIRA, 2004: 93).

Beatriz Bueno (2001: 169-206) traz bastante informação sobre as atuações de Spanoqui (1578-96), Turriano (1594-8) e Alexandre Massay (1617-21) na Europa.

547 MORENO, 1955: 141. 
como o Forte do Mar e a Estância de São Diogo, ${ }^{548}$ além de, a nosso ver, ter refeito a entrada pelo lado sul, construindo dois novos baluartes nos lados da cortina que tinha ao centro a Porta de Santa Luzia (depois São Bento), talvez também trabalhada por ele. $^{549}$

O pouco que se fez não deteria o ataque holandês (a cidade foi ocupada em 1624-5, podendo-se em parte atribuir esse fato à ineficácia do sistema de defesa, que permitiu o acesso à parte alta da cidade pelas ladeiras). A fortificação representada na Pranta... de 1605 (que acompanhava o Livro que dá Razão..., de 1612), circundada pela zona de pântano, era bastante irregular, em função da difícil adaptação ao terreno. Havia seis baluartes voltados para o interior, com os muros já englobando a área franciscana. Também se vêem assinaladas as duas portas, Santa Luzia (depois São Bento, na direção do convento) e Santa Catarina (na direção do convento do Carmo estando os dois conventos fora da muralha).

\subsection{Depoimentos de Diogo Moreno}

Em seu Relatório (1609), Diogo Moreno se refere (no texto ou por indicação nos mapas) às seguintes fortificações: 1-Reduto da ponta de Santo Antônio (da Barra); 2- Porta de Santa Luzia; 3- Estância sobre a Igreja da Conceição; 4- Plataforma que defende a encosta (abaixo da Misericórdia); 5- Reduto Santo Alberto, feito por D. Francisco de Souza (na praia, próximo à atual Igreja do Corpo Santo segundo Teodoro Sampaio); 6- Plataforma ao pé do Colégio de Jesus (alta, avistando todo o porto até a agoa dos meninos); 7- Portas do Carmo, trincheira da banda do Vasadoiro Velho; 8Plataforma das casas de Balthazar Ferraz; 9- Plataforma para o mar depois dessas casas; 10- Forte da ponta da tapagipí, de pedra e cal (Monserrate); 11- Estância de Água de Meninos.

Ao recomendar o plano de Francisco de Frias, diz que assim a Cidade do Salvador pode ser lugar muito forte e bem guardados os navios... (fl. 25v). Já no Livro que dá Razão do Estado do Brasil (1612), ${ }^{550}$ é contundente ao comentar o estado das defesas de Salvador:... convém sustentar-se êste presídio enquanto a fortificação da cidadela está tão atrasada e a cidade é uma aldeia aberta, exposta a todos os perigos enquanto aquela parte se não fortificar. ${ }^{551} \mathrm{Em}$ outra passagem (anterior), também critica os fortes de Santo Antônio da Barra, Monserrate e Água de Meninos por sua fraqueza e má traça, considerando inadequado levar soldados da pouca guarnição da cidade para lhes dar cobertura. ${ }^{552}$

\footnotetext{
548 Trata-se de uma fortificação desaparecida, citada no relatório do Diogo Moreno (1609), que entendemos ficar no local do antigo "baluarte" de S. Jorge (cf. p. 105), não se devendo confundi-la com o forte erguido no Porto da Barra depois da invasão.

549 Como aparece na Pranta... de 1605 e na Planta da Restituição... (c. 1627).

${ }^{550}$ A autoria de Diogo de Campos Moreno não é oficial, mas tida com certa, pois foram praticamente transcritas algumas passagens do relatório de 1609 (cf. OLIVEIRA: 2004: 57).

551 MORENO, 1955: 147.

552 A guarnição na época tinha duas companhias de 80 homens cada (fora os oficiais), o que era bem pouco para o tamanho e importância de Salvador. O efetivo restante viria das ordenanças, tropas muito menos treinadas. Segundo Tamayo de Vargas e outros, a tropa remunerada à época da invasão holandesa era de 80 soldados (cf. OLIVEIRA, 2004: 78).
} 
Houve muitas admoestações às Cortes de Portugal e Espanha sobre a necessidade de melhorar as defesas. Pouco antes da invasão de 1624, com rumores do ataque, trocou-se muita correspondência sobre o tema. Ao mesmo tempo ainda se discutia a necessidade de fazer o Forte da Laje. O governador Diogo Botelho queria muito mais do que isso, clamando pela cidadela, em função da dificuldade de se proteger todo o perímetro da cidade. ${ }^{553}$

As traças de Frias foram provavelmente emendadas por Leonardo Turriano e submetidas a Tibúrcio Spanoqui. ${ }^{554} \mathrm{O}$ resultado aparece em uma das iconografias do Livro que dá Razão..., na versão do Instituto Histórico e Geográfico Brasileiro, no Rio de Janeiro (IHGB) e na da Biblioteca e Arquivo Municipal do Porto, em Portugal (BMP). A da Biblioteca do Porto é mais elucidativa quanto ao projeto, porque a convenção dos traçados, em vermelho - o que se propõe construir - é mais evidente, apesar de pequenos equívocos comuns às duas legendas.

O desenho da fortificação compreendia um perímetro maior de defesas, envolvendo as antigas portas. Dentro desse perímetro maior se previa a cidadela, indo da depressão da Misericórdia à porta de S. Luzia, ${ }^{555}$ cercada por largo fosso nas faces Norte, Sul e Leste, e pela escarpa no Oeste. O projeto previa a demolição de alguns edifícios, como o do Tesouro e Alfândega, à frente do Palácio dos Governadores na atual Praça Municipal, e algumas casas próximas à área e na cortina da face Oeste.

Como vimos, essa imagem chegou a confundir alguns historiadores, que não perceberam se tratar de um projeto (designium para uma cidadela), que Diogo Botelho pedia insistentemente durante a vinda de Diogo Moreno, e talvez não tenha sido executado em função das demolições citadas.

\footnotetext{
${ }^{553}$ Cf. OLIVEIRA, 2004: 78. Cidadela, em linguagem militar, "é a parte mais fortificada de um sistema defensivo", em geral na parte mais elevada, dando a possibilidade de ser o último refúgio quando uma praça foi parcialmente tomada. No projeto de Massé, representado em desenho de Vilhena, há um exemplo interessante, onde a cidadela seria a Mouraria. A projetada por Frias de Mesquita e/ou Turriano no início do século XVII, almejada por Diogo de Mendonça, seria aproximadamente o coração da cidade antiga, como se nota na iconografia de Albernaz no Livro que dá Razão... (nas duas versões).

${ }^{554}$ O Livro que dá Razão do Estado do Brasil - 1612 diz que ela era de... traça de Leonardo Turriano, engenheiro-mor do Reino, confirmada por Tibúrcio Espanocci, engenheiro-mor de Espanha (MORENO, 1955: 141), o que sugere uma participação da engenharia militar espanhola nas principais obras feitas no período de dominação (1580-1640). Já no Relatório de 1609, Diogo Moreno diz que Salvador ficará bem fortificada se for seguido o plano... pelas plantas que fez o Engenheiro Francisco de Frias $e$ confirmou e emendou Tiburtio Espanochi engenheiro-mor de Espanha para as fortificações... Por isso, apesar da informação que está no Livro que dá Razão..., alguns autores defendem que o levantamento foi feito por Francisco Frias (engenheiro-mor do Brasil) e levado a Portugal por Diogo Campos Moreno. Nestor Goulart (REIS Fo, 2000: 308) se refere à Planta de 1605 como parte da ilustração do "códice" Rezão do Estado... por uma série de cartas manuscritas sobre pergaminho atribuídas a João Teixeira Albernaz, infomando que na Biblioteca do Porto ela aparece no texto como cópia de uma apresentada em 1605... para se dar a execução a fortificação daquella cidade.

${ }^{555} \mathrm{Na}$ época a depressão seria bem visível, estando hoje disfarçada por aterros e viadutos (cf. OLIVEIRA, 2004: 82).
} 


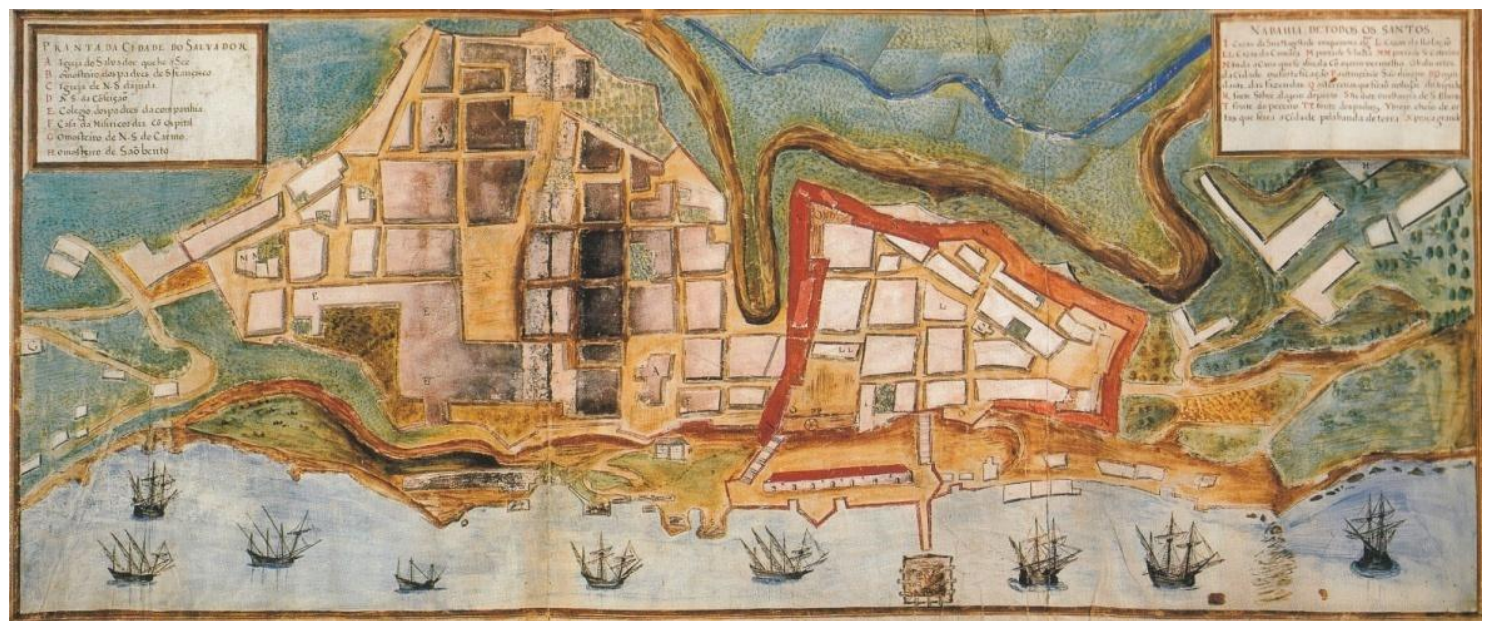

A Pranta da Cidade do Salvador... de 1605 na cópia do códice Livro que dá Rezão... do IHGB do RJ (em REIS Fo, 2000: 18)...

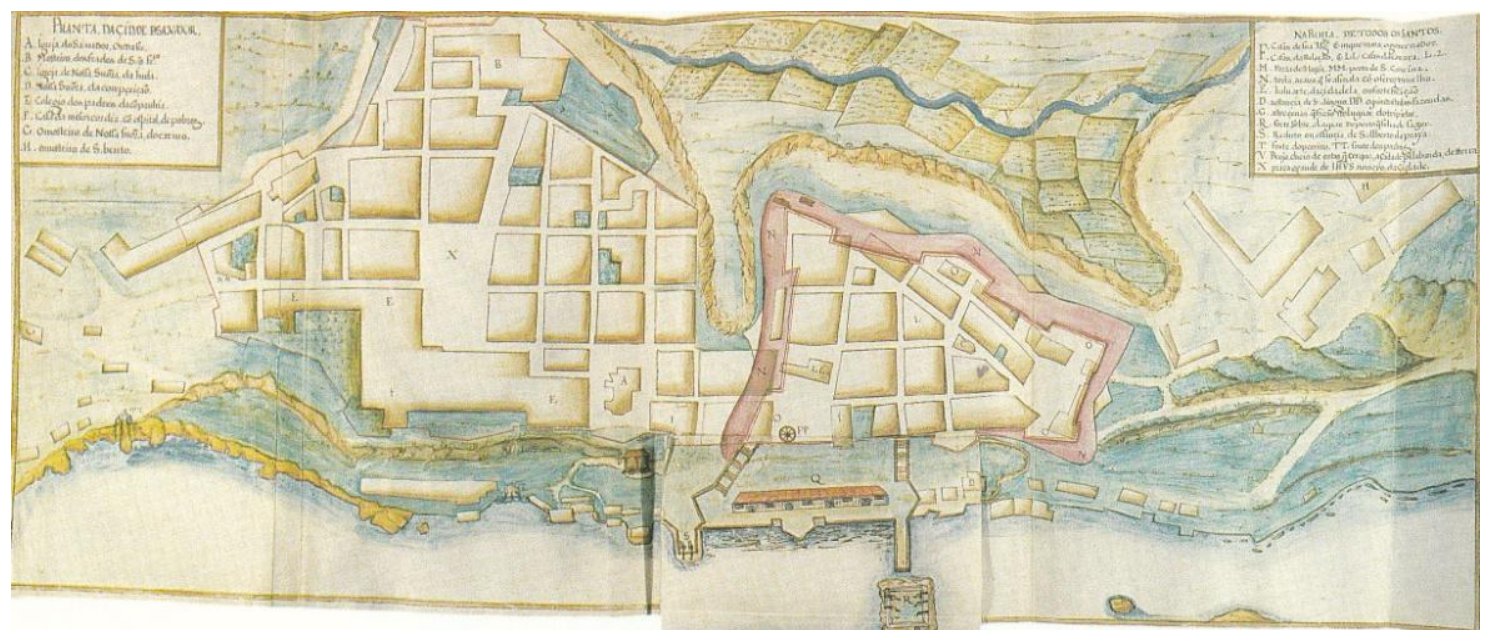

... e na da Biblioteca Pública do Porto (em TEIXEIRA \& VALLA, 1999: 236).

Comentamos em capítulo anterior que na versão da Biblioteca do Porto as aguadas vermelhas são melhores e se vêem claramente os cortes propostos para o tecido urbano existente, ${ }^{556}$ enquanto na brasileira a pintura é mais empastada e mascara esse detalhe (e quando reproduzida em preto e branco dificulta ainda mais).

$\mathrm{Na}$ proposta, dependendo do terreno, as cortinas eram flanqueadas por baluartes imperfeitos e por alguns em ponta de lança. As decisões dos fortificadores eram criteriosas: pelo tempo que levaria a reconstrução daquele perímetro, era conveniente primeiro fazer uma cidadela, garantindo o refúgio da população urbana e dos que viessem do Recôncavo. Em uma segunda fase seriam executadas as outras defesas. Mas esse entusiasmo construtivo não vingou: quando os holandeses chegaram (1624), Frias da Mesquista ainda construía o Forte da Laje com um novo desenho, no local do reduto primitivo que aparece na iconografia do Livro que dá Razão...557

\footnotetext{
${ }^{556}$ Em que nos baseamos para apresentar uma hipótese insegura sobre os baluartes dos anos 1590.

${ }^{557}$ Cf. OLIVEIRA, 2004: 66. É também a opinião de Teodoro Sampaio.
} 
1.3. Francisco Frias de Mesquita e alguns novos fortes (governos de Diogo Botelho a Diogo Mendonça Furtado)

\section{$\underline{\text { Laje }}$}

O primeiro Forte do Mar, do início do século XVII, tinha localização próxima e mesma função estratégica do atual Forte São Marcelo (construído depois, para substituí-lo), o que fez alguns autores (T. Sampaio, S. Campos, M. Teixeira e M. Valla) confundirem os dois. ${ }^{558} \mathrm{~A}$ tese de que são obras distintas foi defendida em 1954 por Luiz Monteiro da Costa, ${ }^{559}$ que demonstrou que o Forte da Laje era mais próximo à praia. Destaca-se em sua argumentação a descrição de Aldenburgk sobre o local na guerra de 1624, em que os holandeses o tomaram ainda inacabado, defendido com cestões, encravando canhões da bateria e fazendo retirada por causa da fuzilaria de terra:... como da cidade faziam nutrido fogo de mosquetaria e arcabuzaria teve de retirar-se para o navio.... ${ }^{560}$

O Forte S. Marcelo fica a cerca de $600 \mathrm{~m}$ do atual Elevador Lacerda, enquanto o alcance de um mosquete na época seria de até $297 \mathrm{~m},{ }^{561}$ a distância máxima possível para o Forte da Laje. Sobre a profundidade entre o forte e a terra, a legenda para a estampa que ilustra o texto de Aldenburgk sobre a tomada de Salvador diz: Uma bateria construída de pedra dura, distante da terra, que na maré alta se pode passar por detraz com um barco... Não seria, portanto, o S. Marcelo, de águas bem mais profundas. Há também o relato de Netscher sobre a invasão e assalto ao Forte do Mar: O próprio Piet Heyn, seguido do corneteiro de seu navio, foi o primeiro a subir na fortificação inimiga obrigando toda a guarnição a escapar, fosse a vau, fosse a nado. ${ }^{562}$ Também não haveria como sair "a vau" (andando em águas rasas) se fosse o atual S. Marcelo.

A Planta de Albernaz (1605) mostra claramente o primeiro forte do mar como um reduto quadrado, com um molhe para recebimento de navios ligando-o a terra. ${ }^{563}$ Esse molhe, mesmo considerando que o artista não fez uso de escala, não poderia ter a dimensão que cobrisse a distância do atual S. Marcelo (o erro não chegaria à diferença de 400 a 500 m na distância entre o forte e a escarpa).

\footnotetext{
558 Laje: "reduto quadrilátero, mais vizinho à Ribeira de então", construído sobre o "afloramento rochoso", a famosa lagem (OLIVEIRA, 2004: 205); São Marcelo, ou Nossa Senhora do Pópulo e S. Marcelo: feito sobre uma "coroa de areia" e concebido "com partido circular" desde a origem (id. ibid.).

559 Tese de concurso para o Instituto Normal da Bahia, 1954 - cf. OLIVEIRA, 2004: 205-6.

${ }^{560}$ ALDENBURGK, 1961: 172.

${ }^{561}$ Cf. OLIVEIRA, 2001: 482-3 - 120 a 125 toesas (=237,6 a 247,5 m), segundo o Marechal Vauban (Regra $X V)$, ou até 150 toesas ( $=297 \mathrm{~m}$ ), segundo o tratadista holandês Goldman.

${ }^{562}$ S/ ref., citado por COSTA, op. cit. - apud OLIVEIRA, 2004: 206.

${ }^{563}$ Molhe = Estrutura marítima enraizada em terra que pode servir de quebra-mar ou cais acostável (Aurélio).
} 


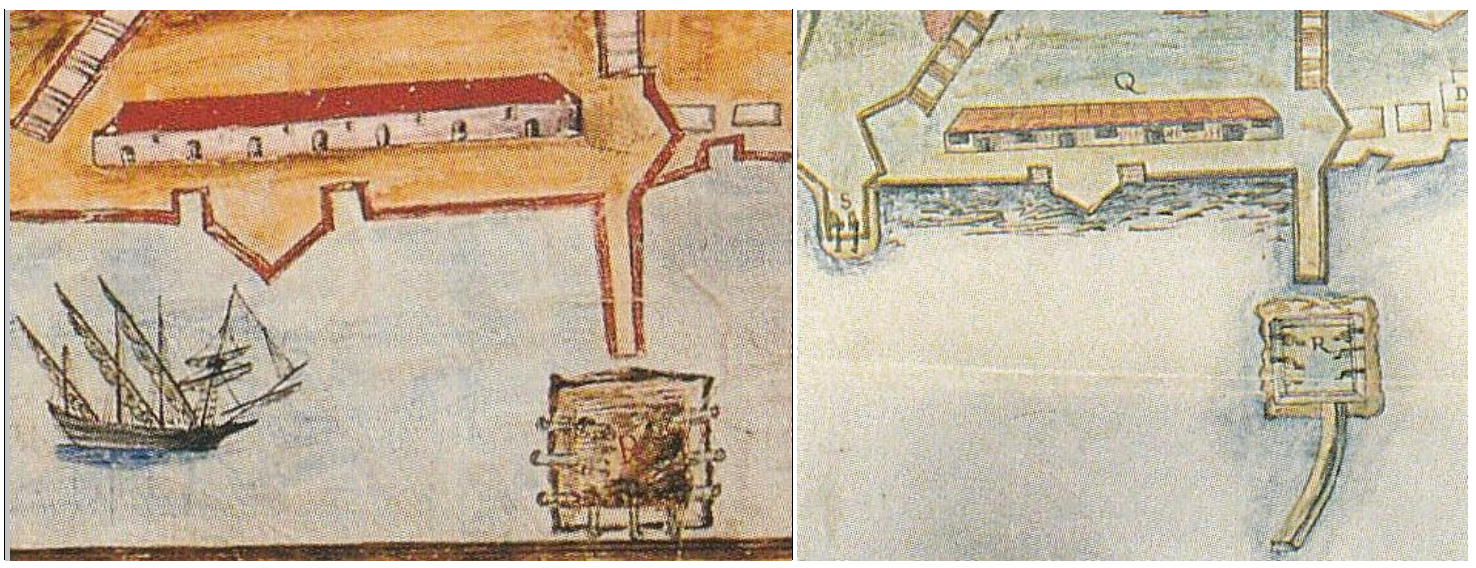

O Forte da Laje nas duas versões (IHGB e BMP) da estampa de Albernaz, estando o da direita no papel colado que mostra o possível projeto de Turriano (confirmado por Spanoqui em 1605, mas sua construção, ou reconstrução, por Frias é de c. 1622 - em REIS Fo, 2000: 18 e TEIXEIRA \& VALLA, 1999: 236).

As imagens em que aparece na forma triangular podem ter levado os autores citados a acreditar que o Forte da Laje ocupasse a mesma ilhota do atual S. Marcelo, já que induzem a acreditar em uma enorme distância entre a fortificação e a linha da praia, comparável à do forte redondo. ${ }^{564}$ Mas ao falar do S. Marcelo, apresentaremos uma ilustração indicando o local do antigo Forte da Laje.

\footnotetext{
${ }^{564}$ Na página anterior, reproduzimos as informações passadas por Mário Oliveira (2004), nas quais acreditamos. Mas apenas como exercício de contra-argumentação, diríamos que não há comprovação definitiva sobre a diferente localização do antigo forte da Laje em relação ao atual S. Marcelo, na medida em que os argumentos (expostos a partir da tese de Luiz Monteiro) se sustentam mais na interpretação de textos antigos do que em provas materiais, notando-se falhas nessa interpretação. Observe-se pela leitura mais ampla do texto de Aldenburgk: Os navios da armada holandesa, em parte, aproaram na direção da grande bateria situada fora da cidade, no mar, próximo à praia, da qual faziam fogo sobre os nossos navios com nove meios-quartaus e falcões. $O$ navio do vice-almirante encalhou diante da bateria; o navio "Groeningen" recebeu dela cerca de setenta tiros...// Contudo, o vicealmirante derrubou as trincheiras e os gabiões [cestões?] e desmontou as peças da bateria, terminando por conquistá-la; indo à terra em vários botes com marinheiros armados, e, desembarcando naquele lugar em que os brasileiros se defenderam valentemente, encravou as peças; como da cidade fazia nutrido fogo de mosqueteria e arcabuzaria, teve de retirar-se para o navio (ALDENBURGK, 1961: 172 grifos nossos - em relação à expressão fora da cidade, no mar, próximo à praia, há uma nota na edição de 1961 já se referindo à utilização da passagem por Luiz Monteiro na tese de 1954, quando identificou "a bateria sobre a lagem, dentro do mar, coeva da invasão holandesa, com o propugnáculo dedicado a São Felipe e São Tiago e a N. Sr. ${ }^{a}$ da Conceição, desaparecido sem deixar vestígios" - idem, p. 260).

$\mathrm{Na}$ expressão indo à terra, que aparece depois do desmonte da fortificação, seria mais lógico que o cronista se referisse à terra firme, onde os brasileiros "se defenderam" (e não à fortificação) valentemente. Assim o "nutrido fogo de mosqueteria e arcabuzaria" não viria do continente (onde os holandeses desembarcaram), mas "da cidade", fortificada por muitas estâncias em defesa da linha da praia. O argumento de que os $600 \mathrm{~m}$ que atualmente separam o S. Marcelo do Elevador Lacerda (sendo que este já estaria dentro do continente pelo menos $150 \mathrm{~m}$ da linha do mar antiga - o São Marcelo fica há cerca de $300 \mathrm{~m}$ do cais atual, avançado cerca de $150 \mathrm{~m}$ em relação à linha antiga) representam uma distância maior do que a coberta pelos mosquetes da época (c. $300 \mathrm{~m}$ ) perderia o sentido numa interpretação de texto em que os holandeses já estivessem em terra firme.

Mesmo na questão de obrigar a guarnição a fugir a "vau" ou a nado (relato de Netscher), pode-se entender que não era uma fuga até terra firme (ou, exagerando, na descrição de uma legenda de estampa em Aldenburgk - não encontrada - de uma "bateria construída de pedra dura, distante da terra, que na maré alta se pode passar por detrás com um barco" - grifo nosso -, argumentar-se-ia que ela vale para o S. Marcelo, pois não está explicitado que a maré baixa impedia a passagem).
} 


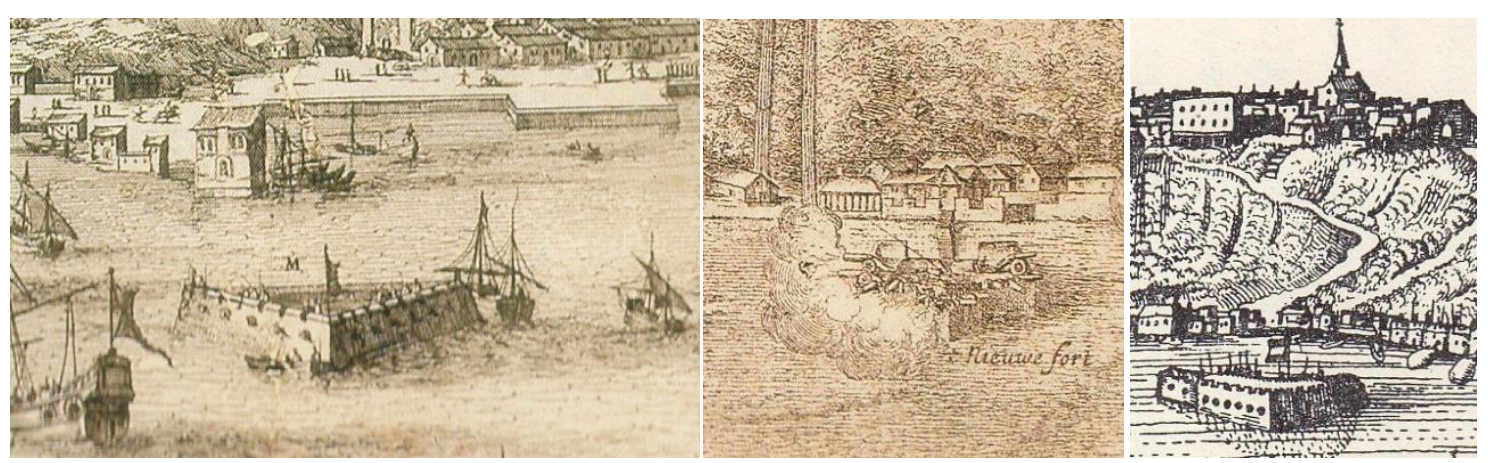

Nas gravuras do livro de Montanus, de Gerritsz (em REIS Fo, 2000: 28-9) e do livro de Aldenburgk (semelhante à outra de Gerritsz, em ALDENBURGK, 1961: 183) cria-se a ilusão de uma distância maior entre a fortificação e a praia.

Para uma eventual dúvida, há também (como lembra M. Oliveira) uma clara distinção entre as duas fortificações nos pareceres dos engenheiros portugueses sobre o projeto de João Coutinho (1685). Enquanto Teodoro Sampaio, abordando a obra de fortificação de D. Francisco de Souza descreve o Forte da Laje sem diferenciá-lo do S. Marcelo, ${ }^{565}$ Nestor Goulart, já distante da eventual polêmica, esclarece:

Na Cidade Baixa, pouco afastado da praia, o desenho [PRANTA DA ÇÍDADE D. SALVADOR] mostra o antigo Forte do Mar, projetado por Leonardo Turriano e em 1605 confirmado por Tiburcio Spanochi, construído apenas anos mais tarde (cerca de 1622), sobre uma laje, bem antes do Forte de São Marcelo (de planta circular), ainda hoje existente e bem mais afastado da praia. ${ }^{566}$

O primeiro Forte do Mar foi feito em um afloramento rochoso, que os antigos chamavam de lagem, como quadrilátero não abaluartado (que na linguagem técnica dos tratadistas era considerado reduto). ${ }^{567}$ Enquadrava-se na categoria de fortificação passageira. O relatório de 1609 do Sargento-mor Diogo de Campos Moreno não menciona qualquer forte do mar. Na cidade baixa refere-se apenas ao reduto de $\mathrm{S}$. Alberto, próximo à Igreja do Corpo Santo, ao fortinho de Água de Meninos (atual S. Alberto ou Lagartixa) e ao de Monserrate.

Pela estampa da Biblioteca do Porto, além de ser uma fortificação passageira (pelo partido quadrilátero; mas sendo na Colônia, podia se tornar permanente), ele não teria nenhuma capacidade ofensiva na direção frontal: as troneiras aparecem nas laterais e o molhe continuava para frente, aonde não havia artilharia. Com isso se supõe que foi executado entre 1609-12, no governo de Diogo de Menezes. Mas na gestão de Mendonça Furtado (1621-4) também houve a insistência do Cap. Frias de Mesquita, Engenheiro-mor no Brasil, em melhorar a proteção do porto, alegando que a defesa de Salvador estava precária tanto em terra como no mar. A autorização chegou tarde, em Carta Régia de 03/08/1622, que diz numa passagem:

... e fazendo de novo sobre a lagem que está defronte da cidade, o forte novo e mole [molhe] para abrigo dos navios, e que a cidade se fortifique por entre ambas as bandas do mar e terra, tudo na forma

\footnotetext{
565 Cf. SAMPAIO, 1949: 294 - “Diogo Botelho mandou construir (1602-7)... o forte de Nossa Senhora do Populo, hoje do S. Marcello, ou Forte do Mar..."

${ }^{566}$ REIS FILHO, 2000: 308-9. Ainda segundo Nestor Goulart, o projeto do Forte é de 1609, posterior ao levantamento (1605), e daí a necessidade de seu acréscimo "em uma folha desdobrável, aplicada como uma colagem".

${ }^{567}$ Cf. OLIVEIRA, 2004: 207-9.
} 
que na traça e relação do engenheiro mor se aponta, e se escuzem os mais fortes da Bahia que não são de effeito... ${ }^{568}$
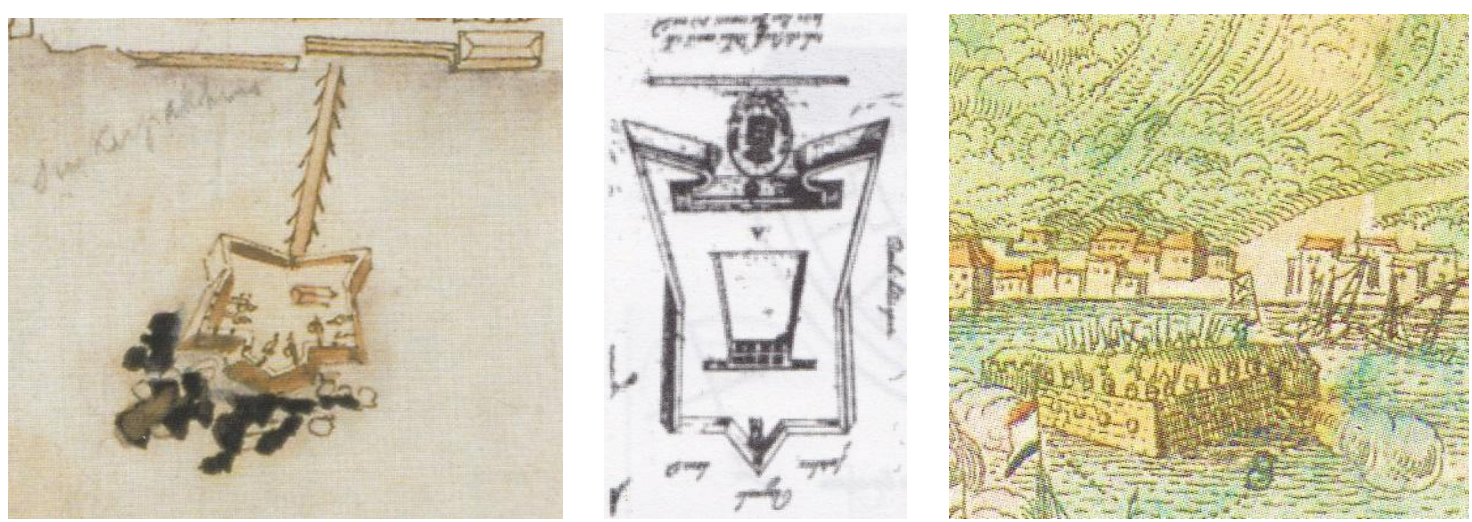

O Forte da Laje em detalhe do Desenho das forteficaçoes... (à esq., original do Museu de Haia c. 1638, em REIS Fo, 2000: 32-4): a contraguarda na face frontal se assemelha (evidenciando na relação com o todo do forte uma filiação direta) à do Forte dos Reis Magos (RN), também de figura "antropomórfica", a obra talvez mais famosa de Frias de Mesquita (ao centro, em OLIVEIRA: 2001: 495 - desenhado em 1614 sobre o de taipa do jesuíta Gaspar Samperes, e aqui invertido para efeito de comparação). Uma hipótese para as muitas representações na forma triangular é que no ano da invasão estivesse concluída apenas essa contraguarda (à dir, detalhe da estampa de H. Gerritsz, c. 1624 - em REIS Fo, 2000: 23-4).

Novamente com Frias de Mesquita, ${ }^{569}$ o reduto recebeu novo projeto para sair da condição de fortificação passageira e se tornar permanente, mesmo sem muitas pretensões defensivas.

${ }^{568}$ Carta Régia de 03/08/1622 - apud COSTA, L. M. da. Certidões de Nascimento..., p. 26/ OLIVEIRA, 2004: 208.

${ }^{569}$ Frias de Mesquita fez muitos trabalhos em Salvador e em várias partes da Colônia. Margarida Valla aponta como dele o Forte São Marcelo, o que é um equívoco, sendo sim o autor do Forte da Laje, que aparece no acréscimo de papel da planta de 1605: "São da sua autoria o forte do Mar ou forte de São Marcelo, na Baía, à imagem do forte do Bugio em Lisboa, desenhado por Alexandre Massai em 1608, de planta redonda (cuja forma vai ser retomada mais tarde para outros fortes em Santos, Vitória e Belém do Pará), o forte de São Diogo, em 1609-1612, o forte de Santa Maria, em 1614, aquando da sua conquista aos Franceses..." (TEIXEIRA \& VALLA, 1999: 134). Pela coincidência de nomes, ela também parece ter confundindo o reduto de São Diogo (mais próximo à cidade, mencionado por Diogo Moreno) com o forte, construído em Salvador por volta de 1630, junto com o de Santa Maria (as datas, 16091612, parecem tiradas das da Relação... e do Livro que dá Razão... de Diogo Campos Moreno). Sobre o forte maranhense de Santa Maria, Frias estava realmente envolvido em sua construção no ano da expulsão dos franceses (1614). A autora também o apresenta como "Luís" Frias de Mesquita, nome com que talvez apareça em documentos portugueses sobre alunos da Aula de Architectura.

Frias de Mesquita é autor de outros fortes maranhenses (também na expulsão dos franceses, em 1614) como os de São Francisco, São José e São Filipe. Também desenhou o forte da Laje (Recife, 1608), Santa Catarina (PB), São Mateus (Cabo Frio, RJ) e Reis Magos (Natal, RN, reconstruído em 1614 - cf. TEIXEIRA \& VALLA, 1999: 134; também para Carlos Lemos - 1989: 243 - o Forte São Mateus, em Cabo Frio é de Frias de Mesquita). Nasceu provavelmente em 1578 (em uma devassa do Rei contra D. Luiz de Sousa, governador entre 1617-21, ele depôs a seu favor declarando sob juramento ter quarenta e seis anos, pouco maes ou menos - cf. OLIVEIRA, 2004: 93-4 e 132 - nota 42). Aos 20 de idade, conseguiu umas das três vagas no curso de arquitetura patrocinado por Filipe II (sob responsabilidade de Nicolau de Frias, possivelmente seu parente - cf. LEMOS, 1989: 239 - o autor dá como certo o seu nascimento em 1578). Por iniciativa dos espanhóis, chegou a Olinda em 1603, aos 25 anos, já tendo completado os estudos e com o importante título de Engenheiro-mor. Dois anos depois já estaria projetando fortificações em Salvador, como consta no relatório de Diogo de Campos Moreno (1609).

Nessa primeira fase prestou ajuda e serviços em diversas regiões do Brasil, atuando "praticamente sozinho" (OLIVEIRA, 2004: 94). Por volta de 1608 trabalhava em Olinda no Forte da Laje (ou Castelo do 


\section{$\underline{\text { São Francisco e Rosário }}$}

A área em que o fortim de S. Francisco foi construído era distante da malha urbana principal, mas as cartas que falam do crescimento de Salvador mostram que esse isolamento durou pouco: logo os armazéns e habitações vizinhas complicariam o seu funcionamento. ${ }^{570}$

Mar, Forte S. Francisco ou do Picão, desenhado por Spanoqui no governo de Matias de Albuquerque obra terminada em 1612 e muito elogiada por Viterbo - cf. LEMOS, 1989: 239 e 241) e em 1612 já estava de volta à Bahia, segundo referência de seu auxiliar, arquiteto Domingos da Rocha. Além de construtor era combatente: estava na excursão que venceu os franceses no Maranhão (1614), onde deu início ao forte de Santa Maria de Guaxenduba, na ilha de S. Luiz. No ano seguinte foi ao Grão Pará, onde ajudou na instalação do primeiro núcleo de Belém, o Forte do Castelo (1616). Neste mesmo ano, além de Engenheiro Militar, foi Provedor no Maranhão, entregando os projetos dos fortes de São Felipe, São Francisco e, provavelmente, São José (MA - cf. NIGRA, D. Clemente da Silva. Francisco Frias de Mesquita. Revista do SPHAN. Rio de Janeiro, no 9, 1945, p. 20/ OLIVEIRA, 2004: 94).

Em 1617 fez o seu projeto de edifício religioso mais prestigiado (cf. LEMOS, 1989: 243), o do mosteiro de S. Bento (RJ - Silva Nigra decifrou em 1942 um manuscrito danificado de Frei Bernardo de S. Bento que dizia sobre a primeira planta do Mosteiro do Rio de Janeiro: Conforme achei na traça antiga do Frias, como se ve de hum papel antigo que foi por onde se principiou este motr. ${ }^{\circ}$ - NIGRA, op. cit., p. 9 apud OLIVEIRA, 2004: 133), indo depois ao Espírito Santo. No ano seguinte, em companhia do Governador Geral, inspecionou o Forte de Santa Catarina, em Cabedelo (PB). A traça do Forte dos Reis Magos (RN) é de 1614, mantendo-se praticamente igual (desenhado sobre o que era de taipa, construído pelo jesuíta Gaspar Samperes em 1598, e parecido com o Forte da Laje de Salvador). Era exigente no acompanhamento da obra, como mostra um Apontamento de 1619 ao governador (Arquivo do Itamarati, citado em NIGRA, 1945: Doc. 8, p. 43-5. Apontam. ${ }^{\text {to }}$ de fran. ${ }^{\text {co }}$ frias Mesquita Ingen. ${ }^{\text {ro }}$ mor deste estado das obras que faltão na fortaleza do Rio grande, pera VS. Mandar se façao se lhe parecercf. OLIVEIRA, 2004: 94 e 133).

A partir do Governo de Diogo Mendonça Furtado, fixou-se mais na Bahia. Em 1622, projetou o Forte da Laje de Salvador, com base nas orientações de Spanoqui (cf. LEMOS, 1989: 243) para defender a cidade dos holandeses, mas estava ainda em construção quando estes chegaram (1624). Sofreu agravos e, depois da expulsão (1625), foi reparado pelo próprio Frias. Depois da retomada de Salvador, veio a tarefa de reaver o que fora destruído pelos combates, bombardeios e vandalismo holandês. As defesas deixadas pelos rivais foram aproveitadas e melhoradas, porque eram de boa qualidade.

Carlos Lemos destaca Junto com Frias a importância do almirante espanhol Diogo Flores Valdez, primeira autoridade a viajar pela costa brasileira com uma visão global da questão defensiva, com planos que seriam orientados principalmente por Tibúrcio Spanoqui (cf. LEMOS, 1989: 239-4). Para este e outros arquitetos de Filipe II, Frias de Mesquista teria refeito traças e executado desenhos arquitetônicos. Também há referências de que nas fortificações da Bahia Frias foi ajudado pelo engenheiro Marcos Ferreira (vindo de Pernambuco em 1627), partícipe na construção do primeiro quartel de alojamento da tropa de Salvador, que passou a ser grande.

Em alguns períodos dos séculos XVI-XVII há referências à falta engenheiros em Salvador, como o seguinte à saída de Frias de Mesquita do Brasil (provavelmente para reforçar as tropas da Restauração, sendo seu último registro de pagamento em 1635). Em Portugal, ainda estava na ativa em 1645, com possíveis 67 anos e mais de 40 de vida profissional "das mais ricas e duras" (OLIVEIRA, 2004: 95), dos quais 32 no Brasil (cf. LEMOS, 1989: 239 - nesse caso, teria voltado realmente em 1635, aos 57 anos). Daí o comentário do comandante da fortaleza de Outão (em carta): A planta della vay com esta, a qual fez o engenheiro Francisco de Frias, que aqui achey; homem velho e de experiemcia, e me parece pessoa de gram talento, o que delle posso affirmar he a grande aplicação e cuidado que tem, não só no tocante ao seu officio, mas achandosse presente a todos, e me parece pessoa de grande préstimo (BN Documentos históricos, 1930, v. 15, p. 155-9 - apud OLIVEIRA, 2004: 95).

${ }^{570}$ Cf. OLIVEIRA, 2004: 244-5. 


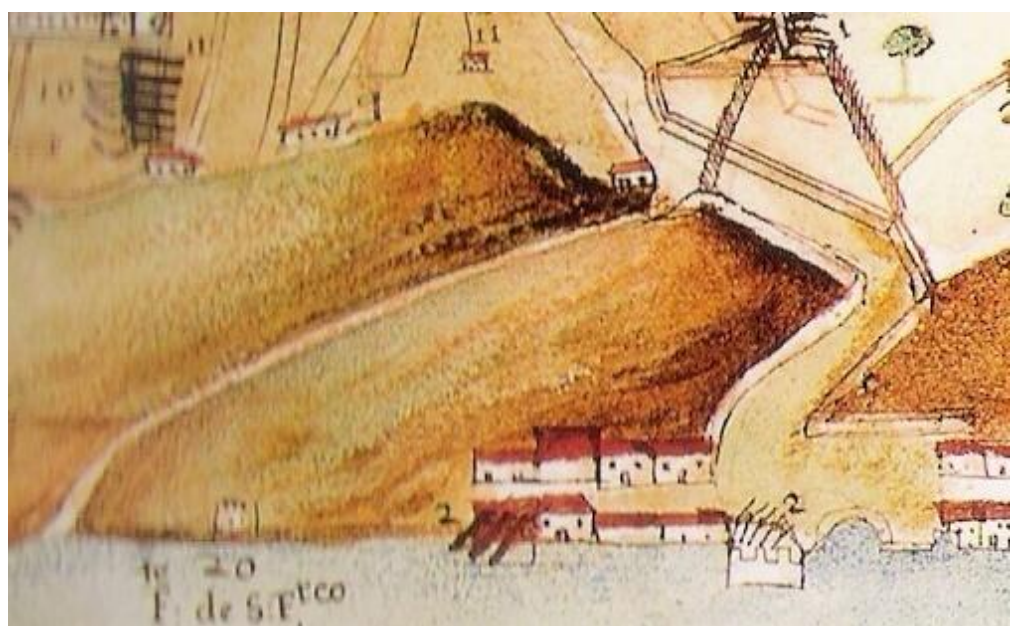

À esquerda, detalhe dos fortins de S. Francisco na Planta da Restituição da Bahia (em Atlas..., $1997: 22$ na legenda, o no 2 corresponde a: praya onde o imigo tihinha muita artelharia).

O fortim, dos mais antigos, era pequeno, mas prestativo na defesa do porto. Ajudado pelas baterias do Santo Alberto e do Forte da Laje (depois Bateria da Ribeira), dava alguma proteção pelo cruzamento de fogos. Segundo Silva Campos há informações de que o forte existia em 1618. O Livro da Razão... (1612) não faz referência a ele, sendo praticamente impossível que fosse da época de D. Francisco de Souza. Ele aparece nitidamente na planta de Haia (1638), mas sem legenda. A partir de lá foi considerado útil e importante, pelo que diz o relatório de Ravasco (1660), o relatório anônimo de 1671 e o parecer de Muniz Barreto. ${ }^{571}$

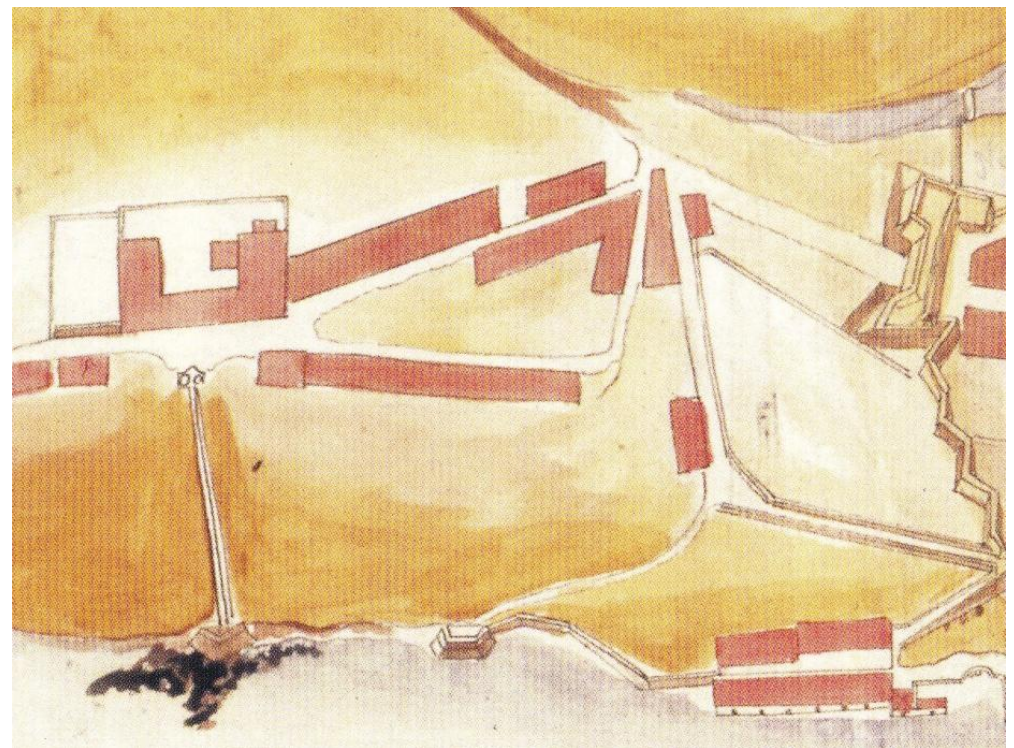

Os fortins do Rosário (à esquerda) e de S. Francisco (ao centro, ambos na "ribeira") na planta do Museu de Haia (1638).

O Fortim do Rosário, que "dava a mão" ao de S. Francisco, era ainda menos expressivo, havendo referência à sua presença na planta do museu de Haia acima (sem nomeá-lo). Pelo desenho, seria mais um estabelecimento militar fortificado.

\footnotetext{
571 "Como a defêza, que fazem estes dois fortes, vem a ser a mesma, tanto para o mar, como p." defender os lados, e desembarques da Marinha, me parece, salvo melhor observação, q' se deveria demolir o de S. ${ }^{\text {to }}$ Alberto [Torre de Santiago], reedificar o de S. Francisco..." (Observaçoens Sobre a Fortificação..., BMP - Mss 686 (Brasil, 1797), fl. 18v).
} 
Documentos indicam que lá se restaurava pólvora e preparavam fogos de artifício e de guerra. Ficava na praia de N. S. do Rosário e adquiriu o nome pela proximidade da capelinha, já desaparecida. Na mesma área, ao pé da encosta, construiu-se a Igreja da Santíssima Trindade, ainda existente. Pela descrição de Vilhena, tentou-se uma melhoria na fortificação no século XVIII, que não foi concluída. Sua ampliação daria maior apoio ao Forte da "Lagartixa" e supriria deficiências do de Santo Antônio do Carmo, de cota elevada para atirar no mar. ${ }^{572}$

\section{Guerras holandesas (1620-40)}

\subsection{Ameaça de um ataque}

A partir do início do século XVII foram produzidos registros escritos sobre a Cidade do Salvador em maior quantidade, e os desenhos mais antigos que se preservaram: as duas versões da Pranta da Çidade do Salvador... (c. 1605), ${ }^{573}$ o Perfil da Çidade do Salvador... (c. 1611), ${ }^{574}$ e a estampa Baÿa de Todos los sanctos (c. 1618). Este último merece citação inicial pelo que representa de real ameaça aos portugueses: é um plano holandês de invasão da cidade, em que se analisa o sistema defensivo indicando, como modo de ocupação, um ataque pela retaguarda. ${ }^{575}$

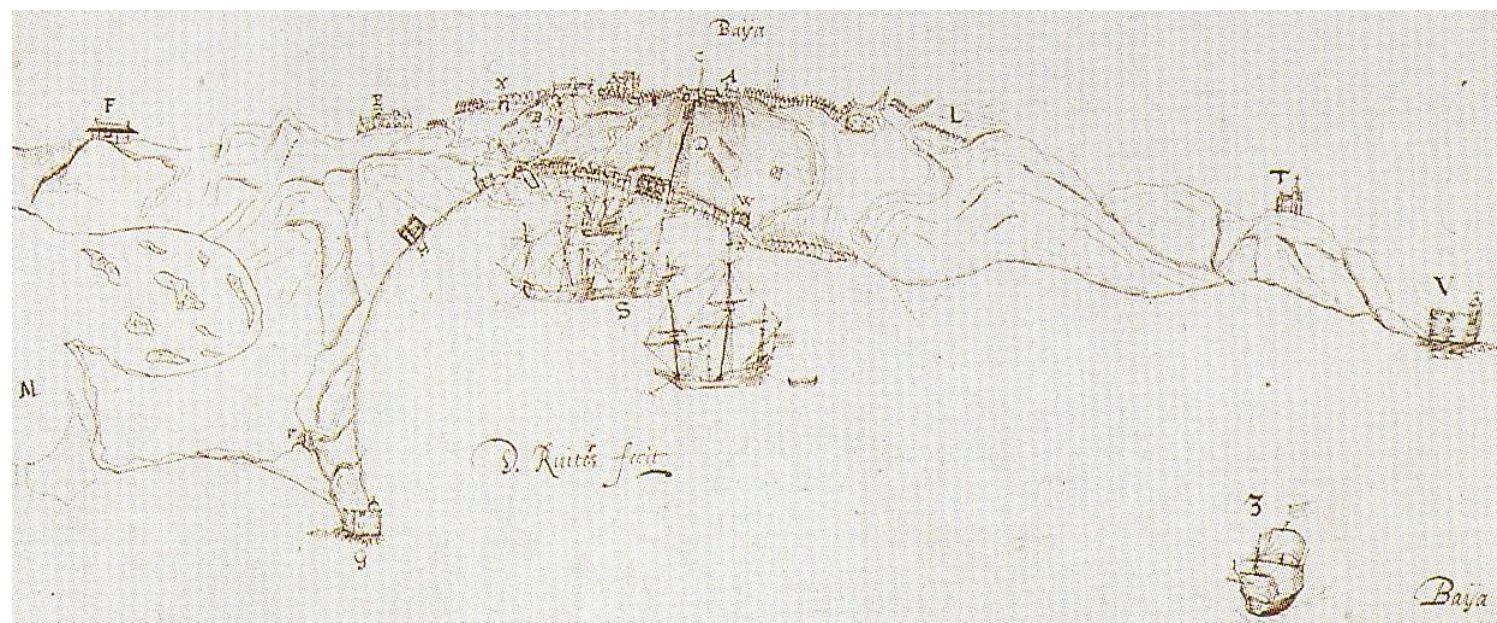

Detalhe da gravura Baÿa de Todos los sanctos (c. 1618), original manuscrito de Dierick Ruisters, do museu de Haia. Aparentemente representa uma muralha na banda norte e apenas o caminho na sul (em LEÃO, 1957 e REIS Fo, 2000: 19 e 310).

Até a última década do século XVI, a única ameaça real à segurança de Salvador eram os índios, para os quais a barreira iniciada com Luiz Dias, mesmo precisando de

\footnotetext{
572 Estava, portanto, entre o Forte de S. Francisco e a Torre de Santiago (depois Santo Alberto ou Lagartixa), não tão ao pé do Forte de S. A. além do Carmo, mas mais próximo do que a Torre. Preferimos abordá-lo junto com o de S. Francisco, mas é provavelmente do período pós-invasão (1625-40).

${ }^{573}$ Os desenhos de Albernaz foram os mais reproduzidos até aqui, principalmente a versão da Biblioteca do Porto. Segundo Nestor Goulart (2000: 310), o levantamento em que se basearam as duas versões da planta é de 1604-5. A da BMP teria sido desenhada por volta de 1616 e a do IHGB por volta de 1626.

${ }^{574}$ Reproduzido em sua totalidade no capítulo que discute a possibilidade de um "perímetro máximo".

575 Cf. LEÃO, 1957 (s/ n).
} 
reconstruções, era suficiente. Os chamados "piratas", 576 sobretudo franceses, traficavam pau-brasil e organizavam as feitorias longe dos portugueses. Mas o crescimento da produção açucareira, do Recôncavo e em Pernambuco, mais a subjugação portuguesa à Espanha (1580), ${ }^{577}$ rival de muitos europeus, sobretudo a Holanda, fizeram o Brasil despertar novo interesse. A Cidade do Salvador foi o primeiro alvo das incursões holandesas, que duraram cerca de meio século. Além de capital, estrategicamente localizada, ela armazenava as riquezas das regiões férteis circunvizinhas. Veio dessa necessidade de defesa todo o primeiro sistema de fortificações em Salvador e às margens do Recôncavo.

Em 1599, uma primeira frota holandesa com sete naus adentrou a baía. 0 governador interino Álvaro de Carvalho impôs resistência e impediu o desembarque, mas por dois meses os holandeses dominaram o mar, incendiando e saqueando a cidade. Em 1604, outra incursão de igual porte foi repelida pelo governador Diogo Botelho, mas fez nova pilhagem nos engenhos de açúcar, retirando-se quarenta dias depois. ${ }^{578}$ Apesar dos fortes da praia, ajudados por estâncias e plataformas, impedirem o desembarque dos invasores, percebeu-se a importância de fortificar mais a cidade, que não suportaria um embate maior. No governo de Diogo Botelho, como vimos, foi escolhido um recife próximo à praia para se construir uma nova fortificação que "cruzasse fogo" com as de terra, iniciando-se assim o Forte da Laje.

Entre 1604-24, os governadores que se sucederam apressaram os empreendimentos para repelir futuros ataques, complementando os fortes da praia e a defesa terrestre, com os castelos erguidos na entrada ao norte (Portas de Santa Catarina/ Carmo) e ao sul (Portas de Santa Luzia/S. Bento). Em 1621, enquanto Diogo de Mendonça Furtado assumia o Governo Geral, a Holanda instituía a Companhia das Índias Ocidentais, escolhendo a Bahia para um ataque inaugural. Em 1624 foi enviada a frota comandada por Jacob Willekens, com 26 navios carregados de munição e soldados.

Informado de um plano holandês bastante estudado, de atacar ao mesmo tempo por mar e terra, Furtado adiantou as obras de resistência, sobretudo o Forte da Laje. Foram cavadas trincheiras, construídos parapeitos, dispostas artilharias e pedida a colaboração dos moradores do Recôncavo, que entraram para o movimento. A demora do ataque e as vozes contrárias (como a do bispo D. Marcos Teixeira, que se queixava da paralisação de outras obras, administrativas, religiosas e particulares) fizeram afrouxar a prontidão, com os trabalhadores rurais voltando às suas terras. Quando as primeiras naus holandesas surgiram na ponta do Padrão, houve nova mobilização, mas sem o mesmo ímpeto.

\subsection{A cidade em guerra}

A batalha de 09 de maio de 1624 teve ações predeterminadas. Cinco barcos holandeses atracaram com seus soldados no porto de Vila Velha (atual da Barra) sem sofrer danos dos canhões do Forte de Santo Antônio. Formadas as forças terrestres,

\footnotetext{
${ }^{576}$ Corsários, "flibusteiros" (MENDONÇA, 2004: 64).

${ }^{577}$ Fim da dinastia Aviz.

${ }^{578}$ Cf. FALCÃO, 1942: 44-5.
} 
fizeram uma arrancada rápida e sem obstáculos, ${ }^{579}$ tomando o Mosteiro de São Bento para na manhã seguinte abrir, de par em par, as portas do sul e apoderar-se da cidade. Outra parte da frota atacava os fortes pelo mar, inutilizando-se na mesma tarde o inacabado Forte da Laje. No dia seguinte, quando fariam o mesmo aos fortes da praia, estes já estavam abandonados, levando o governador a se render. ${ }^{580}$

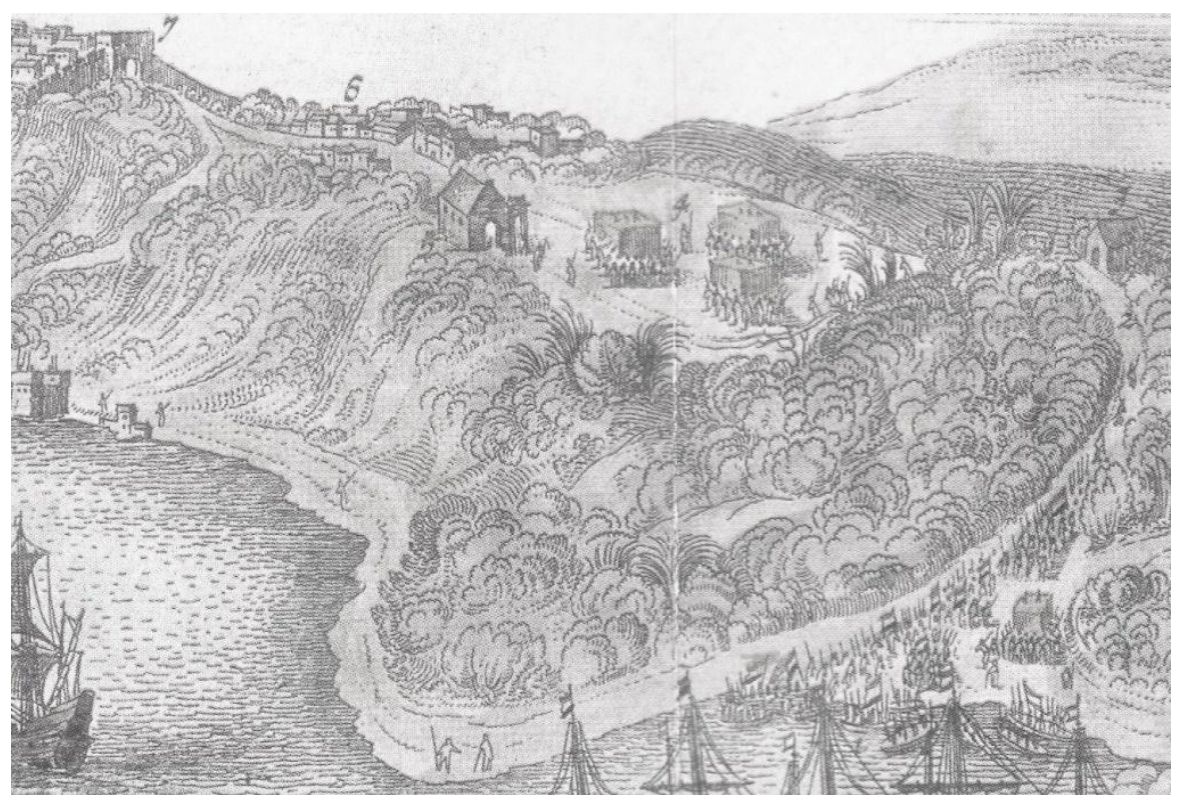

Na estampa S. SALVADOR/ BAYA DE TODOS OS SANCTOS (de Claes Jansz Visscher e Hessel Gerritsz, c. 1624 - em REIS Fo, 2000: 23-4), detalhe do desembarque no Porto de Vila Velha, escalada pela Ladeira da Barra e concentração em frente à igreja da Vitória, vendo-se à frente o Mosteiro (6) e as Portas (7) de S. Bento.

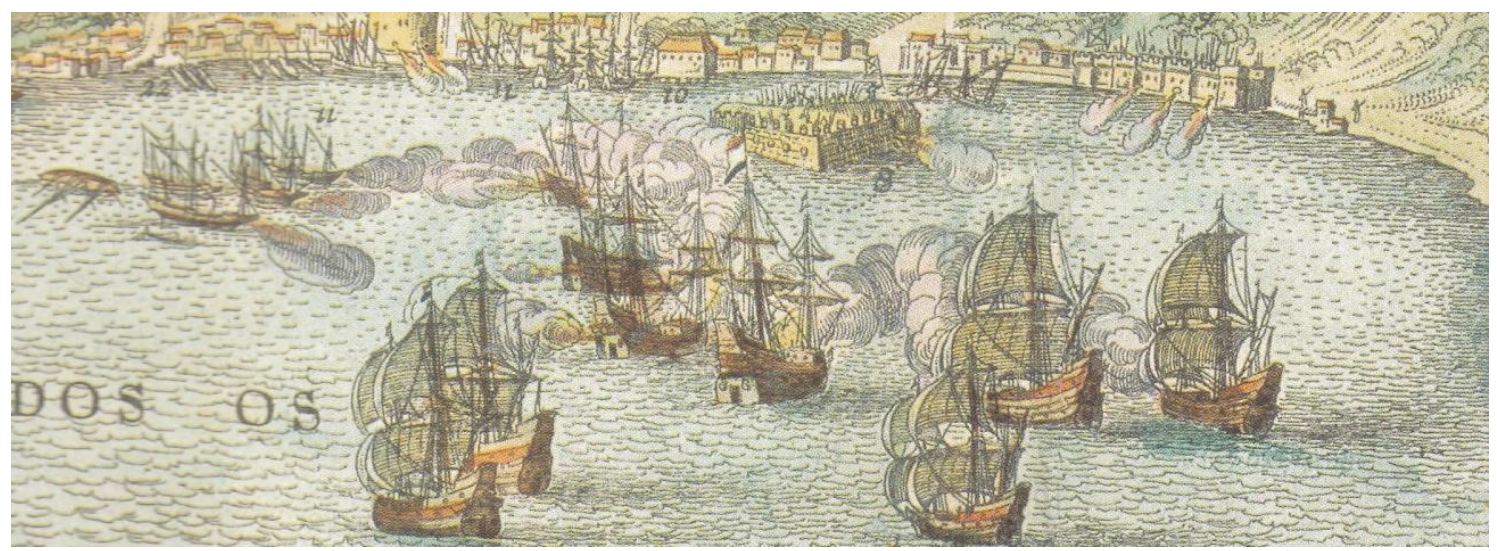

Na mesma gravura, detalhe da batalha naval.

Cinco dias depois da derrota, o bispo de Salvador assumiu o governo civil e militar da capitania, organizando a reação. ${ }^{581}$ Depois de se refugiar na aldeia do Espírito Santo, organizou uma tropa e marchou até o Rio Vermelho, onde se fortificou. Os combatentes conseguiram encurralar os estrangeiros no pequeno perímetro urbano e nos fortes de Santo Antônio da Barra, Monserrate e outros. Durante um ano,

\footnotetext{
579 “... as guarnições de defesa, estacionadas no trajeto, ao avistar o inimigo, sumiram-se em desabalada correria, sem esboçar qualquer hostilidade" (FALCÃO, 1942: 46).

580 Preferiu ser preso "a seguir a turba fugitiva, que foi a população em massa, tomada de indescritível pânico..." (FALCÃO, 1942: 46).

${ }^{581}$ Possivelmente para se redimir da campanha contra o gasto de dinheiro em fortificações.
} 
houve luta de emboscadas, ${ }^{582}$ com substituições na chefia da resistência (de D. Marcos por Francisco Nunes Marinho, e deste por D. Francisco de Moura), até que em março de 1625 chegou à entrada da Barra o socorro esperado: uma frota de 52 navios de guerra com 12,5 mil soldados, enviada pelo rei espanhol.

Como os holandeses, os espanhóis desembarcaram no porto de Vila Velha sem serem incomodados pelos canhões do Forte de Santo Antônio, já em mãos lusobaianas. Fizeram o mesmo trajeto, concentrando-se em três pontos opostos para dar o bote final, mas os batavos se renderam antes. Durante a domínio, o holandês Johan Van Dorth (que se atrasou para a conquista, mas assumiu o governo) reparou as fortificações encontradas e projetou novas obras. Entre elas, o dique das águas do vale, limitando a cidade a leste nos fundos do Convento de São Francisco.

\section{3. Ocupação holandesa}

\section{Dique}

Por não estarem prontas as defesas da cidade, os holandeses entraram com facilidade em 1624, tomaram a praça e trataram de protegê-la (já tendo uma das mais respeitadas escolas de fortificação, perceberam que Salvador estava vulnerável). A primeira medida, básica dos fortificadores, foi limpar os campos de tiro, já que a área urbana estava cercada de matos e com algumas casas tirando a visibilidade dos atiradores (sendo então demolidas). ${ }^{583}$

Fizeram redutos (ou posições defensivas) de terra na ermida de $\mathrm{S}$. Pedro e no atual outeiro do Barbalho, defesas no Santo Antônio Além do Carmo, a barragem do Rio das Tripas para criar o Dique pequeno (depois chamado Dique dos holandeses) e outras proteções menores. Esses trabalhos de fortificação foram reconhecidos em muitos documentos oficiais portugueses, havendo mesmo uma minuta do Conselho Ultramarino que diz:... q..$^{\text {do }}$ os olandezes forteficarão a sidade da baia de mais da forteficação de muralhas que fizerão a segurarão toda pela $p^{\text {te }}$ de cima co hú dique de agoas com que ficou a sidade $m^{\text {to }}$ forteficada ... ${ }^{584}$

Os fortificadores de Salvador em geral reconhecem os méritos do Dique dos holandeses. No projeto assinado por Massé, Miguel Pereira e Gaspar de Abreu (1716), ele era considerado uma peça defensiva de extrema importância:

... e' ultimamente hé muy precizo que o Dique torne ao antigo estado e'm que os Holandezes o puzeram, e' concervaram, por ser huma defença de tanta consequencia para esta Praça; porque hoje esta em muitas partes seco, e' não serca toda a Praça, como e'ntam fazia, o que se conseguirâ levantando os sangradouros por onde desagoa os palmos q' for conveniente; porque crescendo estes alargarâ as partes que estam secas té os extremos onde antigamente chegava; ê hé muito para se fazer cazo desta defença tam principal, que cada ves se vay perdendo mais: não sendo justo que pella conveniencia de alguñs se exponha a de todos; porque duas Hortas que estão junto ao Dique podem ser

\footnotetext{
${ }^{582}$ A melhor narrativa sobre esse período foi feita pelo Padre Antonio Vieira, na Carta Ânua de 1626, de alguns trechos aqui citados (cf. HANSEN, 2003).

${ }^{583}$ Cf. OLIVEIRA, 2004: 57/ ALDENBURK, 1961: 190-1/ CAMPOS, 1940: 17.

584 AHU - Catálogo de Luiza da Fonseca, doc. 1.051, de 06/05/1644 (CD2, 9, 001). Cronistas da restauração de Salvador (Tamayo de Vargas e Valencia Guzmán, transcritos por Mário Oliveira na p. 79 notas 17 e 18) e das ações holandesas (cf. ALDENBURGK, 1961: 201) afirmam ter havido muitas defesas, de repertório variado, protegendo a ocupação.
} 
mais asima e'm qualquer parte, e se para alý as fazerem e'mtulharam aquella parte que o Dique e'nchia, rezão hê torne este a ocupar o que era seu;... 585
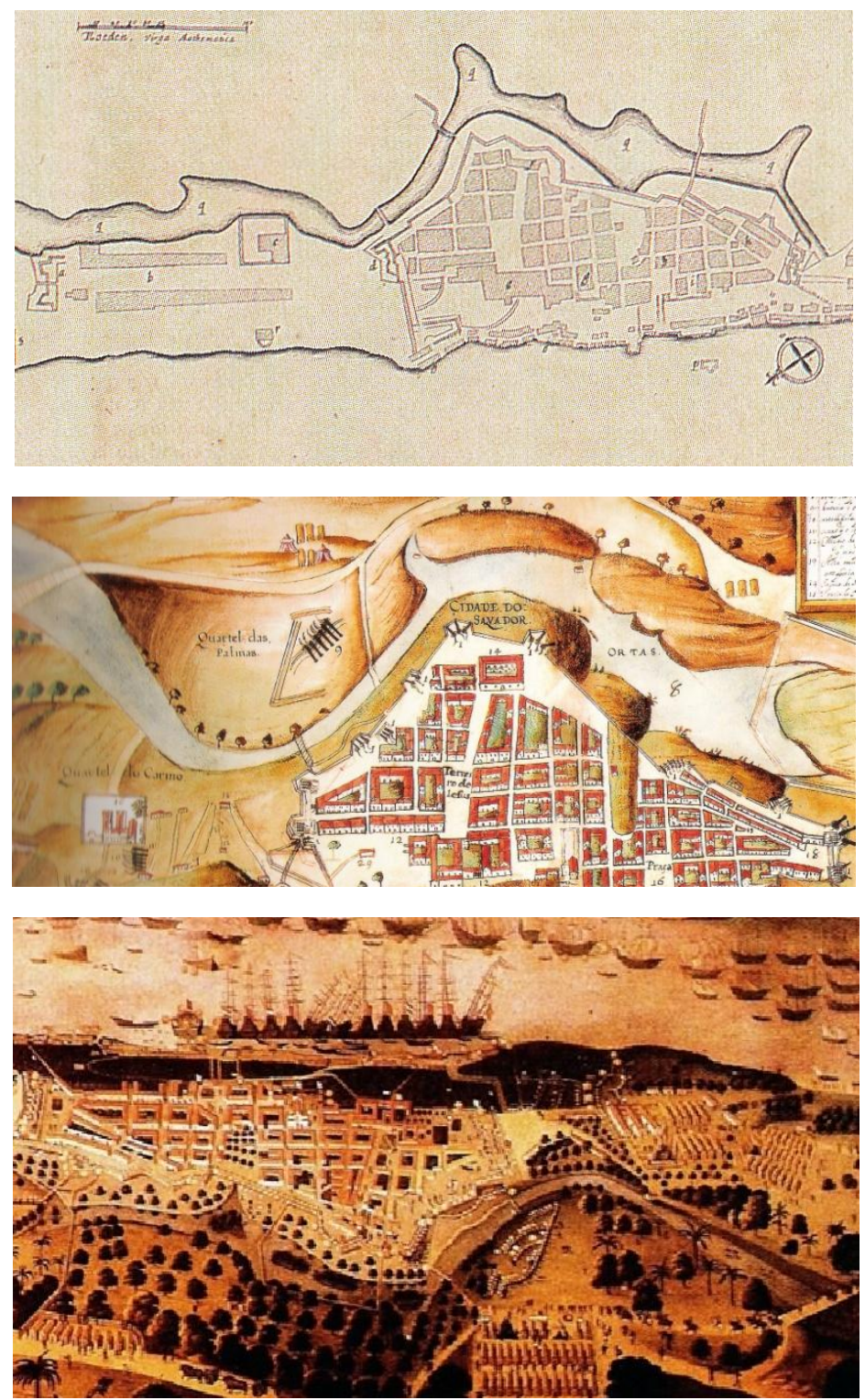

O Dique dos holandeses em detalhes da estampa no libro de Barleus (Civitas S. Salvatoris, c. 1624, em BNP, 2009), da Planta da Restituição... (c. 1627, em Atlas..., 1997) e do quadro anônimo espanhol (em NUNES, 2006). ${ }^{586}$

Falar do Dique dos holandeses nos remete de volta à hipótese defendida por Rafael Moreira, de que a cidade já teria desde o início, com Luiz Dias, as dimensões da Planta de 1605. Os que defendem essa hipótese entendem que as primeiras muralhas se limitariam a linhas transversais nas partes sul e norte da cidade, uma vez que a topografia - os acidentes naturais - dispensaria a proteção das outras faces.

\footnotetext{
${ }^{585}$ Relatório dos engenheiros..., p. 16-7 de transcrição.

586 Essa terceira ilustração, das únicas a mostrar a cidade vista pelo outro lado, foi encontrada e publicada por Marco Dorta, do CEAB (Centro de Estudos da Arquitetura da Bahia), em Evolução Física de Salvador, 1549 a 1800. Salvador: Fundação Gregório de Matos. PMS/ UFBA, 1998, p. 75 (cf. OLIVEIRA, 2004: 68).
} 

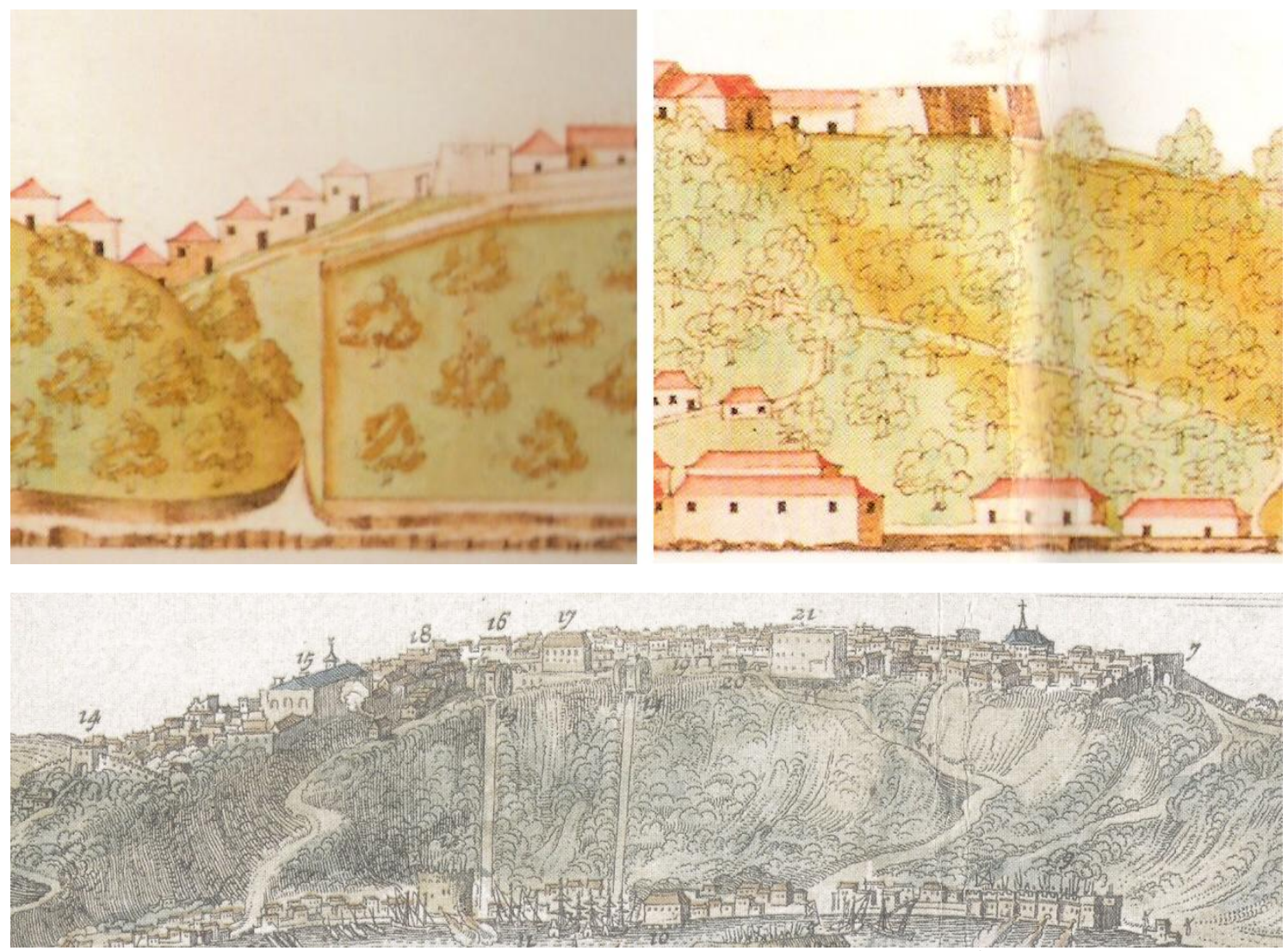

Acima, em detalhes das extremidades, a cidade no perfil atribuído a Cristóvão Álvares (c. 1611). Abaixo, a cidade murada (apenas nas extremidades, como defendem Edison Carneiro e Rafael Moreira) na gravura holandesa de Claes Jansz Visscher e Hessel Gerritsz (em REIS Fo 2000: 20-4).

Por essas duas imagens, já do começo do século XVII - representando 1611 e 1624 - não há evidências de que os fundos da cidade não fossem murados apenas porque a parte da frente, de despenhadeiro acentuado, não o era. Mas essa hipótese passa a ter mais sentido depois da construção do Dique dos Holandeses (1624-5), podendo-se mesmo apoiá-la pela gravura de Haia, que mostra uma muralha transversal à orla, fechando toda a passagem entre o dique e o mar.

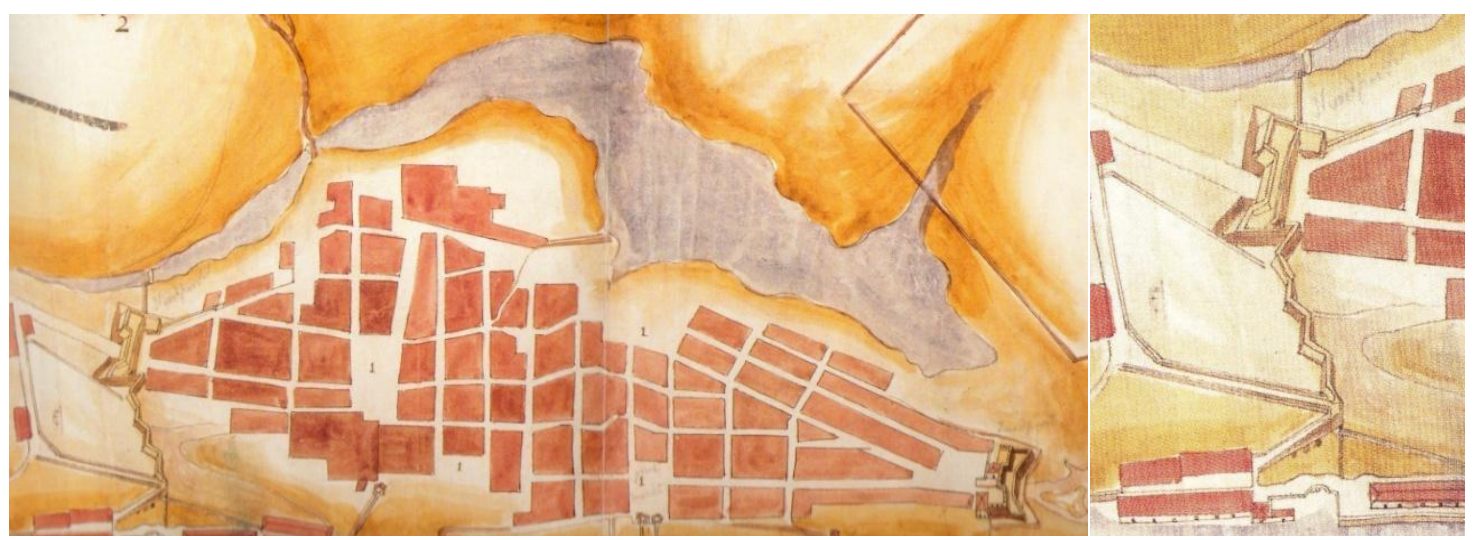

Com o Dique dos holandeses foi possível abrir mão dos muros que protegiam a cidade na face leste (interior) e por conseqüência fechá-la apenas nas extremidades ("gargalos") norte e sul.

É bem provável que a muralha que se estendia para os dois lados da Porta do Carmo realmente existisse, chegando até a Cidade Baixa, como também aparece no 
quadro de Gerritsz (abaixo). Deste trecho seriam, supomos, os vestígios citados por M. Oliveira. ${ }^{587}$

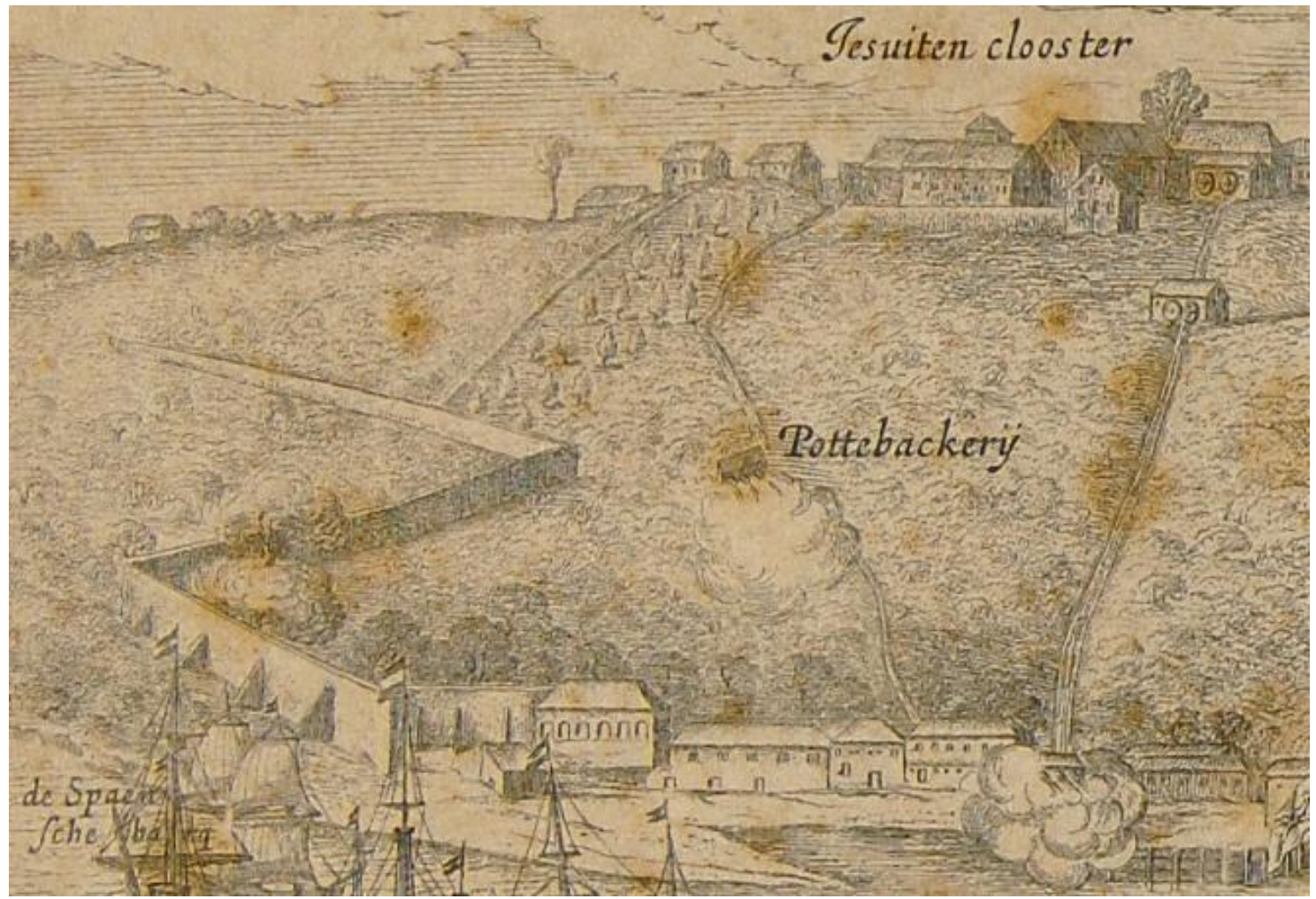

Detalhe da Gravura de Gerritsz, Sanct Salvador, c. 1627 (BN - DSC_1802).

\section{$\underline{\text { Reforma nas portas da cidade }}$}

Na guerra de 1624 foi a única vez que a Porta de Santa Luzia (depois São Bento) foi testada contra um inimigo poderoso. O historiador Silva Campos mostra que há duas versões sobre esse ataque. Na do governador Diogo de Mendonça, a porta estaria bem preparada para resistir, e quando os holandeses a atacaram (na tarde de 09/05/24), a tropa comandada por Antônio Cardoso de Matos repeliu o inimigo. Os holandeses teriam quase desistido, mas voltando na manhã seguinte (depois de pernoitarem no Mosteiro de São Bento), encontraram-na abandonada e a cidade desprotegida. Na versão de Laet, os holandeses só atacaram a porta de fato na manhã do dia 10, encontrando-a vazia. ${ }^{588}$

A gravura holandesa que retrata essa conquista mostra uma cidade já bem desenvolvida, mas de estrutura primitiva. No alto da colina, sobre o barranco, os portões representados em forma de torre (como todas as fortificações, podendo-se observar abaixo que já era fortificada a posição da futura Bateria de São Paulo da Gamboa) fariam parte da muralha, mostrada como se fosse de pedra.

\footnotetext{
587 “... não foram encontrados testemunhos além de um trecho de muralha nas portas do Carmo” (OLIVEIRA, 2004: 56).

${ }^{588}$ Cf. CAMPOS, 1940: 263 (Anais dos feitos..., p. 48).
} 


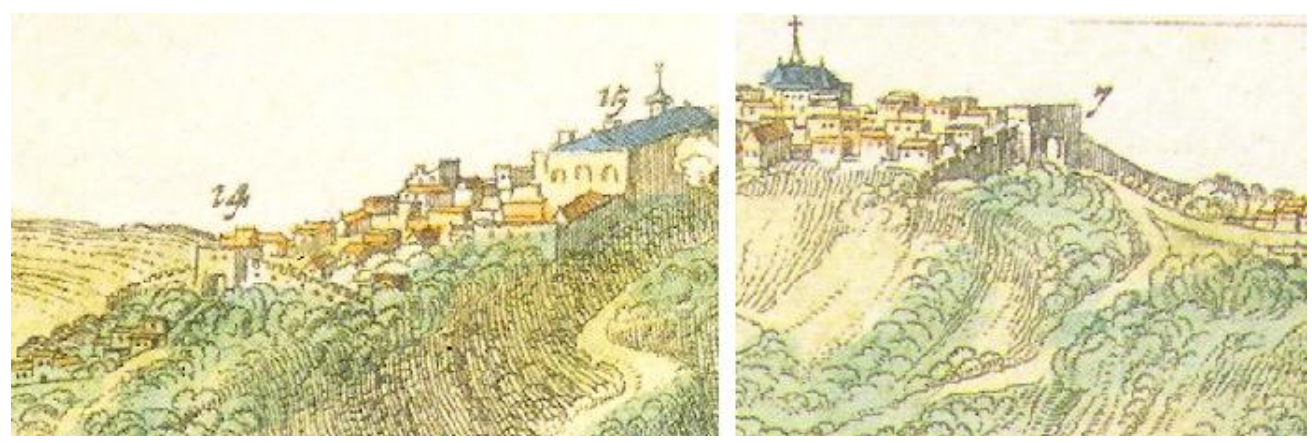

Em mais dois detalhes da gravura de Visscher e Gerritsz (c. 1624 - em REIS Fo, 2000: 23), as portas do Carmo (14) e de S. Bento (7). A gravura ilustra a invasão (como o reproduzido desembarque no atual Porto da Barra e a marcha pela ladeira) e dá uma idéia geral de localização dos edifícios, não tendo compromisso de registro arquitetônico. ${ }^{589}$

Com os holandeses, a fortificação foi chamada Portas de Isenach (nome de seu oficial comandante), sendo construído, segundo Aldenburgk, um hornaveque à direita da porta do capitão Isenach, na direção da ribeira ${ }^{590}$ Foi muito reforçada, conseguindo resistir aos ataques da artilharia luso-castelhana liderada por Dom Fradique de Toledo. ${ }^{591}$ Eram obras de terra que teriam logo desaparecido.

A Porta de Santa Catarina (ou do Carmo) durante a ocupação foi chamada de Porta de Bastefeld. Os holandeses fizeram uma transformação de maior vulto, usando pedras da construção em andamento na Sé. Teriam construído também um hornaveque, logo desaparecido, já que Aldenburgk afirma: ... pelejaram os soldados, pela porta do Capitão Bastefeld, muito bravamente, por estar tão próxima da banda inimiga, que uma das bandeiras do hornaveque foi derrubada pelos tiros... ${ }^{592}$

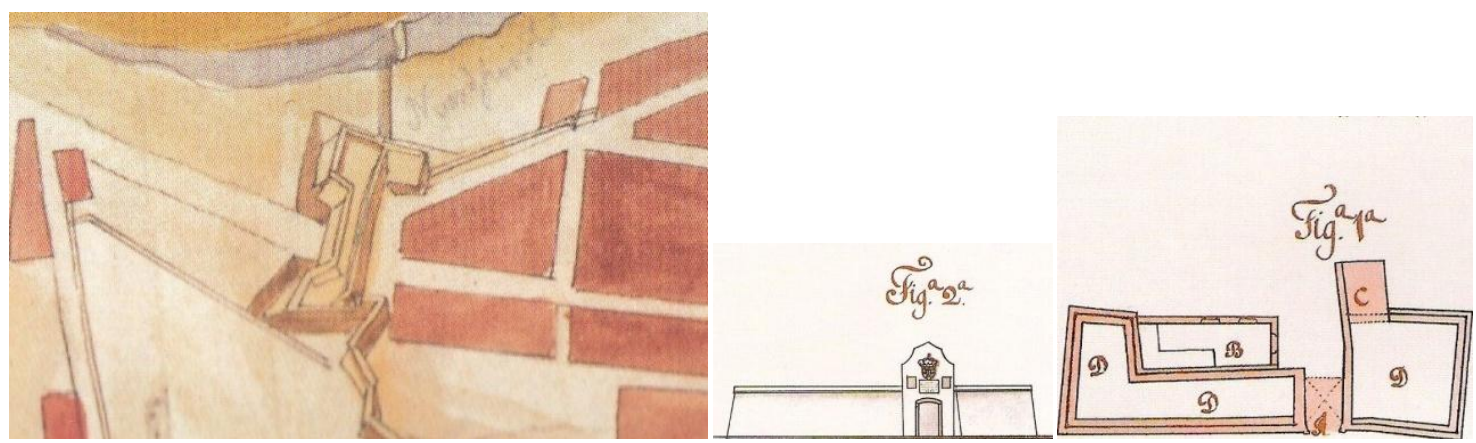

A Porta do Carmo na Planta de Haia (1638) e nos desenhos de Caldas (1759).

\subsection{Período pós-ocupação}

A tomada da cidade pelos holandeses mostrou a fragilidade do sistema defensivo. Os portugueses, mesmo envolvidos nas guerras da Restauração e tendo dificuldades financeiras em função disso, resolveram melhorá-lo investindo algum capital da Fazenda Real, mas principalmente criando imposições. Algumas defesas

\footnotetext{
${ }^{589}$ A ênfase são as batalhas marítimas, mas mostra a cidade confinada pelas muralhas (como se fossem de pedra), as várias ladeiras e planos inclinados da Praça com a Câmara e o Palácio, o Colégio Jesuíta, etc. (cf. REIS Fo, 2000: 311).

${ }^{590}$ ALDENBURGK, 1961: 195.

${ }^{591}$ Cf. CAMPOS, 1940: 263.

592 ALDENBURGK, 1961: 209.
} 
foram restauradas ou melhoradas, principalmente na administração de D. Diogo Luiz de Oliveira (1627-35), havendo ainda a ameaça holandesa.

Em janeiro de 1627 foi restaurada a sede do Brasil, mas o holandês Pieter Heyn continuou dominando as águas da baía, assaltando embarcações e engenhos. Assim, o governador fez construir baluartes nos pontos de desembarque, protegendo o centro urbano pelos lados norte e sul. No seu período administrativo foram construídos os fortes de Santa Maria e São Diogo, próximos entre si, protegendo a enseada de Vila Velha (atual Porto da Barra). No esteiro de Pirajá, aonde já havia uma trincheira provisória (de onde se enfrentava os holandeses instalados em Monserrate), ergueu-se o forte de São Bartolomeu da Passagem. Ao norte da cidade, reforçou-se o reduto de Água de Meninos (Torre de Santiago) com o forte do Rosário próximo a ele, e em terra firme foram feitas (ou refeitas) trincheiras que serviriam de base aos futuros fortes de Santo Antônio Além do Carmo e São Pedro, importantes na luta contra Maurício de Nassau.

Reformaram-se também os fortes de Santo Antônio da Barra e Monserrate, dando-se possivelmente menor atenção ao Forte da Laje para já se pensar na construção do de São Marcelo. Ao sul da baía, guarneceu-se a ponta noroeste da ilha de Tinharé, que dominava o comércio marítimo de cereais, iniciando-se o conjunto de fortificações que deu origem ao presídio do Morro de São Paulo. ${ }^{593}$

\section{Santa Maria e São Diogo}

Depois que a cidade foi retomada (1625), percebeu-se a urgência de reforçar as fortificações, aproveitando-se também o que foi deixado pelos holandeses. O Porto da Barra, onde os invasores aportaram com facilidade, foi um dos locais escolhidos: construíram-se nele os fortins de S. Maria e S. Diogo. A autorização de suas execuções não está em nenhuma Ordem Régia ou documento de governador, sabendo-se mais por deduções ou declarações posteriores. Também há referências a uma trincheira de apoio aos dois pequenos fortes, possivelmente na atual Avenida Sete, entre eles, em frente à praia. ${ }^{594}$

Os dois fortes costumam ser tratados em conjunto por defenderem o mesmo local de desembarque (é assim no Relatório Galeão, do início do século XIX, que se refere ao Fortinho de S. Diogo nas Observações sobre o de Santa Maria). Por serem pequenos, foram chefiados por muito tempo pelo comandante do Forte de Santo Antônio da Barra. ${ }^{595}$ Também há críticas de ineficiência, mas não tão consensuais quanto às feitas ao Forte de Santo Antônio. A primeira mais incisiva foi de Bernardo Ravasco (1660), considerando-os nam serem de utilidade algua'... ${ }^{596}$ O relatório de data próxima a 1671 (que M. Oliveira atribui ao Eng. Antônio Correia Pinto) traz informações importantes, inclusive sobre a suposta autorização das construções:

\footnotetext{
${ }^{593}$ No período posterior à invasão e retomada de Salvador, viu-se a importância de fortificar além da cidade o Morro de São Paulo, estratégico na defesa das Três Vilas (nome dado em documentos reais a Cairu, Boipeba e Camamu), tidas como os celeiros que abasteciam Salvador e sem os quais não se manteria a praça.

${ }_{594}$ Cf. OLIVEIRA, 2004: 194.

595 Idem, p. 195.

${ }^{596}$ Relatório de 1660. AHU - Catálogo de Luiza da Fonseca, doc. 2.264 - apud OLIVEIRA 2004: 195 e 250.
} 
O Forte S. M. ${ }^{a}$ e o de S. Diogo são de pedra e cal: ambos fundou Diogo Luiz de Olivr. ${ }^{\text {a }}$ sendo G. ${ }^{\text {or }}$ e capitam g' deste estado nos extremos de huma praya que fica na boca da barra; donde os Olandezes, e D. Fradique de Tolledo lançarão a gente, que rendeu, e Restaurou esta praça, anbos estão desmantellados: Tambem quando as Naos Inemigas ymfestarão estes Mares servião de emparo aos nossos navios e embarcaçons da costa; ambos se devem comsertar e asestir em cada hu' hu' Alfrs [alferes] ou sargento reformado dos $q^{\prime}$ ha mais antigos co' a mesma praça $q^{\prime}$ vensem, sugeitos ao Capitam do Forte S. Antonio q' há muitos Annos costumão ter os dois a sua ordem. ${ }^{597}$

Nesse caso era dado valor e utilidade às fortificações, o que já não acontece no relatório do Eng. Mil. Miguel Pereira da Costa (1710), principalmente para o de S. Diogo:

P. ${ }^{a}$ a p. ${ }^{\text {te }}$ da cid. ${ }^{\text {e }}$ a menos distanssia de tiro de Mosquete [do de S. Antônio] está o forte de S. Maria quasi quadrado, mas rigurosamente he hum eptagono, com tres angulos reint. ${ }^{\text {es }} \mathrm{m} .{ }^{\text {to }}$ obtuzos: este tem os mesmo incomodos q' o de Sa. Ant. ${ }^{\circ}$. A este se segue o forte de S. Diogo, a tiro de espingarda delle; he uma pequena bateria com tres pessas de artelhr. ${ }^{\text {, }}$, edificada na rais do monte em cuja eminemcia, está a igreja de S. An. ${ }^{\text {to }}$, donde se vê o quam condenado esteja (obra bem escuzada neste local) por ser de pouca serventia; e nestes tres se encerra a forteficação da barra, cuya defensa he impraticável, pois se não se pode impedir a entrada aos navios por resp. ${ }^{\text {to }}$ da sua $\mathrm{m}^{\text {ta }}{ }^{\text {largura. }}{ }^{598}$

Para avaliar a utilidade e eficiência desses dois redutos, deve-se considerar suas escalas e a função proposta: não defendiam a entrada da Barra (indefensável na época), mas dificultavam o desembarque em um porto cômodo. Nassau, em 1638, preferiu enfrentar o forte de S. Bartolomeu da Passagem a desembarcar no local. Podiam ser dominados pelos padrastos vizinhos, mas funcionariam bem como baterias baixas de fortificações maiores que estivessem próximas. ${ }^{599}$

\section{São Bartolomeu "da Passagem"}

O Forte de São Bartolomeu, na região de Itapagipe, fechava a entrada do estuário de Pirajá. Vimos que Teodoro Sampaio o inclui entre as fortificações iniciadas por D. Francisco de Souza (além das quatro que aparecem na estampa de Albernaz), ${ }^{600}$ mas há pouco fundamento nisso. Sua tipologia - polígono estrelado - seria estranha se comparada às outras da época, a não ser que resultasse de muitas alterações feitas posteriormente (como aconteceu ao Forte de Santo Antônio da Barra, à Torre de Santiago, ou nas reconstruções do Forte do Barbalho e de Santo Antônio Além do Carmo). ${ }^{601}$

\footnotetext{
597 DSE - Biblioteca. Relatório anônimo. Códice 1608, doc. 92 - apud OLIVEIRA, 2004: 195 e 250.

${ }^{598}$ Extracto da forteficação..., 1710, fl. 32v (BAj - Documentos Avulsos [54-IX-8] no 60).

599 No Período Imperial, o Relatório do Coronel Beaurepaire Rohan diz que receberam preparativos quando a Questão Christie chamou atenção para o estado das defesas, mostrando que tinham utilidade. M. Oliveira, baseado na descrição de Aldenburgk sobre o desembarque holandês, supõe já terem existido no lugar desses fortes, no início do século XVII, uma estância artilhada em um dos dois locais, de apoio à primitiva Vila Velha: "uma simples bateria postada no alto da colina". Mas não há menções disso no Relatório de Diogo de Campos Moreno (1609) nem no seu Livro da Razão (1612). É mais aceito que foram construídos depois da primeira invasão holandesa, no governo de Diogo Luiz de Oliveira (1627-35, o que se apóia no documento citado), e não na época do governador interino Francisco Nunes Marinho, como propôs Pedro Calmon (cf. OLIVEIRA, 2004: 195-6).

${ }^{600}$ S. Antonio da Barra, Monserrate, S. Alberto e Torre de S. Tiago. Cf. SAMPAIO, 1949: 294.

${ }^{601}$ Cf. OLIVEIRA, 2004: 180.
} 
O forte tinha valor estratégico na proteção da cidade e era importante no sistema de fortificações da época. ${ }^{602} \mathrm{O}$ apelido da Passagem era, segundo Vilhena, “... por passar por ali huma das estradas que de todos os certoens vem entrar na Bahia, sempre por terra". ${ }^{603}$ Se fosse bem guarnecido, artilhado e comandado, Nassau teria dificuldade em desembarcar naquela área em 1638. A sua melhor visão da "ambiência e situação" está numa pintura de Frans Post, em que aparece em primeiro plano seguido da indicação de outras fortificações da Cidade.

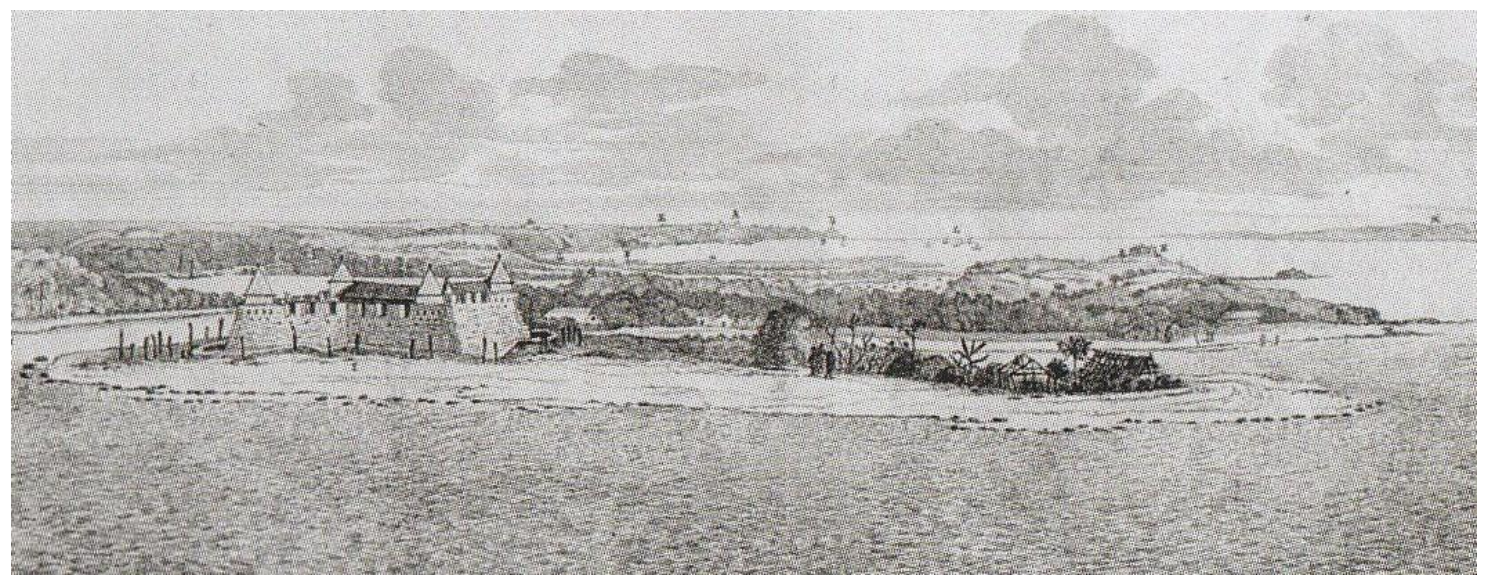

O Forte de S. Bartolomeu "da passagem" em gravura de Frans Post (1612-80) publicada em 1647 (em LAGO, 2006: 403).

\subsection{Segunda investida (1638)}

A Companhia das Índias Ocidentais parecia desistir do Brasil quando o mesmo Pieter Heyn saqueou a "frota da prata" de D. Juan Benevides, dando recursos para a invasão de Pernambuco (1630-54), que estendeu o domínio holandês por quase todo o Nordeste. Maurício de Nassau (conde Johan Mauritius Van Nassau-Siegen), que chegara a Olinda em 1637, tentou no ano seguinte invadir a Bahia com 31 navios de guerra e 4,4 mil soldados. Adentrou a barra desembarcando em Nossa Senhora da Escada, depois de Itapagipe, para atacar a cidade pelo norte (o que indica que a construção dos fortes de Santa Maria e São Diogo inibiu o desembarque e acesso à cidade pelo sul).

Ele ocupou com facilidade a planície ao norte, tomando os fortes de São Bartolomeu da Passagem, Monserrate e "Lagartixa" (deixando abandonado o do Rosário, muito vulnerável ao fogo das trincheiras). Com o avanço da guarda da porta norte pela colina de Santo Antônio Além do Carmo, houve violenta batalha que atravessou a noite de 18 de maio de 1638. Os holandeses chegaram a sobrepujar as obras de defesa iniciadas por Diogo Luiz de Oliveira, mas a tropa de Luiz Barbalho, saindo de um reduto vizinho e chegando à quinta dos Padres, atacou-os pela retaguarda, fazendo com que se retirassem dez dias depois.

Dois anos depois, Nassau quis se vingar dos baianos, enviando uma frota de 20 navios com 2,5 mil soldados. Os holandeses atacaram a ilha de Itaparica e o Recôncavo, incendiando sete engenhos. Novamente foram expulsos por Luiz Barbalho,

\footnotetext{
${ }^{602}$ Cf. OLIVEIRA, 2004: 235.

${ }^{603}$ VILHENA, 1921: 230.
} 
que voltara do Rio Grande do Norte com cerca de 1,5 mil homens. Entre 1647-9 foram as duas últimas investidas, com os holandeses se fortificando em Itaparica e destruindo cinqüenta e três engenhos e outros edifícios.
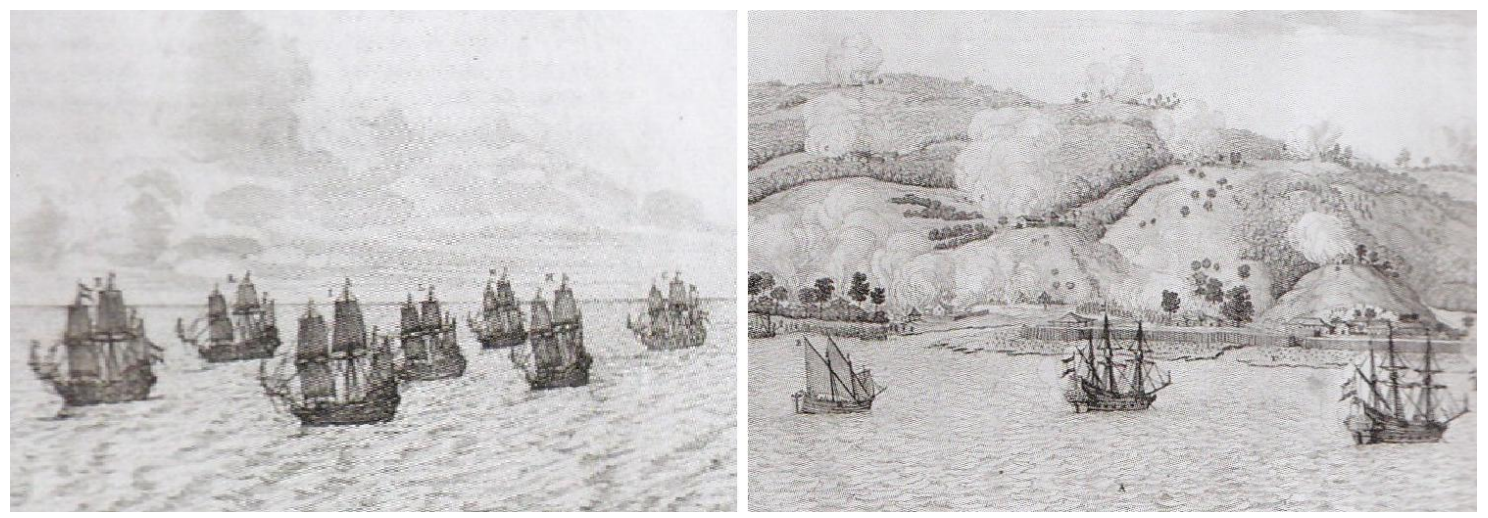

Detalhes de quadros de Frans Post (em LAGO, 2006: 406-7 - fig. G27 e G32): à esquerda, "Frota de Nassau"; à direita, "Incêndio na Baía", mostrando ataque a Itaparica em $1640 .{ }^{604}$

Por meio século, portanto, a Cidade de Salvador e o Recôncavo foram sobressaltados pela ameaça holandesa. Depois de 1624 não se permitiu mais invasão, muito em função das defesas que se ergueram sucessivamente em pontos estratégicos. ${ }^{605}$ Das batalhas de $1624-25$ e 1638 provieram ensinamentos que influíram no feitio das principais fortificações de defesa da malha urbana de Salvador nos séculos XVII e XVIII. Após a agressão, os redutos de Santo Antônio Além do Carmo e Barbalho (ao norte) e São Pedro (ao sul) foram reforçados e depois reconstruídos em pedra e cal. Os governadores portugueses que se sucederam depois de 1640 trataram de aperfeiçoar as obras militares como prevenção a possíveis ataques de outras nações européias.

\section{A nova fase (1640-70)}

\subsection{Crescimento da cidade e ampliação do perímetro fortificado}

Depois da expulsão dos holandeses, Salvador teve um novo período de crescimento, com a malha urbana se estendendo em direção às colinas (Desterro, Palma e Saúde) e continuando a se expandir nas direções norte (Santo Antônio Além do Carmo) e sul (Barra). Em meados do século XVII a cidade e o porto já eram o centro de uma região maior, o Recôncavo baiano, que em 1663 teria 69 engenhos (na época de Moreno eram 46). Em gravuras da época já aparecem mais conventos e fortes duráveis (de pedra e cal), mostrando um território de posse bem consolidada.

\footnotetext{
${ }^{604}$ Registros aqui incluídos assumidamente para "alegrar os olhos", fazendo coro às palavras de Rafael Moreira, que vê a arquitetura militar como "parte integrante da história da arte" (MOREIRA, 1989: 157). 605 Cf. FALCÃO, 1942: 50. Em 1638, "Nassau não pôde repetir a operação de Schouten, porque encontrou o porto de Vila Velha já defendido pelos fortes de Santa Maria e São Diogo". Nas batalhas seguintes, os holandeses não ousaram mais invadir a cidade, só atacando povoados do Recôncavo.
} 
A Cidade de 15 hectares em 1549 e 65 em 1580, em 1651 já ocupava $160 .{ }^{606} \mathrm{Na}$ expansão que se dava pelo cinturão imediato à ribeira da baía, consolidou-se o bairro da Praia como área urbana que ia das igrejas Conceição à do Pilar. Em locais mais afastados foram constituídas as freguesias de Santo Antônio da Barra e de Santo Antônio de Ipitanga (Itapuã). Na consolidação de áreas urbanas da cidade alta, como o largo de Santo Antônio Além do Carmo, os bairros da Palma, Desterro e Saúde, criaram-se ruas estreitas e de cumeadas, ocupando-se o entorno das fontes.

Vimos que quando os holandeses voltaram (1638) a cidade estava mais bem defendida, com tropas comandadas por soldados profissionais (Bagnuolo) e veteranos (Luiz Barbalho). E mais fortificada, principalmente, pelas obras que eles mesmos deixaram. Não houve assim uma segunda invasão. Mas com a tentativa de Nassau, e mesmo depois da Restauração (1640), foram empreendidas algumas obras de defesa, principalmente na curta e objetiva administração do Vice-Rei D. Jorge de Mascarenhas, 1ㅇ Marquês de Montalvão (1640-1). Essas obras se concentraram na restauração e reforço de algumas posições existentes, principalmente as deixadas pelos holandeses. Antônio Teles da Silva (1642-7) continuou as obras de Montalvão e iniciou o perímetro alargado de novas trincheiras. ${ }^{607}$ A Coroa investiu pouco nesse empreendimento, levado adiante com impostos locais e pela contribuição voluntária dos habitantes da Cidade e do Recôncavo.

A vitória portuguesa nas Guerras da Restauração, trazendo Salvador de volta à condição de colônia lusa, contribuiu para o início de um novo período na vida da cidade. Na chegada à Bahia do Vice-Rei Jorge de Mascarenhas, vinha em sua comitiva o confessor, jesuíta de origem irlandesa, Inácio Stafford, professor de matemáticas e fortificações do Colégio de Santo Antão (autor de um refinado códice encadernado). ${ }^{608}$ É bem provável que o padre tenha influenciado o vice-rei na melhoria das defesas. As tensões políticas fizeram com que o marquês voltasse a Lisboa no ano seguinte, mas teve tempo de seguir a recomendação de reedificar o que o Holandês tinha fortificado. ${ }^{609}$

\footnotetext{
${ }^{606}$ Cf. NUNES, 2006. As principais vias passaram a ser o Caminho de Areia (atual Jequitaia), a ladeira e rua do Carmo, a do Taboão, as ladeiras da Palma e da Barroquinha, o Caminho do Conselho (atual Ladeira de São Bento), as ruas da Vala (atual Baixa dos Sapateiros), Cruzeiro de São Francisco, a de baixo de São Bento (atual Carlos Gomes), a do Alvo, do Tijolo, as atuais Rui Barbosa e 28 de Setembro e a Travessa do Desterro.

Além dos militares, os principais edifícios construídos ao longo do século XVII foram: 1- (civis) casa dos sete candeeiros (2 2 metade do século), solares Berquó (1691?), do Unhão e do Ferrão (1690-1701); 2- (religiosos) Catedral Basílica (onde era a igreja do Colégio de Jesus - 1657-72), igrejas da Ordem 3 a do Carmo (1644), de N. S. do Monserrate (e mosteiro -1650), de São Francisco Ordem 1a (e convento 1686), a capela da Palma (1630) e o convento de Santa Tereza.

607 A planta de Salvador do livro de Frézier - 1714, mostrada na p. 186, dá uma idéia desse novo perímetro fortificado.

${ }^{608}$ O jesuíta Inácio Stafford, mentor espiritual do vice-rei e um de seus conselheiros nas fortificações, acompanhou-o na ida e na volta de sua passagem pelo Brasil. O jesuíta escreveu um conceituado tratado de fortificações, em forma de códice, hoje na BNL (cf. COSTA Luiz Monteiro da. O engenheiro jesuíta Stafford, confessor do Marquês de Montalvão: Apontamentos para a história do primeiro vice-Rei do Brasil. Centro de Estudos Bahianos, 1954, p. 3-23/ OLIVEIRA, 2004: 82).

${ }^{609}$ Fizemos a deligência que Vossa Excelência mandou das portas e muralhas da Cidade, com os Mestres de Campo, os quaes acharam que para se fortificar esta Praça hera necessario acrescentar duas pontes nas portas, e alguns baluartes, e derrubar os quarteis que estam feitoz [da época de Diogo Luiz de Oliveira], e algumas cazas de moradores, nos ajustamoz em Reparar o que Vossa Excellencia nos manda
} 
Defender Salvador, mais do que uma decisão administrativa, era uma necessidade: além dos inimigos tradicionais, passou a haver os espanhóis. A preocupação se mostra em uma portaria governamental (04/07/1640):

... e que nas occasioeñs que se esperam de Guerra se ajunta a Camera com os Coroneis, e vizitam os muros e portas da Cidade para se ter visto o que falta para o seu Reparo, e porque lhe rezam que nesta Cidade se uze o mesmo que em Lisboa pois as occasioeñs aqui sam mais sertãs, e a guerra viva... ${ }^{610}$

A decisão de um novo perímetro fortificado também pode ter sido do governo posterior, de Antônio Teles da Silva (1642-7), depois de um triunvirato de interinos. ${ }^{611}$ A expansão do tecido urbano extramuros já ultrapassava o antigo perímetro de defesa, alcançando com casas e propriedades a linha de elevações que corresponde à Palma, ao Desterro e à Saúde, seguindo após a abadia beneditina em direção ao antigo Bairro do Curral, onde está o Forte de S. Pedro, que até então era isolado. Uma referência clara à necessidade de criar outra linha de defesa, com um perímetro mais amplo, é um documento da Câmara (recém-citado) que diz: ...e a verdadeira fortificação dizem todos geralmente que se tem visto por esperiencia a de se fazer por fora da Cidade, como se tem ordenado para que o inimigo não possa nunca chegar ao Carmo nem a Sam Bento, lugares superiores da Cidade... ${ }^{612}$

$\mathrm{Na}$ época de Montalvão também houve uma ordem de executar mais duas mil brasas de fortificasão que se hão de fazer per fora da Cidade, ${ }^{613}$ o que se confirma pelo relatório de Coutinho (1685), que fala em trincheiras feitas a mais de quarenta anos. A obra defensiva empreendida por Teles da Silva era apoiada pelo Eng. Mil. Ten. Gen. Gaspar Pinheiro Lobo, que a partir de 1643 é citado em documentos oficiais, indicando ter sido importante na nova fase de fortificação de Salvador. ${ }^{614}$ Antônio Teles da Silva, já no fim de sua administração, consultou o Conselho de Guerra pedindo um engenheiro francês, ou pessoa que possa saber de fortificação..., ${ }^{615}$ indicando-se, no mesmo documento, o nome de Gaspar Pinheiro Lobo pella particular notícia que tem d'aquella cidade por haver sido quem a fortificou. ${ }^{616}$

em sua Portaria, que he Reedificar o que o Olandês tinha fortificado... (AMS - Docs Históricos do Arquivo Municipal - Atas da Câmara (1625-1641), 1944, v. 1, 1944, p. 445 - apud OLIVEIRA, 2004: 79).

${ }^{610}$ AMS - Atas da Câmara (1625-1641), v. 1, 1944, p. 436 - apud OLIVEIRA, 2004: 67.

${ }^{611} \mathrm{O}$ parágrafo 12 do regimento dado a Antônio Teles da Silva diz: Entenderei com m. ${ }^{\text {to }}$ cuidado $e$ vigilancia na guarda, e deffensas dos postos, de todo aquelle estado prevenindo as couzas da fortificação das fort. ${ }^{\text {as }}$, art. ${ }^{a}$ Polvora e tudo o mais $q^{\text {to }}$ puder ser neces. ${ }^{\text {rio }}$ de manr. ${ }^{a} q$ em nenhua p. $^{\text {te }}$ nos achem desapercebido e para asy ser haveis logo tanto q chegardes mandar avizo a todos os Capitães das Capitanias encomendandolhes a mesma prevenção e vigilançia, e q nos avizem do estado de cada hua dellas e da gente e monições q nellas ha e se tem necessidade de nossa ajuda, e tendoo o socorreis segundo a importançia della e me avizareis de tudo (AHU - Documentos Avulsos, Bahia: AHU_ACL_CU_005, Cx. 1, D. 40 - de 16/06/1642 (CD1, 1, 002, 260-79).

${ }^{612}$ AMS - Atas da Câmara (1625-1641), v. 1, 1944, p. 445 - apud OLIVEIRA, 2004: 68.

${ }^{613}$ AMS - Atas da Câmara (1641-1649), v. 2, 1949, p. 58 - apud OLIVEIRA, 2004: 68.

${ }^{614}$ Cf. VITERBO, 1904: II, 235-7. Pinheiro Lobo pode ter vindo no tempo de Montalvão (Luiza da Fonseca menciona que dois engenheiros ilustres teriam vindo com o vice-rei - cf. FONSECA, Luiza da. Subsídio para história da Cidade da Bahia. Salvador: IHGBA, 1950, p. 413/ OLIVEIRA, 2004: 68), tendo provavelmente regressando a Portugal em poucos anos e voltado depois à Bahia.

${ }^{615}$ VITERBO, 1904: II, 237. Nota-se o começo do prestígio da Escola Francesa de fortificar, continuado depois com a vinda de outros franceses.

${ }^{616} \mathrm{BN}$ - Documentos históricos, 1935, v. 30, p. 363. Registro de Carta Patente: ... por ser sujeito de muitas partes, grande Escrivão, e Contador e na profissão grande riscador de plantas... - apud OLIVEIRA, 2004: p. 68 e 134. Não foi encontrada a provisão de sua volta ao Brasil. Por Decreto Real de 21/05/1647, 


\section{Algumas fortificações documentadas}

Sobre esse novo perímetro fortificado, que abraçaria a cidade avançando por uma segunda linha de montanhas (bairros da Palma, Desterro e Saúde), em 1660 o Secretário de Estado Bernardo Vieira Ravasco relacionou fortalezas e armas, em relatório enviado à Corte. ${ }^{617}$ Eram baluartes, provavelmente de terra, articulados por trincheiras que cercavam a cidade a partir das fortificações marítimas (atravessando a Piedade, Lapa, Mouraria, Campo da Pólvora, Desterro, Saúde, Carmo e Santo Antônio Além do Carmo) e chegavam ao norte nas defesas do porto: S. Jorge ( 2 peças de ferro de $8 \mathrm{~L}$ casa), S. Bento ( 4 peças de ferro, 2 de 9 e 2 de $8 \mathrm{~L}$ ), S. Salvador (3 peças de ferro, 1 de $10 \mathrm{~L}$ e 2 de 8 ), S. Theodosio (2 peças de bronze de $7 \mathrm{~L}$ e um de ferro de 8), S. Antônio ( 3 de bronze de $7 \mathrm{~L}$ e 1 de ferro de 8), S. Luís ( 1 de bronze de $14 \mathrm{~L}$ e 1 de ferro de 10) e S. João ( 5 peças de ferro, 2 de 8 e 3 de 7 L). ${ }^{618}$

$\mathrm{Na}$ ausência de um mapeamento dessas obras (desapareceram os desenhos do projeto do Cap. João Coutinho), o desenho de Frézier dá uma idéia de como elas eram implantadas, assim como a planta do projeto Massé (embora esta não deixe claro o que era projeto e o que estava preservado das defesas dos anos 1640).

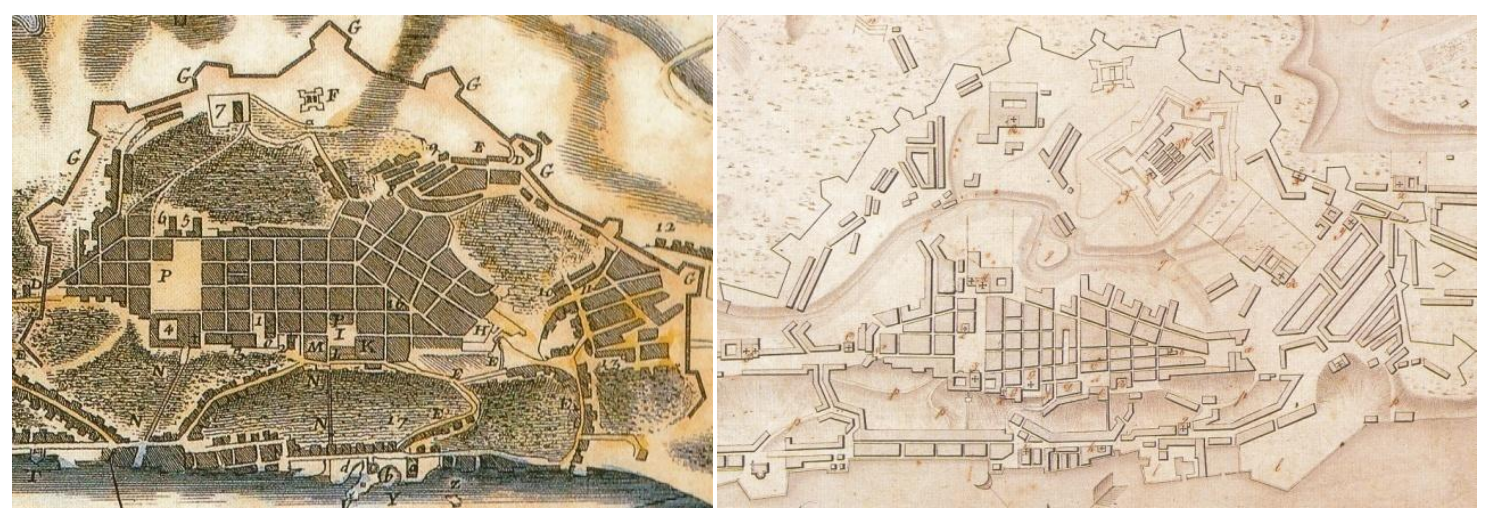

À esq., detalhe da estampa Vue de la Ville de St. Salvador..., ilustração do livro de Amédée F. Frézier, c. 1714. À dir., a Planta do projeto de Massé, detalhe da cópia manuscrita do AHM, c. 1715, ambas mostrando o 2을 perímetro fortificado do período pós-Restauração (em REIS FILHO, 2000: 30-1). Para M. Oliveira, (2004: 204), a primeira planta teria segundas intenções: "os franceses estavam muito interessados no Brasil naquela quadra".

Diogo Paes foi enviado a Salvador para servir como engenheiro (cf. BAj - Documentos Avulsos [51-V49]/ OLIVEIRA, 2004: 68).

${ }^{617}$ Bernardo Vieira Ravasco, nascido e falecido na Bahia (1617-97), era irmão do Padre Antônio Vieira e teve uma vida longa e movimentada. Estudou no colégio dos jesuítas, cursou Humanidades e formou-se em Filosofia. Mas seguiu carreira militar, distinguindo-se na campanha contra os holandeses como Capitão de Infantaria. Reconhecido, foi nomeado Secretário de Estado e Guerra do Brasil. Em 1682 fugiu de uma ordem de prisão para o Recôncavo, em função de divergências com o Gen. Souza Menezes. Com a ordem revogada, voltou a trabalhar. Foi preso depois, acusado de acobertar Antônio de Brito, que matou o Alcaide-mor da Cidade. Cumprida a pena, voltou a exercer o cargo com distinção. Era muito culto, deixando vários escritos (alguns desaparecidos), sendo os mais importantes no tema das fortificações: 1- Discurso político sobre a neutralidade da coroa de Portugal nas guerras presentes das coroas da Europa e sobre os danos que da neutralidade podem resultar a esta coroa e como se devem e podem obviar (18/06/1692); 2- Remédios políticos com que se evitarão os danos que no discurso antecedente se propõem (Bahia, 10/06/1693). Cf. OLIVEIRA, 2004: 79-80 (nota 25).

${ }^{618}$ Relatório de 1660. AHU - Catálogo de Luiza da Fonseca, doc. 2.264. Cf. OLIVEIRA, 2004: 204. 


\subsection{São Marcelo}

\section{Uma filiação inconteste: o Forte do Bugio}

Não há dúvida de que a idéia do forte de planta circular em Salvador, no meio do mar, teve origem na concepção do Forte do Bugio, ou São Lourenço da Cabeça Seca, que desde o fim do século XVI se construía na barra do Tejo em Portugal, também apoiado em uma coroa. Do mesmo modo, o trabalho de engenharia não foi simples: as dificuldades encontradas na construção do forte do Bugio é que podem ter levado a sucessivos adiamentos no início das obras do São Marcelo (que também demorou, mesmo assim, mais de meio século para ser concluído). ${ }^{619}$

Rafael Moreira, em texto sobre a arquitetura militar renascentista, cita a comentada influência italiana da época de D. João III (1521-57), ${ }^{620}$ presente na fortaleza de Mazagão, mostrando que a cultura renascentista provocou "um choque em cadeia" levando à "progressiva substituição das fortificações manuelinas na Índia" (que desapareceram) e à modernização das fortalezas na África, Portugal e Brasil,

${ }^{619}$ É possível traçar paralelos entre as histórias das duas fortificações. Sobre o forte português, a primeira idéia de uma fortificação na barra do rio protegendo o acesso marítimo a Lisboa veio de Francisco de Holanda (em Da fábrica que falece a cidade de Lisboa, de 1571). Foi aceita já no reinado de D. Sebastião, encarregando-se D. Manuel de Almada de erguer a estrutura (1578), sendo indicado como local o areal da Cabeça Seca (nome provavelmente vindo da condição de ilhota que mesmo em maré alta não chegava a submergir; já o nome "bugio" vem do tipo de bate-estacas usado na estrutura primitiva; a fortificação teria a função estratégica de cruzar fogos com a primitiva Torre de São Gião). Com a crise sucessória (morte de D. Sebastião na África) e o medo de uma invasão espanhola, optou-se por uma estrutura de campanha pequena, erguida sobre grossa estacaria de madeira que, entulhada com pedras, serviu de alicerce para uma plataforma com algumas peças de artilharia. Ela foi rendida pelos espanhóis (1580) e desarmada. A fragilidade do material, a instabilidade do banco de areia e a ação das correntes e marés fizeram com que em pouco tempo aquela estrutura ficasse comprometida.

No reinado de Filipe I (1580-98), encomendou-se estudo (1586) ao arquiteto Eng. Mil. Frei Giovanni Casale (italiano) no sentido de melhorar o sistema defensivo na barra de Lisboa, ameaçada por corsários ingleses e holandeses. Casale apresentou no começo de 1590 dois projetos de fortificação, de planimetrias distintas: uma estrelada (atendendo à sugestão de André de Prade na Corte de Madri) e outra circular. Foi escolhida esta segunda, mais sólida frente à dinâmica das águas e permitindo melhor posicionamento da artilharia. Alguns historiadores, como Rafael Moreira ("o Forte do Bugio... seria construído em forma circular, conforme o projeto de Spanoqui..." - MOREIRA, 1989: 157), atribuem o projeto ao sienense Tibúrcio Spanoqui, então Engenheiro-mor da Espanha.

Ainda em 1590 houve ordem para se desenhar as barcas e machinas necessárias para o transporte e lançamento das pedras que serviriam à fundação debaixo d' água, tarefa concluída em 1593, segundo carta de Casale ao Rei. Com a morte de Casale (fins de 1594), dois de seus discípulos foram nomeados para dirigir as obras: Tibúrcio Spanoqui a Anton Coll, justificando-se que ambos conheciam o modo de fabricar y manejar los instrumentos e para que a traça començada não fosse alterada. A partir de 1598 a direção da obra foi assumida pelo arquiteto e então Engenheiro-mor de Portugal Leonardo Turriano (ou Torriani, italiano de Cremona), tendo Gaspar Rodrigues como subalterno. Com as alterações e ampliações de Turriano, o projeto entrou em nova fase. Na Restauração, o forte estava ainda em obras, mas já guarnecido e artilhado. Com D. João IV (1640-56) foi determinado que as obras fossem concluídas por um engenheiro português (1643). Começou assim uma nova etapa construtiva sob a superintendência do Conde de Cantanhede, tendo Frei João Torriani como encarregado, coadjuvado por Matheus do Couto. A obra foi dada por concluída em 1657.

${ }^{620}$ Influência que teve momentos esporádicos já em meados do século XV e uma maior intensidade na passagem para o XVI (talvez pelo mecenato dos duques de Bragança), chegando ao "triunfo" pela "transformação em 1541 do fortim de Mazagão na 'fortaleza roqueira'” (MOREIRA, 1989: 153). 
“numa extensão simultânea que revela um plano maduramente refletido". ${ }^{621}$ Lembra que nessa época o Rei valorizava seus arquitetos, havendo a presença de italianos apenas em consultas esporádicas (Benedetto da Ravenna para Ceuta e Mazagão e Antônio Ferramolino no Seinal, em 1549), mas que na época seguinte sim, o fluxo teria aumentado: no começo eram instrutores militares, passando depois a ocupar cargos oficiais como profissionais estáveis. O grande marco seria a contratação de Filippo Terzi (1576) como engenheiro de D. Sebastião, sendo o responsável por uma nova onda de "italianismo", em que as novas condições criadas pelo domínio espanhol favoreceram o perfil do engenheiro militar especializado.

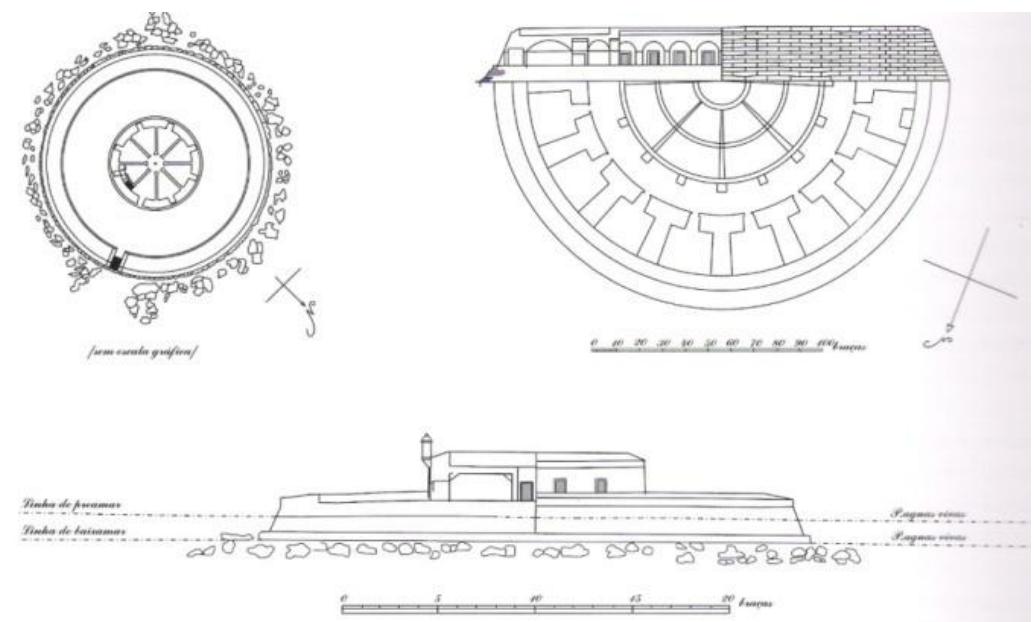

O Forte do Bugio desenhado em Cad sobre o desenho de Frei João Turriano (em OLIVEIRA, 2001: 496), nomeado engenheiro-mor do Reino por D. João IV na Restauração. As plantas e elevações acompanhavam uma carta (1646) que descreve particularidades do projeto, revelando que depois do trabalho de enrocamento (reforço da base) começado pelo Padre Eng. João Vicente Casale, ${ }^{622}$ as obras foram cuidadas pelo seu pai, Leonardo Turriano, que deixou a construção na altura do embasamento (cf. OLIVEIRA, 2004: 209).

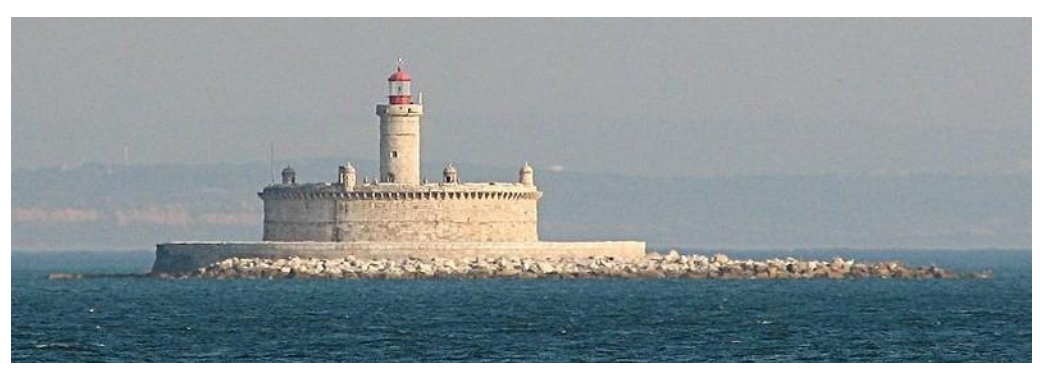

O forte em fotografia do site Google images (15/09/09). Sua estrutura é considerada exemplo de fortificação renascentista, com a planta em forma de círculo perfeito e a construção em alvenaria de pedra (o formato escolhido por Casale dava melhor direção no fogo de artilharia e também mais solidez para resistir à erosão causada pelas correntes do rio e força das marés).

É dessa época, nesse contexto, o surgimento de novas tipologias, como a cidadela isolada junto à cidade (São Filipe em Setúbal, 1582; Santiago da Barra em Viana do Castelo, 1589; Fortaleza Real de São Filipe em Cabo Verde, 1593) e as fortificações de formas perfeitas e linhas abaluartadas regulares. Normalmente os fortes são de figuras geométricas simples: triangulares (Santa Catarina na Figueira da

\footnotetext{
${ }^{621}$ MOREIRA, 1989: 155.

${ }^{622}$ Ou Vicenzio Cazali, que teria ido de Nápoles à Espanha em 1588 e logo a Lisboa com o sobrinho e também engenheiro militar Alexandre Massai, ou Alexandre Italiano.
} 
Fiz, 1598; São Jerônimo em Damão, 1615; Triquilimane em Ceilão, 1622); quadradas (Gale em Ceilão, 1618); pentagonais (aparentemente "antropomórficas": Jesus em Mombaça, 1593; Reis Magos no Rio Grande do Norte, 1598); polígonos estelares para as cercas urbanas (Malaca, 1588; Damão e Baçaim, 1595). ${ }^{623}$ A forma circular, usada por Spanoqui, já existia na tradição italiana.

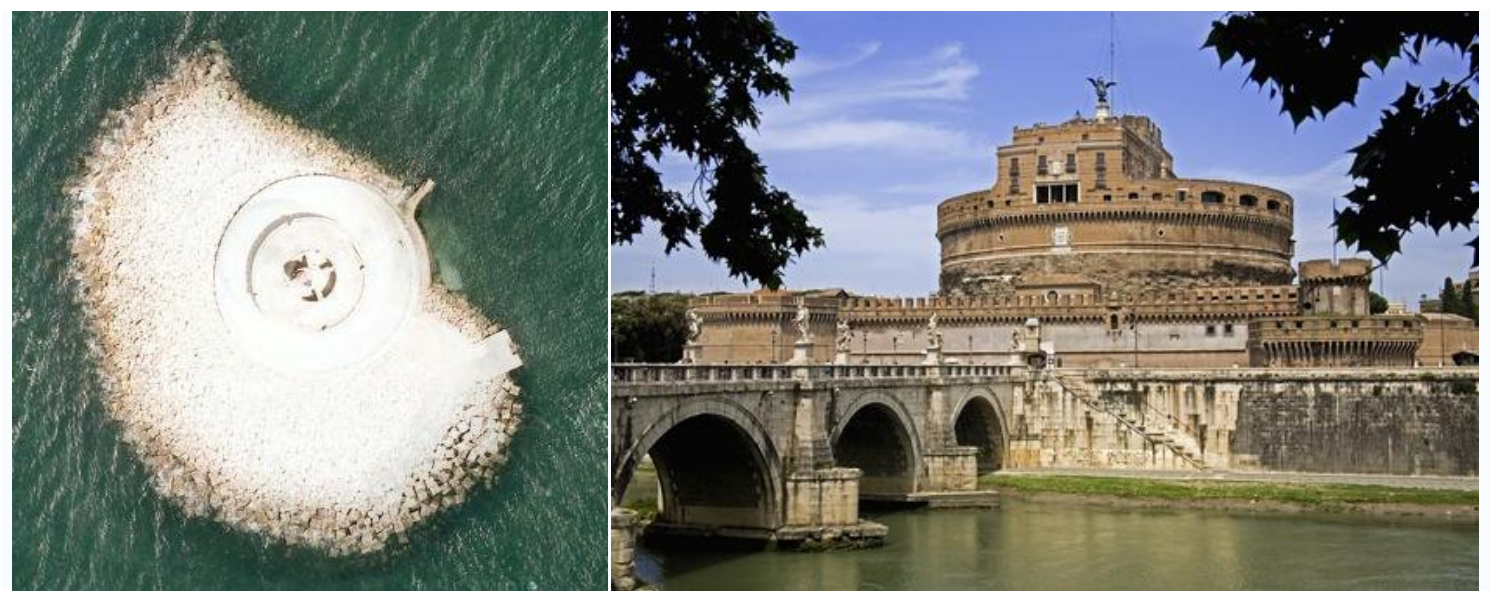

À esquerda, o banco de areia da Cabeça Seca com o forte (imagem do site Google maps em 17/09/09). Dentro da tradição italiana (a começar por Vitrúvio), ${ }^{624}$ a forma circular do Forte do Bugio teria se inspirado no Castelo Sant' Angelo, em Roma (à direita).

Spanoqui, ao que parece, foi quem criou o partido de uso da tipologia do forte redondo para ser assentada em rochas no meio do mar, que seria repetido sem grandes variações até o século XVIII (em Santos, Vitória, Belém e São Luís, sempre na forma do Bugio). Faria assim também na barra de Viana do Castelo e, nas palavras de Rafael Moreira, "daria os desenhos para o Castelo do Mar no Recife e o Forte do Mar em São Salvador da Baía".

Rafael Moreira destaca a figura de Tibúrcio Spanoqui (vindo de Siena para ser engenheiro-mor da Espanha, tendo atividade espalhada por quase todo o mundo) como centro de uma difusão internacional de formas com "alto grau de especulação intelectual". ${ }^{626}$ Foi ele o responsável pela estratégia fortificadora do Atlântico Norte, "com as imensas massas amuralhadas de Cartagena de Índias, Havana e Angra" (Açores), em defesa das principais escalas das frotas da prata da América, e pelas defesas costeiras da Sicília, Espanha, Portugal e Nordeste brasileiro. ${ }^{627}$

Rafael também cita uma interessante polêmica entre Spanoqui e Leonardo Turriano, que em meio à grande erudição, evidencia ser do primeiro a autoria do projeto para o Forte do Bugio (e eventualmente da idéia do São Marcelo): ${ }^{628}$ Spanoqui defendia para a construção militar a "superioridade da forma circular sobre a oval", enquanto Turriano elogiava a oval, dizendo que... si la belleza pusieron los Platônicos

\footnotetext{
${ }^{623}$ Rafael Moreira destaca dentro do que seria um "estilo internacional", "frio e despersonalizado", mas atendendo a "uma nova concepção estética e de funcionalidade", os nomes dos primeiros engenheirosmores: Leonardo Turriano (Portugal), Giovanni Battista Cairati (Índia) e Baccio de Filicaia (Brasil), de grande importância na história das fortificações (cf. MOREIRA, 1989: 156).

${ }^{624}$ E assim, as torres deverão ser feitas arredondadas ou poligonais... (VITRÚVIO, 2006: 47 - I, V, 50 par. trecho citado na parte inicial sobre "origens da fortificação moderna", p. 34 nota 76).

${ }^{625}$ MOREIRA, 1989: 157.

${ }^{626}$ Que, na análise classificatória de Rafael M., estariam “anunciando já a cultura do barroco”.

${ }^{627}$ MOREIRA, 1989: 156.

${ }^{628}$ Cf. MOREIRA, 1989: 156-7.
} 
en el circulo, puedese poner la necessidad en el ovado, y si en la variedad consiste maior belleça, diré que el ovado es mas perfeto que el redondo y mas necessario por la conservaçion de la misma naturaleça... (passando a citar Platão, Hermes Trimegisto, Santo Agostinho, Euclides, Raimundo Lúlio, Dürer, Pedro Nunes, Boécio e mesmo Dante). ${ }^{629}$ Debatia-se o Forte do Bugio, prevalecendo a idéia de Spanoqui. ${ }^{630}$

\section{$\underline{\text { Nossa Senhora del Populo e S. Marcelo }}$}

O São Marcelo, hoje muito reconhecido pelo seu valor arquitetônico, ${ }^{631}$ enfrentou vários problemas construtivos, não sendo perfeitamente redondo no seu anel externo (de cerca de $160 \mathrm{~m}$ de diâmetro). ${ }^{632}$ Nas dimensões, o anel interno do $\mathrm{S}$. Marcelo (de cerca de $70 \mathrm{~m}$ de diâmetro, este sim perfeitamente circular) é comparável à muralha externa do Forte do Bugio (diâmetro de $62 \mathrm{~m}$ por 6 de altura, com alambor). ${ }^{633}$

A construção do S. Marcelo seguiu a experiência do São Lourenço da Cabeça Seca, começando em meados do século XVII e indo até o XVIII. A execução inicial parece ter sido do engenheiro francês Pedro Garcim (ou Garim), ${ }^{634}$ pelas traças vindas do Reino. ${ }^{635} \mathrm{O}$ atual Forte do Mar foi concebido com partido circular, e mesmo com as

\footnotetext{
${ }^{629}$ Leonardo Turriano - apud MOREIRA, 1989: 156. Entende-se pertencer ao seu manuscrito póstumo Dos discursos de Leonardo Turriano sobre el fuerte de S. Lorenzo de Cabeça Seca, que R. Moreira conseguiu que fosse adquirido pela Biblioteca Nacional de Lisboa em 1988, prometendo apresentar estudo (o que provavelmente cumpriu com seu mais recente livro: MOREIRA Rafael, MUNOZ, Alicia Camara e MARINO Vigiano. Leonardo Turriano, Ingeniero del Rey. Madrid: Fundación Juanelo Turriano, 2010).

${ }^{630}$ Rafael Moreira aproveita a citação para mais um desfecho elegante de texto (já parcialmente aqui citado): questões como esta, "em que argumentos filosóficos e considerações estéticas se combinam de modo inextricável com as razões de ordem funcional" é que legitimam a arquitetura militar como "parte integrante da história da arte e analisada à luz das suas categorias estilísticas" (MOREIRA, 1989: 157).

${ }^{631}$ Paulo Azevedo, nos cadernos do IPAC-BA, após descrevê-lo como "desenvolvido segundo planta aproximadamente circular", considera a obra "de notável mérito arquitetônico" (AZEVEDO, 1975: 137).

${ }^{632}$ Nota-se pela fotografia (apresentada na parte final) que ele avança sobre o mar, enquanto o do Bugio está inteiramente sobre o banco de areia. O S. Marcelo é praticamente circular no lado voltado para a baía e "achatado" no que está voltado para cidade, possivelmente porque desse lado o banco de areia era mais íngreme, dificultando o enrocamento de apoio à fundação.

${ }^{633}$ Alambor = aumento de espessura na base.

${ }^{634}$ Pedro Garcim (ou Garim) sucedeu o Engenheiro Felipe Guitão (a metade do século XVII foi quando houve mais engenheiros franceses a serviço de Portugal no Brasil), que trabalhou para D. Antônio Telles de Menezes "Conde de Vila Pouca de Aguiar" (1647-50) e D. Jerônimo de Ataíde "Conde de Atougia" (1654-7, falecendo em meados desse governo). Destemido nos combates (lutou na guerra brazílica de expulsão dos holandeses de Pernambuco), em 1654 foi reconhecido também por sua competência técnica, recebendo de D. João V a patente de capitão engenheiro (cf. VITERBO, 1899: I, 413), registrada em Salvador na administração do Mestre de Campo Francisco Barreto de Menezes (1657-63), que o teria levado à Bahia já em 1657 (cf. BN - Documentos históricos, 1930, v. 19, p. 186/ OLIVEIRA, $2004: 96$ e 133).

${ }^{635}$ Cf. OLIVEIRA, 2004: 209. Carlos Ott (O Forte do Mar na barra da cidade de Salvador da Baía. In: Revista do Patrimônio Histórico e Artístico Nacional. Rio de Janeiro, 1956, v. 13/ MENEZES, 1986: 131) defende essa hipótese, enquanto Luiz Monteiro atribui ao engenheiro Garcim também as plantas. Mas Ott parece estar se referindo ao Forte da Laje, já que teria sido feito "quando se pretendeu fortificar a cidade e a barra, tendo em vista uma possível invasão holandesa", e pelo mesmo raciocínio, "de acordo com o manuscrito Rezão o estado do Brasil... o forte, na sua feição primitiva, já existia em 1612" (MENEZES, 1986: 131). Aqui também entendemos que eram traças vindas do Reino, mas produzidas ou
} 
modificações ocorridas, manteve a configuração. ${ }^{636}$ Como vimos, era um desenho incomum em fortalezas, mas não inusitado. Há outros no Brasil, como o do Forte de Nossa Senhora das Mercês (Belém), iniciado na segunda metade do século XVII pelo engenheiro José Velho de Azevedo.

A feição original devia ser de uma torre simples, pois pela lógica construtiva teria se iniciado pelo torreão central. ${ }^{637}$ As obras ainda estavam em andamento vinte anos depois da autorização da construção, quando Afonso Furtado de Mendonça (1671-5) pediu relatório técnico da situação das defesas de Salvador e Recôncavo. Nele se diz:

A Fortaleza do Mar N. S. ${ }^{\text {ra }}$ do Populo, he de canteria, esta por acabar, e na forma da ordem de S. A. se comesa a tratar de sua obra, he de muita comsideração $p .{ }^{a}$ a siguranca dos navios e não se poderem as Armadas Inemigas chegar fasilmente a dar bateria a Cidade... ${ }^{638}$

A construção do S. Marcelo foi especialmente lenta, desde os trabalhos de enrocamento para dar estabilidade às fundações. No século XVIII os engenheiros ainda tentavam melhorar sua capacidade de defesa, corrigindo as imperfeições. Algumas Cartas Régias, a partir de 1650, mostram que parte das pedras usadas no enrocamento era do Recôncavo (rochas graníticas), parte das vizinhanças (arenitos calcíferos - talvez Itapagipe e zona da Preguiça) e parte ainda de Portugal (calcário - usado como lastros de navios). O que está sugerido nas documentações é também o que aparece em amostras de sondagem. ${ }^{639}$

Aventamos a possibilidade de que mesmo a construção do forte brasileiro tendo sido deliberada em 1650, haveria já o seu projeto, em planta circular para o mesmo local, desde o começo daquele século. Mais do que isso, seria concebido pelo próprio Tibúrcio Spanoqui, como parte do plano de defesa discutido por ele, Turriano e Frias de Mesquita (divulgado por Diogo Moreno no Livro que dá Razão...). O Forte da Laje seria provisório, já se prevendo a construção de uma fortificação definitiva no local da atual (só começando a ser construída meio século depois). ${ }^{640}$

Mário Oliveira, depois de mostrar (pela tese de Luiz M. da Costa) que o Forte da Laje estaria em rocha bem mais próxima à praia, explica que o local hoje já está

na época da primeira grande fortificação (c. 1610) paralelamente às traças do Bugio (e talvez do próprio Spanoqui), ou já da época da Restauração, adaptando-se a idéia original de Spanoqui.

${ }^{636} \mathrm{O}$ projeto do Forte do Bugio mostra que o do S. Marcelo, executado ou não por Garcim, seguiu o de Portugal, principalmente em sua primeira versão com torreão e praça alta. Os desenhos de João Turriano são de 1646, e a Carta Régia autorizando a construção do São Marcelo é de 04/10/1650. O fato do S. Marcelo não ser um círculo perfeito (por circunstâncias da obra) não muda sua filiação.

637 Uma gravura da BNL, reproduzida no Ensaio de iconografia de cidades portuguesas do ultramar, mostra no porto de Salvador uma torre cercada de enrocamento. Outra evidência é a pequena artilharia de nove peças que havia nos anos 1670, segundo a Memoria que pede os [sic] Governador Afonço Furtado de Castro do Rio de Mendonça da Artelharia q. ha nesta prasa assim cavalgada com apeada \& da $q^{\prime}$ tem seus reparos e da que os não tem, e que Artilheiros e Infantes são nesecarios para guarneser os postos que a tem (DSE - Biblioteca. Relatório anônimo. Códice 1608 - apud OLIVEIRA, 2004: 210-11).

${ }^{638}$ DSE - Biblioteca. Relatório anônimo. Códice 1608 - apud OLIVEIRA, 2004: 211.

${ }^{639}$ Cf. OLIVEIRA, 2004: 210.

${ }^{640}$ Como vimos, Tibúrcio Spanoqui é o provável autor do Forte do Bugio, desenhado em finais do século XVI e de construção ainda mais lenta que a do S. Marcelo. Assim como barra do Tejo existiu uma fortificação provisória, teria sido construído o Forte da Laje para desempenhar a mesma função do forte que estaria previsto. Acreditamos, portanto, que desde a época de Frias de Mesquita, o projeto do $\mathrm{S}$. Marcelo (nome dado posteriormente) já estaria definido em sua forma e local de implantação, mas sendo provavelmente bem menor. 
incorporado ao continente em função de sucessivos aterros. ${ }^{641}$ Mas há uma questão relevante: a ilhota onde está construído o São Marcelo já existia bem antes da fundação da cidade. Acreditando-se na descrição de que "aflorava na maré baixa", representava também um perigo no tráfego das embarcações, sendo possível que desde o começo da cidade já houvesse um marco, ou pequena construção sinalizadora de sua localização. Bem em frente ao antigo porto e à Praça Municipal (como mostra a fotografia de satélite que se segue), era, desde os primórdios de Salvador, o lugar potencialmente mais adequado para se construir uma fortificação que defendesse o acesso à cidade pelo mar. Isso aumenta a probabilidade de que já se pensasse, na época do projeto de Frias (verificado e emendado por Spanoqui), em utilizar a ilhota atual, que em sua forma natural comportaria uma fortificação redonda (a elaboração do projeto do Bugio é pouco anterior ao plano de 1605).

A descrição dos acidentes geográficos em que foram construídos os fortes da Laje (c. 1610, retomado em 1623) e de São Marcelo (1650) são semelhantes. ${ }^{642} \mathrm{O}$ fato de haverem duas (ou mais) pedras ou bancos de areia que "afloravam" na maré baixa pode não só ter confundido alguns historiadores como dado a opção de que se construísse primeiro uma fortificação mais simples, provisória, próxima ao cais, dandose bem depois execução à idéia de Tibúrcio Spanoqui.

Beatriz Bueno lembra que no posto de engenheiro-mor da Espanha, Spanoqui foi encarregado de estudar as defesas da Bahia e do Porto do Recife entre 1605-6. Haveria, segundo ela, uma obra "perdida" de Tiburcio Spanoqui, mencionada por Alicia Câmara: ...en 1602 el Rey Felipe III le ordeno que pusiera en libros todas las trazas de fortificación en las que havia intervenido o supervisionado em los reinos peninsulares..., $y$ en America (o que incluiria o Brasil). ${ }^{643} \mathrm{~A}$ diferença de datas não faz descartar a seguinte possibilidade: com a solicitação feita em 1602, Spanoqui estaria trabalhando para atendê-la em 1605-6, produzindo, além da confirmação e emenda da Planta de fortificação de Salvador (1605), "quiçá" um projeto de fortaleza em frente ao porto de Salvador, embrião do que seria o atual Forte São Marcelo.

\footnotetext{
${ }^{641}$ Voltaremos a esse assunto ao abordar do Forte da Ribeira, do séc. XVIII.

${ }^{642} \mathrm{Na}$ descrição de Carlos Ott (cf. MENEZES, 1986: 131), por exemplo, ele está se referindo ao Forte da Laje ("... tendo em vista uma possível invasão holandesa"), mas pensando no S. Marcelo, ao narrar que "existia no meio do porto um rochedo plano, que aparecia à flor da água na maré baixa; poderia constituir um ponto estratégico para a construção dum forte cujos canhões facilmente impedissem a entrada de navios".

${ }^{643}$ Cf. CÁMARA, Alicia. Fortificación y ciudad en los reinos de Felipe II. Madrid: Editorial Nerea, 1998 apud BUENO, 2001: 170. Para Beatriz Bueno, esse conjunto documental posto "en libros" seria o códice de Tubucio Spanoqui de c. 1600 da Biblioteca do Instituto della Arma del Genio (sediada no Castelo de Sant' Angelo, Roma), ao qual não teve acesso.
} 


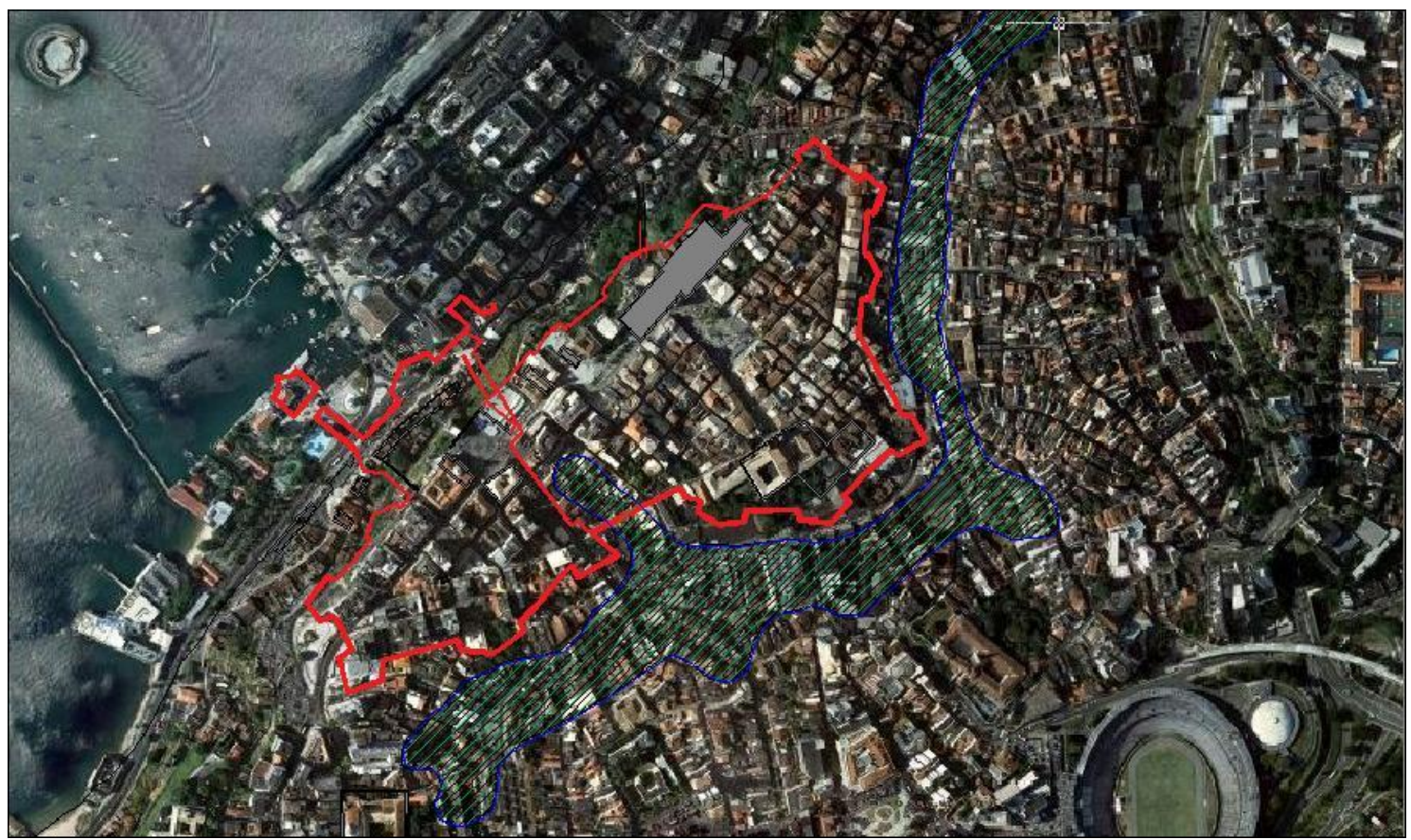

O desenho sobre a fotografia de satélite da cidade atual (do site "Google maps" em 15/09/09), base da ilustração seguinte, mostra a distância do S. Marcelo em relação ao antigo porto e ao cais atual, indicando a provável localização do antigo Forte da Laje.

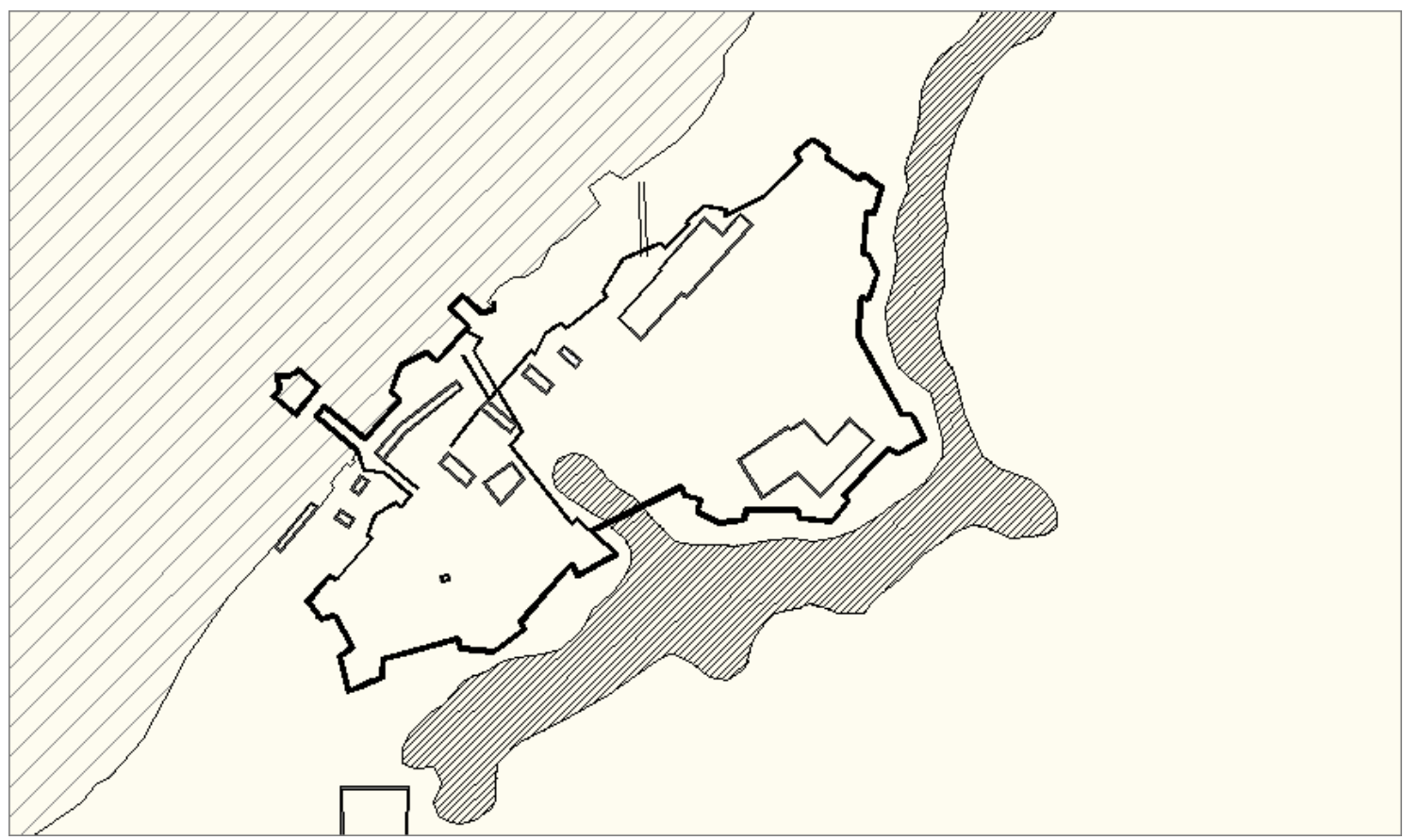

O mesmo desenho de cima, sem a base fotográfica. A partir de conversa com o prof. M. Oliveira, corrigimos a linha praia (atentando também para a direção do molhe em relação às ruas da cidade e baluartes à volta da Porta sul), fazendo coincidir a área da antiga Igreja de N. S. da Conceição da Praia com os fundos da atual (como indicado por ele: a antiga linha da praia seria próxima ao seu adro). Assim, o antigo forte estaria mesmo localizado na área aterrada (da Marinha) próxima ao local em que foi desenhado, como defende o professor da UFBA, com base em desenhos do séc. XVIII. 


\subsection{Dique Grande}

O Dique Grande, hoje conhecido por Dique do Tororó (às vezes confundido com o dique dos holandeses) aparece em toda a sua extensão na planta da época em que esteve na Bahia o Brig. João Massé (1716), que foi depois publicada nas Cartas Soteropolitanas de Vilhena. Também aparece no levantamento do Capitão Joaquim Vieira (1798), com anotações batimétricas sobre ele, que já começava a diminuir (o que também se observa na planta de Salvador ordenada por Galeão).

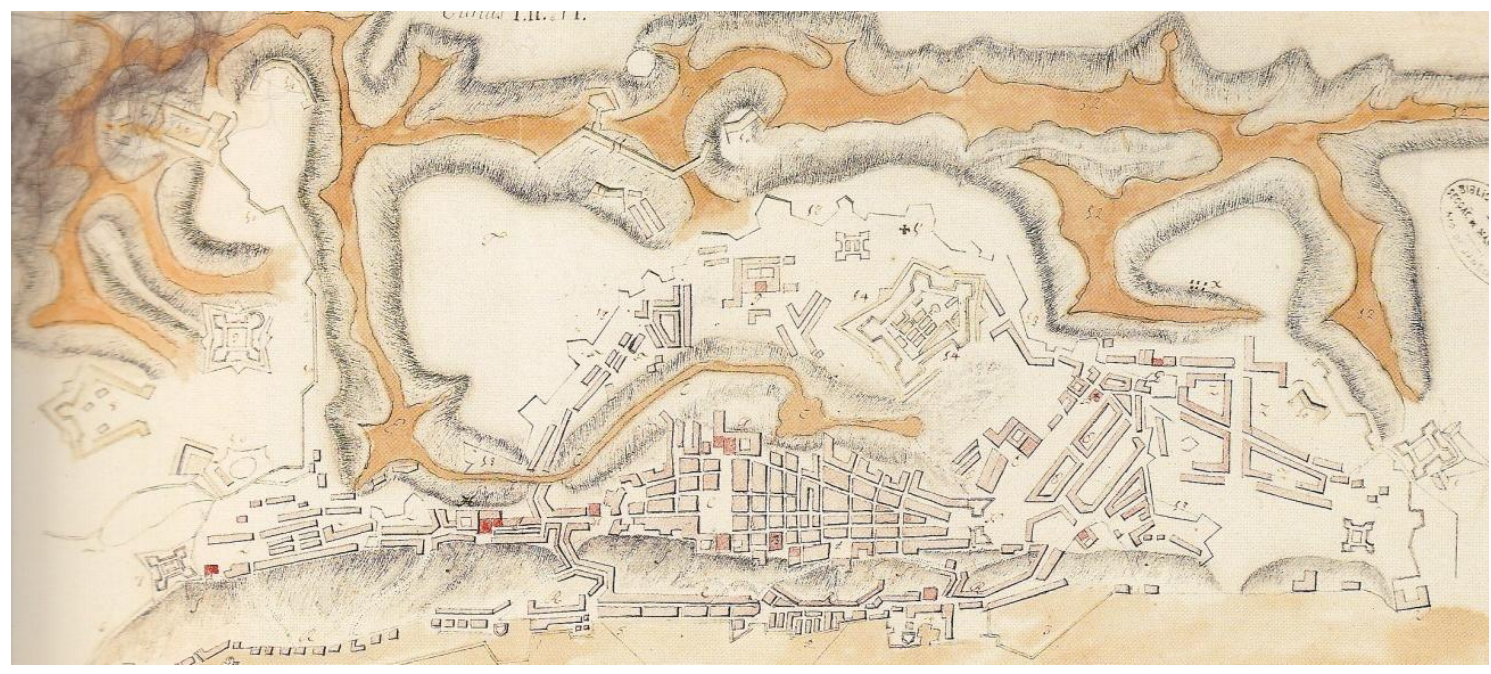

Planta da Cidade da Bahia..., cópia manuscrita baseada no levantamento de J. Massé que ilustra o livro de Vilhena, c. 1715 [1801] (em REIS FILHO, 2000: 37).

O Dique não existia na época dos holandeses, aparecendo em cartografias só o represamento do Rio das Tripas feito por eles. Também a imagem do quadro espanhol (dos poucos com a cidade vista da terra para o mar) mostra apenas o primeiro reservatório, e na planta de 1638 guardada pelo Algemeen Rijksarchief de Haia não há sugestão da represa.

O Adiq Grande (na grafia de João Coutinho) seria uma peça chave no novo perímetro defensivo de Salvador, tendo sido iniciado provavelmente no governo de Antônio Teles da Silva (1642-7). Como obstáculo contra ofensivas militares (não há dúvidas sobre isso), viria acompanhado de uma nova linha de fortificações próximas que o cobririam com mosquetes ou artilharia. Vimos ser provável que esse novo perímetro defensivo, considerado importante na época de Montalvão, tenha sido continuado por Antônio Teles (que sempre se preocupou em defender a Cidade e o Recôncavo). ${ }^{644}$ Esse governador enviou muitas Portarias à Câmara para que ela se responsabilizasse em fabricar trincheiras, com desenhos que os documentos sugerem ser do Ten. Gen. Eng. Gaspar Pinheiro Lobo. Novamente, os recursos para as obras que saíam dos impostos eram desviados de vários modos, já sustentando uma infantaria de guarnição da praça de cerca de três mil homens.

Em 03/01/1643 foi lavrado termo de vereança na Câmara, ${ }^{645}$ com a presença do Eng. Gaspar Pinheiro Lobo, considerando haver a ameaça de uma nova invasão holandesa e avaliando-se que as obras estavam pela metade. A partir de 1644

\footnotetext{
${ }^{644}$ Deve ter vindo com determinações nesse sentido, pois ainda hava a ameaça holandesa.

${ }^{645}$ Cf. fl. 39 em AMS - Atas da Câmara (1641-1649), v. 2, 1949, p. 146-7, transcrita na íntegra em OLIVEIRA, 2004: 83 (nota 97).
} 
aparecem nas Atas da Câmara vários pagamentos parciais ao empreiteiro Jerônimo Miranda por executar braças de trincheiras ao redor desta cidade, ao preço de $4 \$ 000$ rs. a braça e com a garantia de um ano e um dia para as obras executadas em terra batida ou gazonada. Os pagamentos vão pelo menos até 1646, quando há referência ao Dique Grande: uma autorização para contratar índios para as obras. ${ }^{646}$

Acredita-se que havia uma fortificação no local do atual Forte de S. Pedro, provável obra dos holandeses, ${ }^{647}$ mas em 1646 decidiu-se fazer lá um forte real, para... goarda do dique grande que os moradores desta Cidade contribuiram para a despeza delle com dinheiro e seos escravos... ${ }^{648}$ Para realizar a obra, a Câmara contratou João Mendes Palheiros, em tempo integral, como apontador dos negros nas obras do Dique Grande. $^{649}$ O Dique Grande foi, portanto, obra portuguesa, de defesa e sendo assim considerada até pelo menos o final do século XVIII. Era importante no sistema defensivo projetado em 1685 pelo Cap. Eng. João Coutinho. A planta de Salvador organizada por Galeão (1785) diz na legenda: com a Hydrográfica do Grande Dique, que serve de fosso a parte da Praça desta Cidade... ${ }^{650}$

O ensinamento holandês de barrar as águas como defesa continuou a ser praticado na Bahia, sendo também cogitada (mas não realizada) a ampliação do sistema pela inundação do vale que dava acesso aos fortes de S. Maria e S. Diogo, terras baixas da atual Av. Centenário (Rio das Pedrinhas), ruas Miguel Burnier e Afonso Celso para dificultar invasões a partir da costa entre Barra e Itapuã (aproximação pelo sul da cidade). ${ }^{651}$

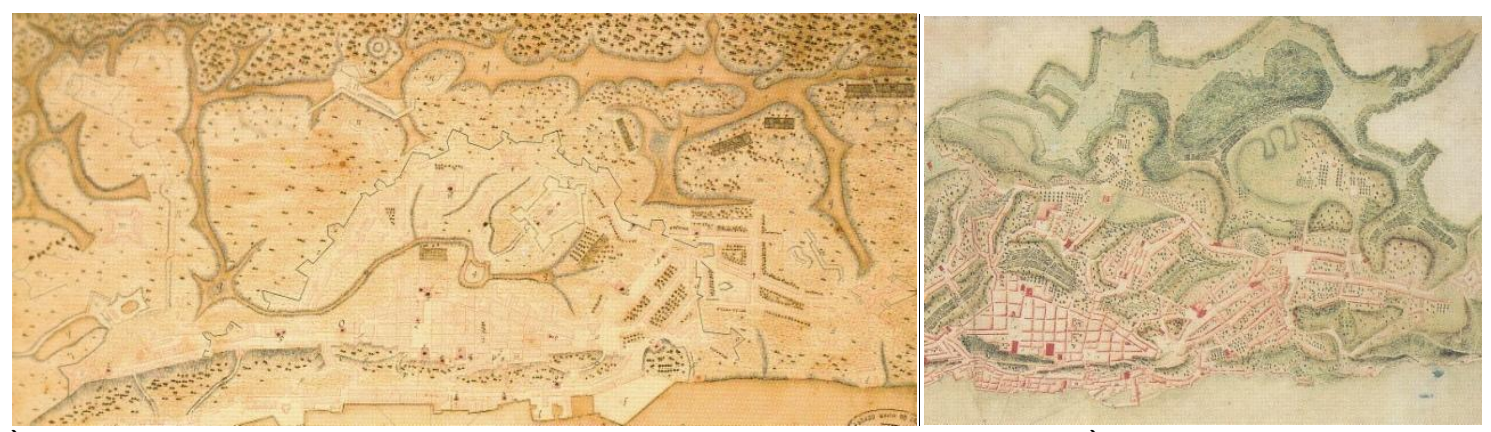

À esquerda, a Planta Ichnografica da Cid. de S. Salvador..., do AHM, 1779. À direita, detalhe do "Adiq" na Geografica Topografica da Cidade Capital de S. Salvador..., original de José G. Galeão do AHM, 1785 (em REIS FILHO, 2000: 37 e 43).

\footnotetext{
${ }^{646}$ Termo de vereação em AMS - Atas da Câmara (1641-1649), v. 2, 1949, p. 308, também transcrito na íntegra por M. Oliveira, p. 83-4 (nota 98).

${ }^{647}$ Cf. OLIVEIRA, M. Mendonça de. Da importância tática e estratégica do Forte de S. Pedro. Revista da Bahia. Salvador: 1999, v. 32, n. 30, p. 62-75/ OLIVEIRA, 2004: 69.

${ }^{648}$ FI. 109 em AMS - Atas da Câmara (1641-1649), v. 2, 1949, p. 328, transcrita na íntegra em OLIVEIRA, 2004: 84 (nota 100).

${ }^{649}$ Cf. AMS - Atas da Câmara (1641-1649), v. 2, 1949, p. 314: ... Paraceo João Mendes Palheiros e por ele foi dito que queria asistir menhã e tarde todos os dias ser apontador de negros que andam no trabalho do dique grande contanto que se lhe havia de dar duzentos e coarenta reis por dia... (apud OLIVEIRA, 2004: 69).

${ }^{650}$ Cf. REIS Fo, 2000: 43.

${ }^{651}$ Cf. FONSECA, Luiza da. Subsídio para história da Cidade da Bahia, p. 412/ OLIVEIRA, 2004: 69.
} 


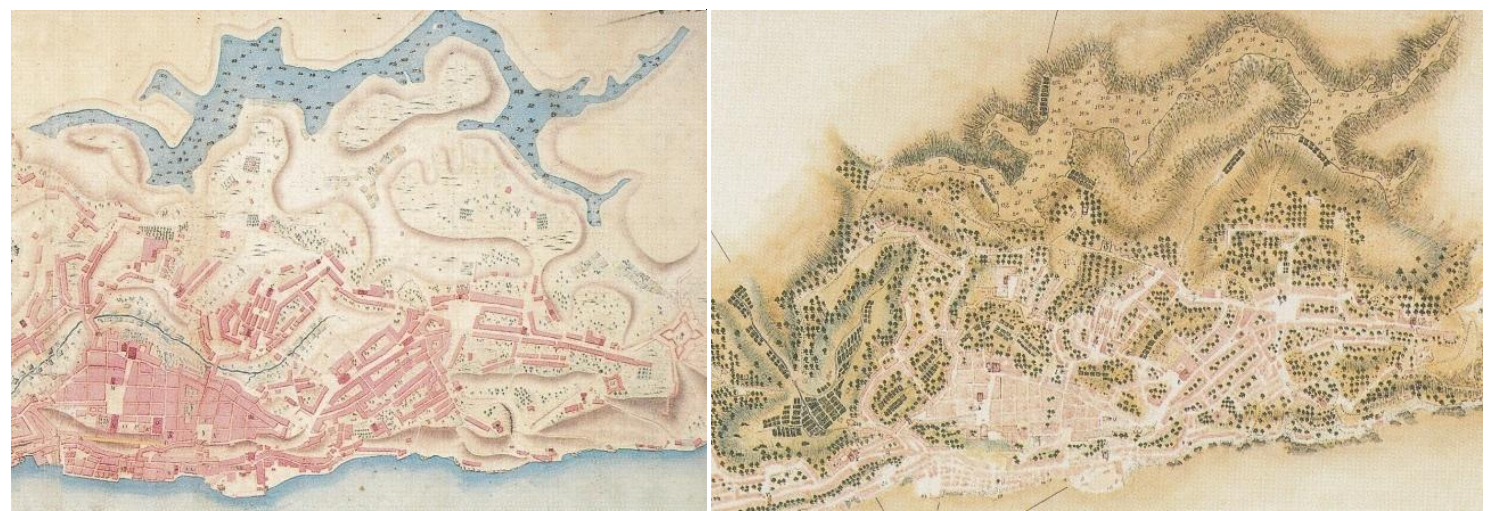

À esquerda, detalhe do "Adiq" no Mappa Topographico da Cidade de S. Salvador na Capitania da Bahia situada..., original do SGE, c. 1785. À direita, mesmo detalhe no desenho de J. Joaquim Vieira da Silva, Topográfica da Cidade Capital..., original manuscrito da DSE, Gab. de Est. Arq. da Eng. Militar, 1798 (em REIS FILHO, 2000: 43 e 48).

Deve-se ressaltar que em todas essas imagens o Dique aparece em sua dimensão máxima, atingida apenas na gestão do Marquês de Angeja (ou Pedro Antônio de Noronha, 1714-8), quando foi feito o represamento de afluentes superiores do rio Urucaia (ele atualmente se encontra reduzido pela construção de aterros particulares ao longo do tempo; o dos holandeses desapareceu completamente, estando suas águas canalizadas sob a antiga Rua da Vala, hoje Baixa dos Sapateiros).

\subsection{Casa da Pólvora do Desterro}

A fabricação e a guarda da pólvora eram de máxima importância militar, havendo o risco de graves acidentes, de alterações na mistura (danificada pela umidade), dificuldades de manuseio e armazenamento. Se por um lado era importante o depósito ficar próximos às fortalezas e quartéis para dar rápida munição, por outro, devia se afastar de locais habitados. Como terceiro complicador, devia estar protegido de ataque inimigo: se ficasse fora do perímetro defensivo, seria o primeiro alvo dos invasores.

Os textos antigos indicam que os primeiros depósitos ficavam nas vizinhanças da Porta de São Bento (ou Santa Luzia), de onde tiveram de sair em função do crescimento da cidade. Quando foi criado o segundo perímetro, escolheu-se a nova localização, por ocasião, segundo Mirales, do governo de Roque da Costa Barreto (1678-82), que... fundou a bem deliniada, e magestoza Caza da Polvora sita no campo do Desterro, dentro das Trincheiras $q^{\prime}$ circulao' a Cid. ${ }^{e}$ por não' haver nella Lugar compet. ${ }^{e}$ em $q^{\prime}$ se goardasse a Polvora sem ameaço de perigo. ${ }^{652}$ Mas os que traziam a pólvora embarcada achavam o acesso difícil, correndo o risco de guardá-la às vezes em seus navios (era também uma maneira de não trocar a pólvora nova pela velha do paiol nas viagens de volta, ameaçadas por piratas). ${ }^{653}$

Ao contrário da dos Aflitos, a Casa de Pólvora do Desterro teve poucos levantamentos gráficos. A sua forma é conhecida pelas plantas da Cidade do Salvador,

\footnotetext{
652 MIRALES, 1900: 151.

${ }^{653}$ Um dos locais de armazenamento, preparo e renovação de pólvora velha era o forte do Rosário, bem situado para o desembarque (cf. OLIVEIRA, 2004: 246).
} 
sendo a mais exata (pelo cuidado e escala escolhida) a de 1779 do Arquivo Militar, provavelmente elaborada com a coordenação de Caldas. Os desenhos mostram um retângulo abaluartado de comprimento comparável à largura do Terreiro de Jesus (de aproximadamente $52 \times 37 \mathrm{~m}$ ), fora os baluartes. Diferentemente da Casa do Aflitos, é provável que os baluartes fossem terraplenados para uso de artilharia, já que os historiadores falam que tinha "artilharia grossa".

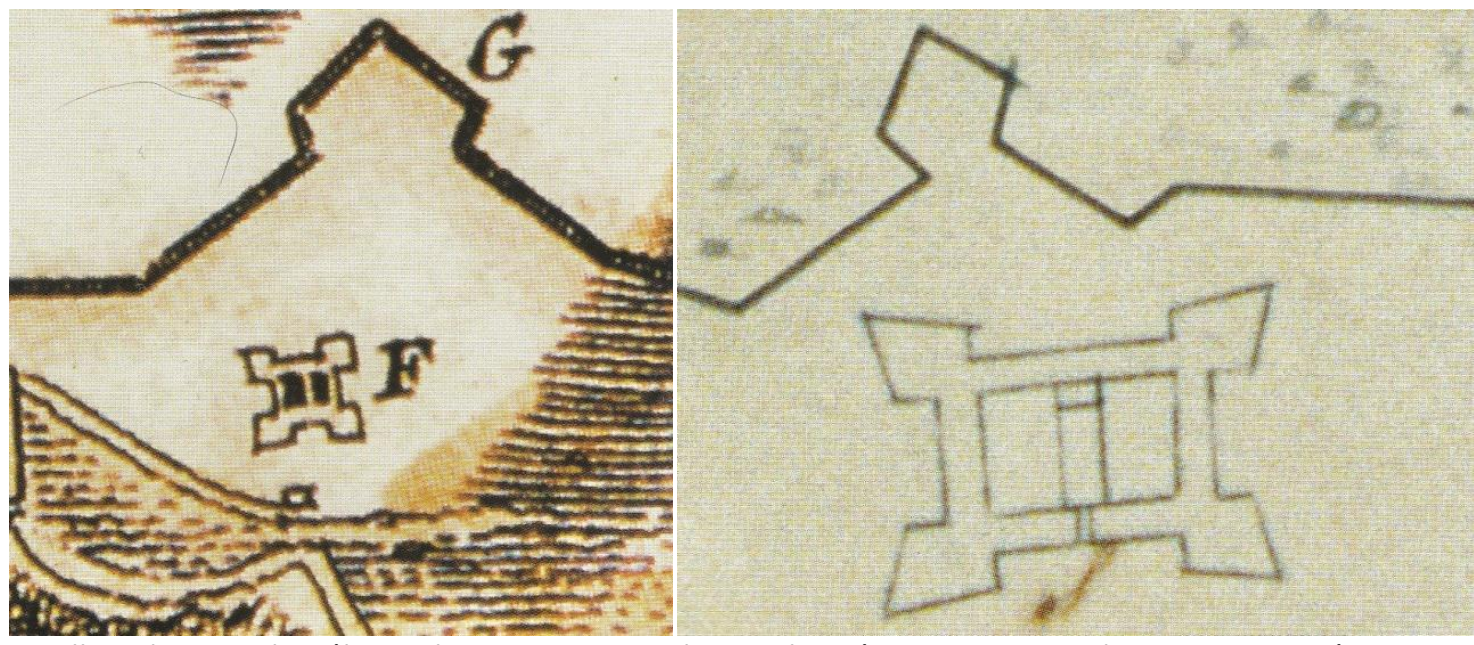

Detalhes da Casa da Pólvora do Desterro nas plantas de Frézier - 1714 - e do projeto Massé - c. 1715 (em REIS Fo, 2000: 30-1).

Segundo Silva Campos, a Santa Casa de Misericórdia teria arrematado o edifício para uso do material de demolição no Hospital Santa Isabel. Em meados do século XIX o edifício estava em ruínas. ${ }^{654}$

4. Relatórios importantes e consolidação da Arquitetura Militar em Portugal (16701700)

Nos vinte anos que antecederam a invasão holandesa (1604-24), alguns passos foram dados no sentido de construir obras que fariam parte de um conjunto, o que já representava um elevado programa de defesas. Esse primeiro programa era fruto de um conhecimento geopolítico mais aprofundado do território, em que a cidade passava a ter de fato um "sistema" de fortificações, caracterizando o momento em que efetivamente se constituía um complexo aparato defensivo, pensando-se, inclusive, nas questões de abastecimento. ${ }^{655}$ Era um sistema um pouco mais apurado, em que a cidade era ainda abraçada como um todo, não mais a partir de baluartes, mas de fortes, o que exigia atenção ainda maior aos gargalos (em especial os acessos norte e sul).

\footnotetext{
${ }^{654}$ Cf. CAMPOS, 1940: 269-71.

655 Nota-se que já havia uma percepção mais ampla do território em que a cidade de estendia (arraigando-se a ele de forma mais intensa), requerendo maior elaboração defensiva. A questão do abastecimento também evidencia a visão integral da cidade, que ao se preparar para enfrentar uma ameaça externa, já pensava na garantia de sua sobrevivência futura.
} 
$\mathrm{Na}$ época dos holandeses, com o seu conjunto de intervenções, passou a haver uma inteligência ainda maior do território. Foi a partir dessa sabedoria geopolítica não vista até então que, quando Salvador voltou a ser colônia portuguesa (1640), a fragilidade da cidade se mostrava evidente. Nesse contexto, passaria a haver em seguida a prática corrente dos relatórios, em que as idéias organizadas por Serrão Pimentel se mostravam bastante presentes. Por ela se observa uma nova percepção integral da cidade, e um ainda mais sofisticado programa para a estrutura de defesa. Os relatórios, mais do que projetos de reforma, fixavam nortes, fazendo com que os períodos posteriores se tornassem devedores daquele momento.

Além de passar em revista toda a configuração da cidade, a eles está inclusive associada a idéia de trazer aulas militares para a Colônia, uma vez que despertavam consciência da necessidade de uma profissionalização permanente, de uma inteligência viva local que estivesse ligada às questões práticas e teóricas da defesa.

\subsection{Antonio Correia Pinto e o relatório de 1671-2}

Antonio Correia Pinto veio ao Brasil indicado por Luís Serrão Pimentel, chegando a Pernambuco em 1669 para cuidar do Forte do Brum. ${ }^{656}$ Em 1671 foi convocado pelo governador, Gen. Alexandre de Souza Freire, para ir à Bahia logo que terminasse sua primeira missão, mas a portaria só saiu em $1674 .{ }^{657}$ Ele é o provável autor do relatório sobre as fortificações da Bahia de 1671-2 (códice encadernado da Biblioteca da Diretoria da Arma de Engenharia, em Lisboa), normalmente citado como "relatório anônimo".

Em fins de 1674 ele foi a São Vicente (o governador pediu ao Conselho da Cidade para pagar o soldo) e de lá a Paranaguá (1675) para examinar e mapear minas. ${ }^{658}$ Passando pelo Rio de Janeiro (1676), foi preso pelo ouvidor Pedro de Unhão Castelo Branco por transportar ouro sem fundição oficial (o que era considerado contrabando). Por servir ao Governador Geral, pediu para voltar à Bahia mesmo estando preso. ${ }^{659}$ Foi salvo por Luís Serrão Pimentel, Engenheiro-mor do Reino, de quem era discípulo e havia sido recomendado, mas sua provisão de soltura só saiu em $22 / 11 / 1677$. No ano seguinte o Governador Geral o enviou de novo a Recife, para fazer medições no forte do Brum.

O códice Papéis Militares, v. 1, no 1608, da biblioteca da Direção dos Serviços de Engenharia do Exército Português (DSE), ${ }^{660}$ é composto de três documentos: o primeiro (№ 90) relaciona receitas e despesas da manutenção da Praça da Bahia; o segundo (№ 91), a artilharia e soldados das fortificações de Salvador e do Recôncavo, com a indicação de que foi encomendado pelo Gov. Afonso Furtado de Castro do Rio

\footnotetext{
${ }^{656}$ Cf. OLIVEIRA, 2004: 97. As informações foram tiradas da apostila de pagamento.

657 Ano em que também pediu registro da patente como engenheiro ad-honorem (cf. BN - Documentos Históricos, 1929, v. 10, p. 98 - 02/01/1674 e BN - Documentos Históricos, 1934, v. 6, p. 264 16/10/1674/ OLIVEIRA, 2004: 97).

${ }^{658} \mathrm{O}$ Gov. Affonso Furtado Rios de Mendonça lhe encomendou a planta dessa cidade (cf. BN Documentos Históricos, 1929, v. 10, p. 457 - 18/03/1675 - OLIVEIRA, 2004: 97).

${ }^{659}$ BN - Documentos Históricos, 1929, v. 11, p. 70 - 13/12/1676 - apud OLIVEIRA, 2004: 97.

660 Esses papéis chegaram a desaparecer, mas foram encontrados em um sebo sessenta anos depois, encadernados em couro junto a outros documentos manuscritos (o que sugere que estivessem em uma casa nobre - cf. OLIVEIRA, 2004: 69).
} 
de Mendonça (10 Visconde de Barbacena, 1671-5); o terceiro (№ 92) é a Memória dos Fortes que ha Nesta Praça da B. ${ }^{a}$ e seu reconcavo, capitaens $q$ os ocupão e soldos $q$ vencem, sendo os três de data próxima a 1671.

São documentos apócrifos, de difícil atribuição da autoria, mas sendo solicitados por Furtado de Mendonça, muito provavelmente foram elaborados pelo Cap. Eng. Antônio Correia Pinto, que serviu em Salvador na época desse governo. 0 relatório não comenta as defesas como um todo nem aponta qualidades nas fortalezas relacionadas. Não é uma análise profunda, mas fala de cada forte e fornece dados importantes, como o de que já havia em Salvador uma linha de defesa com trincheiras $e$ baluartes cercando um perímetro maior que o inicial (são citados alguns baluartes referidos por Coutinho e outros de nomes pouco conhecidos).

\subsection{João Coutinho e sua proposta de fortificação (1685)}

Nos anos 1680, por determinação da Corte, tentou-se fazer um plano de defesa em larga escala para a Salvador, que era reconhecidamente vulnerável. O novo projeto de fortificação foi encomendado ao Cap. Eng. João Coutinho, que estava em Pernambuco e era prestigiado pela sua nomeação como capitão engenheiro $a d-$ honorem (1676, ganhando 25\$000rs ao mês). ${ }^{661}$ Já estivera no Brasil em 1649, comandado pelo Gen. Manuel de Miranda Henriques, tendo uma ampla folha de serviços. Desde 1663 era Ajudante de Engenheiro no Alentejo e em 1667 estava em Trás-os-Montes na mesma função, colaborando nas batalhas do Ameixal e da Reconquista de Évora. Trabalhou em fortificações alentejanas (Vila Viçosa e Montemór-o-novo) e ficou quase um ano em Angola. ${ }^{662}$

Embora tenha feito Aula Militar, aprendeu mais na prática, pelo que se nota no parecer de João Pimentel quando se candidatou pela sua segunda vez para vir ao Brasil, por uma Consulta do Conselho Ultramarino:

E que fora da Aula dos que nella aprenderão havia somente João Coutinho, porque algu's estavão occupados nas Provinçias, e muytos mais que havia forão despedidos c'o as pazes sem se Ihes dar entretenimento, por cujo respeito buscarão outro modo de vida, e muytos se embarcarão, e que este João Coutinho hera de grande engenho, e tivera $\mathrm{m}^{\text {to }}$ exercício em Alentejo, e Trasosmontes, por se

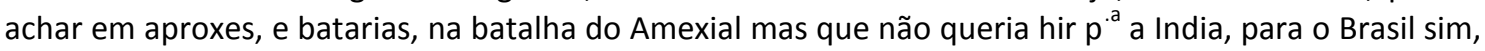
que este homem estava muyto adiante de Lucas $\mathrm{Frr}^{\mathrm{a}}$ por que ainda $\mathrm{q}^{\prime}$ habel, não vira guerra, nem asistira a desenhos, mais q' o anno passado a ver, e ajudar a fazer algu'as de varias partes na Beira. ${ }^{663}$

Em carta de 16/03/1684, o Rei pediu ao Marquês das Minas para avisar João Coutinho que... deixando em Pernambuco onde assiste dispostas as coisas em forma conveniente para continuar ali a obra, passe a essa cidade da Bahia e tanto que a ela chegar faça uma planta da fortificação que eleger, ${ }^{664}$ dando suas explicações a cada decisão. Começava assim o famoso projeto de defesa de Salvador. Em 24/07 daquele ano o governador escreveu a Coutinho para convocá-lo, justificando ao Conselho

\footnotetext{
${ }^{661}$ Cf. VITERBO, 1904: II, 280: ... para que com o dito sirva de emgenheiro na mesma capitania, onde asistira ás fortificações $e$ ás daquelle estado onde for necessario, assy como na Bahia o faz Antonio Correa Pinto (liv. 5 de Officios do Conselho Ultramarino, f. 433v).

${ }^{662}$ Cf. OLIVEIRA, 2004: 97.

${ }^{663}$ AHU - Catálogo de Luíza da Fonseca, doc. 2.615 - 12/11/1674 (CD4, 23, 002, 345-8).

${ }^{664}$ BN - Documentos Históricos, 1945, v. 96, p. 96 - apud OLIVEIRA, 2004: 98.
} 
Ultramarino que as linhas ampliadas de então eram imperfeitas, e que... necessariamente devia supor que por elas havia o engenheiro de fortificá-la e como eram muito dilatadas havia mister muito cabedal e muitos anos para o fazer. ${ }^{665}$ Experiente em castramentação, ele deveria dispor de todas as facilidades. Assim, o Provedor-mor também recebeu Portaria (13/10/1684) para que desse todo o material e apoio logístico na medição das fortificações. ${ }^{666}$ O projeto de reforços do sistema defensivo pode ter se iniciado por volta dessa data.

Mário Oliveira considera esse projeto para as fortificações de Salvador, o "documento de engenharia militar mais importante do século XVII" sobre a Bahia, "não só pelas abalizadas observações do experiente Coutinho, como também pelos pareceres anexos dos mais importantes engenheiros do Reino" ${ }^{667}$ Na última parte, Coutinho fez um interessante estudo de custos do projeto, mostrando conhecimento do Brasil e capacidade técnica como engenheiro militar. Mesmo tendo desaparecido suas várias plantas, o relatório tem grande importância na história urbana de Salvador. Muitos projetos de fortificação da cidade no século XVIII (inclusive o do Brig. João Massé) se basearam nas observações e propostas de Coutinho, que em 1685 voltou a Pernambuco, onde faleceu um ou dois anos depois.

$\mathrm{Na}$ época do projeto, Coutinho ainda encontrou as trincheiras de 40 anos citadas no relatório anônimo. Mas a cidade precisava atualizar o seu sistema defensivo, para estar na melhor perfeição. À exceção de algumas partes, o projeto nunca foi executado (Bernardo Vieira Ravasco, irmão do Padre Antônio Vieira e Secretário de Estado e da Guerra por muitos anos, refletiu em seu Discurso: Morreu o Engenheyro, despoz o Gov. ${ }^{\text {or }}$ Mathias da Cunha, tudo ficou no mesmo ser athé hoje, $\boldsymbol{e}$ só crescerão as ruynas, e nellas os Arvoredos). ${ }^{668}$ Recebeu aprovação do Rei, mas para que se construísse de terra o que se propunha ser de pedra e cal.

Lamenta-se a perda dos desenhos desse "extraordinário documento para a nossa história urbana", 669 particularmente das fortificações. O rolo de plantas deve ter circulado por vários lugares em Portugal, colhendo a opinião de importantes engenheiros do Reino. Um dos consultados foi Hyeronymo (Jerônimo) Velho de Azevedo, que no seu parecer diz que os desenhos já estavam danificados. ${ }^{670} \mathrm{~A}$ correspondência dos governadores gerais mostra que nenhuma cópia ficou no Brasil, o que contribuiu para a perda dos desenhos. Mas ao menos o Rei ordenou que se transcrevesse no Livro de Registro de Cartas Régias o relatório que acompanhava os

\footnotetext{
${ }^{665}$ BN - Documentos Históricos, 1950, v. 68, p. 25. Consultas do Conselho Ultramarino - apud OLIVEIRA, 2004: 98.

${ }^{666}$ Cf. OLIVEIRA, 2004: 98.

667 OLIVEIRA, 2004: 98. Refere-se ao Relatório de João Coutinho (AHU - Códice Ms 245, Bahia, fls. 12336), pertencente ao Livro de Transcrição de Ordens Régias (por ordem do Rei).

${ }^{668}$ BME - Códice CV/1-17 - apud OLIVEIRA, 2004: 58. Na fl. 285 tem início o discurso feito por Bernardo Vieira Ravasco (pequena parte do texto, com reflexões táticas e estratégicas sobre a defesa do Brasil, e particularmente da Bahia, foi transcrita por Alberto Silva na Coleção do Centro de Estudos Baianos, 1952 , v. 12). Bernardo Ravasco informa que o projeto era de grande qualidade, reconhecido até pelos que discordavam de sua magnitude e custo, mas nunca foi levado adiante.

${ }^{669}$ OLIVEIRA, 2004: 70.

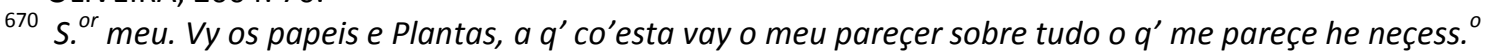
fazer-se, $e^{\prime}$ com esta vão tambem as Plantas $e^{\prime}$ mais papeis no mesmo canudo, o qual me entregou o proprio $m^{\text {to }}$ mal tratado, $q^{\prime}$ me pareçe cahio com elle, $e^{\prime}$ me custaram $m .{ }^{\text {to }}$ torna-lo a endireitar... (Relatório de João Coutinho. AHU - Códice Ms 245, Bahia, fl. 128v - apresentamos a transcrição e resumo em anexo).
} 
desenhos e os pareceres de outros engenheiros, estando hoje o seu códice em boas condições, no Arquivo Histórico Ultramarino.

\section{$\underline{\text { O Relatório na íntegra }}$}

O memorial se inicia por uma rápida descrição geográfica da cidade. Na primeira parte, Coutinho faz um levantamento de suas áreas, dividindo-as em sete itens numéricos. Em seguida adentra o assunto específico nas fortificações, designando-as de A a $\mathrm{T}$, em provável correspondência à legenda do desenho desaparecido (sintetizamos antes de cada trecho apenas o que é dito sobre as fortificações encontradas, modificações sugeridas e fortificações propostas).

Informação, e pareçer da Planta da Bahia, que enviou João Cout. ${ }^{\circ}$ Engenhr. ${ }^{\circ}$ de Pern. ${ }^{\text {co }}$ (fl. 124 - final)

Relação da forteficação da Cid. ${ }^{e}$ da B. ${ }^{\text {a }}$ de Todos os Sanctos, e da forma em q' se deve fazer. Discrição da Cidade.

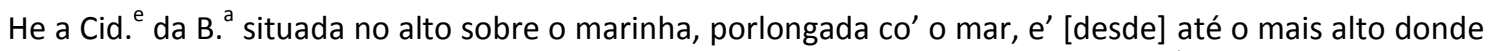
está a Cid. ${ }^{\mathrm{e}}$, haverá cento e cincoenta palmos medidos, [fl. 124v] prependicularm. ${ }^{\text {te }}$, e he tão ingreme o terreno, q' sôbe da praya á cidade q' não he possivel sobir a ella se não por ladeira, q [vêitão] a huã , e' outra p. ${ }^{\text {te }}$ p. ${ }^{\text {a }}$ façilitar melhor a subida, das quaes ha quatro, huã he a chamada do Carmo, outra a da Praça, e a terçeira a da Concepção; e a ult. ${ }^{a}$ a da perguiça.

No primeiro item ele diagnostica o problema das casas construídas em terra arrancada do barranco ou avançadas no mar em caixas de pedra, prejudicando as defesas e principalmente tirando os flancos do forte de S. Francisco (por voto seu, conseguiu-se que fosse demolido um cais recém-construído junto a esse baluarte). Isso acontecia em geral pelo descaso da Câmara ao dar licenças que só poderiam ser dadas pelo Rei, levando ao alto custo de refortificar a marinha. Seu estudo visava diminuir esse valor, reacomodando as casas e deixando livres as serventias.

1. Na Praya se tem fabricado huã grande povoação de casas, $q^{\prime}$ tomão todo o comprim. ${ }^{\text {to }}$ da Cid. ${ }^{\text {de }}$, a qual de huã grande ... Freguezia e de $\mathrm{m}^{\text {to }}$ rendim. ${ }^{\text {to }}$ por seus $\mathrm{m}^{\text {tos }}$ freguezes; $\mathrm{e}^{\prime}$ como o terreno não dava lugar bastante p. $^{\text {a }}$ estas Casas se fazerem, huñs cavarão a terra da raiz do outeiro, e fabricarão ao pee delle, e' os mais entraram p'lo mar dentro co' caexas de pedra, e fundarão sobre ellas e' ainda não contentes com fazerem isto , aonde não prejudicava ás defensas das Fortaz. ${ }^{\text {as }}$, houve tão pouco cuidado, $\mathrm{q}^{\prime} \mathrm{m}^{\text {tos }}$ se poserão diante dos flancos do Beluarte de São Fran. ${ }^{\text {co }}$ impidindo-lhe as defenças delles; e' ha poucos dias mandou o Marques, e General, por voto meu, desmanchar hum caes, q' hum Pedreiro desaforadam. ${ }^{\text {te }}$ começava a fazer junto ao $\mathrm{d}^{\circ}{ }^{\circ}$ Baluarte, saindo mais ao mar $q^{\prime}$ o Angulo flanqueado delle; e' álem deste dano, está a marinha de sorte, q' não tem lugar livre em q' se possa servir o povo, e' a causa tem sido a Camara conçedendo estas licenças sem Ihe toccarem, pois só a SMg. ${ }^{\text {de }}, \mathrm{q}^{\prime} \mathrm{D}^{\prime} \mathrm{s}$ g. ${ }^{\text {de }}$ toccão os logradouros do povo no Salgado; e' em todo o Brazil se tem abusado tanto desta ley, q' cada qual fas o q' Ihe pareçe, sem haver quem lho contradiga; e' estas I. ças são causa de agora ser neçessario tanto custo $p$. ' forteficar a marinha, sendo $q^{\prime}$ nos apontam. ${ }^{\text {tos }} q^{\prime}$ fis ao Marques General deu meyos para custar $m .{ }^{\text {to }}$ menos de seu justo valor, e ficar o povo bem aco'modado, e as servintias delle livres. ${ }^{671}$

\footnotetext{
${ }^{671}$ Uma das grandes dificuldades de defender Salvador era o crescimento desordenado. Mesmo com as ordenanças e regimentos para disciplinar a ocupação do solo, pairaria um "atavismo visceral dos locais para o não cumprimento de normas" (OLIVEIRA, 2004: 58-9), já que o Reino ficava a milhares de quilômetros. As construções abusivas contavam com a "vista grossa" de alguns administradores, chegando a haver autorizações da Câmara (benevolente com amigos e protegidos) para o que regimentalmente não poderia: construir em terrenos da marinha (o salgado), de permissão exclusiva do rei. O crescimento desordenado foi maior na Cidade Baixa: os comerciantes, para aproveitar a fina faixa de terra entre a escarpa e o mar, cortavam o pé da montanha para implantar imóveis. Além de criar
} 
Descreve em seguida a natureza acidentada dos terrenos e cita o "Adiq" pequeno (dos holandeses) que antes era cheio, servindo de fortificação (indo da Porta do Carmo à de S. Bento), e estava então "desalagado", invadido por hortas, enquanto as Portas eram inúteis por estar tudo "comunicável" da Cidade às trincheiras pelo "Adiq", já bastante povoado.

2. O mais da Cid. ${ }^{e}$ na circunvalação della he todo o terreno muy desigual, com m. ${ }^{\text {tos }}$ altos e baixos, assý da p. $^{\text {te }}$ de dentro das trinchr. ${ }^{\text {as }}$ como de fora dellas; $\mathrm{e}^{\prime}$ entre a prinçipal povoação da Cid. ${ }^{\text {e }}$, e as d. ${ }^{\text {as }}$ trinchr. ${ }^{\text {as }}$ corre huã grande quebrada co' os diferentes [torçícolos], $q^{\prime}$ mostra a Planta, chamado o Adiq pequeno, o qual estava antigam. ${ }^{\text {te }}$ cheo de água, $q^{\prime}$ servia de forteficação, cujos extremos se defendião co' a porta do Carmo, de huã p. ${ }^{\text {te }}, \mathrm{e}^{\prime}$ as de São Bento da outra: hoje está todo desalagado, $\mathrm{e}^{\prime}$ a mayor p. $^{\text {te }}$ delle povoado de Hortas, com q as portas não servem de nada, porq' tudo esta co'municavel da Cid. ${ }^{\mathrm{e}}$, até as trinchr. ${ }^{\text {as }}$ p'lo mesmo Adiq, e m. ${ }^{\text {to }}$ povoado daquem e dalem.

As trincheiras externas antigas ainda estavam lá, e Coutinho chega a elogiar a qualidade construtiva delas. Além da boa terra, sustentável com "faxina" barreada, facilmente crescia grama para conter a erosão.

3. As trinch. ${ }^{\text {as }}$ de terra $q^{\prime}$ estão feitas, se mostão nas Plantas com as linhas vermelhas, as quaes foram tiradas exatam. ${ }^{\text {te }}$ assý, e da man. ${ }^{\text {a }}$ que estão riscadas nellas, e levantadas no terreno. Estas trinchr. ${ }^{\text {as }}$ acho que se fizeram ha mais de quarenta annos, e estão com pouca ruina, porq' a terra de q' são feitas, julgo $p^{\prime}$ la melhor $q^{\prime}$ se póde imaginar $p^{a}{ }^{a}$ semelhantes obras, $e^{\prime}$ se sustenta sem fachina, ${ }^{672}$ revestindo-a por fora co' torrão tirado dos alagadissos, e depois de ligada pareçe taipa de pilão, é álem de tudo isto the nasçe logo grama em grande quantid. ${ }^{e}$, por ser todo o territorio cuberto della; a cor da terra eh vermelha escura, com mistura de saibro, e algum cascalho, e em p. ${ }^{\text {tes }}$ [tira] a amarelo.

A destruição das trincheiras não era causada pela natureza, mas pelos moradores, abrindo passagens, atravessando o gado no que ainda havia de fosso, e principalmente retirando deles o saibro para obras, sem ter havido repressão no

problemas de instabilidade na encosta, invadiam o mar com as construções, prejudicando o campo de tiro dos poucos fortins, estâncias e plataformas, impedindo com isso a defesa do porto.

Esse quadro foi bem descrito nesse 1o item do relatório de João Coutinho, aparecendo nos documentos de engenheiros militares do início do século XVIII a nas Notícias Soteropolitanas de Vilhena (“... por ser aquelle caes extensissimo, todo ao correr da falda da montanha escarpada se vão abrindo, e fazendo cazas no plano que formão onde arrancarão a baze da montanha, ficando no inevitavel risco de serem mais anno, menos anno, todas subterradas" - VILHENA, 1921: 76), mostrando ter continuado ao longo daquele século. Para melhorar o problema na Cidade Baixa, eminentemente comercial, Coutinho fez uma proposta inteligente de legislação sobre o que hoje se diz solo criado, disciplinando a ocupação do mar por autorização real, desde que o interessado construísse o cais um pouco além de seu armazém, deixando uma circulação de uso público entre o edifício e o mar, possibilitando a instalação de baterias em caso de ataque. Essa necessidade foi reafirmada no relatório de Massé, Miguel Pereira e Gaspar de Abreu (1715). A circulação seria servida de ruas transversais que permitiriam trazer com agilidade as carretas de artilharia, que estariam protegidas por cestões ou parapeitos à barba para cobrir o porto.

Como em outros casos, essas medidas levariam tempo para ser adotadas: Coutinho as propôs em 1685 , só havendo uma ação efetiva a partir de 1725, quando o então Sargento-mor Eng. Nicolau Abreu de Carvalho foi designado para fazer esses alinhamentos (já um pouco comprometidos). Pouco antes, em portaria de 21/02/1718, os proprietários de trapiches ao longo do cais que quiseram ganhar espaço foram notificados (cf. BN - Documentos históricos, 1937, v. 54, p. 335/ OLIVEIRA, 2004: 59), provavelmente por efeito do projeto de Massé, que retomava a idéia de Coutinho.

${ }^{672}$ Faxina = trançado de madeira na construção de pau-a-pique. 
passado a esses comportamentos (só não foi pior porque os acidentes causaram medo). ${ }^{673}$ Na parte alta à volta da cidade ainda era possível usá-las como defesa.

4. As ruinas $\mathrm{q}^{\prime}$ bem estas trinchr. ${ }^{\text {as }}$ não são causadas do tempo, se não feitas p'lo povo, por fazerem servintias superfluas, cortando-as, e façilitando as subidas por ellas, e deixando subir o gado, e'

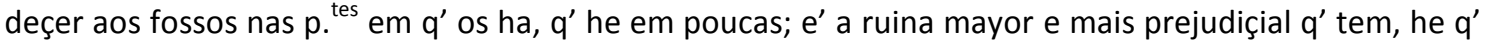
os Pedreiros, $e^{\prime}$ moradores, por se aproveitarem do trabalho $q^{\prime}$ acharão feito nos fossos $p$. $^{\text {a tirarem }}$ saibro ( $q$ ' serve de area nas obras, porq. ${ }^{\text {to }}$ aquy ha falta della) forão minando por baixo das d. ${ }^{\text {as }}$ trinchr. ${ }^{\text {as }}$, seguindo [betas] della, $q^{\prime}$ em $\mathrm{m}^{\text {tas }} \mathrm{p}$. ${ }^{\text {tes }}$ as arruinarão de tal sorte, $\mathrm{q}^{\prime}$ foi grande descuido não se castigar vigurozam. ${ }^{\text {te }}$ quem isto fazia (como agora se fas) e' senão fora o reçeo de lhe ficarem os negros debaixo dellas, mortos, como aconteçeo a alguns, $m .{ }^{\text {to }}$ mayor ruina terião, sendo $q^{\prime}$ não são mais $p .{ }^{a}$ a defensa,

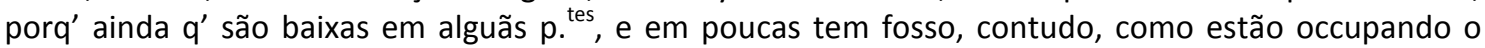
mais alto do terreno, $q^{\prime}$ ha à [roda] da Cid. ${ }^{e}$, podem se defender co' [vantajas]: e' ha de notar, q' sendo a Campanha tão desigual, estão estas trinchr. ${ }^{\text {as }}$ quasi todas [ao livel], excepto aonde atravessa [fl. 125] o Adiq' pequeno de tras do Carmo, e na quebrada da fonte de Gabriel Soares.

O terreno fora das trincheiras era irregular, com quebradas que levavam ao "Adiq" grande e ao mar, sendo impossível flanquear todas as muralhas a não ser de mosquete, podendo o inimigo chegar a mil pés da estrada encoberta sem ser visto.

5. O terreno de fora das trinchr. ${ }^{\text {as }}$ he todo muy desigual , fazendo $\mathrm{m}^{\text {tas }}$, e profundas quebradas, $\mathrm{q}^{\prime}$ girão a diferentes . $^{\text {tes }}$, como mostra a Planta, e quasi todas vão a parar no Adiq' grande, e alguãs no mar, as quaes não he possivel flanquear todas das muralhas q' se fizerem, senão dentro de tiro de vehemente de mosquete, porq' até mil pes da estrada encuberta poderá chegar o inimigo por m. ${ }^{\text {tas }} \mathrm{p} .^{\text {tes }}$, sem ser visto della, senão á dita distançia de mil pees pouco mais, ou menos, por cuja causa fis a Planta na forma seg. ${ }^{\text {te }}$.

Lembra que o assédio à cidade só podia ser feito por dois lados: o norte, onde estavam os precários (menores, de terra) fortes de S. Antonio do Carmo e do Barbalho, e o sul, onde estava o de S. Pedro. ${ }^{674}$ Outros lados eram dificultados (principalmente na artilharia e bagagem) pelo "Adiq" grande, que circundava a Cidade até esses extremos. Assim, recomenda a feitura de "pedra e cal" dos fortes S. Pedro e S. Antonio, e a ampliação do Barbalho para 400 pés em cada lado exterior, ficando mais próximo

\footnotetext{
${ }^{673}$ Além do que ocorria no salgado, também havia a invasão de trincheiras e redutos com quintais, a remoção do saibro das fortificações para a construção de casas particulares, o uso dos fossos das fortalezas para pastagem de gado, abertura de acessos por escarpas e contra-escarpas, etc. (na frase de Fernando Fonseca, as defesas de Salvador sofreram "dissabores causados mais pelos homens do que pelo tempo" - FONSECA, F. Luiz da. Arquitetura Militar da Cidade do Salvador: introdução ao estudo. Salvador: FAUUFBA - Tese em edição mimeografada, 1971, p. 56 - apud OLIVEIRA, 2004: 59; lembra o início do relatório assinado por Miguel Pereira, Gaspar de Abreu e Massé, na menção à antiga trincheira de terra:... esta se acha com algumas ruínas em várias partes, umas causadas do tempo, outras pelos moradores).

${ }^{674}$ Depois das guerras holandesas, os engenheiros compreenderam (mantendo-se o raciocínio no século XVIII) que havia duas rotas possíveis de invasão: 1- pelo Norte, com penetração de esquadra pela baía (de grande largura, impossível de ser fechada pelo Forte de Santo Antônio na Ponta do Padrão), desembarcando em seguida as tropas no Recôncavo mais vizinho (como fez Nassau em 1638) e marchando para a cidade pela Estrada das Boiadas; 2- desembarcando ao Sul, como fizeram os holandeses em 1624, no atual Porto da Barra, assaltando a cidade pela Estrada da Vila Velha (subindo mais ou menos a atual Ladeira da Barra, passando pelo Corredor da Vitória e seguindo pela atual Av. Sete de Setembro até o Mosteiro de São Bento), podendo também desembarcar em diversos locais entre o Rio Vermelho e Itapuã (rota que se tornou mais evidente com a primeira invasão, sendo então feitos os redutos de Santa Maria e São Diogo para dificultar o desembarque naquele local). Esse raciocínio norteou os engenheiros em todos os planos de defesa nas fases seguintes (cf. OLIVEIRA, 2004: 66-7 - fig. 19).
} 
ao extremo do "Adiq" (conforme a Planta) para se o inimigo o tomasse pudessem combatê-lo dos baluartes do Carmo e S. Antonio (estrategicamente, a muralha voltada para cidade seria mais tênue). A idéia também era cruzar fogo com o de S. Antonio, que seria melhorado para também proteger a orla e outras quebradas.

6. Prim. ${ }^{r a}{ }^{\text {te }}$, p. $^{\text {a }}$ qualquer inimigo cometer a Cid. ${ }^{e}$ da $B .^{a}$ ha de ser por huã de duas $p .^{\text {tes }}, a$ primeira, e principal p'la do Forte de $\mathbf{S}^{\text {to }}$ Ant. $^{\circ}$ do Carmo, e ainda co' mais co'modo [será] p'lo Oiteiro chamado do Barbalho, no qual se fes, governando nesta Praça, Alexandre de Sousa, no anno de $\underline{669}$., hum fortim coadrado de terra de meyos Beluartes, e sem fosso, como mostra a Planta. Não he essa a obra q' convem neste oiteiro, tanto p'la debilid. ' della, como por não estar no lugar mais conveniente delle.

7. A outra p. te $^{\text {te }}$ por onde pode aco'meter he $p^{\prime}$ lo outro extremo aonde está o Forte de São $\mathbf{P}^{\circ}{ }^{\circ}$,

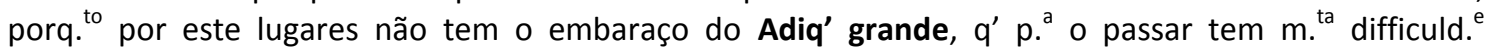
prinçipalm. ${ }^{\text {te }}$ co' $^{\prime}$ artelhar. ${ }^{a}$ e bagages, e como este Adiq' çircunvala desde perto ao d. ${ }^{\circ}$ Forte de S. P. ${ }^{\circ}$, até o pee do Oiteiro do Barbalho, $q^{\prime}$ Ihe fica no outro extremo, defendidas estas duas passagens, [constitu] em huã dobrada forteficação, p. $^{\text {a }}$ cobrir a q' se fizer na Cid. ${ }^{e}$, porq $^{\prime}$ não he possivel chegar o inimigo a combate-lo, sem p. ${ }^{\text {ro }}$ deixar ganhada alguã dessas Fort. ${ }^{\text {zas }}$, o q' lhe não custará pouco a conseguir, e q. ${ }^{\text {do }}$ o consiga terá perdido $\mathrm{m}^{\text {ta }} \mathrm{p}^{\text {te }}$ do seu poder, porq' nunca convem, $\mathrm{q}^{\prime}$ o inimigo do prim. ${ }^{\text {ro }}$ movim. ${ }^{\text {to }}$, chegue logo a tiro de mosquete da Cid. ${ }^{\text {, }}$ o q' se lhe não pode evitar em razão do terreno, senão co' estas Fort. ${ }^{\text {zas }}$, e Adiq; e de mais desta utilid. ${ }^{\text {e }}$, se segue outra não pequena, $q^{\prime}$ he ficar entre o Adiq e a Cid. ${ }^{\mathrm{e}}, \mathrm{m}^{\text {to }}$ terreno livre . $^{\text {a }}$ pastos de gado, $\mathrm{q}^{\prime}$ ha de ser o prinçipal mantim. ${ }^{\text {to }}$ dos defensores. $\mathrm{E}$ considerando eu todas estas razões, me resolvo a dizer, $q^{\prime}$ se deve conservar o Forte de São $P$. $^{\circ}$, fazer-se de pedra, e cal, e o mesmo o de $\mathbf{S}^{\text {to }^{\prime}}$ Ant. ${ }^{\circ}$ do Carmo, e no oiteiro do Barbalho fazer outro mais capaz $q$ qualquer destes, $\mathrm{q}^{\prime}$ tenha ao menos 400 pes de lado de poligono exterior, como mostra a Planta, a qual ponho mais chegado ao extremo do Adiq', p. ${ }^{\text {a } ~ o ~ d e s c o b r i r ~ m e l h o r, ~ e ~ o ~ i n i m i g o ~ n a ̃ o ~ p o d e r ~ p a s s a r ~ p ' l o ~ a o ~}$ pee delle; e tambem porq' se o inimigo o ganhar, se possa bater melhor dos Beluartes do Carmo, e $\mathbf{S}^{\text {to }}$ Ant. ${ }^{\circ}$, e' p. ${ }^{a} q^{\prime}$ o inimigo se não cubra com elle contra a Cid. ${ }^{e}$, se lhe deve fazer o terrapleno por tres lados som. ${ }^{\text {te }}$, deixando-Ihe o lado $q^{\prime}$ olha $p^{a}{ }^{a}$ a Cid. ${ }^{e}$ sem elle, $\mathrm{e}^{\prime}$ a muralha mais tenue $\mathrm{q}^{\prime}$ as ordin. ${ }^{\text {rias }}, \mathrm{p.}^{\text {a }}$ façilm. ${ }^{\text {te }}$ se arruinar com a artilhr. ${ }^{a} d a$ Cid. $^{e}, \mathrm{e}^{\prime}$ tambem deste lugar fica cruzando bem as ballas co' o de S. ${ }^{\text {to }}$ Ant. ${ }^{\circ}$, e' impedindo o não passar o inimigo por entre ambos. O de S. $^{\text {to }}$ Ant. ${ }^{\circ}$ se deve conservar tambem p'la mesma razão, álem, $q^{\prime}$ delle se descobre melhor as quebradas, $q^{\prime}$ ha entre os $d .{ }^{\circ{ }^{\circ}}$ Fortes, e o oiteiro chamado do P. ${ }^{\text {e Ribr. }}{ }^{\circ}$, e p. ${ }^{\text {a o Mar }}$. $^{\text {ta }}$ p. ${ }^{\text {te }}$ da praya do Rozairo [sic], e de Monserrate: e' co' estas obras me pareçe fica bem cuberta a nova forteficação da Cid. ${ }^{e}, e^{\prime}$ co' dobradas forsas p. ${ }^{a}$ resistir a hum poderozo ... Exercito.

Ele critica o modo como a cidade foi feita, a Alta e a Baixa alongadas no sentido da ribeira, com áreas de pasto dentro das trincheiras e casas fora delas, aumentando o custo das defesas (em quadro, a mesma área coberta com 124 bocas de fogo necessitaria de 316 na forma alongada, o mesmo valendo para a quantidade de braças na muralha). $\mathrm{O}$ remédio seria demolir grande parte dos bairros de $\mathrm{S}$. Bento e Carmo, mas o projeto teve em consideração preservá-los ao máximo.

Os moradores da Cid. ${ }^{e}$ da Bahia fabricarão a Povoação na peor forma $q^{\prime}$ se podia fazer $p^{a}{ }^{a}$ se forteficar; ${ }^{675}$ mas como som. ${ }^{\text {te }}$ tratarão das suas conveniençias, se [estendendo] assý na Cid. ${ }^{e}$ em sima, como na praya, $p^{\prime}$ la vista do mar, fazendo hum exçessivo comprim. ${ }^{\text {to }}$ por esta $p .^{\text {te }}$, e deixando de povoar o grande terreno $\mathrm{q}^{\prime}$ ha desocupado dentro das trinchr. ${ }^{\text {as }}, \mathrm{e}^{\prime}$ o mais ha $\mathrm{q}^{\prime}$ [terem] feito a mayor $\mathrm{p}^{\text {te }}{ }^{\text {destas }}$ Casas fora das $\mathrm{d}^{\text {as }}$ trinchr. $^{\text {as }}$, depois dellas feitas, sem repararem o dano $q^{\prime}$ nisto fazia a sua propria faz. ${ }^{a}$, $q^{\text {do }}$ se forteficasse a Cid. ${ }^{e}, e^{\prime}$ quem tinha a seu cargo o prohibir-lhes, o não fes, porq' não he possivel meter de dentro da muralha o [arrebalde] de $S .{ }^{\text {to }}$ Ant. ${ }^{\circ}$ do Carmo, nem o bairro do Curral da f. ${ }^{\text {te }}$ do Forte de São [F. $\left.{ }^{c}\right]$, e ainda assý fica a forteficação em forma prolongada, e por essa causa demais custo, e de mayor guarnição; e' [fora] fabricada em melhor forma, se podia fazer a mesma capaçid. e a menos custo.

675 Mesma opinião do Capitão Barreto Domingos Alves B. Muniz Barreto (cf. Observaçoens sobre a fortificação... BMP - Mss 686, Brasil, 1797). 
A exemplo disto seja hú Esquadrão de soldados cuberto por igual, sejão hum quadro de $g .{ }^{\text {te }}$ de 900. [picas], estas se cobrem por igual a hum com 124. bocas de fogo; e' se puserrmos as mesmas 900. [picas] com $\underline{6}$ de fundo, e gran [fratite], serão neces. ${ }^{\text {ras }}$ p. ${ }^{a}$ se cobrirem 316 . bocas de fogo. 0 mesmo seuçede à forteficação da B. ${ }^{\text {, }}$, podendo-se cobrir. V.g. 900. Casas, com 124. braças de muralha, são neçess. $^{\text {ras }} 316$. braças p. ${ }^{\text {a }}$ cobrir as mesmas 900 . Casas, $e^{\prime}$ ainda $q^{\prime}$ esta diferença não era co' tanto excesso, o tinha grãde, e' p. $^{\text {a }}$ remedea-lo bem, era neçess. ${ }^{\text {ro }}$ distruir e mayor p. $^{\text {te }}$ do bairro de São Bento, e' o Conv. ${ }^{\text {to }}$ do Carmo, e m. ${ }^{\text {tas }}$ Casas, junto a elle, ${ }^{676} \mathrm{e}^{\prime}$ por não distruir tantas, e me pareçer bastantem. ${ }^{\text {te }}$ aco'modada a obra p'lo lugar por onde o dizenhey, como se vé da Planta, remediando p. ${ }^{\text {te }}$

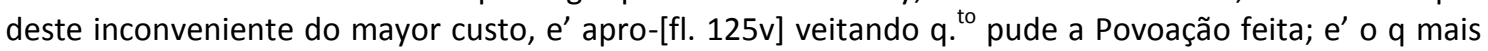
me obrigou, foi [o sear] o terreno por onde a lansey o mais ac'omodado, [e se epecir] p. ${ }^{a}$ a defensa.

Passa então a descrever o desenho da nova fortificação pela quebrada onde estava a fonte de Gabriel Soares (entre o Curral de S. Bento e o mar), lembrando que exceto lá e no outro extremo (atrás do Carmo, onde passa o "Adiq" pequeno), as trincheiras de terra que rodeavam a Cidade estavam em nível alto. Propõe subir (aproximar da Cidade) o baluarte de S. Teresa, construído em terreno instável da escarpa. O "outeirinho" em que estava (escolhido para cobrir a quebrada que saía do mar) seria desfeito, usando-se a terra (em falta, pois a maioria dos fossos era natural) para terraplenos. O baluarte passaria a flanquear a explanada. A alteração do local também defendia o baluarte de ser atacado de um ponto mais alto (do qual também haveria proteção quando se construísse a muralha), além de economizar um baluarte na marinha, reduzindo a Planta "à melhor forma" (encurtando).

\section{Forteficação prinçipal da Cidade.}

Ascima tenho dito, $\mathrm{q}^{\prime}$ as trincher. ${ }^{\text {as }}$ de terra, $\mathrm{q}^{\prime}$ estão feitas, ocupão o terreno mais superior, $\mathrm{q}^{\prime}$ huã roda da Cid. ${ }^{e}$ e estão quasi todas ao livel, excepto nos dous extremos, a saber, detrás do Carmo, aonde a atravessão o' Adiq pequeno, e' na quebrada entre o Curral do bairro de São Bento, e' o mar, aonde está a fonte de Gabriel Soares; $e^{\prime}$ começando por esta p. ${ }^{\text {te }}$ desinhey a d. ${ }^{\text {a }}$ nova forteficação na man. ${ }^{\text {ra }}$ seg. ${ }^{\text {te }}$.

A. O Beluarte de $S .^{\text {ta }}$ Thereza, $q^{\prime}$ fica sobre o mar, ellegý no lugar, $q^{\prime}$ na Planta se vé, retirado $p .{ }^{a}$ dentro, por tres razões; a prim. ${ }^{\text {ra }}$, por ocupar com elle o lugar mais superior, e defensavel, porq. ${ }^{\text {to }}$ os ult. ${ }^{\text {os }}$ [veacentes] da trinchr. ${ }^{a}$ estão pendurados p'la terra abaixo, co' o fim de delles se descobrir a quebrada q' sae ao mar, e' como o oiteirinho em que elles estão he cousa limitada, ficando-lhe de huã p. ${ }^{\text {te }}$ o mar, da outra a grande quebrada da d. ${ }^{\text {a }}$ fonte, não fis caso do dito oiteiro $p .{ }^{\text {a }}$ nelle fazer obra, e faço conta de $q^{\prime}$ a terra delle sirva $p{ }^{a}$ os terraplenos, $p^{\prime}$ la falta que por esta $p .^{\text {te }}$ ha della, em razão de serem as mayores $p^{\text {tes }}$ dos fossos feitos p'la natureza; e desfeito o d. ${ }^{\circ}$ oiteiro, se fica descobrindo da nova estrada emcuberta a rais da ... quebrada, com q' fica bem flanqueada a explanada ${ }^{67}$ deste Beluarte. A seg. ${ }^{\text {da }}$ razão, $q^{\prime}$ me obrigou a restringir este Beluarte foi, por me não ir meter debaixo do [bezo], sobre a quebrada, e' q. ${ }^{\text {to }}$ mais me desviey da d..$^{a}$ quebrada, e pus o Beluarte no [fexo] dáquí della, tanto mais cuberto fico do $d^{\circ} .^{\circ}$ [teza], $q^{\prime}$ he mais superior, $q^{\prime}$ o terreno, por onde nesta $p .^{\text {te }}$ vay a forteficação, mas depois de levantadas as muralhas ficarão os defensores cubertos contra o d. ${ }^{\circ}$ [tezo]. Alem destas duas razões se seguio a terçeira, $q$ ' foi poupar fazer mais hum Beluarte na marinha, $p .{ }^{a}$ me vir atar com este, e demais por reduzir a Planta a melhor forma, encurtando $p^{\prime}$ lo comprim. ${ }^{\text {to }}$, como della se vé.

Novo baluarte nas trincheiras da Piedade, sem aproveitar o existente de terra, para não ter de fazer outro entre este e o de S. Teresa (que faria a obra atravessar a grande quebrada da fonte, com uma muralha onerosa e tendo de cobrir com entulho a parte da quebrada que ficasse dentro dos muros, fazendo um terrapleno, além de uma obra exterior para "dar mão" ao Forte S. Pedro no terreno de fosso). A economia de

\footnotetext{
${ }^{676}$ Exemplo de planejamento urbano: cidade e fortificação a cargo dos engenheiros militares.

${ }^{677}$ Explanada = terreno urbano plano e descoberto.
} 
um baluarte também ajudava a estar dentro das medidas necessárias à linha de defesa. Como em frente ao ângulo flanqueado deste baluarte o terreno ia a nível para o Forte S. Pedro até uma quebrada (que sai abaixo da fonte), projeta nesse ponto (entre as fortificações) uma obra coroa (ou obra coroada), de nome N. S. da Vitória, que faria cobertura numa eventual infiltração inimiga.

B. O Beluarte Nossa S. ${ }^{\text {ra }}$ da Piedade ellegý fóra das trinchr. ${ }^{\text {as }}$ e me não aproveitey do de terra, $q^{\prime}$ está feito nellas, $p^{\prime}$ las razões seg. ${ }^{\text {tes }}$. A prim. ${ }^{\text {ra }}$ porq' servindo-me delle, era neçess. ${ }^{\text {ro }}$ fazer outro entre este, e o de $\mathbf{S} .^{\text {ta }}$ Thereza e' neste caso atravessava com a obra a grande quebrada da fonte, $e^{\prime}$, custando exçessiva] faz. ${ }^{a}$ a muralha $q^{\prime}$ nella se fizesse, $e^{\prime}$ outro tanto os terraplenos. $p^{a}{ }^{a}$ se entulhar o $q^{\prime} d a$ quebrada ficasse dentro da muralha e' multiplicando estes gastos, sempre me era neçess. ${ }^{\text {ro }}$ ocupar o mais terreno de fossa co' alguã obra exterior p. ${ }^{\text {a }}$ me dar a mão ao Forte de São Pedro como agora faço; com $q^{\prime}$ estas razões me obrigarão a em lugar de dous Beluartes fazer hum só, principalm. ${ }^{\text {te }} q .{ }^{\text {do }}$ me ficavão dentro das medidas $q^{\prime}$ se requer $p .{ }^{a}$ as linhas da defensa, como se vé da Planta.

Defronte do Angulo flanqueado deste Beluarte da Piedade corre o terreno direito [A linel] p. ${ }^{\text {a }} \mathrm{o}$ Forte de São $P .{ }^{\circ}$, até huã quebrada $q^{\prime}$ fica entre o d. ${ }^{\circ}$ Beluarte e o Forte (em quasi meyo caminho) $q^{\prime}$ vem a sair abaixo da fonte; e como do d. ${ }^{\circ}$ Beluarte, nem do Forte, se pode descubrir a d. ${ }^{a}$ quebrada, $\mathrm{e}^{\prime}$ outra q' fica da . $^{\text {te }}$ da terra, disenhey a Coroa, q' mostra a Planta, a q' pus o nome de Nossa S. $^{\text {ra }}$ da Victoria, da qual se descobrem as $\mathrm{d}^{\text {as }}$ quebradas, $\mathrm{e}^{\prime}$ fica o Forte de São $P .{ }^{\circ}$ desta Coroa a tiro vehemente de mosquete, dando a mão a esta obra exterior, cjuntam. ${ }^{\text {te }}$ á forteficação da Cidade.

Propõe o baluarte de S. Bento mais para dentro, próximo ao da Piedade (o antigo estava muy pendurado na face e flanco voltados ao da Ajuda). O novo local possibilitava fazer fosso com poucas contra-escarpas de alvenaria para a estrada encoberta (não fosse assim, as obras seriam onerosas).

C. O Beluarte de São Bento cheguey mais ao da Piedade, e recolhy hum pouco porq. ${ }^{\text {to }}$ o terreno em q' está o de terra, está muy pendurado da $\mathrm{p}^{\text {te }}$ da façe, $\mathrm{e}^{\prime}$ flanco $q^{\prime}$ olha ao Beluarte de Nossa S. $^{\text {ra }}$ da Ajuda: e' no lugar em q' agora o faço, tem terreno por fora $p .{ }^{\text {a }}$ se lhe fazer o fosso natural, co' pouca

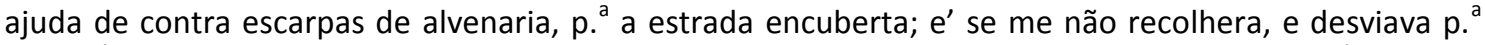
esta . $^{\text {te }}$ da Piedade custaria tanto a contra escarpa, como a muralha, e se conduziria de $\mathrm{m}^{\text {to }}$ longe a terra p. ${ }^{a}$ os terraplenos, em razão da quebrada [fl. 126] que da entre este, e' o da Ajuda.

Desenhou avanço na ponta (ângulo flanqueado) do baluarte da Ajuda para melhor cruzar fogo com o de S. Bento, para que dentro o terreno ficasse mais plano, sustentando o terrapleno sem uso de contra-muralhas (a quebrada da trincheira para dentro exigiria muito entulho do pé ao alto da muralha), e para ocupar a melhor parte (mais alta) do oiteiro. Propunha soluções construtivas para isso.

D. O Beluarte de Nossa S. $^{\text {ra }}$ da Ajuda avançey mais fora o angulo flanqueado delle, $p .{ }^{a}$ descobrir melhor a quebrada, $q^{\prime}$ está entre o dito, e o de São Bento; e' tambem $p{ }^{a}{ }^{\prime} q^{\prime}$ dentro delle me ficasse o terreno mais plano, e capaz de se sustentar o terrapleno, sem ser neçess. ${ }^{\text {ro }}$ contra muralhas, porq. ${ }^{\text {to }}$ da trinchr. ${ }^{a}$ p. ${ }^{a}$ dentro ha huã grande quebrada q' seria neçess. ${ }^{r o}{ }^{\text {ta }}{ }^{\text {ta }}$ terra $p .{ }^{a}$ entulhar da rais della, até o simo da muralha; $\mathrm{e}^{\prime}$ a principal razão foi ficar agora o angulo flanqueado na melhor $\mathrm{p} .{ }^{\text {te }}$ do oiteiro, por ficar no mais superior delle.

As contra escarpas entre este Beluarte, e o de São Bento, se devem fazer a trainel, co' seus [Redentos], porq' atravessão a quebrada; $\mathrm{e}^{\prime}$ ainda q se podião ganhar a o livel posto q' custa bem mais) acho não convem, porq' então não podem os tiros da cortina varrer a explanada da estrada encuberta porq. ${ }^{\text {to }}$ do Beluarte de Nossa S. ${ }^{\text {ra }}$ da Ajuda deçe o terreno p. ${ }^{\text {a }}$ a p. ${ }^{\text {te }}$ do de São Bento, é ficando este mais baixo q' aquelle, não póde a Cortina deixar de correr a trai-nel, e a contra escarpa de a seguir.

Projetou o hornaveque (ou "obra corna") São José para reforçar o baluarte da Palma (o terreno entre este e o da Ajuda era quase a nível, mas o oiteiro indo até o 
"Adiq" grande precisaria de obra exterior para segurar o baluarte e cobrir as quebradas). Aproximou este baluarte ao do Desterro (por causa de uma quebrada entre eles que dava no "Adiq" Grande, impedindo obra intermediária), ${ }^{678}$ facilitando o apoio recíproco (em seguimento aos "axiomas da fortificação").

E. Do Beluarte da Ajuda, ao de Nossa S. ${ }^{\text {ra }}$ da Palma, he o terreno quase ao livel, mas defrõte do Angulo flanqueado do da Palma, corre hum oiteiro . $^{a}$ fora p. $^{\text {a }}$ a p. $^{\text {te }}$ do Adiq grande, $e^{\prime}$ como esse oiteiro neçessitava de huã obra exterior, p. $^{a}$ melhor segurar o d. ${ }^{\circ}$ Beluarte, e descobrir as quebradas de

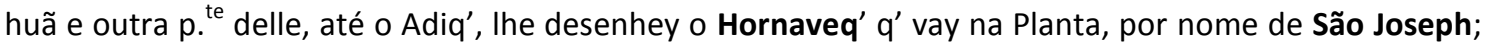
$\mathrm{e}^{\prime}$ porq. ${ }^{\text {to }}$ este se não [esentava], recolhy mais dentro o d. ${ }^{\circ}$ Beluarte da Palma, e Ihe pus o Angulo flanqueado no mais alto lugar do terreno, p. ${ }^{a}$ melhor dominar a obra exterior; e' como entre este Beluarte, e o do Desterro, não podia haver outro corpo, em razão da grande e profunda quebrada, q' ha entre elles, q' vay a parar no Adiq' grande, e a distançia entre ambos, era grande, e fora dos termos, e Axiomas da forteficação, cheguey cada hú delles mais p. ${ }^{a}$ a quebrada, p. $^{a} q^{\prime}$ me ficasse $o$ lado do Polígono exterior em medida conveniente $p^{a}{ }^{a}$ a forteficação como agora se vè, porq' he tal a quebrada, $q^{\prime}$ não consente hum [Badente] no Angulo da tenalha, $p^{\prime}$ la exçessiva profundidade $q^{\prime}$ fas, sendo q' não he neçess. ${ }^{\text {ro }}$, porq' o Hornaveq defende bem tudo.

Além de mais próximo ao da Palma, o Baluarte do Desterro foi colocado mais para dentro, por estar na parte de fora "muy pendurado sobre a descida do oiteiro", sem lugar para abrir fosso (que se fosse artificial sairia caro, e no desenho o ângulo flanqueado ficaria na parte mais alta).

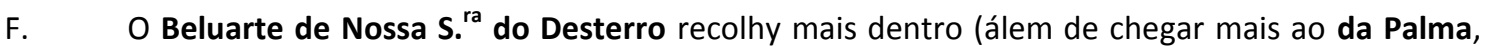
porq. $^{\text {to }}$ o de terra está muy pendurado sobre a deçida do oiteiro da $\mathrm{p}^{\text {te }}$ de fora, e não tinha lugar em $\mathrm{q}^{\prime}$ Ihe abrir fosso natural, e seria grandissimo custo faze-lo artifiçial, e agora recolhido, cessa este inconveniente, e' fica o Angulo flanqueado no mais superior do terreno.

Cita mais dois baluartes: o de S. Jorge, na direção norte, que não poderia estar muito distante do Desterro por motivos táticos de cobertura de fogo, e o de S. Batista, projetado por ele. Essa linha em direção norte deveria curvar, grosso modo, em direção nordeste para o Baluarte do Carmo, próximo ao atual convento. ${ }^{679}$

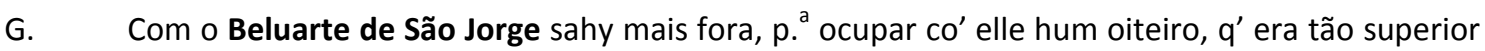
à trinchr. ${ }^{a}, \mathrm{q}^{\prime}$ hú homem deitado no chão nelle, descobria tudo dentro das tricheiras, e' agora ocupey este sitio co' o d. ${ }^{\circ}$ Beluarte, e' p. ${ }^{\text {a }}$ esta elleição se escusava ${ }^{680}$ Engenhr. ${ }^{\circ}$, porq' qualquer soldado a podia fazer, $q^{\prime}$ o terreno estava pedindo.

Deste Beluarte de São Jorge corre o terreno até o Adiq' de tras do Carmo em linha retta, e' o livel, com pouca queda (excepto junto ao Adiq'). Por fora deste terreno corre huã quebrada, tambem quasi em linha recta, a distançia de 400 [700?] pes, pouco mais, ou menos da trinchr. ${ }^{\text {, }}$, e desta quebrada torna a subir o terreno, fazendo hú oiteiro chamado a cabeça do negro, q' ficará o alto delle a 1200. pes, pouco mais, ou menos da d. ${ }^{a}$ trinchr. ${ }^{a}$, seguindo o mesmo rumo da quebrada, mas como tenho dito não fica mais superior ao d. ${ }^{\circ}$ oiteiro, com q' como o terreno não dava lugar a fazer em Angulos os Poligonos desenhey o Beluarte de São João Baptista sobre linha recta; e da estrada encuberta delle, e do de São Jorge, e' do do Carmo, se descobrirá bem a rais da quebrada, como tambem das muralhas delle.

Pondera que por este lado era difícil uma aproximação inimiga, pela dificuldade em descer do alto à quebrada. Como haveria risco em colocar lá uma bateria, propõe o

\footnotetext{
${ }^{678}$ Corresponde hoje aproximadamente à Rua da Independência, já que a atual Avenida Joana Angélica não era plana nesta parte (cf. OLIVEIRA, 2004: 84-5).

${ }^{679}$ Cf. OLIVEIRA, 2004: 70.

${ }^{680}$ Portanto, escusar $=$ dispensar.
} 
Forte do Barbalho, que enquanto não fosse tomado, impediria o inimigo de acampar na área.

H. Por esta p. $^{\text {te }}$ me pareçe, $q^{\prime}$ o inimigo não intentará o aproche, porq' lhe será muy dificcultozo deçer co' elle do alto á quebrada; $\mathrm{e}^{\prime}$ tambem $\mathrm{p}$. ${ }^{\mathrm{a}}$ pór delle bateria, será com $\mathrm{m}$. ${ }^{\text {to }}$ risco seu, porq. ${ }^{\text {to }} \mathrm{lhe}$ fica no lado o Forte $q^{\prime}$ se deve fazer no Oiteiro do Barbalho; e' emq. ${ }^{\text {to }}$ este se não perder, não he possivel q' o inimigo se aloje nesta paragem; e' se me disserem q' o fará depois de o ganhar, a isso respondo, q' neste caso, $q^{\prime}$ mais co' modo lhe tem conservar-se nelle, valendo-se das suas ruinas, e atacando a Praça $p^{\prime}$ la p. ${ }^{\text {te }}$ da [guosa bruca], [sé-] do-lhe escusado tomar outro quartel aonde tem mais risco, pois tem contra sý a dificuldade do aproche, e tres Beluartes à mão [tante].

Descreve então a área seguinte e propõe que o reforço da defesa ao norte fosse assegurado por obras avançadas desse primeiro perímetro, acobertado pelos fortes do Barbalho e pelo Forte de Santo Antônio do Carmo, para o qual seria preciso um hornaveque de reforço, não desenhado por a colina estar ocupada "com duas ruas de casas" que teriam de ser demolidas (no comprimento não haveria obstáculo, estando a área entre os fortes a nível). A obra avançada tiraria a deficiência apontada no relatório da época de Furtado de Mendonça. ${ }^{681}$

I. Do Beluarte da Nossa S. $^{\text {ra }}$ do Carmo, ao Beluarte de $\mathbf{S}^{\text {to }}$ Ant. ${ }^{\circ}$, ha huã grande quebrada, $\mathrm{q}^{\prime}$ he o Adiq' pequeno, e este lado de Poligono o atravessa, a qual quebrada tem de largo no fundo 200. pes, os

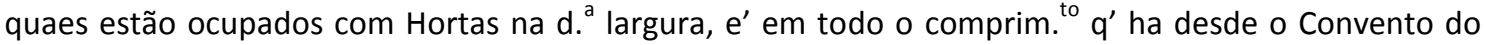
Carmo, até o pé do oiteiro do Barbalho.

O alto da . $^{\text {te }}$ do Beluarte do Carmo, he menor, $q^{\prime}$ o do Beluarte de S. ${ }^{\text {to }}$ Ant. ${ }^{\circ}, e^{\prime}[\mathrm{fl} .126 \mathrm{v}]$ começa

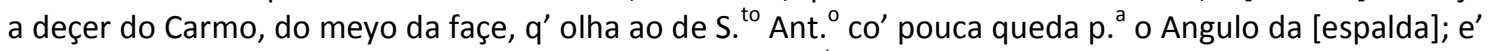
será neçessr. ${ }^{\circ}$ fazer huã Praça baixa no flanco delle da . $^{\text {te }}$ do Adiq', $e^{\prime}$ correr a cortina ao livel della, $e^{\prime}$ indo assy ficará bem alta, e de to $^{\text {to }}$ custo. E o Beluarte de s. ${ }^{\text {to }}$ Ant. ${ }^{\circ}$ he neçessr. ${ }^{\circ}$ que a façe $q^{\prime}$ olha ao do Carmo, seja feita em duas praças, huã baixa junto ao flanco, e' outra alta p. $^{\text {a }}$ a p. $^{\text {te }}$ do Angulo flanqueado, e' ainda assý hão de subir bem ambas, $p$. $^{\text {a }}$ ganharem ao livel do Angulo flanqueado. $O$ fosso deste poligono ha de ser artificial, levantando a contra escarpa, e' aterraplanando a explanada da estrada encuberta em comprim. ${ }^{\text {to }}$ de mais de 300.pes; e' os [neysos] da d. ${ }^{a}$ contra escarpa p. $^{\text {a }}$ huã e outra . $^{\text {te }}$ ha de sobir a trainel com [Redentes] p. à cobrir melhor os defensores da dita estrada encuberta.

L. $\quad O$ lado do poligono pequeno $q^{\prime}$ fica defronte do Forte de $\mathbf{S}^{\text {to }}$ Ant. $^{\circ}$ não fis mayor, porq. ${ }^{\text {to }} \mathrm{o}$ terreno me não deu mais lugar, a q. ${ }^{\text {to }}$ mais me recolhy por dentro da trinchr. ${ }^{\text {a }}$; tanto mayor o pude fazer, porq. $^{\text {to }}$ o terreno por essa $p .{ }^{\text {te }}$ he huã colina estreita, $q^{\prime}$ vay da $d .^{a}$ trinchr. ${ }^{a}$ direita até o Forte de $S^{\text {to }}{ }^{\text {to }}$ Ant. ${ }^{\circ}$, ficando-lhe de huã p. ${ }^{\text {te }}$ o despinhadeiro do Mar, e da outra huã quebrada chamada [aguoa bruca], e como não tem capaçid. ${ }^{\mathrm{e}}$ p. ${ }^{\mathrm{a}}$ se Ihe fazer outra obra, me pareçe se poderá cobrir este lado de Poligono pequeno com hú Hornaveq p. ${ }^{\text {a }}$ delle dar melhor a mão ao Forte de S. $^{\text {to }}$ Ant. ${ }^{\circ}$, a qual obra não desenhey

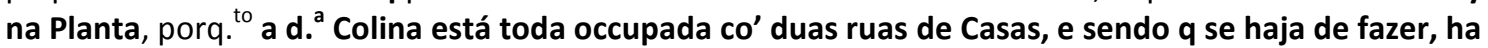
de ser no lugar q' ellas ocupão, mas o comprim. ${ }^{\text {to }}$ póde ser todo o q' se quizer fazer, porq. ${ }^{\text {to }}$ desde estes Beluartes, até o Forte de S. ${ }^{\text {to }}$ Ant. ${ }^{\circ}$ he tudo ao livel.

Cita o baluarte de Monserrate, de localização incerta, sugerindo-se pelo texto que ficava na encosta abaixo do Carmo (essa dúvida seria facilmente tirada com o desenho). ${ }^{682}$ Coutinho projeta um "muro singelo" descendo dele ao de S. Francisco junto ao mar (como a cortina ficaria grande, fez nela um flanco com uma bateria de duas peças, aumentando-se a partir daí a espessura da muralha).

\footnotetext{
${ }^{681}$ Cf. OLIVEIRA, 2004: 71.

${ }^{682}$ A descrição mostra não ser o Forte de Monserrate: ...fica no alto do despenhadr. ${ }^{\circ}$; que cáe sobre o Mar... Deste Beluarte deve de ir deçendo pla costa abaixo hum muro singelo co' seu parapeito, até fechar co' o Beluarte de S. Fran. ${ }^{\text {co }}$ fundado no mar.
} 
M. O Beluarte de Monserrate fica no alto do despenhadr. ${ }^{\circ}, q^{\prime}$ cáe sobre o mar, e por esta p. $^{\text {te }}$ não neçessita de terraplenos, nem grossos Parapeitos, como tambem lhe não são neçess. ${ }^{\text {ros }}$ grandes grossuras de muralha, e sóm. ${ }^{\text {te }}$ as $q^{\prime}$ bastarem $p$. $^{\text {a }}$ fechar a obra.

Deste Beluarte deve de ir deçendo p'la costa abaixo hum muro singelo co' seu parapeito, até fechar co' o Beluarte de S. Fran. ${ }^{\text {co }}$ fundado no mar; e' porq. ${ }^{\text {to }}$ este comprim. ${ }^{\text {to }}$ de cortina he grande, Ihe fis no meyo o flanco q' mostra a Planta, p. ${ }^{a}$ nelle se fazer huã bateria de duas peças, a qual terá as grossuras neçess. ${ }^{\text {ras }}$ e o parapeito à prova, e delle até o Beluarte de São Fran. ${ }^{\text {co }}$ póde correr a cortina co' a mesma grossura de muralha, $q^{\prime}$ tiverem os Beluartes, $e^{\prime}$ cortinas da marinha; $e^{\prime}$ se pareçer $q^{\prime}$ a $g$. ${ }^{\text {te }}$ não fica bem cuberta da meya cortina, q' sóbe a trainel do flanco p. ${ }^{a}$ sima, se lhe podem fazer algúns [travetes], em distançia conveniente huñs dos outros.

Propõe avançar mais ao mar o baluarte de S. Francisco, o que exigiria fundações dentro d'água, deslocando-o mais em direção ao centro da Cidade e diminuindo a cortina entre ele e o seguinte (Santa Bárbara).

N. O Beluarte de São Fran. ${ }^{\text {co }}$ se deve fazer mais metido no mar, o q' mostra a Planta, porq'

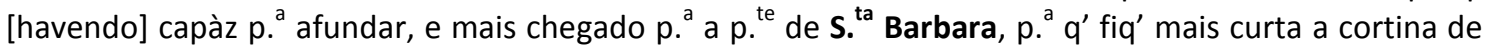
entre ambos.

Aproximou do baluarte de Santa Bárbara pelo mesmo motivo (diminuir a cortina) facilitando a sua reedificação, já que o mar era menos profundo. ${ }^{683}$ Isso também aliviaria a questão das casas e trapiches entre o Forte Real e o cais de $\mathrm{S}$. Bárbara, com a cortina passando por fora deles e deixando a serventia livre.

O. O Beluarte de $\mathbf{S}^{\text {ta }}$ Barbara cheguey mais $p .{ }^{a}$ o de São Fran. ${ }^{\text {co }}$, p $^{\prime}$ la razão já dita, de ficar a cortina interior, e de mais desta, por buscar menos fundo, porq' defronte do dito Caes de s. ${ }^{\text {ta }}$ Barbara he mais [alcantilado], e no lugar em q' eu faço o Beluarte, saindo tanto fora com elle, não chega a huã braça de fundo na baixa-mar: e' como do Forte Real até o cais de $S .{ }^{\text {ta }}$ Barbara, saem as Casas, $e^{\prime}$ Trapiches mais ao mar, $q^{\prime}$ nas outras $p .{ }^{\text {tes }}$ da marinha, he neçess. ${ }^{\text {ro }}$ sair mais ao mar co' o Beluarte de $S .{ }^{\text {ta }}$ Barbara, $p .{ }^{a} q^{\prime}$ a cortina de entre elle, e' o Real, Ihe passasse por fora de todas as Casas, e Trapiches, e houvesse servintia livre de huã, e outra p. ${ }^{\text {te }}, \mathrm{e}^{\prime}$ ainda assý não fica nesta cortina tão capàz como nas mais.

Projetou o baluarte de S. Filipe e Santiago mais avançado no mar (todos esses avanços tinham como causa as construções indevidas, principalmente na Cidade Baixa, prejudicando o flanqueamento das defesas na costa).

P. O Beluarte de São Phelippe, e Santiago metý mais ao mar, pella razão da dita Cortina atras.

Também fez nova posição para o baluarte da Conceição, sem aproximá-lo do de Santa Teresa em função das rochas que fariam sua fundação (diminuindo esse custo) e para atar melhor as cortinas.

Q. $\quad$ O Beluarte de Nossa S. ${ }^{\text {ra }}$ da Concepção ellegy naquelle sitio, $q^{\prime}$ mostra a Planta, e' o não cheguey mais ao de $\mathbf{S}^{\text {ta }}$ Thereza, porq' neste lugar estão huñs arrecifes de pedra, $\mathrm{q}^{\prime}$ saem ao mar em distançia conveniente de sobre elles fundar o dito Beluarte, e saindo bem fóra, ata melhor a cortinas, q' sóbe $p^{\prime}$ la ladeira asima, ${ }^{684}$ e fica bem defendida, custando $\mathrm{m}^{\text {to }}$ menos os fundam. ${ }^{\text {tos }}$ deste Beluarte, em razão dos $d{ }^{\text {os }}$ arreçifes.

Subiu as cortinas do baluarte da Conceição para o de Santa Tereza, como fez no de S. Francisco.

\footnotetext{
${ }^{683}$ Huã braça $=2,20 \mathrm{~m}$.

${ }^{684}$ Pleonasmo de uso comum.
} 
Deste Beluarte subo com a cortina na mesma forma $q^{\prime}$ o fis no [fl. 127] de São Fran. ${ }^{\text {co }}$, fazendo-lhe o mesmo flanco de [travetes] se forem neçess. ${ }^{\text {ros }}$ até fechar co' o Beluarte de S. $^{\text {ta }}$ Thereza.

Colocou três portas principais para o sistema defensivo: uma na cortina ligando o baluarte da Piedade ao de S. Bento, para acesso à estrada que ia à Vila Velha e à Barra; uma entre o Baluarte do Desterro e o de S. Jorge, no atual Bairro de Nazaré; outra na "cortina pequena detrás do Carmo" (em relação ao que chamou de poternas ou postigos, deixou sensatamente a critério dos executores da obra que saberiam a vocação do terreno e as antigas serventias de circulação da população - o que é uma recomendação comum nos tratados portugueses, de Antonio Rodrigues a Serrão Pimentel). ${ }^{685}$

R. S. T. Faço nesta Planta tres Portas prinçipaes; a saber, huã na cortina de entre o Beluarte da Piedade, e' o de São Bento, $q^{\prime}$ he $p .{ }^{a}$ a servintia da estrada de . $^{\text {to }}$ Ant. ${ }^{\circ}$ da barra. Outra na cortina entre

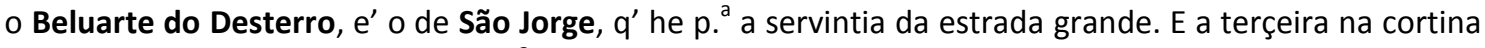
pequena destras do Carmo, $\mathrm{q}^{\prime}$ vay p. ${ }^{\mathrm{a}}$ a estrada de Tapagipe.

Os Postigos, e Portas falsas não os fis no lugar em q' se devem fazer, porq' quem executar a Planta os fará aonde forem mais convenientes $p .^{a}$ a servintia do povo, como també as abertas da marinha.

Propôs o armazém de pólvora na marinha para guardar o material (que supriria os grandes fortes, S. Marcelo, Monserrate, Barra) ao ser desembarcado, podendo ser usado na defesa do porto e evitando o difícil transporte para o Campo da Pólvora, já que havia o manifesto perigo de incêndios no comportamento dos capitães dos navios, que por causa dessa distância preferiam guardar a pólvora em suas casas. Propôs o depósito no Forte de S. Francisco, relativamente isolado das habitações.

Tenho satisfeito na forma $q^{\prime}$ entendo, ao $q^{\prime}$ SMg. ${ }^{\text {de }}$, $q^{\prime}$ Deos g. ${ }^{\text {de }}$, me manda. Demais se me offereçe dizer, $q^{\prime}$ se deve fazer huã Casa p. $^{\text {a }}$ polvora na Praça, assy p. ${ }^{a}$ na ocasião prover a forteficação da marinha, e' Fortes do Populo, Monserrate, e da Barra, como p. ${ }^{\text {a }}$ servir de guardar a dos navios, porq' de a não haver se podem seguir $\mathrm{m}^{\text {tos }}$ danos. 0 prim. ${ }^{\text {ro, }}$, faltar o socorro a estas Fortalezas, com a promptidão $q^{\prime}$ convem. O seg. ${ }^{\text {do }}$, estar esta Cid. ${ }^{\text {e }}$ com manifesto perigo de hum incendio, em razão de $q^{\prime}$ os Mestres dos navios, guardão a polvora delles em suas Casas por lhes ficar desviado do Mar a Casa que se fes nova. O terçeiro, $q^{\prime}$ não he possivel fazer-se a troca dos dous barris, na forma da Provisão, porq' como não tem p. $^{\text {te }}$ em $q^{\prime}$ publicam. ${ }^{\text {te }}$ a metão ocultão-na, e se os obrigarem à da troca, darão a peor $q^{\prime}$ tiverem.

O lugar mais conveniente $q^{\prime}$ ha na marinha, he o Forte de São Fran. ${ }^{\text {co }}$, por estarem as Casas afastadas delle de huã, e outra p. ${ }^{\text {te }}$ mais de 200.palmos, e' boa servientia assý p. ${ }^{a}$ o mar, como p. ${ }^{a}$ a terra; e como tem largura bastante, póde ficar a d. ${ }^{a}$ Casa bem afastada da ladeira, e' livre da umidade, e' capaz p. ${ }^{\text {a }}$ o intento.

A conclusão faz lamentar a perda dos desenhos, descritos com a humildade necessária ao tipo de discurso (também se notam cuidados de decoro e conveniência em passagens como... na forma $q^{\prime}$ entendo, ao $q^{\prime} S M g .^{d e}, q^{\prime}$ Deos $g .{ }^{d e}$, me manda...).

Tudo o sobredito se colherá melhor das Plantas, q' ainda q' não vão riscadas com aq'ela perfeição $q^{\prime}$ ellas pedião, ao menos prezo me $m^{\text {to }}$, de $q^{\prime}$ vão sertas nas medidas, assy' das linhas, como do valor dos Angolos, q' he o q mais importa. As medidas das grossuras e altura das muralhas se

\footnotetext{
${ }^{685}$ O maior exemplo em Pimentel, aqui citado, está em trecho do capítulo "Das partes interiores da Fortaleza, Cidade, ou Villa fortificada" em que diz: ... \& todas as medidas sobreditas de mais, ou menos se entendem tambem, conforme a capacidade da povoaçã̃, sobre $q^{\prime}$ o engenheiro deve proceder com juizo, \& boa consideraçaõ... (PIMENTEL, 1993: 321 - Parte I, Secção II, Cap. XI).
} 
podem bem colher do Perfil q vay na Planta, e melhor no papel do orsam. ${ }^{\text {to }}$ do custo da obra. Bahia 30.de Março de 1685 / O Engenhr. ${ }^{\circ}$ João Coutinho./

Depois de mais alguns comentários feitos a posteriori por engenheiros do Reino, chegamos à folha em que é feito o orçamento. Nele estão dadas importantes medidas das obras.

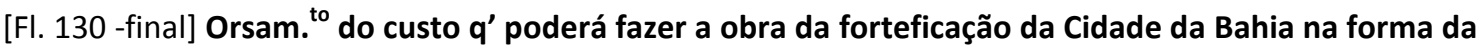 Planta junta}

Para esse orsam. ${ }^{\text {to }}$ faço as supposições seg. ${ }^{\text {tes }}$ Que a muralha de sima da Cid. ${ }^{e}$, medida $p^{\prime}$ la linha Ichnografica superior, e' exterior della, tem de comprido onse mil cento, e' settenta e' oito pés. $E$ q' as obras exteriores medidas p'la mesma linha tem de comprido cinco mil pés. E q' a muralha da marinha, e' ladeiras, medida p'la mesma linha, tem de comprimento sette mil, çento e' cincoenta e hum pés.

São analisados os materiais e a possibilidade de se conseguir preços baixos pela concorrência entre os empreiteiros (também apresenta questões relacionadas ao trabalho e à propriedade, avaliando a viabilidade econômica na exploração particular da propriedade pública - ou da família real).

A muralha da Cid. ${ }^{e}$ ha de ser à escarpa de [quarto]; q' sem embargo de a terra ser boa, e sólida, he a cal $\mathrm{m}^{\text {to }}$ fraca; $\mathrm{e}^{\prime} \mathrm{q}$ há de sobir do fundo do fosso, até o leito de sima do cordão, vinte e quatro pés, $\mathrm{e}^{\prime} \mathrm{q}^{\prime}$ do cordão $\mathrm{p}^{\text {a }}$ sima ha de sobir a plumo seis pés, e' em grossura de quatro, q' são os em q'ha de acabar em sima do cordão com q' deve principiar em dez pés de grosso. Tambem suponho q' o aliçerçe ha de fundiar dous pés sóm. ${ }^{\text {te }}$, abaixo do fundo do fosso, e ter onze de grosso: e' ainda $q^{\prime}$ estas alturas, e grosuras hão de ser varias, a resp. ${ }^{\text {ito }} 686$ das suas baixas grandes, $\mathrm{q}^{\prime}$ ha no terreno, tambem me pareçe $\mathrm{q}^{\prime}$ em outras . $^{\text {tes }}$ se [obrará] com pedra, e não serão neçess. ${ }^{\text {ros }}$ aliçerçes, nem fazer tão altas muralhas, e' ficará huã cousa, p'la outra. ${ }^{687}$

Para as obras exteriores suponho q' as muralhas sobirão até vinte pés, entrãdo nelles o aliçerçe, e $q^{\prime}$ podem acabar em tres pés, seguindo a escarpa do quarto, com q' devem começar em oito pés de grosso.

Para a forteficação da marinha, suponho $q^{\prime}$ os fundam. ${ }^{\text {tos }}$ debaixo da agoa, serão huñs por outros de seis pés de alto na baixa mar, e' de sette de grosso. E' [fl. 130v] q' daquy p. ${ }^{a}$ sima sobirá à escarpa do oiteiro, p. ${ }^{a} q^{\prime}$ começará em çima [10] pés de grosso, e acabará em quatro, e sobirá oito pés.

E ainda q' estas medidas forão tomadas p'la dita linha Ichnografica q' não he a verdad. ${ }^{\text {a }}$ por onde se deve medir a obra, mas mayor algum tanto, co'tudo, como sempre a ereçem çircunstançias, com q' se acresçenta a dita obra, Ihe dou a medida p'la dita linha.

Supponho custar cada braça de alvenaria na muralha da Cid. ${ }^{e}$ a quatro mil rs', $q^{\prime}$ he o preço porq' hoje aquy se fas em preto; e' ainda que a obra de muralhas grossas dá mais proveito dos empreiteiros, do $q^{\prime}$ as delgadas, isto he sóm. te no feitas das mãos, $q^{\prime}$ os ingredientes sempre são os mesmos; mas como os [longes] desta obra são grandes, entendo ficará huã cousa p'la outra.

A dificuld. ${ }^{e} q^{\prime}$ acho he, $q^{\prime}$ a pedra $q^{\prime}$ ha aquy á roda, não fará a metade da obra, e será necess. ${ }^{\text {ro }}$ hi-la buscar $\mathrm{m}^{\text {to }}$ longe, e por mar, com $\mathrm{q}^{\prime}$ de meya obra por diante, será muy custosa; mas isto me pareçe se remedeará com haver já então $\mathrm{m}^{\text {tos }}$ empreiteiros, $\mathrm{q}^{\prime}$ lansem huñs contra os outros, e tenhão fabrica p. ${ }^{a}$ isso, porq' entendo q' não haverá na B. ${ }^{a}$ empreiteiros, $q^{\prime}$ no prinçipio da obra se obriguem a remata-la toda junta, $e^{\prime}$ ainda q' os houvera, me pareçe não era conveniente arremata-la logo toda, porq' como ella tiver dado ganho aos prim. ${ }^{\text {ros }}, \mathrm{e}^{\prime}$ cabedal a outros, todos hão de querer ter p. $^{\text {te }}$ no ganho, p. ${ }^{a}$ o q' hão de lançar huñs contra outros, e' pode ser q' abaixe ainda de presso.

Tambem se deve resalvar na arrematação, $q^{\prime}$ se acaso nos fossos se achar alguã pedreira, será o empreiteiro obrigado a pagar a pedra, q' se tirar della, p'la avaliação q' se achar val ao pé da obra, porq. ${ }^{\text {to }}$ esta pedra se ha de arrancar por conta da faz. ${ }^{\text {da }}$ real, pois os fossos se hão de abrir pella mesma.

\footnotetext{
${ }^{686}=$ A despeito.

${ }^{687}$ Não adeptos de uma "teoria do desleixo", entendemos também essa expressão como simples parecer técnico.
} 
Fez então o orçamento detalhado da obra, que era de $457.325 \$ 969$ réis, junto a um estudo em que indicava meios e recursos de financiamento que o copista chamou de Papel do Enginhr. ${ }^{\circ}$ João Cout. ${ }^{0}$ p. $^{a}$ o Marques das Minas . $^{\text {or }} \mathrm{g} .^{\text {al }}$ do Brazil, sobre a forteficação da Bahia, e meyos . $^{a}$ se conseguir a obra em menos tempo; e co' mais brevid. ${ }^{\text {e } 688}$

\section{Custo de toda a obra reduzida a dinhr. ${ }^{\circ}$}

$x$ Alvenaria da muralha com as medidas atras escrittas importa 2392092.pés cubicos, $q^{\prime}$ fazem 32293.braças p121/500avos de braça, $q^{\prime}$ a preço de $4 \$$ rs a braça, importa $29.172 \$ 968$.

$x$ Alvenaria das obras exteriores com as medidas atras escritas, importa 550000.pés cubicos, $q^{\prime}$ fazem 7425.braças, q' [aditos] quatro mil rs importa $29.700 \$ 080$.

$x$ Os fundam. ${ }^{\text {tos }}$ debaixo d'agua no Caís da marinha de pedras grandes em [804o], com as medidas atras ditas, importa 300342 pés cubicos, q' fazem 4054.braças p617/1000esimos de braça, q' a $5 \$$ rs braça, q' tanto faço custar. $20.273 \$ 085$. $x$ A muralha sobre este fundam. ${ }^{\text {to }}$ importa 257436. pés cubicos $q^{\prime}$ fazem 3475.braças p193/500avos de braça, $q^{\prime}$ sendo forrada por fora de [enchedaria] forca, faço custar a braça a sei mil $r s, e^{\prime}$ importa.

$20.857 \$ 316$.

x O Parapeito de alvenaria sobre esta obra, feito em comprim. ${ }^{\text {to }}$ de 70.00 pés, em razão das abertas $p .{ }^{a}$ a servientia, importa 112000 pes cubicos, q' fazem 1512 braças, q' a preço de $4 \$$ rs a braça rebocada importa. $6.048 \$ 000$ $x$ As alvenarias das contra escarpas $p .{ }^{a}$ os fossos artifiçiaes nas paragen's $q^{\prime}$ for neçess. ${ }^{r o}$ na forteficação da Cid. ${ }^{e}$ faço importarem pouco mais, ou menos, 3000 braças, $q^{\prime}$ a $4 \$$ rs a braça, importa.

$12.000 \$ 000$

$\mathrm{x}$ O Parapeito de tijolo singelo $\mathrm{p} .{ }^{\mathrm{a}}$ guarita da estrada das rondas, na forteficação prinçipal da Cid. ${ }^{\mathrm{e}}$, de çinco palmos de alto, e' 165000 de comprido, abatido o q' hão de ocupar as guaritas fas 825 braças, q' em preto custa aqui a braça a $2 \$ r s, e^{\prime}$ importa $1.650 \$ 000$

x $\mathrm{O}$ reboq $^{689}$ deste parapeito por dentro, é por fora, importa 1650 braças, $q^{\prime}$ a preço de 320 rs a braça,importa $528 \$ 000$

[fl. 131]

x O Cordão da obra da Cid. ${ }^{e}$ abatido o q' ocupão as guaritas podem ter 16550 palmos de comprido, e' palmo e meyo de alto, e' outro tanto de sacada, fas 3 palmos $3 / 4$ de lavoura de largo, e' tudo fas 62062 palmos e' meyo, $q^{\prime}$ reduzidos a varas de sette palmos e' meyo cada huã como he estylo, importão 8275 varas, $q^{\prime}$ a preço de 800 rs importão $6.620 \$ 000$ $x$ Os Beluartes de sima da $C^{\text {de }}, q^{\prime}$ ao onze, levão cincoenta $e^{\prime}$ cinco [cunhos] confrontados, e [re]salteados em oito palmos por cada façe de largo, $q^{\prime}$ na altura de 23.pés até a rais do cordão, faço lãzar $p^{\prime}$ la escarpa vinte e tres, e tres quartos, e seis do cordão $p .{ }^{a}$ sima, $q^{\prime}$ fazem palmos quarenta $e^{\prime}$ quatro $\mathrm{p} 5 / 16$, e' tudo 39270 palmos superfiçiaes, $q^{\prime}$ reduzidos a varas de sette pamos e meyo, importa 5236.varas, $q^{\prime}$ a preço de 600 rs importa.

$3.141 \$ 600$

Val a Sauda atras. $229.985 \$ 969$ $229.985 \$ 969$

x Para 35.guaritas de pedraria, e' tijolo; a saber, duas nos Beluartes de S. ${ }^{\text {ta }}$ Thereza, e ' 24.nos [d.] q' se seguem p'la p. ${ }^{\text {te }}$ da terra, e' duas nos Beluartes de $S .{ }^{\text {to }}$ Ant. ${ }^{\circ}$, e huã ... no de Monserrate, e' duas nos flancos da ladeira, e' 4.nos 4.Beluartes da marinha, $q^{\prime}$ avalio cada huã em 100\$\$rs, e' todas importa.

$3.500 \$ 000$

x Para guaritas de menos custo na obra Coroada, e' Hornaveq' e' tres Reveliñs diante das tres portas, avalio cada huã em $80 \$$ rs e' importão todas. $640 \$ 000$

$x$ Tres portas prinçipaes com seus corpos de guarda, contra muralhas, portas interiores, abobedas, caza

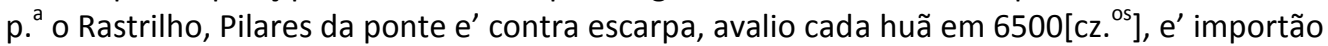

$7.800 \$ 000$

$x$ Tres Portigos $p{ }^{\text {a }}$ serventia do povo, $e^{\prime}$ álem delles seis portas falcas $q^{\prime}$ todos hão de passar por baixo dos terraplenos, co' muralhas, e' abóbedas, faço custar cada huã $600 \$ 000$ rs, e' todas nove

$5.400 \$ 000$

\footnotetext{
${ }^{688} \mathrm{~S} /$ ref. - apud OLIVEIRA, 2004: 71 (grifo nosso, pela redundância).

${ }^{689}=$ reboco.
} 
$x$ Os lagedos p. ${ }^{a}$ as explanadas da artilhr. ${ }^{a}$ em todos os Beluartes poderão ter 40000 varas, o qual custa aquy a vara assentado a $2 \$ \mathrm{rs}, \mathrm{q}^{\prime}$ importa $200 \$ \mathrm{cruz}^{\mathrm{dos}}{ }^{\mathrm{e}} \mathrm{e}^{\prime}$ vindo do $\mathrm{Rn} .{ }^{\circ}$ por lastro dos navios, será demais [dara], p'la pedra, ser melhor, e' faço custar aquy posto, e' assentado na obra a $1 \$$ rs a vara, e' importa $40.000 \$ 000$

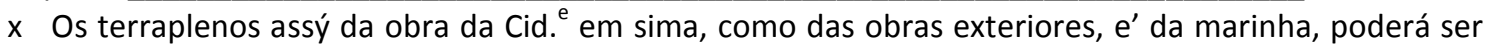
tudo 250000 braças, $q^{\prime}$ faço custar cada braça, entrando 60 por milhar $p$. $^{\text {a }}$ conçerto das ferram. ${ }^{\text {tas }}$, $e^{\prime}$ caminhos [\$]400 braça, $q^{\prime}$ importa $100.000 \$ 000$

x O Forte novo, q' se deu fazer no Oiteiro do Barbalho poderá custar acabado de tudo $80 \$$ cruzados.

x O Forte de S. $^{\text {to }}$ Ant. ${ }^{\circ}$ poderá custar acabado $40 \$$ cruz. $^{\text {dos }}$ $32.000 \$ 000$

O Forte de São Pedro outro tanto. $16.000 \$ 000$ $16.000 \$ 000$

x Para portas de madeira, e' pontes levadiças, ferragens, correntes, $e^{\prime}$ tudo o $q^{\prime}$ tocca a ferreiro, e carpintr. ${ }^{\circ}$, poderá importar toda esta obra $15 \$$ cruzados. $6.000 \$ 000$

$457.325 \$ 969$.

Com o q' faço importar esta obra hú milhão, e duz. ${ }^{\text {tos }}$ mil cruz. ${ }^{\text {dos }} ; q^{\prime}$ supposto esta conta não chega a tanto, e lhe faltão vinte e dous co'tos, seisçentos e' settenta e quatro mil rs, q' fazem $56 \$$ e tantos cruz. $^{\text {dos }}$, creo $q^{\prime}$ estes serão neçess. ${ }^{\text {ros }}$ p. $^{\text {a }}$ ordenados dos [off. ${ }^{\text {aes }}$ ] $q^{\prime}$ hão de assistir a esta obra, nos annos q' ella durar. Bahia 30.de Abril 1685

O Engenheiro João Cout. ${ }^{\circ} /$

As observações sobre os fortes de Santo Antonio Além do Carmo, Barbalho e São Pedro, ainda de terra, foram deixadas para a parte seguinte, já que se tornaram obras definitivas no século XVIII. São fortificações que se destacarão pela grandeza e regularidade em seus projetos. O do Barbalho, de fato, é ainda maior que os outros dois. Não se pode afirmar se a forma e dimensão com que foram orçados por Coutinho eram as atuais, mas chama atenção o fato de o Barbalho ser bem mais oneroso (o dobro de cada um dos outros dois).

\subsection{A referência de Serrão Pimentel}

Referimo-nos na parte inicial à figura de Luís Serrão Pimentel (1613-78), primeiro lente da Aula de Fortificação e Arquitetura Militar da Ribeira das Naus (decretada por D. João IV em 13/07/1647, mas de funcionamento posterior), ${ }^{690}$ onde ensinou arte de matematiquas navegação, fortiffiquação, castramentação, expugnação e defenção das Praças. ${ }^{691}$ Com ele, o filho (Manoel Pimentel, 1687-1723) e o neto, houve grandes avanços na matemática e cosmografia de Portugal na segunda metade do século XVII e início do XVIII. O Methodo Lusitanico..., de publicação póstuma (1680), foi dos textos mais citados e seguidos por engenheiros portugueses e brasileiros por quase um século. ${ }^{692} \mathrm{Na}$ Bahia, os engenheiros militares que serviram na virada do século XVII para o XVIII foram seus discípulos ou recomendados, como o Cap.

\footnotetext{
${ }^{690}$ Pimentel é considerado pai da Engenharia Militar portuguesa por inspirar e criar em Lisboa, em meio às guerras da Restauração, a Aula da Ribeira das Naus, primeira escola de formação de oficiais,. Decorrem dela as Aulas Militares das colônias, entre elas a da Bahia, Pernambuco e outras capitais.

${ }^{691}$ ANTT - Chancelaria de Afonso VI, liv. 29, fl. 267 - apud VITERBO, 1904: II, 270. Para Viterbo, Serrão Pimentel "... foi um homem de merecimento pouco vulgar, honrando a engenharia portuguesa, tanto na theoria como na pratica, tanto na guerra como na paz" (idem, p. 269).

${ }^{692}$ M. Oliveira observa as novas formulações para o traçado das fortificações de Serrão Pimentel como reflexões sobre ensinamentos da Escola Holandesa, da qual era seguidor (cf. OLIVEIRA, 2004: 50 acentuando que a holandesa era a escola "mais prestigiosa de seu tempo").
} 
Eng. Antônio Correia Pinto, salvo do processo de prisão (por contrabando de ouro) pela interferência do mestre.

Se o relatório de João Coutinho (1685) evidencia a maneira conjunta (espelhada) de se pensar Cidade e Fortificação, vamos encontrar no Methodo Lusitanico a teoria em que se explicita essa relação, especialmente no capítulo Das partes interiores da Fortaleza, Cidade, ou Villa fortificada, ${ }^{693}$ que define os conceitos ligados às fortalezas e ao urbanismo. Ao descrever a estrutura urbana no interior da fortaleza, Serrão estabelece as hierarquias dos espaços pela sua dimensão e localização. É proposta uma cidade modelo que funcionaria melhor que as existentes, sendo distribuídas as ruas, praças, edifícios públicos e particulares pelo critério de melhor utilização civil e militar. ${ }^{694}$

É ao estabelecer as diretrizes urbanas que ele defende nem sempre ser possível usar os princípios da fortificação regular em obras existentes, sendo necessária às vezes uma adaptação, que seria feita, como ressaltamos, a critério do arquiteto ou engenheiro militar:

Nas Cidades, Villas, ou lugares antigos, que de novo se fortificaõ, senaõ podem dispor as partes interiores com a perfeição que nas que de novo se fabricaõ; mas convem que nos cheguemos quanto puder ser a mayor regularidade, que assim para ornato, como para a cõmodidade dos usos civis, \& principalmente dos militares se costuma dar no cõpartimento das ruas, praças, edificios públicos, \& particulares naquellas Fortalezas, ou povoaçoens que de novo se fundão com melhor repartimento, \& ordem do que fazião os antigos. ${ }^{695}$

... \& todas as medidas sobreditas de mais, ou menos se entendem tambem, conforme a capacidade da povoação, sobre q o engenheiro deve proceder com juizo, \& boa consideração, tomando as medidas, \& tirado a planta, para que no papel veja primeiro como em hum espelho a representação de toda a obra, \& que sitios Ihe ficão para os edificios, \& casas de que diremos. ${ }^{696}$

O Relatório de Coutinho é o documento que evidencia claramente, com base na tratadística, o expediente da visão integral de cidade, no qual o desenho é o instrumento e meio de conhecimento essencial. A diretriz que o engenheiro impõe no seu Relatório, apoiado em Serrão Pimentel (estariam à mostra nos desenhos que foram perdidos, e que fariam ver "como em um espelho a representação de toda a obra"), norteará por décadas os empreendimentos, estando patente nos projetos do século XVIII, em especial o de Miguel Pereira da Costa e o Relatório Massé.

Como destaca a professora Beatriz Bueno, no tratado de Serrão Pimentel a cidade aparece "subordinada à questão da distribuição interna da própria fortificação". ${ }^{697}$ Ao longo do capítulo são detalhadas suas condições básicas e dadas medidas recomendáveis para a praça central (120 a 200 ou 250 palmos), ruas principais (30 a 35 palmos) e secundárias (25 a 30), estradas à volta das cortinas (20 a 30 ou 36 palmos), praças diante de baluartes (150 a 200 palmos de lado), praças menores ( 80 a 100 palmos de lado), casas (24 a 36 ou 40 para frente de lote e 68 a 70

\footnotetext{
${ }^{693}$ Cf. PIMENTEL, 1993: 319 (Parte I, Secção II, Cap. XI).

${ }^{694}$ As teorias de estruturação da área urbana fortificada em cidades portuguesas sempre consideraram a coexistência dessas duas funções no espaço urbano.

695 PIMENTEL, 1993: 319 (grifos nossos). O exemplo seria Palmanova.

${ }^{696}$ PIMENTEL, 1993: 321 (Parte I, Secção II, Cap. XI).

697 BUENO, 2001: 450 (grifo nosso). Na seqüência, Beatriz confronta essas medidas com as de vilas e cidades brasileiras, como fizeram Renata Araújo e José Manuel Fernandes (para aquelas fundadas no século XVIII - cf. nota 256, p. 450).
} 
ou 80 de profundidade) e casa do governador ( $80 \times 40 \times 25$ palmos). Pimentel dá certa flexibilidade a esse modelo, contando com o "bom senso" do engenheiro na hora de empregá-lo:

... O Engenheiro experto, \& de juizo poderá accõmodar as mais particularidades com bom discurso, \& consideração. Não trago fig. com as disposiçoens das ruas, praças \& sitios das casas em Planta por me parecer se pòde escusar, \& que sem Ella se entende tudo o sobreditto, por não multiplicar mais figuras na impressão, \& porque quem as quizer ver, as acharà nos livros de muitos autores, \& porq muito poucas vezes se podem dispor na fòrma apontada para a praça em tudo ser regular; quando quasi todas as que de novo se fortificão são cidades, \& villas antigas, onde senã̃ podem accomodar as cousas com tanta regularidade, ainda que se derribem, \& cortem muitas casas; pois não se devem arruinar as povoações mais que no for muito preciso... ${ }^{698}$

A descrição de regras teóricas no interior da "Praça" aparece definindo o que seria a cidade modelo, baseada em conceitos renascentistas, mas ligada aos ideais militares de defesa. ${ }^{699}$ Essa cidade ideal se limitaria por uma linha de muralhas em forma de polígono regular, tendo ao centro a praça principal, "Praça de Armas", de lados paralelos às cortinas ou lados da fortificação regular, de dimensão conforme a grandeza da fortaleza. Da praça principal sairiam ruas diretas para os baluartes (de 30 a 35 palmos) e outras para as cortinas (de 25 a 30), havendo ainda aquelas necessárias para servir melhor a civis e militares (20 a 25) e dar mayor fermosura da povoação, ${ }^{700}$ atravessando ordenadamente as que viriam do centro da vila, cidade ou fortaleza.

As praças menores, também dimensionadas, ficariam nos cruzamentos dessas ruas com as principais ou no encontro das de acesso aos baluartes com a estrada de armas que corria junto às muralhas, servindo a mercados e outros usos civis. ${ }^{701} \mathrm{~A}$ descrição de ruas e praças mostra uma definição hierárquica não só pelas dimensões, mas pela função e orientação em relação à praça principal e aos lados do polígono (perímetro) da fortaleza.

Esse ideal de cidade se baseia em conceitos renascentistas, com constantes referências a Palmanova. Diversos tratados do século XVII fazem referência a cidades planejadas e construídas já com sistemas de fortificação modernos, de novas tecnologias da época e com certa regularidade, como Coeverdan, Philipsbourg e Manheim. Pimentel também faz referência, alegando razões defensivas, à localização de edifícios públicos, incluindo igrejas, hospitais, a Câmara e todos os edifícios militares (quartéis, armazéns de armas e casa do governador). ${ }^{702}$

\footnotetext{
698 PIMENTEL, 1993: 325 (Parte I, Secção II, Cap. XI) - grifo nosso. Na Introdução citamos a primeira frase deste trecho.

${ }^{699}$ Cf. TEIXEIRA \& VALLA, 1999: 130.

700 PIMENTEL, 1993: 321.

701 Vimos que nos primeiros anos de Salvador, o largo formado junto à Porta Sul, principal acesso da cidade, serviu de local a uma primeira feira semanal de mercadorias.

702 Não são definidas as medidas de hospitais e casas da Câmara, porque dependeria da dimensão da Praça ou vila e do número de habitantes, mas para os edifícios militares são dadas localizações e medidas como parte integrante da estrutura urbana. Até para as casas particulares as dimensões são dadas conforme a grandeza da "Praça" fortificada: Ordinariamente se fazem de 60. atè 70. ou 80. Pés de comprido, \& de largo 24. até 36. ou 40. em que se accõmoda hua morada (PIMENTEL, 1993: 323).

Junto à descrição do traçado urbano ideal para uso militar e civil, e à localização e medição de equipamentos públicos e casas privadas, ele inclui as infra-estruturas necessárias ao funcionamento, como o fornecimento de água e moinhos, mostrando uma visão totalizadora de intervenção na cidade ou vila fortificada. A sua escolha de sítio considera a possibilidade de sobrevivência em caso de cerco, e por isso leva em conta fornos, água próxima às casas e a possibilidade de se construir moinhos. Vê como
} 
O sítio ideal para a cidadela seria num dos lados da fortaleza ou no ângulo do perímetro interior da praça, havendo nesse caso duas portas, uma para o exterior e outra para o interior da praça. ${ }^{703}$ Há no tratado uma referência especial às portas das fortalezas, em menor número possível, em função da capacidade da praça e dos caminhos principais necessários à articulação. O lugar adequado da porta seria o meio da cortina ou mais próximo a um flanco que outro, conforme o traçado da rua, evitando-se grande derrubada de casas existentes (o que mostra que João Coutinho tinha sua atitude conservacionista teorizada no tratado português). ${ }^{704}$ Se de fato necessário, admitia-se a abertura de uma nova rua: De outro modo he necessario fazer nova rua para serventia da Porta ainda que se derribem alguas casas que bastem para vir a dar em outra da Praça por onde se faça a serventia. ${ }^{705}$ As portas deveriam ter uma expressão rude e austera, simbolizando a invencibilidade de uma fortaleza formidável perante os inimigos, ou uma Praça inexpugnável. ${ }^{706}$

necessários os poços de água, de preferência na praça principal. A questão da defesa é, portanto, prioritária na concepção da estrutura urbana.

${ }^{703} \mathrm{Na}$ descrição destes principais elementos e sua localização em um modelo ideal de cidade, Serrão Pimentel quer aplicá-los àquelas que seriam reconstruídas, notando que em Portugal não havia fortificações regulares, já que as fortificações eram aplicadas em vilas ou cidades antigas. Daí seu método se basear na regularização de polígonos irregulares. O exemplo de referência de fortificação irregular é a da cidade de Estremoz, desenhada por ele incluindo todos os elementos existentes (castelo, povoação principal, bairro de São Tiago, fontes e conventos - cf. TEIXEIRA \& VALLA, 1999: 130-1).

Sobre construir cidadelas ou castelos na vila ou cidade, ele justifica de duas maneiras: necessidade de impor o poder na cidade (como em cidadelas da Itália, Nápoles e Milão) e de socorrer a cidade em um ataque e refugiar moradores perseguidos (como em Clès, Amiens e outras cidades da França e de Flandres). Elas seriam em geral quadrangulares, ou pentagonais. Muitas, como os antigos castelos, ficavam em lugares eminentes e dentro das Praças, rodeados pela cidade (como o castelo de São Jorge em Lisboa, que antes não teve aquela localização).

${ }^{704}$ Cf. TEIXEIRA \& VALLA, 1999: 130. No tratado de Pimentel, a realidade portuguesa é tão presente que a cidade ideal é descrita sem ser desenhada, já que raramente poderiam se colocar em Portugal os elementos urbanos dessa forma em uma praça regular. Acrescenta que nas vilas e cidades existentes não se deveria destruir tudo, mas só o necessário para as obras de fortificação em si, como muralhas e fossos. Outras obras, como a praça principal, outras praças e algumas ruas principais, deveriam ser feitas ainda que em locais diferentes do padrão:... pois de outro modo serà necessario aruinar tudo \& tornar a edificar á vontade... (PIMENTEL, 1993: 325). Era constante a preocupação em não destruir a vila ou praça que se pretendia fortificar, o que foi bem assimilado por Coutinho. Diz que a cidade ideal descrita seria sempre irreal no contexto português, a menos que houvesse grandes destruições, e lembra que... senaõ faz taõ facilmente com a obra como com o pensamento ou como o desenho no papel, quãdo ainda houvera cabedal para executar ideas fantasticas (id. ibid.).

705 PIMENTEL, 1993: 147 (Parte I, Seção I, Cap. XXXV: “Dos Portaes, \& entradas das Fortalezas, ou Praça fortificada").

${ }^{706}$ Sobre essa expressão rude e austera simbolizando a invencibilidade, M. Oliveira explica que na Arquitetura das Fortificações as concessões decorativas eram radicalmente limitadas, havendo eventualmente no bocel separando o parapeito da saia da muralha (porém com alguma função prática), algumas modenaturas nas guaritas e principalmente um portaló ou a portada, inspirada nas antigas ordens, principalmente a Toscana, variante da Dórica. Essa escolha da ordem seguiria a recomendação de Vitrúvio "de usar as ordens másculas (dórica e toscana) para os templos e edifícios dedicados às divindades da força e da guerra, como Hércules e Marte" (OLIVEIRA 2004: 38 - as fortalezas seriam como "templos de Marte").

Tanto na parte externa quanto na interna, as construções militares apresentariam a "sobriedade espartana" como parte do decoro (vitruviano) do edifício. Ele se fundamenta justamente em Serrão Pimentel: Por esta razão convem que sua fabrica [das portadas] seja da ordem Toscana ou da Dórica das Cinco a que a Architectura Civil está reduzida: da Toscana por ter muito de forte, \& robusta apta a sustétar todo o peso grave (diz Vincenzo Scamozzi) \& que por tanto semelha o modo agigantado: da 

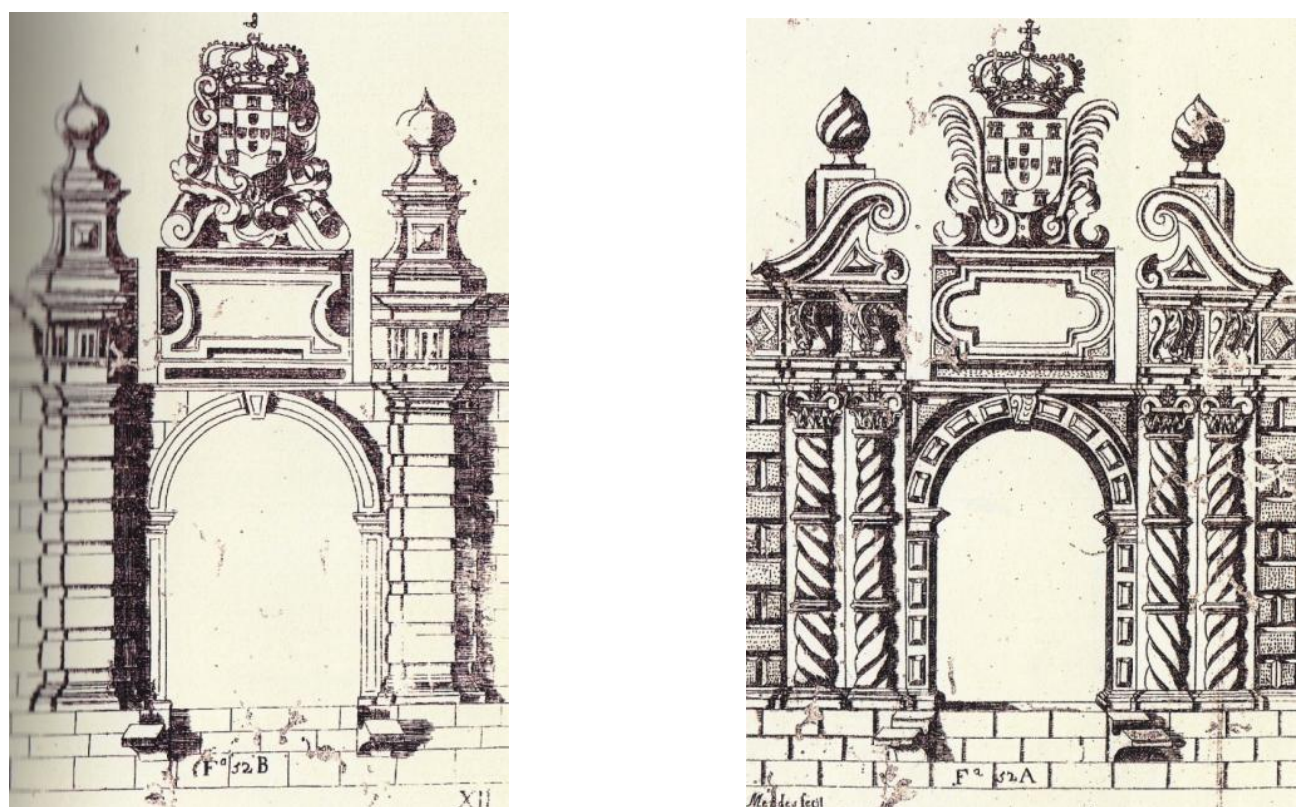

Os portais barrocos em contraste com a severidade das paredes nas fortificações (em PIMENTEL, 1993: $152-3)^{707}$

Dorica por ser de corpo, partes, \& membros fortes, \& galhardos representando muito do modo Hercúleo, por cuja causa foi pellos antigos Architectos dedicada a Hercules (PIMENTEL, 1993: 147 - uma nota na lateral da página especifica a referência em Vincenzo Scamozzi: “Part.2.lib.6.cap.1.pag.3.").

${ }^{707}$ Em sua análise das construções militares portuguesas, Rafael Moreira diz que as figuras que ilustram o tratado de Serrão Pimentel mostrariam a complexidade como parte da concepção e construção do que ele chama de uma "Arquitetura Militar Barroca", "marcada por um sistema articulado e dinâmico de múltiplos elementos em estreita relação de proporção uns com os outros" (BUENO, 2001: 453). Os portais "salomônicos" barrocos contrastam com a severidade das paredes, como se vê nas figuras sugeridas por Pimentel: Resta finalmente pormos aqui algûas figuras de Portaes exteriores que trazem Wilhelmo Dilichio, Nicolao Goldman, Sebastiano Serlio, \& Vincenzo Scamozzi para cada hum escolher a fabrica que mais Ihe agradar, ou de outro Autor, ou de invençaõ propria (PIMENTEL, 1993: 150 - Parte I, Seção I, Cap. XXXVI).

Para Rafael Moreira, o século XVII se caracterizaria por uma "concepção dinâmica da fortificação", que prioriza o "partido tirado das condições topográficas" sobre "as soluções puramente geométricas, que tanto havia fascinado os fortificadores da época maneirista" (MOREIRA, R. Do rigor teórico à urgência prática: a arquitetura militar. In: MOURA, Carlos. História da Arte em Portugal. O limiar do barroco. Lisboa: Alfa, 1980, p. 80 - apud BUENO, 2001: 453). Embora deva haver cautela em relação a esse tipo de visão classificatória (ou reducionista), tratando-se de Rafael Moreira, uma das maiores autoridades na História da Arte Portuguesa, é importante sua leitura. Para ele, a Arquitetura Militar seiscentista típica seria "barroca" na medida em que "... participa, de fato, das características gerais do estilo: predomínio da mobilidade e do dinamismo sobre o estático, tendência para formas intrincadas de exuberante desenho, gosto por jogos de figuras geométricas e uso de espaços poligonais, contraste entre a severidade das paredes e ostentação decorativa dos portais" (idem, p. 75 - grifo nosso). 
PARTE IV - Século XVIII: novo plano de fortificação e a formalização do ensino

\section{Novos planos e grandes reconstruções (1700-40)}

\subsection{Um engenheiro em destaque: Miguel Pereira da Costa}

No início do século XVIII começou uma nova fase da engenharia militar na defesa de Salvador, com profissionais mais fixos servindo à Praça. Miguel Pereira da Costa se destacou na engenharia militar portuguesa e do Brasil, praticamente inaugurando a nova fase de fortificações na cidade. Ele participou ativamente dos principais trabalhos de defesa da primeira metade do século XVIII. O seu relatório Extracto da forteficação desta Praça da Bahia estado em q se acha, remédio de $q$ neçeçita, encaminhado a Portugal em $1710,{ }^{708}$ é particularmente interessante.

Ele veio para o Brasil com uma das maiores patentes da especialidade, engenheiro experimentado nas campanhas do Alentejo, combatente e fortificador. ${ }^{709}$ Foi convocado para servir em Salvador como engenheiro fixo, por ocasião da morte do Eng. Gregório Gomes e em meio a desentendimentos do governador com o Sargentomor Antônio Roiz Ribeiro. Ao chegar, além de ter um choque cultural, ${ }^{710}$ manifestou desespero por encontrar uma cidade completamente despreparada e sem defesas para um eventual ataque. ${ }^{711} \mathrm{Em} 1709$ foi nomeado Tenente de Mestre de Campo da Bahia. $^{712}$

\footnotetext{
${ }^{708}$ Extracto da forteficação... BAj - Documentos Avulsos [54-IX-8] № 60.

${ }^{709}$ Cf. BN - Documentos históricos, 1936, v. 34, p. 313-4 (de 06/11/1709) / OLIVEIRA, 2004: 106. Miguel Pereira entrou como soldado em 20/03/1699 e teve rápida ascensão, servindo em Cabo Verde, na Corte e no Alentejo, passando a ajudante, capitão e sargento-mor engenheiro, sempre ligado à Infantaria (arma de prestígio). Trabalhou nas fortificações de Mértola, Serpa e Moura, que defendeu e recompôs depois da retirada do inimigo.

${ }^{710}$ Há muitos registros sobre ele, além de suas cartas, que chegam a falar de sentimentos íntimos (como o da saudade de Portugal, que Capistrano chamou de Transoceanismo - cf. a Carta do Engr. ${ }^{\circ}$ da Bahya e a carta ao padre (BAj - Documentos Avulsos [54-IX-8] no 61 e 62). Apesar do choque cultural na chegada a Salvador, acabou gostando do lugar (vindo de país pequeno e com rigores na vida militar, encontrou um lugar belo, grande, selvagem, livre, sensual, permissivo; já velho teve de ir a Portugal para tratar dos "achaques" - ataques de doença, talvez adquirida nos trópicos -, mas pediu ao Rei para voltar e fez questão de passar o fim da vida na Bahia).

${ }_{711}$ Na Carta... ao padre (antigo professor, provavelmente jesuíta) de 18/06/1710 (BAj-Documentos Avulsos [54-IX-8] no 62 e [54-XI-25] o 65), diz:... está tudo aqui no maior dezamparo, a praça aberta, $e$ exposta a q.' q. $^{r}$ invazão, o q . $^{\text {to }}$ destes morad. ${ }^{\text {es }}$ não considerão, pella aversão $q$ tem a se fortificarem, diz. ${ }^{\text {do }}$ ser impraticavel o vir cá o inim..$^{\circ}$ q. $^{\text {do }}$ já o experimentaram no tempo q os Holandezes ocuparão esta praça, e he rediculo o dizerem se não poderá aqui conservar, pois não considerão a perda das part. ${ }^{\text {es }}$, a $q$ terá El Rey na falta de tão import. ${ }^{e}$ frota, e o q será necssr. ${ }^{\circ}$ sahir de Portugal $p^{a}{ }^{a}$ expulsar este inim. ${ }^{\circ}$; $e$ $q^{\text {to }}$ ao impraticavel pella aspereza dos bosques, ou estreteza dos pasos, seria asim se nelles, houvesse quem o impedisse, mas na tal occazião os poucos brancos cuidarão em transportar o preciozo a p. ${ }^{\text {te }}$ segura, os negros em procurar a liberdade, $q .{ }^{\text {to }}$ mais $q$ sem venser aquellas difilculd. ${ }^{e s}$ tem o inim. ${ }^{\circ}$ aqui perto da cid. ${ }^{e}$ p. $^{a}$ onde fasa dezembarque sem oposição... (cf. Anexo 4, p. 344).

712 Em 9/11. Sua patente no Brasil foi registrada (10/02/1710) e lavrada pelo Secretário de Estado Gonçalo Ravasco Cavalcanti e Albuquerque (sobrinho de Antônio Vieira), recebendo 40 mil réis mensais (cf. BN - Documentos históricos, 1943, v. 59, p. 80-2; provisões, patentes e alvarás, 1699-1711/ OLIVEIRA, 2004: 106).
} 
Personagem de muitas qualidades, ${ }^{713}$ Miguel Pereira teve uma longa permanência na Bahia, trabalhando sempre no sistema fortificado do Morro de São Paulo, em Itaparica e nas fortalezas de Salvador, no início ajudado pelo então Cap. Eng. Gaspar de Abreu e depois por Nicolau Abreu de Carvalho. Só se afastou para trabalhos profissionais em Angola (fortificações) e no levantamento das estradas para as minas de Rio de Contas. ${ }^{714}$

O primeiro grande projeto em que se envolveu na Bahia foi continuar a implantação do sistema fortificado do Morro de São Paulo, considerado importante pelos especialistas. ${ }^{715}$ Nessa época, em Salvador o Cap. Francisco Pinheiro tocava as obras do Forte São Pedro, seguindo as especificações de Miguel Pereira. Inseguro sobre o andamento, o governador pediu o retorno de Miguel Pereira, que tinha recomendado um encamisamento de pedra (era ainda uma construção de terra). No ano seguinte, Miguel Pereira voltou ao Morro para vistoriar as obras arrematadas pelo mestre pedreiro Manuel Gonçalves da Silva (uma Portaria a este autorizou a elaboração de um paredão para suportar o terrapleno das ditas esplanadas, ${ }^{716}$ aconselhado por Miguel Pereira e que não constava na arrematação, sendo feito um tipo de aditivo contratual).

Enquanto supervisionava as fortificações, era incumbido de outros projetos, como o da igreja de Santa Cruz de Cabrália, mostrando versatilidade nessa área. ${ }^{717}$ Mas a defesa de Salvador era sua prioridade. Depois do Extracto da forteficação... (1710), de que ainda falaremos, ele foi designado (1712) a fazer novo relatório das defesas da Cidade e Recôncavo, observando onde havia antigas fortificações. ${ }^{718}$ No documento ele destaca a necessidade de estarem perfeitos os fortes de Itaparica e o

\footnotetext{
713 “... competente e íntegro engenheiro...” (OLIVEIRA, 2004: 107).

${ }^{714}$ Trabalho que foi elogiado pelo Conselho Ultramarino, propondo-Ihe a comenda do Hábito de Cristo com uma tença e o agradecimento pessoal do Rei por carta (uma consulta do Conselho sobre as minas de Jacobina e de Rio de Contas fala do mapa elaborado por Miguel Pereira, dizendo estar... feito tudo com grande direção e desvelo, tendo nela [missão] um insuportável trabalho e perigo de vida, pois se recolheu da dita viagem com os braços caídos, estando de cama mais de cinco meses, e ainda se não acha restituído... Mas adiante, diz:... Ao conselheiro o doutor João de Souza lhe parece o mesmo que ao Conselho, e acrescenta que por este particular serviço que Vossa Majestade lhe faça mercê de sua mera graça do Hábito de Cristo, com $60 \$ 000$ réis de tença efetivos - BN - Documentos históricos, 1952, v. 98, p. 5-8 - apud OLIVEIRA, 2004: 138, nota 155). Cf. também AHU - Documentos Avulsos, Bahia: 005. Cx. 56, D. 4833 (CD6, 002, 315-22). Carta Régia agradecendo a planta de Rio de Contas, de 21/08/1736.

${ }^{715}$ Lá, recebeu carta do Gov. D. Lourenço de Almada (02/11/1710), informando do envio de parte das ferramentas solicitadas (tiradas das disponíveis nas tendas dos ferreiros, por não haver almoxarifado) e que atenderia às outras solicitações. Cogitava-se usar madeiras nas esplanadas para artilharia, sendo o engenheiro autorizado a usar as do local. Miguel Pereira ponderou não haver madeira serrada em pranchões e o governador decidiu que as esplanadas fossem de pedra, de maior durabilidade, prometendo o embarque imediato do material. Ainda se vê o antigo pavimento de pedra no Baluarte da Conceição. O do forte da Ponta do Facho é aparentemente posterior (na pressa em reedificar as fortificações do Morro, D. Lourenço determinou com rigor excessivo que fossem presas as pessoas que faltarem a sua obrigação na reedificação desse forte - BN - Documentos históricos, 1938, v. 41, p. 278. Carta de 02/11/1710 - apud OLIVEIRA, 2004: 108). Para M. Oliveira, foram os dissabores nas obras do Morro (que acertadamente defendia ter grande importância estratégica) que o abalaram para, já velho, ser levado à loucura e à morte.

${ }^{716} \mathrm{BN}$ - Documentos históricos, 1941, v. 53, p. 84. (de 06/08/1711) - apud OLIVEIRA, 2004: 108.

${ }^{717}$ Cf. BN - Documentos históricos, 1941, v. 53, p. 149, portaria de 14/03/1712/ OLIVEIRA, 2004: 138 (nota 167). A igreja é de partido semelhante ao da Palma em Salvador.

${ }^{718}$ Cf. BN - Documentos históricos, 1941, v. 53, p. 156, portaria de 09/04/1712.
} 
antigo de São Bartolomeu do Pirajá. ${ }^{719} \mathrm{O}$ relatório provavelmente reforçou a decisão de fortificar Salvador e foi também incluído no roteiro de consultorias do Brig. João Massé. ${ }^{720} \mathrm{Na}$ defesa do Recôncavo foram lembradas as pequenas fortificações do Rio Paraguaçu, como o fortim da Santa Cruz, de planta levantada por Miguel Pereira. ${ }^{721}$ Não se sabe se não chegou a ser elaborado, ou se foi extraviado, o inventário com as plantas de todas as fortificações da cidade e das mais da jurisdição deste Governo Geral que Ihe foram cobradas. ${ }^{722}$ Elas dariam a referência do que existia antes do projeto coordenado pelo Brig. João Massé.

Trabalhando com Massé no projeto de fortificação, Miguel Pereira foi promovido de Tenente de Mestre de Campo para Mestre de Campo: um reconhecimento do Rei à sua competência e dedicação. ${ }^{723}$ Com o projeto de fortificação, possivelmente concluído em $1716,{ }^{724}$ e sua aprovação na Corte, a responsabilidade do engenheiro se viu aumentada, iniciando-se ou continuando-se grandes construções, como os fortes de S. Marcelo, S. Pedro, Barbalho e o sistema do Morro de S. Paulo. Houve constantes fiscalizações, medições para pagamentos de empreiteiros, orientações técnicas. ${ }^{725}$ Tornaram-se importantes os ajudantes promovidos da Aula Militar, João Batista Barreto, Gonçalo da Cunha Lima e João Teixeira de Araújo.

Depois da excursão ao Rio de Contas, ${ }^{726}$ que acabou comprometeu de vez sua saúde, ${ }^{727}$ em 1728 ele pediu adiantamento de salário para voltar a Portugal, ${ }^{728}$ onde

\footnotetext{
${ }^{719}$ Reparos que só foram concluídos depois de 1718, com uma consulta ao Conselho Ultramarino sobre dar seu comando vitalício a Braz Pereira de Lago, se pagasse a conclusão das obras orçadas em 600 mil réis por Miguel Pereira.

${ }^{720}$ Cf. BN - Documentos históricos, 1952, v. 96, p. 31 e 63. Consultas do Conselho Ultramarino de 17/07/1711 e 06/08/1712. O parecer de Manuel Pimentel, Engenheiro-mor do Reino, foi favorável ao relatório.

${ }^{721}$ Cf. BN - Documentos históricos, 1941, v. 53, p. 241, portaria de 20/06/1713.

722 Cf. BN - Documentos históricos, 1941, v. 53, p. 250, portaria de 24/07/1713 atendendo a Ordem Régia de 08/11/1712.

${ }^{723}$ Cf. BN - Documentos históricos, 1943, v. 61, p. 210. A promoção foi por Carta Patente Real de 01/06/1714, registrada na Bahia em 20/09/1714. O posto equivale ao de Coronel.

${ }^{724}$ Cf. BN - Documentos históricos, 1941, v. 54, p. 172 (em 29/06/1716 Massé recebeu ordens no Marquês de Angeja para ir a Pernambuco).

${ }^{725}$ Como seu antecessor Roiz Ribeiro, Miguel Pereira era íntegro. Vendo os abusos cometidos nas obras, propôs ao Marquês de Angeja (recebendo despacho favorável) um Regimento tratando dos procedimentos da medição e avaliação (cf. BN - Documentos históricos, 1945, v. 69, p. 149), documento que registrou nos livros da Secretaria de Estado (possivelmente em 1721, mas não foi encontrado). Para M. Oliveira, Miguel Pereira não teria a fama dos alentejanos, mesmo no calor dos trópicos, apesar do medo de se tornar um mandrião com a vida que levava. Sempre havia trabalho ou ele mesmo se ocupava para fugir às muitas "tentações da carne" (OLIVEIRA, 2004: 110).

${ }^{726} \mathrm{O}$ interesse pelo ouro e outros minérios levou a Corte Portuguesa a querer aperfeiçoar as rotas e estradas até as jazidas. Os governadores interinos de 1719-20 (o triunvirato: D. Sebastião Monteiro da Vide, arcebispo da Bahia, João de Araújo e Azevedo e Caetano de Brito Figueiredo) lançaram Portaria para que Miguel Pereira, subindo por Cachoeira, fizesse roteiro até as minas de Rio de Contas, relatando toda a geografia e tempo de cada percurso, possibilidades de água e abastecimento, etc. Visando o bom desempenho, deram carta de recomendação para que a caravana tivesse o apoio de todos os Coronéis, Sargentos-mores e Capitães das ordenanças dos sertões na logística (carros, animais, guias, mantimentos, alojamentos). Também havia uma espécie de Regimento orientando os procedimentos (cf. BN - Documentos históricos, 1945, v. 68, p. 305, de 13/04/1720, 306 e 325, de 07/05/1720; dessa expedição de reconhecimento Participou o Ajud. Eng. João Teixeira de Araújo, apoiando Miguel Pereira nos levantamentos e mapeamento - na volta ele substituiu Gonçalo da Cunha Lima, já falecido, no cargo de Capitão Engenheiro - cf. OLIVEIRA, 2004: 111).
} 
deve ter ficado do ano seguinte até 1731 (este último por prorrogação, já que os médicos não o consideraram curado). ${ }^{729}$ Antes da viagem, tinha concluído o projeto definitivo para o Morro de São Paulo, aprovado pelo Engenheiro-mor do Reino, Manoel Azevedo Fortes. ${ }^{730}$ Entre 1731-2 voltou a Salvador, onde já tinha laços. Amargurou ainda uma questão com o Provedor-mor sobre as obras do Morro de S. Paulo, em que foi defendido pelo colega Nicolau Abreu de Carvalho e pelo Governador Geral. ${ }^{731}$ Pode também ter piorado depois do desabamento de um pedaço da cortina do Forte de São Pedro, construção sob sua responsabilidade mesmo quando estava em Portugal.

\subsection{Observações e propostas em seu relatório de 1710}

No século XVIII, havendo ainda a ameaça de invasões, a Coroa quis mais uma vez fazer um sistema fortificado que correspondesse à importância da capital portuguesa nas Américas. O Extracto da forteficação desta Praça da Bahia..., posterior em 25 anos ao projeto de João Coutinho, traz as observações do Mestre de Campo, engenheiro na Bahia. Ele foi severo em suas críticas, poupando apenas o plano de Coutinho, que começou pelos baluartes de N. S. da Palma e Ajuda, mas parou por ali. Recomendava mesmo, com base na planta, que essa obra devese contenuar, pois me pareçe não ser defetuoza. ${ }^{732}$

Na primeira parte do documento ele faz críticas ao que encontra, iniciando pelo perímetro fortificado (o que nos dá uma boa referência sobre o que havia de muros e trincheiras). Começa explicando que a fortificação da cidade era feita por uma trincheira antiga (dos anos 1640?) que serviria de terrapleno para uma muralha que se

${ }^{727}$ A missão durou sete meses (cf. AHU - Documentos Avulsos, Bahia: 005. Cx. 33, D. 3039 - CD4, 36, 002, 311-40 - requerimento do Eng. João Teixeira de Araújo - 21/05/1729) e na volta Miguel Pereira ficou cinco meses de cama. A recuperação nunca foi completa: as poucas referências aos seus achaques fazem supor que se tratava de um acidente circulatório, possivelmente derrame, porque há referências de dificuldades de movimento e paralisia.

${ }^{728}$ Cf. BN - Documentos históricos, 1947, v. 90, p. 152. Em resolução de 17/04/1728, o Conselho Ultramarino achou o precedente perigoso, mas recomendava a ajuda de custo.

${ }^{729}$ Cf. AHU - Documentos Avulsos, Bahia: 005. Cx. 35, D. 3167, de 19/12/1729 (CD5, 38, 001, 112-4). Sofria de paralisia, como mostra a petição examinada em 1729 no Conselho. Teve atestado médico (23/01/1730) para ficar mais um ano, tomando banho nas caldas. Em Lisboa, pleiteou ao Rei mais uma vez o posto de Brigadeiro, pela sua vasta folha de serviços à Coroa, não sendo atendido. Mesmo o Conselho Ultramarino reconhecendo seus méritos, foi ponderado que assim se equipararia a Manoel de Azevedo Fortes e João Massé. Mas recebeu gratificação (cf. AHU - Documentos Avulsos, Bahia: 005. Cx. 35, D. 3219 - CD5, 38, 003, 430-6), petição feita em Lisboa com despacho de 11/02/1730).

${ }^{730}$ Era praticamente o que ainda se vê, tirada a parte derrubada pelo mar nas ressacas da segunda metade do século XVIII (segundo Vilhena), de reconstrução que simplificou o desenho primitivo do Forte da Ponta do Facho.

${ }^{731}$ Este último rebateu as críticas: Foy tão desordenada a paixão com que sempre procedeo o Dez.or Pedro de Freytas Tavares Pinto servindo de Provedor mor da Fazenda, a respeito do M. ${ }^{e}$ de Campo Enginheiro Miguel Pereyra da Costa, que cuydou por todos quantos meyos podia escogitar a malevolencia em desluzir a sua grande capacidade, e aquelle honrado procedimento, desinterece, $e$ exação com que se asignalou, e destinguio no serviço de $\mathrm{V}$. Mag. ${ }^{\text {de }}$ com notoria satisfação de suas obrigações, de sorte que moralmente me persuado que foi a total cauza de passar a sua melancolia, a doudisse, e desta á morte (AHU - Documentos Avulsos, Bahia: 005. Cx. 49, D. 4355 - CD6, 55, 001, 18398). Informação do Conde de Sabugoza, de 17/11/1734, em atenção à Carta Régia de 03/07/1734).

${ }^{732}$ Extracto da forteficação..., fl. 33. 
intentava revestir. ${ }^{733}$ Sem methodo, o desenho dessa fortificação não defendia bem a praça e exigia um número excessivo de baluartes, o que se tentou corrigir pelo projeto de João Coutinho, que diminuía de 18 para 11 os que estavam em terra, somando-se aos quatro próximos ao mar. Com a planta de Coutinho, começou-se a construir os baluartes da Palma e da Ajuda, única obra em andamento desse perímetro, tendo suas dimensões imprecisas e apresentando já algumas ruínas.

A forteficação com q' se acha esta praça no Recinto principal, he hua' trinxr. $^{\text {a }}$ de terra $\mathrm{m}^{\text {to }}$ antiga: este reparo foi feito $p$. servir de terrapleno á muralha de $q^{\prime}$ se intentava revestir; mas como a direç̧ão desta trinxr. ${ }^{\text {a }}$ ou Methodo porq' foi deliniada, alem de não defender a praça na melhor forma, aumentava $\mathrm{m}^{\text {to }}$ o num. ${ }^{\circ}$ dos baluartes, pois consta de dezouto som. ${ }^{\text {te }} p^{\text {a a }}$ a terra e alguns incapazes pella sua pequenhez, veiyo João Coutinho sarg ${ }^{\text {to }}$ mor emgenhr. ${ }^{\circ}$ de Pernamb. ${ }^{\text {co }}$, a esta praça no anno de outenta e sinco, e fes nova planta mais bem acomodada ao terreno, e com, menos baluartes, tendo onze ${ }^{a}{ }^{a}$ a terra, e quatro na marinha; e com esta planta se deo principio á forteficasão nos baluartes N. Sr. ${ }^{a}$ da Palma e da Ayuda, $q^{\prime}$ se achão em diverssas alturas, arrespeito [= a despeito] do [trainel/ painel?] do terreno, como em doze, quinze e vinte palmos, e a nivel pella $p .{ }^{\text {te }}$ superior, cuja muralha corre sobre a [berma] de terreno natural, $\mathrm{q}^{\prime}$ ficava de vinte palmos, e com $\mathrm{m}^{\text {ta }}$ parte de seu fosso feito; e nestes se ençerra toda a nova forteficasão, já com duas ruinas na façe direita do do baluarte da Ayuda.

Comenta em seguida a inadequação da muralha de contenção dos terraplenos que estava começada, de espessura de palmo e meyo $[33 \mathrm{~cm}=1$ pé $]$ de taipa de formigão (é fácil perceber que ela não suportaria o empuxo do terrapleno com essa dimensão, ainda mais sendo só de terra - essa construção já causara devassas e prisões no fim do século XVII, envolvendo empreiteiros e o Cap. Eng. José Paes Esteves).

Esta muralha he de formigão com largura de palmo, e meyo $q^{\prime}$ he pouca p. ${ }^{\text {a }}$ sustentar o pezo do terrapleno, rezistir á inclemencia do tempo, ao estrondo da artelhr. ${ }^{a}$ em occazião de salvas, e á bateria inimiga se algum dia lha puzeçem; ainda desta grossura lhe diminuião os empreiteiros, e vistarão os materiais, cauza por $q^{\prime}$ houve aquellas ruinas: o terreno da trinxr. ${ }^{\text {a }}$ he de boa qualid. ${ }^{\text {e }}$; porq' a mayor $\mathrm{p}^{\text {te }}$ se contenua em sua forma e sô tem algúas [prosoens] aruinadas, pello pouco cuidado que havia, porq' os parteculares q yunto della fabricavão edificios se aproveitavão do seo saibro p. ${ }^{a}$ estas obras, seg. ${ }^{\text {do }}$ me informou o sarg. to mor emgenheiro; a mayor p. $^{\text {te }}$ desta trinxr. ${ }^{\text {a }}$ está cuberta do mato com hortas, cazas, e quintais unidos a ella, em termos q' impedem a sua comunicasão.

A partir daí ele fala dos fortes, começando pelos de beira-mar (que para ele não mereciam ser chamados "fortes") com o de Santo Antônio da Barra. Ele critica a falta de um depósito de pólvora, de uma cisterna, e principalmente a proximidade de um padrasto (o atual morro do Gavazza). ${ }^{734}$

No q' respeita a fortes da marinha, o pr. ${ }^{\circ}$ emtrando . $^{\text {a }}$ esta B. ${ }^{a}$ he o De S. An. ${ }^{\text {to }}$ da barra (nomeando-os com o cumum, impropriam. ${ }^{\text {te }}$ por fortes) em figura de dés lados, irregularissimo, com seis angulos salientes e quatro reintrantes, sem baluarte algum, nem caza capáz p. a polvora; este forte está dominado de hum gr. ${ }^{\text {de }}$ padrasto $\mathrm{q}^{\prime}$ lhe fica superior a tiro de espingarda do qual se descobre toda a aria do $d .{ }^{\circ}$ forte, e como aquelle se pode subir sem impidimento, por varias partes, ocupado este pelo inim. ${ }^{\circ}$, fica o d..$^{\circ}$ forte inutil; porq' os artelheiros, e defensores não poderão aturar o fogo inimigo: tambem não tem cisterna p. ${ }^{a}$ agoa e lhe fica distante a de q' gastão.

No parágrafo seguinte, ${ }^{735}$ ele vê no Forte de Santa Maria os mesmos incômodos do de Santo Antônio, seguindo-se (para fechar a praia como local de desembarque, já

\footnotetext{
733 FI. 32.

734 “Posição mais elevada que permite atacar, com vantagem, uma fortificação” (OLIVEIRA, 2004: 85).

${ }^{735}$ Fl. 32v.
} 
que entrada da Barra era indefensável) o de S. Diogo, construído ao pé da igreja de S. Antonio (que por isso era dispensável e estava condenado). ${ }^{736}$

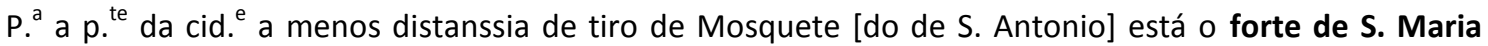
quazi quadrado, mas rigurosamente he hum eptagono, com tres angulos reint. ${ }^{\text {es }} \mathrm{m}^{\text {to }}$ obtuzos: este tem os mesmo incomodos q' o de Sa. Ant. ${ }^{\circ}$ A este se segue o forte de s. Diogo, a tiro de espingarda delle; he uma pequena bateria com tres pessas de artelhr. ${ }^{a}$, edificada na raiz do monte em cuja eminemçia, esta a Igreja de S. An. ${ }^{t}$, donde se ve o quam condenado esteja (obra bem escuzada neste lugar) por ser de pouca serventia; e nestes tres se ençerra a forteficação da barra, cuya defensa he impraticável, pois senão pode impedir a entrada aos navios por resp. ${ }^{\text {to }}$ da sua $\mathrm{m} .{ }^{\text {ta }}$ largura.

Fala em seguida do Forte do Mar (S. Marcelo), que tinha então o torreão central mais alto, sem condição de trabalhar bem a artilharia e comprometendo a segurança da praça baixa (anel externo). Essa crítica aparece em muitos documentos do século XVIII, sendo provavelmente no XIX que adquiriu a forma atual. Naquele estágio construtivo, não tinha eficiência. Critica também o Baluarte da Ribeira, uma provável reconstrução do antigo Forte da Laje (de primeira versão próxima a 1609 e segunda no projeto de Frias de Mesquita, de obra inacabada em 1624). ${ }^{737}$

Lá dentro na $\mathrm{Pr}^{a}{ }^{a}$ desta cid. ${ }^{\mathrm{e}}$ está o forte do mar, distante de terra, mais de um tiro de mosquete, em forma circular; com hua praça alta, mas esta alem de ter pouca capacid. ${ }^{\mathrm{e}}$ incomoda a baixa, e ficão ambas sem a retirada sufissiente $p .{ }^{a}$ a artelhr. ${ }^{a}$ nas funssoens militares; na praya da cid. ${ }^{e}$ desta $p .{ }^{\text {te }} q^{\prime}$ vamos tratando, o prim. $^{\text {ro }}$ forte he o da Ribeira em forma quadrilonga, com hum baluarte plano, no meyo de hum de seos lados mais comprido opposto ao mar; este forte he muy limitado, e o baluarte tal $q^{\prime}$ tem quinze palmos de facce, e nove de flanco e nesta obra mal cabe a artelhar. ${ }^{a}$ grossa com q' se acha, e na ocazião de salvas se expirimenta o detrim. ${ }^{\text {to }} q^{\prime}$ esta padeçe no seu recuo, $q^{\text {do }}$ mais se for nececario fazer fogo vigorozo, pois he certo q' os seus reparos aturarão poucos tiros.

Em seguida avalia o baluarte de S. Francisco como defeituoso pela sua pequenez (que tinha, de fato) e descreve a Torre de Santiago (no atual Forte de S. Alberto, ou "Lagartixa"), o que chama a atenção por ser em sua forma circular original.

A este se segue o forte de S. Fran. ${ }^{\text {co }}$, q he hum baluarte plano defeituozo por pequeno; estes se não flanqueão, por q' se tem fabricado edifiçios mais avançados ao mar: do forte de S. Fran. ${ }^{\text {co }}$ p. ${ }^{a}$ a parte de Monserrate, esta hum pequeno fortim junto a praya do Rozario, fabricado em [porção] de circulo, obra de pouca entidade pella sua limitasão; e deste ao forte de Monserrate he huã distancia, praya de area, sem defensa alguã.

Considera o Forte de Monserrate um fortim, sem muitas possibilidades de flanqueamento das cortinas e de operar com artilharia pesada. Eram limitações de sua estrutura quinhentista, que praticamente não teve transformações e assim ficou superada. ${ }^{738}$ Também fala, "de passagem", do Forte de S. Bartolomeu da Passagem.

O forte de Monserrate fica no interior da ençeada, desta B. ${ }^{a}$ em hua ponta q' ali faz a terra, com a qual sò por húa partte se cumunica essa pinimsula: he este hum exagono, irregular, sem baluarte, nem capacid. ${ }^{e}$ p. ${ }^{a}$ ouzo da artelhr. ${ }^{a}$ com q' se acha; p. ${ }^{\text {a }}$ esta p. $^{\text {te }}$ faz o mar algúas emtradas, e na mais proxima a este territorio dobrando a ponta de Monserrate, e outra immediata, fica o forte da pasaje, muy distantes daquelle, com varios outeiros de [premejo]: he este húa estrella, edificado na marinha onde

\footnotetext{
${ }^{736}$ Para M. Oliveira (2004: 72), de fato haveria maior proteção se em vez da igreja fosse atualizada a fortificação da Vila Velha.

737 A descrição da obra reforça essa possibilidade. Àquela altura, a área já estaria incorporada por aterros da Cidade Baixa, deixando de ser uma ilhota.

${ }^{738}$ Mas para nós, é nessa antiguidade que reside o seu grande valor cultural, histórico e arquitetônico.
} 
[fenesse] este braço de mar, p. $^{\text {a }}$ defensa das embarcacoens $q^{\prime}$ ali emcalhavão no tempo $q^{\prime}$ o inim. ${ }^{\circ}$ andou por estas partes estes são os fortes q' se achão nesta Marinha.

Passando às fortificações de terra, ${ }^{739}$ descreve o Forte de Santo Antônio Além do Carmo como um quadrado com quatro baluartes, sendo que um estava voltado para o mar e assim não tinha efeito (na cota em que está a artilharia, não operaria com ângulos muito abaixo da horizontal e à distância, não tendo eficiência para acertar navios invasores). Mas o principal problema era a igreja de S. Antônio, que ficava no centro da atual praça, a um tiro de pistola do forte e em cota superior. Se ela fosse tomada, cairia o forte.

Emq. ${ }^{\text {to }}$ a forteficasão da terra, deichando a trinxr. ${ }^{a}$ em $q^{\prime}$ ja tratey, marchando desta $p .{ }^{\text {ta }}$ de Monserrate p. ${ }^{a}$ a cid. ${ }^{e}$, e subindo do Rozario ao Alto em q' fica a Igreja de S. An. ${ }^{\text {to }}$, quasi no nivel da cid. ${ }^{\text {e }}$, esta o forte de S. An. ${ }^{\text {to }}$ do carmo, exterior a forteficação da cid. ${ }^{e}$; he um quadrado com quatro baluartes, e hum ládo p. ${ }^{a}$ o mar, mas de pouco efeito p. $^{\text {a }}$ [fl. 33] este, respeitando a m. $^{\text {ta }}$ altura em $q^{\prime}$ fica: este alem de alguns erros consideraveis, cometidos na sua ezecusão, está dominado da Igreja de $S$. An. ${ }^{\text {to }} q^{\prime}$ Ihe fica superior na estrada emcuberta: nesta Igreja principia orrebalde [o arrebalde] da cid. ${ }^{e}$, com húa rua thé o convento do carmo onde se continua a cid. ${ }^{\mathrm{e}}$; e p. ${ }^{\mathrm{a}}$ o interior della a tiro de mosquete desse comvento, comheça baxa de [premejo], fica a porta e chamada do carmo, com húa bateria p. ${ }^{\text {a }}$ sua defensa, no tempo em q nesta porta se terminava a cid. ${ }^{\mathrm{e}}$, mas hoje de pouca serventia.

Também considerou ineficiente a bateria da Praça do Palácio, de altura exagerada, tornando-se nada mais que um ornato (ela já era representada nas iconografias do tempo das invasões). As portas de S. Bento e do Carmo, envolvidas pela cidade, já não tinham serventia. Descreve ainda o Forte de S. Pedro, então de terra, com quatro baluartes regulares, bloqueando a entrada q então premetia o Dique (daí sua importância: ele passou a ser peça chave do sistema defensivo ampliado da época de Antônio Teles da Silva). Mas conclui que todos os fortes eram pequenos para o uso da artilharia da época e estavam... em miserável estado.

Na praça da cid. . está outra bateria p. ${ }^{a}$ o mar, mas [pella] altura em q' fica, a faz q' sirva mais de ornato, $q^{\prime}$ de defenssa a porta de s. Bento, $q^{\prime}$ como a do Carmo era algum dia o termo da cid. ${ }^{\text {e }}$ [;] tem [obras] obra corna, e feita então p. $^{\text {a }}$ sua defensa; e [sup. ${ }^{\text {dos }}$ ] esta fica $p .{ }^{a}$ a p. $^{\text {te }}$ do mar tem a mesma serventia $q^{\prime}$ a da praça asima fora, da forteficasão principal, na estrada de S. An. ${ }^{\text {to }}$ da barra, esta o forte de S. Pedro, quadrado feito de terra, regullar com quatro baluartes, fabricado naquelle lugar $p$. $^{\text {a }}$ defensa de alguas avenidas $q^{\prime}$ por esta . $^{\text {te }}$ ha $p .^{\text {a a }}$ praça, e por ser a entrada $q^{\prime}$ então premetia [permitia] o Dique neste extremo, sendo o outro em s. An. ${ }^{\text {to }}$ do Carmo; estas são as obras com q' esta praça se acha p. ${ }^{a}$ sua defenssa, e todas em miseravel estado porq' sendo tão pequenos, $q^{\prime}$ não tem a capacid. ${ }^{e}$ nececr. ${ }^{a} p^{a}{ }^{a} o$ uzo da artelhr. ${ }^{a}$, pois sendo neçecario fazer fogo violento em poucos tiros ficara emcapaz de laborar tem o seo pavim. ${ }^{\text {to }}$, ou explanada em termos de não poder rodar qualquer pessa, e necessitando tudo de promto remedio me paresse discorer sobre o referido na seg. ${ }^{\text {da }}$ forma.

Tendo, portanto, concluído que tudo precisava de promto remédio, passa então a relacionar as medidas mais urgentes. É interessante como considera ainda válido o projeto de João Coutinho, defendendo que ele fosse seguido na fortificação da Cidade. $^{740}$

Emq. ${ }^{\text {to }}$ a forteficasão principal da praça, como com a planta de João Coutinho se deu conta a S. Mg. ${ }^{\text {de }} q^{\prime}$ D. ${ }^{\text {s }}$. ${ }^{\text {de }}$ e o d.o s. ${ }^{\text {or }}$ resolveu q' por ella se forteficase, deve-se contenuar, pois me pareçe não ser defeetuoza, o q não pude observar, porq' o terreno por onde ha de correr se acha com os impidim. ${ }^{\text {tos }} q^{\prime}$

\footnotetext{
${ }^{739} \mathrm{Fl} .32 \mathrm{v}-33$.

${ }^{740}$ FI. 33-33v.
} 
apontey; porem a muralha de difer. ${ }^{\text {te }}$ modo, por q' os baluartes da Palma, e a Ajuda se achão em pouca altura, e ja nesta com duas ruinas, pella pequena grossura q' se daria ao formigão fazendo de palmo e meyo, e inclinádo, seg. ${ }^{\text {do }}$ a escarpa do terrapleno tendo a mesma grossura no fundam. ${ }^{\text {to }}$, e na p. $^{\text {te }}$ superior: q' esta grossura seja pouca, suponho não haverá quem o negue, pois nas nossas pracãs he dobrada a q se dá ao formigão dos parapeitos, sendo p. $^{\text {a }}$ sustentaar difer. ${ }^{\text {te }}$ pezo, donde se ve não ser aquella suficiente p. $^{\text {a }}$ ter, [mas/mão] em todo o terrapleno; e q' a inclinação da muralha se não deva admitir, me persuado a q' ningem o contradirá, pellas $m{ }^{\text {tas }}$ rezoes $q^{\prime}$ o theoricos sabem, e aos práticos não

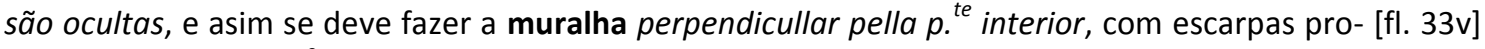
porcionadas a qualid. ${ }^{e}$ dos materiaes, e de grossura convenientes.

Admitia o uso de materiais diversos (pedra, tijolo e taipa de pilão), dependendo de onde fossem empregados, mas as fundações deveriam ser sempre de pedra. Tinha preferência geral pelo uso de pedra, mas diz que vinha de longe: era fácil trazê-la por mar, mas era transportada para o alto da cidade á cabesa de negros.

A pedra q' se conduz p. ${ }^{\text {a }}$ esta çid. ${ }^{\mathrm{e}}$ fica distante, e o transporte por mar athé a praya, não he tão custoso, como desta a forteficasão, por ser lonje hua terrível subida, conduzindose á cabesa de negros, e por cauza da gr. ${ }^{\text {de }}$ despeza q faz, ja hoje os parteculares fabricão os seus edifícios de tigolo, q' se não he mais barato, o achão mais promto; o formigão estou informado q' sendo feito em sua conta, he de duração, e assim se poderá a muralha obrar destes tres generos, $p^{{ }^{a}}{ }^{\prime}$ se adiantar mais a obra porq' os fundam. ${ }^{\text {tos }}$ podem ser de pedra e cal, e o restante de tigolo, [ou] formigão; ou aos lanços divididos, ou cortinas de hum, flancos e faces de outro; tambem vi algúas muralhas antigas das nossas praças serem feitas com pillares de alvenaria e entre estes formigão; outras com arcos de ladrilho, e o vão destes de formigão; mas havendo boa expedição no transporte da pedra, desta fizera $\mathrm{m}^{\text {ta }}$ parte; a largura de vinte palmos de [terra/berma] he ta $^{\text {ta }}$, e no cazo de admitir [cinco de rara] mais: não [sej] se intentarião fazer aqui falsa braga, mas sendo aquella largura gr. ${ }^{\text {de }}$, p. $^{a}$ [berma], he pequena . $^{\text {a }}$ falsa braga.

Propunha iniciar as fortificações pela marinha e reforçar os locais de desembarque com baterias e fortes. Sugeriu que viessem do Reino lajes de pedra para fazer as explanadas (plataformas) de artilharia, pois considerou a pedra local de baixa qualidade.

Mas como esta marinha se acha aberta sem a deff. ${ }^{a}$ nececr. ${ }^{a}$, deve a forteficasão principiar-se por esta p. ${ }^{\text {te }}$, porq' ja q' na barra se não pode impedir a entrada aos navios, achem a marinha forteficada, e capáz della impedir o dezembarque; e nas $p .{ }^{\text {tes }} q^{\prime}$ nesta vizinhança ficão fora da forteficasão, e ofereçem comodidade p. ' dezembarque, fabricão fortes, e baterias, comforme a obra de q' o sitio necicitar; pois seria erro concideravel ficando hua pasajem bem defendida com huà bateria, edificar nella hum forte, ou nececitando deste, edificar aquella; e he percizo $q^{\prime}$ do Reino se transporte lagedo $p .{ }^{a}$ as explanadas da artelhr. ${ }^{a}$ de comprimento e grossura suficiente, porq' toda está com ruim pavimento e feito do lagedo deste paiz, he hum dispendio continuo, pella pouca duração porq' [lhe] a conthenuação das agoas o desfaz; os de Portugal he com mais comodo, ademais dura, o q' a experiençia mostra na sé $e$ collegio desta cid. ${ }^{\text {; }}$; q' [este] pormete [promete?] larga duração, e aquella pouca ezistençia, porq' foi fabricado o seo frontespiçio com cantaria da terra, aquelle com o do Reino, fazendo este menos desp. ${ }^{\mathrm{a}} \mathrm{q}$ aquella.

Era necessário limpar o mato das trincheiras do perímetro externo, ${ }^{741}$ restabelecendo a ligação cortada pela invasão de quintais e propriedades na área.

Pella p. $^{\text {te }}$ de terra cerca a esta praça a trinxr. ${ }^{a}$ de $q^{\prime}$ assima tratei e como esta forteficasão não seja p. $^{\text {a }}$ desprezar, por ser defenssa $q^{\prime}$ a praça tem pella $p .{ }^{\text {te }}$ da terra, deve-se a limpar do mato $q$ a reveste reparar algúas ruinas, dezempedir a cumunicação dos quintais horrtas, e algúas cazas tudo tão contiguo, $\mathrm{q}^{\prime}$ se acha ocupando a aria de alguns baluartes, e desta sorte fica a praça serrada [emq. ${ }^{\text {to }}$ ] a terra, aplicando todo o cuidado som. ${ }^{\text {te }}$ a forteficação da marinha, como mais principal e necesario.

${ }^{741}$ As citadas trincheiras, provavelmente construídas na época de Montalvão e Antônio Teles da Silva. 
Fala em seguida do Forte de S. Antônio da Barra, ${ }^{742}$ dizendo que o certo seria tê-lo feito no alto (Morro da Gavazza), deixando na Ponta do Padrão apenas uma bateria baixa. Recomenda resolver os problemas da cisterna e da casa da pólvora. Os outros dois fortes da área (S. Maria e S. Diogo) deveriam também receber esplanadas de terra para artilharia, mas não mereciam muito investimento.

O Forte de S. An. ${ }^{\text {to }}$ da barra se hoje se edificase o farya no alto, $q^{\prime}$ o domina, por não ser $m .^{\text {to }}$ elevado, ficava [dominábe], capaz de se defender, e descobria algúas avenidas q' daquelle [sem vem], e defendia o forte de s. Maria, e no lugar em $q^{\prime}$ o $d^{\circ}{ }^{\circ}$ forte eziste som. ${ }^{\text {te }}$ húa bateria. P. ${ }^{a}$ pavim. ${ }^{\text {to }} d a$ artelhr. ${ }^{a}$ deste forte se fica juntando lagedo, e se dara remedio á caza da polvora, como tambem se fará húa pequena cisterna, se a sua capacid. ${ }^{\mathrm{e}}$ o premitri: o Forte de s. Maria também não tem pavim. ${ }^{\text {to }}$ capaz $\mathrm{p}^{\mathrm{a}}$ artelhr. ${ }^{\mathrm{a}}$ : o De s. Diogo he feito há poucos annos, nem com elle se deve fazer despeza de concequencia pella pouca serventia $\mathrm{q}^{\prime}$ tem as suas tres pessas.

Propôs a ampliação da fundação do Forte de S. Marcelo com enrocamento para aumento do seu anel externo, reduzindo a sua praça alta (torreão), considerada de pouca utilidade pela sua limitação.

O Forte do mar q. ${ }^{\text {do }}$ foi edificado não havia naquelle lugar capacid. ${ }^{e}$ p. ${ }^{a}$ se fazer mayor, mas hoje a tem na mayor parte de sua circunferencia por ali se descarregar o lastro dos navios, como de baxa mar se ve claram. ${ }^{\text {te }}$, e aplicando a isto algum cuidado sem a menor despeza se terá em todo aquelle ambito fundam. ${ }^{\text {to }}$ capaz de nova obra; e como a praça alta (sendo de pouca entid. ${ }^{e}$ pela sua limitasão) incomoda a baxa, por lhe tirar a aria preciza $p^{\text {a }}$ o uzo da artelhr. ${ }^{a}$ : deve-se aquella apear, $p .^{\text {a }} q^{\prime}$ esta fique capaz de laborar nella a artr. ${ }^{a}$ grossa com q' se acha, e exterior a ella, aumentando-lhe o diametro a distançia proporcionada, se pode fabricar nova circunferençia, cuja muralha, e pavim. ${ }^{\text {to }}$ seja praça baxa, e a $\mathrm{q}^{\prime}$ agora o hé elevar-çe hum pouco, p. $^{a} q^{\prime}$ fique sendo alta; e esta obra hè de grande conceq. ${ }^{a}$, por ser naquelle lugar, e na distançia q' curça a sua artelh. ${ }^{a}$, não poderá paçar embarcação, sem o risco de grd. ${ }^{e}$ ofenssa q' reseberá com os seos tiros horizontais, não sô, os melhores em qualquer p. $^{\text {te }}$, mais próprios p. ${ }^{a}$ o mar por serem de mayor efeito: e cazo q' esta obra se não admita sempre o torreão, ou praça alta $q^{\prime}$ hoje hé, deve ser abatida pello q' fica dito.

Não indica solução para os fortes da Ribeira e S. Francisco, por estarem prejudicados com o avanço das casas nas laterais, tendo apenas defensa Recta. Fala de um fortim junto à práya do Rozario que tudo indica ser a Torre de Santiago. Diz ser limitado, mas que por estar desimpedido podia ser ampliado (como depois o foi, em reforma coordenada por ele) com um hornaveque. ${ }^{743}$

Dos fortes da Ribr. ${ }^{\text {, }}$, e S. Fran. ${ }^{\text {co }}$, não ha que tratar, porq' exterior a cada hum delles fica hum baluarte dos quatro q' a nova forteficação ha de ter na marinha: nem os ditos fortes tem mais q' a defensa Recta, porq' a lateral lhe tem tirado os $\mathrm{m}^{\text {tos }}$ edifícios $\mathrm{q}^{\prime}$ se tem fabricado mais avansados ao mar. $\mathrm{O}$ fortim junto à práya do Rozario he tão pequeno, q' ao mais permitirá ter pessas de campanha; mas este se acha dezempedido, e com capacid. ${ }^{e}$ na sua vizinhança de se poder alargar p. ${ }^{a}$ qualquer parte: neste lugar se pode fazer hum Hornaveque, cujos ramais sejão o fundo desta obra, com a distancia nececr. ${ }^{a}$ p. $^{a}$

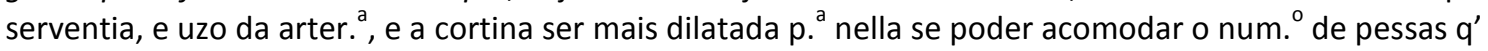
parecer conveniente, e com os seos dous meyos baluartes defenderá aquella praya vizinha; porq' o da parte da cid. ${ }^{e}$ flanquear se há [fl. 34v] com o ultimo baluarte da forteficasão, e o da p. ${ }^{\text {te }}$ de Monserrate com a obra q' entre este e aquelle se fizer.

Considerou necessário fortificar o espaço entre a Torre de Santiago (que então seria transformada no Forte da Lagartixa) e o de Monserrate, que tinha praias de desembarque sem defesas. $O$ de Monserrate foi considerado insignificante, mas

\footnotetext{
$742 \mathrm{Fl} .34$.

${ }^{743}$ Ao falarmos do forte, mostraremos o desenho de M. Oliveira de como seria esse hornaveque.
} 
podendo receber ampliação e o reforço de um fosso aquático (o que era talvez inviável, por estar muito acima do mar em terreno rochoso). Recomendou a restauração do Forte de S. Bartolomeu, que tinha hum lansso de contra escarpa arruinado pelo mar e os parapeitos mal seguros no reparo superior.

Deste fortim ao forte de Monsserrate he húa longa distancia, e toda de areal, e como esta he capaz de dezembarque nececita de obra q' a defenda, e o fasa Reciporcam. ${ }^{\text {te }}$ [sic] com o forte de Monserrate, e fortim asima dito. O forte de Monserrate he pouco mayor q húa Atalaya [?] das nossas praças fronteiras, e naquelle sitio tem húa porção de terreno suficiente $p$. $^{a}$ se poder alargar, ficando o forte $q$ hoje he servindo como parte de todo $q$ ha de ser, e com pouca despeza se lhe pode fazer hum fossete [fosso] aquatico, cortando a pequena distancia em $q^{\prime}$ esta peninsula se une com a terra $p$. $^{\text {a }} q^{\prime}$ se cumunique o mar. $O$ forte da pasaje neçeçita de reparação, porq' ja o mar lhe arruinou hum lansso de contra escarpa, e no reparo superior estão os parapeitos mal seguros.

Para o Forte de Santo Antônio Além do Carmo propôs, como Coutinho, ser realocado em posição que pudesse descobrir pontos por onde os inimigos atacariam sem ser vistos, estando posicionado ali por inércia (onde era o fortim de terra). Explica o seu erro de implantação e muitos outros por não ter sido executado por engenheiro (os leigos não poderiam perceber esses erros).

O forte de S. An. ${ }^{\text {to }}$ do Carmo he . $^{\text {a }}$ sentir, $q^{\prime}$ podendo-se fazer em parte, naquella vizinhança, onde

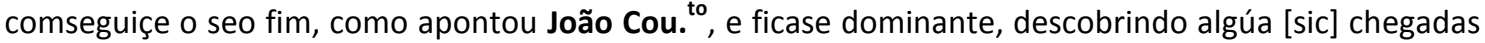
$q$ agora lhe estão ocultas, o forão edificar naquelle lugar, com o pretexto de $q^{\prime}$ ali estava hum fortim de terra, $q^{\prime}$ antiguamente tivera gr. ${ }^{\text {de }}$ serventia, ou por então não haver outro melhor, nem a occazião dar lugar a se fazer, ou porq' o Dique lhe aumentava a defenssa, não premitindo outra pasajem $\mathrm{p}^{\text {a }}$ ser atacado por diferente parte; mas como não foi por direccção de engenhr. ${ }^{\circ}$ he menos culpavel este errô, e os $\mathrm{m}^{\text {tos }}{ }^{\mathrm{q}}$ ' na sua ezecusão se cometerão, os quais nem a todos são patentes, porq' o vulgo julga pellos vistozo, e aparente, e não pellas circunstançias do Methodo com q' húa obra melhor consegue os seos fins, porq' o curiozo não pode perver [sic] todos os comodos, e incomodos $q^{\prime}$ sucedem na defensa da forteficasão, como o professor $q^{\prime}$ na theoria o aprendeu, e na pratica o experimentou: mas como o d. ${ }^{\circ}$ forte se acha acabado, no q' toca ao reparo superior, e nelle feita despeza de quarenta mil cruzados, deve-se aperfeisoar o seu fosso, e estrada encuberta; mas não sej $q^{\prime}$ remedio tenha a lgreja de $S$. An. ${ }^{\text {to }} q^{\prime}$ fica nesta.

Achou o Forte de S. Pedro pequeno, mas suficiente. Sendo de terra, tinha locais arruinados. Propôs uma cortina de pedra e cal, de pouco espessura, para conter o terrapleno e sua erosão.

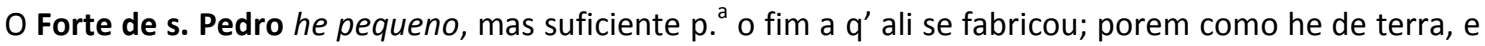
antiguo, vai se desmoronando, e assim se deve revestir com húa camiza de muralha, de pouca grosura, porq' o terrapleno está ja como natural e bastará aquella p. ${ }^{a}$ o sustentar. ultimam. ${ }^{\text {te }}$ deve-se aplicar todo o cuidado, em fortificar a marinha e segura-la fazendo em cada sitio a obra de q' nesecitar; isto repeti yá asima algúas vezes, e torno agora a fazer, por ser tão precizo, quanto o mostra o dezempáro em q' esta se ácha, exposta a qualquer invazão; e pella parte de terra reparar a trinxr. ${ }^{a}$, cerrando a praça, e tirandoIhe os impidim. ${ }^{\text {tos }}$ p. ${ }^{\text {a }}$ ficar em defenssa.

Na parte final, Miguel Pereira se mostra conhecedor da guerra e dos problemas do assédio, preocupando-se com a questão do abastecimento. Propõe armazéns para a conservação da farinha excedente - o que era uma questão estratégica - com acesso a embarcações pelo mar (então principal meio de transporte de alimentos). ${ }^{744}$

\footnotetext{
${ }^{744}$ O que, nas palavras e M. Oliveira (2004: 74), “... implicava a segurança de Itaparica e do Morro de S. Paulo". É mais um exemplo da visão "sistêmica" do território.
} 
Esta praça não tem em sy provim. ${ }^{\text {to }}$ algum de boca, e todo o $q^{\prime}$ lhe vem de fora se transporta por mar, e com poucas embarcasõens se lhe pode impidir este socorro; termos em q' padecerá a mayor fome [fl. 35] e se aquellas ezistirem nesta operação, se vera a praça reduzida a extrema neçecid. ${ }^{\text {, }}$, com tão riguorozo asedio; e asim seria muy comveniente haver armazem com o sobrecelente, ao menos da farinha a qual se podia concevar, municiando della a guarnição, e porvendo [provendo] o pouco, e a q' p. ${ }^{\text {a }}$ estes vem, ser em refeisão daquella como ja em algum tempo aqui se praticou: tambem não tem a guarnição competente porq' he pouca a de dous terços, e ainda estes muy diminutos.

A Ilha de Itaparica, defronte desta cid. ${ }^{\text {e }}$, tem hum porto de tanta concequencia q' nelle esteve a armada holandeza, e se forteficou a Infantaria em terra; este se acha sem o menor obstaculo p. ${ }^{\text {a }}$ impedir a qualquer navio, ou esquadra dar fundo nelle, onde fára gr. ${ }^{\text {de }}$ perjuizo às $\mathrm{m}^{\text {tas }}$ embarcasoes deste Reconcavo.

O Morro he bem notorio o de quanta concequençia seja, pois com capacid. ${ }^{\text {e }}$ p. ${ }^{\text {a }}$ grandes armadas, e ocupado este, ou o de Itaparica pelo inimigo, experimentará esta praça a nececid. ' q' asima apontey, por delles se impedir totalm. ${ }^{\text {te }}$ a cumunicação das embarcações. e asim q' bem se ve o quam percizo seja fortifica-los, fazendo nelles obra q' impida aquelle projecto, pois da sua comcervasão depende tanto a da praça.

Das mais partes desta vizinhança não posso dar notícia, porq' as não vizitej, e me dizem haver parajens de grande concidesação; e isto he o q' posso dizer nesta materia, pois havendo pouco tempo aqui chegej, he o q' pude ver, e colher por notiçias; a tudo se deve dar promto remedio, por estar a praça exposta a ser invadida[;] o q apontey he o q' me pareçe, seg. ${ }^{\text {do }}$ o q' li nos livros, aprendy nas Aulas, e vi na nossa guerra, $q^{\prime}$ he a experiençia com $q^{\prime}$ hum engenheiro Portuges pode allegar, no discursso de seis annos sitiando, e sendo sitiado, sugeitando-me em tudo ao pareçer de quem na materia tiver melhor voto. B. ${ }^{a} 17$ de Junio de 1710 .

Não tive tempo de fazer outra, nem de ver esta, [VR $\left.{ }^{\mathrm{ma}}\right]$ me advirtirá do q' for menos adequado, porq' aonde falta a sciencia sobrão os erros. ${ }^{745}$

Miguel Pr. ${ }^{a}$ d Costa [SS]

\subsection{O projeto assinado por João Massé (1715)}

Em 1711, a cidade do Rio de Janeiro foi invadida pelos franceses, mexendo com a administração da Colônia: seguidas portarias mandavam retirar dos almoxarifados provisões para as casas da parlamenta e paióis das fortalezas. Completaram-se os quadros de artilharia e foram tomadas medidas para suprir Salvador de munição, farinha (a farinha de guerra, vinda das Três Vilas) e carne (gado encaminhado diretamente do sertão à capital). Também a Capitania do Espírito Santo foi provisionada e assistida, porque dependia diretamente de Salvador. O Cap. Eng. Gaspar de Abreu foi incumbido de acudir prontamente ao reparo das fortificações assim da barra como das demais que há na Capitania... ${ }^{746}$

João Massé recebeu a patente de Brigadeiro para vir à Colônia como especialista da castramentação, ${ }^{747}$ tendo a missão de aperfeiçoar as defesas de

\footnotetext{
${ }^{745}$ Em elegante defesa do iluminismo.

${ }^{746}$ Cf. BN - Documentos históricos, 1941, v. 53, p. 100-49/ OLIVEIRA, 204: 108-110.

747 O Brig. João Massé, que marcou época na História da Engenharia Brasileira, veio enviado pelo Rei para ser o "consultor" dos projetos de fortificação nas praças do Brasil. Sua Carta Patente de vinda (17/06/1712) foi registrada no Rio de Janeiro (09/06/1713) e na Bahia (30/05/1714), com soldo de $90 \$ 000$ réis mensais. Sua origem não era francesa, como muitos historiadores e até documentos antigos supuseram, mas inglesa, sendo o seu nome de batismo possivelmente John Massey (a demonstração de
} 
importantes cidades brasileiras (Salvador, Recife e Rio de Janeiro), depois que a Coroa Portuguesa reconheceu a fragilidade dessas praças e de outras vizinhas. Em Salvador, ele teve a colaboração de engenheiros locais que já conheciam o terreno, principalmente o M. de Campo Miguel Pereira da Costa e o Cap. Gaspar de Abreu (este, lente da Aula de Arquitetura Militar da Bahia, criada em 1713).

Produziu-se um majestoso projeto de fortificação para a cidade, do qual mais uma vez não foram encontrados os desenhos originais, mas cópias. ${ }^{748}$ Ele foi executado de forma muito aquém da proposta, adiando-se, como em outras cidades, a defesa da Praça. ${ }^{749}$ A vinda ao Brasil do Brig. João Massé, considerado um especialista em fortificações, é controversa e foi supervalorizada por alguns historiadores. Era sim um profissional competente e conhecedor do ofício, mas o que propôs, em tão pouco tempo de observação, só pode ter vindo da assessoria dos profissionais locais. $\mathrm{Na}$ Bahia, o projeto foi assinado conjuntamente por Miguel Pereira da Costa e Gaspar de Abreu. Observando o relatório de Miguel Pereira (1710) e o memorial do projeto atribuído a Massé, nota-se que alguns trechos foram transcritos e muitas propostas são semelhantes. E ambos se apoiavam, em muitos pontos, no projeto do Capitão Coutinho, anterior a este em mais de 25 anos.

O memorial que acompanharia o desenho do projeto de fortificações é dividido em 12 itens. Do 1ㅇ a 4으o são descritas as fortificações existentes, com algumas frases e expressões idênticas às do relatório de Miguel Pereira (1710), o que mostra a sua participação na redação. ${ }^{750}$

sua nacionalidade está em CHABY, C. Synopse dos decretos..., Maço 64 - Decreto de 23/01/1705 sobre oficiais ingleses indicados para Portugal; também em MADUREIRA DOS SANTOS, Cel. H. M. Decretos do extinto Conselho de Guerra. Lisboa: Imprensa Nacional, 1976 - Decreto de 04/11/1720. Maço 79 - Sobre licença de Massé ir à sua pátria, a Inglaterra/ OLIVEIRA, 2004: 138-9 - nota 173).

${ }^{748}$ Duas delas estão guardadas no Arquivo do Exército do Rio de Janeiro. A outra, acima, foi reproduzida nas Notícias Soteropolitanas de Luiz Santos Vilhena.

749 Comentamos na introdução que pouco dos projetos para Salvador não foi executado. Na Planta de 1715 (mostrada na p. 235) se destaca, por exemplo, o desenho de uma cidadela ( $n$ o 14), que ficou apenas como proposta. Fernanda Fernandes (que compara a Planta à de Massé do Rio de Janeiro, em 1714, notando em comum a "cidadela projetada", de "efeito combinado com os das fortificações préexistente" - SILVA, 1991: 203) nota que “... também o contorno de muralhas fortificadas com baluartes, cuja finalidade era estabelecer o fechamento da cidade em relação ao interior,... não foi realizado" (id. ibid.). Mas percebe pela necessidade de defender a cidade também em direção ao interior que há um evidente "caráter de cidade fortificada" (grifo nosso) dado ao centro urbano. Previa-se assim a "construção de uma grande muralha que circundaria todo o perímetro urbano, e o uso freqüente de acidentes topográficos" que funcionassem de defesa natural ("além de dificultarem o assédio dos inimigos face sua altura, teriam o mérito complementar de permitirem uma melhor visibilidade do território circundante" - idem, p. 206 - grifo nosso).

${ }^{750}$ Miguel Pereira participou intensamente desse projeto de fortificação, normalmente mais atribuído a Massé. Há frases inteiras transcritas do Extracto da forteficação... Foi um momento importante, de atualização de conceitos no sistema fortificado da Bahia, um trabalho em equipe que trouxe a modernização dos fortes. O projeto também ajudou a formar uma nova geração, com a citada promoção de dois discípulos da Aula Militar a Ajudantes e futuros engenheiros da praça: Gonçalo da Cunha Lima e João Batista Barreto, que tiveram como complemento de aprendizagem poder colaborar com profissionais experimentados da teoria e prática da fortificação. 
[11B] Exm. ${ }^{\circ}$ senhor. ${ }^{751}$

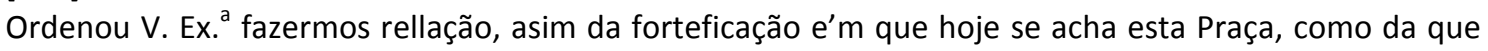
se intenta fazer, a que satisfazemos na forma seguinte.

He' esta Praça cercada de huma antigua Trincheira de terra, que foi feita para se fechar com mais brevidade, e' para servir de terrapleno á muralha com que se intentava revistir; esta se acha com algumas ruinnas e'm varias partes, humas cauzadas do tempo, outras pellos moradores.

Asim como a Trincheyra cerca toda a Praça, pella parte da terra tambem o Dique a Rodea quazi toda, servindo-Ihe de fosso aquaticco; obra que os Holandezes fizeram por reconhecerem o de quanta utelidade e'ra a' defença da Bahya, ficando-lhe sométe nos dous extremos as entradas de Sam Pedro, e' Sancto Antonio do Carmo; nesta tem o Forte do mesmo Sancto, que como foi feito por quem não sabia de ataque, e' defença de Praças, não está no lugar que devia, nem defende a dita e'mtrada como he' necessario, e estâ dominado da Igreja a tiro de pistola, e' de outras cazas particullares: lateral, e' fronteyro a este fica outro, chamado, do Barbalho, de terra com coatro meyos balluartes, mas muy pequenno no todo; e' alem deste para a mesma parte, estâ outro chamado do Camaram, que he' hum Reducto de terra, no monte que olha ao tanque dos Padres da [12B] Companhya, na outra e'mtrada de Sam Pedro está o Forte do mesmo sancto revestido de muralha, tê a altura do cordam.

$\mathrm{Na}$ marinha tem, primeyramente e'ntrando pera a Bahya o Forte de Santo Antonio da Barra nomeando-os como comum impropriamente nos fortes que hé um reducto [decagonico] irregular com seis angullos salientes, e coatro reintrantes; este he dominado de hum monte vezinho a menos de tiro de Mosquete, que lhe descobre toda a arca: segue-ce-lhe logo o de Sancta Maria que hé outro Reducto menor, e eptagonico com os mesmos iinconvenientes; e logo está o de Sam Diogo, que hé menos que os antecedentes, e' feito na rais do monte da Igreja de Santo Antonio, e' nestes tres reductinhos, que soão mais do que sam, e' estando tão proximos, se se unicem, não fazião huma bataria ca- pas, se incerra a forteficação desta Barra; cuja defença hé impraticavel, por se não poder impedir a entrada aos Navios, a despeito da [em respeito à] sua muita largura.

Já dentro na Bahya, e' na Praya da Cidade [ribeira], onde chamão de Preguiça, esta principiado o balluarte da Conceigção que he' huma grande bateria, e' bem necessaria naquella paragem: segue-ce o forte da Ribeyra quadrilongo com hum tal balluartinho que tem quinze palmos de face, e nove de plano e' por isso incapás de artilharia; a este se segue o de Sam Francisco que hê hum Revelim tam Redicullo, como o da Ribeyra, adiante na Praya do Rozario, e principio da Gequitaya, estava hu' pequeno reducto circular que se acresentou, e' se há de acabar; e' tem já toda a muralha feita á custa do seu Capitam, para ficar huma bataria mais capas: de fronte do forte da Ribeyra, e' a dous tiros de mosquete fica o do mar que hé hum circullar, e tem [14B] huma praça alta, mas essa alem de ter pouca capacidade incomóda a baxa, não tendo a retirada sufeciente para a artilharia laborar: há no interior da Cidade a bataria da porta do Carmo, e' Hornaveque da Porta de Sam Bento, feitos no tempo que nas tais portas terminava a Cidade; mas hoje de nenhuã serventia, nem tambem a tem a bataria de Pallacio a respeito da muita altura e'm que fica pera o mar; e' he toda a forteficação que prezentemente tem a Praça da Bahya, e' a que se intentava fazer a seguinte.

Passando então às cogitações de ataque e do que deveria ser reforçado e melhorado (itens 5ㅇ a 12ㅇ), comentam as hipóteses tradicionais de invasão da cidade pelo norte e pelo sul, considerando a primeira mais viável porque o desembarque em mar aberto seria realmente difícil (pela dificuldade de apoio da artilharia embarcada), bastando algumas baterias para resolver essa defesa. Mesmo havendo esse desembarque, o Forte de S. Pedro e o Dique Grande seriam defesas suficientes.

${ }^{751} \mathrm{O}$ documento foi transcrito a partir de microfilme impresso no próprio AHU (Documentos Avulsos, Bahia: Cx. 8, doc.29/ AHU_ACL_CU_005. Cx. 10, D. 840), sendo depois localizado em Documentos digitalizados..., CD2, rolo 10 , pasta 002 . Na seqüência do microfilme as folhas aparecem sem numeração e aparentemente embaralhadas. Os números aqui colocados correspondem à ordem em que aparecem as 26 folhas. A maioria delas foi preenchida um duas colunas (aqui representadas como A e B), com a seqüência ocorrendo em geral pela mesma coluna na folha seguinte. 
Portanto era mais provável um desembarque em praias dentro da baía, com o ataque sendo feito pelo Norte da Cidade.

[14B] Como e'sta Praça tem somente as duas e'ntradas dos Fortes de Sam Pedro, e' Sancto Antonio do Carmo, e'm qualquer parte que $\mathrm{p}$ inimigo dezembarque pêra a atacar por huma destas a há de buscar; e' pello que respeita a do Forte de Sam Pedro, hê mui duvidoza, porque para o inimigo fazer marcha por esta parte, ha de dezembarcar no Ryo Vermelho, ou a Barra; qualquer destes dous portos, alem de ser muito pequeno, quazi sempre estam incapazes de chegarem lanchas a terra, pella desinquietação com que o mar bate na Praya: e' dado que o intentem fazer, com huã bataria, e' com os fuzileyros necessários e'mbuscados no mato, que chega té a Praya se lhe pode disputar o dezembarque, quanto mais que este se costuma fazer debayxo do fogo da Artilharia das Naus, asim para lhe dar callor, como para afastar da Praya os disputantes; e' para tornar a reçeber a sua gente se não puder dezembarcar, o que aqui não pode ser, porque para estarem [à lappa] correm as agoas muito, e' não se hão de conservar no lugar que lhe for necessario; para ancorarem há de ser mui afãstado da terra a respeito do mar fundo, que he' de recifes, e' razos, e' entam de pouco effeito a sua Artilharia para terra.

[15B] Dado que dezembarquem contra toda a opozição, e' que da mesma sorte continuem a sua marcha, no Forte de Sam Pedro acharam huma grande rezistencia, porque feitos os parapeitos acabada a estrada Cuberta, e' posto e'm sua ultima perfeição', Ihe impede totalmente a passagem, por ficar no meyo do unico caminho que tem por esta parte, e'm hum alto e'ntre duas baxas do Dique, e' mar; e' continuando hum lanço de Trincheyra thé o Dique, asim como tem outro tê o despenhadeyro que cay sobre o mar, lhe deficulta totalmente a passagem.

Deviam-se reforçar as defesas no norte, onde o inimigo poderia tomar posições no outeiro do Padre Ribeiro ou da Soledade, entrando na brecha entre as fortalezas do Barbalho e Santo Antônio. Para melhor apoio das defesas existentes foi proposta uma obra coroa desenhada no projeto. O fortim do Barbalho foi considerado muito pequeno e mal situado, sendo decidida sua re-locação e ampliação na defesa da depressão entre ele e o de Santo Antônio, onde foi projetada uma obra coroada e a cobertura do Dique (que na época ia até Sete Portas, juntando-se ao Rio das Tripas, que formava o Dique Pequeno, ou, dos Holandeses). Também restaurariam o Fortim do Camarão, que era de terra. ${ }^{752}$

[15B] Pello que respeita á entrada do Forte de Sancto Antonio do Carmo hê a por onde o inimigo há de âtacar esta Praça; porque entrando pella Barra tem o dezembarque das Prayas de gequitaya, Itapagipe, e Praya grande onde pode lançar gente muito a salvo de qualquer opozição, pella extenção destas Prayas, e' poderem surgir e'm qualquer das duas partes para calorearem com artilharia as suas operaçoins: feito o dezembarque e postos em marcha para a Cidade, depois de huma e' outra se lhe disputar todo o possivel, se emcaminharâm ao outeiro do Padre Ribeyro, ou sitio da Soledade opostos aos Fortes de Sancto Antonio do Carmo e' do Barbalho, e' dentro do tiro forte de Artilharia: e' asim hé conveniente no alto lateral ao de Sancto Antonio, $e^{\prime}$ mais avançado ao do Barbalho, fazer hum Coroa que ocuppe aquelle terreno, e' fique defendendo a passagem, e batendo ao inimigo quando na Soledade se alojar.

Hê precizo tambem fazer, hum forte quadr. ${ }^{\circ}$ no sitio e'm que estâ o do Barbalho; porque este he' incapasicimo pella sua pequenhes, pois ficara' o d. ${ }^{\circ}$ [16B] Forte dominando, e' defendendo a obra Coroa, o Forte de Santo Antonio, e' as duas pasagen's, que ficão a hum e' outro lado deste novo Forte, a saber á esquerda [em] baxa e'ntre elle, e' o de Sancto Antonio, a direita [em] baixa e'ntre elle e o Dique, que hé o Caminho que vem do tanque dos Padres, ficando a Coroa servindo de obra exterior ao dito Forte; pois hé precizo ocupar com ella aquella colinna, por se extender para esta parte do Tereno: o

\footnotetext{
752 Ele já não existe. Ficava na eminência que domina a atuais estradas da Rainha e da Baixa de Quintas (Rua General Argolo), de Frente para a Quinta dos Padres (jesuítas), área alagada por um braço do Dique Grande e pelo Rio das Tripas, que ocupavam todos os terrenos baixos dificultando a progressão dos trens de artilharia de exércitos agressores (cf. OLIVEIRA, 2004: 76).
} 
Reducto do Camarão se deve reparar pois fica avançado para aquele lado sobre a quinta, ou tanque dos Padres, servindo de Atallaya, ${ }^{753}$ para observar algum movimento que por aquella parte se intente: ao Forte d Sancto Antonio se devem alterar os parapeitos, aperfeiçoar a estrada cuberta, e' advertir que este fica dominamdo da Igreja, e' de outras cazas; e nesta forma fica toda esta passagem forteficada, e' com a defença que o terreno permite.

Consideraram útil a antiga trincheira que vinha do bairro de Nazaré e girava em direção ao Convento do Carmo. Poderia funcionar como segunda linha de defesa se fossem tomados os fortes do Barbalho e de Santo Antônio. Como os especialistas anteriores, acharam importantíssimo recuperar o Dique pequeno, feito pelos holandeses (na época, essa defesa aquática já tinha quase desaparecido com a instalação de hortas no terreno, não sendo justo que alguns se beneficiassem em detrimento de todos).

[16B] Nam se deve desprezar a trincheyra de terra com que a Praça antiguamente foi fechada, principalmente naquellas partes que olhão os Fortes de Sam Pedro, e Sancto Antonio do Carmo; por que se o inimigo depois de huma larga rezistencia, vencer a deficuldade de penetrar aquellas obras, ache na Trincheyra huma nova opozição; aonde os defençores retirados fação outra não menor defença; mayormente não sendo precizo fazer alguma despeza para a conservação da Trincheyra, e reparação de suas ruinnas: e' ultimamente He muy precizo que o Dique torne ao antigo estado e'm que os Holandezes o puzeram, e' concervaram, por ser huma defença de tanta consequencia para esta Praça; porque hoje esta em muitas partes seco, e' não serca toda a Praça, como e'ntam fazia, o que se conseguirâ levantando os sangradouros por onde desagoa os palmos q' for conveniente; porque crescendo estes alargarâ [alagará] as partes que estam secas té os extremos onde antigamente chegava; ê hé muito para [17B] se fazer cazo desta defença tam principal, que cada ves se vay perdendo mais: não sendo justo que pella conveniencia de alguñs se exponha a de todos; porque duas Hortas que estão junto ao Dique podem ser mais asima e'm qualquer parte, e se para alý as fazerem e'mtulharam aquella parte que o Dique e'nchia, rezão He torne este a ocupar o que era seu; e huma defença e'm que o Holandes pos tanto cuidado, não o devemos deprezar. ${ }^{754}$

Seguindo João Coutinho, propunham um cais ao longo das casas e armazém da Cidade Baixa, contando-se com a boa vontade dos moradores em ceder áreas de frente das casas para uso público e atividades militares. Quiseram continuar a obra da Bateria da Conceição, que completaria a defesa do Porto com os fortes de S. Francisco e Rosário.

[17B] Pello que respeita a marinha se deve fazer hú caés na extenção de toda a Praya, o qual de boa vontade faram os moradores, cada hum na fronte de suas cazas. E' nesta forma ficarâ todo co' tinuado com á largura necessaria para os uzos melitares, e' serventia do povo; e' na Preguiça côtinuar o baluarte da Conceipção, porque com esta bataria, outra ao mâr do Forte de Sam Francisco, e' a do Rosario, fica esta Praya bem defendida; $e^{\prime}$ às dist. ${ }^{\text {as }}$ deixar algumas entradas para se recolherem os barcos do Reconcavo, e'm as tromentas do Sul, que nesta Bahia sam [desabridas]: e'ntre a bataria da Conpceição e' Ribeyra das Naus fica hum lagamar capas de huma boa Ribeyra, porque a que hâ hé muy pequena para as duas repartiçoin's de Coroa e' junta.

Falaram em ampliar o Forte de N. S. do Pópulo e S. Marcelo tirando o torreão já condenado por Miguel Pereira em 1710 (há uma especificação assinada pelo Brigadeiro Massé acompanhando Portaria de 04/10/1714 em que o Provedor-mor manda pôr em praça a obra do Forte do Mar). ${ }^{755}$

\footnotetext{
${ }^{753}$ Torreão de vigia nas fortalezas, ou lugar elevado (mirante) que serve para a observação.

754 Nota-se um constante elogio às técnicas holandesas.

755 ABN - Documentos históricos, op. cit., 1941, v. 53, p. 296-9. Provisões (1717-1718) e Portarias (17111715) - apud OLIVEIRA, 2004: 76.
} 
[17B] O Forte do mar deve ser acresentado á roda tirando-se o torreão, e sobindo toda a bataria baxa a ser praça alta, e' o novo acresimo ficar sendo praça baxa, e' deste para terra o molhe continuando ${ }^{756}$ [13B] na forma da planta: no baxo que estâ ao mar deste forte se pode fazer huma forteficação para que este o Porto fique melhor defendido.

Projetaram uma cidadela na atual zona da Palma (aproximadamente na atual Mouraria), mas dizendo que o local mais adequado seria o de S. Bento, já ocupado pelo convento beneditino.

[13B] Emquanto á Cidadella o seu verdadeyro lugar e'ra o bairro de Sam Bento por ficar este sitio dominamte a todos, com capacidade bastante para dentro se fazerem quarteis, armazen's, e todos os mais comódos precizos em huma Cidadella, mas como se tem asignado [assinalado] o sitio da Palma respeitando só a menor despeza, acommodamo-nos ao que lhe permite, na forma que reprezenta a planta, na qual vay todo o terreno superior, com o valle que a rodea. V. Ex. ${ }^{\text {a }}$ ordenam'oque for servido. Bahya vinte e tres de Julho de mil e setesentos, e quinze. Joam Massê./. Miguel Pereyra da Costa./. Gaspar de Abreu. ${ }^{757}$

\section{O projeto foi inteiramente orçado:}

[26] ORsam. ${ }^{\text {to }}$ de todas as obras da forteficação dezenhadas p. $^{\text {a }}$ se fazer de novo na Cidade da B. ${ }^{a}$ de todos os Sanctos reprezentadas na planta e relação dela tirada pellas Medidas Convenientes ás ditas obras, e pellos preços Mais Comuns da terra no qual se tem abatido parte do trabalho do transporte das terras, q' se pode refazer por faxina.

A Cidadella no Citio da Palma com todas as suas incumbencias _......

$54.037 \$ 000$

A obra coroa por diante nos fortes do Barbalho e $S .{ }^{\text {to }}$ An. ${ }^{\text {to }}$ do Carmo

P. a acabar As obras Apontadas ao forte de S. P. ${ }^{\circ}$

P. $^{\text {a }}$ o acresintam. ${ }^{\text {to }}$ do forte doMmar com seus intulhos no mar .....

P. ${ }^{a}$ o Molhe q' vai da praya ao d. ${ }^{\circ}$ forte com seus entulhos _.....- $26.980 \$$

$P{ }^{a}$ por o dique no estado em $q^{\prime}$ ha de ser fazendo-Ihe huma calçada ponte e algumas retidas p. as agoas

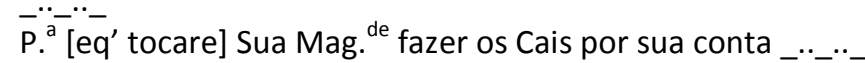

$10.000 \$$

P. ${ }^{\text {a }}$ reparar os fortes do Barbalho, e do Camaram revestindo-os de muralha _......

$24.000 \$$

Soma tudo _.....

$12.600 \$$

$189.700 \$ 000$

B. ${ }^{a}$ de todos os Santos em 1ㅇ de Agosto de 1715 / João Massé

Não se pode afirmar que esse orçamento foi pensado para que todas essas obras fossem integralmente realizadas. Ele no mínimo fixava um horizonte de intervenções desejáveis, abrindo um campo de negociação. Na prática, o projeto não foi totalmente executado, mas ao menos inspirou a construção das maiores fortificações, destacando-se o atual Forte de S. Pedro e sua bateria baixa S. Paulo da Gamboa, ${ }^{758}$ o do Barbalho e a ampliação do Forte S. Marcelo e do Morro de S. Paulo (no arquipélago de Tinharé do outro lado da baía). Em todos eles, Miguel Pereira acompanhou a maior parte da execução, apesar das muitas dificuldades surgidas.

\footnotetext{
${ }^{756}$ Portanto, como o Forte da Laje, tinha molhe, falando-se mesmo em continuá-lo "para terra"; por esse aspecto não se poderia então diferenciar as duas fortificações (emenda-se aqui da folha 17 à 13 , mostrando que está visivelmente fora de ordem).

${ }^{757} \mathrm{O}$ relatório propriamente dito termina aí, sendo complementado pelo orçamento (fl. 26).

${ }^{758}$ Nome derivado da Camboa de pesca que havia.
} 


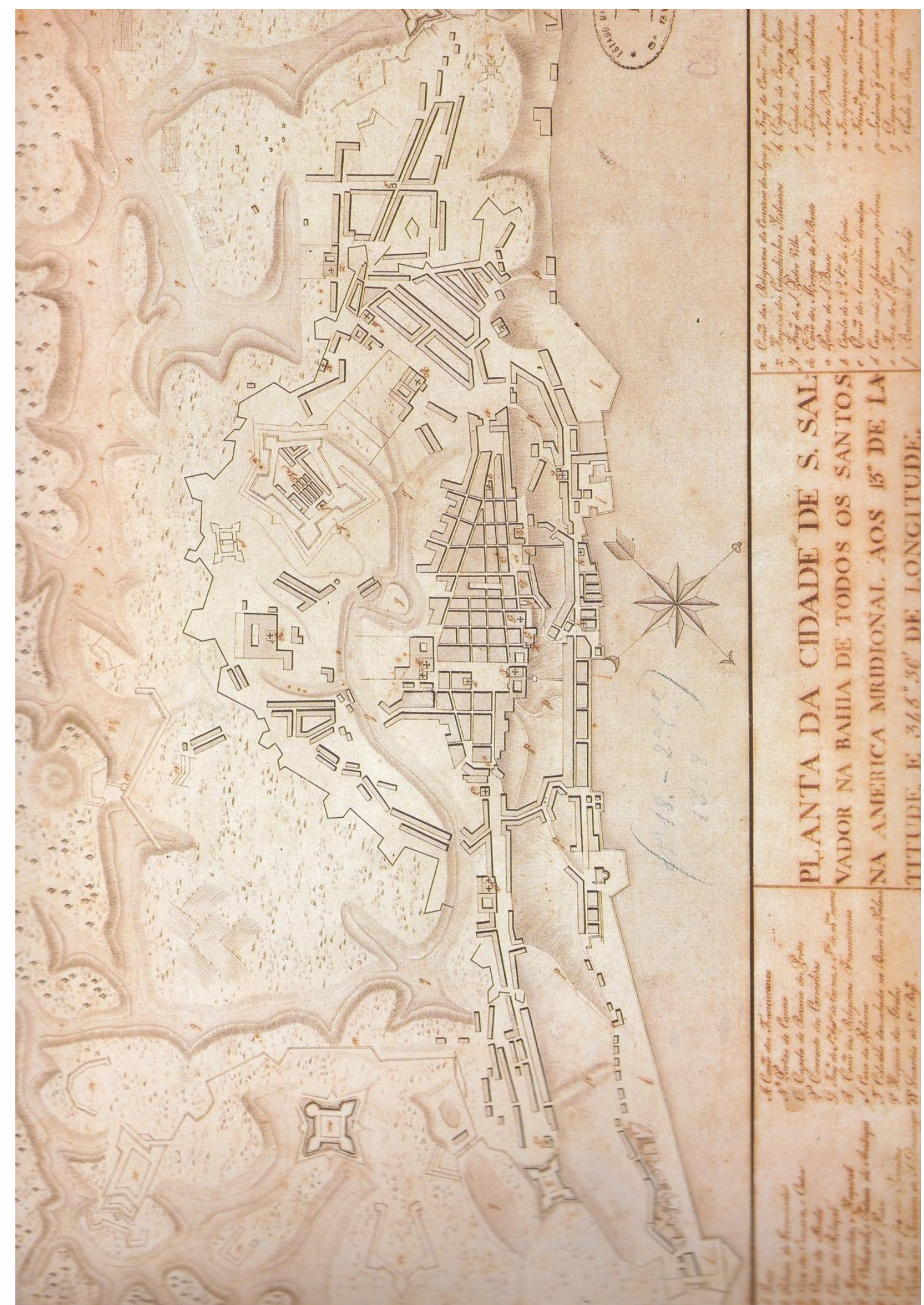

A Planta da Cidade de S. Salvador..., cópia manuscrita do AHM, c. 1715 (em REIS Fo, 2000: 31). Na legenda reproduzida em Vilhena (1921: 232-3) se lê: A- Praça do Palacio de Residência dos Governadores. B- Sé Cathedral. C- Praça do Terreiro de Jesus. D- Convento de S. Francisco e Terreiro da sua Ordem. E- Pantano que algum dia fortificava a Cidade e hoje a infesta por ficar dentro. F- Bairro de N. S. da Saude muito povoado hoje. G- Mosteiro das Freiras de Santa Clara do Desterro. H- Convento do Carmo e Terceiros da sua ordem. I- Bairro da Ladeira do Carmo e Rua do Passo $\mathrm{m}^{\text {to }}$ povoados. L-Bairro de Santo Antonio alem do Carmo, e Cruz do Pascoal. M- Portas do Carmo e sequito da rua direita para o 
Terreiro. N- Portas de S. Bento e quitanda onde se acha o pilourinho. O- Convento de S. Bento e bairro do mesmo nome. P- Freguezia e bairro de S. Pedro Velho. Q- Praça hoje da Piedade, donde segue a rua de João Per. ${ }^{\text {a }}$ the o Forte. R- Praya, ou Cidade baixa onde se faz todo o comercio. S- Colina sombranceira a Praya ou Cidade baixa. T- Campo do Nazareth onde já chega a povoação vindo do Desterro. V- Sitio em que se acha o Cemiterio perjudicialissimo [sic] á Cidade. X-Continuação da Povoação novamente. ZBairros da Piedade, S. Raimundo e Mercez onde hoje se achão $\mathrm{m}^{\text {tas }}{ }^{\text {ruas. }}$

1- Forte de S. Pedro no Passo Sêco do Sul. 2- Bateria de S. Paulo. 3- Muralha avançada, e projectada para defeza do Porto. 4- Arcenal, Ribeira das Naos, pequena Caldeira, e Bateria da Ribeira. 5- Cais projectado para defença da marinha. 6- Fortificação e muralhas projectadas para impedir o facil dezembarque ao inimigo por agoa de Meninos, e ingresso pella ladeira de S. Antonio. 7- Forte de S. Antonio. 8- Obra Coroa no alto da Soledade para vedar ali o alojam. ${ }^{\text {to }}$ ao Inimigo. 9- Forte do Barbalho. 10- Diferentes fortificaçoens exteriores projectadas. 11- Fortificação do Caquende. 12- Dique. 13- Trincheira. 14Cidadela.

\subsection{As fortificações do período}

Até o fim do século XVII ainda prevalecia a polêmica entre defender Salvador com fortificações de pedra e cal ou de torrão (terra). Era um velho dilema entre poupar a Fazenda Real (austera ou de poucos recursos) e fazer fortificações adequadas e duráveis. Houve discussões acaloradas, bravatas inconseqüentes, e pouca coisa foi feita. ${ }^{759}$ Como prevenção a possíveis ataques estrangeiros, houve na administração de D. João de Lencastro (1694-1702) tentativas de aperfeiçoamento das obras militares. Mas no começo do século XVIII, o Sarg.-Mor Eng. Antônio Roiz Ribeiro se queixava do estado das fortificações, lutando sozinho contra os atos de corrupção. Poucos anos depois, o Mestre de Campo Miguel Pereira da Costa se afligia com a mesma situação, sendo categórico ao descrever a guarnição e seus soldados:

... e q. ${ }^{\text {to }}$ ao impraticavel [ataque] pella aspereza dos bosques, ou estreteza dos pasos, seria asim se nelles, houvesse quem o impedisse, mas na tal occazião os poucos brancos cuidarão em transportar o preciozo a . $^{\text {te }}$ segura, os negros em procurar a liberdade, $q .^{\text {to }}$ mais $q$ sem venser aquellas difilculd. ${ }^{\text {es }}$ tem o inim. ${ }^{\circ}$ aqui perto da cid. $^{e}$ p. $^{a}$ onde fasa dezembarque sem oposição;... ${ }^{760}$

No governo de Pedro Antônio de Noronha (Marquês de Angeja, 1714-8) foram feitas reformas radicais e acabamentos de obras complementares, obedecendo ao plano do arquiteto brigadeiro João Massé. Foi edificado o Forte de São Paulo, na Gamboa, como prolongamento até o mar para reforço do de São Pedro. Foram concluídas na forma atual todas as demais fortalezas, de alvenaria ciclópica. Também é dessa época um novo represamento de afluentes superiores do rio Urucaia, fazendo com que o dique do Tororó inundasse o extenso vale que ia a Oeste das imediações do Barbalho até o forte de São Pedro. Também na administração de André de Mello e Castro (Conde das Galveas, 1735-49) foram feitos aperfeiçoamentos nas obras militares.

\footnotetext{
759 O Gov. Câmara Coutinho (1690-4) chegou a parafrasear Platão e dizer que... as verdadeiras muralhas haveriam de ser os peitos dos soldados... BN - Documentos Históricos, 1950, v. 89, p. 187. Consultas do Conselho Ultramarino - Bahia 1673-95 - apud OLIVEIRA, 2004: 58 (sobre essa "estratégia da valentia", Serrão Pimentel diz: Jà prescreveo a vaidade dos Spartanos que presumião fazer muros dos peitos dos Cidadãos co' seu imenso estrago, \& mostrou a experiencia q' mais seguramente se defendião as Cidades co' reparos de terra desanimada, $q^{\prime}$ co' muros de animados peitos - PIMENTEL, 1993: Summaria Noticia, p. 2).

${ }^{760}$ Carta de Miguel Pereira da Costa... (BAj - Documentos Avulsos no 62 e 65, de 18/06/1710).
} 


\section{Santo Antônio além do Carmo}

Quando Maurício de Nassau tentou invadir Salvador (1638), deparou com a posição de Santo Antônio Além do Carmo muito fortificada, não conseguindo passar por ela. Não se sabe quando foi assentada a primeira obra defensiva, mas na ocupação de 1624 havia guerrilhas no local. ${ }^{761}$ A documentação não é suficiente para afirmar, mas os holandeses devem ter feito trincheiras avançadas para segurar as incursões luso-baianas. Essa hipótese se apóia na cartografia de Barleus, Civitas S. Salvatoris (publicada em 1647, mas mostrando a cidade entre 1624-5), em que no local aparece um hornaveque. Aos luso-baianos parece que só houve interesse em manter lá uma posição fortificada no governo de Diogo Luiz de Oliveira, posterior à ocupação.
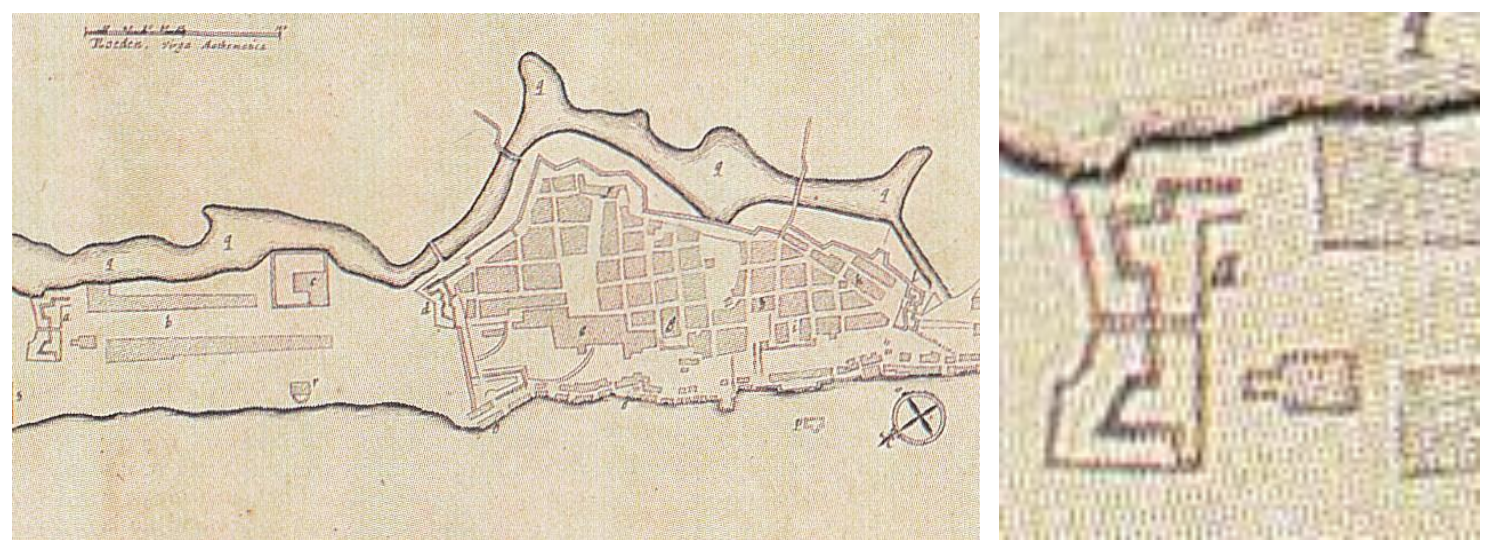

O registro em Barleus de uma fortificação no local do S. A. Além do Carmo à época da ocupação holandesa (REIS FILHO, 2000: 25).

Mirales é quem se refere a essa fortificação em tempo mais antigo, ao falar da tentativa de invasão em 1638 e das providências tomadas pelo conde de Banholo: ... goarnecendo, e fortificando mais hua Trincheira a $q^{\prime}$ pela import. ${ }^{a}$ do Sítio, tinha dado

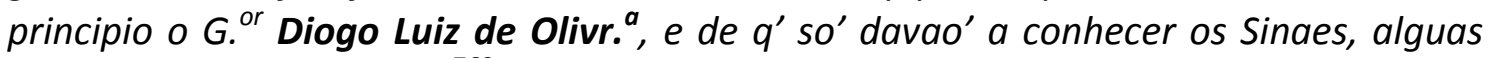
ruinnas $q^{\prime}$ conservavao.... ${ }^{762}$ Mas a cartografia de Barleus mostra que já havia algo construído antes desse governo.

Na carta das fortificações dessa época, há uma construção quadrada defendida por dois hornaveques, um para o norte e um para o sul, fazendo parte da trincheira sustentada por Banholo (ou Bagnuolo), que os holandeses não conseguiram ultrapassar. Não se sabe se a forma foi reproduzida corretamente pelo desenhista, mas as de outras fortificações (em especial a do Forte da Laje) o foram.

\footnotetext{
${ }^{761}$ Segundo Frei Vicente do Salvador, nelas se destacaram Manoel Gonçalves, responsável por incursões ao norte, Francisco Padilha, atacando em todas as partes, Afonso Rodrigues Cachoeira e outros.

762 MIRALES, 1900: 140 (grifos nossos).
} 


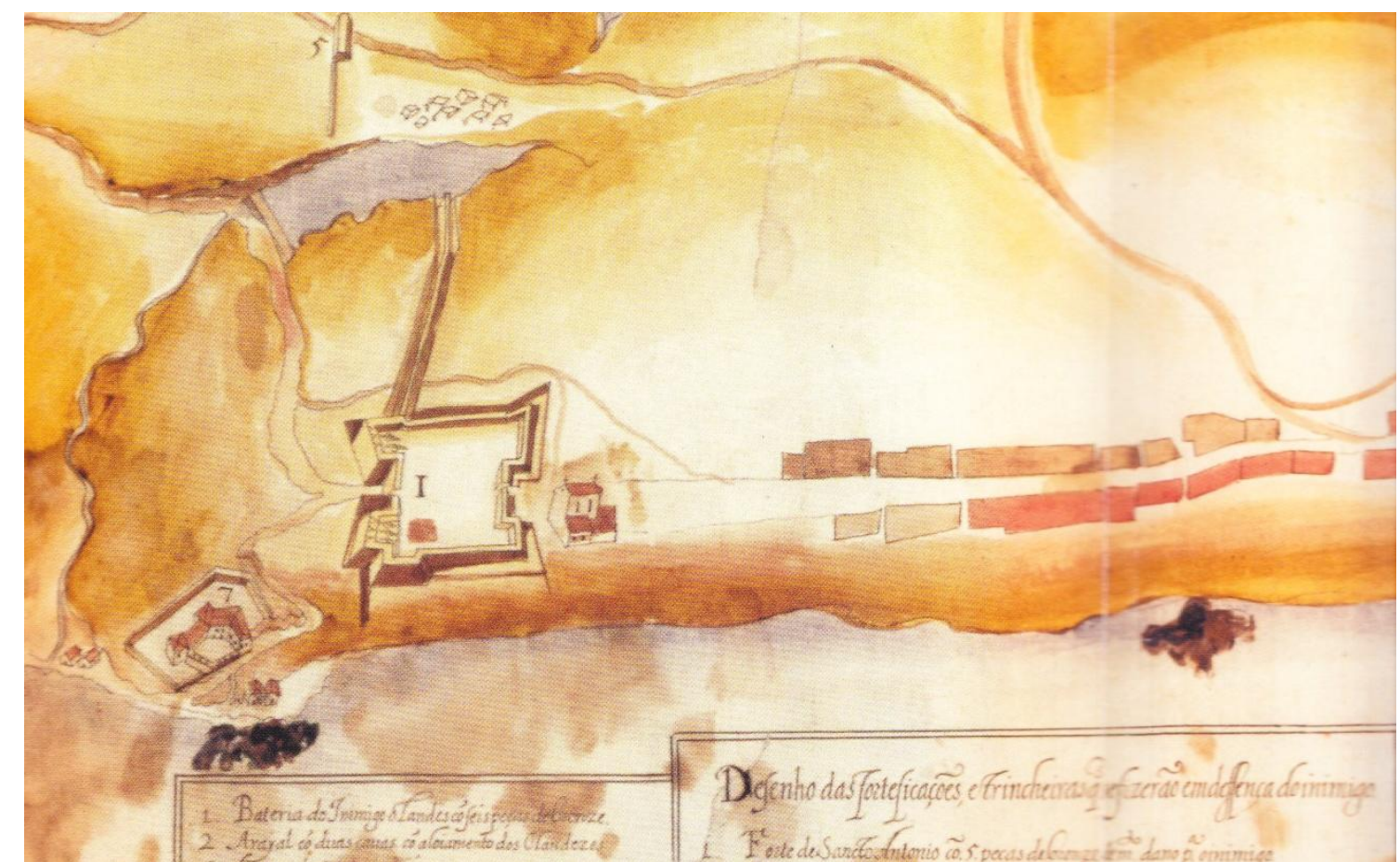

Detalhe do Forte no Desenho das forteficaçoes... (Haia, 1638 - em REIS FILHO, 2000: 32-4). Ao lado dele a Cap. ${ }^{\text {la }}$ de S. $^{\text {to }}$ Ant. $^{\circ}$ allem do Carmo (MIRALES, 1900: 140). À direita, abaixo, sua descrição na legenda: Forte de Sancto Antonio cõ. 5. peças de bronze de to $^{\text {to }}$ dano p. ${ }^{a}$ oinimigo.

A antiga igreja de Santo Antônio (orago que deu nome à fortaleza), ${ }^{763}$ próxima ao centro da praça atual, diminuía a segurança da fortificação (então um reduto) por oferecer um padrasto aos seus atacantes. Mas o crítico Bernardo Ravasco, em geral severo, foi brando com a fortaleza: ainda que não he' regular esta obrado com perfeiçam, em tudo o que o terreno permetio... ${ }^{764}$ Diz ter então sete peças de ferro: uma de $12 \mathrm{~L}$, duas de 10 e quatro de 8 . Por essa artilharia, supõe-se que não era de grandes dimensões.

Uma lápide do edifício diz que no consulado de Francisco Barreto, sob o reinado de $D$. Afonso IV, foram feitas reformas, concluídas em 1659. Mas o relatório anônimo de 1671 (encomendado pelo Gov. A. Furtado de Castro do Rio de Mendonça, 10 Visconde de Barbacena, 1671-5, provavelmente a A. Correa Pinto) diz que naquele ano ainda havia uma construção de terra, que era de boa qualidade.

A construção de pedra e cal deve ser da passagem do século XVII para o XVIII. Segundo Mirales, a reforma foi de D. João de Lencastro e concluída na gestão de D. Rodrigo da Costa (1702-5). Nesse caso, teria trabalhado nela o Sargento-mor Engenheiro Antônio Roiz Ribeiro, que não o fez "porque os esquemas corruptos da Fazenda procuravam afastar este 'indesejável' que não aceitava as negociatas". ${ }^{765}$ Segundo Miguel Pereira da Costa, restou improvisado como engenheiro o capitão de artilharia Francisco Pinheiro, que o Mestre de Campo não considerava competente.

Vimos que no relatório de 1710, Miguel Pereira da Costa descreve a fortaleza já com seus quatro baluartes em ponta de lança (como foi cadastrado por Caldas em

\footnotetext{
${ }^{763}$ Mais antiga, enquanto a nova Igreja de Santo Antônio é possivelmente do século XIX, pois na planta cadastral de Salvador (do Ajudante Engenheiro Joaquim Vieira, em 1798) ainda estava no centro da praça atual.

${ }^{764}$ AHU - Catálogo de Luiza da Fonseca, doc. 2.264 - apud OLIVEIRA, 2004: 221.

765 OLIVEIRA, 2004: 221
} 
meados do século XVIII), ${ }^{766}$ e que pouco depois o relatório da equipe comandada por João Massé fez críticas ao forte, sem sugerir modificações no traçado (era uma obra ainda recente), mas o reforço de obras externas. ${ }^{767}$

\section{$\underline{\text { São Pedro }}$}

Como em relação ao Santo Antonio além do Carmo, há controvérsias sobre a origem do forte e de sua obra avançada, a bateria de S. Paulo da Gamboa. Uma das hipóteses é que junto à ermida de S. Pedro (no mesmo local da atual, mas de terra batida) havia um fortim ou trincheira portuguesa que os holandeses aprimoraram durante a ocupação de 1624-5. Outra, de Vilhena, é que foi feito pelos holandeses: “... pela parte do sul havia hum passo seco entre o Dique e o despenhadeiro para o mar e que para evitar por ali a entrada para a cidade havião os Hollandezes feito de terra o forte chamado hoje de S. Pedro". ${ }^{768}$

O Forte de S. Pedro não está no relatório de Diogo de Campos Moreno (1609) nem no seu Livro que dá Razão... (1612). Também não aparece na descrição de Mirales sobre o desembarque e a tomada de Salvador pelos holandeses, nem na Ânua de Vieira ou nos textos de Bartolomeu Guerreiro, Frei José de S. Teresa ou dos batavos Aldenburgk e Laet. Apenas na cartografia de Barleus, como observou M. Oliveira, ele aparece no local correspondente com o nome F. S. lao. Assim, é bem provável que sua origem seja mesmo holandesa. Se houve algum aparato de defesa antes dos holandeses, teria sido montado entre 1612-24 por Frias de Mesquita, não havendo documentos com essa referência (como há sobre a reforma do Forte da Laje).

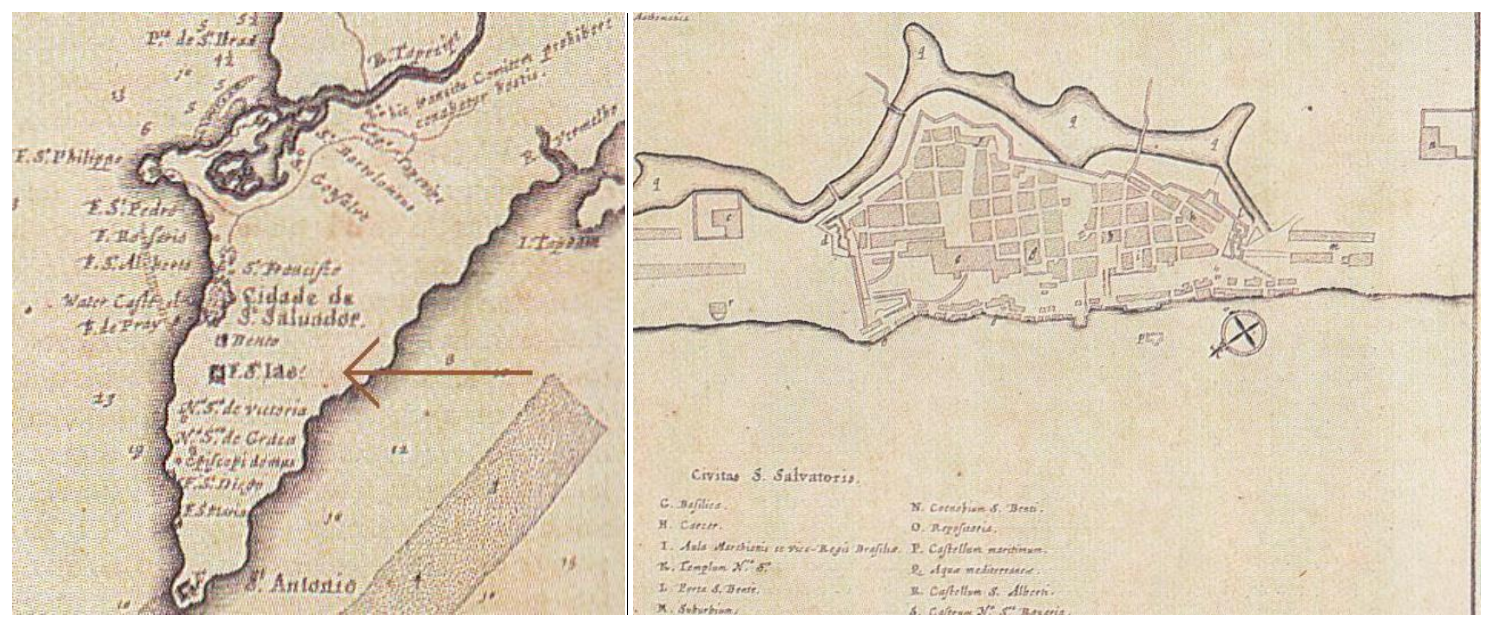

Dois detalhes da cartografia de Berleus (c. 1624, publicada em 1647 - cf. REIS FILHO, 2000: 25, TEIXEIRA \& VALLA, 1999: 238 e site da $B N L)^{769}$. O detalhe da planta da cidade, à direita, chega apenas até 0 quadrado que representa o Coenobium de S. Benti.

\footnotetext{
766 ... ao alto em q' fica a Igreya de S. An. ${ }^{\text {to }}$; quazi no nivel da cid. ${ }^{\text {e; }}$ está o forte de S. An. ${ }^{\text {to }}$ do Carmo, exterior a forteficação da cid. ${ }^{\text {; }}$, he um quadrado com quatro baluartes... (Extracto da forteficação...).

767 ... he comveniente no alto lateral as de S. An. ${ }^{\text {to }}$ e mais avançado ao do Barbalho fazer hua coroa que oculpe aquelle terreno, e fique defendendo a pasagem... (Relatório dos engenheiros..., fl. "15-B").

${ }^{768}$ VILHENA, 1922: 235.

${ }^{769}$ Bibl. Nac. Digital - http://purl.pt/4129.
} 
Silva Campos considera que foi construído no governo de Antônio Teles da Silva (1642-7), citando a portaria de 1646 com a reforma que o transforma em um "forte real". ${ }^{770}$ Mas a referência segura mais antiga ao forte é de Bernardo Ravasco:

O dito forte de Sam Pedro, he' regular, e esta accabado co' toda aperfeiçam, tem somente quatro peças de ferro, duas de 12 L. $^{\text {as }}$ e 2 de 9 . he capaz de 16. Esta nelle o Sarg. ${ }^{\text {to }}$ mor Francisco de Letur (Françes de nação) que foi o do Terço do Mestre de Campo Theodosio Hostratem. ${ }^{771}$

Em 1661, no governo de Francisco Barreto, o forte de terra tinha um acesso precário em madeira. Uma portaria ordenou que fosse feito de pedra e cal. Supõe-se que por descaso administrativo e proximidade de propriedades agrícolas houve danos comprometedores nas construções de terra (animais de criação invadiam os fossos e terraplenos; uma portaria de 1669 ordenava ao comandante que matasse as reses). ${ }^{772}$ Depois da referência de Bernardo Ravasco, ele aparece no relatório anônimo das fortificações (c. 1671), que é mais informativo:

O Forte São Pedro he fabricado de Terra, o milhor e o mais regular que ha nesta praça, e dos de maior ymportancia della, porque domina toda a campanha da parte do Sul: fecha os caminhos que vem das prayas de S. Diogo e S. Ant. ${ }^{\circ}$ e Porto do Rio Vermelho, e segura a yminencia em que está. Ao pe della se primcipia hum dique [Grande, ou do Tororó], que pela parte extirior vay cingindo todas as fortificacons Reaes que ocupam as colinas, a que a praça fica ymfirior as defenças na inclusa, nem outra que esta da banda do Rio Vermelho (ambas mui precizas a conservação do mesmo dique q' eh a principal segurança das fortificacons gerais), tem defença alguma. O forte esta em sua prefeição; mas por dous lados sem cava, pela ymcapasidade do terreno; e por causa dele he coase ymfirior a huma yminencia vizinha. ${ }^{773}$

O restante do documento indica que era uma fortificação taticamente limitada, bem menor que a atual e de pouca capacidade de fogo (a mesma descrita por Ravasco). No governo de Roque da Costa Barreto (1678-82) houve reparos substanciais no forte, como está no parecer dos engenheiros do reino sobre o relatório de João Coutinho:... esta cidade tem som. ${ }^{\text {te }}$ duas entradas, e são aonde esta o Forte de são Pedro, $q$ he feito tambem de terra, já foy reparado em tp. ${ }^{\circ}$ do Gov. ${ }^{\circ}$ de Roq.e da Costa Barreto h'u grande lanço... ${ }^{774}$

Se o relatório de 1671 já falava em seu significado estratégico, João Coutinho esmiuçou o assunto com base na morfologia do terreno e no episódio holandês para dizer que Salvador dificilmente seria tomada pelo porto (mesmo vencidas as fortificações do mar e feito o desembarque, seria difícil subir sob fogo cerrado a escarpa que liga a Cidade Baixa à Alta), restando a investida pelo sul (com desembarque na Barra ou do Rio Vermelho a Itapuã), ou pelo norte da cidade (desembarcando dentro da baía, longe das artilharias, como tentou Nassau em 1638). Por essas hipóteses, ficava evidente a importância do Forte São Pedro. Vê-se na planta do projeto de fortificação de Massé (1715) o Dique Grande (ou Tororó) indo até a

\footnotetext{
${ }^{770}$ CAMPOS, 1940: 137. Depois salta para 1712, como se fosse a mesma obra, falando da conclusão do fosso, para em seguida dizer que "dez anos mais tarde, em 12 de agosto de 1723, no consulado do vicerei Vasco Cesar, foi que ficou terminado".

${ }^{771}$ AHU - Catálogo de Luiza da Fonseca, doc. 2.264. Relatório de Bernardo Ravasco (11/09/1660) - apud OLIVEIRA, 2004: 214.

772 Cf. OLIVEIRA, 2004: 216.

773 DSE - Biblioteca. Relatório anônimo. Códice 1608 - apud OLIVEIRA 2004: 214 (grifos nossos).

${ }^{774}$ Relatório de João Coutinho, fl. 123 v (AHU - Documentos Avulsos, Bahia, Cx. 8, doc. 29).
} 
Ladeira da Fonte, ficando um espaço pequeno que era coberto pelas armas do forte. ${ }^{775}$ Na direção da baía só havia o despenhadeiro e o mar.

Mas não houve grande novidade no forte (nem em outras fortalezas) até a época do Discurso do Secretário de Estado Bernardo Vieira Ravasco, ${ }^{776}$ no final do século XVII. No início do XVIII foi feita a reforma em que provavelmente se ampliou a primitiva construção de terra batida (ou gazon) com o Mestre de Campo Miguel Pereira da Costa, que foi responsável pela reconhecida importância do forte, depois de considerá-lo em estado insuficiente para as necessidades. ${ }^{777}$

No relatório de Miguel Pereira da Costa (1710), ele era ainda... de terra e pequeno. O Mestre de Campo orientou algumas melhorias, que seriam anteriores, portanto, à vinda do Brigadeiro João Massé:... se deve revestir com húa camiza de muralha, de pouca grosura. ${ }^{778}$ Já no relatório conjunto de Miguel Pereira com Massé e Gaspar de Abreu (1715), é dito: [Item 2]... na outra entrada de S. . $^{\circ}$ estâ o forte do mesmo santo revestido de muralha the a altura do cordão - o citado encamisamento de pedra. ${ }^{779}$

Nesse relatório (1715), sua importância é bastante reconhecida: dado que dezembarquem [os inimigos] contra toda a opozição, e q da mesma sorte continuem a sua marcha; no Forte de S. $\boldsymbol{P}^{\circ}{ }^{\circ}$ acharão hua grande rezistencia... ${ }^{780}$ Massé era seguidor de Vauban, procurando em seu projeto enfatizar o caráter sistêmico (traço característico da escola francesa) a ser dado ao forte. É provável que seja também de sua autoria a bateria de S. Paulo da Gamboa, articulada ao Forte de S. Pedro como parte de um complexo de defesas ao sul da Cidade.

O projeto de Massé também melhorou o bloqueio da passagem, prevendo uma cortina na direção da escarpa (fazendo assim a articulação com a bateria de S. Paulo, no nível do mar). O desenho dessa cortina foi ligeiramente alterado nos ângulos reentrantes e salientes, como mostra esta figura de cadastro da passagem do século XVII para o XVIII, com todas as obras externas. O perímetro de defesas internas contaria com o velho dique dos holandeses, que seria restaurado.

\footnotetext{
${ }^{775}$ Cf. OLIVEIRA, 2004: 215.

${ }^{776}$ Cf. BME - Códice CV/1-17 fl. 293 (o discurso de Bernardo Vieira R. começa na fl. 285). Bernardo Ravasco foi Secretário de Estado e Guerra do Brasil (o segundo cargo mais importante da Colônia, só abaixo do de Governador Geral) desde 1649, falecendo em 1697.

777 Cf. OLIVEIRA, 2004: 216-7.

${ }^{778}$ Extracto da forteficação... BAj - Documentos Avulsos [54-IX-8] no 60 - fl. 34 v.

${ }_{779}$ AHU - Documentos Avulsos, Bahia: Cx. 8, doc. 29 - fl. 22 da transcrição.

${ }^{780}$ Idem, fl. 15B da transcrição.
} 


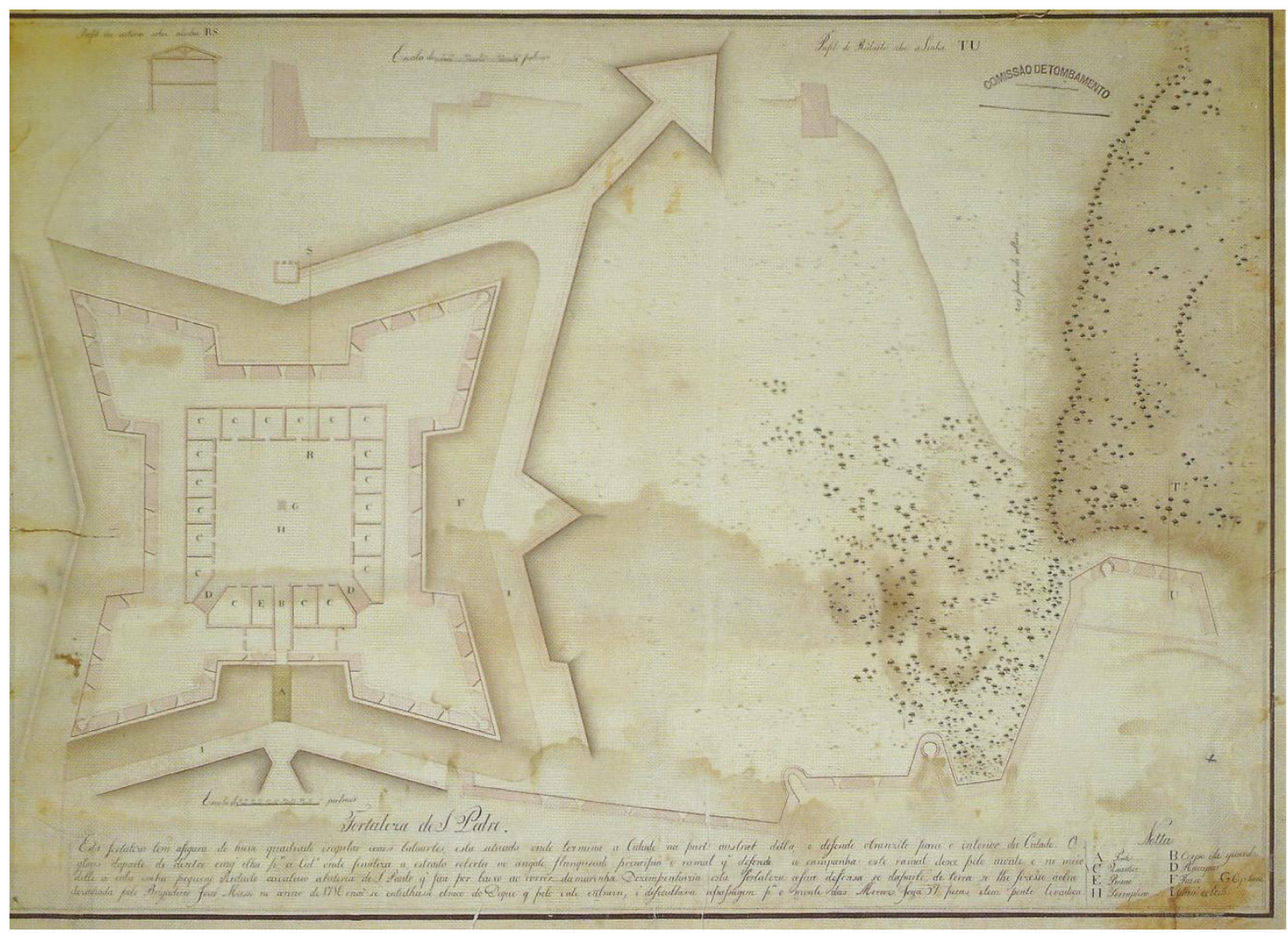

Planta e perfil esquemático do Forte de S. Pedro (do AHM, reproduzida em OLIVEIRA, 2004: 215 - a sudoeste, a estrada coberta e a cortina de proteção de acesso à Bateria de S. Paulo da Gamboa). O partido da fortificação regular, de quadrilátero com quatro baluartes em ponta de lança (duas faces e dois flancos), como já era o do primitivo forte de terra, só foi mais divulgado depois das invasões dos holandeses, que eram grandes fortificadores. Os teóricos Dögen, Marolois, Stevin, Freitag e outros influenciaram decisivamente os engenheiros portugueses no século XVII, inclusive o tratadista e Engenheiro-mor do Reino Luís Serrão Pimentel.

Em 1716 o Vice-rei Marquês de Angeja informou ao Rei: O Forte de S. Pedro estâ já com os parapeitos, e sô lhe falta o entulharse para se Ihe asentar as batarias. ${ }^{781}$ Quando Massé foi trabalhar em Pernambuco, as obras no Forte S. Pedro prosseguiram. Portaria de 1717 solicitou ferramentas ao Mestre Domingos Gonçalves, e no ano seguinte, mais ferramentas para a faxina a cargo dos Ajudantes Engenheiros. ${ }^{782} \mathrm{Em}$ 1719, os trabalhos continuavam intensos, com os Coronéis Sebastião da Rocha Pita e Domingos da Costa de Almeida (incumbidos da faxina da fortaleza) recebendo Portaria... mandando os soldados das Companhias dos seus regimentos escravos seus a trabalhar nas ditas faxinas não obrigarão aos ditos soldados a que vão com as suas pessoas assistir o dito trabalho (privilégio dos soldados ricos). ${ }^{783}$ Nesse ano também foram ordenadas mais ferramentas ao Provedor para os Ajudantes Engenheiros.

\footnotetext{
781 Idem, fl. 6A-7A da transcrição.

782 Segundo Oliveira (2004: 217), “certamente os baianos Gonçalo da Cunha Lima e João Batista Barreto", ex-discípulos da Aula Militar da Bahia.

783 BN - Documentos históricos, 1945, v. 68, p. 262. Cartas Régias (1681-1690), Portarias (1719-1720). Documento de 03 de agosto de 1718 - apud OLIVEIRA, 2004: 217 e 254. M. Oliveira acredita que pouco depois a cortina do baluarte sul (próximo ao atual portão do fundo) tenha ruído e foram possivelmente autorizados reparos (o professor, também especializado em restauro, orientou a remoção do reboco na parte inferior da muralha, notando que havia um aparelho irregular da alvenaria, diferente dos outros baluartes). Os reparos foram autorizados provavelmente em 1726.
} 
Em 1720 (gestão do vice-rei Vasco Fernandes), com a obra adiantada, ordenouse a medição ao Mestre de Campo Miguel Pereira (acompanhado do Provedor-mor e Procurador da Fazenda) para pagamento dos empreiteiros. Em 1721, para que os fortes de S. Pedro e do Mar fossem postos em sua última perfeição, foi ordenado que se sustasse a obra do Barbalho, também em andamento. Enfim em 1723 (12/08, segundo a placa comemorativa) se inaugurou a modernização do Forte de $\mathrm{S}$. Pedro, mas que em poucos anos precisaria de reparos (como acontece em muitas obras púbicas). A documentação atesta a autoria do Mestre de Campo Miguel Pereira da Costa. Diz sua petição de promoção: Ha 16 annos, que serve com o posto de Mestre de Campo com o cuidadozo zelo q mostra ter acabado á fundamentis o Forte de S. Pedro com todas as suas obras exteriores até a ultima perfeição. ${ }^{784}$

O relatório de Muniz Barreto narra a decadência do Forte de S. Pedro:

Esta Fortaleza se deu por inutil em tempo que governava a Bahia Manoel da Cunha de Menezes [17749], e por isso achou [sic - a dou?] no meu Mappa como demolida. Por este errado projeto se lhe mandou levantar dentro hum aquartelamento para o Regimento de Artilheria. Com esta intempestiva obra, hé que ficou inutil, e só lhe achava o defeito de ser necessario, pela sua grandeza, muita gente para a guarnecer. Isto porem se deveria remediar, com se fazêr ter a hum dos Regimentos de Infanteria Auxiliar exercicio de Artilhar. ${ }^{\text {, }}$, fazendo-se-lhe duas vezes no mez exercicio, em huma dia Santo de arma, e em outro de pessa.

Tanto hé de grande utilid. ${ }^{\mathrm{e}}$ este For- [fl.17v] Forte, que se elle estivesse construido no tempo que os Holandezes forão Senhorar-se daquella Capitania, não terião o passo desembaraçado, para sem obstaculo algum fazerem a sua marcha, desde, desde o Rio vermelho [?] (praia q'. fica antes de penetrar a barra) até o interior da Cidade. ${ }^{785}$

\section{Bateria de São Paulo (Gamboa)}

Embora a Gamboa, ou "Camboa", porto e povoado de pescadores, seja antiga (talvez anterior à fundação de Salvador), não há referências à Bateria da Gamboa, obra avançada do Forte de S. Pedro, até o século XVIII. ${ }^{786}$ Concebida no projeto de fortificações de 1715, ela reforçava o sistema da fortaleza, que segundo Muniz Barreto... para a parte do Mar hé pouco offensiva, não só por ficar longe do canal, mas por estar algum tanto a Cavalleiro do nível d'agoa. ${ }^{787}$

\footnotetext{
${ }^{784}$ AHU - Documentos Avulsos, Bahia: 005, Cx. 35 D. 3176 (CD5, 38, 002, 228-34).

785 Observaçoens Sobre a Fortificação... BMP - Mss 686, Brasil (1797) - fl. 17-17 v. Com mais de trezentos anos, o forte nunca atirou contra inimigos externos, mas acompanhou ou participou de todos os movimentos armados ocorridos na cidade: as "conspiratas libertárias" lideradas por Pedro de Freitas Guimarães (1819, dentro do forte), o "prelúdio" da Guerra da Independência (1821), a própria Guerra (1823), a amotinação do Batalhão dos Periquitos (1824), a Sabinada (1838) e a revolta do 19 Batalhão (1923, transferindo-se a tropa, durante a 2a Guerra Mundial, para o novo quartel da Narandiba). Também recebeu visitas importantes como D. João VI e Pedro II. Em 1897 chegou-se a noticiar sua venda ou cessão ao município, com a ameaça de ser demolido (cf. OLIVEIRA, 2004: 213).

O aparente descaso da transformação da fortaleza em quartel está associado ao crescimento da cidade, que sufocou a "velha praça de guerra" tirando seus campos de tiro, como aconteceu com outros fortes. Silva Campos explica que reformas urbanas maiores, a partir do início do século XX, vieram a "mutilar e desfigurar" as suas obras externas (cf. CAMPOS, 1940: 155).

${ }^{786}$ Cf. OLIVEIRA, 2004: 219 Por causa do nome do porto, alguns autores chegam a dizer que ela é da primeira metade do século XVII, mas segundo Oliveira, "em nenhuma lista ou levantamento de fortificações elaborados até o século XVIII aparece qualquer referência".

787 Observaçoens Sobre a Fortificação... BMP - Mss 686, Brasil (1797) - fl. 17. Muniz Barreto faz confusão ao dizer que além de suprir essa deficiência, a Bateria de S. Paulo... hé muito util para impedir
} 
Disparando no nível do mar, era uma defesa realmente eficiente, compensando a pequena limitação do Forte de S. Pedro. O Mestre de Campo Miguel Pereira da Costa credita sua autoria e execução de projeto ao Cap. João Teixeira de Araújo:

... querendo dar princípio a Bataria de Sam Paulo na marinha por baxo do Forte de Sam Pedro encarreguei a sua construção ao Cap. ${ }^{a m}$ Eng. ${ }^{\circ}$ João Teixr. ${ }^{a}$ de Araujo, o q. ${ }^{\text {al }}$ deu a execução a minha instrução que the dei para aquella obra, fazendo executar nella tudo o que lhe foi encarregado athe a por na sua ultima perfeição. ${ }^{788}$

\section{Barbalho}

Sobre a cornija de sua entrada principal, uma epígrafe solene, lavrada em lioz português, parece definir a autoria da Fortaleza do Barbalho, a maior e das mais ilustres de Salvador:
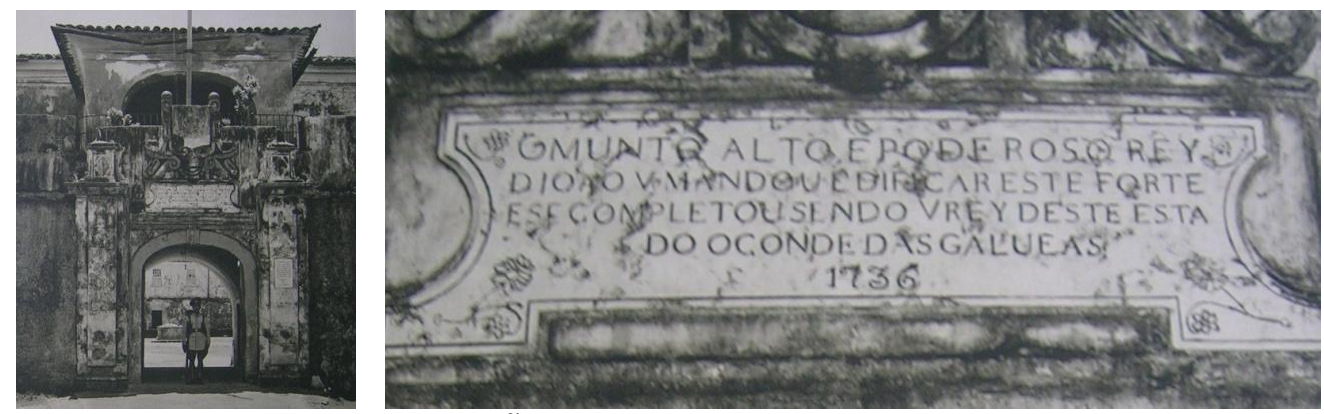

O MUNTO ALTO E PODEROSO REY D. JOÃO V MANDOU EDIFICAR ESTE FORTE E SE COMPLETOU SENDO VREY DESTE ESTA DO O CONDE DAS GALUEAS 1736 (fotografias em FALCÃO, 1949: 41-2).

Mas há divergências entre os historiadores sobre o verdadeiro autor. Concordase, em geral, que a primeira obra fortificada no local foi do pernambucano Luiz Barbalho, que chegou com sua tropa do Rio Grande do Norte e foi decisivo na luta contra os holandeses, comandados pessoalmente por Maurício de Nassau. Foi preciso fortalecer a posição porque os batavos haviam instalado baterias no outeiro do Padre Ribeiro (ou Bartolomeu Ribeiro, hoje "Soledade"), apontadas contra as defesas ao norte da Cidade, e ameaçavam com repetidos ataques de tropas as fortificações lusobaianas. Luiz Barbalho pode ter feito a partir dali o movimento de ataque pela retaguarda, causando enorme confusão e levando os inimigos a desistir da invasão. ${ }^{789}$

Para Silva Campos, ${ }^{790}$ Luiz Barbalho teve de preparar essa primeira trincheira de modo ultra-rápido, contando com 1000 homens. Mas pela representação na cartografia de 1638, já seria um reduto. Ainda segundo esse autor, no governo de Alexandre de Sousa Freire (1667-71), o Cap. de Mar e Guerra João Calmon "reedificou sob melhor traço e mais segura fábrica" o forte pelo que havia de ameaça holandesa, mas ele era ainda de terra. ${ }^{791}$ Entre outros documentos que atestam isso estão os comentários do Cap. João Coutinho sobre a defesa da Cidade.

o desembarque da praia do Unhão, e protege $m .{ }^{\text {to }}$ os fortes de S. Diogo, e S. ${ }^{\text {ta }}$ Maria, e de muito melhor modo o fará se forem demolidos, e se construir de novo húa Fortaleza regular, como ficou dito. Tem cavalgadas 19 pessas de ferro do Calibre de 24 (fl. $17 \mathrm{v}$ ).

${ }_{788}$ AHU - Documentos Avulsos, Bahia, 005, Cx. 33, D. 3039 (CD4, 36, 002, 311-40).

${ }^{789}$ Cf. OLIVEIRA, 2004: 224.

${ }^{790}$ Cf. CAMPOS, 1940: 168-79.

${ }^{791}$ CAMPOS, 1940: 169. 
O Cap. Eng. João Coutinho foi o responsável por uma "revolução total e radical" no desenho do forte, ${ }^{792}$ considerando-o de suma importância (mas depois de sua morte em Pernambuco, ficou tudo no mesmo ser em relação ao projeto). Como vimos, ele escreveu:

... me resolvo a dizer, q se deve conservar o Forte de São $P{ }^{\circ}$ fazerse de pedra e cal e o mesmo no de $S .{ }^{\text {to }}$ Ant. ${ }^{\circ}$ do Carmo, e no oiteiro do Barbalho fazer outro mais capaz q qualquer destes, $q$ tenha ao menos 400 pes $\left[132 \mathrm{~m}\right.$ ] de lado de poligono exterior, ... o qual ponho mais chegado ao extremo do Adiq. ${ }^{e}$, p. $^{a}$ o descobrir melhor... ; e tambem porq... deste lugar fica cruzando bem as balas co' o de S. ${ }^{\text {to }}$ Ant. ${ }^{\circ}$, e impedindo o não passar o inimigo por entre ambos... ${ }^{793}$

Só no século XVIII algumas de suas idéias seriam colocadas em prática, entre elas a de fazer o Barbalho mais poderoso que os fortes de $\mathrm{S}$. Pedro e S. Antônio. $\mathrm{O}$ polígono externo ficou ainda maior, com 500 a 600 pés (165 a $198 \mathrm{~m}$ ). O Mestre de Campo Miguel Pereira e seus comandados construíram algo próximo ao sugerido por Coutinho, tendo ainda o fosso com escarpa e contraescarpa. Nas plantas mais fiéis e pela espessura do parapeito se nota que a cortina no lado norte é mais espessa na direção de maior probabilidade de ataque. ${ }^{794}$
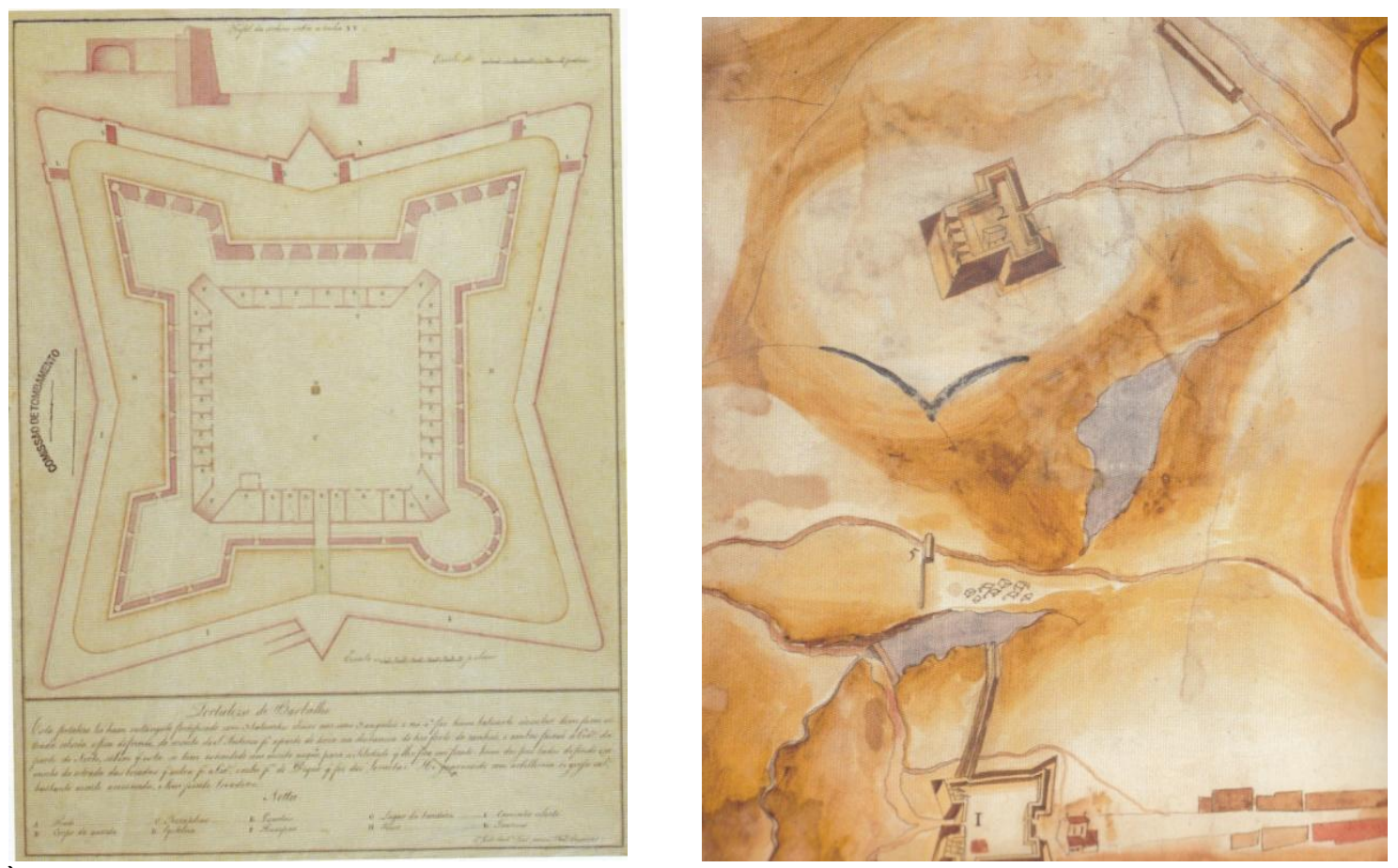

À esq., desenho (planta e corte parcial) do 10 Ten. João da Silva Leal Teixeira (AHM, Ba-28/ OLIVEIRA, 2004: 228). À dir. detalhe do reduto anterior na planta de Haia (abaixo o de S. A. além do Carmo - em REIS Fo, 2000: 32).

Depois do destaque dado à posição do forte pelo Cap. Eng. João Coutinho, isso passou a ser mais comentado nos documentos. Bernardo Ravasco, que não se referiu à fortaleza em 1660, mencionou providências requeridas pelo Marquês das Minas:

\footnotetext{
792 OLIVEIRA, 2004: 225.

793 Relatório de João Coutinho (1685) - AHU - Códice Ms 245, Bahia, fl. 125.

${ }^{794}$ Cf. OLIVEIRA, 2004: 225
} 
Tornou o Márquez a mostrar, por outro Papel, quantas imposibiliades o empedião, e com se porem as Fortificações em sua prefeyção, fabricarsse hum Forte de Torrão na eminecia q' chamão do Barbalho, emportantissimo, e reedificar os de S. Pedro, e Morro, de Pedra e Cal, pella parte aruynada. ${ }^{795}$

No século XVIII se intensificaram medidas para fazer a nova fortaleza no Barbalho. Mirales atribui a iniciativa ao Marquês de Angeja, ao falar das atividades de sua gestão: "... fazendo dar nova fr. ${ }^{\text {a }}$, e mayor grandeza ao de N. S. ${ }^{a}$ do Monte do Carmo, chamado de Barbalho, q. ${ }^{\text {e }}$ está adiante do Forte de $\mathrm{S} .^{\text {to }}$ Ant. ${ }^{\circ}$ alem do Carmo...". ${ }^{796}$ O nome da elevação se relaciona ao fato do terreno ter sido dos Carmelitas, que o cederam à Coroa para a nova fortaleza. ${ }^{797} \mathrm{~A}$ implantação de medidas para a ampliação vem do governo anterior, de Pedro de Vasconcelos e Sousa, que enviou ao Conselho Ultramarino e ao Rei uma Lista das fortallezas e Redutos que ha nesta Praça da B. ${ }^{a}$, seus Arrebaldes e recôncavo, em que declara:

O forte do Barbalho, que he de torrão se achava com bastantes ruinas, se obrigou Joseph Lopes de Brito a reedificallas á sua custa, e mandar fazer de pedra e cal todas as obras, que apontou o Tenente General Enginhr. ${ }^{\circ}$ [Miguel Pereira da Costa]; e pello serviço que fas a V. Mag. ${ }^{\text {de }}$ vista a importancia do mesmo forte, por estar em hum Sitio que serve de padrasto a Fortalleza de Santo Antonio alem do Carmo; me paresse se lhe deve passar patente de Capitão com Soldo de $4 \$$ [mil] rs. por mes. ${ }^{798}$

A maior parte construção do Barbalho ocorreu no governo de D. Vasco Fernandes César de Menezes (1720-35), mas a inauguração foi em 25/08/1736, já na gestão de D. André de Melo e Castro (1735-49). As obras foram conduzidas pelo M. de Campo Eng. Miguel Pereira da Costa, que muitas vezes prestava contas diretamente ao Rei. Ele enfrentou os percalços de uma construção gigantesca, tendo de fazer as medições, acertar divergências de competência entre os empreiteiros, ${ }^{799}$ enfrentar pressões de atraso no pagamento e até paralisação da obra (o Rei dava prioridade às obras concomitantes do S. Pedro e do S. Marcelo).

\section{$\underline{\text { Reduto do Camarão }}$}

No século XVII, o reduto tinha prestígio e era importante na defesa norte da cidade. Silva Campos explica que na segunda guerra holandesa, enquanto Luiz Barbalho levantava nas vizinhanças a primeira trincheira do forte que recebeu seu nome, "o celebrado índio Dom Antonio Filipe Camarão edificava um fortim em eminência próxima do campo inimigo, donde o descortinava". ${ }^{800}$ Segundo Campos, Brito Freire estimava em "mil passos" (720 m) a distância entre as duas defesas.

No relatório do "Projeto Massé" se destaca a importância do reduto no contexto geral da fortificação. Há documentos anteriores a 1715 que registram trabalhos de reparação: uma portaria ordenou ao Capitão-mor do Terço de "gente preta" (os soldados abastados podiam mandar escravos para os trabalhos pesados)

\footnotetext{
795 BME - CV/1-17. FI. 293. Discurso de Ravasco - apud OLIVEIRA, 2004: 225 e 255. Em outra passagem da carta, Bernardo chegou a fazer "um apelo patético" (OLIVEIRA, 2004: 225) para que o Rei olhasse a sua Colônia e em particular para o Forte do Barbalho.

796 MIRALES, 1900: 164.

797 Antiga documentação mostra que na área havia um sítio onde se matava gado (Sítio Matança) - cf. OLIVEIRA, 2004: 226.

${ }^{798}$ AHU - Documentos Avulsos, Bahia: 005. Cx 9, D. 741 (CD2, 9, 003, 551-62).

${ }^{799}$ Cf. BN - Documentos Históricos, 1945, v. 68, p. 266/ OLIVEIRA, 2004: 227.

${ }^{800}$ CAMPOS, 1940: 271-2
} 
enviar soldados para a faxina, época em que Miguel Pereira da Costa indicava as providências. Como vimos, o $2 \%$ item do relatório diz: E alem deste [Forte do Barbalho] $p^{a}{ }^{a}$ a mesma $p^{\text {te }}$ estâ outro, chamado do Camarãm $q$ he hum reducto de terra, no monte, $q$ olha as [sic] tanque dos Padres da comp. ${ }^{a} . . .801$ No 8 o item é feita uma recomendação: $O$ reducto do Camarão se deve reparar pois fica avançado $p^{a}{ }^{a}$ aquelle lado sobre a quinta, do tanque dos $P .^{\text {es }}$, servindo de Atalaya $p^{a}{ }^{a}$ observar algum movim. ${ }^{\text {to }} q$ por aquella $p .{ }^{\text {te }}$ se intente... ${ }^{802}$ Pelo valor do orçamento $-12.600 \$ 000 \mathrm{rs}-$ seria uma posição fortificada importante. ${ }^{803}$

Provavelmente não houve levantamentos cadastrais do forte. Sua imagem é a da planta do "Projeto Massé", de cópia no Arquivo Histórico do Exército (RJ):

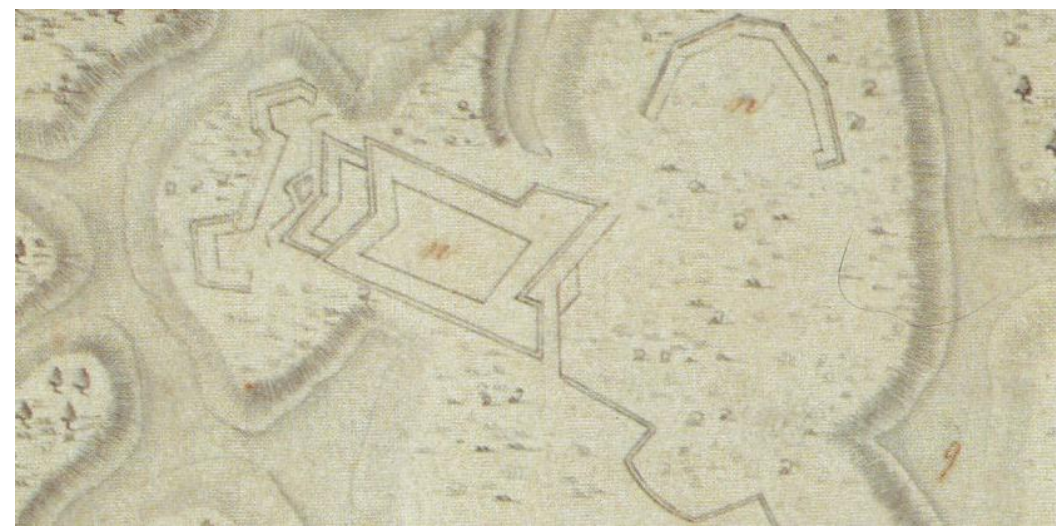

Detalhe da PLANTA DA CIDADE DE S. SALVADOR..., cópia manuscrita do AHM, c. 1715 (em REIS Fo, 2000: 31). Na descrição de Mário Oliveira (2004: 241), "um quadrilátero típico dos redutos, de composição irregular, com dois meio-baluartes para o sul e uma tenalha simples para o norte, reforçada externamente por outra tenalha e um pequeno revelim".

No desenho há obras externas, que pela topografia seriam baterias baixas de dois baluartes interligados por uma cortina. É mais provável que as obras não tenham seguido o desenho. Na planta de Salvador de 1779 ele aparece como um simples quadrilátero, sem defesa externa. ${ }^{804}$

Em 1734 o Sargento-mor Nicolau Abreu de Carvalho foi incumbido de inspecionar o novo reduto, mas não se conhece o relatório. Supõe-se que recebeu obras em seguida. Em 1776, Diogo Alves Branco solicitou ao Conselho Ultramarino uma segunda via da Carta Patente de confirmação de comando do Camarão. ${ }^{805}$ Ele ainda solicitou a D. Maria, muitos anos depois, o posto de sargento-mor do forte. Diogo era pai de Domingos Alves Branco Muniz Barreto, que comandou por algum tempo as obras do Morro de S. Paulo e escreveu relatório sobre as Fortificações da Bahia, em que diz (1797) sobre o fortim do Camarão:

Está de todo lançado por terra, sem signal algum, de q' alli houve fortificação, ao mesmo tempo, q' tanto este, como Forte do Barbalho sempre forão húas das orincipaes Fortificaçoens, $q^{\prime}$ conservarão em

\footnotetext{
${ }^{801}$ Relatório dos engenheiros... (AHU - Documentos Avulsos, Bahia: Cx. 8, doc. 29), fl. 11.

802 Idem, fl. 16.

803 Idem, fl. 26. Mas nota-se que é um valor conjunto ao da reforma do Barbalho: $P$. $^{a}$ reparar os fortes do Barbalho, e do Camaram revestindo-os de muralha... 12.600.

${ }^{804}$ Cf. OLIVEIRA, 2004: 241.

${ }^{805}$ Id. ibid.
} 
bom estado os Holandezes, para impedir a entrada para o interior da Cidade, pelo facil desembarque das praias da [sic] Itapa- (fl.23) Itapoam. ${ }^{806}$

Também Vilhena, no fim do século XVIII, ao tratar do Forte do Barbalho já se refere ao reduto do Camarão como algo do passado: “... onde havia um fortinho chamado do Camarão o qual defendia hum braço do Dique Superior que hoje erradamente está servindo de hortas, entulhado já pelos jesuítas...". ${ }^{807}$

\section{Casa da Pólvora dos Aflitos}

Foi o edifício que sucedeu, no início do século XVIII, a já em ruínas Casa da Pólvora do Desterro, passando a fazer parte do sistema fortificado da cidade e produzindo a pólvora, que era fundamental às outras defesas. ${ }^{808}$ Quando foi construída havia a necessária distância do tecido urbano habitado (pelo risco de explosões e incêndios). Miguel Pereira mostra que o projeto veio do Reino, e que uma das portas (portaléus) copiaria a figura de Serrão Pimentel:

... e p. ${ }^{a}$ a fabrica nova de polvora q aqui se fes: vierão desse reino 3 plantas $p$. $^{a}$ se fazerem as oficinas divid. $^{\text {as }}$ por cauza dos incendios, q costuma haver; e não obst. ${ }^{\text {e }}$ serem feitas por um raro engenho, em andadas pelo con. $^{\mathrm{co}}$; o Pinhr. ${ }^{\circ}$ cá contraponteou, e se fez tudo yunto por húa sua; nella pos uma húa portas das duas q o Meth. ${ }^{\circ}$ trás suas fig. ${ }^{\text {as }}$, em q se esmerou gastd. ${ }^{\circ}$ nella 1000 r.s, qd. ${ }^{\circ}$ esta caza de polvora podia ter menos porta, e mais agua, pois lhe esqueseu fazer cisterna, tendo vão capas p. ${ }^{a}$ tudo... ${ }^{809}$

No desenho do edifício se nota não haver terraplenos e lugar para peças de artilharia (os baluartes não eram terraplenados para trabalhar com artilharia mais pesada), já que os espaços internos eram utilizados na preparação da pólvora. Mas talvez também servisse de apoio, com armas leves, à cortina que descia do São Pedro para a Bateria de S. Paulo da Gamboa. ${ }^{810}$

\section{Obra ligada à defesa da cidade: o Fortim do Rio Vermelho}

Esta vigia estava deteriorada no início do século XVIII, levando o Rei a determinar a D. Rodrigo da Costa a restauração de velhas trincheiras de terra (ocasião em que foram ordenadas as construções do forte da praia nas vizinhanças da Casa da Torre, das defesas da Barra de Camamu e da ampliação do sistema fortificado do Morro de São Paulo). Sua origem remonta ao tempo em que foi construída uma vigia de sinalização da presença de embarcações vindas do norte. Sobre ela há muitas suposições e alguns fatos concretos, mostrados na série Documentos Históricos da Biblioteca Nacional de Lisboa.

\footnotetext{
${ }^{806}$ Observaçoens Sobre a Fortificação..., BMP - Mss 686, Brasil (1797), fl. 22v-23.

${ }^{807}$ VILHENA, 1922: 237.

${ }^{808}$ Em Portugal, destacava-se a Real Fábrica de Pólvora de Barcarena, que funcionou do século XVI ao XX (provavelmente havia uma grande diferença entre os investimentos feitos nos dois locais). Silva Campos está entre os que não consideram a Casa da Pólvora dos Aflitos uma fortificação, excluindo-a de suas pesquisas.

${ }^{809}$ Carta de Miguel Pereira da Costa ao padre... BAj-Documentos Avulsos [54-XI-25] no 65, fl. 31v.

${ }^{810}$ Cf. OLIVEIRA, 2004: 230.
} 
A primeira referência à Vigia do Rio Vermelho é de 1635: uma Provisão (19/11) que designa João Correia Feio para o seu comando. ${ }^{811}$ Sendo uma vigia, devia possuir ao menos uma trincheira de terra. Esse documento remete à fortificação em um período anterior, porque diz que o comandante nomeado sucede o pai, Diogo Sodré Feio. Só muitos anos depois a mercê foi confirmada por Patente Real. A sucessão do comando em família indica que as obras eram feitas por seus membros (evidenciando o amadorismo das guarnições), já que um "pitoresco" Alvará Real (19/05/1676) dá a João Correia Feio o direito de sucessão a pessoa q. case com uma de suas filhas. ${ }^{812}$

A possível trincheira de terra não foi arrolada por Bernardo Ravasco em 1660 e não era, portanto, uma fortificação expressiva. Pode ter tido várias formas. Informações colhidas por M. Oliveira sugerem que foi de início uma obra defensiva de terra, arruinada repetidas vezes com as chuvas. Na época de Miguel Pereira, os reparos estavam a cargo da tropa, mas que era miliciana e as obras parecem ter sido lentas. Em 1711 o Cel. Francisco Barreto recebeu ordem para enviar uma de suas companhias a cada dois dias para a faxina dos parapeitos. Em seguida, o Sargento-mor Inácio Teixeira Rangel foi incumbido de demolir as casas e o mais que fizer prejuízo aos redutos do Rio Vermelho. ${ }^{813}$ A documentação mostra que para concluir a obra, a faxina precisou de membros da milícia de Garcia d'Ávila Pereira (em número que o Gov. Pedro de Vasconcelos achou insuficiente para o avanço da obra, cobrando dele mais soldados). Um ano depois da conclusão dos reparos, reses e criação miúda pastavam no local, danificando fossos e parapeitos (episódio comum e para o qual se solicitava providências).

\section{O bom nível técnico e a grande produção de desenhos (1740-80)}

\subsection{A Aula Militar da Bahia}

Em meados do século XVIII talvez já se vivesse a perspectiva da mudança de capital, ocorrida em 1763. Possivelmente outras características do momento histórico também se associam à impressão de que não bastavam mais os grandes relatórios feitos por engenheiros que não tivessem residência fixa em Salvador: na época se consolidavam as aulas de engenharia militar, investindo na formação de brasileiros.

As aulas militares no Brasil começaram oficialmente em $1699,{ }^{814}$ mas na Bahia e em Pernambuco há indícios de que já existiam informalmente muito antes. Em 1674, ao ser recomendado para o Brasil, Antônio Correia Pinto se declarou capaz de ensinar fortificação. ${ }^{815}$ Em 1696, uma Portaria do governador dizia: O Capitão Engenheiro José

\footnotetext{
${ }^{811}$ Cf. BN - Documentos históricos, 1930, v. 16, p. 264/ OLIVEIRA, 2004: 239 e 257.

812 BN - Documentos históricos, 1934, v. 27, p. 50/ OLIVEIRA, 2004: 239.

${ }^{813}$ BN - Documentos históricos, 1941, v 53, p. 120/ OLIVEIRA, idem.

${ }^{814}$ Cf. AHU - Códice Ms 246, Bahia. Registro de Cartas Régias referentes à criação da Aula Militar da Bahia: S. ${ }^{e}$ o haver Aula na B. ${ }^{a}$ co' $^{\prime}$ engenhr. ${ }^{\circ}$ a ensinar a forteficação - apud OLIVEIRA, 2004: 100.

${ }^{815}$ Cf. AHU - Catálogo de Luiza da Fonseca, doc. 2.615 (CD4, 23, 002, 345-8). Consulta do Conselho Ultramarino de 12/11/1674, informando sobre o Eng. Antônio Correia Pinto: Enquanto ao que o dito Secretario Ihe perguntava se Antonio Correa Pinto, que estava na B. ${ }^{a}$, era capaz de ensinar algu's sojeitos; dizia que o faria excellentemente, e lhe parecia muyto conveniente. E que acerca dos partidos
} 
Pais Esteves venha todos os dias à tarde, à casa que tenho destinada junto ao Corpo da Guarda... ensinar aos oficiais e soldados e mais pessoas, que quiserem aprender e dar lição da castramentação e da fortificação. ${ }^{816}$

O primeiro lente oficial na Bahia foi Antônio Roiz Ribeiro, que chegou em 1700 ou 1701. Ele provocou tensões ao pedir que o Rei dispensasse seus alunos das guardas e revistas quando estivessem em aula. ${ }^{817} \mathrm{Em} 1713$ foi criada uma Aula de Arquitetura Militar, ministrada por Gaspar de Abreu. O governador Pedro de Vasconcellos recebeu Carta Régia com os seguintes termos:

Gov. $^{\text {or }}$ e Capitão geral do estado do Brazil Am. ${ }^{\circ}$ Etc. Vi a conta q me destes da rezolução q. tomastes em mandar abrir Aulla da Architetctura e odenar ao Capitão engenhr. ${ }^{\circ}$ Gaspar de Abreu dictasse postilla á qual acudia bastante gente; porem q vos parecia conv. ${ }^{\text {te }}$ p.a se augmentar, o conceder mais partidos do q. os tres asentados... ${ }^{818}$

Em 1725 o curso era de seis anos, transcorrendo sem interrupções até 1767, quando o Gov. D. Antonio Rolim de Moura Tavares (Conde de Azambuja) diz tê-la encontrado abandonada, recomendando aumentar o número de partidistas. ${ }^{819} \mathrm{O}$ motivo do abandono era a morte de Manuel Cardoso Saldanha, deixando como único engenheiro encarregado das aulas o ex-partidista baiano Capitão José Antônio Caldas, que em 1767 estava destacado para uma série de levantamentos no Espírito Santo.

Em ordem cronológica, os "lentes" que mais se destacaram foram: Cap. José Paes Esteves (antes da Ordem Régia, por determinação do Governador Geral), Sargento-mor Antônio Roiz Ribeiro, Mestre de Campo Miguel Pereira da Costa, Sargento-mor Gaspar de Abreu (lente de Arquitetura Militar), Tenente de Mestre de Campo Nicolau Abreu de Carvalho, Coronel Manoel Cardoso de Saldanha, Sargentomor José Antônio Caldas e (com a morte de Caldas, adentrando o século XIX) Brigadeiro José Gonçalves Galeão.

Manuel Cardoso Saldanha descreveu assim a Aula Militar da Baía:... por ter com sumo desvelo criado discípulos, que bem podem servir de Engenheiros, dictando-Ihes 15 tratados com as doutrinas mais modernas e especiais, ensinando-os a desenhar $e$ configurar terrenos... ${ }^{820}$ As lições de teoria nessa época já seguiam principalmente as obras de origem francesa. A leitura básica ainda era os tratados de Vauban, indicados em documento oficial de 15/07/1763, assinado por D. Luiz da Cunha (Secretário de

\footnotetext{
$q^{\prime}$ se podião consignar aos $q^{\prime}$ aprendesem, lhe pareçia bastante seis partidos, e para aquellas partes quatro, attendendosse sempre a carestia da terra porem que não era de pareçer que os partidos se dam a soldados, e menos a refformados, ainda que pareça conveniente, porque a experiensia lhe tinha mostrado, que como vão com animo de seguirem som. ${ }^{\text {te }}$ o caminho da soldadesca se aplição ao estudo da forteficação mais por vencerem os partidos, que por saberem, e seguirem a arte; e os refformados com a oppinião dos postos $q^{\prime}$ tiverão hão de querer comer os partidos sem utilid. ${ }^{e}$....

${ }^{816}$ Apud OTT, Carlos. O Forte de Santo Antônio da Barra. Revista do Patrimônio Histórico e Artístico Nacional. Rio de Janeiro: MEC, 1959; n. 14, p. 135-9 (confirma-se na carta patente de Sargento-mor recebida por Estevens, p. 156) / OLIVEIRA, 2004: 100.

${ }^{817}$ Cf. AHU - Códice Ms 246, Bahia, fls. 235A-235Av e 151v. Sobre dispensa dos alunos da aula de Ant. ${ }^{\circ}$ Roiz Ribr. ${ }^{\circ}$, de 18/11/1707/ OLIVEIRA, 2004: 100.

${ }^{818}$ Carta de 06/03/1713: AHU - Códice Ms 246, Bahia, fls. 333-333v - apud OLIVEIRA, 2004: 100.

819 ... Dei tal impulso a essa arte, que a Aula, quase abandonada quando cheguei, conta, agora, com entusiasmados estudantes... - apud SMITH, 1998: 58 (nota 183). Essa frase ao mesmo tempo soa como pura retórica, não se sabendo se pode ser tomada como testemunho.

${ }^{820}$ Apud BUENO, 2001: 506.
} 
Estado dos Negócios Estrangeiros e da Guerra). ${ }^{821}$ O livro O Ataque e a Defesa de Praças (Tomos I e II), de Vauban, servia de base ao ensino da Engenharia e Fortificação, orientando o programa de estudos e exercícios das Aulas dos Regimentos de Artilharia em várias partes do Brasil. ${ }^{822}$

Quanto ao método de ensino, o fato dos partidistas receberem exercícios nos tempos de Caldas mostra que no Brasil as palavras de Azevedo Fortes foram válidas até o final do século, ressaltando a importância do desenho na aprendizagem de conceitos: Os que houverem de fazer profissão da Fortificação, e da Geometria poderão começar por copiar as estampas, para as ter à vista estudando; e este trabalho thes não será inútil, exercitando-se a riscar as plantas, como Ihes he precizo. $^{823}$ Eram dados exemplos teóricos e o repertório clássico na formação do arquiteto ou engenheiro militar na época, como para os franceses. Do mesmo modo que os alunos de Lisboa, os partidistas da Aula da Baía copiavam estampas do La science des ingénieurs... de Belidor e de outros tratados. Alguns desenhos dos alunos de Caldas guardados no Arquivo Histórico Ultramarino são reproduções de estampas do tratado de Belidor, ou de outros notáveis da época. ${ }^{824}$

Entre os textos clássicos utilizados na formação dos docentes e alunos, destacam-se os tratados portugueses mais famosos, então editados, o Methodo Luzitanico de Serrão Pimentel e o Engenheiro Português de Azevedo Fortes. ${ }^{825}$ Algumas fontes manuscritas indicam que ainda no século XVIII, além de desenhos, eram feitas maquetes. $^{826}$

${ }^{821}$ Cf. PARDAL, P. Brasil 1792: início do ensino da engenharia civil e da Escola de Engenharia da UFRJ, 1985, p. 56/ BUENO, 2001: 520.

${ }^{822} \mathrm{Na}$ França esse método já estava sendo substituído pelo tratado de Bernard Forest de Bélidor, La Sicence des Ingénieurs dans la conduite des Travaux de Fortifications et d'Architecture Civile... (1729 e 1749), que passou a ser a principal referência das Academias Militares. O Plano que sua Magestade manda seguir, e observar no estabelecimento, estudos, e exercícios das Aulas dos Regimentos de Artilharia, documento assinado por D. Luiz da Cunha em 1763, mostra que o Nouveau Cours de Mathematique à l'usage de l'artillerie et du génie, publicado por Bélidor (1720), era recomendado, enquanto o seu tratado de engenharia e fortificações era ainda desconhecido (Cf. BUENO, 2001:511-2 o Nouveau Cours... era tão importante entre os livros consultados que recebeu tradução portuguesa em 1764-5: Novo Curso de Matemática... - trad. de Manuel de Sousa... Lisboa; Off. de Miguel Menescal da Costa, 1764-5).

${ }^{823}$ FORTES, 1993: I, Prólogo ao leitor.

${ }^{824}$ Cf. AHU - Cartografia Manuscrita, Bahia, no 990 a 1000. Também no Arquivo Público do Estado da Bahia, há um documento divulgado por Robert Smith (reproduzido por Beatriz Bueno, 2001: 519-20) que descreve o trabalho de José da Silva Leal, aluno em 1795-9 (quando o número de partidistas aumentou para seis), recomendado a capitão em 1810 por sua habilidade no desenho.

825 O Methodo Luzitanico..., como vimos, era da época em que a escola holandesa de fortificar tinha grande reputação. Uma parte do texto do parecer do Cap. Eng. Miguel Lescolles, comentando o Relatório do Cap. Eng. João Coutinho sobre a defesa de Salvador, diz: A fortificação proposta, $e$ delineada na Planta $p .{ }^{l a} p{ }^{\text {te }}$ da terra, he regular, com boas defensas, é as maximas da forteficação holandesas, ou do Engenheiro mor Luis Serrão Pimentel bem seguidas... (AHU - Códice Ms 245, Bahia, fl. 128). Já o tratado de Azevedo Fortes é de influência francesa, principalmente da doutrina de Vauban.

${ }^{826} \mathrm{Na}$ Itália elas caíram em desuso entre os eruditos em meados do século XVI, mas "não parecem ter sido preteridas pelas representações gráficas em Portugal" (BUENO, 2001: 520). Há a curiosa referência a uma "planta" da cidade de Salvador feita de barro que seria encaminhada a Portugal. Em Portaria de outubro de 1716 o governador pede que... o Desembargador Provedor-mor da Fazenda Real deste Estado mande entregar ao Ajudante Manuel de Almeida mais $20 \$$ em dinheiro para comprar tinta e óleos para pintar a cidade que está fazendo de barro... Em outra, de agosto de 1718, que o mesmo Desembargador mandasse... meter nos navios da frota, ou nau de guerra a planta desta cidade que fez de barro o Capitão Manuel de Almeida Mar, recomendando aos Mestres dos navios em que se embarcar 


\subsection{José Antônio Caldas}

A maior referência dos assuntos lecionados na Aula Militar da Bahia é a documentação ligada a José Antônio Caldas, com as disciplinas dadas por ele. Nos seu curso havia três dias da semana para estudos teóricos e três para aplicações ao desenho, atividade que só se iniciava depois dos discípulos mostrarem proficiência em Arith. ${ }^{a}$ e uma boa parte de geometria. O curso completo exigia o estudo de inúmeros tópicos, mostrando-se bastante trabalhoso tanto para o professor quanto para o aluno:

As materias $q^{\prime}$. tenho ditado, ensinado, e explicado na dita Academ. ${ }^{a}$ sam Arithmetica, Algebra, Geometria Elementar, Trigonometria, Geometria pratica onde alem de tratar da Longemetria, Altimetria, Planimetria, Stereometria, Geodezia, e Pantometria, se tratou tambem do nivelamento, ${ }^{827}$ Arpentage, ${ }^{828}$ e medisam das obras de Cantaria, Alvenaria, e Carpentaria, e uma boa parte de Geografia, modo de tirar as Cartas Geograficas, Topograficas, e Ichnograficas, e a dezenhar toda a qualidade de plantas Militares, e Civis; com um ensaio da Optica p. ${ }^{a}$ a extrasam dos prospectos: Fortificasam das Prasas, calculo de sua despeza e toda a qualidade de edeficios Militares, e Civis q'. nelas se empregam, Ataque de Prasas, Defensas de Prasas, Castramentasam em q'. nam só se tratou do acampamento particular das Tropas, mas tambem o g.' de um Exercito, e se [ilegível] uma Arte de guera com varios principios da Tactica dos Corpos de Infantaria, cavalaria etc., e hum apendis da Fortificasam Pasageira, ou de Campanha: Artelhr. ${ }^{\text {, }}$, Arte de Bombas Theorica, e Praticamente, Fogos Artificiaes da Guerra, e os Festivos, Mecanica, Statica, o mecanismo das abobedas com o calculo das Muralhas e pés direitos, Hidraulica, e finalmente Arquitectura Civil. Tendo ditado a Artilharia, e Arte de Bombas tres vezes por mandado dos Exm. ${ }^{\text {os }}$ Generaes p. ${ }^{\text {a }}$ instrusam do seu corpo, cujo ensino pratico tambem me foi encarregado por expaso de 2 anos desde 1774 até o de $1776 .{ }^{829}$

Caldas recebeu estudos importantes, como o apêndice especial de Smith (1998) e o resumo anexo à publicação fac-símile do seu manuscrito, a Notícia Geral... (1951). Baiano, fez carreira típica de soldado com exercício de engenheiro, estudando e trabalhando principalmente no Brasil. Foi um dos engenheiros militares mais importantes, destacado e reconhecido em seu tempo nas várias atividades que exerceu, mas principalmente na de professor. ${ }^{830}$

a levem com todo o cuidado para que não chegue com o menor dano (Documentos do Arquivo Nacional, v. LV. Rio de Janeiro, BN, p. 72 - apud BUENO, 2001: 520).

${ }^{827}$ Nas estampas de seus alunos aparecem resumos desses procedimentos.

${ }^{828}$ Termo francês para Topografia, por influência de Belidor.

${ }^{829}$ AHU - Catálogo de Castro e Almeida, Bahia. Doc. 10.151 (20/05/1779) - CD7, 50, 001, 151-3? Carta de José Antônio Caldas a Martinho de Mello e Castro pedindo soldo de lente, atividade que vinha exercendo por 12 anos./ OLIVEIRA, 2004: 142 (nota 261).

830 "... dedicado e competente engenheiro" (OLIVEIRA, 2004: 122), “... o primeiro professor baiano de arquitetura e engenharia" (idem, p. 124). M. Oliveira faz questão de ressaltar que, ao contrário dos que deveram sua ascensão mais ao apadrinhamento que à competência, Caldas construiu sua vida apoiado na capacidade pessoal, lutando contra o preconceito de ser baiano (que foi causa de muitas injustiças: preterido nas promoções apesar da admirável folha de serviços à educação, engenharia militar, arquitetura e sociedade em geral) e contras as pedras colocadas pelos invejosos, "que a mediocridade move aos homens de valor" (OLIVEIRA, 2004: 124). Cf. também OLIVEIRA, 2001: I, 535-50.

“... engenheiro, acadêmico, escritor, estatístico, medidor das obras urbanas da Cidade do Salvador, nobre figura de militar entre as mais ilustres do seu tempo...". "Não sofre contestação tenha sido ele o primeiro da série dos engenheiros brasileiros, profundamente vinculados ao seu país, suprindo com suas próprias forças a escassez de lições e a pobreza de modelos, em uma sociedade ainda desabituada ao livro, ao debate no campo das idéias, à especulação das escolas, à emulação profissional e à teoria pura, sempre perseverante, modesto e eficiente, como um bom operário graduado e ótimo soldado" (CALDAS, 1951: apêndice). 
Nasceu provavelmente em 1725 (há muitos documentos relacionados a fatos da época em que ele mesmo declara a idade), ${ }^{831}$ vindo de família modesta, mas não tão desprovida. ${ }^{832}$ Seu bom estilo literário, formação e erudição mostram que já era bem preparado quando passou a soldado de Infantaria em 20/03/1745. Como não há indícios de que tenha saído de Salvador, supõe-se que estudou no Colégio dos Jesuítas, ${ }^{833}$ sendo colega do amigo Manoel de Oliveira Mendes. ${ }^{834}$

Formou-se na Aula Militar da Bahia, da qual seria lente por 17 anos. Foi o aluno preferido de Manoel Cardoso de Saldanha, participando de missões e assinando conjuntamente algumas plantas, ou desenhando para ele os levantamentos de campo, como o da estrada para as minas de Salitre de Montes Altos. ${ }^{835} \mathrm{Em} \mathrm{1751}$, já atuando em Salvador, assinou desenho do Seminário da Imaculada Conceição que seria administrado pelos jesuítas. Entre 1753-8 fez desenhos em que aparece como Cabo de Esquadra e praticante do número na Academia Militar da Cidade da Baía, aluno de Manuel Cardoso Saldanha. ${ }^{836}$

Em 1755, o Vice-Rei Conde dos Arcos escolheu Caldas como um dos melhores engenheiros da Aula para projetar fortificações nas ilhas de São Tomé e Príncipe na costa da África. ${ }^{837}$ Ele partiu em março de 1757, e chegando a S. Tomé fez relatório

\footnotetext{
"É importante percorrermos a trajetória do mais importante engenheiro do Brasil, para verificar o alcance das suas ações, envolvendo projetos de Arquitetura Militar, Civil e Religiosa, levantamentos topográficos, obras de infra-estrutura urbana (calçamento das ruas da cidade, melhorias no cais, etc.), bem como funções administrativas junto à Câmara local" (BUENO, 2001: 510).

${ }^{831}$ Cf. AHU - Catálogo de Castro e Almeida, Bahia, doc. 8.946 (de 16/10/1775) CD7, 45, 001, 11-200: do Auto de Devassa do desembargador Miguel C. Caldeira Castelo Branco): José Ant. ${ }^{\circ}$ Caldas, Profeço na Ordem de Christo... que diz ser de sincoenta annos, testemunha jurada aos Santos Evangelhos...

${ }^{832}$ Cf. AHU - Catálogo de Castro de Almeida, Bahia, doc. 10.151 e 10.917 (CD7, 50, 001, 137-45 e CD8, $53,003,415-503)$. Sabe-se que ainda como Cabo de Esquadra, foi à Corte e Cidade de Lisboa e suas dependências, permanecendo mais de um ano (por causa dessa viagem, Roberto Smith chegou a achar que ele não fosse baiano, mas corrigiu-se lendo o escrivão José Goularte da Silveira, de 1778 (cf. OLIVEIRA, 2004: 124).

${ }^{833} \mathrm{Em}$ uma de suas inúmeras petições, Caldas informa:... E na verd. ${ }^{e}, \mathrm{Illm} .^{\circ}$ e Exm. ${ }^{\circ}$ Snr., fui eu o primr. ${ }^{\circ}$ $q^{\prime}$. comesei aprender no Exercicio da Literatura... (AHU - Catálogo de Castro de Almeida, Bahia. Doc. 10.151 - CD7, 50, 001, 137-45).

${ }^{834}$ Filho de Felipe de Oliveira Mendes, que fez obras ilustres no século XVIII como, na Bahia, a frontaria da Igreja do Santíssimo Sacramento e Sant'Ana. Manoel de O. Mendes foi aluno de filosofia dos jesuítas e recebeu o diploma de Mestre em Artes. Seu filho, Luiz Manoel de Oliveira Mendes, batizado na igreja feita pelo avô, recebeu de D. Pedro Il o título de Barão de Traripe.

${ }^{835}$ Cf. AHU - Cartografia Manuscrita, Bahia, no 978 (Dimensão 328 x 580/ OLIVEIRA, 2004: 124-5). São dois mapas, datados de 19/09/1758, um com o caminho de São Félix à Serra dos Montes Altos e outro com o traçado da região de salitre nessa serra, desenhados por Saldanha, que assina como Acadêmico da Academia Militar (cf. BUENO, 2001: 508). Desde 1751 Caldas auxiliava o mestre na preparação dos desenhos, procedimento didático que era parte da metodologia de ensino (os partidistas deviam estagiar com os mestres paralelamente ao aprendizado de teoria). M. Oliveira ressalta que Saldanha, talentoso em muitos ramos da arte e ciência, possivelmente contribuiu muito na formação de Caldas, orgulhando-se disso.

${ }^{836}$ Cf. BUENO, 2001: 506 e SMITH, 1998: 43-5.

${ }^{837}$ Saldanha foi quem lhe proporcionou essa primeira grande oportunidade de mostrar talento. Quando o Rei mandou o governador... escolher hum Engenheiro dos melhores q. houver na Aula Militar dessa Cid. ${ }^{e}$ da Bahia, e o mandareis em comp. ${ }^{a}$ do Gov. ${ }^{\text {or }}$ daquela Ilha q. ahi se acha, $p .^{a}$ q. veja e desenhe a fortificação q. se deve fazer na mesma Ilha do Principe, e remeter a planta da Ilha, e da fortificação com seu parecer por escrito... (AHU - Códice Ms 250, Bahia. Registro de Cartas Régias 1749-61, fl. 125v, carta de 30/08/1755 - apud OLIVEIRA 125), Saldanha foi consultado e logo sugeriu o nome do então Cabo de
} 
sobre as rendas públicas da Colônia, censo da população e descrição das casas e do comércio. Fez plantas dos fortes e um prospecto geral da cidade de Santo Antônio, propondo nova residência do governador.

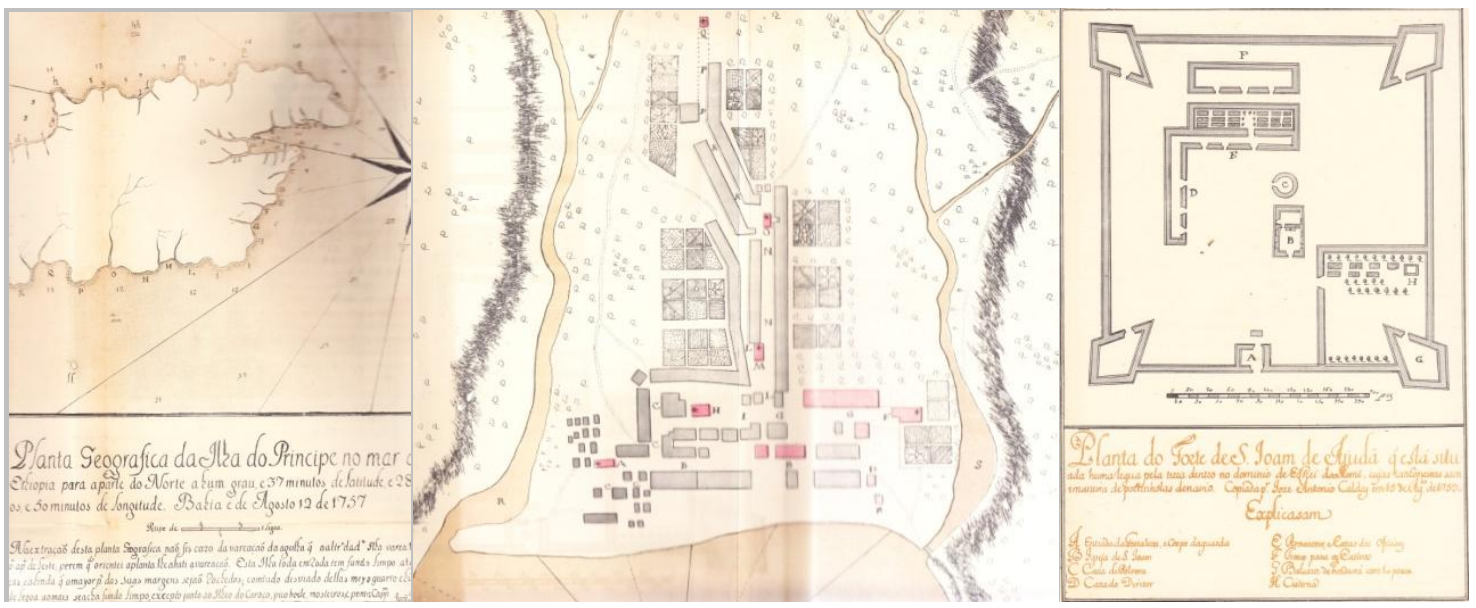

Desenhos de Caldas em S. Tomé e Príncipe: a Planta Geografica da Ilha do Principe no mar de Etiopia..., a Planta Ichnografica da Cidade de Santo Antonio... e a Planta do Forte de S. Joam de Ajudá... (em CALDAS, 1951: 224-5). O trabalho realizado em S. Tomé e Príncipe e outras ilhas do arquipélago também está minuciosamente descrito em relatórios, "mapas" (tabelas demonstrativas) de palamenta e munições, gastos com guarnição e observações demográficas. ${ }^{838}$

Dessa missão, M. Oliveira destaca o desenho "elegante e muito bem concebido" para a Catedral da llha de S. Tomé, ${ }^{839}$ de originais na Biblioteca e Arquivo Histórico do Ministério do Equipamento, do Planejamento e da Administração do Território, em Lisboa. A missão deu-Ihe prestígio e o posto de Capitão de Infantaria com exercício de engenheiro, por Patente Real de 03/04/1761, sentando praça em 20/06 daquele ano. ${ }^{840}$

Esquadra, partidista da Aula Militar da Bahia, indicação referendada em Carta Régia de 13/05/1757 (cf. AHU - Códice Ms 250, Bahia, fls. 154v a 155v).

${ }^{838}$ Muitos dos desenhos originais estão preservados em AHU - Cartografia Manuscrita, S. Tomé e Príncipe, nos 171 (Prospectos das fortificações... para defesa da cidade de S. Antonio...), 172 (Prospecto da cidade de S. Antonio), 173 (Planta geográfica de toda a ilha do Príncipe) 174 (Planta Iconográfica da Cidade de S. Antonio), 175 (Planta da baía e cidade de S. Antonio da llha do Príncipe) e s/n (Prospecto da Ilha do Ano Bom [S. Tomé]), todas de 1757 (cf. OLIVEIRA, 2004: 143 - nota 271).

839 OLIVEIRA, 2004: 125.

${ }^{840}$ Cf. AHU - Catálogo de Castro e Almeida, Bahia, doc. 15.224-30 de 09/03/1793 (CD11, 75, 001, 16774). Cópia da Carta Patente de Caldas, de 03/04/1761 e ANTT - Registro de Mercês, D. José I, liv. 15, fl. 437. O posto havia sido recomendado dois anos antes pelo Vice-Rei em reconhecimento aos trabalhos feitos em São Tomé e Príncipe. Na recomendação o Conde dos Arcos sugeriu que ele lecionasse na Aula Militar da Bahia, defesa e ataque de praças-fortes e geometria especulativa, com soldo de $26 \$ 000$ rs mensais. Nessa época, Caldas e Saldanha fizeram as plantas de conclusão da Catedral da Bahia, e supervisionaram a obra (cf. BUENO, 2001: 508). 

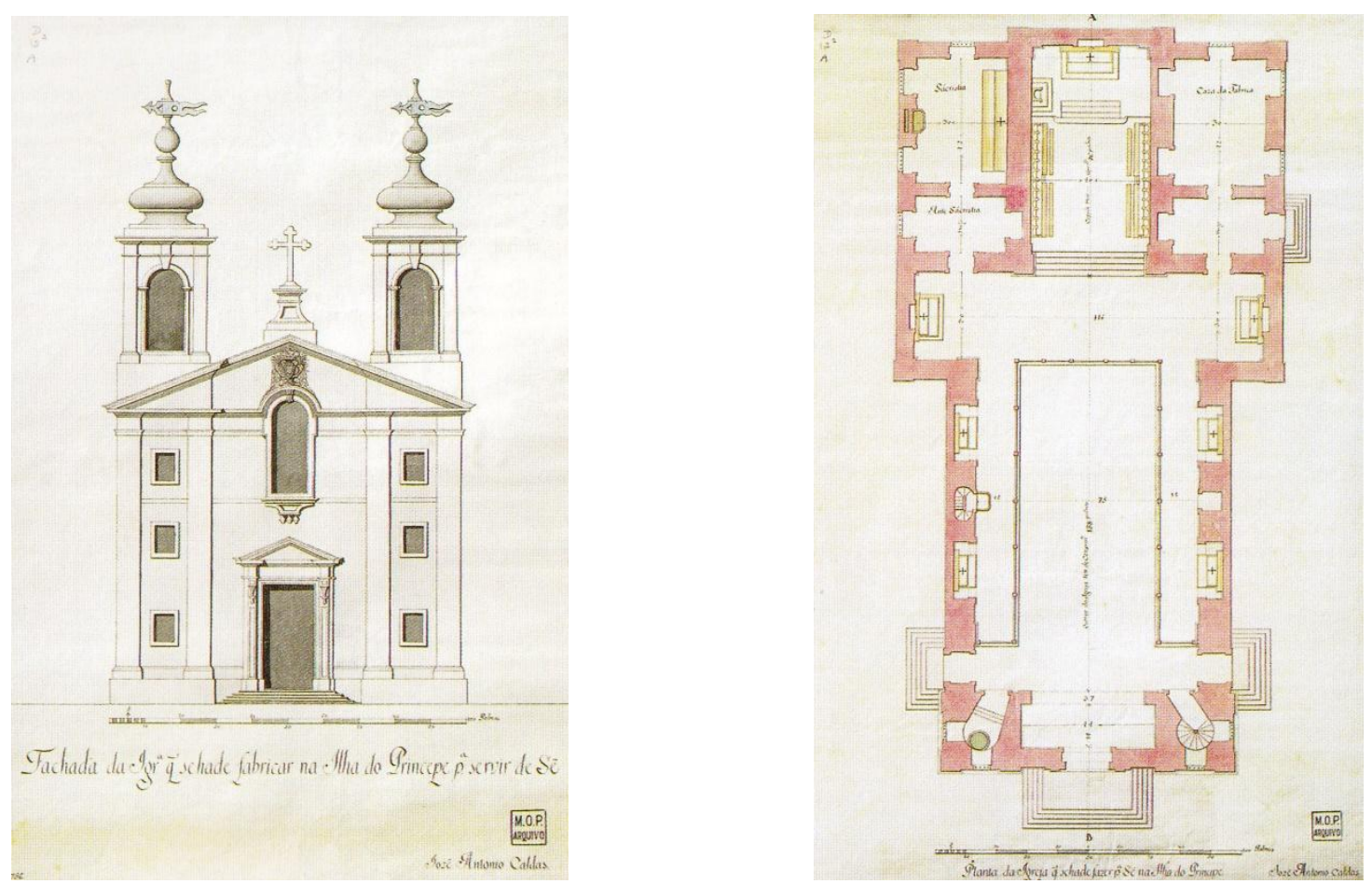

Projeto de fachada e planta para a catedral de S. Tomé (em OLIVEIRA, 2004: 125).

Em agosto de 1757 já estava de volta à Bahia, trabalhando com o Ten. Cel. Manuel Cardoso Saldanha num grandioso prospecto da cidade assinado por ele em 13/04/1758. Era parte de um amplo relatório publicado no ano seguinte, a Notícia Geral de toda esta Capitania da Bahia desde o seu descobrimento até o presente ano de 1759.

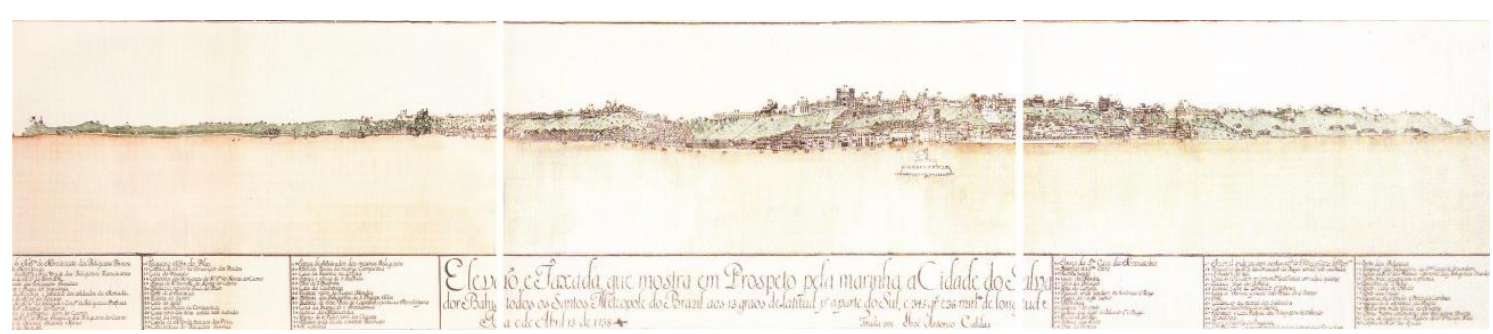

Elevação, e Faxada, que mostra em Prospeto pela marinha a Cidade do Salvador... (em REIS Fo, 2000: 446).

Em 1763 foi tesoureiro municipal, inspecionando novos pavimentos. Em vistoria às fortificações do Espírito Santo, assinou as plantas em 8 e 10/10/1767, com destaque para o Prospecto da Vila da Victoria capital da Capitania do Espírito Santo, em que usou uma camara obscura. ${ }^{841} \mathrm{Em}$ 24/10/1767, já em Salvador, foi consultado por pedreiros sobre o encanamento da fonte de Água de Meninos.

${ }^{841}$ Cf. BUENO, 2001: 508. 

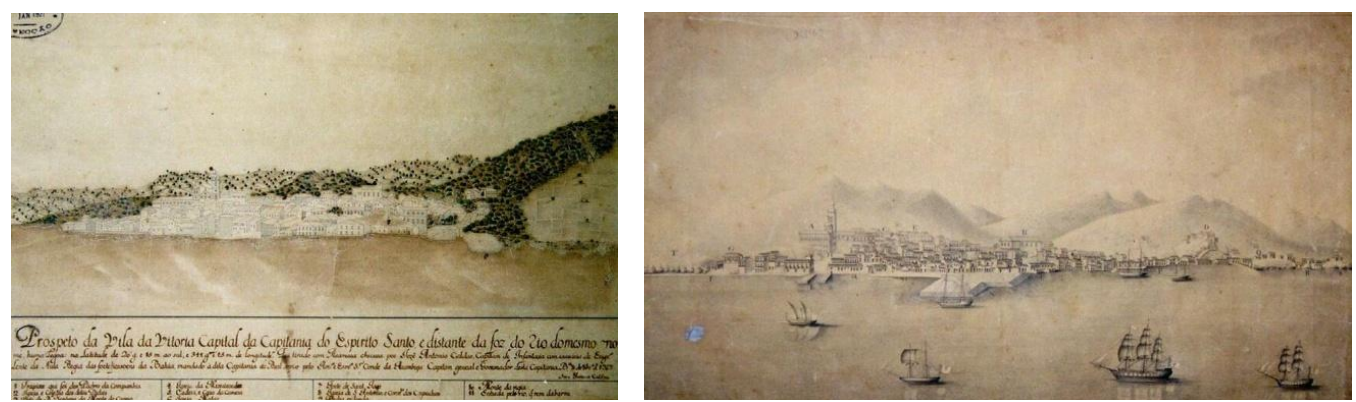

À esq., o Prospecto da Vila da Victoria... À dir., a Perspectiva da Vila de Vitória..., de Caldas, copiada pelo aluno José C. Vasconcellos Pimentel em 1805 (do site “homepage.mac.com/bahia..." em 04/07/10).

Lente-substituto por seis anos (desde 1761) na Aula Militar da Baía, com a morte de Manuel Cardoso Saldanha (1767) foi promovido em 13/10/1768 a Sargentomor de Infantaria com exercício de engenheiro e chamado a ser o titular da cátedra. Em 1770 fez uma detalhada planta topográfica da Cidade de Salvador. ${ }^{842}$ Em 1776 foi de novo ao Espírito Santo, chefiando pequena excursão para reconstruir fortes e formar milícia local, por causa de um possível ataque espanhol. Em 1777, já na Bahia, inspecionou o cais da cidade e aprovou a construção de um novo, produzindo um mapa de toda a área. ${ }^{843}$

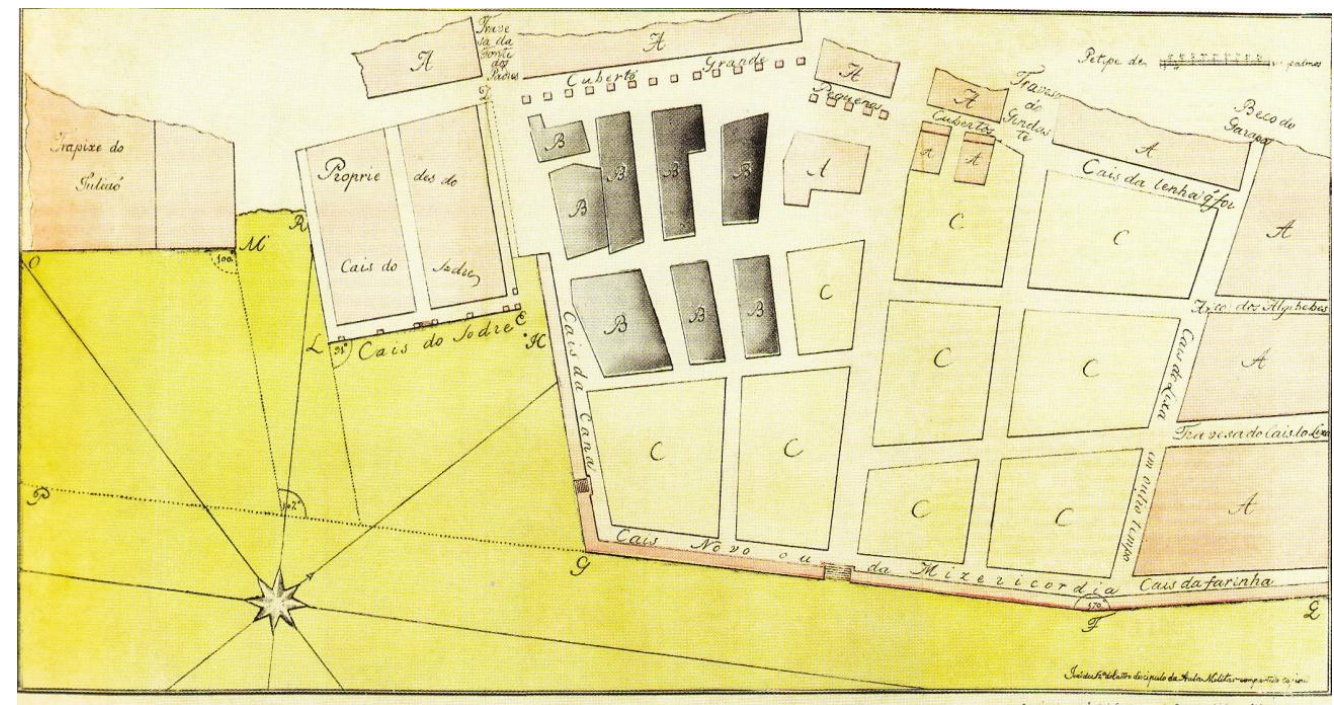

Projeto urbanístico para trecho da Cidade Baixa (em CALDAS, 1951 - anexos na parte final). ${ }^{844}$

${ }^{842}$ A informação também foi tirada da tese da profa. Beatriz Bueno, havendo dúvida se não seria a Topografica da B. ${ }^{a}$ de todos os S. ${ }^{\text {tos }}$..., datada de 1771 e mostrada em apêndice da Notícia Geral... Há também, mencionada por Mário Oliveira, uma planta de Salvador de 1779 localizada no Arquivo Militar do Rio de Janeiro (AHM - Plantas da Bahia. Ref. BA - 196 de A a F), com mais de dois metros e enorme riqueza de detalhes, não assinada, fragmentada em seis pedaços e de precisão notável para a época (foi verificada em sua escala gráfica e comparada a levantamento aerofotogramétrico), conhecida mas não publicada por Nestor Goulart em Imagens de Vilas... por causa das dimensões. M. Oliveira cogita (reconhecidamente sem apoio documental, mas com algumas evidências) ser de autoria de Caldas pela precisão não verificada nas plantas "vistosas e bonitas" do levantamento coordenado por Galeão (1785) nem na elaborada por Joaquim Vieira da Silva (1798, em que há erro na escala gráfica) e pelo fato de Caldas ter pedido várias vezes a governadores e ao Rei recursos para fazer uma planta cadastral da Cidade de dimensões razoáveis (cf. OLIVEIRA, 2004: 127-8).

${ }^{843}$ Cf. BUENO, 2001: 509.

${ }^{844}$ Caldas teria feito dois projetos de urbanização para Salvador: um para a Ribeira das Naus e outro para a zona dos trapiches na Cidade Baixa (cf. OLIVEIRA, 2004: 127). Neles se observa a exatidão dos traçados e cuidadosos levantamentos de campo sobre o qual se projetava as intervenções. 
Em 1779 se queixou da não remuneração pelo longo serviço de ensino na Aula Militar. Solicitando promoção, enviou a Conselho Ultramarino um conjunto especial de 46 desenhos feitos por seus alunos com bico-de-pena, para demonstrar o alcance e importância de sua atividade didática. São exercícios de teoria feitos na Aula, seguindo um programa com base em pelo menos cinco disciplinas: Geometria, Geometria Prática (Longimetria, Planimetria e Altimetria), Trigonometria, Arquitetura Civil e Religiosa (Teoria das Ordens Clássicas) e Arquitetura Militar (Castrametação, ${ }^{845}$ Elementos da Fortificação, Ataque e Defesa das Praças). Os desenhos, hoje no Arquivo Histórico Ultramarino (Lisboa), são de cinco alunos: Inácio José (1779), Joaquim Vieira da Silva (1779), Antônio Mendes (1778), João de Souza (1778) e Manuel Antônio Ribeiro (1779). ${ }^{846}$

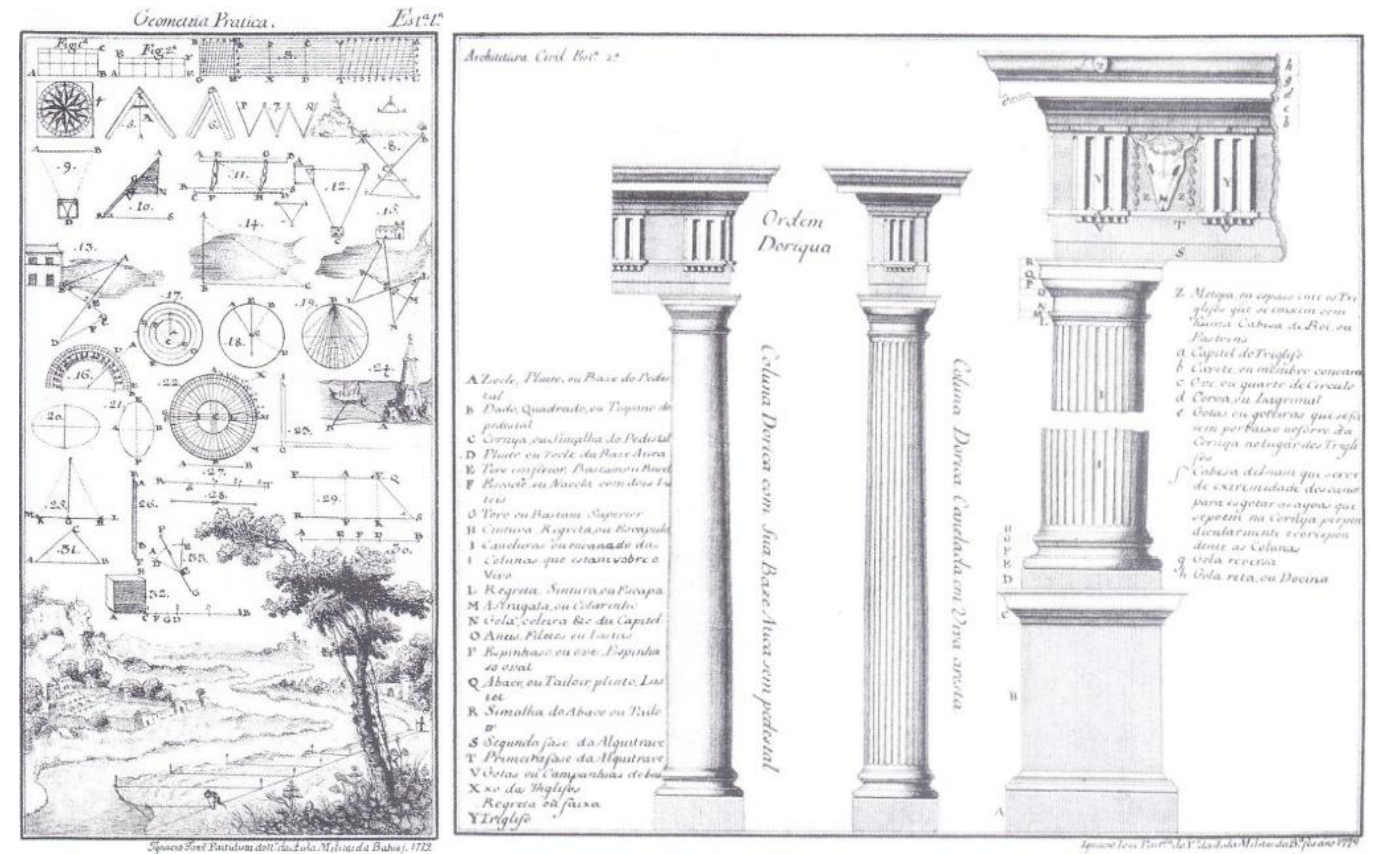

Nesta página e na seguinte, desenhos dos alunos de José Antonio Caldas (AHU: Ba 991, 999, 1003 e 1006 - em OLIVEIRA, 2004: 39 e 101).

\footnotetext{
${ }^{845}$ Escolha e levantamento de terreno para fortificação, acampamento, arraial ou povoação.

${ }^{846}$ Beatriz Bueno (2001: 513-7) mostra o conteúdo da série de 30 desenhos do partidista Ignacio Jozé (1779), a série de Joaquim Vieira da Silva, Cabo de Esquadra do Regimento de Artilharia e discípulo da Aula Militar (1779), a série de desenhos de Antonio Mendes, Cabo de Esquadra da Artiharia e discípulo da Aula Militar da Baía (1778), a série de desenhos de João de Souza (1778) e a série de Manuel Antonio Ribeiro, furriel do Regimento de Artilharia e discípulo da Aula Militar da Baía (1779), que, como exemplo, tinha seis estampas sobre a métrica dos capitéis, entablamentos, pedestais, base das colunas das cinco Ordens Clássicas presentes em Vignola ou nos fragmentos des plus beaux edifices antiques de Rome (Toscana, Dórica, Jônica, Coríntia e Compósita, às vezes confrontada com Scamozzi) e a cópia exata das estampas do Livro $V$ de La science des ingénieurs... de Belidor, mantendo-se até as inscrições em francês.
} 

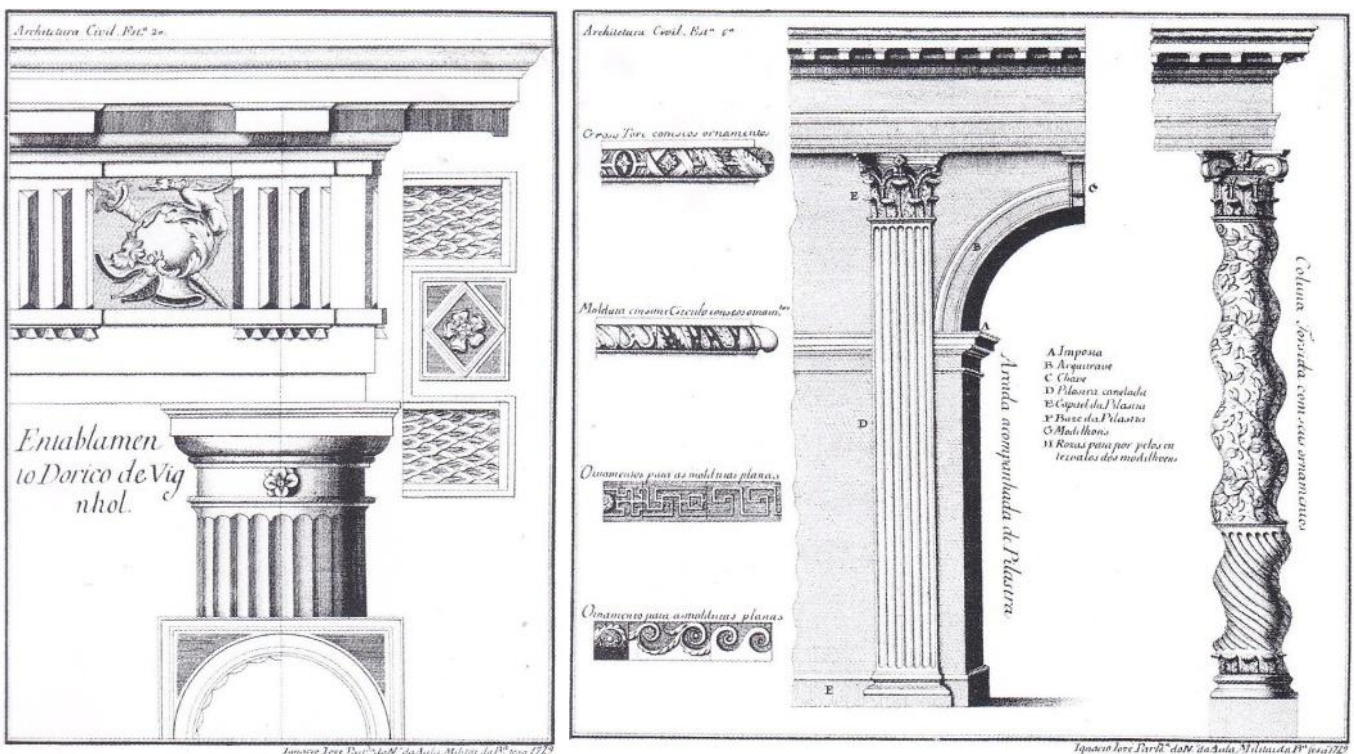

Essa preciosa série documental mostra a "sólida bagagem teórica mobilizada no âmbito dessas primeiras Academias direcionadas ao ensino da Arquitetura e Engenharia no Brasil". ${ }^{847}$

Os belos desenhos a bico-de-pena dos alunos da Aula da Baía mostram, junto à perícia e bom aproveitamento do curso (valorizando o pedido do professor Caldas), que o tratado La science des ingénieurs..., de Bernard Forest de Belidor, embora não pertencesse à lista dos recomendados por D. Luiz da Cunha em 1763, era na década seguinte a principal literatura de referência das Aulas em Portugal e no Brasil. A novidade desse tratado estava em mesclar as questões tradicionais da Arquitetura Militar com as da Arquitetura Civil. ${ }^{848}$

Percebe-se o quanto Caldas tinha apreço pela função de mestre em uma carta de1759 ao Conselho Ultramarino, quando tentava pela terceira vez voltar a Portugal:

Terceira vez agora the pedi licensa p. $^{a}$ me retirar nesta frotta por ter com summo dysvello criado discípulos, q. bem podem servir d'Engenheiros dictandolhes quinze Tratados com as doutrinas mais modernas e especiaes, ensinnando-os a desenhar, e a conferir terrenos [levantamento topográfico cadastral], tirando com elles o prospecto desta Cidade [sendo ele o principal responsável], q. concervo p. ${ }^{a}$ oferecer a El Rey meu Senhor, quando tiver a honra de beijarlhe os pés: Hum destes [ele mesmo] foi á llha do Principe e configurou a Planta da Ilha, o seu prospecto, e desenhou a Fortificasam, q. entendeu necessaria p. $^{\text {a }}$ a sua defesa. ${ }^{849}$

Quando esteve em Lisboa depois de aprender com Saldanha (autorizado por provisão real de 29/01/1755), procurou atualizar seus conhecimentos com o Cel. Felipe Roiz de Oliveira, ${ }^{850}$ reputado mestre da Real Academia da Corte e assistente por

${ }^{847}$ BUENO, 2001: 517.

${ }^{848}$ Cf. BUENO, 2001: 518. O tratado do catalão B. F. de Belidor (c. 1697-1761), ou Belidoro, como era chamado em Portugal, foi o principal texto didático utilizados pelos lentes de fortificação no século XVIII. Semelhante a uma enciclopédia de engenharia militar e civil, é considerado uma obra notável da época, sendo o seu autor um dos engenheiros mais respeitados do Exército Francês. A principal edição de La Science des Ingénieurs utilizada em Portugal e no Brasil foi a de Claude Jombert, de seis volumes, impressa em 1729. Documentos do AHU que mostram o envio para o Brasil de diversos artigos (como instrumentos de engenharia e de desenho para Aula Militar) mencionam as coleções do tratado de Belidor (cf. OLIVEIRA, 2004: 101 e 136 - nota 116).

${ }^{849}$ AHU - Catálogo de Castro de Almeida, Bahia, doc. 4472 (CD3, 21, 002, 390-3).

${ }^{850}$ Cf. VITERBO, 1904: II, 404 / OLIVEIRA, 2004: 126. O “abnegado engenheiro serviu nada menos do que 50 anos ao Rei, dos quais 41 ao ensino na Academia da Corte" (OLIVEIRA, 2004: 143). 
muitos anos de Manoel de Azevedo Fortes, que já falecera. É o que mostra a seguinte carta (com queixas de discriminação): ${ }^{851}$... Sendo oje o Sarg. ${ }^{\text {to }}$ mor mais antigo q. se acha nas tropas pagas e Auxiliares desta Capitania, como também o Lente mais antigo que há em Todo o Reino a excepsam do dessa Corte Felipe Roiz de Oliveira de . $^{m}$ tive a onra tomar algumas instrusoens.

Caldas foi um professor dedicado e pouco reconhecido pelas instâncias administrativas burocráticas. Orgulhava-se do sucesso de seus discípulos a ponto de citar nas petições onde estava e o que fazia cada um. ${ }^{852}$ Mesmo elogiado em sua honra e ciência, foi modesto: em carta de 1777, repetiu ao Secretário de Estado Francisco Xavier de Mendonça Furtado o que havia dito em Lisboa: ${ }^{853}$

E ainda q. expus ao Exm. ${ }^{\circ}$ Secretr.o de Estado Francisco $X .^{\text {er }}$ de Mend.a Furtado mais de uma vez a minha pouca Capacid. ${ }^{\mathrm{e}}$ p. ${ }^{\mathrm{a}}$ exercer a ocupasam de lente, me respondeu, q. acharam os Engenhr. ${ }^{\text {os }} \mathrm{q}$. me haviam examinado en sua presensa q. eu podia satisfazer com o d. ${ }^{\circ}$ emprego, e q. no mesmo ministerio me instruiria melhor. ${ }^{854}$

Promoveu muitas conclusões anuais solenes, com exames, ${ }^{855}$ presença de altas autoridades, motivando manifestações de orgulho do professor, que não temia a avaliação de seus discípulos, nem a própria. Uma dessas sessões, com a presença do Marquês de Lavradio, aconteceu na Sala do Docel do Palácio dos Governadores e foi relatada em códice do Arquivo e Biblioteca da Universidade de Coimbra. ${ }^{856}$

${ }^{851}$ AHU - Catálogo de Castro de Almeida, Bahia. Doc. 10151 (CD7, 50, 001, 137-45). Carta de Caldas a Martinho de Mello e Castro, fazendo pedido e enviando desenhos de seus alunos (apud OLIVEIRA, 2004: 126).

${ }^{852}$ Cf. AHU - Catálogo de Castro e Almeida, Bahia, doc. 8.532 de 16/08/1770 (CD6, 43, 001, 112-3) Relasam dos Discípolos da Aula Militar que tem sahido dela p. ${ }^{a}$ se empregarem no serviso de S. Mag. ${ }^{\text {e }}$ nas Tropas, e nos Tribunais da Cidade da Bahia: ... e se encontram no meu livro de ponto 118 dicipolos q. senam aplicaram, e nam deram a conhecer a sua Capacid. ${ }^{e}$. Para M. Oliveira (2004: 126), como bom docente, ele seria "amigável e disponível, mas rigoroso". Cf. também AHU - Catálogo de Castro e Almeida, Bahia, doc. 10.151 (CD7, 50, 001, 137-45):... nas Tropas desta Capitania sam raros os Oficiaes, q. nam tenham sido instruídos, em uma ou outras materias das q. se tem tratado nesta Aula, onde acham sempre o Lente pronto . $^{a}$ Ihe soltar as suas duvidas.

853 O que mostra que "chegou a docente devidamente sabatinado", com conhecimento do assunto específico (OLIVEIRA, 2004: 126).

${ }^{854}$ AHU - Catálogo de Castro de Almeida, Bahia, doc. 10151 (CD7, 50, 001, 137-45). O documento também mostra que ele era generoso, chegando a sustentar as aulas com recurso próprio:... fazendo dispezas anuaes com os Dicipulos $q^{\prime}$ se aplicam ao Dezenho, asistindolhe com todo o necessario para esse fim, por serem indigentes.../... a continuada dispeza q. faz neste exercicio, nam so com papel, tintas etc. mas ainda com o aseio da mesma Academia, e suprindo os Dicipolos aplicados com o q' pode para assim fomentar a sua aplicasam.

855 "... verdadeiras defesas de teses da Academia" (OLIVEIRA, 2004: 126).

${ }^{856}$ Segundo o cronista, Caldas, que presidia a sessão, saudou assim o marquês ilustre:

Esta incomparavel honra, $1 / \mathrm{m}^{\circ}{ }^{\circ}$ e Ex. ${ }^{\mathrm{mo}} \mathrm{S}^{r}{ }^{r} q^{\prime}$ agora tivemos de dar conta dos nossos estudos na presença de V. Ex. ${ }^{a}$ farà nos fastos da nossa Regia Academia memoravel o presente dia $q^{\prime}$ já o he na estoria pelo felisissimo nascimento de V. Ex. ${ }^{a} . /$ A materia das Concluzões $q^{\prime}$ sustentarmos foi escolhida, por ser respectiva a húa parte de arte da Guera [sic], a mais principal, a mais util, e a mais necessaria a todos os Militares./ A eficacia da aprovação de V. Ex. ${ }^{a}$ tem feito incontestavel esta verd. ${ }^{e}$ assim como o metodo, a ordem, e a direção, com $q^{\prime} V$. Ex. ${ }^{a}$ tem mandado regular a mesma Academia nos tem feito conhecer em tão poucos dias, $q^{\prime}$ o seu progresso será indefectivelmente grande pois só com a proteção de V. Ex. ${ }^{a}$ em quem todos Veneramos hum Heroe magnifico, e hum General completo na Sciencia Militar, se vivificarão e crescerão estas novas plantas na seria applicação dos seus estudos... (Biblioteca Central da Universidade de Coimbra - Códice 1332. Poesias e orações dedicadas ao Marquês do Lavradio - apud OLIVEIRA, 2004: 126-7). 
Em 1782 Caldas se queixou de novo ao Conselho Ultramarino, solicitando promoção a Tenente-Coronel, alegando ser vítima de discriminação: eram 14 anos sem que fosse promovido. Mesmo com recomendações nos pareceres dos governadores (como o Conde de Povolide e o Marquês de Valença), não recebeu a solicitada gratificação pela função de lente, nem a promoção a Tenente Coronel, mesmo sendo o mais antigo Sargento-mor. Seu processo com os documentos originais foi extraviado. $^{857}$

Antes daquele ano fora admitido como membro da Ordem Militar de Cristo, em Portugal, recebendo pensão (assim como José Fernandes Pinto Alpoim). Em 24/10/1782, pouco antes de morrer, mostrou seu último trabalho: plantas e orçamento para a reforma do Colégio que tinha sido dos jesuítas e estava arruinado.

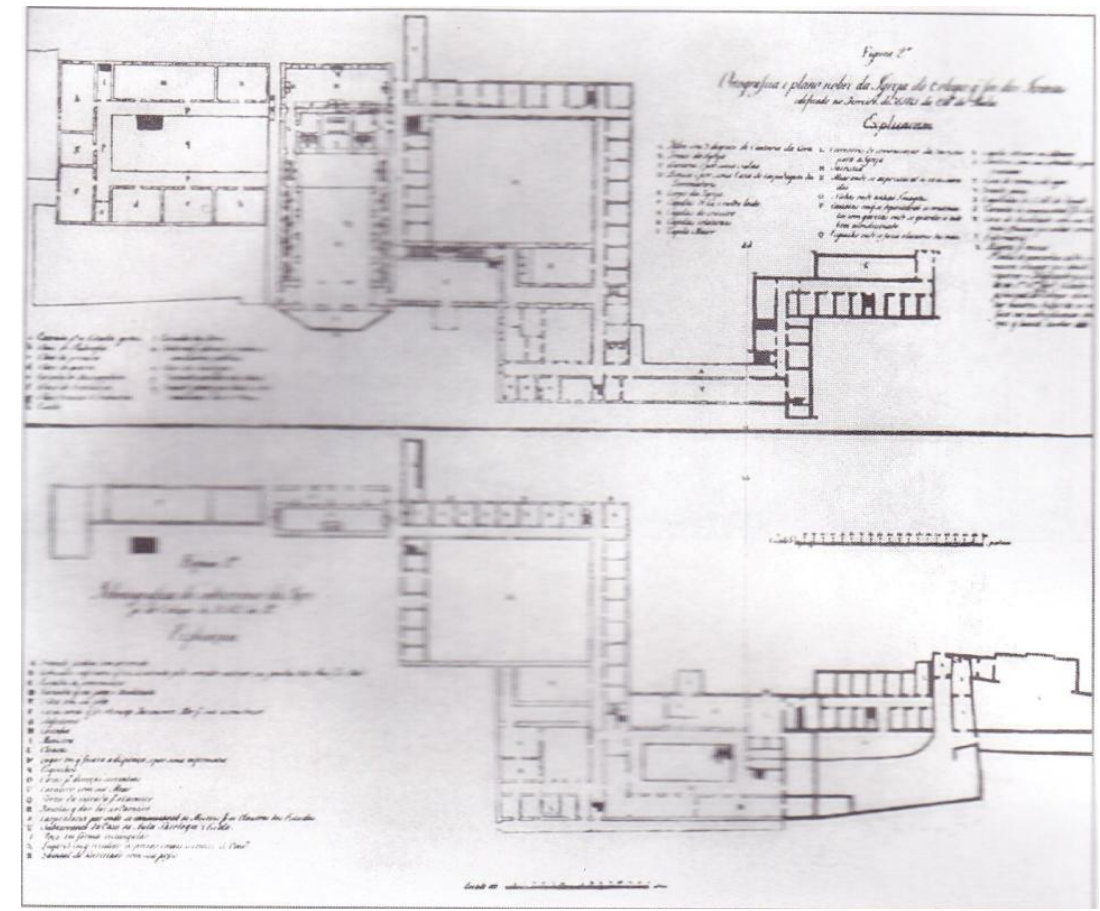

Planta da Igreja e Colégio Jesuíta: em cima (fig. 2A), andar térreo; em baixo (1A), pavimento inferior (em SMITH, 1998: 65).

Morreu uma semana depois, sendo sepultado com o hábito da Ordem de Cristo, na igreja da Ordem Terceira do Carmo, à que pertencia. ${ }^{858}$ Como dissemos, entre as tantas e diferentes atividades, destacou-se a habilidade de desenhista, com a qual registrou as principais fortificações da Bahia.

\footnotetext{
${ }^{857}$ Já o seu sucessor na Aula Militar, Cap. José Gonçalves Galeão, "entrou com todas as remunerações" a que tinha ou não direito (OLIVEIRA, 2004: 127), o que foi levantado pelo escrivão da Vedoria (cf. AHU Catálogo de Castro e Almeida, Bahia, doc. 15.236 de 30/01/1793 - CD11, 75, 001, 186-7).

858 Pertencer à Ordem de Cristo e ser enterrado na igreja da Ordem Terceira do Carmo mostra o seu prestígio social como principal engenheiro da Praça. Como diz o texto anônimo que acompanha as Notícias Gerais..., ele foi enterrado, com toda a "pompa em caixão, amortalhado em seu hábito de cavalheiro professo da Ordem de Cristo", "no dia de todos os Santos" (01/11/1782 - Liv de Obios da Sé 1778 a 1796, fl. 75, Arq. Do Paço Arquiepiscopal da Bahia - apud CALDAS, 1951: apêndice). Caldas era provavelmente solteiro e toda essa reverência não se dava por ser um ilustre da terra (nascido e criado em Salvador, como lembra M. Oliveira, 2004: 122), mas pela sua relevância profissional.
} 


\subsection{Tipologias e dimensões variadas nas fortificações}

Antes de apreciarmos a qualidade técnica dos desenhos de José Antônio Caldas sobre as construções de defesa, chamamos a atenção para a grande diversidade de formas experimentadas. O saguão de entrada do Forte de São Pedro é decorado com uma escultura em baixo relevo mostrando essa variedade tipológica dos edifícios que defendiam a principal cidade da Colônia. ${ }^{859}$ Chegamos a fotografá-la, mas em função de sua baixa qualidade artística, substituimos o registro por esta colagem, em que o uso das escalas gráficas também permite comparar as dimensões. ${ }^{860}$

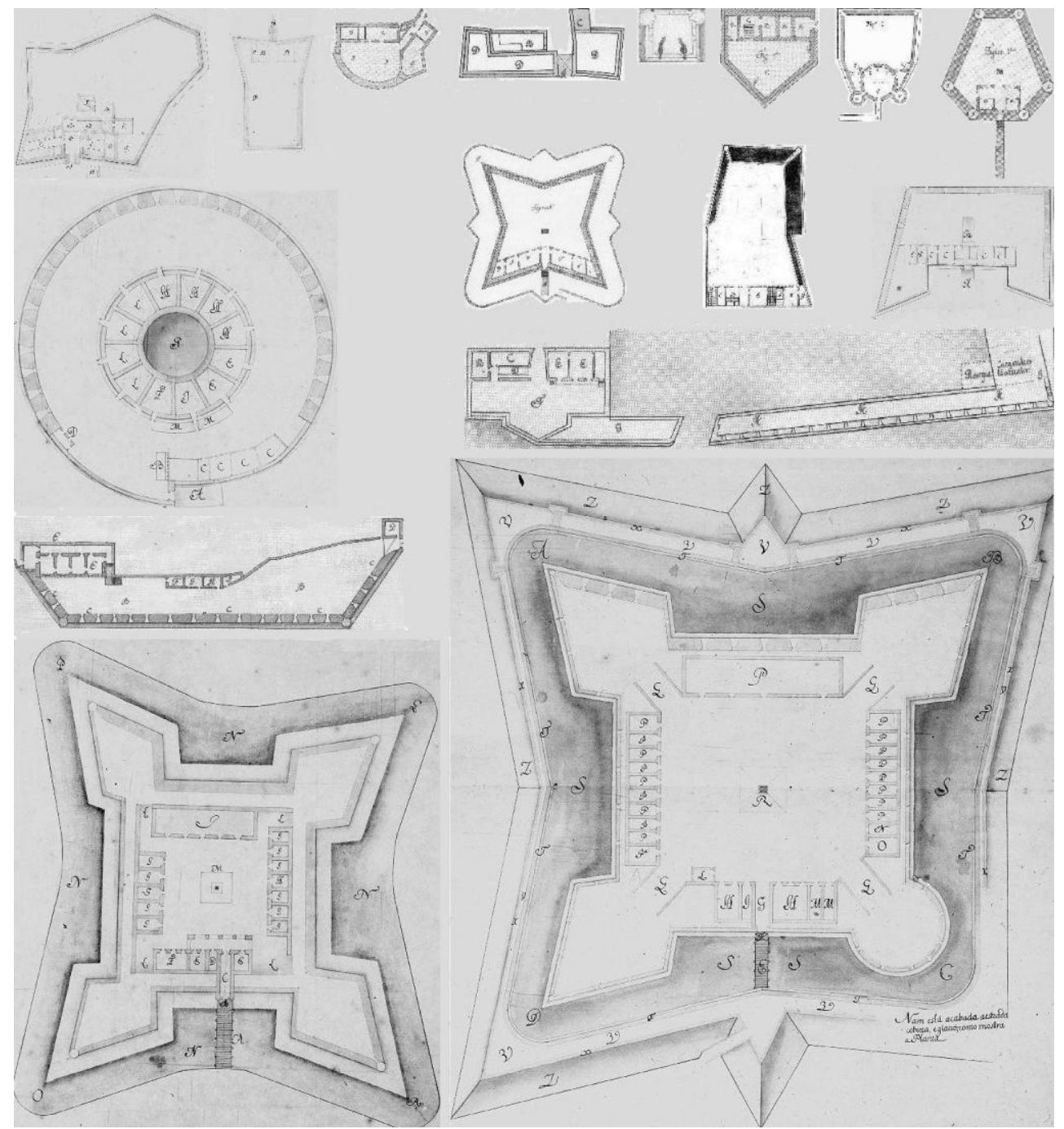

Fortes de S. Antonio da Barra, S. Maria, S. Diogo, Porta do Carmo (o desenho de Caldas para a Porta de S. Bento não apresenta escala gráfica), S. Alberto (desenhado por Albernaz), S. Francisco, S. Alberto (antiga Torre e S. Tiago), Monserrate, S. Bartlolomeu, S. Cruz, S. Lourenço, S. Marcelo, Bat. Da Ribeira, Bat. S. Paulo, S. Antonio além do Carmo e Barbalho.

\footnotetext{
${ }^{859}$ O painel provavelmente foi feito sob encomenda para o local. Tendo acima o nome Fortificações Históricas de Salvador, aparecem em seqüência, no mesmo estilo, os fortes S. Fernando (1796-1811), S. Maria, Barbalho, Monserrate, S. Antonio da Barra, S. Pedro (em grande destaque), S. Marcelo, Bateria da Ribeira, S. Alberto (c. 1598-c. 1673), S. Antonio além do Carmo, S. Paulo da Gamboa e S. Diogo.

${ }^{860}$ Elas aparentemente não correspondem à realidade, mas pelas fotografias de satélite na parte final de "Alguns registros..." (p. 317) se verá que as distorções são pequenas (algumas estampas de escala gráficas mais duvidosas, como as dos fortes de S. Fernando e do Rio Vermelho, em Vilhena, não foram utilizadas).
} 
Nota-se que a arquitetura "rude e austera" dos "templos de Marte", predominantemente utilitária, não podia deixar de ser engenhosa, cabendo novamente ao profissional "de bom juízo" avaliar a adaptação ao terreno ou forma geométrica condizente com o programa de necessidades (flancos, alvo principal, entrada, obstáculos). Se as formas são antes de tudo funcionais, estão exploradas as muitas possibilidades de uso da régua e compasso. Lembremos também que as referências e soluções teóricas registradas por Caldas não eram exclusivas de seu tempo: elas remontam a práticas largamente consolidadas, muitas delas plenamente identificadas em Salvador.

\section{$\underline{\text { Tipos }}$}

É quase uma coincidência, mas entre os fortes que ainda existem, há na tipologia um divisor de águas bastante evidente (observação não notada em outros estudos) que é o ano de 1640. Ele separa os que foram construídos à beira-mar (de linha de tiro apenas frontal e lateral, trazendo duas áreas bem definidas: o terrapleno no lado do mar e o edifício de entrada no de terra) dos da faixa mais ao interior (de linha de tiro em todas as direções), na forma em que foram reconstruídos no início do século XVIII. ${ }^{861}$

As três grandes fortalezas dessa época (Barbalho, São Pedro e Santo Antonio além do Carmo) são de uma tipologia que podemos chamar de praça retangular com entrada no meio de um dos lados, seguindo um desenho que, como vimos no capítulo inicial, aparece primeiramente no tratado de Pietro Cataneo (1567), ainda como proposta de fortificação para cidades. Esse desenho traz soluções coordenadas com as de experimentações geométricas anteriores, vindas, por exemplo, do tratado de Francesco di Giorgio Martini.

É o tipo de praça fortificada que se consagrou, por mais de um século (de meados do XVII em diante), em todo o Brasil.
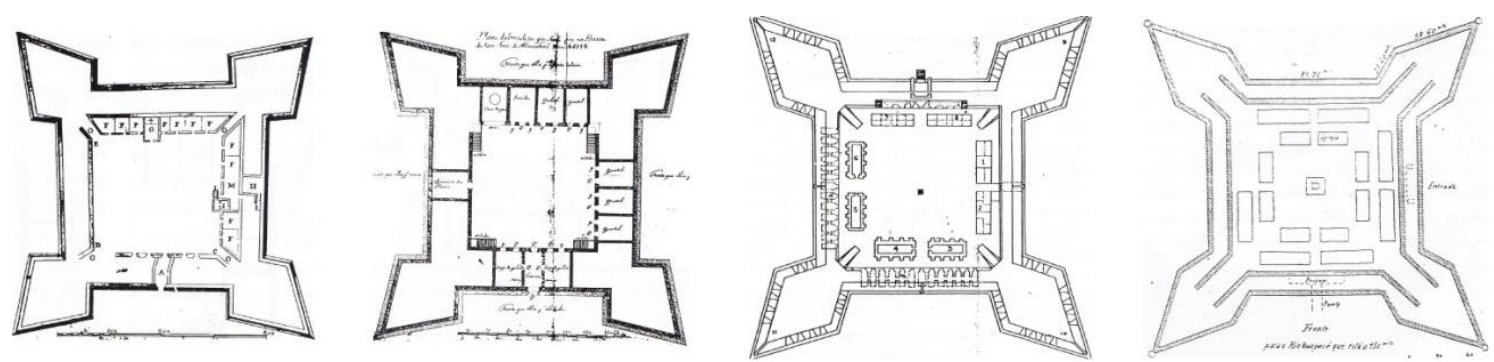

Da esq. para a dir., os fortes de Santa Cruz de Itamaracá (PE, 1631), São Luiz (MA, 1718), São José do Macapá (AP, 1764) e Real Príncipe da Beira (RO, 1776)- em SILVA, 1991: 179, 180, 183 e $185 .{ }^{862}$

\footnotetext{
${ }^{861}$ Eles já existiam no período espanhol, mas eram menores e de terra. Ao serem refeitos, seguiu-se um novo padrão, assim como para a beira-mar se estabeleceu o novo tipo das baterias horizontais, no sentido da linha do mar (S. Paulo e Ribeira).

${ }^{862}$ Por essas datas, Fernanda F. Silva (1991: 175) observa que "temos mais de um século a comprovar a durabilidade do modelo". Não nos aprofundamos para saber se o forte pernambucano é realmente de 1631 ou se foi reconstruído no século XVIII, como ocorreu com todos os desse formato em Salvador.

Para os fortes da Bahia, embora faça a observação genérica de que "as obras propostas eram de maior porte do que as que foram efetivamente realizadas" (p. 184), ela considera como datas de construção aquelas próximas à invasão holandesa, em que foram concebidos em formato e tamanho que não se pode afirmar com segurança: 1624 para o Forte de São Pedro e 1626 para o de Santo Antonio Além do Carmo. Sobre este último, faz uma interessante observação sobre a "sutil
} 
Apoiamo-nos nos estudos de Fernanda Fernandes, que trazem algumas observações importantes. Uma delas de que, não por acaso, esse tipo é o que mais reflete as teorias que aproximam cidade e fortificação. Neste caso, o perímetro poligonal (de simetria radial) com baluartes nos ângulos se resume a uma estrela simples, de apenas quatro ângulos, fazendo com que a malha interna, quadrangular, se tornasse paralela às quatro cortinas. ${ }^{863}$ Essa família de fortificações quadrangulares com baluartes nos ângulos seguiria propostas de Pietro Cataneo, mas recebendo "contribuições inovadoras de vários arquitetos até atingir a sofisticação... [das] propostas de Vauban". ${ }^{864}$

Nesse tipo de "planta quadrangular de vértices dilatados" para "abrigar os baluartes", ${ }^{865}$ a ordenação simétrica de localização dos edifícios no interior da praçaforte sugere, pelo seu caráter abstrato, mais "um esquema de organização do que uma efetiva implantação dos mesmos". ${ }^{866}$

Outro tipo de integração de baluartes com adequação dos esquemas geométricos também pode estar na origem desta "fórmula consagrada" de forte retangular com baluartes nos ângulos: o formato, para alguns, "antropomórfico", utilizado por Frias de Mesquita no Forte da Laje (semelhante ao dos Reis Magos, em Natal). ${ }^{867}$ Esse tipo está entre os vários que floresceram nas lutas de formação de cidades-estado italianas, depois adotados na política expansionista européia. ${ }^{868}$
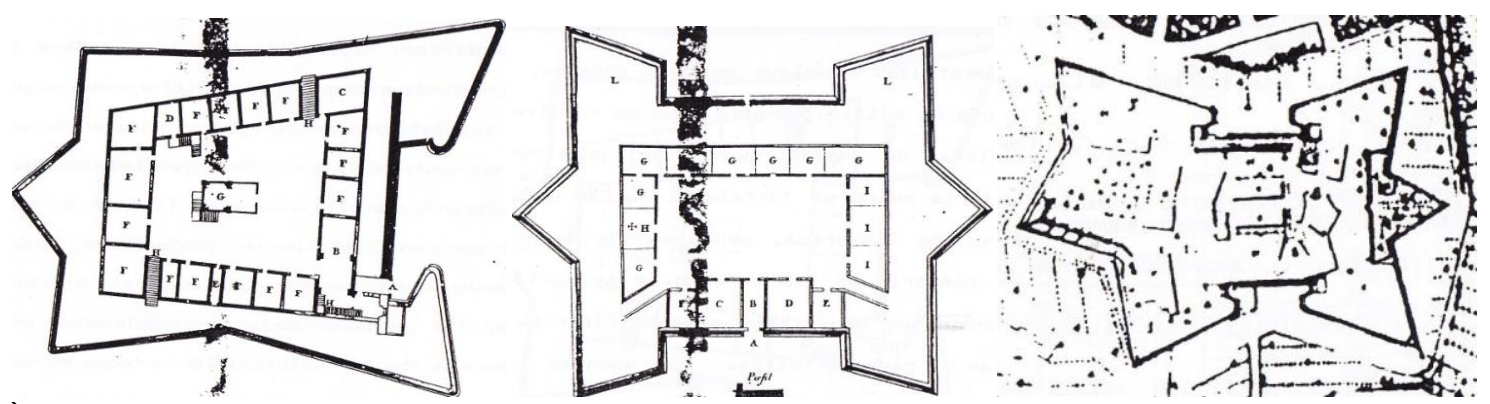

À esq. e ao centro, os fortes dos Três Reis Magos (RN, 1598) e de Santo Antonio do Buraco (PE, 1630). A influência italiana pode ser notada pelo terceiro desenho, da fortificação do Belvedere em Florença (em SILVA, 1991: 168, 170 e 172).

irregularidade" provocada pelas "diferentes angulosidades assumidas pelos baluartes", que dá à figura a impressão de um "movimento rotatório". Esse movimento poderia ter influído na disposição dos edifícios internos, fazendo com que as partes se encaixassem "uma após a outra", "lembrando a inspiração circular desse tipo de solução" (SILVA, 1991: 176).

863 Fernanda observa que esses modelos “... mantêm das cidades fortificadas o núcleo urbano, nelas representada pela praça-forte, local de reunião das tropas, e o perímetro murário com angulações. Utilizam, portanto, a cidade como paradigma, mas procedem como se delas tivessem sido retiradas todas as outras atividades representativas da vida em comunidade, enfatizando exclusivamente seu aspecto militar, o que compreende seu sistema de ataque e defesa" (SILVA, 1991: 186).

${ }^{864} \mathrm{Idem}$, p. 173. Essa tipologia representaria assim uma transformação do modelo inicial do século XVI renascentista, concebido a partir de "princípios estáveis" refletidos na "tranqüilidade da forma" (p. 186). Passaria então a haver um "movimento de pulsão" nas figuras pelas suas "saliências e reentrâncias", o que estaria relacionado a um "pensamento próprio da época maneirista", em que há "noção de arbítrio no sistema de regras estabelecido" (idem).

865 Idem, p. 176.

${ }^{866}$ SILVA, 1991: 184 - grifos nossos.

${ }^{867}$ O forte de Natal foi erguido pelo projeto do jesuíta Gaspar de Samperes em 1598, sendo reformulado por Frias de Mesquita em 1614 possivelmente com referência em desenho de Tibúrcio Spanóqui.

${ }^{868}$ Cf. SILVA, 1991: 165. 

citados:
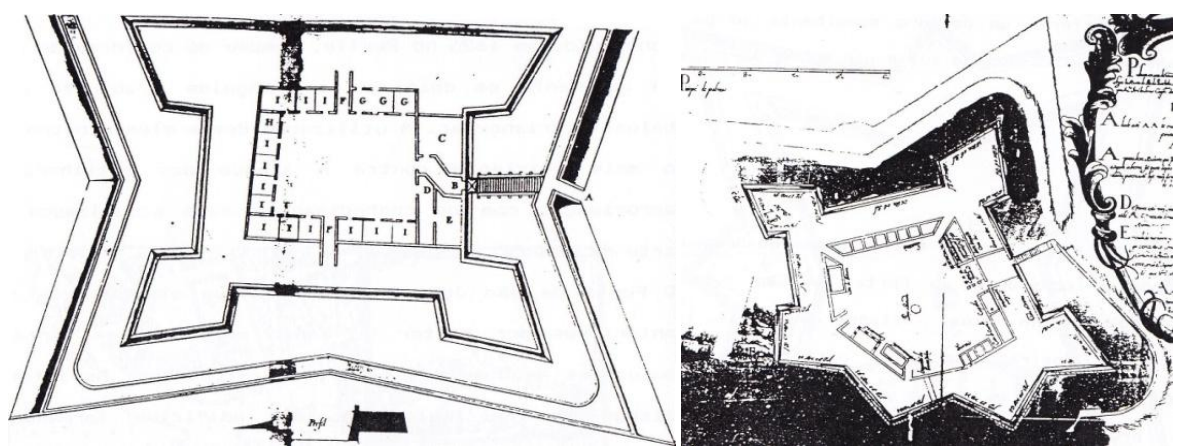

Os fortes de S. João Baptista do Brum (PE, 1626) e de S. Catarina do Cabedelo (PB, 1586) - em SILVA, 1991: 174 e 187.

Já o Forte de S. Bartolomeu da Passagem é um caso isolado, talvez o único construído no Brasil em forma estelar, que Fernanda (datando o edifício como de 1624) considera "próximo à tipologia... das soluções quadrangulares com baluartes", mas "ainda não enquadrada no rigor construtivo geométrico" delas. ${ }^{869}$ Prosseguindo nessa comparação, ela diz:

O perímetro dos fossos envolve a estrela e a ela se contrapõe ao apresentar ângulos salientes, quando aquela apresenta ângulos reentrantes. Assim, os espaços dos fossos ficam dilatados exatamente nos pontos em que a construção interior se retrai, indicando seus pontos frágeis e fortalecendo desta forma o sistema defensivo, pensado de forma dupla e complementar. ${ }^{870}$
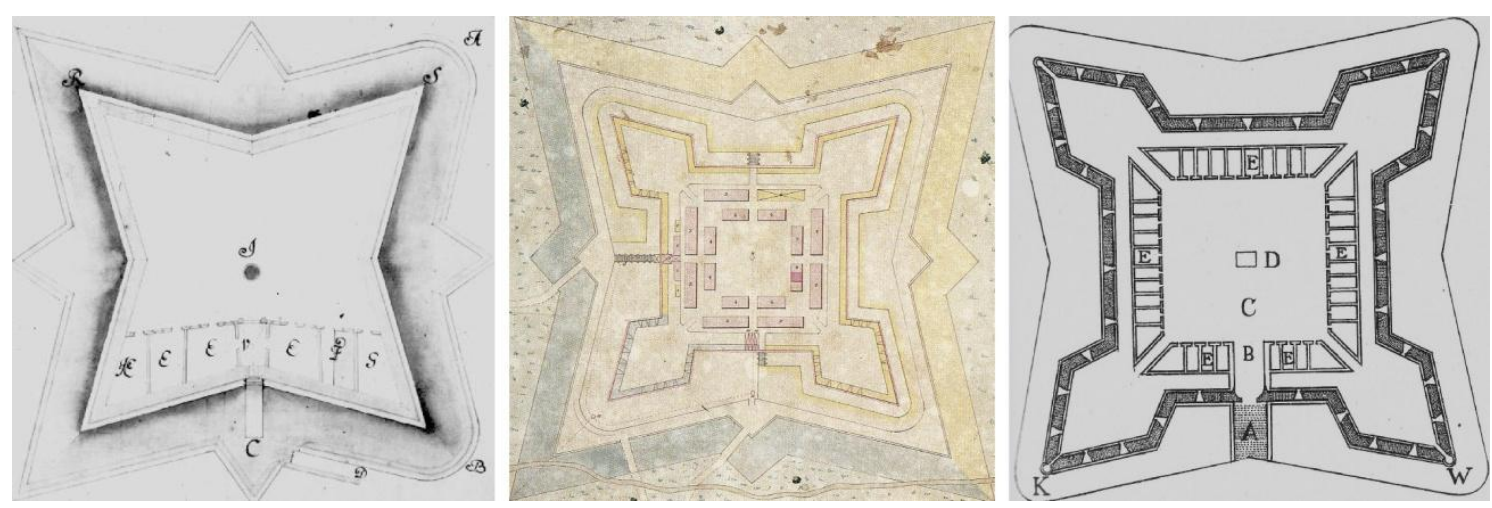

Desenhos dos fortes S. Bartolomeu da Passagem (Cartas topográficas...- BNP), do Príncipe da Beira (RO, 1776 - em REIS Fo, 2003: 63 - tendo como particularidade, pouco visível na reprodução, as guaritas nas pontas dos baluartes) e de S. Pedro (em VILHENA, 1921: 234-5), notando-se semelhança pela forma estelar que também deriva das obras externas.

O esquema quadrangular com baluartes nos ângulos, articulado a fosso e revelins foi a matriz de sofisticados esquemas geométricos estelares, que alcançaram desenvolvimento máximo em Vauban. Para Fernanda Fernandes, "tantos as fortificações estelares quanto as de formato circular são derivações de um mesmo núcleo que se desenvolveram paralelamente", citando em relação à circular o desenho de Düher, em que teria atingido a "perfeita solução". ${ }^{871}$

\footnotetext{
${ }^{869}$ SILVA, 1991: 188.

870 Idem, p. $188-90$.

${ }^{871}$ 1991: 197 - grifo nosso.
} 


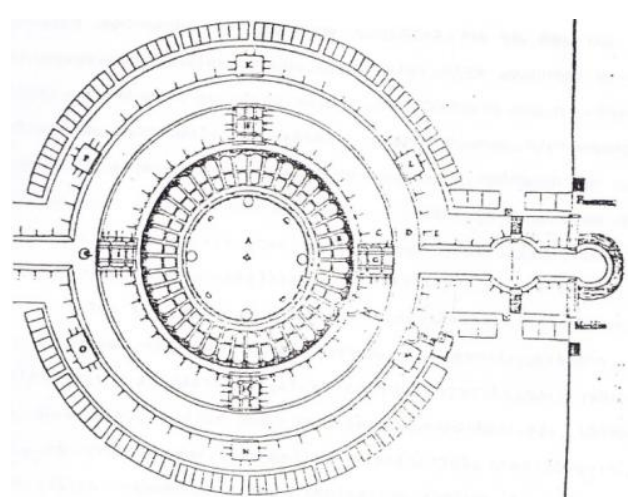

Planta circular no tratado de Alberti Düher (em SILVA, 1991: 106).

Em Salvador, a primeira leva de fortificações duráveis é do período espanhol (quando também foram iniciadas as fortificações na faixa mais ao interior, ainda menores e de terra). Todas as fortificações a beira-mar já estavam construídas quando da Restauração portuguesa, ${ }^{872}$ embora duas (Santo Antonio da Barra e "Lagartixa") tenham sofrido acréscimos (em fins do XVII e início do XVIII) para se parecerem com as outras. As primeiras, desenhadas por Baccio da Filicaia, tinham precedentes nos tratados renascentistas italianos. Além de regulares, foram concebidas a partir de formas geométricas puras. Fernanda considera a referência teórica mais direta para elas o tratado de Francesco di Giorgio, por "suas propostas de fortificações ou cidades fortificadas que se valem dos polígonos elementares - quadrado, pentágono, hexágono, etc., para a conformação do seu perímetro, com torreões circulares nos ângulos". 873

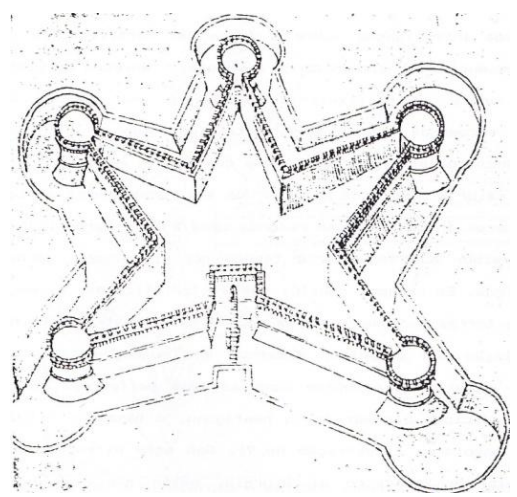

Fortaleza poligonal com torreões circulares nos vértices, desenhada por Francesco di Giorgio, 1482 (em SILVA, 1991: 89).

Fernanda vê semelhança entre "as fortalezas de N. S. de Monserrate (1586) e Santo Alberto (1594)", ${ }^{874}$ que se difeririam da família das fortificações quadrangulares com baluartes nos ângulos por serem esquemas híbridos "pertencentes ao momento

\footnotetext{
${ }^{872}$ Não consideramos o Forte da Jiquitaia, que é do século XIX (c. 1817).

${ }^{873}$ Essa concepção acompanha a forma das cidades com perímetros angulares, consideradas "as que melhor atendem às necessidades da defesa". SILVA, 1991: 191.

Ela vê como principal referência tratadística as "formulações feitas por Francesco di Giorgio, como a utilização de figuras geométricas elementares e torreões circulares incrustados nos ângulos", o que representaria uma "concepção anterior àquela que redundou na utilização de bastiões triangulares" (SILVA, 1991: 169 - ela prefere o termo "bastiões triangulares" a "baluartes").

${ }^{874}$ Id. ibid., com a antiga Torre de Santiago sendo considerada em sua forma final, do início do século XVIII, adicionado o terrapleno desenhado por Miguel Pereira da Costa.
} 
de transição entre as obras medievais e as formulações que se valem de baluartes triangulares elaboradas durante o século XVI renascentista" ${ }^{875}$ A esses dois fortes ela acrescenta o de Santa Maria como parte de um mesmo tipo.

Sobre a fortaleza de Monserrate, observa em particular ser "a que melhor representa esse tipo de solução", pelos seus torreões circulares e perímetro fortificado hexagonal, "dispostos simetricamente em relação ao eixo longitudinal". ${ }^{876} \mathrm{Em}$ seu desenho, "os lados do hexágono se articulam em ângulos obtusos que abrigam os torreões e estão situados a dois terços do comprimento em relação à fachada" ${ }^{877}$ As dimensões desiguais dos lados faz com que os "braços" mais longos "provoquem a expansão do edifício em direção ao continente, o que o faz assumir um formato oblongo, considerado por Francesco di Giorgio como o mais adequado a esse tipo de solução". Em oposto à fachada voltada para o mar, as dependências da guarnição se resolvem no mesmo edifício de entrada do forte.

Sobre o Forte de Santo Alberto (antiga Torre de Santiago), notamos que com o acréscimo do terrapleno e a posterior "retificação" da parte edificada (que abrigava a guarnição), ficou realmente semelhante aos do período espanhol: uma figura geométrica de seis lados, mas que se difere do hexágono e tem menor dimensão na entrada (aparentemente não considerando que o desenho atual - como o de Caldas, reproduzido por ela - resulta de uma reforma, Fernanda entende que "... o perímetro exterior e a organização interna dialogam formando um esquema integrado"). ${ }^{878}$

Já no de Santa Maria ela nota que "o retângulo inicial se desdobra num polígono de sete lados, resultando... em uma figura muito mais expansiva, alongada e dotada de flancos dilatados e pontiagudos". Seu partido seria semelhante ao de Monserrate pelo terrapleno voltado para o mar, oposto ao "edifício que abriga as tropas e demais dependências da fortificação", onde se localiza a entrada (lado em que, ao contrário do anterior, há o "espaço obtido pelo alargamento da figura"). ${ }^{879}$ É o que pode ter inspirado a reforma feita por Miguel Pereira da Costa na Torre de Santiago.

$\mathrm{Na}$ classificação de Fernanda, o forte se filiaria ao ramo das fortificações estelares, seguindo alguns mesmos princípios (mas que permitem chegar a diferentes resultados). Pode não ter a idéia de centralidade característica das concepções estelares, mas se resolve em formas longitudinais, com o terrapleno funcionando como espaço de reunião dos soldados. Também observamos que não há torreões, mas guaritas nos ângulos retos do perímetro.

\footnotetext{
${ }^{875}$ Id. Ibid.

${ }^{876}$ Idem, p. 191-3.

${ }^{877}$ Idem, p. 193 - grifo nosso, pela interessante observação.

${ }^{878}$ Ela vê como "dado marcante na concepção desse objeto arquitetônico... a idéia de multiplicação dos lados a partir de uma figura geométrica elementar - o quadrado, e que pode se fragmentar até o infinito, seguindo a noção desenvolvida ainda por Francesco di Giorgio em seu tratado" (p. 193).

Seria um caso específico em que "é possível acompanhar o pensamento orientador desse tipo de solução e traçar o percurso seguido no processo de contínuas derivações obtidas a partir do desdobramento de uma forma inicial" (idem, p. 193-5). Fernanda conclui que, "de fato, assumindo-se o quadrado como forma matriz, ocorre que um de seus lados se desdobra em outros três, possibilitando o desenvolvimento de ângulos e bastiões, e fornecendo o processo gerador da forma arquitetônica baseado num raciocínio matemático" (idem, p. 195).

${ }^{879}$ Cf. SILVA, 1991: 195.
} 
Devemos lembrar que os esquemas híbridos já existiam na associação das torres circulares às novas soluções defensivas renascentistas. A principal característica era a articulação dessas torres (no lugar das quadradas, mais freqüentes na Idade Média) com estrutura murária que se projetava, constituindo plataformas para manobra ou largas tenalhas. A fortificação podia coincidir com um baluarte de formato nem sempre regular, ou seja, com um reduto. Essas soluções caracterizam os experimentos e teorizações presentes nos trabalhos renascentistas do século XV. Embora a forma "clássica" do baluarte articulado à muralha se consagre apenas no $\mathrm{XVI}$, as soluções "híbridas" não desapareceram e em muitos casos foram aconselhadas como mais eficazes.

\subsection{Os Fortes da Bahia nos desenhos de José Antonio Caldas ${ }^{880}$}

\section{Forte de S. Antonio da Barra}

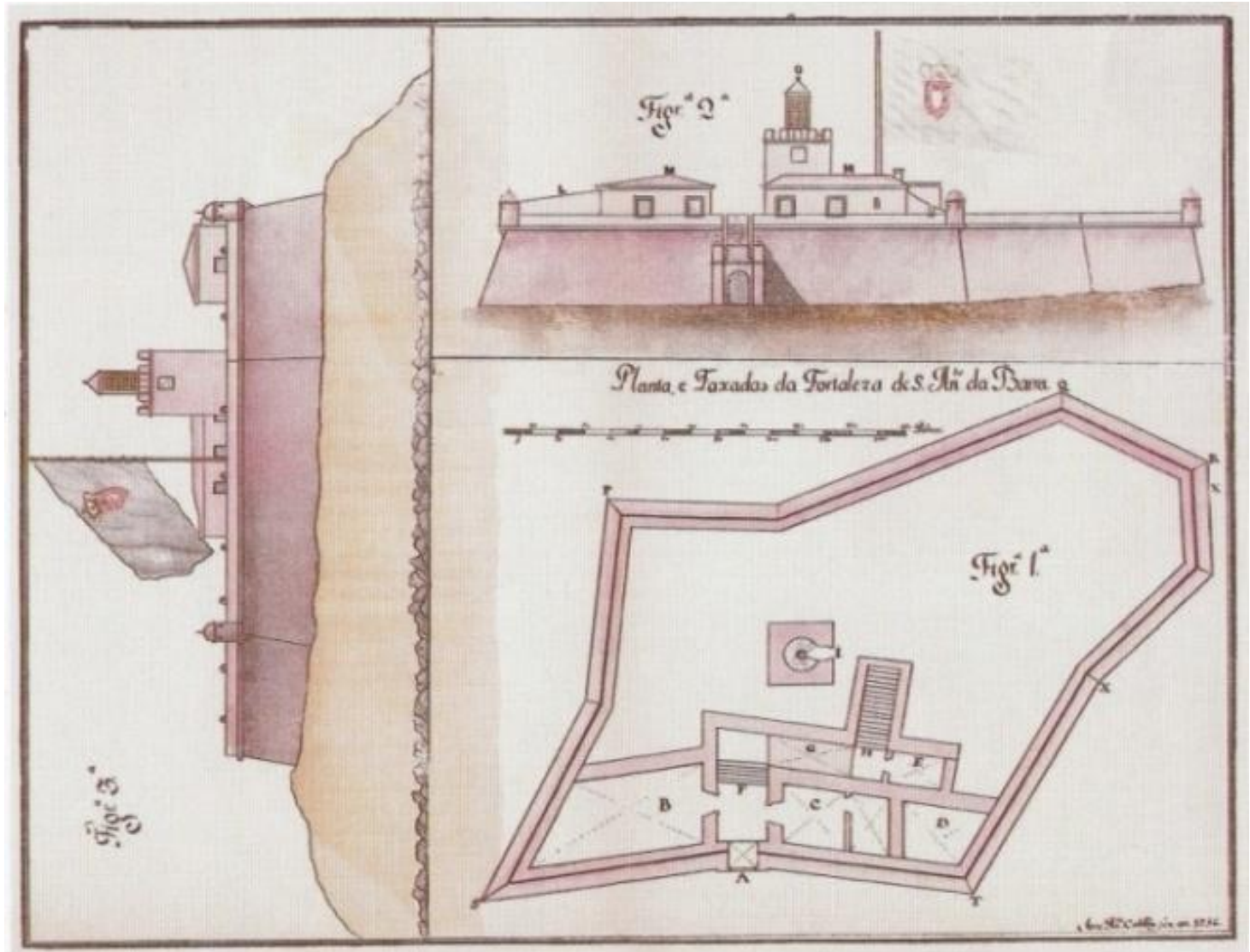

O Forte no desenho de Caldas em 1756 (1951: 356-7).

Em sua Explicasáo da Planta, Caldas diz:

A Figura 1a mostra a Planta da dita Fortaleza, em que A he a sua entrada: B Corpo de Guarda: C prizáo: D Cisterna: E Caza de guardar a palamenta, e petreichos: F.G.H sobida por escadas, rampa para o terrapleno do Forte; porque todas esras cazaz sáo subterraneas: I torre na qual esta um farol para sinal das embarcasoes que cruzao' de noite para náo darem a Costa, e se desviarem do baixo. A Figura 2ạ

${ }^{880}$ Mantivemos a ordem em que estão relacionados na Notícia Geral..., seguindo-se o "Fortinho de S. Alberto" que só aparece nas Cartas Topograficas... 
mostra a faxada do dito edifício pela parte de terra por onde a sua entrada notada na Planta com [SF], na qual de ve' a elevasam que tem a dita Fortaleza: L Caza de pólvora: M cazas do Comandante: O farol e torre. A Figura 3a mostra o Prospeto que fas frentre para a marinha notado na Planta com P Q e R. Os lados XX da dita Fortaleza estáo arruinados. ${ }^{881}$

Pela sua descrição, a forma... he um exagono irregular com quatro angulos reintrantes, e seis salientes, porq' assim o permite o terreno. ${ }^{882}$ Seria, portanto, uma fortificação propositalmente irregular, de formato resultante da adaptação às condições topográficas. Mas podemos observar pela "desconstrução" abaixo que a forma parece resultar da adição da construção existente a um desenho regular que lembra o Forte de S. Maria. Os ângulos do canto superior direito mostram onde estaria a antiga torre desenhada por Albernaz (o que também parece confirmar a representação hexagonal feita por Diogo Campos Moreno).

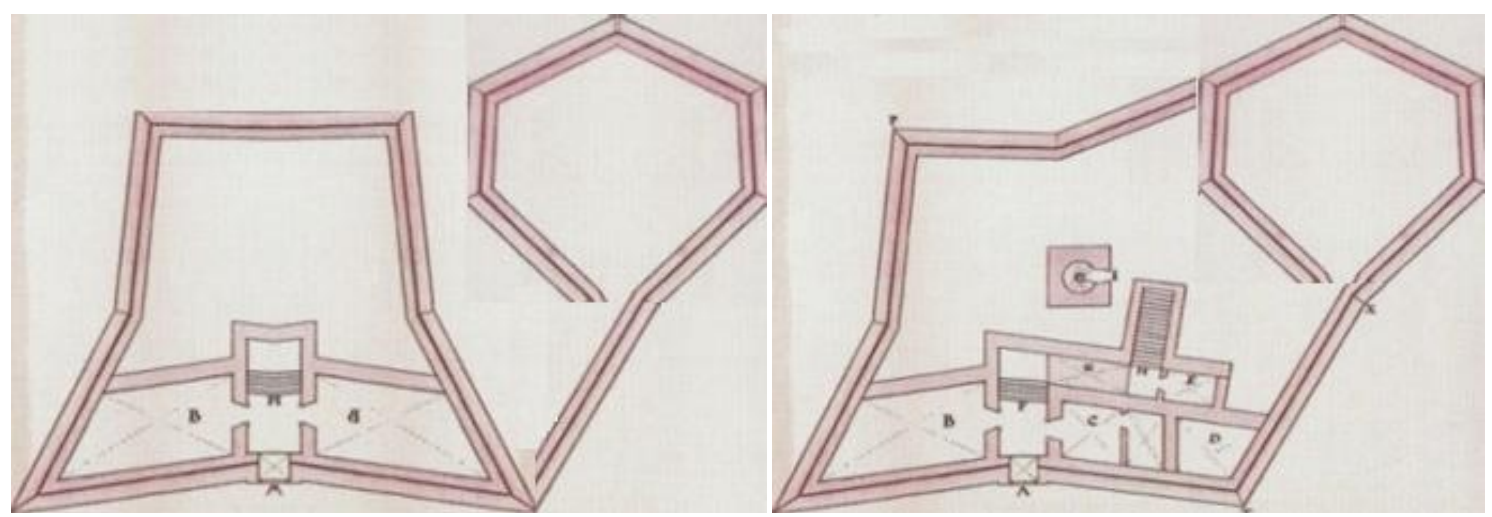

Exercício nosso de fragmentação e "espelhamento" sobre o desenho de José Antônio Caldas, indicando que a forma final parece partir de um desenho regular (fig. à esquerda).

Diogo Moreno, como vimos, chamou o forte de adorno, já que para a defesa da entrada da barra era de nenhum efeito. Em 1660, Bernardo Vieira Ravasco fez novas críticas ao Santo Antonio da Barra, reclamando dos três fortes na entrada da baía... estarem quazy juntos, e nam serem de utilidade algua' a quem nelles asiste... ${ }^{883}$

A grande reforma de ampliação foi feita no governo de D. João de Lencastre (1694-1702), aumentando em muito a sua capacidade de fogo. ${ }^{884}$ Mas o prestígio do Santo Antônio continuou baixo, pelo que se viu declarado (enfaticamente) no relatório de Mestre de Campo Eng. Miguel Pereira da Costa (1710). ${ }^{885}$ Para Miguel Pereira, teria sido melhor construir o forte no padrasto e colocado em seu lugar uma bateria. Ela não impediria a entrada na baía (o que era impossível), mas protegeria a praia de

\footnotetext{
${ }^{881}$ CALDAS, 1951: 355-6.

882 CALDAS, 1951: 353.

${ }^{883}$ Relatório de Bernardo Ravasco (11/09/1660): AUH - Catálogo de Luiza Fonseca, doc. 2.264 - apud OLIVEIRA, 2004: 185.

${ }^{884}$ Carlos Ott entende que o projeto de transformação teria participação do Cap. Eng. João Coutinho (cf. OLIVEIRA, 2004: 185), o que parece estranho, porque no relatório e projeto para a defesa de Salvador (1685), ele simplesmente ignora o forte (sua maior preocupação era reforçar o segundo perímetro de linhas estabelecido em 1640).

${ }^{885}$... o de S. An. ${ }^{\text {to }}$ da barra (nomeandoos com o cumum, impropriam. ${ }^{\text {te }}$ por fortes) em figura de dés lados, irregularissimo, com seis ângulos salientes e quatro reintrantes, sem baluarte algum, nem caza capás p. ${ }^{a}$ polvora; ... está dominado de hum grd. ${ }^{e}$ padrasto... do qual se descobre toda a ária do d. ${ }^{\circ}$ forte...: tambem não tem cisterna... (Extracto da forteficação..., fl. 1 - grifos nossos).
} 
desembarques. O forte e a bateria dariam melhor cobertura aos fortins de S. Maria e S. Diogo na defesa do Porto da Barra.

A fortificação sempre teve como principal função vigiar a barra da Baía de Todos os Santos, sendo reconhecida por isso. Desde os primeiros tempos da Ponta do Padrão, ${ }^{886}$ a posição privilegiada servia para avisar de embarcações que viessem do norte em direção à baía (vindo daí o apelido de Vigia da Barra). Nesse sentido, ainda no século XVII foi instalado um farol (torre-farol de base quadrada que existiu até o século XIX) para prevenir os navegantes de pedras e pouca profundidade, já adquirindo funções, mais do que bélicas (de eficiência sempre contestada), de vigilância e segurança à navegação. ${ }^{887} \mathrm{~A}$ feição atual é muito próxima à dos finais do século XVII, exceto pela área coberta do terrapleno.
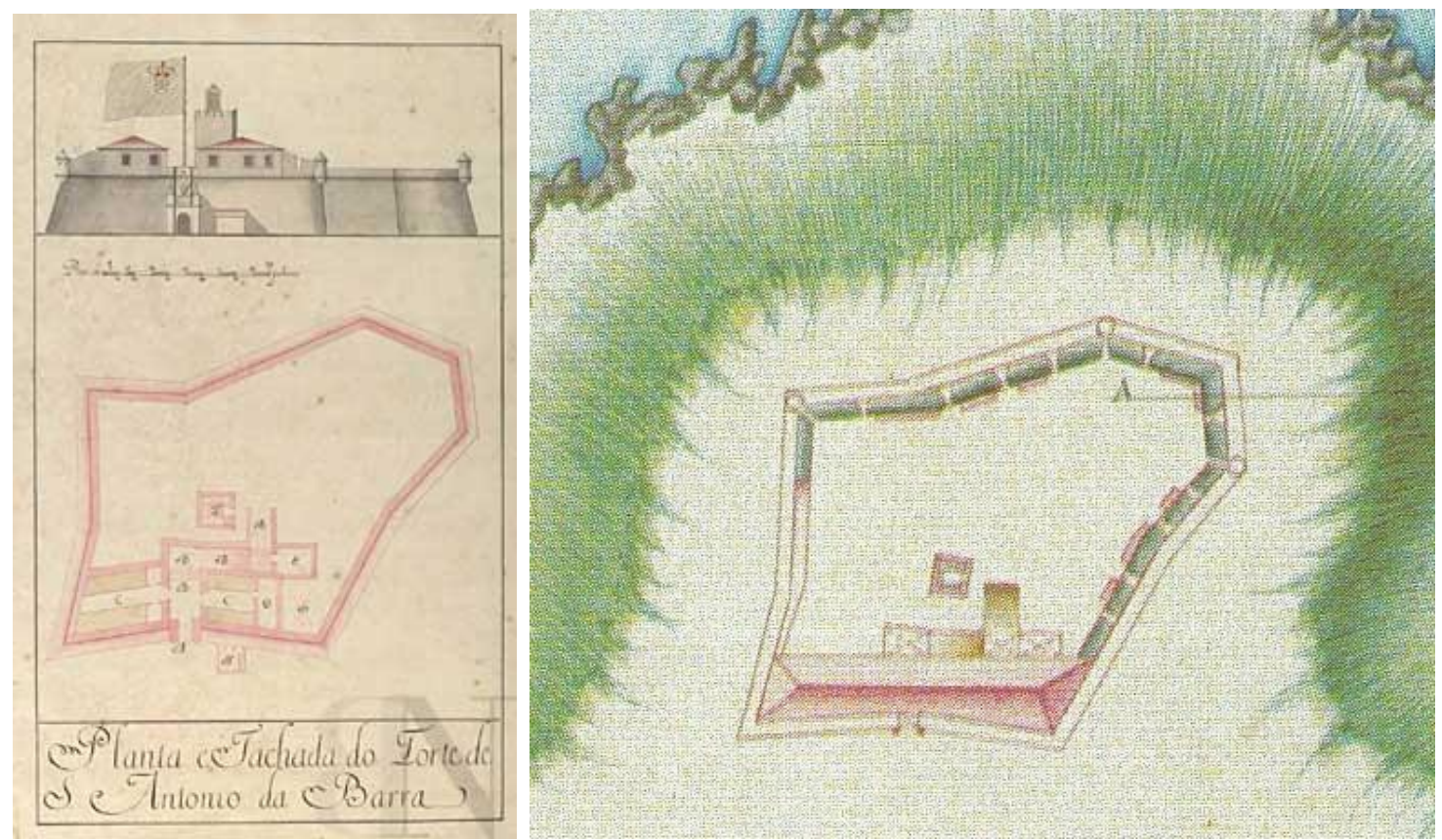

À esq., o Forte nas Cartas topográficas... (c. 1762 - BNL). À dir. Em detalhe do desenho de João Teixeira, do início do séc. XIX (em OLIVEIRA, 2004: 187).

\footnotetext{
${ }^{886}$ Alguns historiadores dizem que na Ponta do Padrão foi plantado o marco do descobrimento da Baía de Todos os Santos, por André Gonçalves. Já o relatório do Capitão Domingos Alves B. M. Barreto (Observaçoens sobre a Fortificação...: BMP, Mss 686) diz que quando D. Manuel enviou o... Capitão Christovão Jacques, para fazer mais prudentes, e demoradas observaçoens, foi este o primeiro, $q^{\prime}$ dmarcou a Carta veio dar com a Enseada da Bahia, a q' deu o nome 'de Todos os Santos'.

${ }^{887} \mathrm{O}$ farol em torre cilíndrica é do século XIX (Vilhena ainda a representa quadrada em fins do XVIII). Segundo Silva Campos, a instalação do equipamento de iluminação (comprado da Inglaterra) seria da reforma por Ordem Imperial de 06/07/1832. Em 1890 foi instalado novo equipamento europeu, reformado em 1904 e eletrificado em 1937 (CAMPOS, 1942: 96).
} 


\section{Forte de Santa Maria}
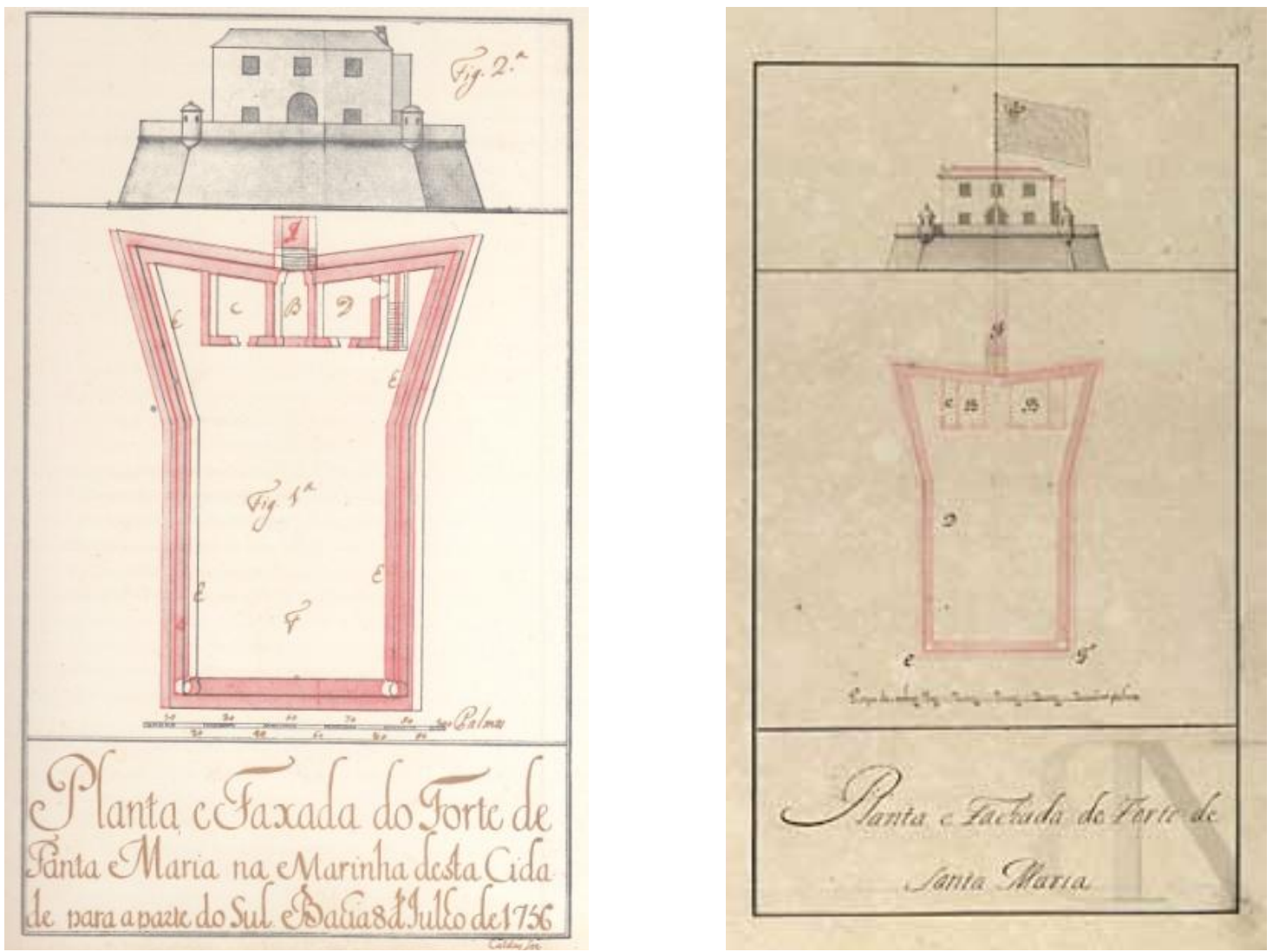

O Forte de Santa Maria no levantamento de plantas e fachadas de 1756 (CALDAS, 1951: 352-3) e nas Cartas topográficas... (c. $1762-$ BNL).

\section{Na Explicasam da Planta, é dito:}

A Figura 1a mostra a Planta desta Fortaleza, na qual se ve que $A$ hé a ponte levadisa: $B$ o seo tranzito: $C$ Caza de Polvora: D Caza, onde se guarda a palamenta, que ambas estáo no nivel do terrapleno, e por sima destas cazas no andar superior hé o quartel do Comandante: $\mathrm{E}$ parapeito a barba: $\mathrm{F}$ terrapleno. A Figura 2a mostra a elevasam e faxada da dita Fortaleza pela parte da marinha, para onde tem o seu exercício. $^{888}$

\section{Em sua descrição inicial, diz:}

... he hum reduto como oblongo com tres angulos reintrantes, e quatro salientes: porem para a parte do mar fas a figura de hum reduto para onde tem o seo maior exercício. Esta situado sobre rochedo bem a beira da marinha por cuja cauza sáo os seos tiros orizontaes: estâ reidificado de novo... ${ }^{889}$

O forte construído no governo de Diogo Luiz de Oliveira (1627-35), apoiado na pequena ponta de rocha do limite esquerdo da enseada (atual Porto da Barra), mostra já em sua concepção de desenho a intenção de dar maior capacidade de fogo no flanqueamento e cobertura da praia, que era sua função limitada e específica. Os desenhos e escritos de Caldas, como os de Vilhena mostram que o atual parapeito das canhoeiras seria à barbeta (mais baixo e contínuo), para apenas receber mais artilharia e aumentar a varredura dos canhões, o que comprometia a segurança dos artilheiros.

\footnotetext{
${ }^{888}$ CALDAS, 1951: 358.

889 Idem, p. 357.
} 
... não ha muito tempo que se repararão imperfeitissimamente os seus parapeitos, e forma que da cintura para sima, fica a guarnição exposta aos tiros do inimigo, sem outro algum recurço mais que retirar-se antes que elle dispare: não tem esta capacidade para montar mais de sette athé nove peças. $^{890}$

No Relatório de 1671 ele aparece com... uma peça de bronze de 14 L. $^{\text {as }}$ e 2 de ferro de $6 \mathrm{~L}^{\text {as }}$, sendo solicitadas mais três. Para Mário Oliveira, sete peças seriam suficientes pelo seu plano de fogo, embora Silva Campos mencione um documento de 1809 dizendo haver artilharia de 18 peças. ${ }^{891}$ Como detalhe pouco comum a outras fortalezas, já na época de Vilhena havia uma banqueta de tiro para mosqueteiros defensores das cortinas. ${ }^{892}$

O forte teve ponte levadiça de madeira, substituída por uma fixa, ainda de madeira e depois de alvenaria. Segundo Silva Campos, sua atual forma é da época administrativa de D. João de Lencastro (governo em que todos os fortes da Barra receberam restaurações), de reforma concluída em 11/12/1694. Pelo desenho do fim do século XVIII, notam-se modificações na área coberta, ampliada com redução do plano de fogo das armas leves, não comprometendo o desenho geral das cortinas. ${ }^{893}$

\section{Forte de S. Diogo}
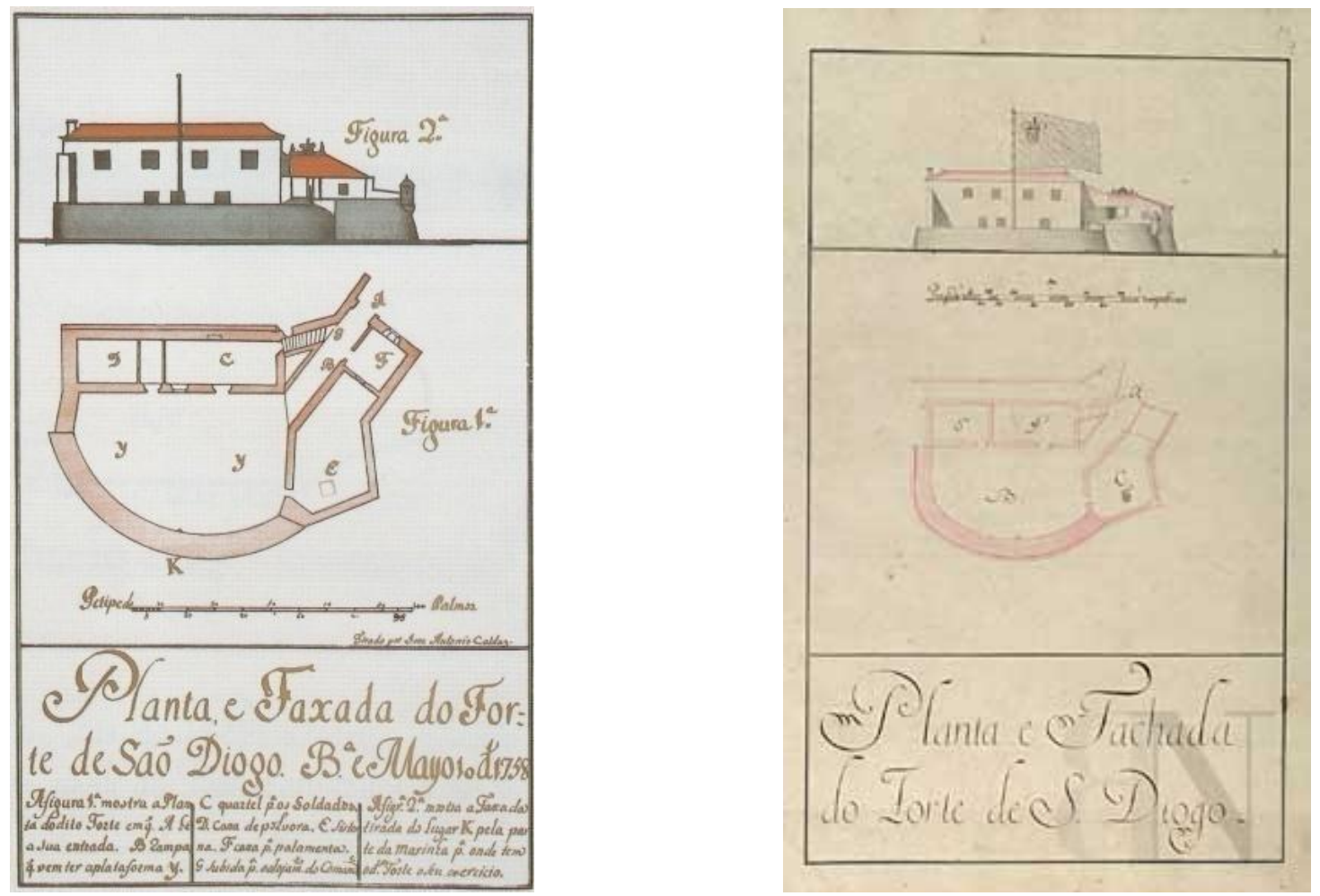

O forte no levantamento de plantas e fachadas de 1758 (CALDAS, 1951: 360-1) e nas Cartas topográficas... (c. $1762-\mathrm{BNL}$ ).

\footnotetext{
${ }^{890}$ VILHENA, 1921: 220.

${ }^{891}$ CAMPOS, 1940: 89. Esse dado foi repetido por Francisco Vicente Viana (Memória Histórica, p. 406), mas para Mário Oliveira, "ou a informação estava errada" (na leitura do antigo manuscrito), "ou existiam peças apeadas, esperando remoção, porque não tinha capacidade para tantas bocas de fogo" (OLIVEIRA, 2004: 197).

${ }^{892}$ Cf. OLIVEIRA, 2004: 197.

893 Idem, p. 198.
} 
A explicação desta planta é feita no próprio desenho:

A figura 1a mostra a Planta do dito Forte em q' A hé a sua entrada. B rampa $q^{\prime}$ vem ter a plataforma Y. C quartel $p .{ }^{a}$ os Soldados. D. caza de pólvora. E sisterna. $F$ caza p. ${ }^{a}$ palamenta. $G$ subida $p .{ }^{a}$ o alojamento do Comand. ${ }^{\mathrm{e}}$. A figr. ${ }^{\mathrm{a}}$ 2a mostra a Faxada tirada do lugar $\mathrm{K}$ pela parte da marinha $\mathrm{p}^{\mathrm{a}}{ }^{\mathrm{a}}$ onde tem o d. ${ }^{\circ}$ Forte o seu exercício.

Sua forma é descrita como de... hum meio reduto em porção circular, que... flanquea a marinha para onde tem o seo exercício, estando... reparado de novo. Descreve então suas pesas de ferro (dois canhões de calibre 12 e um 8), munições e apetrechos e sua guarnição (1 capitão comandante e 2 soldados artilheiros).

O Fortim, também obra de D. Diogo Luiz de Oliveira, foi descrito pelo documento de 1671 como uma fortificação irregular, feita ao pé da colina onde era o primitivo núcleo da Vila Velha de Pereira Coutinho, com sua cerca e torre. ${ }^{894}$ Sua função era cruzar fogo com o forte de S. Maria, evitando novo desembarque no Porto da Barra. Seu desenho é irregular, adequado à morfologia do terreno, sendo uma parte da cortina em forma de arco. O parapeito é ainda à barbeta, mantendo-se muito do desenho primitivo. A maior modificação foi na entrada principal, pois uma foto de 1949 mostra ainda a rampa interna de acesso, mas já com escada no portão de entrada. A atual guarita frontal foi reconstruída, porque na foto há apenas a mísula de suporte da guarita original. ${ }^{895}$

\section{Fortaleza de S. Pedro}

A Notícia Geral... não traz desenho desta fortaleza, que é apresentada com o seguinte texto:

A Fortaleza de S. Pedro he a que fexa o recinto desta Cidade, e a sua fortificasao se comunica por huá cortina e ramal ate a Bateria de S. Paulo que defende a marinha. Na Planta da Cidade se mostra o ambito que cerca esta fortificasaó a qual defende a entrada da Cidade pela parte do Sul. A sua figura he hum retângulo como mostra a Planta que se segue com sua fachadas e profis. ${ }^{896}$

Segue-se a descrição de sua artilharia (peças de bronze e de ferro), ${ }^{897}$ das munições e apetrechos (balas, pólvora, soquetes, bandeira, etc.), da guarnição (um capitão comandante e três soldados) e uma Explicasáo da Planta:

\footnotetext{
${ }^{894}$ Como foi mencionado em nota sobre a construção do forte no século XVII, é provável que depois de desaparecidas as defesas primitivas tenha sido colocada na área uma bateria ou trincheira (referida por Aldenburgk), já que estava em cota mais elevada e se caísse em mãos inimigas neutralizaria os fortins de baixo.

${ }^{895}$ No último capítulo (“Alguns registros...”, p. 308) estão reproduzidas as fotografias de Edgard Falcão (1949) e de B. Mulock, com o forte e a igreja de S. Antônio (c. 1860). A primeira mostra que houve uma grande mutilação da topografia e na rampa interna, possivelmente na implantação do CIREX (clube recreativo dos oficiais da 6a $\mathrm{RM}$ - cf. OLIVEIRA, 2004: 200). A segunda mostra o forte na forma menos modificada e um caminho em ziguezague pelo lado do forte até o alto da Igreja de S. Antônio, que também aparece em plantas antigas do Arquivo Militar.

${ }^{896}$ CALDAS, 1951: 361 (grifo nosso). Quanto à menção que faz a uma Planta da Cidade, ver nota sobre o ano 1770 em "José Antonio Caldas".

897 Já em seu tamanho maior, contava com cinco colubrinas de bronze (duas de calibre 10, duas de 8 e uma de 3) , um morteiro também de bronze e 37 peças de ferro de vários calibres (uma de 2, uma de 6, quinze de 8 , quatro de 12 e dezesseis de 24$)$.
} 
N. Planta da Fortaleza. O. Estrada encuberta com seos travezes. P. Lingua de serpente avansada a Campanha. Q. Foso. R. Lanso de muralha que se continua pela contraescarpa ate abrasar o ramal $\mathrm{S}$ que fica na parte mais baxa do monte em que esta situada a Fortaleza porem fica a cavaleiro pela espalda da Bateria de S. Paulo. ${ }^{898}$

Na Elevação, e Faxada... que mostra... a Cidade..., já reproduzida, pode-se notar a articulação dos dois fortes. Na falta da planta de Caldas, reproduzimos também aqui a que aparece no livro de Vilhena.

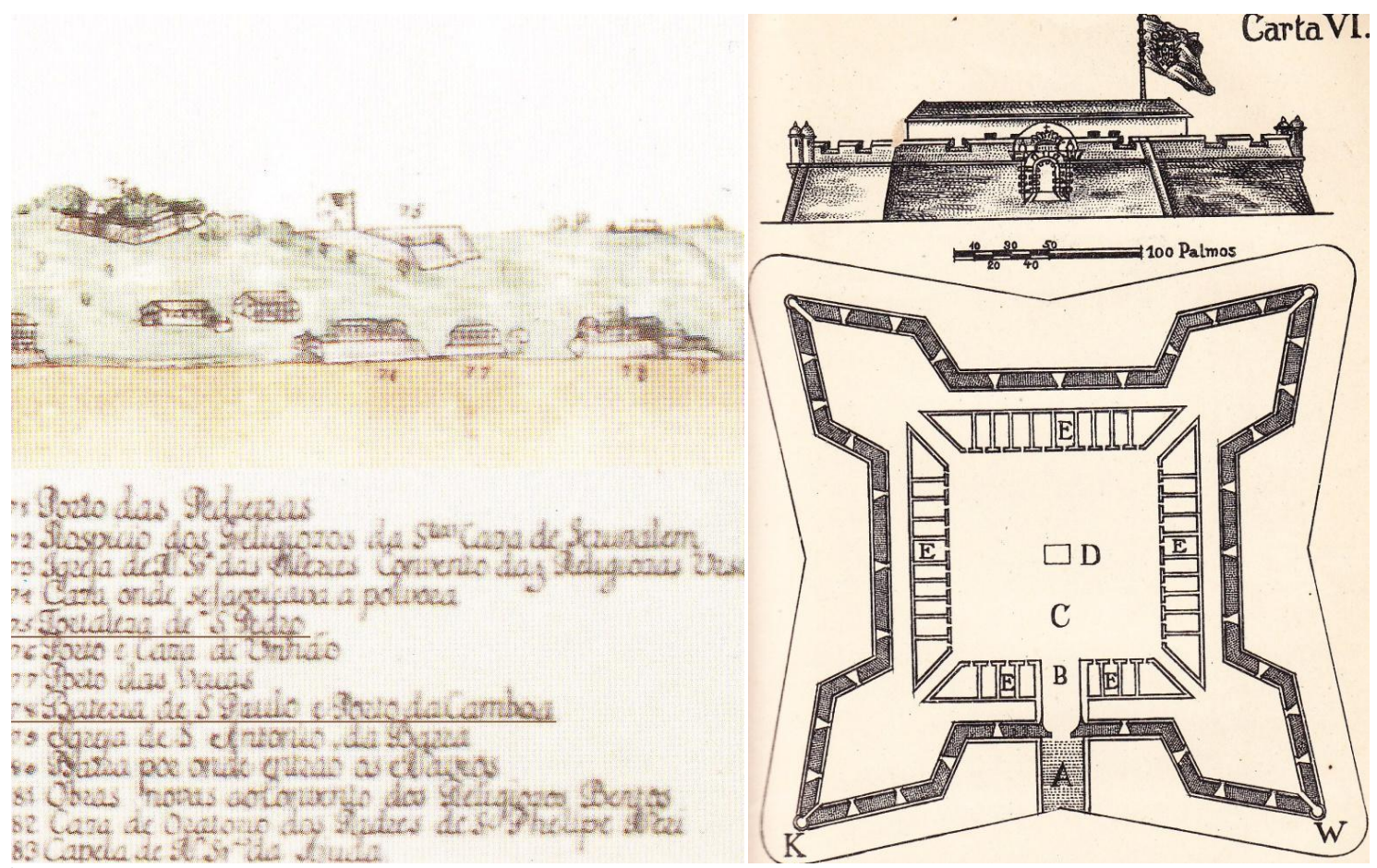

À esq., a Fortaleza de S. Pedro e a Bateria de S. Paulo e Porto da Camboa correspondendo no desenho aos números 75 e 78 da legenda (em REIS Fo, 2000: 46). À dir., o Forte de S. Pedro no desenho da publicação de Vilhena (1921: 234-5), em Plano e Prospecto ("visto pello lado KW"), apresentando outra legenda: A - Ponte, B - Entrada, C - Terrapleno, D - Cisterna e E- Quartéis. Diferentemente de Caldas, Vilhena o descreve como "hum quadrado com quatro baluartes". ${ }^{899}$

${ }^{898}$ CALDAS, 1951: 362. Pode-se acompanhar essa seqüência pela Planta e Perfil do AHM apresentada no capítulo anterior.

${ }^{899}$ O levantamento utilizado por Vilhena é em alguns casos cópia fiel do de Caldas, como o do Forte S. Alberto ("Lagartixa"). O mesmo não se pode dizer do Forte de S. Pedro, já que Vilhena diz na legenda: "Esta Planta he defeituoza pois lhe faltão todas as obras exteriores, e da mesma forma creio que pouco exactas as suas dimençoens; por descuido de quem alevantou".

Sabe-se muito pouco sobre Luiz dos Santos Vilhena, apenas que era português, pobre, casado (não se sabe o nome da mulher, dos pais ou dos filhos), professor de Língua Grega em Salvador. Foi militar na juventude (servindo em Setúbal), aproveitando o tempo livre para estudar latim e grego. As ilustrações do livro seriam reproduções (no prefácio, Braz do Amaral fala em “... desculpa não serem reproduzidos completamente..."), como a Planta da Cidade da Bahia, da Planta da Cidade de S. Salvador, do trabalho coordenado por João Massé. Os realizadores do livro se abasteceram, certamente, dos muitos trabalhos de cópia feitos por alunos da Aula Militar. Pelo menos de um dos fortes que aparece em Vilhena, o de $S$. Fernando, seguramente o desenho não é cópia de Caldas, já que a construção é de data posterior (1796). 


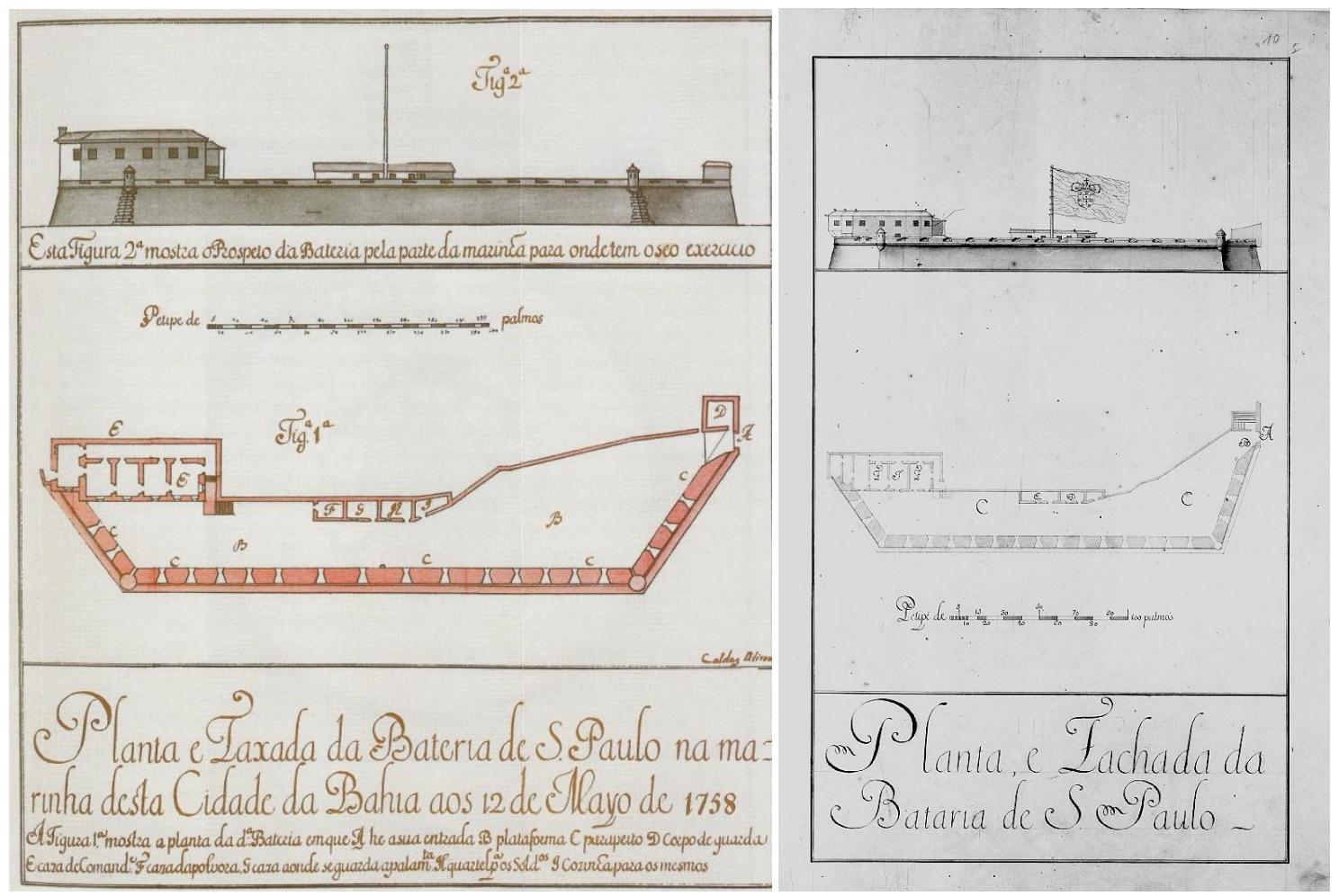

A "bataria" na Notícia Geral... com desenho de 1758 (CALDAS, 1951: 364-5) e nas Cartas topográficas... (c. $1762-\mathrm{BNL})$.

Também neste caso, a explicação é feita no próprio desenho:

A Figura 1a mostra a planta da d. ${ }^{\text {a }}$ Bateria em que $A$ he a sua entrada $B$ pltaforma $C$ parapeito $D$ corpo de guarda E caza de Comand. ${ }^{\text {e }} \mathrm{F}$ caza da polvora G casa aonde se guarda a palam. ${ }^{\text {ta }} \mathrm{H}$ quartel p. ${ }^{\text {a }}$ os Sold. ${ }^{\text {os }}$ । cozinha para os mesmos.

No texto ele explica que a bateria... assenta sobre a marinha, e por hum lanso de cortina se comunica o ramal com a Fortaleza de S. Pedro. Segundo Vilhena, no fim do século XVIII muitos a consideravam uma das melhores fortificações da Bahia, ${ }^{900}$ com significativas 19 peças de artilharia.

Para M. Oliveira, suas limitações se devem a não se poder considerá-la separadamente, pois nasceu como auxiliar do sistema de S. Pedro, cobrindo o seu ponto fraco no alto e sendo por ele coberta. Ele credita ao "bom trabalho" do Cap. Eng. João Teixeira nas muralhas do terrapleno o fato do forte resistir ainda ao ataque das ondas "e ao descaso". ${ }^{901}$ Foi considerado útil e teve conservação até o período imperial (o relatório de 1863, de Coronel Rohan, diz que o forte... foi todo reparado a pouco tempo e acha-se por isto em bom estado), tendo então o parapeito "à barbeta". Mas em sua concepção inicial, como mostra o desenho de Caldas, era "com canhoeiras e merlões", mantendo-se assim até o final daquele século.

$\mathrm{O}$ atrativo pitoresco do forte, a chamada Peça Vovó (hoje em frente ao Quartel General do Exército, na Mouraria, à espera de um restauro da Bateria), é assim descrito por Silva Campos:

\footnotetext{
900 Cf. VILHENA, 1922: 234-5.

${ }^{901}$ OLIVEIRA, 2004: 219.
} 
Por aviso do Ministério da Guerra, de 28 de outubro de 1873, foi mandado para esta Província um canhão Armstrong calibre 250, pesando 13 toneladas, a maior peça de artilharia e primeira daquele fabricante que já viera ao Brasil, sendo montada no ano de $1875 .^{902}$

\section{Forte da Ribeira e sua Bateria adjacente}

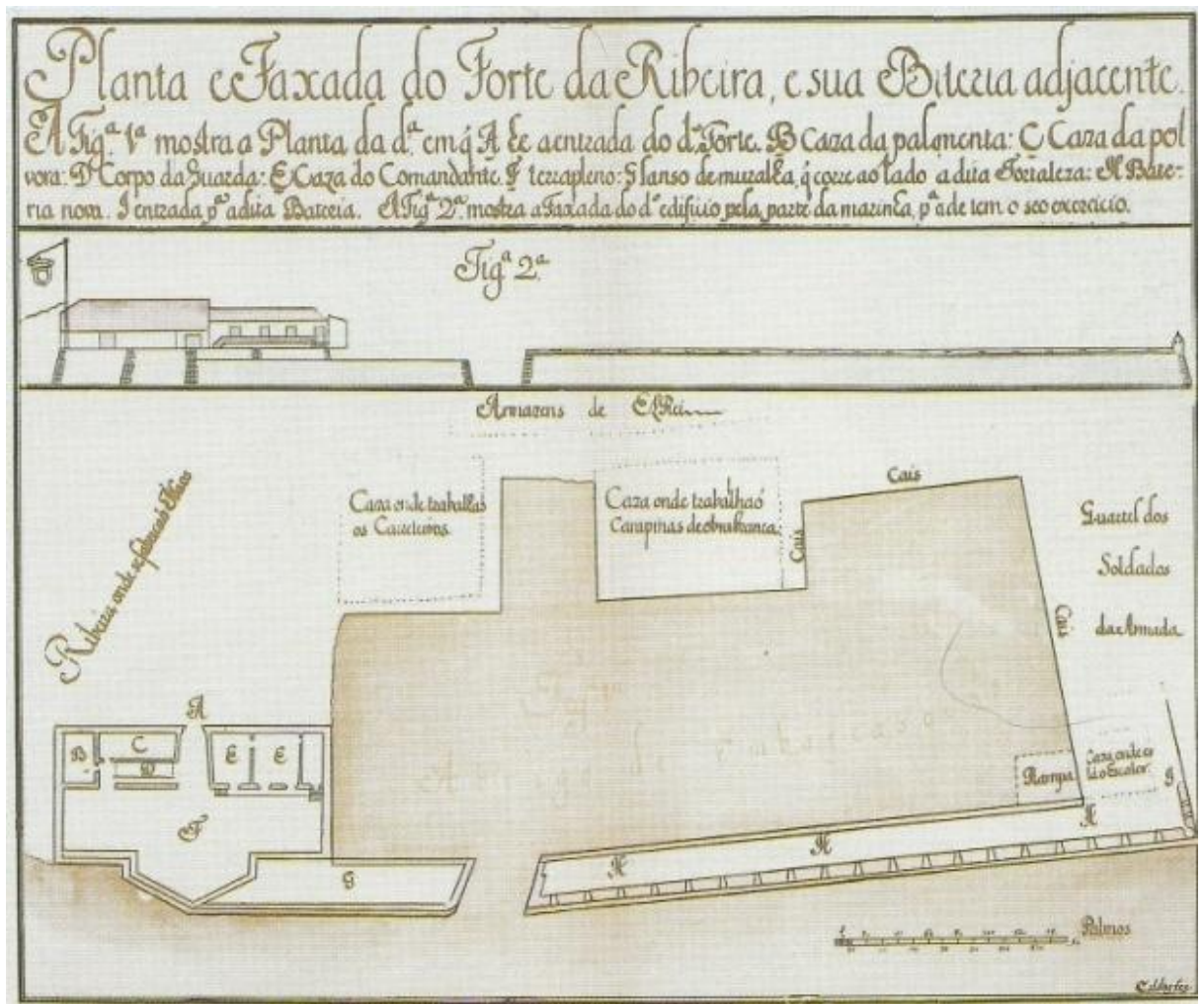

Desenho de Caldas em que aparece o antigo Forte da Laje, então da Ribeira, adjacente à Bateria (CALDAS, 1951: 364-5).

Para este forte, Caldas faz primeiro uma localização geográfica: A Fortaleza da Ribeira esta situada sobre a marinha defronte da Fortaleza do Mar;... defende vários portos, e com especialidade a Ribeira das Naos, armazens e arcenal de S. Magestade... Depois de falar de sua artilharia, munições, apetrechos e guarnição, faz uma explicação precisa da planta:

A Faxada e Planta em fronte mostra com individuasáo cada huma das suas partes, na qual se ve ser esta Fortaleza hum Baluarte plano com hum lanso de muralha que lhe corre pela parte esquerda, que serve de Bateria e feixa o abrigo das embarcasoens Reais, ficando pela parte direita desta Fortaleza a Ribeira em que se fabricao' as Naos Reais, e circundáo a muralha pela parte de terra oz Armazens, e Arcenal de El Rei..., de sorte que estes edificios junto com o Forte e Bateria da Ribr. ${ }^{\text {a }}$ feixáo hum recinto, q' comunicandose o mar por hua' aberta entre a bateria, e o Forte fica hu' abrigo muito suficiente $p .{ }^{\text {a }}$ todo o genero de embarcasoens pequenas. As Plantas seg. e suas explicasoens mostráo o dito.

902 CAMPOS, 1940: 109. Com essa montagem se conseguiu finalmente, no século XIX, "um artefato bélico que cobria o mar da Bahia até a ilha de Itaparica" (OLIVEIRA, 2004: 220), que nas poucas vezes que atirou "destruiu vidraças de toda a vizinhança" (id. ibid.); quando foi inaugurado, deixou uma mangueira secular da ilha "reduzida a um montão de lenha" (CAMPOS, 1940: 109). 


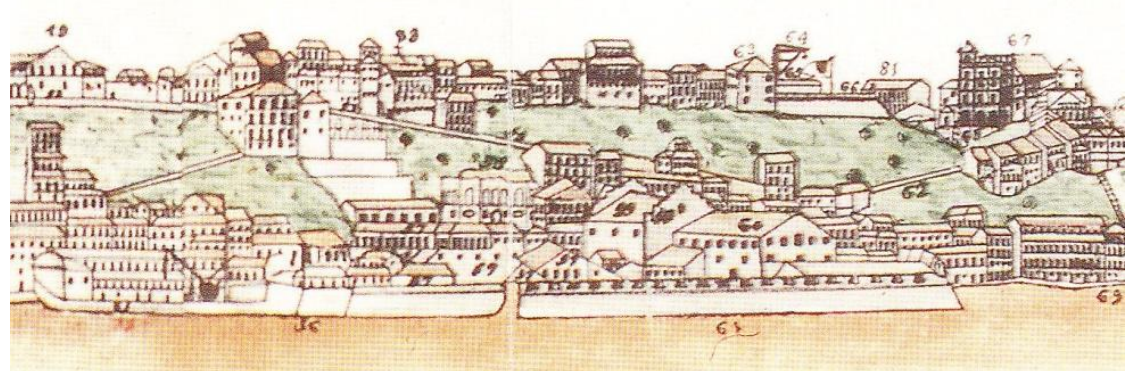

A bateria da Ribeiro em detalhe do... Prospeto... (no 61 - em REIS Fo, 2000: 46).

A fortificação da Ribeira era provavelmente uma transformação do antigo Forte da Laje, ocorrida com o aterramento da Cidade Baixa. A cartografia antiga e os desenhos do Livro da Razão... mostram que no começo da cidade, a área de terra baixa era uma faixa ínfima, cabendo apenas uma linha de armazéns grudados na encosta e o muro do antigo cais (o antigo Forte de Santo Alberto, onde hoje é a igreja do Corpo Santo, era apoiado em afloramento rochoso que se estendia pelo mar). ${ }^{903}$ Também foi chamado de "Forte Real de S. Felipe e S. Tiago", ou só "Forte Real", e de "Bateria da Ribeira das Naus".

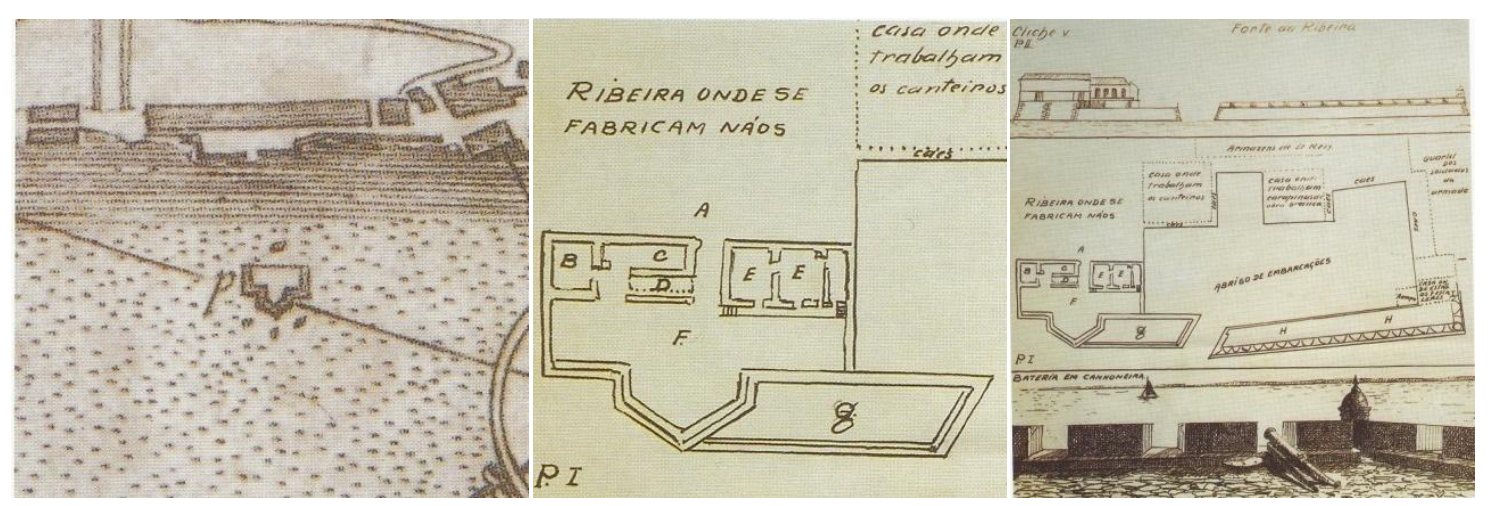

O Forte da Ribeira (ou Laje) no desenho para o texto de Hondius sobre a invasão de 1624 (à esq.) e em detalhe (ao centro - OLIVEIRA, 2004: 209) do desenho (à dir.) de Magalhães Correa (BN - 120 NE 297-4 em OLIVEIRA, 2004: 242).

Na opinião de Silva Campos (da qual discordamos), a fortificação em sua origem seria a mesma de Luiz Dias quando da fundação da Cidade, construída em syma do rochado... que joga pera todo o mar... estruturada com paos de mange que se criam nagoa e san como fero. ${ }^{904}$ Sobre este rochedo ser o da Laje Artilheira ou Forte da Laje, feito depois por Frias de Mesquita, Silva Campos diz:

Elevou-se aí, certamente, a Estância de Nossa Senhora da Conceição, onde, em agosto de 1604, o governador geral Diogo Botelho estabeleceu o quartel-general, dirigindo a defesa da cidade contra os piratas de Caarden, com os quais tantos tiros trocou a fortificação, ao dito tempo em obras, assim como estava a ribeira das naus, à qual era anexa. ${ }^{905}$

\footnotetext{
903 Cf. OLIVEIRA, 2004: 242. Por isso Luiz Monteiro da Costa chama o Forte da Laje de "forte inacabado 'só igual com as ondas' [na invasão de 1624], mais tarde batizado 'S. Felipe, São Thiago e Nossa Senhora da Conceição' e finalmente, da 'Ribeira', já desaparecido..." COSTA, 1958: 27 (grifo nosso).

904 Carta de Luiz Dias (ao Rei - ANTT). Como já dissemos, não há referência de que o rochedo do primeiro Baluarte da Ribeira submergisse na maré cheia.

${ }^{905}$ CAMPOS, 1940: 241.
} 
Seria assim o mesmo forte do Livro da Razão..., que se fez na lagem da praia. A Bateria da Ribeira, de inúmeros desenhos e em feição reduzida na cartografia do século XVIII, era importante na defesa do porto, como afirmam os engenheiros militares e historiadores. No início servia principalmente para flanquear o porto e o abrigo de naus nas laterais. Era de pedra (a estrutura começada) e estava inacabada quando chegaram os holandeses, que a concluíram, como mostra Aldenburgk: ...acabando-se o forte de pedra do mar, junto à ribeira, no qual foram colocados nove meios-quartaus e falcões... ${ }^{906}$

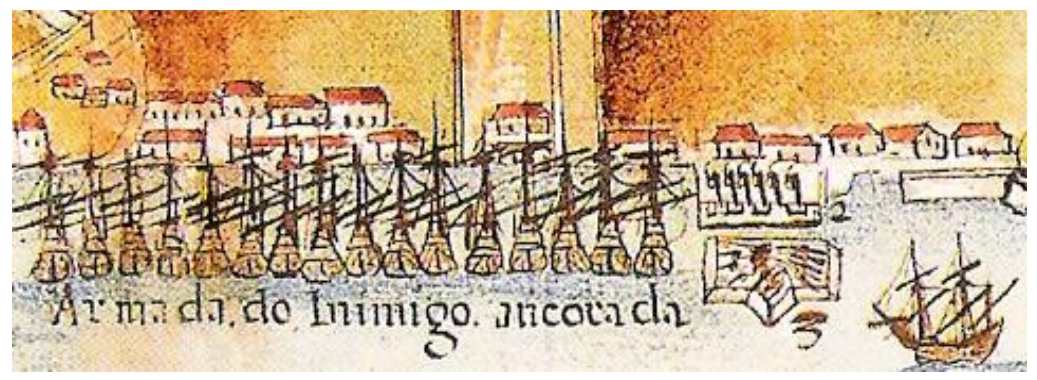

Detalhe do Forte da Ribeira (ou Laje) na Planta da Restituição da Bahia (em Atlas..., 1997: 22).

O crescimento da cidade e o avanço desordenado sobre o mar teriam "engolido" o antigo forte da Laje, que deixou de poder dar tiro de flanco. Assim, a lateral do edifício teria sido simplificada, ficando apenas o pequeno baluarte frontal. Essa preocupação do tiro frontal se observa na evolução do desenho, sendo criada a bateria ao longo do cais representada no desenho de Caldas (havendo ainda um aumento de canhoeiras no parapeito pelo que se vê no desenho do texto de Vilhena, do fim daquele século). ${ }^{907}$

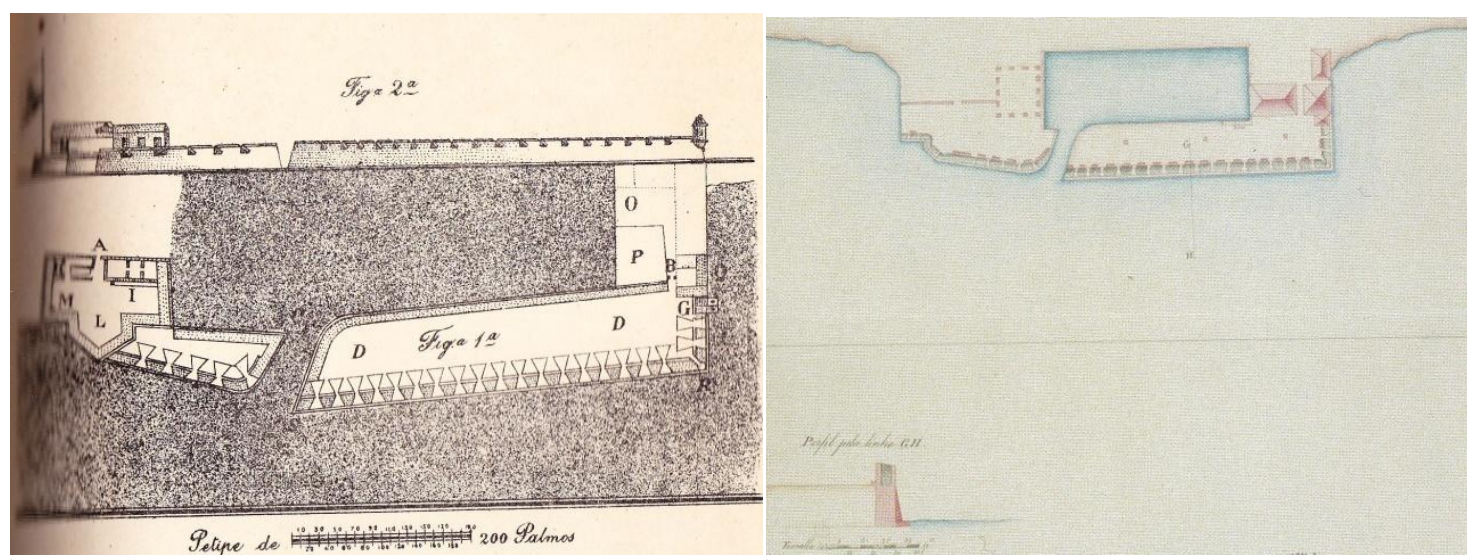

À esq., o desenho do livro de Vilhena (1921: 224-5). À dir., o belo desenho do então Cap. João da Silva Leal Teixeira (início do séc. XIX), representando a bateria já sem a fortificação que deu origem à defesa no local, dando a entender que foi "arrasada para ceder espaço à movimentação das peças de artilharia no novo direcionamento dos planos de fogo, exclusivamente frontais, da dita bateria" (OLIVEIRA, 2004: 244).

\footnotetext{
${ }^{906}$ ALDENBURGK, 1961: 201. O Padre Antonio Vieira fez uma descrição elogiosa do forte: é a praia da cidade embaixo estreita, e defendem-na três fortes, dois em terra e um no mar, avantajado aos mais por razão do sítio e fortaleza (HANSEN, 2003: 81). Narra em seguida sua tomada pelos holandeses: saíram logo das naus inimigas muitos batéis com os soldados em pinha, e, cercando o forte, depois de muitas cargas de mosquetaria o abordaram, para entrar com os nossos. Mas eles resistiram valorosamente,... matando e ferindo a muitos (idem, p. 84-5). Mas, por estarem já cansados... cederam da fortaleza...

${ }^{907}$ Cf. OLIVEIRA, 2004: 243-4.
} 


\section{Fortaleza do Mar}
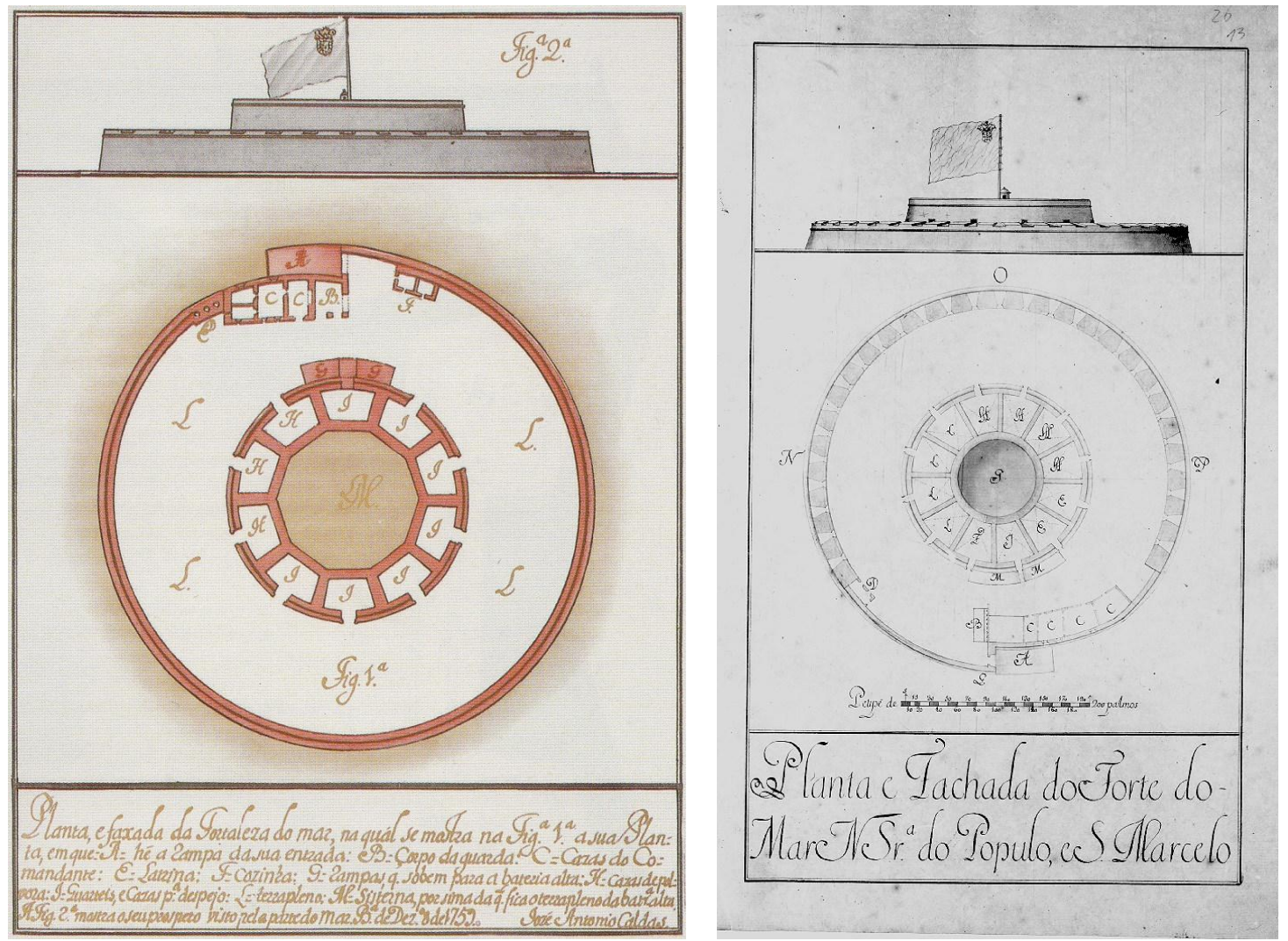

O Forte no levantamento de 1759 (CALDAS, 1951: 368-9) e nas Cartas topográficas... (c. 1762 - BNL).

Também aqui a explicação foi feita no próprio desenho:

Planta e faxada da Fortaleza do mar, na qual se motra na Fig. ${ }^{\text {a }}$ 1a a sua Planta, em que: A: hé a rampa da sua entrada: B: Corpo de guarda: C: Cazas do Comandante: E: [Lanina]: F: cozinha: G: Rampas q. sobem para a bateria alta: H: cazas de polvora: I: Quarteis, e cazas p. ${ }^{a}$ despejo: L: terrapleno: M: sisterna, por sima da q. fica o terrapleno da bat. ${ }^{a}$ alta. A Fig. $2^{\text {a }}$ mostra o seu prospeto visto pela parte do Mar. B. ${ }^{\text {a }}$ de Dez. 8 de 1759. José Antonio Caldas.

Vimos que no começo do século XVIII o forte ainda precisava de ajustes, mantendo a forma de torreão central mais alto com canhoeiras. $O$ anel externo era mais baixo, também com canhoeiras e maior densidade de artilharia. No relatório de 1710, o Mestre de Campo Miguel Pereira da Costa se manifestou contra essa solução, que o tornaria quase idêntico ao Forte do Bugio, no Tejo. O parecer de Miguel Pereira só seria acatado muito tempo depois. ${ }^{908}$

Nos desenhos de Caldas o forte ainda aparece com o torreão e as canhoeiras, como também em desenhos de 1782 (perfil da cidade do Cap. José Francisco de Souza) e 1801 (perfil de Vilhena). O relatório das fortificações de 1810, coordenado pelo Brig.

\footnotetext{
908 Quando o conceituado Eng. Mil. Brig. João Massé veio ao Brasil dar assessoria às fortificações (a segunda invasão francesa ao Rio de Janeiro havia provocado uma grande mobilização pela defesa das cidades mais importantes), na chegada a Salvador (1713), o S. Marcelo estava ainda inacabado, já que ele elaborou as instruções de abertura de concorrência para obras do forte. As especificações falavam em um enrocamento de 20 palmos $(4,4 \mathrm{~m})$ além do diâmetro que estava na planta, com os alicerces passando em até dois palmos $(0,44 \mathrm{~m})$ da altura da maré baixa e uma sapata de três palmos $(0,66 \mathrm{~m})$ subindo com a muralha (em arrasto de 1/5 palmo, ou $20 \%$ (cf. OLIVEIRA, 2004: 212).
} 
Galeão, fez algumas críticas ao torreão elevado, às troneiras e casamatas, o que indica que as transformações que fizeram desaparecer a praça alta e substituir as troneiras por um parapeito a barbeta são posteriores a essa data. ${ }^{909}$
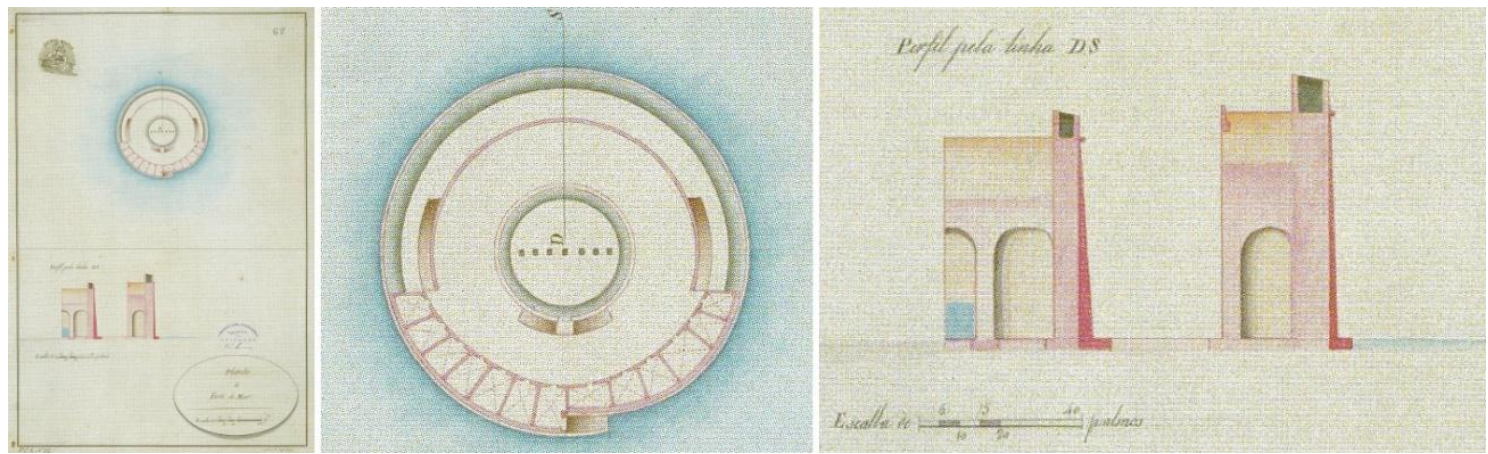

O desenho (inteiro e com duas aproximações) de João da Silva Leal Teixeira, já como capitão (pós-1810), mostrando o S. Marcelo na forma atual (em OLIVEIRA, 2004: 213).
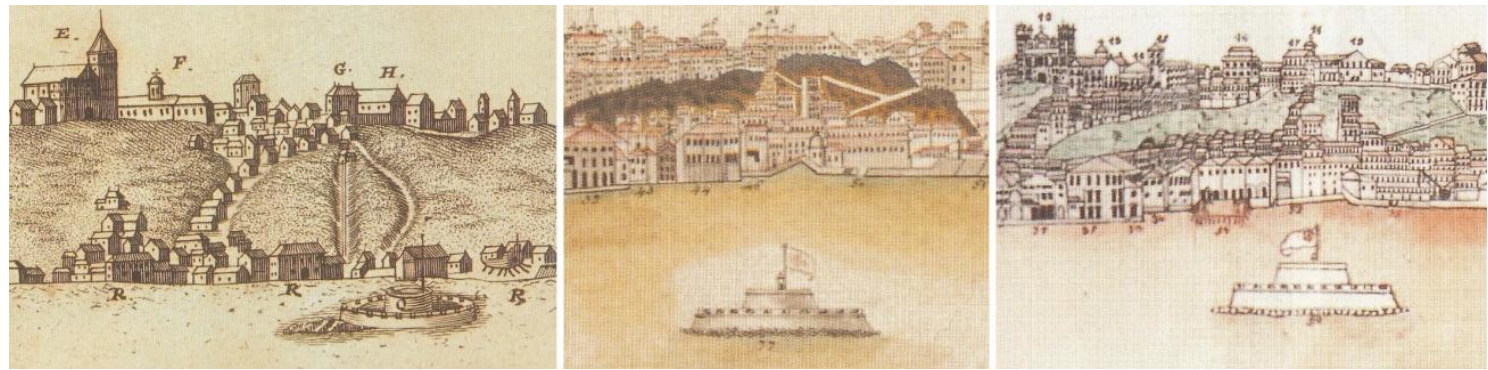

Detalhes do S. Marcelo ainda com a torre alta em vários perfis: St. SALVADOR Ville Capitale du Bresil, ilustração do livro de Froger, c. 1695 (1698); PERSPECTO DA CIDE DE S. SALVADOR/ BAHIA DE TODOS OS SANTOS, original manuscrito de Manoel R. Teixeira da DSE, Gab. de Est. Arq. da Eng. Militar, Lisboa, c. 1797; Elevação, e faxada..., levantamento de José A. Caldas que ilustra a Notícia Geral..., 1758;...

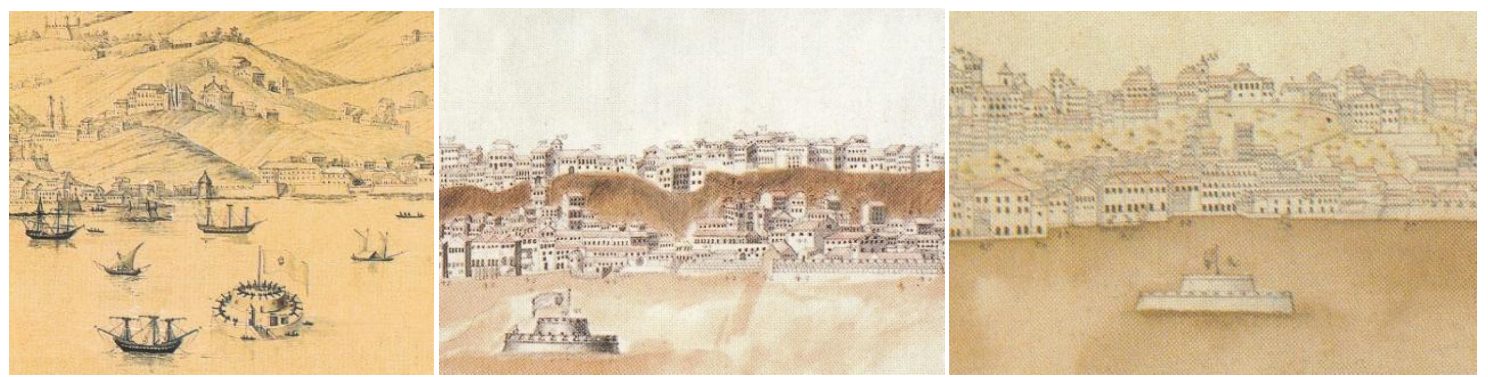

...Demonstração da Cidade de S. Salvador..., original manuscrito da DSE, Gab. de Est. Arq. da Eng. Militar, Lisboa, 2a met. do séc. XVIII; Prospecto que pella parte do Mar faz a Cidade..., desenho que ilustra o livro de Vilhena, original manuscrito da BN; Prospeto da Cidade da Bahia de todos os Santos..., João F. de S. e Almeida, Gab. de Est. Arq. da Eng. Militar, Lisboa, 1782 (em REIS FILHO, 2000: 35-58).

909 O relatório de inspeção (1810) propunha erguer um novo anel externo ao terrapleno da altura do torreão central. A comissão chefiada por Galeão tinha bons desenhistas, como o Cel. Manoel Rodrigues Teixeira, o Ten. Cel. José Francisco de Souza e o Cap. Joaquim Vieira da Silva, mas principalmente o 1응 Ten Eng. João da Silva Leal Teixeira, que deixou uma coleção de desenhos de fortalezas de ótima qualidade, com muitas reproduções e cópias em arquivos de Portugal e do Brasil.

Para M. Oliveira (2004: 212), o forte é hoje "um dos exemplares mais expressivos das fortificações do Brasil Colônia", que "sobrevive a duras penas". Em sua avaliação, necessitaria, "urgentemente, de socalque de suas fundações e enrocamento de proteção", pois sem esses cuidados mínimos ruirá o anel externo e depois o resto. Ainda para ele, mesmo sem participar de qualquer ação militar em defesa do porto, o S. Marcelo é "um dos cartões-postais mais expressivos da Salvador de 450 anos", defendendo assim sua recuperação pela iniciativa privada (a federação teria outras prioridades). 

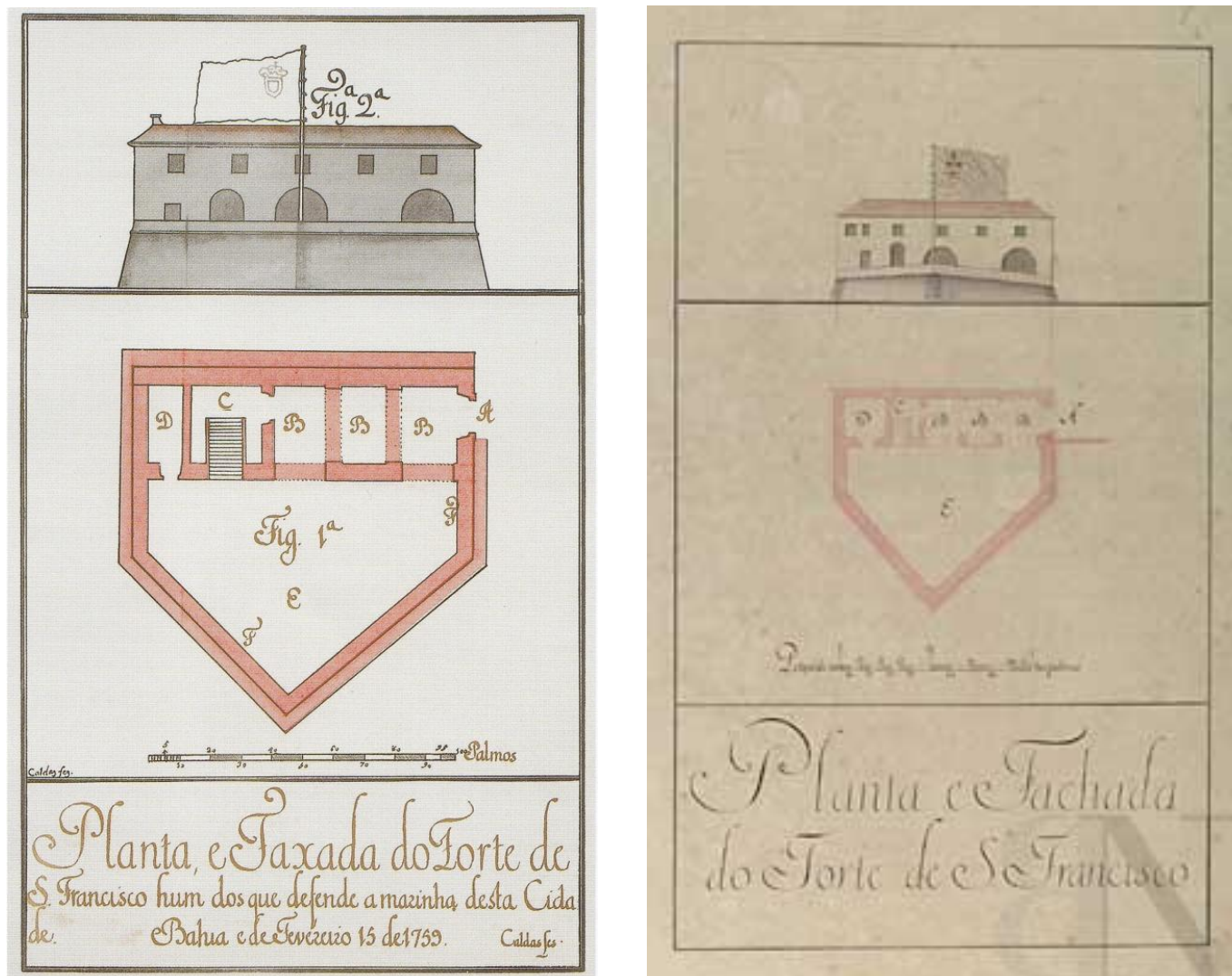

À esq., planta e fachada do Forte de S. Francisco (em CALDAS, 1951: 370-1). À dir., nas Cartas topográficas... (c. 1762 - BNP).

Na Notícia Geral... ele é descrito como... hum Baluarte plano, que se avansa sobre a marinha. Passando à explicação do desenho, Caldas diz:

Da Planta e Faxada em fronte se mostra, que A he entrada desta Fortaleza: B Corpo de Guarda: C Caza de polvora: D Caza onde se guarda a palamenta, e por sima destas Cazas está o alojamento do Comandante: E terrapleno da dita Fortaleza: F seo parapeito a barba: A Figura 2a mostra a faxada que faz esta Fortaleza pela parte da marinha, para onde tem os seo exercício...

No projeto de João Coutinho ele foi considerado importante no flanqueamento da marinha, pedindo-se a construção de mais uma bateria, talvez por estar mais de um tiro de mosquete do de S. Filipe (aparentemente os engenheiros desconsideraram a bateria de Santa Bárbara, que perdera eficácia). Coutinho enfatizou que o forte era prejudicado pelas construções abusivas, propondo o seu reposicionamento. No século XVIII, a malha urbana aos poucos envolveu o reduto, já que a recomendação de Coutinho não foi seguida. Assim, para Miguel Pereira, ele era pouco importante na defesa da cidade. Mesmo com as críticas, o forte ainda sobreviveu até o tempo das Notícias de Vilhena (mas já não aparece no Relatório de Galeão de 1810), quando foi considerado pouco útil por ser...

... hum baluartezinho plano, defeituozo e sem defeza, por estar entre edificios, que lateralmente avanção para a marinha, ficando-lhe pela espalda a montanha quazi inacessivel por onde se dice que em 1795 correrão não menos de treze propriedades das cazas. ${ }^{910}$

${ }^{910}$ VILHENA, 1921: 226. 
Chamava atenção assim também para a instabilidade da encosta. O simples troar de sua artilharia já poderia causar deslizamentos (recebeu o apelido de "quebrapratos" pela tradição de que a vibração de seus disparos tinha esse efeito na vizinhança). ${ }^{911}$

\section{Fortaleza de S. Antonio do Carmo}
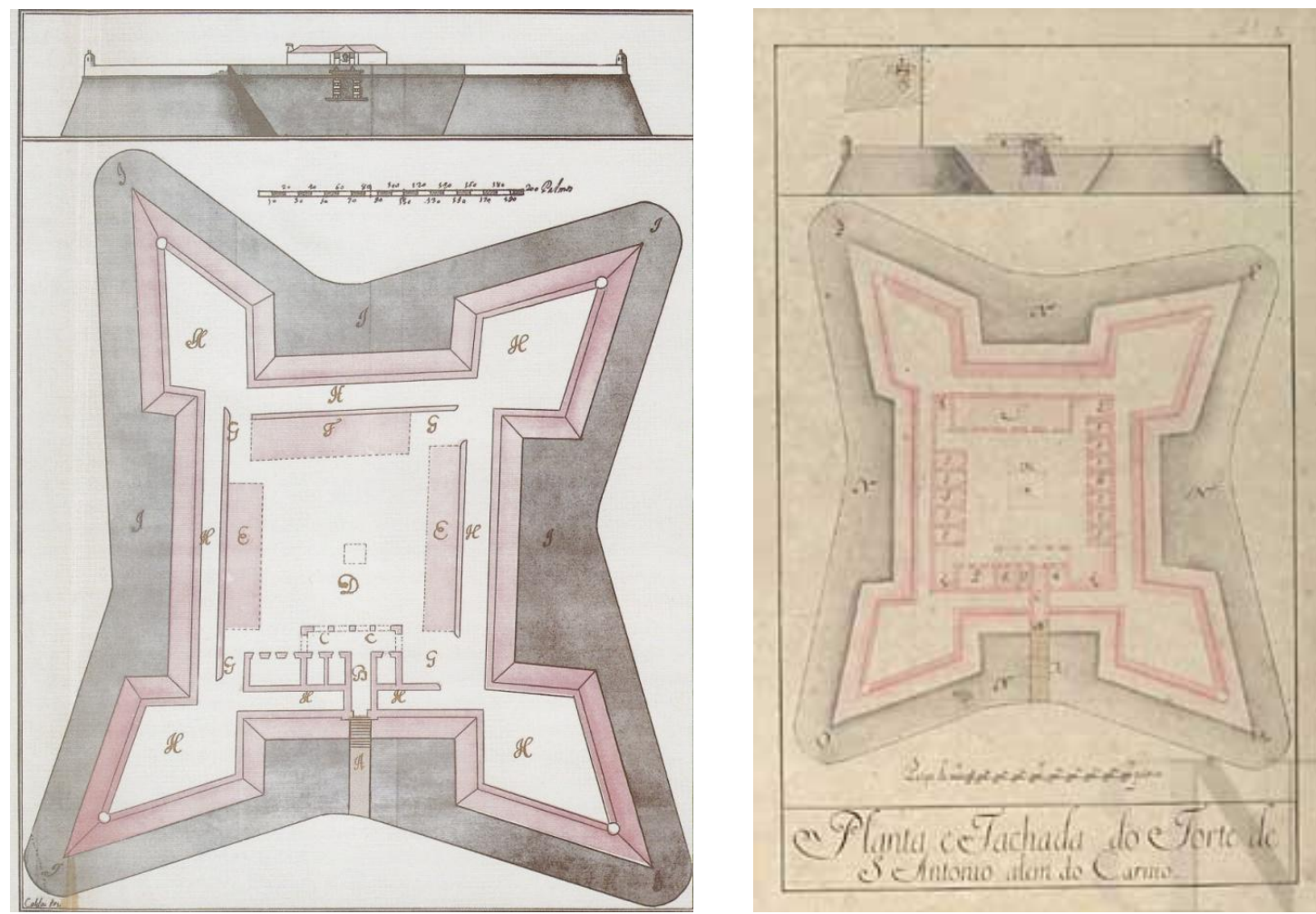

A fortaleza de S. Antonio além do Carmo no desenho de Caldas de 1759 (CALDAS, 1951: 372-3) e nas Cartas topográficas... (c. $1762-$ BNL).

\section{Na Explicasam da Planta, Caldas diz:}

A Ponte de madeira. B Tranzito. C Quarteis com Caza do Comand. ${ }^{\text {te }}$ por sima. D Plano da entrada, e Cisterna no meio. E Cazas de despejos . $^{\text {a }}$ guardar a palamenta. F Quarteis. G Rampas por onde se sobe para o terrapleno. H Terrapleno. I Foso: e a Contraescarpa q' é de terra está arruinada./ A Figura 2a mostra a faxada da dita Fortaleza pela parte da entrada. Baía e de Ourtubro 21/ de $1759 .{ }^{912}$

$$
\text { Na descrição, diz que o forte... }
$$

... fica eminente a marinha sobre o oiteiro em que asenta a Cidade. Por hum lado, he retangular com seos baluartes cortinas flanquos [ $\&^{\text {va' }}$ ] como mostra a Planta; por hum lado defende a marinha, e pellos tres a parte de terra. Impede o transito de Itapagipe para a Cidade... ${ }^{913}$

O desenho do forte no século XVIII é um clássico quadrilátero com quatro baluartes em ponta de lança, ligeiramente irregular. Hoje está muito desfigurado pela perda de dois baluartes do lado sul e pelos acréscimos que foram feitos quando se

\footnotetext{
911 Cf. CAMPOS, 1940: 250-3.

912 CALDAS, 1951: 372.

${ }^{913}$ CALDAS, 1951: 371.
} 
tornou cárcere público. ${ }^{914}$ É provável que a perda dos baluartes tenha ocorrido em uma operação de "belezura" do bairro (criando-se ou aumentando a praça em frente, sem que houvesse ainda uma cultura de conservação da memória). Nas prospecções arqueológicas de épocas recentes foi descoberta a sua imensa cisterna de água, que já foi coberta por uma abóboda. Com a restauração atual, ela está bem à vista. ${ }^{915}$

Vilhena fez poucos comentários, dizendo que ainda possuía fossos $e$ contraescarpas até o fim do século XVIII. Pouco depois, o Relatório do Brig. Galeão (1810) também não faz comentários relevantes sobre o forte, que talvez já estivesse comprometido em sua função defensiva pelo crescimento da cidade, não compensando investimentos.

\section{Fortaleza do Barbalho}

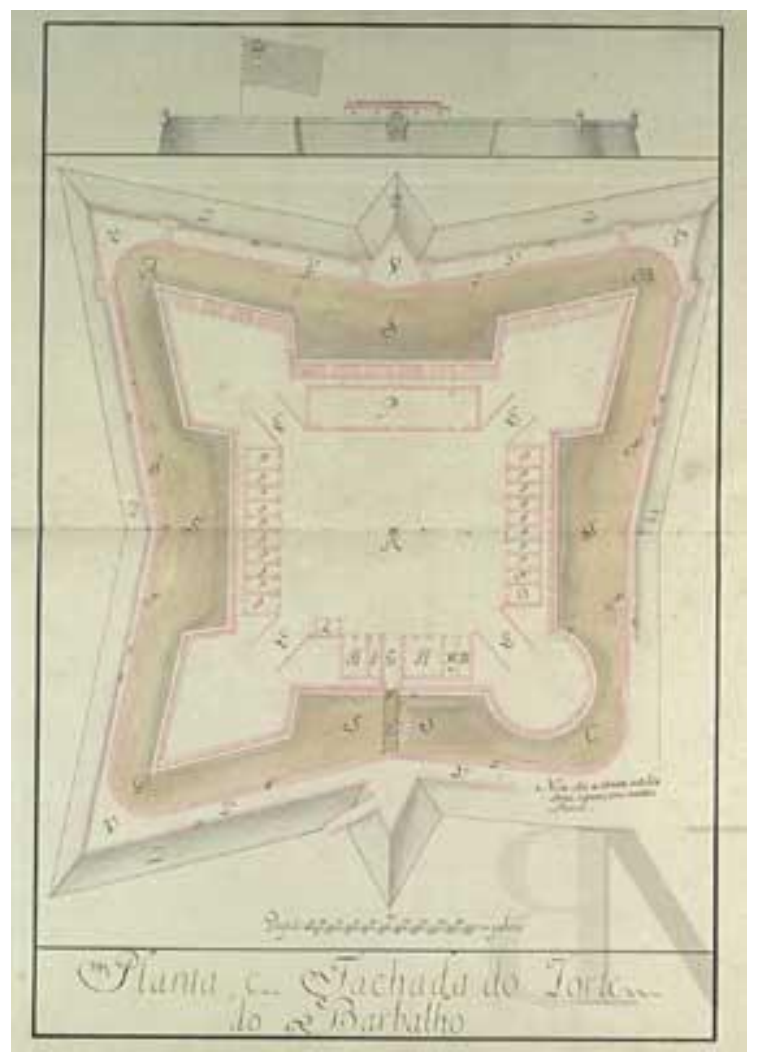

O Forte do Barbalho aparece apenas nas Cartas topográficas... (c. 1762 - BNP).

\footnotetext{
${ }^{914}$ O Forte de Santo Antônio foi desde o princípio utilizado como presídio, e transformado depois em Casa de Correção da Cidade do Salvador. Segundo Silva Campos, o imóvel foi cedido ao município para este fim em 09/03/1830 (Período Imperial), a pedido da Câmara de Salvador. Mas a nova função não foi implantada, pois em relatório de 1847, o Presidente da Província sugere consertos para se tornar quartel da Guarda Nacional. Ainda segundo Silva Campos, a transformação em presídio só ocorreria em 1863.

M. Oliveira (2004: 223) fala de seus "prisioneiros ilustres" quando ainda era fortificação: Sebastião de Castro Caldas (Guerra dos Mascates), José Correia de Castro (ex-governador de S. Tomé e Príncipe), Antônio Soares da Franca (Mestre de Campo), Cristóvão Tavares de Morais (Desembargador), Sebastião da Veiga Cabral (Sargento-mor de Batalha), José Inácio de Abreu e Lima, Luiz Lopes Pegado Serpa (antigo provedor-mor) e outros. Também abrigou presos políticos do regime militar de 1964: Alberico Bouzon e Maria Lúcia Carvalho (economistas), José Pugliesi (advogado), Luiz Contreiras e Marco Antônio de Medeiros (engenheiros), Roberto Argolo (físico e professor da UFBA), os irmãos Santana (Marcelo, Sérgio e Yeda), Carlos Marighela e outros.

915 Ela aparece em fotos do último capítulo ("Alguns registros...", p. 312).
} 


\section{Sem desenho na Notícia Geral..., o forte é assim descrito:}

A Fortaleza do Barbalho he hum quadrado com tres baluartes em ponta, e hum em forma circular com seo foso entrada encuberta [ ${ }^{\mathrm{a}}$ ]. Esta Fortaleza esta situada na Campanha para defensa do caminho que pela p. $^{\text {te }}$ do Norte se comunica oara a Cidade. Na Planta da Cid. ${ }^{\text {e }}$ se mostra o lugar em que ela esta situada... ${ }^{916}$

O projeto da edificação deve ser do tempo do Brigadeiro Massé. Tanto ele quanto Miguel Pereira e Gaspar de Abreu estiveram envolvidos. O memorial do projeto descreve o velho edifício de terra e destaca o papel estratégico do novo: Lateral, e fronteiro a este [S. Antônio Além do Carmo] fica outro, chamado do Barbalho, de terra com quatro meyos baluartes, mas muy piq. ${ }^{\text {no }}$ no todo ... ${ }^{917}$

Há no forte o inusitado baluarte redondo. ${ }^{918}$ Não se trata de uma simplificação, pois na planta de Vilhena (copiada do Projeto Massé) e na cópia do Arquivo Militar do Rio de Janeiro já está assim, fazendo parte, portanto, do projeto inicial. É possível que fosse uma direção secundária, improvável de ser atacada (não há explicação documental para o fato).

No fim do século XVIII, o forte começou a funcionar como prisão. ${ }^{919}$ A partir de 1828 e no regime militar de 1964 também serviu de Cadeia Pública, recebendo muitos presos políticos. ${ }^{920}$ Hoje está sob a guarda do 70 Batalhão de Polícia Militar, que até pouco tempo o utilizava como quartel. Nos últimos 50 anos ocorreram adições de elementos arquitetônicos espúrios desfigurando o desenho dos baluartes e a harmonia do conjunto, mas tanto aqueles quanto as cortinas de perímetro central estão sólidos, por serem bem construídos. ${ }^{921}$ Fala-se em projetos culturais para a sua restauração e reutilização. ${ }^{922}$

\footnotetext{
${ }^{916}$ CALDAS, 1951: 373.

${ }_{917}^{917}$ Relatório dos engenheiros... AHU - Documentos Avulsos, Bahia: Cx. 8, doc. 29 (CD2, 10, 002,...).

${ }^{918}$ Para M. Oliveira (2004: 227), é uma fortaleza clássica, em quadrilátero, com três baluartes em ponta de lança e um redondo, anacronismo que aparentemente "não se justifica em fortificação do século XVIII".

919 Sílvia Campo (1940: 173 e 175) enumera alguns de seus "prisioneiros ilustres": oficiais franceses trazidos de S. Tomé, o inglês Tomaz Lindley (contrabandista) e família, Davi Leopoldo Targine (revolucionário republicano, que lá faleceu), Carlos César Burlamaqui (Brigadeiro), João Estanislau da Silva Lisboa (assassino da "bela" Julia Fetal) e outros.

${ }^{920}$ M. Oliveira $(2004,228)$ enumera alguns deles e lamenta que ao ser reconhecido como local de tortura teria manchado a história dos "vetustos baluartes" que eram "sinal de liberdade do domínio português" (enaltecimento não muito justificável, pois a construção militar também pressupõe guerra e violência).

${ }^{921}$ Cf. OLIVEIRA, 2004: 229.

${ }^{922}$ Nas Guerras da Independência da Bahia sua guarnição esteve fiel ao General Madeira de Melo, que o abandonou na retirada de Salvador, "encravando os seus canhões" (OLIVEIRA, 2004: 229). O Alferes Adrião Lemos desencravou duas das peças para saudar com os 21 tiros de praxe o cortejo de 02/07/1823 e o hasteamento da bandeira do império brasileiro (a fortaleza que deu nome ao bairro, como o Forte de São Pedro, sempre esteve envolvida nos movimentos revolucionários da cidade arrolados por M. Oliveira - como a Sabinada).

O relatório Rohan atestou sua incapacidade de funcionar como fortaleza, mas foi restaurado e continuou como sede de unidades militares até hoje. Embora o forte tenha sido batizado em homenagem ao comandante pernambucano, não deixou de ter um orago protetor religioso. Em documentos antigos aparece a expressão N. S. ${ }^{a}$ do Monte do Carmo, chamado Barbalho, assim como na História Militar do Cel. D. Iosé Mirales, o que pode estar relacionado à toponímia do local, que foi de propriedade dos Carmelitas. Também no Arquivo Ultramarino, em documento do Catálogo de Castro de Almeida, há um papel no qual o Engenheiro Militar Nicolau Abreu de Carvalho, que esteve muitos anos
} 

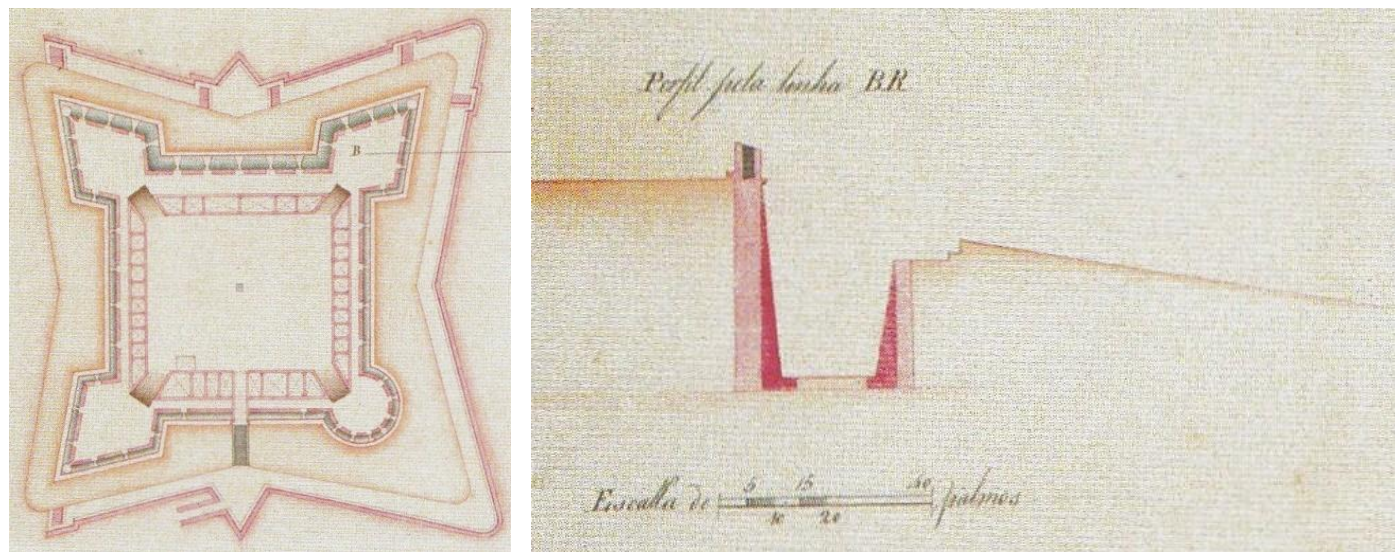

Detalhes (Planta e corte parcial) do desenho do então Cap. João da Silva Leal Teixeira (GEAEM, 4558_13/ OLIVEIRA, 2004: 229).

\section{Fortaleza de N. S. de Mont Serrate}
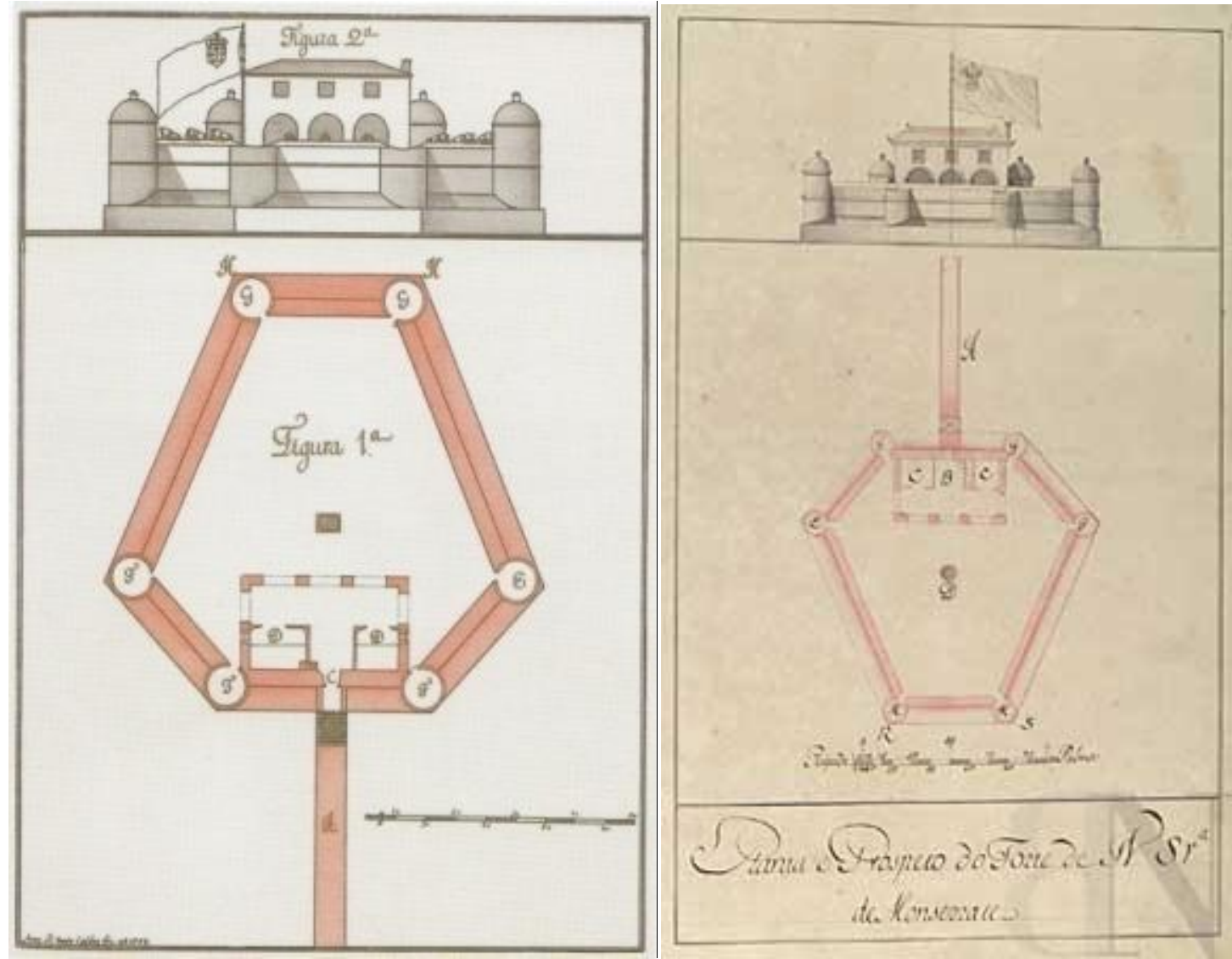

Os desenhos da Notícia Geral... (1759 - CALDAS, 1951: 376-7) e das Cartas topográficas... (c. 1762 BNP).

Há uma longa Explicasam da Planta em fronte, em que já se descreve a fortaleza... situada sobre hú oiteiro que finaliza a sua fralda na marinha em hua ponta ou língua de terra que forma a enseyada e fica ao norte desta Cidade em distancia de quaze huá legoa: ${ }^{923}$

na Bahia, fez inspeção no Barbalho em 1737 para opinar sobre seu estado e utilidade, chamando-o de $S$. Nicolau Bispo, conhecido popularmente como Barbalho.

${ }^{923}$ CALDAS, 1951: 375. 
A Planta e Faxada da Fortaleza de N. Sr. ${ }^{a}$ de Mont Serrate he a que se ve em fronte. Esta Fortaleza he hum Exagno irregular com turrioens nos seos angulos (fortificasam antigua e defectuoza) como mostra a Figura 1 a da estampa na qual se ve que $A$ he a rampa da sua entrada $B$ ponte levadisa para a parte de terra: C porta da Fortaleza DD quartéis para os soldados, e por sima Caza do Comandante E torriao' que serve de caza de polvora, e os trez FFF servem para guardar a mais palamenta. Os dous torrioens GG estao' demolidos ate o nível da declividade do parapeito $q^{\prime}$ he a barba. A Fig. ${ }^{\text {a }} 2$ mostra a faxada da dita

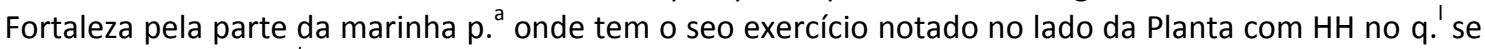
vem as altr. ${ }^{\text {as }}$ regul. ${ }^{\text {das }}$ pelo seo [petyx/ petipe]. Os torriens estao' sentados sobre hua' Berma com 8 palmos de alto, onde principia a escarpa com 4 palm. ${ }^{\text {as }}$ e $1 / 2$ de altura que finaliza na raiz da muralha e vem a ter toda a berma de alto 12 palmos e $1 / 2$, e 8 e $1 / 2$ de grosura. Tudo se vê distintamente na planta, e faxada tirada em 20 de Julho de $1758 .^{924}$

Embora elogiado em sua arquitetura, vimos que no relatório de 1710 e em outros também foi muito criticado pela pouca eficiência. Para Miguel Pereira, era um forte pequeno e esquecido, pouco mayor $q^{\prime}$ hua' atalaya das nossas praças fronteiras, mas que podia ser melhorado (o que não ocorreu). ${ }^{925}$ Poderia receber um maior número de peças, mas não mais que 6 ou 7, segundo o Mestre de Campo Eng. Miguel Pereira da Costa em outra carta:

... e asim no de Monserrate $q^{\prime}$ tem treze pesas se podem tirar sete; porq' com seis tem sufficiente artelharia, por que o inim. ${ }^{\circ}$ pode dezembarcar; e marchar sem fazer cazo do d. ${ }^{\circ}$ fortim; e quando o intente ganhar, com seis pessas pode fazer $\mathrm{m}^{\text {to }}$ boa defenssa, por ser este o num. ${ }^{\circ}$ competente a sua grandeza, pois se não devem dar a hum Pigmeo as mesmas armas q' a hú gigante... ${ }^{926}$

Caldas, pouco antes da Explicasam..., em que o considera uma fortificasam antigua e defectuosa, fala de sua artilharia de nove pesas de ferro (8 de calibre 10 e 1 de 12), considerando-a mais do que suficiente para o seu poder de fogo. 0 texto transcrito mostra que o forte tinha então os dois torreões da frente cortados até a altura da barbeta (que em algum momento foram reconstruídos). Os torreões diminutos (vulgarmente chamados de "guaritas") serviam para flanquear as cortinas com o tiro de mosquete. ${ }^{927}$

${ }^{924}$ CALDAS, 1951: 376.

${ }^{925}$... naquelle sitio tem hu'a porção de terreno suficiente $p$. $^{\text {a }}$ se poder alargar, ficando o forte $q^{\prime}$ hoje he servindo como parte do todo q' há de ser; e com pouca despeza se lhe pode fazer hum fosso aquatico, cortando a pequena distancia em $q^{\prime}$ esta peninsula se une com a terra $p .{ }^{a} q^{\prime}$ se comunique o mar (Extracto da forteficação... BAj - Documentos Avulsos [54-IX-8] n. 60).

${ }_{926}$ Carta do Engr. ${ }^{\circ}$ da Bahya (BAj - Documentos Avulsos [54-IX-8] n. 61).

${ }^{927} \mathrm{Em}$ algum momento, portanto, os dois da frente, que flanqueavam pouco, foram cortados para aumentar a linha de fogo. $O$ parapeito à barbeta (o parapeito, parte da muralha que se eleva acima do terrapleno, pode ser contínuo - à barbeta - ou com merlões - canhoeiras - cf. OLIVEIRA, 2008: 181) era mal visto pelos artilheiros, que ficavam mais expostos ao disparo inimigo. Mas era um artifício para aumentar a capacidade de fogo, cabendo maior número de peças e aumentando a visibilidade do tiro frontal.

Entre outros defeitos, o forte tinha o mais comum entre as fortificações de Salvador de estar próximo a um padrasto da colina (onde hoje é sede do CRA, em cota superior à do forte - cf. OLIVEIRA, 2004: 188-9). Mário Oliveira faz ainda outras considerações sobre "a fragilidade do propugnáculo e sua escassa função na defesa da Cidade do Salvador", em concordância com os autores Campos e Falcão. Uma pergunta que se pode fazer em relação a isso é se a cidade poderia ser tomada sem a sua fortificação (que estaria no mínimo guardando armas e munições), para a qual há uma resposta em Vellozzo (2005: 30-6): "estar em poder dela significa dominar o outro no prazo médio".

O forte só teve uma "terceira aventura guerreira" (CAMPOS, 1940: 128) quando foi ocupado pela Sabinada em 1837. Os ocupantes chegaram a trocar tiros com a Armada Imperial, mas renderam-se diante da artilharia mais moderna das naus, que desembarcaram apoiados pelo destacamento legalista 

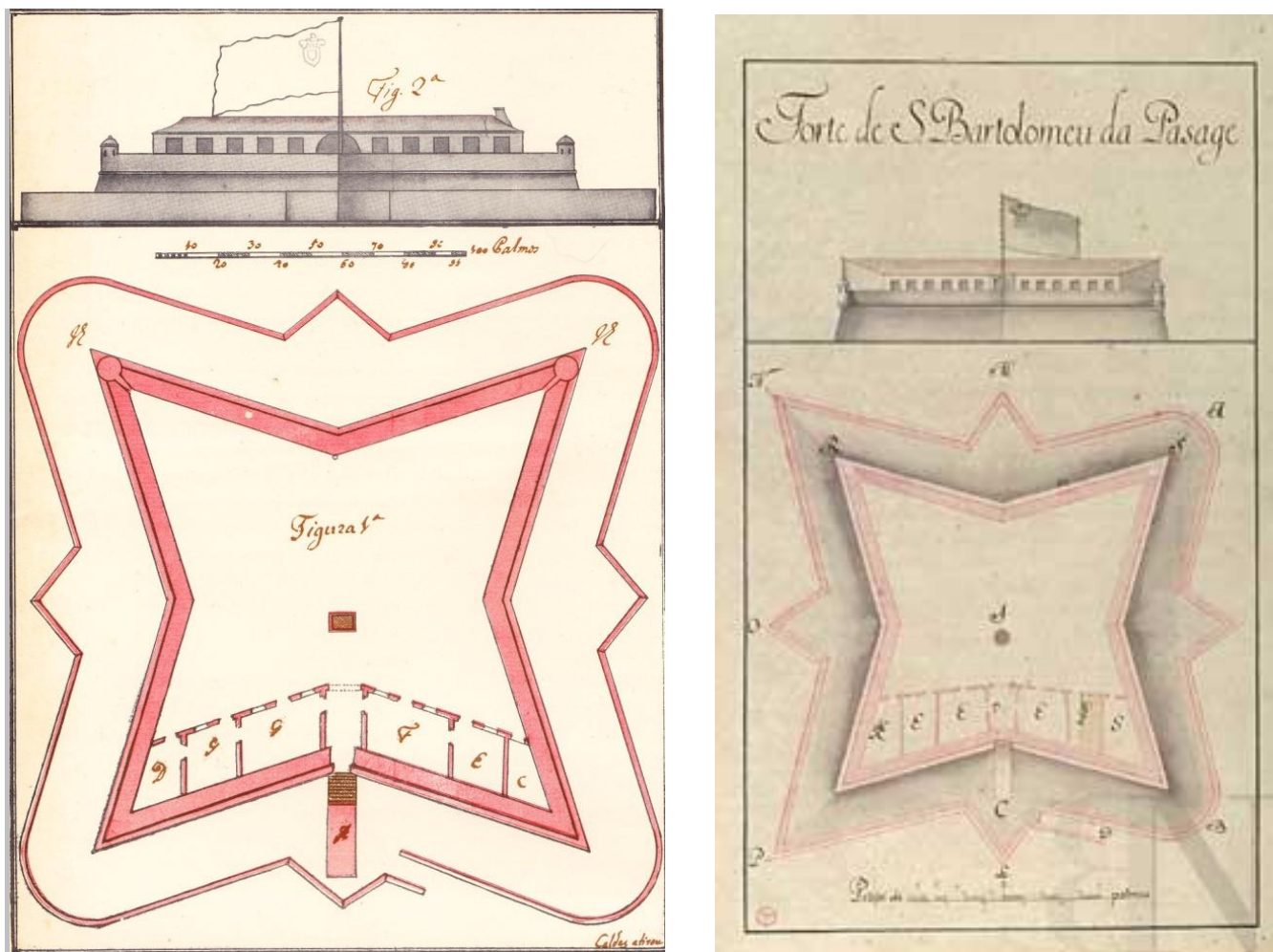

O Forte na Notícia Geral... (CALDAS, 1951: 378-9) e nas Cartas topográficas... (c. 1764 - BNP).

Explicasaó da Planta ${ }^{928}$

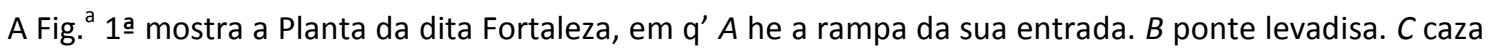
da polvora. $D$ Cozinha. $E$ Caza das Palamentas. $F$ quartéis para Sold. ${ }^{\circ}$ G. Caza do Comandante, o mais serve com [disunsao'] na Planta: he cercada de foso, e a sua contraescarpa tem so des palmoz de altura. $\mathrm{O}$ lado $\mathrm{HH}$ por onde se ve o prospeto $\mathrm{q}^{\prime}$ mostra a Fig. ${ }^{\mathrm{a}}$ 2 $\mathrm{a}$ tem o seo exercício para a marinha, e a contraescarpa he hua' muralha simples sem explanada como se ve no Prospeto tirado com a Planta em 22 de Julho de 1758.

Descreve o forte como... em forma de estrela, dizendo estar... situado em Itapagipe na margem da marinha da dita enseada para defender algua invazão que pela dita parte se intente fazer, distando... hua legoa da cidade... buscando $p^{a}{ }^{a}$ a parte do Leste. $^{929}$

Vimos que ele teve fraco desempenho no ataque de 1638. Foi depois comandado pelo Cap. Francisco Pereira do Lago (Conde da Torre), que havia se destacado na defesa da cidade e se comprometeu a guarnecê-lo por conta própria, com uma companhia de infantaria espanhola. Desde o início havia problemas

que avançava em terra. Em 1863, com a "questão Christie", foi proposta e realizada uma reforma, com recomendações do Coronel Beaurepaire. A restauração seguinte, quando já se encontrava "em estado deplorável" (OLIVEIRA, 2004: 190), ocorreu no governo de Góis Calmon, como parte do "projeto de 'embelezamento' das áreas de Monserrate" (id. ibid.), com comissão formada pelo Capitão de Mar e Guerra Cunha Menezes, Prof. Alberto de Assiz e Prof. Eng. Américo Furtado de Simas. As restaurações mais recentes, feitas pelo Exército Brasileiro, foram pequenas e com consulta a autoridades (M. Oliveira foi quem recomendou desentaipar a arcaria sob a casa do comandante e remover o "reboco da cantaria das cercaduras de pedra das envasaduras" - id. ibid.).

928 CALDAS, 1951: 378.

${ }^{929}$ CALDAS, 1951, 377. 
construtivos, causando ruínas e uma necessidade constante de reparos. Aparentemente era pela implantação junto à água, sem estar sobre rocha como os outros (principalmente uma das pontas deveria se apoiar em estacas ou enrocamento, pelo que se nota nos desenhos antigos). ${ }^{930}$

Ele aparece no relatório de Bernardo Vieira Ravasco (1660):

O forte de Sam Bartholomeu, tem quatro peças de ferro todas de $7 \mathrm{~L}^{\text {as }}$ e 2 de 6 . Esta provido nelle por Cap. ${ }^{\mathrm{m}}$ An. ${ }^{\text {to }} \mathrm{Glz}$. Seabra por patente do Gov. ${ }^{\text {or }}$ e Cap. ${ }^{\mathrm{m}} \mathrm{g}$.' deste Estado Francisco Barreto, por se haver accabado o tempo da de S. Mg. ${ }^{\text {de }}$ com elle nam tem soldo; so se lhe pagão quatro vinteis cada dia em dr. ${ }^{\circ}$ e farinha: Este forte fez Diogo Luiz de Oliveira, em Tapagype na boca do Rio de Piraja p. ${ }^{a}$ segurança dos navios, q ally mandava recolher. ${ }^{931}$

Ainda segundo Bernardo Ravasco, naquela época já seria uma construção de pedra e cal. Tinha um grande defeito logístico: ficava isolado, havendo um enorme trecho desguarnecido entre ele e a ponta de Monserrate (atual Ribeira), com inúmeros locais de desembarque. Por isso houve a sugestão do Mestre de Campo Miguel Pereira de instalar trincheiras nesses locais:

A extenssão das prayas desta B. ${ }^{a}$, da barra p. $^{\text {a }}$ dentro, he tão dilatada q' por agora se não pode acudir a todas, e assim tratando da mais proxima, e sem defença he de Tapagipe thé o fortim de S. Ber. ${ }^{\text {meu }}$ da passage; nesta se deve fazer algum reparo detrás do qual possão os defensores impedir o dezembarque: a mais breve obra com q' esses se podem cobrir he fazendo húa trinxr. ${ }^{a}, q^{\prime}$ lhe sirva de parapeito, aproveitando de algúas cazas de palha cerca de hortas $\mathrm{p}^{\mathrm{a}} \mathrm{q}^{\prime}$ o trabalho seja menos; e nessa, a distancia $q^{\prime}$ apontarei, dous redutos em q' se posão montar a quatro peças; porq' com esses, e fortim de S. Ber. ${ }^{\text {meu }}, q^{\prime}$ logo deve ser reparado, fica essa praya com bastante defença nem a occasião permite obra mais dilatada. ${ }^{932}$

A restauração do forte foi orientada por Miguel Pereira, mas não há informação de defesas que se fariam naquele trecho. O relatório de Galeão (início do século XIX) também propõe o preenchimento do trecho, mostrando que nada fora feito. ${ }^{933} \mathrm{Em}$ meados do XVIII, o engenheiro Manoel de Oliveira Mendes (filho do Mestre Felipe de Oliveira Mendes) foi chamado a fazer reparos na muralha, por causa dos problemas da implantação.

O partido arquitetônico do forte estrelado foi bastante adotado no século XVII, também em outras partes do Brasil. Alguns dos edifícios foram erguidos em terra (taipa de pilão ou gazon). Há indicações para esse traçado em tratados holandeses e no de Serrão Pimentel, mas os desenhos não são acompanhados de textos com a justificativa teórica. Para M. Oliveira, há uma evidente deficiência de flanqueamento de tiro. ${ }^{934}$ No século XVIII o modelo se tornou escasso e restrito a fortins, enquadrados na categoria de fortificação passageira ou transitória.

\footnotetext{
${ }^{930}$ Cf. OLIVEIRA, 2004: 235.

${ }^{931}$ AHU - Catálogo de Luiza da Fonseca, doc. 2.264 - apud Oliveira, 2004: 235.

${ }^{932}$ Carta do Engenheiro... (BAj - Documentos Avulsos [54-IX-8] no 61 -28/02/1712).

933 As requisições de obras eram poucas vezes atendidas de imediato: em 1717 foram solicitados os apontamentos e desenhos de Miguel Pereira para obras no forte, pedindo-se, no ano seguinte, novos orçamentos e reparos. Já havia na época o recurso de aceitar da iniciativa privada que fizesse investimentos pelo Estado, o que podia significar concessões do Rei a uma dinastia familiar: em 1639, Francisco Pereira do Lago foi nomeado comandante da fortificação, e em 1718, Brás Pereira do Lago pediu a mesma mercê em troca de reedificá-lo pelas especificações de Miguel Pereira; em 1743, Antônio Pereira do Lago estava no comando.

${ }^{934}$ Cf. OLIVEIRA, 2004: 237.
} 

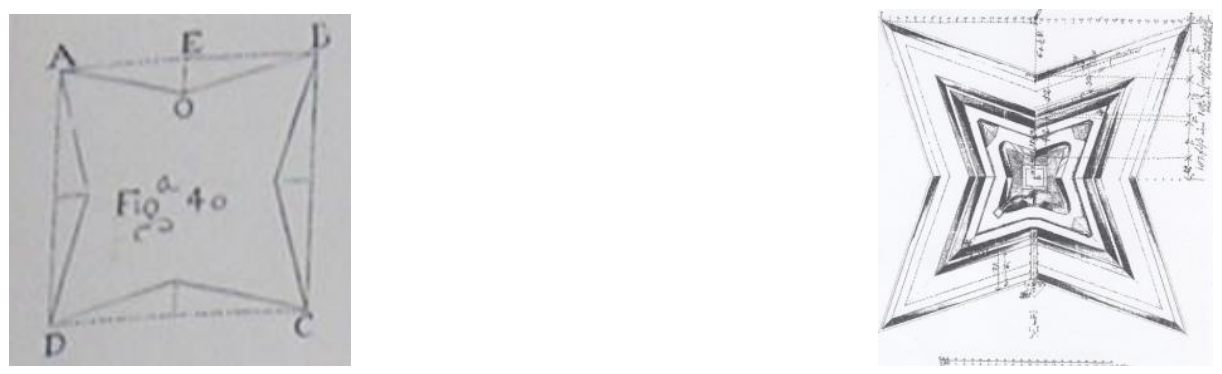

Forte estrelado de quatro pontas em Serrão (PIMENTEL, 1993: 104-5) e em desenho holandês (BNL - D266 P - em OLIVEIRA, 2004: 237).

A ineficiência do desenho estrelado era conhecida dos antigos especialistas. 0 Relatório Galeão diz: ... até a fortaleza da Passagem, a qual pode ser figura estrellada é pouco defensável por que os seis [?] angulos reintrantes de que se compõe, são seis angulos mortos, e os salientes flanqeião aparentemente... ${ }^{935}$ A descrição de Vilhena é mais simples e correta: hé este forte hum quadrado, fortificado em estrella, com angulos reintrantes, no meyo dos seus lados. ${ }^{936}$

Silva Campos, ao contrário, diz que se trata de um "polígono estrelado irregular de oito pontas, quatro das quais tinha no vértice guaritas": ${ }^{937}$ inclui assim as suas obras externas, praticamente sem entrada encoberta e pelas quais não se define o partido principal; se fossem "ângulos" e não "pontas", ela estaria correta, partindo do polígono estrelado central que é o núcleo da fortaleza. Como diz Vilhena, o traçado da forma estrelada parte de um quadrado. As guaritas não eram quatro, mas duas, no lado do mar, como sugere o desenho de Leal Teixeira.

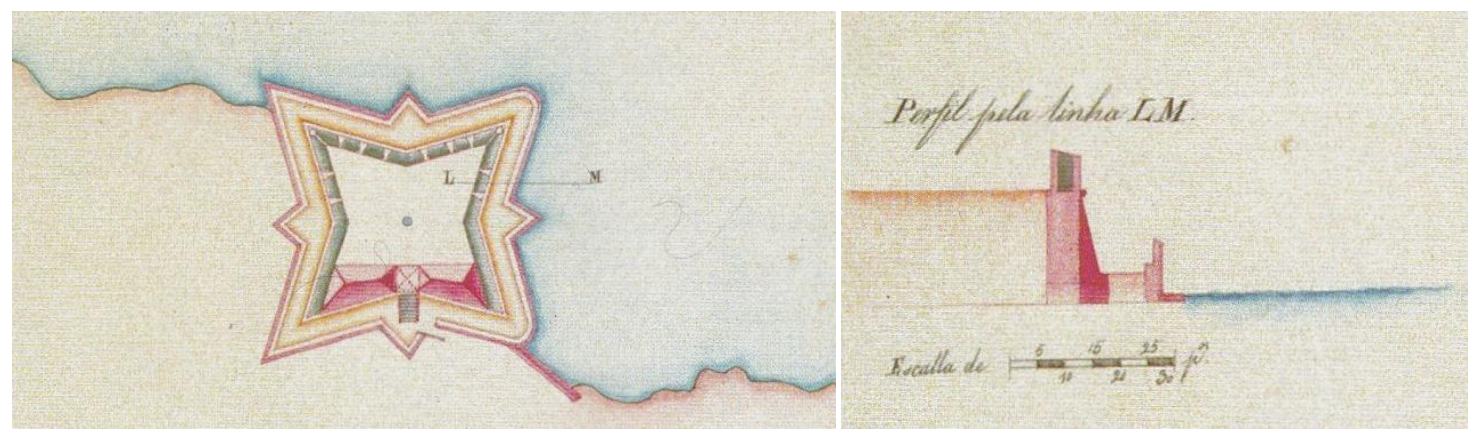

O Forte de São Bartolomeu em detalhes do desenho de J. S. Leal Teixeira para o relatório de Galeão no início do séc. XIX (em OLIVEIRA, 2004: 236).

Ao contrário de outras defesas que jamais foram acionadas, o Forte de São Bartolomeu teve participação (mesmo que "inglória") na invasão de Nassau e bem depois nas guerras da Independência, quando foi ocupado por Madeira, que o considerava logisticamente importante para o abastecimento que vinha do mar. Por causa disso, recebeu tiros das tropas brasileiras da outra margem e de outros ângulos, danificando-o e obrigando os portugueses a se retirar. ${ }^{938}$

\footnotetext{
${ }^{935}$ Apud SILVA, 1919-40: IV, 315.

936 VILHENA, 1921: 230.

${ }^{937}$ CAMPOS: 1940: 258.

${ }^{938}$ Cf. OLIVEIRA, 2004: 238. Também no Período Imperial foi ocupado pela Sabinada (como quase todos os fortes) e posto a comando do Ten. Pedro Vitor de Alcântara, que foi desalojado de lá pelas tropas legalistas com baterias nos padrastos vizinhos. Em 16/03/1844 o Ministério da Fazenda autorizou sua demolição para reutilização da cantaria na ponte da Alfândega. A ordem ainda chegou a ser sustada para "que se estudasse melhor a conveniência" da demolição, mas o começo da destruição agravou o
} 

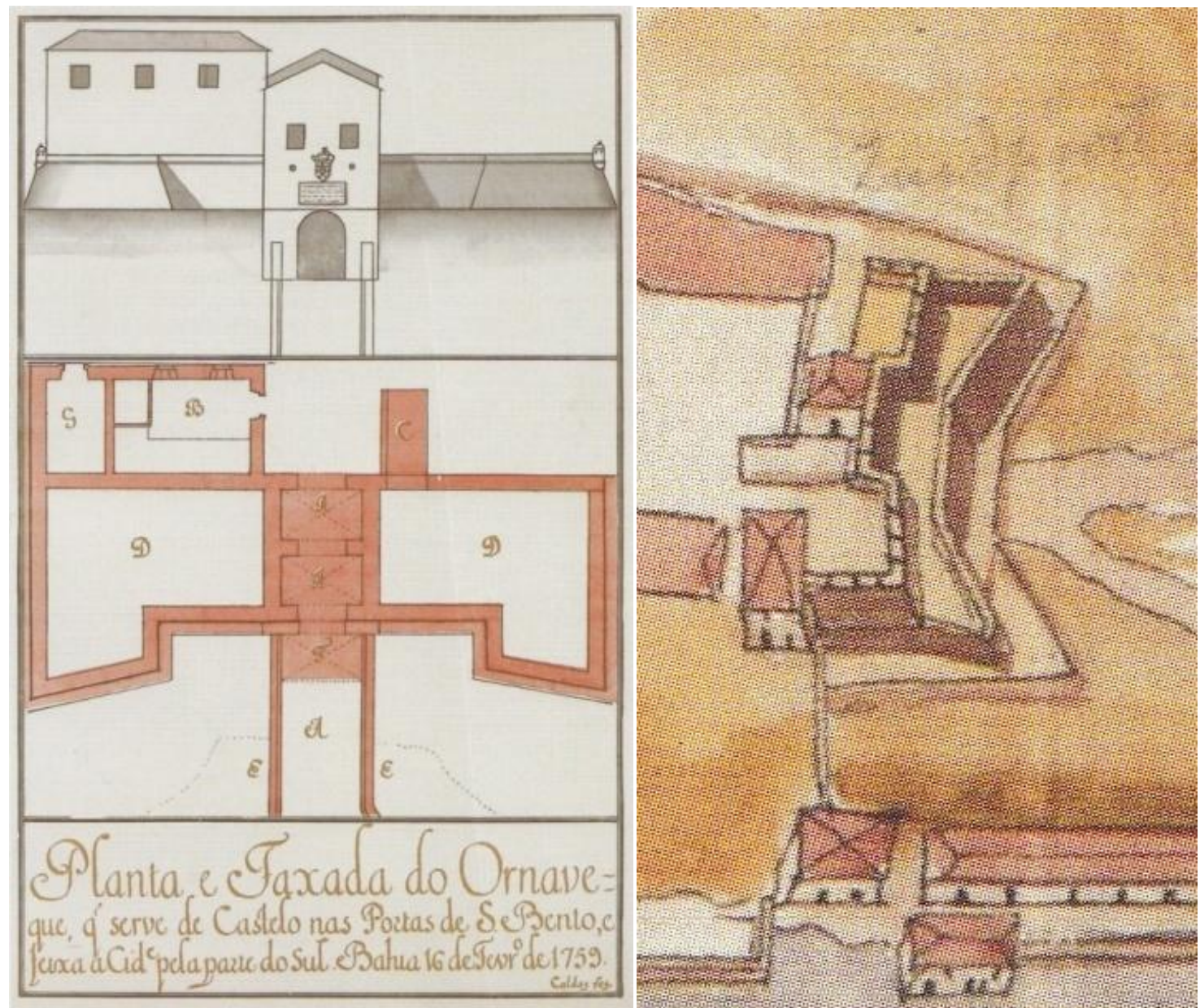

Planta e fachada da Porta de S. Bento na Notícia Geral... de 1759 (CALDAS, 1951: 380) e em perspectiva militar no Desenho das forteficaçoes... do museu de Haia, c. 1638, p. 314 (em REIS Fo, 2000: 32-4).

\section{Lê-se na Explicasao' da Planta:}

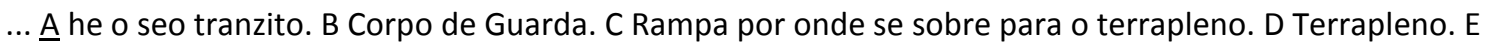
muralha de hua' contra parte para comunicamsam do tranzito, a qual cerca o Ornaveque como contraescarpa. $F$ ponto de calsada sobre abobeda, $q^{\prime}$ asenta no foso, e fica nivelando com a rua. $G$ Armazem, e por sima dele, e o Corpo de Guarda fica a Caza de Armas; e por sima do tranzito o Calabouso ou prizam dos Soldados, e Ofic. ${ }^{\text {es }}$ que se ve no Prospeto. Todo este Ornaveque fica elevado ao nível da Campanha em hua' eminencia de sorte q' o tranzito de comunicasam fica por bx da rais da muralha como bem se ve no Prospeto. ${ }^{939}$

Descreve o "castelo" como... hum hornaveque com dous meios baluartes e dous ramaes, estando nele... a caza de armas da Cidade, e pule:

estado de suas cortinas, e em 1863 "encontrava-se em completo estado de eversão [destruição, ruína], abandonado fendidas as muralhas em diversos pontos" (CAMPOS, 1940: 261). Já não valia a pena reformá-lo e pensou-se na reconstrução. Ainda no Período Imperial, o titular do Ministério da Marinha, Visconde de Guaí (baiano), conseguiu pela Câmara a autorização de demoli-lo, o que só ocorreu na República, em 1903, pelo Intendente José Eduardo Freire de Carvalho. Foi a última fortificação demolida.

${ }^{939}$ CALDAS, 1951: 380. 
O Castelo das Portas de S. Bento he o que fexa o recinto da Cidade pela parte do Sul. Nele esta a prizao' dos Soldados, e o tranzito para os mais bairros ainda que esta Cidade nao' he fexada. Nele rezide hua' guarda [ae tual] de Infantaria com vinte soldados hum oficial Thenente ou Alferes, dous Sargentos e hum tambor do qual Corpo de Guarda se deitao' rondas para os bairros de S. Bento Preguisa [ $\&^{\mathrm{Ra}}$ ], para socego dos habitadores. ${ }^{940}$

Em capítulo anterior, falamos de uma provável transformação da Porta de Santa Luzia durante a ocupação holandesa. Mesmo que a forma final tenha sido dada pelos portugueses, houve no mínimo uma influência da escola flamenga, que se nota em seu hornaveque bem definido.

Depois da invasão, o Gov. Diogo Luiz de Oliveira ordenou restaurações (1629) fazendo de novo a porta interior e a tenalha que defendia a entrada (a câmara, com apoio do povo, colocou um estanque [imposto] sobre o vinho de mel [cachaça] té se tirar o custo das Portas da Cidade...). ${ }^{941}$ Uma década depois, o Marquês de Montalvão (1640-1) pediu vistoria nas portas, concluindo-se precisar de... duas pontes nas portas $^{942}$ sendo provavelmente providenciadas. Com D. João de Lencastro (1695) foram feitos os hornaveques que resistiram até o século XVIII (quando da informação do seu estado precário de conservação) e o reduto a cavalheiro. ${ }^{943}$ Uma Carta Regia (17/03/1695) elogia a praça de armas que fizestes nas portas da cidade de São Bento. ${ }^{944}$

O detalhe do Desenho das forteficaçoes..., que colocamos ao lado, mostra que nessa época (1638) ela já teria as dimensões em que aparece do desenho de Caldas. Sabe-se que no século XVIII a construção iria de largura do alto da montanha (edifício do Montepio, na Praça Castro Alves) até os fundos do prédio do jornal A Tarde ${ }^{945}$ Seria uma "verdadeira fortificação" (Silva Campos), com os dois meios baluartes (hornaveques) e um corredor abobadado ao meio, ligando o centro da cidade aos bairros extramuros a sul.

\footnotetext{
${ }^{940}$ CALDAS, 1951: 379.

${ }^{941}$ AMS - Atas da Câmara (1641-1649), v. 1, 1944, p. 154 - apud MENDONÇA, 2004: 232. Mário Oliveira deduz por essa medida que na época as Portas eram consideradas defesas importantes, o que aparentemente contradiz a sua avaliação inicial de que nunca foram poderosas e sim "enormemente emblemáticas", conservando-se até o século XVIII "mais pelo valor simbólico". Entende-se que a qualidade técnica não invalidaria o aspecto simbólico, embora ambos se comuniquem: como emblemas do poderio da cidade, a importância também estaria na capacidade bélica.

Em relação ao aspecto simbólico, entende-se que não tê-las (independente da eficácia) seria indecoroso (indecente para com a dignidade do traçado regular moderno e dos valores e expedientes do decoro, como mérito, imponência, ordem). Assim, o comentário recorrente em muitos analistas de que as fortalezas de Salvador e do Brasil acabaram por exercer uma função muito mais políticoadministrativa (no sentido de demarcar a assegurar a posse do território) do que propriamente militar (seria impossível impedir o desembarque de invasores não-portugueses ao longo dos mais de oito mil $\mathrm{km}$ de costa oceânica) ganha um novo sentido. Por exemplo, pode-se explorar o valor simbólico no parecer do leigo Frei Vicente do Salvador sobre o Forte de Santo Antônio da Barra (não importando se a forma era menos desenvolvida que a atual) de que tanto ele quanto o de S. Felipe (Monserrate)... são mais para terror que para efeito.

942 AMS - Atas da Câmara (1641-1649), v. 1, 1944, p. 445 - apud MENDONÇA, 2004: 233. Na gravura de 1638 está representado um fosso ao redor desta fortificação (e não de toda a cidade, como era previsto no projeto de 1605), parecendo haver uma rampa de saída da fortificação para a cidade. Também no desenho de Caldas entende-se haver uma rampa, mas de entrada. Deduz-se serem essas as duas pontes, havendo também a possibilidade de que se refira às duas fortificações de acesso.

${ }^{943}$ Cf. OLIVEIRA, 2004: 233.

${ }^{944}$ AB, I, p. 114 - apud CAMPOS, 1940: 264.

${ }^{945}$ Cf. VILHENA, 1921: 245 e CAMPOS, 1940: 262-3.
} 
Essa "polé" que aparece no texto de Caldas (... nele esta a caza de armas da Cidade, e pule) já figurava em 1711 em uma ordem ao provedor para o seu pagamento (época em que o Eng. Miguel Pereira da Costa estava em Salvador). O termo é ambíguo, significando tanto instrumento de tortura quanto mecanismo de rodas (usado na ponte levadiça, indicando que esta ainda funcionaria): na Porta existia um calabouço para presos militares e um cadafalso (ou simples forca) na parte externa. ${ }^{946}$

Por volta de 1732, quando Miguel Pereira projetava o adro da Sé, também relacionou as obras necessárias à reparação dessa Porta, que estava mais uma vez arruinada. ${ }^{947}$ É provável que na época ela fosse mais quartel do que defesa. Já na época do desenho em questão (1759), havia mais armamento, mostrando que houve aumento dos planos de fogo ao longo do tempo. ${ }^{948}$ Já nas Cartas topográficas... (de 1764, quando Caldas era Capitão), não há referência às portas da cidade como fortificações.

Muitos documentos falam de reformas na Porta de S. Bento, umas aumentando o seu poderio defensivo, outras recuperando o madeiramento da cobertura e pisos (tomado por cupins), ou resolvendo problemas estruturais das abóbadas. Em 1796, D. Fernando José de Portugal ordenou a demolição das partes abobadadas lesionadas, mantendo alguns espaços para abrigar as tropas de guarda. A demolição total da Porta se deu na gestão do Conde da Ponte (1806), dando lugar ao Teatro Público. ${ }^{949}$

Nas palavras de Vilhena...

Este castello hé o que pelo lado do Sul fechava o recinto da cidade; constava de dois meyos baluartes, por meyo dos quaes havia huma porta por onde se tranzitava para todos os bairros; e esta com o seu arco e parte dos baluartes mandou o Exmo. D. Fernando José de Portugal demolir, tanto porque de nada servia já aquella Fortificação por estar concentrada na cidade, como por ameaçar o arco sua ruína, ficando com tudo huma guarda de official e vinte soldados que sempre ali existirão, em attenção a ser naquelle logar o trem das armas, se bem que com impropriedade, por ficar sujeito a tiros de bombas que o inimigo the pode lançar do mar e arrazallo. ${ }^{950}$

\footnotetext{
${ }^{946}$ Cf. OLIVEIRA, 2004: 233-4.

${ }^{947}$ Cf. BN - Documentos históricos, 1947, v. 75, p. 104 (10/11/1732) / OLIVEIRA, 2004: 234 e 256.

${ }^{948}$ Pelo armamento se percebe que na época do Livro da Razão... (1612) a fortificação tinha forma diferente da que foi cadastrada e desenhada por Caldas (1759). Ela foi descrita com apenas dois camelos pedreiros de quatorze quintais (balas de pedra de 14 libras $=822,5 \mathrm{~kg}$ ), sendo relatada em 1759 como um hornaveque com dous meios baluartes e dous ramaes. Bernardo Ravasco, na descrição das fortificações (1660), diz: A porta da Cidade de Sam Bento (que he' da bando do Sul) tem por deffença, dous baluartes, em que ha' sinco peças de bronze, 2 de 10 L.as e 3 pedreiros de 12 L.as. Nesta ha' hum corpo de guarda em que entra todos os dias huma Companhya, da qual se prové os postos, das forteficações daquella parte (AHU - Catálogo de Luiza da Fonseca, doc. 2.264 - apud OLIVEIRA, 2004: 233). Era então um quartel de soldados responsáveis pela ordem pública das áreas próximas a $\mathrm{S}$. Bento e Preguiça. Para Oliveira, o armamento sugere uma construção menor, que embora fosse de dois baluartes deve ter sido aumentada com D. João de Lencastro.

${ }_{949}$ Cf. CAMPOS, 1940: 265.

${ }^{950}$ VILHENA, 1921: 245.
} 


\section{Castelo das Portas do Carmo}
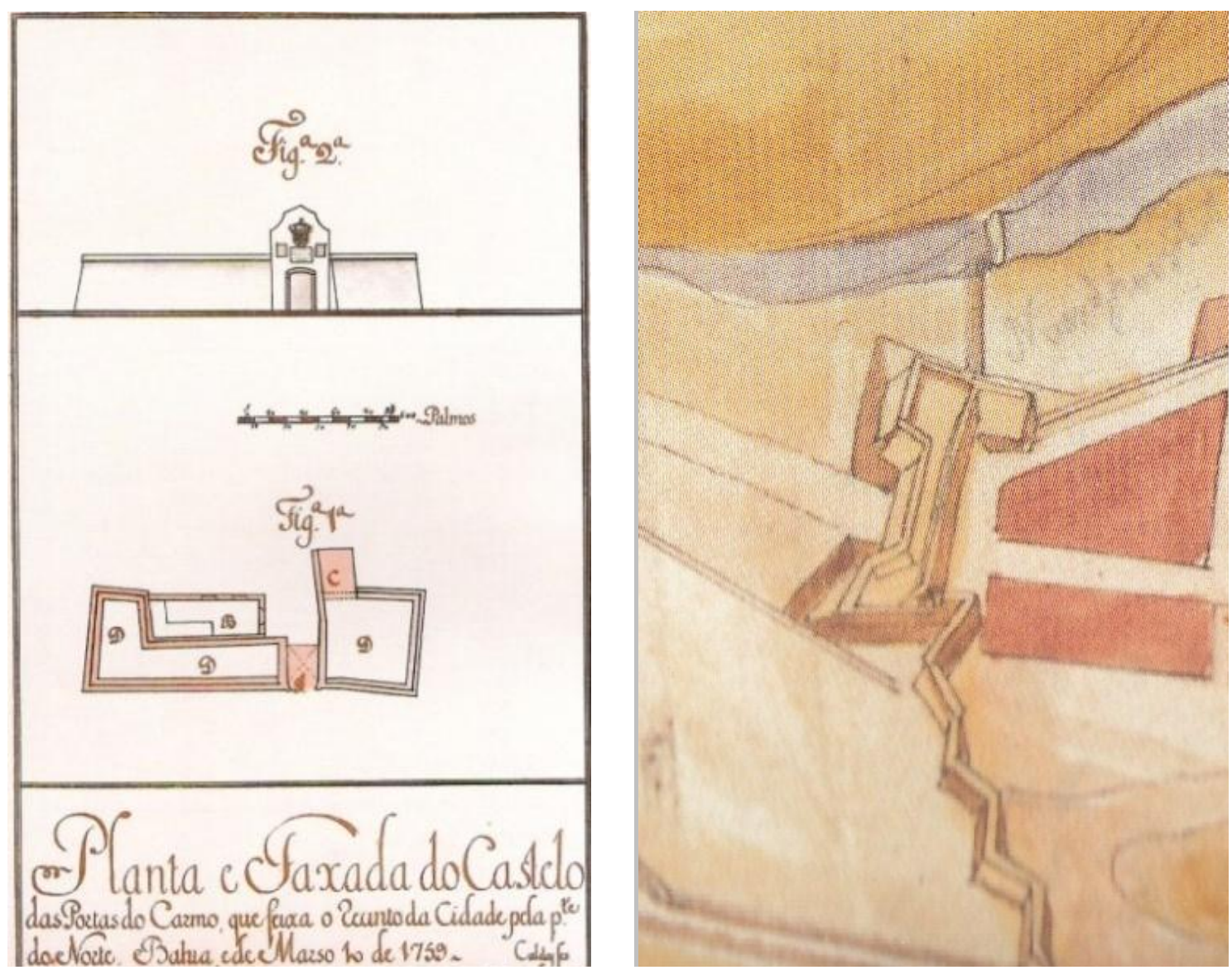

À esq., o desenho de 1759 na Notícia Geral... (em CALDAS, 1951: 382). À dir., como aparece na planta do museu de Haia (em REIS Fo, 2000: 32-4).

Depois de uma rápida apresentação (... he o que fexa o corpo da Cidade pela parte do Norte, sendo... hum simples Cavaleiro), Caldas diz na Explicasaõ da Planta:

A Figura 1a mostra a Planta deste Castelo, que fica em hua' eminencia, e dele se flanquea todo o recinto quazi do bairro da Saude, baixa dos Sapateiros, e ladeira do Carmo. Ela mostra a sua figura irregular, e tambem se ve que A he o seo tranzito. B Corpo de Guarda. C Rampa que sobe para o terrapleno. D terrapleno no qual estao' as pesas ja ditas: o seo parapeito he a barba. A Figura 2a mostra a Faxada do dito Castelo. ${ }^{951}$

As plantas e fachadas de Caldas nos mostram a última tipologia das Portas da Cidade, já que suas versões iniciais são do século XVI e as referências mais precisas do XVII, com as primeiras representações em gravura. Entre o XVII e o XVIII elas aparecem com ligeira variedade de formas. Com pequeno poder de fogo (principalmente no Carmo, em que o traçado sequer permitia flanquear a entrada), elas faziam parte dos perímetros fortificados antigos, que foram maciçamente ultrapassados pela malha urbana ao longo do século XVII, diminuindo-Ihes a função.

Depois das guerras holandesas as Portas do Carmo tiveram uma história parecida com as de S. Bento, mas chegariam ao século XVIII com outro desenho (mais simplório, como resultado de muitas alterações). Cogita-se que elas tivessem vedações

${ }^{951}$ CALDAS, 1951: 381. 
de grade do tipo guilhotina de ferro ou madeira, mas é pouco provável. ${ }^{952}$ Como nas de S. Bento, o Hornaveque foi reconstruído, já que Mirales afirma que D. João de Lencastro (1694-1702)... além de mandar fazer o forte de S. $^{\text {to }}$ Antonio, allem do Carmo, Levantar o Ornavee [hornaveque] e Reducto a Cavalr. ${ }^{\circ} q^{\prime}$ defende as 2 portas da Cid. $^{e}{ }^{9}{ }^{953}$

$\mathrm{Na}$ época de Vilhena ela era uma fortificação modesta, com cinco peças de artilharia. A demolição foi ordenada pelo governador não só pelo estado decadente do edifício, mas como reforma urbanística:

Castello das Portas do Carmo, tinha 5 pessas [de artilharia]. Neste terminava o recinto da cidade pelo Norte e constava de huma bateria simples. O Exmo. Governador D. Rodrigo José de Menezes, foi quem no breve tempo de seu governo o mandou demolir, não só pelas mesmas cauzas do antecedente, como por alargar a rua e dar passagem franca, aformozeando aquella parte da cidade que era funebre e perigoza; conservando sempre ali huma guarda igual á outra para acudir a algum incidente que por aquelle bairro possa acontecer. ${ }^{954}$

\section{Reduto do Rio Vermelho}

Na Notícia Geral... ele está apenas descrito, na mesma página em que aparece a Bateria em Palacio (que aparece no Prospeto da Cidade... junto aos arcos do Palacio do Senhor Vi Rey). Caldas não desenhou a vigia porque ela já estava bastante danificada, sendo depois abandonada:

Este Reduto he deterra, e estâ arruinado instituiose para impedir algum desembarque, que em hum porto pequeno, que ahi há, se podese fazer. As pesas que nele existem estão no chão, e a sua palamenta se guarda em hua' caza vizinha, e não ha de que se tire planta. Tem sinco pesas deferro no estado que já dise: 48 balas de Artilharia, 2 coxarras, hum soquete; 3 sacatrapos 4 espeques, 4 pes de cabra e 5 arrobas de bala de chumbo miuda e 13 livras. ${ }^{955}$

O reduto foi reconstruído em pedra e cal a partir de 1798, recebendo o nome (invocação) de Forte de São Gonçalo do rio Vermelho. ${ }^{956}$ A utilidade desse projeto foi questionada por Vilhena:

Ao correr desta marinha, na barra do Rio Vermelho, por onde só podem entrar por pouca distância canoas, e saveiros se está inutilmente fazendo uma fortaleza, que nunca poderá servir para mais do que uma comprida trincheira, ou reduto de terra calcada, e que com pouco reparo, e módica despesa faria tanto, ou mais que aquele forte em que S. Majestade não há de gastar menos de quarenta mil cruzados, sendo muito para persuadir, que o inimigo não irá por divertimento expor-se aos tiros da artilharia, quando a pouca distância, sem este risco pode desembarcar muito à sua vontade. ${ }^{957}$

\footnotetext{
952 Cf. OLIVEIRA, 2004: 234.

953 MIRALES, 1900: 158.

954 VILHENA, 1921: 245 (grifo nosso).

${ }^{955}$ CALDAS, 1951: 383 (grifo nosso).

${ }^{956}$ Cf. BARRETO, 1958: 169.

${ }^{957}$ VILHENA, 1922: 218-9.
} 


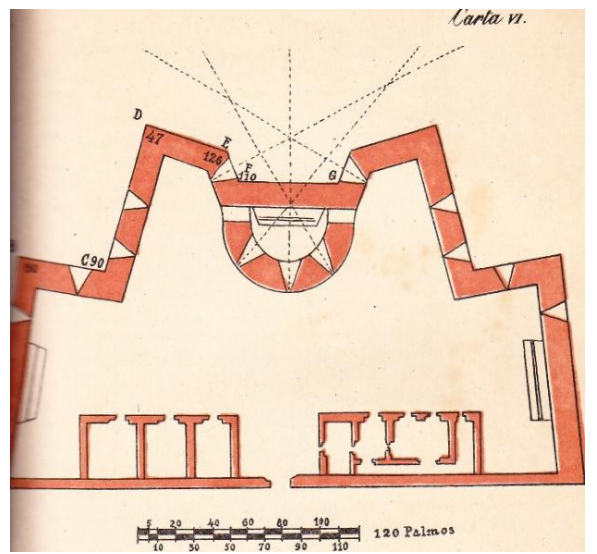

O Fortim em registro do livro de Vilhena (1921: 218-9).

A construção que ainda existia no século XX resultava desse projeto. Embora Silva Campos a descrevesse em 1940 como uma das fortificações arruinadas, ${ }^{958}$ na fotografia de Cerqueira Falcão, ${ }^{959}$ da mesma época, as muralhas ainda estão bem conservadas.

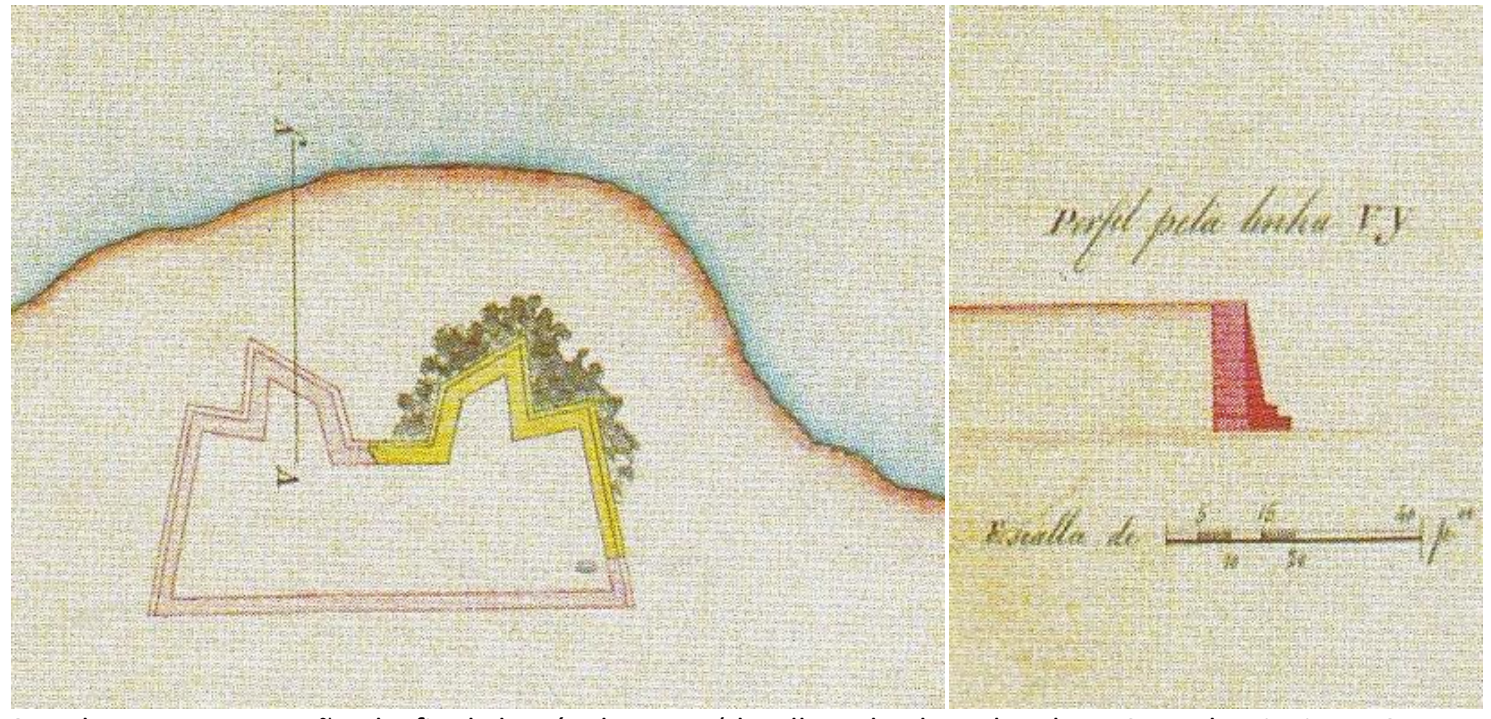

O reduto na sua versão do final do século XVIII (detalhes do desenho de J. S. Leal Teixeira - GEAEM 4558/16 - em OLIVEIRA, 2004: 240).

958 Cf. CAMPOS, 1940; 209-14.

959 Ela foi reproduzida no capítulo final, “Alguns registros...”, p. 310. 

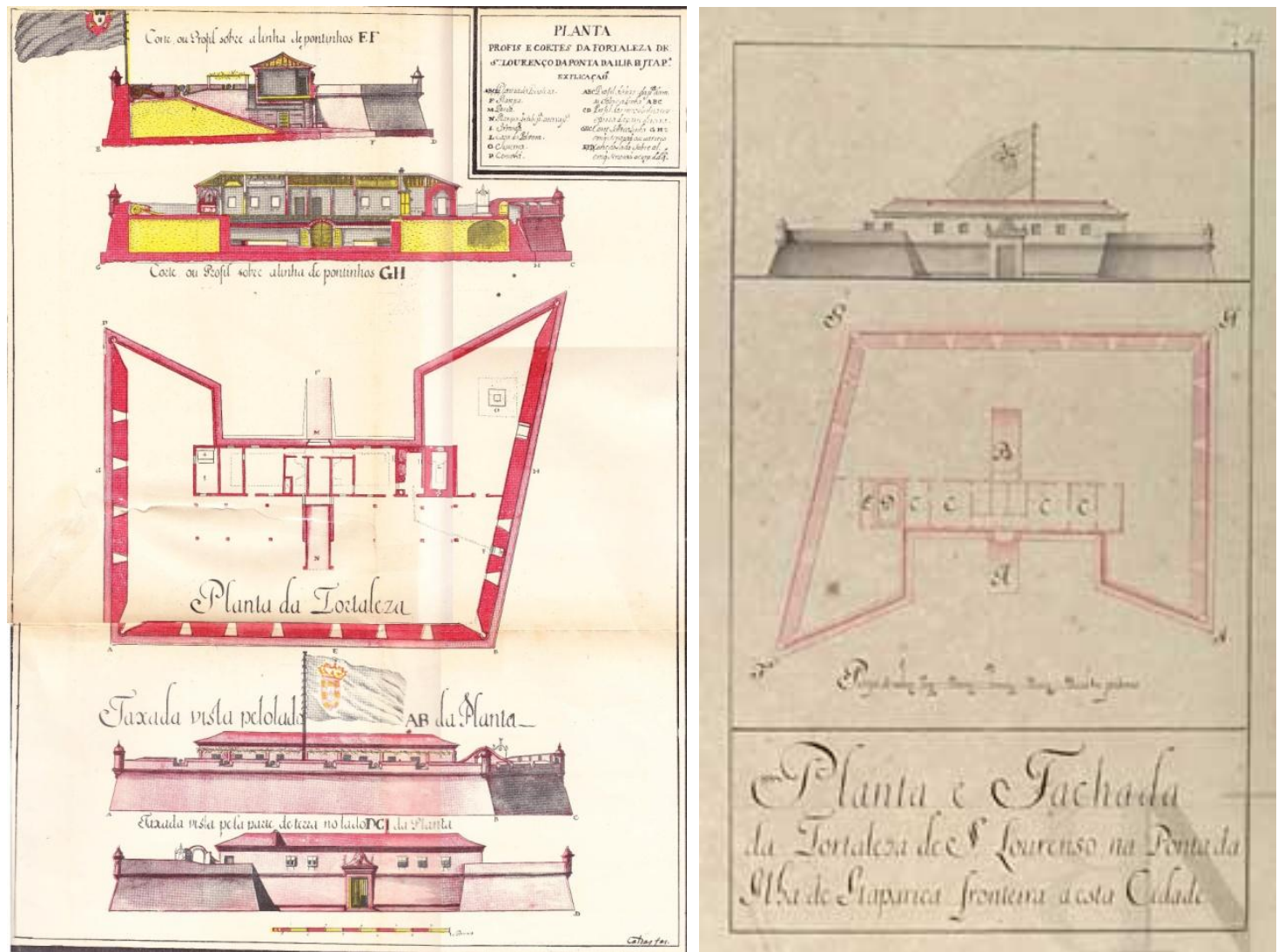

O Forte na Notícia Geral... (CALDAS, 1951: 386-7) e nas Cartas topográficas... (c. 1764 - BNP).

Na Notícia Geral..., Caldas diz: A Fortaleza de S. Lourenso he hum Ornaveque irregular: está situada na ponta da Ilha de Itaparica, e defende a entrada da barra do Rio Paraguasú, e Jaguaripe. Está distante desta Cidade quatro legoas...

O desenho não está datado e embora esteja escrito embaixo que... Caldas fes, a qualidade da apresentação é diferente da dos outros (em cima há dois cortes... sobre a linha de pontinhos $\mathrm{EF}$ e $\mathrm{GH}$, o que não costuma aparecer, assim como a apresentação de duas fachadas que há embaixo). Na legenda do canto superior direito, em que faz a explicaçaõ, a letra não é reconhecível, podendo ser de um discípulo. Já no álbum das fortificações (Cartas topográficas...), toda a qualidade é reconhecível.

$\mathrm{Na}$ crítica de Vilhena, o forte aparece como... hum ornaveque simples com defensas muito Curtas, e defeituozas. ${ }^{960}$

${ }^{960}$ VILHENA, 1921: 238-9. 

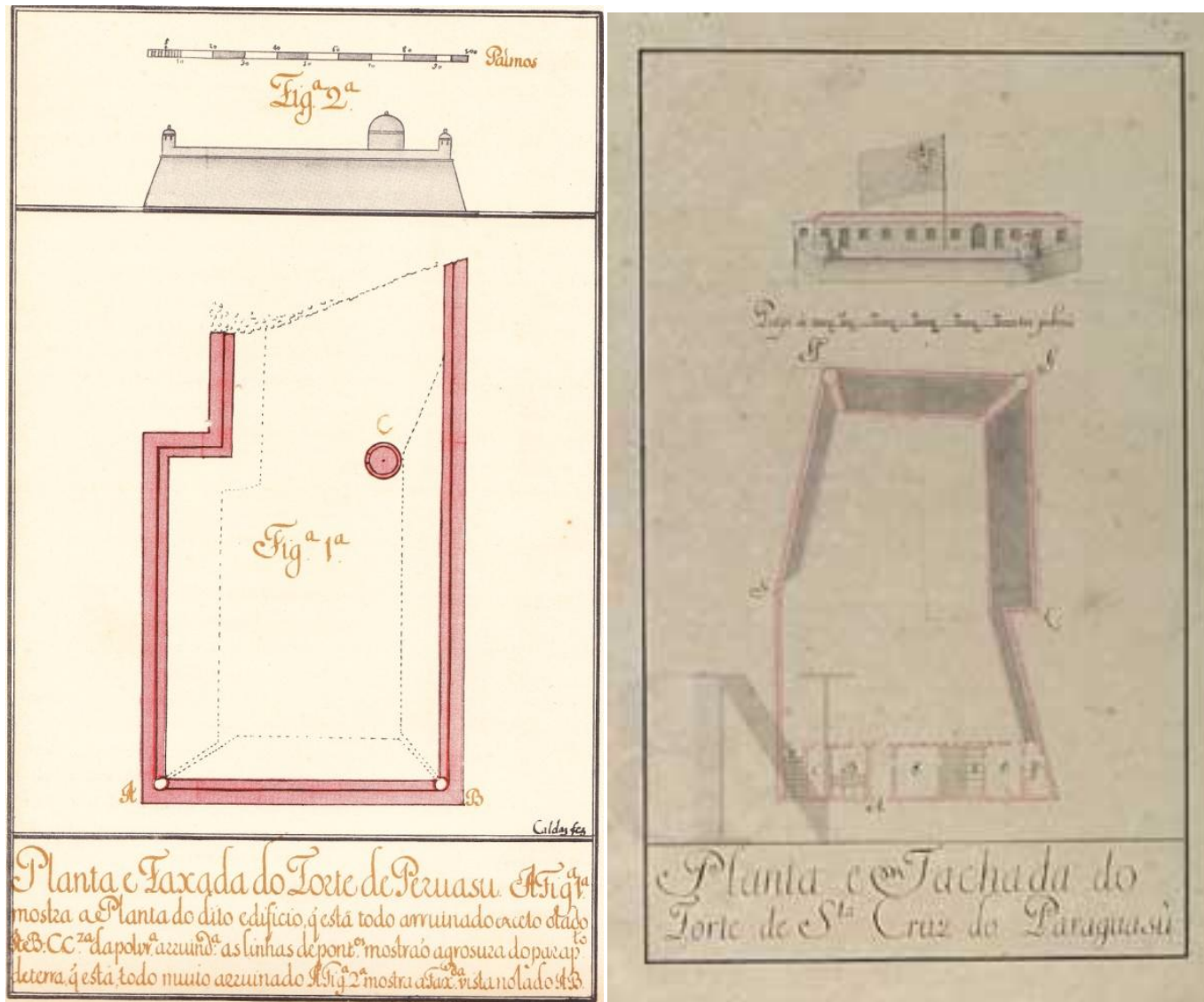

A Planta de Faxada do Forte de Peruasu na Notícia Geral... (CALDAS, 1951: 388-9) e a Planta e Fachada do Forte de S. ${ }^{\text {ta }}$ Cruz do Paraguasù nas Cartas topográficas... (c. 1764 - BNP).

Na Notícia Geral... o que aparece é o Forte de Peruasu (ou da Forsa, como aparece no texto e no índice), com a seguinte legenda no próprio desenho:

A Fig. ${ }^{a}$ 1a ostra a Planta do dito edifício, $q^{\prime}$ está todo arruinado exceto o lado A e B: C C. ${ }^{2 a}$ da polvr. ${ }^{a}$ arruind. ${ }^{a}$ : as linhas de pont. ${ }^{\circ \mathrm{s}}$ mostrao' a grosura do parap. ${ }^{\text {to }}$ de terra, $q^{\prime}$ está todo muito arruinado. A Fig. ${ }^{\text {a }}$ - mostra a Fax. ${ }^{\text {da }}$ vista no lado AB.

No texto de apresentação ele faz uma clara distinção entre os dois. Falando primeiro do Forte de Paraguasu (que Vilhena descreve como... hum exagono irregularissimo), ${ }^{961}$ diz estar... situado na margem do Rio Paraguasú tres legoas para dentro da sua barra,... arruinado com as cazas cahidas e az pesas desmontadas, sendo... hua' forma de Bateria com seo parapeito. Fala em seguida do Forte da Forsa, que... esta fronteiro a este na parte oposta da outra banda do Rio Paraguasu:

He um simples parapeito de terra, com seo terrapleno, onde laboravao' duaz pesas embebido no meio de hum monte, que lhe serve de espalda: fica a cavaleiro dominando o outro Forte. Esta trincheira fizeram os Portuguesez do Forte de Paraguasú, que infestavao' todo o Reconcavo: hoje esta toda arruinada esta trincheira, e se conservao' as duaz pesas, que estao' inuteis, e desmontadas. ${ }^{962}$

\footnotetext{
961 VILHENA, 1921: 240-1.

962 CALDAS, 1951: 387-8.
} 


\section{Morro de S. Paulo}

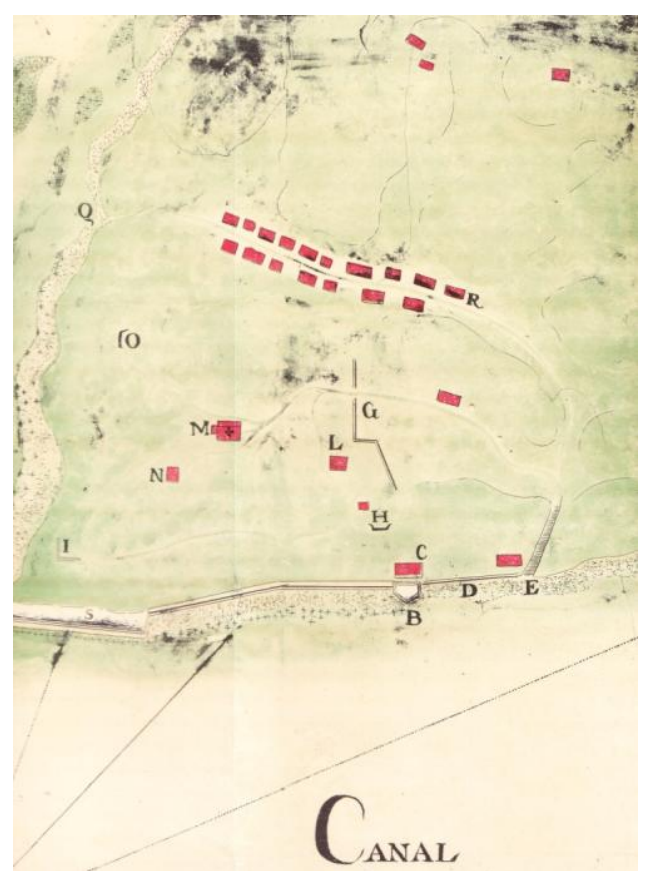

Detalhe da Planta do Morro de S. Paulo 13 legoas ao Sul da Cidade da Bahia, feita por loão de Abreu e Carvalho (em CALDAS, 1951: 390-1), em que aparecem as letras Q - Pequeno porto onde entra o riacho de agoa doce, I, O e H - baterias, N - Caza do Capellão do Prezidio, M - Capella de Nossa Snr. ${ }^{a}$ de Lus no mais altp do monte, L - Caza $q^{\prime}$ serve de almazem da polvora, G - Porção de muralha da Forteficação, $q^{\prime}$ se fes a 20 annos, mas ainda imperfeita, \& sem terrapleno, C - Corpo da guarda, \& caza do Capitão, B Baluartinho plano em $q^{\prime}$ estão montadas sette pessas, mas . $^{\text {la }}$ pequenhes da sua area não podem laborar ao mesmo tempo, D - Lanço de muralha em $q^{\prime}$ estão 7 pessas rodando sobre o terreno $p^{a}$ deffença do porto e $\mathrm{E}-$ Portaló $q^{\prime}$ he' o porto onde surgem os barcos.

\section{Como última fortificação dessa seqüência nas Notícias Gerais..., Caldas} descreve o Morro de S. Paulo como...

... hua Ilha, que fica desviada barra em fora desta Cidade para o Sul doze legoas, por entre ela, e terra firme corre hum canal que dá comunicasao' para para as Vitas do Cairu, Camamu, Boibepa \&. ${ }^{\text {, }}$, a sua ponta de Noroeste esta fortificada pela marinha com hua' Bateria..., e corre hum lanso de cortina para o Sudueste com hum angulo reintrante, e se comunica com hum baluarte placo ao lado do qual corre outro lanso de cortina e outras fortificasoens que mostra a Planta ainda que esta tambem he muito antiga, hoje se acha a fortificasao' com mais perfeisao' e tambem a povoasao' da dita Ilha. ${ }^{963}$

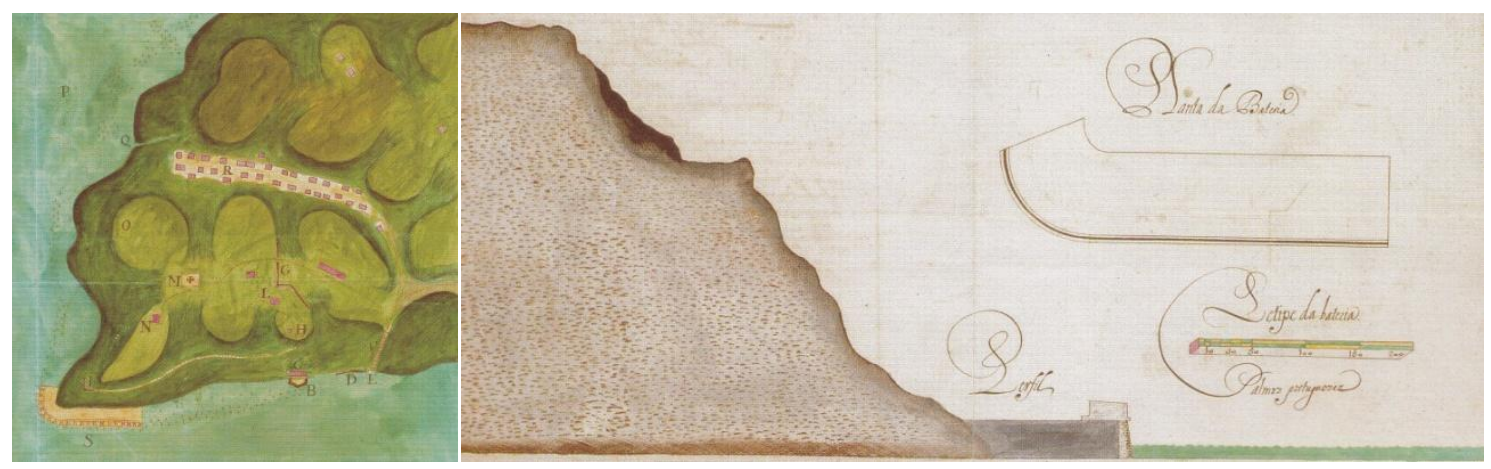

O forte em detalhes da planta e perfil elaborados por Miguel P. da Costa (AHU - Iconografia manuscrita, Ba-963 em OLIVEIRA, 2004: 109).

${ }^{963}$ CALDAS, 1951: 389. 


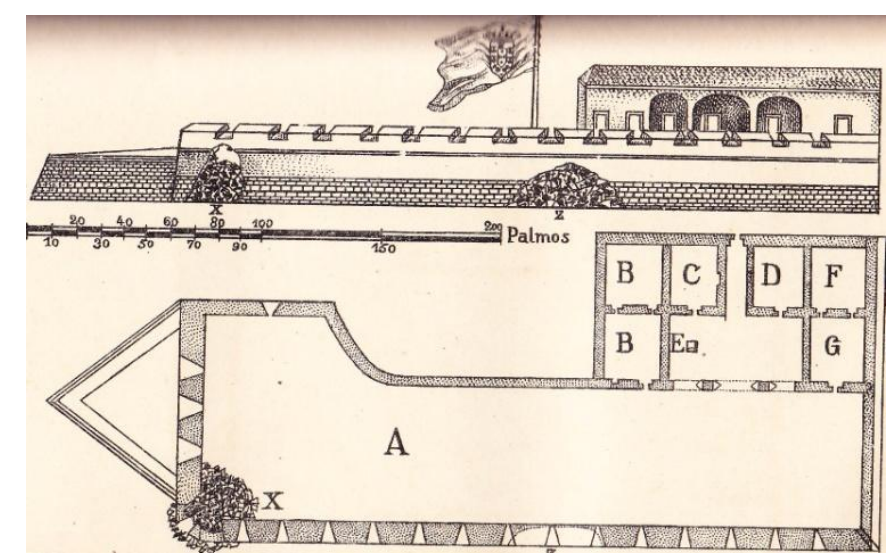

Em Vilhena (1921: 242-3), sendo... A, Terrapleno. B, Caza do official. C, Corpo de Guarda, e quartel. D, Prizão. E, Cisterna. F, Caza da Polvora. G, Cloacas.

M. Oliveira destaca o Morro de São Paulo por ser não só uma grande fortaleza, mas o "sistema defensivo de uma ilha inteira". Junto com Itaparica, tinha reflexos na defesa da cidade mesmo sem estar diretamente ligado a ela, sendo importante "no abastecimento da praça de Salvador". ${ }^{964}$

Formavam defesas no Recôncavo: as da Barra de Camamu, o Forte de S. Lourenço e da eminência em Itaparica, os redutos de Santa Cruz e Conceição no Paraguaçu, as estâncias de Cajaíb e Matuim, e as fortificações provisórias na Guerra da Independência.

\section{Fortinho de S. Alberto}

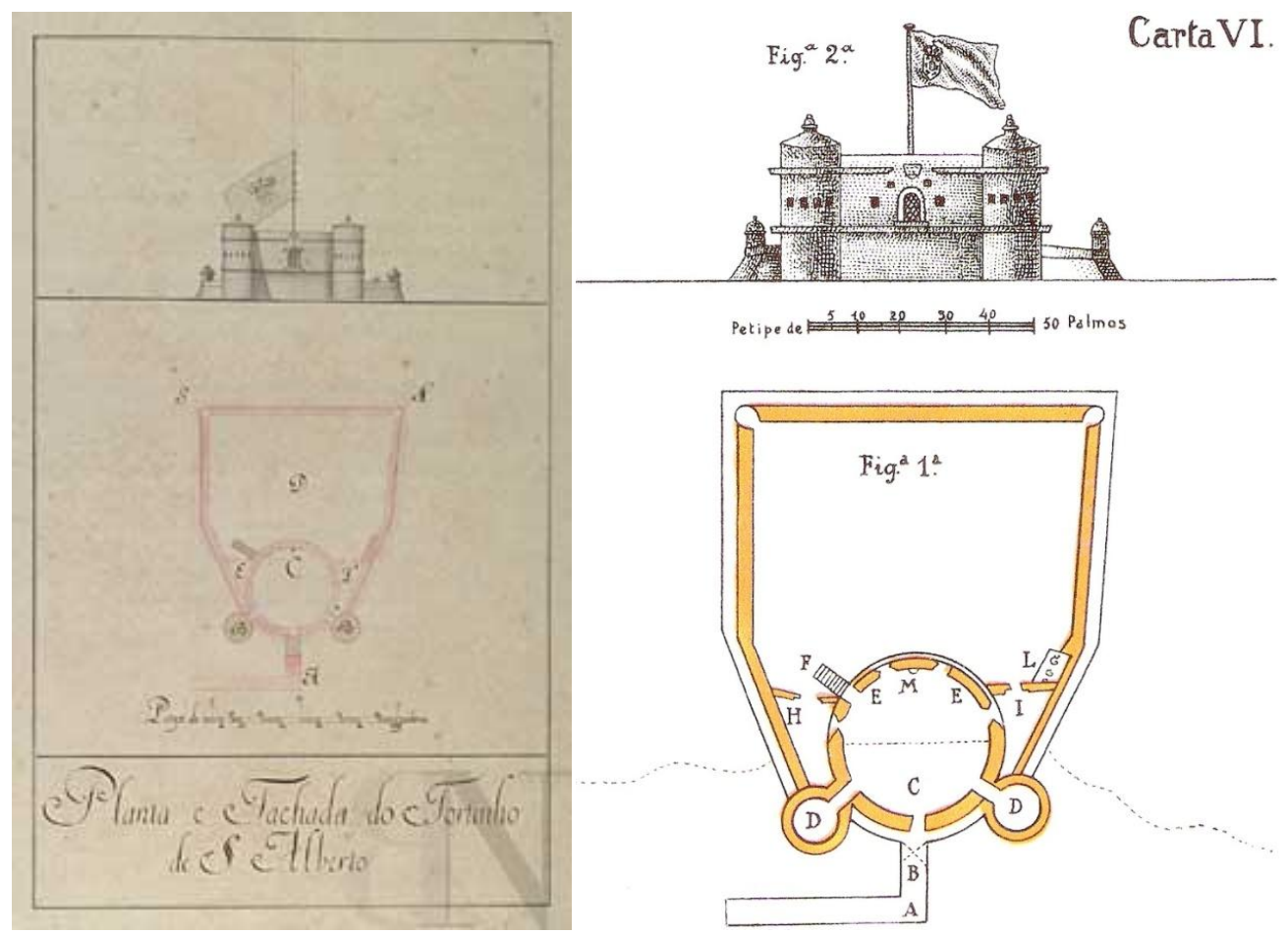

Nas Cartas topográficas... (c. 1762 - BNP) e na publicação Vilhena (em VILHENA, 1921: 226-7).

O forte que não aparece na Notícia Geral... sofreu no início do século XVIII a reforma do Mestre de Campo Miguel Pereira da Costa, que combinava o partido da

964 OLIVEIRA, 2004: 246. 
antiga torre (transformada em uma espécie de cavaleiro) com o terrapleno mais desenvolvido, de linhas retas, para aumentar o poder da artilharia. A primeira idéia era fazer um hornaveque, mas, como vimos no relatório, a obra teve de ser simplificada. ${ }^{965}$ Mário Oliveira fez uma representação do que supõe ter sido essa primeira idéia:

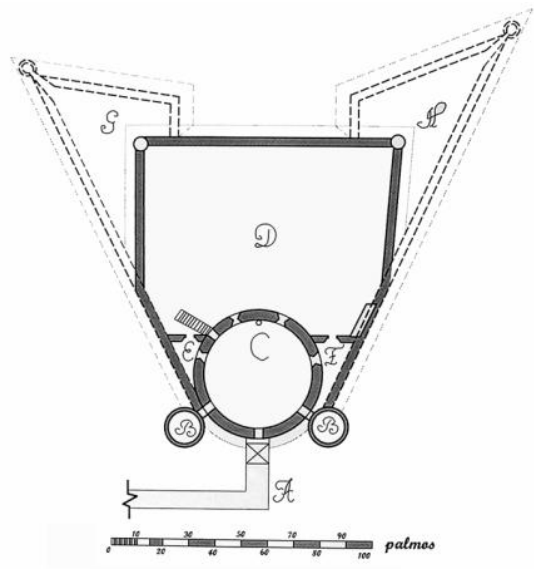

Em pontilhado, a hipótese de M. Oliveira para a forma imaginada por Miguel Pereira, sobre o desenho de Caldas (Cartas topográficas... ou Álbum de desenhos de Fortificações, 1762 - em OLIVEIRA, 2009: 5).

Na visita do Brigadeiro Massé a obra de transformação estava em andamento, como mostrou o relatório assinado por ele, Miguel Pereira e Gaspar de Abreu. ${ }^{966}$ Os documentos são claros quanto ao projeto de reforma ser do Mestre de Campo Engenheiro:

O forte de Santo Alberto que está alem da praya de Agoa de meninos, estava em muitas partes aruinado, alem de ser summam. ${ }^{\text {te }}$ pequeno, se obrigou Illario de Olivr. ${ }^{\text {a }}$ a reedificallo, acressentando o na forma dos apontamentos do Tenente General Enginhr. ${ }^{\circ}$ passandose lhe patente de Capitão delle, e por hora está Servindo de Capitão do mesmo forte, deve ser, pello Serviço que faz a V. Mag. ${ }^{\text {e , Capitão }}$ com Soldo de $4 \$$ rs. por mes. ${ }^{967}$

Apesar de suas limitações de projeto, o forte contribuiu na defesa de Salvador, impedindo que tropas desembarcadas em Itapagipe avançassem pela praia até a cidade, já que a passagem entre o mar e a escarpa era estreita. Sua principal função era defender a praia onde os navios atracavam para se abastecer da água das redondezas. Seus defeitos eram a simplicidade do projeto e estar próximo ao enorme padrasto na retaguarda (por isso foi tomado sem muita resistência nas duas invasões holandesas). ${ }^{968}$

965 ... O fortim junto á praya do Rozario he tão pequeno, q' ao mais permitirá ter pessas de campanha; mas este se acha dezempedido, e com capacid. ${ }^{e}$ na sua vizinhansa de se poder alargar . $^{a}$ qualquer parte: neste lugar se pode fazer hum Hornaveque, cuyos ramais sejão o fundo desta obra, com a distancia nececr. ${ }^{a}$ p. ${ }^{\text {a }}$ serentia, e uso da arter. ${ }^{a}$, e a cortina ser mais dilatada . $^{\text {a }}$ nella se poder acomodar o num. ${ }^{\circ}$ de pessas $q^{\prime}$ parecer conveniente, e como os seos dous meyos baluartes defenderá aquella praya vizinha; porq' o da parte da cid. ${ }^{e}$ flanquear se há com o ultimo baluarte da forteficasão, e o da p. ${ }^{\text {te }}$ de Monserrate com a obra q' entre este e aquelle se fizer (Extracto da forteficação... BAj).

966 ... adiante na praya do Rozario, e principio da Gequitaya estava hum pequeno reducto circular, q se acrescentou e se há de acabar; e tem ja toda a muralha feita a custa do seu capp. ${ }^{\mathrm{m}}$, para ficar huma bateria mais capaz... (Relatório dos engenheiros..., fl. 12-B da transcrição).

${ }_{967}$ AHU - Documentos Avulsos, Bahia: 005. Cx. 9, doc. 741 (CD2, 9, 003, 551-62).

968 Cf. OLIVEIRA, 2004: 193. Na primeira, com a tomada da cidade, sua guarnição ficou isolada. Os holandeses, reconhecendo a função de controle da aguada, guarneceram-no. Na invasão de Nassau 


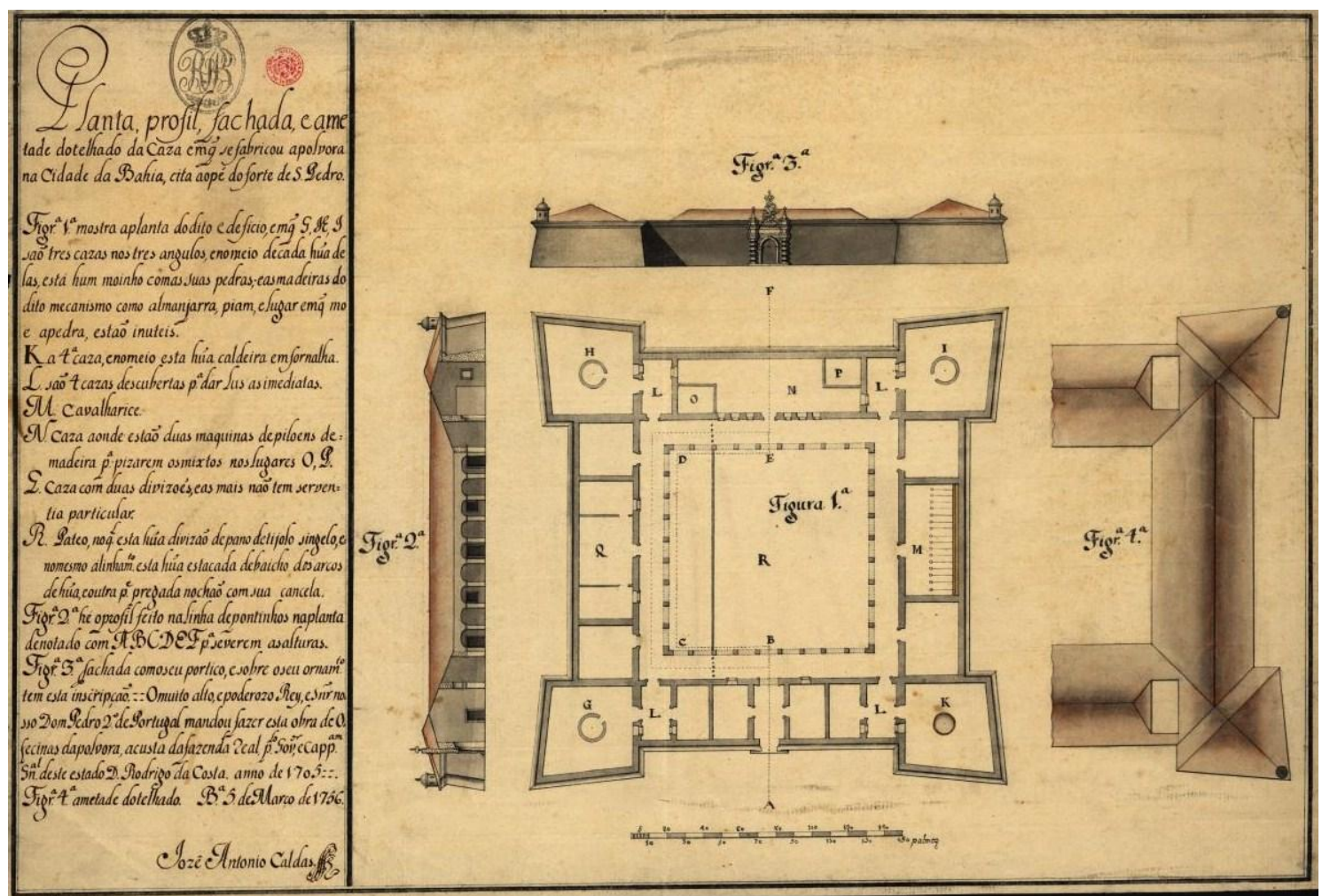

Casa da Pólvora dos Aflitos no desenho de José Antônio Caldas (1756 - BNP/ Estampa D. 259 V da BNL).

Também não incluído nas Notícias Gerais... é o desenho de Caldas para este edifício de que falamos no capítulo anterior. Há um interessante acervo de desenhos sobre a construção. Sabe-se que em meados do século XVIII, com a cidade crescendo em sua direção, foi cogitado o uso do edifício para outras finalidades, sendo o seu cadastro executado outras vezes ou copiado. Um deles é assinado pelo mestre da aula militar Manoel Cardoso de Saldanha (1751), com as explicações feitas também com sua letra. Outro foi elaborado por Bernardo José Jordão (1755), ex-aluno de Saldanha, a pedido do Conselheiro e Intendente Geral do Ouro Wenceslau Pereira da Silva, declarando no título: Caza que servia da fabrica de refinar a polvora (estando, portanto, desativada). Como vimos, Caldas também era discípulo de Saldanha. Outro desenho, do mesmo ano do dele (1756) é o de Inácio Lopes Azevedo, também aluno partidista.

(1638), que ocorreu pelo norte, foram assentadas baterias justamente no padrasto que lhe era desfavorável. Sem alternativa, o comandante Bagnuolo ordenou a retirada da guarnição.

Além da guerra holandesa, participou nas lutas pela Independência da Bahia (disparou um canhão como "sinal de retirada das tropas do General Madeira de Melo, iniciando-se o desfile triunfal da entrada na cidade das tropas brasileiras vitoriosas, no 2 de Julho 1823" - OLIVEIRA, 2004: 194) e depois na Sabinada. No inicio do século XX, com sucessivos aterros das obras de implantação do porto acabou "encravado entre o mar e a montanha, estando hoje entre duas vias de grande movimento". Na década de 60, "suas instalações foram convertidas em sede do Clube de Subtenentes e Oficiais do Exército" (SANTIAGO, C. C. Da Torre de São Tiago... - apud OLIVEIRA, 2004: 194), desfigurando-o parcialmente, mas sem destruí-lo. "As escavações empreendidas no local demonstraram a existência da Torre de São Tiago e seus vestígios podem ser observados através do acesso que foi deixado no projeto de restauração" (OLIVEIRA, 2004: 194). 


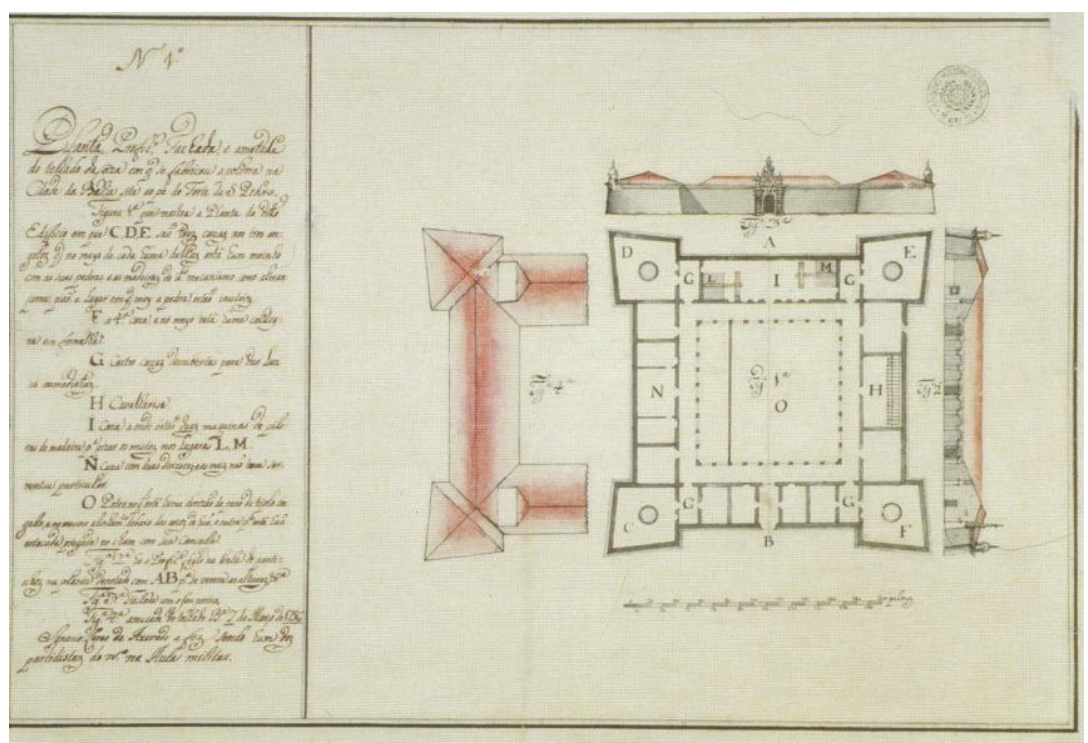

Desenho de Inácio Lopes de Azevedo, aluno partidista da Aula Militar da Bahia (AHU, 968-BA em OLIVEIRA, 2004: 231). Mário Oliveira o considera de qualidade ligeiramente inferior, mas com "mais detalhes, como a posição do mecanismo dos pilões de madeira" (p. 230). ${ }^{969}$

Hoje como Quartel Central do Comando da Polícia Militar da Bahia, a edificação dos Aflitos (a segunda feita na cidade para fabricar a pólvora, que era símbolo de soberania) foi desfigurada por acréscimos e "roupagem" neogótica, mas se mostra em bom estado de conservação.

\section{As épocas seguintes}

\subsection{Final do século XVIII e início do XIX (mudança de capital e Relatório Galeão)}

Na história de Salvador há uma grande diferença entre o começo do século XVIII, quando houve grande expansão econômica e aperfeiçoamento do sistema de defesa, ${ }^{970}$ e o final, em que a transferência de capital (1763) causou decadência. Assim,

\footnotetext{
969 M. Oliveira (2004: 232) observa que por este trabalho gráfico se nota que "a moagem da pólvora era feita com galgas", dotadas de mós de pedra e acionadas por tração animal, em três dos pseudobaluartes, havendo até "espaço para abrigo dos animais que se revezavam na tração". Nota-se também o espaço dos pilões de madeira usados no preparo da pólvora.

${ }^{970}$ Cf. NUNES, 2006. Que junto à importância política, era acompanhado de crescimento urbano. Novas áreas foram ocupadas acompanhando o sentido da praia, atingindo a península de Itapagipe (ao norte) e a Barra (ao sul). O caminho que ligava a cidade à Vila do Pereira foi consolidado, destacando-se a reconstrução da igreja da Vitória. Também houve ampliação de área urbana na direção das colinas a leste, chegando à Mouraria, Santana e Nazaré. O porto, cada vez mais importante na primeira metade do século, consolidou o Bairro do Comércio, com edificações de quatro e cinco andares. Ao mesmo tempo, em outros bairros (Pilar, Preguiça, São Bento e Sé), as construções irregulares em terrenos de encosta causaram vários desmoronamentos.

Em termos de área urbana, dos 15 hectares de 1549, 65 em 1580 e 160 em 1651, Salvador em 1798 passaria a ocupar 430 hectares. Os bairros consolidados no século XVIII foram: as freguesias do Passo, de São Pedro e da Vitória, Nazaré, Santana, Mouraria, Barbalho, Pirajá, Mares, Penha, Bonfim, Itapagipe, Boa Viagem; os espaços públicos da atual Praça Castro Alves (disponibilizados com a construção da Muralha da Montanha e derrubada da Porta de São Bento), a Praça da Piedade (1796), os adros da
} 
a segunda metade do século XVIII representa ainda o auge do sistema defensivo, que declinou em seguida. $O$ crescimento incessante do casario urbano e a inatividade a partir da emancipação política desfizeram a eficiência dessas construções bélicas. As mais espaçosas se adaptaram, a partir daí, a diversas funções: quartéis, presídios, hospitais de emergência em epidemias e outras repartições públicas (mais recentemente, museus e centros culturais).

Com a mudança da sede administrativa para o Rio de Janeiro, não se pensou mais em um sistema de fortificações adequado para Salvador. ${ }^{971}$ Os fortes já estavam precários e pouca coisa nova foi feita: o fortim de S. Fernando (concluído em 1796, segundo Vilhena), ${ }^{972}$ uma bateria na eminência da parte de terra dos fortes da Barra (também citado por Vilhena), ${ }^{973}$ e o Forte de Jiquitaia (de 1819, para proteger o canal da Calçada). ${ }^{974}$ Não há informações sobre a manutenção das velhas trincheiras e não houve nenhuma obra de vulto além dessas.

Igreja da Boa Viagem, da Casa Pia dos Órfãos de São Joaquim e da Igreja de N. S. da Barroquinha; as vias Estrada da Rainha (atual), Avenida Joana Angélica (atual), as ruas dos Perdões, do Passo e São José de baixo (ligando o Santo Antônio à Soledade).

Afora os militares, são do século XVIII os seguintes edifícios: Arquitetura Civil - Paço Arquepiscopal (1705), Paço do Saldanha (1699, depois Liceu de Arte e Ofícios), Casa do Coronel (Massaranduba, 1756), Solar Bandeira (segunda metade do século), Solar Conde dos Arcos, no Garcia (1781), Solar do Gravatá ou Solar Silveira Mendes, na atual Praça dos Veteranos (1733) e Solar do Sodré (começo do séc. XVIII); Arquitetura Religiosa - igrejas da Ordem Terceira de S. Francisco (1702), de N. S. do Rosário dos Pretos (1704), de N. S. de São Pedro dos Clérigos (1709), igreja e hospital N. S. da Boa Viagem (1712), igreja de N. S. da Barroquinha (1722), da Ordem Terceira de S. Domingos (1731-2), Casa Pia e Colégio dos Órfãos de S. Joaquim (1709-59), Convento das Mercês (1735), Capela Particular do conjunto Solar do Unhão (1715-40), igrejas dos Aflitos (1735) e do Santíssimo Sacramento da Rua do Paço (1737), Capela de S. Lázaro e hospital junto à igreja (1734-59), Igreja da Basílica de N. S. da Conceição da Praia, substituindo a antiga capela (1739), Convento da Lapa (1744), igrejas Basílica de Nossa Senhora do Bonfim (1745) e do Santíssimo Sacramento e Santana (1746), reconstrução da Igreja da Graça (1770) e reforma da Igreja de Brotas (1772).

${ }^{971}$ Entre os motivos que levaram o Marquês de Pombal (então Conde de Oeiras, passando depois a ser o poderoso ministro de D. José I) a transferir a capital estavam o grande lucro das Minas Gerais (no auge da exploração de ouro e diamante, que escoava a produção e aferia impostos no Rio de Janeiro) e o fato da baía de Guanabara ser muito mais defensável que a de Salvador (segundo Mário Oliveira - 2004: 85 -, Belidor, o mais prestigiado engenheiro do exército francês da época, autor de importantes trabalhos sobre engenharia militar, considerava a baía da Guanabara das mais defensáveis do mundo em sua conformação natural).

972 Cf. OLIVEIRA, 2004: 85 (nota 127). O Forte de S. Fernando já nasceu comprometido pela proximidade de edifícios civis e foi considerado ainda mais incômodo que o de S. Francisco (que era apelidado de "quebra pratos" e foi impedido de dar salvas por comprometer a estabilidade da encosta; houve inclusive manifestações populares contra o seu funcionamento, alegando-se que a vibração dos disparos quebrava louças e vidraças).

973 "Para supprir em parte os defeitos destas duas Fortalezas [S. Maria e S. Diogo] que indispensavelmente hão de ser atacadas por quem ali quizer fazer dezembarque, se levantou a menos de meya ladeira do monte proximo e distante 600 para 800 passos e que inteiramente as domina, como aquelle de Santo Antonio huma trincheira de terra quazi como a do Rio Vermelho... donde os tiros, pouco menos que mergulhantes, podião bem inquietar e fazer estrago em quem dezembarcasse no porto, limpo de pedras para huma armação que nelle está, quando paresse seria mais acertado o lançarIhas e difficultar por ahi o dezembarque, pois que nelle o fizerão os Holandezes, quando tomarão esta cidade" (VILHENA, 1921: 221 - grifo nosso).

974 Próximo ao Antigo Noviciado dos Jesuítas (hoje Casa dos Órfãos de S. Joaquim), sendo construído já no fim do domínio português, para defender a entrada do canal que passava pela Calçada (ainda pode ser visto e aparece em foto do Google, mostrada na p. 317). 


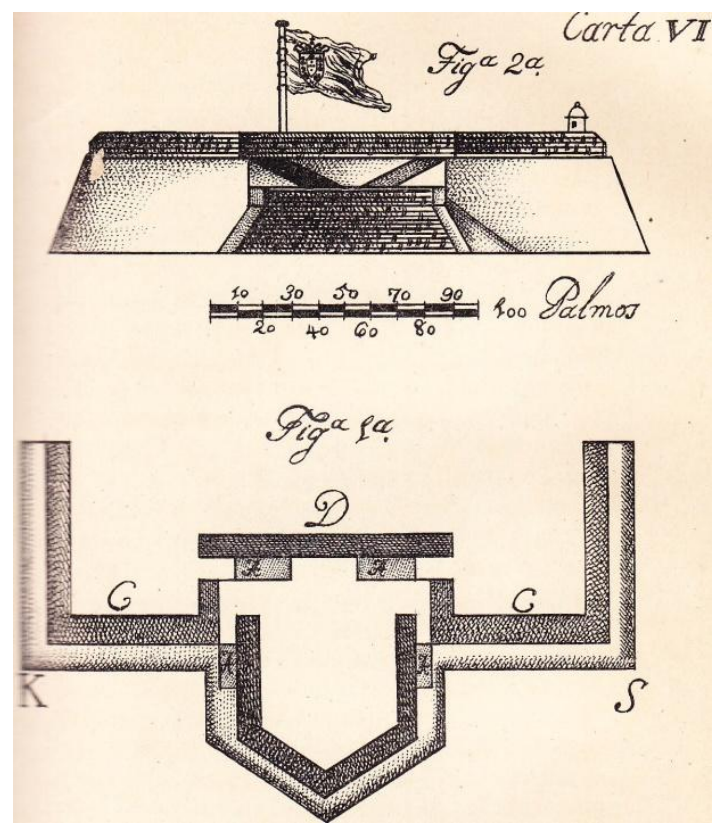

O Reducto de S. Fernando desenhado em Vilhena (1921: 22-3). "He elle Construido de faxina e terra a meia Ladeira do oiteiro contiguo a Capella de Santo Antonio da Barra, em pozição e distancia dominante ao dezembarque que lhe fica em frente; com a vantagem de Cobrir os acessos Lateraes, que dão ingresso para a cidade e comandar de revez as Fortalezas de Santa Maria, e S. Diogo que se achão na mesma quadratura, e linha da Marinha. Foi mandado levantar no tempo do Governo do Ilmo. E Exmo. D. Fernando Joze de Portugal no anno de 1797 e tem para se laboratório 11 pessas d0 calibre de 8 e 12 ". “A. Rampas. B. Terrapleno do Rebelim. C. Baluartes. D. Cortina".

O próprio Marquês de Pombal chegou a comentar em carta ao vice-Rei do Brasil que o Rei de Espanha fora aconselhado pelo Marquês de Grimaldi a não atacar o sul do Brasil, distante e mais guarnecido, mas... em outros lugares mais comodos, e de seguro golpe; ou a os Portos, em que estamos mais desprevenidos; quaes são, Bahia e Pernambuco. ${ }^{975} \mathrm{O}$ governo português, portanto, sabia dessa fragilidade.

Também no fim do século XVIII, o baiano Domingos Alves Branco Muniz Barreto, então Capitão de Infantaria do Regimento de Estremoz, fez o relatório em que retratou com contundência o estado das defesas da Bahia:

Sendo vastissimos os dominios q' a Nação Portuguesa possue no Brazil, não só se tem abuzado inteiramente da riqueza, $q^{\prime}$ liberalm. ${ }^{\text {te }}$ Ihes offerece, mas q' pouco, ou nada se tem cuidado em segurala, na defeza dos portos, $q^{\prime}$ igualmente permitem hu'a navegação sem limite. A razão deste disconcerto tem diversas origens, $q^{\prime}$ todas se podião ter precavido, se os planos offerecidos por aquelles $q^{\prime}$ sabem o que convem á sua Nação achassem o remédio ou algu'a dispozição para se adoptarem, ainda em tempo, $q^{\prime}$ se podiam remediar os errados detalhes dos primeiros, que forão encarregados de levantar as Povoaçoens naquelle Novo Mundo, que só olharam a sua natural cobiça deixando tudo o mais com diformidade. ${ }^{976}$

No começo do século XIX foi feita a avaliação das fortificações de Salvador pela equipe do então Brig. José Galeão. As informações do texto mostram que o Forte $S$. Marcelo só teve as transformações para a forma atual algum tempo depois, já que

\footnotetext{
${ }^{975}$ Carta de 03/08/1776 - sobre o verossimil Projeto de Invasão, Bombardeamento, e Contribuição, ou saque, da Bahia de Todos os Santos. AHM - 2a Divisão, 1a Seção, cx. 1, doc. no 22 - apud OLIVEIRA, 2004: 60.

${ }^{976}$ Observaçoens Sobre a Fortificação... BMP - Mss 686, Brasil (1797), fl. 1.
} 
ainda é citado o torreão. ${ }^{977}$ O Relatório Galeão foi o último grande estudo sobre as fortificações de Salvador e sua estratégia de defesa no Período Colonial. Galeão era apenas um dos autores do documento, ${ }^{978}$ também assinado pelo Cel. Eng. Manoel Rodrigues Teixeira, pelo Ten. Cel. de Artilharia José Francisco de Souza e Almeida, pelo Cap. Eng. Joaquim Vieira da Silva Pires e pelo 1으. Ten. Eng. João da Silva Leal (este último, autor dos desenhos que ilustram o texto, muitos deles reproduzidos aqui).
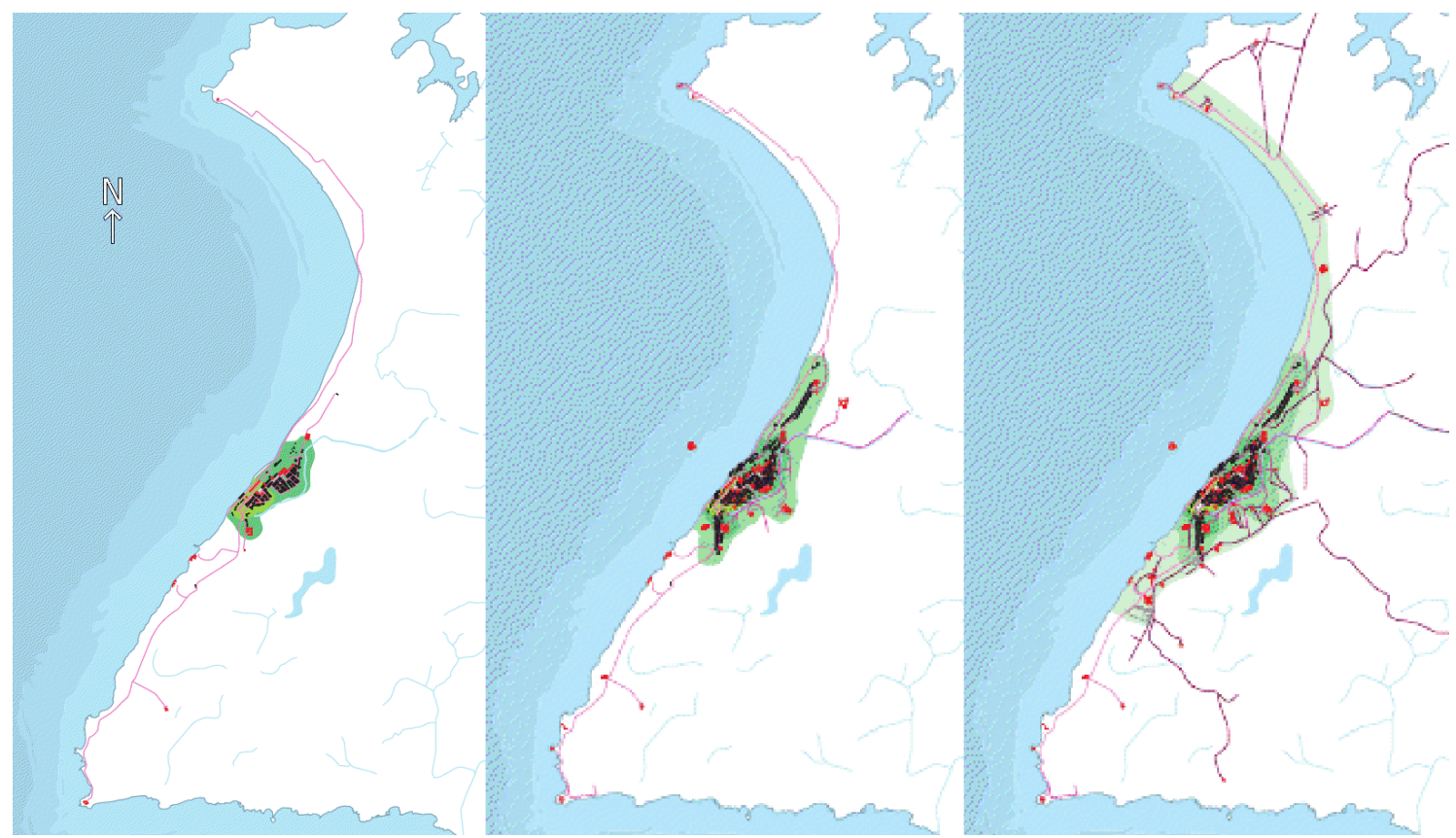

Mapa mostrando a área urbana de Salvador nos três finais de século, XVI, XVII e XVIII (desenhado sobre a geografia atual - fonte: NUNES, 2006).

977 Cf. SILVA, 1919: 310. "Esta fortaleza é circular e está collocada na frente da Ribeira na distancia de dous tiros fortes de mosquete, e consta de uma praça alta, e outra baixa fazendo duas baterias concêntricas".

978 Galeão ocupou a regência da Aula Militar depois da morte do Sargento-mor José Antônio Caldas (1872), mas sua competência não estava na arte do desenho e sim na artilharia. O texto traz observações importantes sobre o emprego das ars tormentaria na defesa da Bahia, invocando velhos ensinamentos de Vauban e do Cavaleiro de Ville e discutindo ensinamentos mais atuais de Trincano e Montalembert, com a famosa polêmica das casamatas para artilharia.

Em seu relatório preliminar (de 15/09/1809) ele destaca o problema crônico da guarnição paga da Cidade, que à época tinha dois regimentos de linha com... 1275 soldados comprehendendo o numero de doentes no Hospital, invalidos e recrutas..., e mesmo somando a todos os habitantes aptos a pegar em armas dava um número... muito diminuto para a defeza de toda a marinha. O documento previa um efetivo mínimo de 7.176 homens para defender Salvador no começo do século XIX (cf. OLIVEIRA, 2004: 77). 


\subsection{Mapa de localização dos fortes na enseada}

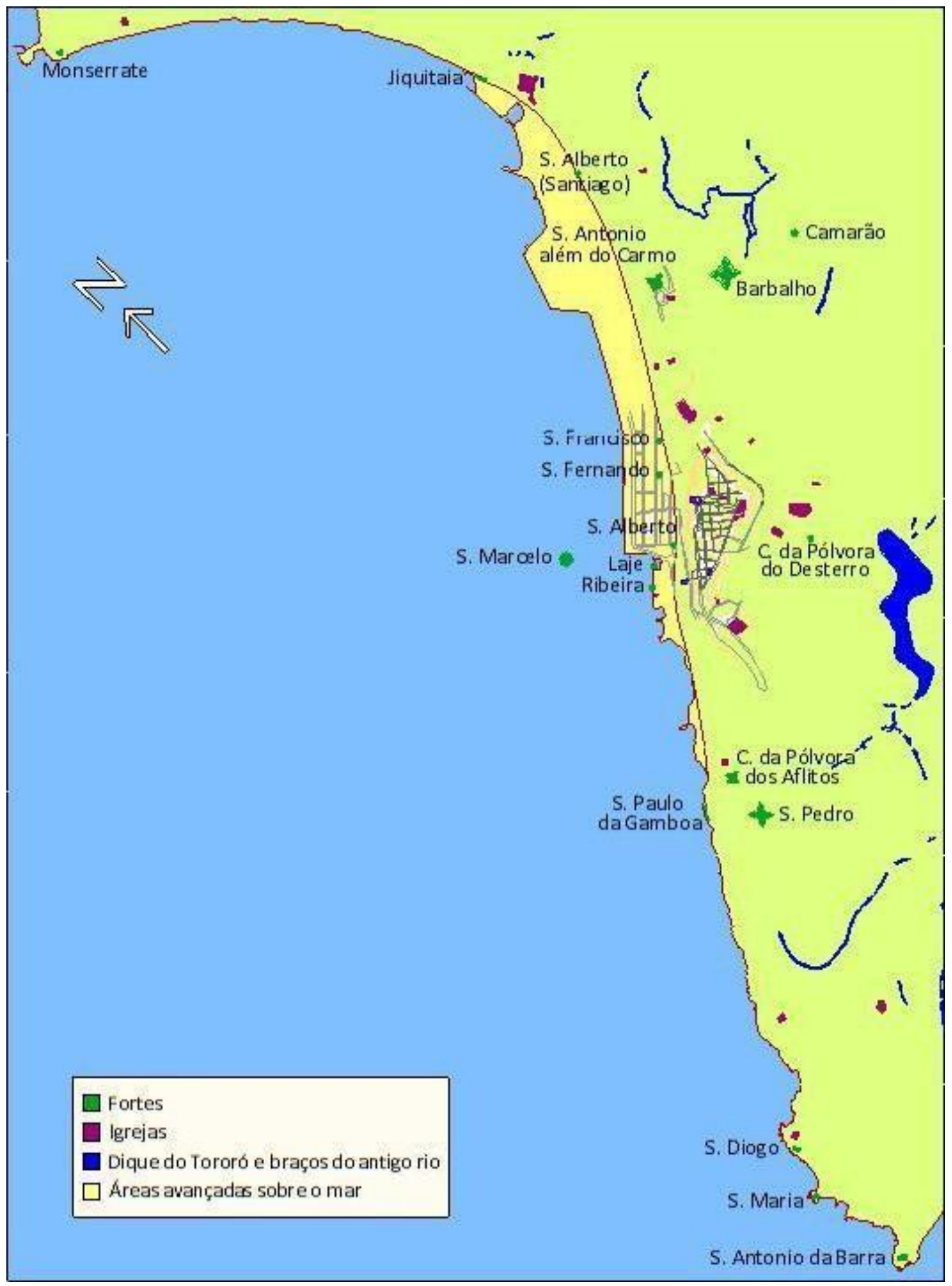




\subsection{Alguns registros de épocas posteriores (pintura e fotografia)}

\section{Santo Antônio da Barra}

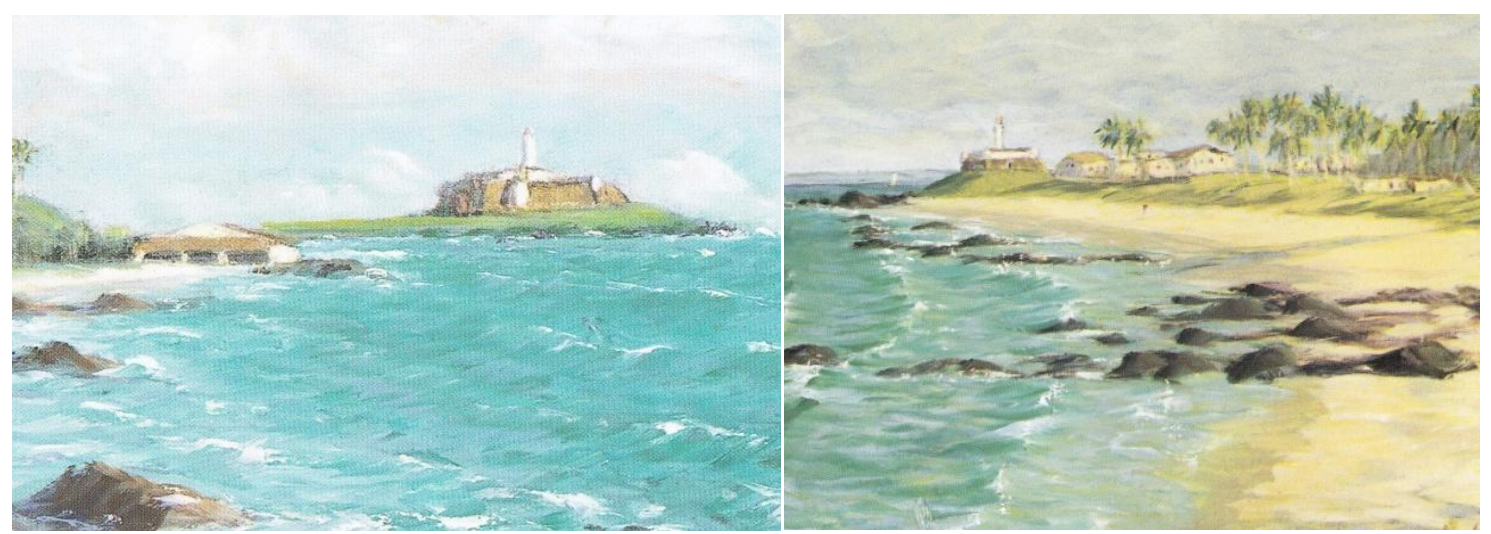

Pinturas em REBOUÇAS, 1996: 189 e 193.

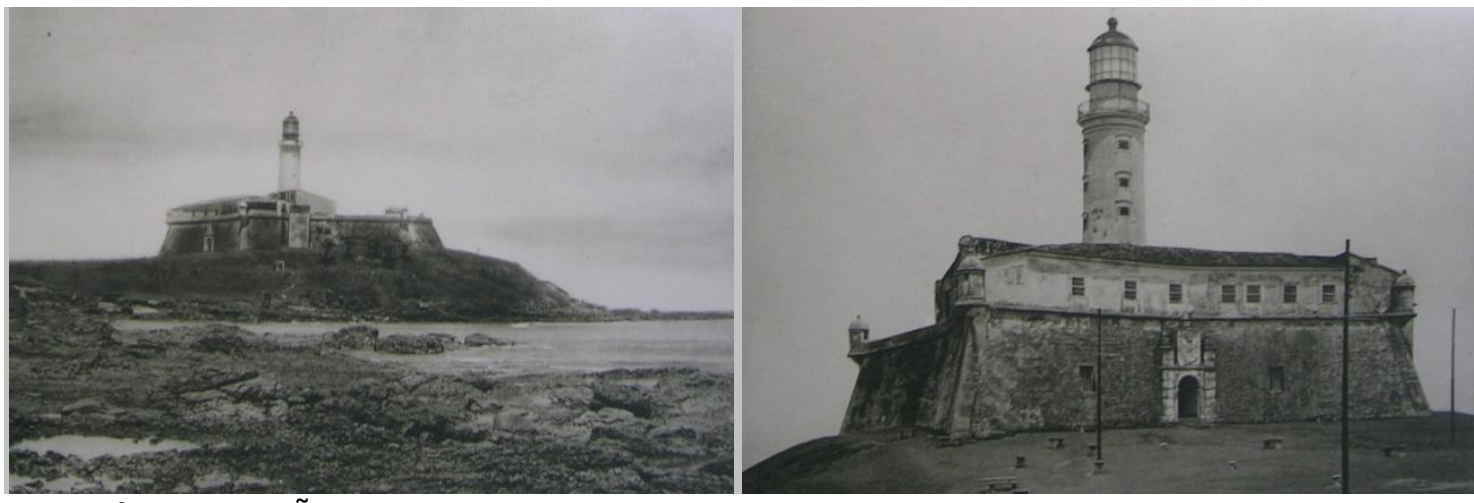

Fotografias em FALCÃO, 1949: 15 e 17.

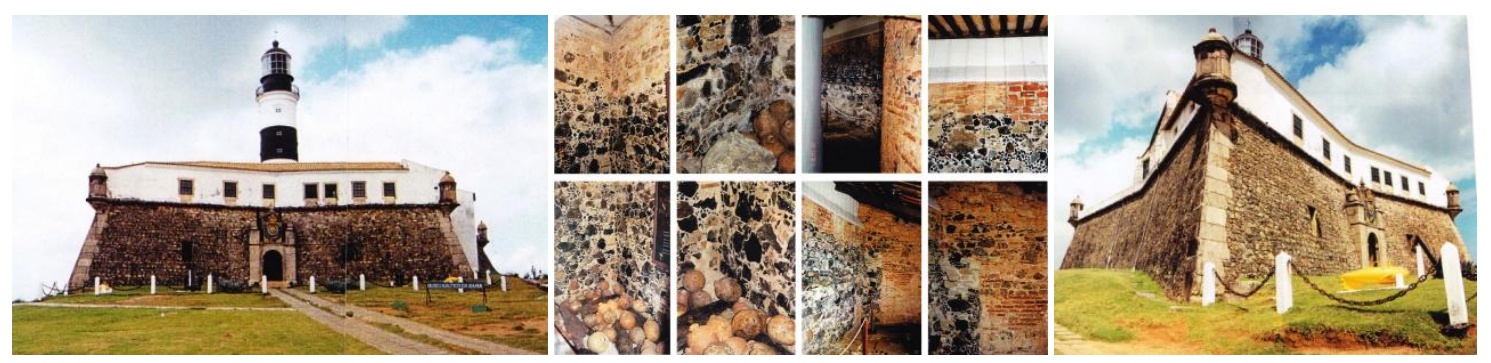

Em fotografias nossas de out/01, ao centro com as paredes internas mostrando diferentes fases construtivas.

\section{Monserrate}

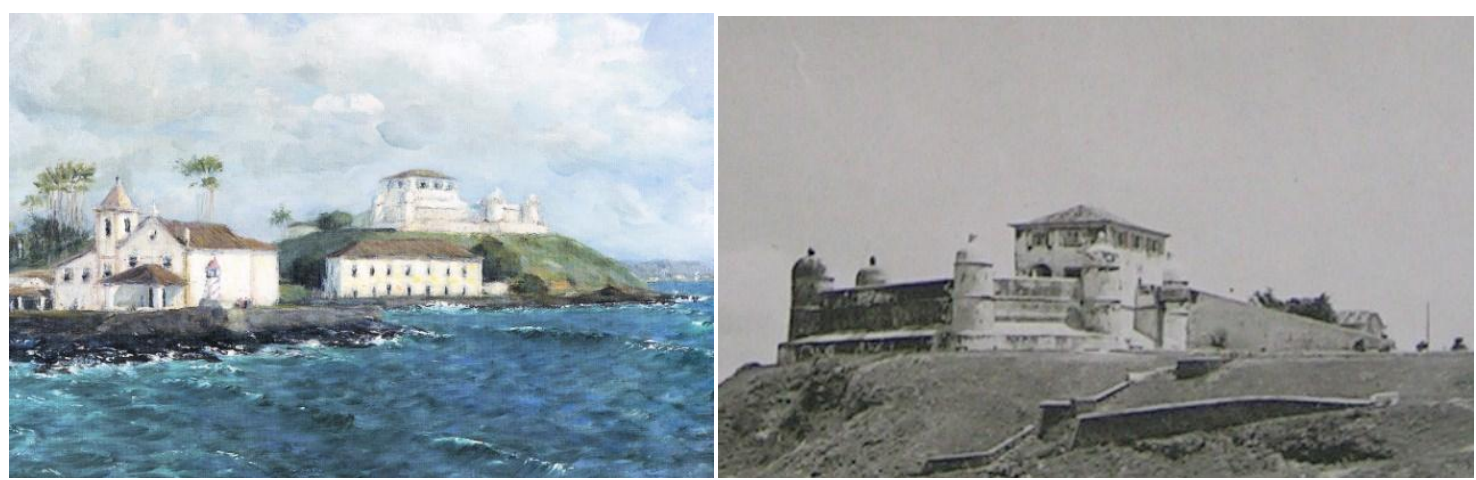

Pintura em Rebouças (1996: 229) e fotografia em Falcão (1949: 33). 


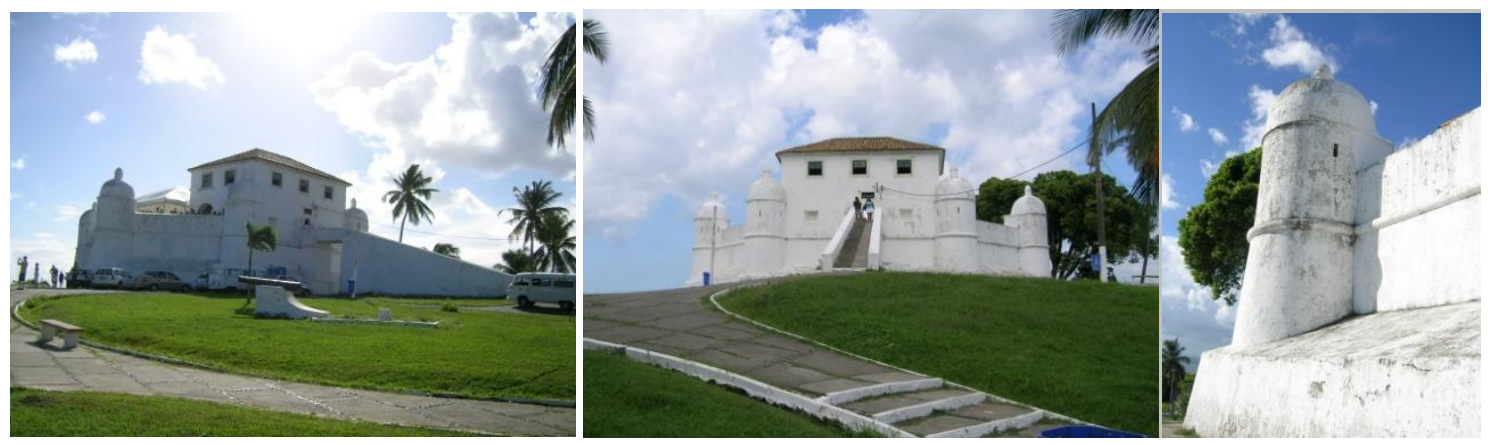

Fotografias nossas (mar/08)

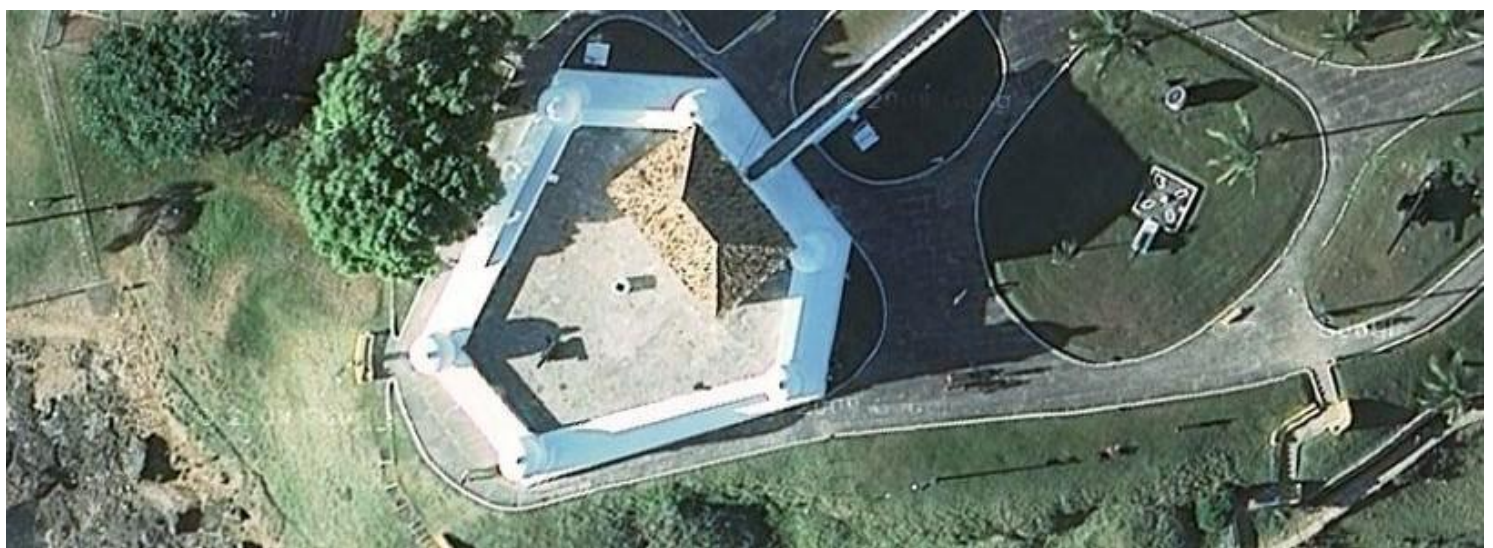

Fotografia no Google (30/07/09).

\section{Santa Maria}

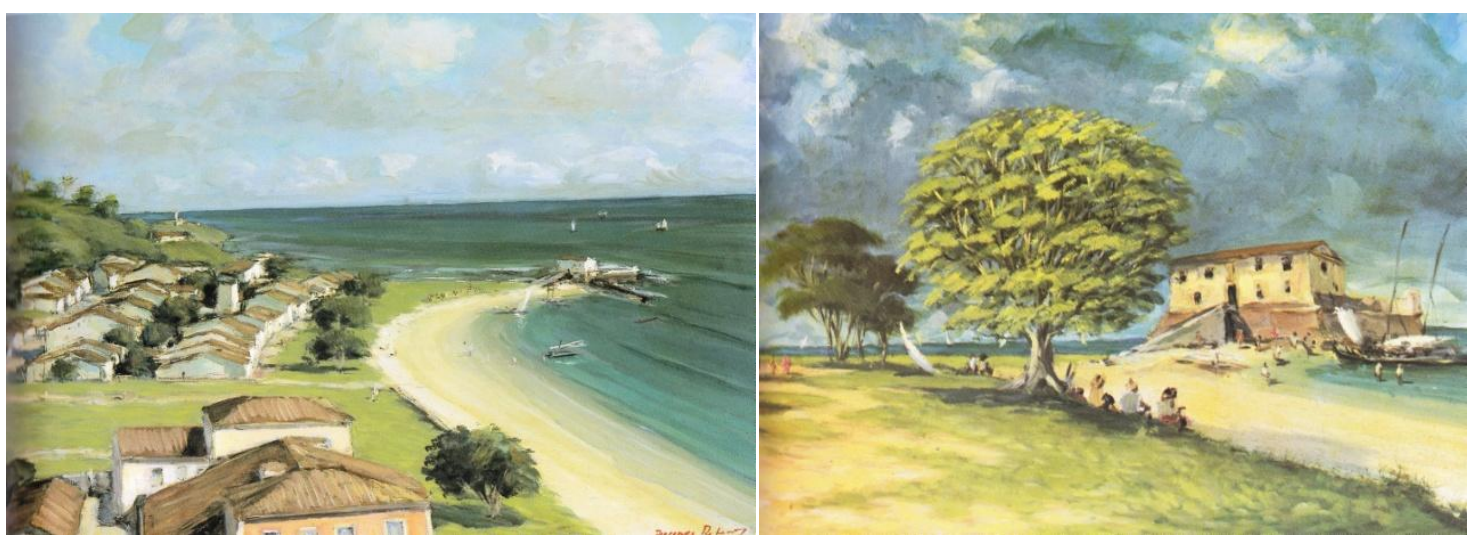

Pinturas em REBOUÇAS, 1996: 183 e 186-7.
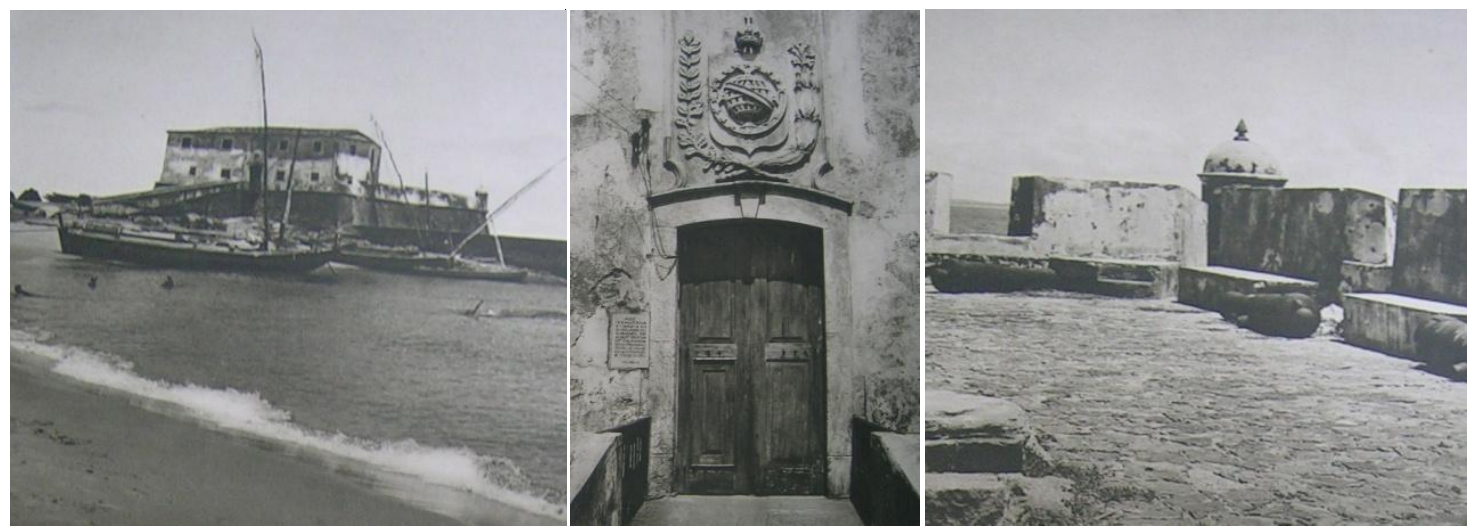

Fotografias em FALCÃO, 1949: 18-20. 

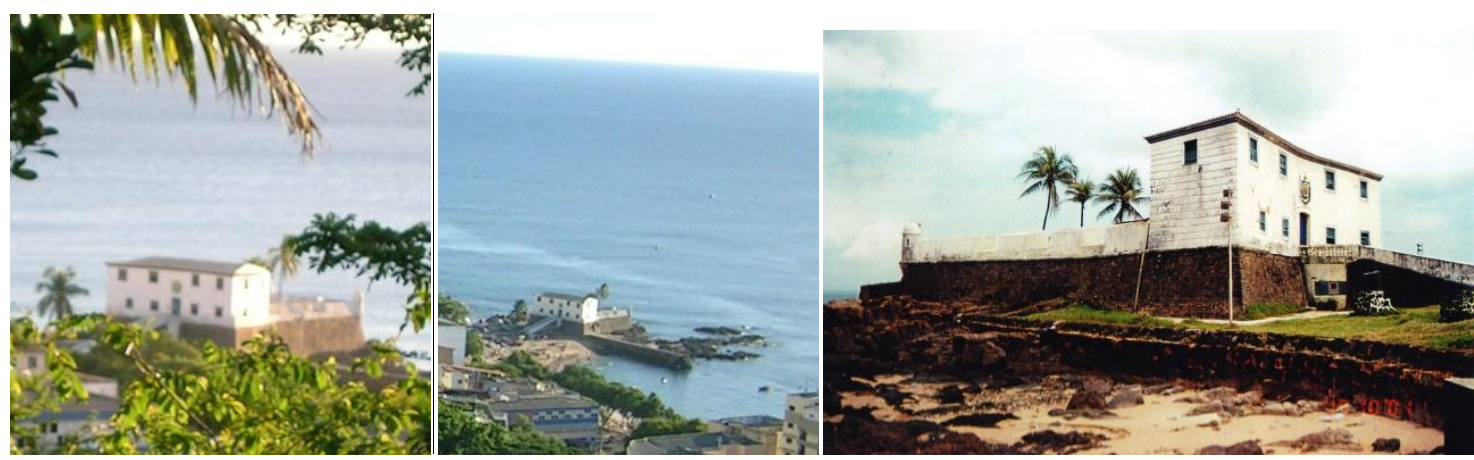

Fotografias nossas (08/03/08 e 10/10/01).

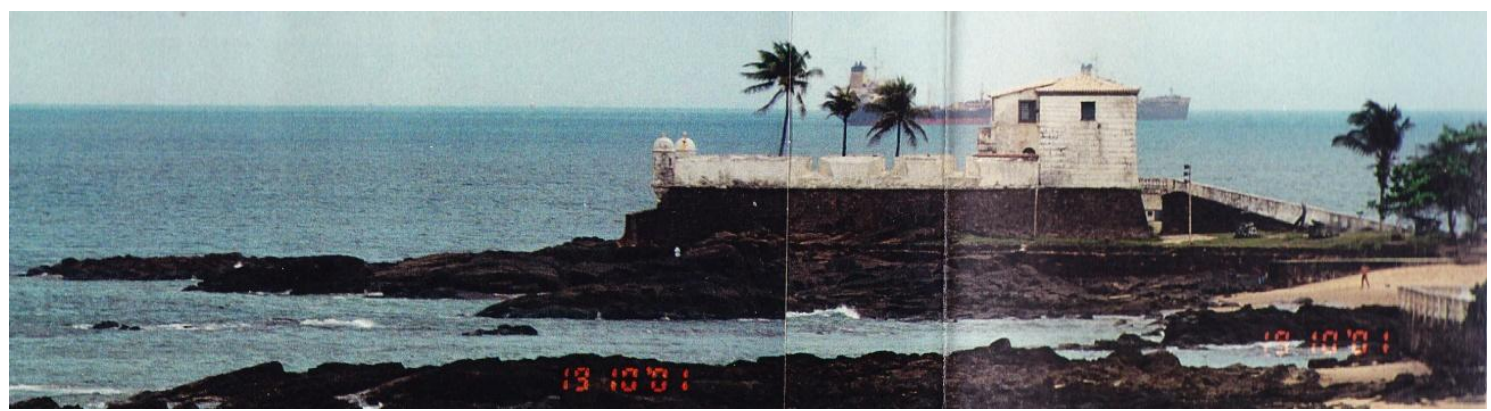

Fotografia nossa $(19 / 10 / 01)$

\section{São Diogo}

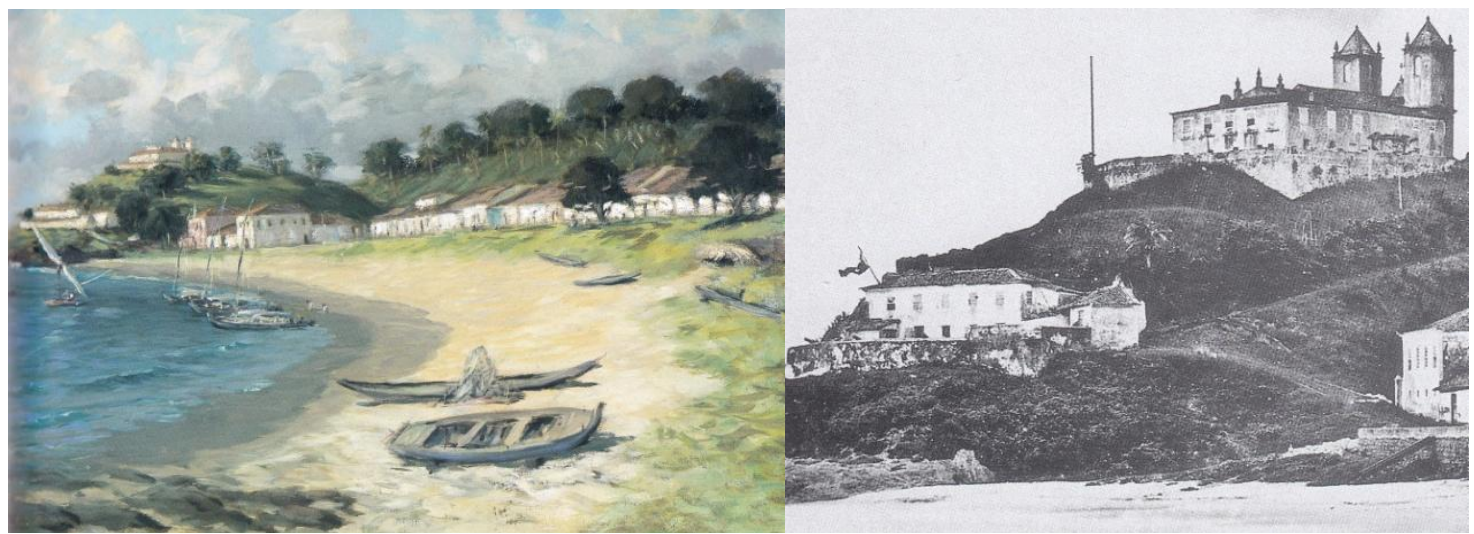

Pintura em REBOUÇAS, 1996: 185 e fotografia de B. Mulock (c. 1860) em OLIVEIRA, 2004: 201.

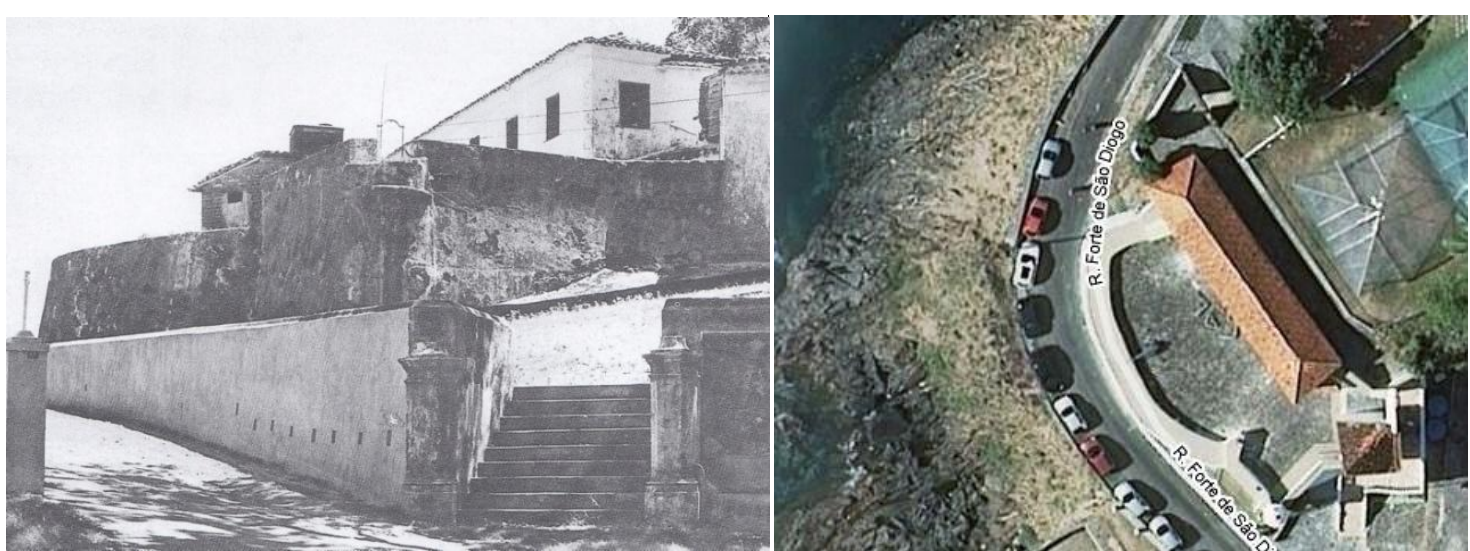

Em fotografia de Falcão (1949: 22) e do Google Maps (30/07/09). 
Santo Alberto (ou "Lagartixa", antiga Torre de Santiago)

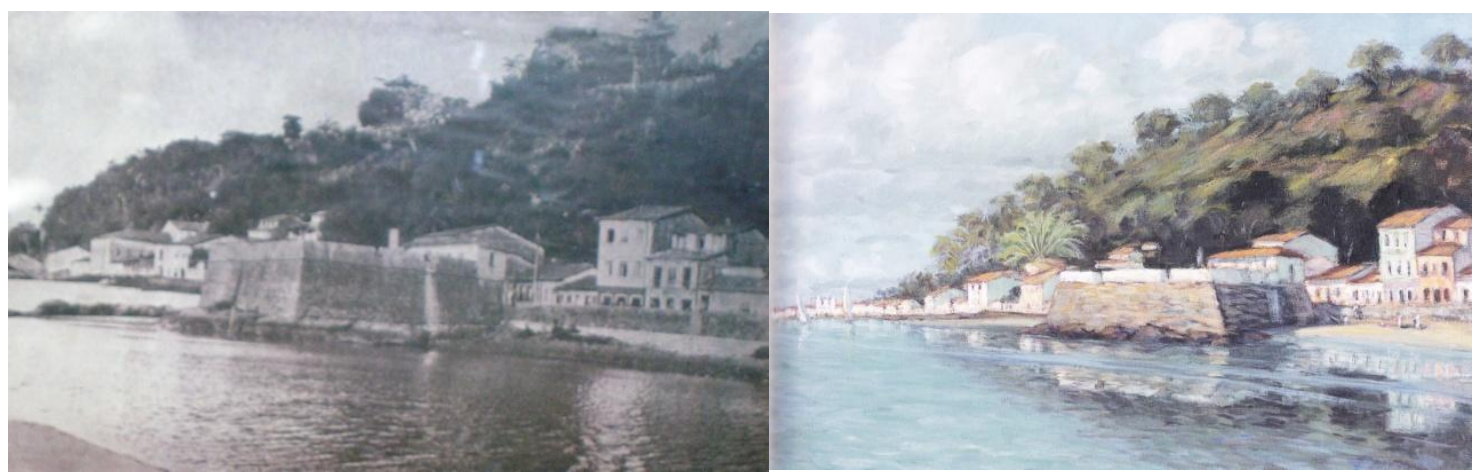

Fotografia do séc. XIX (quadro encostado em uma das paredes internas do forte na visitação de mar/08, s/ ref.) e pintura de Diógenes Rebouças (1996: 223).

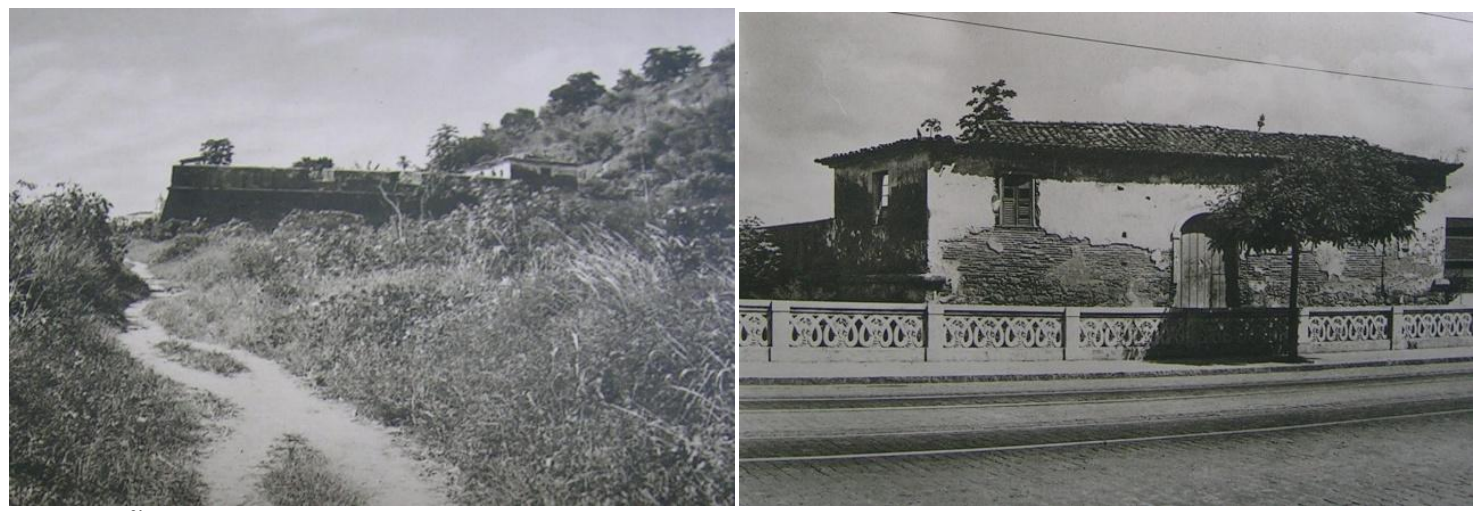

Em FALCÃO, 1949: 31-2.

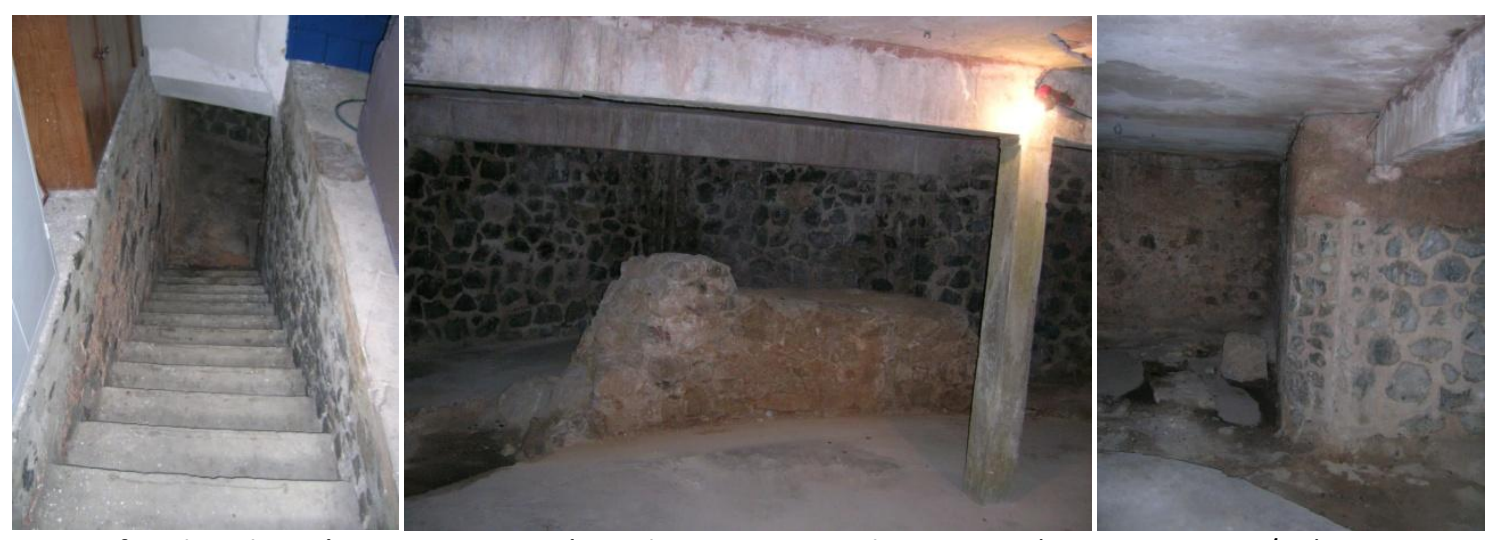

Fotografias do subetrrâneo com os vestígios da antiga Torre de Santiago (nossas, em mar/08)

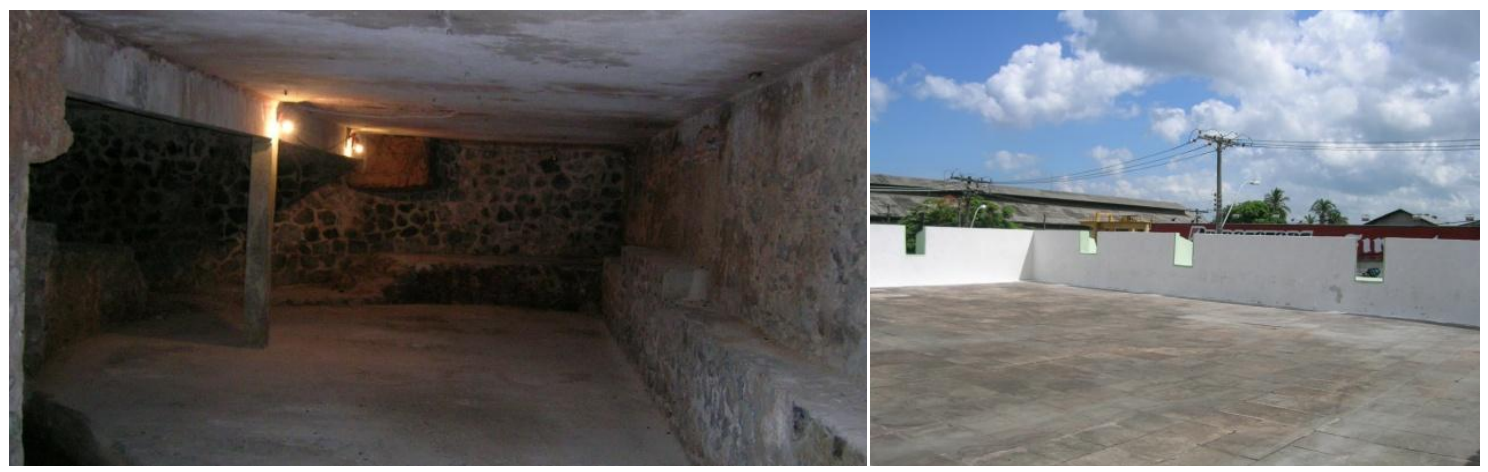

Subterrâneo e terrapleno (nossas em mar/08). 


\section{Fortim do Rio Vermelho}
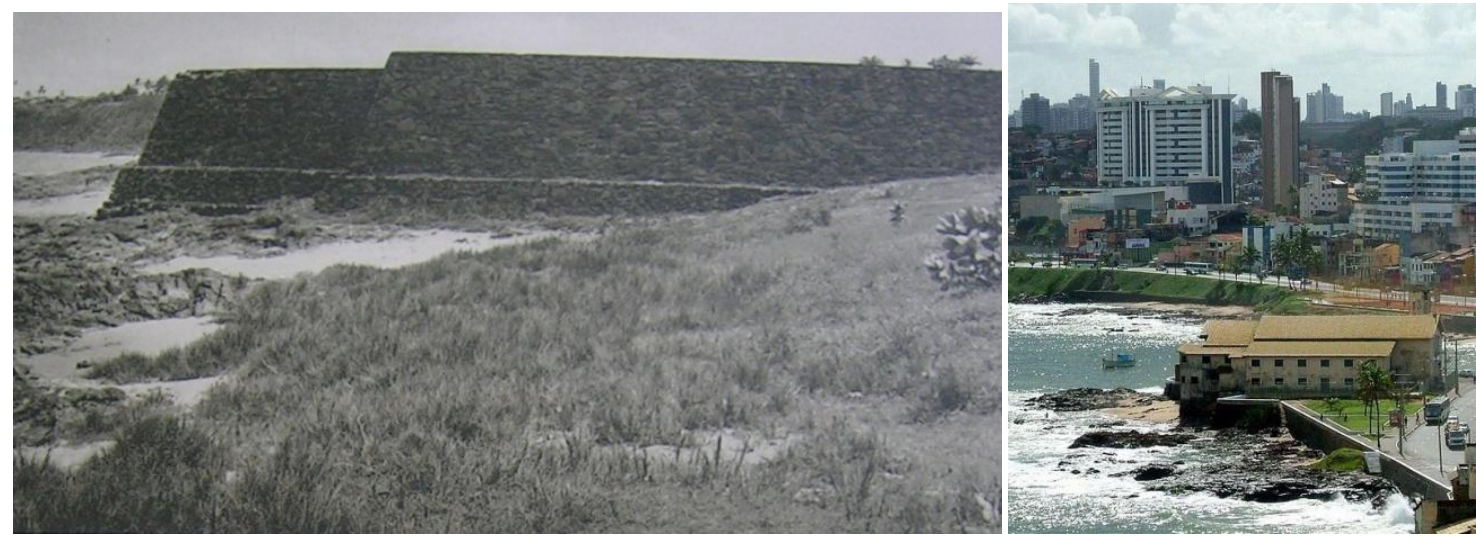

As muralhas do reduto fotografadas por E. C. Falcão (Relíquias da Bahia) e seus vestígios em uma fotografia atual (Google imagens, mar/2010)

\section{São Marcelo}

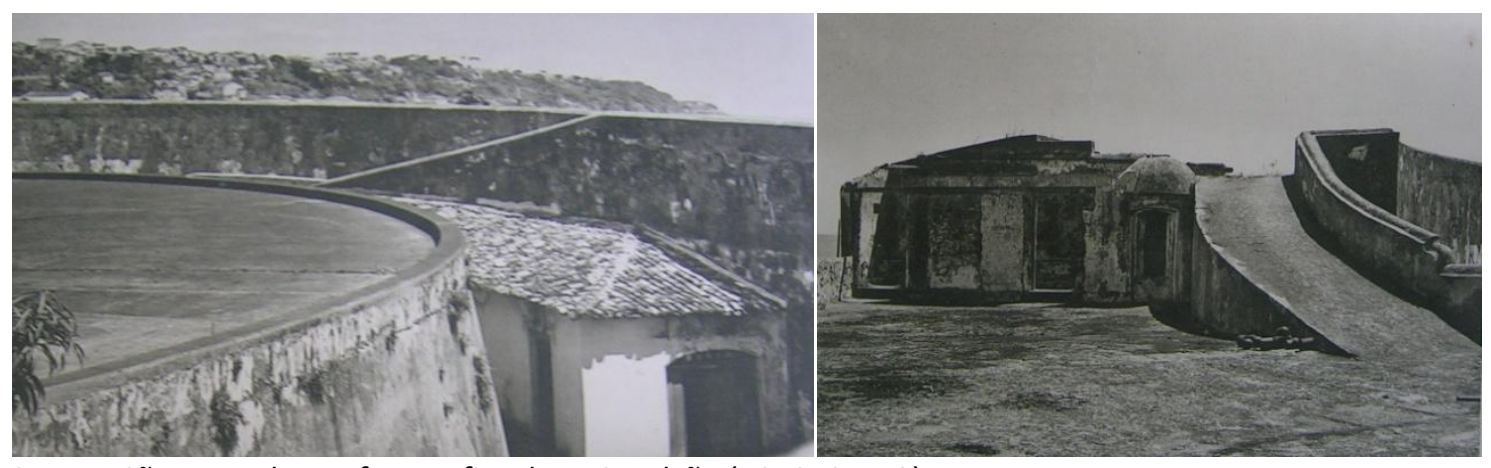

O Forte São Marcelo em fotografias de E. C. Falcão (1949: 8 e 13).
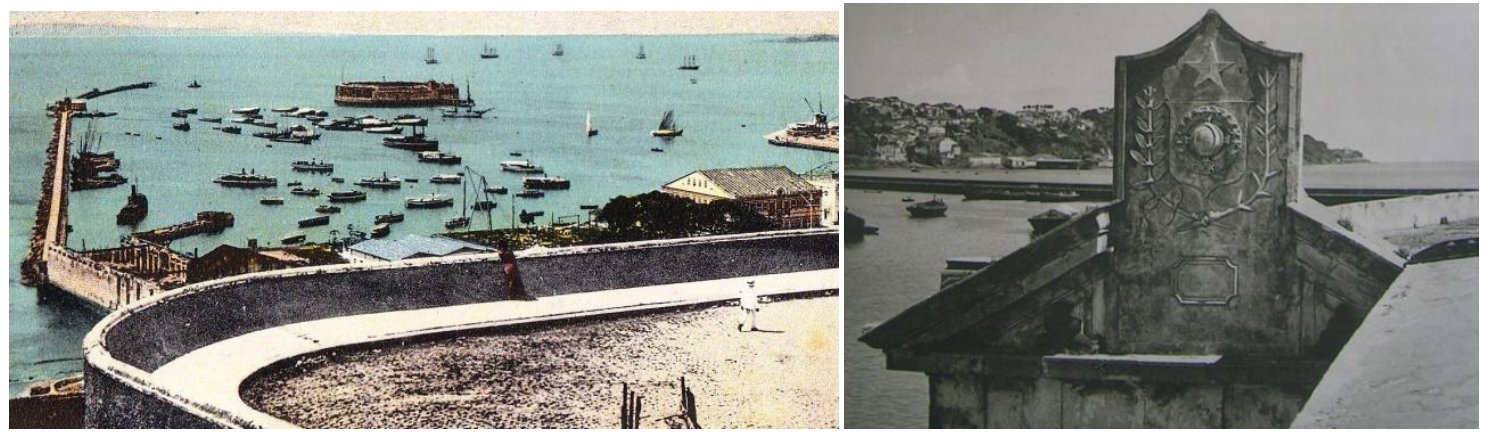

Em cartão postal antigo e em mais uma fotografia de Falcão (1949: 5).

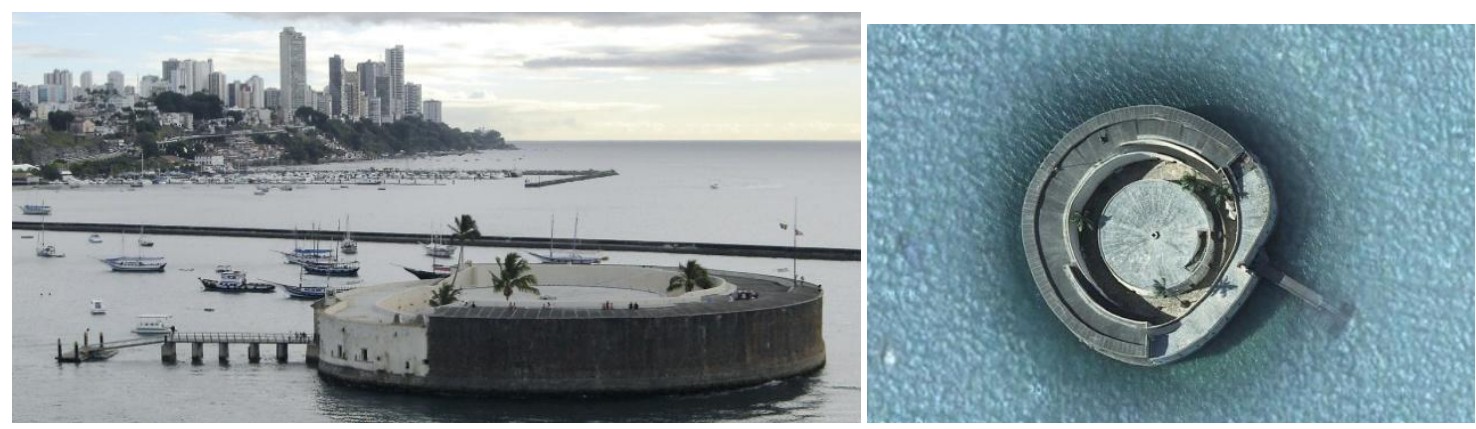

Em fotografia do "Google images" e no site "Google maps" (29/07/09) 


\section{Dique Grande}

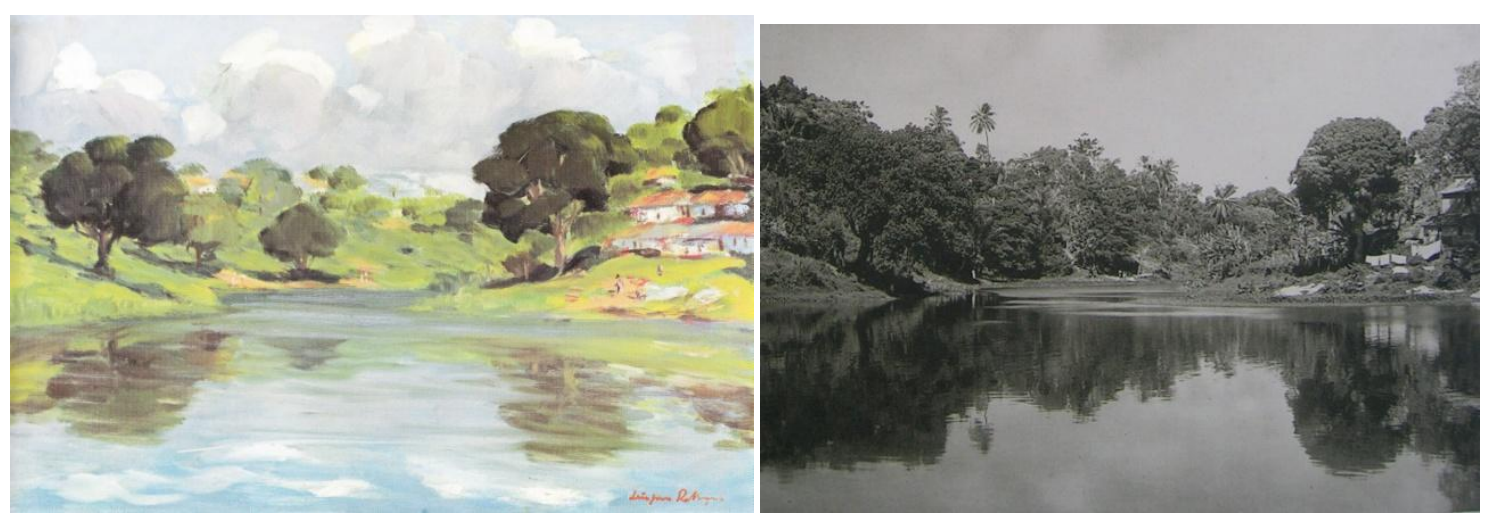

Em Rebouças (1996: 209) e Falcão (1949: 47).

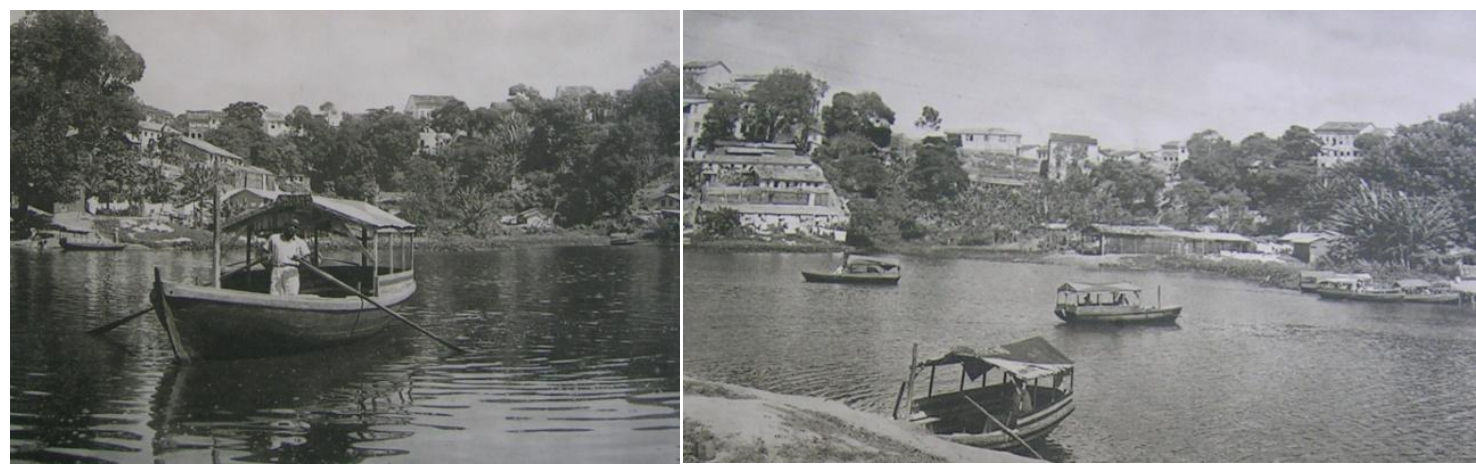

Em Falcão (1949: 48-9).

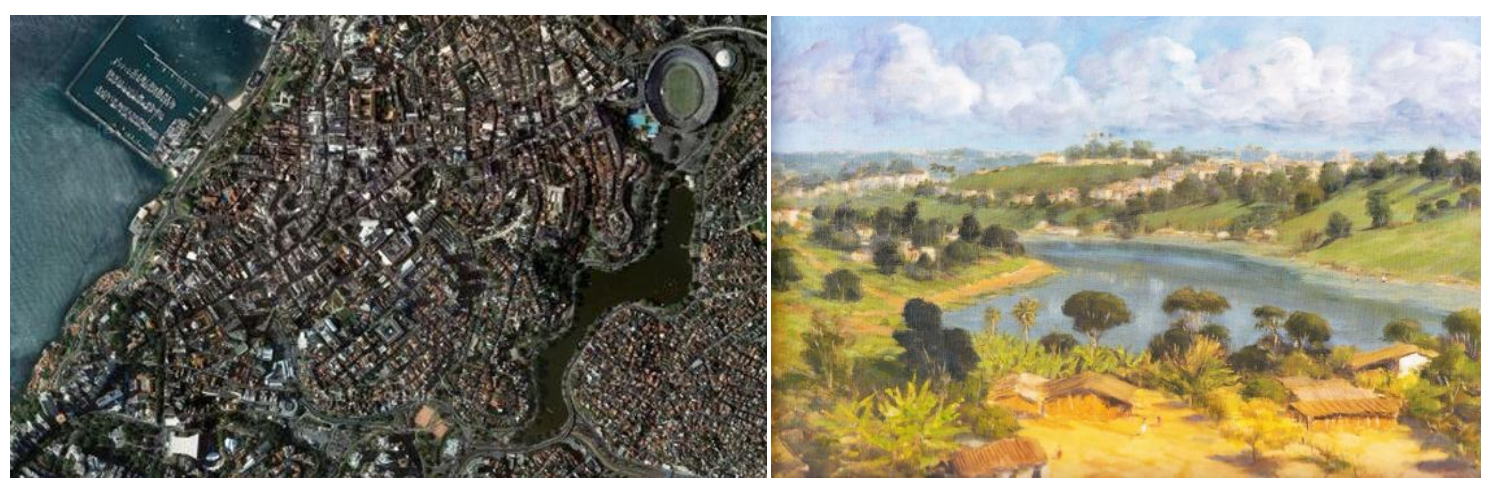

Em fotografia de satélite do Google, mostrando o tamanho atual, e em Rebouças (1996: 207).

\section{Casa de Pólvora dos Aflitos e Morro de São Paulo}

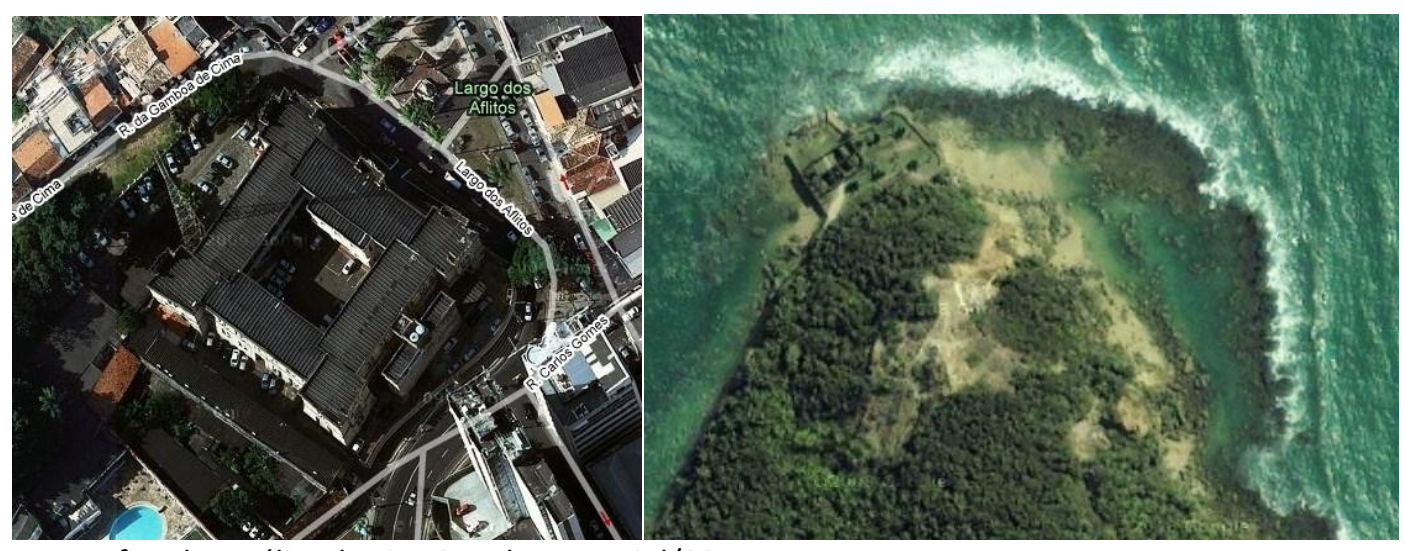

Fotografias de satélite do site Google Maps, jul/09. 


\section{Santo Antônio além do Carmo}
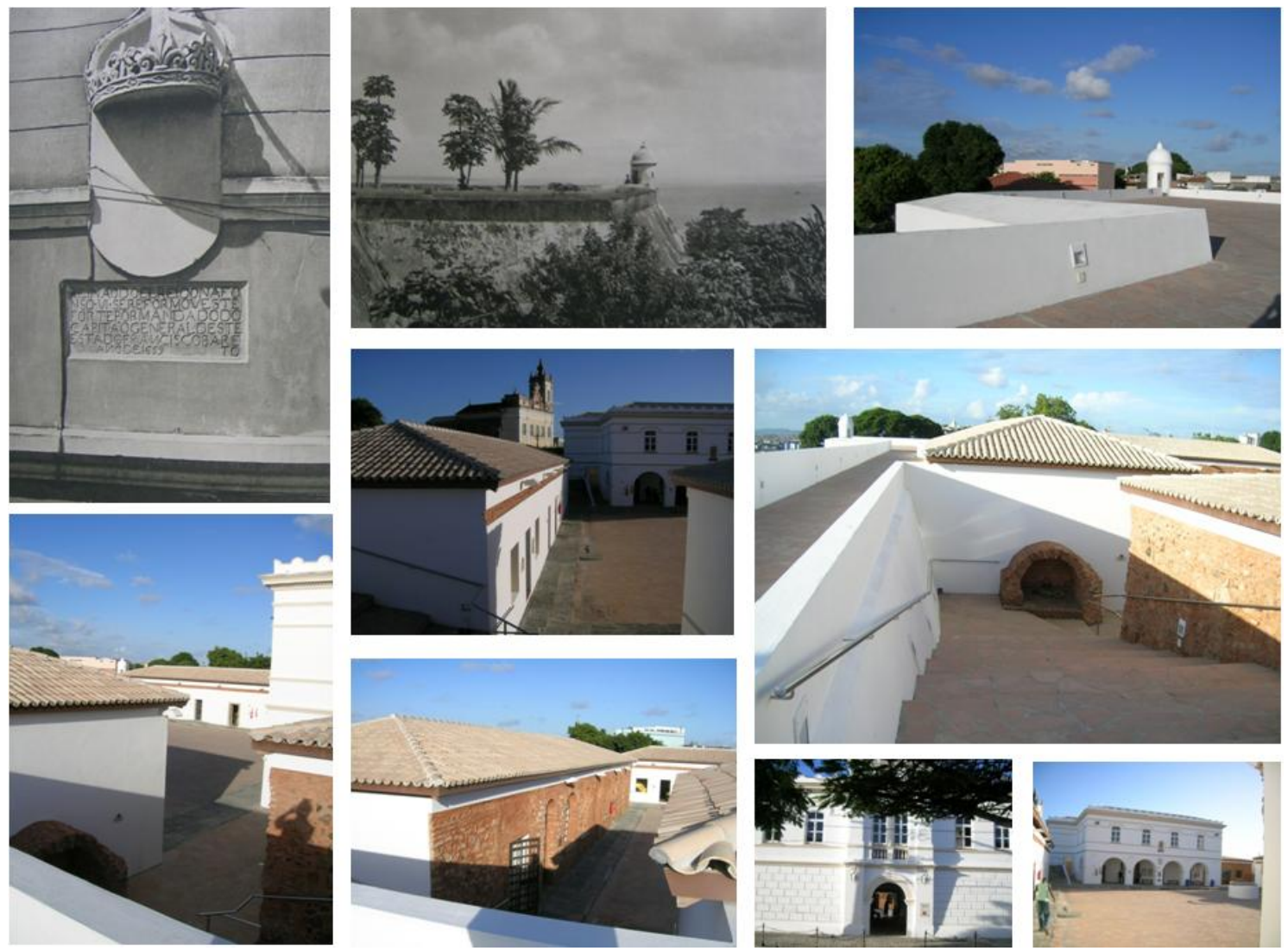

Duas fotografias de Falcão (1949: 37-8) e outras nossas (mar/08).
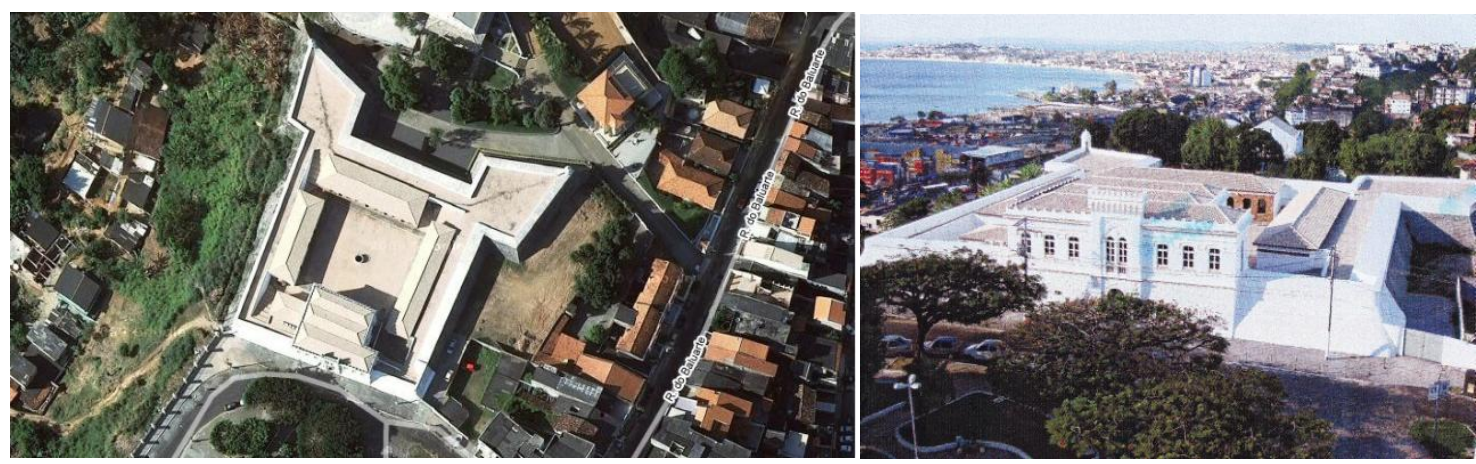

Fotografia do Google (29/07/09) e de folheto distribuído no forte em visita de 2008.

\section{Barbalho}
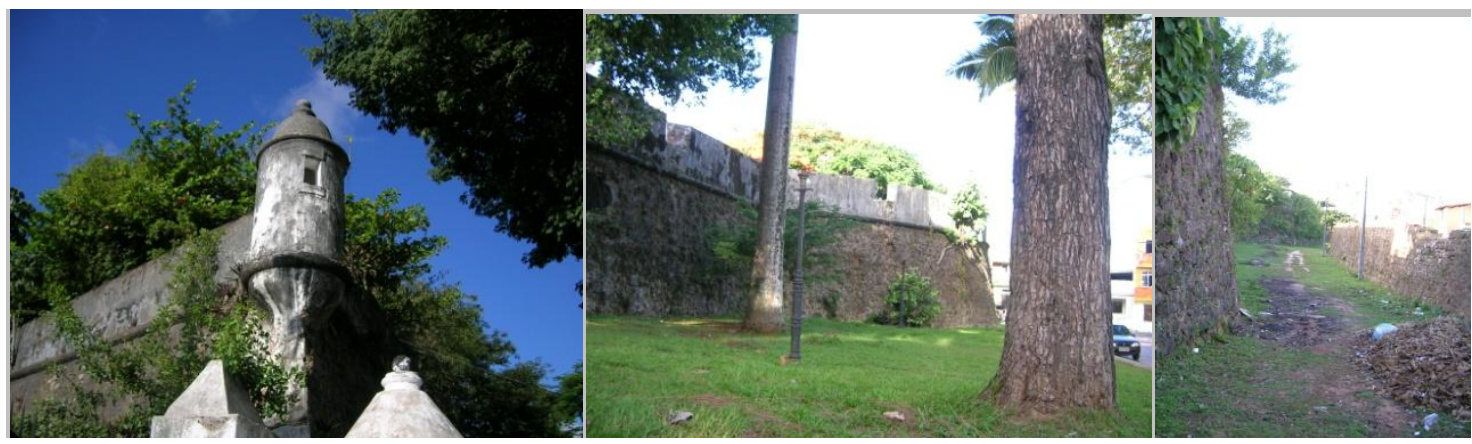

Fotos nossas (mar/08). 


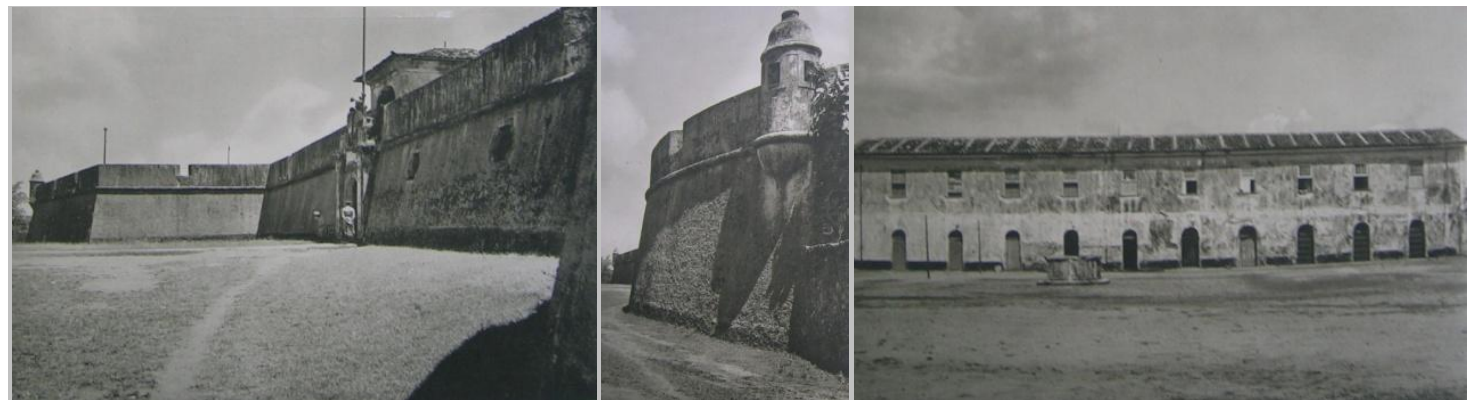

Fotos de Falcão (1949: 39-40 e 43).

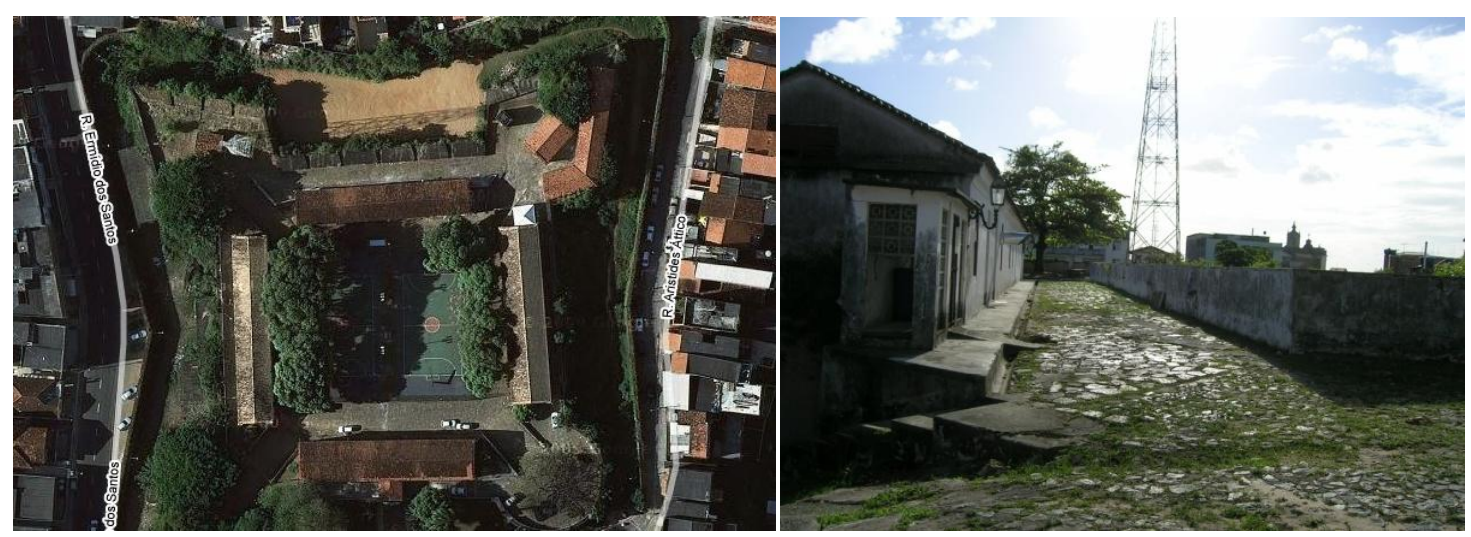

Foto Google (29/07/09) e nossa (mar/08).
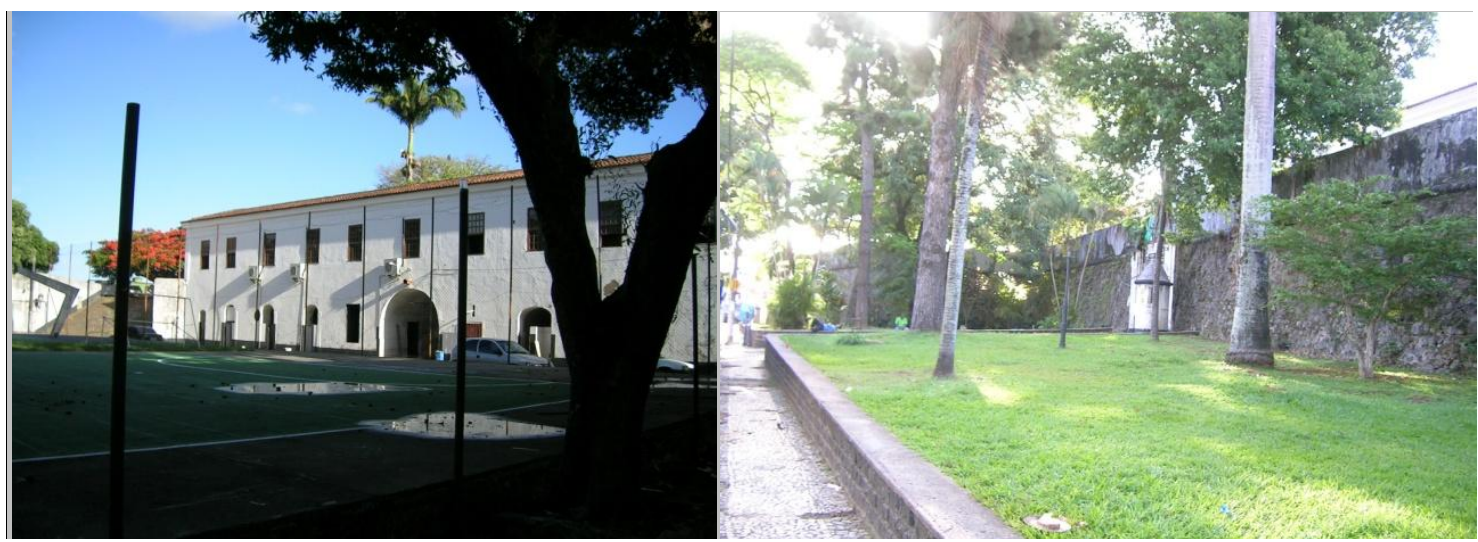

Fotos nossas (mar/08).

\section{São Pedro}

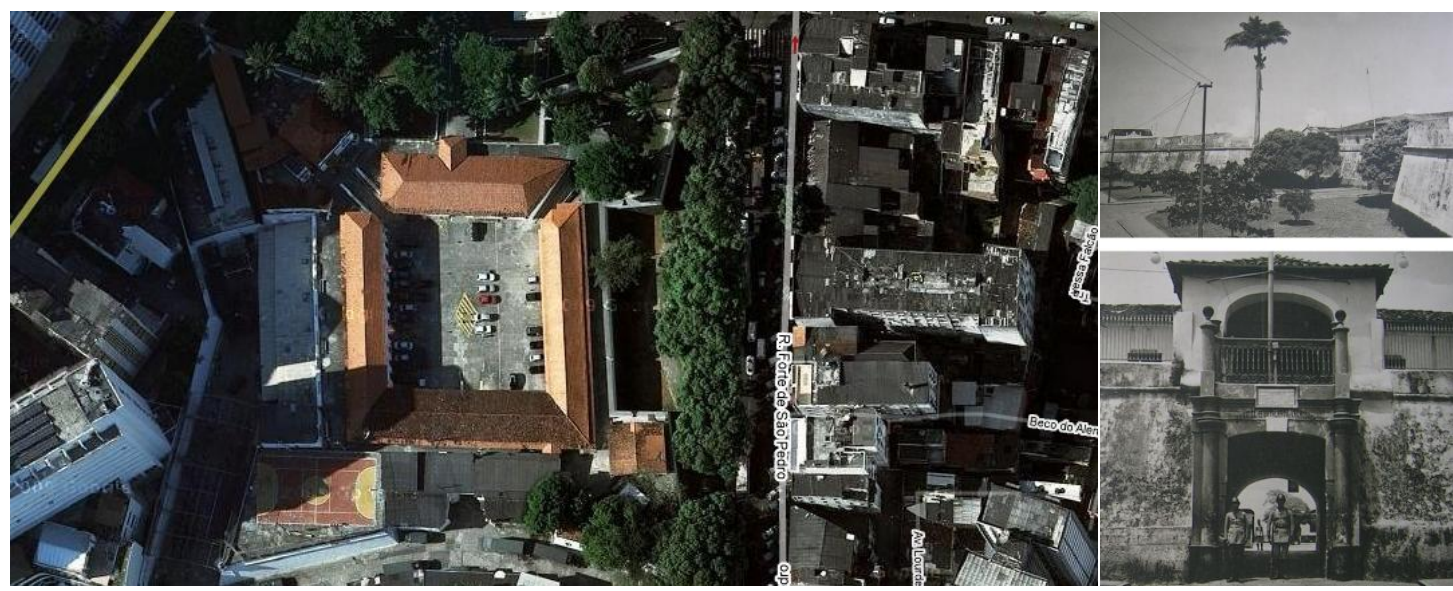

Foto Google (30/07/09) e duas fotos de Falcão (1949: 44-5). 

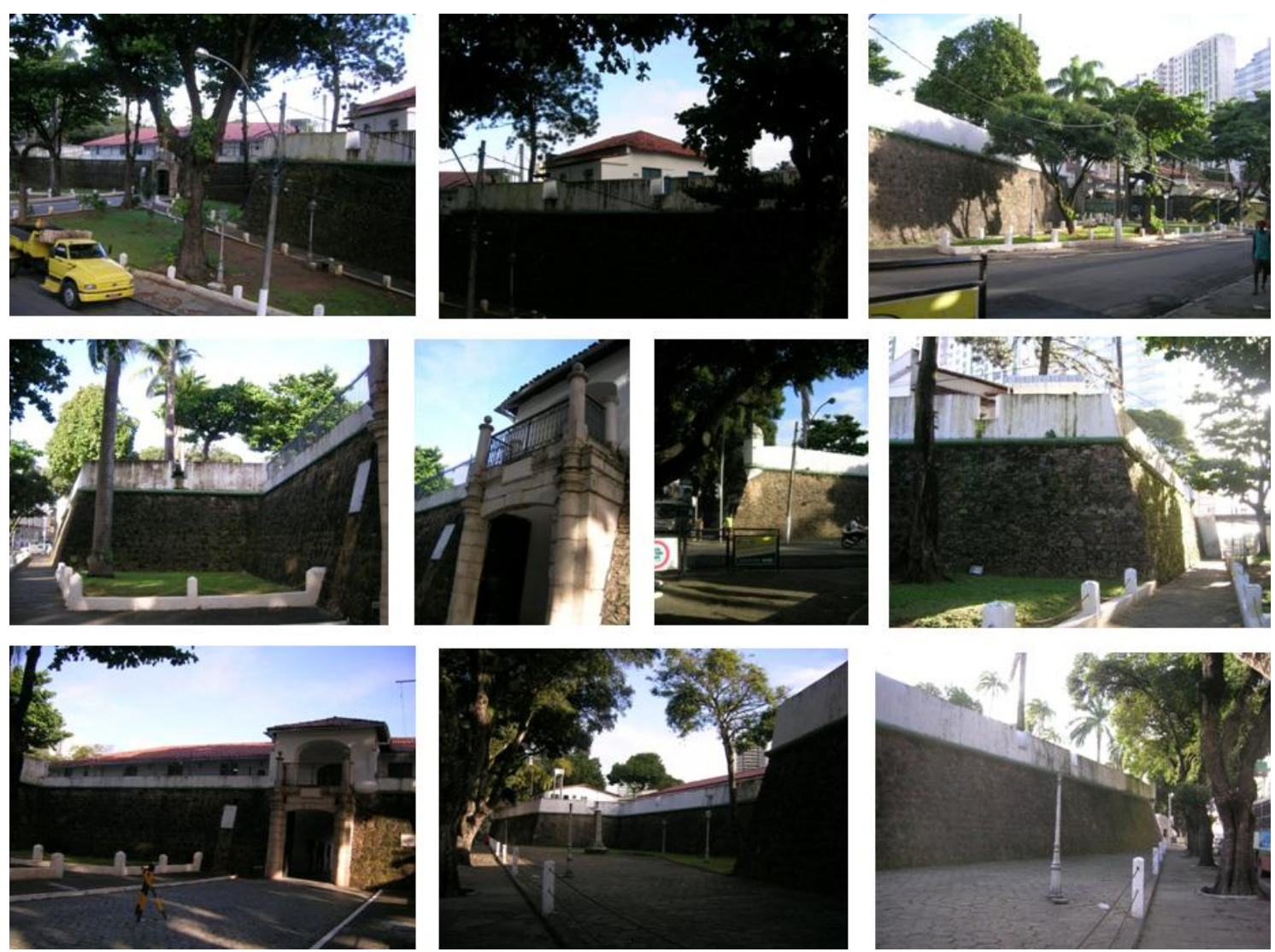

Fotos nossas (jul/08).

\section{Bateria S. Paulo}

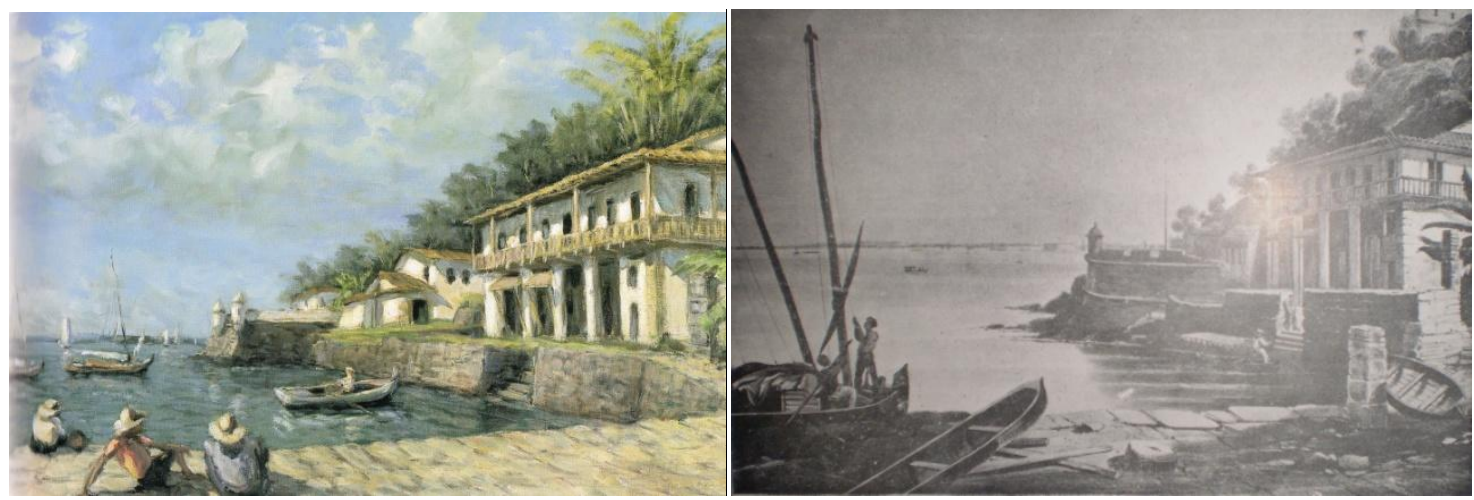

Quadro de Rebouças e fotografia de pintura antiga, s/ ref. (em REQUIÃO, 1953).

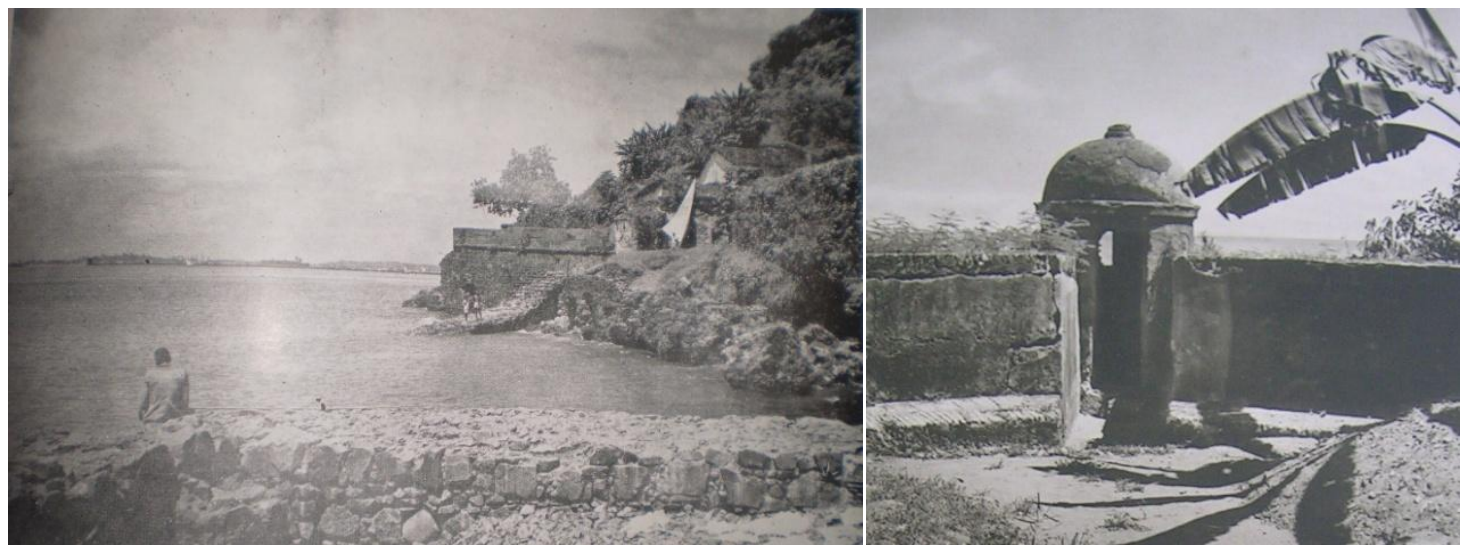

Fotografia antiga, s/ ref. (em REQUIÃO, 1953) e de Falcão (1949: 28). 

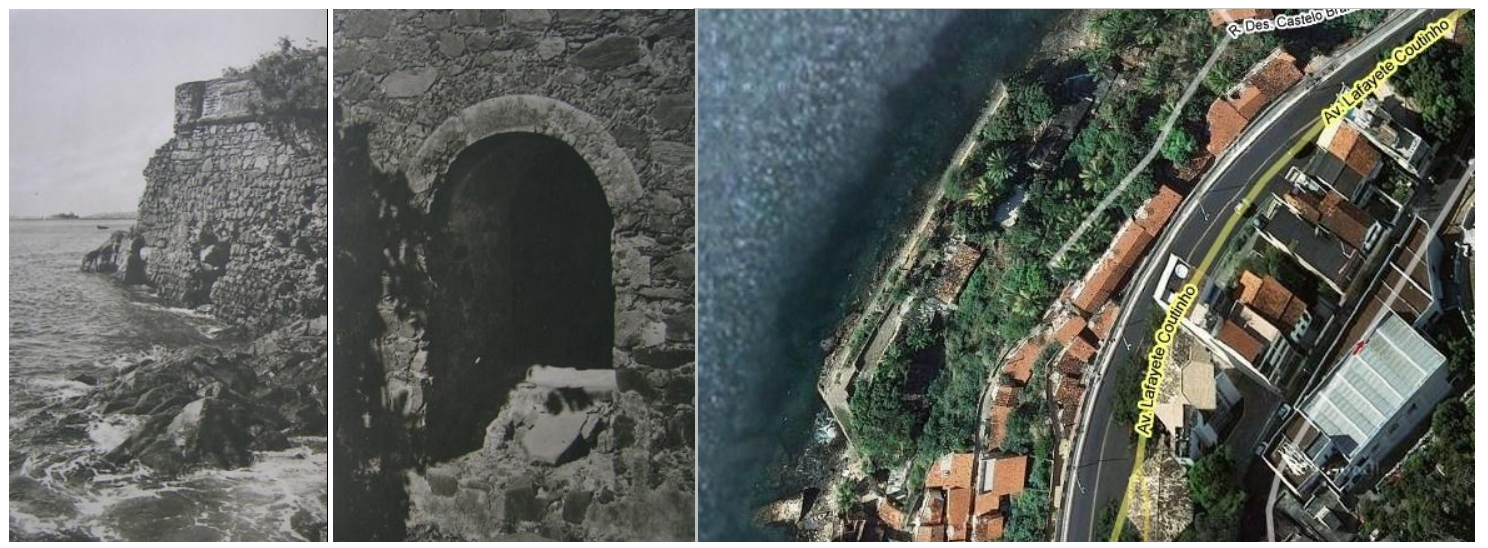

Fotografias de Falcão (1949: 26 e 29) e do Google (30/07/09).

\section{São Lourenço (Itaparica)}

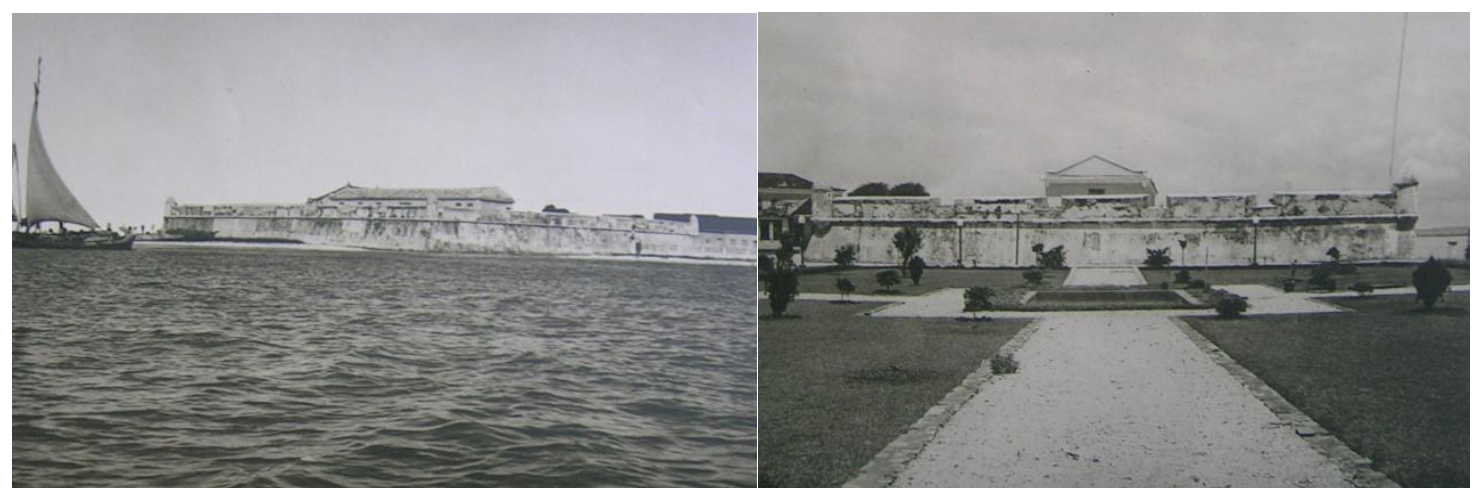

Em Falcão (1949: 430-1).

\section{Santa Cruz do Paraguaçu e Jiquitaia}

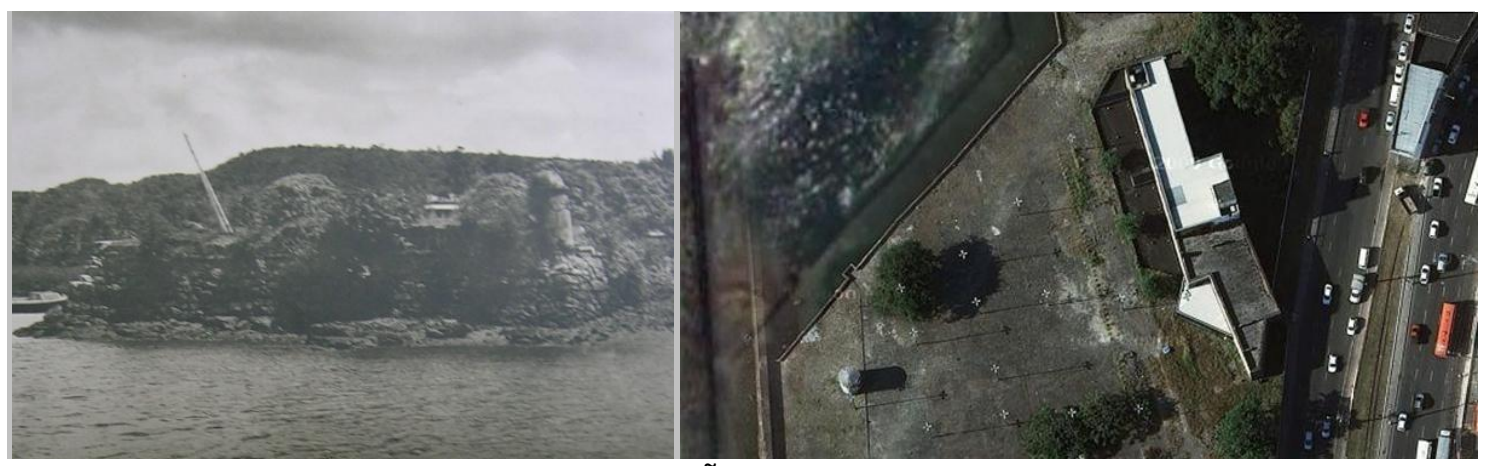

Ruína do forte à beira do rio Paraguaçu (em FALCÃO, 1949: 432) e fotografia do Google (20/08/10).

\section{Casa da Torre}
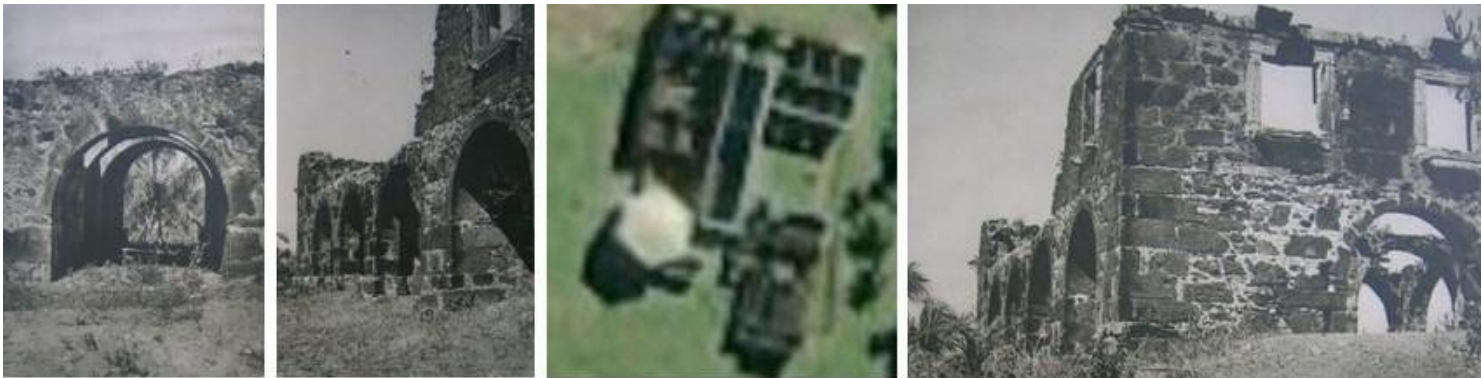

Ruínas fotografadas por E. C. Falcão (1949: 408-17) e por satélite no Google (em 19/08/10, ao centro). 

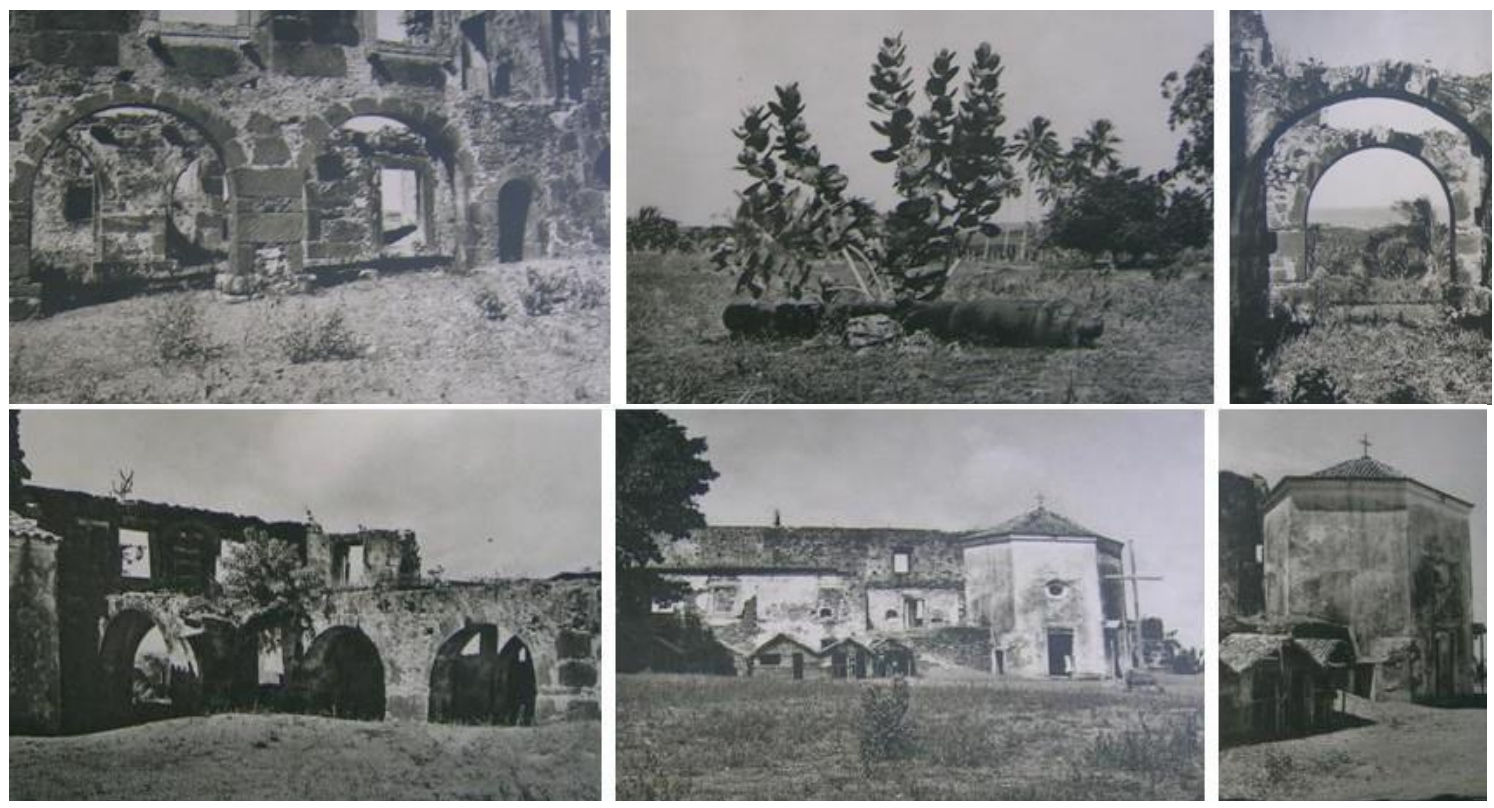

Ruínas fotografadas por E. C. Falcão (1949: 408-17).

\section{Seqüência comparativa das dimensões}
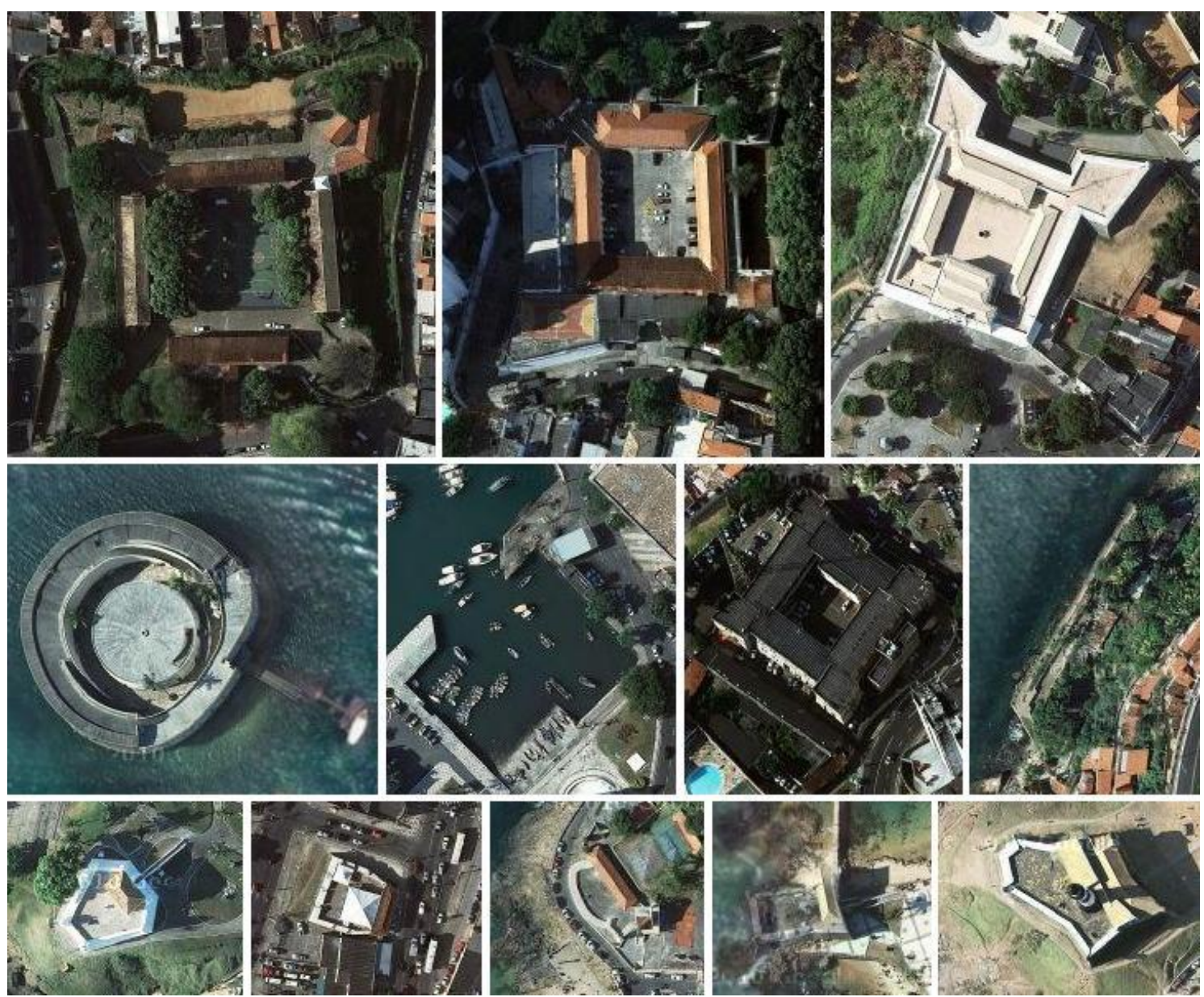

Em mesma escala, os fortes do Barbalho, de S. Pedro, S. Antonio além do Carmo, S. Marcelo, a área da antiga Bateria da Ribeira, a Casa da Pólvora dos Aflitos, a Bateria S. Paulo e os fortes de Monserrate, S. Alberto, S. Diogo, S. Maria e S. Antonio da Barra (em Google, 18/12/10). 
No Brasil, uma proposta urbanística mais erudita começa pela história de Salvador. Hoje se sabe mais das teorias usadas pelos portugueses para construir obras públicas e particulares na Colônia, que no caso especial dessa cidade, eram das mais sofisticadas. Salvador nasceu não apenas de um plano, mas de um desígnio político (e uma política edificatória) cujas raízes doutrinárias se valiam em muito de práticas e teorizações forjadas no chamado Renascimento, mas que se estenderam por toda a época colonial. A cidade que se pensava permanentemente, que recebia diretrizes concretas mediante desenhos, regimentos, relatórios com propostas de melhoria, era aquela que trazia em suas primícias o pré-cogitar, predefinir e prescrever próprios ao designium renascentista. Via de regra sua realidade era outra, permeada de impasses diversos em um contexto sócio-econômico de muitas variáveis.

Pela elaboração de novos planos, o esforço de concepção integral da cidade, em suas diferentes formulações, sempre se impôs em mais de dois séculos, como perspectiva de governo e defesa da cidade de Salvador. Os planos, mesmo quando não executados, eram veículo de orientação para as intervenções, tornando-se importante entendê-los em sua elaboração dentro da história urbana. Há neles aspectos gerais que se repetem, pois no foco das intervenções estavam sempre questões de segurança (por exemplo, era preciso defender o porto, por onde passava a riqueza; ainda na época de Luiz Dias se colocou dois fortes na Ribeira, protegendo-se as extremidades e já se pensando, possivelmente, em cruzar fogos).

Como vimos, os sistemas variaram em função do tamanho da cidade, da evolução técnica e das novas diretrizes políticas. ${ }^{979} \mathrm{Em}$ todos os trabalhos desenvolvidos pelos portugueses existiu uma tensão entre a idealização e sua realização. O chamado "pragmatismo" só pode ser entendido como ferramenta de ajuste, operando em um campo de tensão entre a proposta teórica e realidade prática. ${ }^{980} \mathrm{O}$ conhecimento tratadístico da engenharia militar jamais foi abandonado, ou se mostrou um recurso ineficaz para a melhor ordenação do espaço urbano. Muitas vezes seguido à risca em atenção a aspectos particulares de cada fortificação, ele sobressaiu principalmente quando se pensava o sistema, cujas concepções variaram ao longo do tempo.

Ao menos no âmbito militar (havia também uma tensão entre as visões de cidade dos vários agentes da conquista: militares, religiosos, mercadores), ${ }^{981}$ a cidade

\footnotetext{
${ }^{979}$ Mesmo assim observamos, entre outras coisas, que a idéia de amuralhar todo o recinto não chegou a ser descartada. Ao contrário, foi defendida nas várias épocas em que se pensou a cidade como um todo. No século XVIII, ela foi retrabalhada com uma nova perspectiva de cidadela, de localização mais favorável (mas também determinada pela topografia, como fizemos questão de frisar).

980 Não pela flexibilização da teoria, mas sempre na perspectiva de uma gestão ótima dos recursos.

981 Era diferente, por exemplo, no pensamento de cidade por uma perspectiva religiosa (de ação catequizadora), em que a defesa (segurança) só era considerada prioritária quando se sentia a falta dela. Vimos um exemplo em Salvador quando, nos anos 1550, Nóbrega quis instalar os jesuítas fora da cidade-fortaleza por não se sentir ameaçado pelos índios (que eram papel branco para receber sua doutrina), mas logo no ano seguinte já defendia a catequização por meio temor e sujeição (cf. NÓBREGA, 1988: 88-96, Carta IV, e 103-13, Carta VI). Em outro exemplo, do início do século XVII, o bispo de Salvador que era contra a prioridade que se dava às construções militares, quando veio a invasão quis se redimir e foi o primeiro assumir a liderança na luta armada pela expulsão dos holandeses. Durante essa ocupação, outro jesuíta, o Padre Antonio Vieira, também assumiu uma leitura militarista
} 
foi sempre pensada a partir de planos de fortificação. Pela sua visão integral, com a qual se pensava a urbe e sua defesa, havia uma necessidade permanente de negociação e ajuste do plano.

Para Salvador, ter um plano com diretrizes de intervenção era tão importante quanto ter edificações militares: era a peça chave na administração da urbe. Mesmo nas diretrizes dadas à construção de um forte isoladamente, pressupunha-se a concepção integral de cidade. Sempre se pensava a partir de uma visão de conjunto, ponderando tensões, fragilidades ou qualidades e vantagens de medidas a serem tomadas. É o que se explicitou em cada plano, pela fixação de diretrizes.

Se a fortificação era um componente das atividades urbanas, é certamente por ela que se pensava a urbe de modo integral. Continuamos acreditando ser impossível separar a cidade de sua ordem maior e da dinâmica, conceber as fortificações sem que estivessem integradas à definição dos arruamentos, da praça e do porto. Isso é o que a fez pedir sempre, quando se tornou objeto de estudo em resposta às novas tecnologias de guerra, um projeto integral. ${ }^{982} \mathrm{~A}$ ideação da cidade é peça chave para entender o modo como os engenheiros pensaram a fortificação da cidade nos séculos XVI, XVII e XVIII. ${ }^{983}$ Na cidade pensada, sempre com um sentido de coesão, inexistia a realidade espontânea; para além dela restava o imprevisível, o conflito e a negociação.

Ao longo deste estudo procuramos mostrar que a constituição do profissional da Engenharia Militar em Portugal, fortificador e projetista das principais vilas e cidades brasileiras na época colonial, atravessou fases e características relacionadas à história portuguesa de consolidação do Reino, expansão ultramarina e manutenção das conquistas. ${ }^{984}$ Os estudos de Beatriz Bueno (Desenho e Desígnio: o Brasil dos engenheiros militares), complementando os de Nestor Goulart, Rafael Moreira e outros, já falam da boa capacitação profissional dos engenheiros que atuaram no Brasil, relacionando-a a um grande desenvolvimento no conhecimento teórico português e estando claro que nas obras e projetos desenvolvidos para a defesa de Salvador "a teoria orientava a prática" ${ }^{985}$ Depois da disseminação no século XVI do uso

da situação (cf. HANSEN 2003: 77-117 - Carta Ânua ao geral da Companhia de Jesus, de 30 de setembro de 1626; a narrativa da guerra está entre as páginas 82-103).

982 O Plano é o que mostra a articulação das fortificações com a praça, muralha, porto, caracterizando uma cidade integral. Determina (esclarece) uma situação ideal de defesa - os parâmetros de intervenções efetivas, em que a visão integral sempre se impõe. Por isso, todos os governadores quiseram ter o seu.

983 Lembrando que no XVIII o plano também seria veículo de constituição e otimização de uma rede de cidades, em larga escala territorial.

984 Logo no começo, procuramos as raízes dessa especialização, mostrando o reconhecimento da Arquitetura como exercício intelectual em épocas renascentistas, quando ainda era relacionada a outras artes do desenho (pintura e escultura). Vimos que antes da especialização do engenheiro militar, grandes artistas da humanidade desenharam fortificações, como Michelangelo, chamado a defender Florença das ameaças de Carlos V, e Leonardo, que produziu algumas volumetrias de fortalezas em seus cadernos (artistas que, embora não haja parâmetros estáveis de comparação, são considerados por muitos os maiores de todos os tempos).

985 É parte do conteúdo dos tratados de fortificação o ensinamento que, a nosso ver, mais representa o tipo de arquitetura e articulação urbana desenvolvido nos principais núcleos do Brasil (os que contaram com a atuação de engenheiros militares - pela presença do Estado português - em suas obras e no planejamento) no período colonial: o de que toda técnica, ou preceito, deve antes passar pelo crivo do 
do baluarte (o elemento moderno da arquitetura militar, substituindo os torreões quadrados das muralhas medievais), no XVII a fortificação se desenvolveu como ciência apoiada principalmente na matemática: buscava-se alcançar para a defesa o melhor ângulo do baluarte, o melhor dimensionamento de suas várias partes, a interligação mais funcional com a cortina. Da variação geométrica dessas relações viriam os diferentes métodos usados para a melhoria defensiva, caracterizando os diversos tratados de fortificação.

Desde a Escola Particular de Moços Fidalgos do Paço da Ribeira, para a qual foram produzidos os tratados de Antônio Rodrigues, passando pela Aula de Architectura do Paço, ${ }^{986}$ começada na época de Terzi, até chegar à Aula de Fortificação e Arquitectura Militar da Ribeira das Naus, fundada por Luís Serrão Pimentel e que oficializou o título de Engenheiro Militar, os horizontes da profissão se ampliaram, de modo a constituir um verdadeiro corpus disciplinar. Os tratados com teorias de fortificação proliferaram principalmente no século XVII, quando o maior desenvolvimento das armas de fogo fez reformular os sistemas de defesa das cidades, tornando a Architectura militar uma ciência (como a preferiu chamar Adam Fritach) ou arte (na preferência de Mathias Dogen). ${ }^{987}$ Em Portugal, é no tratado de Serrão Pimentel que o paralelismo entre cidade e fortificação se oficializa e é teorizado, por um Methodo de fortificação que estabelece regras de urbanismo.

Em Salvador, desde o seu traçado em solo, passando pelas várias fases em que recebeu projetos de atualização da sua capacidade de defesa (organizando também as funções administrativas e principalmente tornando compreensível a lógica de sua espacialidade), é nítida a relação que se estabeleceu entre urbe e fortificação. Durante o pouco mais de dois séculos em que foi capital, fortificou-se de diferentes maneiras, mas havia entre elas um denominador comum: a integração inequívoca entre o seu sistema fortificado e as demais modalidades de ordenação urbana, obedecendo-se, em cada período, a diretrizes gerais de uma concepção unificada. Em função das localizações de cada unidade, o conjunto de fortificações era a grande marca da cidade, influenciando diretamente nas formas de organização urbana e estruturação do território.

Vários estudos mostram que a cidade teve períodos de características urbanas específicas, aos quais correspondem fases, também identificáveis, da Arquitetura Militar. A segunda metade do século XVI representa o impulso inicial de uma cidade de fortificações provisórias e próximas à sede administrativa. Na passagem para o século XVII começou-se a instalar um sistema mais complexo e de área mais ampla, que passaria por um primeiro e único teste: a guerra dos holandeses. Na segunda metade

profissional experiente. Essa idéia está declarada em essência no Tratado de Arquitetura de Vitrúvio, já tendo sido expressa, provavelmente (como a maior parte do conteúdo do livro romano), pelos gregos.

${ }^{986}$ Que formou, além de grandes arquitetos, os principais engenheiros militares que atuaram no Brasil na primeira metade do século XVII: Francisco de Frias da Mesquita (vindo em 1603 e nomeado 2ㅇo ou 3으 engenheiro-mor local por volta de 1616), Diogo Paes (3o ou 4을 engenheiro-mor do Brasil por volta de 1635) e João Nunes Tinoco (de atuação em Pernambuco).

987 Como diz Pimentel no início de sua Summaria Noticia (Methodo lusitanico..., 1680). Atentando especificamente aos edifícios militares, viu-se que nos séculos XVII e XVIII Portugal passou a ter também influência de outras escolas de fortificação, em especial a holandesa e a francesa. Mas deve-se considerar que todas elas são aparentadas (incluindo-se uma possível escola portuguesa, expressa em seus tratadistas mais famosos, Serrão Pimentel e Azevedo Fortes), descendendo da escola italiana que criou o front melhorado. 
daquele século o sistema seria ampliado e aperfeiçoado, paralelamente ao aprofundamento teórico especialmente com Serrão Pimentel, das relações entre arquitetura militar e urbanismo.

Vimos pelo Regimento de D. João III que antes de Salvador ser fundada havia suas traças. Embora o desenho de Miguel de Arruda tenha desaparecido, há consenso de que ele tinha pleno conhecimento das novas divisas teóricas e da práxis da arquitetura afirmada com o Renascimento. Era uma cidade concebida como um todo, com seu plano traçado mostrando uma visão de conjunto. ${ }^{988}$ Nele se previa um sistema abaluartado que teria, junto à muralha, portas fortificadas, quadras geométricas e praça principal para edifícios mais importantes.

Havia também uma amostra, o que já se pensou se tratar de um modelo em miniatura e hoje se entende como uma representação gráfica combinando planta e elevação, o que de qualquer modo reforça essa visão do todo e de cidade coesa. Antes da implantação foi feito o estudo do lugar (com Tomé de Souza e Luiz Dias), avaliandose logo a adaptação necessária do modelo desenhado. É bem provável que as modificações ocorridas na sua reprodução em solo tenham sido substanciais, já que por questões defensivas se decidiu pelo ponto mais alto da encosta.

O conceito de baluartes em pontas de lança (como aparecem nas gravuras do século XVII, supondo-se que fossem assim já na fundação, em número de quatro) mostra que se seguia uma nova concepção dentro da tradição urbana portuguesa, já bem distante da cidade medieval. O aspecto prévio, a construção calcada em projeto caracterizava um novo entendimento de urbe. Mesmo que fundações coloniais com diretrizes de traçado existissem desde a Antiguidade (com gregos, romanos e outros), o que se diferenciava em Salvador era essa visão integral de cidade, vinculando a forma a um modo de urbanidade, de decoro, de "polícia", próprio à ordem civil.

A simples existência da traça (planta) e da amostra (especificações) representava uma atitude renascentista de projeto, derivada dos tratados italianos, que sustentava o empreendimento português em Salvador. ${ }^{989}$ Eles antecipavam o conjunto de elementos que dariam unidade à urbe (no planejamento de quadras, praça principal, amuralhamento, localização de portas e sistema de baluartes). Como parte dessa concepção unitária, que obriga a pensar um conjunto de elementos, podese cogitar a existência de modelos de referência para os principais edifícios da cidade, mas não há referências disso. ${ }^{990} \mathrm{O}$ que estaria representado pelo artifício do desenho

\footnotetext{
988 O "todo articulado" como soma harmoniosa das partes, refletindo a concepção integral de cidade a partir de uma visão unitária, pré-estabelecida.

${ }^{989}$ Há muitos elementos mostrando na concepção de Salvador uma influência decisiva do conhecimento tratadístico primeiramente desenvolvido na Itália. Como vimos, o reinado de D. João III, que deu início à colonização do Brasil, se caracterizava pela aproximação do gosto palaciano por esse tipo de método. Principalmente Vitrúvio, mas também Alberti, Francisco di Giorgio e Düher despertaram grande interesse nos intelectuais portugueses.

990 Mesmo nas condições arredias de sobrevivência da fase inicial, haveria critérios de associação entre o planejamento e a arquitetura dos edifícios, principalmente na substituição dos de taipa pelos de pedra e cal, feita algumas décadas depois. Em relação às outras artes do desenho, pintura e escultura, em menos de dez anos já havia uma arte sacra "ao romano" na igreja jesuítica e na capela particular da Casa da Torre (inclusive sua arquitetura).
} 
era principalmente a definição de uma idéia, o traçado e a orientação em relação ao porto próximo, em acordo com a tradição portuguesa.

É importante assinalar que pouco depois de se anunciar na Europa, com o Renascimento, uma nova concepção de cidade, em Salvador ela tomava corpo, mesmo que se articulando a um novo paradigma de condições sociais e econômicas. 0 processo em que a cidade foi fundada seguiu, no Brasil, o melhor exemplo de estratégia urbanística dentro de uma concepção plena de urbe, principalmente por se tratar de um recinto fortificado. Como em todo o território aqui conquistado, a fortificação teve um papel chave.

O mesmo fenômeno vai se verificar nos projetos de ampliação da área fortificada, com exemplo na cidadela desenhada no início do século XVII (como parte do plano que teria participação do italiano Tibúrcio Spanoqui): há uma nova proposta para a cidade, mas visando ainda abraçar todo o conjunto. A concepção de cidade como um todo não se perdeu de vista com o crescimento urbano, nem o sentido de coesão, o que se mostra principalmente pelo sistema fortificado. Essa primeira imagem (que no Livro que dá Razão de Diogo Moreno afirma se tratar de projeto) é a prova material de que se pensava em um novo traçado, alterando-se as muralhas da parte que serviria de cidadela.

A muralha ampliada, que supomos ser do final do século XVI, passou a ser ainda mais orgânica. ${ }^{991}$ Esse segundo momento prepara a passagem para uma nova concepção de cidade, articulando-se a um sistema de fortes que compunha a rede de defesas. ${ }^{992}$ Essa transformação, em que a cidade deixa de ser fechada e estabelece uma nova relação com o território (apoiada em seu sistema de fortificações), foi acompanhada de uma evolução no campo da teoria. Se a cidade em sua fase original (anos 1550) era integrada e coordenada, pois tinha um projeto, logo na primeira fase de crescimento foi elaborado o plano de expansão, em que não se perderia a idéia de cidade una.

\footnotetext{
991 Entendemos que as portas dos anos 1590, que aparecem nas duas gravuras de Albernaz (1605 e 1631) não eram construções transitórias. Não é improvável, em nossa interpretação, que o traçado da nova muralha tenha sido acompanhado por Baccio di Filicaia, que neste caso teria também supervisionado a reconstrução das portas. O sistema abaluartado apresenta uma fortificação de visão abrangente, compreensiva de todo o espaço urbano. É importante destacar que a idéia da segunda muralha (eventualmente envolvendo algumas novas áreas, como a franciscana) não desqualifica o primeiro traçado, havendo uma permanente perspectiva de que a cidade pedia (precisava de) uma fortificação integral. Do segundo projeto, com ênfase na cidadela, pode-se pensar em um diálogo com a situação primeira. Havia sempre uma perspectiva colocada, que no plano de 1605 ela era de segurar invasões, mostrando muralhas que mesmo não sendo construídas (embora as gravuras digam o contrário) respondiam a essa expectativa. Tudo indica que a visão de conjunto embasava cada decisão.

992 Salvador era reflexo no Brasil do longo processo ocorrido na Europa de substituição da cidade murada por aquela defendida com um sistema articulado de fortificações em pontos estratégicos. Era um processo acompanhado da superação da condição urbana como unidade isolada (incapaz, em caso de guerra, de se defender com uma simples muralha de armas cada vez mais poderosas), passando a fazer parte de um amplo território político. No fundo, a tecnologia de guerra libertou a cidade de suas muralhas.

Assim, em toda a época colonial, os modelos de urbanização de Salvador acabaram se apoiando em seus sistemas de fortes. Se no começo a preocupação era defender o território imediatamente à volta, junto com o crescimento da malha urbana veio a ampliação das áreas de domínio e influência econômica. Também o sistema fortificado, sujeito às melhorias técnicas de cada período, passava a abranger áreas cada vez maiores, preocupando-se também em defender os acessos entre elas.
} 
Ao terminar o período espanhol, com a Restauração em Portugal e o fim dos assédios holandeses, a cidade passou por uma nova fase. Nela se confirmaria o modelo de articulação entre a cidade murada e o seu sistema de fortes. Logo no começo dos anos 1640 foram iniciados os trabalhos de fortificação de uma nova linha demarcatória para o perímetro urbano de Salvador, já bem mais ampla do que aquela traçada no Plano de 1605. Os registros não indicam que se quisesse construir uma muralha contínua, mas sim combinar trincheiras, fossos, torreões e baluartes para configurar o novo perímetro fortificado (que estaria também defendido por uma nova área alagada, bem mais ampla que a do primeiro dique). Todo esse planejamento tinha a base teórica dos tratados produzidos para as Aulas de Engenharia Militar, sendo contemporâneo à organização em Portugal da Aula da Fortificação... da Ribeira das Naus (1647). ${ }^{993}$

O planejamento com base nos tratados foi expresso nos relatórios das épocas seguintes. O de João Coutinho (1685), principal plano do século XVII, seria rediscutido e em alguns pontos colocado em prática na primeira metade do XVIII, sendo especialmente aproveitado em reformulações urbanas (com destaque para as áreas de porto) e na construção de novos fortes (estes também com as bases teóricas expressas nos tratados de Arquitetura Militar) e redutos articulados em defesa do perímetro, que eram, nessa condição, estruturadores no contínuo processo de expansão da malha urbana.

Deste modo se consumava no século XVIII (em continuidade ao trabalho feito no XVII) a idéia presente e ensaiada desde a fundação da cidade, quando se construíram os primeiros redutos: a de uma articulação integral da cidade, vinculando praças, edifícios públicos, religiosos, o porto, etc., mediante um rigoroso traçado que tinha no sistema defensivo sua condicionante principal. No século XVIII foi possível construir grande parte do que estava definido nos anos 1680 (pela proposta de João Coutinho), concluindo-se em alvenaria (sem mais o caráter provisório das de terra) fortificações já iniciadas havia longa data. A partir daí, as principais resistiram ao tempo, no geral em boas condições.

\footnotetext{
993 A organização pela articulação de todo o espaço urbano a partir das fortificações se mostra em um elenco de preocupações e medidas que avançariam no século XVII. Foi quando Salvador ganhou o seu plano integral, um sistema cuidadosamente elaborado de fortificações como produto de revisões e ampla discussão teórica. A cidade foi rigorosamente pensada como um todo: a estrutura urbana abraçada por uma segunda linha de muralha e torreões mostrava a sua articulação integral, que era incipiente até o início daquele século, e ao final dele tomava nova dimensão.

Os projetos visando a defesa e manutenção da cidade mostram um ideal português apoiado nos muitos preceitos teóricos da Arquitetura Militar, de conteúdos tratados nas Aulas de Fortificação. Esses preceitos não só estão por trás de todas as fortificações de Salvador, como podem ser verificados no tipo de "fechamento" da cidade com uma nova cerca abaluartada que dá conta (ao menos em projeto) de toda a malha urbana. Como parte desse fechamento, envolvendo um território maior, foi construído o novo dique, também abraçando a cidade. No mar, uma nova série de fortes procurava anular todas as possibilidades de assédio. Por trás de tudo estava o conhecimento dos tratados de fortificação: a cidadefortaleza era um sistema sofisticado em termos de Arquitetura Militar, feito a partir de uma também sofisticada elaboração em desenho. Àquela altura os portugueses já se apropriavam do que era mais importante em conhecimentos e regras de Arquitetura Militar dos italianos, holandeses e franceses, o que se materializaria na construção de fortes com novos desenhos.

Além de responder às variações tecnológicas, em todos os períodos se tirou partido do que havia de mais avançado na tratadística. Em todos eles se deu prioridade (como estaria prescrito nos tratados de Serrão Pimentel e Azevedo Fortes) à proteção da área administrativa, correspondendo sempre à parte mais antiga, desenhada em Lisboa e construída por Luiz Dias.
} 
ANEXOS

\section{Cartas de Luís Dias}

A Miguel de Arruda $(13 / 07 / 1551)^{994}$

Pera o senhor Miguel d' Arruda - meu senhor

No galeão ia o malogrado do Diogo Peres e levava as mostras como as mandou pedir e para ele informar V. M. [Vossa Mercê] do que fosse necessario, e com isto levava alguma pouca [quantia] por que razão que eu cá pude apanhar emprestado ainda, porque de el-Rei do soldo digo um só cetil [moeda velha sem valor, tostão] me deram nem pagaram, nem ai de quem mo pagar, por o que vem do Reino é ferro velho como o que se vende na feira em Lisboa, e com isto se paga a pobre gente que cá trabalha, que os rendimentos do Brasil com que cá nos mandavam pagar é tudo burlaria, porque não há aí com que se pague meio ordenado dum destes senhores. Eu mandava uma certidão do agravo que cá fizeram em me tirarem o mantimento e dois meses que vim pelo mar e em não me passarem certidão do que me deviam. Agora irá, se Deus quiser. Peço-lhe muito pelo amor de Deus, porque o meu soldo é de pedreiro e não é ordenado de ofício que Sua Alteza me desse, e perdoe Deus a Manuel de Moura [escrivão da vedoria da Fazenda] que o foi pôr na minha carta ordenado. Eu espero em Deus que V. M., dando-lhe Deus saúde, me fará emendar isto; e sendo caso que el-Rei me não queira passar alvará para que me paguem lá tudo o que me deverem e com alvará, que me paguem em Pernambuco, porque ali há renda se a haja no Brasil e o melhor açúcar que cá há; e far-me-á nisto mui grande mercê.

A nau de Diogo Peres teria naufragado com as mostras (desenhos encomendados por Miguel de Arruda) e o pouco dinheiro que ele enviava (conseguido de empréstimo, pois o soldo - que não vinha - era bem menor no Brasil em relação a Portugal). Também ia uma queixa por escrito (certidão) por não ter sido paga a despesa de mantimento nos dois meses na travessia de ida, solicitando esse reconhecimento (em certidão) e reclamando do salário (de pedreiro, quando seu ofício era maior), alegando haver renda do açúcar em Pernambuco.

Esta carta e estas amostras vão neste navio pela via dos Ilhéus, e quando tivermos outro navio irá a segunda via. Em quantos navios de cada partirem até quarta via hei de mandar amostras para ver se chegarão lá alguma, porque este ano de 50 se perderam 5 ou 6 navios com os que tomaram os Franceses, porque [foi to]mada uma vaneta dos Franceses [...] peis e agora vai aí esta amostra [que cá mandou to]mar Pero de Góis com um astrólogo que [...] que se chama Filipe Guilén. A minha am [ostra...] vai monteada e a Ribeira quão mais baixa [está do] que o assento da cidade nos lugares que me pareceu necessário. [Assim] donde a água pode tornar para a mais baixa que o andar da cidade dezesseis braças e meia, tirando-as de vinte e sete e duas terças que é o que jaz mais baixa a Ribeira do mar que o andar da dita cidade. Verá que Ihe ficam se seda [assento] pera moinhos ou engenhos de açúcar ficam dez braças e meia e duas [ter]cãs que é a menor que daqui há de nenhum engenheo, porque a maior [é] de sete braças.

Mandava a carta e as amostras (modelos em desenho) pelo navio que ia a Ilhéus (mandaria até quatro vias se houvesse outros, já que a cada dez naus uma era tomada pelos franceses). A amostra ia "monteada", estando a ribeira bem abaixo do local que achou adequado (a cidade variaria em altura entre 16,5 e 27,7 braças acima do nível do mar, havendo boas áreas para moinhos e engenhos de açúcar a 10,5 braças, que estariam então entre 0,7 e 7).

994 ANTT, Corpo Cronológico, Parte I, maço 86, doc. 87 - apud BUENO, 2001: 137-41. Lacunas preenchidas, ortografia e pontuação atualizadas para melhor compreensão (grifos nossos em negrito). 
Assim leva monteados dois vales pequenos que estão dentro da cidade e no maior deles fizemos um poço muito grande de 20 palmos de vão e tem no Verão 6 palmos de água muito excelente e 9 de corda. E na mostra vão escritas as casas que são feitas [;] e tem cada chão dos que estão povoados 8 casas, e o que menos tem dão 6 casas; e são as 10 de taiparia, que as outras são de parede de mão e de madeira de barro e feno. Vai a amostra o melhor que eu entendi e $V$. M. a manda retirar pera a ver el-rei. Muitas casas se podem fazer nestas ladeiras, se isto houver de ir avante. E nela verá de banda do mar, digo da Ribeira do Góis uma estância de madeira, digo fez Pero de Góis porque Ihe disse o Governador que pusesse o seu trabalho e o da sua gente e que se chamaria o Baluarte de Góis, e ele e eu fomos cortar a madeira de mangue muito poderosa e que não apodrece debaixo da água; é sobre esses penedos, como verá na amostra. E no outro cabo da ribeira fizemos outra estância que se chama Santa Cruz; as quais têm muitas artilharias grossas.

A amostra representava os dois vales pequenos (no maior se fez um poço de excelente água), e no desenho (mostra), ${ }^{995}$ as quadras de 8 e 6 casas (10 já taipadas, sendo as outras de pau-a-pique). Diz ter feito a amostra o melhor que pôde (recomenda mostrá-la ao Rei) e que tudo dando certo seria possível construir muitas casas nas ladeiras. Pero de Góis fez na praia (Ribeira do Góis), a mando do governador, o Baluarte de Góis (eles dois cortaram da boa madeira de mangue, forte e resistente à água), sobre as pedras (como se verá na amostra). Do outro lado fizeram a estância de Santa Cruz, as duas bem artilhadas.

Já tenho escrito a V. M. como no ano de 50 em quarta-feira a derradeira oitava de Páscoa começaram as taiparias que então acabávamos de fazer, de cair da Porta de Santa Catarina até a estância sobre o mar, que se agora chama de São Jorge, e logo no baluarte de São Tiago até a estância de São Tomé. E até o cunhal e para baixo [...] muito pouco dela se aprovei[tou porque foi...] para nenhuma ficar de pé. Porque foi o mais [forte temporal] e tormenta que nunca nesta terra se viu ${ }^{996}$ e o seg[uimento foram...] muito recentes. Pelo qual 6 oficiais que as tinh[am andam per]didos porque houveram entre todos seis, perdas de se[ssen]ta mil réis. E a culpa que aí eles têm e [minha cons]ciência é que foram mal taipadas e muito [mal reboca]das de riba e de baixo, que não andavam senão [... e] eu com um dardo que trazia na mão as desmanchava [em alguns] lugares, que me não podia valer com eles. E o senhor Governador [por ou]tra parte andava que nunca [al] fazia senão pelejar pe[lo que] lhe eu dizia, até tomar um escrivão fazer-Ihe requerimento que a reparassem por baixo e por riba. Assim que agora andam os pobres homens pagando. Parecia-me a mim que, se lhe a V. M. parecesse bem, por amor de Deus falasse uma fala ${ }^{997}$ a el-Rei que lhos quitassem e lhes pagassem o tempo que cá têm servido por o virem servir tão longe e os enganarem com tais pagamentos, e que haviam de dar de comer, e dão-lhe um pouco de farinha de pau com um pouco de vinagre e azeite e sem outra carne nem peixe. Isto assim me valha a verdade como é verdade. E toda a taiparia que tínhamos recebida por Sua Alteza não caiu dela 30 braças por 130 mil reais, que acima digo não custariam 30 mil reais em Portugal a Sua Alteza.

Refere-se à carta de um ano antes, quando acabavam de fazer as taiparias que iam da Porta de Santa Catarina à estância sobre o mar (São Jorge) e do baluarte de São Tiago à estância de São Tomé, dando conta de que nada ficou de pé por causa de uma forte chuva (por causa dela, os seis oficiais perderam ao todo 60 mil réis). Reconhece que as muralhas estavam mal taipadas e rebocadas, tanto que já havia desmanchado propositalmente alguns trechos com um dardo. Por isso, conseguiu do governador requerimento para que os trabalhadores as refizessem (embaixo e em cima) a custo deles, mas pondera sobre o pouco que ganhavam (e eram ainda enganados, em lugar

\footnotetext{
995 Como já disssemos, seria uma técnica semelhante à de Diogo Teles: "essa amostra parece mesclar planta e alçado numa mesma representação gráfica” (BUENO, 2001: 138, nota 145).

${ }_{996}$ Ou que talvez ele, Luiz Dias, jamais tivesse visto.

${ }^{997}$ Ora, pois...
} 
inóspito) inclusive em alimento (teriam caído menos de 30 braças a 130 mil reais, que em Portugal custariam ao Rei menos de $30 \mathrm{mil}$ ).

E agora ao presente o que temos feito é termos já tudo levantado e na altura de $\mathbf{1 1}$ palmos, que dantes eram o mais baixo de 16 e 18, e tudo abaixamos nesta outra altura. Que nunca houve homem que nesta terra achássemos que falasse verdade, mas antes a todos Ihes pesou com a nossa vinda por quão mal viviam. Temos por levantar da estância de São Tomé até abaixo do cunhal. Parece-me, dando-nos Deus saúde e paz com este gentio, o qual está um pouco duvidoso por quão maus os fez o demônio, a teremos levantada e rebocada de cal em que agora andamos rebocando até o Natal, querendo Deus todo-poderoso; e se nos dão guerra com eles, dizem que não poderemos haver cal porque no-la fazem em Taparica na ilha que está defronte de nós.

Explica a redução da altura ao refazer a muralha (de 16 e 18 para 11 palmos), dependendo ainda da pacificação dos índios (por vontade de Deus) a possibilidade de produzir a cal do reboco (feita em Itaparica) para levantá-la e revesti-la até o Natal. ${ }^{998}$

Senhor, o meu parecer é que estas taipas rebocadas de cal muito bem como imos fazendo e com os baluartes que estão não [... devem du]rar 20 anos, e que não devia [gastar mai]s dinheiro até não ver se ia esta [cidade em aument]o e não tivesse muita renda e este [o digo pelo que] deve-me Deus de saúde na alma e no corpo e [deveríeis v]os, Senhor, de aconselhar a Sua Alteza.

Por esse modo de rebocar as taipas de cal nas muralhas e baluartes, deveriam durar 20 anos, sem custar muito e até a cidade crescer para ter renda própria.

[Também] vos quero, senhor, pedir pelas cinco chagas de Jesus Cristo que [vós] me queirais tirar de cá, pois foi sua vontade que eu viesse cá [neste cargo?] e ainda que fosse todo o proveito meu e honra também [de minha] parte, pois que por ele me veio. Isto direi até à morte e os meus filhos assim mo dirão para haverem a minha bênção e por isto, senhor, [eu] terei muito em mercê não ficar eu cá mais que estes três [anos] porque saiba certo que se mais fico que não tornarei a Portugal [pois já] eu não tenho a metade da força que eu tinha nem a metade da vista nem quantos cá estão. E se lhe parecer que Sua Alteza queira mandar fazer alguma obra cá está um oficial que se chama Pero de Carvalhar e Francisco Gomes, filho de Fernão Gomes de Porto de Mós, que são bons alvenéis, e alguma coisa sabem de pedraria, e eu Thes deixarei eligido e principiado e modelo feito para que acabem a coisa, se dela V. M. não mandar modelo do que se houver de fazer. E se se não houver de fazer nada, um taipeiro que cá há o melhor que há o mundo basta para ter cuidado desta taiparia, e de a reparar e olhar todo o ano, que isto bastará 20 anos, como acima digo, para ele durar. E quando Sua Alteza quiser fazer obra mandará mestre. E duma maneira ou doutra folgaria que V. M. me mandasse ir, por amor de Nosso Senhor, porque the certifico que se cá morrer hei de ir direto ao inferno. E mais the digo, senhor, que não se pode lá dizer tanto que mais não passemos cá de fome e trabalho. Enquanto esta Bahia não tiver cem moradores em que entrem cinqüenta de cavalo nunca deles farão bons nem comerão bom bocado, porque terras de criação de todas as coisas deste mundo não há aí em toda a terra como esta, mas gentio dela é demônios.

Luiz Dias implora para voltar (sente que não resistirá por muito tempo a essa espécie de exílio já de quase três anos), recomendando passar o cargo a Pero de Carvalhaes (Provedor das Obras Reais desde 1535) e Francisco Gomes (ele escolheria e deixaria começado o modelo, se o Rei não enviasse outro). Diz que um bom taipeiro de lá faria a conservação por 20 anos e que quando houvesse obra nova o Rei poderia enviar um mestre. Insiste na volta (invocando Deus), dizendo que passa fome e risco de vida, e que a cidade precisa de ao menos cem moradores (50 com cavalo) para serem bons e se alimentarem (as terras eram boas, mas os índios, "demônios").

\footnotetext{
${ }^{998}$ Encaixou-se na seqüência a necessidade de falar mal dos índios: nenhum falaria a verdade, achando que a vinda dos portugueses Ihes fez mal, quando já viveriam muito mal (por culpa do demônio).
} 
Isto vai um pouco prolixo e a minha ventura não quis que chegasse lá Diogo Peres, que bem lembrado sou eu da senhora Margarida de Arruda, cujas mãos beijo e rogo à Virgem Maria Nossa Senhora que haja do seu bendito filho Jesus que o entretenha no seu amor verdadeiro e a senhora e filhos e no amor e serviço de el-Rei nosso senhor. Beijo as mãos de V. M. mil vezes, e beije aos mãos por mim ao senhor Pero Carvalho, ${ }^{999}$ e se lhe parecer necessário alguma desculpa de lhe não escrever desculpe-me V. M., porque lhe quis [enviar uma caixa?] de açúcar e não o há bom senão e, Pernam[buco] está lá um navio que mandou lá o senhor Governador a arrecadar [as ren]das desde o Março de 50, que vem [agora. Nunca] mais tive carta nenhuma desse Reino, e estamos [aqui] parados homens que nunca saíram desse Rei[no] que cá está quem se chama tesoureiro de el-Rei [e tire-me Deus] de saúde se ele tem 30 mil réis de valia e[m moeda que] não prestam para nenhuma coisa. Por descargo de vossa con[sciência] o devíeis de dizer a el-Rei, porque cativos nunca passaram [o que nós cá] passamos. Deixo isto e não o escrevo a el-Rei nosso senhor por[que ele não] se folgará dela por quão maltratados estamos, porque tirando [trin?]ta homens todos os outros não comem senão farinha e um pouco de azeite, e eu da Páscoa para cá não tenho pão de Portugal nem vinho. Vieram cá ter 3 ou 4 navios desses outros lugares que nos dizem que há um ano que dela partiu um navio para esta Bahia. Feita a 13 dias de Julho da era de 1551 anos. Servidor de Vossa Mercê. Luis Dias.

Lastima de novo o naufrágio de Diogo Peres, que seria próximo de Margarida de Arruda (filha mais velha de Miguel de Arruda, como explica a professora Beatriz Bueno, interpretando que "este pousava com ela e sua família quando estava em Lisboa"), ${ }^{1000}$ bajula Pero de Carvalhaes (a quem tentou enviar do bom açúcar de Pernambuco), reclama de não receber cartas, da sorte de outros (um tesoureiro pode ter 30 mil réis que não tem no que gastar nem como cuidar da saúde), de levarem uma vida pior que a de cativos (fora 30 homens, os outros comiam muito mal - ele mesmo não teve pão nem vinho português desde a Páscoa, ouvindo de poucos navios que chegavam que viriam em nau enviada há mais de um ano).

$$
\text { Ao Rei }(15 / 08 / 1551)^{1001}
$$

Senhor. Pelo galeam São João vierão ca hums apontamentos de Vosa Alteza pera o governador Tome de Sousa, os quaes mandava que vise commigo, aos quoaes eu satisfiz e respondi a elles conforme ao que V. A. mandava e logo despedi de caa hum sobrinho meu muito bom oficial, que comigo de la veyo e V. A. mandou pedir. Socede[u] se perderse este galeam em Pernambuqo e o meu sobrinho meteose em outro navio e ia com as amostras pera V. A. onde temos caa per novas que tão bem se perdeo, de maneira que nem $V$. A. as amostras nem nos caa teremos a resposta que dela esperavamos.

Fala provavelmente do mesmo caso narrado a Arruda (as datas são próximas), de naus que se perderam com as amostras e cartas.

Pelo que determiney per hum navio que dos Ilheos hia pera laa, per omde o governador e todos os oficiass de V. A. Ihe escrevem, fazer eu ho mesmo em lhe mandar de novo amostra ... cidade conforme a como per V. A. e per seus apontamentos ... mandando pedir eu a mando laa com os papeis do governador ... avelo e ordenará ho que seu serviço for pólo ... portador que se perdeo escrevia a V. A. desta sua obra e ... muros da cidade e em que depois de feito ho muro ... hûa envernada tamanha que nos deribou parte dos que feito tínhamos, ainda que não foy em tanta cantidade por me parecer que no caso isto de serem hum pouco altas pera taipa sem cal, os emendamos e fizemos de maneira que estão pera ha tera muito bons, fiquom já asy acabados e se compesão jaguora ${ }^{1002}$ a revocar de cal de dentro e de fora, de maneira que com elas revocadas ficarão tam fortes que duraram muitos anos ate $V$. A. tenha na terra mais rendimentos com que pelo tempo em diante posa gastar mais em fazelos como

\footnotetext{
${ }^{999}$ Provedor das Obras Reais.

1000 BUENO, 2001: 140.

${ }^{1001}$ ANTT, Corpo Chronológico, Parte I, 86, III - apud BUENO, 2001: 145-6 (grifos nossos em negrito).

1002 "Começam agora"?
} 
qiser e hos baluartes estão muito fortes e muito ... lados como madeira pela taiparia de dentro que durão depois que tão bem forem revocados ho que qiserem. Isto me parece que sobeja e abasta pera esta terra.

Determinou ir por outro navio os apontamentos oficiais e uma amostra da cidade feita por ele mesmo, com os muros, explicando (como a Arruda) que foram desmanchados em parte pelas chuvas, concluindo serem altos para a taipa sem cal. Refeitos, estavam melhores e prontos, começando então a receber reboco de cal (de dentro para fora) para ficar resistentes e duráveis até que se quisesse investir mais (com rendimentos próprios da terra). Também os baluartes de madeira na taiparia ficariam fortes quando rebocados, o que era suficiente para a necessidade.

E asy fizemos dous baluartes, hum na Ribeira de Goes, muito poderoso, em syma do rochado, que V. A. verá na mostra que joga pera todo o mar da baya e joga as duas esperas de marqa mayor que vierão e dous camelos e dous falcões e hûa dúzia de berços: este ainda que he de madeira tão forte que durará segundo dizem vinte anos por ser de paos de mange que se criam nagoa e sam como fero.

Fala dos dois baluartes, começando pelo da Ribeira, forte, sobre a pedra, defendendo o desembarque com duas boas esperas, dois camelos, dois falcões e doze berços (mesmo de madeira, a boa qualidade dela - paus de mangue - faria durar vinte anos).

O outro baluarte de Santa Cruz he mais pequeno e joga nele hûa espera e dous falcões e meya duzia de berços e isto ate saber se V.A. os quer ter asy ate os diante os fazer de pedra e cal ou logo como ele ordena.

O de Santa Cruz era menor, com uma espera, dois falcões e seis berços, podendo ser refeito de pedra e cal a mando do Rei.

E asy fezemos cadeya muito boa e bem acabada com casa daudiencia e camara em syma e na ribeyra de Goes casa da fazenda e alfândegas e almazens e ferarias, tudo de pedra e baro revocadas de cal e telhados com telha, que servem já, de maneira que pelo presente me parece que isto he acabado ate ho tempo mostrar de sy mais cousas, pelo que peço a V. A. ajaa por bem de me mandar ir com o governador Tome de Sousa por ser velho e mal desposto e já ao presente não aver necesydade de mim e nisto me fará muita esmola e merce e muito serviço a Deus pera amparo de hûa velha que tenho e rogarey sempre a Deus pelo acrecentamento e estado de V. A. como o da Rainha e príncipe nossos senhores que os entretenha sempre pera seu santo serviço e lhe acrecente os dias de vida amem. Desta sua cidade do Salvador Baya de todolos Santos, a quinze dias dagosto de mil quinhentos cinqüenta e hum anos - Luys Dias

Diz ter construído na parte alta uma boa cadeia, casa da audiência e câmara, e na Ribeira do Góes (depois Cidade Baixa) a casa de fazenda, alfândega, armazéns e ferrarias, tudo de pedra e baro revocadas de cal e telhados com telha, já estando em funcionamento. Com tudo pronto, pedia para retornar com Tomé de Souza, pois já não precisam dele, que estava debilitado e precisava cuidar de sua velha. 


\section{Relatório de Diogo Moreno (1609) ${ }^{1003}$}

[Fl. 25] Bahia de todos os santos/ Sempre fes cabeça' de todo o estado do Brasil a sidade do salvador bahia de todos os santos que está em 13 graos ao sul do iquinocial a grandeza desta' bahia a sua fermozura e o sitio notavel a faz sêr a melhordo mundo; ten a dita sidade en hun' alto a mesa ${ }^{1004}$ legoa da barra e ponta de santo' Antonio donde goza da viração do mar [fazer] pella [ponta] e assento sendo o lugar e milhor vista mais sadio [ $q^{\prime}$ tem] asentado de toda a costa do Brazil ten [rodeando deste] muitas fontes de $\mathrm{m}^{\text {tas }}$ boas agoas e hun vale $\mathrm{q}^{\prime}$ teria a sidade pela banda [de lesti] povoado destas ao coal atravessa' hun' ribeiro $q^{\prime}$ [o faz] fromozo e no $q^{\prime}$ [toca as entalis] as ten todas as $q^{\prime}$ em portugal [são servidos] frutas despinho e sementes; [depende] tamben' ten mais $q^{\prime}$ todos os lugares de $q^{\prime}$ tratado avemos; he o $\mathrm{pr}^{\circ}$ lugar ao sul de equinocial em q' se dão marmellos en cantidade $q^{\prime}$ [se tem] marmello' tam boa como' a do Rejno. tem $\mathrm{m}^{\text {tas }}$ romans' [huns] e figos com $\mathrm{q}^{\prime}$ en tudo se reprezenta muittas vezes hu' [ussao] [perpetio] de Reino. ${ }^{1005}$

Inicia por uma descrição elogiosa da natureza à maneira de Caminha (1500) e Gândavo (1576), comumente interpretada como incentivo à vinda de colonos, mas que em nada deixa de corresponder à realidade física do lugar. Embora o Brasil fosse farto em sítios sadios e de bons ares, a escolha daquela baía para fundar a capital remete com certeza à questão vitruviana da salubridade.

ten esta sidade muitas cazas boas de pedra e cal q' custão [e na'-]tem muitto e outros bens edeficios cazas fermozas e ben asentadas ruas ten hù colegiô de $\mathrm{p}^{\text {es }}$ da companhia sunteozo' e [bonnido] e povoado delles donde' se ten todas as siencias com q' nellas os filhos do Brazil fam frutto; ten hú [muttiy] de frades descalsos bem obrado perfeito e de grande exemplo outra de sam Bento q' não está acabado mas ten a en sua' fabrica imeginaçois grandes... [Fl. 25v] ... outrô convento do Carmo q' tudo ten [dus melhas] suas fazendas de q' se [ouidão] e huma caza da misericordia con hû hospital em q'se agazalhão e curão muittos pobres e ten' este grande convento de irmandade e gastos donde concorem esmollas de importancias e a Igreja da sê contas as duas [de sidades] seu bispo [subido] sua capella con todos os dimais menistros eclesiasticos e [couzas] pertencentes ao culto devino; alen destas igrejas ten ermidas fora e dentro da sidade ben ornadas [alguãs] con panos em q' todos os annos em louvor de Deus [e de] santos se selebrão festas de $\mathrm{m}^{\text {to }}$ [gasto] e posuem muitta prata de serviso as demais das capellas en cruzis castisais e lampadarios di grande frutto.

Passa à descrição da cidade à época em que aparece pela primeira vez ilustrada (Pranta... de 1605). Na ênfase às construções religiosas, a descrição orgulhosa do luxo das igrejas lembra agora as de Gabriel Soares de Sousa (1587) e Fernão Cardim (1601).

nesta sidade ten sua' Mag $^{\mathrm{e}}$ a pessoa do seu governador geral [he] asento e asin muittos outros menistros [da justitia] e da faz ${ }^{a}$ e da gerra [cusos] de [lasios] importão muito e se pagão nos [diversos] desta capitania q' con todas' as demais do sul [nos dese] este anno de 608 pesa a faz ${ }^{a}$ de sua mag $^{\text {e }} 11$ mil cruzados. ficará este lugar en tudo [aventejado] e as cazas do estado tomarão asento' con' a vinda da Relacão que se espera.'

Fala de questões administrativas, ou da presença do Estado na cidade, preparando, ao mencionar os recursos necessários à sua melhoria, o parágrafo seguinte em que adentrará a questão defensiva.

\footnotetext{
${ }^{1003}$ ANTT - Ministério do Reino - Mç. 599, doc. 68: Relatório de Diogo de Campos Moreno, datado de 1609; Coleção de Plantas, Mapas e outros documentos iconográficos. Relação das praças, fortes, povoaçons, e cousas de importancia q' Sua Magestade tem na costa do Brazil; fazendo principio dos baixos, ou ponta de são Roque para o sul, do estado e defenção dellas, de seus feittos e rendimentos, feitta pello Sargento Mor desta costa Dioguo de Campos Moreno. / No ano de 1609. 1004 = meia.

${ }^{1005}$ Compara-se às descrições de Nóbrega, Soares de Souza e do padre Vieira.
} 
A sidade do salvador pode ser lugar mui forte' e ben guardados os navios q' nella estiveren' fazendo-se o q q sua mag $^{\mathrm{e}}$ tem mandado o anno de seis sentos e seis pelas plantas' $q^{\prime}$ fes o engenheiro fran ${ }^{\circ}$ de frias e confirmou e emendou tiburtio espanochi engenheiro mor despanha para' as coais fortificaçons sua' mag $^{\mathrm{e}}$ mandou aplicar a emposiçao dos vinhos' desta' ditta sidade e deu mais de mil os ${ }^{1006}$ [pezado] de sua fazenda vinte mil cruzados pos [maneira] que... [FI. 26]... fazendos-se a ôbra' [q' nesta besada ficará] este lugar milhor e mais forte [g'asâ] ${ }^{1007}$ da equinocial pesa' o sul [esteje] podera esta terra ser escalla da India oriental se sua mag for servido pois pera' a ída e pera'a vinda a todo o tempo a póden tomar as naos [e valerense] en suas nessessidades q' con forteficação ficão muj remedeados os enconvenientes da fazenda em a Relacão e sua mag ${ }^{e}$ ben servido e a Republica sen ver tantas perdas i mortes como nas Ilhas q não a de mandar ou na costa de giné lhes acontesse.

Destaca assim a possibilidade ("pode ser") de a cidade ter uma defesa eficiente, que ainda não havia. Para ser uma praça forte, deveriam executar o plano desenhado por Frias com seus ajustes e aprovações (as emendas de Leonardo Turriano e Tibúrcio Spanoqui, mencionadas neste e em outros documentos), que resultaram na Pranta... desenhada por Abernaz (em suas duas versões). ${ }^{1008}$

nesta sidade pode avêr almazens pera conserto [escoreda] de todas as naos q' aqui vierem porq' há' sitios [pera dar gzerna] como são o de [matuin] etaparica [matuin] a coatro legoas da sidade milhor e mais abrigado a todos os ventos e defronte da mesma sidade se dão e poden dar largos [pindores] a todo [o serrafro] e ha' madeiras excelentes para coais quer fabricas navais e sitios em q' se poden fabricar naos $\mathrm{m}^{\text {to }}$ grandes.

Fala das boas condições de cais, armazéns e madeiras nativas para estaleiros.

encoanto se cuida nestas couzas ao menos pode sua magestade mandar q' daqui lhe leven a lisboa [garlindeos] e [carlingas] digo [as taboans] pera estas [pessas] q' em portugal nem en Espanha não de aver tais como aqui e que tão baratas tantas dão fortes [serão].

Retifica o parecer de Luiz Dias de durarem vinte anos os paos de mange que se criam nagoa e sam como fero.

nesta capitania forteficada e [ileinhada] ${ }^{1009}$ como [asi] se mostra em a relacão [se e sen] o fazeren con a pedra e cal [ne ouza] [se coner..] ${ }^{1010}$ armadas de enemigos [non] ${ }^{1011}$ apertar [basão] [corsários] [farinha] ${ }^{1012} \mathrm{q}^{\prime}$ os moradores do [reconcavo] [deixen] de fazer [aduelo] ${ }^{1013}$ por acudiren a sidade a [nas] [hesfir] $^{1014}$ lugar de defenderen' suas cazas, [o vê em]... [FI. 26v]... quanto se nao fortefica. paga sua mag $^{\text {e }}$ mais de duzentos soldados de [prezidio] q' sempre são poucos pera muitto a q' ['haq'] acudir q' ter os moradores da sidadi hapenas se juntão [dos] vezinhos em ao mas' a hú repente con [30] oras nao ha

\footnotetext{
${ }^{1007}$ Que haja? poema, Triste Bahia).

1009 Desenhada?

1010 Não poderão conter?

1011 Nem aportar?

1012 Fazendo?

1013 De tudo?

1014 Se não lhes fica?
}

${ }^{1006}$ Do milhor? Ou, “... mais de mil os pesos”.

1008 Quanto a mencionar a possibilidade de Salvador se tornar escala de ida e de volta da Índia, de fato, a cidade foi ponto importante da rota comercial portuguesa ao longo dos séculos XVII e XVIII. Principalmente os donos de terra, mas também burocratas e eclesiásticos consumiam produtos vindos da Europa e também do Oriente, que eram trocados pelo que se produzia na Bahia - principalmente os derivados do plantio da cana e da criação de gado, além do fumo (a promiscuidade desse comércio, ou máquina mercante, inspirou Gregório de Matos a escrever em meados do século XVII seu mais famoso 
q' esperar' outro socorro de nenhuma parte e os [portos] somente $q^{\prime}$ Don Fran ${ }^{\text {co }}$ de souza fez de pedra e cal onde se partiu a artelharia segundo os lugares donde estão separados e a distancia ha mister cada hú muitto maior guarda do q' en si tem'. o todo da sidade q' como he aberto ai se ha de dezemparar' o [o nauidio] aos fortes ou os fortes an de ficar dezemparados por guardar a sidade e se aver partilhas an de ser de sorte q' corra nisto huma outra couza [co's] fortes q' tanto embaracão são de tam pouco effeito $q^{\prime}$ [pasa q'] menos servia he aquillo pera q' forão feittos, e porq' milhor se [ruyão] os peitos ${ }^{1015}$ e partes q' guarda [se devia'] [ueramos] [opsy]... ${ }^{1016}$

Adentra enfim a questão mais importante (para os engenheiros militares) da defesa da "Cidade", recomendando seguir os passos iniciados com Dom Francisco de Souza (já traçados e defendidos por Luiz Dias) de erguer em pontos certos as fortalezas definitivas ("de pedra e cal"). A cidade era em si fortaleza capaz de abrigar moradores do Recôncavo reunidos para defendê-la contra uma investida de nação estrangeira. Daí o projeto de cidadela, elaborado por Frias de Mesquita e conferido pelos engenheiros-mor de Portugal e Espanha, que aparecerá no Livro que dá Razão... (1612). Fala de questões práticas sobre a fortificação necessária, mostrando que sem construí-la, a Coroa seguia gastando mais em soldados de presídio. Os fortes de pedra e cal construídos por Dom Francisco de Souza (Santo Antônio da Barra, Monserrate, Santo Alberto e São Tiago) eram em realidade os redutos que poderiam receber os moradores do Recôncavo, e poderiam ser mobilizados em 30 horas para o caso de uma tentativa de invasão (que de fato ocorreria, quinze anos depois).

... forte santo Ant $^{\circ}$ na entrada da barra na letra A que se fes para a defender como he averiguado que $o$ [disaguen] [e baten] e entrão e saien cada dia naos armadas de corsários sem q $^{\prime}$ a artelharia q' aqui está Ihe faça danos, e inda que tenha [culubrinas] ${ }^{1017}$ de sesenta quintais nunca totalmente podera' defender a barra: aproveitta' o ditto forte somente pera guardar as caravellas ou embarcaçons pequenas $q^{\prime}$ de mar en fora viven [assas] onde mandando [oposta as coais] chegados o forte a $q^{\prime}$ andasen dentro na bahia [the] na barra a tivesen [nesta] he o mesmo efeito $q^{\prime}$ fas esta artelharia neste [sitio] e se [pesati] este [benefisio] e para adorno [de bem nieugai] [desta] e de [nva] ${ }^{1018}$ he [bem q] se tenha q [a] sustente o ditto forte, conven [imendar-se]... [FI. 27]... A ditta forteficação dando-lhe seu [irenezes] ${ }^{1019}$ e menbros $q^{\prime}$ a defendam cen coalquer guarda per pequena $q^{\prime}$ seia e $q^{\prime}$ não [esti] ${ }^{1020}$ tão sugeita a Ihe poderen [asimar] escadas como esta' [esê].

Diogo Moreno foi o primeiro a considerar sem valor estratégico ou tático o Forte de Santo Antônio da Barra, chamando-o ironicamente de "adorno da barra" ${ }^{1021}$

ten este forte hun capittão con sesenta mil [rs] de paga' cada anno q' prove sua' mag ${ }^{\mathrm{e}}$ e des soldados pagos de presidio con hun cabo de iscoadra todos mosqueteiros con coatro pessas de bronze hum bombardeiro $q^{\prime}$ de [centino] ${ }^{1022}$ con os soldados ali asiste e ten alen disto [os den] os moradores do Rio Vermelho ali vezinho de acudiren con suas armas e escravos ao ditto forte para q con elles fique provido [en todos] con sincoenta pessoas q' [para] sua capasidade ha' guarda ordinaria bastão estes q' ajudão a andar com a artelharia.

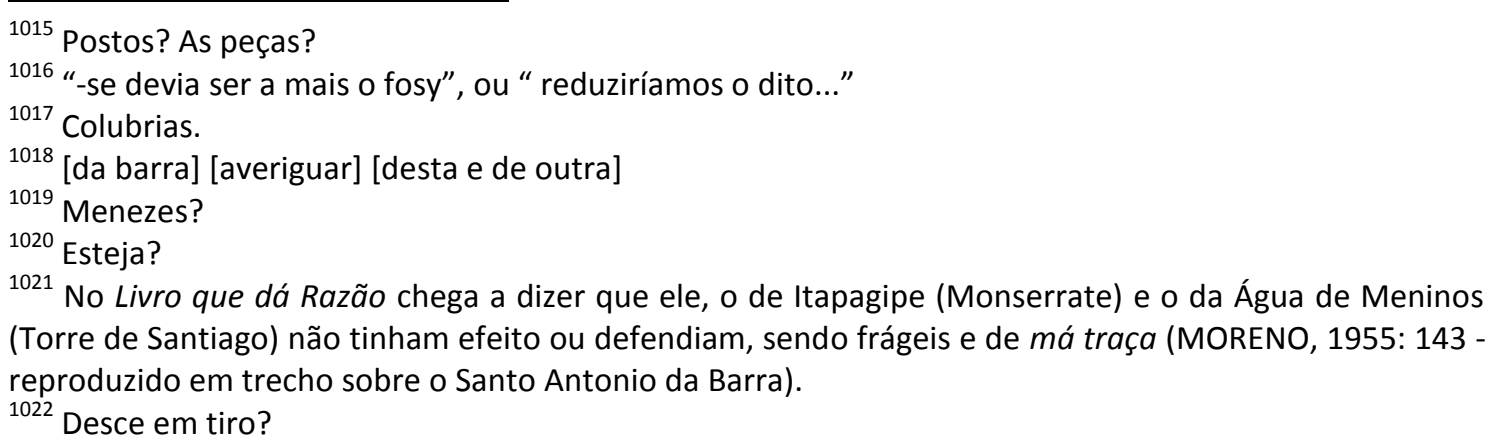


Descreve a capacidade de fogo do dito forte, em função de seu plantel e capacidade de receber ajuda do (atual bairro vizinho do) Rio Vermelho.

deste forte de S. Antonio hatè a sidade ha uma legoa pequena e nesta legoa' algumas colheitas q' guardam con corpos de guarda ou con gente solta q' as vende, porq' as lanchas as não acometão e por ellas lansen' gente en terra [e vinhão] fazer' [auguada] em alguãs partes que ha' pera' isto, como são pegado' ao forte e à meia legoa delle, tamben outro lugar' q' chamão agoa' de graviel soares de modo q' por todos estes [respeittos] he forsozo guardar tudo isto.

Mostra que já havia preocupação em defender - mas eram defesas precárias - o trecho entre a entrada da barra e a cidade, exatamente o local escolhido pelos holandeses para o início da invasão, 15 anos depois.

na' entrada' da sidade na porta de santa Luzia [estão em tuorna] instancia sobre a misma porta tres pessas de bronze e dois [predreiros] con hum [binbasahy] pago con seus ajudantes q' não levão mais soldo q' os privilegios.

Passa a descrever a fortificação da cidade propriamente dita e seu armamento, começando pela Porta de Santa Luzia (São Bento, ou São Pedro, próxima ao local onde foi construído o forte, primeiro com os holandeses).

[aiqe] ${ }^{1023}$ das cazas de sua mag ${ }^{\text {e }}$ sobre a igreja de conceição [Avista] outra [intentir] con tres pessas de bronze q' no meio da montanha debaixo [de razão] a misericordia esta tamben huma plataforma q' defende a [ancoresa] ${ }^{1024}$ no porto junto a sidade da [ndesta] tres pessas de bronze e hua [de ferro]. [Fl. $27 \mathrm{v}$ ] ten esta instancia nessesidade de artelharia de alcansi pelo [ben q'] daqui obra a guarda do posto como fica ditto. nella ha hu [bombardey] pago con seus ajudantes [a pedil-la] pera q' [roge] $^{1025}$ o lume [dagoa] esta Santo Alberto instancia de pedra e cal que fes Don fran ${ }^{\text {co }}$ de Souza con tres pessas de bronze e hum bonbardeiro pago e seus ajudantes.

Menciona a Estância sobre a Igreja da Conceição, a Plataforma que defendia a encosta (abaixo da Misericórdia) e o Reduto de Santo Alberto, feito por D. Francisco de Souza (na praia, próximo à atual Igreja do Corpo Santo, segundo Teodoro Sampaio), com suas peças de artilharia e soldados operadores.

continuando na montanha da sidade ao pé do Colegio de Jesus esta outra plataforma bem alta' q' olha todo o porto e ancoraria até a agoa dos meninos q' como se vé, he huma enseada grande [e aqui] estão [2] pessas de muito alcanse [cen] ${ }^{1026}$ hu bonbardeiro pago e dous aiudantes de previlegios som ${ }^{\text {te }}$.

Da mesma maneira, cita a Plataforma ao pé do Colégio de Jesus (alta, avistando todo o porto até a Água dos Meninos).

Na ultima porta q' vay pera' o Carmo está outro [cubello] q' defende aquella entrada con duas pessas de pouco efeitto milhores [pesa asudão] ${ }^{1027}$ ofenderão de outras $q^{\prime}$ a pesa q' [oie] [se uzão] não são de efeitto tem hu [bombard'ro] pago e dous ajudantes. na praza da cidade na ponta das trincheiras da banda do viradouro velho esta' huma instancia con duas pessas de bronze con hu [bombardr. ${ }^{\circ}$ ] pago e seus ajudantes. mais adiante nas cazas de batterias [ferras] estão duas pessas mais avante pela praia estão mais dous [falemi] [delavasi] [enmeçadosas a] banda q' as ten [a hea] conta jogão nos [daqui] das

\footnotetext{
1023 Ao pé?

1024 O ancoradouro?

1025 Jogue?

${ }^{1026}$ Com?

${ }^{1027}$ Melhor se espera acudam?
} 
trincheiras. en toda a praia há mais coatro pessas de ferro [coado] de pouca importancia contudo [seman etenteuz] [experio].

Fala da existência dos seguintes redutos, com o quadro de pessoal e as peças instaladas: Portas do Carmo, trincheira da banda do Viradouro Velho, plataforma das casas de Balthazar Ferraz, ${ }^{1028}$ e plataforma para o mar depois dessas casas.

para a banda do norte desta sidade ha uma legoa está outra ponta chamada tapagipe q' na planta se asinala con a leyta $\mathrm{G}$, donde paresse outro forte de pedra e cal da mesma traça de $\mathrm{S}$. Ant ${ }^{\circ}$ dizen $\mathrm{q}^{\prime}$ ten huma sisterna dentro [mayer etira mais xxx xxgov' de nea fegusa messen]... [FI. 28]... [Aver] nen couza q' o defenda', sen hù capittão por sua mag ${ }^{\mathrm{e}}$ [em] outenta mil rs' e des soldados de prezidio e hun tenente e hu bonbardr ${ }^{\circ}$ con sinco pessas de bronze e ferro, todo [este] forte e artelharia dizem $q^{\prime}$ pera $q^{\prime}$ coando

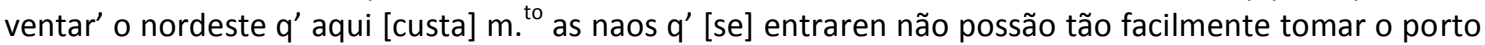
da cidade porq' onde não pesa o [cançarem] [avisar] perto desta ponta e pesa que ao seu abrigo não venhão seguros os barcos que vierem [doseceneano] ${ }^{1029}$ a sidade huma' e outra rezão são quoais Deus [os me der e não Jesui], pois temos o forte mostrão coão pouco [serve] somente se ha de adeavertir q' hê o de mais reputação que ha na bahia e que não ten trassa [neste] modo de defença a huma a huã escalla porq' pera nenhum destes fortes há mister artelharia senão d'escadas de vinte palmos e mosqueteiros q' não deixen descobrir os de dentro por muittos q' [usão] e assi digo q' são instancias como [mestrado].

Ao abordar o Forte de Monserrate, o de mais reputação que há na Bahia, dá o importante testemunho de parecer ser da mesma traça do de Santo Antônio, o que fortalece a tese de que as quatro importantes fortalezas construídas de pedra e cal no governo de Dom Francisco de Souza, de plantas retratadas por Albernaz I, eram mesmo de Baccio da Filicaia.

fica de pouco effeito e queda [ad] [muinto] trabalho [nenhú] noutra instancia q' [me fica] entre este tapagipe e a sidade q' chamão Agoa dos meninos donde estão duas pessas de bronze as coais pessas sen [duvida de] ser trarão daqui porq' paresse [patranha] quen for soldado cuidar q' [ensezão] pode acudir a tanta [bitoza] [seza] nesta nossa [enoa] não ha' alguma' ley que da lisensa à a por [estas] pessas de artelharia donde as deixen [levar] dos enimigos nesta sidade pera acudir as couzas dittas [uteis] [e contio deal] depois [do rebate] a entrada dos enemigos se juntão de fora e de dentro ate 200 homens.

Cita, voltando em direção à Cidade, a Torre de Santiago, descrevendo a artilharia e também criticando sua eficácia, alertando para o perigo de ser facilmente tomada.

Deus sabe com q' [deste de] pello q' acudindo a prasa fortes e portos tudo fica muy [fado] com muita facilidade... [Fl. $28 \mathrm{v}$ ]... Pode aconteser' huma' desgraça grande, cas couzas não [são pesa] menos encoanto na ssidade não há forteficação $q^{\prime}$ com muito pouco guarde as cazas mulheres [e Igrejas] [eunez]demais acuda' en cazo [primi] a donde convenha.

Alerta sobre a vulnerabilidade da cidade (casas, mulheres, igrejas), enquanto não se construia um sistema fortificado eficaz.

Juntão-se nessa sidade perto de mil homens en doze companhias a saber defesa: oito da ordenança e duas mais da cidade [cas] duas de prezidio toda a mais gente fica en goarda das fazendas de fora per [amor] dos negros da terra e de gine'; [ten conhed ${ }^{\circ}$ ] asi de' capitania mais de tres mil moradores brancos q' oje chegão ate o camamu e morro de s. Paulo mas estes não acoden a sidade a couza' alguma' porq' viven longe: ...

${ }^{1028}$ Segundo M. Oliveira (2004: 82 - nota 74).

${ }^{1029}$ Do oceano? 
Este trecho foi citado e comentado em nota sobre os índices populacionais dos anos 1580 (comparado ao registro de Gabriel Soares de Sousa).

... os engenhos que nesta capitania fazen[-se] armar são os seguintes.

$\sim$ o eng $^{\circ}$ da sidade de Rafael barboza./ o del Rey em pirajá./ o de Inrique menis em Pirajá./ o de Vicente Rangel em Pirajá./ o de Bernardo pimentel en [cutigipe]./ o de [Marcio] Peres [no d. perto]./ $\sim$ o de gaspar Dias de moura em [llese]./ o de Ant ${ }^{\circ}$ cardozo de barros en [sacaraganga]./ $\sim$ o de Ant ${ }^{\circ}$ cardozo [o de carnubado]/ o de gaspar pereira em Matuin./ o de gaspar pereira no [otum]./ o de Ant $^{\circ}$ vas en [contugipe]./ $\sim$ o de Baltazar peres en [cutejipe]./ o de Domingo [banhoray];/ [Fl. 29] $~ 0$ eng $^{\circ}$ de Ant $^{\circ}$ Vieira./ $\sim$ o de Luis vas de [poiua]./ o de [Pleuro'] de Britto freire en [tritão] Vieira./ $\sim$ o de Migel ferreira./ o de fran ${ }^{\circ}$ Duarte [do imenez]./ o de Paulo [das goulo]./ o de Pedro garsia./ o de João Serrão./ o de Martin Carvalho./ o de Estevão de britto freire./ o de Vasco de britto./ o de fran $^{\circ}$ Ribeiro./ $\sim$ o de Domingos [Roiz]./ o de Dioguo de Noronha./ o do conde en sergipe./ $\sim$ o de fran $^{\circ}$ [garsa] Luis./ o trapiche junto o conde./ o de Bernardin [fr] em [Ponatu]./ o de Baltezar de aragão./ otro novo de Baltezar daragão./ o de Andre Lopes na ponta'./ o da cachoeira./ o de Ant ${ }^{\circ}$ Cardozo de [pesista]./ o de [frittrião de abrozhe]./ [40] o de Duarte [esquil] en tapariqua./ [FI. $29 \mathrm{v}$ ] [40] o engenho do mulato en tapariqua./ o de Sebastião pacheco en tapariqua./ o de Luis de [fgezedo] en jaguaripe./ o de nicolau soares en jaguaripe./ o de fernão Ribeiro de Souza en tinesi./ o dos padres da companhia en camamu./ [46] o de Baltezar' aranha' en taparica.

Passa a relacionar 46 engenhos do Recôncavo que poderiam ajudar na defesa, dando o nome de seus proprietários.

todo o [trato] desta capitania a esta sidade he por mar [e asi se] ten todas estas fazendas as duas barcas grandes [e a da] Sausador ${ }^{1030}$ hum barco mais pequeno $q^{\prime}$ chamão [rodeiros] de modo q' se poden por a vella mais de duzentas embarcacões latinas todas com marinheiros [nativos] da terra e de giné tamben e gente nobre que há' muitta ten cavalos de q' uzão nas festas inda q' não en tanta cantidade como' em pernambuco $q^{\prime}$ tudo o $q^{\prime}$ se fas he por terra.

Descreve o uso e a grande quantidade de embarcações, uma vez que todos os principais acessos eram feitos por mar, havendo índios e negros também preparados para velejar. Os cavalos eram principalmente usados nas festas, havendo menos que em Pernambuco, onde os principais acessos eram feitos por terra.

todas as aldeias do gentio da terra q' há nesta capitania estão a cargo dos padres da companhia sem q' algum branco entenda ou possa entender com ellas depois de pazes que se fizerão con os aymores [fica] todo o sertão desta capitania quieto e assin os moradores [darião] a sua mag. ${ }^{e}$ de rendas hu' tizoiro grande pella fertilidade da terra se tivesen ajuda dos indios q' como lhes fazen cas fazendas de forsa se an de fazer com os de ginè que tanto custão os lavradores que dão proveitto a fazenda Real empobrecen' e tudo ven a ser de mercedores ${ }^{1031} q^{\prime}$ não tratão em aumentar a terra' senão [ensancar]'seu [fry] pera' mendaren [a seus] maiores e daqui nacen mil ruinas de fazendas e de bons... [FI. 30]... homens' pera ellas couza $q^{\prime}$ [devia] [em huã] rezão de sê remedear ou dando-lhes aos moradores indios da terra que os ajuden ou favoresendo-os para q' não pagen suas [viedas] mais q' com o feitto das fazendas. e asim crecerão em modo q' a sua mag ${ }^{e}$ se lhe siga hum' grande serviço.

Em espécie de análise sócio-econômica da força de trabalho, explica que, feitas as pazes no sertão, os índios eram de uso exclusivo dos padres da Companhia, saindo caro para os colonos adquirirem escravos africanos e ainda pagarem impostos para produzirem e bem servirem à Coroa, resultando na ineficiência de suas fazendas (defende a escravização dos índios).

\footnotetext{
${ }^{1030}$ Salvador?

${ }^{1031}$ Mercadores.
} 
ha' no Amazen desta capitania $q^{\prime}$ he a camasa ${ }^{1032}$ de munição de todo este estado [senone'] de [polva] 12 quintais e [33] de [murao] de chumbo em [partas] [epilousos] $1 \underline{6} 3600$ ballas de artelharia de toda' a sorte seis falconetes de bronze com seus serviços oito sen [rebichos] nen serviços dous [esmirilhois] de bronze de [culher] 350 mosquetes aparelhados e duzentos arcabuzes $\mathrm{m}^{\text {to }}$ enxofre.

$\sim$ fas de gasto a gente de gerra desta capitania

$\sim$ fas de gasto o eclesiastico bispo e ordinarias'

$\sim$ fas de gasto toda a gente da fazenda governador e mais oficiais como se mostra.

$\sim$ ten esta capitania de bronze com as q' estão [dos] no almazen 44 pessas e sinco de ferro coado na praia' as $1 \underline{0}$ são de bronze falcons e falconettes sen serviço digo as q' estão no almazen. na fundição de Pernambuco de toda' esta artelharia se poden fazer pessas de alcance q' escuzen [dispensem] camaras e fação grande serviço.

Descreve as armas e munições da Casa de Pólvora, gastos necessários e a possibilidade de otimização pela casa de fundição instalada em Pernambuco.

\section{[FI. 30v] Camamu}

Ao sul da bahia de todos os santos esta o camamu morro de São Paulo en catorze graos cuja terra vai povoada de moradores da bahia de todos os santos q' viven de suas grangearias de mentimentos e curais de gados e criaçoins miudas e de fazeren excelentes madeiras vermelhas q' chamão de gitai [fena] e de angelin e outras. com a gerra dos barbaros aymores estava tudo isto despovoado, oje ten neste sitio hum engenho os padres da companhia inda q' a terra ali não hê por se [faça] muy [madeira de canas].

No limite da Capitania da Bahia, Camamu, ao sul, podia fazer parte do sistema de defesas, indo bem com sua economia de subsistência e padres da Companhia produzindo madeiras (depois de vencidos os índios hostis).

[Legenda do Mapa] Bahia

A. Ponta de santo Ant. ${ }^{\circ}$ donde esta' hû redutto con artelharia.

B. Rio vermelho na costa do Mar.

C. Itapoam penedos na costa q' chamão muitto as agoas.

D. sidade do salvador cabeça de todo o estado asentada no alto.

E. Reduto ao pe da sidade chamado [Reduto] santo Alberto.

F. Reduto chamado agoa dos Meninos meia legoa da sidade.

G. Ponta de tapagipe onde està forte' Santiaguo.

H. Boca' de Pirajá onde dão [guerena] os navios.

I. [ha praya] grande donde há $\mathrm{m}^{\text {tas }}$ fazendas de lavradores.

L. [--- rio ha hun deb, boanes defendo].

M. Ilha de maré q' [desmas de suas] [---] as mais cazas.

N. Ilha de [togates] junta' [ascera congs]

O. [Rio lepotigua] $\mathrm{q}^{\prime}$ tem $\mathrm{m}$. ${ }^{\text {tos }}$ eng. ${ }^{\text {os }}$

P. Rio de Pitanga $\mathrm{q}^{\prime}$ tem $\mathrm{m} .{ }^{\text {tos }}$ eng. ${ }^{\text {os }}$

Q. Ilha das fontes com hû engenho.

R. Ilha dos frades em q' há moradores e sô dà mantimentos.

S. Boqueirão da llha dos frades.

T. Ilha de [desazaiba].

U. Rio de Sergipe do conde de Linhares com muittos eng. ${ }^{\text {os }}$ e [carnes].

X. Rio do [Açu] com m. ${ }^{\text {tos }}$ mantim. ${ }^{\text {tos }}$

$A A$. Praia de saubarà com currais.

BB. [Barra] do Rio [Parrasú] donde entrão naos da India [tem dentro] outras bahias e Rios de grosos eng. ${ }^{\text {os }}$ e faz. ${ }^{\text {das }}$

CC. Ilha do medo q' so tem lenhas.

DD. A llha de taparica com [m. ${ }^{\text {tos }}$ ] eng. ${ }^{\text {os }}$ e $\mathrm{m}^{\text {tas }}$ fazendas [de do C. castanhr. ${ }^{\mathrm{a}}$ ]

EE. Ilha defronte da [barra] de jaguaripe do mesmo fica por detras de taparica mas hé mui perigoza para sair ao mar e de embarcaçois pequennas.

FF. Barra da grande bahia de todos os santos de duas legoas de boca. ${ }^{1033}$

1032 Câmara? Talvez "casamata”, depósito.

1033 Seguem-se relações e mapas de outras capitanias: Ilhéus, Pernambuco (com informações de Salvador), Itamaraguá, Rio Grande e Paraná. 


\section{Pareceres de engenheiros sobre o Relatório de João Coutinho ${ }^{1034}$}

[Fl. 123]... Parecer dos Engenheir. ${ }^{\text {os }}$ desta Corte, sobre as forteficações da Cid. ${ }^{e}$ da B. ${ }^{a}$, de q trata a Carta ..., e'veyo incluso no Decreto de S.Mg. ${ }^{\text {de }}$, por onde Ella se expedio.

[Sobre as fortificacoens da Cidade da Bahia de que trata a carta asima]

Foy VMg. ${ }^{\text {de }}$ servido, q' nós os abaixo assinados, em presença do Gov. ${ }^{\text {or }}$ Roq' da Costa Barr. ${ }^{\text {to }}$ vissemos as Plantas, e relação da Cid..$^{\text {e }}$ da B. ${ }^{\text {a }}$ de Todos os S. ${ }^{\text {tos }}$, q fez o Enginh. ${ }^{\text {ro }}$ João Cout. ${ }^{\circ}$, e juntam. ${ }^{\text {te }}$ vissemos os pareçeres dos Engenhr. ${ }^{\circ \mathrm{s}}$ das Prov. ${ }^{\text {cias }}$ deste $\left[\mathrm{Rn} .{ }^{\circ}\right]$, e tomassemos todas as notiçias do d. ${ }^{\text {to }} \mathrm{Gov}$. Roq' da Costa Barreto, $e^{\prime}$ dissessemos o $q^{\prime}$ se nos offereçesse mais comveniente ao serviço de VMg. ${ }^{\text {de }}$

Primei. ${ }^{\text {ra }} \mathrm{m}$. ${ }^{\text {te }}$ nos pareçeo, $q^{\prime}$ a nova forteficação $p^{\prime} l a ~ p .{ }^{\text {te }}$ do mar se devia escusar, $p^{\prime} l o s ~ m . ~{ }^{\text {tos }}$, $e^{\prime}$ grandes Armazens, $q^{\prime}$ ha dentro em elle, sobre caes, a $q^{\prime}$ vulgarm. ${ }^{\text {te }}$ os paizanos daquella Cid. ${ }^{\text {e }}$ chamão Trapiches, aonde os mercadores recolhem os asucares, e tabacos, $q^{\prime}$ vem dos Eng. ${ }^{\text {os }}$, por lhes ficar mais façil o recolhim. ${ }^{\text {to }}$; e sahida delle p. $^{\text {a }}$ as Frotas, com q' escuzão e excessiva desp. ${ }^{\text {a }}$ de os sobir, e' deçer por guindastes do alto da Cid. ${ }^{\text {e }}$ como sucçede às faz. ${ }^{\text {as }} \mathrm{q}^{\prime}$ vão em as Frotas desse [Anc. ${ }^{\circ}$ ], e' como esses Armazens, ou Tragiches são $\mathrm{m}^{\text {to }}$ grandes, [eja em] huñs mais e menos ao mar, tem qualquer delles bastante capacid. ${ }^{e}$ p. ${ }^{a}$ em qualquer occasião, q' huã Armada inimiga, por mais poderosa, q' seja, intente invadir essa Cid. e p'la marinha [o haja] artilhr. ${ }^{a}$, e mosquetaria, p. ${ }^{a}$ defender o desembarq' em esse sitio: álem do q' em a dita marinha estão feitas duas Plataformas sahidas ao mar a q' chamão o Forte Real e o

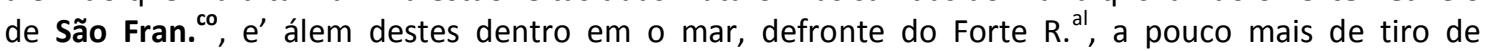
mosquete, ha hum Forte de Figura Esferica guarneçido com quatorze peças, e tudo junto flanquea bastantem. ${ }^{\text {te }}$ toda a marinha. E q. ${ }^{\text {do }}$ a tal armada intente buscar esta Cid. ${ }^{\mathrm{e}}$, pareçe $\mathrm{q}^{\prime}$ há de buscar o desembarq' [em] salvo, e fogir donde possa achar qualquer resistençia, [e' pareçe] será antes de chegar a ella, ou passado avante do Forte de S. ${ }^{\text {to }}$ Ant. ${ }^{\circ}$, por ser boa a praya. Assý o fizerão os Holandeses por duas veses q' forão [a esta] Cidade, não estando cuberta a Marinha de tantos Trapiches, como hoje está; Alem do $q^{\prime}$ a desp. ${ }^{\text {a }}$ ha de ser muy consideravel, $q^{\prime}$ os Beluartes, e Cortinas q' cobrem esta p. ${ }^{\text {te }}$ hão de fazer por serem fundados em dez palmos de agoa de baixa mar, e será trabalho eterno, como tambem a dos seus reparos de terra, por serem [condosidos] do alto da Cid. ${ }^{\mathrm{e}}$, e' com esta [nocea linha] de tão grande despeza, nos pareçe senão ganha mais q' afirmo [siera].

E p'lo q' toca à nossa Linha da forteficação $q^{\prime}$ cinge a Cid. ${ }^{e} p^{\prime}$ la $p .^{\text {te }}$ da Campanha, desenhada p $^{\prime}$ lo d. ${ }^{\circ}$ Engenhr. ${ }^{\circ}$ João Cout. ${ }^{\circ}$, nos pareçe se deve de seguir o seu... [FI. 123v]... desenho, visto a linha da forteficação velha, $q^{\prime}$ he a $q^{\prime}$ se mostra na Planta de cor encarnada, [estar] arruinada em $\mathrm{m}^{\text {tas }} \mathrm{p}$. ${ }^{\text {tes }}$ e sem fossos por ser de terra, sem [emb. ${ }^{\circ}$ ] do d. ${ }^{\circ}$ Engenhr. ${ }^{\circ}$ dizer na sua relação ser feita ha quarenta annos, [embp'] de VMg. ${ }^{\text {de }}$ se reformou com grande desp. ${ }^{\text {, }}$, e havendo de se reformar, e abrir fossos, melhor será seguir o novo desenho, $q^{\prime}$ fica com melhores defensas, e se aparta pouco da linha antiga, e fazerIhe a camisa de pedra, e cal, por ser de mais duração, sendo certo q' a de terra (posto q' he excelente) se ha de arruinar a cada paço, como tem mostrado a experiençia[;] e posto $q^{\prime}$ a de pedra e cal seja de $\mathbf{m}^{\text {to }}$ mayor dispendio com tudo he gastos q' se faz por huã ves; e se escusa a desp. ${ }^{\text {a }} q^{\prime}$ de todos os annos será neçessaria, p. a reparar essa forteficação, não tendo camisa de pedra e cal, e se pode justam. $^{\text {te }}$ reçear, $q^{\prime}$ não haja na [q'la] Cid. ${ }^{e}$ a dilig. ${ }^{a}$ neçess. ${ }^{\text {ra }}$, p. $^{a}$ a continua reparação sendo de terra; e havendo tanta pedraria cal[cunaria] $p^{\prime}$ la mayor $p .{ }^{\text {te }}$ deste resinto da Campanha se devem fazer em este sitio fornos de cal, pois tem juntam. ${ }^{\text {te }}$ com a pedra, a lenha: e' supposto dizzer o d. ${ }^{\circ}$ Engenhr. ${ }^{\circ}$ João Cout. ${ }^{\circ}, q^{\prime}$ a Campanha he aspera, e o Adiq' grande, $q^{\prime}$ se mostra na Planta de azul, [cobre] a mayor $p .{ }^{\text {te }}$ deste resinto; buscando o inimigo p'la Campanha, esta Cidade tem som. ${ }^{\text {te }}$ duas entradas, e são aonde está o Forte de São Pedro, q' he feito tambe de terra, já foy reparado emtão do Gov. ${ }^{\circ}$ de Roq' da Costa Barreto hú grande lanço; e' a outra ser aonde defenda o novo Forte; com tudo ha m. ${ }^{\text {tas }}$ pasagens ${ }^{1035} \mathrm{p.}^{{ }^{a}}$ se pode deser ao Adiq', e' [vade] alto co' fasilid. ${ }^{\text {, }}$, com as machinas q' hum Exerçito asalta; ${ }^{1036}$ e nos pareçe se deve confirmar o d. ${ }^{\circ}$ Forte de São Pedro, e fazer o novo Forte, fazendo-lhe o Polígono exterior de 500. p. $^{\text {a }} 600$ pes, permitindo-o o sitio, e tambem as obras Coroa de Hornabeq' de obra mais delgada, porq' he sem duvida, $q^{\prime}$ se esta Cid. ${ }^{e}$ for invadida ha de ser p'la Campanha e não por mar; pois

${ }^{1034}$ São os comentários que acompanham (antes e depois) o Relatório de João Coutinho: AHU - Códice Ms 245, Bahia, fl. 12. Documentos Avulsos, Bahia, Cx. 8, doc. 29 [AHU_ACL_CU_005. Cx. 10, D. 840]. Documento que encaminha à Corte o relatório da proposta de fortificação assinado por João Massé, Miguel Pereira da Costa e Gaspar de Abreu.

1035 Paragens?

1036 Arasta? 
não podera haver Principe $q^{\prime}$ de tão longe possa $m .{ }^{\text {dar }}$ huã Armada tão poderosa, $q^{\prime}$ por mar e terra ataq' esta Cidade, por ser o resinto grande. Tambem nos pareçe $q^{\prime}$ o Armazem apontado $p$. $^{a}$ a polvora na marinha he conveniente, por ser mais prompta a forneçella e receber a polvora dos navios, q' vão àquelleEstado.

Em esta Cidade ha seis mil homes q' pegão em armas da ordenança; e porq' o desentulho dos fortes, levado aos terraplenos, fazendo-se por conta da faz. ${ }^{\text {da }}$ real fará huã grossa adição, pareçe-nos q' se deve repartir igualm. ${ }^{\text {te }} p^{\prime}$ las Comp. ${ }^{\text {as }}$ das ordenanças, a $q^{\prime}$ chamamos impreitadas, ao comprim. ${ }^{\text {to }} q^{\prime}$ couber a cada huã, nomeando-Ihe a largura e altura; e q. ${ }^{\text {do }}$ estas Comp. ${ }^{\text {as }}$ não podem co' este trabalho, e estas do Brazil não são . $^{\text {a }}$ m. $^{\text {to }}$, costumão os seus Cap. ães buscar gastadores, e co' elles se consertão, e aq'le tanto terão [essés] dos soldados, com q' se pagão estes gastadores, e elles da sua mão fazem estes pagam. ${ }^{\text {tos }}$, com q' ficão livres de algú [eserugulo], $p .^{\text {a }}$ o $q^{\prime}$ ha de haver em cada Terço [Thez. ${ }^{\text {ro }}$ ], e Escrivão, co' L. ${ }^{\circ}$ de receita, e desp. ${ }^{a}$ como houve na forteficação desta Cid. ${ }^{e}$ rubricado p'lo Mestre de Campo ou Coronel. Isto he o q' podemos dizer. Pl'o q' vemos das Plantas, relação e' informações q' nos deu o Gov. ${ }^{\text {or }}$ Roq' da Costa Barreto.

Ao Mestre de Campo Miguel de Lascole Engenhr. ${ }^{\circ}$ da Provinçia dentre Douro, e Minho, pareçeo, q' a nova forteficação p'la marinha se devia de fazer de pedra e cal, na forma do desenho do Engenhr. ${ }^{\circ}$ João Cout. ${ }^{\circ}$, e' a nova fortificação $p^{\prime} l a ~ p .{ }^{\text {te }}$ da Campanha, $p^{\prime}$ lo mesmo se devia escusar, e reparar a fortificação velha de terra, fazer as obras Coroa, Hornabeq', e novo Forte, consenciando o de São Pedro.

O mesmo pareçeo ao Sargento mor Hieronymo Velho de Azevedo Engenhr. ${ }^{\circ}$ da Provincia da Beira.

Ao Sarg. ${ }^{\text {to }}$ mor Ant. ${ }^{\circ}$ Roiz de [Carus. ${ }^{\circ}$ ], e Cap. ${ }^{\text {ão }}$ Gregorio Pacheco de [Mores] Engenhr. ${ }^{\circ}$ da Prov. ${ }^{\text {cia }}$ do Alentejo, pareçeo se conservasse o Forte de São Pedro, $q^{\prime}$ está feito, e se fizesse o novo Forte, e se reedificassem as trinchr. ${ }^{\text {as }}$, e $q^{\prime}$ p'la marinha se fizessem alguñs vedantes; ${ }^{1037}$ e considerarão] valer a

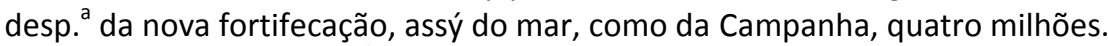

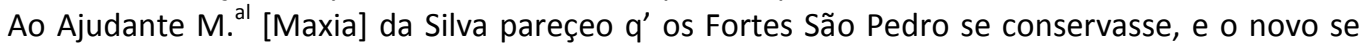
fizesse, e a forteficação velha se reparasse, havendo[-a], e nos dois despenhadeiros nos extremos da Cid. ${ }^{\text {e }}$, q' ce[hem] sobre... [Fl. 124]... o mar, se fizessem huãs Trinchr. ${ }^{\text {as }}$ com seus [redentos], ${ }^{1038} \mathrm{e}$ [travezes], tudo de terra, e p'la p. ${ }^{\text {te }}$ do mar se fizesse mais capaz a Plataforma, $q^{\prime}$ chamão São Phelippe, e ella com a de São Fran. ${ }^{\text {co }}$, fazendo-se mais alguã era bastante $p$. $^{\text {a }}$ flanquear ${ }^{1039}$ marinha com o $q^{\prime}$ se ficava poupando huã consideravel desp. ${ }^{a}\left[\right.$ Lx. $^{a}$ ] 21.de Março de 1686 / Franc. ${ }^{\text {co }}$ Pimentel / Matheos do Couto / M. ${ }^{\text {al }}$ Gomes Ferr. ${ }^{\mathrm{a}}$ /

Os engenhr. ${ }^{\text {os }}$ abaixo assinados vimos as Plantas da forteficação da Cid. ${ }^{\mathrm{e}}$ da B. ${ }^{\mathrm{a}}$ de Todos os S. ${ }^{\text {tos }}$, e relação feita, huã e outra couza feita p'lo Enhgenhr. ${ }^{\circ}$ João Cout. ${ }^{\circ}$, como també os pareceres dos Engenhr. ${ }^{\text {os }}$ das Prov. ${ }^{\text {cias }}$ de [Se Pinh. ${ }^{\circ}$ ] e nos conformamos com o parecer Emgenhr. ${ }^{\text {os }}$ o Sarg. ${ }^{\text {to }}$ mor Mattheus do Coito, o Cap. ${ }^{\text {ao }}$ Franc. ${ }^{\circ}$ Pimentel, e o Ajudante $M{ }^{\text {el }}$ Gomes Ferr. ${ }^{\text {, }}$, porq' a camisa de pedra e cal he desp. ${ }^{a}$ feita por huã ves, e não avendo a forteficação he sem duvida, $q^{\prime}$ he neçess. ${ }^{\circ}$ huã gr. ${ }^{\text {de }}$

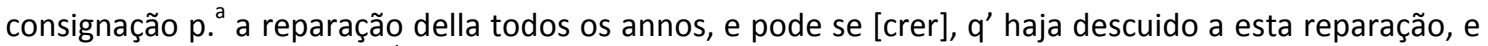
$q^{\prime}$ a consignação $q^{\prime}$ VMg. ${ }^{\text {de }}$ Ihe consignar, se [deceirta] em outros [affeitos]. E declaramos q' esta forteficação se ha de priçipiar p'la p. ${ }^{\text {te }}$ de $S^{\text {to }}{ }^{\text {Ant. }} .^{\circ}$ [L/E. F.M.], e nesta forma ir até o outro extremo $p^{\prime} l o$ novo desenho, até o Baluarte A., e fazer o novo Forte, q' está desenhado no outeiro do Barbalho, fazendo seu poligono de 500; ou 600. pes, podendo ter, e então passar às obras Coroa, e Hornaveq'; co' declaração, q' os [corpos] dos Baluartes da Linha q' [singa] a Cid. ${ }^{\text {e }} p^{\prime}$ la $p .{ }^{\text {te }}$ da Campanha, perfira a tudo, [e ult. ${ }^{a}$ m. $^{\text {te }}$ ] as Cortinas. Isto he o q' pareçeo VMg. ${ }^{\text {de }}$ mandará o q' for servido. [Ix. ${ }^{a}$ ] 23. De Março

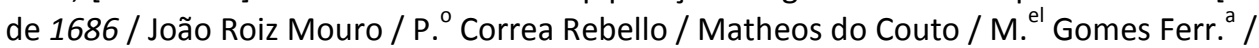

Papel q veyo por copia [imelaso] no dito [Desenho], sobre se minorarem os preços das obras das forteficações da Cid. ${ }^{e}$ da B. ${ }^{a}$

Pareçe conveniente se dé abatim. ${ }^{\text {to }}$ ao preço em $q^{\prime}$ João Cout. ${ }^{\circ}$ analisou a obra da forteficação declarando $q^{\prime}$ não erão neçess. ${ }^{\text {ros }}$ duz. ${ }^{\text {tos }}$ mil cruz. ${ }^{\text {dos }}$ p. $^{\text {a }}$ os Beluartes, $q^{\prime}$ se escusão na marinha; nem

\footnotetext{
${ }^{1037}$ Redantes?

${ }^{1038}$ Vedantes?

${ }^{1039}$ A?
} 
duz. ${ }^{\text {tos }}$ e çincoenta mil cruz. ${ }^{\text {dos }}$, $q^{\prime}$ elle orsou p. ${ }^{\text {a }}$ os fortes da Praça, a quatrocentos [he] a braça, porq' não ha de faltar na B. ${ }^{a}$ quem abra os fossos por treze, até catorza vinteis a braça, q. ${ }^{\text {do }} \mathrm{SMg} .{ }^{\text {de }}$ queira [alicciar] as ordenanças, e g. ${ }^{\text {te }}$ paga deste trabalho, ou desta desp. ${ }^{a}$ Também orçou João Cout. ${ }^{\circ}$ o lagedo $p .{ }^{a}$ toda a artelhr. ${ }^{a}$, em cem mil cruz. ${ }^{\text {dos }}$, a contra escarpas artificial da alvenaria em cincoenta mil cruz. ${ }^{\text {dos }}$, quer revestir os Fortes antigos de São $\mathbf{P}^{\circ}$, e' $^{\prime}$. $^{\text {to }}$ Ant. ${ }^{\circ}$, co' camisa de pedra, e cal, por oitenta mil cruz. ${ }^{\text {dos }}$, construir de novo outro Forte no oiteiro do Barbalho $\mathrm{co}^{\prime}$ oitenta mil cruz. ${ }^{\text {dos }}$, sendo q' estas obras exteriores, e [desatacadas], podem ficar de [gazon], ou torrão, por ser o terreno acomodado p. ${ }^{a}$ isso em obras pequenas, e o lagedo p. ${ }^{\text {a }}$ uso da artilhr. ${ }^{\text {a }}$; e a contra escarpa arteficial de alvenaria, estão avaliadas $\mathrm{m}^{\text {to }}$ caras; $\mathrm{e}^{\prime}$ assý pareçe $\mathrm{q}^{\prime}$ o Marques das Minas $\mathrm{q}^{\text {do }}$ ajustar, deve procurar minorar estes preços o mais $q^{\prime}$ for possivel.

Escrito do Bispo Secretr. ${ }^{\circ}$ de Estado p. ${ }^{a}$ o Conde de Valde Reys Presidente do Conc. ${ }^{0}$ p. ${ }^{a}$ se lançarem em [S]. ${ }^{\circ}$ os papeis q' co' elle vierão sobre as forteficações da Cid. ${ }^{e}$ da B. ${ }^{a}$

[A Margem. A Planta remeterey a (VZ. $\left.{ }^{a}\right)$ hoje. ${ }^{1040}$

S. Mg. ${ }^{\text {de }} \mathrm{q}^{\prime}$ Deos g. ${ }^{\text {de }}$ me manda dizer a V.S ; $\mathrm{q}^{\prime}$ [passadas as ordens] $\mathrm{q}^{\prime}$ hão de ir à Bahia sobre a forteficação, em virtude do Decreto q' será com este escrito. V.S. ${ }^{a}$ ordena, $q^{\prime}$ todos os papeis q' vão co' o dito Decreto se copiem em hú L. ${ }^{\circ}$ p. ${ }^{a}$ ficar no Conc. ${ }^{\circ}$; e os proprios se tornem a m. ${ }^{\text {dar }}$ à secretr. ${ }^{a}$ de Estado p. $^{a}$ ficarem nella; e q' VS. ${ }^{a}$ tenha particular advertencia de procurar se [se] executa assý. Ds g. ${ }^{\text {de }}$ a V.S. ${ }^{a}$ m. ${ }^{\text {tos }}$ annos. Paço 25.de Março de 1686 / O Bispo Fr. M. ${ }^{\text {el }}$ Pr. ${ }^{\text {a } /}$

[Fl. 127 - Final] [Á margem da Letra de Roq'/ Montr. ${ }^{\circ}$ Paim/ SMg. ${ }^{\text {de }}$ se conformou co' o assento /incluso e [nas ordens] q' se passa/vem, manda por as declara-/ çoens, q' aponta Roq' da Costa/ Barr. ${ }^{\text {to }}$. Ln. ${ }^{\text {a }}$ em 22.de Março/ de 686 / Roq' Mont. ${ }^{\text {ro }}$ Paim./ Da [lebra] de Luis Teix. ${ }^{\text {ra }}$ de/ Carv. ${ }^{\circ}$ / Deste papel não ha de ir a cópia/ ao Brazil, e' assý se adverte].

Escrito de Roq' da Costa Barreto, p. ${ }^{\text {R }}$ Roq' Montr. ${ }^{\circ}$ Paim, sobre a forteficação da Bahia.

Sý o papel dos Engenhr. ${ }^{\text {ss }}$ sobre a forteficação da B. ${ }^{\text {a }, ~ e ~ m e ~ p a r e c ̧ e ~ q ' ~ e s t a ́ ~ c o n f o r m e, ~ c o m ~ o ~ q ' ~ h o n t e m ~ s e ~}$ assentou na junta; mas tambem seria conveniente, $q^{\prime}$ no mesmo papel se desse 0 abatim. ${ }^{\text {to }}$ ao preço, em q' João Cout. ${ }^{\circ}$ avaliou aquella obra, declarando, $q^{\prime}$ não erão neçess. ${ }^{\text {ros }}$ duzentos mil cruz. ${ }^{\text {dos }}$ p. $^{\text {a }}$ os Beluartes, $q^{\prime}$ se escuzão na marinha; nem duz. ${ }^{\text {tos }}$ e cincoenta mil cruzados, $q^{\prime}$ João Cout. ${ }^{\circ}$ orçou p. ${ }^{a}$ os fossos da Praça, a quatrocentos rs a braça, porq' não há de faltar na Bahia que abra os fossos por treze, até quatorze vinteis a braça, ${ }^{1041}$ q. ${ }^{\text {do }} \mathrm{SMg} .{ }^{\text {de }}$ queira aliviar as ordenanças, e g. ${ }^{\text {te }}$ paga deste trabalho, ou desta despeza. Tambem orçou o lajedo p. ${ }^{\text {a }}$ toda a artilhr. ${ }^{a}$ em cem mil cruz. ${ }^{\text {dos }}$, a contra escarpa artifiçial de alvenaria em cincoenta mil cruz. ${ }^{\text {dos }}$, quer revestir os Fortes antigos de São P. ${ }^{\circ}$, e de S. $^{\text {to }}$ Ant. ${ }^{\circ}$, com camisa de pedra, e' cal, por oitenta mil cruz. ${ }^{\text {dos }}$, construir de novo outro Forte ${ }^{1042}$ no oiteiro do Barbalho com oitenta mil cruz. ${ }^{\text {dos }}$, sendo $q^{\prime}$ estas obras exteriores, e desatacadas, podem ficar de gazon, ou torrão, por ser o terreno aco'modado . $^{a}$ isso em obras pequenas; e' o lajedo p. ${ }^{a}$ o uso da artilhr. ${ }^{a}, e^{\prime}$ a contra escarpa artificial de alvenaria, estão avaliadas $\mathrm{m}$. ${ }^{\text {to }}$ caras. Deos $\mathrm{g}$. ${ }^{\text {de }}$ a $\mathrm{VM} \mathrm{m}^{\text {tos }}$ annos. 22.de Março de 1686 / Roq da Costa Barreto./

Escrito do Secretr. ${ }^{\circ}$ de Estado Fran. ${ }^{\text {co }}$ Correa de Lacerda, p. ${ }^{a}$ Roq Montr. ${ }^{\circ}$ Paim.

Vy todos os papeis q' VM me entregou sobre a forteficação da Bahia, e falley com o Conde M. ${ }^{\text {el }}$ Telles; e no $q^{\prime}$ falta à marinha me conformo com os Emgenheiros de [Lx. ${ }^{a}$ ], e $e^{\prime}$ [ter neste] com os Engenhr. ${ }^{\text {os }}$ do Minho, Beira, e Alentejo, $q^{\prime}$ estão conformes, começando o trabalho $p^{\prime}$ las duas $p .{ }^{\text {tes }}$, por onde a Cidade póde ser aproxada, e logo p'la Casa da polvora, q' preme, e urge mais aq' le perigo, q' outro algú. D’s g. ${ }^{\text {de }}$ a VM. Casa Sabbado. Fran. ${ }^{\text {co }}$ Correa de Lacerda./

[FI. 127v] Parecer do Engenhr. ${ }^{\circ}$ Fran. ${ }^{\text {co }}$ Pimentel incluso no ezercitto atras, p. $^{\text {a }}$ Roq Montr. ${ }^{\circ}$ Paim

\footnotetext{
${ }^{1040}$ Anotação à parte.

1041 Trecho igual ao da FI. 124.

1042 Outro pleonasmo como parte da linguagem (em geral não se constrói “de novo" “outro”...).
} 
A minha doença não me dá lugar a assistir na conferencia, $p .^{a} q^{\prime}$ VM me chamou, acerca da forteficação da Cidade da B. ${ }^{\text {a }, ~ e ' ~ d o ~ p a r e c ̧ e r ~} q^{\prime}$ sobre ella deu Fran. ${ }^{c o}$ Correa de Laçerda - Tomey por tanto a confiança de dizer a VM o meu voto por escritto.

Resolveo Fran. ${ }^{\text {co }}$ Correa de Laçerda, $q^{\prime}$ a çircunvalação da Cid. ${ }^{e}$ por $p .{ }^{\text {te }}$ da Campanha se fizesse de terra, aco'modando-se co' os [restos] dos Engenhr. ${ }^{\circ \text { s }}$ de Alentejo, fundados por [ventara], em q' não havia pedra, e cal naquelle Estado; e' q' a Cid. . podia sóm. ${ }^{\text {te }}$ ser aco'metida por duas entradas, aonde estão desenhados dous Fortes nos fins do Adiq' grande. Mas estas supposições são falças, por falta das noticias q' dá o g. ${ }^{\text {al }} \mathrm{q}^{\prime}$ foy Roq' da Costa Barreto, affirmando haver abundancia de alvenaria e cal e poder o Adiq' ser [vadeado], e' aco'metida a Cid. ${ }^{e}$ por qualquer $p$. $^{\text {te }}$. Pello $\mathrm{q}^{\prime}$, assý como dizem, $\mathrm{q}^{\prime}$ as $\mathrm{d} .^{\text {as }}$ entradas se fortifiquem co' Fortes bem capazzes, deve p'la mesma razão, ser o mesmo em toda a linha. Entendo $q^{\prime}$ se Fran. ${ }^{c o}$ Correa deLaçerda se não fundara naq'las supposições, houvera de ser de pareçer $q^{\prime}$ a forteficação se fizesse de pedra, e cal, por ser mais duravel, e' permanente. E não [obita], q' seja de mayor custo, porq' isto he gasto $q^{\prime}$ se fás por huã só ves, $q .{ }^{\text {do }}$ fazendo-se de terra, será neçess. ${ }^{\text {ra }}$ huã consignação larga, . $^{\text {a }}$ se andar continuam. ${ }^{\text {te }}$ reedificando, pois he sem duvida $q^{\prime} p^{\prime}$ la qualid. ${ }^{\text {e }}$ da obra de terra, e' p'las continuas chuvas daq'le clima se há de ir arruinando continuam. te. Pello q' sou do mesmo pareçer, q' tenho já dado, a saber q' esta obra se faça de pedra e cal.

$Q^{\text {to }}$ á Linha $q^{\prime}$ se ha de seguir, me pareçe, $q^{\prime}$ seja a nova $q^{\prime}$ João Coutinho desenhou, pois he sem duvida $q^{\prime}$ está mais bem flanqueada, $q^{\prime}$ a antiga, $e^{\prime}$ assý o confessa Miguel de Lescolle, e' os mais Engenhr. ${ }^{\text {os }}$ nos seu pareceres. Ao $q^{\prime}$ se acresçenta, $q^{\prime}$ a linha antiga está $p^{\prime l}$ la mayor . $^{\text {te }}$ arruinada, e havendo de se reformar, se deve fazer (sem emb. ${ }^{\circ}$ de haver de custar alguã cousa mais) em melhor forma, $q^{\prime}$ he a desenhada por João Cout. ${ }^{\circ}, e^{\prime} q^{\prime}$ esta seja em melhor forma todos o confessão. Isto he o $q^{\prime}$ julgo p'la Planta, e relações; e' só vendo o terreno, a Cid. ${ }^{\text {e }}$ poderia dar melhor voto. Ds g. ${ }^{\text {de }}$ a VM m. ${ }^{\text {tos }}$ annos. De Casa 25.de Março de 1686 / Fran. ${ }^{\text {co }}$ Pimentel./

Carta de Matthias da Cunha p. ${ }^{a}$ o Bispo Secretr. ${ }^{\circ}$ de Estado, sobre as Plantas do Brazil

Sñor. Com esta remeto a VS. ${ }^{a}$ as Plantas da Cid. ${ }^{e}$ da B. ${ }^{a}$, e descurso do terreno dellas, $q^{\prime}$ me entregou p. ${ }^{a}$ dar ao Mestre de Campo Engenhr. ${ }^{\circ}$ Miguel de Lescolle, com o pareçer delle. G. ${ }^{\text {de }}$ Deos a VS. ${ }^{a} /$ Matthias da Cunha /.

Pareçer do Engenhr. ${ }^{\circ}$ Miguel de Lescolle incluzo na Carta asima, sobre a forteficação da Bahia.

S. ${ }^{r}$ G. ${ }^{\text {al }}$ Vy, e examiney meudam. ${ }^{\text {te }}$, as Plantas da forteficação ... antiga, e nova, propostas p. ${ }^{a}$ a Cid. ${ }^{\text {e }}$ da B. ${ }^{a}$

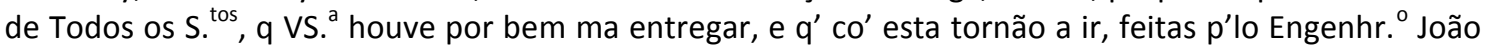
Cout. ${ }^{\circ}$ co' o papel da explicação das d. as $^{\prime}$ Plantas. O lanço da forteficação proposta nellas p'la p. ${ }^{\text {te }}$ do mar, me pareçe $\mathbf{m}^{\text {to }}$ acertado, conveniente e mais preciso $q^{\prime}$ nenhuã outra cousa, por ser a $p .^{\text {te }} q^{\prime}$ se póde presumir será a prim. ${ }^{\text {ra }}$ aco'metida de huã Armada inimiga, e de donde póde vir os mayores reçeos, e do Perfil q' está na Planta, $q^{\prime}$ provavelm. ${ }^{\text {te }}$ he só $p^{\prime}$ la forteficação da $p .{ }^{\text {te }}$ da terra, nem se póde bem julgar a quantid. ${ }^{e}$ de braças cubicas de mil palmos de alvenarias, e de terras poderá haver na fabrica deste lanso, p. ${ }^{\text {a }}$ o q' ao fim de poder fallar com alguã aparençia de çerteza, supús outro Perfil de huã parede de alvenaria de pedra, e' cal de $27^{[1 / 2]}$ palmos de alto, ate seu cordão, com 10.palmos de gros-... [FI. 128]... so por sima, e' $15^{1 / 2}$ por baixo a sua escarpa exterior; ficando de hum palmo sobre çinco, e por sima delle hum parapeito à barba da mesma alvenaria dos 10.palmos de grosso a prumo com $4^{1 / 2}$ palmos de altura interior, e de 3 no exterior, começando esta parede de hú dos [Redentes] da ladeira, até o outro oposto, q' segundo este Perfil farão quatro mil, e noventa e sette e meya braças cubicas de obra, aq'la altura me pareçe poderá bastar, por se dizer no papel asima apontado, q' o mais fundo da agoa, nos lugares em q' se hão de assentar os quatro Beluartes deste Santo, não passa de dez palmos de fundo nas marés vazias; e' se estou lembrado, as marés daquella Costa de preamar são de dez, até doze palmos de alto, e talvez menos, $q^{\prime}$ são vinte, a vinte e dous palmos de altura, e' . $^{\text {to }}$ os tiros da artilhr. ${ }^{\text {a }}$ avesinhão mais do [Rento] da superfiçie da agoa, mais certos são, e de mayor effeito nas embarcações contr. ${ }^{\text {as }}$ Dei mais este papel , $q^{\prime}$ este fundo he fixo, e seguro, e o q' confirma a vezinhança das Casas dos $m .^{\text {res }}, q^{\prime}$ se chegão até dentro do mar, . $^{a}$ o q' nem aponta aliçerses nenhús a esta parede de braço, daquella suponho só fará hum Rampardo de terra de quatro palmos de largura por sima, com sua escarpa natural p'lo interior, e de vinte e tres e meyo palmos de altura, igual a da pouco mais, ou menos, largura bastante p. ${ }^{a}$ o jogo da artilhr. ${ }^{a}$ mais grossa (e nenhuã neçessid. ${ }^{e}$ trinta e seis palmos de largura poderião bastar em particular nas cortinas.) Este Rampardo assý suposto, fará treze mil, quatroçentos e sessenta braças cubicas de terra, com q' seria façil, p'los preços q' do papel dito asima, 
[dei] estão em outro papel dos orsam. ${ }^{\text {tos }}$ das obras, $q$ 'tambem remeteo, se saber o çerto, $q$ ' estes poderão fazer.

A forteficação proposta, e delineada na Planta $p^{\prime}$ la $p .{ }^{\text {te }}$ da terra, he bem regular, com boas defensas, $e^{\prime}$ as maximas da forteficação olandezas, ou do Engenheiro mor Luiz Serrão Pimentel bem seguidas, ${ }^{1043}$ e

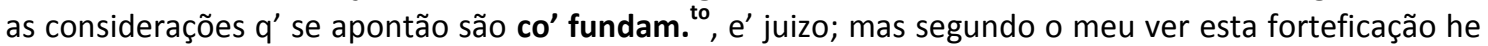
superflua, e o Perfil da Planta della he exçessivo, sendo capaz, e de [sobejo] p. ${ }^{a}$ se oppor às baterias dos Ex. ${ }^{\text {tos }}$ mais poderosos, $q^{\prime}$ hoje se estão na Europa esecuzando hum dispendio dobrado do neçessario.

Esta forteficação proposta, guarda a mesma situação, e terreno, q' a velha, com pouca differença; Aquella velha, ainda q' ella não seja co' a regularid. ', e perfeição da proposta, e' co' maximas extravaganttes, mais baixa, $e^{\prime}$ em alguãs $p .{ }^{\text {tes }}$ sem fossos, não deixa de se flanquear em todas as $\mathbf{p} .{ }^{\text {tes }}$, e o fosso natural profundo, e na mayor p. ${ }^{\text {te }}$ com agoa, $q^{\prime}$ na Planta chamão o Adiq' grande, se [copre] bastantem. ${ }^{\text {te }}$ a baixeza e' irrigularid. ${ }^{\text {e }}$ de sua forteficação, e' a [pençeridade] dos seus fossos, e' os mil, ou mil e duz. ${ }^{\text {tos }}$ pes, em q' se diz, q' o inimigo se póde chegar da forteficação, sem ser visto, nem he defeito mortal, $\mathrm{q}^{\prime} \mathrm{m}$. ${ }^{\text {tas }}$ Praças tidas por boas a padessem, e mayorm. ${ }^{\text {te }}$ nesta, $\mathrm{q}^{\prime}$ por o inimigo se chegar a esta Praça na distançia della tem ainda p. ${ }^{\text {a }}$ atravessar a profundeza do Adiq', ou buscar huã das duas avenidas, q' este Adiq' deixa abertas, q' serão forteficadas sobre sy, como se dirá depois, o q' não se fas

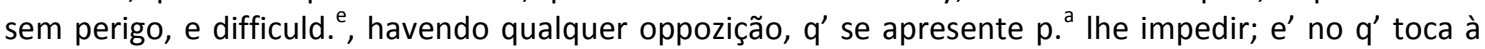
distançia dita, em q' o inimigo se póde chegar sem ser visto, os aproxes de hoje se costumarão começar adiante das melhores Praças em mesma distançia; e' hum Engenhr. ${ }^{\circ}$ pratico não deixa de Ihos [desputar] o terreno, e de o [renfadar]; e se deve considerar, q' o inimigo q' ha de vir buscar esta Praça, não será dos Carejos, ou Tapuis dos erredores, q' húa numeroza quantid. ${ }^{\text {e }}$ desta, pois o[vereo] poderá causar, por lhes faltar as formas, meyos, e metodos de acometer; ${ }^{1044}$ mas q' este inimigo ha de vir do mar em fora, e q' a mayor, e mais poderoza Armada, $q^{\prime}$ possa vir de qualquer $p$. $^{\text {te }}$ do Norte $q^{\prime}$ seja, apenas desembarcará dez mil soldados, e $m .{ }^{\text {to }}$ pouca Cavalhr. ${ }^{a}$ em razão $q^{\prime}$ a distançia do transito não o permite, $e^{\prime} q^{\prime}$ a artilhr. ${ }^{a}$ de $q^{\prime}$ ella se ha de servir, ha de ser dos proprios navios, daquella a mais grossa, nem passará de 24.libras de balla, $\mathrm{e}^{\prime}$ ainda $\mathrm{q}^{\prime}$ ella possa ser $\mathrm{m}^{\text {ta }}$, ha de começar suas baterias de $\mathrm{m}^{\text {to }}$ longe, por causa do Adiq grande, e dez mil homes acometendo huã Praça deste porte, não a Levando de [repelão], assý q' se pode presumir desta, em breves semanas se [altinua], e' impossibilita p'lo continuo trabalho, $\mathrm{q}^{\prime}$ este pequeno numero de g. ${ }^{\text {re }}$ está obrigado a padeçer, com $\mathrm{q}^{\prime}$ teria de pareçer, $\mathrm{q}^{\prime}$ se

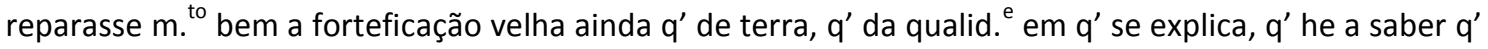
em passante de quarenta annos $q^{\prime}$ he feita, não lhe suscçedeo ruina nenhuã, senão aquella $q^{\prime} \circ$ descuido, e negligencia permitio se lhe fizesse, $q^{\prime} p{ }^{a}$ huã forteficação se deva fazer preferir, e ter por melhor , q' as muralhas de alvenaria, causa q' a experiençia tem mostrado em varias occasioes de todas suas ruinas, e aberturas superfluas, $e^{\prime}$ se continuar os seus fossos nas $p .{ }^{\text {tes }}$ neçess. ${ }^{\text {ras }}$ reparando, ou fazendo de novo os seus parapeitos da mesma terra, nas $p$. $^{\text {tes }} q^{\prime}$ serão falsos delles, e çercando o todo de hú parapeito de estrada cuberta, ajuntando-Ihe as obras exteriores, formadas de hum leve Rampardo, ${ }^{1045}$ nas p. $^{\text {tes }} q^{\prime}$ mais o pedirem, como no Lugar da obras coroada, Hornaveq', e façe do Beluarte sinalado G. da forteficação proposta, e' q' o mesmo se faça e da mesma terra do Forte de São $\mathbf{P}^{\circ}{ }^{\circ}, \mathbf{q}^{\prime}$ tomará espaço todo o Largo do [terzo] em q' elle está situado, [atroq'] da p. ${ }^{\text {te }}$ da largura dos fossos dos seus lados, cairem no pendente do terreno das duas profundezas q' os acompanha, e de não ter parapeito da estrada cuberta, senão na dianteira delle na . $^{\text {te }}$ do Sudoeste, p. $^{\text {a }}$ melhor tapar essa avenida, q' deixa entre sy os dous Adiques grande, e pequeno. ${ }^{1046} \mathrm{E}$ tambem me pareçe a proposito a fabrica do Forte novo proposto, da outra p. ${ }^{\text {te }}$ opposta ao de São Pedro na outra avenida q' chamão do Barbalho, porem desejava q' elle fora de Poligono exterior, mayor q' o proposto, p'la mesma razão dita, como de quinhentos, a seiscentos pees, ou de settenta e cinco, a novéta braças craveiras, conforme o terreno o poder sofrer, formado todo da dita... [Fl. 128v]... terra; e' q'se começasse esta forteficação por estes dous Fortes, e' p'lo lanço de ao longo do mar, deixando a reparação da forteficação velha, e a fábrica de suas obras exteriores p'lo derradeiro. Mediante o $q^{\prime}$ pareçe $q^{\prime}$ esta Praça terá bastante $p^{a}$ empatar os intentos de qualquer Armada por poderoza q' possa ser; as quaes obras, a saber, da reformação da forteficação velha, suas obras exteriores, parapeitos da estrada cuberta, e dos dous Fortes feitos de terra, creyo se poderá fazer com cento e' vinte mil cruz. ${ }^{\text {dos }} \mathrm{E}$ q. ${ }^{\text {do }}$ se pareça seguir a forteficação nova proposta, por mais elegante, e de melhores maximas, sempre reformaria o exçesso

\footnotetext{
1043 Cf. OLIVEIRA, 2004: 102 e 182 (nota 940).

1044 Início da mais longa frase.

${ }^{1045}$ Rampardo?

${ }^{1046}$ Ufa!
} 
do seu demasiado Perfil, e' fizera a sua face exterior toda de terra, visto ser tão boa q. ${ }^{\text {to }}$ elle diz, o $q^{\prime}$ a pouparia $\mathrm{m}^{\text {to }}$ dispendio de pedra e cal, o q' lá não ha sobeja, e' assý feita toda de terra, seg. ${ }^{\text {do }}$ os muy orsam. $^{\text {tos }}$, não passaria a sua fabrica de duz. ${ }^{\text {tos }} \mathrm{e}^{\prime}$ vinte mil cruzados, álem dos cento e vinte mil já ditos; Isto he o q' se me offereçe, e' posso dizer sobre o particular desta forteficação, e de suas Plantas. Sua Mag. ${ }^{\text {de }} q^{\prime}$ Deos g. ${ }^{\text {de }}$, mandará dispor o q' se achar mais conveniente a seu real serviço. A pessoa de VS. ${ }^{a}$

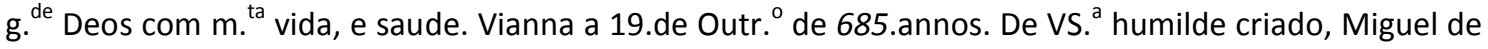
Lescolles

Carta do Sarg. ${ }^{\text {to }}$ mor Engenhr. ${ }^{\circ}$ da Beira Hieronymo Velho de Az. ${ }^{\text {do }}$ p. ${ }^{\text {a }}$ Roq. Montr. ${ }^{\circ}$ Paim, sobre a forteficação da Bahia.

S. ${ }^{\text {or }}$ meu. Vy os papeis e Plantas, a q' co'esta vay o meu pareçer sobre tudo o q' me pareçe he neçess. ${ }^{\circ}$ fazer-se, e' com esta vão tambem as Plantas e' mais papeis no mesmo canudo, o qual me entregou o proprio $\mathrm{m}^{\text {to }}$ mal tratado, $\mathbf{q}^{\prime}$ me pareçe cahio com elle, $\mathrm{e}^{\prime}$ me custaram $\mathrm{m}^{\text {to }}{ }^{\text {torna-lo a endireitar. }}{ }^{1047}$ Fico sempre às orden's de VM, cuja pessoa g. ${ }^{\text {de }}$ Deos feliçes annos. Almeida 12 de Março de 686 / Criado de VM. Hieronymo Velho de Azevedo /

Pareçer do Engenhr. ${ }^{\circ}$ Hieronymo Velho de Az. ${ }^{\text {do }}$ incluso na Carta asima, sobre a forteficação da B. ${ }^{a}$

Com atenção vy as Plantas nova, e velha, feita p'lo Engenhr. ${ }^{\circ}$ João Cout. ${ }^{\circ}$ p. ${ }^{\text {a a }}$ Cid. ${ }^{\mathrm{e}}$ da Bahia de Todos os $\mathrm{S}^{\text {tos }}, \mathrm{e}^{\prime}$ co' ellas sua explicação por Letra; e' tudo ponderado, digo meu parecer.

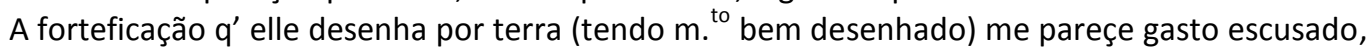
porq' quasi vay $p^{\prime}$ la mesma . $^{\text {te }}$ da trinchr. ${ }^{\text {a }}$ [volta a q cid.] está bastantem. ${ }^{\text {te }}$ defendida, ainda q' não esteja co' a perfeição daq'elle desenhado novo, basta estar bem defendida, e' ocupar (como elle diz) as p. ${ }^{\text {tes }}$ mais eminentes. E q. ${ }^{\text {to }}$ à matr. ${ }^{\text {a }}$ de $q^{\prime}$ deve ser feita, vistas as razões q' elle dá da duração do terreno, se devem consertar suas ruinas; $e^{\prime}$ se deve ter grande cuidado a quem dá causa a ellas, $p$. $^{a} q^{\prime}$ assý se conservem, fazendo-se $p$. $^{\text {a }}$ as servintias as portas neçess. ${ }^{\text {ras }}, q^{\prime}$ em terreno tão bom (como dis he) se escusa gasto de muralhas, $q^{\prime}$ he certo se fora possivel, se tirarão de qualquer praça, na occasião q' fosse atacada, pois aquellas se não fazem, se não p. ${ }^{a}$ a duração contra os temporaes, a qual duração tem os terrenos ditos. $\mathrm{E} \mathrm{q}^{\prime}$ seus fossos se irão continuando nas $\mathrm{p}^{\text {tes }} \mathrm{em}^{\prime} \mathrm{q}^{\prime}$ Ihe faltão, fazendo â dita trinchr. ${ }^{\text {a }}$ seus parapeitos, tudo de terra co' suas façes de torrão, e por fora do fosso sua estrada encuberta. $E$ [posi] pella d. ${ }^{\text {ta }}$ p. ${ }^{\text {te }}$ de terra, dis não pode ser atacada senão por duas $\mathbf{p .}^{\text {tes }}$, dando mais outra, $\mathbf{q}^{\prime}$ fas tres, e nessas ha de passar quem o fizer, e p. ${ }^{a}$ huã q' dis se deve fazer o Forte de São $\mathbf{P}^{\circ}{ }^{\circ}$, dando-se-lhe todo o comprim. ${ }^{\text {to }} q^{\prime}$ poderem a seus Poligonos, . $^{\text {a }} \mathrm{q}^{\prime}$ fiq' mais capaz do q' mostra a Planta, ainda $q^{\prime}$ seu fosso, $e^{\prime}$ estrada encuberta, deça p. ${ }^{\text {a }}$ os baixos, ficando elle sñor de todo o alto, de modo q' seguir bem a abertura entre os dous Adiques. E o Forte novo he bem feito na $p .{ }^{\text {te }}$ assinalada, pois he outra [p. ${ }^{\text {te }}$ ], e fica dando a mão ao de S. $^{\text {to }}$ Ant. ${ }^{\circ} q^{\prime}$ he a outra, e as tres $q^{\prime}$ dis; com declaração, $q^{\prime}$ o novo $q^{\prime}$ vem desenhado não tem mais de 375. Pés de Poligono exterior, e acho ser pouco, $q^{\prime}$ sempre os quisera de 500. p. $^{\text {a }}$ sima, . $^{\text {a }}$ serem capazes. E estes Fortes, sendo como he ( $p^{\prime} l o$ q' dis) o terreno tão bom, e de tanta [terra], se farão sóm. ${ }^{\text {te }}$ de terra, co' sua façe de torrão, levando tambem seus fossos, e' estrada encuberta. E no q' toca às obras Coroa, e'... [Fl. 129]... Hornaveq', por os Fortes, nem trinchr. ${ }^{a}$ poderem descobrir, e chegar aonde ellas se podem fazer, mas mais delgadas; $e^{\prime}$ isto despois de feitos os ditos Fortes, $e^{\prime}$ reedificado a trinchr. ${ }^{a}$ velha, $q^{\prime}$ os Fortes em prim. ${ }^{\text {ro }}$ lugar, em seg. ${ }^{\text {do }}$ a trinchr. ${ }^{\text {, }}$, e depois ellas; co' declaração, q' os reparos dos Fortes sejão mais moderados, do q' mostra o Perfil.

$E$ q. ${ }^{\text {to }}$ à $p .^{\text {te }}$ do Mar, ainda $q^{\prime}$ tras defensas da fixante de mil çento e vinte, mil çento e quarenta

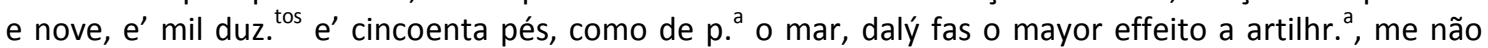
pareçe mal o fazer-se; bem sey $\mathrm{q}^{\prime}$ o gasto ha de ser $\mathrm{m}^{\text {to }}$, mas com elle feito, não pode ser por alý co'metida, e sem ella, pode com mais, ou menos risco, lansar g. $^{\text {te }}$, ainda $\mathrm{q}^{\prime}$ seja de noite, e ganhar terra. E o q' chamão Forte de São Franc. ${ }^{c o}$, q' na Planta tem Letra X., he feitio de hú Beluarte pequeno, e' o de São Phelippe, e' Santiago, Letra V. tambem pequeno, e' ambos cousa $q^{\prime}$ som. $^{\text {te }}$ são Plataformas, p. $^{\text {a }}$ alguã artilhr. ${ }^{a}, q^{\prime}$ lançando-lhe g. ${ }^{\text {te }}$ não tem defensa, e fica a artilhr. ${ }^{a}$ ganhada, e' o inimigo nelles; $e^{\prime}$ ou esta, ou outra se lhe deve fazer, . $^{\text {a }} \mathrm{q}^{\prime}$ por aquella p. $^{\text {te }}$ se lhe não possa fazer dano. $\mathrm{E}$ q. ${ }^{\text {do }}$ o gasto he feito neçess. ${ }^{r a} m .^{\text {te }}$, he cousa forçosa. E vejo $p^{\prime}$ la Planta, $q^{\prime}$ alý se não podem fazer obras, $q^{\prime}$ se defendão por sý; e' sem estas, não estando tudo fechado, em se tomando terra, as q' ha ficão sem serviço e perdida a artilhr. ${ }^{a}$ [VS. ${ }^{a}$ ] e assý q' me não pareçe mal o fazer-se, podendo. Isto he o q' me pareçe, p'lo q' vejo das

${ }^{1047}$ Portanto, já no seu parecer, os desenhos estavam danificados. 
Plantas e' declaração dellas, feitas p'lo d. ${ }^{\circ}$ João Cout. ${ }^{\circ}$, ao qual se deve dar o mayor credito, pois o está palpando, do q' a informações de pessoas, q' não tem a profissão, q' ainda q' fossem [áq'la Cidade] todavia não póde dar a razão, q' dá o q' olha co' a çiençia: e' o mesmo digo sobre os materiaes e preços

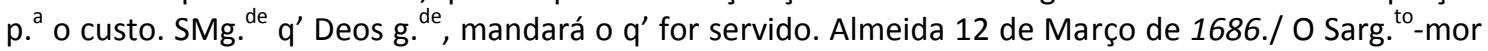
Engenhr. ${ }^{\circ}$ Hieronymo Velho de Azevedo/

\section{Carta de Denis de Mello de Castro p. ${ }^{\text {R }}$ Roq' Montr. ${ }^{\circ}$ Paim, sobre a forteficação da Bahia}

S. ${ }^{\text {or }}$ meu. Remeto a VM o pareçer dos Engenhr. ${ }^{\text {os }}$ desta Provincia, sobre a forteficação da Bahia; $e^{\prime}$ a Planta vay dirigida às mãos de João Duarte offiçial do Correyo mor, p. $^{a}$ q' a entregue com toda a confiança nas de VM, a cujo serv. ${ }^{\text {co }}$ assistirey sempre como devo. Deos g. ${ }^{\text {de }}$ a VM m. ${ }^{\text {tos }}$ annos. Villa viçosa 8.de Fev. ${ }^{\text {ro }}$ de 686/ Servidor de VM. Dinis de Mello de Castro./

Pareçer da Planta da forteficação da Bahia p'los Engenhr. ${ }^{\text {os }}$ Gregorio Pacheco de Moraes, e Ant. ${ }^{\circ}$ Roiz de Carv. ${ }^{\circ}$, incluso na Carta asima.

Chamados do G. $^{\text {or }}$ das armas desta Provinçia Dinis deMello de Castro, vimos a Planta da forteficação nova, q' se quer fazer na Cid. ${ }^{\text {e }}$ da B. ${ }^{a}$ de Todos os $S^{\text {tos }}{ }^{\prime}$ E considerados alguñs inco'modos, fazemos a VMg. ${ }^{\text {de }}$ prez. ${ }^{\text {te }}$ nosso pareçer.

Em prim. ${ }^{\text {ro }}$ lugar a Cid. ${ }^{e}$ da B. ${ }^{a}$ tem m. $^{\text {tos }}$ inconvenientes $p .^{\text {a }}$ se forteficar de pedra, e cal, por $\mathrm{m}^{\text {tas }}$ razões. A prim. ${ }^{\text {ra }}$, Não tem em sý nenhúa pedra de cantaria; e' alguns e'difiçios q' lá estão fabricados co' ella, como são os P. ${ }^{\text {es }}$ da Comp. ${ }^{a}$ [VS. ${ }^{a}$ ], forão de Lx. ${ }^{a}$ as pedras. Alvernaria, $q^{\prime}$ são as pedras ordinarias, não a há tambem, porq' as serras as levantou a natureza de huã materia quasi como ferro, mesturado co' huã aréa de cascalho grosso, tudo inutil p. ${ }^{a}$ abrir pedreiras; mas muy forte em sý, e' as Casas na dita Cid. ${ }^{\mathrm{e}}$ ( $q^{\prime}$ he bastante prova) se fabricão todas de taipa. He verd. ${ }^{\mathrm{e}}$ ser esta tão forte, como a mesma pedra, e cal. Esta se fas de cascas de ostras; a quantid. ${ }^{e}$ della basta $p .{ }^{a}$ fabricar os e'difiçios pouco, e' pouco, mas p. ${ }^{a}$ huã obra tão dilatada, nunca se póde fazer cal bastante. E' q. ${ }^{\text {do }}$ p'lo sertão se ache alguã alvenaria, serão os gastos de condução tantos, $q^{\prime}$ ficará o prestimo della inutil. ${ }^{1048}$

He verdade não damos essas razões co' tenção de senão forteficar a Praça, mas pode fazer-se co' o co'modo, q' melhor for. Que do modo da Planta, mais he fazer huã Cidade, pella maquina grande, [afastada], ${ }^{1049} q^{\prime}$ pella neçessidade util.

$\mathrm{O} \mathrm{q}^{\prime}$ nos parece melhor (fundados nas mesmas razões do Engenhr. ${ }^{\circ}$ ) he o seg. ${ }^{\text {te }}$. Diz elle no paragrafo G. estas formais palavras. Prim. ${ }^{\text {ra }}{ }^{\text {te }}{ }^{\text {t }}$ p. ${ }^{\text {a }}$ qualquer inimigo commeter a Cidade da B. ${ }^{\text {a }}$ ha de ser por huã de duas p. ${ }^{\text {tes }}$ A prim. ${ }^{\text {ra }}$; e' prinçipal, pella do Forte de S. ${ }^{\text {to }}$ Ant. ${ }^{\circ}$ do Carmo, e' ainda co' mais co'modo seu, pello Oiteiro chamado do Barbalho [VS. ${ }^{a}$ ]... E no paragrafo .J. dis. A outra p. ${ }^{\text {te }}$ por onde podem co'meter,... [FI. 129v]... he pello extremo, aonde está outro Forte de São P. ${ }^{\circ}$, porq..$^{\text {to }}$ por estes lugares não tem o embaraço dos Adiques, $q^{\prime} p{ }^{a}$ o passar tem $m .{ }^{\text {ta }}$ difficuld. ${ }^{\text {de }}$ [Vc. ${ }^{a}$ ] E mais abaixo no mesmo paragrafo diz. Porq' não he possivel chegar o inimigo a combate-lo, sem prim. ${ }^{\text {te }}$ deixar ganhada alguã destas Fortalezas, o q' lhe não custará pouco a conseguinr. ${ }^{\text {ca }} \mathrm{O}$ mais q' por diante vay, tambem fas a nosso pareçer. $O q^{\prime}$ visto, claram. ${ }^{\text {te }}$ se segue poder passar a Cid. ${ }^{\text {e }}$ da B. ${ }^{\text {a }}$ sem huã tão grandissima, e' exçessiva çircunvalação, bastando-lhe (segundo nosso pareçer) forteficar muy bem, com duplicados Fortes os dous extremos de S. ${ }^{\text {to }}$ Ant. ${ }^{\circ}$ do Carmo, e de São P. ${ }^{\circ}$, $e^{\prime}$ atar pella p. ${ }^{\text {te }}$ dos Diques de novo. Desta forma será bem defendida a Praça e co' $\mathrm{m}^{\mathrm{a}}{ }^{\mathrm{a}}$ difficuld. ${ }^{\mathrm{e}}$ tomada. E póde servir de exemplo $\mathrm{q}^{\text {tos }}$ annos a sustentou o inimigo, $\mathrm{co}^{\prime} \mathrm{m} .{ }^{\text {to }}$ menos forteficação, e' menos Fortes. ${ }^{1050}$

Fazendo-se a dilatada çircunvalação, $q^{\prime}$ a Planta aponta, corta-se grande $p^{\text {te }}$ da [pousação], em grande dano dos $\mathrm{m}^{\text {res }}$ (como das Plantas se mostrou) e' havendo co'modo (como o q' apontamos) mais se deve conservar os vassallos, $q^{\prime}$ distruir-lhes as faz. ${ }^{\text {das }}$

Mais, custará tanto executar a Planta, $\mathrm{q}^{\prime}$ por $\mathrm{m}^{\text {tos }}$ annos não poderá acabar-se a obra, porq' gastará VMg. ${ }^{\text {de }}$ tanto de sua real faz. ${ }^{\text {da }}$, que Ihe não hão de bastar quatro milhões, e mais, com o exçessivo gasto de quatro Beluartes na marinha, q' tambem póde forteficar-se com huñs [Redantes]. Esse he nosso pareçer. VMg. ${ }^{\text {de }}$ mandará o q' for servido. Evora [nos] $\underline{6}$.de Fev. ${ }^{\text {ro }}$ de $1686 /$ Ant. ${ }^{\circ}$ Roiz de Carv. ${ }^{\circ}$ / Gregorio Pacheco de Moraes./

\footnotetext{
1048 Sobre a inconveniência do uso da pedra.

1049 Afamada?

${ }^{1050}$ Holandeses na Holanda? Em Recife?
} 
Pareçer sobre a Planta da forteficação da Bahia pello Ajudante de Engenhr. ${ }^{\circ} \mathrm{M}^{\text {el }}{ }^{\text {[Menia] }}$ da Silva, tambem incluso na Carta atras.

Por ordem de V.S. ${ }^{a}$ vý as Plantas da Cid. ${ }^{\mathrm{e}}$ da B. ${ }^{a}$ de Todos os S. ${ }^{\text {tos }}$, assý a do assento da Cid. ${ }^{\text {e }}$, como a da nova forteficação, deçenhada pello Engenhr. ${ }^{\circ}$ João Cout. ${ }^{\circ}, e^{\prime}$ me pareçe, $q^{\prime}$ o sitio p'la natureza está assas forte $e^{\prime} \mathrm{q}$ com.$^{\text {to }}$ menos custo póde ficar huã Praça fortissima, pois o sitio ajuda, assý da p. $^{\text {te }}$ da marinha, como da . $^{\text {te }}$ da terra firme, pellos grandes Diques, de quem fica rodeada; $e^{\prime}$ segundo minhas informações he altissimo seu despenhadeiro, e' a terra quasi cortada a plumo, e' se sustenta por ter o terreno summam. ${ }^{\text {te }}$ forte, e' tenás, e o mesmo he da $p$ te $^{\text {te }}$ do mar, posto $q^{\prime}$ com mais declividade, mas altissima, e' dificil na sobida, e ainda mais alta, q' os 150.palmos, $\mathrm{q}^{\prime}$ o dito Engenhr. ${ }^{\circ}$ Ihe assina.

$\mathrm{O} \mathrm{q}^{\prime}$ se deve nesta Cid. ${ }^{\mathrm{e}}$ forteficar são as entradas da terra firme $\mathrm{p}^{\mathrm{a}}{ }^{\mathrm{a}}$ C Cid. ${ }^{\mathrm{e}}, \mathrm{q}^{\prime}$ só por aquy tem chegada ... o inimigo, $q^{\prime}$ a quiser invadir, $p$. $^{a}$ o $q^{\prime}$ me pareçe $m$. $^{\text {to }}$ bem os Fortes $q^{\prime}$ na Planta tras, $e^{\prime}$ ainda acho ser pequeno, o $q^{\prime}$ novam. ${ }^{\text {te }}$ desenha. A Coroa $q^{\prime}$ tambem se vé he obra $m .{ }^{\text {to }}$ boa, p. $^{\text {a }}$ segunda retirada do Forte de São $\mathrm{P}^{\circ}{ }^{\circ}$, em caso $\mathrm{q}^{\prime}$ seja pendido, e terem os inimigos por aquy mais largo o passo, $\mathrm{e}^{\prime}$ [se foor] expugnação, com o $q^{\prime}$ será $\mathrm{m}^{\text {to }}$ conveniente o fazer-se, ou em seu lugar algum Fortim de bom Prefil, atacado á trinchr. ${ }^{\text {, }}$ obra q' sóm. ${ }^{\text {te }}$ basta á çircunvalação da Cid. ${ }^{\mathrm{e}}$

Os Beluartes do mar são escuzados, e Ihe não acho servintia, nem co'modidade a se fazerem, e ser obra de grande custo, e dilatada, pendurando as duas cortinas pella [servanía] abaixo, ademais de serem todas larguissimas, e fóra da defensa efficaz de mostquete.

Basta sóm. ${ }^{\text {te }}$ da p. $^{\text {te }}$ do mar, por sima da [servanía], fazer alguñs [Redentes] em forma de trinchr. ${ }^{a}$, feita de taipa, ou formigão, $q^{\prime}$ corra segundo seu comprim. ${ }^{\text {to }}$, tomando as mesmas voltas, e quebras da terra, p. ${ }^{\text {a }}$ q sejão defendidas; e' nas extremidades das sobidas a estas trinchr. ${ }^{\text {as }}, q^{\prime}$ venhão de baixo em o alto dellas, se forteficarão co' alguñs [travezes], ou Flancos, p. ${ }^{a}$ as defenderam, se o inimigo por aly quiser sobir, $\mathrm{e}^{\prime}$ aco'meter a trinchr. ${ }^{\text {a }}$, será com $\mathrm{m} .{ }^{\text {to }}$ dano seu, pois nunca o pode fazer com $\mathrm{m} .{ }^{\text {ta }} \mathrm{g} .{ }^{\text {te }}, \mathrm{e} \mathrm{co}^{\prime}$ grande frente... [Fl. 130]... ficando os de sima com $\mathrm{m}^{\text {tas }}$ ventagens', será inutil o intento. Embaixo na marinha no lugar do Forte de São Phelippe, se pode acresçentar alguã obra defensavel, e capaz de resistir á artilhr. ${ }^{a}$ do mar, p. $^{\text {a }}$ defender os desembarcadoiros a huã e outra p. ${ }^{\text {te }}$, e' em caso q' não alcanse bem a flanquear todas as . $^{\text {tes }}$, se fará outra forsa, donde melhor se flanquee, como no Forte de São Fran. ${ }^{\text {co }}$, ou em outra $\mathrm{p}^{\text {te }}, \mathrm{q}^{\prime}$ melhor pareçer. Com isto fica inexpugnavel desta $\mathrm{p} .{ }^{\text {te }}$

Da p. ${ }^{\text {te }}$ da terra, e Diques, são escuzados os Beluartes de tão grande Prefil, nem ha mister parapeitos, e' terraplenos à prova de Canhão, tão largos, e profundos fossos, pois tal Prefil se fas naq'las Praças situadas em campanha raza, e nos confins de algú poderozo inimigo, $q^{\text {to }}$ mais $q^{\prime}$ este difficultosam. $^{\text {te }}$ Ihe poderá caber nos alvos, sem se [despenhar] todo o fosso, e estrada de fora delle, [ $z^{\prime}$ ] em p. ${ }^{\text {tes }}$ feita artificialm. ${ }^{\text {te }}$ com toda a baze demais de 250.pés de largura, em todo reparo, seria hum gasto intoleravel, e huã obra perpetua, sem causa alguã.

Na Planta se vé huã trinchr. ${ }^{a}, q^{\prime}$ dis ser feita p'lo Holandes, da qual me não dão notiçia as pessoas q' lá assistirão, e dizem q' he tão desigual, q' não ha por onde possão correr com o acesso do terreno, ou se a houve algum tempo estarão por terra, mas se estas estão em pé, bastará só repara-lla, e' acresçenta-las, segundo pedir a melhor defensa, fazendo-lhe seu Prefil como de Fortes de Campanha, q' nesta p. $^{\text {te }}$ he bastantissimo; porem se sóm. ${ }^{\text {te }}$ ha alguñs vestigios, não será incoveniente (podendo ser) fazerem-se os Beluartes q' tras na Planta, mas co' seu Prefil $m .{ }^{\text {to }}$ moderado, e pouco mais fortes, $q^{\prime}$ os dos Fortes de Campanha.

De sorte $q^{\prime}$ só as estradas se forteficarão com Fortes capazes, $q .^{\text {to }}$ possa ser, $e^{\prime}$ bons reparos, e Prefil de Forte real, escuzando estrada de rondas, como no Prefil da Planta se vé; e' na Cidade basta a çircunvalação de trinchr.a, disposta em boa forma: e' na marinha, hum, ou dois Fortes p. ${ }^{a}$ flanquear o [Rio], e desembarcadoiros; e' co' isto se vem a poupar hum immenso custo, e' ainda este he assás [de gran-] de. Ds. ${ }^{\text {g g. }}{ }^{\text {de }}$ a VS. ${ }^{\text {a }}$ os annos de seu desejo. O liccença 4.de Fev. ${ }^{\text {ro }}$ de 1686 / M. ${ }^{\text {el }}$ Mexia da Silva /.

Escritto de Luis Teixr. ${ }^{a}$ de Carv. ${ }^{\circ}$ p. ${ }^{a}$ o Conde de [Valde] Reys Presidente do Conç. ${ }^{\circ}$ [Vltr. ${ }^{\circ}$ ] p. ${ }^{a}$ se lansarem em L. ${ }^{\circ}$ os papeis q' com elle vierão sobre a forteficação da Cid. ${ }^{\mathrm{e}} \mathrm{da}$ B. ${ }^{\mathrm{a}}$

Sn'or. Os papeis inclusos são conçernentes aos q' remety a V.S. ${ }^{a}$ sobre a forteficação da B. ${ }^{a} \mathrm{e}^{\prime}$ os remeto a V.S. ${ }^{a}$, porq' como SMg. ${ }^{\text {de }}$, $\mathrm{q}^{\prime} \mathrm{D}^{\prime}$ 's g. ${ }^{\text {de }}$, ordena se lansem em L. ${ }^{\circ}$ nesse Conc. ${ }^{\circ}$, pareçe conveniente, $\mathrm{q}^{\prime}$ tambem estes se lansem nelle, e depois tornarão; e' não forão todos de huã ves, porq' bem notorio he a VS. ${ }^{a}$ os çirculos q' lerão. D's g. ${ }^{\text {de }}$ a VS. ${ }^{a}$ m. ${ }^{\text {tos }}$ annos. Secretaria 28.de Março de 686/ Servidor de VS. ${ }^{a}$ Luis Teix. ${ }^{\text {ra }}$ de Carmo./ 


\title{
4. Cartas de Miguel Pereira da Costa
}

\author{
Ao padre confessor $(18 / 06 / 1710)^{1051}$
}

[FI. 31] Meu Senhor foi V. A. servido trazer-me a esta cidade com 72 dias de viagem depois de largos trabalhos, mas sempre com saúde; agora é que padeço moléstias porque a terra me tem hospedado mal; as quais suponho irão em aumento vendo que parte esta frota, e não posso voltar nela para Portugal; e assim que para alívio da minha saudade peço a V. Altíssima me de novas de sua saúde, que se for como eu desejo, é certo lhe assistirá mui perfeita, pois só esta notícia mitigará a minha pena, assim como no Alentejo suavizava a minha mágoa; e se lá tolerava mal os poucos dias em que não tinha novas de V. Altíssima, que será agora cá em muitos meses, e talvez anos.

Confesso a V. Altíssima que se entenderá o estado em que esta praça se achava nenhuma conveniência me vencerá a aceitar a [cumisão]; ${ }^{1052}$ mas enganei-me, ou enganaram-me; e é bem empregado já que cri de leve e se o interesse das riquezas é tão poderoso, que se persuadiu o demônio a que com ele venceria ao mesmo Cristo, não é muito que este me enganasse; porque só o poder de um [S. Bento] resiste a tal tentação; o soldo que eu cuidava seria para larguezas, é para passar moderado, porque a exorbitância em que tudo está nesta terra é maior que a desse Reino; exceto a farinha, e vaca; e observando que a receita é mal para a despesa, vou vivendo moderadamente, com muita honra, não por virtude, mas por necessidade; ${ }^{1053}$ admirando-me da largueza com que aqui se vive, sem consciência, nem lembrança de outro mundo; e assim peço a [V. A.] me tire de tal terra, e não desampare da sua graça, porque vejo aqui mui arriscada a salvação das Almas. ${ }^{1054}$

Achei nesta praça um sargento-mor engenheiro, ${ }^{1055}$ que a poucos dias morreu, ao qual tratavam indignamente; mil desatenções lhe faziam, e 3 vezes o meteram na [alcova]; ${ }^{1056}$ mas o que mais me admirou foi ter ele resolução para sofrer tudo, e não se embarcar em qualquer navio; é verdade que, segundo ouço, dava causa a muitas coisas, porque ainda que era zeloso, aplicava mal o seu zelo e por falta de discurso ${ }^{1057}$ andava sempre embicado com os governadores: todos me dizem que não sabia de seu oficio, como se na matéria tivessem voto, que é bem galante coisa ser um homem julgado por idiotas; este me é de fazer grande falta, porque me havia informar de mil trapaças ocultas, que não posso adivinhar, em obras de grande importância que estão por medir, e me aproveitaria a notícia que ele em 10 anos tinha adquirido do Pais.

No decurso ${ }^{1058}$ deste tempo o não ocuparam no tocante à sua profissão, ${ }^{1059}$ por haver aqui outro engenheiro: é este um Francisco Pinheiro capitão da artilharia, que foi carpinteiro ex-professo, o qual cuidando ser o mesmo cortar um madeiro em esquadria, ou buscar o vivo a uma [Fl. 31v] peça, que fortificar uma praça, passou a sua curiosidade ajudada do que leu em Luis Serrão, ${ }^{1060}$ a intitulá-lo engenheiro, e esta ocupação teve até agora: mas falando com ele algumas vezes vejo que interpreta mal o texto, e em nada fala com formalidade; tem feito mil ridicularias, e algumas de conseqüência: isto sucede aos boticário, quando querem passar a médicos. ${ }^{1061}$

$\mathrm{O}$ do forte de S. Antonio do Carmo se conhece isto melhor, porque há um processo de erros; e para a fábrica nova da pólvora que aqui se fez: vieram desse Reino 3 plantas para se fazerem as oficinas

${ }^{1051}$ Baj Ms. Av. 54-XI-25, no 65. Trata-se do mesmo texto que o de no 62, isto é, há duas cópias do mesmo documento, o que torna a comparação entre eles linguisticamente interessante, pelas seguidas variações ortográficas. Não devendo ser esta questão aqui aprofundada, optou-se pelo de n 65 , de melhor caligrafia e com um adendo final inexistente no outro documento.

1052 Missão? Comissão?

1053 A "humildade" como figura de retórica, principalmente neste caso de hierarquia religiosa, mas também na civil e militar.

1054 Pode-se relacionar às citações religiosas de Luiz Dias (... dando-nos Deus saúde e paz com este gentio, o qual está um pouco duvidoso por quão maus os fez o demônio...) e outros.

${ }^{1055}$ Antônio Roiz Ribeiro.

1056 "Enchovia".

1057 Comunicava-se mal.

1058 Usa a palavra "discurso".

1059 De Antônio Roiz Ribeiro.

${ }^{1060}$ A simples leitura (teoria), portanto, era considerada insuficiente.

${ }^{1061}$ Mais uma vez, a importância do saber medicinal (sem truques). 
divididas por causa dos incêndios que costuma haver; e não obstante serem feitas por um raro engenho, e mandadas pelo conselho; o Pinheiro cá contraponteou, e se fez tudo junto por uma sua; nela pôs uma porta das duas que o Methodo traz nas duas figuras, em que se esmerou gastando nela 1000 réis, quando esta casa de pólvora podia ter menos porta, e mais água, pois lhe esqueceu fazer cisterna, tendo vão capas para tudo: ultimamente costumava assistir as medições, e assiná-las (dizem que por ordem do conselho) sobre que aviso, nem tal consentirei por nenhum caso, porque além de ser indecoroso assinarmos ambos, é coisa indigna que medição que eu fizer haja mister a aprovação do [sujeito], quando nesse Alentejo as que fazia em diferente posto, não se cometia o seu exame a quem as podia aprovar: o sargento-mor que morreu na fortificação do Morro que principiou ${ }^{1062}$ fez uma guarita de pedra que custou 217 réis com que um e outro eram bons para [resolução dos defeitos e ausências]. ${ }^{1063}$

Aqui tive notícia que S. Majestade, que Deus guarde, mandou ler [outra vez o Methodo de Azevedo] na Aula, ${ }^{1064}$ o que duvidei, por se achar em diferente dignidade: na relação junta (que é copia de uma que o governador $D$. Lourenço de Almeida me pediu para remeter a S. Majestade) verá V. Altíssima as misérias desta casa, ainda que por tosca frase, e palavras menos coerentes, ${ }^{1065}$ mas a falta de eloqüência é porque há muito estou esquecido da Rethorica, e o não ser o discurso genuíno para o intento, é por a minha inércia me não ajudar a fazer melhor narração; e entenda V. Altíssima que está tudo aqui no maior desamparo, a praça aberta, e exposta a qualquer invasão, o que muito destes moradores não consideram, pela aversão que tem a se fortificarem, dizendo ser impraticável o vir cá inimigo, quando já o experimentaram no tempo que os holandeses ocuparam esta praça, e é ridículo o dizerem se não poderá aqui conservar, pois não consideram a perda dos [particulares], ${ }^{1066}$ a que terá el Rei na falta de tão importante frota, e o que será necessário sair de Portugal para expulsar este inimigo; e quanto ao impraticável ${ }^{1067}$ pela aspereza dos bosques, ou estreiteza dos passos, seria assim se neles, houvesse quem o impedisse, mas na tal ocasião os poucos brancos cuidarão em transportar o precioso a parte segura, os negros em procurar a liberdade... [FI. 32]... quanto mais que sem vencer aquelas dificuldades tem o inimigo aqui perto da cidade para onde faça desembarque sem oposição; e se as conseqüências [de cadix], [e tollon] fizeram serem aquelas praças intentadas, as desta não são de menos importância, ao menos pela vizinhança das minas; com a diferença que aquelas são tão fortes como se sabe, e esta aberta como a vejo; lá com boa guarnição, e os [fortes], cá sem nenhum, com poucos, e ruins soldados; e ainda que tenho pouca notícia do país, pelo que ouço e vejo, podia ser a melhor conquista do mundo, porque tem largueza, e conveniência para tudo, e se não digam a presente frota.

Não são poucas as saudades que tenho do nosso Alentejo, porque só nele teria ocasião de aprender alguma coisa, e aqui me farei mandrião, ${ }^{1068}$ como os mais das conquistas: de [bom grado] ${ }^{1069}$ tornaria para ele se V. Altíssima cooperasse para mo permitirem; acomodava-me melhor lá com o trabalho da nossa guerra, do que cá com este descanso, que como estava acostumado à vida [cigana] ${ }^{1070}$ estranho a de palaciano: Deus me cumpra meus desejos, pois nem são de durar aqui, nem de servir sempre a El Rei, e se me não faltar com as [diversas inspirações] ${ }^{1071}$ que tantas vezes me tem dado, hei de buscar parte onde com vagar cuide da minha salvação, porque me lembram em muitas ocasiões as palavras do Espírito Santo por boca do profeta statutum est hominib, ${ }^{1072}$ e a vista delas conheço ser tudo o mais vanitas vanitas e como Deus me tem livrado de perigos tão [evidentes] ${ }^{1073}$ em ocasiões que não sei a conta que lhe havia dar da minha vida, quisera tratar de me preparar para ela; mas é o mesmo $[\ldots]^{1074}$ servido, não ponha eu ainda em execução este intento pelas causas que ele sabe, e me faltava

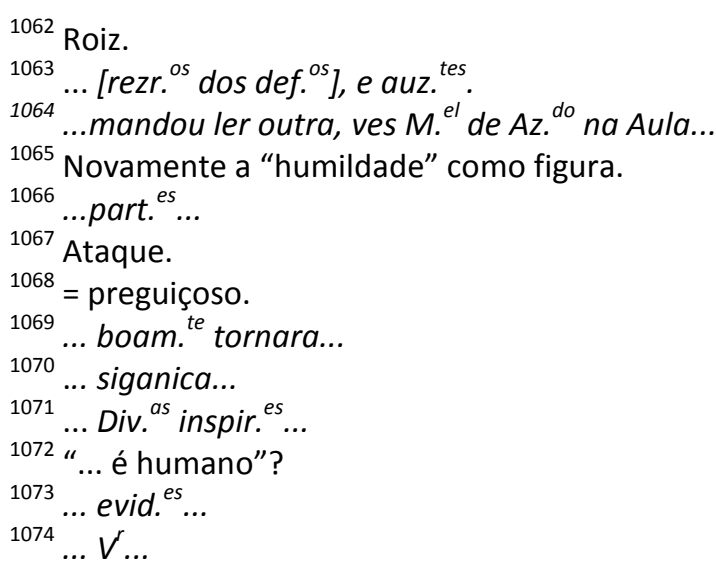


ver este novo mundo, para me servir de maior desengano; nem V. Altíssima entenda ser isto em mim é [arejar] $^{1075}$ do pensamento, pois só Deus sabe as lágrimas com que presentemente me acompanham ao escrever deste [capítulo], ${ }^{1076}$ causa porque eu só o quis escrever; e assim peço a V. Altíssima me encomende a Ele para que me não desampare da sua graça; e já que não mereço a V. Altíssima esta esmola por outra razão, ao menos como próximo lhe mereço esta piedade. ${ }^{1077}$

Os fortes que aqui há são uns limitados redutos, e partindo a frota entrarei e remendá-los, e alargar a alguns ao menos para que possa ter uso a artilharia com que se acham: também me parece farei alguma obra nova, e sempre sairá como o relógio de sol que [Malley] fez em Estremoz; mas à vista do que por cá vai não deixará de parecer bem, porque na terra dos cegos, dizem lá; o negócio destas partes está mui atenuado, porque o melhor é o da costa da [China] onde este ano tem roubado 40 embarcações, por cuja causa valem aqui os negros a 150 e 200 réis: um francês que anda nesta costa tem colhido bastantes embar-... [FI. 32v]... cações que vinham do Rio, e algumas mui importantes: como o trabalho aqui há de ser muito peço companheiro que me ajude, e já que não tive a [fortuna] ${ }^{1078}$ de que fosse Pedro Gomes folgaria que viesse algum que se não parecesse comigo, porque então ninguém nos entenderá, e eu nunca desejei estar só porque estimo muito ter um reparador das minhas ações para me as advertir quando forem mal encaminhadas, e se for homem ancião melhor, porque me dará [bons] conselhos, que os meus poucos anos tudo requerem, e se souber francês melhor porque será texto tudo quanto disser, e eu por tal o venerarei sem o provar com [duas] oposições de geometria que é o refugio de quem não sabe aquele idioma.

Sempre me pareceu que a vaidade era espécie de loucura, ${ }^{1079}$ e por isso não aprovo o desvanecimento; mas se é certo o que dizem os livros, o que V. Altíssima, e mais lentes me ensinaram, e o que vi nas nossas praças, e guerra, que é a experiência com que pode chegar um pobre português que não militou em Flandres com o Duque de Malbaruc, nem na Itália com o [Príncipe] ${ }^{1080}$ Eugenio, suponho que se estes Srs. quiserem, e não faltarem os meios, iremos fazendo algum serviço a El Rei, se é que me mandarão a isso, e a este povo; a este porque vivemos segurando, e viverá algum dia com menos sustos, àquele porque não [saldará] a sua despesa como aqui tem sucedido em muitas obras, que depois de feitas se não consegue com elas o fim a que se encaminhavam.

Ao Senhor Conde de S. Vicente dou conta de tudo, porque assim me ordenou; e ao conselho de algumas coisas: a ambos falo em alguns Regimentos que faço, não por conveniência minha, mas pela do Real Serviço; e estimarei dêem remédio a tudo, e muito mais me mandem ir embora, porque me acho com umas arrobas de ouro o que baste para tratar de alguns particulares, e ir acabar os meus dias na vida eremita, e se não puder chegar aos desertos da [thebaida], ficarei na terra do [busaco]: meu Padre Mestre entenda V. Altíssima que está isto em estado que será do primeiro que vier, vale-nos andarem as Nações ocupadas, porque o ouro lhe havia [de] meter inveja, e ainda que com poucas barbas, e menos ciência digo o que entendo, e falo como português, pois nem umas, nem outra é necessário para conhecer o que está tão claro a qualquer mediano entendimento; falo com V. Altíssima desta sorte pela [maneira] ${ }^{1081}$ que sempre me fez, e peço muito a V. Altíssima se algum dia se falar nesta matéria me não de por A., pois se escandalizará o Sr. Conde de S. Vicente, e ele não é para galhofas: digo isto a V. Altíssima porque este engenheiro que aqui morreu, ${ }^{1082}$ ou por ter conhecimento com o Padre confessor, ou levado de algum zelo, Ihe fez alguns avisos, e o dito padre os representou a El Rei, que Deus tem, o qual mandou se virem no conselho de que resultou ter o dito Engenheiro uma grande repreensão do conselho dizendo-Ihe escusasse ${ }^{1083}$ mais de dar contas, que cá tinha governador a quem recorrer: é verdade que aquele tratavas... [Fl. 33 $]^{1084} \ldots$ tratava de satirizar, e eu não sou figura que me alargue a tanto, nem me meto com a vida de ninguém, quanto mais em razões de estado, quando

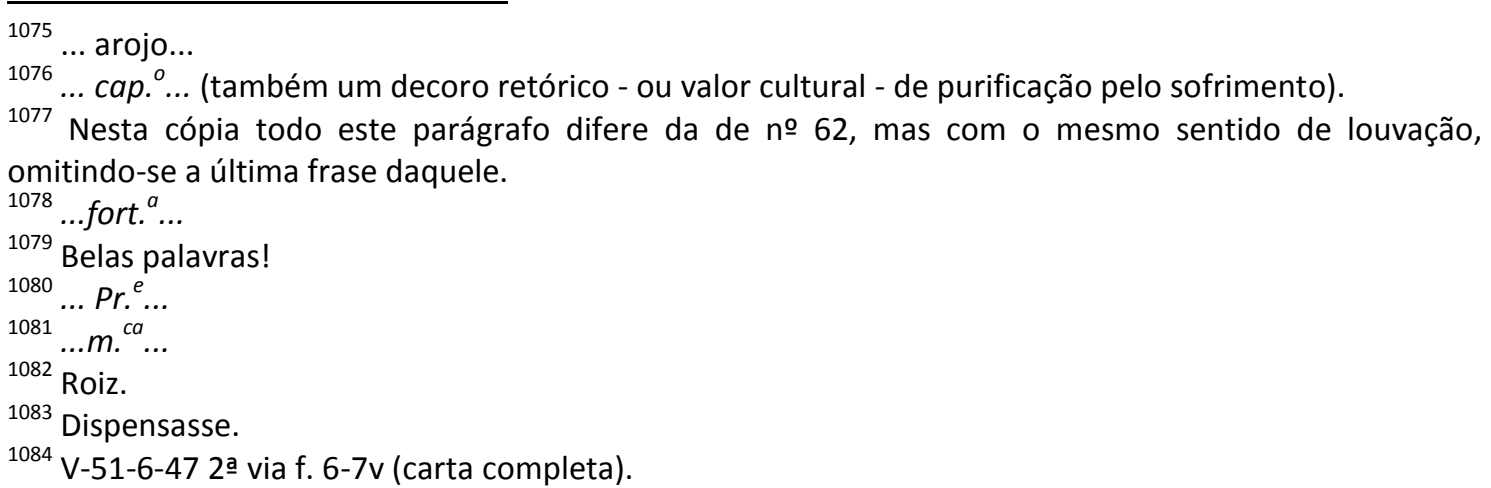


conheço que sou um pobre ignorante no que devia saber, como obrigação minha, e mal posso dizer das alheias.

A Luiz Cesar de Menezes devi notáveis honras enquanto governou, as mesmas farei por merecer ao novo governador; e estou obrigadíssimo a estes cavalheiros da terra pelas cortesias que lhe devo: com os [A] ditos Padres da Companhia não tive ainda tempo de tratar fartamente, e só falei com um padre já decrépito Italiano, ${ }^{1085}$ que me dizem ser grande matemático, ao menos por obra sua que vi, conheço ser insigne geógrafo; e Padre Priér francês, ou sabojano me diz que também é engenheiro, e que mais devagar falaremos; sei que tem as obras do Conde Pagan, e outros muitos livros; e como o papel se acaba saiba V. Altíssima que me tem nesta terra com aquela antiga vontade de lhe obedecer, pois nem as distâncias nem os tempos me farão esquecer da minha obrigação, e assim lhe peço me dê ocasiões de seu gosto, porque só assim verei o meu satisfeito: V. Altíssima me não falte com suas novas, pois com elas não sentirei tanto este degredo, Deus guarde a V. Altíssima como desejo; Bahia 18 de junho de $1710 .^{1086}$ / De V. Altíssima/ Discípulo muito amante e [servo] ${ }^{1087}$ muito obrigado/ Miguel Pereira da Costa $[\mathrm{Hv}]$

$$
\text { ... do Engenheiro da Bahia }(28 / 02 / 1712)^{1088}
$$

[Fl. 26] Qualquer praça, ainda das realmente fortificadas, pode ser perdida por tantos modos, como superada; que ordinariamente se reduzem a traição, motim, surpresa, e ataque, e sendo estes os modos ofensivos com que o inimigo intenta ganhar, a eles se devem opor os meios defensivos para não perder: deve-se primeiramente fazer secreta, e contínua pesquisa dos [afetos] dos moradores, assim cidadãos, como militares; para que reconhecendo-se dissipar os que forem repugnantes, e danosos; e por este caminho não tomará pé o tumulto, nem a surpresa, ou traição terá progresso sufocando-a em seus mesmos princípios; diligência que se não deve desprezar, pois o engenho humano se vale de todos os meios com que pode conseguir o que intenta; e pela muita confiança se tem perdido tantas cidades, de quantas são testemunhas suas lamentáveis ruínas; e por um pequeno descuido de acharam muitos despossuídos momentaneamente de honra, e liberdade.

É opinião seguida que esperando-se o inimigo em qualquer praça, antes de se apresentar, se façam sair dela as bocas inúteis, para que não gastem o provimento que está para os defensores: nesta praça, mais que em outras, se deve pôr nisso grande cuidado, pelo grande número que há de meninos, e mulheres de várias cores, as quais além da sua inutilidade, serão mui perniciosas com os clamores, lágrimas, e persuasões.

Devem os moradores ser obrigados a ter a provisão competente a suas famílias, ou em suas casas, ou em parte destinada para o tal provimento, que na ocasião se distribuirá com igualdade proporcionalmente, para que assim satisfeitos tenham todos união, e um propósito firme de resistir à necessidade, e ostentar-se em a tolerância fiéis vassalos.

As munições de guerra nunca por muitas foram danosas; mas como não há parte donde com brevidade possam vir, por força com as que houver nos devemos remediar; e só se deve cuidar na divisão delas assim par os fortes como para as partes da cidade em que podem ser necessárias: nas de boca, que se transportam por mar, e com facilidade podem ser cortadas, se deve cuidar muito para que não falte mantimento se o sítio for dilatado.

É sem duvida que fazendo o inimigo desembarque de gente para invadir estar praça, em qualquer parte que a lance sempre há de buscar a Cidade por hum dos dois caminhos [,] ou pelo forte de S. Pedro, ou pelo de S. Antonio do Carmo; termos em que ao mesmo tempo que se deve cuidar no como se lhe disputará o desembarque, e retardar-lhe a marcha, já em terra, se devem segurar aquelas entradas, para que repentinamente não penetre o interior da Cidade.

\footnotetext{
${ }^{1085}$ Personagem ainda não identificada?

${ }^{1086}$ [Extra] O grande trabalho que na presente ocasião se me juntou me não deu lugar a fazer esta $2^{a}$ via, e me foi necessário valer de secretário; $V$. Altíssima como costumado a revelar minhas faltas perdoará agora meus erros: se na relação $V$. Altíssima me advertir alguma coisa das muitas que vão menos adequadas, o estimarei muito, porque se de outra qualquer pessoa havia de abraçar a advertência, de $V$. Altíssima muito melhor por todas as razões; nela quis dizer o mais que podia, mas não me resolvi; isto é muito longe, os remédios são tardos, e só agora me tomara ver com o dose da agilidade para chegar, dizer, e voltar; Deus se lembre de nós, e tome este seu Reino muito à sua conta. 1087 ... S. . ...

${ }^{1088}$ Carta do Engr. ${ }^{\circ}$ da Bahya (BAj - Ms. Av. 54-IX-8, no 61).
} 
A extensão das praias desta Bahia, da barra para dentro, é tão dilatada que por agora se não pode acudir a todas, e assim tratando da mais próxima, e sem defesa é de Tapagipe até o fortim de $\mathbf{S}$. Bartolomeu da Passagem; nesta se deve fazer algum reparo detrás do qual possam os defensores impedir o de-... [Fl. 26v]... sembarque: a mais breve obra com que estes se podem cobrir é fazendo uma trincheira, que lhe sirva de parapeito, aproveitando de algumas casas de palha, cerca de hortas para que o trabalho seja menos; e nesta, a distâncias que apontarei, dois redutos em que se possam montar a quatro peças; porque com estes, e fortim de S. Bartolomeu, que logo deve ser reparado, fica esta praia com bastante defesa, nem a ocasião permite obra mais dilatada.

Depois de o inimigo vencer essa dificuldade, e fazer desembarque nesta praia, ou em outra mais remota, principiar marcha para a Cidade, se lhe deve esta retardar com repetidas emboscadas, e cortaduras feitas nos passos estreitos, para que com maior trabalho, e dilação ${ }^{1089}$ chegue a presentearse ao forte de S. Antonio do Carmo; no qual se devem levantar mais os parapeitos da parte de terra, para que os defensores, e artilharia fiquem cobertos, meses as munições de guerra, e boca com [peças], ${ }^{1090}$ reparos de sobressalente para a artilharia, e o mais que apontarei em relação particular para o dito forte; e a primeira coisa será arrasar à roda ${ }^{1091}$ do dito forte tudo o que pode servir ao inimigo para o expugnar; que de [outra] sorte serão [baldadas] ${ }^{1092}$ as mais diligências, pela comodidade com que o inimigo se aproximará a ele com risco: também se deve pôr a estrada coberta em sua perfeição, na qual se anda trabalhando, mas vagarosamente, e necessita de mais gente, e com fervor.

A Igreja do dito santo, no caso de ficar, se deve do dito forte guarnecer com uma esquadra de mosqueteiros bem provida de granadas para as torres, porque se o inimigo a ganhar dominará toda a área do forte, por lhe ficar superior na estrada encoberta; por cuja causa não podemos miná-la para na ocasião se [bolar], porque as suas ruínas maltratariam a guarnição. O forte do Barbalho que fica lateral a este necessita de artilharia, e mais provimento e porque o inimigo pode afastar-se destes fortes, e sem fazer caso deles buscar a Cidade, pois o terreno lhe permite capacidade para isso, deve na rua direita ${ }^{1093}$ que vem ao Carmo fechar-se a trincheira ficando posta ${ }^{1094}$ para serventia do povo e toda a daquela vizinhança limpa, e comunicável, atando a porção que está arruinada na horta do Carmo, com a da fonte dos Sapateiros, como [está] e deve ser para estar em defesa; porque de outra sorte está aquela entrada sem oposição.

Posta toda a muralha de terra, ou trincheira por esta parte na forma referida, deve na mesma rua do Carmo haver algumas vigas, paus, estacas, cestos, e ferramentas para com mais prontidão se fazerem as cortaduras, que em algumas daquelas ruas hão de ser necessárias, se a trincheira se perder; e porque poderá o inimigo fazer marcha pela praia, se lhe deve cortar o caminho no fortim da Jequitaia, no Rosário, e no Pilar, por serem passos estreitos, cobrindo-o com um lanço de trincheira desde o despenhadeiro até o mar, que em qualquer das ditas partes é pequena distância.

Naqueles cais da marinha que parecerem convenientes fazer baterias de artilharia, pois são capazes de a acomodar, as quais não são tanto para impedir desembarque, pois o inimigo não há de fazer nesta parte, como para afastar as embarcações que se aproximarem a bombear a Cidade.

[FI. 27] Pelo que respeita à entrada do forte de S. Pedro, se o inimigo a buscar será fazendo desembarque da Barra, ou Rio Vermelho, mas tendo mais cômodo, e vantagens da barra para dentro, não o fará na costa nestes portos, por serem limitados, e com qualquer [mareta] incapazes de lanchas; nem os navios podem dar calor ao desembarque com a sua artilharia; porque se surgirem há de ser muito ao largo por causa dos recifes; ${ }^{1095}$ porém supondo sempre o pior, e respeitando á defesa dos ditos portos, o do Rio Vermelho se acha com um grande lanço de trincheira, e três redutos, nos quais se podem montar algumas peças, e é a defesa que basta para o tal porto: o da Barra temos três fortins, e o do meio ${ }^{1096}$ com menos artilharia da que tem é suficiente defesa para aquele porto.

No caso de o inimigo desembarcar em um ou outro, se fará a mesma diligência, acima apontada, de emboscadas cortaduras [... $]^{1097}$ para que vagarosamente chegue ao forte de S. Pedro, no

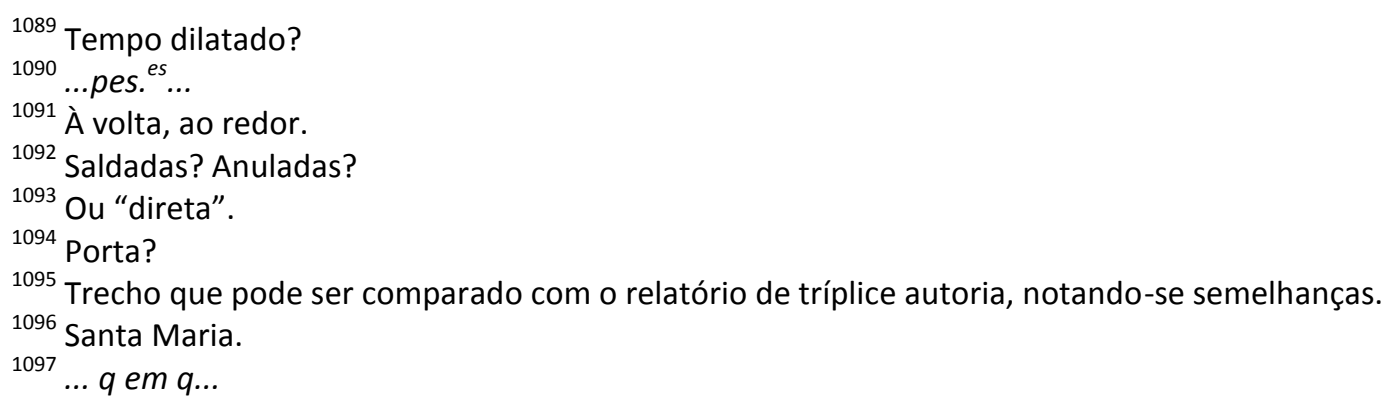


qual se devem meter as munições [competentes] e o mais que apontarei sendo necessário: entre este forte e o Dique há distancia por onde o inimigo pode marchar para a Cidade sem dele se Ihe impedir; e assim seria mui conveniente atar o dito forte ao Dique com uma trincheira, e seus redutos, como tem da parte do mar até o despenhadeiro.

A trincheira do Caminho da Piedade, [forca] e mais vizinhança deve ser reparada na forma que se apontou para a da parte do Carmo; pondo-a em defesa, e desembaraçada, para os usos militares; e não pareça que a trincheira coberta de mato serve de defesa alguma à praça, como alguém imaginou, o que é engano manifesto, pois se não verá ao inimigo, senão quando em cima do parapeito aparecer: não haverá $A$ que da defesa de praças escreve-se, nem soldado de experiência que as atacasse, que diga ser conveniente à praça para sua defesa ter na muralha, fosso, e explanada mato, árvores, ou outra qualquer coisa com que o inimigo se possa cobrir; e assim quando mais descobertas estiverem estas partes melhor se flanquearão, e menos se chegará o inimigo, ou com mais vagar, e mais perda.

Depois de disputado o desembarque em qualquer parte, feito oposição na marcha, defendido da entrada do Carmo, ou S. Pedro, resistido da trincheira, e cortaduras, ainda esta praça tem outra defesa onde se pode fazer o ultimo esforço, e é por interior da Cidade desde as Portas do Carmo até as de S. Bento; ${ }^{1098}$ porque para a parte do mar

é despenhadeiro, e para a de terra houve em algum tempo o dique pequeno, e trincheira; e suposto hoje esteja ocupada com casas, pode-se desde agora ver o como nos valeremos delas na ocasião, porque exterior as tais casas continuam de porta, a porta hortas descobertas no lugar que era o tal Dique, como se vê na do Maciel, S. Francisco, Gravatá, e S. Bento.

[Fl. 27v] O recinto desta praça é mui dilatado, que suposto se não haja de guarnecer todo, deve haver guarnição suficiente para na ocasião reforçar a parte acometida, e como os regimentos atuais não tenham o número que baste, e ainda deles se hão de dissipar as guarnições dos fortes, é preciso que dos regimentos de fora mais vizinhos se engrosse a guarnição, vindo a terça parte de cada um deles estar na praça vinte, ou trinta dias, e esta ser mudada por outra terça parte; porque assim fica o trabalho mais suave, igual para todos, e com menos incômodo, e a praça com mais defensores, que na ocasião não podem vir tão prontos, ou não poderão entrar: também pelo grande númer de negros cativos que há nesta Cidade, e a maior parte destemidos, se podem desde logo alistar os capazes, e fazer-lhe companhias, ou separados, ou agregados aos regimentos, aos quais seus senhores tenham armas prontas; porque além de ser gente muita necessária na ocasião, evita-se o andarem na Cidade roubando, ou fazendo motim.

A Casa de Pólvora do Desterro está mui exposta a qualquer infortúnio, por não ver a sentinela, que está de uma parte, o que da outra se faz; e assim é preciso se lhe faça afastado da parede um fosso, ou estacada para que ninguém possa chegar a ela se não pela porta; e para que por qualquer acidente se não exponha a desgraçar toda, deve-se logo dividir em três, ou quatro partes; e também porque na ocasião será difícil vir buscar munições a parte tão distante; e assim para as portas de S. Bento, Carmo, e Praia deve haver armazéns menores, por quem se divida, e da mesma sorte a bala miúda: de pólvora e bala se deve fazer outro armazém fora da praça a seis, ou mais léguas de distância, onde o inimigo não possa queimar; assim para provimento dos que vierem socorrer a praça, como para alguma facção que se pode oferecer; e se houvesse mais artilharia, não seria desacerto ter também lá quatro peças de campanha.

Muitas vezes se costuma pôr fogo na praça em alguma casa, ou armazém, por inteligência do inimigo, para que acudindo os soldados ao incêndio, possa naquela desordem aproveitar-se da ocasião; e será bom por evitar esta confusão haver ordem para que nenhum dos militares acuda a fogo, nem largue o posto em que se achar, é mui preciso que se junte bom número de ferramentas, assim para a praça, como para os dois fortes, candeeiros de muralha para de noite alumiar os fossos e se verem as operações do inimigo, cavalos de [frisa] mui prontos, e próprios para a brecha, e cortaduras, canais de madeira para de cima do parapeito se alojarem bombas ao fosso, cestos grandes e pequenos os mais que se puderem juntar, estacas grandes e pequenas, reparos de sobressalente para a artilharia, [cabrilhos] $^{1099}$ para montar o que o inimigo desmonta, sacos e saquinhos, grande número de cartuchos para a artilharia e mosqueteria, porque a pólvora solta além de não ser tão pronta, na ocasião é causa de muitas desgraças. ${ }^{1100}$

\footnotetext{
${ }^{1098}$ Cidadela.

1099 Carrilhos?

${ }^{1100}$ É o único trecho em que descreve alguns equipamentos necessários às fortificações.
} 
[Fl. 28] Como esta praça se acha sem a artilharia necessária para as baterias da praia, trincheira, forte do Barbalho, Tapagipe, Rio Vermelho e mais partes em que for precisa, nos devemos valer da que estiver supérflua em alguns fortes, sem se admitir objeção em contrário; porque quando esta artilharia se meteu nos ditos fortes, não havia outra parte em que a colocar, mas agora em todas aquelas nos é necessária; então era tempo de pax, e servia de ornato, agora é-nos precisa para a defesa; nem os ditos fortes devem ser considerados pelo nome, mas sim pela sua capacidade, e conseqüência; e assim no de Monserrate que tem treze peças se podem tirar sete ${ }^{1101}$ porque com seis tem suficiente artilharia, porque o inimigo pode desembarcar; e marchar sem fazer caso do dito fortim; e quando o intente ganhar, ${ }^{1102}$ com seis peças pode fazer muito boa defesa, por ser este o número competente à sua grandeza, pois se não devem dar a um pigmeu as mesmas armas que a um gigante. ${ }^{1103}$

O forte de S. Antonio do Carmo não necessita de artilharia no lado que olha ao mar, por ficar sobre o despenhadeiro por onde não há de ser atacado, nem para aquela parte tem a que fazer pontaria, e como se acha com vinte cinco peças, se lhe podem tirar dez; porque com quinze lhe fica artilharia proporcionada a sua capacidade, e bastante para sua defesa: o fortim de S. Antonio da Barra tem dezessete, e com seis, até oito, tem a que sobre para defesa daquele portinho; nem ali tem outra serventia porque a largura da barra dá lugar a que os navios passem sem a artilharia os impedir: o de $\mathbf{S}$. Maria tem treze peças e nem pode, nem deve ter mais que seis pelas mesmas razões que o de $S$. Antonio: o forte da Ribeira tem doze, e apenas poderão nele laborar sete; e desta sorte poderemos remediar a falta de artilharia, enquanto não chega de Portugal.

Nos fortes de Monserrate, Barra, e partes distantes, se deve meter a guarnição de artilheiros competente ao número de peças que tiverem, e de Infantes proporcionado à capacidade e grandeza de cada um: no de S. Francisco, e Ribeira, guarnecê-los somente com os artilheiros necessários para o trabalho das peças: nos de S. Pedro, e S. Antonio do Carmo a guarnição de artilheiros necessária, tendo nomeada a de Infantaria que há de ir para cada um deles, que não é preciso [semeta] logo à primeira vista do inimigo, senão depois de reconhecido o projeto da sua primeira operação, porque nunca pode ser tal que de um jato bloqueie os ditos fortes, pela distância destes à praia e vizinhança da Cidade.

Toda a Infantaria que houver se deve dividir em três corpos, um no Terreiro, outro em S. Bento, e outro no Carmo, por... [Fl. 28v]... estarem assim prontos a acudir àquela parte a que o inimigo se encaminhar, e porque pode ser necessário apressadamente juntar tudo a uma só parte, por o inimigo aplicar a ela toda a sua força, e se não fará com brevidade estando divididos em mais partes.

Não ponho aqui as mais coisas precisas para a defesa de uma praça, porque assim como qualquer Engenheiro na delineação de uma praça, sem embargo de ter um excelente Methodo de fortificar, se não deve totalmente amarrar a ele, mas sim acomodar-se ao terreno, da mesma sorte na defesa não pode seguir em todas as praças as mesmas regras, mas acomodar-se à qualidade e circunstâncias da que quer defender; ${ }^{1104}$ e assim só aponto o que é preciso nesta ocasião, para defesa da Bahia, não entrando aqui coisa que se não podia fazer com brevidade; havendo bastante gente que trabalhe com zelo e fervor; advertindo que qualquer coisa que agora deixe de se fazer, causará na ocasião um grande embaraço, e será mui sensível a falta do que se podia ter obrado.

Bem reconheço que muita parte deste discurso excede a esfera da minha obrigação, porque esta só se dirige ao fim da fortificação assim para a ofensa, como para a defensa de uma praça, sem se misturar com as cuidadosas disposições de quem governa, porém com[o] devo saber os modos, caminhos, e circunstâncias com que a praça estará mais segura, ou melhor defendida, e esta segurança e defesa se não pode conseguir sem uma muito particular atenção a todo o referido, resultando de qualquer leve descuido uma ferida mortal aos defensores, me pareceu apontar os remédios para evitar os sintomas ${ }^{1105}$ que nos podem conduzir à sepultura. Bahia, fevereiro 28 de 1712. [Capitão] Engenheiro Miguel Pereira da Costa

\footnotetext{
${ }^{1101}$ Propõe a reordenação das peças de artilharia em função da nova realidade (o mínimo que se podia fazer sem custo extra ou obra). Nota-se que a "trincheira" foi colocada lado a lado com os fortes, como local importante a se guarnecer.

${ }^{1102}$ Como defende Vellozo, conquistar a fortificação é garantir a posse do território em médio prazo.

${ }^{1103}$ Nem pérolas aos porcos: observa-se na construção do discurso a influência da retórica religiosa. Se Estado e Igreja já eram menos imbricados que no século XVI, a religião católica era preponderante no dia a dia e nas decisões. Por isso a carta, sinal de amizade entre o militar e o padre.

1104 Observações importantes.

1105 Já Vitrúvio falava na importância do saber medicinal para o Arquiteto.
} 
8. Relatório assinado por João Massé, Miguel Pereira da Costa e Gaspar de Abreu $(04 / 02 / 1716)^{1106}$

[FI. 1] ${ }^{1107}$ Bahia

10 de Março / 1716

Vendo-se neste Conselho a Carta de dez de julho de 1714 que o Marquês Vice-Rei do Brasil escreveu a serviço de Estado Diogo de Mendonça Corte Real, em que dava conta a V. Majestade dos sítios que achava mais próprios para se obrar a Cidadela, que dele encarregou em defesa daquela praça, e das dificuldades que se the ofereçam para se pôr em execução a tal obra e que determinava em mais ponderação, e vagar, examinar os portos da marinha, medindo-os, e tirando a planta deles, para informar a V. Majestade com seu parecer, sobre principiar a trabalhar nos dois lados, que são São Pedro e Santo Antonio, e obrigar que os trapiches façam diante da sua frente cais, para se lhe correr cortina, e ficar a marinha defendida; foi V. Majestade servida por carta de 18 de dezembro do mesmo ano, agradecer-Ihes o zelo com que se aplicara nas defesas daquela praça em que esperaria continuasse, como matéria tão importante, e que quando mandasse as plantas e desenhos das fortificações, enviasse também os pareceres do Brigadeiro João Massé e mais Engenheiros.

A esta carta responde o dito Marquês Vice-Rei, por outra de 8 de agosto do ano passado, em que representa remeter a planta das fortificações que o Brigadeiro João Massé achou serem precisas para a defesa daquela praça, e o papel que fizeram os Engenheiros... [Fl. 2]... a quem envio ${ }^{1108}$ sobre $^{2}$ este particular, com o seu parecer a margem dele, para tudo ser presente a V. Majestade resolver o que for mais conveniente a seu Real Serviço mandando V. Majestade declarar, de que consignação se há de tirar esta despesa, e a quantia que em cada um [peso] se há de aplicar para a obra que na dita fortificação se fizer.

E sendo vistas as Cartas referidas, e papéis que com esta se enviam as Reais mãos de V. Majestade.

Pareceu ao Conselho, representar a V. Majestade, que e a fortificação da Cidade da Bahia, desenhada pelos Engenheiros, não só necessita de um dilatadíssimo tempo, mas de uma imensa despesa, e de se demolirem uma grande parte dos edifícios dela, e de [consertos], em que [ou] é certo resultará um grande dano naqueles moradores, não sendo fácil de se compor esta perda. E que nesta consideração, parece que por [hora a] obra mais conveniente que a trincheira, e Dique com que os holandeses a cercaram pela banda de terra, se reforme e restabeleça ao seu antigo estado na mesma forma em que estão conformes os Engenheiros, e [excelentíssimo] Vice-Rei, pela sua grande utilidade, e que depois disso se passe ao Forte do Mar, porque [não] convém que este faça afastar os navios, para que não ofendam tanto a Cidade com a sua artilharias, e que aos moradores não só se dê licença, mas que os persuada o Vice-Rei, a que façam um Cais na marinha, na forma que desenharem os Engenheiros, ficando nela lugar para jogar a artilharia; e para as defesas... [Fl.3]... com as aberturas necessárias para o desembarque dos barcos, ${ }^{1109}$ nas partes que forem convenientes; e que para a obra da trincheira, e Dique, e Forte do Mar, haja V. Majestade, por bem que se despendam todos os anos sessenta mil cruzados do rendimento da dízima da alfândega, que V. Majestade mandou aplicar a este mesmo efeito, sendo este o fim principal para que se introduziu, porque segundo a informação dos

${ }^{1106}$ Relatório dos engenheiros... AHU - Documentos Avulsos, Bahia: Cx. 8, doc. 29 [AHU_ACL_CU_005. Cx. 10, D. 840]. Documento pelo qual foi encaminhado o relatório da proposta de fortificação assinado por João Massé, Miguel Pereira da Costa e Gaspar de Abreu// Conselho Ultramarino: Brasil - Baía/ 1716, Fevereiro, 4, Lisboa/ "CONSULTA do Conselho Ultramarino ao rei D. João V sobre o que responde [o vice-rei e governador-geral do Brasil, marquês de Angeja, D. Pedro Antônio de Noronha Albuquerque e Sousa] a respeito da ordem que teve para mandar as plantas e desenhos das fortificações da praça da Bahia e pareceres do brigadeiro João Mascarenhas e mais engenheiros". Anexo: 7 docs.

1107 Os documentos estão em folhas não numeradas. Os números aqui colocados servem para identificar a seqüência em que aparecem no microfilme do AHU. Omitimos os trechos do relatório propriamente dito, já reproduzidos no subcapítulo IV-1.3., “O projeto assinado por João Massé (1715)”. 1108 Ouvi-o?

${ }^{1109}$ (Posto não ser de carruagens ou elevadores). 
mesmos Engenheiros, entendem que estas obras são as mais úteis, e depois de findas, se poderão então continuar, nas que se tiverem por mais necessárias, e convenientes. [Lisboa] ${ }^{1110} 4$ de Fevereiro de 1716. João Massé. ${ }^{1111}$

..Telles... / Joze ... Abreu / Antonio ... / Antonio Roiz da Costa / Joseph Gomes de Azevedo /

\section{[FI. 4] 4 de Fevereiro / Do Conselho Ultramarino}

Bahia

O Marques Vice-Rei do Brasil responde à ordem que teve para mandar as plantas e desenhos das fortificações da Praça da Bahia; e pareceres do Brigadeiro João Massé e mais Engenheiros; e [vão os] papéis que se [enviam]. ${ }^{1112}$

[FI. 5-A] Senhor

Logo que recebi esta ordem de V. Majestade, que Deus guarde, chamei o Brigadeiro João Massé, e o Mestre de Campo Miguel Pereira, para se entrar a dar [...] ${ }^{1113}$ pela execução, do que V. Majestade era servido mandar-me nela, e ponderando a preferência, que V. Majestade é servido mandar dar as obras em que se há de ter princípio o trabalho, vendo os registros dos nossos pareceres, que fizemos presente a V. Majestade, em que estavam conformes os Engenheiros e eu, nos persuadimos entender-se esta ordem de V. Majestade, não [e] só com as trincheiras, que hoje se acham de terra, na mesma forma que a fabricaram os holandeses, mas também com as obras principais, que hão de ser atadas à dita trincheira, e as mais necessárias, para fechar esta Praça da Bahia, e que sendo esta a própria causa por que V. Majestade manda preferir esta obra às outras, se devia continuar com a obra exterior; e entrada encoberta do forte de São Pedro, para a fechar com o Dique, ficando nesta forma defendida a entrada que o inimigo pode ter quando desembarque no Rio Vermelho, ou nas praias desta barra, e acabar por este lado toda a obra, que pertence à defensa daquele ataque, e que ao mesmo tempo se deve também pegar a trabalhar na principal defensa da banda de Santo Antonio, principiando-se por aquela obra que se julgar mais necessária, e as trincheiras se tenham limpas, porque para a sua re-acomodação é trabalho que em breve tempo se pode conseguir... ${ }^{114}$

[FI. 5-B] Dom João, por graça de Deus Rei de Portugal e dos Algarves, d'aquém e d' além mar, em África Senhor de Guiné [Vossa]. ${ }^{1115}$ Faço saber a vós meu Vice-Rei e Capitão Geral de mar e terra do Estado do Brasil que fazendo-se me presente o que [insinuais], sobre as fortificações desta Praça, com a planta que delas fez o Brigadeiro João Massé, e papel que fizeram os Engenheiros que tudo remetestes, como se vos havia encomendado, esperando a minha resolução para se por em prática, o que me parecesse mais conveniente do meu serviço, e se vos declarasse de que consignação havia a sair a tal despesa; lhe pareceu mandar nos dizer por resolução de dez do presente mês e ano, em consulta do meu Conselho Ultramarino, que por hora será mais conveniente que a trincheira e Dique, com que os holandeses cercaram essa Cidade pela banda da terra, se reforme e re-estabeleça ao seu antigo Estado, na mesma forma em que estão conformes os Engenheiros, e [vossa...] o estais, pela sua grande utilidade, e que depois disto se passe ao Forte do Mar, porque convém que este faça afastar os navios para que não ofendam tanto a Cidade com a sua artilharia, e que aos moradores não só se dê licença, mas que os persuadais a que façam um Cais na marinha na forma que desenharem os Engenheiros ficando neste lugar para jogar a artilharia, e para as defensas com as aberturas necessárias para o desembarque dos barcos nas partes que forem convenientes. E para a obra da Trincheira, e Dique, e Forte do mar; hei por bem que se despendam todos os anos sessenta mil cruzados do rendimento da dízima da alfândega por ser este o fim principal para que se introduziu, e pelo que respeita as mais obras findas estão se poderá então continuar, nas que se tiverem por mais necessárias, e convenientes. EL REY Nosso Senhor o mandou por João Telles da Silva, e Antonio Rodrigues da Costa, Conselheiros do seu Conselho Ultramarino, e se passou por duas vias. Miguel de Macedo Ribeiro a fez em Lisboa a vinte e seis de março de mil setecentos, e [...] O Secretario Andre [Joges dela]... ${ }^{1116}$ [FI. 6-A]... o inimigo não há de buscar esta Praça pela parte que está coberta com as trincheiras, senão por um dos lados abertos dela,

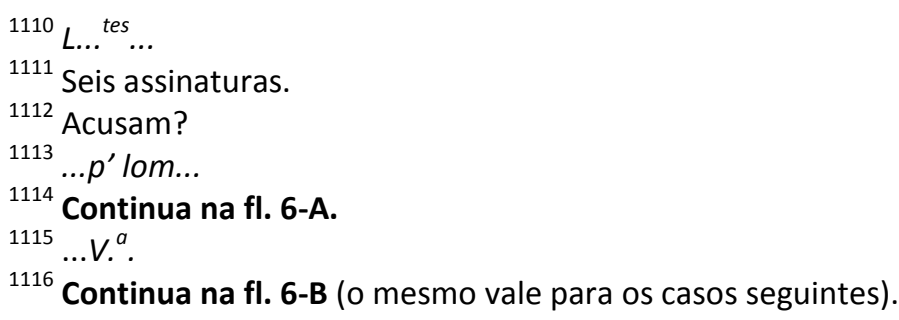


desembarcando ou no Rio Vermelho e praias da barra, ou na chamada praia grande, de Tapagipe, de trás de Monserrate, que é o mais próprio, e quanto a mim o único e melhor desembarque para vir buscar esta Cidade, e como entendem os ditos Emginheyros, e eu, se não falta a ordem de V. Majestade, porque mandando, que pela banda de terra se reforme e estabeleça a fortificação das trincheiras, e o seu antigo estado, como da sua re-edificação depende o atar-lhe nos lados estas obras, parecesse se não separava da ordem o trabalho delas.

O Forte do Mar vai continuando no seu entulho, e como é obra mui vigorosa, e se não continuar, poderá o mar levar o já trabalhado, se entendeu ser conveniente não se alterar a consignação, que eu the tinha já feito, porque se continuasse com esta, o pouco trabalho que pode produzir; porém se lhe não acrescentasse mais consignação, nem se entrasse no trabalho da comunicação para a Cidade, por a preferência que V. Majestade foi servido, ordenar tivesse as obras de terra.

No que toca ao Cais, logo, que saírem os [comboios], ${ }^{1117}$ entrarei em persuadir os moradores na utilidade que se lhe há de seguir de o fazer.

O Forte de São Pedro está já com os para-... [Fl.6-B]... [ure] a fez escrever. João Teles da Silva / Antonio Roiz da Costa. $2^{\text {a }}$ via

[Fl. 7-A]... peitos, e só lhe falta o entulhar-se para se lhe assentar as baterias. E é tudo o de que posso dar conta a V. Majestade, sobre o que me manda nesta Provisão: estimarei que na execução dela se dê V. Majestade por bem servido. A Real Pessoa de V. Majestade guarde Nosso Senhor como seus vassalos havemos mister: Bahia, junho 18 de 1716./ Marque de Angeja

[FI. 8-A] Senhor ... [= p. 5] [Final: “... é trabalho que em breve tempo se pode conseguir..."] [FI. 8-B] Dom João por graça de Deus... [= Fl. 5-B até "o que me parece mais conve..." - rasurado até o final][Fl. 9-A Rasurado] [Fl. 9-B]...Teles da Silva/ Antonio Roiz da Costa. 2. ${ }^{a}$ via. [=fl. 6-B] [FI. $10=$ fl. 6-7A]

[Fl. 11-A] O defeito que se considera neste forte pelo próximo da igreja, e casas ce heteraes, se sê facilíssimo de emendar, com demolir um, e outro defeito: porém sê necessário que S. Majestade ordene, no caso da demolição da Igreja, se faça esta por conta de sua Real fazenda, tanto pela razão de a mandar tirar dali, quanto pela obrigação do Padroado.

[Fl. 11-B] ${ }^{1118}$ (trecho reproduzido no corpo do texto, continuando na fl. 12-B).

[Fl. 12-A] Assim é como dizem os Engenheiros, e acrescento, que o forte de São Diogo é escusado; ${ }^{1119}$ enquanto a impedia a entrada da barra, e não podem por nenhum impedimento: com tudo, o Forte de Santo Antonio que está na ponta da barra, posto que não defenda a entrada, contudo, não deixa de a embaraçar, e me inclino muito a que findas as fortificações, que se desenham à Cidade, se construísse uma, com melhor methodo no dito sítio, não só alargando-lhe as baterias para o mar, mas ocupando o monte que a domina, com defesas para a terra, à imitação da Fortaleza de São Julião da Barra; ${ }^{1120}$ por não deixar de considerar grande respeito em todas as entradas da Barra, o achar-se uma fortaleza considerável, quanto mais, que sucedendo desembar[car] o inimigo pela parte do Rio Vermelho (ainda que não sê fácil) sê natural, não há de vir buscar a Cidade, deixando no flanco e costas uma Praça, que pode ocupar dois mil homens, com os quais lhe podem cortar a comunicação e estar sempre inquietando na marcha, e quartel que tomarem.

O Baluarte e bateria da Conceição de nenhuma necessidade é, antes o tenho por inútil, ${ }^{1121}$ porque pela parte da praia que corre para a barra é tudo rochedo e quase a pique: para a direita é tudo Cidade; e conseguindo o fechar-se o molhe com o forte do mar, recobre algum tiro que poderá fazer ao fundo dos navios que ancoram defronte da Bahia, e para o mar, só poderá atirar a algumas [sumacas], e navios de pouco fundo, que os mais podem estar ancorados sem que lhe chegue a artilharia: contudo não a desaprovo, para se trabalhar nele a seu tempo, e haver de [fericir de têuta], ou principio de Cais que há...

1117 ...Comboys...

${ }^{1118} \mathrm{O}$ relatório propriamente dito começa aqui (seguindo-se sempre pela coluna B).

1119 Dispensado.

${ }^{1120}$ Trecho importante: mostra a idéia de Miguel Pereira para a fortificação da Barra.

${ }^{1121}$ Lembra frase dos jesuítas: “... antes os têm por selvagens". 
[12-B] (trecho reproduzido no corpo do texto, continuando na fl. 14-B).

[Fl. 13-A]... boa bateria, capaz de receber número proporcionado de canhões, atando o forte que está no alto de Monserrate à dita bateria e construindo alguma pela parte da Praia para defender a dita praia.

Quanto á Cidadela sê sem questão, ser o sítio de São Bento o melhor para a sua construção porém tenho por impraticável, o poder-se ali fazer, por se achar aquele sítio todo ocupado de conventos, e muitos edifícios nobres, e é necessário para se formar ali a dita Cidadela uma tão grande despesa, que nunca se há de acabar a dita Cidadela, por causa desta, e pelos demasiados embaraços que se hão de encontrar na demolição dos conventos, igrejas e edefícios que estão naquele sítio. $\mathrm{O}$ sítio da Palma é o que se acha para que com mais facilidade, e menos despesa se possa formar nele a dita Cidadela: e pelo que conheço, que o dito sítio seja estreito, e descortinado do monte de São Bento, e do da Casa da Pólvora, contudo, tem a área que basta para receber em si os terços desta Praça, e alguns mais [que os] houver, e tê-los em disciplina, aquartelados e fechados, que é o preciso para não parecerem paisanos, e não continuarem arrojados dispersamente pela Cidade, no pouco serviço em que estão. E quando pelo tempo adiante pareça alargar-se a dita Cidadela, se pode fazer, atacando-lhe o monte da Casa da Pólvora, o que não só lhe servirá de a alargar, e dar todo o alojamento necessário, mas também Ihe ganhará aquela ofensa./ [assinatura].

[Fl. 13-B] (trecho reproduzido - continuação da fl. 17-B). ${ }^{1122}$

[Fl. 14-A]... de correr por toda a Praia da Cidade: e sobretudo, para o molhe, que se há [de] construir, obra mui útil, e necessária, para recolhimento de [lumacas] e outras embarcações em ocasião de temporal.

Ao quinto, me parece o mesmo.

[FI. 14-B] (trecho reproduzido).

[FI. 15-A] O mesmo.

O mesmo: mas porque o inimigo, sucedendo desembarcar na praia de Jequitaia, e dela não buscar o outeiro do Padre Ribeiro, continuando pela mesma praia a atacar o Forte de Santo Alberto, e a bateria de São Francisco, para por aquele ataque entrar na Cidade na Povoação da Praia, e coberto de toda a artilharia do Forte de Santo Antonio obra nova, e Barbalho, será preciso que na Bateria de São Francisco como [está], ou lado do cais que há de correr pela praia, para a parte direita, se lhe faça contra este ataque, a qual se ate com o Forte de Santo Antonio, ou como melhor parecer à vista do terreno.

O oitavo o mesmo

[FI. 15-B] (trecho reproduzido).

[Fl. 16-A] O nono tambem sou do mesmo parecer; e só acrescento, que na passagem seca se faça uma ponte com arcos sobre os quais se pode fazer ponte levadiça, e quando se não queira fazer esta, na ocasião se pode romper, e enquanto não há esta, continuar o serviço da comunicação dos campos para a Praça.

[FI. 16-B] (trecho reproduzido).

[Fl. 17-A] No decimo: parece-me mui preciso o Cais apontado, e que principie no Baluarte da Conceição e acabe no de São Francisco no Rosário, e que entre o da Conceição e o da Ribeira se faça o Molhe [de lagamar] que dizem, para que entre estas duas baterias fique o arsenal das naus, e os dois molhes.

Também me parece que se acrescente o Forte do Mar na forma da planta, e se construa outro, no baixo que fica ao mar deste, e acrescento que na ponta de Monserrate se deve fazer uma...

[Fl. 17-B] (trecho reproduzido, emendando-se à fl. 13-B).

[Fl. 18] Senhor

1122 O relatório propriamente dito parece terminar aqui, sendo complementado pelo orçamento (fl. 26). 
Foi V. Majestade servido ordenar-me no ano de [1]713 que passasse a este Estado do Brasil para nele examinar, e reparar as fortificações de suas praças, e fazer as mais obras que fossem necessárias para a sua conservação e defesa. Em virtude destas Reais ordens me embarquei para o Rio de Janeiro onde cheguei em junho de [1]713, e achando aquela praça mui arruinada pela invasão dos franceses, desenhei, com parecer do Governador daquela capitania Francisco de Távora, algumas obras, e reparação daquelas ruínas, e a tudo se deu logo princípio.

Em 1714, fui em companhia do dito Governador visitar a Praça de Santos, aonde desenhei dois fortes; um na barra grande, e outro na mesma Vila: nesta ocasião passei tambem à Ilha Grande, e Ilha de S. Sebastião, e recolhendo-me ao Rio de Janeiro fiz plantas, e relações de tudo que entreguei ao mesmo Governador para remeter a V. Majestade.

No mesmo ano de [1]714, achando o dito Governador que já não era necessária a minha assistência naquela praça, passei a esta da Bahia de todos os Santos, e nela me tenho ocupado debaixo das ordens do Marquês de Angeja Vice-Rei deste Estado, e com o parecer, e assistência do Mestre de Campo Miguel Pereira da Costa examinando a sua fortificação, e desenhando as obras e reparação necessária para sua defesa, cujo desenho e relação remeteu o dito Vice-Rei a V. Majestade na frota de [1]715. No princípio deste ano acompanhei ao mesmo Vice-Rei a visitar todoo Recôncavo desta Bahia, de que ele terá dado inteira conta a V. Majestade, e é o que tenho obrado do Real serviço de V. Majestade no decurso ${ }^{1123}$ destes três anos de assistência do Brasil;

[Fl. 19] Para dar inteiro cumprimento às Reais ordens de V. Majestade passarei na presente monção à Praça de Pernambuco a fazer a mesma diligência como nas referidas praças tendo executado, e acabada que seja voltarei a esta Cidade conforme a instrução do dito Vice-Rei; e como nestas praças principais, se acham Engenheiros mui capazes de executar tudo o que nelas se tem desenhado, com toda a devida e humilde [sumição] peço a V. Majestade seja servido conceder-me licença de me recolher a Portugal, quando o dito Marquês Vice-Rey acabando o seu governo voltar por ordem de V. Majestade a esse Reino. É o que se me oferece de dar conta a V. Majestade. Deus guarde a Real pessoa de V. Majestade. Bahia em 25 de julho de 1716./ João Massé

[... terra e mercê continuando...]

[Fl. 20-A] Na primeira frota que daqui partiu depois de eu chegar a esta terra, dei conta a V. Majestade das fortificações que entendia se deviam fazer nela, as quais também parecia ao Brigadier João Massé: em reposta desta conta, foi $\mathrm{V}$. Majestade servido, mandar-me, que remetesse os riscos, que o dito João Massé tivesse feito, e que sobre eles, e as ditas fortificações, ouvisse os mais Engenheiros, e que do parecer de todos, lhe desse conta junto também com o meu parecer, e tudo remetesse naquela frota a V. Majestade, o que fiz entregando ao Mestre da nau de guerra as plantas, e dentro do canudo de folha de flandres, em que elas iam, os pareceres do Brigadier, Engenheiros, e meu.

Como V. Majestade foi servido ordenar-me lhe remetesse riscos, e pareceres das novas fortificações, fiquei entendendo ser aquela ordem para V. Majestade tomar a resolução que fosse servido, ${ }^{1124}$ sobre a construção das tais fortificações, e assim ficava eu [inibido] ${ }^{1125}$ de entrar a trabalhar na obra delas sem primeiro receber a resolução de V. Majestade, e como me não tinha até agora chegado esta, ignoro totalmente o que V. Majestade haverá resoluto, e se a disposição em que fala esta Provisão do Conselho

pertencia só aos desenhos, estão executados; porque os desenhos se acham feitos, e remetidos a V. Majestade. E como o Brigadier o tenha já feito, Ihe tendo ordenado (na forma que V. Majestade manda) passe a Pernambuco, na própria monção e [Pataixo] dos Padres da Companhia, para naquela Praça executar as ordens que trouxe de V. Majestade.

[Fl. 20-B] Dom João por graça de Deus Rei de Portugal e dos Algarves, d'aquém e d' além mar, em África Senhor de Guiné [V. Senhoria]. Faço saber a vós meu Vice-Rei, ${ }^{1126}$ e Capitão General de mar e terra do Estado do Brasil, que tendo João Massé desenhado nessa Capitania da Bahia o que tenho disposto sobre as fortificações dela me pareceu ordenar-vos, que logo o façais ir para Pernambuco, para obrar naquela

\footnotetext{
${ }^{1123}$ Novamente, usa-se "discurso".

${ }^{1124}$ Passa a impressão de falha comunicativa

1125 ... enhebido... Incumbido?

${ }^{1126}$ Até aqui, $=$ fl. 5-B.
} 
Praça ${ }^{1127}$ o desenho da Cidadela que tenho resoluto se obre nela. El Rey Nosso Senhor o mandou por João Teles da Silva e Antonio Roiz da Costa, conselheiros do seu Conselho [Vice-Reinado] e se passou por duas vias. Miguel de Macedo Ribeiro a fez em Lisboa, a cinco e março de mil setecentos e dezesseis. O Secretário André Lopes de Laure a fiz escrever. João Telles da Silva. Antonio Roiz da Costa [já V. Alteza] [Portugal] do Conselho [Vice-Reinado] de 05 de Março de 1716./.

[Fl. 21] As fortificações em que se têm trabalhado nesta é o entulho do Forte do Mar, por ser obra mui dilatada e sem que [o tão] precisa, mandei continuar nela; e o Forte de São Pedro, que também achei principiado, e se acha já com todos os parapeitos andando se the tirando o entulho, e logo se há de entrar na estrada encoberta, com a qual pretendemos emendar os erros do dito forte, já por aquela [parte] fica esta Praça fechada: nas mais que o desenho aponta se não tem bolido, por se esperar a Resolução de V. Majestade de que depende a tal obra. A Real Pessoa de V. Majestade guarde Nosso Senhor como seus vassalos havemos mister. Bahia e junho 5 de 1716./ Marques de Angeja

[Fl. 22 = fl. 11-B] Ordenou V. Excelência [que] fizéssemos relação, assim da fortificação com que hoje se acha.../É esta praça cercada...

Assim como a Trincheira cerca toda a praça... chamado do Camarão, que é um reduto de terra, no monte que olha ao tanque dos Padres da... [= fl. 12-B]

...Companhia, na outra entrada de São Pedro está o Forte...

Na marinha tem... Jequitaia estava um pequeno reduto circular, que se acrescentou...

[Fl. 23 = fl. 12-B]... e se há de acabar; e tem... fica o do Mar que é Circular, e tem... [= fl. 14-B]... uma praça alta; mas esta além de ter...

Como esta Praça tem somente as duas entradas dos fortes de São Pedro e Santo Antonio do Carmo... [=fl. 15-B] Dado que desembarquem contra toda a oposição...

Pelo que respeita à entrada do Forte de Santo Antonio do Carmo... e poderem surgir em qualquer das duas partes para calorearem com artilharia as suas operações: feito o desembarque e postos em marcha..

[Fl. 24 = fl. 15-B] ... para a Cidade, depois de uma e outra se lhe disputar... e batendo ao inimigo quando na Soledade se alojar.

É preciso também fazer, um forte quadrado no sítio em que está o do Barbalho; porque este é incapazíssimo pela sua pequenês, pois ficará o dito... [= fl. 16-B]... forte dominando, e defendendo a Obra Coroa, o Forte de Santo Antonio..., e com a defesa que o terreno permite.

Não se deve desprezar a trincheira de terra com que a Praça antigamente foi fechada.... E há muito a... [= fl. 17-B]... se fazer caso desta defesa tão principal, que cada vez se vai perdendo mais: não sendo justo que pela conveniência...

[Fl. 25 = fl. 17-B] ... de alguns se exponha a de todos; porque duas hortas que estão junto ao Dique ... Pelo que respeita a marinha se deve fazer um cais...

O Forte do Mar deve ser acrescentado à roda tirando-se o torreão, e subindo toda a bateria baixa a ser praça alta, e o novo acréscimo ficar sendo praça baixa, e deste para terra o molhe continuado... [= fl. 13B]... na forma da planta: no baixo que está ao mar deste forte se pode fazer uma fortificação para que este Porto fique melhor defendido.

E quanto à Cidadela o seu verdadeiro lugar... ordenará o que for servido. Bahia 23 de Julho de 1715.

Miguel Pereira da Costa / Gaspar de Abreu / João Massé

[Fl. 26] (trecho reproduzido: orçamento - final do relatório).

${ }^{1127}$ Realizar a obra de engenharia. 
6. Amostra dos documentos transcritos
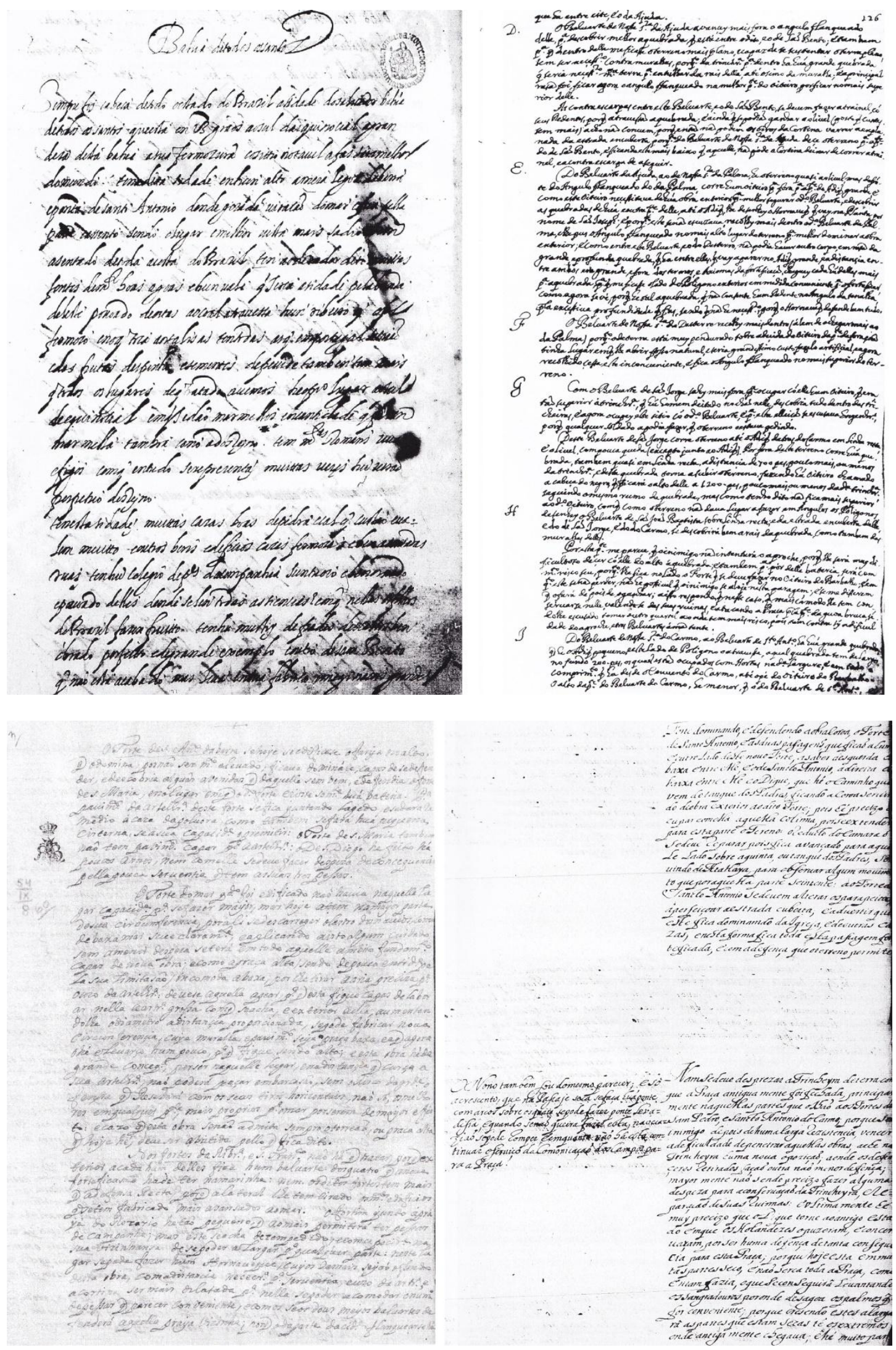

Em seqüência, a fl. 25 da Relação de Diogo Campos Moreno (1609), a fl. 126 do Relatório de João Coutinho (1685), a fl. 34 do Extracto da forteficação de Miguel Pereira da Costa (1710) e a p. 16 da transcrição do "Projeto Massé". 


\section{Casa da Torre (atualmente em ruínas)}

O Regimento de D. João III ordenando a construção de Salvador também incentivou que cada novo colono fizesse uma torre ou casa forte para acelerar o crescimento da economia local (produção e comércio de alimentos) e dar início à exportadora (plantio e venda da cana-de-açúcar). ${ }^{1128}$ Gabriel Soares de Sousa (1584-7) descreveu sumariamente as construções importantes das redondezas de Salvador, que eram cerca de quarenta. ${ }^{1129}$ Entre elas estava o núcleo da Casa da Torre, residênciafortaleza dos descendentes de Garcia d'Ávila, que vindo com Tomé de Souza (seu padrinho e talvez pai biológico), ${ }^{1130}$ foi incentivado a construí-la para cumprir o Regimento. ${ }^{1131}$

Francisco Doria cita um mapa do início do século XVII sugerindo que a Torre de Garcia d' Ávila fosse "um bastião quadrangular, como os que os portugueses tinham em Arzila", podendo ser ainda uma fortificação defensiva costeira como "o torreão principal do castelinho de Tavira, ou alguns dos torreões do centro histórico, medievalesco, de Faro, no Algarve". ${ }^{1132}$

A chamada Casa da Torre, hoje preservada em ruínas, foi ampliada pelo neto de Garcia d' Ávila no século XVII e concluída por outros descendentes no XVIII, transformando-se em verdadeira casa-fortaleza, sede de uma fazenda que teve como principal atividade a criação extensiva de gado (estendendo sua sesmaria pelo sertão nordestino até o Piauí). ${ }^{1133}$ A região é hoje conhecida por Praia do Forte possivelmente por causa das ruínas da casa-grande (única feita de blocos de granito, provavelmente agregados com argamassa de óleo de baleia e cal), semelhantes às de um castelo. ${ }^{1134}$

\footnotetext{
${ }^{1128}$ Regimento..., 1998: 15. ... para serviço e manejo dos ditos engenhos d'açúcares Ihe dareis aquela terra... e as ditas pessoas se obrigarão a fazer cada um em sua terra uma torre ou casa forte da feição $e$ grandura que lhe declarardes nas cartas... para segurança e povoadores de seu limite. Também para as outras capitanias foi ordenado... que nos assentos das povoações dos sitos engenhos se façam torres ou casas fortes... (p. 18).

${ }^{1129}$ Cf. SOUSA, 1971: 162 e SMITH, 1969:36.

${ }^{1130}$ Cf. DORIA, 1999: 27-32.

${ }^{1131}$ Garcia d' Ávila foi também feitor da Cidade e Almoxarife da Alfândega (cf. BUENO, 2001: 563).

1132 DORIA, 1999: 29.

${ }^{1133}$ A fazenda, uma das maiores do Brasil, também produziria açúcar. A informação de B. Bueno (2001: 563) de que Garcia d' Ávila “iniciara a criação de gado em 1551, ao fundar o Curral de São Pedro de Rates - freguesia junto a Póvoa de Varzim, de onde o Governador Geral do Brasil e ele próprio seriam naturais" não parece correta, uma vez que ele chegou à Bahia em 1549.

${ }^{1134}$ A transformação do primeiro solar no imponente bloco palaciano em U ocorreu no século XVIII, com uma equipe de pedreiros contratada em Vila Nova de Gaia em 1716 por Garcia de Ávila Pereira (16941734), então dono da casa e primeiro morgado (BUENO, 2001: 562-3).

Robert Smith (1969: 38) descreve a Casa da Torre como um grande retângulo de cerca de 50 metros de comprimento na face sul, disposto à volta de um pátio de pouco mais de 14 metros de frente, circundado pelas arcadas. Para ele, mostra a tradição do sistema grandioso e rude da arquitetura medieval, ao mesmo tempo em que a planta "mostra perfeita compreensão dos princípios formalísticos de disposição de planta do Renascimento" (p. 40), avaliação que difere da de Sandra Baldessarini (1989), de que a ampliação da casa teria sido feita no século XVIII seguindo estilo de inspiração mais barroca. Como as ordens e simetrias ressaltadas no Renascimento também foram assimiladas pelo Barroco, principalmente em planta, é difícil, por este aspecto, definir o estilo

Francisco Doria (1999: 90) lança luz sobre essa questão ao observar que a construção na íntegra lembraria provavelmente o Mosteiro de São Bento ou o Convento de S. Antônio no Rio, "mistura de convento e casa fortificada", tratando-se assim de um "insólito uso leigo de uma arquitetura típica para edifícios com função religiosa: a Casa da Torre é mais um convento fortificado que um castelo".
} 
Alguns autores defendem que possa ter mesmo existido a torre, como Sandra Baldessarini, que se baseia em ruínas encontradas perto da praia. Na conclusão de seu estudo, diz:

...o núcleo restante dá base à identificação de determinadas características comuns às estruturas consideradas como 'torres' na arquitetura tradicional portuguesa.//... a partir desse núcleo deveria erguer-se a chamada Torre, cujo nome sobreviveu à imagem. Seus restos encontram-se quiçá enxertados em outras partes, ou soterrados... ${ }^{1135}$

Segundo os cadernos do IPAC, "não há vestígios de que tenha existido uma torre no corpo da casa" ${ }^{1136}$ Os muitos restos de fundações descobertos em escavações a oeste norte da capela são possivelmente de construções ligadas à produção agropecuária (como a Casa de Farinha), além do provável muro de circunvalação.

O que há de mais relevante na relação com outras fortificações (chegando a figurar na gravura de Claes Jansz e Hessel Gerritsz, de 1624) aparece nas considerações de S. Baldessarini: as atividades desenvolvidas por Garcia d'Ávila "foram de caráter predominantemente militar, ou seja, dar combate ao gentio bravio e vigiar a costa"; "o papel da Torre não era apenas bélico..., mas estratégico". ${ }^{1137}$ Dela, como diz Azevedo, "se alertava a capital da aproximação de barcos inimigos, através de sinais de fogo e fumo que eram transmitidos por postos intermediários" (o fortim do Rio Vermelho). ${ }^{1138}$

Para Robert Smith (1969: 38), o solar dos Ávilas apresentaria semelhanças arquitetônicas com as "torres do Minho" por empregar as mesmas lajes pesadas de granito. E “... a pedra baiana, patinada quase de preto pelos ventos do mar, é de aparência muito semelhante à do norte de Portugal". Segundo Smith, o construtor de Francisco d'Ávila, neto de Garcia, pode ter sido assessorado por Frias de Mesquita. Ele também afirma que Garcia d'Ávila teria dado à primeira construção o nome São Pedro de Rates, homenageando a região ao pé de Braga na província do Entre-Douro-e-Minho, ligada à família de Tomé de Souza e de onde veio grande parte dos colonizadores da Bahia (dessa região teriam vindo tradições de arquitetura doméstica que predominaram no litoral, interior e Minas). Assim, o próprio nome estaria ligado à construção minhota, pois os solares daquela região costumavam ser chamados de "casas da torre".

Mas também a capela e o terceiro andar da parte central podem ter dado ao conjunto o nome de Casa da Torre (e se existiu realmente uma torre, seria um caso único de torre, casa-grande e capela). No testamento de 1609, Garcia d'Ávila se diz morador em sua torre, ter "seis léguas de terra" e que nelas fez "muitas benfeitorias como são a Igreja de N. S. da Conceição, e as casas da Torre, pegada a ela, e outras muitas terreiras, Olarias cercadas de Hortas" (BALDESSARINI, 1989: 201).

1135 BALDESSARINI, 1989: 224. Segundo M. Oliveira, Wanderley de Pinho também declarou haver "um corpo retangular saliente que bem poderia ser antigamente uma torre", mas que "não se conhece a localização exata desse elemento no conjunto monumental da casa-forte de Tatuapara", podendo-se imaginar que seria "o ponto de partida da ocupação da colina". Lembra que o Regimento... incentivava "a construção desses quadriláteros fortificados em todas as sesmarias concedidas, principalmente aquelas com a finalidade de montar-se fazenda e moagem da cana-de-açúcar" (... as ditas pessoas se obrigarão a fazer cada uma em sua terra uma torre ou casa forte...). Se para um reduto defensivo a forma quadrada era a mais simplificada, "a torre não passaria da verticalização desse reduto" (OLIVEIRA, 2004: 177).

${ }^{1136}$ AZEVEDO, 1975-8: II, 89.

1137 BALDESSARINI, 1989: 222.

1138 AZEVEDO, 1975-8: II, 89. Segundo Oliveira (2004: 186-7), vários documentos (BN - Documentos Históricos) falam nos sinais com fogos "que percorriam toda a costa, desde a Casa da Torre, avisando da aproximação de navios e os disparos que eram feitos de fortaleza a fortaleza indicando mais de quatro naves que entrassem pela barra". 


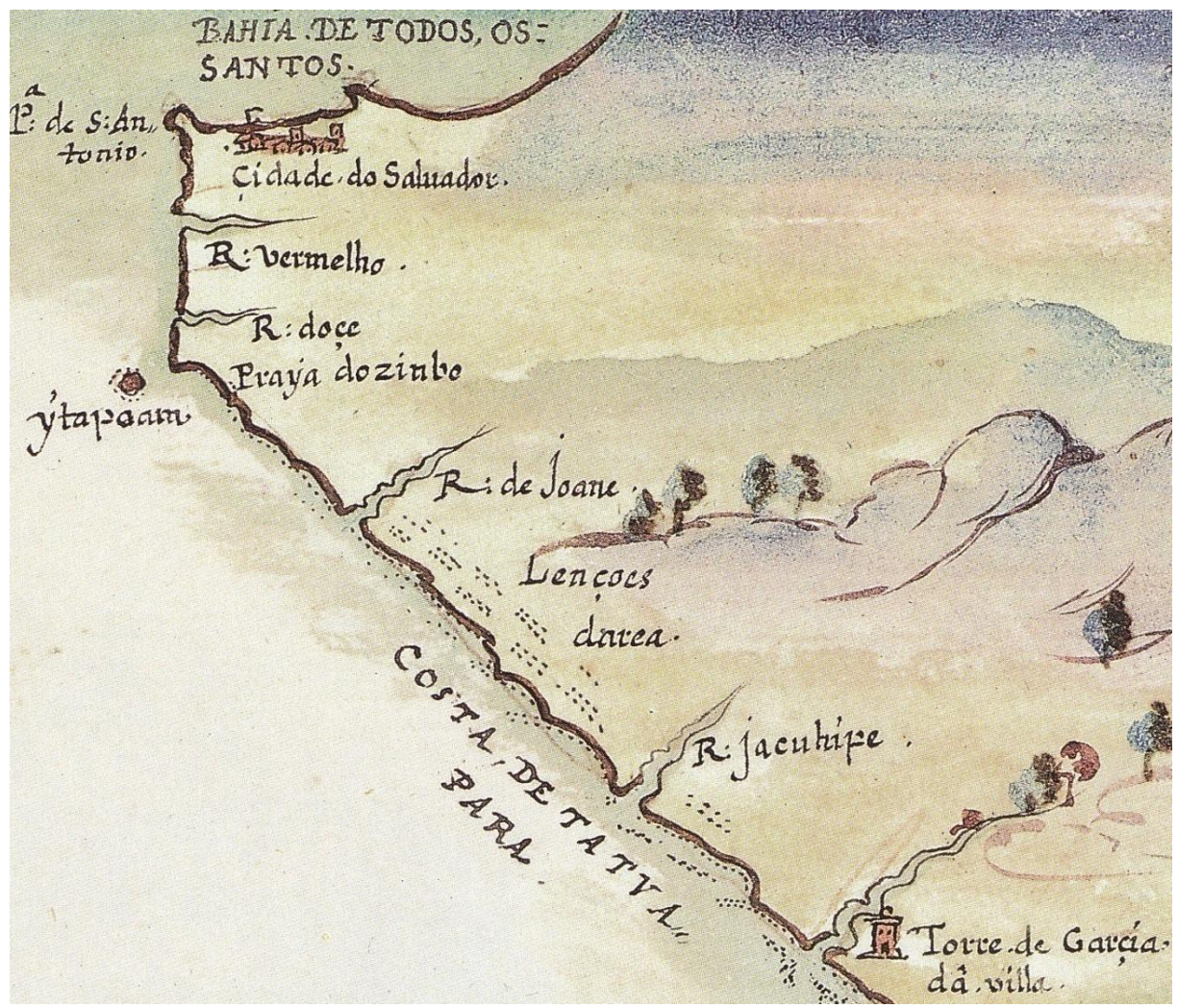

Detalhe do desenho de Albernaz (coleção de 1631) mostrando Salvador e a Casa da Torre (em Atlas do Estado do Brasil..., 1997: 23).
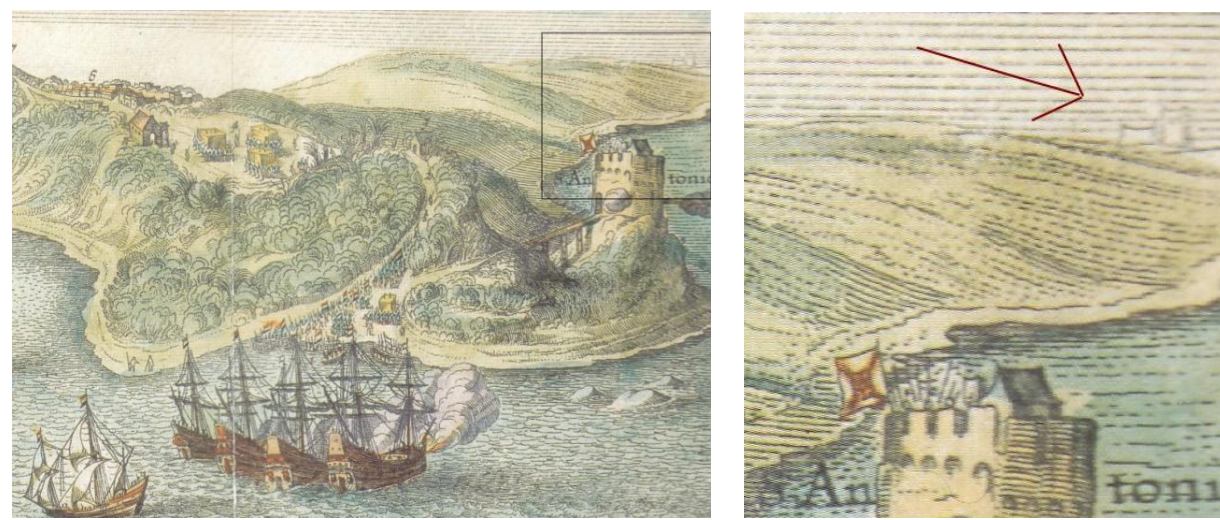

Detalhe da gravura de Claes Jansz e Hessel Gerritsz (c. 1624) - REIS FILHO, 2000: 23-4 (fig. 6).

\section{Capela (restaurada)}

A Capela da Casa da Torre é o exemplo mais antigo de Arquitetura Religiosa com traça atribuída a engenheiro militar. ${ }^{1139}$ Erudita, ${ }^{1140}$ renascentista em sua planta central hexagonal, com altura de torre, ela fazia parte do núcleo primitivo junto com os três recintos de piso nobre e abóbadas de aresta de tijolo (a sesmaria de Tatuapara foi concedida em 1560 pelo Conde da Castanheira, o que faz supor que o conjunto primitivo - casa e capela - tenha sido construído entre 1560-80).

1139 Cf. BUENO, 2001: 562/ MOREIRA, Rafael. A arte luso-brasileira: modelos, síntese, autonomia. In: BETHENCOURT, F. e CHAUDHURI, K. (dir.). História da Expansão Portuguesa. Navarra: Círculo de Leitores, 1998, v. 3, p. 465.

1140 “... em alvenaria de pedra trazida de longe com camadas de tijolo chato nas delicadas abóbadas de aresta e perfis das molduras" (BUENO, 2001: 564). 
O autor é desconhecido, mas supõe-se a concepção de alguém vindo do Reino, talvez Lopo Machado, ex-morador de Tomar, que veio ao Brasil em 1555 como mestre das obras do 2ㅇ Gov. Geral Duarte da Costa (1553-57) e ficou até 1563. Já existia em 1587 (Gabriel Soares de Sousa diz que tinha como orago N. S. da Conceição), sendo evidente a relação com a arquitetura italiana. ${ }^{1141}$ Era famosa quando foi descrita por Fernão Cardim (1601): ... é a mais formosa que há no Brasil, feita toda de estuque e tintim, ${ }^{1142}$ de obra maravilhosa de molduras, laçarias e cornijas, e de abóbada sextavada com três portas, e tem-na mui bem provida de ornamentos. ${ }^{1143}$
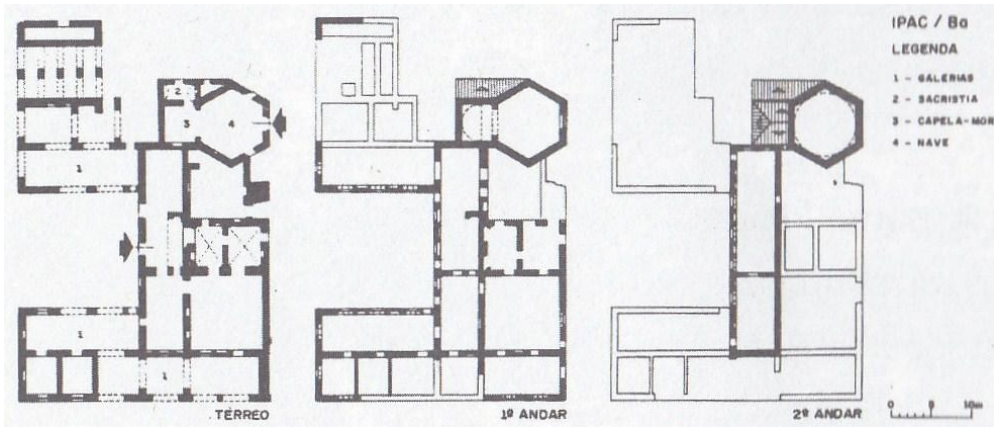

A planta de como seria a Casa da Torre e sua capela no séc. XVIII (em AZEVEDO, 1978: II, 89).

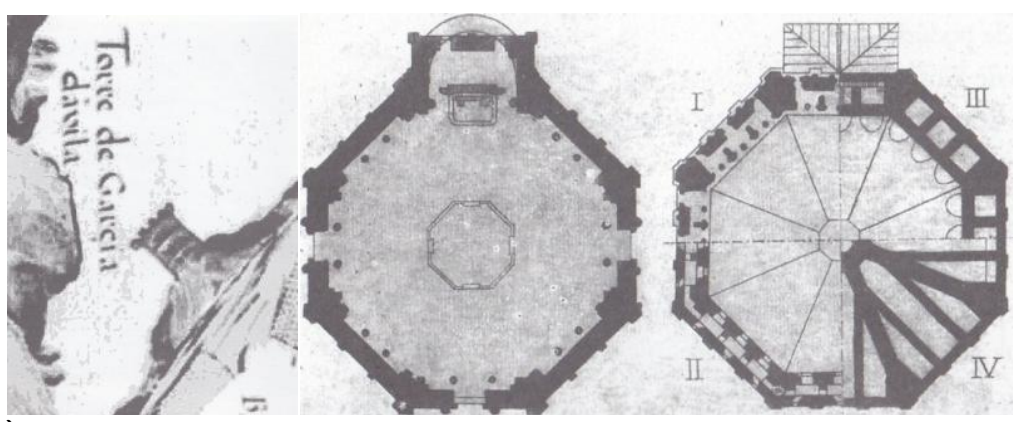

À esquerda, desenho do século XVII reproduzido no Livro que dá Rezão... À direita, planta do século XIX (guia de U. de Villard) do Battistero de Florença (em DÓRIA, 1999: 86 e 90).

${ }^{1141}$ Os cadernos do IPAC (AZEVEDO, 1975-8: II, 89-90) consideram que "não há exemplo anterior em Portugal" a não ser o simultâneo de S. Gregório de Tomar (embora S. Baldessarini - 1989: 231- cite o da Igreja de São João da Foz) e dizem que teria influenciado outras plantas baianas, como a também dedicada a N. S. da Conceição e de igual forma capela do Seminário Jesuíta de 1751, não executada, e a capela octogonal de Bom Jesus de Bouças, no Engenho d’Água.

Para Rafael Moreira, a capela de residência rural de "importante comitente" (de condições financeiras e influência política para contratar o melhor profissional atuando em Salvador), de planta geométrica regular perfeita e poucas aberturas no alçado (como as torres de defesa), tinha as formas preferidas dos mestres das obras de fortificação da época, influenciados pelo Renascimento italiano exemplo de aclimatação de modelos eruditos da Europa: "A capela tinha por orago N. S. da Conceição, padroeira da Ordem de Cristo, e a sua abóbada de fino lavor de estuques e retábulos em três nichos de igual tamanho, de delicadeza florentina, refletem a cultura do pleno Renascimento vigente em Portugal nos meados do século em construções dessa ordem de que dependia o governo espiritual da Colônia: nomeadamente as ermidas de Santo Amaro (1549), em Lisboa, e São Gregório (1564), em Tomar, ambas poligonais e atribuíveis a Diogo de Torralva. É lógico que seu sentido não escaparia à elite cultural da cidade, a que Garcia de Ávila e os seus hóspedes jesuítas pertenciam, e que tão estranha forma hexagonal coberta por uma cúpula esférica - alusão ao 'globus mundi' - fosse, afinal, uma homenagem ao Salvador" (MOREIRA, R., op. cit, 1998, v. 3, p. 466 - apud BUENO, 2001: 564-5).

1142 Cf. BUENO, 2001: 563 (nota 337). Tintim (tetim) = palavra originalmente usada para certa pozolana dos Açores, vermelha, também utilizada como pigmento em pintura; passou depois o designar o pó do tijolo usado para fazer o betume bastante usado em lugares úmidos.

${ }^{1143}$ CARDIM, 1980. 


\section{Algumas notas biográficas}

\section{Luís Serrão Pimentel}

Serrão Pimentel (1613-78) nasceu em Lisboa e começou sua formação com os jesuítas aos 18 anos (1631). Foi aluno dos padres irlandeses Ignacio Stafford e Simon Fallonio (os melhores lentes da Aula de Esfera na arte da Fortificação e dos primeiros a introduzir a matéria), tendo como colega o padre Luiz Gonzaga. Quis trabalhar em regimentos portugueses e interrompeu os estudos para ir à Índia com um tio, mas a viagem não deu certo. Na volta estudou Matemática por dez anos com os mestres do Colégio e com o Cosmógrafo-mor Valentim de Sá. Aos 29 anos (1641) ocupou interinamente o cargo de Cosmógrafo-mor do Reino (no lugar de António Mariz Carneiro, ${ }^{1144}$ do qual aprovou o Regimento de Pilotos), permanecendo nele até 1651 .

Também em 1641 ajudou a fundar e comandou a cátedra da Aula da Artilharia e Esquadria no Paço da Ribeira, que em 1647 foi transferida para a Ribeira das Naus como Aula de Fortificação e Arquitectura Militar, ainda encabeçada por ele (assim permanecendo por cerca de 30 anos). Foi também em 1647 (13 de julho) sua diplomação como Cosmógrafo-mor, embora exercesse interinamente o cargo desde 1641 . $^{1145}$

Em 1648 Pimentel era Engenheiro-diretor do exército do Alentejo, região em que se concentraram suas maiores intervenções, participando inclusive das principais batalhas, como a das Linhas de Elvas e do Ameixial. Também interveio em obras de fortificação de Estremoz, Évora, Elvas, Portalegre, Castelo de Vide, Vila Viçosa, Mourão e outras. ${ }^{1146}$ Em 1663 foi nomeado Engenheiro-mor do Reino.

Com a morte de Mariz Carneiro (1671), foi também nomeado (definitivamente) cosmógrafomor. ${ }^{1147}$ O cargo incluía ensinar cosmografia e Arte de Navegar na Ribeira das Naus, tendo de examinar homens do mar, pilotos, cartógrafos, instrumentos náuticos, etc. (atribuições que existiam desde o primeiro cartógrafo-mor, Pedro Nunes, em 1559). Publicou dois livros ligados à navegação, o Roteiro do Mar Mediterrâneo (1675, único livro publicado em vida) e a Arte Prática de Navegar (impresso em 1681, depois aditada e retocada pelo filho Manuel Pimentel).

Em 1678, com cerca de 65 anos, morreu ao cair de um cavalo. Em 1680 foi publicado o Methodo Lusitanico de Desenhar as Fortificaçoes Regulares, \& Irregulares, Fortes de Campanha, e outras Obras pertencentes a Architectura Militar..., e o seu filho Manuel foi nomeado cosmógrafo-mor do Reino.

Serrão Pimentel justifica a realização de seu tratado pelo pouco material didático acessível aos lentes das aulas de fortificação. Ressalta que antes o ensino tinha principalmente a sua base prática, e que "agora" ficaria mais "fácil", podendo-se apoiar em sua base teórica. Em suas aulas, apresentou processos de traçados e métodos como Hercotectônica Militar, Tratado de Castramentação, Poliorcética, Antipoliorcética, só impressos postumamente, em $1678 .{ }^{1148}$

Beatriz Bueno cita uma polêmica. Embora Serrão Pimentel fosse pouco conhecido nos principais centros europeus de estudo dos tratados de fortificação moderna, foi criticado e teve querelas com outros engenheiros, como o francês Pierre de Sainte Colombes, contratado para trabalhar

\footnotetext{
1144 Carneiro ocupava o cargo desde 1631 e foi afastado por motivo grave, desconhecido, sendo degredado para o Brasil em 1641.

${ }^{1145}$ Ele já era lente da Lição de Matemática, o que pelo Regimento de 1592 competia ao cosmógrafomor (cf. MOTA, A. Teixeira da. Os Regimentos do Cosmógrafo-Mor de 1559 e 1592 e as Origens do Ensino Náutico em Portugal. Agrupamento de Estudos de Cartografia Antiga. Lisboa: 1969, p. 32/ TEIXEIRA \& VALLA, 1999: 129).

${ }^{1146}$ Cf. TEIXEIRA \& VALLA, 1999: 129.

1147 Foram Cosmógrafos-mores de Portugal até 1680 (não se sabendo a seqüência posterior): Pedro Nunes (1559) João Baptista Lavanha (1591), Manuel de Figueiredo (1608), Valentim de Sá (1623-4), Antonio de Mariz Carneiro (1631-47, substituído interinamente por Luís Serrão Pimentel em 1647-51), Luís Serrão Pimentel (1671) e Manuel Pimentel (1680). Com a nomeação de Serrão Pimentel a Engenheiro-mor (1663), e a definitiva a Cartógrafo-mor do Reino (1671), ele teve uma dupla cátedra (uma de cada posto) na Ribeira das Naus (Beatriz Bueno - 2001: 426 - transcreve de VITERBO, 1904: II, 270 - a Carta em que Serrão Pimentel é nomeado Cosmógrafo-mor - Torre do Tombo - Chancellaria de D. Affonso VI, liv. 29, fl. 267).

${ }^{1148}$ Cf. TEIXEIRA \& VALLA, 1999: 129.
} 
em Portugal (1648) em torno da fortificação de Évora. ${ }^{1149}$ Não se sabe se eram acusações fundamentadas, mas Colombes dizia que Pimentel era homem meramente theorico e tão alheio da pratica. ${ }^{1150}$

Sainte Colombes evocava autores "modernos", dando a entender que Pimentel estaria ultrapassado por estar ancorado nos "antigos". Não há elementos para se julgar essa questão, mas a querela é "quiçá um sintoma de uma tendência para mudança na postura desses engenheirosdiretores ${ }^{1151}$ que progressivamente se converteram em altos funcionários do Estado, homens de gabinete mais que engenheiros de campo". ${ }^{1152}$

A querela também mostra que as obras não se faziam sem ampla discussão no Conselho de Guerra, por desenhos e discursos enviados para aprovação. A Resposta Apologetica... era acompanhada da planta de Sainte Colombe com as tais meias-luas, um perfil sobre a proposta de Pimentel e outro perfil sem assinatura. O desenho era importante na concepção, aprovação, supervisão e prestação de contas das obras, mas a Aula Régia do século XVII nunca teve um lente-desenhista incumbido de ensinar a matéria, o que só aconteceria na gestão seguinte, com Azevedo Fortes no começo do século XVIII.

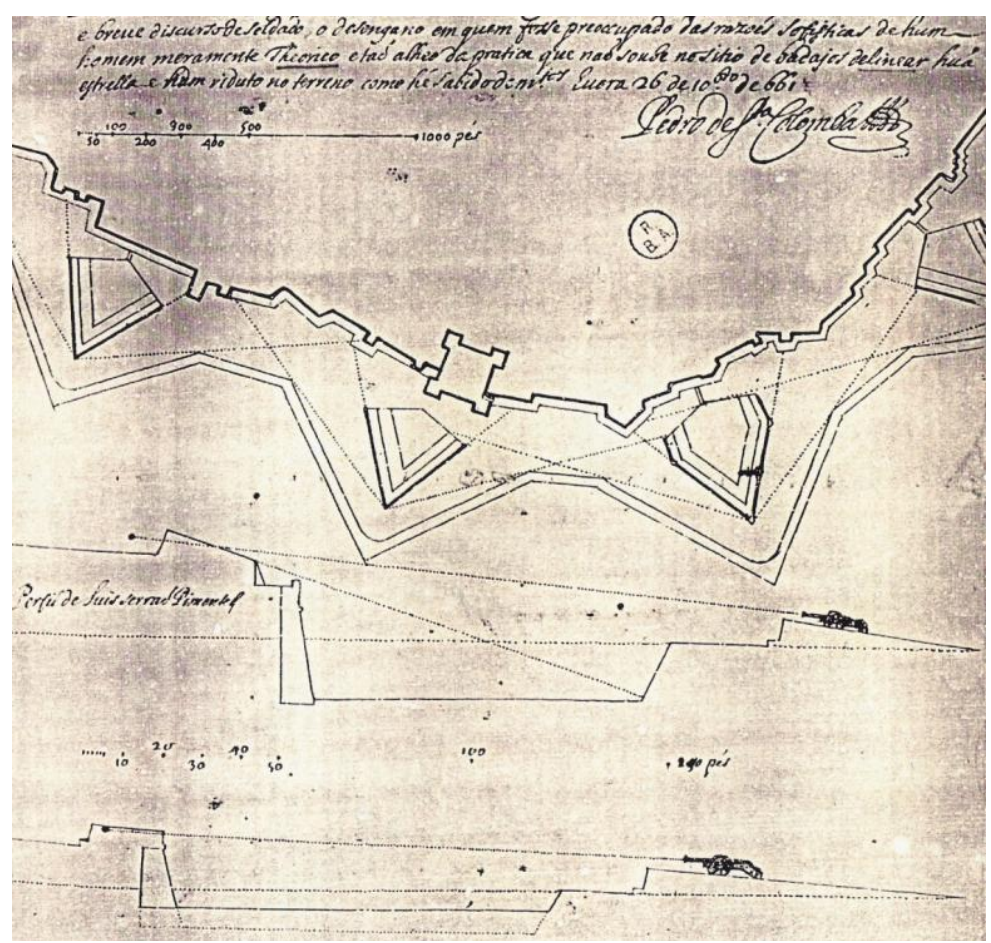

llustração da Resposta Apologetica... na querela entre Serrão Pimentel e Pierre de Sainte Colombe (em BUENO, 2001: 155).

\section{Manoel de Azevedo Fortes}

O Brigadeiro Manoel de Azevedo Fortes (1660-1749) foi um profissional dinâmico e reconhecido na primeira metade do século XVIII. Nomeado engenheiro-mor do Reino em 1719, opinou sobre muitas questões brasileiras (atribui-se a ele os traços de algumas fortalezas, como S. José de Macapá).

${ }^{1149}$ Cf. BUENO, 2001: 454.

${ }^{1150}$ Carta de 26/10/1661 ao conselho de Guerra [BAj 51-VI-1] tendo como título Resposta Apologetica do $T^{\text {te }} G^{a l} P .^{o}$ de $S^{\text {ta }}$ Colomba em defensão de sua Planta de Evora; ao papel de Luís Serrão Pimentel Lente da Mathematica (apud BUENO, 2001: 454). Nela Colombes se defende de objeções de Pimentel e faz outras acusações, transcritas por Beatriz Bueno (cf. p. 454-5). A discussão é sobre o emprego ou não de meias-luas, revelins e baluartes, sobre a fortificação ser ou não de terra (mais barata e rápida de construir). Cf. BUENO: 2001: 454-9.

${ }^{1151}$ Cf. BUENO, 2001: 459. Luís Serrão Pimentel era então Engenheiro-diretor da Província do Alentejo, e foi depois nomeado (1663) Engenheiro-mor do Reino.

1152 BUENO, 2001: 459. 
Nascido em Portugal, fez os primeiros estudos na Universidade Imperial da Espanha, indo para a Universidade de Alcalá e depois para a França, onde estudou no Colégio de Plessis. Brilhante e com fina formação em ciências e filosofia, ${ }^{1153}$ no início do século XVIII competiu em Siena (Itália) por uma carreira de filosofia, vencendo, surpreendentemente, os oponentes italianos (era fluente em diversas línguas; diz-se que, avesso à mediocridade, negava-se a opinar em projetos mal feitos).

Escreveu e publicou algumas obras, das quais Souza Viterbo destaca o Tratado do modo mais facil e o mais exato de fazer as cartas geographicas (1722), Lógica racional, geometrica e analytica (1744) e o notório $O$ Engenheiro Portuguez (bastante difundido e aplicado). Neste último tratado abrangia os ensinamentos mais atualizados da Escola Francesa, esforçando-se em ser claro e didático, como diz no Prólogo:... ${ }^{1154}$ E porque a escuridão, e ambiguidade dos termos he um dos maiores obstaculos para poder chegar ao perfeito conhecimento das Sciencias; puz hum grande cuidado em definir exactamente, determinando-Ihes a sua verdadeira significação.

Os tratados de Azevedo Fortes foram muito consultados em Portugal e nas colônias. A obra continuava atual na metade do século XVIII, sendo referência ("cartilha") básica no levantamento e demarcação de terrenos para traçar vilas e cidades. Um exemplo é a citação do Tratado do modo mais fácil... no Termo de Demarcação e Assignação do Terreno contido no Registro dos Autos da erecção da real villa de Monte-mór o Novo da America, na Capitania do Ceará Grande (1764). ${ }^{1155}$

Sua pesquisa proliferou em outros tratados, recebendo inúmeras citações: Exame de Bombeiros (1748) de José Fernandes Pinto Alpoim (Aula do Terço de Artilharia, RJ); Architectura Militar (1743) do engenheiro português Diogo da Sylveyra Vellozo, responsável pela Aula do Recife; ${ }^{1156}$ apêndice do Tratado de Ruação para emenda das Ruas das cidades, villas, e lugares deste Reyno (redigido provavelmente entre 1759-69) de José de Figueiredo Seixas (pintor, arquiteto e mestre da Aula de Riscar da cidade do Porto), com menção explícita e cópia integral de parte do Tratado do Modo mais fácil..

\section{Gaspar de Abreu}

A atuação Gaspar de Abreu foi discreta não por falta de brilho, mas por ser subordinado a Miguel Pereira da Costa, responsável direto pelas ordens. A Aula de Arquitetura Militar, ${ }^{1157}$ substituindo a antiga Aula Militar, foi criada para que ele fosse o regente (portanto, mesmo discreto, seria um profissional talentoso, conhecendo bem arquitetura e artes náuticas). ${ }^{1158}$ Sua vida de soldado começou em 30/05/1698, como declara em uma petição de 1710. ${ }^{1159}$. Em 1703 foi nomeado Ajudante de Infantaria, adquirindo no ano seguinte o título Ajudante Inginheiro da Praça de Abrantes. ${ }^{1160}$

No início do século XVIII teve várias missões navais (pelo conhecimento que tinha da área) e também em terra. Aos poucos se desincumbindo delas, em 1710 já era capitão engenheiro das fortificações da Praça de Abrantes, quando foi designado a servir no Brasil. ${ }^{1161}$ Veio como capitão, mas sem os benefícios de promoção aos que serviam no além-mar. Sem recursos, conseguiu do Rei receber o salário a partir de sua saída. ${ }^{1162}$ Sua função era apoiar o trabalho de Miguel Pereira da Costa e, principalmente, ser o lente da Aula de Arquitetura Militar (já que Pedro Gomes Chaves não foi à Bahia).

${ }^{1153}$ Cf. OLIVEIRA, 2004: 51

${ }^{1154}$ FORTES, 1993: Proêmio.

1155 Transcrito por Beatriz Bueno nas páginas 480-1, mostrando a patente semelhança com o texto de Azevedo Fortes (p. 481-2). O mesmo assunto é tratado em BUENO, Beatriz P. S. Os engenheiros militares e a construção de cidade. In: V Congresso Brasileiro de História da Arte, 1995.

${ }^{1156}$ Como comentamos, o único escrito inteiramente no Brasil.

1157 Cf. AHU - Códice Ms 246, Bahia. Fls. 333-333v (Carta de 06/03/1713).

${ }^{1158} \mathrm{O}$ aluno Gonçalo da Cunha Lima, expert em arquitetura naval, possivelmente adquiriu dele os conhecimentos.

${ }^{1159}$ Cf. AHU - Documentos Avulsos, Bahia: Cx. 6, D. 532 (CD1, 7, 002, 357-94).

1160 Decreto Real de 18/09/1704. Teria galgado postos não por proteção, mas por competência. Para chegar a ajudante passou por soldado, foi promovido a cabo de esquadra, ajudante supranumerário e, enfim, ajudante do número, quadro efetivo do exército

1161 Recebeu Carta Patente de Capitão Engenheiro da Praça da Bahia em 15/06/1711 (cf. ANTT Chancelaria de D. João V, liv. 7, fl. 539/ VITERBO, 1899: I, 2 - BNL - Conselho Ultramarino, liv. 12 de Officios, fl. 163).

${ }^{1162}$ Cf. VITERBO, 1899: I, 2 - BNL - Conselho Ultramarino, liv. 4 de Provisões, fl. 451/ OLIVEIRA, $2004: 112$. A Carta Patente só foi registrada na Bahia em 19/10. 
Muitas vezes assinou projetos junto com Miguel Pereira, como a planta da Igreja de Nossa Senhora de Palma. ${ }^{1163}$ Sua colaboração no projeto de fortificações coordenado pelo Brig. João Massé deve ter sido importante, principalmente nos desenhos, tendo na equipe os alunos (por ele recomendados) Gonçalo da Cunha Lima e João Batista Barreto, nomeados Ajudantes. ${ }^{1164}$

Logo que chegou houve a invasão francesa à Baía da Guanabara. A Capitania do Espírito Santo, pela proximidade, estava exposta, porque o inimigo podia mui facilmente intentar, qualquer empresa, fiado no descuido que experimentou na Praça do Rio de Janeiro. ${ }^{1165}$ Gaspar de Abreu foi mandado para melhorar urgentemente as defesas de lá, pois era tido como prático e experimentado no país (essa segunda afirmação da portaria não procede, pois acabara de chegar). Mas a estadia durou pouco, sendo chamado de volta para cuidar das fortificações de Salvador, pois Miguel Pereira era vítima de achaques. $^{1166}$

Enquanto participava dos projetos em Salvador, fez petição ao Rei para passar a Sargento-mor. O Conselho Ultramarino preferiu que cumprisse mais dois anos como capitão:... que por ora lhe não deve Vossa Majestade de deferir ao acrescentamento que pede, mas que Vossa Majestade Ihe deve mandar declarar pelo vice-rei que continuando mais algum tempo na aula com aproveitamento dos discípulos que Vossa Majestade atenderá aos seus requerimentos para haver de o promover. ${ }^{1167}$ Quando veio a patente solicitada, foi pouco aproveitada, porque morreria em 1718, ainda jovem. É possível que pouco antes, como sargento-mor, a Câmara o tenha nomeado medidor e arrematador das obras de Salvador, sendo uma de suas funções fazer os termos de alinhamentos e vistorias. ${ }^{1168}$

\section{Manoel Cardoso de Saldanha}

O Cel. Saldanha, figura das mais marcantes da Engenharia Militar da Bahia, foi o provável projetista da Basílica da Conceição da Praia (de desenho hábil, refinado e inspirado). Segundo Viterbo, ${ }^{1169}$ "exerceu principalmente sua atividade no estado do Brazil, tendo sido nomeado em 1749 sargento-mor de engenheiros para ir servir na Bahia, podendo ao fim de oito anos voltar ao reino". Servir oito anos e depois voltar em geral era um logro, porque a falta de engenheiros bons e experientes fazia com que os governadores adiassem e dificultassem esse retorno. Muitos acabavam por se erradicar ou morrer no Brasil, como foi o caso de Saldanha. ${ }^{1170}$

Provavelmente Saldanha também trabalhou fora do Brasil. Quando chegou como Sargentomor, já seria Capitão em Portugal (teve história na vida militar). Tinha origem nobre, ${ }^{1171}$ mas não

${ }^{1163}$ Cf. AHU - Iconografia manuscrita, Bahia, no 961.

${ }^{1164}$ Cf. BN - Documentos históricos, 1941, v. 53, p. 281 - 25/07/1714.

1165 BN - Documentos históricos, 1941, v. 53, p. 108 - Portaria de D. Pedro de Vasconcellos, de 13/04/1720/ OLIVEIRA, 2004: 112.

${ }^{1166}$ Cf. BN - Documentos históricos, 1945, v. 70, p. 120 (de 31/12/1711.

1167 Parecer de 27/11/1714, acatado pelo Rei. Segundo M. Oliveira (2204: 112), a protelação pode ter causa em informação do Marquês de Angeja (passada em AHU - Documentos Avulsos, Bahia: Cx. 7, doc. 115).

${ }^{1168}$ Apud VITERBO, 1899: I, 3 (BNL - Conselho Ultramarino, liv. 13 de Officios, fl. 159v .

1169 VITERBO, 1899: I, 163 (ANTT - Decretos do Conselho de Guerra, maço 108, no 41).

1170 Essa violência era ditada pela necessidade, sendo praticamente confessa em carta de D. Marcos de Noronha (governador do Brasil) a Thomé J. da Costa C. Real (do Conselho Real): Eu Iha neguei [licença para ir a Portugal], segunda vez, por me persuadir, $q^{\prime}$ não era justo deixar esta Praça sem hum Official Engenheiro com a capacidade necessr. ${ }^{a}$ p. ${ }^{a}$ cuidar no reparo da Fortificação della, e p. ${ }^{a}$ assistir as medições das obras, $q^{\prime}$ se costumão fazer por conta da Real Faz. ${ }^{d a}$, por $q^{\prime}$, supposto aqui se ache o Tenente Coronel Nicoláo de Abreu Carvalho, a sua avançada idade, e os achaques, q' padece, não permittem $q^{\prime}$ elle possa supprir à tudo . $^{a}$ o que se faz preciza a assistencia dos Engenheiros./ Justissimam. $^{\text {te }}$ se queixarà a S. Mg.e este Sargento mayor da violencia $q^{\prime}$ Ihe faço em Ihe negar a Licença $q^{\prime}$ tem pertendido, havendolla o mesmo Sno'r conferido logo $q^{\prime}$ completasse os oito anos por $q^{\prime}$ foi mandado passar p. ${ }^{a}$ esta Cidade... (AHU - Catálogo de Castro de Almeida, Bahia. Doc. 3886: Carta de D. Marcos de Noronha pedindo mercê para Manoel Cardoso de Saldanha, de 18/12/1758 - CD3, 19, 001, 129-33).

${ }^{1171}$ Cf. AHU - Documentos Avulsos, Bahia: 005, Cx. 104, D. 8191 (CD12). Requerimento de Saldanha para D. José I, para isentá-lo de servir na Câmara da Bahia, alegando nobreza/ OLIVEIRA, 2004: 120. 
abastada, ${ }^{1172}$ tendo méritos pessoais. Na Bahia desenvolveu intensa atividade, não só como lente da Aula Militar (formando discípulos famosos, como José Antonio Caldas e Manoel de Oliveira Mendes, e oficiais de tropa), mas examinando construções em mau estado (como a Sé) e sendo responsável por muitos projetos de arquitetura de vários tipos, e um dos principais responsáveis pelas missões de exploração e produção de salitre na Serra de Montes Altos (Sertão baiano).

Seus principais discípulos foram Caldas e Manoel de Oliveira Mendes, ambos de boa formação intelectual, vindos do Colégio jesuíta do Terreiro de Jesus. Caldas era excelente desenhista, e Manoel era filho do Mestre Felipe de Oliveira Mendes, que riscava sofrivelmente, mas era ótimo construtor, trabalhando desde menino com o pai (era filho único). A predileção de Saldanha por Caldas se mostrou não só ao indicá-lo como melhor aluno da Aula Militar para cumprir missão nas ilhas de S. Tomé e Príncipe, mas também porque quase todos os seus projetos foram feitos em parceria ou desenhados por Caldas, como seu levantamento da estrada para Serra de Montes Altos e o projeto para o Seminário Jesuíta de N. S. da Conceição, no bairro da Saúde, nunca executado. ${ }^{1173}$

Há muitos documentos sobre a epopéia das minas de salitre em Montes Altos. A pólvora era de suma importância nas conquistas e defesas das lutas por hegemonia e poder. Os Governadores Gerais sempre a requisitavam e clamavam por ela. Sua conservação era problemática pela alta umidade dos trópicos e frágeis instalações de guarda. Assim, a busca na América de jazidas de salitre $\left(\mathrm{KNO}_{3}\right)$, um dos três componentes da pólvora negra, (além do enxofre e do carvão, de fácil obtenção) era uma das obsessões da Coroa. Com as notícias dos sertanistas de que havia salitre na Serra de Montes Altos, uma expedição partiu de barco de Salvador, passando por Cachoeira e subindo por Muritiba adentrou o Sertão em longa viagem no lombo de animais. ${ }^{1174}$ A caravana era acompanhada por soldados escolhidos, tropeiros e guias. Nela Saldanha foi o responsável pela cartografia do roteiro ${ }^{1175}$ e exames do material. Em 1761 ele ainda voltou a Montes Altos com a missão de levar o trem (parafernália) para implantação da fábrica de refino do salitre próxima à jazida. ${ }^{1176}$

De seus projetos, faz parte na história de Salvador o de melhoria da nova Casa da Pólvora dos Aflitos (hoje Quartel General da Polícia da Bahia, muito alterado e com adições neogóticas). Também se destaca o projeto para os quartéis da Piedade (próximos ao atual jardim da Piedade e adjacências, com referências às conhecidas ruas da Forca e do Portão da Piedade (todos eles contando com seu dedicado aluno José Antônio Caldas). ${ }^{1177}$

Em 1761, bem depois dos oito anos que se comprometera por decreto a passar no Brasil (terminados em 14/12/1757), voltou a Portugal pela terceira vez, já promovido a Coronel

1172 Metade do seu salário era paga em Portugal, para manter familiares Cf. AHU - Documentos Avulsos, Bahia: Cx. 100, D. 7881 (CD12). Os parentes seriam irmãs: Tenho Irmans em Estremos dozellas sem outro amparo mais do q a minha impossibilidade. Também em AHU - Catálogo de Castro e Almeida, Bahia. Doc. 4472. Carta de Saldanha a Thomé Joaquim da Costa Corte Real, de 19/07/1759 (CD3, 21, 002, 3903).

${ }^{1173}$ Cf. SMITH, 1998. O desenho apresentado por Smith (do AHM, segundo ele) foi feito por Caldas quando ainda Cabo de Esquadra e discípulo da Aula Militar em 1751.

${ }^{1174}$ D. Marcos de Noronha fez relatório pormenorizado, começando pela escalação dos responsáveis:... Em cartas de dezenove, e vinte e quatro de Mayo deste prezente anno [1758] avizei a V. Ex. ${ }^{a}$, que tinhão

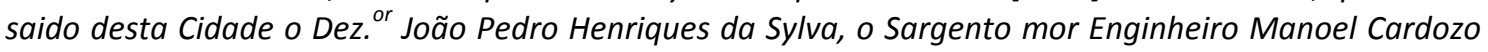
de Saldanha e o Thenente de Infantaria Francisco da Cunha de Araujo, a incorporar-se com o M. ${ }^{e}$ de campo Pedro Leolino Mariz, que na Capela de N. Snr. ${ }^{a}$ da M.e de Deos pouco distante da Serra de Montes Altos os havia estar esperando... (AHU - Catálogo de Castro de Almeida, Bahia. Cota 3587: Carta do Conde D. Marcos de Noronha a Thomé Joaquim da Costa Corte Real do Conselho de Sua Majestade, de 15/09/1758 - CD2, 17, 002, 359-400).

${ }^{1175}$ Caldas, com as anotações de Saldanha do roteiro, desenhou o mapa do percurso (está em AHU Cartografia Manuscrita, Bahia, no 978).

${ }^{1176}$ Do grupo participava o Eng. Mil. Luiz Antônio de Almeida Pimentel, vindo de Portugal para ser o superintendente da fábrica (personagem que não teve qualquer atividade na engenharia das fortificações, sabendo-se que era engenheiro por declarações próprias em cartas a Saldanha; cf. AHU Catálogo de Castro e Almeida, Bahia: Cx 28, D. 5314-8 - CD4, 26, 001, 152-9). O empreendimento renderia muitas histórias, da instalação da fábrica aos descaminhos da Fazenda Real, com insurreição de militares, até a reserva diminuir e já não compensar a exploração.

1177 Cf. desenhos de José Antonio Caldas para os quartéis da Piedade e da Palma no site da BNP, http://purl.pt/854/1/P1.html, fichas 1314082 e 1314085 de visualização ISBD. 
principalmente pelos serviços prestados na primeira expedição da Serra de Montes Altos. A promoção, com apoio do Governador Geral, pode ter sido um artifício (ou argumento) de D. Marcos Noronha para que ficasse mais tempo em Salvador. Foi convencido mais uma vez a ir à Serra de Montes Altos, podendo depois voltar a Portugal, como informa Saldanha em carta a Francisco Xavier de Mendonça:...

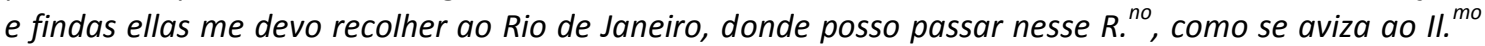
Ex. ${ }^{\text {mo }}$ Conde de Boubadela. ${ }^{1178}$ Não estava escrito que ainda voltaria a Portugal; carta do conde de Azambuja (16/03/1767), informando da morte de Saldanha, confirma que não voltou mais à terra onde nasceu. $^{1179}$

${ }^{1178}$ AHU - Catálogo de Castro de Almeida, Bahia: Cx 28, D. 5314-8. Carta de 29/07/1761 (CD4, 26, 001, 152-9).

${ }^{1179}$ Cf. AHU - Catálogo de Castro de Almeida, Bahia. Doc. 7549 (CD6, 38, 001, 182-4). 
Bibliografia

Atlas do Estado do Brasil, Coligido das Mais Sertas Noticias q' pode Aiuntar Dõ leronimo de Ataide, por Joaõ Teixeira Albernas, Cosmographo de Sua Mag ${ }^{\text {de }}$, Anno 1631. Rio de Janeiro: Nova Fronteira/ Banco BBM, 1997 (fac-simile).

Cartas topograficas. Contem as plantas e prospectos das fortalezas que defendem a cidade da Bahia de Todos os Santos e seu Recôncavo por mar e terra... Manuscrito de José Antonio Caldas, c. 1764 [1762]. BNL - F. R. 698/ D. A. 4A.

Carta do Engr. ${ }^{\circ}$ da Bahya. Carta do Capitão Engenheiro Miguel Pereira da Costa em 28/02/1712. BAj-Ms. Av. 54-IX-8, no 61.

Carta de Miguel Pereira da Costa ao padre (antigo professor) em 18/06/1710 (Cartas e relatório do Mestre de Campo Eng. Miguel Pereira da Costa). BAj Documentos Avulsos [54-IX-8] no 62 e [54-XI-25] no 65.

Città Difese e Archittetura collana diretta da Ennio Poleggi - coleção de desenhos de cidades fortificadas, ISCAG (Biblioteca Atlante 51), Roma.

Documentos digitalizados do AHU: Catálogo de Castro e Almeida (25 CDs), Catálogo Luísa da Fonseca (6 CDs), Documentos Avulsos (32 CDs), coleção disponibilizada pela FCM, patrocinadora do Projeto Resgate.

Extracto da forteficação desta Praça da Bahia estado em q se acha, remedio de $q$ neçeçita. Relatório preliminar do Mestre de Campo Miguel Pereira da Costa em 17/06/1710. BAj-Documentos Avulsos [54-IX-8] no 60.

Obras digitalizadas de Caldas, José Antonio, da BNP digital; http://purl.pt/854/1/P1.html.

Observaçoens Sobre a Fortificação da Cidade da Bahia e Govêrno do Asenal, pela Intendencia da Marinha, e Armazens Reaes. Ordenadas Por Domingos Alves Branco Muniz Barreto, Capitão de Infanteria do Regimento de Estremôz. BMP - Mss 686, Brasil (1797).

Regimento do Governador e Capitão-General Tomé de Souza dado em Almeirim, Portugal, a 17 de dezembro de 1548: "constituição prévia" do estado do Brasil. Salvador: FGM, 1998 (adaptado à língua atual).

Relação das praças, fortes, povoaçons, e cousas de importancia q' Sua Magestade tem na costa do Brazil; fazendo principio dos baixos, ou ponta de são Roque para o sul, do estado e defenção dellas, de seus feittos e rendimentos, feitta pello Sargento Mor desta costa Dioguo de Campos Moreno. No ano de 1609. ANTT Ministério do Reino - Mç. 599, doc. 68: Relatório de Diogo de Campos Moreno, datado de 1609; Coleção de Plantas, Mapas e outros documentos iconográficos.

Relatório de João Coutinho (1685) - Documentos Avulsos, Bahia, Cx. 8, doc. 29 [AHU_ACL_CU_005.Cx. 10, D. 840] - AHU - Códice Ms 245, Bahia.

Relatório dos engenheiros sobre fortificações da Bahia (assinado por João Massé, Miguel Pereira da Costa e Gaspar de Abreu em 04/02/1716, com propostas encaminhadas à Corte). AHU - Documentos Avulsos, Bahia: Cx. 8, doc. 29 [AHU_ACL_CU_005.Cx. 10, D. 840] (=CD2, pasta 10/ rolo 10, 002).

Lista das fortallezas e Redutos que ha nesta Praça da B. ${ }^{a}$, seus Arrebaldes e reconcavo. AHU - Documentos Avulsos, Bahia: 005. Cx 9, D. 741 (CD2, 09, 003, 551-62).

Sanct Salvador/ Baya de Todos os Sanctos - gravura de Claes Jansz Visscher e Hessel Gerritsz (c. 1624), cópia digitalizada do original da Seção de Iconografia da BN. 
ACKERMAN, James S. The Fortifications of Florence. In: The Architecture of Michelangelo. Chicago: University of Chicago Press, 1986. p. 120-35.

ALBERTI, Leon Battista. L' Architettura [de re aedificatoria] (testo latino e traduziona a cura di Giovanni Orlandi). Milano: Edizioni Il Polifilo, 1996, v. 1-2.

ALDENBURGK, Johann Gregor. Relação da conquista e perda da Cidade do Salvador pelos holandeses em 1624-1625. Brasiliensia Documenta I, organizada por Edgard de Cerqueira Falcão. São Paulo: Revista dos Tribunais, 1961.

ANCHIETA, José de. Primeiros Aldeamentos da Baía. Rio de Janeiro: S. D. do MES, 1946 (Col. Bras. De Divulgação, Série IV, História, № 2).

ARAÚJO, Renata Malcher de. Engenharia Militar e Urbanismo. In: MOREIRA, Rafael (Dir.). História das Fortificações Portuguesas no Mundo. Lisboa: Alfa, 1989, p. 255-72.

ARISTÓTELES. Das dimensões e da situação da Cidade. In: Tratado da Política. Lisboa: Europa-América, 2000, p. 65-72 (liv. II, cap. 7).

ARMAS, Duarte de. Livro das Fortalezas (fac-simile). Lisboa: A.N.T.T. e Inapa, 2006.

AZEVEDO, Paulo O. D. de (org.). Inventário de Proteção do Acervo Cultural - BA. Salvador: Secretaria da Indústria e Comércio, 1975-8, v. I, Monumentos do Município do Salvador, II e III Monumentos e Sítios do Recôncavo. Salvador: Secretaria da Indústria e Comércio, 1975 e 1978.

BAÊNA, Miguel S. de. A Artilharia moderna. In: MOREIRA, Rafael (Diretor). História das Fortificações Portuguesas no Mundo. Lisboa: Alfa, 1989.

BALDESSARINI, Sônia R. A Casa da Torre de Garcia d'Ávila. São Paulo: FAU-USP (doutoramento orientado por Sylvio Sawaya), 1989.

BARRETO, Annibal (Coronel). Fortificações do Brasil. Rio de Janeiro: Biblioteca do Exército Editora, 1958.

BAZIN, Germain. A Arquitetura Religiosa Barroca no Brasil. São Paulo/ Rio de Janeiro: Record, 1956, v. I (Estudo Histórico e Morfológico) e II.

BURY, John B. Benedetto da Ravenna (1485-1556). In: MOREIRA, Rafael (Apres.). A Arquitectura Militar na Expansão Portuguesa. Porto: Castelo de S. João da Foz, 1994, p. 130-34

BELUZZO, Ana M. de M. O Brasil dos Viajantes. São Paulo: Metalivros e Ed. Objetiva, 1999.

BOSI, Alfredo. Colônia, culto e cultura/ Do antigo Estado à máquina mercante. In: Dialética da Colonização. São Paulo: Companhia das Letras, 1992, p. 11-63 e 94-118. BOSI, Alfredo. História Concisa da Literatura Brasileira. São Paulo: Cultrix, 1994.

BUENO, Beatriz P. S. Desenho e Desígnio: o Brasil dos engenheiros militares, 1500-1822. São Paulo: FAU-USP, Doutorado orientado por Nestor Goulart Reis Filho, 2001.

BUENO, Beatriz P. S. O Ensino de Arquitetura nas Aulas de Engenharia Militar da Bahia no século XVIII. Desígnio 1 (março 04). São Paulo: Annablume/ FAUUSP, 2004, p. 93-100; Os exercícios dos alunos da Aula Militar da Bahia nos tempos de José Antonio Caldas (1778-1779). In OLIVEIRA, Myriam A. R. de e PEREIRA, Sônia G. (org.). Anais do VI Colóquio Luso-Brasileiro de História da Arte. Rio de Janeiro: CBHA/ PUC-Rio/ UERJ/ UFRJ, 2004, v. 1, p. 135-47.

BUENO, Eduardo. Capitães do Brasil: a saga dos primeiros colonizadores. Rio de Janeiro: Objetiva, 2006-1. 
BUENO, Eduardo. A Coroa, a Cruz e a Espada: lei, ordem e corrupção no Brasil Colônia. Rio de Janeiro: Objetiva, 2006-2.

CABRAL, P. Luiz Gonzaga. Jesuítas no Brasil - Século. XVI. São Paulo/ Rio de Janeiro/ Recife/ Cayeiras: Melhoramentos, 1925.

CALDAS, José A. Notícia Geral da Capitania da Bahia desde o seu descobrimento até o presente ano de 1759. Salvador: Prefeitura, 1951 (edição fac-símile).

CAMPOS, J. da Silva. Fortificações da Baía. Publicações do SPHAN no 7. Rio de Janeiro: Ministério da Educação e Saúde, 1940.

CARDIM, Fernão. Tratado da Terra e Gente do Brasil. S. Paulo/ Belo Horizonte: Edusp/ Itatiaia, 1980; S. Paulo: Hedra, 2009.

CARITA, Rui. A Bahia no Reino Português/ A Fundação de Salvador da Bahia e as Ilhas Atlânticas. In: Anais do IV Congresso de História da Bahia. Salvador: IGHB/ Fundação Gregório de Mattos, 2001, v. 1, p. 381-90.

CARNEIRO, Edison. A Cidade do Salvador (1549): uma reconstituição histórica/ A Conquista da Amazônia. Rio de Janeiro: Civilização Brasileira/ INL-MEC, 1980.

COELHO FILHO, Luiz Walter. A Fortaleza do Salvador na Baía de Todos os Santos. Salvador: Secr. da Cultura e Turismo, 2004.

COSTA, Luiz Monteiro da. Na Bahia colonial: apontamentos para a história militar da Cidade do Salvador. Salvador: Progresso, 1958.

COULANGES, Fustel de. A Cidade Antiga. São Paulo: Martins Fontes, 1998.

DE SETA, Cesare e LE GOFF, Jacques (eds.). La Ciudad y las Murallas. Madrid: Cátedra, 1991.

DIAS, Carlos M., VASCONCELOS, E. e GAMEIRO, R. (dir.). História da Colonização Portuguesa no Brasil. Porto: Litografia Nacional, 1924 (v. III - A Idade Média Brasileira, 1521-1580, p. 327-83).

DORIA, Francisco Antonio. Caramuru e Catarina: lendas e narrativas sobre a Casa da Torre de Garcia d'Ávila. São Paulo: SENAC, 1999.

FALCÃO, Edgar de C. Fortes Coloniais da Cidade do Salvador. São Paulo: Livraria Martins, 1942.

FALCÃO, Edgar de Cerqueira. Relíquias da Bahia (Brasil). São Paulo: Ind. Graphicars-F. Lanzara, 1949.

FARA, Aurelio. II Sistema e la città: archittetura fortificata dell' Europa moderna dai trattati alle realizzioni 1464-1794. Genova: Sagepi e Ditrice, 1989.

FORTES, Manoel de Azevedo. O Engenheiro Portuguez: dividido em Dous Tratados. Lisboa: Direcção da Arma de Engenharia/ Direcção do Serviço de Fortificações e Obras do Exército, 1993, tomos I e II (fac-simile da edição original em Lisboa, 1728-9).

HANSEN, João Adolfo (org.). Cartas do Brasil/ Antônio Vieira. São Paulo: Hedra, 2003.

HOLANDA, Sérgio Buarque de. Raízes do Brasil. Rio de Janeiro: José Olympio, 1987.

JOHNSON, Harold \& SILVA, M. Beatriz Nizza da (coord.). O Império LusoBrasileiro: 1500-1620. In SERRÃO, Joel e MARQUES, A. H. de Oliveira (dir.). Nova História da Expansão Portuguesa, vol. VI. Lisboa: Editorial Estampa, 1992.

KATINSKY, Júlio Roberto. Monumentos quinhentistas da Baixada Santista. Revista USP no 41 (março a maio/99). São Paulo: Coordenadoria de Comunicação Social da USP (acervo do historiador Waldir Rueda), 1999. 
KATINSKY, Júlio. Povoados, Vilas e Cidades Coloniais do Brasil. In: Desígnio 1 (março 04). São Paulo: Annablume/ FAUUSP, 2004, p. 81-92.

KEATING, Vallandro \& MARANHÃO, Ricardo. Caminhos da Conquista: a formação do espaço brasileiro. São Paulo: Terceiro Nome, 2008.

LAGO, Pedro \& Bia Corrêa do. Frans Post (1612-1680): obra completa. Rio de Janeiro: Capivara, 2006.

LEÃO, Joaquim Sousa. Salvador da Bahia de Todos os Santos: iconografia seiscentista desconhecida. Rio de Janeiro/ Amsterdam: Kosmos/ Haia, 1957.

LEITE, Serafim S. I. História da Companhia de Jesus no Brasil. Lisboa/ Rio de Janeiro: Livr. Portugália/ Civ. Brasileira, 1938, 10 volumes (v. I: Século XVI - O estabelecimento).

LEMOS, Carlos A. C. Arquitetura Brasileira. São Paulo: Melhoramentos, 1979.

LEMOS, Carlos. O Brasil. In MOREIRA, Rafael (Diretor). História das Fortificações Portuguesas no Mundo. Lisboa: Alfa, 1989, p. 235-54.

LOBO, Cel. José de Figueirêdo. Fortificações Coloniais da Bahia. Salvador: Fundação Gonçalo Moniz, 1953.

MACIEL, M. Justino. Vitrúvio e a Arquitectura Paleocristã: o caso paradigmático das Regionum Constitutiones. In: Desígnio 9-10. São Paulo: Annablume, 2009, p. 21-5.

MARINS, P. C. G. . A cidade colonial na América Portuguesa: morfologia urbana, atores sociais, presença do Estado (Salvador, séculos XVI a XVIII). In: CARVALHO, Margarida Maria; LOPES, Maria Aparecida de S.; FRANÇA, Susani Silveira Lemos. (Org.). As cidades no tempo. Franca/ São Paulo: UNESP/ Olho d'Água, 2005, p. 229-46.

MARINS, P. C. G. . Através da rótula - sociedade e arquitetura no Brasil, séculos XVII a XX. São Paulo: Humanitas / FFLCH / USP, 2001.

MARTINI, Francesco di Giorgio. Trattati di Architettura Ingegneria e Arte Militare. Milão: Ed. II Polifilo, 1967.

MENEZES, José L. M. Fortificações Portuguesas no Nordeste do Brasil, séculos XV, XVII e XVIII. Recife: Pool Editorial, 1986.

MIRALES, D. losé de. Historia Militar do Brazil. Rio de Janeiro: leuzinger, 1900.

MONTEIRO, John Manuel. Negros da terra: índios e bandeirantes nas origens de São Paulo. São Paulo: Companhia das Letras, 1995.

MOREAU, Filipe E. Os índios nas cartas de Nóbrega e Anchieta. São Paulo: Annablume, 2003.

MOREIRA, Rafael. A Arte da Guerra no Renascimento. In: MOREIRA (Dir.). História das Fortificações Portuguesas no Mundo. Lisboa: Alfa, 1989, p. 143-58.

MOREIRA, Rafael. A Artilharia em Portugal na 2a Metade do século XV. In: MOREIRA, Rafael (apres.). A Arquitectura Militar na Expansão Portuguesa. Porto: Castelo de S. João da Foz, 1994, p. 17-26.

MOREIRA, Rafael. Caravelas e Baluartes. In: MOREIRA, Rafael (Apres.). A Arquitectura Militar na Expansão Portuguesa. Porto: Castelo de S. João da Foz, 1994, p. 85-100.

MOREIRA, Rafael \& ARAÚJO, Renata M. de. A engenharia militar do século XVIII e a ocupação da Amazônia. In MAGALHÃES, Joaquim R. (comis.). Amazônia Felsínea Antônio José Landi: itinerário artístico e científico de um arquitecto bolonhês na Amazônia do século XVIII. Lisboa: Comissão Nacional para as Comemorações dos Descobrimentos Portugueses, 1999. 
MOREIRA, Rafael. A Arte da Ruação e a Cidade Luso-brasileira/ O Arquiteto Miguel Arruda e o Primeiro Projeto para Salvador. Cadernos de pesquisa do LAP 37. São Paulo: FAUUSP, 2003; Anais do 4o Congresso de História da Bahia (Salvador 450 anos). Salvador: IGHBA/ FGM, 2001, v. 1.

MOREIRA, Rafael. A Scientia de Vitrúvio em Portugal nos séculos XV e XVI. In: Desígnio 9-10. São Paulo: Annablume, 2009, p. 11-20.

MORENO, Diogo de Campos. Livro que dá Razão do Estado do Brasil - 1612. Recife: Arquivo Público Estadual, 1955 (edição crítica com introdução e notas de Hélio Viana).

MORI, Victor H., LEMOS, Carlos A. C. e CASTRO, Adler H. F. de. Arquitetura Militar: um panorama histórico a partir do Porto de Santos. São Paulo: Imprensa Oficial do Estado e Fundação Cultural Exército Brasileiro, 2003.

MUMFORD, Lewis. A Cidade na História. Belo Horizonte: Itatiaia, 1965, v. 2.

NÓBREGA, Pde. Manoel da. Cartas do Brasil. Belo Horizonte/ São Paulo: Itatiaia/ Edusp, 1988.

NUNES, Débora (coord.). História Urbana de Salvador (CDR). Coordenação de Extensão Comunitária/ Curso de Arquitetura e Urbanismo da UNIFACS, 2006.

OLIVEIRA, Mário Mendonça de. Morfologia dos Fortes do Mar da defesa de Salvador. In: Anais do IV Congresso de História da Bahia. Salvador: IGHB/ Fundação Gregório de Mattos, 2001, v. 1, p. 481-97.

OLIVEIRA, Mário Mendonça de. Sargento-mor José Antonio Caldas, um professor. In: Anais do IV Congresso de História da Bahia. Salvador: IGHB/ Fundação Gregório de Mattos, 2001, v. 1, p. 535-50.

OLIVEIRA, Mário Mendonça de. Desenho de Arquitetura Pré-Renascentista. Salvador: Edufba, 2002.

OLIVEIRA, Mário Mendonça de. As Fortificações Portuguesas de Salvador quando Cabeça do Brasil. Salvador: Fundação Gregório de Matos, 2004.

OLIVEIRA, Mário M. de. As Fortalezas e a Defesa de Salvador. Brasília: Iphan/ Programa Monumenta, 2008.

OLIVEIRA, Mário M. de. Contribuição de um alentejano à fortificação da Bahia. Salvador: UFBA, 2009 (texto inédito).

PEDRO, Ana P. G. A Cidade Fortificada, Vitrúvio e o Renascimento: visões modernas sobre um ideal antigo de cidade (trabalho de iniciação científica orientado por Mário H. S. d' Agostino). Campinas: FAU-PUC, 2008.

PEIXOTO, Afrânio. Breviário da Bahia. Rio de Janeiro: AGIR, 1945.

PEREIRA, Mário. Da Torre ao Baluarte. In: MOREIRA, Rafael (Apres.). A Arquitectura Militar na Expansão Portuguesa. Porto: Castelo de S. João da Foz, 1994, p. 35-42.

PIMENTEL, Luiz Serrão. Método Lusitânico de Desenhar as Fortificações das Praças Regulares e Irregulares. Lisboa: Direcção da Arma de Engenharia/ Direcção do Serviço de Fortificações e Obras do Exército, 1993 (ed. fac-símile do original de 1680).

PITA, Sebastião da Rocha. História da América Portuguesa. São Paulo/ Belo Horizonte: Edusp/ Itatiaia, 1976.

PRADO, J. F. de Almeida. A Bahia e as Capitanias do Centro do Brasil (15301626). História da Formação da Sociedade Brasileira. Tomo I: São Paulo, Rio de Janeiro, Recife, Baía, Pará, Porto Alegre, 1945. 
PYRARD, Francisco. Do Brasil e suas singularidades e do que ali aconteceu enquanto o autor lá esteve. In: Viagem de Francisco Pyrard, de Laval. Porto: Livraria Civilização, 1944 (trad. Joaquim H. da C. Rivara; ed. A. de Magalhães Bastos), v. 2, p. 227-38 (cap. XXVI).

REBOUÇAS, Diógenes. Salvador da Bahia de Todos os Santos no século XIX. Salvador: Fundação Odebrecht, 1996.

REIS FILHO, Nestor Goulart. Contribuição ao Estudo da Evolução Urbana do Brasil (1500 / 1720). São Paulo: Pioneira/ Edusp, 1968; 2a edição revisada e ampliada, São Paulo: Ed. Pini, 2001.

REIS FILHO, Nestor Goulart. Notas sobre História da Arquitetura e aparência das vilas e cidades. Cadernos de pesquisa do LAP 20. São Paulo: FAUUSP, 1997.

REIS FILHO, Nestor Goulart. Imagens de Vilas e Cidades do Brasil Colonial. São Paulo: Edusp/Imprensa Oficial do Estado/ FAPESP, 2000.

REIS FILHO, Nestor G. Leituras Cartográficas Históricas e Contemporâneas. São Paulo: MAC, Fund. C. Exército Brasileiro e outros, 2003.

REIS FILHO, Nestor G. São Paulo, Vila, Cidade, Metrópole. São Paulo: Prefeitura/ Bank Boston, 2004.

REQUIÃO, Altamirando (introd.). Bahia de Ontem e de Hoje. Salvador: Prefeitura, 1953.

RIBEIRO, Darcy e MOREIRA NETO, Carlos de Araújo. A Fundação do Brasil: testemunhos (1500-1700). Petrópolis: Vozes, 1992.

SALVADOR, Frei Vicente do. História do Brasil: 1500-1627 (revisão de C. de Abreu, R. Garcia e Frei V. Willeke; apresentação de A. Leite). São Paulo: Melhoramentos, 1965.

SAMPAIO, Teodoro. Historia da Fundação da Cidade do Salvador. Salvador: Tip. Beneditina, 1949.

SANTOS, Paulo F. O Barroco e o Jesuítico na Arquitetura do Brasil. Rio de Janeiro: Livraria Kosmos Editora, 1951.

SILVA, Fernanda Fernandes da. Fortificações Brasileiras: máquinas de guerra e de memória. São Paulo: FFLCH-USP, 1991.

SILVA, Cel. Ignacio Accioli de Cerqueira e. Memórias Históricas e Políticas da Província da Bahia. Salvador: Imprensa Official do Estado: 1919 a 1940 (6 volumes).

SILVEIRA, Luís (org.). Fortalezas, Cidades e Povoações da Índia Oriental. Lisboa: Min. do Planej. e da Admin. do Território/ Secr. de Estado da Ciência e Tecn./ Inst. de Invest. Científica Tropical, 1991.

SIRO, Giulio. Francesco di Giorgio. Milano: Electa, 1993.

SMITH, Robert C. Arquitetura Colonial. Livraria Progresso Editora (Coleção As Artes na Bahia, I parte), 1955.

SMITH, Robert C. Arquitetura Civil no Período Colonial. Separata da Revista do Patrimônio Histórico e Artístico Nacional - 17. Rio de Janeiro: 1969.

SMITH, Robert C. Arquitetura Jesuítica no Brasil. São Paulo: FAU-USP, 1962 (trad. Eunice R. R. Costa, introd. Nestor Goulart R. Fo/ In: Cadernos de pesquisa do LAP 25. São Paulo: FAU-USP, 1998 (cap. Engenheiros militares portugueses no Brasil, p. 3669).

SOUSA, Gabriel S. de. Tratado Descritivo do Brasil em 1587. São Paulo: Nacional/ Edusp, 1971. 
TAVARES, Gen. A. de Lyra. A Engenharia Militar Portuguesa na Construção do Brasil. Biblioteca do Exército Brasileiro, 1965.

TEIXEIRA, Manuel C. \& VALLA, Margarida. O Urbanismo Português: séculos XIIIXVIII (Portugal-Brasil). Lisboa: Livros Horizonte, 1999.

TEIXEIRA, Manuel C. A cidade da Bahia no contexto da modernização dos traçados urbanos portugueses quinhentistas. In: Anais do IV Congresso de História da Bahia. Salvador: IGHB/ Fundação Gregório de Mattos, 2001, v. 1, p. 391-405.

TELLES, Augusto C. da S. Atlas dos Monumentos Históricos e Artísticos do Brasil. Rio de Janeiro: MEC, 1980 (2 2 edição).

TOLEDO, Benedito Lima de. Do século XVI ao início do século XIX: maneirismo, barroco e rococó. 3 - FAUUSP. S. Paulo: Moreira Salles, 1983, p. 124-39.

VARNHAGEN, Francisco Adolfo de. História Geral do Brasil antes de sua separação e independência de Portugal (revisão e notas de Capistrano de Abreu e Rodolfo Garcia). São Paulo: Melhoramentos, 1962 (notas de Capistrano de Abreu secção XXIV, v. 1, p. 51 - e Rodolfo Garcia - v. 2, p. 85-8).

VASCONCELOS, Simão de. Crônica da Companhia de Jesus. Petrópolis: Vozes/ MEC, 1977, v. I e II.

VELLOZO, Diogo da Sylveyra. Arquitetura Militar ou Fortificação Moderna. Salvador: PPG-AU/EDUFBA/EU, 2005.

VERNANT, J-P. Espaço e organização política na Grécia antiga. In: Mito e Pensamento entre os Gregos. Rio de Janeiro: Paz e Terra, 1990, p. 227-46.

VIEIRA, Padre Antonio. Sermão pelo Bom Sucesso das Armas de Portugal contra as de Holanda. Biblioteca Online de Ciências da Comunicação (http://www.bocc.uff.br, acessado em 16/04/10).

VILHENA, Luiz dos Santos. Recopilaçõo de notícias soteropolitanas e brasílicas. Salvador: Imprensa Official do Estado, 1921 (notas e comentários de Braz do Amaral). Em especial: Carta Sexta (p. 217-47): "Em que se dá huma compendioza noticia da Fortificação actual da cidade do Salvador dentro da Bahia de Todos os Santos. Descripção das suas Fortalezas tanto pela marinha como pelo interior, mostrando ao mesmo tempo o modo porque parece ficaria melhor fortificada"; Notas e commentarios feitos a sexta e setima cartas de Luiz Vilhena pelo professor Braz do Amaral (p. 271-7).

VITERBO, Francisco de Sousa. Diccionario [Historico e Documental] dos Architectos, Engenheiros e Constructores Portuguezes [ou a Serviço de Portugal]. Lisboa: Imprensa Nacional, 1899 (v. I, A-G), 1904 (v. II, H-R) e 1922 (v. III, S-Z, patrocinado pela Academia das Sciencias de Lisboa).

VITRÚVIO. Tratado de Arquitectura (Trad. M. Justino Maciel). Lisboa: IST (Inst. Sup. Técnico), 2006. 